\title{
Repertorio bibliográfico anotado de monografías de artes marciales asiáticas publicadas en España
}

\author{
Mikel PÉREZ-GUTIÉRREZ ${ }^{*}$, Eduardo ÁLVAREZ DEL PALACIO² \& Carlos GUTIÉRREZ- \\ GARCÍA ${ }^{2}$ \\ ${ }^{1}$ Universidad Autónoma de Chile (Chile) \\ 2 Universidad de León (España)
}

Recepción: 22/05/2013; Aceptación: 30/07/2013; Publicación: 02/08/2013.

\section{Resumen}

ORIGINAL PAPER

Objetivo: El objetivo del presente estudio fue crear un repertorio bibliográfico anotado de todas las monografías de artes marciales asiáticas publicadas en España hasta el año 2009.

Método: Para la extracción de información se utilizaron las principales bases de datos nacionales e internacionales, las bibliografías específicas de artes marciales así como las propias monografías. El análisis documental de las monografías, la presentación de las referencias y la estructuración del repertorio bibliográfico estuvieron determinados por las normas UNE 50-104-1994, UNE 50-103-1990, UNE 50-121-1991, así como por el trabajo previo de los autores.

Resultados/Conclusiones: Se obtuvieron un total de 1.564 referencias bibliográficas, correspondientes a 2.403 ediciones de obras sobre artes marciales asiáticas, que fueron divididas en 17 categorías y 40 subcategorías. Este estudio ha recopilado más de un siglo de historia de monografías de artes marciales publicadas en España, convirtiéndose en una obra de referencia para académicos y aficionados a las artes marciales.

Palabras clave: Bibliografía; artes marciales; deportes de combate; España.

\begin{abstract}
Annotated bibliography about Asian martial arts monographs published in Spain

\section{Abstract}

Aim: The aim of the present study was to create an annotated bibliography of all Asian martial arts monographs published in Spain until 2009.

Method: Main national and international databases, martial arts bibliographies as well as the own Asian martial arts monographs were used for data mining. The documentary analysis of monographs, the presentation of references and the preparation of the bibliography structure was determined by UNE 50-104-1994, UNE 50-103-1990, UNE 50-121-1991 rules together with the previous work developed by the authors.

Results/Conclusions: A total number of 1.564 bibliographic entries, referring to 2.403 editions of martial arts monographs were obtained. These references were grouped in 17 categories and 40 subcategories. The present study has gathered more than a century of history of martial arts monographs, becoming a reference work for academics and martial arts fans.
\end{abstract}

Keywords: Bibliography; Martial arts; Combat sports; Spain.

\section{Repertório bibliográfico de monografias sobre artes} marciais asiáticas, publicadas em Espanha

\section{Resumo}

Objetivo: 0 principal objetivo do presente estudo foi criar um repertório bibliográfico de todas as monografias de artes marciais asiáticas publicadas na Espanha até 2009.

Método: Para o apuramento da informação, utilizaram-se as principais bases de dados nacionais e internacionais, as bibliografias específicas sobre as artes marciais, bem como as próprias monografias. A análise documental das monografias, a apresentação das referências e a estruturação do repertório bibliográfico foram determinadas pelas normas UNE 50-1041994, UNE 50-103-1990 e UNE 50-121-1991, assim como o trabalho prévio dos autores.

Resultados/Conclusões: Obtiveram-se um total de 1.564 referências bibliográficas, correspondentes a 2.403 edições sobre artes marciais asiáticas, que foram divididas em 17 categorias e 40 subcategorias. Este estudo recompilou mais de um século de história de monografias sobre as artes marciais publicadas em Espanha, convertendo-se numa obra de referência para académicos, investigadores e simpatizantes das artes marciais.

Palavras-chave: Bibliografia; artes marciais; desportos de combate; Espanha.

\footnotetext{
*E-mail: mikel.perez@uautonoma.cl. Dirección: Universidad Autónoma de Chile. Facultad de Educación. Avda. Alemania 01090, Temuco (Chile).
} 


\section{Índice}

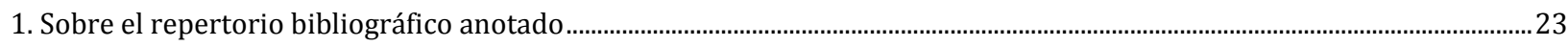

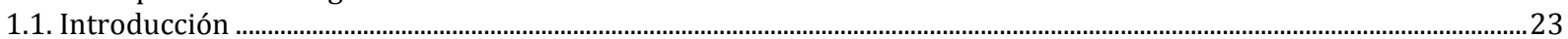

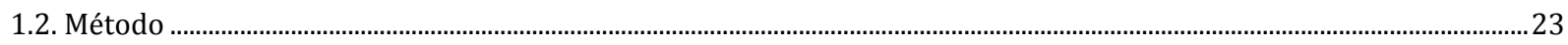

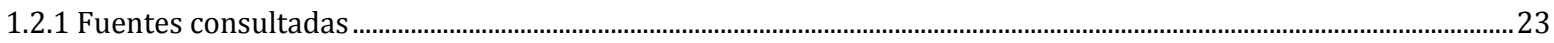

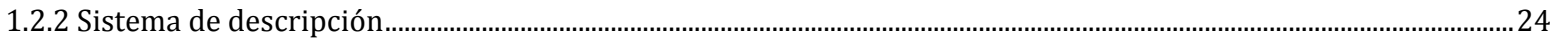

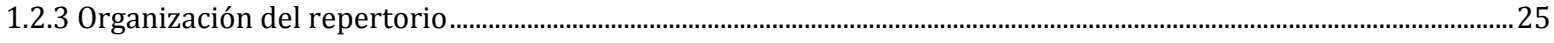

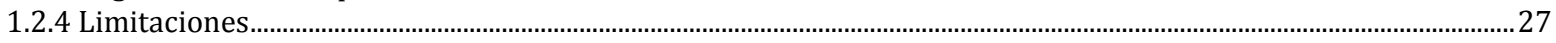

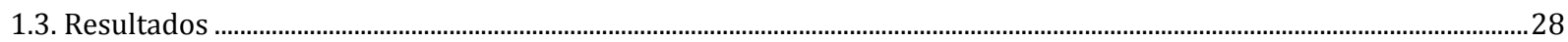

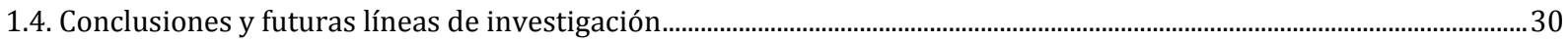

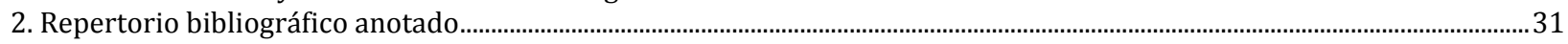

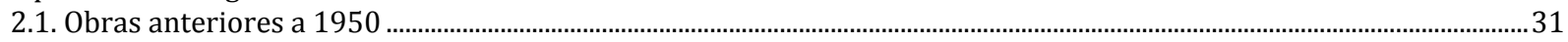

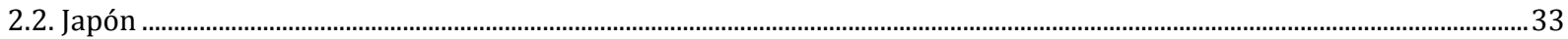

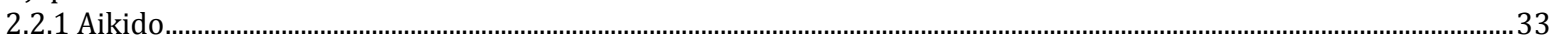

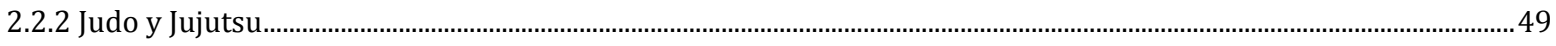

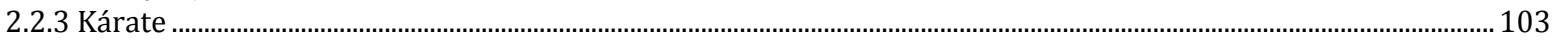

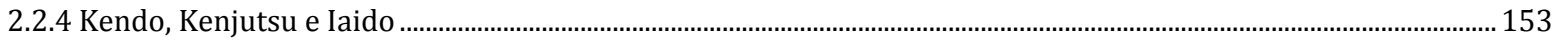

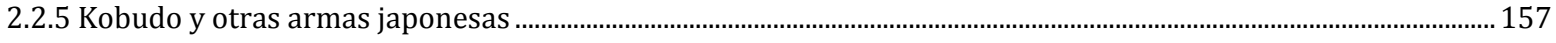

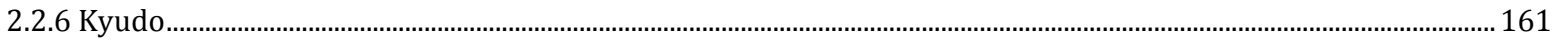

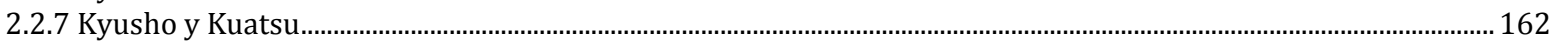

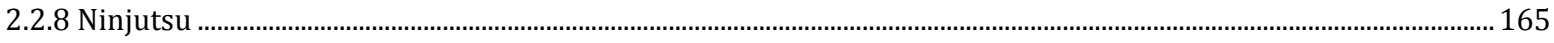

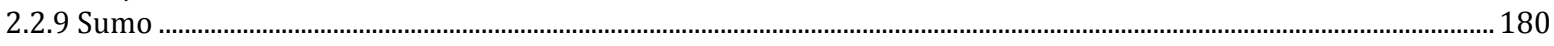

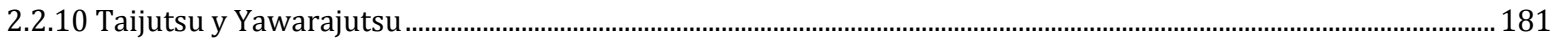

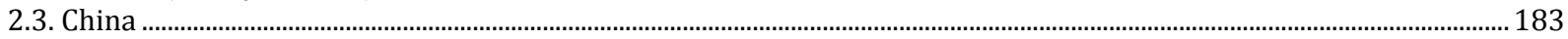

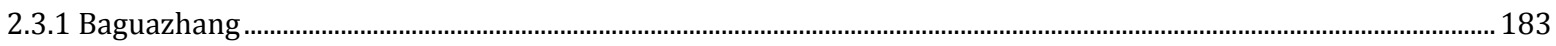

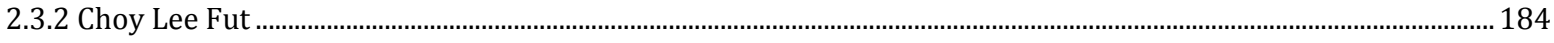

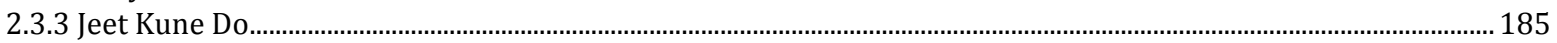

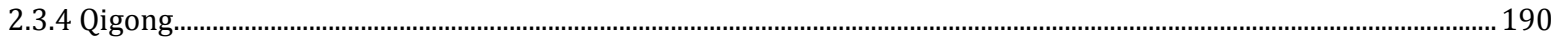

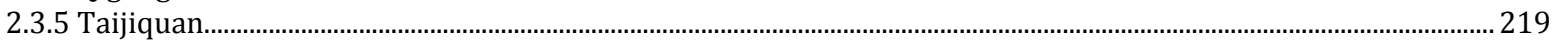

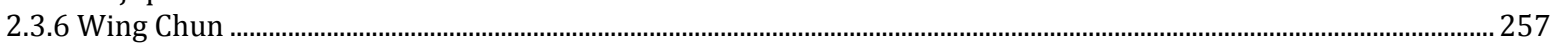

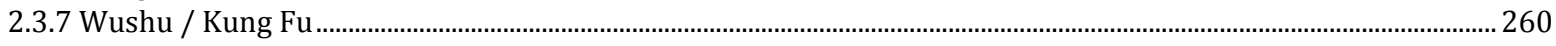

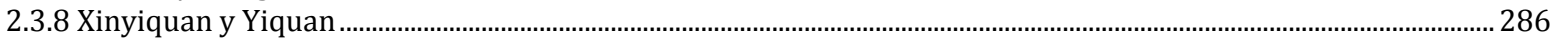

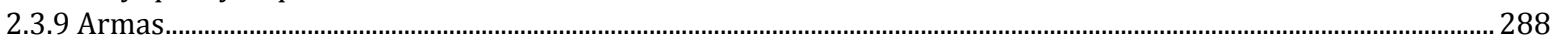

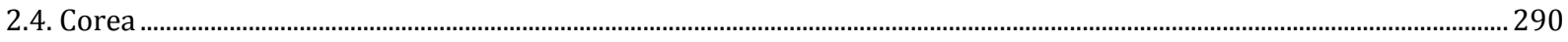

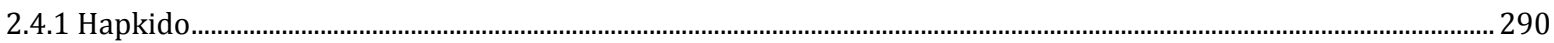

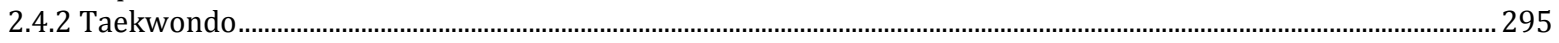

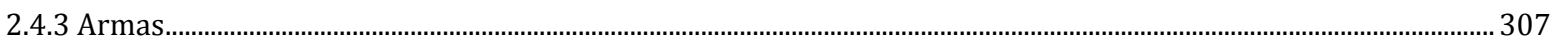

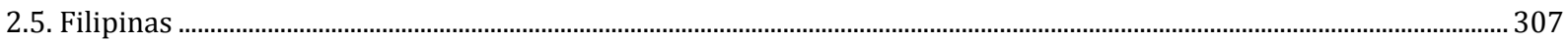

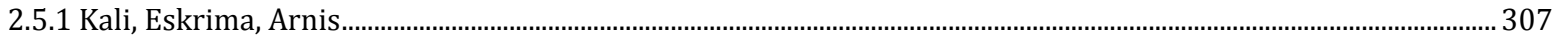

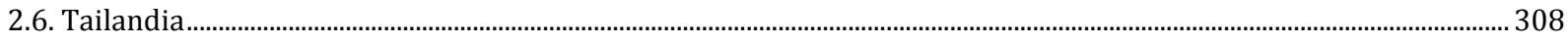

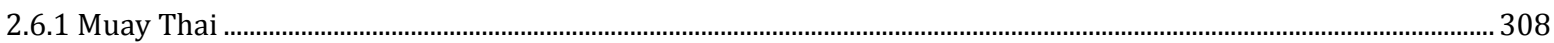

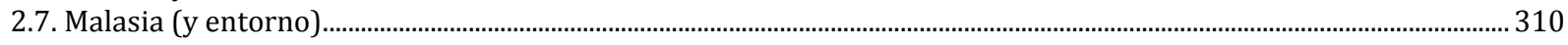

2.7.1 Pencak Silat

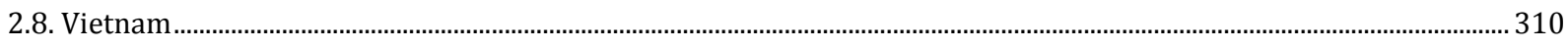

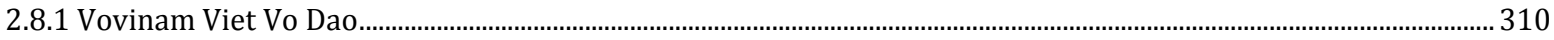

2.9. Tibet

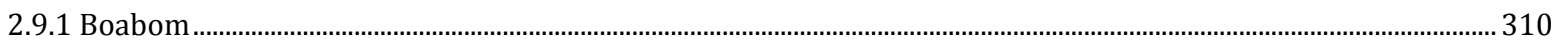

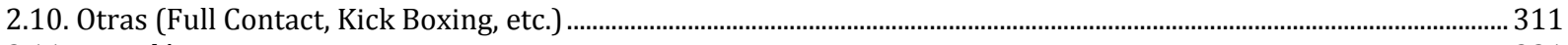

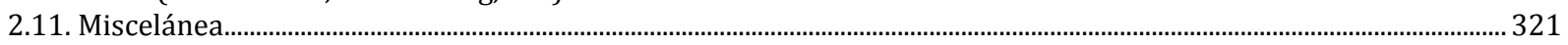

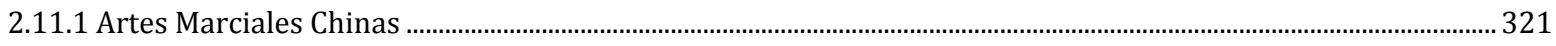

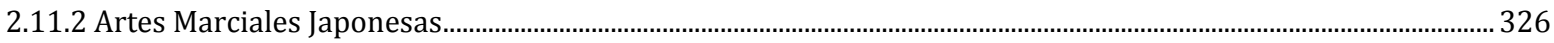

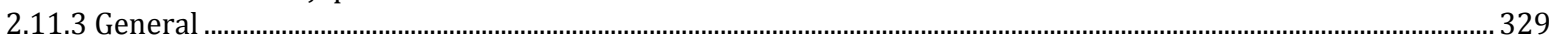

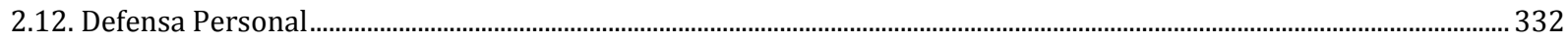

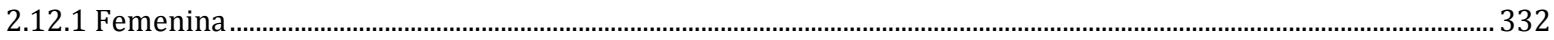

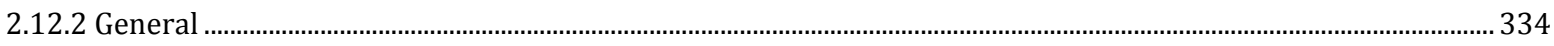

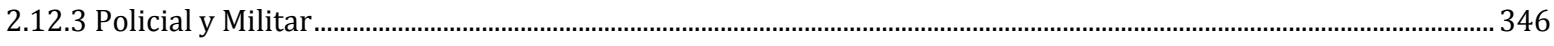

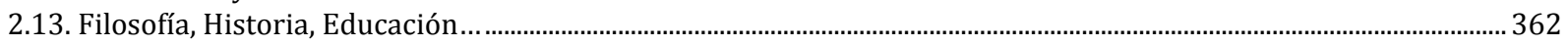

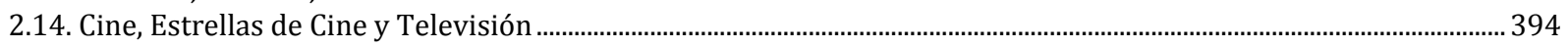

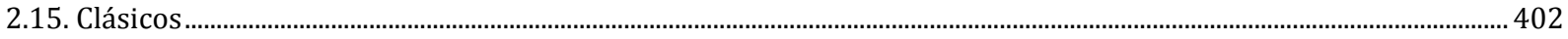

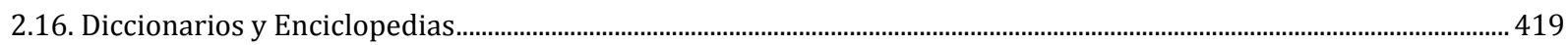

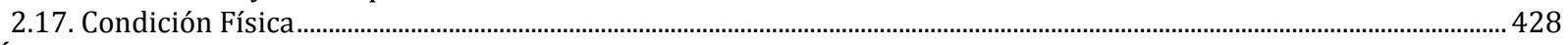

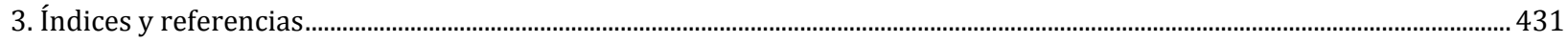

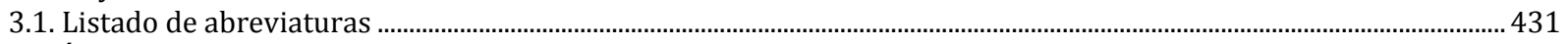

3.2. Índice onomástico ......................................................................................................................................................... 431

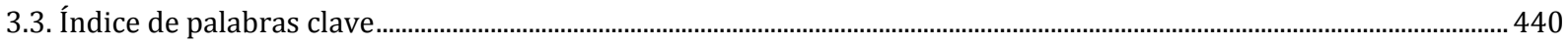

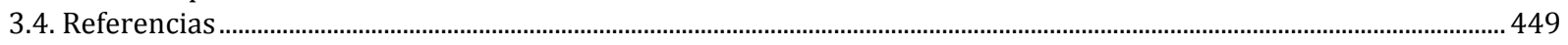




\section{Sobre el repertorio bibliográfico anotado}

\subsection{Introducción}

La preparación y publicación, en el año 2008, del primer repertorio bibliográfico sobre las monografías de artes marciales asiáticas editadas en España, supuso el descubrimiento de un amplio campo de conocimiento que hasta el momento había pasado inadvertido para los estudiosos de este ámbito (Pérez-Gutiérrez \& Gutiérrez-García, 2008a). Como ya se comentó en aquella obra, las compilaciones bibliográficas sobre artes marciales asiáticas eran inexistentes en nuestro país y muy escasas a nivel internacional. Más aún cuando hablamos de repertorios bibliográficos anotados, ya que estos trabajos requieren una gran cantidad de tiempo, esfuerzo, y obligan a la consulta directa de los documentos referenciados para ofrecer un comentario o resumen de los contenidos de los mismos.

Mientras que este primer repertorio recogía el listado de libros de artes marciales asiáticas publicados en España entre 1906 y 2006, detallando únicamente la referencia bibliográfica de cada obra, el trabajo que presentamos ahora profundiza en un ámbito informativo. De este modo, ofrece al lector y/o investigador no solo la referencia bibliográfica que identifica a cada publicación, sino también un resumen selectivo ${ }^{2}$ de sus contenidos y las palabras clave más significativas relacionadas con dichos contenidos (Moreiro González, 2004), todo ello con el propósito de aumentar la utilidad del repertorio.

En este sentido, la preparación de este repertorio bibliográfico anotado exigió la consulta directa de las propias monografías con el objeto de desarrollar un análisis documental en profundidad tanto de la forma como del contenido de las obras de artes marciales. Así, el tratamiento documental que ha recibido cada publicación no solo ha posibilitado el ampliar la información contenida en cada referencia bibliográfica, sino también el ofrecer una mayor rigurosidad y exhaustividad en los datos presentados para cada documento y la correcta clasificación de cada obra en su respectiva categoría y, en su caso, subcategoría ${ }^{3}$.

De esta manera, el repertorio bibliográfico anotado que presentamos incluye las monografías sobre artes marciales asiáticas publicadas en España y escritas en alguna de sus lenguas oficiales entre 1906 y 2009. Sin embargo, al igual que en el primer repertorio (PérezGutiérrez y Gutiérrez-García, 2008a), se ha incluido una excepción que corresponde a la obra 100 lances de jiu-jitsu. (Ataques y quites), de Émile André (André, 1906), ya que fue el primer libro sobre artes marciales asíaticas immpreso en castellano (Gutiérrez-García, 2007), aunque se publicase en la parisina imprenta de la viuda de Ch. Bouret.

\subsection{Método}

\subsubsection{Fuentes consultadas}

Para la búsqueda de las obras más antiguas se consultaron las bibliografías especializadas sobre artes marciales realizadas por Jones (1943), Kjöstolf (1950), Smith (1959), Steiner (1979), Baldwin (1982), Salling (1983), Nelson \& Whitaker (1988), European Society for the Scientific Study of Judo (1989), Palmer, Palmer y Meyers (1995) y Jacob (2005), todas ellas en el ámbito internacional. En el ámbito nacional, se consultaron las bibliografías de Blanco y Sánchez (1927) y Pastor Pradillo (1995), sobre las obras relacionadas con la educación física, debido a la falta de

\footnotetext{
2 El resumen selectivo o informativo-indicativo contiene "información sobre todas las partes que componen el original, pero no todas ellas son trasladadas con profundidad” (Moreiro González, 2004, p. 236).

${ }^{3}$ El primer repertorio bibliográfico (Pérez-Gutiérrez \& Gutiérrez-García, 2008a) clasificaba cada obra en su respectiva categoría y subcategoría atendiendo al título de la misma, mientras que el presente trabajo atiende a la temática principal de sus contenidos tras su consulta directa. Con ello se han evitado los problemas de clasificación derivados de títulos poco claros o ambiguos como por ejemplo Kárate taekwondo: técnicas para la competición (Choi, 1974) o Pedazos de ti mismo (Gali, 1980), entre otros.
} 
repertorios bibliográficos especializados y puesto que las mismas incluyen algunas referencias bibliográficas relacionadas con las artes marciales asiáticas. No se encontró ninguna referencia en el catálogo colectivo de el deporte en el libro antiguo (Consejo Superior de Deportes, 2000). También se utilizó el trabajo de Gutiérrez-García (2003), centrado en los orígenes del judo en España desde principios del s. XX hasta 1965, puesto que recopila más de 300 referencias sobre judo y jujutsu publicadas en España entre 1907 y 1999. Por último, se tomó como referencia principal el ya citado trabajo de Pérez-Gutiérrez y Gutiérrez-García (2008a), para confirmar, o no, sus datos bibliográficos.

Respecto a las fuentes de información en línea, de las cuales se extrajo la mayor parte de información indirecta, se utilizaron las principales bases de datos bibliográficas nacionales, como son los catálogos de la Biblioteca Nacional de España, la Red de Bibliotecas Universitarias (REBIUN), las Bibliotecas Públicas del Estado, el Catálogo Colectivo del Patrimonio Bibliográfico Español y la Agencia española del ISBN. También se consultaron específicamente los catálogos de la biblioteca de la Facultad de Ciencias de la Actividad Física y el Deporte de Madrid (antiguo INEF de Madrid), al ser esta la principal biblioteca deportiva española. Complementariamente, se han utilizado otras bases de datos tanto nacionales como internacionales, como son la web de Iberlibro y las bases de datos de las propias editoriales a nivel nacional, y los catálogos de la Library of Congress, la British Library y la Bibliothèque Nationale de France a nivel internacional.

Una vez elaborado el listado de obras a consultar, las fuentes de información utilizadas fueron las propias monografías localizadas en diversas bibliotecas españolas ${ }^{4}$, en las cuales también se registraron las estanterías donde se ubicaban los fondos de temática deportiva en busca de ejemplares aún no catalogados en línea.

\subsubsection{Sistema de descripción}

Los datos bibliográficos principales 5 fueron tomados de la portada de cada obras, tal como señala la norma UNE 50-104-1994. Durante el proceso de elaboración del repertorio se utilizó la ficha de descripción bibliográfica integrada dentro del programa gestor de referencias Endnote X3. Esta ficha fue adaptada para atender a las características del presente trabajo de acuerdo a las recomendaciones propuestas por las normas UNE 50-104-1994 "Referencias bibliográficas: contenido, forma y estructura", que regula la realización de citas en artículos, libros y otros documentos de investigación y estudio (AENOR, 1994); UNE 50-103-1990 "Preparación de resúmenes", que establece las pautas para la preparación y presentación de los resúmenes de documentos (AENOR, 1990); y UNE 50-121-1991 "Métodos para el análisis de documentos, determinación de su contenido y selección de los términos de indización", que atiende a las técnicas para analizar temáticamente un documento y extraer sus palabras clave (AENOR, 1991). En esta ficha de descripción bibliográfica también se incluyeron algunos elementos para facilitar la creación del repertorio bibliográfico anotado (e.g., palabras clave normalizadas, reediciones), la recuperación de información (e.g., biblioteca y/o dirección URL para la extracción de información), y el análisis estadístico sobre las publicaciones de artes marciales asiáticas (e.g., materia, década).

\footnotetext{
4 Las bibliotecas consultadas fueron, en orden alfabético, las siguientes: Archivo de Navarra, Biblioteca Central de Cantabria, Biblioteca de Asturias "Ramón Pérez de Ayala”, Biblioteca del Instituto Vasco de Educación Física (IVEF/SHEE), Biblioteca de la Facultad de Ciencias de la Actividad Física y del Deporte de la Universidad de Las Palmas de Gran Canaria, Biblioteca de la Facultad de Ciencias de la Actividad Física y del Deporte de la Universidad de León, Biblioteca de la Facultad de Ciencias de la Actividad Física y del Deporte de la Universidad Politécnica de Madrid (antiguo INEF de Madrid), Biblioteca Nacional de España, Biblioteca Nodal de Ourense, Biblioteca Nodal de Pontevedra, Biblioteca Nodal de Vigo, Biblioteca Pública de La Rioja, Biblioteca Pública de León, Biblioteca Pública de Madrid (Central y Manuel Alvar), Biblioteca Pública de Navarra, Biblioteca Pública de Palencia, Biblioteca Pública de Salamanca, Biblioteca Pública de Valladolid, Biblioteca Pública de Zamora, Biblioteca Pública del Estado en Gijón, Biblioteca Pública del Estado en Las Palmas de Gran Canaria, Biblioteca Regional de Madrid "Joaquín Leguina”, Casa de Cultura Ignacio Aldecoa, Centro Cultural Hispano-Japonés de Salamanca,

${ }^{5}$ Los elementos bibliográficos principales se refieren a aquellos denominadas como mínimos para caracterizar a una publicación: autor, año de publicación, título, editorial y lugar de edición.
} 
No obstante, en la presentación de cada referencia bibliográfica se alteró el orden de ciertos elementos con el fin de facilitar la presentación de las obras publicadas por un mismo autor, de forma cronológica y sin atender al título de la obra (como propone la antecitada norma), ya que las monografías se integran dentro de un repertorio bibliográfico con carácter retrospectivo, lo que confiere una mayor importancia al año de publicación de la obra que a su título. De este modo, partiendo de una organización alfabética de autores en cada categoría y subcategoría, dentro de cada categoría/subcategoría se encuentran las publicaciones de un mismo autor en orden cronológico, mostrando su producción respecto a dicha categoría. En relación a los autores, todos ellos han sido citados independientemente del número de coautores de cada obra en cuestión, lo cual permitió su inclusión en el índice onomástico.

También hay que mencionar la inclusión de un elemento final, previo a las palabras clave y al resumen, referente al número de edición y el año de publicación de las subsiguientes reediciones. Ya que la norma UNE 50-121-1991 no señala el lugar de colocación de los términos de indización respecto a la referencia bibliográfica, se optó por incluir dichos términos entre la propia referencia y las palabras clave y el resumen del documento. Con todo, el esquema de cada una de las referencias bibliográficas es el siguiente:

Responsabilidad principal (Año). Título (Título: Subtítulo). Publicación (Lugar: Editor). Edición. Extensión: Ilustraciones; Tamaño (Alto $\mathrm{x}$ Ancho). Número normalizado. Publicaciones posteriores (Edición, Año de publicación). Palabras clave. Resumen.

\section{Ejemplo:}

André, Émile (1906). 100 lances de jiu-jitsu (ataques y quites). París: Librería de la Viuda de Ch. Bouret. $1^{\underline{a}}$ ed. 137 p. : il. ; 10x17 cm. ISBN: No ISBN. Depósito legal: no. (2ª ed., 1909; $3^{a}$ ed., 1911; 4⿳亠丷厂 ed., 1923). Palabras clave: fundamentos técnicos, defensa personal. Resumen: Manual técnico de jiu-jitsu. El libro está formado por 2 partes, precedidas por un prólogo que resalta las características y beneficios del jiu-jitsu, una nota explicativa de las ilustraciones y una comparación del jiu-jitsu con los métodos de combate de Francia. La primera parte describe e ilustra los golpes y defensas básicas del jiu-jitsu que sustituyen a los empleados en el boxeo inglés y francés. La segunda parte comenta las características y ejecución de las principales técnicas de jiu-jitsu, como zancadillas, enganches, agarres, asiduras, defensas ante las asiduras y ante ataques directos. También comenta la práctica del kuatsu, la adaptación de las técnicas de jiu-jitsu a la mujer, el comentario del Sr. Dubois sobre el jiu-jitsu, una descripción de la localización a algunos puntos vitales y la descripción e ilustración de varias técnicas de torsión del brazo y las piernas.

\subsubsection{Organización del repertorio}

Tomando como referente la clasificación propuesta por Pérez-Gutiérrez y Gutiérrez-García (2008a), después de consultar cada documento se procedió a ubicar el mismo en diversas categorías y subcategorías atendiendo a diversos criterios que detallaremos a continuación. Ha de señalarse que ya en dicho trabajo de constató la imposibilidad de clasificar las monografías de artes marciales asiáticas atendiendo a un único criterio debido a su cantidad y gran heterogeneidad. También hay que mencionar que fue necesario crear una nueva categoría para atender a la publicación de dos obras centradas en el estudio del arte marcial tibetano del boabom.

Los criterios fundamentales para el establecimiento de categorías han sido tres. En primer lugar, atendiendo a un criterio cronológico, se ha considerado como categoría independiente el reducido conjunto de obras publicadas entre 1906 y 1950 - catorce en total -, debido a su pertenencia a una "primera época" de desarrollo de las artes marciales en España, con un marcado significado histórico propio respecto a las épocas sucesivas (Gutiérrez-García, 2004). En cualquier caso, la mayoría de estas obras están dedicadas al judo/jujutsu (12), y dos de ellas se ubican en la categoría de "Clásicos". Así, la primera categoría del repertorio la componen:

\section{Obras anteriores a 1950.}

Rev. Artes Marciales Asiát., 8(1), 21-450 2013 
En segundo lugar, atendiendo a un criterio geográfico, una parte de las obras posteriores a 1950 se ha organizado atendiendo al país de origen de cada arte marcial (e.g., kárate - Japón), obteniéndose de esta forma las siguientes diez categorías:
2. Japón.
7. Malasia (y entorno).
3. China.
8. Vietnam.
4. Corea.
9. Tíbet
5. Filipinas.
10. Otras
6. Tailandia.
11. Miscelánea.

El que un país no esté contemplado en el listado (e.g. India) significa que aún no se ha publicado ninguna monografía sobre alguna de las artes marciales habitualmente consideradas de dicho país, en ningún caso quiere decir que dicho país carezca de manifestaciones de las artes marciales.

Dentro de la categoría "Otras" se han incluido aquellas artes marciales que se conforman como la mezcla de otras de orígenes geográficos diversos - en ocasiones ni siquiera creadas en Asia, pero contando con una gran influencia de una o varias artes marciales asiáticas -, siendo el caso por ejemplo del full contact -nacido de la fusión del kárate con contacto y el boxeo-, o el kickboxing, versión deportivizada y modificada del muay thai tailandés (Perreca \& Malori, 2000, 2003). Respecto a la categoría "Miscelánea", esta incluye aquellas obras que se dedican a varias artes marciales de diversos países, por ejemplo el libro titulado Taichi y aikido (Poponic, 2009) - i.e., China y Japón -, o a prácticas marciales cuya aplicación puede referirse a varias artes marciales, como es el caso de los rompimientos.

En tercer y último lugar, atendiendo a un criterio temático, las últimas seis categorías se componen de monografías que versan sobre diversos aspectos relacionados con las artes marciales pero que tienen entidad propia en sí mismas, y por lo tanto parece pertinente su diferenciación respecto al resto de categorías. Las categorías a las que nos referimos son:

\section{Diccionarios y enciclopedias. \\ 13. Clásicos. \\ 14. Filosofía, historia y educación.}

\author{
15. Defensa personal. \\ 16. Condición física. \\ 17. Cine, estrellas de cine y televisión.
}

Dentro de la categoría "Diccionarios y enciclopedias" se han incluido aquellas obras de referencia generales que aclaran la terminología propia de las artes marciales, y por otro lado aquellas obras que se dedican ampliamente al mundo de las artes marciales en una serie de volúmenes. La categoría de "Clásicos" se refiere a obras que reeditan, amplían o comentan aquellas monografías que forman parte de una literatura de gran entidad debido a su antigüedad. Este es el caso por ejemplo de las distintas ediciones de El arte de la guerra, de Sun Tzu, obra dedicada a la explicación de principios tácticos y estrategias militares aplicables a la guerra pero que constituye uno de los grandes clásicos de las artes marciales, o de diversos tratados sobre el bushido (camino del guerrero) como el Libro de los Cinco Anillos de Miyamoto Musashi.

Dentro de la categoría "Filosofía, historia y educación" se incluyen las monografías que estudian el mundo de las artes marciales desde ciencias como las que dan nombre a la categoría. Esto significa un conocimiento periférico o que rodea al mundo de las artes marciales en sí mismas, lo que no implica un menor grado de importancia, ya que sin prestar atención a ningún arte marcial de manera concreta sus contenidos aportan un conocimiento de carácter general, descriptivo y explicativo.

El conjunto de publicaciones dedicadas a la defensa personal, desde la aplicación de una o varias artes marciales o como simple compendio de conocimientos de varias artes marciales se ha reunido dentro de la categoría titulada "Defensa personal". De un modo similar, las obras que abordan la preparación física de los artistas marciales, el desarrollo de ciertas cualidades físicas, o la preparación física de un arte marcial en concreto se incluyeron dentro de la categoría de 
"Condición Física". En último lugar aparece la categoría denominada como "Cine, estrellas de cine y televisión" que incluye dentro de sus referencias a aquellas obras que se refieren al mundo de las artes marciales desde la esfera de los medios de comunicación, y que tanta impotancia ha tenido en la difusión de las artes marciales por todo el mundo (Acevedo, Gutiérrez-García y Cheung, 2010; Hunt, 2003). Estas obras suelen estar dedicadas a las celebridades del celuloide, como el famoso Bruce Lee, que han dado fama internacional a las artes marciales y por tanto han contribuido a su difusión.

Por otra parte, debido a la especificidad de las monografías de artes marciales asiáticas, diez categorías del total de diecisiete fueron divididas en una o varias subcategorías (véase índice general). Los criterios utilizados para determinar estas subcategorías fueron las propias artes marciales originarias de cada país (p.e. Baguazhang, Choy Lee Fut y Jeet Kune Do entre otras para la categoría China) así como la aplicación y orientación de un arte marcial a un determinado grupo de personas o colectivo (p.e. Femenina, General, Policial y Militar para la categoría Defensa Personal).

Dentro de la categoría titulada "Japón", ha de mencionarse el caso particular de la subcategoría Judo/Jujutsu, que integra las obras dedicadas a estas prácticas marciales publicadas con posterioridad a 1950 debido a que su proceso de institucionalización las diferencia de las prácticas anteriores, siendo agrupadas en la categoría "Obras anteriores a 1950" (Gutiérrez-García, 2004). El escaso número de publicaciones dedicadas a las prácticas denominadas Kyusho y Kuatsu junto con su carácter complementario dentro del entrenamiento de distintas artes marciales (p.e. Aikido, Judo, Kárate), se consideró necesario agrupar ambas prácticas dentro de la misma subcategoría.

En un último nivel de concreción, dentro de cada categoría o subcategoría la organización de las referencias es de tipo alfabético, al ser esta la más habitual y aquella que se deriva de forma natural del sistema de descripción bibliográfica utilizado.

El repertorio bibliográfico anotado se completa con un listado de abreviaturas utilizadas, y un índice onomástico y y otro de palabras clave - aquellos que se han considerado más útiles para futuras tareas de consulta e investigación -, que tienen por objeto facilitar la búsqueda de información sobre los autores de las monografías y sus temáticas. La lista de referencias bibliográficas está numerada para facilitar el acceso a la información a través de estos índices. Aunque alguno de los términos del índice de palabras clave contiene un gran número de referencias (e.g., entrenamiento), que puede dificultar el proceso de consulta, se ha preferido que el índice esté presente a obviarlo y hacer aún más arduo el trabajo de los futuros interesados.

\subsubsection{Limitaciones}

Respecto a las limitaciones del presente estudio, la localización de las monografías para su posterior consulta directa siguió supeditada fundamentalmente a fuentes de información secundarias. En este sentido, durante el transcurso de la investigación se constató que aún no se habían completado totalmente los procesos de descripción bibliográfica en línea de los fondos bibliográficos de varios centros documentales, por lo que la información proporcionada por estas fuentes secundarias sigue siendo incompleta. Además, el desarrollo de esta investigación puso de manifiesto el alto coste de tiempo y recursos que supone visitar los centros documentales que reúnen estas monografías y que, en algunos casos, estaban integradas dentro de colecciones privadas particulares.

También ha de señalarse la considerable dificultad que ha supuesto la elaboración de la clasificación de categorías y subcategorías del repertorio, debido como se ha señalado a cantidad y gran heterogeneidad de monografías de artes marciales asiáticas publicadas en España. Asimismo, la complejidad de clasificación de algunas obras por poder pertenecer a dos o incluso más categorías; en este caso el criterio seguido fue la mayor pertinencia a alguna de las mismas según el juicio de los autores. También somos conscientes que pueden existir monografías sobre artes marciales asiáticas que, bien sea por no figurar en las bases de datos, fuentes de información y

Rev. Artes Marciales Asiát., 8(1), 21-450 2013 
centros documentales consultados, o por estar mal catalogadas en los mismas, pueden no estar referenciadas.

Por último, el repertorio bibliográfico anotado incluye información detallada de los contenidos de 1.521 obras respecto del total de 1.564 monografías, es decir, un $97.2 \%$ del número total de publicaciones sobre artes marciales asiáticas que se han editado en España. Sólo un 2.8\% de las obras incluidas en el presente trabajo no pudieron ser consultadas debido principalmente a la antigüedad, escasa distribución y limitada tirada de ciertas monografías, lo que hizo inviable su consulta directa. Rogamos al lector que sepa disculpar estas omisiones y nos ayude a ampliar y mejorar este repertorio.

\subsection{Resultados}

El principal resultado obtenido en esta investigación es el repertorio bibliográfico anotado que se expone en el siguiente apartado. También se realizó un estudio bibliométrico, algunos de cuyos resultados - productividad por categorías y subcategorías y evolución temporal presentamos a continuación, simplemente a título ilustrativo, para ejemplificar su utilidad en el estudio de la presencia y evolución de las artes marciales asiáticas en España.

El número total de referencias bibliográficas recogidas ascendió a 1.564, correspondientes a 2.403 entradas o ediciones, lo que supone un 35\% de reediciones. Las categorías con mayor número de monografías son Japón y China, con 603 y 405 obras respectivamente. Ambas categorías acumulan el $64 \%$ de la producción total. Por otra parte, destaca la escasa productividad de países como Tailandia, Filipinas, Tíbet, Malasia y Vietnam, que no superan la decena de publicaciones (Tabla 1).

Tabla 1. Número de monografías totales y primeras ediciones distribuidas por categorías

\begin{tabular}{lcc}
\hline \multicolumn{1}{c}{ CATEGORÍA } & TOTAL & 1as EDICIONES \\
\hline Japón & 933 & 603 \\
China & 606 & 404 \\
Clásicos & 223 & 88 \\
Defensa personal & 159 & 115 \\
Filosofía, Historia, Educación & 155 & 124 \\
Corea & 109 & 64 \\
Otras & 49 & 33 \\
Miscelánea & 41 & 32 \\
Cine, Estrellas de Cine y Televisión & 38 & 36 \\
Diccionarios y Enciclopedias & 32 & 25 \\
Obras anteriores a 1950 & 22 & 14 \\
Condición física & 18 & 12 \\
Tailandia & 9 & 5 \\
Filipinas & 5 & 5 \\
Tíbet & 2 & 2 \\
Malasia & 1 & 1 \\
Vietnam & 1 & 1 \\
TOTAL & $\mathbf{2 . 4 0 3}$ & $\mathbf{1 . 5 6 4}$ \\
\hline
\end{tabular}

Respecto a las subcategorías con mayor número de publicaciones, destacan dos de ellas por superar las 200 publicaciones. Así, la subcategoría Judo/Jujutsu alcanza las 215 obras mientras que Kárate recopila 206 publicaciones. Estas dos subcategorías reúnen el 26.9\% del total de referencias bibliográficas (primeras ediciones). Por el contrario, existe un conjunto de 16 subcategorías que no superan las 10 publicaciones respectivamente (Tabla 2). 
Tabla 2. Distribución de subcategorías en relación al número de primeras ediciones

№ TOTAL DE
PUBLICACIONES

\begin{tabular}{|c|c|}
\hline Más de 200 & Judo/Jujutsu (215/328) - Kárate (206/338) \\
\hline Entre 100 y 199 & $\begin{array}{l}\text { Taijiquan (149/239) - Filosofía, Historia, Educación }(124 / 155) \text { - Wushu/Kung Fu } \\
(113 / 174)\end{array}$ \\
\hline Entre 50 y 99 & $\begin{array}{l}\text { Qigong (93/132) - Clásicos (88/223) - Aikido (62/119) - Ninjutsu (61/65) - Defensa } \\
\text { Personal Policial (54/58) - Defensa Personal General (53/91) - Taekwondo (50/91) }\end{array}$ \\
\hline Entre 10 y 49 & $\begin{array}{l}\text { Cine, Estrellas de Cine y Televisión (36/38) - Otras }(33 / 49) \text { - Diccionarios y } \\
\text { Enciclopedias (25/32) - Kobudo (19/37) - Kendo }(17 / 21) \text { - Jeet Kune Do }(17 / 21) \text { - } \\
\text { Miscelánea AM Chinas }(15 / 21) \text { - Obras anteriores a } 1950(14 / 22) \text { - Hapkido }(13 / 17) \\
\text { - Condición Física }(12 / 18) \text { - Wing Chun }(11 / 15) \text { - Kyusho/Kuatsu }(11 / 13)\end{array}$ \\
\hline Menos de 10 & $\begin{array}{l}\text { Defensa Personal Femenina }(8 / 10)-\text { Miscelánea AM Japonesas }(8 / 11)-\text { Miscelánea } \\
\text { General (8/9) - Armas (China) }(7 / 8)-\text { Taijutsu/Yawarajutsu (7/7) - } \\
\text { Xinyiquan/Yiquan }(5 / 5) \text { - Choy Lee Fut }(6 / 8)-\text { Kali, Eskrima, Arnis }(5 / 5)-\text { Muay Thai } \\
\text { (5/9) - Kyudo (4/4) - Baguazhang }(3 / 4)-\text { Boabom }(2 / 2)-\text { Armas (Corea) }(1 / 1)- \\
\text { Pencak Silat }(1 / 1) \text { - Sumo }(1 / 1) \text { - Vovinam Viet Vo Dao }(1 / 1)\end{array}$ \\
\hline
\end{tabular}

Nota: Entre paréntesis se detalla en primer lugar el número total de primeras ediciones, y en segundo lugar el número total de ediciones.

Respecto a la evolución temporal, el Gráfico 1 muestra una escasa producción bibliográfica en la primera mitad del siglo XX, y un crecimiento ininterrumpido, aunque discontínuo, hasta la primera década del siglo XXI, en la que casi se alcanza el millar de ediciones, lo cual muestra un mercado editorial en constante aumento. Dentro de esta evolución, existen diferentes patrones según las diversas categorías y subcategorías consideradas en los que no entraremos aquí, pero que pueden consultarse en Pérez-Gutiérrez (2012).

Gráfico 1. Número de monografías totales y primeras ediciones distribuidas por décadas

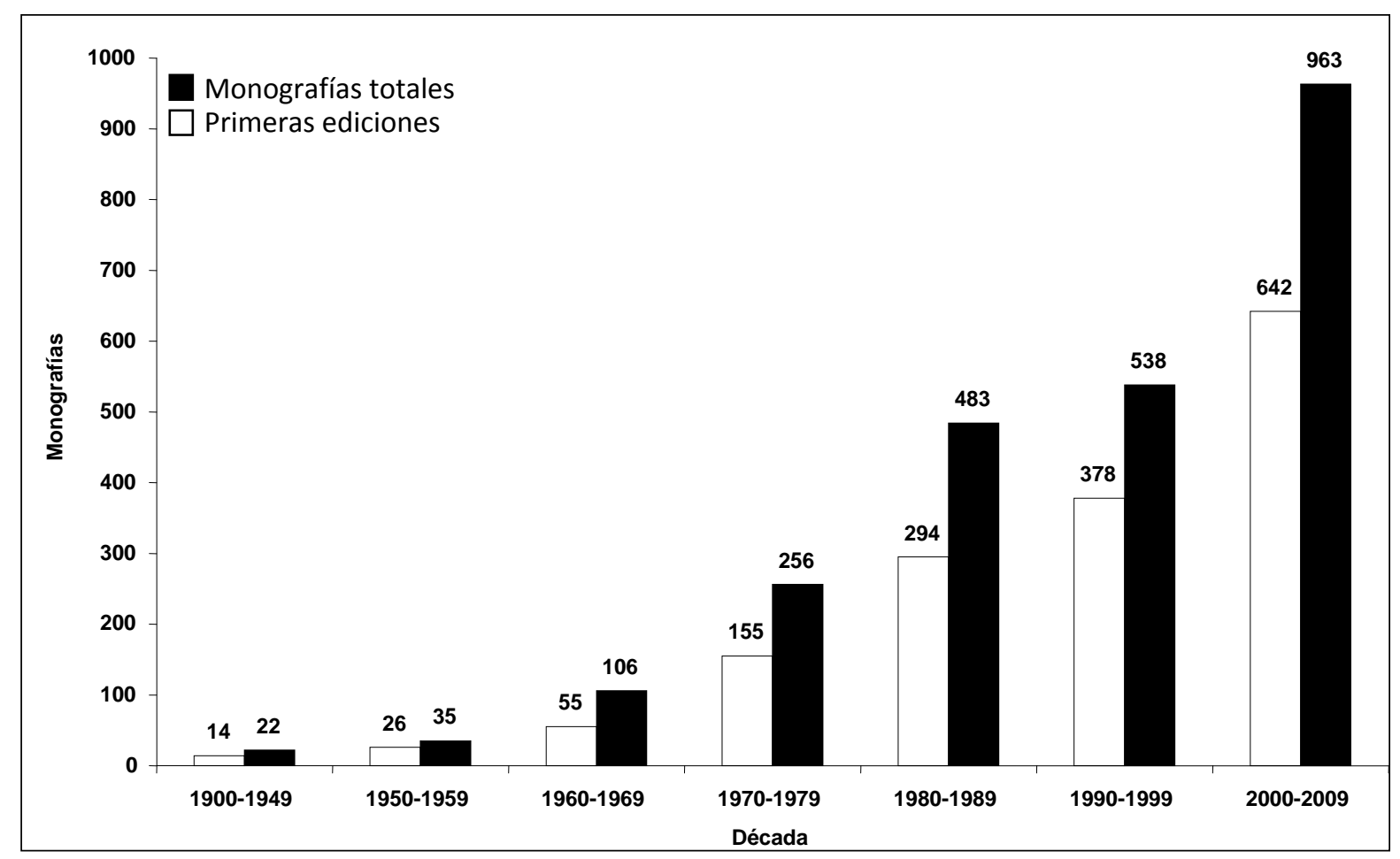




\subsection{Conclusiones y futuras líneas de investigación}

A partir de la un proceso de consulta directa de las obras, se ha elaborado un repertorio bibliográfico anotado de las monografías de artes marciales asiáticas publicadas en España, en el que se incluyen y clasifican un 1.564 referencias numeradas que corresponden a un total de 2.403 ediciones. Este repertorio es una herramienta útil para conocer, buscar y organizar la información que se ha publicado sobre artes marciales asiáticas en forma de monografía desde 1906 hasta el año 2009. Como tal, compila y detalla una parte de la historiografía de las artes marciales asiáticas en España, reflejando un proceso de transmisión de las artes marciales complementario a la propia práctica o entrenamiento marcial.

Algunas de las líneas de investigación que pueden desarrollarse a partir de estudios bibliográficos como el presente son análisis bibliográficos históricos (Gutiérrez-García, 2007) y análisis bibliométricos (Gutiérrez-García \& Pérez-Gutiérrez, 2008; Pérez-Gutiérrez \& GutiérrezGarcía, 2008b, 2009). Futuras investigaciones podrían profundizar en el análisis bibliométrico de aspectos como las relaciones de colaboración existentes entre los autores de estas monografías, analizar los contenidos de estas publicaciones mediante el análisis temático de contenido, así como interpretar, desde el ámbito de la sociología del deporte, la evolución de la producción bibliográfica de artes marciales como un reflejo de los cambios sociales acaecidos en España. 


\section{Repertorio bibliográfico anotado}

\subsection{Obras anteriores a 1950}

1. André, Émile (1906). 100 lances de jiu-jitsu (ataques y quites). París: Librería de la Viuda de Ch. Bouret. $1^{\underline{a}}$ ed. 137 p. : il. ; 10x17 cm. ISBN: No ISBN. Depósito legal: no. (2ª ed., 1909; 3aㅡ ed., 1911; 4ª ed., 1923). Palabras clave: fundamentos técnicos, defensa personal. Resumen: Manual técnico de jiu-jitsu. El libro esta formado por 2 partes, precedidas por un prólogo que resalta las características y beneficios del jiu-jitsu, una nota explicativa de las ilustraciones y una comparación del jiu-jitsu con los métodos de combate de Francia. La primera parte describe e ilustra los golpes y defensas básicas del jiu-jitsu que sustituyen a los empleados en el boxeo inglés y francés. La segunda parte comenta las características y ejecución de las principales técnicas de jiu-jitsu, como zancadillas, enganches, agarres, asiduras, defensas ante las asiduras y ante ataques directos. También comenta la práctica del kuatsu, la adaptación de las técnicas de jiu-jitsu a la mujer, el comentario del Sr. Dubois sobre el jiu-jitsu, una descripción de la localización a algunos puntos vitales y la descripción e ilustración de varias técnicas de torsión del brazo y las piernas.

2. Bádenas Padilla, José (Capitán) (1934). Deportes de combate: Boxeo inglés. Boxeo francés. Lucha grecorromana. Lucha libre. Esgrima de palo. Jiu-Jitsu. Kuatsu. Toledo: Establecimiento tipográfico de Rafael G. Menor. 1aㅡ ed. 152 p. y 184 p. : il. ; 14x21,5 cm. ISBN: No ISBN. Depósito legal: no. Palabras clave: historia, fundamentos teóricos, fundamentos técnicos, defensa personal, anatomía, kuatsu. Resumen: Manual teórico y técnico de artes marciales. La obra consta de 5 libros o partes, precedidos por un preámbulo que señala el instinto de lucha innato en el ser humano y la clasificación del autor sobre los deportes de combate. El primer libro narra la historia del pugilismo, sus características, ventajas e inconvenientes para luego analizar los objetivos, fundamentos teóricos y fundamentos técnicos del boxeo inglés y francés, describir los ejercicios propios de su entrenamiento del boxeo y hacer una comparación de los mismos. El segundo libro comenta la historia de la lucha, su desarrollo y práctica en Suiza, Turquía, India, Japón, América y España, detalla las funciones de la lucha, las cualidades para su práctica, los principios para su entrenamiento, y después describe la historia, fundamentos teóricos y fundamentos técnicos de la lucha grecorromana clásica y la lucha libre. El tercer libro expone la historia de la esgrima de palo, describe las características del palo y el bastón, explica sus fundamentos teóricos y describe los ejercicios y fundamentos técnicos para el entrenamiento. Adjunta secuencias fotográficas del boxeo inglés, boxeo francés, lucha grecorromana, lucha libre y esgrima de palo. El cuarto libro expone la historia del jiu-jitsu, sus beneficios y características, los principios de su enseñanza y entrenamiento, describe el método de entrenamiento japonés de todo el cuerpo junto con la descripción de algunos de sus ejercicios y sus fundamentos técnicos. El quinto libro ofrece consejos para el estudiante de cualquier deporte de combate y señala los principios didácticos aplicables a estos deportes. Adjunta dos apéndices explicando la actuación de las técnicas de jiu-jitsu sobre el cuerpo humano junto con la descripción del sistema nervioso, y la ejecución de algunas técnicas de reanimación (kuatsu). También adjunta las secuencias fotográficas del jiu-jitsu, defensa contra puñal y técnicas de kuatsu.

3. C.D.T. (trad.) (1907). Tratado de ju-jutsu y sus secretos. Barcelona: La Ibérica. 1a ed. 127 p. : il. ; $13 \times 19$ cm. ISBN: No ISBN. Depósito legal: no. Palabras clave: fundamentos técnicos, defensa personal. Resumen: Manual teórico y técnico de ju-jutsu. El libro esta formado por 3 capítulos precedidos por un prólogo que presenta las características y beneficios del ju-jutsu. El primer capítulo describe e ilustra la ejecución de varios ejercicios de calentamiento. El segundo capítulo incluye la breve descripción e ilustración de las principales técnicas de proyección, luxación y estrangulación del jujutsu. El tercer capítulo explica la ejecución de varios ataques acompañados de su representación gráfica.

4. Gante, Emilio (191?-192?). ¿Quiere usted aprender a defenderse en la calle? Barcelona: F. Granada. $1^{\mathrm{a}}$ ed. 63 p. : il. ; 11x19 cm. ISBN: No ISBN. Depósito legal: no. Palabras clave: fundamentos técnicos, defensa personal, jujutsu, boxeo. Resumen: Manual técnico de boxeo, jiu-jitsu. Comienza la obra con prólogo dedicado a relatar algunas situaciones de peligro en las que son necesarias el conocimiento de la defensa personal para salir airosos de ellas. A continuación ofrece algunos consejos prácticos para encarar las situaciones de enfrentamiento y comienza la primera parte detallando las técnicas de golpeo y defensa del boxeo, tanto con las manos como con los pies. La segunda parte explica algunas de las técnicas de proyección, luxación y estrangulación del jiu-jitsu y la tercera algunos ataques y defensas con el bastón. El último apartado es una conclusión en la que se resume lo tratado en cada capítulo. Cada capítulo ofrece ilustraciones de las técnicas descritas.

5. Gistau, Miguel y Songel (Capitanes de la Guardia Civil) (1915). Destreza. Método práctico para prender, asegurar, conducir delincuentes y de luchar con éxito contra ellos si se oponen á la detención. Madrid: s.n.

Rev. Artes Marciales Asiát., 8(1), 21-450 2013 
(obra publicada en la Revista Técnica de la Guardia Civil, no ${ }^{61}$ ). $11^{\mathrm{a}}$ ed. 75 p. : il. ; desc.xdesc. cm. ISBN: No ISBN. Depósito legal: no. Palabras clave: fundamentos teóricos, fundamentos técnicos, defensa personal, principios de actuación, armas. Resumen: Manual teórico y técnico de jiu-jitsu. El libro esta formado por 10 capítulos precedidos por un comentario sobre la importancia y beneficios del jiu-jitsu para las fuerzas públicas. El primer capítulo comenta los contenidos de la obra, localiza los puntos vulnerables del cuerpo humano y ofrece algunos consejos de actuación ante las situaciones de defensa personal. El segundo capítulo describe varias técnicas de defensa personal acompañadas de su representación gráfica. El tercer capítulo explica varias formas de inmovilizar a un hombre junto con sus ilustraciones. El cuarto capítulo expone algunas técnicas de detención de un individuo. Los siguientes tres capítulos describen varias formas de conducir a un hombre a tierra, llevarle a cuestas y conducirle andando incluyendo su representación gráfica. El octavo capítulo incluye la descripción e ilustración de varias técnicas de defensa personal ante agarres, golpes y ataques armados. El noveno capítulo presenta varias técnicas de defensa contra ataques de bastón, cuchillo y revólver. El último capítulo ofrece varios consejos prácticos para la conducción de presos. Adjunta una conclusión final.

6. Koyama, A. y Minami, K. (1916). La lucha corporal japonesa. Barcelona: s.n. 1a ed. 79 p. : il. ; desc.xdesc. cm. ISBN: No ISBN. Depósito legal: no.

7. López Romero, Francisco (1922). Manual de educación física : generalidades. Higiodinánima, aparatos portátiles, aparatos fijos, jut-jutsu. Barcelona: Juan Ruíz Romero. $1^{\mathfrak{a}}$ ed. 148 p. : il. ; $13 \times 19 \mathrm{~cm}$. ISBN: No ISBN. Depósito legal: no. Palabras clave: historia, fundamentos teóricos, defensa personal, ejercicios, equipamiento, entrenamiento. Resumen: Manual teórico y técnico de educación física. El libro esta dividido en cuatro partes. La primera parte comenta las generalidades de la educación integral, la historia de la educación física, la clasificación de los juegos según diversos autores, explica la anatomía ósea, muscular y del sistema nervioso, el funcionamiento de los músculos y su acción sobre el resto de sistemas del cuerpo humano y describe los órganos de los sentidos. La segunda parte explica las diferentes formaciones y movimientos que puede adoptar un grupo de alumnos, explica las acciones de andar, marchar, correr, saltar, bailar, nadar y trepar, y describe diferentes ejercicios sin aparatos para el entrenamiento de las diferentes partes del cuerpo. La tercera parte expone las características de las mazas, pesas y picas así como algunos de sus ejercicios. La cuarta parte describe las características de algunos aparatos fijos como las poleas, la escalera horizontal, la escalera oblicua, la escalera dorsal, la escalera homoplática, las escalas, las paralelas, el banco torácico, el caballo de saltos y el trampolín junto con la descripción de algunos de sus ejercicios. Adjunta un apéndice con la descripción de varios ejercicios de fortalecimiento y endurecimiento específicos del jut-jutsu así como algunas de sus técnicas de defensa personal acompañadas de su representación gráfica.

8. Montespín, Barón René De (1910). Los sports de moda. Foot-ball. Water-polo. Jiu-Jitsu. Barcelona: IberoAmericana. $1^{\underline{a}}$ ed. 114 p. : il. ; desc.xdesc. cm. ISBN: No ISBN. Depósito legal: no. Palabras clave: fundamentos teóricos, defensa personal, jujutsu, deporte. Resumen: Manual teórico y técnico de fútbol, waterpolo y jiu-jitsu. El libro esta dividido en 3 partes. La primera parte comenta la preparación física y entrenamiento del fútbol, su higiene y vestimenta, su desarrollo y táctica, las funciones de los delanteros, medios, defensas, portero, del capitán y ofrece algunos consejos a los jugadores. La segunda parte comenta las características y consejos para los baños de mar y río, expone la forma de aprender a nadar, describe algunos ejercicios preparatorios para la natación, narra la historia del waterpolo y presenta el reglamento del waterpolo. La tercera parte narra el origen del jiu-jitsu, comenta las características de su entrenamiento y describe varias técnicas de defensa personal acompañadas de su representación gráfica.

9. Nitobe, Inazo (1909). Bushido : el alma del Japón. Madrid: Daniel Jorro. 1a ed. 169 p. ; 12x19 cm. ISBN: No ISBN. Depósito legal: no. Palabras clave: educación, filosofía, ética, samurái, seppuku. Resumen: Tratado teórico y filosófico del bushido. La obra esta compuesta por 17 capítulos. Los dos primeros capítulos explican el origen de la caballería y las fuentes filosóficas y sociales que dieron lugar al bushido. A continuación profundiza en la explicación de los valores y actitudes que regían el bushido, esto es, la rectitud, el valor, la bondad, la cortesía, la sinceridad, el honor y el deber de fidelidad. Continúa con la narración del tipo de educación que recibía el samurái y el control de si mismo que tenía. Los dos siguientes capítulos detallan el significado del suicidio, la reparación de los agravios, y el sable como el alma del samurái; para después explicar la condición de la mujer y su educación. Finaliza con el análisis de la influencia del bushido en el resto de la sociedad, su repercusión en la sociedad actual y su porvenir dentro de ella.

10. Nitobe, Inazo (1941). El bushido : el alma del Japón. Madrid: Gráficas Ibarra. 1a ed. 252 p. ; $12 \times 17$ cm. ISBN: No ISBN. Depósito legal: no. (2ª ed., 1943). Palabras clave: educación, filosofía, ética, samurái, seppuku. Resumen: Tratado teórico y filosófico del bushido. La obra esta compuesta por 17 capítulos. Los dos primeros capítulos explican el origen de la caballería y las fuentes filosóficas y sociales que dieron lugar al bushido. A continuación profundiza en la explicación de los valores y actitudes que regían el bushido, esto es, la rectitud, el valor, la bondad, la cortesía, la sinceridad, el honor y el deber de fidelidad. Continúa con la narración del tipo de educación que recibía el samurái y el control de si 
mismo que tenía. Los dos siguientes capítulos detallan el significado del suicidio, la reparación de los agravios, y el sable como el alma del samurái; para después explicar la condición de la mujer y su educación. Finaliza con el análisis de la influencia del bushido en el resto de la sociedad, su repercusión en la sociedad actual y su porvenir dentro de ella.

11. Rit-Jou-Ku (191?). Modo de defenderse sin armas : la defensa en la calle. Cómo hacerse inexpugnable.

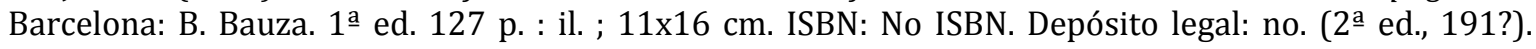
Palabras clave: fundamentos técnicos, defensa personal, jujutsu, boxeo. Resumen: Manual teórico y técnico de jiu-jitsu. La obra esta dividida en 9 capítulos. El primer capítulo comenta los inconvenientes de las diferentes formas de defensa personal armada así como las ventajas y aplicación de las principales técnicas de la defensa personal a manos vacías. Los siguientes cuatro capítulos describen la ejecución de algunos puñetazos, patadas, golpes de cabeza y torsiones además de su efectividad sobre el adversario. El sexto capítulo incluye la descripción de 3 llaves de jiu-jitsu. El séptimo capítulo describe e ilustra la aplicación de varias técnicas de jiu-jitsu en situación de defensa personal incluyendo su representación gráfica. El octavo capítulo explica la ejecución de varias torsiones del jiujitsu en una situación de defensa personal acompañadas de su ilustración. El último capítulo expone cómo librarse del golpe del padre Francisco utilizado por los apaches.

12. s.a. (1908). Breve tratado de jiu-jitsu : principales llaves de defensa que usan los más renombrados campeones de la lucha japonesa. Barcelona: Imprenta de la viuda de J. Cunill. 1aㅡ ed. 16 p. : il. ; $11 \times 18 \mathrm{~cm}$. ISBN: No ISBN. Depósito legal: no. (2ª ed., 1908). Palabras clave: fundamentos técnicos, principios técnicos, kuatsu. Resumen: Manual técnico de jiu-jitsu. La obra explica en qué consiste el jiu-jitsu, cuáles son sus reglas y sus beneficios para luego comentar los fundamentos y principios técnicos del jiu-jitsu a través de la explicación de algunas técnicas de zancadilla, torsión, llaves, proyección y estrangulación y su representación gráfica. También ofrece algunos consejos para la práctica y nombra las técnicas de reanimación o kuatsu.

13. s.a. (1909). Los secretos del jiu-jitsu. Madrid: s.n. $1^{\mathrm{a}}$ ed. 28 p. : il. ; desc.xdesc. cm. ISBN: No ISBN. Depósito legal: no. Palabras clave: historia, fundamentos teóricos, fundamentos técnicos. Resumen: Manual teórico y técnico de jiu-jitsu. El libro comenta las exhibiciones de Raku, las características y beneficios del jiu-jitsu, narra su historia, sus fundamentos teóricos y describe la preparación del jiujitsu ofreciendo consejos sobre nutrición, respiración e higiene, y explica la ejecución de algunos ejercicios físicos de calentamiento y técnicas de jiu-jitsu acompañadas de su representación gráfica.

14. Saimbraum, Dr. (seud. de Bardina, Joan) (1914). Modos de defenderse en la calle, sin armas. Lecciones prácticas de boxeo, jiu-jitsu, lucha greco-romana, etc. Barcelona: Talleres Gráficos de la Sociedad General de Publicaciones. 1a ed. 141 p. : il. ; 12x18,5 cm. ISBN: No ISBN. Depósito legal: no. (2 ${ }^{\underline{a}}$ ed., 1930, 128 p.; $3^{\text {a }}$ ed., 1939, Hymsa, 128 p.). Palabras clave: fundamentos técnicos, defensa personal. Resumen: Manual técnico de defensa personal. La obra esta compuesta de 2 partes. La primera parte comienza explicando la correcta ejecución de una posición de guardia y pasa a describir e ilustrar distintos puñetazos, golpes con los pies, zancadillas, torceduras, golpes dados con la cabeza y sus respectivas paradas, así como algunos consejos prácticos para afrontar un combate. La segunda parte comienza explicando los principios básicos a tener en cuenta durante el combate cuerpo a cuerpo, para después describir algunos golpes especiales, golpes propios de los apaches, algunos consejos sobre el enfrentamiento real o contra varios adversarios con o sin armas, y finaliza con una breve descripción del jiu-jitsu y dos de sus técnicas.

\subsection{Japón}

\subsubsection{Aikido}

15. Ceresa, Fabio (2000). Lecciones de aikido. Barcelona: De Vecchi. 1a ed. 111 p. : il. ; 17x24 cm. ISBN: 84315-2530-4. Depósito legal: B. 43035-2000. Palabras clave: fundamentos teóricos, fundamentos técnicos, principios técnicos, biografía, vestimenta, cortesía, etiqueta, maestros. Resumen: Manual teórico y técnico de aikido. La obra esta formada por 6 capítulos precedidos por una introducción que presenta la práctica del aikido. El primer capítulo narra la biografía del maestro Ueshiba. El segundo capítulo describe el dojo, la vestimenta y las normas de etiqueta del aikido. El tercer capítulo explica la ejecución de las distintas guardias, desplazamientos, tai sabaki y ukemis acompañados de sus ilustraciones. El cuarto capítulo expone los principios tácticos del aikido junto con la descripción técnica de las presas y los ataques incluyendo su representación gráfica. El quinto capítulo explica la ejecución de las técnicas de elevación articular ikkyo, nikkyo y sankyo junto con su aplicación marcial y su secuencia fotográfica. El sexto capítulo presenta las técnicas de proyección, variantes y aplicación marcial de shiho nage, irimi nage, kaiten nage, kote gaeshi, tenchi nage, koshi nage y suwari waza junto con su secuencia fotográfica. Adjunta un glosario específico. 
16. Coll Alentà, Ricard (2008). Aikido : práctica y sensaciones. Barcelona: Océano Ambar. 1a ed. 156 p. : il. ; 18x18,5 cm. ISBN: 978-84-7556-548-4. Depósito legal: B. 32038-LI. Palabras clave: historia, fundamentos teóricos, principios técnicos, entrenamiento, biografía, vestimenta, cultura, lesiones, maestros. Resumen: Manual teórico y técnico de aikido. La obra esta formada por 8 capítulos precedidos por un prólogo y una introducción que comenta los objetivos de la obra. El primer capítulo narra la biografía del maestro Ueshiba, sus relaciones con la daito ryu aiki jutsu y Onisoburo Deguchi, y la historia de la daito ryu aiki jutsu. El segundo capítulo expone las diferencias culturales entre Oriente y Occidente, el papel del profesor en la clase, el objetivo final del aikido, su evolución y principios. El tercer capítulo relata los comienzos del autor en la práctica del aikido, el papel de las técnicas y los tipos de entrenamiento. El cuarto capítulo comenta la historia y significado de la etiqueta en las artes marciales, el ambiente y funcionamiento del dojo y la relación con los compañeros. El quinto capítulo expone los principios técnicos del aikido junto con la explicación e ilustración de varias de sus técnicas. El sexto capítulo explica el significado de la forma, detalla la visión del maestro Yamada sobre el aikido y narra la evolución del aikido. El séptimo capítulo muestra las lesiones y molestias más comunes en la práctica del aikido y explica algunos principios técnicos para evitarlas. El último capítulo narra la experiencia del autor en un curso de aikido para luego comentar sus beneficios. Adjunta un glosario, un índice onomástico y bibliografía.

17. Federación Española de Judo y Disciplinas Asociadas, Departamento Nacional de Aikido (1996). Programa de monitor aikido. Madrid: Federación Española de Judo y Deportes Asociados. 1ae ed. 37 p. : il. ; desc.xdesc. cm. ISBN: No ISBN. Depósito legal: no.

18. Font Roig, Fidel (2001). Una visión del aikido a partir de Hito Emi. Barcelona: Paidotribo. 1a ed. 114 p. : il. ; 15x21,5 cm. ISBN: 84-8019-507-X. Depósito legal: no. Palabras clave: aikido, maestros. Resumen: Manual teórico-técnico de aikido. Tras explicar los fundamentos del concepto Hito Emi, pasa a aplicar dicho concepto a la actitud del practicante y que puede ser extrapolable a su vida y actitud interior. En el tercer capítulo aplica esta idea al aikido y sus fundamentos técnicos y actitudinales. También lo aplica a las diferentes técnicas y ataques del aikido, para finalizar con la descripción de las etapas en el aprendizaje de Hito Emi y sus ejercicios.

19. Hoffer, Bruno y Douté, Pascal (2007). Curso de aikido. Barcelona: De Vecchi. 1á ed. 157 p. : il. ; 17x24 cm. ISBN: 978-84-315-3632-9. Depósito legal: B. 21692-2007. Palabras clave: fundamentos técnicos. Resumen: Manual técnico de aikido. La monografía esta compuesta por 6 capítulos. El primer capítulo narra el origen e historia del aikido y su fundador, para luego detallar las distintas organizaciones nacionales e internacionales que gobiernan este arte. El tercer capítulo describe los aspectos más generales del aikido, como las distintas escuelas que existen, los exámenes de grado, el dojo, la vestimenta, las armas y el saludo. El siguiente capítulo detalla e ilustra la ejecución técnica de las distintas caídas, y posteriormente de los desplazamientos. El último capítulo profundiza en los fundamentos técnicos del aikido, explicando e ilustrando los agarres y atemis, las principales inmovilizaciones y técnicas de proyección, un ejemplo de entrenamiento con dos oponentes, y algunos ejemplos técnicos del enfrentamiento con bokken, jo y tanto. Adjunta un glosario y un resumen de los métodos de trabajo.

20. Homma, Gaku (2000). La estructura del aikido : correlación de movimientos del sable y la mano vacía. Kenjutsu y taijutsu. Barcelona: Paidotribo. 1aㅡ ed. 195 p. : il. ; 21x27,5 cm. ISBN: 84-8019-476-6. Depósito legal: no. (2 $2^{\mathrm{a}}$ ed., 2007). Palabras clave: kenjutsu, taijutsu. Resumen: Manual teórico y técnico de aikido taijutsu. La obra esta compuesta por 7 capítulos que relacionan el kenjutsu con el aikido taijutsu. Después del primer capítulo introductorio en el que se explica el propósito de la obra, el segundo capítulo introduce los aspectos formales y el manejo del ken, para en el tercero explicar los movimientos corporales básicos. El cuarto capítulo explica los movimientos del sable y su relación con los movimientos del taijutsu. El siguiente capítulo explica la progresión y afinidad entre las técnicas del kenjutsu y el taijutsu a través de una serie de ejemplos técnicos mientras que el sexto describe la ejecución técnica de las caídas. El último capítulo presenta e ilustra las técnicas de sujeción, técnicas de proyección, técnicas de proyección con luxación articular, técnicas de la empuñadura del sable, y las técnicas de extracción del sable y de un sólo corte, comparando la ejecución en el kenjutsu con la realizada en el aikido taijutsu.

21. Isidro Casas, José Luis (2003). Aikido : una visión desde Occidente. Madrid: Librería Argentina. 1aㅡ ed. 165 p. : il. ; 17x24 cm. ISBN: 84-89836-44-2. Depósito legal: M. 47473-2003. Palabras clave: historia, fundamentos teóricos, fundamentos técnicos, programa técnico, principios técnicos, principios éticos, defensa personal, entrenamiento, respiración, biografía, vestimenta, aikido, escuelas, legislación, maestros, samurái, armas. Resumen: Manual teórico y técnico de aikido. El libro esta formado por 31 capítulos precedidos por una breve biografía del autor, agradecimientos, dos presentaciones del libro y un prólogo que señala los objetivos del libro. El primer capítulo narra la biografía del maestro Ueshiba. El segundo capítulo enumera los diferentes estilos de aikido. El tercer capítulo comenta las características del aikido kenkido ryu y continúa exponiendo su método de entrenamiento. Los dos siguientes capítulos describe las características y entrenamiento con el jo y el sable, mientras que el 
siguiente explica el método de entrenamiento con el sable. El octavo capítulo explica los beneficios del estudio del aikido. El siguiente capítulo define el término mokuso y describe su ejecución. El décimo capítulo detalla el significado de kokyu y describe sus tipos de ejercicios. El siguiente capítulo explica el principio de kimusubi y su forma de entrenamiento. Continúa definiendo los conceptos de ma-ai y deai. Los siguientes tres capítulos exponen los principios técnicos y tipos de kamae y tai sabaki así como el principio de irimi-tenkan. El décimo sexto capítulo describe la ejecución de las técnicas de ukemi waza y sus principios técnicos mientras que el siguiente presenta la ejecución correcta de la respiración. Los dos siguientes capítulos muestran el cuadro de grados y las diversas formas de ataque; para luego enumerar los contenidos técnicos por cinturones hasta 5o dan. Los siguientes cuatro capítulos presentan la secuencia fotográfica de diversas técnicas de tachi waza ante jodan tsuki, ryo te dori y ai hanmi katate dori, varias técnicas de jo dori y tachi dori, defensas contra tanto y contra un agarre a la solapa y cuchillo en el abdomen. El vigésimo quinto capítulo expone las normas de etiqueta en el tatami para luego señalar los valores del aikido, la aplicación del aikido en situaciones de defensa personal junto con su legislación correspondiente, comentar las actitudes ante una situación de defensa personal, relatar la historia de los samuráis y su modo de vida, y destacar los beneficios de la práctica del aikido. Adjunta un glosario específico y un listado de los fundamentos técnicos del aikido.

22. Isidro Casas, José Luis (2004). Aikido : más allá de las técnicas. Madrid: Librería Argentina. 1aㅡ ed. 126 p. : il. ; $17 \times 24$ cm. ISBN: 84-89836-53-1. Depósito legal: M. 17402-2004. Palabras clave: filosofía, maestros, religión, armas. Resumen: El primer capítulo reflexiona sobre la vertiente marcial del aikido en la actualidad para luego relacionar los conceptos de círculo, espíritu y armonía con su práctica. Los dos siguientes capítulos exponen el carácter del guerrero y el espíritu del budo, para enumerar algunos conceptos básicos del kenjutsu en el quinto capítulo. Los siguientes capítulos describen las aportaciones de la tradición, el zen, el shinto y el bushido a las artes marciales, y continua explicando la formación del bushi a través de las distintas épocas y escuelas. Los 3 siguientes capítulos relatan la historia y evolución del kenjutsu, el iaijutsu y el iaido, continuando con la explicación del significado y utilización del bokken como elemento común a ambas artes marciales. Luego incluye una biografía de Miyamoto Musashi, la historia y evolución del sable japonés, y la vida y obra de Morihei Ueshiba. El décimo-octavo capítulo expone las distintas formas de trabajo con el sable así como los principios básicos para su correcta práctica. Los últimos capítulos incluyen una breve reflexión sobre el concepto de efectividad y la actitud en el entrenamiento actual, un diccionario de términos, el alfabeto japonés, un diccionario de romanji a kanji, el mapa de Japón y Kanto, y varias fábulas.

23. Isidro Casas, José Luis (2006). Aikido policial : manual práctico del guardaespaldas. Madrid: Librería Argentina. $1^{\underline{a}}$ ed. 135 p. : il. ; 17x24 cm. ISBN: 84-89836-99-X. Depósito legal: M. 2472-2006. Palabras clave: fundamentos técnicos, defensa personal, educación, legislación. Resumen: Manual teórico y técnico de aikido o defensa policial. El libro esta formado por 34 capítulos. El primer capítulo justifica la utilización del aikido como método de defensa policial y luego relata una anécdota sobre la aplicación del aikido ante una situación de secuestro. Los dos siguientes capítulos enumeran y explican las actitudes ante una situación de defensa personal y unas nociones básicas relacionadas con la seguridad y la autodefensa. Los siguientes 3 capítulos recopilan los principios para sobrevivir en la calle y las características de las técnicas más efectivas ante ataques de cuchillo, armas de fuego y un ataque en grupo. El noveno capítulo analiza, clasifica y explica las variantes de la defensa personal, para continuar con la progresión de contenidos técnicos de la defensa policial y el comentario de las técnicas defensivas contra la pared, las técnicas de intervención, las técnicas de sacrificio, las técnicas de bloqueo y contra-ataque. Continúa con el comentario de los principios que rigen el aikido policial, y un listado de los contenidos que integran el programa de formación de un escolta junto con un ejemplo de los contenidos a estudiar en un sistema de defensa integral. El vigésimo capítulo analiza la labor diario del escolta para luego exponer los contenidos básicos de su formación como las medidas preventivas, la protección dinámica, la protección con vehículo y maniobras evasivas y los ejercicios de tiro. El siguiente capítulo reflexiona sobre los características del terrorismo en la actualidad. Los siguientes capítulos presentan brevemente el procedimiento de identificación de un sospechoso y el uso de medios para luego ilustrar varias técnicas de protección a VIP, de autoprotección, de intervención, de desarme, de conducción de detenidos, de autodefensa contra arma larga y de protección de arma personal. Finaliza con un ejemplo de varias clases de aikido policial, un comentario sobre la defensa personal y la ley 23/1992, de 30 de Julio, de seguridad privada.

24. Kitaura, Yasunari (1999). La plenitud del vacío : ensayos sobre el aikido y otros aspectos de la cultura japonesa. Madrid: Compañía Literaria. 1aㅡ ed. 120 p. : il. ; 17x24 cm. ISBN: 84-8213-064-1. Depósito legal: M. 48360-1999. Palabras clave: principios filosóficos, principios éticos, filosofía, aikido, arquitectura, maestros, pintura. Resumen: Tratado teórico sobre el aikido. La obra esta formada por 3 capítulos precedidos por un amplio prólogo que explica las razones del autor para publicar este texto que formaba parte de un ciclo de conferencias sobre la cultura y la paz, y los agradecimientos. El primer capítulo explica los objetivos y principios técnicos y filosóficos del aikido como ejemplo para relacionar al individuo con su entorno. El segundo capítulo esta compuesto por 4 ensayos que 
reflexionan sobre la relación entre el budo y la cultura, y sus manifestaciones en la arquitectura, la pintura, y la relación entre cuerpo, alma y paisaje. El tercer capítulo presenta varias fotos del maestro Kisshomaru Ueshiba y de sus visitas a España.

25. Makiyama, Thomas H. (1964). Aikido : la ciencia de la auto-defensa. Barcelona: Hispano Europea. 1a ed. 124 p. : il. ; 14x20,5 cm. ISBN: No ISBN. Depósito legal: B.28265-1964. (2ª ed., 1967; 3ae ed., 1975, ISBN: 84-255-0115-6). Palabras clave: fundamentos técnicos, defensa personal, aikido. Resumen: Manual técnico de aikido. Después de una breve introducción donde se explica el origen e historia del aikido así como de enumerar los principios básicos del alumno ante la práctica, describe la posición de guardia del aikido en la defensa personal. Los siguientes capítulos ilustran y describen diferentes técnicas de defensa personal, dividiendo cada técnica en distintas partes y señalando los puntos clave a recordar en cada parte. Los dos primeros capítulos de esta parte práctica proponen una serie de ejercicios para mejorar el equilibrio y la coordinación, y la preparación y resistencia. Después comienzan los ejercicios dedicados a la defensa personal y que son las siguientes: ejecución de una llave en "V" invertida de muñeca, codo y espalda combinada con una proyección, defensas contra golpes por encima de la cabeza, defensas contra un adversario que sujeta o agarra una sola muñeca con una de sus manos, con ambas manos, defensa contra una presa simple de solapa, defensas contra un adversario que nos coge con ambas manos, defensas contra los puñetazos al cuerpo y a la cara, defensas contra diversas tácticas de golpear y sujetar, y defensas contra ataques con porras y cuchillos.

26. Mantovani, Cesarino (1991). Curso de aikido. Barcelona: De Vecchi. 1a ed. 143 p. : il. ; 17x24 cm. ISBN: 84-315-1019-6. Depósito legal: no. (2ª ed., 1992; $3^{\underline{a}}$ ed., 1995; $4^{\mathrm{a}}$ ed., 1996; $5^{\mathrm{a}}$ ed., 1998, ISBN: 84-3151934-7; 6 a ed., 1999, ISBN: 84-315-1934-7; 7aㅡ ed., 2000, ISBN: 84-315-1934-7). Palabras clave: historia, fundamentos técnicos, armas, vestimenta, maestros. Resumen: Manual teórico y técnico de aikido. La obra esta formada por 5 capítulos, precedidos por una introducción que define el término aikido y su práctica. El primer capítulo detalla la biografía de Morihei Ueshiba y el origen del aikido. El segundo capítulo enumera e ilustra los fundamentos técnicos del aikido, describe la ejecución de la posición de guardia y los movimientos con la ayuda de esquemas gráficos, presenta los conceptos de distancia y atemi, e ilustra los diferentes tipos de caídas. El tercer capítulo comenta las características físicas del dojo, expone las reglas de comportamiento en el mismo y describe la ejecución del saludo y la estructura de un entrenamiento de aikido. El cuarto capítulo incluye una tabla con las técnicas presentadas en el siguiente capítulo. El último capítulo describe brevemente las principales técnicas de inmovilización, proyección y con el uso de armas además de incluir la secuencia fotográfica de las mismas. Adjunta un glosario.

27. Monclús Arbó, Fermín; Gil, Antonio y Monclús, Javier (1987). El aikido visto por el médico : memorandum de aikido, con el programa hasta 3er dan. Barcelona: Alas. 1aㅡ ed. 80 p. : il. ; 15x21,5 cm. ISBN: 84-203-0209-0. Depósito legal: B. 27933-1987. Palabras clave: historia, fundamentos técnicos, programa técnico, exámenes, reglamentos, salud. Resumen: Manual teórico y técnico de aikido. La obra esta formada por 2 partes, precedidas por un prólogo que señala la tarea del autor. La primera parte consta de cinco capítulos. El primer capítulo expone la relación entre salud y ejercicio físico a través de la historia. El segundo capítulo describe la práctica del aikido y señala las diferencias respecto a otras artes marciales. El tercer capítulo explica brevemente la fisiología humana para luego detallar los beneficios de la práctica del aikido. El cuarto capítulo expone las características del aikido y su adecuación para las mujeres y practicantes de cualquier edad. El quinto capítulo explica la aplicación del aikido como método de defensa personal. La segunda parte es un memorándum de aikido que incluye un resumen de su historia, las normas del dojo Aikikai, el programa de contenidos técnicos hasta 3er dan, un vocabulario básico, la ilustración de las principales formas de ataque y defensa, enumera las principales técnicas de defensa, y describe e ilustra el ritual de examen de cinturón negro.

28. Monreal Sevilla, Miguel Ángel (dir.) (2001). 25 años de aikido en Navarra: 1976-2001. Navarra: Federación Navarra de Judo y D. A. y Asociación Cultural de Aikido de Navarra. 1ae ed. 42 p. : il. ; 21x27 cm. ISBN: No ISBN. Depósito legal: NA. 3219-2001. Palabras clave: historia, entrenamiento, aikido, clubes, eventos, fotografía. Resumen: Reportaje gráfico de la historia de aikido en Navarra. El libro esta compuesto por 8 partes, precedidos por un capítulo introductorio sobre la biografía de Morihei Ueshiba, Kisshomaru Ueshiba, Moriteru Ueshiba y Yasunari Kitaura. La primera parte comenta los cursos de aikido realizados en Navarro durante estos 25 años, incluyendo fotografías de sus participantes, profesores y recortes de periódico que se hacían eco de tales eventos. La segunda parte presenta aquellos cursos de aikido realizados fuera de Navarra con participación de aikidokas navarros incluyendo fotografías de dichos participantes. Las siguientes dos partes presentan las exhibiciones y entrenamientos conjuntos desarrollados durante este período de tiempo incluyendo numerosas fotografías. La quinta parte incluye un listado con los clubes que han impartido aikido en Navarra, los alumnos con danes en cada club, y algunas fotografías de sus directivos, alumnos y escudo del club. La sexta parte incluye el listado y fotografía de los profesores, danes y 1er kyu de aikido de 
Navarra. La séptima parte presenta varias fotografías de la vida social de estos practicantes para finalizar con la exposición fotográfica del curso y cena de gala del 25 aniversario del aikido en Navarra.

29. Nagashima, Sato (seud. de Nalda Albiac, José Santos) (1978). Aikido básico. Barcelona: Alas. 1a ed. 111

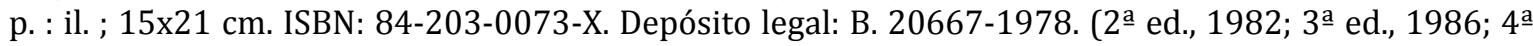
ed., 1994). Palabras clave: fundamentos técnicos, ejercicios, sistemas de entrenamiento. Resumen: Manual teórico y técnico de aikido. La obra comienza con la explicación de lo que es el aikido y cuáles son sus principios dinámicos. Después comenta los diferentes trabajos que se pueden realizar durante una clase de aikido junto con la explicación de algunos fundamentos como el kamae y el tai sabaki. Una vez comentadas las partes del entrenamiento (jumbi undo, tekubi udo, ukemis, tai sabaki, shikko, aiki taiso y las técnicas), profundiza en cada una de ellas, presentando ejercicios de las mismas. Antes de pasar a la descripción de las técnicas de aikido, detalla e ilustra las formas de ataque, repite los principios fundamentales de las técnicas, ofrece algunos consejos prácticos y las características de las técnicas fundamentales de defensa. El siguiente capítulo describe e ilustra las técnicas de base sobre agarre de una mano, para finalizar con algunas de las aplicaciones que tiene el aikido en técnicas con compañero, cuando ambos contendientes están arrodillados y cuando la defensa es contra varias personas.

30. Nagashima, Sato (seud. de Nalda Albiac, José Santos) (2006). Aikido : método de entrenamiento. Barcelona: Alas. 1aㅡ ed. 295 p. : il. ; 17x23,5 cm. ISBN: 84-203-0441-7 (978-84-203-0441-0). Depósito legal: no. Palabras clave: fundamentos técnicos, didáctica, ejercicios, unidades didácticas. Resumen: Manual técnico-didáctico para el maestro de aikido. Después de exponer brevemente las características que debe poseer un buen maestro comienza a desarrollar las distintas lecciones que componen el libro y que sirven de programación para el maestro. Están agrupadas en 4 apartados. El primer grupo de lecciones desarrollan los fundamentos técnicos y tácticos del aikido, ya que el segundo grupo presenta y desarrolla los principios físicos y biomecánicos del arte. El tercer grupo de lecciones ofrece lecciones para desarrollar los aspectos actitudinales que preconiza el aikido, y continúa con las lecciones dedicadas al desarrollo ético de sus practicantes. El último apartado del libro ofrece un amplio compendio de ejercicios educativos para desarrollar las cualidades físicas específicas del aikido.

31. Nalda Albiac, José Santos (1981). Apuntes de aikido. Barcelona: Alas. 1aㅡ ed. 136 p. : il. ; $15 \times 21 \mathrm{~cm}$. ISBN: 84-203-0126-4. Depósito legal: B. 41870-1980. Palabras clave: fundamentos teóricos, fundamentos técnicos, principios técnicos, filosofía, defensa personal, vestimenta, bushido, grados, meditación, respiración, violencia. Resumen: Manual teórico y técnico de aikido. La obra esta formada por 25 capítulos que explican los fundamentos filosóficos y técnicos del aikido a modo de cómic. Los tres primeros capítulos comienzan explicando el significado del ki, la respiración y la relación entre el espíritu y el cuerpo además de su aplicación e interpretación dentro del aikido. Los siguientes cinco capítulos profundizan en los principios y conceptos técnicos del aikido como son el kokyu-ho (potencia respiratoria abdominal), la coordinación entre mente y cuerpo, la armonía en el trabajo con el compañero, los tipos de reacciones ante el ataque (sen no sen) y las trayectorias de neutralización de los ataques. Los dos capítulos siguientes ofrecen varios consejos prácticos ante las situaciones de defensa personal y ante el entrenamiento. Continúa con la explicación del tai-sabaki, los atemis y algunas de las principales técnicas, su descripción técnica e ilustración. El decimocuarto capítulo expone los principios del aikido, cómo se desarrollan las clases y cuáles son los métodos de entrenamiento que existen. A continuación detalla las normas dentro del dojo y estudia los conceptos de hara, do, la no violencia, la defensa personal, el código bushido, la importancia de la voluntad, el miedo, los paradigmas del aikido, los cinturones y la posición de zazen.

32. Nalda Albiac, José Santos (1983). Aikido : metodología. Madrid: Cabal. 1a ed. 125 p. : il. ; 21x30,5 cm. ISBN: 84-7034-088-3. Depósito legal: M. 38801-1983. Palabras clave: katas, fundamentos teóricos, fundamentos técnicos, principios técnicos, defensa personal, ejercicios, entrenamiento, anatomía, armas. Resumen: Manual teórico y técnico de aikido. El libro esta formado por 44 capítulos. Los dos primeros capítulos describen el movimiento de las articulaciones y la acción de los músculos. Los tres siguientes capítulos comentan los fundamentos teóricos de la fatiga muscular, la respiración y el control del esfuerzo. El sexto capítulo presenta el desarrollo de una clase mientras que el séptimo define los tipos de reflejos. Los dos siguientes capítulos ofrecen consejos para el calentamiento y la alimentación del deportista. Continúa definiendo los conceptos de pedagogía, metodología y didáctica, así como los principios didácticos del profesor junto con su decálogo de actuación. El capítulo decimotercero expone los principios didácticos aplicables al aikido para luego detallar los objetivos, contenidos y evaluación del programa de enseñanza, y algunos consejos prácticos para el desarrollo de una sesión práctica. El decimosexto capítulo describe la ejecución de la meditación. El siguiente capítulo explica los tipos de movimientos reflejos así como los distintos ukemis. El resto de capítulos presentan los fundamentos técnicos, conceptos y ejercicios del aikido como son tai-sabaki, sikko, kokyo-ho, kiawase, seika no iten ki, henka-waza, kaeshi-waza, taninzu-dori, renzoku-waza, renrakuwaza, tanto-dori, tahi-dori, kumi-tachi, algunas técnicas fundamentales de sable, jo-dori, kumi-jo, los 
principios técnicos ante ataques de cuchillo y varias técnicas de defensa personal, bokken-jutsu, una kata de bokken, algunos ejercicios de entrenamiento especial, el ritual para el examen de cinturón negro, la aplicación del entrenamiento mental, las leyes de la atención, algunos ejercicios de percepción y para alcanzar la mente-espejo, acompañados de su representación gráfica y esquemas de movimiento.

33. Nalda Albiac, José Santos (1989). Aikido contra armas. Barcelona: Alas. 1a ed. 91 p. : il. ; 15x21,5 cm. ISBN: 84-203-0243-0. Depósito legal: B. 41131-1989. (2ª ed., 1996, 104 p.). Palabras clave: armas, defensa personal. Resumen: Manual teórico y técnico de aikido. La obra esta formada por 8 capítulos precedidos por una introducción que señala las características y beneficios del entrenamiento del aikido con armas. Los ocho capítulos expone las características del entrenamiento de tanto dori, tambo jutsu, defensa con el tambo, tachi dori, jo dori y defensa con el jo, define los tipos de ataque con estas armas, y describe la ejecución de algunas de sus técnicas acompañadas de su secuencia fotográfica.

34. Nalda Albiac, José Santos (1990). Aikido : fundamentos. Barcelona: Alas. 1ạ ed. 157 p. : il. ; 15x21 cm. ISBN: 84-203-0249-X. Depósito legal: no. (2 ${ }^{\underline{a}}$ ed., 1990; 3a ed., 1996). Palabras clave: historia, fundamentos teóricos, pedagogía, principios técnicos, ejercicios, entrenamiento, calentamiento, vestimenta, aikido, reglamentos, armas. Resumen: Manual teórico y técnico de aikido. La obra esta formada por 12 capítulos precedidos por los prólogos a las ediciones anteriores y la presentación de la obra. El primer capítulo narra los orígenes de la espada e ilustra sus partes. El segundo capítulo comenta la historia y vida de los samuráis. El tercer capítulo expone algunas de las normas de protocolo del samurái junto con el ritual de combate a sable entre samuráis. El cuarto capítulo relata los orígenes del aikido. El quinto capítulo explica e ilustra las normas de etiqueta con el sable y la forma correcta de empuñarlo. El sexto capítulo describe los ejercicios preparatorios al comienzo de una clase de aikido acompañados de su representación gráfica. El séptimo capítulo explica el concepto de ki, sus fundamentos teóricos y sus principios para el entrenamiento así como los principios de la respiración. El octavo capítulo detalla el significado del hara, describe un ejercicio para tomar conciencia del mismo, y señala su aplicación en el aikido y la vida cotidiana. El noveno capítulo analiza el diálogo corporal entre los practicantes de aikido, estudia los tipos de agarres, propone varios ejercicios para comprender el principio del diálogo corporal y expone los principios técnicos de la postura defensiva. El décimo capítulo explica los principios pedagógicos del profesor y las etapas de aprendizaje. El décimo primer capítulo detalla los conocimientos extraídos del análisis de la técnica y analiza los principios técnicos del aikido. El último capítulo explica el entrenamiento de la mente y del espíritu. Adjunta varios apéndices sobre el desarrollo del examen de cinturón negro, un comentario sobre los beneficios de la respiración, su relación con el movimiento y la descripción de varios ejercicios, un estudio de los factores que influyen en el autocontrol y la explicación del entrenamiento de jiyu waza.

35. Nalda Albiac, José Santos (1990). Artes marciales : el aikido. Barcelona: Paidotribo. 1aㅡ ed. 252 p. : il. ;

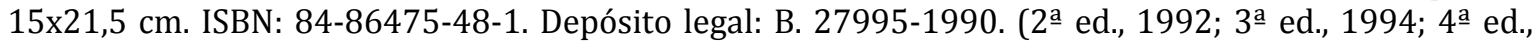
1996; $5^{\mathrm{a}}$ ed., 1999; $6^{\underline{a}}$ ed., 2002; 7aㅡ ed., 2009). Palabras clave: fundamentos teóricos, entrenamiento. Resumen: Tratado teórico sobre los fundamentos del aikido. El libro esta dividido en 18 capítulos y cada uno de ellos profundiza en alguno de los fundamentos del aikido, así el primer capítulo lo hace sobre la definición y paradigmas del aikido. Continua con la vestimenta, las normas de etiqueta en el dojo y el programa de contenidos para cada grado y dan. El quinto capítulo comienza el estudio de la propia práctica, con la explicación de los diferentes tipos de entrenamiento. Continúa con la descripción del papel y características del maestro así como algunas consideraciones pedagógicas para facilitar la realización de los entrenamientos. El séptimo capítulo explica la ejecución de las caídas y luego pasa a comentar la actitud mental, física y corporal a adoptar en el entrenamiento. Los tres siguientes capítulos estudian los desplazamientos, el tai sabaki y las distancias de combate para luego ofrecer algunos ejercicios por parejas para comprender la relación yin-yang. El capítulo decimotercero define los ejercicios de kiawase y presenta algunos de ellos, así como los siguientes capítulos abordan el flujo del ki, el hara y los ejercicios para desarrollarlos. El decimosexto capítulo reflexiona sobre los aspectos estratégicos y su entrenamiento en distintas situaciones, para finalizar la obra con dos capítulos que presentan ejercicios de combinaciones y contraataques.

36. Nalda Albiac, José Santos (1994). Aikido : la armonía universal. Barcelona: Paidotribo. 1aㅡ ed. 277 p. : il. ; 15x21,5 cm. ISBN: 84-8019-176-7. Depósito legal: B. 25090-1994. (2 $2^{\underline{a}}$ ed., 1997; $3^{\mathrm{a}}$ ed., 1999; 4⿳亠丷厂 ed., 2003; 5a ed., 2006, ISBN: 978-84-8019-176-0). Palabras clave: fundamentos teóricos, principios técnicos. Resumen: Ensayo práctico sobre este arte marcial desde una fundamentación teórica básica. Dividido en 2 partes, la primera analiza los aspectos teóricos y cómo aplicarlos al aikido a través de una serie de ejercicios. Comienza con el estudio y aplicación de los principios físicos de gravedad, inercia, energía, movimiento y palanca para continuar con los principios biológico-naturales de los ritmos y la adaptación de los conceptos japoneses de kiawase, wu-wei, ki, adaptabilidad del agua, kototama, ho-jutsu, y cuerpo-mente al aikido. Antes de comenzar la segunda parte dedicada a la práctica, indica los principios morales a seguir en ésta. La segunda parte presenta, en orden ascendente de 
dificultad, los ejercicios que conforman el aikido, comenzando por el lenguaje corporal, su significado e interpretación y continuando por los "educativos de base" (aiki-taiso), los atemis y sus combinaciones y la estrategia. Los dos últimos capítulos desarrollan las dos prácticas más complicadas, suwari-waza y las variantes (henka-waza).

37. Nalda Albiac, José Santos (1995). Enciclopedia del aikido : tomo primero. Programa de cinturón blanco, cinturón amarillo, cinturón naranja. Barcelona: Alas. 1ae ed. 202 p. : il. ; 17x24 cm. ISBN: 84-203-0370-4. Depósito legal: B. 26174-1995. (2aㅡ ed., 2008, 207 p., ISBN: 978-84-203-0370-3). Palabras clave: fundamentos teóricos, fundamentos técnicos, principios técnicos, entrenamiento. Resumen: Manual teórico y técnico de aikido. La obra consta de 5 capítulos precedidos por el prólogo del autor y el decálogo del aikidoka. El primer capítulo describe los fundamentos teóricos del aikido, como son su significado, su fundador e historia, las características del dojo y la vestimenta, y el funcionamiento del sistema de grados. El segundo capítulo profundiza en los fundamentos teóricos y técnicos del aikido, explicando las reglas de cortesía, las formas de saludar, los objetivos y ejecución del mokuso, la descripción del entrenamiento de shite (tori) y aite (uke), describe brevemente los ejercicios incluidos dentro del aiki taiso y sus objetivos junto con algunas ilustraciones, explica la ejecución técnica de las posturas básicas del aikido, las distintas formas de caer, desplazarse y realizar tai-sabaki junto con su representación gráfica y progresión de entrenamiento. El tercer capítulo presenta la representación gráfica de las técnicas incluidas dentro del programa de cinturón blanco junto con un comentario sobre el espíritu y entrenamiento del aikido y un breve glosario técnico. El cuarto capítulo relata el origen de las técnicas de suwari-waza (arrodillado), explica el significado de kokyu ryoku, el principio de desequilibrio (kuzushi), las formas de ataque y agarre básicas, las distintas distancias entre los compañeros, ilustra algunos ejercicios para progresar en las caídas así como los fundamentos técnicos de cinturón amarillo, e incluye un comentario sobre la actitud del principiante ante el entrenamiento y un glosario de términos específicos. El último capítulo describe e ilustra el funcionamiento del sistema nervioso periférico, ofrece algunos consejos para progresar en el entrenamiento y mejorar la actitud mental, incluye algunos ejercicios para dominar las formas de caer, expone los principios de la respiración durante la práctica, las generalidades del entrenamiento go-no-keiko y del atemi-waza, para finalizar con la representación de los fundamentos técnicos de cinturón naranja, un comentario sobre la cortesía hacia el compañero y un glosario específico.

38. Nalda Albiac, José Santos (1995). Enciclopedia del aikido : tomo segundo. Programa de cinturón verde, cinturón azul, cinturón marrón. Barcelona: Alas. 1ae ed. 220 p. : il. ; 17x24 cm. ISBN: 84-203-0371-2. Depósito legal: B. 41841-1995. (2aㅡ ed., 2008, 253 p., ISBN: 978-84-203-0371-0). Palabras clave: fundamentos teóricos, fundamentos técnicos. Resumen: Manual teórico y técnico de aikido. La obra consta de 3 capítulos, precedidos por varios prólogos de la obra. El primer capítulo expone los fundamentos del cinturón verde como son la representación de algunos ejercicios de ukemi-waza, los métodos de entrenamiento keiko-ho, los principios del te-sabaki y del kihon katame waza con su representación, explica la relación entre el kenjutsu y el aikido, y el principio de no-resistencia; describe el significado del término shisei, la esfera aiki y su aplicación en la práctica, la teoría yin/yang en el aikido; ilustra las técnicas de tachi-waza, ushiro-waza y suwari-waza de cinturón verde; e incluye varios ejercicios de flexibilidad y un glosario específico. El segundo capítulo describe las generalidades de te katana, las distintas formas de entrenamiento, algunas formas de ataque avanzadas, la simbología utilizada en el aikido, explica el significado de algunas actitudes del aikido, la relación entre consciente y subconsciente, describe la fiesta de la gratitud, el respeto y la amistad, presenta el decálogo del bushido, ilustra las técnicas de tachi-waza, ushiro-waza y suwari-waza del cinturón azul junto con un glosario específico. El último capítulo expone los fundamentos, como el papel de uke, el significado del ki y el hara; las generalidades, como las lesiones, las precauciones en el entrenamiento y el significado del "do"; y los fundamentos técnicos del cinturón marrón, incluyendo la representación gráfica de las técnicas de tachi-waza, hanmi handachi-waza, ushiro-waza y suwari-waza; además de incluir un comentario sobre el orgullo y un glosario específico. Adjunta un apéndice con un comentario sobre la práctica del aikido después de los 40 , el funcionamiento de la termorregulación corporal y la importancia de la hidratación.

39. Nalda Albiac, José Santos (1996). Enciclopedia del aikido : tomo tercero. Aprender a enseñar. Barcelona: Alas. 1a ed. 205 p. : il. ; 17x24 cm. ISBN: 84-203-0381-X- Depósito legal: B. 32777-1996. Palabras clave: fundamentos teóricos, pedagogía, filosofía, didáctica, defensa personal, fisiología, legislación. Resumen: Tratado teórico de aikido. El libro esta formado por 3 partes, precedidas por varios prólogos. La primera parte consta de 16 lecciones que explican los fundamentos teóricos de la enseñanza del aikido, como son la importancia de adoptar una metodología definida, la formulación de objetivos, los métodos de enseñanza, el significado y aplicación del feedback, como programar una clase desde el punto de vista pedagógico y técnico, los principios de enseñanza, como estructurar los contenidos, comenta las características del principiante y sus formas de aprendizaje, expone las características del calentamiento y vuelta a la calma en una clase de aikido, detalla la fisiología básica y los sistemas energéticos, describe e ilustra varios juegos para dinamizar las clases, detalla los 
principios biomecánicos que actúan en el aikido, además de comentar las principales lesiones del aikido, las formas de evitarlas, y explicar la importancia y funcionamiento del ki y la respiración durante la práctica. La segunda parte consta de 5 capítulos que exponen los principios filosóficos del aikido como son las reglas de cortesía, el principio de no-violencia, detalla los fundamentos teóricos e históricos del aikido, explica los principios y actitudes aiki y desarrolla la relación existente entre cuerpo y mente. La última parte incluye 3 capítulos que exponen las características de la relación profesor-alumno, comentan algunas de las premisas del profesor ante la enseñanza, exponen las características de un buen profesor de aikido y comentan la legislación relativa al uso del aikido como medio de defensa personal.

40. Nalda Albiac, José Santos (1997). Enciclopedia del aikido : tomo cuarto. Programa de cinturón negro de

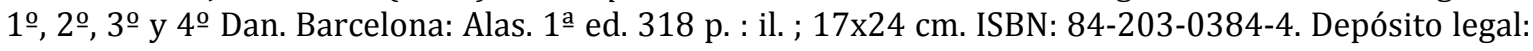
B. 15470-1997. Palabras clave: katas, fundamentos teóricos, fundamentos técnicos, iaido, zen, exámenes, grados. Resumen: Manual teórico y técnico de aikido. La obra esta formada por 4 capítulos precedidos de varios prólogos. El primer capítulo relata el origen del sistema de grados, enumera las distintas formas de entrenamiento, expone la preparación física, técnica y mental para el examen de cinturón negro 1er dan, describe el desarrollo del examen, explica los fundamentos y principios técnicos de las defensas contra cuchillo, incluye la representación gráfica de varias técnicas de defensa contra cuchillo, describe varios ejercicios de futari dori (defensa contra varios adversarios), la ceremonia de entrega del cinturón negro, y comenta la actitud mushin y la dinámica de los ataques, defensas y agarres en aikido. La segunda parte enumera las cualidades del candidato a $2 \underline{0}$ dan, comenta la etapa de aprendizaje en que se encuentra y algunas de las formas entrenamiento para mejorar en el aprendizaje junto con la ilustración por partes de las técnicas de henka-waza y jo dori. El tercer capítulo expone algunos consejos para la preparación para el examen de 3er dan, explica en qué consiste dicho examen, comenta los valores del aikido y el poder los sonidos, describe la estructura de la hakama, incluye un glosario específico y comenta los principios técnicos de taninzu gake, tachi dori y renzoku waza, junto con la representación gráfica e ilustración de algunas técnicas. El cuarto capítulo describe el examen de $4^{o}$ dan, comenta los conceptos de estrategia y eficacia aplicados al aikido, expone la relación entre el zen y las artes marciales, comenta los principios del trabajo de kumi tachi y kumi jo junto con su representación gráfica, además de ilustrar algunas de las técnicas de kaeshi-waza, las partes del sable y las katas de iaido de la escuela muso shinden ryu.

41. Nalda Albiac, José Santos (2000). Enciclopedia del aikido : tomo quinto. Principios y actitudes de 5o Kyu a 5o Dan. Barcelona: Alas. 1aㅡ ed. 319 p. : il. ; 17x24 cm. ISBN: 84-203-0397-6. Depósito legal: B. 131942000. (2 ${ }^{\text {a }}$ ed., 2007, ISBN: 978-84-203-0397-0). Palabras clave: fundamentos técnicos, principios técnicos, principios filosóficos, biomecánica, grados, planificación del entrenamiento, preparación psíquica, programa técnico. Resumen: Manual teórico y técnico de aikido. La obra esta formada por 3 partes, precedidas por varios prólogos. La primera parte consta de 5 capítulos que explican los principios físicos, técnicos y actitudes ante los niveles de 5 o a 1er kyu respectivamente, incluyendo numerosas ilustraciones explicativas y esquemas. La segunda parte consta de 7 capítulos, explicando los cinco primeros los principios físicos, técnicos, mentales y actitudinales desde 1er dan hasta 5o dan, para finalizar con un comentario sobre la ética y el entrenamiento en artes marciales, y describir las características y tipos de trabajo de buki-waza. La tercera parte consta de 11 capítulos, desarrollando los 7 primeros capítulos la progresión de aprendizaje para las técnicas de ushiro eri dori, irimi nage, ai hanmi katate dori, yokomen uchi, ushiro dori, mune dori, ushi kaiten sankyo, mae ryo kata dori, menu oshi, kokyu nage, chudan tsuki, jodan tsuki, gyaku yubi waza, en torno a dos ataques seguidos, futari dori, en torno a la percepción-reacción simultánea, al ideal del aikido y a los stages de aikido. Los tres siguientes capítulos ilustran distintas técnicas de henka-waza, renraku-waza y kaeshi-waza. El último capítulo describe las partes de una katana, los tipos de agarre, junto con algunos ejemplos gráficos de ataque y defensa. Adjunta un apéndice con una propuesta de renovación de los programas de cinturón negro.

42. Nalda Albiac, José Santos (2002). Enciclopedia del aikido : tomo sexto. Entrenamiento integral (shin-gitai). Barcelona: Alas. 1aㅡ ed. 318 p. : il. ; 16x24 cm. ISBN: 84-203-0414-X. Depósito legal: B. 14585-2002. Palabras clave: fundamentos teóricos, entrenamiento, fundamentos técnicos, principios técnicos, filosofía, competición, ética, preparación física, preparación psíquica, unidades didácticas. Resumen: Tratado teórico de aikido. La obra esta dividida en 3 partes precedidas por varios prólogos. La primera parte incluye 17 fichas sobre la preparación física del aikidoka, que explican como entrenar la fuerza, potencia, resistencia, velocidad, flexibilidad, agilidad, equilibrio corporal, coordinación, calentamiento, exponen los principios del entrenamiento, ejercicios para aprender las caídas, desarrollar los reflejos con el jo, los mecanismos de percepción-reacción, desarrollar la visión periférica, los fundamentos teóricos del hara, del aprendizaje a través del cuerpo y el kokyu. La segunda parte 37 fichas sobre la preparación técnica del aikido, explicando los distintos métodos de entrenamiento, algunos ejercicios para aprender los principios técnicos, varias propuestas de clase para evaluar la condición física del practicante, el entrenamiento en suwari-waza, como arrebatar el sable a un samurái, principios 
estratégicos ante diferentes ataques, la práctica del diálogo corporal aiki, integrarse en la acción de uke, desarrollar los conceptos de omote-ura y irimi-tenkan, el principio de no-resistencia, el papel de uke, el principio de adaptabilidad, actuar de forma coordinada, desarrollar la consciencia corporal, destacar la importancia del atemi, ejemplos de entrenamiento en jiyu-waza y futari-dori, incluye la ilustración de distintas técnicas de henka-waza, renraku-waza, kaeshi-waza, tanto dori, y el comentario sobre la progresión del entrenamiento para dominar la técnica y una propuesta de ejercicios para fomentar el descubrimiento personal. La última parte consta de 17 fichas sobre la preparación psicológica del aikido, diferenciando algunos conceptos de filosofía, explicando el origen del budo y significado del do, y discutiendo el concepto de "yo", los enemigos internos, la interdependencia cuerpo-mente, las características de la mente y su forma de entrenamiento, el entrenamiento de las actitudes, cómo controlar las emociones, la actitud justa, la estrategia aiki, el conocimiento de las personas que nos rodean, los valores presentes en la sociedad actual, detalla el código de honor aiki, los principios morales del maestro Ueshiba, los secretos aiki (okuden aiki), y un modelo de programa integral de trabajo.

43. Nalda Albiac, José Santos (2004). Aiki ne waza : aplicación de los principios del aikido a la lucha en el suelo. Barcelona: Alas. 1a ed. 188 p. : il. ; 17x24 cm. ISBN: 84-203-0428-X. Depósito legal: B. 1651-2004. Palabras clave: fundamentos técnicos, principios técnicos, principios filosóficos, defensa personal, ejercicios, calentamiento, anatomía, fisiología, legislación, preparación psíquica. Resumen: Manual teórico y técnico de aikido. La obra esta formada por 17 capítulos precedidos por un prólogo que señala la utilidad de la obra. El primer capítulo señala la importancia del combate en el suelo y sus principios. El segundo capítulo expone los contenidos técnicos del ne waza así como sus principios técnicos. El tercer capítulo estudia el desarrollo del combate en el suelo junto con los objetivos del aiki ne waza. El cuarto capítulo describe varios ejercicios individuales y por parejas de calentamiento en el suelo acompañados de su ilustración. El quinto capítulo expone los principios técnicos del enlace entre tachi waza y katame waza además de incluir la descripción e ilustración de varias técnicas. Los siguientes seis capítulos describen la ejecución técnica de distintas combinaciones de hanmi handachi waza-katame waza, suwari waza-katame waza y katame waza-katame waza desde distintas posiciones acompañados de sus secuencias fotográficas. El décimo segundo capítulo explica el significado del término aiki, su origen y principios. El décimo tercer capítulo describe la estructura anatómica del cerebro y sus respuestas ante una agresión. El siguiente capítulo detalla las estructuras que forman el sistema nervioso, explica su funcionamiento ante una agresión y enumera los cambios fisiológicos. El décimo quinto capítulo comenta las características del autocontrol, enumera los factores de control dentro del aikido y explica las condiciones para mantener la serenidad. El décimo sexto capítulo cita los principios del aikido, expone la puesta en práctica del ai nuke y los principales errores de su entrenamiento. El último capítulo expone los principios de actuación ante una agresión, la legislación referente a la defensa personal y el desarrollo de una clase de aikido con el objetivo de "impedir herir sin herir".

44. Nalda Albiac, José Santos (2007). Aikido. Barcelona: RBA. 1a ed. 281 p. : il. ; $13 \times 20$ cm. ISBN: 978-84473-5232-6. Depósito legal: M. 18178-2007. Palabras clave: fundamentos teóricos, principios técnicos. Resumen: Ensayo práctico sobre este arte marcial desde una fundamentación teórica básica. Dividido en 2 partes, la primera analiza los aspectos teóricos y cómo aplicarlos al aikido a través de una serie de ejercicios. Comienza con el estudio y aplicación de los principios físicos de gravedad, inercia, energía, movimiento y palanca para continuar con los principios biológico-naturales de los ritmos y la adaptación de los conceptos japoneses de kiawase, wu-wei, ki, adaptabilidad del agua, kototama, ho-jutsu, y cuerpo-mente al aikido. Antes de comenzar la segunda parte dedicada a la práctica, indica los principios morales a seguir en ésta. La segunda parte presenta, en orden ascendente de dificultad, los ejercicios que conforman el aikido, comenzando por el lenguaje corporal, su significado e interpretación y continuando por los "educativos de base" (aiki-taiso), los atemis y sus combinaciones y la estrategia. Los dos últimos capítulos desarrollan las dos prácticas más complicadas, suwari-waza y las variantes (henka-waza).

45. Nomura, Kazuo (2009). Aikido : yamato aikikai. Madrid: Budo International. 1aㅡ ed. 127 p. : il. ; 17x24 cm. ISBN: 978-84-92484-37-9. Depósito legal: M. 21789-2009. Palabras clave: fundamentos teóricos, fundamentos técnicos, ejercicios, entrevistas, respiración. Resumen: Manual teórico y técnico de aikido. La obra esta formada por 9 capítulos precedidos por las notas biográficas de Morihei Ueshiba, Bansen Tanaka y el autor además del prólogo del editor. El primer capítulo incluye la entrevista realizada al autor sobre la práctica y entrenamiento del aikido. El segundo capítulo explica los conceptos de ki, nagare y en/ten en el entrenamiento. El tercer capítulo señala la importancia de la respiración y describe e ilustra varios ejercicios para desarrollar su poder. El cuarto capítulo explica el movimiento de tai-no-tenkan acompañado de su representación gráfica y esquemas de movimiento mientras que el quinto presenta los desplazamientos de sabaki y su combinación con el movimiento de tenkan. Los siguientes tres capítulos incluyen la secuencia fotográfica de varias técnicas contra ataques 
por la espalda, técnicas sentadas y técnicas de armas. El último capítulo describe e ilustra la respiración hacia los kami.

46. Pérez Peña, Ishana (2007). Metodología para la formación en el arte del aikido. Tenerife: Ishana Pérez Peña. 1a ed. 368 p. : il. ; 15x24 cm. ISBN: 978-84-611-9652-4. Depósito legal: TF. 2040-2007. Palabras clave: fundamentos teóricos, fundamentos técnicos, pedagogía, vestimenta, cortesía, budo, etiqueta, instalaciones, programa técnico. Resumen: Tratado teórico y pedagógico de aikido. El libro esta compuesto por 3 capítulos precedidos por una introducción que señala los objetivos de la obra y resume sus contenidos. El primer capítulo analiza y define los aspectos externos e internos del aikido, comenta la regulación de la vida para la práctica del aikido, expone los aspectos formales del aikido y detalla los obstáculos diarios para la práctica. El segundo capítulo comenta el proceso de establecimiento de un dojo, discute algunos términos relacionados con la enseñanza de las artes marciales, las características de los distintos tipos de clases y estudiantes, analiza el papel de los compañeros y el sensei, las etapas de aprendizaje y presenta el sistema técnico, la estructura de una clase y los fundamentos teóricos para realizar una planificación del entrenamiento o de diversas actividades. La tercera parte señala la importancia del grado, su proceso de formación, actitud y objetivos, comenta las diferencias entre práctica y estudio, la importancia del estudio de las armas, los contenidos técnicos que conforman los grados desde $6^{\circ}$ hasta $1^{\circ}$ kyu, los fundamentos de la evaluación en el aikido y la utilización del video y el papel del sensei en la evaluación. Adjunta 16 anexos con la ilustración de ejemplos prácticos de fichas, plantillas y cuadros para el control del aprendizaje, el estudio, la evaluación, el entrenamiento y un diploma.

47. Planells i Garcés, Encarna (2005). Aikido : una guía para la prevención y recuperación de lesiones. Madrid: Eyras. 1aㅡ ed. 159 p. : il. ; 17x24 cm. ISBN: 84-96492-04-4. Depósito legal: M. 48135-2005. Palabras clave: fundamentos teóricos, enfermedades, lesiones, medicina, rehabilitación. Resumen: Tratado teórico sobre lesiones en el aikido. La obra esta formada por 3 capítulos. El primer capítulo define el concepto de lesión, clasifica las lesiones y comenta los síntomas principales y las características de los 3 períodos que sigue una lesión. El segundo capítulo presenta el aikido y analiza las técnicas más utilizadas atendiendo a los músculos que intervienen, las lesiones más frecuentes durante cada técnica, los primeros auxilios a aplicar en cada caso, cómo hacer la rehabilitación de la zona afectada y cuáles son las medidas de prevención par evitar esas lesiones. Las técnicas estudiadas e ilustradas en el segundo capítulo son: ikkyo, nikyo, sankyo, iriminage, hijikimeosae, shihonage, udekimenage, yonkyo, gokyo, kaitennage, kotegaeshi, tenchinage, kokyunage, koshinage, kiriotoshi, sumiotoshi. Además incluye un cuadro resumen de los motivos de las diferentes lesiones. El último capítulo describe las lesiones óseas (fracturas), articulares (ligamentosas, luxaciones, menisco, artritis, artrosis, contusión y bursitis), musculares (roturas, hematomas, contracturas, distensión, contusión, miositis, lesiones tendinosas) y de la piel más frecuentes en la práctica del aikido, explicando sus tipos, la localización, los síntomas y diagnóstico, el tratamiento y la rehabilitación de las mismas.

48. Protin, André (1990). Aikido : un arte marcial (acceso a otro modo de ser). Barcelona: Ibis. 1a ed. 322 p. : il. ; 15x22 cm. ISBN: 84-86512-34-4. Depósito legal: no. (2ª ed., 1993; $2^{\underline{a}}$ ed. y $1^{\mathrm{a}}$ reimp., 1998). Palabras clave: historia, fundamentos teóricos, pedagogía, principios técnicos, principios filosóficos, vestimenta, cortesía, fundamentos filosóficos, etiqueta. Resumen: Tratado teórico de aikido. El libro esta dividido en 5 partes precedidas por una introducción que señala los objetivos de la obra y un prefacio que comenta el estudio y modernización de las artes marciales. La primera parte consta de 4 capítulos. El primer capítulo relata la historia y fundamentos teóricos del shintoismo, budismo, taoísmo y confucianismo, y expone las cualidades y comportamientos humanos según los autores y textos orientales. El segundo capítulo comenta el significado, importancia e influencia del bushido y el budismo zen. El tercer capítulo narra la evolución histórica de las artes marciales desde el bujutsu al budo. El cuarto capítulo explica la biografía y obra de Morihei Ueshiba. La segunda parte consta de 7 capítulos. El primer capítulo explica en qué consiste el aikido y cuáles son sus vertientes. El segundo capítulo analiza el significado de los fundamentos técnicos del aikido. El tercer capítulo comenta los contenidos técnicos de las artes marciales y describe los principios técnicos del aikido. El cuarto capítulo detalla las actitudes del practicante para progresar en el entrenamiento. El quinto capítulo expone las cualidades del aikido como método de defensa. El sexto capítulo analiza el principio de no violencia en la práctica del aikido. El séptimo capítulo analiza el papel de los guerreros en la transmisión de las artes marciales. La tercera parte consta de 6 capítulos. Los primeros cuatro capítulos describen el significado y enseñanzas de los comportamientos en el dojo, la etiqueta y los rituales, la postura seiza y la respiración. El quinto capítulo analiza el significado de la postura meditativa y la respiración voluntaria en el aikido y las compara con el yoga. El sexto capítulo explica el significado de los distintos símbolos que componen el aikido. La cuarta parte consta de 3 capítulos. El primer capítulo discute los peligros de la deportivización de las artes marciales. El segundo capítulo describe el método de enseñanza de las artes marciales en la antigüedad. El tercer capítulo analiza la influencia del aikido sobre el desarrollo psicológico del practicante. La quinta parte consta de 4 capítulos. El primer capítulo presenta la imagen del hombre desde el pensamiento oriental. El segundo 
capítulo comenta las etapas de aprendizaje de los fundamentos técnicos del aikido. Los dos últimos capítulos explican el significado del do y el kokyu. Adjunta un epílogo, un glosario específico y bibliografía.

49. Puig-Siscar (1968). Aiki-do : método de combate de los guerreros samuráis. Barcelona: Alas. 1a ed. 80 p. : il. ; 10x15,5 cm. ISBN: No ISBN. Depósito legal: B. 36543-1968. Palabras clave: historia, fundamentos teóricos, fundamentos técnicos, defensa personal, grados. Resumen: Manual teórico y técnico de aikido. La obra esta formada por 5 capítulos, precedidos por una introducción que narra la historia del aikido, comenta en qué consiste su práctica, su evolución y sus beneficios. El primer capítulo resalta la aplicación del aikido en los cuerpos de seguridad y sus beneficios. El segundo capítulo comenta cómo debe realizarse la formación del practicante para progresar en el aikido, mientras que el tercer capítulo detalla las cualidades físicas, técnicas y mentales de un buen practicante. El cuarto capítulo describe la vestimenta y el sistema de grados del aikido. El último capítulo describe e ilustra la ejecución técnica de algunas formas de caer así como de distintas técnicas de luxación y proyección aplicadas a la defensa personal y explicadas por partes.

50. Ruglioni, Giuseppe (2003). Ki aikido : unificación de la mente y el cuerpo. Según las enseñanzas del Maestro Koichi Tohei. Barcelona: Paidotribo. 1aㅡ ed. 201 p. : il. ; 15x21,5 cm. ISBN: 84-8019-683-1. Depósito legal: no. (2 $\underline{a}$ ed., 2006). Palabras clave: fundamentos teóricos, pedagogía, principios técnicos, aikido, aplicación marcial. Resumen: Manual teórico y técnico de aikido. La obra esta compuesta de 2 partes. La primera parte estudia la práctica del ki, definiendo la práctica, explicando la unificación cuerpo-mente y realizando recomendaciones para verificar el ki, unificar la mente y el cuerpo, desarrollar el fudoshin, mejorar la meditación y respiración ki, realizar los ejercicios de gimnasia ki, describe la ejecución de distintos ejercicios de la gimnasia ki y expone algunas recomendaciones sobre el kuatsu. También expone las características del aikido, las recomendaciones para la práctica, las fases de aprendizaje, el empleo del randori, la utilización del bokken y jo, y los criterios para comprender los taigi (secuencias de movimientos). La segunda parte expone la metodología de enseñanza del ki y del ki aikido que ha realizado el autor y su aplicación a niños y escuelas, a terapeutas, a personas discapacitadas, a educadores, a artistas, al deporte y al trabajo. Adjunta un apéndice con el esquema de recomendaciones, la secuencia gráfica de los ejercicios de ki taiso y aiki taiso, y un listado mundial de centros.

51. s.a. (2009). Aikido : la herencia de Ueshiba en Occidente. Los maestros occidentales. Madrid: Budo International. $1^{\underline{a}}$ ed. 207 p. : il. ; $17 \times 24$ cm. ISBN: 978-84-92484-49-2. Depósito legal: M. 44865-2009. Palabras clave: entrevistas, maestros. Resumen: Manual teórico de aikido. El libro esta formado por 13 capítulos precedidos por una introducción que comenta el desarrollo del aikido y los contenidos de la obra. El primer capítulo presenta la figura de Ángel Álvarez así como su reflexión sobre la práctica dinámica del aikido y sus beneficios. El segundo capítulo incluye la entrevista realizada a Christian Tissier sobre su entrenamiento en Japón. El tercer capítulo expone las reflexiones de Alfonso Longueira sobre la eficacia del aikido, sus métodos de trabajo, las antiguas técnicas del aikido y la evolución del aikido e incluye la secuencia fotográfica de varias técnicas de aikido. El cuarto capítulo explica el concepto de kimusubi, el sistema de defensa policial de José Luis Isidro Casas, el ma-ai, la respiración en el aikido, el trabajo de kumi-tachi del aikido, el concepto de uchi-kaiten y diferencia las prácticas de aikijutsu y aikijujutsu. El quinto capítulo comenta el entrenamiento del aikido por parte de las mujeres. El sexto capítulo incluye la entrevista realizada a Steven Seagal sobre su entrenamiento marcial. El séptimo capítulo expone el entrenamiento y técnicas de Mushin aikido del Shihan Francis. El octavo capítulo comenta las características del Tomiki aikido de Ken Broome. El noveno capítulo incluye la entrevista realizada a Paolo Corallini sobre su entrenamiento con el Sensei Saito. El décimo capítulo comenta las características técnicas de la escuela Kisei Dojo de aikido. Los tres últimos capítulos incluyen las entrevistas realizadas a Giampietro Savegnago, Jacek Wisocki y Harvey Konigsberg sobre el entrenamiento marcial y el aikido.

52. Sánchez Díaz, Tomás (2001). Aikido : el maestro y el método. Móstoles: Arkano Books. 1ae ed. 187 p. : il. ;

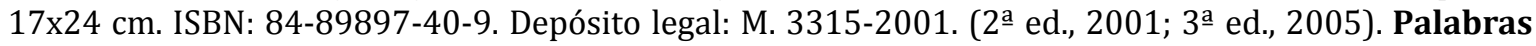
clave: fundamentos técnicos, principios técnicos, exámenes, grados. Resumen: Manual teórico y técnico de aikido. La obra esta compuesta por 7 capítulos. El primer capítulo presenta la metodología de enseñanza utilizada en el aikido tradicionalmente, para luego explicar el contacto del autor con el aikido y señalar las características de este arte marcial. Los dos siguientes capítulos comentan los conceptos relacionados con el dojo y la etiqueta y la importancia de un método correcto para la práctica. El cuarto capítulo expone los fundamentos conceptuales y técnicos del aikido, profundizando en las posiciones básicas, su correcta ejecución y posibilidades de desplazamiento, las caídas, los ataques y zonas de golpeo de la mano, las armas utilizadas, la ilustración de los ejercicios básicos con bokken y jo (palo corto), la relación e importancia entre el sable y el aikido, y la ilustración por parte de las principales técnicas de suwari waza (ikkyo, nikyo, sankyo, yonkyo, gokyo, iriminage, kotegaeshi), hammi handachi waza (shihonage, uchi kaitennage, ikkyo, kotegaeshi), hammi handachi ushiro (sankyo, kotegaeshi), ushiro waza (ikkyo, shihonage), tachi waza (ikkyo, nikyo, shihonage, kotegaeshi, 
iriminage, tenchinage, koshinage), tanto dori (tsuki kotegaeshi, yokomen uchi shihonage, tsuki gokyo, yokomen uchi gokyo, shomen uchi gokyo, kokyunage con tenkan, entrando en irimi, sin nombre, kokyunage, ninin gake). El quinto capítulo detalla el aprendizaje por niveles, de kyu a dan, de los contenidos técnicos del aikido; para finalizar con dos capítulos que exponen el desarrollo de un examen junto con sus características, preparación, ceremonial, vestimenta y participantes, y el significado de la demostración. Adjunta un glosario.

53. Sánchez Díaz, Tomás (2009). Aikido : el practicante y la técnica. Móstoles: Dojo. 1ạ ed. 302 p. : il. ; 17x24 cm. ISBN: 978-84-935400-8-1. Depósito legal: M. 4497-2009. Palabras clave: fundamentos teóricos, principios técnicos, exámenes, grados, fundamentos técnicos. Resumen: Manual teórico y técnico de aikido. La obra esta compuesta por 4 partes, precedidas por un capítulo introductorio que relata la aproximación del autor al aikido y la instauración de este arte marcial en España, acompañado de numerosas fotografías ilustrativas. La primera parte esta compuesta de varios capítulos que presentan la práctica del aikido, como son las características del principiante, del buen alumno, los términos relacionados con el dojo, las normas de etiqueta, la vestimenta y las armas para la práctica junto con sus ilustraciones y las respuestas a algunas de las preguntas más frecuentes; explican sus fundamentos teóricos y principios técnicos básicos, como son la preparación mental y física para la práctica, los tipos de posiciones y los principios técnicos en la posición erguida, la distancia entre compañeros, los desplazamientos y taisabaki, los beneficios de los ukemis (caídas) y sus características, las formas de aplicación de la técnica, algunas nociones básicas sobre los desequilibrios, el control y la inmovilización junto con sus ilustraciones; describen la preparación de la mano y la muñeca para el entrenamiento junto con algunos ejemplos ilustrados de la utilización de la mano en las técnicas; exponen las características de los ritmos de la práctica según el grado o nivel y finaliza comentando las dificultades y beneficios de la práctica así como la relación de la mujer con el aikido. La segunda parte comenta los principios técnicos para dirigir la energía y cómo el control del codo facilita dicho dominio, además de incluir la ilustración detallada de la técnica Ikkyo. La tercera parte explica los criterios de eficacia del aikido para luego ilustrar las técnicas, tanto en omote como en ura, incluidas dentro del programa nacional desde 6⿳⺈ hasta 1er kyu y las técnicas con armas. La cuarta parte comenta cómo se realiza la preparación para el examen y sus características. Adjunta la conclusión final del autor y un glosario.

54. Sánchez Díaz, Tomás y Prat Banús, José María (1981). Aikijo : el arte del bastón corto japonés. Barcelona: Alas. 1aㅡ ed. 110 p. : il. ; 15x21,5 cm. ISBN: 84-203-0118-3. Depósito legal: B. 29906-1981. Palabras clave: katas, historia, fundamentos técnicos, aplicación marcial, maestros. Resumen: Manual teórico y técnico de aikido. La obra esta compuesta por 4 capítulos. El primer capítulo explica las características del aikido, los beneficios de la práctica con el jo y el ken, la descripción técnica e ilustración de katame waza ikkyo, ushiro ryo te dori iriminage y katatedori-shihonage ura como aplicación del taijutsu en el aikido. El segundo capítulo comenta las características y evolución del bastón corto "jo", su historia en Japón en las distintas épocas hasta la creación del método policial de defensa o taiho-jutsu. El tercer capítulo presenta la biografía de Morihei Ueshiba, el desarrollo del aikido, su práctica y sus maestros. El último capítulo presenta el esquema técnico del jo en la escuela Shindo Muso Ryu, las facetas del jo dentro del aikido, la ejecución técnica del aikijo kata, enumerando las técnicas y adjuntando una secuencia fotográfica de la misma, y la ilustración de su aplicación práctica. Adjunta un glosario.

55. Saotome, Mitsugi (1994). Aikido o la armonía de la naturaleza. Barcelona: Kairós. $1^{a}$ ed. 283 p. : il. ; 18x24,5 cm. ISBN: 84-7245-306-5. Depósito legal: B. 24088-1994. (2 $2^{\underline{a}}$ ed., 1996; $3^{\mathrm{a}}$ ed., 1998; $4^{\mathrm{a}}$ ed., 1999; 5a ed., 2001; 6 ${ }^{a}$ ed., 2006; 7a ed., 2009). Palabras clave: historia, fundamentos teóricos, fundamentos técnicos, filosofía, vestimenta, aikido, relatos. Resumen: Tratado teórico y filosófico sobre el aikido. Esta dividido en 14 capítulos, comenzando con la historia, biografía y anécdotas de Ueshiba. El segundo capítulo trata sobre la filosofía que fundamenta en el aikido, para en el tercero pasar a explicar las fuerzas naturales y su aplicación en el aikido. El cuarto capítulo explica el objetivo final del aikido a través de ejemplos y relatos. Los dos siguientes capítulos abordan la justicia y la armonía de la naturaleza y cómo se aplican en el aikido. El séptimo capítulo describe el proceso de formación del bujutsu en el Japón y todos sus condicionantes, para en el siguiente capítulo desarrollar el budo. El noveno capítulo describe la práctica del aikido desde un punto de vista filosófico, estando en concordancia con la naturaleza. El siguiente capítulo explica el significado del ki y su manipulación dentro del aikido, y continua con los conceptos teóricos fundamentales del entrenamiento. El decimosegundo capítulo reflexiona sobre los fundamentos de la técnica y de su entrenamiento, y describe algunas técnicas. El penúltimo capítulo ofrece algunas anécdotas sobre el entrenamiento del autor junto con Ueshiba y finaliza con las reglas básicas del practicante de aikido al entrar al dojo, no sólo formales sino también actitudinales.

56. Saotome, Mitsugi (2001). Los principios del aikido. Barcelona: Paidotribo. $1^{\mathrm{a}}$ ed. 241 p. : il. ; 21x27,5 cm. ISBN: 84-8019-611-4. Depósito legal: no. (2a ed., 2006). Palabras clave: fundamentos teóricos, fundamentos técnicos, filosofía. Resumen: Manual teórico y técnico de aikido. La monografía esta 
compuesta de 21 capítulos. Comienza con una breve introducción seguida de 4 capítulos en los que expone la actitud del practicante ante el entrenamiento, el musubi y algunos ejercicios para desarrollar esta sensibilidad, la importancia de un correcto ukemi durante la práctica, el significado de la espada en el aikido y la importancia del ikkyo en cualquier ejercicio. Los siguientes ocho capítulos presentan la ejecución de diferentes técnicas a partir de shomenuchi, yokomenuchi, katadori, chudantsuki, katatedori, ryotedori, sihammmi katati y ushirowaza, y algunas técnicas avanzadas. Cada técnica esta descrita e ilustrada por una secuencia de fotografías. Los cuatro capítulos siguientes reflexionan sobre la filosofía del budo, el sentido del estudio, la explicación del aikido realizada por su fundador e hijo, y el significado del dojo para la práctica del aikido. El decimoctavo capítulo incluye los extractos de algunas conferencias dadas por 0 Sensei sobre la importancia del estudio y la finalidad del aikido; para finalizar con tres breves capítulos que describen el significado del hakama, el camino del autor dentro del aikido y la reflexión sobre el futuro del aikido. Adjunta un glosario y una breve biografía del autor.

57. Shioda, Gozo y Shioda, Yasuhisa (1999). Aikido total : el curso maestro. Barcelona: Paidotribo. 1a ed. 216 p. : il. ; 15x21,5 cm. ISBN: 84-8019-429-4. Depósito legal: B. 20906-1999. (2ª ed., 2001; 3a ed., 2006; 4a ed., 2009, ISBN: 978-84-8019-429-7). Palabras clave: fundamentos técnicos, defensa personal, principios técnicos. Resumen: Manual teórico y técnico de aikido. La obra esta compuesta por 5 secciones, precedidos por un capítulo que explica como utilizar el libro. La primera sección describe los principios del aikido, incluyendo fotografías ilustrativas de los mismos, el sistema de entrenamiento y la explicación de la terminología especial. La segunda sección profundiza en los fundamentos del movimiento del cuerpo, describiendo e ilustrando la postura básica, la potencia del codo, el cambio de movimiento del cuerpo, andar sobre las rodillas, las caídas, los ataques frontales, laterales, las sujeciones y sus defensas. La tercera sección estudia las técnicas básicas de los controles ikkyo, nikyo, sankyo y yonkyo, explicando el movimiento de ambos practicantes, los puntos importantes e ilustrando el movimiento por partes con un análisis más detallado de la finalización de cada técnica. La cuarta parte presenta algunas de las técnicas de auto-defensa, incluyendo la secuencia fotográfica y una descripción de su ejecución técnica. La última sección comenta los principios avanzados de la práctica del aikido. Adjunta el listado de dojos IYAF.

58. Stevens, John (1998). Paz abundante : la biografía de Morihei Ueshiba, fundador del aikido. Barcelona: Kairós. 1aㅡ ed. 139 p. : il. ; 18x24,5 cm. ISBN: 84-7245-415-0. Depósito legal: [B.] 16793-1998. (2a ed., 2005). Palabras clave: fundamentos teóricos, filosofía, biografía. Resumen: Biografía de Morihei Ueshiba. El primer capítulo ofrece la historia de la vida de Ueshiba, desde los hechos históricos y sociales hasta las personas que más le influenciaron. El segundo capítulo nos ofrece los detalles de cómo se fue formando como maestro de artes marciales, cómo se fue configurando su pensamiento y del mismo modo su arte marcial y entrenamiento. El último capítulo detalla la filosofía del aikido, de sus técnicas y de su entrenamiento. Adjunta bibliografía e índice.

59. Stevens, John (2002). El libro del aikido : una introducción imprescindible a la filosofía y práctica del arte marcial conocido como "el Camino de la Paz". Barcelona: Kairós. 1aㅡ ed. 143 p. : il. ; 14x22 cm. ISBN: 847245-523-8. Depósito legal: B. 17849-2002. Palabras clave: fundamentos técnicos, filosofía, aikido, escuelas, maestros. Resumen: Tratado teórico de aikido. El libro esta compuesto por cuatro capítulos. El primero de ellos narra la biografía de su fundador, Morihei Ueshiba, tanto a nivel personal como marcial. Continua con la descripción del aikido y sus fundamentos básicos, saludo, vestimenta, posiciones, desplazamientos y técnicas, a través de fotografías y explicaciones profusas sobre estos aspectos. El tercer capítulo profundiza en los principios filosóficos y morales que impregnan el aikido y finaliza con una breve explicación de los aspectos que ha tomado el aikido de otras artes marciales así como las diferentes escuelas y estilos de aikido que se pueden encontrar el practicante. Adjunta bibliografía y glosario.

60. Suenaka, Roy y Watson, Christopher (2001). Aikido completo : la guía completa al camino de la armonía. Barcelona: Obelisco. 1aㅡ ed. 277 p. : il. ; 20x27 cm. ISBN: 84-7720-857-3. Depósito legal: B. 26456-2001. Palabras clave: historia, fundamentos técnicos, principios técnicos, biografía, aikido, escuelas, instituciones, sociedad. Resumen: Manual teórico y técnico de aikido. El libro esta dividido en 2 partes. La primera parte consta de 10 capítulos que narran la educación marcial del autor desde su niñez, su primer contacto con el aikido, su entrenamiento con Ueshiba, sus traslados a Japón, Okinawa, Charleston, la formación de la Sociedad Internacional del Ki, el establecimiento del Suenaka-Ha Tetsugaku-Ho Aikido y su organización, el desarrollo del gasshuku de verano, y comenta las anécdotas del autor, sus conversaciones y enseñanzas con otros maestros, su idiosincrasia y sus principios marciales. La segunda parte esta compuesta por 10 capítulos que presentan las normas de etiqueta y cortesía del Suenaka-Ha Tetsugaku-Ho Aikido, los cuatro principios técnicos básicos, la forma de respiración correcta y su entrenamiento, el objetivo y características del kiai, los beneficios y entrenamiento de los estiramientos junto con la descripción e ilustración de varios ejercicios para todo el cuerpo, describe e ilustra la ejecución de las técnicas de caída y rodar desde distintas posiciones, las principales técnicas de aiki-taiso, algunos de los ejercicios de ki-no-taiso, y finaliza con la descripción de las técnicas generales del Suenaka-Ha Tetsugaku-Ho Aikido y algunas de las técnicas de 
sometimiento junto con su secuencia fotográfica y los errores más comunes de las mismas. Adjunta una biografía marcial de Morihei Ueshiba y un glosario.

61. Sunadomari, Kanshu (2007). El corazón el aikido. Móstoles: Arkano Books. 1ae ed. 189 p. : il. ; 17x24 cm. ISBN: 978-84-96111-26-4. Depósito legal: M. 3859-2007. Palabras clave: entrenamiento, filosofía. Resumen: Tratado filosófico de aikido. La obra esta formada por 36 capítulos que conformaron los escritos publicados en la revista del dojo del autor. El primer capítulo expone los objetivos del autor en la enseñanza del aikido, mientras que el segundo agradece la aportación de las personas que ha conocido. Los siguientes capítulos reflexionan sobre las enseñanzas espirituales de Morihei Ueshiba sobre el aikido como son los objetivos de los practicantes de aikido, la actitud ante el entrenamiento, los compañeros, la vida diaria y el mundo, las máximas del aikido, el significado de "Takemusu Aiki" y su objetivo, el futuro del dojo Maseikan, el espíritu del practicante y del universo, el estado de la sociedad actual, el camino hacia la paz del universo, los bienes materiales, la gratitud, el significado de "shugyo", la vida, el significado de la fuerza y el espíritu del Aiki Manseido, incluyendo numerosas fotografías y varios aforismos para la reflexión.

62. Tamura, Nobuyoshi (2002). Aikido, etiqueta y transmisión : manual para uso de los profesionales. Barcelona: Paidotribo. $1^{\underline{a}}$ ed. 157 p. : il. ; 15x21,5 cm. ISBN: 84-8019-650-5. Depósito legal: no. (2aㅡ. ed., 2007, ISBN: 978-84-8019-650-6). Palabras clave: fundamentos teóricos, pedagogía, didáctica. Resumen: Manual de enseñanza del aikido. Con un texto breve y conciso, presenta los aspectos que debe considerar el maestro para practicar este arte marcial. El primer capítulo trata sobre la actitud y cualidades del enseñante ante el proceso de enseñanza, para continuar comentando los objetivos que pueden buscarse en las clases. El tercer capítulo reflexiona sobre el método de enseñanza, dividiéndolo en el aspecto técnico y mental, y los medios para conseguirlo. Continua con los aspectos más formales referidos a la etiqueta y disciplina en el dojo. El quinto capítulo refiere los distintos lugares que pueden servir para entrenar y cuáles son los métodos fundamentales de práctica. El sexto capítulo propone la ampliación del conocimiento con el resto de artes marciales, para luego reflexionar sobre los actos de limpieza en las clases. Los siguientes capítulos profundizan en la actitud del profesor ante un nuevo practicante, el significado de los grados, los aspectos relacionados con los exámenes y cómo el aikido fue presentándose poco a poco al público. El siguiente capítulo presenta el material utilizado en el aikido y cómo se debe cuidar, para finalizar con los principios didácticos del maestro Ueshiba y un breve relato.

63. Thomas, Raymond (1971). Aikido : programa para cinturón blanco y amarillo. Barcelona: Alas. 1 a ed. 75 p. : il. ; 11x18,5 cm. ISBN: No ISBN. Depósito legal: 43464-1971. (2a ed., 1975, ISBN: 84-203-0321-6). Palabras clave: historia, fundamentos técnicos, principios técnicos, grados. Resumen: Manual teórico y técnico de aikido. La obra esta dividida en 10 capítulos. El primer capítulo incluye las reglas de entrenamiento en el Aikikai. El segundo capítulo narra brevemente la biografía del maestro Morihei Ueshiba, mientras que el tercero comenta las características de la práctica del aikido. El cuarto capítulo explica el objetivo principal y principio técnico del aikido. El quinto capítulo expone la postura y principales desplazamientos del aikido junto con el sistema de grados. El sexto capítulo describe la ejecución de las técnicas que componen el programa para cinturón blanco, mientras que el séptimo incluye el programa técnico de cinturón amarillo, acompañados de la representación gráfica de cada movimiento y esquemas de movimiento. El octavo capítulo analiza las diferencias entre el judo y el aikido, para finalizar con algunos consejos técnicos para el aprendizaje del aikido y la clasificación de sus técnicas.

64. Thomas, Raymond (1972). Aikido : programa para cinturón azul y marrón. Barcelona: Alas. 1aㅡ ed. 78 p. : il. ; 11x18,5 cm. ISBN: No ISBN. Depósito legal: B. 16112-1972. Palabras clave: fundamentos técnicos, defensa personal, armas. Resumen: Manual teórico y técnico de aikido. La obra esta dividida en 3 capítulos. El primer capítulo describe la ejecución de las técnicas que componen el programa para cinturón azul, mientras que el segundo incluye el programa técnico de cinturón marrón, acompañados de la representación gráfica de cada movimiento. El tercer capítulo incluye la descripción de algunas técnicas de defensa personal ante ataques armados con cuchillo y katana.

65. Thomas, Raymond (1972). Aikido : programa para cinturón naranja y verde. Barcelona: Alas. 1a ed. 76 p. : il. ; 11x18,5 cm. ISBN: No ISBN. Depósito legal: B. 2498-1972. (2ª ed., 1975, ISBN: 84-203-0320-8). Palabras clave: fundamentos técnicos. Resumen: Manual teórico y técnico de aikido. La obra esta dividida en 2 capítulos. El primer capítulo incluye la definición de algunos términos específicos del aikido para luego describir e ilustrar los fundamentos técnicos del cinturón naranja. El segundo capítulo describe la ejecución técnica de los fundamentos del cinturón verde junto con su representación gráfica así como una explicación de los principios técnicos del aikido y un glosario técnico.

66. Tucci, Alfredo (2007). Aikido : el legado de Ueshiba. Maestros y estilos del aikido para el s. XXI. Madrid: Budo International. 1aㅡ ed. 239 p. : il. ; 17x24 cm. ISBN: 978-84-935919-1-5. Depósito legal: M. 324762007. Palabras clave: historia, principios técnicos, filosofía, relatos, entrevistas, maestros. Resumen: Tratado teórico de aikido. La obra consta de 32 capítulos, precedidos por un prólogo que explica la 
evolución mundial del aikido. El primer capítulo incluye una entrevista con Kishomaru Ueshiba. El segundo capítulo narra la biografía y legado de Koichi Toehi. Los dos siguientes capítulos presentan las entrevistas realizadas a Moriteru Ueshiba. Los siguientes siete capítulos exponen las ideas de Yamada sensei respecto al aikido, la muerte de Kishomaru Ueshiba, las cualidades de un buen profesor, el futuro del aikido, los principios básicos del aikido y el aikido en los Estados Unidos. El decimosegundo capítulo compara la vida y obra de Mishima y Ueshiba respectivamente. El siguiente capítulo expone la entrevista realizada a Kensho Furuya. Los siguientes cuatro capítulos presentan varios artículos sobre el proceso de aprendizaje, la parábola del melocotón, la parábola del agua y de la luna y el problema del entrenamiento. El vigésimo capítulo describe los fundamentos y principios técnicos de Kenneth Furuya sobre el manejo del tanto en el aikido junto con la ilustración de algunas técnicas. El siguiente capítulo describe el legado de Haruchika Noguchi y de su escuela. Los dos siguientes capítulos incluyen la secuencia fotográfica de algunas técnicas de Itsuo Tsuda y la entrevista realizada a Toshishiro Obata respectivamente. El vigésimo cuarto capítulo expone los principios del manejo del bokken interpretados por Sueyoshi Akeshi. Los siguientes cinco capítulos narran la biografía de Miyako Fujitani y su marido Steven Seagal, sus ideas y reflexiones sobre el aikido y las artes marciales, y los principios de la Tenshin Dojo Aikido. Los últimos tres capítulos incluyen las entrevistas realizadas a Tetsutaka Sugawara, Sakanashi Masafuni y Hiroshi Kato.

67. Ueshiba, Kisshomaru (1988). El espíritu del aikido. Madrid: Eyras. 1aㅡ ed. 139 p. : il. ; 14x24 cm. ISBN: 84-85269-61-6. Depósito legal: M. 41633-1988. (2ª ed., 1998). Palabras clave: historia, fundamentos teóricos, principios técnicos, filosofía, entrenamiento, kenjutsu, maestros. Resumen: Tratado filosófico, técnico e histórico de aikido. La obra esta formada por 7 capítulos. El primer capítulo presenta las características del aikido como exponente de las artes marciales japonesas, el origen del ki y su aplicación en la vida equilibrada, y su implicación en el aikido y la vida cotidiana. El segundo capítulo explica el concepto "nen" y la rotación esférica como fundamentos de la práctica del aikido, incluyendo varias fotografías del fundador. El tercer capítulo presenta la práctica del aikido tanto en niños como en mujeres, el tipo de entrenamiento y las razones de estos grupos para practicarlo, y la continuidad de la tradición dentro del aikido. También incluye una serie fotográfica de irimi-age. El cuarto capítulo explica el proceso de entrenamiento para alcanzar el objetivo final del aikido y la relación existente entre el aikido y el arte del sable. El quinto capítulo enumera las advertencias en la práctica del aikido, comenta el carácter de los practicantes de aikido, la naturalidad de los movimientos y la aplicación de la teoría del yin y yang a las técnicas del aikido. El sexto capítulo narra la historia de la denominación oficial de aikido y la fundación del santuario Aiki, incluyendo además varias series fotográficas del fundador haciendo demostraciones técnicas. El último capítulo describe el proceso de internacionalización del aikido y el objetivo final del aikido en busca del bienestar de la humanidad. Adjunta un listado mundial de direcciones de aikido y un glosario.

68. Ueshiba, Kisshomaru (1990). Aikido : la práctica. Madrid: Eyras. $1^{\underline{a}}$ ed. 189 p. : il. ; 18x25,5 cm. ISBN: 84-85269-68-3. Depósito legal: M. 20425-1990. Palabras clave: fundamentos técnicos, historia, defensa personal. Resumen: Manual técnico de aikido. Después de hacer una breve introducción, desarrolla los aspectos técnicos del aikido dividiéndolos en ejercicios preparatorios básicos tanto en solitario como por parejas, en técnicas básicas de proyección, control e inmovilización y en aplicación de las técnicas, donde se incluyen técnicas contra ataques a manos vacías y contra armas. Todos estos aspectos técnicos son explicados con claridad y mediante secuencias fotográficas y esquemas de movimiento. Finaliza con la historia y evolución del aikido hasta la actualidad y adjunta un apéndice de artículos sobre el aikido y otros caminos marciales, un análisis de sus principios dinámicos, sus beneficios sobre la salud, las reglas durante la práctica y algunos pensamientos del fundador. También adjunta un glosario.

69. Ueshiba, Kisshomaru (2008). El espíritu del aikido. Móstoles: Dojo. 1aㅡ ed. 139 p. : il. ; 14×24 cm. ISBN: 978-84-935400-6-7. Depósito legal: M. 29390-2008. Palabras clave: historia, fundamentos teóricos, principios técnicos, filosofía, entrenamiento, kenjutsu, maestros. Resumen: Tratado filosófico, técnico e histórico de aikido. La obra esta formada por 7 capítulos. El primer capítulo presenta las características del aikido como exponente de las artes marciales japonesas, el origen del ki y su aplicación en la vida equilibrada, y su implicación en el aikido y la vida cotidiana. El segundo capítulo explica el concepto "nen" y la rotación esférica como fundamentos de la práctica del aikido, incluyendo varias fotografías del fundador. El tercer capítulo presenta la práctica del aikido tanto en niños como en mujeres, el tipo de entrenamiento y las razones de estos grupos para practicarlo, y la continuidad de la tradición dentro del aikido. También incluye una serie fotográfica de irimi-age. El cuarto capítulo explica el proceso de entrenamiento para alcanzar el objetivo final del aikido y la relación existente entre el aikido y el arte del sable. El quinto capítulo enumera las advertencias en la práctica del aikido, comenta el carácter de los practicantes de aikido, la naturalidad de los movimientos y la aplicación de la teoría del yin y yang a las técnicas del aikido. El sexto capítulo narra la historia de la denominación oficial de aikido y la fundación del santuario Aiki, incluyendo además varias series fotográficas del fundador haciendo demostraciones técnicas. El último capítulo describe el proceso de 
internacionalización del aikido y el objetivo final del aikido en busca del bienestar de la humanidad. Adjunta un listado mundial de direcciones de aikido y un glosario.

70. Ueshiba, Morihei (1992). Budo : las enseñanzas del fundador del aikido. Madrid: Eyras. 1aㅡ ed. 135 p. : il. ; 19x26,5 cm. ISBN: 84-85269-74-8. Depósito legal: M. 9907-1992. Palabras clave: fundamentos teóricos, fundamentos técnicos, principios técnicos, entrenamiento, sistemas de entrenamiento. Resumen: Manual teórico y técnico de aikido. La obra esta dividida en 2 partes, precedidas por una introducción que narra la historia y biografía de Morihei Ueshiba y el aikido, incluyendo varias fotografías. La primera parte explica el significado del budo, sus métodos, sus principios técnicos, describe la ejecución de algunas técnicas seleccionadas acompañadas de sus ilustraciones explicativas e incluye algunos poemas sobre el "do". La segunda parte incluye la secuencia fotográfica de las técnicas del noma dojo. Adjunta notas del traductor.

71. Ueshiba, Morihei (1999). Ai-kido : el arte de la paz. Valencia: Ahimsa. 1aㅡ ed. 123 p. : il. ; 13x21 cm. ISBN: 84-931254-0-7. Depósito legal: M. 47837-1999. (2ª ed., 2000). Palabras clave: fundamentos teóricos, principios técnicos, principios filosóficos, entrenamiento, biografía, aforismos. Resumen: Tratado teórico de aikido. La obra esta dividida en 3 partes. La primera parte narra la biografía del maestro Ueshiba junto con una tabla cronológica y la genealogía del aikijutsu y aikido. La segunda parte recopila un amplio conjunto de citas del maestro Ueshiba reflexionando sobre los principios del aikido, el entrenamiento, el combate, la vida y el camino junto con algunas canciones poéticas de la vía. La tercera parte expone los principios teóricos y filosóficos del aikido, explica en qué consiste su práctica, cuáles son los diferentes estilos y sus características, la ejecución de seiza, la hakama, su sistema de grados, presenta las reglas de comportamiento en clase y para la práctica, y sus beneficios. Adjunta un glosario de términos específico y de técnicas básicas.

72. Ueshiba, Morihei (2000). Entrenamiento del budo en el aikido. Barcelona: Paidotribo. 1a ed. 220 p. : il. ; 15x21,5 cm. ISBN: 84-8019-426-X. Depósito legal: no. (2ª ed., 2006). Palabras clave: fundamentos técnicos, aikido. Resumen: Manual de aikido. Esta dividido en 3 capítulos, el primero de ellos compila un conjunto de aforismos y poemas sobre el budo y su enseñanza. El segundo capítulo presenta los fundamentos de cualquier técnica de aikido, tanto de pie, como arrodillados o por detrás. El último capítulo presenta las técnicas de aikido, con una explicación concisa y varias ilustraciones, de pie y arrodillados (Suwari waza: shome, yokomen, kata, sode, ryosode, mune, kubijime, te, hanmi handachi; Tachi waza: shomen, yokomen, kata, sode, ryo kata, katate, aikinage, kokyu, shiho nage, mune, mune to te, kubijime, ushiro eri, kata, ude, tekubi).

73. Ueshiba, Morihei (2007). Budo : las enseñanzas del fundador del aikido. Móstoles: Dojo. 1a ed. 135 p. : il. ; 17x25,5 cm. ISBN: 978-84-935400-1-2. Depósito legal: M. 25650-2007. Palabras clave: fundamentos teóricos, fundamentos técnicos, principios técnicos, entrenamiento, sistemas de entrenamiento. Resumen: Manual teórico y técnico de aikido. La obra esta dividida en 2 partes, precedidas por una introducción que narra la historia y biografía de Morihei Ueshiba y el aikido, incluyendo varias fotografías. La primera parte explica el significado del budo, sus métodos, sus principios técnicos, describe la ejecución de algunas técnicas seleccionadas acompañadas de sus ilustraciones explicativas e incluye algunos poemas sobre el "do". La segunda parte incluye la secuencia fotográfica de las técnicas del noma dojo. Adjunta notas del traductor.

74. Ueshiba, Moriteru (2009). Aikido paso a paso : una guía práctica. Barcelona: Kairós. 1a ed. 197 p. : il. ; 18x24,5 cm. ISBN: 978-84-7245-699-0. Depósito legal: B. 3690-2009. Palabras clave: fundamentos teóricos, fundamentos técnicos, armas, combate, entrenamiento. Resumen: Manual teórico y técnico de aikido. La obra esta compuesta por 6 capítulos. El primer capítulo expone las características y beneficios del aikido además de explicar el significado del ki, de los conceptos técnicos básicos y los principios que rigen la práctica. El segundo capítulo comenta las características de los fundamentos técnicos básicos como son: kamae, ukemi, shikko, te-gatana, los movimientos del cuerpo y kokyu-ho, y explica la ejecución técnica por partes de varios ejemplos de cada uno de ellos con sus respectivas ilustraciones explicativas y notas. El tercer capítulo comenta cuales son los métodos de entrenamiento (tanren-ho) y los métodos de técnica (gi-ho) para luego ofrecer un comentario general, la descripción técnica por partes junto con sus ilustraciones y las notas de 9 técnicas de nage-waza, 16 técnicas de katame-waza y 3 técnicas de nage-katame-waza. El cuarto capítulo mantiene la misma estructura de sus contenidos para profundizar en las variaciones técnicas y describir otras 5 técnicas de nage-waza y 8 de katame-waza. El quinto capítulo comenta los aspectos generales, describe e ilustra por partes 5 técnicas de nage-waza, 4 de katame-waza, 2 de nage-katame-waza, 4 de tanto-dori (ataque con cuchillo) y 2 de futari-dori (ataque de dos compañeros) además de incluir notas sobre los detalles técnicos de cada una de ellas. El último capítulo describe e ilustra las formas de saludar, algunos ejercicios de calentamiento de las muñecas y de estiramiento de la espalda, y unas nociones básicas sobre la vestimenta del aikido y su colocación.

75. Ueshiba, Morihei (2009). El arte de la paz. Barcelona: Kairós. 1ae ed. 108 p. : il. ; $13 \times 20$ cm. ISBN: 97884-7245-713-3. Depósito legal: B. 23480-2009. Palabras clave: fundamentos teóricos, principios técnicos, principios filosóficos, entrenamiento, biografía, aforismos. Resumen: Tratado teórico de 
aikido. El libro esta dividido en 3 partes precedidas por un prefacio que comenta los contenidos de la obra y la explicación de algunos términos. La primera parte narra la biografía del maestro Ueshiba. La segunda parte explica en qué consiste el aikido en contraposición con el arte de la guerra. La tercera parte recopila un amplio conjunto de citas del maestro Ueshiba reflexionando sobre los principios del aikido, el entrenamiento, el combate, la vida y el camino.

76. Westbrook, Adele y Ratti, Oscar (2001). Aikido y la esfera dinámica. Barcelona: Obelisco. 1a ed. 349 p. : il. ; 20x27 cm. ISBN: 84-7720-878-6. Depósito legal: B. 39906-2001. (2ª ed., 2005; 3a imp., 2009). Palabras clave: fundamentos teóricos, principios técnicos, entrenamiento. Resumen: Manual introductorio al aikido desde sus aspectos más prácticos. Después de presentar en el primer capítulo al aikido y sus características distintivas respecto de otras artes marciales, pasa a describir los fundamentos que formaron su base, esto es, su fundador, el resto de artes marciales, sus fuentes de inspiración y su ética. El tercer capítulo presenta los aspectos organizativos del arte, desde la jerarquía hasta el protocolo. El siguiente capítulo ahonda en los principios físicos, dinámicos y técnicos que deben presidir las prácticas para luego pasar a definir la teoría de la defensa con sus respectivos fundamentos. El sexto capítulo incide sobre la preparación física del practicante mostrando ejercicios sobre flexibilidad, coordinación y volteretas. Continua con la explicación práctica de los factores funcionales del aikido (postura, movimiento y técnicas) para luego pasar a describir, literal y gráficamente, las principales técnicas de neutralización (inmovilizaciones, proyecciones y combinaciones). El noveno capítulo progresa en la enseñanza del arte con ejercicios avanzados (de rodillas, con bastón, contra un arma o contra un ataque múltiple). Tras la presentación de las conclusiones o ideas finales aparece un glosario, la sección bibliográfica y los índices analítico, de cuadros y tablas, y general.

\subsubsection{Judo y Jujutsu}

77. Adams, Neil (1992). Luxaciones : técnicas maestras de judo. Barcelona: Paidotribo. 1a ed. 145 p. : il. ; 15x21,5 cm. ISBN: 84-8019-013-2. Depósito legal: B. 9688-1992. Palabras clave: fundamentos técnicos, defensa personal, competición. Resumen: Tratado técnico sobre las luxaciones del judo. Después de ofrecer una visión personal sobre estas técnicas y explicar brevemente su historia, describe la ejecución de cada técnica, apoyándose en material gráfico, algunas de sus variantes de competición, y ejemplos reales de su aplicación en la competición. Las técnicas descritas son: jujigatame, ude-gatame, ude-garami, waki-gatame, luxaciones de pie, hara-gatame y combinaciones especiales. Finaliza con la aplicación de algunas luxaciones en la defensa personal y la narración de la aplicación de luxaciones por parte de competidores de alto nivel en la competición. Adjunta un breve epílogo.

78. Adams, Neil y Ferrie, Eddie (1992). Los agarres : técnicas maestras de judo. Barcelona: Paidotribo. 1a ed. 160 p. : il. ; 14x21,5 cm. ISBN: 84-86475-98-8. Depósito legal: B. 40474-1992. Palabras clave: fundamentos teóricos, fundamentos técnicos, entrenamiento. Resumen: Manual técnico sobre el kumikata de judo. Después de hacer una valoración personal de la importancia y papel del agarre en la competición de judo, presenta la utilización del agarre a lo largo de la historia. Los dos capítulos siguientes ofrecen una clasificación de los tipos de agarre así como los métodos para utilizar éstos agarres. A continuación describe los métodos de defensa para evitar los diferentes agarres y su estrategia. El sexto capítulo ofrece algunos ejercicios para desarrollar la fuerza del agarre y finaliza con un breve comentario sobre el papel que puede jugar un buen agarre para utilizar el judo como sistema de defensa personal. Adjunta epílogo y apéndice sobre el reglamento referente a la vestimenta.

79. Aguilar Cruz, Miguel Angel (2009). Desarrollo de las cualidades físicas y coordinativas a través de los deportes de lucha : el judo en la escuela. Granada: Ada book. 1aㅡ ed. 170 p. ; 17x24 cm. ISBN: 978-8492990-31-3. Depósito legal: no.

80. Álamo Mendoza, José Miguel (2008). La iniciación al judo en la Educación Física escolar. Sevilla: Wanceulen. $1^{\text {a }}$ ed. 78 p. : il. ; 17x23,5 cm. ISBN: 978-84-9823-220-2. Depósito legal: SE5936-2008. Palabras clave: historia, pedagogía, educación, vestimenta, cortesía, competición, deportes de combate, etiqueta, planificación del entrenamiento, programa técnico. Resumen: Tratado teórico de judo. El libro esta compuesto de 6 capítulos. El primer capítulo define los deportes de lucha y relata la génesis y evolución de estas prácticas. El segundo capítulo narra el origen del judo, su introducción en España y su llegada a Canarias. El tercer capítulo analiza los aspectos formales de la competición de judo, como el tatami, la vestimenta, la interacción entre los competidores, el sistema de puntuación y las penalizaciones. El cuarto capítulo comenta las características específicas de la Educación Física y las distintas formas de incluir los deportes de lucha y el judo dentro de la misma, mostrando la adaptación de sus contenidos y objetivos al planteamiento educativo. El quinto capítulo clasifica los contenidos del judo, analiza sus particularidades y expone sus objetivos y progresión de aprendizaje. El último capítulo presenta la relación entre los objetivos del judo y los objetivos didácticos, las formas de 
aproximación a la situación de lucha a través del juego, las etapas del proceso de enseñanzaaprendizaje y los criterios para programar los contenidos de los deportes de lucha y el judo. Adjunta bibliografía.

81. Alavedra, José (1958). Aprenda y practique el judo. Barcelona: Alas. 1aㅡ ed. 16 p. : il. ; 15x21 cm. ISBN: No ISBN. Depósito legal: B. 2877-1958. Palabras clave: fundamentos teóricos, fundamentos técnicos. Resumen: Manual teórico y técnico de judo. Los dos primeros capítulos narran brevemente la historia del judo en Europa y España así como la biografía de Jigoro Kano. El tercer capítulo explica en qué consiste el judo y cuáles son sus principios técnicos, para luego resaltar sus beneficios físicos y relatar el combate entre un judoka (Raku) y un luchador de greco-romana (Salvador). Los dos siguientes capítulos explican los contenidos técnicos del judo y sus métodos de entrenamiento. Los tres siguientes apartados exponen las características de la posición correcta, la manera de agarrar al adversario y los principios tácticos en el combate. El décimo apartado presenta las caídas y continúa ensalzando la belleza del judo al proyectar al adversario. Los siguientes cuatro capítulos describen el área de competición, las características generales de la competición, la forma de ganar un combate, su duración y arbitraje. Los dos últimos apartados describen e ilustran las principales técnicas de proyección e inmovilización y de estrangulación y luxación.

82. Alavedra, José y Bastenier, M.A. (1966). Practique judo : el deporte de defensa por excelencia. Barcelona: Alas. 1aㅡ ed. 91 p. : il. ; 10x15 cm. ISBN: No ISBN. Depósito legal: B. 12797-1966. Palabras clave: fundamentos técnicos, principios técnicos, defensa personal, entrenamiento, competición, preparación física, armas. Resumen: Manual teórico y técnico de judo. El libro esta dividido en dos capítulos. El primer capítulo esta formado por varios apartados que narran brevemente la historia del judo en Europa y España así como la biografía de Jigoro Kano; explican en qué consiste el judo y cuáles son sus principios técnicos; resaltan sus beneficios físicos; explican los contenidos técnicos del judo y sus métodos de entrenamiento; exponen las características de la posición correcta, la manera de agarrar al adversario y los principios tácticos en el combate; presentan las caídas; describen el área de competición, las características generales de la competición, la forma de ganar un combate, su duración y arbitraje; y exponen e ilustran las principales técnicas de proyección e inmovilización y de estrangulación y luxación. El segundo capítulo esta compuesto por cinco apartados. El primer apartado describe algunos ejercicios para fortalecer la musculatura del cuello así como la respuesta defensiva a varias situaciones de estrangulación. El segundo apartado explica la defensa ante dos situaciones distintas con dos atacantes desarmados. El tercer apartado describe 6 situaciones de defensa ante ataques armados con palo, silla y cuchillo. El cuarto apartado describe varios ejercicios para fortalecer y dotar de flexibilidad a las extremidades inferiores y cadera, así como su utilización en una situación de defensa personal. El último apartado describe la resolución de diferentes situaciones de defensa personal ante un ataque armado con una pistola desde distintas direcciones y distancias.

83. Alba Alonso, Carlos (1994). Jiu-Jitsu : la herencia de los samuráis. Programa oficial de cinturón negro. Madrid: Esteban Sanz Martínez. 1ํeㄹ. 283 p. : il. ; 17x24 cm. ISBN: 84-85977-56-4. Depósito legal: TO. 850-1994. Palabras clave: historia, fundamentos técnicos, principios técnicos, programa técnico. Resumen: Manual teórico y técnico de jiu-jitsu. La obra esta compuesta de 4 partes. La primera relata la historia del jiu-jitsu, su introducción en España y pioneros; y continúa con la explicación de la formación del gokio oficial de jiu-jitsu en España. La tercera parte desarrolla los contenidos incluidos dentro del gokio, explicando los fundamentos de los golpes, bloqueos, controles, proyecciones y trabajo en el suelo. La última parte y más extensa estudia la progresión técnica desde los kius hasta el cinturón negro 1er dan explicando los contenidos técnicos de cada nivel e incluyendo fotografías. Además, enumera el trabajo para los niveles de $2^{\circ}$, 3er, $4^{\circ}$ y $5^{\circ}$ dan, incluyendo las fotografías de algunas de sus técnicas.

84. Alonso, Marcelo; Tucci, Alfredo y el equipo de reporteros de Cinturón Negro (2008). La familia Gracie y la revolución del jiu-jitsu. Madrid: Budo International. 1a ed. 287 p. : il. ; $17 \times 24$ cm. ISBN: 978-84936306-0-7. Depósito legal: M. 6683-2008. Palabras clave: historia, jujutsu, vale tudo, entrevistas, maestros. Resumen: Tratado histórico de jiu-jitsu. La obra consta de 23 capítulos, precedidos de un prólogo que comenta los contenidos de la obra. Los tres primeros capítulos incluyen las entrevistas realizadas a Helio Gracie, Rickson Gracie y un comentario sobre los combates "sin reglas" actuales. El cuarto capítulo presenta describe e ilustra la ejecución técnica de tai-otoshi. El resto de capítulos incluyen las entrevistas y artículos, acompañados de numerosas fotografías, aparecidos en la revista Cinturón Negro sobre Carlos Gracie Jr., Royce Gracie, Royler Gracie, la formación de Carlson Gracie, Joao Alberto Barreto; la vida deportiva de Carlson Gracie, Renzo Gracie, Carlos Gracie, Rorion Gracie, Kyra Gracie, Robson Gracie, Pedro Hemetério, Royler Gracie, Rickson Gracie, la historia del vale tudo en Brasil, un resumen de la vida de Carlson Gracie tras su muerte, la vida de Conde Koma y sus enseñanzas a Carlos Gracie, Francisco Mansur y otra entrevista con Helio Gracie.

85. Álvarez, Vicente (1961). Defensa personal. Barcelona: Atlas. 1aㅡ ed. 114 p. : il. ; 13x18,5 cm. ISBN: No ISBN. Depósito legal: B. 11916-1961. Palabras clave: fundamentos técnicos, defensa personal, ejercicios, kyusho, preparación física, armas. Resumen: Manual teórico y técnico de jiu-jitsu. La obra 
esta formada por 19 capítulos, precedidos por unas observaciones generales previas a la práctica. El primer capítulo localiza los puntos sensibles del cuerpo humano. El segundo capítulo describe algunos ejercicios para endurecer la mano para luego explicar las distintas formas de caer acompañadas de su ilustración y esquemas de movimiento. Los siguientes capítulos presentan la descripción y representación gráfica de las paradas y ataques contra los empujones de pecho, el agarre de solapa, las presas de muñeca, el estrangulamiento por detrás, una presa de cintura, ataques por la espalda y el costado y una presa de cabeza. El décimo segundo capítulo muestra los distintos golpes con las manos y luego los golpes con el codo, incluyendo su representación gráfica y esquemas de movimiento. Los siguientes seis capítulo expone las defensas contra patadas, agarres del cabello, ataques con palo y navaja, distintas formas de reducir a un agresor, defensas en el suelo y contra el ataque de un perro, incluyendo numerosas ilustraciones y esquemas de movimiento.

86. Amador Ramírez, Fernando; Villamón Herrera, Miguel; Simon Wack, Wolfgang Josep; Dopico Calvo, Jorge; Iglesias Soler, Eliseo; Blas Pérez, Fernando; Carratalá Deval, Vicente; Idarreta Galarraga, Julen; Torres Casado, Guillermo y Espartero Casado, Julián (1997). El judo y las ciencias de la educación física y el deporte. Vitoria: Instituto Vasco de Educación Física. 1aㅡ ed. 178 p. : il. ; 21x29,5 cm. ISBN: 8489703-75-2. Depósito legal: BI. 2290-1997. Palabras clave: historia, fundamentos teóricos, didáctica, entrenamiento, investigación. Resumen: Compendio de estudios científico-técnicos sobre el judo. Compuesto por 11 capítulos o estudios, los temas tratados son: la conceptualización y clasificación de los deportes de lucha; las raíces históricas y filosóficas del judo; la introducción de las actividades de lucha en el currículum; el análisis de la acción de lucha desde la teoría de sistemas; una propuesta de aprendizaje en judo a través de las capacidades coordinativas; el análisis de las variables del proceso de enseñanza-aprendizaje para optimizarlo; la propuesta de sistemas para optimizar la ejecución técnica y táctica; la mejora del rendimiento a través del randori y shiai; la resistencia específica a través del randori; los factores de riesgo en las proyecciones; y el entrenamiento de Goshinjutsu-nokata como medio para desarrollar la defensa personal.

87. Antón López, Julio (1964). Educación física y judo. Ceuta: Imprenta Imperio. 1a ed. 68 p. : il. ; 16x21,5 cm. ISBN: No ISBN. Depósito legal: CE. 56-1964. Palabras clave: didáctica, ejercicios, entrenamiento, psicología, competición. Resumen: Tratado teórico de judo. El libro esta formado por 15 capítulos. El primer capítulo discute la utilización de la fuerza en el judo. El segundo capítulo define las características físicas y psíquicas de los distintos tipos de deportistas según su nivel de entrenamiento. El tercer capítulo resalta la importancia de la voluntad tanto para los resultados en el entrenamiento como para la vida. El cuarto capítulo expone las etapas de crecimiento del ser humano, las características psíquicas de cada etapa y la aplicación de la Educación Física a cada una de ellas. El quinto capítulo describe la exigencia física de judo y ofrece algunos consejos sobre la respiración en su práctica. Los siguientes tres capítulos describen las características del niño, el joven y la mujer, y la aplicación y beneficios del judo a éstos. El noveno capítulo comenta algunas de las cuestiones referentes a la vertiente deportiva del judo, como el entrenamiento de pesas y el peso de los participantes. El décimo capítulo expone la aplicación del judo en la escuela, la oficina y el taller. Los dos siguientes capítulos describen el entrenamiento para el atleta pícnico y para el resto de tipos de atletas, incluyendo la descripción de distintos ejercicios gimnásticos para su desarrollo. El capítulo decimotercero comenta las particularidades del entrenamiento para la competición. El siguiente capítulo ofrece algunos consejos prácticos para mantener la higiene del judoka. El último capítulo describe la ejecución de los desequilibrios y el saludo, comenta la alimentación del judoka, presenta el masaje y la helioterapia como ayudas para el judo, y expone los efectos terapéuticos del judo. Adjunta el programa para el examen de cinturón negro y un decálogo de consejos para el practicante.

88. Arpin, Louis (1974). Guía de judo : técnica en pie. Tachi-waza (Go-kyo). Bilbao: Mensajero. 1a ed. 175 p. : il. ; 13×20 cm. ISBN: 84-271-0831-1. Depósito legal: BI. 623-1974. Palabras clave: historia, fundamentos técnicos, principios técnicos, programa técnico. Resumen: Manual teórico y técnico de judo. La obra esta formada por 9 capítulos. Los tres primeros capítulos incluyen un breve léxico de judo, una nota aclaratoria sobre la pronunciación japonesa, los números en japonés, una introducción que resume los contenidos del libro, y la historia mundial del judo. El cuarto capítulo explica brevemente en qué consiste la práctica del judo y describe brevemente los fundamentos del judo como el agarre, los desplazamientos y el tai-sabaki, el desequilibrio, la construcción del movimiento, el encadenamiento, las caídas, los roles de los practicantes y la enumeración de las técnicas incluidas en el go-kyo. Los siguientes cinco capítulos presentan las 40 técnicas del gokyo, divididas en cinco grupos, describiendo su ejecución técnica, algunos consejos avanzados, las contrapresas y encadenamientos más frecuentes, los posibles peligros de su ejecución, e incluyendo su ilustración.

89. Arpin, Louis (1974). Guía de judo en el suelo : ne-waza. Bilbao: Mensajero. 1a ed. 157 p. : il. ; 14x21 cm. ISBN: 84-271-0838-9. Depósito legal: BI. 660-1974. Palabras clave: fundamentos teóricos, fundamentos técnicos, filosofía. Resumen: Manual técnico del trabajo de judo en el suelo. Esta dividido en cuatro capítulos, precedidos por un vocabulario específico de judo, la historia del autor y las máximas de Jigoro Kano. El primer capítulo aborda las técnicas de inmovilización, ofreciendo una 
breve explicación y numerosas fotografías. El segundo capítulo presenta las técnicas de estrangulación, con la descripción de sus puntos clave y apoyo gráfico, y el siguiente las técnicas de luxación de la misma manera. El cuarto capítulo es un compendio de conocimientos generales del judo, como los cinturones, la competición y su reglamento, el dojo, algunos consejos prácticos para el entrenamiento y la forma de colocarse el judogi. También incluye el esquema de la nage-no-kata y la katame-no-kata así como unas breves anotaciones sobre el kiai, el katsu, el saludo, el tanden, el tatami, el uchi-komi, el zen, las mujeres, los jóvenes y los menos jóvenes.

90. Arruza Gabilondo, Josean (1996). Estado de ánimo, esfuerzo percibido, frecuencia cardiaca. Un estudio aplicado al entrenamiento de judo. Bilbao: Servicio Editorial de la Universidad del País Vasco. 1aㅡ ed. 285 p. : il. ; $17 \times 24$ cm. ISBN: 84-7585-792-2. Depósito legal: BI. 797-1996. Palabras clave: judo, entrenamiento, tests, fisiología. Resumen: Tratado teórico sobre judo. La tesis analiza la fiabilidad del esfuerzo percibido como medida de control del esfuerzo en el judo, validado a través de la frecuencia cardiaca y el estado de ánimo. La obra esta dividida en 5 partes. La primera parte resume los contenidos tratados de la obra y comenta sus antecedentes. La segunda parte realiza una revisión teórica y una propuesta de las variables estudiadas, como son las formas de entrenamiento, la intensidad, la frecuencia cardiaca, el esfuerzo percibido y el estado de ánimo. La tercera parte enumera los objetivos, describe la metodología aplicada en la realización del estudio y presenta los resultados obtenidos y discusión en la medición de dichas variables en el entrenamiento de judo. La cuarta parte expone las conclusiones alcanzadas en cada una de las variables y la última parte incluye la bibliografía consultada.

91. Artímez, José Antonio (1991). Seréis campeones : judo. Estella: La Vanguardia. 1aㅡ ed. 62 p. : il. ; 14×20,5 cm. ISBN: 84-87584-45-4. Depósito legal: NA. 1436-1990. Palabras clave: historia, fundamentos técnicos, principios técnicos, biografía, competición, maestros. Resumen: Manual teórico y técnico de judo. La obra esta compuesta por 5 capítulos. El primer capítulo narra los orígenes del judo, su difusión en Europa y la labor de Jigoro Kano. El segundo capítulo comenta las características de la competición durante sus inicios y algunas de sus anécdotas durante sus primeras apariciones en los JJ.00. El tercer capítulo describe la vestimenta, el sistema de grados, el tatami, un resumen de las reglas de competición, las formas de saludo y la clasificación de los contenidos técnicos del judo. El cuarto capítulo expone la secuencia de ejercicios para el aprendizaje de las caídas, describe los fundamentos y principios de las técnicas de proyección, estrangulación, inmovilización y luxación, junto con la explicación de la ejecución técnica de sus principales técnicas y sus errores; y ofrece algunos consejos prácticos para la enseñanza del judo en la infancia. El último capítulo presenta la biografía, acompañada de una foto, de Anton Geesink, Jigoro Kano, Wilhelm Ruska y Yashuire Yamashita. Adjunta vocabulario.

92. Azcarate Sumalde, Enrique (1974). Agenda-memoria del judoka. Pamplona: Gráficas Iruña. 1a ed. 117 p. : il. ; 15x21 cm. ISBN: No ISBN. Depósito legal: NA. 829-1974. Palabras clave: katas, fundamentos técnicos. Resumen: Manual técnico de judo. La monografía esta formada por 6 partes, precedidas por una tarjeta de filiación del judoka, una tabla de los grados y títulos adquiridos, una tabla de resultados en competiciones, espacio para notas sobre los grados y resultados obtenidos y un pequeño vocabulario. Las seis partes mantienen la misma estructura de contenidos, incluyendo la representación gráfica de las técnicas presentadas junto con su nombre y un espacio libre para incluir notas. La primera parte esta compuesta por 3 capítulos que incluyen una ilustración y el nombre de las principales técnicas de proyección de pierna, de cadera y de brazo respectivamente, además de un espacio para notas sobre cada grupo de técnicas. La segunda parte esta formada por 3 capítulos que presentan las principales técnicas de sacrificio de enrollamiento, echando el cuerpo hacia atrás y hacia un lado. La tercera parte consta de 3 capítulos que exponen las principales técnicas aplicadas en el suelo incluyendo las técnicas de inmovilización, estrangulación y luxación respectivamente. Las tres últimas partes ilustran y nombran las secuencias técnicas de la nague-no-kata, la katame-no-kata y la kime-no-kata respectivamente, seguidas de varias hojas para tomar notas.

93. Bagnulo, Giancarlo (2003). Lecciones de ju jitsu. Barcelona: De Vecchi. 1a ed. 111 p. : il. ; 17x24 cm. ISBN: 84-315-2949-0. Depósito legal: B. 18819-2003. (2a ed., 2009, ISBN: 978-84-315-2949-9). Palabras clave: historia, fundamentos técnicos, defensa personal, legislación, armas. Resumen: Manual teórico y técnico de jujutsu. El libro esta formado por 8 capítulos. El primer capítulo narra la evolución histórica del jujutsu, su difusión y su introducción en España. El segundo capítulo comenta las responsabilidades penal y civil del instructor en la enseñanza del jujutsu así como el código penal y el derecho a defenderse. El tercer capítulo explica las principales lesiones dentro de las clases y las actuaciones más recomendadas como primeros auxilios para tratarlas. El cuarto capítulo comenta la vestimenta dentro de las clases de ju jitsu, la progresión en el aprendizaje junto con los grados y la estructura de una clase normal. El quinto capítulo describe la ejecución técnica de las guardias y las caídas para luego comentar las características de los golpes, las paradas y técnicas de esquiva, las palancas y torsiones articulares, las proyecciones y las estrangulaciones incluyendo las fotografías de sus principales técnicas. Los siguientes tres capítulos describen la ejecución técnica por partes de las 
técnicas de defensa de mano vacía contra un agresor desarmado, contra un agresor armado y técnicas de defensa con objetos comunes, incluyendo varias fotografías de cada técnica.

94. Barioli, Cesare (1988). Judo : manual completo ilustrado. Las técnicas originales japonesas explicadas por un gran campeón y maestro. Barcelona: De Vecchi. $1^{\underline{a}}$ ed. 173 p. : il. ; 17x23,5 cm. ISBN: 84-3150678-4. Depósito legal: B. 45602-1988. (2ª ed., 1994). Palabras clave: fundamentos teóricos, fundamentos técnicos, programa técnico, entrenamiento. Resumen: Tratado técnico sobre judo. La monografía esta dividida en seis capítulos y el primero presenta los conceptos básicos de este arte marcial, como son el saludo, las posiciones, los desplazamientos, el tai-sabaki, los ukemi y las direcciones de desequilibrio. A continuación ofrece una descripción de la programación en la enseñanza del judo, detallando los elementos técnicos para incluir en cada nivel. El tercer capítulo explica los aspectos formales, desde la jerarquía hasta la colocación del judogi, la clasificación de las técnicas, el desarrollo de un entrenamiento, la condición interior y los atemis. El cuarto capítulo es el más extenso y desarrolla en 9 lecciones, el aprendizaje de las distintas técnicas del judo, comenzando por las técnicas de judo-pie y su ejecución con diferentes desplazamientos, para terminar con el trabajo de judo-suelo, los contraataques y las combinaciones. El quinto capítulo describe los diferentes métodos de perfeccionamiento técnico, como son el uchi-komi, el butsukari y el kakke-ai. El último capítulo explica brevemente el significado de la kata, sus diferentes formas y un compendio de preguntas y respuestas.

95. Barioli, Cesare (1997). El libro del judo : las técnicas originales japonesas explicadas por un gran campeón y maestro. Barcelona: De Vecchi. 1aㅡ ed. 173 p. : il. ; 17x24 cm. ISBN: 84-315-1856-1. Depósito legal: B. 44489-1997. Palabras clave: fundamentos técnicos, pedagogía, entrenamiento, sistemas de entrenamiento. Resumen: Manual teórico y técnico sobre el judo. Después de comentar brevemente los conceptos básicos del arte, algunas consideraciones en el plan de entrenamiento y aprendizaje, y las nociones fundamentales antes de comenzar la práctica, pasa a un bloque de capítulos en los que desarrolla una progresión de aprendizaje. Así, el cuarto capítulo comienza con la enseñanza de varias técnicas en las que uke toma la iniciativa, con explicaciones claras y fotografías que las acompañan. El siguiente capítulo centra su atención en las técnicas de suelo y el control del oponente. Continua con técnicas de proyección en las que uke se mueve hacia atrás antes de realizar la técnica. El séptimo capítulo estudia la continuidad entre las técnicas de proyección y el trabajo de suelo, detallando los aspectos fundamentales para mantener siempre el control. El siguiente capítulo presenta el movimiento circular como medio previo para realizar una proyección. A continuación describe algunos ejercicios de lucha en el suelo y detalla los aspectos de efectividad de cada técnica. El décimo capítulo estudia los contraataques a realizar bajo el ataque de ciertas técnicas. Los dos últimos capítulos de este bloque de contenidos proponen otros ejercicios para trabajar la lucha en el suelo y una miscelánea en la que se realizan variantes de algunas técnicas vistas anteriormente, estrangulaciones o la teoría de los contraataques. El penúltimo capítulo describe los ejercicios de perfeccionamiento de la técnica, esto es, el uchi-komi, el butsukari y el kake-ai; para finalizar con la explicación del significado de la kata.

96. Barioli, César (Barioli, Cesare) (1969). 100 llaves infalibles para aniquilar a cualquier adversario (jiujitsu). Barcelona: De Vecchi. $1^{a}$ ed. 180 p. : il. ; 13x19,5 cm. ISBN: No ISBN. Depósito legal: V. 2717-1969. (2 ${ }^{\underline{a}}$ ed., 1971, 182 p.; $3^{\text {a }}$ ed., 1973, 182 p., ISBN: 84-315-0655-5). Palabras clave: fundamentos técnicos, rehabilitación, principios técnicos, defensa personal, entrenamiento, aikido, judo, jujutsu, kárate, kyusho, preparación física, armas. Resumen: Manual teórico y técnico de jiu-jitsu. El libro esta dividido en 6 capítulos. El primer capítulo comenta los objetivos del libro, resume la historia del jiujitsu y judo, el kárate y el aikido, describe las características técnicas de los deportes de combate occidentales, y presenta los contenidos técnicos de las artes marciales antes mencionadas. El segundo capítulo define en qué consisten los atemi-waza, enumera sus principios técnicos, describe la utilización de las diferentes partes del cuerpo utilizadas para golpear y algunos ejercicios de calentamiento, fortalecimiento y endurecimiento de dichas partes, y localiza los puntos vitales del cuerpo junto con las consecuencias de su manipulación. El tercer capítulo expone los principios técnicos de las proyecciones y sus fases, describe las características y ejecución de las técnicas de ashi barai, o soto otoshi, ippon seoi nage, tai otoshi, sukui nage, o goshi, tomoe nage, y ofrece algunos consejos prácticos para el entrenamiento de estas técnicas. El cuarto capítulo describe la ejecución de las distintas palancas en la muñeca y en el codo, las técnicas ude garami, ude hishigi juji gatame, ashi guruma; las técnicas de estrangulación kata juji jime, hadaka jime; y comenta las características de las técnicas de inmovilización y presión (kyusho waza) así como su entrenamiento. El quinto capítulo presenta los diferentes desplazamientos que se realizan en las artes marciales incluyendo su representación gráfica, comenta la importancia de las técnicas de distracción (kasumi) y de kiai, expone la actitud ante el combate e incluye los principios tácticos, expuestos por algunos grandes maestros de artes marciales, sobre el combate. El último capítulo expone las técnicas de defensa a utilizar en algunas situaciones de agresión comunes como en el apresamiento del traje, presas en las muñecas y cintura, intentos de estrangulamiento sin armas, presa en las piernas, contra puñetazos desde diferentes direcciones, puntapiés, y defensas contra ataques con pistola, navaja y bastón. 
También incluye varios consejos sobre la progresión de entrenamiento de estos ejercicios y las técnicas de socorro ante un estrangulamiento. Adjunta un apéndice con el significado de algunas palabras japonesas.

97. Barioli, César (Barioli, Cesare) (1971). El judo en 12 lecciones. Barcelona: De Vecchi. 1a ed. 232 p. : il. ; 17x23,5 cm. ISBN: No ISBN. Depósito legal: B. 43433-1971. (2ª reimp., 1975, ISBN: 84-315-0821-3; 3a ed., 1978, ISBN: 84-315-0821-3; 4aㅡ ed., 1979, ISBN: 84-315-0821-3; 5a ed., 1980, ISBN: 84-315-08213). Palabras clave: katas, historia, fundamentos técnicos, pedagogía, entrenamiento, competición, programa técnico. Resumen: Manual teórico y técnico de judo. El libro esta compuesto de 12 lecciones o capítulos precedidos por un prólogo que comenta la historia más relevante de Japón y una introducción que explica la formación del judo Kodokan y sus principios. La primera lección presenta las instalaciones para la práctica del judo, la vestimenta, las normas de cortesía, el sistema de entrenamiento, la clasificación de sus técnicas y métodos de entrenamiento, describe la ejecución de las caídas y ofrece consejos para la práctica. La segunda lección explica las peculiaridades del gokyo, su estructura técnica y presenta la clasificación de sus técnicas para en las siguientes tres lecciones describir la ejecución técnica, señalar los puntos más importantes e ilustrar por partes las técnicas del 1 er, $2^{\circ}$ y 3 er kyo. La sexta lección analiza el combate cuerpo a cuerpo (katame-waza) y los principios técnicos que rigen en las inmovilizaciones, luxaciones y estrangulaciones, para luego describir la ejecución técnica, defensas y combinaciones de sus principales técnicas. La octava lección explica los fundamentos educativos, características y objetivos de las katas de judo y después describe e ilustra la ejecución de la nage-no-kata. La novena lección reflexiona sobre el combate y sus objetivos, paradigmas, forma de desarrollarse y combinaciones. El siguiente capítulo incluye el reglamento de competición del judo, la historia del judo español, un conjunto de consejos para la competición junto con las combinaciones y contraataques técnicos más importantes. La última lección incluye unas nociones básicas sobre las técnicas de reanimación (kuatsu). Adjunta un apéndice sobre la redacción de programas de adiestramiento y las peculiaridades que conlleva dependiendo de la edad y destreza de los sujetos, además de algunos consejos prácticos para los profesores y un ejemplo práctico.

98. Barra Nogués, Armando y Barra Nogués, Carlos (1986). Judo : arte y técnica de la defensa personal. Valencia: A. Barra. 1aㅡ ed. 172 p. : il. ; 15x22 cm. ISBN: No ISBN. Depósito legal: V. 2278-1986. Palabras clave: fundamentos teóricos, táctica, fundamentos técnicos, entrenamiento, kyusho, aplicación marcial, legislación, respiración. Resumen: Manual teórico y técnico de judo. El libro esta formado por 8 capítulos. El primer capítulo describe las características de la postura correcta y sus ventajas. El segundo capítulo comenta los diferentes tipos de caídas que existen en el judo y describe la ejecución de los distintos tipos de desplazamientos junto con su esquema de movimientos. El tercer capítulo localiza los puntos vulnerables del cuerpo humano, describe las distintas armas naturales del cuerpo junto con su utilización, ilustra su aplicación, comenta las características de las presiones ilustrando algunas de sus técnicas y enumera las distintas paradas que existen y su forma de entrenamiento. El cuarto capítulo expone las oportunidades para atacar y las características del kiai, su entrenamiento y utilización. El quinto capítulo expone la forma de entrenar el espíritu, explicando las formas de respiración El sexto capítulo describe la ejecución técnica, entrenamiento y aplicación en las situaciones de defensa personal de las técnicas seoi-nage, o-soto-gari, o-goshi, de-ashi-barai, haraigoshi, o-uchi-gari, koshi-guruma, tsuri-komi-goshi, sasae-tsuri-komi-goshi, tai-otoshi, ko-uchi-gari, kosoto-gake, tomoe-nage, ushiro-goshi, soto-maki-komi, sukui-nage, morote-gari, utsuri-goshi, yokoguruma, te-guruma, ude-gatame, waki-gatame, ude-garami y hara-gatame. El séptimo capítulo comenta los aspectos legales de la legítima defensa; y el último capítulo expone algunos de los principios tácticos a seguir durante una situación de defensa personal. Adjunta un epílogo.

99. Barra Nogués, Armando y Barra Nogués, Carlos (1987). Ataques : judo - jiu jitsu. Valencia: A. Barra. 1aㅡ ed. 137 p. : il. ; 15x22 cm. ISBN: No ISBN. Depósito legal: V. 413-1987. Palabras clave: fundamentos teóricos, táctica, principios técnicos, defensa personal, judo, jujutsu, aplicación marcial. Resumen: Manual teórico y técnico de judo. La obra consta de 10 capítulos. El primer capítulo comenta el principio fundamental del judo para luego describir e ilustrar las técnicas de defensa personal ante ataques frontales, laterales y por la espalda sin peligro. El segundo capítulo comenta los principios técnicos del control del cuerpo y explica la ejecución de varias técnicas de defensa personal ante ataques frontales y laterales con un peligro medio. El tercer capítulo expone los principios de actuación cuando estamos en el suelo y somos atacados, destaca las ventajas de los atemis y presenta varias situaciones de defensa personal en el suelo. El cuarto capítulo define una situación de peligro, los principios tácticos ante dicha situación y describe la aplicación de distintas técnicas de proyección, estrangulación ante distintos ataques y agarres. El quinto capítulo expone los principios tácticos ante un puñetazo y distintas técnicas defensivas ante los mismos. El sexto capítulo expone el entrenamiento de las patadas, clasifica las distintas técnicas y propone varias técnicas de defensa personal ante una patada frontal, una lateral y una circular. Los siguientes tres capítulos describen las características de un ataque armado, los principios de actuación ante los mismos y describe las técnicas de defensa personal ante un ataque de cuchillo, con un palo y con una silla con distintas trayectorias. El último 
capítulo describe los principios de actuación ante un ataque con arma automática y describe varias situaciones de defensa personal ante la misma junto con su ilustración. Adjunta un epílogo que comenta el comportamiento humano y las tensiones emocionales.

100. Barra Nogués, Armando y Barra Nogués, Carlos (1987). Katas : judo - jiu jitsu. Valencia: A. Barra. 1aa ed. 182 p. : il. ; 15x22 cm. ISBN: No ISBN. Depósito legal: V. 412-1987. Palabras clave: katas, combate. Resumen: Manual teórico y técnico de judo. El libro esta formado por 3 capítulos. El primer capítulo comenta en qué consisten las katas, cuáles son sus características y cómo debe ser su entrenamiento. El segundo capítulo describe la ejecución técnica de las katas shodan jitsu no kata, nidan jitsu no kata y sandan jitsu no kata, incluyendo su representación gráfica explicativa. El tercer capítulo presenta la ejecución técnica de las katas kime no kata y goshin jitsu no kata, ilustrando por partes sus técnicas. Adjunta un epílogo.

101. Benítez de Aragón, Salvador (1959). El judo. Madrid: Imprenta Fernando Franco. 1aㅡ ed. 80 p. : il. ; 15x21 cm. ISBN: No ISBN. Depósito legal: M. 8859-1959. Palabras clave: historia, fundamentos teóricos, fundamentos técnicos, programa técnico, judo, competición, instituciones, reglamentos. Resumen: Manual teórico y técnico de judo. El libro esta formado por 7 capítulos. El primer capítulo define en qué consiste el judo, su expansión mundial, narra su origen y evolución, enumera sus beneficios, comenta la vestimenta y material para la práctica, el desarrollo de las clases y las competiciones, describe los contenidos técnicos del judo y su clasificación, y comenta el sistema de grados y de examen. El segundo capítulo comenta la organización del judo en España, enumera las diferentes salas y escuelas de judo federadas así como los cinturones negros que existen en la actualidad. El tercer capítulo incluye el reglamento interno de la Federación Española de Lucha, para en el siguiente ilustrar los contenidos del programa técnico hasta cinturón negro. El quinto capítulo presenta los estatutos del Colegio Español de cinturones negros de judo. El sexto capítulo expone las reglas internacionales de competición de la Unión Europea de Judo. El último capítulo incluye los estatutos de la Federación Internacional y de la Unión Europea de Judo.

102. Benítez de Aragón, Salvador (1962). Introducción al judo. Madrid: Comité Olímpico Español. 1a ed. 102 p. : il. ; $13 \times 20$ cm. ISBN: No ISBN. Depósito legal: M. 15244-1962. (2ª ed., 1966, 138 p.). Palabras clave: historia, fundamentos teóricos, fundamentos técnicos, judo, jujutsu, competición, instituciones, programa técnico, reglamentos. Resumen: Manual teórico y técnico de judo. El libro esta formado por 3 partes. La primera parte define lo que es el judo y el jiu-jitsu, narra sus orígenes y evolución, explica la aplicación del judo a la defensa personal y a la educación, comenta el pase de grados, la etiqueta y los distintos métodos o escuelas que existen. La segunda parte describe los fundamentos técnicos del judo, como la forma de saludar, las caídas, los desplazamientos, los principios técnicos, el agarre, los materiales utilizados, y comenta los beneficios del judo para el practicante, el significado de las categorías de peso, la deportivización del judo, los fundamentos del kiay, la definición de las katas, y el desarrollo de las clases y los combates. La tercera parte incluye las reglas internacionales de competición de la Unión Europea de Judo, los estatutos de la Federación Española de Lucha y el Colegio Español de Cinturones Negros de Judo, la ilustración del programa técnico hasta cinturón negro, un extracto de las normas de examen hasta 3er dan, un listado de las federaciones y delegaciones del territorio nacional, de las salas y gimnasios de judo, y de los cinturones negros en la actualidad.

103. Berbel Jiménez, Sonia (2009). El judo en la Educación Física de Primaria como aspecto didáctico. Guadix, Granada: Comala. 1aㅡ ed. 55 p. : il. ; 20x28,5 cm. ISBN: 978-84-92659-32-6. Depósito legal: GR. 42-2009. Palabras clave: historia, fundamentos teóricos, pedagogía, fundamentos técnicos, entrenamiento, programa técnico, sistemas de entrenamiento. Resumen: Tratado teórico de judo. El libro esta formado por 9 capítulos. El primer capítulo comenta a modo de introducción las características de los deportes de lucha y los objetivos de la obra. El segundo capítulo resume la evolución histórica de los deportes de lucha. El tercer capítulo expone las reglas básicas de la competición de judo, detalla las capacidades físicas implicadas en su práctica, comenta el método de entrenamiento de dichas capacidades, describe los fundamentos teóricos del entrenamiento técnico y táctico además de incluir un listado de la clasificación de las técnicas que se enseñan en el ámbito del judo infantil-escolar. El cuarto capítulo describe brevemente las principales técnicas de judo-pie y judo-suelo. El quinto capítulo analiza las acciones motrices de los agarres, proyecciones, caídas, inmovilizaciones, empujes y tracciones, desplazamientos, giros y rotaciones, barridos y bloqueos. El sexto capítulo enumera los distintos factores que implican peligrosidad en la práctica del judo. El séptimo capítulo incluye los contenidos técnicos de los programas de especialidad de la lucha libre olímpica y lucha grecorromana así como la determinación de los periodos de entrenamiento y los porcentajes de trabajo de cada capacidad física. El octavo capítulo describe el desarrollo de una sesión de judo para niños de 13-16 años dentro del ámbito escolar y una clase senior, un análisis de las conclusiones extraídas tras la realización de dichas clases y la comparación entre dichas clases. El último capítulo analiza la estructura de la técnica, los factores mecánicos del movimiento, además de describir una sesión práctica de deportes de lucha para los tres ciclos de primaria y una tabla de análisis de la técnica y la táctica en judo. Adjunta bibliografía. 
104. Burger, Roland (1989). Judo (primer ciclo). Madrid: Agrupación Deportiva de Estudiantes y Licenciados de Educación Física (ADELEF). 1aㅡ ed. 122 p. : il. ; 13x21 cm. ISBN: 84-404-3944-X. Depósito legal: M. 4087-1989. Palabras clave: historia, fundamentos técnicos. Resumen: Tratado histórico y técnico sobre el judo. El primer capítulo describe la historia y desarrollo del judo hasta la actualidad, para continuar con la explicación de sus fundamentos, el saludo, las posiciones, los agarres, los desplazamientos, la utilización de la fuerza, el uchikomi, el renraku-waza y el trabajo en el suelo, todo ello a través de sencillos gráficos y esquemas de movimiento. El último capítulo hace una clasificación de sus técnicas y una explicación concisa de los puntos más importantes de cada una de ellas incluyendo su representación gráfica.

105. Butcher, Alex (2002). Judo : guía básica para conocer este arte marcial. Arganda del Rey: Edimat. 1a ed. 96 p. : il. ; 20x27 cm. ISBN: 84-9764-134-5. Depósito legal: no. Palabras clave: historia, fundamentos teóricos, principios técnicos, defensa personal, competición. Resumen: Manual teórico y técnico de judo. El libro esta formado por 7 capítulos. El primer capítulo narra la historia del judo y sus orígenes, y comenta en qué consiste esta práctica. El segundo capítulo expone los fundamentos para comenzar en el judo como son la vestimenta, el dojo, las normas de cortesía y una serie de ejercicios de estiramientos y precalentamiento. El tercer capítulo expone los fundamentos técnicos de las caídas, describiendo e ilustrando la ejecución de las diferentes caídas y ante distintas proyecciones. El cuarto capítulo describe el trabajo de judo en el suelo, explica las principales inmovilizaciones con la ayuda de varias ilustraciones y cómo escapar de ellas, cómo utilizar las piernas en el trabajo del suelo, cómo girar al compañero y cómo realizar y evitar estrangulaciones y luxaciones en el suelo incluyendo la secuencia fotográfica de cada técnica. El quinto capítulo comenta los fundamentos de las proyecciones para luego explicar por partes las principales técnicas de proyección, de siega, de barrido, de sacrificio y algunas técnicas para evitar ser proyectado. El sexto capítulo describe e ilustra la secuencia técnica de las combinaciones de dos técnicas, los contraataques y el trabajo continuado entre distintas proyecciones y el trabajo en el suelo, incluyendo además un resumen de las reglas de competición. El último capítulo presenta la aplicación del judo ante dos situaciones de defensa personal en las que el atacante nos agarra por el cuello y por detrás, describiendo su ejecución por partes y a través de numerosas fotografías. Adjunta un listado con la dirección de asociaciones nacionales de judo y un glosario.

106. Butler, Pat (1965). El judo completo. Barcelona: Sintes. 1a ed. 241 p. : il. ; 15x21,5 cm. ISBN: No ISBN. Depósito legal: P.M. 1202-1965. Palabras clave: katas, fundamentos teóricos, fundamentos técnicos, programa técnico, principios técnicos. Resumen: Manual teórico y técnico de judo. El libro esta formado por 12 capítulos. El primer capítulo es introductorio y comenta el origen y evolución del judo, su expansión a Gran Bretaña y el resto del mundo, los principios técnicos que fundamentan la práctica del judo, los beneficios derivados de su práctica y sus fundamentos teóricos. El segundo capítulo expone las características de un buen instructor, compara las ventajas e inconvenientes de los diferentes centros de enseñanza del judo, presenta su vestimenta y forma de saludar y describe algunos ejercicios de calentamiento de todo el cuerpo con sus ilustraciones. El tercer capítulo describe e ilustra los fundamentos técnicos básicos del judo, como son las caídas en diferentes direcciones, varios ejercicios para comprender los principios de kuzushi y tsukuri, y las técnicas osotogari, tsurikomiashi, ogoshi, deashiharai y las técnicas de inmovilización kesagatame y katagatame acompañadas de sus ilustraciones. El cuarto capítulo presenta los contenidos técnicos del cinturón blanco, describiendo e ilustrando las proyecciones ukigoshi, hizaguruma, haraigoshi; las técnicas de estrangulación gyakujujijime, namijujijime; las técnicas de inmovilización kamishihogatame, yokoshihogatame; y las técnicas de luxación jujigatame y udegarami. El quinto capítulo describe la ejecución de las técnicas de cinturón amarillo como son seoinage, ipponseoinage, eriseoinage, tsurikomigoshi, sasaetsurikomigoshi, sodetsurikomigoshi, kotsurikomigoshi, okurierijime, katahajime, hizagatame, udegatame, kuzurekesagatame y kuzurekamishihogatame; junto con sus ilustraciones. El sexto capítulo expone la descripción técnica de los contenidos del cinturón naranja, como son ashiguruma, ouchigari, kouchigari, hadakajime, sodeguruma, ashigatame y yokoshihogatame con su representación gráfica y comenta la importancia del trabajo en el suelo y explica una forma de escapar al agarre cuando se está en el suelo. El siguiente capítulo presenta los contenidos técnicos del cinturón verde de judo como son tomoenage, taiotoshi, katajujijime, y explica como mantener la inmovilización tras kamishihogatame y la aplicación de diferentes variantes de la luxación de brazo desde el trabajo sobre el suelo, adjuntando varias fotografías explicativas. El octavo capítulo describe e ilustra las técnicas de cinturón azul como okuriashiharai, hanegoshi, uchimata, tateshihogatame, ushirokesagatame; y expone la aplicación de las técnicas de luxación al hombro, codo y muñeca junto con algunas de las estrangulaciones por la espalda desde la posición de pie. El siguiente capítulo comenta las técnicas incluidas en la nagenokata, la forma de ejecución de sus técnicas, comenta como se evoluciona en el osaekomiwaza a través del entrenamiento de diferentes tácticas y presenta la ejecución de la katamenokata. El décimo capítulo expone los contenidos del cinturón negro describiendo e ilustrando la ejecución de la gonosennokata (demostración de los contralanzamientos) 
así como de las técnicas oguruma, koshiguruma, osotogake, y explica varios métodos para deshacer la posición defensiva del oponente. El siguiente capítulo comenta las cualidades técnicas que debe poseer un $2^{\circ}$ y 3 er dan de judo además de describir las técnicas taniotoshi, yamaarashi y hanemakikomi con sus ilustraciones. El último capítulo es una miscelánea que comenta la preparación del judoka para la competición, la formación de los instructores, el objetivo de las graduaciones, los problemas en la formación de un club de judo y la aplicación del judo para niños y mujeres. Adjunta un glosario de términos japoneses, los temarios de graduación de la asociación de judo amateur y de la asociación de judo inglesa, el premio que concede el Duque de Edimburgo, un resumen del reglamento internacional de las competiciones de judo, el organigrama de la asociación de judo amateur de Gran Bretaña, bibliografía y un índice temático.

107. Butler, Pat (1969). Judo para <<juniors >>. Barcelona: Sintes. $1^{\mathrm{a}}$ ed. 70 p. : il. ; 15x21,5 cm. ISBN: No ISBN. Depósito legal: B. 36106-1969. Palabras clave: fundamentos técnicos, principios técnicos. Resumen: Manual teórico y técnico de judo. La monografía esta compuesta por 6 capítulos entre los que se intercalan las ilustraciones técnicas explicativas. El primer capítulo es introductorio y comenta la llegada del judo a Gran Bretaña, los paradigmas del judo y los contenidos del libro. El segundo capítulo describe e ilustra los fundamentos técnicos del judo como son las caídas, el saludo y algunos ejercicios para comprender los principios de kuzushi y tsukuri. El tercer capítulo describe la ejecución técnica de las proyecciones o-soto-gari, o-goshi, tsuri-komi-goshi, harai-goshi, seoi-nage, ippon-seoinage, eri-seoi-nage, uki-goshi, seoi-otoshi, de-ashi-harai, okuri-ashi-harai, tsuri-komi-ashi y tai-otoshi. El cuarto capítulo incluye la descripción técnica de o-uchi-gari, ko-uchi-gari, hane-goshi, uchi-mata, tomoe-nage, yoko-guruma, kata-guruma, o-guruma, utsuri-goshi y ko-soto-gake. El quinto capítulo expone los diferentes trabajos que existen en el suelo, sus ventajas y beneficios, y explica las técnicas kesa-gatame, kata-gatame, kuzure-kesa-gatame, kami-shiho-gatame, yoko-shiho-gatame, kuzure-yokoshiho-gatame, ushiro-kesa-gatame y tate-shiho-gatame. El último capítulo explica las principales técnicas de estrangulación y luxación como ude-garami, juji-gatame, ashi-gatame, nami-juji-jime, gyaku-juji-jime, kata-ha-jime, okuri-eri-jime, sode-guruma, y algunas combinaciones de inmovilización y luxación. Adjunta un resumen del reglamento básico de competición, los temarios de graduación de la Asociación de Judo Amateur (AJA) y la British Judo Association (BJA), los premios que concede el Duque de Edimburgo y un glosario de términos japoneses.

108. Cabot Saval, Toni (1996). Miriam Blasco, el precio del oro. Alicante: Toni Cabot. 1aㅡ ed. 105 p. : il. ; 12x20,5 cm. ISBN: 84-605-5994-7. Depósito legal: A. 963-1996. Palabras clave: historia, competición. Resumen: Ensayo histórico sobre la vida de Míriam Blasco. La obra consta de 14 capítulos. Los tres primeros capítulos narran el fallecimiento de Sergio Cardell, entrenador de Míriam Blasco. El cuarto capítulo comenta los entrenamientos con Josean Arruza y el quinto su traslado a Alicante. El sexto capítulo detalla su competición en los Mundiales de Belgrado y Barcelona. El séptimo capítulo comenta las desavenencias entre Míriam y su marido. El octavo capítulo describe la inauguración de los Juegos Olímpicos de 1992. Los dos siguientes capítulos narran los pormenores y desarrollo del día de competición de Míriam Blasco en dichos Juegos. El undécimo capítulo describe las celebraciones tras alcanzar el oro en la competición de judo. Los tres últimos capítulos comentan la crisis de Míriam tras los Juegos Olímpicos, los hechos que condujeron a su no participación en los Juegos de Atlanta'96 y sus logros como entrenadora.

109. Caffary, Brian (1994). Judo para expertos. Barcelona: Paidotribo. 1a ed. 165 p. : il. ; 15x21,5 cm. ISBN: 84-8019-115-5. Depósito legal: B. 075-1994. Palabras clave: katas, historia, fundamentos técnicos, principios técnicos, competición, lesiones, preparación física. Resumen: Manual técnico de judo. La monografía esta dividida en 12 capítulos. El primero de ellos comenta brevemente la historia de Kano, Abbe y el judo Kodokan, y continúa con la presentación de algunos ejercicios de acondicionamiento general para todo el cuerpo. El tercer capítulo describe los principios de las técnicas de proyección y explica la ejecución de las principales con apoyo gráfico. Los dos capítulos siguientes continúan con las técnicas de contraataques y algunas combinaciones. El sexto capítulo presenta las técnicas de inmovilización mientras que el séptimo y octavo hacen lo mismo con las estrangulaciones y las luxaciones respectivamente. El noveno capítulo analiza brevemente la competición de judo y continúa con la reflexión sobre el papel de las katas, cuáles son y qué técnicas son las que incluyen cada una de ellas. El undécimo capítulo ofrece unas recomendaciones muy generales sobre las lesiones y su tratamiento para finalizar con un vocabulario de judo.

110. Carmeni, Bruno (1998). Judo para deportistas ciegos. Madrid: ONCE (Organización Nacional de Ciegos Españoles). 1a ed. 258 p. : il. ; 15x23 cm. ISBN: 84-484-0211-1. Depósito legal: 35742-1998. Palabras clave: pedagogía, competición, legislación, vista, enfermedades. Resumen: Ensayo sobre la integración de los ciegos en la práctica y competición de judo. La monografía esta dividida en 12 capítulos y el primero de ellos establece la clasificación visual y analiza el decreto del Ministerio de Sanidad de la República Italiana sobre la aptitud de las personas discapacitadas y la práctica competitiva. El segundo capítulo analiza el cuerpo y la posición corporal de los ciegos, para en el siguiente capítulo presentar las patologías y las consideraciones a tener en cuenta en el entrenamiento. El cuarto capítulo resalta 
los aspectos beneficiosos del deporte y del judo para los ciegos. Continúa con la descripción de los aspectos más relevantes para alcanzar los objetivos marcados con los ciegos debido a sus circunstancias, como son la motricidad, la psicología y la integración social. El sexto capítulo ofrece un análisis cronológico de los orígenes de la federación italiana de discapacitados, los juegos paralímpicos y el judo. Luego describe el dojo, el saludo, la posición de za zen y la autodisciplina, para continuar con una explicación de la respiración, sus métodos y su importancia durante la práctica. El noveno capítulo presenta una progresión técnica para que el ciego pueda entrenar adecuadamente y según los objetivos marcados, haciendo además una clasificación de los contenidos que pueda servir como base para el diseño del propio entrenamiento. El décimo capítulo aborda los aspectos relevantes del profesor, desde sus cualidades hasta su filosofía y metodología. El último capítulo esta dedicado a la presentación de las reglas que normalizan la práctica de los ciegos en la competición de judo. Adjunta bibliografía.

111. Carratalá Deval, Vicente y Carratalá Sánchez, Enrique (2000). La actividad física y deportiva extraescolar en los centros educativos : judo. Leganés: Consejo Superior de Deportes. 1aㅡ ed. 199 p. : il. ; 15x21 cm. ISBN: NIPO: 178-00-001-X. Depósito legal: no. Palabras clave: pedagogía, didáctica, judo. Resumen: Tratado sobre judo y su aplicación al ámbito escolar. La monografía consta de 4 bloques, presentando el primero de ellos la historia del judo a nivel mundial y nacional así como el enfoque educativo de esta práctica propuesto por los autores. El segundo bloque describe los contenidos esenciales del judo y su realización dentro del contexto escolar, desde los aspectos reglamentarios hasta los técnicos, tácticos y actitudinales. El tercer bloque centra su atención en la enseñanza del judo con la descripción del acto motor en judo, los elementos que rodean el proceso de enseñanzaaprendizaje, la progresión lógica en la enseñanza de los contenidos del judo, así como la programación de dichos contenidos en función de la edad del practicante. También se incluyen dentro de este bloque un capítulo dedicado a la secuenciación de las técnicas de judo en función del grado o kyu del practicante así como otro dedicado a la importancia de la competición en el proceso formativo. El último bloque esta compuesto por la bibliografía recomendada y los recursos utilizados.

112. Castarlenas, Josep Lluis y Molina, J. Pere (coords.) (2002). El judo en la educación física escolar : unidades didácticas. Barcelona: Hispano Europea. 1aㅡ ed. 192 p. : il. ; 17x23 cm. ISBN: 84-255-1445-2. Depósito legal: B. 32114-2002. Palabras clave: katas, pedagogía, educación, didáctica, defensa personal, judo, deportes de combate, unidades didácticas. Resumen: Manual teórico y práctico de judo. El libro esta compuesto por dos partes, precedidas por una introducción que comenta el origen y objetivos de la obra. La primera parte esta formada por dos capítulos, describiendo el primero de ellos las características del judo, sus aspectos educativos y beneficios, los posibles paradigmas de su enseñanza, la influencia de las etapas y condiciones de aprendizaje, comenta los principios de su enseñanza, la evaluación del proceso de enseñanza-aprendizaje, y la relación del judo con otras disciplinas y temas transversales. El segundo capítulo describe las características, ventajas e inconvenientes del proceso de enseñanza del judo a través de su técnica así como de las nuevas aportaciones alternativas, para luego presentar una clasificación de los deportes de contacto, integrar al judo dentro de ellos, analizar su estructura, funcionalidad y principios tácticos y didácticos que deben guiar el proceso de enseñanza. La segunda parte esta formada por 7 capítulos, que presentan distintas unidades didácticas de desarrollo desde la Educación Primaria hasta el Bachillerato. El primer capítulo presenta el marco didáctico, objetivos, contenidos, estrategias metodológicas, temporalización, actividades y evaluación de una unidad didáctica dedicada a la introducción de las actividades de lucha dentro de la Educación Primaria, siendo el contacto corporal el objetivo más general. El resto de capítulos de esta parte mantienen la misma estructura de contenidos, señalando el marco didáctico, los objetivos, contenidos, estrategias metodológicas, temporalización, actividades y evaluación de unidades didácticas dedicadas al desarrollo del contacto corporal y las habilidades de lucha en la lucha por los espacios y objetos, la lucha de uno contra uno, el desarrollo de las habilidades específicas de las actividades de lucha junto con una introducción a las normas del judo, el desarrollo de las habilidades específicas del judo, la aplicación de algunas técnicas de judo a las situaciones de defensa personal y el aprendizaje de la Ju-no-kata respectivamente.

113. Cecchini Estrada, José Antonio (1989). El judo y su razón kinantropológica. Gijón: G.H. Editores. 1ạ ed. 186 p. : il. ; 21x20,5 cm. ISBN: 84-86015-58-8. Depósito legal: AS. 3895-1989. Palabras clave: fundamentos teóricos, pedagogía, psicología, cualidades físicas, personalidad. Resumen: Tratado teórico de judo. El libro consta de 9 capítulos acompañados de numerosas fotografías y esquemas explicativos. El primer capítulo analiza la práctica del judo desde el punto de vista de sus tareas (abiertas o cerradas), del objeto de su práctica (del cuerpo instrumento al cuerpo vivido), la técnica como un proceso compendiador, la relación entre atacante y defensor y el proceso del acto motor. El segundo capítulo expone el principio de equilibrio, el centro de gravedad y su determinación, la estabilidad, para luego analizar la postura natural y los distintos tipos de agarre. El tercer capítulo explica los mecanismos perceptivos del judoka, analizando los canales perceptivos, la velocidad de reacción, la atención selectiva, la información directa, el conocimiento deducido y las fuentes de 
incertidumbre en el judo. El cuarto capítulo analiza los diferentes mecanismos de procesamiento de la información en el judo, como la inteligencia y memoria motriz, los esquemas motores, el principio de acción-reacción y sus tipos, el movimiento directo, el análisis del desarrollo de un combate, el programa motor y la estrategia de combate. El quinto capítulo define las cualidades físicas de fuerza, velocidad, flexibilidad y resistencia, y analiza la implicación de dichos factores en el judo. El sexto capítulo comenta las características de los factores emocionales de personalidad, motivaciones y emociones así como su importancia y papel dentro de la competición. El séptimo capítulo incluye la descripción de la elaboración y control de un programa motor. El octavo capítulo explica los fundamentos del aprendizaje como el movimiento reflejo, el movimiento voluntario, el movimiento automático, el aprendizaje de las habilidades defensivas y ofensivas, y las etapas de aprendizaje y sus características. El último capítulo comenta los valores educativos del judo. Adjunta bibliografía.

114. Centro de Cultura por Correspondencia, (Franco de Sarabia, Fernando) (1955). Curso D-B : judo y jiujitsu. Guipúzcoa: Centro de Cultura por Correspondencia. 1aㅡ ed. 286 p. : il. ; $21 \times 27 \mathrm{~cm}$. ISBN: No ISBN. Depósito legal: no. (2ª ed., 1957, 3aㅡ ed., 1964, $4^{a}$ ed., 1965). Palabras clave: historia, fundamentos técnicos, principios técnicos, defensa personal, entrenamiento, jujutsu, relatos, competición, sistemas de entrenamiento. Resumen: Manual teórico y técnico de judo. La obra esta compuesta por 12 volúmenes, que constan de dos lecciones cada uno de ellos. La primera lección del primer volumen presenta la historia del judo, en qué consisten el judo y el jiu-jitsu, las características de la vestimenta, el juramento del judoka, los contenidos de la obra y su forma de estudio, un gráfico ilustrando los puntos anatómicos más importantes, los principios técnicos de las caídas junto con la descripción técnica, observaciones y representación gráfica de la caída de espaldas. La segunda lección explica la ejecución y entrenamiento de la caída de costado y de frente junto con sus ilustraciones explicativas, detalla como aprender las técnicas de jiu-jitsu y describe la defensa contra un empujón, señalando sus efectos y entrenamiento. También incluye la leyenda japonesa titulada "la verruga desaparecida". Adjunta una hoja de ejercicios de evaluación y la hoja de filiación del judoka. El segundo volumen incluye la tercera lección, que comenta las características del lugar de entrenamiento, el sistema de grados, la ejecución del saludo, los criterios técnicos de la posición fundamental, ofrece algunos consejos para el entrenamiento, describe el contraataque para el agarre de solapas, e incluye un extracto de Quevedo que señala la importancia de la práctica. La cuarta lección explica los fundamentos teóricos de los desequilibrios junto con su representación gráfica, explica la ejecución de la técnica de-ashi-harai, describe su ejecución, puntos clave y precauciones de una maniobra para conducir a una persona. También incluye la leyenda de "el conejo y el cocodrilo", algunas fotografías y la hoja de ejercicios de evaluación. El tercer volumen consta de la quinta lección, que propone algunos consejos para alcanzar la victoria en judo, explica la forma de caminar, la ejecución de la técnica deashi-harai en combate, describe e ilustra la ejecución de hiza-guruma y sasae-tsuri-komi-ashi, expone algunas normas de salud para el cuerpo y el espíritu, e incluye la descripción técnica e ilustración de la defensa contra el agarre doble de muñeca y las reflexiones de Suzanne Aguisson respecto al judo y su práctica. La sexta lección describe e ilustra las técnicas uki-goshi, o-soto-gari y la defensa contra el estirón de manga, comenta los principios de actuación ante un ataque armado hacia nuestra cabeza e incluye el relato de "el batallón del tigre blanco". Adjunta fotografías y ejercicios correspondientes al capítulo III. El cuarto volumen presenta la séptima lección, que explica en qué consisten las katas, el randori, los shiais y su entrenamiento, comenta el entrenamiento en movimiento de las técnicas aprendidas hasta el momento, expone la descripción técnica y representación gráfica de o-goshi, ouchi-gari y las defensas contra los agarres de muñeca y al brazo, y señala algunos consejos técnicos para el entrenamiento. La octava lección comenta las características generales de las proyecciones por el hombro y las inmovilizaciones, describe la ejecución y precauciones de ippon-seoe-nage y hon-kesagatame respectivamente, expone distintas formas para soltarse del agarre de una mano a la muñeca con sus gráficos explicativos y relata la historia de "Minamoto No Yoshie y el clan Abe". Adjunta fotografías sobre las técnicas explicadas en este volumen y los ejercicios correspondientes al capítulo IV. El quinto volumen consta de la novena lección que expone la aplicación en combate de las técnicas aprendidas en la lección anterior, explica el trabajo de piernas cuando se alcanza una inmovilización, y describe la ejecución de kuzure-kesa-gatame, makura-kesa-gatame, kata-gatame, ushiro-kesa-gatame y la técnica contra un ataque de espaldas por la cintura junto con sus respectivas ilustraciones. La décima lección presenta la descripción técnica y puntos clave de ko-soto-gari, ko-uchi-gari, koshiguruma, tsuri-komi-goshi junto con su representación gráfica, esquemas de movimiento y progresión de entrenamiento. También explica distintas defensas contra puntapiés e incluye un extracto del reglamento de competición de judo, las fotografías de las técnicas explicadas en este volumen y los ejercicios correspondientes al capítulo V. El sexto volumen contiene la lección undécima que explica la aplicación en randori de las técnicas aprendidas en la lección anterior, describe la ejecución de o-kuriashi-harai, tai-otoshi y un golpe de codo al hipocondrio en situación de defensa personal, y relata un combate de jiu-jitsu celebrado en París. La siguiente lección presenta la descripción técnica acompañada de la ilustración y esquema de movimiento de harai-higoshi, uchi-mata y la aplicación de 
una rotación dolorosa a la cabeza enemiga. También ofrece consejos sobre la forma de respirar y sus beneficios para la salud, fotografías de las técnicas explicadas y los ejercicios correspondientes al capítulo VI. El séptimo volumen incluye las lecciones 13aㅡ y 14으. La decimotercera lección profundiza en el entrenamiento en randori de las técnicas o-kuri-ashi-harai, tai-otoshi, harai-higoshi y uchi-mata, además de exponer la ejecución de las inmovilizaciones yoko-siho-gatame, kuzure-yoko-shiho-gatame y la técnica de defensa personal para llevar la muñeca del contrario a la espalda. También expone las características, cualidades y debilidades de los distintos tipos de judoka. La decimocuarta lección presenta las técnicas kami-shiho-gatame, kuzure-kami-shiho-gatame, tate-shiho-gatame y kuzure-tateshiho-gatame y la torsión de muñeca del jiu-jitsu, acompañadas de su representación gráfica, comenta el camino de perfección del judo, la compatibilidad del judo con las tareas maternas y relata la historia de "el cerezo color de otoño". Adjunta fotografías de las técnicas explicadas y los ejercicios correspondientes al capítulo VII. La primera lección del octavo volumen describe y representa la ejecución técnica de ko-soto-gake, tsuri-goshi, yoko-otoshi, ashi-guruma y una defensa contra la estrangulación, además de comentar la enseñanza del gokyo y la historia de tres famosos judokas japoneses como Saigo, Yokoyama y Nagaoka. La decimosexta lección expone el trabajo en movimiento de las técnicas explicadas anteriormente, detalla la ejecución de hane-goshi, harai-tsuri-komi-ashi, tomoe-nage, kata-guruma y otra defensa contra la estrangulación, y comenta las técnicas más empleadas en la competición, las oportunidades para aplicar las técnicas explicadas y la práctica femenina del judo. Adjunta los ejercicios correspondientes al capítulo VIII. El noveno volumen incluye la decimoséptima lección que comenta las generalidades y tipos de estrangulaciones para luego describir la ejecución de nami-juji-jime, kata-juji-jime, gyaku-juji-jime, hadaka-jime, su aplicación en randori y exponer una defensa contra el agarre de solapas. También incluye algunos términos de arbitraje y la explicación sobre la aplicación del principio de ceder a la fuerza del oponente. La decimoctava lección detalla las características de las luxaciones y describe e ilustra las técnicas udegarami, ude-hishigi-juji-gatame y ude-hishigi-waki-gatame junto con su aplicación en movimiento, la defensa de jiu-jitsu contra el doble agarre de las solapas. Discute sobre el verdadero objetivo del judo, las características del ne-waza (trabajo en el suelo) y las formas de llevar al adversario al suelo, y relata la introducción de Mitsu Hiro Nakayama en el Kodokan. También incluye unas viñetas de humor y los ejercicios correspondientes al capítulo IX. La primera lección del décimo volumen explica las combinaciones técnicas de-ashi-harai y de-ashi-harai, de-ashi-harai y tai-otoshi, hiza-guruma y o-sotogari incluyendo su representación gráfica y describe la defensa para auxiliar a una persona que es atacada con un arma. La vigésima lección describe las contrapresas de las técnicas de-ashi-harai e hizaguruma, respondiendo con la misma técnica, detalla la técnica defensiva para auxiliar a una persona que esta siendo atacada en el suelo, y comenta la modernización y perfeccionamiento de las distintas vertientes del judo. Adjunta viñetas de humor y los ejercicios correspondientes al capítulo X. El decimoprimer volumen incluye la vigésimo primera lección que explica y representa la ejecución de las combinaciones tsuri-komi-goshi y o-uchi-gari, o-uchi-gari y ko-uchi-gari, de-ashi-harai y tai-otoshi, las contrapresas contra o-soto-gari, o-uchi-gari, enumera los principios técnicos de la postura de defensa en randori, y describe la ejecución de varias salidas contra un abrazo a la cintura por debajo de los brazos y por delante, un agarre a la solapa, un agarre a ambas muñecas y cómo conducir a un individuo. La siguiente lección profundiza en la descripción técnica de las combinaciones de-ashi-harai y seoi-nage, o-kuri-ashi-harai y sasai-tsuri-komi-ashi, las contrapresas contra ko-uchi-gari, koshiguruma, tsuri-goshi y tsuri-komi-goshi, define los métodos de entrenamiento uchi-komi, randori y competición, y explica las defensas contra una estrangulación por la espalda, un agarre por la espalda y un ataque con un palo. También incluye viñetas de humor y los ejercicios correspondientes al capítulo XI. El último volumen consta de dos lecciones. La primera de ellas expone las técnicas más apropiadas dependiendo de las características físicas del practicante y describe e ilustra la ejecución de varias defensas contra agarres del brazo por la espalda y ataques con cuchillo, junto con sus esquemas de movimiento. La última lección enumera las precauciones tácticas al iniciar una competición y explica la ejecución de varias defensas contra ataques con pistola acompañadas de sus respectivas ilustraciones. También incluye una tabla índice con las técnicas, combinaciones y contrapresas presentadas en la obra y comenta el entrenamiento con pesas para el judoka. Adjunta los ejercicios correspondientes al capítulo XII.

115. Ceracchini, Augusto (1971). ABC del judo. Barcelona: Molino. 2a ed. 151 p. : il. ; 13x19,5 cm. ISBN: No ISBN. Depósito legal: B. 7488-1971. Palabras clave: fundamentos técnicos, principios técnicos, ejercicios, entrenamiento, calentamiento, competición, programa técnico, reglamentos, sistemas de entrenamiento. Resumen: Manual teórico y técnico de judo. El libro esta formado por 4 partes. La primera parte consta de 5 capítulos, explicando el primero de ellos en qué consiste el judo. El segundo capítulo describe la forma de saludar y los distintos ejercicios de calentamiento y fortalecimiento del judo. El tercer capítulo explica la posición fundamental, los principios técnicos de kuzushi, tsukuri y kake, el tai-sabaki y la utilización de la fuerza. El cuarto capítulo expone la clasificación de contenidos técnicos del judo (gokyo) y las diferentes katas que tiene el judo. El quinto capítulo describe la 
ejecución técnica de las formas de caer y el kumikata (agarre). La segunda parte incluye dos capítulos, detallando el primero de ellos la ejecución de las principales técnicas de proyección, acompañadas de su representación gráfica y esquemas de movimiento. El segundo capítulo comenta las características y desarrollo de los métodos de entrenamiento butsukari y randori. La tercera parte consta de 4 capítulos. Los tres primeros capítulos presentan la descripción técnica de las principales inmovilizaciones, estrangulaciones y luxaciones de judo junto con su representación gráfica y esquemas de movimiento. El cuarto capítulo detalla el desarrollo de un combate de competición y su sistema de puntuación. La última parte incluye un breve vocabulario japonés-castellano, la traducción de los términos japoneses utilizados en el texto y el programa de examen hasta cinturón marrón.

116. Charlot, Emmanuel y Bridge, Jane (2008). Curso de judo. Barcelona: De Vecchi. 1aㅡ ed. 205 p. : il. ; 17x24 cm. ISBN: 978-84-315-3956-6. Depósito legal: B. 38746-2008. Palabras clave: historia, fundamentos teóricos, fundamentos técnicos, grados, lesiones. Resumen: Manual teórico y técnico de judo. El libro esta formado por 13 capítulos, precedidos por una presentación que comenta la creación del judo en Japón y su introducción en España. El primer capítulo explica los beneficios y aplicación del judo a niños, adultos y mujeres. El segundo capítulo expone las contraindicaciones que presenta el judo ante algunas deficiencias y enfermedades así como las lesiones más frecuentes. El tercer capítulo explica el significado de los grados o cinturones y la estructura de contenidos en el pase de grados. El cuarto capítulo presenta los fundamentos teóricos del judo como son el saludo, las caídas, las diferentes posiciones, los ejercicios, el aprendizaje de la técnica, el randori, la competición, el ippon y la kata. Los siguientes capítulos que componen el libro están formados por la descripción e ilustración, por partes y desde diferentes ángulos, de las principales técnicas de judo que existen en la actualidad, como son las caídas, las técnicas de manos, las técnicas de caderas, las técnicas de piernas, las técnicas de sacrificios, las técnicas de sacrificios laterales, las técnicas de inmovilización, las técnicas de estrangulamiento y las técnicas de luxación.

117. Cheek, Soke Bryan (2006). Jukoshin ryu jiu-jitsu. Madrid: Budo International. 1a ed. 287 p. : il. ; 17x24 cm. ISBN: 84-96492-61-3. Depósito legal: M. 52759-2006. Palabras clave: historia, fundamentos técnicos, programa técnico, principios técnicos, entrenamiento, kyusho, armas. Resumen: Manual teórico y técnico de jiu-jitsu. La obra consta de 43 capítulos, precedidos por una introducción al estilo, una carta de reconocimiento, la biografía, currículum profesional y los agradecimientos del autor, y un prólogo. El primer capítulo enumera las reglas de comportamiento en el dojo y el saludo. El segundo capítulo narra la historia del jiu-jitsu junto con las características técnicas del estilo jukoshin jiu-jitsu. El tercer capítulo muestra la relación del estilo con otras artes marciales, mientras que el cuarto presenta su programa de estudios dividido por cinturones. El quinto capítulo analiza los requisitos físicos necesarios para la práctica del jukoshin jiu-jitsu. Los siguientes cuatro capítulos exponen las características técnicas de las caídas, posturas de combate, técnicas de bloqueo y golpes con la mano. Continúa detallando la utilización de los codos, muñeca, rodilla, pie y cabeza como armas incluyendo numerosas fotografías explicativas. El décimo quinto capítulo comenta los efectos de la manipulación de los puntos de presión. El siguiente capítulo describe e ilustra la ejecución de algunas técnicas de escape ante distintos agarres. Los siguientes siete capítulos señalan los principios técnicos de las llaves de dedo y pulgar, muñeca, codo, hombro, cuello, tobillo-pierna y columna vertebral, adjuntando numerosas fotografías explicativas. El vigésimo segundo capítulo ofrece una clasificación de las técnicas de proyección y continúa con un comentario del trabajo de agarres en el suelo, las defensas en el suelo, las defensas contra patadas estando en pie, las defensas contra ataques con cuchillo y bastón, incluyendo la ilustración de algunas de sus técnicas. El trigésimo primer capítulo señala las características del entrenamiento con armas para luego estudiar el manejo del bastón, el jo, el tonfa, el tanto y el bo además de mostrar algunas secuencias técnicas. El trigésimo séptimo capítulo enumera las katas incluidas dentro del sistema, para luego resumir el objetivo del libro. Los últimos cinco capítulos presentan los títulos existentes en el jukoshin jiu-jitsu, las cualidades del profesor y su relación con los estudiantes, el comportamiento de un maestro, la ética de la enseñanza y la composición del comité mundial de calificación de grados del jukoshin ryu.

118. Chutang, Ling (1986). Judo. Barcelona: Editors. 1a ed. 156 p. : il. ; $13 \times 20$ cm. ISBN: 84-7561-388-8. Depósito legal: B. 42775-1986. (2ª ed., 1988, $3^{\mathrm{a}}$ ed., 1990). Palabras clave: fundamentos técnicos. Resumen: Manual teórico y técnico de judo. La obra consta de 23 capítulos, precedidos por una introducción que comenta los contenidos de la obra. Los siete primeros capítulos describen brevemente las posturas, comentan la ejecución de las caídas, el agarre y la función de cada mano, los tipos de desequilibrios y las características de las proyecciones incluyendo sus representaciones gráficas. Los cinco siguientes capítulos presentan la ejecución técnica de las principales técnicas de proyección de piernas, de cadera, sacrificios, de hombros y de brazos respectivamente, incluyendo la representación gráfica de algunas de ellas. Los dos siguientes capítulos comentan y enumeran las técnicas en el suelo y las características de las técnicas de luxación junto con algunas observaciones para su entrenamiento. Los siguientes seis capítulos explican la ejecución de distintas técnicas de luxación partiendo desde seis posiciones distintas entre tori y uke. Los dos siguientes capítulos 
describen la ejecución de las técnicas básicas de luxación a las piernas y al cuello respectivamente acompañadas de la ilustración de algunas de ellas. Los dos últimos capítulos describen la ejecución de las técnicas básicas de inmovilización y estrangulación junto con sus variantes, además de incluir la representación de algunas de ellas.

119. Club de Judo Fon-Do-Kan (1997). 25 aniversario. 1972-1997. Valencia: Club de Judo Fon-Do-Kan. 1a ed. 182 p. : il. ; 21x30 cm. ISBN: No ISBN. Depósito legal: no. Palabras clave: historia, judo, clubes. Resumen: Ensayo histórico sobre la evolución del judo en la localidad de Ontinyent. Narra la evolución del judo en Valencia y concretamente en Ontinyent, con la creación del club de judo Fon-do-kan. La narración divide el periodo estudiado en tres etapas distintas, quedando ilustrada con numerosas fotografías. La última parte del libro esta compuesta por numerosos capítulos que aportan información concreta sobre la historia del judo, los clubes valencianos de mayor importancia, la sala de entrenamiento del club Fon-do-kan, la evolución de sus practicantes en cuanto a licencias, cinturones y titulaciones.

120. Costa, Cosimo (2000). Ju-jitsu para todos : un método eficaz de defensa personal. Madrid: Tutor. 1a ed. 197 p. : il. ; 17x24 cm. ISBN: 84-7902-259-0. Depósito legal: M. 18911-2000. (2ª ed., 2003; 3를. ed., 2006). Palabras clave: fundamentos técnicos, defensa personal. Resumen: Manual técnico de ju-jitsu. La monografía esta compuesta por 5 capítulos. Comienza con una introducción en la que aporta algunas nociones teóricas sobre el origen del ju-jitsu, la traumatología, la teoría del entrenamiento, cómo progresar en el aprendizaje del ju-jitsu y luego explica tres técnicas de la escuela tradicional y las guardias de defensa. El siguiente capítulo describe e ilustra la ejecución de las técnicas de defensa del ju-jitsu, agrupándolas bajo distintos grupos como son: defensa contra estrangulamiento y agarre, defensa contra agarre al cuerpo, defensa contra ataques en el suelo, defensa contra ataque de puño, defensa contra ataques cuerpo a cuerpo, defensa contra intento de palanca, defensa contra patada, defensa contra ataque armado y defensa contra ataques singulares. Las técnicas de estos grupos son descritas y representadas por partes para facilitar su ejecución. El tercer capítulo ilustra las fases más significativas en la ejecución de las técnicas fundamentales de ju-jitsu, tanto proyecciones como estrangulaciones, luxaciones, controles, patadas, ataques, paradas y las caídas. El cuarto capítulo describe algunos ejercicios de defensa libre para finalizar con 3 ejemplos de técnicas de defensa personal para la mujer. Adjunta un glosario.

121. Departament de Cultura de la Generalitat de Catalunya (1991). Diccionari de judo. Barcelona: Enciclopedia Catalana. 1aㅡ ed. 117 p. ; 13x19,5 cm. ISBN: 84-7739-227-7. Depósito legal: B. 14920-1991. Palabras clave: fundamentos técnicos, combate, competición, equipamiento, instalaciones, instituciones. Resumen: Diccionario de judo. La obra consta de 3 capítulos, precedidos por una introducción que comenta la introducción del judo en España, los objetivos y metodología utilizada para confeccionar este diccionario, su forma de consulta y el grupo de trabajo que ha realizado dicho diccionario. El primer capítulo presenta las abreviaturas utilizadas, mientras que el segundo muestra los campos de estudio presentados en el diccionario. El tercer capítulo incluye los términos del diccionario referentes a las instalaciones, el personal, el equipo, las técnicas y movimientos, y la organización del judo. Cada término esta numerado y contiene su traducción al resto de idiomas oficiales de los Juegos (español, francés e inglés) y su definición en catalán. Adjunta índices alfabéticos en castellano, francés e inglés, y bibliografía.

122. Díaz Martínez, Juan José (1974). Judo para niños : su metodología. Madrid: Juan José Díaz Martínez. 1a ed. 219 p. : il. ; 15x21,5 cm. ISBN: 84-400-7575-8. Depósito legal: M. 16537-1974. Palabras clave: fundamentos técnicos, pedagogía, juegos. Resumen: Manual teórico y técnico de judo. La obra esta formada por 19 capítulos. El primer capítulo presenta las características del niño en la infancia desde los 3 a los 12 años, para luego clasificar los juegos y explicar el funcionamiento de varios de ellos en su aplicación con los niños. Los dos siguientes capítulos comentan el concepto de metodología didáctica y enumeran las funciones del profesor frente al alumno. El quinto capítulo narra los orígenes del judo, relatando la historia del cerezo y el sauce y la biografía de Jigoro Kano. Los tres siguientes capítulos exponen la relación y beneficios del judo sobre el niño, las características del judo desde el punto de vista psicológico y los valores que incluye esta práctica. El noveno capítulo enumera y clasifica los contenidos técnicos de judo en el programa de suelo y de pie. El décimo capítulo presenta las partes de una clase, explicando la correcta ejecución del saludo y comentando el tipo de trabajo y actividades de cada parte. Los siguientes 7 capítulos describen la ejecución de las caídas, las inmovilizaciones, los movimientos de piernas, de hombros, de brazos, de caderas y los sutemis, dividiendo cada movimiento en partes, señalando los puntos importantes y los errores a evitar y adjuntando fotografías. Los dos últimos capítulos describen e ilustran la realización de diferentes maneras para volcar a un adversario o escapar de las inmovilizaciones. Adjunta bibliografía.

123. Domínguez González, Julio (2009). Fundamentos del judo para la iniciación en educación física. Madrid: Adhara. $1^{a}$ ed. 79 p. : il. ; $15 \times 21 \mathrm{~cm}$. ISBN: 978-84-8144-620-3. Depósito legal: no.

124. Dominy, Eric (1959). Judo : principios básicos. Madrid: Aguilar. 1aㅡ ed. 174 p. : il. ; 12x18 cm. ISBN: No ISBN. Depósito legal: 7455-1959. (2ª ed., 1961). Palabras clave: fundamentos teóricos, fundamentos 
técnicos, principios técnicos. Resumen: Manual teórico y técnico de judo. La obra esta dividida en 12 capítulos. El primer capítulo presenta los contenidos y objetivos del libro a modo de introducción. El segundo capítulo expone los fundamentos teóricos básicos del judo, describiendo e ilustrando su vestimenta, enumerando el sistema de graduación y examen, comentando la progresión de contenidos, los principios técnicos de relajamiento y desequilibrio, el agarre, los principios técnicos en los volteos y el ceremonial de saludo. El tercer capítulo describe e ilustra las caídas en distintas direcciones. Los siguientes seis capítulos describen la ejecución de las principales técnicas de tobillo, de manos, de cadera, de piernas, de hombro y de sacrificio respectivamente, incluyendo numerosos gráficos explicativos y esquemas de movimiento de pies y brazos. El cuarto capítulo presenta la ejecución de las técnicas deashiharai, okuri-ashi-harai, kosotogari, kohosoto-gari, kouchi-gari, osoto-gari y ouchi-gari. En el quinto capítulo las técnicas descritas son ma-mae tewaza y ma-ushiro tewaza. El sexto capítulo incluye ogoshi, harai-goshi, hane-goshi y uchi-mata. El séptimo capítulo expone taiotoshi, yoko taiotoshi, ashi-guruma e hiza-guruma. El octavo capítulo incluye seoinage, moroteseoi nage y seoi otoshi. El noveno capítulo incluye tomoenage. El décimo capítulo describe la ejecución de las técnicas de inmovilización kesagatame, yokoshihogatame, kamishihogatame, kuzure-kamishihogatame, gyakukesagatame y algunas de sus variantes, resaltando sus puntos clave e incluyendo su representación gráfica. El undécimo capítulo comenta los fundamentos teóricos y técnicas de las estrangulaciones para luego describir namijugi, gyakujujijime, katajujijime, gatame, katahajime y hadakajime. El último capítulo presenta la ejecución de las técnicas de luxación udehishige-jujigatame, udekujiki, gyaku udekujiki, udegarami, ude appaku-suru con su representación gráfica y señalando sus puntos más importantes y algunas de sus variantes.

125. Dopico Calvo, Jorge; Iglesias Soler, Eliseo y Romay, Bernardo (1998). Judo : habilidades específicas. Santiago de Compostela: Lea. $1^{a}$ ed. 119 p. : il. ; 15x24 cm. ISBN: 84-89947-25-2. Depósito legal: C. 371998. Palabras clave: pedagogía, entrenamiento, cualidades físicas, habilidades motrices. Resumen: Manual teórico y técnico de judo. El libro esta dividido en 8 capítulos, comenzando con una introducción sobre los objetivos que persiguen los deportes de contacto. El segundo capítulo discute el proceso de enseñanza-aprendizaje y la clasificación de las técnicas según diversos criterios, para luego pasar a describir los esquemas básicos de las habilidades motrices en relación al judo y que serán explicados en los siguientes capítulos. El cuarto capítulo explica los aspectos comunes de las técnicas con giro previo a la situación tanto con apoyo doble como sencillo, continúa con aquellas técnicas que no requieren de este giro previo y pueden realizarse tanto en el espacio lateral como frontal y proyectar al oponente hacia delante y hacia atrás. El sexto capítulo estudia las técnicas que parten de la posición de tendido supino y el séptimo aquellas maneras de atacar al oponente cuando éste se encuentra en el suelo. Finaliza con el análisis de las capacidades condicionales del judo y el entrenamiento de las mismas. Adjunta bibliografía general.

126. Dopico Calvo, Jorge; Iglesias Soler, Eliseo y Clavel San Emeterio, Iván (2002). Habilidades de lucha: introducción a las habilidades específicas de judo. A Coruña: Centro galego de documentación e edicións deportivas. $1^{a}$ ed. 250 p. : il. ; 21x29,5 cm. ISBN: 84-688-0660-9. Depósito legal: C. 2632-2002. Palabras clave: historia, fundamentos teóricos, pedagogía, deportes de combate, iniciación deportiva, maestros, planificación del entrenamiento, programa técnico, reglamentos. Resumen: Tratado teórico de judo. El libro esta formado por 9 capítulos. El primer capítulo es una introducción que resalta los objetivos de la obra y resume sus contenidos. El segundo capítulo clasifica los deportes de lucha y describe sus requerimientos motrices básicos. El tercer capítulo narra los orígenes históricos del judo, su evolución, la biografía de Jigoro Kano, explica el papel del reglamento dentro de cualquier deporte y la evolución del reglamento de judo, expone las características de los reglamentos, analiza el reglamento de competición en judo y el proceso de enseñanza-aprendizaje de las habilidades coordinativas y cognitivas. El cuarto capítulo expone las distintas clasificaciones existentes sobre los contenidos del judo. El quinto capítulo presenta una propuesta de clasificación de las habilidades específicas del judo atendiendo a los criterios de estructura general del movimiento, base de sustentación, espacio de ubicación y espacio de proyección. El sexto capítulo describe las características de las principales técnicas de judo clasificándolas en 3 grupos de técnicas como son aquellas con giro previo a la ejecución, técnicas sin giro previo a la ejecución y técnicas con paso a tendido supino previo a la ejecución. El séptimo capítulo clasifica las técnicas propias del judo suelo incluyendo numerosas fotografías explicativas. El octavo capítulo expone las etapas del proceso de iniciación deportiva para luego presentar una propuesta de distribución de los contenidos técnicos del judo en dichas etapas. El noveno capítulo define el concepto de iniciación deportiva, clasifica los contenidos, métodos de enseñanza y estructuración temporal de los contenidos de judo e incluye algunos ejemplos de ejercicios psicomotrices y juegos de oposición. Adjunta bibliografía.

127. Equipo Lidisa (1980). Ultimas técnicas de combate. Madrid: Difusión Librera. 1aㅡ ed. 146 p. : il. ; $14 \times 21$ cm. ISBN: 84-85265-62-9. Depósito legal: M. 25431-1980. Palabras clave: katas, fundamentos teóricos, fundamentos técnicos, defensa personal, entrenamiento, programa técnico. Resumen: Manual teórico y técnico de judo. La monografía esta compuesta por 3 partes, precedidas de una 
introducción que resume las vertientes del judo y su historia. La primera parte presenta los aspectos teóricos del judo en los que explica su práctica, la vestimenta, el saludo, el tatami, los distintos entrenamientos, las posturas, los agarres, los desplazamientos, los principios técnicos, las caídas, los encadenamientos, el gokyo, los grados, las competiciones, el dojo y las kata. La segunda parte describe la ejecución, contrapesas y encadenamientos de las técnicas de la nage-no-kata así como las técnicas de inmovilización kesa-gatame, kata-gatame y kami-shio-gatame junto con sus variantes, y las técnicas de estrangulamiento, incluyendo ilustraciones de sus ejecuciones. La tercera parte presenta las direcciones y zonas de ataque con un cuchillo para luego explicar las defensas contra dichos ataques, incluyendo una descripción detallada y varias ilustraciones. También presenta la ejecución técnica de presas, los puntos vitales del cuerpo, las distintas zonas de golpeo con la mano, el codo, la cabeza, la rodilla, el pie y sus respectivos ataques, incluyendo gráficos y esquemas de movimiento explicativos. Adjunta los reglamentos mundiales de competición, las máximas de Jigoro Kano y un vocabulario.

128. Ewen, Harry (1970). Tu libro de judo. Barcelona: Sintes. 1a ed. 38 p. : il. ; $15 \times 21 \mathrm{~cm}$. ISBN: No ISBN. Depósito legal: B. 37020-1970. Palabras clave: fundamentos técnicos, principios técnicos, vestimenta, competición, grados, instalaciones, reglamentos. Resumen: Manual teórico y técnico de judo. El libro esta compuesto por 5 capítulos, precedidos por un prólogo que comenta los contenidos del libro, la historia del judo deportivo y ofrece algunos consejos para la práctica. El primer capítulo explica los requisitos básicos para la práctica del judo, como la vestimenta y el tatami, además de presentar el sistema de grados. El segundo capítulo describe e ilustra la progresión de ejercicios para aprender a caer. El tercer capítulo explica la forma de desequilibrar al compañero para luego exponer la ejecución de una proyección de tobillo, de espaldas, de cadera, de cuerpo, de hombro, de riñones y de estómago, acompañadas de la secuencia fotográfica explicativa. El cuarto capítulo explica en qué consiste el combate en el suelo y sus principios técnicos junto con la descripción de varias técnicas de inmovilización y luxación. El último capítulo ofrece varias recomendaciones para la práctica del judo y la competición. Adjunta un extracto de las normas de competición de la Asociación de Judo Amateur.

129. Falsoni, Ennio (1975). El jiu-jitsu : la más terrible defensa personal. Barcelona: De Vecchi. 1a ed. 96 p. : il. ; 14x20,5 cm. ISBN: 84-315-3866-X. Depósito legal: M. 38322-1975. Palabras clave: fundamentos técnicos, judo, jujutsu, kárate. Resumen: Manual técnico de jiu-jitsu. Después de comentar en el primer capítulo la historia del jiu-jitsu pasa a describir las posiciones fundamentales y sus conceptos esenciales, y continúa con la explicación de la ejecución de las técnicas de puño, mano abierta, codo, pies, rodilla y las paradas. El quinto capítulo detalla la importancia del kiai dentro de las artes marciales para luego pasar a describir las defensas contra un agresor desarmado y utilizando técnicas propias de un karateka. Los siguientes capítulos se centran en contenidos propios del judo y así comienza explicando los principios generales de las proyecciones y algunas de sus técnicas más comunes, las posiciones fundamentales de judo, es decir, algunas de las proyecciones más habituales, y los principios técnicos de las estrangulaciones y luxaciones junto con la explicación de la ejecución de algunas de ellas. Adjunta un vocabulario.

130. Federación Española de Judo (1969). Judo : programa para maestro de judo no 1 . Madrid: Federación Española de Judo y Deportes Asociados. 1ํㅡㄹ ed. 47 p. : il. ; 21x29,5 cm. ISBN: No ISBN. Depósito legal: M. 17517-1969. Palabras clave: fundamentos técnicos. Resumen: Manual teórico y técnico de judo. El libro esta dividido en 10 capítulos. Cada capítulo tiene la misma estructura de contenidos, explicando las características generales de cada técnica, su descripción técnica acompañada de sus fotografías explicativas y esquemas de movimiento, sus puntos clave, los errores a evitar, los mejores momentos para aplicar dicha técnica, sus esquivas y defensas, sus combinaciones, sus contrapresas, sus encadenamientos y ejercicios específicos. Las técnicas presentadas son: o-goshi, ippon-seoi-nage, hizaguruma, de-ashi-barai, o-soto-gari, hon-gesa-katame, yoko-shiho-gatame, ushiro-gesa-katame, kamishiho-gatame y tate-shiho-gatame.

131. Federación Española de Judo (1969). Judo : programa para maestro de judo $n^{o}$ 3. Madrid: Federación Española de Judo y Deportes Asociados. 1aㅡ ed. 38 p. : il. ; 21x29,5 cm. ISBN: No ISBN. Depósito legal: M. 17517-1969. Palabras clave: fundamentos técnicos. Resumen: Manual teórico y técnico de judo. El libro esta dividido en 10 capítulos. Cada capítulo tiene la misma estructura de contenidos, explicando las características generales de cada técnica, su descripción técnica acompañada de sus fotografías explicativas y esquemas de movimiento, sus puntos clave, los errores a evitar, los mejores momentos para aplicar dicha técnica, sus esquivas y defensas, sus combinaciones, sus contrapresas, sus encadenamientos y ejercicios específicos. Las técnicas presentadas son: ko-uchi-gari, o-uchi-gari, taiotoshi, okuri-ashi-barai, koshi-guruma, kuzure-tate-shiho-gatame, kuzure-yoko-shiho-gatame, kuzuremakura-kesa-gatame, kuzure-kami-shiho-gatame y kuzure-tate-shiho-gatame.

132. Federación Española de Judo (1969). Judo : programa para maestro de judo no 4. Madrid: Federación Española de Judo y Deportes Asociados. 1ํㅡㄹ ed. 45 p. : il. ; 21x29,5 cm. ISBN: No ISBN. Depósito legal: M. 17517-1969. Palabras clave: fundamentos técnicos. Resumen: Manual teórico y técnico de judo. El libro esta dividido en 10 capítulos. Cada capítulo tiene la misma estructura de contenidos, explicando las características generales de cada técnica, su descripción técnica acompañada de sus fotografías 
explicativas y esquemas de movimiento, sus puntos clave, los errores a evitar, los mejores momentos para aplicar dicha técnica, sus esquivas y defensas, sus combinaciones, sus contrapresas, sus encadenamientos y ejercicios específicos. Las técnicas presentadas son: hane-goshi, ko-soto-gari, tomoe-nage, uchi-mata, kata-guruma, juji-jime, morote-jime, hadaka-jime, sode-guruma y ashi-gatamejime.

133. Federación Española de Judo y Disciplinas Asociadas (1982). Programa de nague-waza para monitores (texto oficial). Madrid: Federación Española de Judo y Deportes Asociados. 1aㅡ ed. 126 p. : il. ; 17x24 cm. ISBN: 84-500-7828-8. Depósito legal: no. Palabras clave: fundamentos teóricos, fundamentos técnicos, principios técnicos. Resumen: Manual teórico y técnico de judo. La obra esta compuesta por 20 lecciones o capítulos, precedidas de una introducción que explica la estructura de los contenidos del libro y el significado de la simbología utilizada. La primera lección presenta los fundamentos teóricos básicos del judo como son el lugar de entrenamiento, la vestimenta, los cinturones, las formas de saludar, las caídas, las posturas, la forma de agarrar, los desplazamientos y movimientos del cuerpo, los desequilibrios, la preparación y la proyección, los diferentes métodos de trabajo y la clasificación de las técnicas de proyección. El resto de lecciones contienen la misma estructura de contenidos en la que explican la ejecución básica de diferentes técnicas, las oportunidades para realizar dichas técnicas, sus puntos técnicos clave, los errores a evitar, las defensas, combinaciones, encadenamientos y contras para dichas técnicas y la descripción de los métodos de entrenamiento tandoku renshu y sotai renshu de cada técnica explicada. Las tres siguientes lecciones describen e ilustran la ejecución técnica de las proyecciones de mano: seoi-nage, kata guruma, tai otoshi, sumi otoshi, sukui nague y uki otoshi. Los siguientes cuatro capítulos presentan la ejecución de las proyecciones de cadera: uki goshi, o goshi, koshi guruma, tsuri goshi, tsuri komi goshi, harai goshi, hane goshi, uchi mata de koshi waza, ushiro goshi y utsuri goshi. Los siguientes siete capítulos detallan las técnicas de pierna: de ashi harai, okuri ashi harai, hiza guruma, sasae tsuri komi ashi, o soto gari, o soto guruma, o uchi gari, ko uchi gari, ko soto gari, ko soto gake, uchi mata, harai tsuri komi ashi, ashi guruma y o guruma. La siguiente lección estudia las técnicas de sacrificio frontal como: tomoe nage, sumi gaeshi y ura nague. Las últimas cuatro lecciones presentan las técnicas de sacrificio lateral como: uki waza, yoko otoshi, tani otoshi, yoko wakare, yoko guruma, yoko gake, soto makikomi y hane makikomi.

134. Federación Española de Lucha, Departamento Nacional de Judo (1965). Judo : arbitraje. Madrid: Talleres Tipográficos. 1aㅡ ed. 46 p. : il. ; 15x20,5 cm. ISBN: No ISBN. Depósito legal: M. 96-1965. Palabras clave: arbitraje, competición, reglamentos. Resumen: Tratado teórico de judo. El libro presenta el reglamento internacional de arbitraje de judo, comentando cada uno de sus artículos y dejando una hoja en blanco para los apuntes personales. También incluye una breve descripción y la representación gráfica de los gestos del árbitro así como las categorías de pesos.

135. Fernández Almodóvar, Amadeo (1985). Judo básico. Madrid: Alhambra. 1aa ed. 81 p. : il. ; 17x24 cm. ISBN: 84-205-1103-X. Depósito legal: M. 1897-1985. (1aㅡ reimp., 1986; 2a reimp., 1986). Palabras clave: katas, fundamentos técnicos, grados. Resumen: Manual técnico de judo. La obra esta formada por 6 capítulos. Los 5 primeros capítulos dividen los fundamentos técnicos del judo en los cinturones amarillo, naranja, verde, azul y marrón. El primer capítulo explica la forma de saludar, las posturas, el kumikata, los desplazamientos y movimientos del cuerpo, las fases de tsukuri, kake y los tipos de kuzushi, cómo se realizan las caídas y las técnicas de proyección o goshi, ippon seoi nage, de ashi barai, hiza guruma y osoto gari. El segundo capítulo describe e ilustra las técnicas sasae tsuri komi ashi, o uchi gari, ko uchi gari, morote seoi nage y uki goshi, además de exponer las características de los métodos de entrenamiento tandoku renshyu y sotai renshyu. El tercer capítulo describe e ilustra las técnicas okuri ashi barai, koshi guruma, tsuri kumi goshi, harai goshi y tai otoshi, explicando luego los métodos de entrenamiento uchi komi, yaku soku geiko, kakari geiko, randori y algunas formas de defensa. El cuarto capítulo describe e ilustra las técnicas uchi mata, hane goshi, ko soto gari, kata guruma y tomoe nage, y comenta el trabajo de combinaciones (renraku waza) y encadenamientos (renzoku waza) adjuntando varios ejemplos. El quinto capítulo describe e ilustra las técnicas kosoto gake, ashi guruma, harai tsuri kumi ashi, utsuri goshi, uki otoshi y te guruma. El último capítulo presenta la ejecución técnica de los tres primeros grupos de la nage no kata, con un esquema e ilustración de cada técnica. Adjunta bibliografía.

136. Ferret, José (1974). Judo. Barcelona: Plaza \& Janés. 1a ed. 30 p. : il. ; 22x25,5 cm. ISBN: 84-01-70024-8. Depósito legal: B. 46058-1974. Palabras clave: historia, fundamentos técnicos, principios técnicos, entrenamiento, vestimenta, cortesía, etiqueta, grados. Resumen: Manual teórico y técnico de judo. El libro consta de 14 capítulos. El primer capítulo comenta las diferentes vertientes que tiene la práctica del judo y explica en qué consiste cada una de ellas. El segundo capítulo narra la historia del judo, su evolución deportiva y llegada a España. El tercer capítulo expone las características del lugar y vestimenta de entrenamiento. El cuarto capítulo presenta el sistema de grados y el desarrollo de los exámenes hasta alcanzar el cinturón negro. El quinto capítulo explica los principios técnicos del judo, el desarrollo de una clase, sus métodos de entrenamiento y sus contenidos técnicos. El sexto capítulo comenta las reglas de competición. El séptimo capítulo expone los diferentes tipos de caídas y describe 
la ejecución de la caída de frente. Los dos siguientes capítulos exponen los principios de no-resistencia y de equilibrio junto con su forma de entrenamiento. El décimo capítulo explica los principios técnicos de las proyecciones para luego comentar las características de las técnicas de ashi-waza, koshi-waza, kata-waza, te-waza y sutemi-waza, además de describir algunas de las técnicas más comunes de las mismas. Los tres siguientes capítulos comentan las características técnicas de las inmovilizaciones, luxaciones, estrangulaciones y atemis, explicando la ejecución técnica de algunas de ellas. El último capítulo expone los objetivos del judo y su práctica. Incluye fotografías explicativas a lo largo del texto.

137. Franco de Sarabia, Fernando (1954). Ataque y defensa con judo y jiu-jitsu. Madrid: Gimnasio Escuela de judo Bushidokwai. 1aㅡ ed. 96 p. : il. ; 11x16 cm. ISBN: No ISBN. Depósito legal: no. Palabras clave: fundamentos técnicos, defensa personal, aplicación marcial. Resumen: Manual teórico y técnico de judo. El libro esta formado por 33 capítulos, precedidos por una introducción que comenta los contenidos de la obra. El primer capítulo describe la ejecución de las distintas formas de caer acompañadas de sus ilustraciones. El segundo capítulo explica los desequilibrios y cómo deben realizarse. El tercer capítulo describe dos técnicas de ataque de frente (o-soto-gari y de-ashi-harai) señalando el movimiento de los brazos, las piernas y el cuerpo junto con su representación gráfica. Los siguientes tres capítulos exponen la descripción técnica e ilustración de dos proyecciones de cadera, una proyección de hombro y dos técnicas de sutemi. El séptimo capítulo detalla la ejecución de las principales técnicas de estrangulación y continúa con la explicación de las técnicas básicas de inmovilización y sus respectivas ilustraciones. El noveno capítulo describe las técnicas de jiu-jitsu contra los agarres a las muñecas para continuar en los siguientes capítulos con la descripción de las técnicas defensivas contra agarres a las solapas, por la espalda, a la cintura, al cuello, contra un empujón, la estrangulación al cuello y cómo conducir a una persona en distintas situaciones. Los dos siguientes capítulos presentan una proyección de pierna y la salida contra una estrangulación. El último capítulo comenta algunos consejos prácticos sobre el entrenamiento y la defensa personal.

138. Franco de Sarabia, Fernando (1954). Judo y jiu-jitsu : cuaderno no 1 . Madrid: Imprenta Fernando Franco. $1 \underline{a}$ ed. 16 p. : il. ; 14x20,5 cm. ISBN: No ISBN. Depósito legal: no. Palabras clave: fundamentos técnicos, defensa personal. Resumen: Manual técnico de judo y jiu-jitsu. La obra comienza con una explicación de las generalidades sobre el jiu-jitsu, la caída de espaldas, los desequilibrios y los agarres, para continuar con la explicación de la ejecución técnica de 2 proyecciones de pierna, 2 de cadera y 2 técnicas de agarres de mano ante ataques de frente. Cada técnica adjunta varias ilustraciones.

139. Franco de Sarabia, Fernando (1954). Judo y jiu-jitsu : cuaderno no 2. Madrid: Imprenta Fernando Franco. $2^{\underline{a}}$ ed. 16 p. : il. ; 15x21 cm. ISBN: No ISBN. Depósito legal: no. Palabras clave: fundamentos técnicos, defensa personal. Resumen: Manual técnico de judo y jiu-jitsu. La obra comienza con la descripción de la caída de costado y pasa a describir la ejecución de 2 técnicas de proyección de pierna (Giza-guruma y Osoto-gake), 2 proyecciones de cadera (Tsuri-goshi y Koshi-guruma) y 1 proyección de hombro (Kata-seoe). Continúa con la explicación de kata-juji-jime y defensas contra agarre a la solapa y contra estrangulación, utilizando los agarres de mano. Todas las técnicas están ilustradas.

140. Franco de Sarabia, Fernando (1954). Judo y jiu-jitsu : cuaderno no 3. Madrid: Imprenta Fernando Franco. 1aㅡ ed. 16 p. : il. ; 15x21 cm. ISBN: No ISBN. Depósito legal: no. Palabras clave: fundamentos técnicos, defensa personal. Resumen: Manual técnico de judo y jiu-jitsu. La obra explica la ejecución técnica de la caída de frente, 2 proyecciones de pierna (Ouchi-gari y Kouchi-gari), 2 proyecciones de cadera (Ushiro-goshi y Tsurikomi-goshi), 1 proyección de hombro (Seoe-nage), 1 técnica de sacrificio (Tomoe-nage) y dos estrangulaciones (Giaku-juji-jime y Yoko-juji-jime). La parte de defensa personal incluye la defensa ante una ataque por la espalda con agarre por el cuello y con agarre por debajo de los brazos. Las técnicas explicadas están ilustradas.

141. Franco de Sarabia, Fernando (1954). Judo y jiu-jitsu : cuaderno no 4. Madrid: Imprenta Fernando Franco. $1^{a}$ ed. 16 p. : il. ; 15x21 cm. ISBN: No ISBN. Depósito legal: no. Palabras clave: fundamentos técnicos, defensa personal. Resumen: Manual técnico de judo y jiu-jitsu. La obra describe e ilustra la ejecución técnica de varias combinaciones de técnicas de proyección de pierna y de cadera, para luego incluir la descripción de la $15^{\underline{a}}$ proyección (Kata-Guruma), el $2^{\underline{o}}$ sutemi, la $4^{\underline{a}}$ y $5^{\underline{a}}$ técnicas de estrangulación acompañadas de sus ilustraciones explicativas. La segunda parte presenta varias técnicas de defensa personal contra un agarre alto, un agarre por detrás del cuello y la salida contra un agarre bajo, incluyendo su representación gráfica.

142. Franco de Sarabia, Fernando (1954). Judo y jiu-jitsu : cuaderno no 5. Madrid: Imprenta Fernando Franco. 1aㅡ ed. 17 p. : il. ; 22x16 cm. ISBN: No ISBN. Depósito legal: no. Palabras clave: fundamentos técnicos, defensa personal. Resumen: Manual técnico de judo y jiu-jitsu. La obra describe la ejecución de 2 técnicas de proyección de pierna, 2 proyecciones de cadera y 1 proyección de hombro. Continúa con la explicación de kata-ja-jime y varias técnicas de defensa personal contra ataques laterales. Todas las técnicas están ilustradas.

143. Franco de Sarabia, Fernando (1971). Cinturón negro de judo : programa para cinturón negro y entrenador regional de judo. Madrid: Gráficas Saldaña. 1aㅡ ed. 238 p. : il. ; [17x[25] cm. ISBN: No ISBN. Depósito legal: M. 22181-1971. (2ª ed., 1971, ISBN: 84-400-2367-7; 3를. ed., 1977, 262 p., ISBN: 84- 
85977-17-3). Palabras clave: katas, fundamentos técnicos, programa técnico. Resumen: Manual técnico de judo. La obra esta dividida en 7 partes, precedidos por varios capítulos introductorios que comentan la historia del judo, explican el programa que se describe en la monografía y detallan los aspectos formales (lugar de entrenamiento, vestimenta y saludos) y fundamentos técnicos básicos del judo (caídas, posturas, desequilibrios, desplazamientos, tai sabaki, forma de caminar, agarre, kuzuchi, tsukuri y kake, forma de sujetar y nomenclatura). Las siguientes cinco partes presentan los contenidos técnicos de los cinturones amarillo, naranja, verde, azul y marrón de judo, describiendo e ilustrando las respectivas técnicas de proyección, inmovilización, estrangulación y/o luxación. En las técnicas de proyección explica la postura inicial, los principios de kuzuchi, tsukuri y kake, los puntos más importantes en su ejecución y los mejores momentos para desarrollar dicha técnica, acompañada de la secuencia fotográfica de su ejecución. En las técnicas de inmovilización comenta sus generalidades y describe la posición de los brazos, del cuerpo y de las piernas y los puntos más importantes para su correcta ejecución, además de incluir varias representaciones gráficas. En las estrangulaciones y luxaciones expone su ejecución técnica, resalta los puntos más importantes de las mismas y señala las diferentes variantes de cada técnica, incluyendo diferentes ilustraciones. La sexta parte presenta el programa para cinturón negro 1er dan, comentando el trabajo de combinaciones, contraataques y confusión. La última parte presenta la ejecución de diferentes combinaciones y contraataques para adquirir el cinturón negro. Adjunta varios capítulos finales que describen la ejecución de la nage-nokata, presentan varios ejercicios de lucha en el suelo, defensas contra un adversario entre las piernas, formas de atacar en el suelo, formas de volcar a un adversario que se mantiene a la defensiva a cuatro patas, formas de volcar cuando se esta tumbado boca-abajo, salidas de kata-gatame, kuzure-kamishiho-gatame, yoko-shiho-gatame y tate-shiho-gatame, y un breve comentario sobre la ejecución de la nage-no-kata.

144. Frutos Molinero, José Luis de (1981). Fundamentos de ne-waza y mi tate-shio-gatame. Madrid: José Luis de Frutos Molinero. 1aㅡ ed. 119 p. : il. ; 18x26,5 cm. ISBN: 84-300-4094-3. Depósito legal: M. 9459-1981. Palabras clave: fundamentos técnicos, calentamiento. Resumen: Manual teórico y técnico de judo. La obra esta formada por 11 capítulos. El primer capítulo presenta e ilustra un calentamiento específico para el trabajo en el suelo (ne-waza) para luego enumerar e ilustrar los fundamentos de las inmovilizaciones y las posiciones básicas. El cuarto capítulo ilustra las principales inmovilizaciones desde varios puntos de vista para luego describir e ilustrar las salidas a dichas inmovilizaciones. El sexto capítulo explica los fundamentos del randori de ne-waza y ofrece algunos métodos para su entrenamiento. El siguiente capítulo explica brevemente e ilustra mediante una secuencia fotográfica las posiciones de trabajo y defensa en el suelo, para luego exponer distintas formas de soltar una pierna enganchada por uke y distintas formas de encadenar el trabajo de pie y en el suelo. El décimo capítulo presenta la técnica de especialización (tate-shio-gatame) del autor y sus variaciones; para finalizar con un conjunto de fotografías comentadas sobre la vida deportiva del autor.

145. García García, José Manuel; Valle Díaz, Sagrario del; Díaz González, Paz y Velázquez Velázquez, Remedios (2006). Judo : juegos para la mejora del aprendizaje de las técnicas. Badalona: Paidotribo. 1a ed. 325 p. : il. ; 15x21,5 cm. ISBN: 84-8019-865-6. Depósito legal: no. Palabras clave: didáctica, judo, juegos. Resumen: Compendio de juegos para el aprendizaje de los contenidos de judo. La obra esta dividida en 2 partes, precedidas por una introducción que comenta los aspectos teóricos del juego y ofrece la clasificación de los juegos que se presentan posteriormente. La primera parte recopila las fichas de los juegos encaminados a desarrollar la técnica general de judo, como son las caídas, el agarre, las posiciones, las proyecciones, los controles y el randori-suelo. La segunda parte recoge las fichas de los diferentes juegos que desarrollan el aprendizaje de las técnicas específicas de cinturón amarillo, naranja y verde. Cada ficha esta compuesta por el nombre del juego, los aspectos informacionales, cualidades físicas y técnicas que trabaja y una representación gráfica junto con su explicación y las variantes del juego.

146. García García, José Manuel y Delgado Tostado, Juan (1982). Jiu-jitsu moderno : técnica y progresión en su metodología. s.l.: Academia General Militar. 1aㅡ ed. 197 p. : il. ; 21x30,5 cm. ISBN: 84-300-7151-2. Depósito legal: no. Palabras clave: katas, fundamentos técnicos, programa técnico, principios técnicos, defensa personal, judo, armas. Resumen: Manual teórico y técnico de jiu-jitsu. El libro esta dividido en 10 capítulos. El primer capítulo explica en qué consiste la posición de guardia, describe su ejecución, clasifica los tipos de desplazamientos acompañados de su representación gráfica y esquemas de movimiento, ilustra las distintas formas de caer y presenta la explicación e ilustración de varias técnicas ante distintas estrangulaciones y agarres con resolución por control y atemi. El segundo capítulo describe la ejecución de diversas técnicas ante ataques de estrangulación, agarres y presas con resolución por proyección y atemi. El tercer capítulo presenta la progresión de aprendizaje de varias técnicas de jiu-jitsu contra puñetazos y patadas incluyendo sus ilustraciones explicativas. El cuarto capítulo ilustra las distintas formas de empuñar y atacar con un cuchillo junto con algunas de sus principales defensas. El quinto capítulo explica los principios de actuación ante un ataque con arma larga y con arma de fuego para luego describir e ilustrar sus formas de ataque y algunas técnicas de 
defensa personal ante distintas situaciones con estas armas. El sexto capítulo clasifica los tipos de atemi, ilustra sus principales técnicas así como las defensas básicas. El séptimo capítulo expone los tipos de katas y presenta la explicación de varias katas para el entrenamiento de los contenidos antes mencionados. El octavo capítulo nombra e ilustra los fundamentos técnicos del judo y el aikido. El noveno capítulo incluye el programa de contenidos del curso de instructores de defensa personal de la Escuela Central de Educación Física. El décimo capítulo incluye el programa de contenidos de jiu-jitsu hasta cinturón marrón.

147. Gaspar Cortina, Víctor Manuel (1977). Judo junior : 1ํ. Cinturón blanco y cinturón amarillo. Bilbao: Fher. $1^{\underline{a}}$ ed. 45 p. : il. ; 17x24 cm. ISBN: 84-243-1412-3. Depósito legal: BI. 2069-1977. (2aㅡ ed., 1978; $3^{\underline{a}}$ ed., 1980). Palabras clave: fundamentos teóricos, fundamentos técnicos, vestimenta. Resumen: Manual técnico de judo. El primer capítulo explica la vestimenta y la forma de saludar. El segundo capítulo describe e ilustra los distintos tipos de caídas y la forma de agarrar (kumi-kata). El tercer capítulo explica los desequilibrios para luego presentar la ejecución técnica por partes de las proyecciones de ashi barai, hiza guruma, o soto gari, o goshi, ippon seoi nage, las inmovilizaciones hon kesa gatame, kata gatame, yoko siho gatame, kami siho gatame y tate siho gatame además de incluir la secuencia gráfica de su ejecución y comentar los métodos de entrenamiento tandoku renshyu y sotai renshyu para el cinturón blanco; y las proyecciones sasae tsuri komi ashi, o uchi gari, ko uchi gari, uki goshi, morote seoi nage, y las inmovilizaciones kuzure kesa gatame, ushiro kesa gatame, makura kesa gatame, kuzure yoko siho gatame y kuzure kami siho gatame para el cinturón amarillo.

148. Gaspar Cortina, Víctor Manuel (1977). Judo junior : 2ํㅜ Cinturón naranja y cinturón verde. Bilbao: Fher. $1^{\underline{a}}$ ed. 46 p. : il. ; 17x23,5 cm. ISBN: 84-243-1413-1. Depósito legal: BI-2068-1977. (2ª ed., 1978; $3^{\text {a }}$ ed., 1980; 4⿳a ed., 1981). Palabras clave: fundamentos técnicos. Resumen: Manual técnico de judo. El libro presenta los principales métodos de entrenamiento del judo (uchi komi, yaku soku geiko, kakari geiko y randori) para luego describir la ejecución técnica de las proyecciones okuri ashi barai, koshi guruma, tsuri komi goshi, harai goshi, tai otoshi; algunas variantes de las principales técnicas de inmovilización; distintas formas de entrar cuando el compañero está en el suelo y las técnicas de estrangulación okuri eri jime, hadaka jime para el cinturón naranja; y las proyecciones ko soto gari, uchi mata, hane goshi, kata guruma, tomoe nage, las estrangulaciones kata juji jime, giaku juji jime, nami juji jime, kata ha jime, dos entradas más cuando el compañero está en el suelo y las luxaciones al codo juji gatame y ude garami para el cinturón verde.

149. Gaspar Cortina, Víctor Manuel (1977). Judo junior : 3ํ․ Cinturón azul y cinturón marrón. Bilbao: Fher. 1a ed. 45 p. : il. ; 24x17 cm. ISBN: 84-243-1480-8. Depósito legal: no. (2ª ed., 1978; 3aㅡ ed., 1981). Palabras clave: fundamentos técnicos. Resumen: Manual técnico de judo. El libro presenta los fundamentos técnicos del cinturón azul y marrón respectivamente. Comienza describiendo la ejecución de las técnicas ko soto gake, harai tsuri komi ashi, uki otoshi, utsuri goshi, ashi guruma, o guruma, las diferencias entres técnicas parecidas y 3 entradas de frente, 3 entradas estando sobre la espalda, 3 entradas de costado y 3 formas de salida de piernas, incluyendo la representación gráfica de todas ellas. Para el cinturón marrón presenta la ejecución e ilustración de las técnicas o soto otoshi, te guruma, 3 entradas por la espalda, 2 entradas estando sobre la espalda, ashi gatame jime, morote jime, ude gatame, waki gatame, hiza gatame y las diferencias entre técnicas similares.

150. Gaspar Cortina, Víctor Manuel (1996). El libro del judoka. Bilbao: Víctor Manuel Gaspar Cortina. 1a ed. 145 p. : il. ; 17x24 cm. ISBN: 84-605-5165-2. Depósito legal: BI. 921-1996. (2ª ed., 2009). Palabras clave: katas, historia, fundamentos teóricos, fundamentos técnicos, programa técnico, entrenamiento, arbitraje, sistemas de entrenamiento. Resumen: Manual teórico y técnico de judo. El libro esta dividido en 8 partes, precedidas por varios capítulos introductorios que relatan la historia del judo, los beneficios físicos y psíquicos de su práctica, sus máximas y cómo atarse el cinturón. La primera parte presenta los contenidos teóricos y técnicos del cinturón blanco-amarillo describiendo e ilustrando la forma de saludar, las caídas, el agarre, las proyecciones uki goshi, o soto gari y o uchi gari, las inmovilizaciones hon kesa gatame y kami shioho gatame y dos entradas cuando uke está en cuadrupedia y estirado. La segunda parte expone los fundamentos teóricos y técnicos del cinturón amarillo como la postura, los desplazamientos, las proyecciones koshi guruma, harai goshi y seoi nage; las inmovilizaciones kuzure kesa gatame, yoko shiho gatame y las salidas de las inmovilizaciones vistas hasta el momento; las combinaciones o uchi gari-o soto gari y o soto gari-o uchi gari; y tres entradas cuando uke esta en cuadrupedia, estirado y entre las piernas. La tercera parte explica los métodos de entrenamiento tandoku rensiu, sotai rensiu, uchi komi y nage komi, además de describir las proyecciones de ashi barai, o goshi, ipon seoi nage; las inmovilizaciones kata gatame y tate shiho gatame; las combinaciones ouchi gari-de ashi barai y uki goshi-harai goshi; y dos entradas cuando uke esta en cuadrupedia y tori entre las piernas respectivamente. La cuarta parte expone los principios técnicos del cinturón naranja, como son kuzushi, tsukuri y kake; describe la ejecución de tai otoshi, sasae tsuri komi ashi, okuri ashi barai y harai goshi junto con sus ilustraciones; la inmovilización kuzure yoko shiho gatame, una salida para hon kesa gatame y el principio de flotación para mantener la inmovilización; las combinaciones harai goshi-o soto gari y harai goshi-o uchi gari; dos entradas 
cuando uke esta entre las piernas y tori entre las piernas respectivamente; y propone distintas situaciones de proyección en movimiento. La quinta parte incluye los contenidos del cinturón naranjaverde, explicando el randori y el yaku soku geiko; las técnicas hiza guruma y ko uchi gari; las combinaciones o soto gari-hiza guruma, o uchi gari-tai otoshi, o uchi gari-harai goshi y ko uchi gariharai goshi. La sexta parte detalla los métodos de entrenamiento kakari geiko y shiai, además de comentar la ejecución de morote seoi nage y uchi mata; kuzure kami shiho gatame y su salida; discutir la utilización de la fuerza en el judo; comentar la importancia de los controles con las piernas; presentar la forma de inmovilizar cuando uke esta en cuadrupedia, estirado y entre las piernas y proponer varias situaciones de estudio de las proyecciones. La séptima parte describe la ejecución técnica de tomoe nage, yoko tomoe nage, makura kesa gatame y sankaku gatame acompañadas de su respectiva ilustración, ofrece consejos para el progreso en el aprendizaje y presenta la forma de inmovilizar a uke cuando esta entre las piernas, cuando tori está entre las piernas así como algunas situaciones de estudio de las proyecciones. La última parte explica el trabajo de renraku waza, describe la ejecución de las técnicas incluidas en el nivel de cinturón marrón, como son uki otoshi, kata guruma, ko soto gake, ko soto gari, ashi guruma, o guruma, juji gatame y ude garami con su ilustración, presenta algunos ejemplos de combinaciones y encadenamientos, describe e ilustra las 3 primeras series de la nage-no-kata, enumera los términos más comunes en el arbitraje de una competición e incluye varias tablas para anotar los resultados y asistencias a competiciones y cursos. Adjunta páginas para notas y cromos para pegar en el libro.

151. Gaspar Cortina, Víctor Manuel (1997). Nuevo judo junior. Bilbao: V.M.G. 1aㅡ ed. 134 p. : il. ; 17x24 cm. ISBN: 84-923186-0-0. Depósito legal: BI. 2112-1997. Palabras clave: fundamentos técnicos. Resumen: Manual teórico y técnico de judo. El libro presenta a modo de cómic los fundamentos teóricos y técnicos desde cinturón blanco hasta cinturón negro. Describe la forma de ejecutar el saludo, las caídas, el agarre, los desequilibrios, las principales técnicas de proyección, inmovilización, luxación y estrangulación, sus combinaciones, entradas y salidas, y un comentario sobre los diferentes métodos de entrenamiento. La primera parte explica las técnicas de-ashi-barai, hiza-guruma, o-soto-gari, ogoshi, ippon-seoi-nage; las inmovilizaciones hon-kesa-gatame, kata-gatame, yoko-siho-gatame, kamisiho-gatame, tate-siho-gatame; y los métodos de entrenamiento tandoku-renshyu y sotai-renshyu. La segunda parte explica: kuzure-kesa-gatame, ushiro-kesa-gatame, makura-kesa-gatame, kuzure-yokosiho-gatame, kuzure-kami-siho-gatame; junto con los métodos uchi-komi, yaku soku geiko, kakari geiko y randori. La tercera parte incluye la descripción de las técnicas okuri-ashi-barai, koshi-guruma, tsuri-komi-goshi, harai-goshi, tai-otoshi; las entradas en el suelo, las estrangulaciones o-kuri-eri-jime y hadaka-jime y algunas combinaciones. La cuarta parte describe las técnicas ko-soto-gari, uchi-mata, hane-goshi, kata-guruma, tomoe-nage, kata-juji-jime, gyaku-juji-jime, nami-juji-jime; las luxaciones juji-gatame, ude-garami, ude-gatame, hiza-gatame, waki-gatame, hara-gatame; las estrangulaciones kataha-jime, ko-soto-gake; y comenta las diferencias entre de-ashi-barai, ko-soto-gari y ko-soto-gake. La quinta parte describe las técnicas harai-tsuri-komi-goshi, uki-otoshi, utsuri-goshi; las entradas al trabajo en suelo de frente y de costado y las salidas de piernas. La última parte describe ashi-guruma, o-guruma, o-soto-otoshi, te-guruma, las entradas al suelo por la espalda, las estrangulaciones ashigatame-jime y morote-jime y la luxación ude-gatame.

152. Ghetti, Roberto (2000). Lecciones de judo. Barcelona: De Vecchi. 1a ed. 111 p. : il. ; 17x24 cm. ISBN: 84315-2340-9. Depósito legal: B. 3354-2000. (2a ed., 2001). Palabras clave: fundamentos técnicos. Resumen: Manual técnico de judo. El libro esta dividido en 4 partes. La primera de ellas narra la historia del judo hasta su entrada en la competición. La segunda parte describe el lugar y la vestimenta que se porta en la práctica, cuáles son las divisiones por edad y peso, cuál suele ser la progresión de contenidos en el entrenamiento y unos fundamentos básicos sobre las posiciones del cuerpo, el agarre y los desplazamientos. La tercera parte desarrolla las técnicas de proyección del método Kodokan, explicando cada una de ellas en partes y ofreciendo varias ilustraciones tanto del movimiento general como de sus detalles. La cuarta parte describe las técnicas de control del método Kodokan, ofreciendo una explicación de la ejecución de cada técnica y varias ilustraciones.

153. Gimnasio Club Abascal (Ungría, Bernardo) (1952). Judo y jiu-jitsu. 40 lecciones prácticas de fácil interpretación. Madrid: Gráficas Express. 1aㅡ ed. 43 p. : il. ; 22x17,5 cm. ISBN: No ISBN. Depósito legal: no. Palabras clave: fundamentos técnicos, principios técnicos, defensa personal. Resumen: Manual técnico general de judo. La obra esta dividida en 40 lecciones que desarrollan algunos conceptos teóricos sobre el judo y sus objetivos, distintas situaciones de defensa contra ataques armados y desarmados, los principios de las proyecciones junto con algunas situaciones de defensa, la teoría de la lucha en el suelo y las inmovilizaciones, las estrangulaciones y algunas defensas con rotura. A continuación describe los puntos débiles del cuerpo, los principios generales de los golpeos, las técnicas de sacrificio, el kuatsu, el kiai, y finaliza con la explicación de una clase de entrenamiento en judo y los beneficios morales derivados de la práctica del mismo. Cada lección esta acompañada de ilustraciones y algunos breves comentarios complementarios. 
154. Gladman, George (1954). Jiu-jitsu y judo : preparación, entrenamiento, técnica. Barcelona: Sintes. 1a ed.

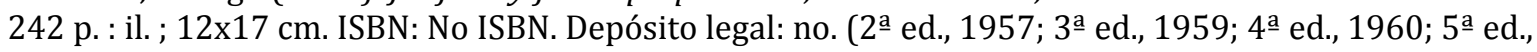

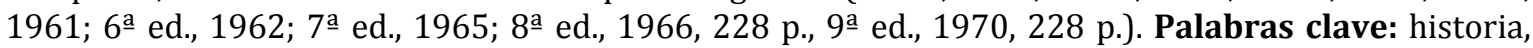
fundamentos teóricos, fundamentos técnicos, principios técnicos, kyudo, sumo, wushu. Resumen: Manual teórico y técnico de jiu-jitsu. La obra esta dividida en 8 capítulos, precedidos por una introducción que comenta en qué consiste el jiu-jitsu. El primer capítulo narra la historia y evolución del jiu-jitsu y el judo, incluyendo algún comentario sobre el sumo, el wushu y el kyudo. El segundo capítulo explica cómo funciona el jiu-jitsu ante una situación de defensa personal, resalta sus beneficios y enumera las cualidades que exige al practicante. El tercer capítulo describe distintos ejercicios de calentamiento y flexibilidad, tanto individuales como por parejas, y las distintas formas de caer, además de comentar las reglas generales para el entrenamiento y los principios técnicos del jiujitsu. El cuarto capítulo describe la vestimenta del judo, su sistema de grados, los principios físicos que explican las proyecciones, la posición y guardia normal, enumera los principios generales de las proyecciones, describe e ilustra las técnicas fundamentales de proyección, de inmovilización, de estrangulamiento junto con sus principios teóricos, y expone las formas de obtener un punto y los actos prohibidos de la competición de judo. El quinto capítulo describe las principales técnicas de luxación de brazo, de pierna y de cuello estando el adversario en distintas posiciones. El sexto capítulo describe algunas variantes de las técnicas de inmovilización presentadas anteriormente incluyendo su representación gráfica. El séptimo capítulo explica la ejecución de algunas proyecciones complementarias a las anteriormente presentadas y algunas técnicas de sacrificio junto con sus ilustraciones. El último capítulo presenta la ejecución técnica de otro conjunto de técnicas de estrangulamiento con su representación gráfica.

155. Gleeson, G. R. (1977). Judo para occidentales. Barcelona: Hispano Europea. 1aㅡ ed. 246 p. : il. ; 13x19,5 cm. ISBN: 84-255-0444-9. Depósito legal: B. 5988-1977. Palabras clave: pedagogía, fundamentos técnicos. Resumen: Manual sobre los métodos de enseñanza, el entrenamiento de la técnica y sus principios en el judo. La monografía consta de 5 capítulos, con el primero de ellos presentando los aspectos generales de los métodos de enseñanza y reflexionando sobre la importancia de la planificación del entrenamiento, la organización de la clase, el profesor, el alumno, la interacción profesor-alumno, el control de la clase y algunos métodos para guiar el aprendizaje. El segundo capítulo ahonda en el análisis de la práctica del judo y sus técnicas para así encontrar los principios que deben regir el entrenamiento técnico y reflexionar sobre su aplicación en los diferentes ejercicios. El tercer capítulo aplica los principios de enseñanza comentados anteriormente sobre el propio entrenamiento, comentando su correcta aplicación práctica. El cuarto capítulo profundiza en la enseñanza de la técnica de judo hasta un nivel intermedio, ofreciendo ejemplos de dicho proceso. El último capítulo describe los exámenes para acceder a las diferentes titulaciones de judo así como los contenidos técnicos que se deben enseñar hasta el nivel de 1er dan. También incluye el gokyo y un glosario.

156. Goenaga Larrañaga, Amaia (1998). Entrenatzaile eta irakasleentzako, fitxa didaktikoak : judoa. San Sebastián: Deba Bailarako Euskara eta Kirol Zerbitzuak. 1aㅡ ed. 63 p. : il. ; 21x15 cm. ISBN: 84-9202479-8. Depósito legal: SS. 817-1998. Palabras clave: historia, fundamentos teóricos, entrenamiento, fundamentos técnicos, didáctica, competición, juegos, reglamentos. Resumen: Manual teórico y técnico del judo. La obra consta de 9 capítulos. El primer capítulo detalla la historia del judo y la aportación de Jigoro Kano al mismo. El segundo capítulo presenta los elementos básicos del judo, como la vestimenta, el saludo, la posición natural, el agarre, los desplazamientos, los principios técnicos y los métodos de entrenamiento. El tercer capítulo describe distintos ejercicios de calentamiento tanto para el entrenamiento como para la competición. El cuarto capítulo resume los elementos básicos del reglamento de competición. El quinto capítulo describe la progresión didáctica para el aprendizaje de las caídas junto con algunos de sus juegos, ilustra las principales técnicas de proyección, de inmovilización, de estrangulación y de luxación y expone la progresión didáctica para conseguir el dominio técnico de estos fundamentos técnicos. El sexto capítulo incluye la descripción de algunos ejemplos prácticos sobre la progresión didáctica de las principales técnicas de proyección e inmovilización. El séptimo capítulo describe la ejecución de distintos juegos de oposición sin judogi. El octavo capítulo expone la estructura de una sesión práctica de judo, enumerando los ejercicios y su tiempo de realización. El último capítulo incluye un breve diccionario básico de judo.

157. Gómez, Dardo y Seguí, Rafael (1987). Judo i boxa amateur. Barcelona: GS Consultores de comunicación. $1^{\mathfrak{a}}$ ed. 14 p. : il. ; 24x16 cm. ISBN: No ISBN. Depósito legal: B. 44161-1987. (2a ed., 1990). Palabras clave: fundamentos técnicos, historia, vestimenta, judo, boxeo, competición, reglamentos. Resumen: Manual teórico y técnico de judo y boxeo. El libro esta formado por dos partes. La primera parte explica los contenidos técnicos del judo, su indumentaria, las categorías de peso, el lugar de competición (tatami), el desarrollo del combate y las técnicas aplicadas, el sistema de puntuación y las reglas básicas. La segunda parte narra la historia del boxeo, sus categorías de peso, su indumentaria y accesorios, las técnicas básicas utilizadas y su reglamento. 
158. González Álvarez, Amador (1998). Teoría y práctica del judo : con especial referencia a la ESO. Villaviciosa de Odón: Universidad Europea-CEES Ediciones. 1aㅡ ed. 126 p. : il. ; 21x29,5 cm. ISBN: 8488881-71-1. Depósito legal: M. 14931-1998. Palabras clave: pedagogía, didáctica, biomecánica. Resumen: Tratado teórico y pedagógico del judo en la Educación Secundaria Obligatoria (ESO). La obra esta dividida en 11 capítulos y comienza analizando en los dos primeros capítulos la ESO y el área de Educación Física, para luego pasar a comentar sucintamente la historia del judo, sus relaciones interdisciplinares y con los temas transversales de la ESO. El cuarto capítulo presenta los objetivos que pueden perseguir las clases de judo y el quinto los contenidos tanto conceptuales como procedimentales y actitudinales que pueden trabajar los profesores. El sexto capítulo describe las técnicas de judo ( 9 técnicas de judo suelo y 20 técnicas de judo pie) que forman parte de la unidad didáctica y que son las más utilizadas dentro de la competición. El séptimo capítulo analiza los niveles de la táctica individual y prosigue con la explicación de los tipos de fuerza, su entrenamiento y propone ejemplos de programación dependiendo del momento de la temporada. El noveno capítulo describe los distintos estilos de enseñanza que se pueden aplicar al judo y finaliza con una clasificación de las proyecciones y unos criterios técnicos para la correcta realización de los gestos deportivos en el décimo capítulo y unas nociones generales sobre la evaluación en el último capítulo.

159. González Enríquez, Victorino y Artímez, José Antonio (1992). Los deportes olímpicos y los grandes especialistas gallegos : Judo. A Coruña: La Voz de Galicia. 1ํㅡㄹ ed. 62 p. : il. ; 15x20,5 cm. ISBN: 84-8528799-1. Depósito legal: C 250-1992. Palabras clave: historia, fundamentos teóricos, fundamentos técnicos, didáctica. Resumen: Manual teórico y técnico de judo. La obra esta formada por 6 capítulos. El primer capítulo relata los orígenes del judo, la creación de Jigoro Kano y su expansión a Europa. El segundo capítulo comenta la evolución de la competición y sus normas, así como su inclusión en el programa de los Juegos Olímpicos. El tercer capítulo explica en qué consiste el judo, las características técnicas del tatami, los principales términos utilizados en la competición, y narra la historia del judo gallego. El cuarto capítulo describe la ejecución técnica y principales errores de las distintas formas de caer y las técnicas de-ashi-barai, hiza-guruma, o-soto-gari, o-goshi, seoi-nage, sasae-tsuri-komi-ashi, uki-goshi, o-uchi-gari, okure-ashi-barai, tai-otoshi, comenta los fundamentos teóricos de las proyecciones, describe las posiciones básicas de las técnicas de inmovilización como kesa-gatame, kata-gatame y shiho-gatame junto con sus variantes, las principales técnicas de estrangulación y luxación e incluyendo alguna ilustración de sus detalles técnicos. También comenta las características del judo en la infancia, sus principios didácticos y la importancia de los juegos. El quinto capítulo incluye una breve biografía de Anton Geesink, Jigoro Kano, Victorino González Enríquez y Pilar Veira Lauzara. El último capítulo incluye un vocabulario básico de judo.

160. González Humanes, Ángel Luis (2002). Jiu-jitsu : programa oficial. Madrid: Universidad Autónoma de Madrid. 1a ed. 177 p. : il. ; 21x29,5 cm. ISBN: 84-7477-847-6. Depósito legal: M. 45091-2002. (2ª ed., 2004, 189 p., ISBN: 84-7477-947-2). Palabras clave: historia, fundamentos técnicos, educación, kyusho, competición, exámenes, reglamentos, juegos, preparación física, programa técnico. Resumen: Tratado teórico de jiu-jitsu. El libro esta compuesto de 12 capítulos, precedidos por la biografía deportiva y profesional del autor y su colaborador Manuel Alejandro Guerrero Henche. Los dos primeros capítulos relatan la historia del jiu-jitsu y su introducción en España. El tercer capítulo enumera e ilustra los contenidos técnicos del gokyo de jiu-jitsu junto con la ilustración de las katas. El cuarto capítulo localiza los puntos vitales del cuerpo humano así como las distintas partes del cuerpo utilizadas para golpear. El quinto capítulo incluye las hojas de examen desde 1er hasta $5^{\circ}$ dan. El sexto capítulo enumera los criterios de evaluación y puntuación. El siguiente capítulo presenta las tesinas de jiu-jitsu y las normas de enseñanza para los cursos de titulación de jiu-jitsu. El octavo capítulo describe los objetivos y consideraciones deportivas del jiu-jitsu en la infancia. El noveno capítulo expone los objetivos y ejecución de distintos juegos para el jiu-jitsu. El décimo capítulo muestra la estructura de un combate. Los dos últimos capítulos incluyen un resumen de la teoría del entrenamiento respecto a la preparación física además de las reglas de competición. Adjunta un glosario y bibliografía.

161. González Núñez, Anton (1981). El viejo ju-jitsu. Barcelona: Alas. 1aㅡ ed. 150 p. : il. ; 15x21,5 cm. ISBN: 84-203-0120-5. Depósito legal: B. 33374-1981. Palabras clave: historia, fundamentos técnicos, programa técnico, didáctica, defensa personal, entrenamiento, aplicación marcial, maestros, sistemas de entrenamiento. Resumen: Manual teórico y técnico de ju-jitsu. El libro esta dividido en 3 partes. La primera parte comenta la historia del ju-jitsu, la aportación de los maestros Kano y Kawaishi, ofrece algunos consejos para escoger un gimnasio, comenta la organización del ju-jitsu en España, su práctica, sistema de grados y titulación de sus profesores, explica las cualidades que debe poseer un buen maestro, el desarrollo de un test de condición física para el principiante, la estructura de una clase, los métodos de entrenamiento, ofrece algunos consejos didácticos y comenta la importancia de crear el reflejo condicionado, el funcionamiento del kiai y el kuatsu, y el estudio de las pupilas. La segunda parte define las formas y tipos de ataque, describe la forma de saludar y la actitud en el dojo, explica la ejecución técnica de las diferentes formas de caer, las guardias, desplazamientos y tai-sabaki acompañados de sus correspondientes ilustraciones, enumera los puntos vitales del cuerpo humano y 
sus efectos, los atemis, técnicas de estrangulación y luxación básicas junto con su representación gráfica, y comenta la actitud y entrenamiento psicológico del practicante. La tercera parte incluye los programas técnicos por cinturones hasta el nivel de cinturón negro presentando los contenidos técnicos de cada nivel e incluyendo la descripción e ilustración de algunas de las técnicas de defensa personal de cada nivel. Finaliza enumerando las ventajas e inconvenientes del entrenamiento de jujitsu. Adjunta bibliografía.

162. Grupo Gimnasios Unidos Madrid (1980). Judo. Madrid: Imprenta Taravilla. $1^{\mathrm{a}}$ ed. 61 p. : il. ; 11x15,5 cm. ISBN: No ISBN. Depósito legal: M. 268-1980. Palabras clave: katas, historia, fundamentos teóricos, fundamentos técnicos, primeros auxilios. Resumen: La libreta esta formada por una página inicial de datos personales, breve historia del judo japonés, listado del palmarés internacional del judo español, tabla-resumen de los campeonatos del mundo y sus campeones, un listado de las reglas de higiene y decoro, los momentos de saludar, la puntuación en la competición, algunos términos de arbitraje, un espacio libre para anotar las principales competiciones del propietario, una tabla con el programa de judo en pie y en el suelo con el término japonés y su traducción, un espacio libre para anotar los clubes, domicilios, profesores y teléfono de los mismos, un listado con los principales encadenamientos y contrapesas de judo, los grados que existen, la explicación de los fundamentos técnicos básicos (kumikata, desplazamiento, tai-sabaki, uchi-komi, resumen de la sesión de entrenamiento), un espacio libre para anotar los resultados de las competiciones del propietario, un listado de las técnicas a utilizar como defensa personal ante distintos ataques, la enumeración de las partes de una lección de judo, la ilustración de distintos ejercicios de calentamiento, las caídas, las posturas, y finaliza con una tabla resumen de las principales técnicas de judo y su ilustración así como la secuencia gráfica de la ejecución de la nage-no-kata, la katame-no-kata y la kime-no-kata. Adjunta un pequeño diccionario y varios gráficos sobre cómo vendar la articulación del tobillo, codo y hombro.

163. Grupos Universitarios de Lucha del S.E.U. (Madrigal, Sergio y Sanchis, Rafael) (1956). Judo. Grupos Universitarios de Lucha: S.E.U. (Primer cuaderno). Madrid: S.E.U. 1a ed. 16 p. : il. ; $16 \times 21 \mathrm{~cm}$. ISBN: No ISBN. Depósito legal: no. Palabras clave: fundamentos técnicos. Resumen: Manual técnico de judo. La obra comienza describiendo brevemente las direcciones de desequilibrio y las caídas para luego pasar a explicar la ejecución técnica del trabajo de pie: De-Ashi-Harai, Hiza-Guruma, Sasae-Tsurikomi-Ashi, Uki-Goshi, Osoto-Gari, O-Goshi, Ouchi-Gari, Seoe-Nage; y del trabajo de suelo: Hon-Kesa-Gatame, Kuzure-Kesa-Gatame, Makura-Kesa-Gatame, Ushiro-Kesa-Gatame y Kata-Gatame. Todas las técnicas están ilustradas y acompañadas de un apartado de observaciones donde explica el detalle técnico más significativo.

164. Grupos Universitarios de Lucha del S.E.U. (Madrigal, Sergio y Sanchis, Rafael) (1956). Judo. Grupos Universitarios de Lucha: S.E.U. (Segundo cuaderno). Madrid: S.E.U. 1a ed. 17 p. : il. ; 22x16 cm. ISBN: No ISBN. Depósito legal: no. Palabras clave: fundamentos técnicos. Resumen: Manual técnico de judo. La obra explica la ejecución, junto con algunas observaciones, de las técnicas del combate en pie: Ko-SotoGari, Ko-Uchi-Gari, Koshi Guruma, Tsurikomigoshi, Okuri-Ashi-Harai, Tai-Otoshi, Harai-Goshi, UchiMata; y del combate en el suelo: Yoko-Shiho-Gatame, Kuzure-Yoko-Shiho-Gatame, Kami-Shiho-Gatame, Tate-Shiho-Gatame y Kuzure-Tate-Shiho-Gatame.

165. Guedea Adiego, José Ángel (2003). iVivir el judo! : iniciación al rendimiento deportivo. Zaragoza: Combra. 1a ed. 153 p. : il. ; 17x24 cm. ISBN: 84-95508-62-1. Depósito legal: Z 2747-2003. Palabras clave: pedagogía, didáctica, entrenamiento, competición. Resumen: Ensayo teórico de judo. El libro esta compuesto de 4 partes. La primera parte explica la evolución del profesor de judo hasta alcanzar un nivel de enseñanza dedicado al rendimiento, comentando las características y motivaciones del profesor, su evolución en la enseñanza, el intercambio de ideas con otros profesionales, el seguimiento del deportista y sus problemas con el peso, la relación e influencia del entrenador con el deportista y los padres. La segunda parte analiza los aspectos relacionados con la enseñanza y presenta la organización de los grupos de alumnos, la estructura de las clases, la influencia del horario sobre el rendimiento, el planteamiento de los distintos objetivos y su secuenciación, la metodología utilizada, los contenidos para cada cinturón, la motivación, la detección de talentos, las adaptaciones del entrenamiento para un discapacitado y su influencia sobre el resto del grupo, las fases de evolución del entrenador y del deportista, las lesiones y su repercusión, y relata el entrenamiento del autor en Japón. La tercera parte profundiza en los aspectos relacionados con el entrenamiento como el momento de empezar la preparación física, la importancia de las cualidades físicas, los distintos métodos de entrenamiento, el entrenamiento en distintas categorías, sus principios, y las características del entrenamiento táctico y psicológico. La última parte detalla los aspectos competitivos del judo como son sus características, beneficios para el participante, la función del entrenador, la estrategia, la preparación y desarrollo de un combate, y la evaluación de la competición.

166. Guedea Adiego, José Ángel (2005). ;Vivir el judo II! : artículos y reflexiones de un profesor de judo. Fundamentos de judo. Barcelona: March Editor y Consejo Superior de Deportes. $1^{\text {a }}$ ed. 200 p. : il. ; 17x24 cm. ISBN: 84-95068-71-5. Depósito legal: Z. 1360-2005. Palabras clave: fundamentos técnicos, didáctica, entrenamiento. Resumen: Ensayo reflexivo sobre la situación actual del judo. La primera 
parte recoge las reflexiones del autor y algunos artículos sobre los problemas que se le plantean al profesor de judo, al entrenador como persona que educa y en el entrenamiento, los problemas ligados al mundo deportivo del judo y los efectos de la competición. La segunda parte comenta los fundamentos del judo, ofreciendo una visión general de los mismos y comentándolos.

167. Gutiérrez García, Carlos (2004). Introducción y desarrollo del judo en España (de principios del siglo XX a 1965): el proceso de implantación de un método educativo y de combate importado de Japón. León: Secretariado de Publicaciones y Medios Audiovisuales de la Universidad de León. 1aㅡ ed. 493 p. : il. ; 17x24 cm. ISBN: 84-9773-064-X. Depósito legal: LE. 385-2004. Palabras clave: historia, artes marciales, budo, bujutsu, jujutsu, bibliografía, eventos, Fuerzas Armadas, instituciones, maestros, sociedad. Resumen: Tratado histórico de judo. La obra consta de 5 capítulos precedidos por una introducción que comenta las características de la tesis doctoral y un resumen de cada capítulo. El primer capítulo explica la metodología utilizada en el estudio comentando la historiografía del judo, el planteamiento de las hipótesis, describiendo las fuentes de información utilizadas y sus problemas. El segundo capítulo define el concepto de artes marciales y sus distintas vertientes a lo largo de la historia para finalizar comentando la aportación de Jigoro Kano y la evolución del judo en Japón. El tercer capítulo relata y analiza la aparición del judo en España desde principios del s. XX hasta 1914, las primeras noticias aparecidas, los espectáculos de jujutsu, los valores aparejados a la práctica, los maestros que hicieron popular al judo, y la práctica del judo como deporte. El cuarto capítulo narra la actividad del jujutsu entre 1914 y 1939, comentando el desarrollo del judo en Europa, el declive del jujutsu, su inclusión en las Fuerzas Armadas, y en los espectáculos de lucha tras la Primera Guerra Mundial. El último capítulo analiza la transformación del jujutsu al judo junto con los valores asociados a la práctica, las claves que posibilitaron el desarrollo del judo en España como fue la institucionalización internacional del judo, el asentamiento en Madrid y Barcelona y la institucionalización del judo en España, y la consolidación del judo en España a través de su difusión en distintas ciudades, el incremento de gimnasios, la aparición de la competición deportiva, el desarrollo de la institucionalización del judo, la profesionalización de la enseñanza y la producción bibliográfica. Adjunta conclusiones, fuentes utilizadas y bibliografía.

168. Hansenne, Marcel (1963). El judo. Madrid: Comité Olímpico Español. 1a ed. 241 p. : il. ; 11x16,5 cm. ISBN: No ISBN. Depósito legal: M.14357-1963. Palabras clave: historia, fundamentos teóricos. Resumen: Ensayo sobre la evolución del judo. A modo de relato e incluyendo en algunos capítulos el diálogo entre un joven y un judoka, el autor comienza su relato con la victoria de Geesink en los campeonatos del mundo de judo celebrados en París. A partir de este hecho nos relata lo que es el judo, su simbología, quienes son sus maestros, cómo se comportan, cómo son sus técnicas, etc. Después pasa a relatar la evolución del judo en Occidente, el entrenamiento de kata y randori, el paso de grados, el porvenir del judo, y los campeonatos del mundo y de Europa con sus resultados. También inserta una historia sobre el karate y otra sobre el aikido. Adjunta apéndices sobre el judo en España, los cinturones, el vocabulario y explica las técnicas de mayor eficacia en la competición (uchi-mata, seoinage, uchi-gari y tai-otoshi).

169. Harrington, Anthony Patrick (1965). Cómo defenderse con el judo. Barcelona: Corona. 1 a ed. 191 p. : il. ; 14x21,5 cm. ISBN: No ISBN. Depósito legal: B. 8727-1965. Palabras clave: fundamentos teóricos, táctica, fundamentos técnicos, principios técnicos, defensa personal, ejercicios, calentamiento, judo, aplicación marcial, armas. Resumen: Manual teórico y técnico de judo. El libro esta compuesto por 47 capítulos. El primer capítulo describe e ilustra varios ejercicios de fortalecimiento y calentamiento. El segundo capítulo presenta la progresión de ejercicios de aprendizaje para dominar las distintas formas de caer, incluyendo su representación gráfica. El tercer capítulo expone varios ejercicios para aprender a desplazarse y coordinarse con el compañero, buscando su desequilibrio. El cuarto capítulo presenta y comenta los trece principios técnicos y tácticos fundamentales en la lucha defensiva en posición vertical. El resto de capítulos describen la ejecución de distintas técnicas de judo aplicadas a diversas situaciones de defensa personal como la presa frontal y desde atrás sobre el cabello, varias presas sobre la solapa de la chaqueta, presa bajo y sobre los brazos desde delante, presa en la cabeza, la doblenelson, presas sobre el cuello desde atrás y desde delante, presa bajo y sobre los brazos desde atrás, varias presas de muñeca, empujón sobre el pecho, golpe al tórax, topetazo con la cabeza, patada desde delante, puñetazo directo al tórax, gancho al rostro, puñetazo al vientre, agresión con una botella, agresión frontal, ataque con un cuchillo, un bastón, un rodillazo, diversos golpes a corta distancia, lucha en el suelo, presas de inmovilización, llave de agarrotamiento y tijera aplicada en el suelo desde atrás, presa sobre los brazos con las rodillas, algunas formas de defenderse en el suelo, distintas llaves sobre un brazo desde el suelo, doble llave de pierna y espinazo, varias llaves de pierna, de codo, de cuello y de espinazo, e incluyendo la representación gráfica de todas ellas.

170. Harrington, Patricia (2005). El libro total del judo : basado en las enseñanzas de Kyuzo Mifune. Madrid: Tutor. 1a ed. 170 p. : il. ; 21x28 cm. ISBN: 84-7902-507-7. Depósito legal: no. Palabras clave: fundamentos teóricos, fundamentos técnicos, didáctica, arbitraje, instituciones, reglamentos. Resumen: Tratado teórico sobre el judo. La monografía esta compuesta de 9 capítulos. El primer 
capítulo presenta la expansión del judo y su organización institucional, para continuar con la descripción de sus aspectos formales, como las normas de disciplina, el dojo y tatami, la vestimenta y el sistema de grados. El tercer capítulo comenta los fundamentos más básicos del judo como el agarre, el calentamiento, las técnicas del Kodokan y el saludo. El cuarto capítulo ofrece algunos consejos pedagógicos para los futuros instructores y luego describe los requisitos para cada cinturón en la categoría senior. El siguiente capítulo recopila e ilustra las técnicas requeridas para examinarse de cinturón 1er dan y los últimos tres capítulos enumeran los requisitos necesarios para los exámenes de grado en menores de 16 años, menores de 13 años y menores de 10 años respectivamente. También incluyen una secuencia gráfica de los contenidos técnicos. Adjunta un apéndice con el reglamento de arbitraje de la Federación Internacional de Judo.

171. Harrison, E. J. (1959). Judo para los jóvenes. Madrid: Aguilar. 1ae ed. 77 p. : il. ; $12 \times 18$ cm. ISBN: No ISBN. Depósito legal: M. 12097-1959. Palabras clave: fundamentos teóricos, fundamentos técnicos, principios técnicos. Resumen: Manual técnico de judo. La obra esta dividida en 7 capítulos. El primero introduce brevemente el arte marcial, la etiqueta, los métodos de entrenamiento y la clasificación de sus técnicas. El segundo capítulo explica los fundamentos de las proyecciones además de ofrecer apoyo gráfico sobre los mismos. Continúa con la descripción de la ejecución de las técnicas de proyección más representativas, incluyendo gráficos explicativos. De la misma forma, el cuarto capítulo explica algunas de las técnicas de sacrificio frontales y laterales; para proseguir con una selección de inmovilizaciones. Los dos últimos capítulos presentan algunas técnicas de estrangulación y luxación incluyendo gráficos aclaratorios.

172. Harrison, E. J. (1959). Judo para mujeres. Madrid: Aguilar. 1a ed. 102 p. : il. ; $12 \times 18$ cm. ISBN: No ISBN. Depósito legal: M. 11075-1959. Palabras clave: historia, fundamentos técnicos, principios técnicos, programa técnico. Resumen: Manual teórico y técnico de judo. La obra esta dividida en 6 capítulos. El primer capítulo comenta el comienzo de la práctica del judo por parte de las mujeres, explica las particularidades de su morfología para la práctica así como los beneficios de la práctica sobre el organismo de la mujer. El segundo capítulo narra el origen y expansión del judo en Europa, describe la forma de saludar y la forma de ganar un combate, explica la clasificación de las técnicas de judo y ofrece algunos consejos para el progreso en el aprendizaje de la mujer. El tercer capítulo describe los fundamentos y principios técnicos básicos del judo, como son la postura natural y defensiva, el agarre, el movimiento de los pies y el tai-sabaki y los principios de kuzushi, tsukuri y kake. El cuarto capítulo explica le ejecución técnica de las caídas en diferentes direcciones incluyendo su representación gráfica. El quinto capítulo comenta las características generales y describe la ejecución de las principales técnicas de proyección como son: seoinage, kataguruma, taiotoshi, ukigoshi, haraigoshi, tsurikomigoshi, hanegoshi, okuriashibarai, uchimata, osotogari, osoto-otoshi, ouchigari, haraitsurikomiashi, kosotogari, ashiguruma, tomoenage, uranage, sumigaeshi, yokogake, yokoguruma, ukiwaza y sotomakikomi, junto con sus ilustraciones explicativas. El último capítulo incluye la descripción de las características técnicas y ejecución de algunas de las técnicas de judo-suelo como: kesagatame, katagatame, kamishihogatame, yokoshihogatame, namijujijime, gyakujujijime, sodeguruma, okurierijime, hadakajime, udegarami, udehishigi-udegatame, udehishigi-hizagatame, ashigarami y udehishigi-jujigatame con sus respectivos gráficos.

173. Heim, Jean (1967). El judo. Madrid: Espasa-Calpe. 1a ed. 64 p. : il. ; $13 \times 18$ cm. ISBN: No ISBN. Depósito legal: M. 6699-1967. Palabras clave: fundamentos técnicos, defensa personal, ejercicios, calentamiento, vestimenta, competición, reglamentos. Resumen: Manual teórico y técnico de judo. El libro esta formado por 9 capítulos. El primer capítulo explica en qué consiste el judo, sus beneficios, su vestimenta y la estructura del lugar de práctica. Los dos siguientes capítulos exponen la ejecución de las formas de saludar, la guardia y el agarre de judo. El cuarto capítulo describe e ilustra diversos ejercicios de calentamiento y flexibilidad. El quinto capítulo muestra los diferentes tipos de desequilibrios posibles. El siguiente capítulo describe la ejecución de las distintas formas de caer. El séptimo capítulo describe por partes la ejecución y contraataques de las principales técnicas de proyección de pierna, de cadera, de sacrificio y de hombro junto con las principales técnicas de inmovilización, acompañadas de sus ilustraciones explicativas. El siguiente capítulo incluye un extracto del reglamento de competición; y el último capítulo presenta la aplicación de algunas técnicas de judo a las situaciones de defensa personal ante intentos de estrangulamiento, agarre y golpes armados.

174. Heydt Dietzold, Cristina (1982). Manual de judo. Madrid: Ediciones S.M. 1a ed. 79 p. : il. ; 13x18 cm. ISBN: 84-348-0990-7. Depósito legal: M. 38700-1981. Palabras clave: fundamentos técnicos, didáctica. Resumen: Manual técnico-didáctico hasta cinturón marrón de judo. El libro esta dividido en 7 partes, dando primeramente unas nociones generales sobre lo que es el judo, su historia, principios y vocabulario básico. El segundo capítulo presenta los fundamentos más básicos como son el saludo, las caídas, la postura, la oportunidad, el desequilibrio, el agarre y la proyección. Los siguientes cinco capítulos están dedicados cada uno de ellos a un nivel o cinturón, explicando las técnicas de cada nivel con un gráfico y el tsukuri y kuzushi correspondientes. 
175. Hierro Jarne, José Ángel y Bergua Bernués, Marta (2004). Mini kiu. Jaca: Club de Judo Kanpai. 1aㅡ ed. 56 p. : il. ; 10x20 cm. ISBN: No ISBN. Depósito legal: HU. 424-2004. Palabras clave: historia, fundamentos técnicos, programa técnico, arbitraje, clubes. Resumen: Manual técnico de judo. Los dos primeros apartados presentan la historia del Club Judo Kanpai y la carta a los padres. El tercer apartado incluye el código moral del judo. Los siguientes 9 apartados nombran e ilustran los contenidos teóricos y técnicos desde cinturón blanco hasta marrón. Continúa con una tabla para apuntar las kinsas o ventajas para realizar el examen de grado, una tabla para apuntar el pase de grado, explica cómo conseguir el 1er dan, el código ético del judo, enumera los términos más comunes de la competición, incluye una tabla de participación en competiciones como cronometrador, la carta de presentación de la federación española y aragonesa de judo, y varias tablas para anotar las participaciones en campeonatos, cursos y autógrafos.

176. Inman, Roy y Soames, Nicolas (1988). Judo : las técnicas de los campeones en combate. Madrid: Eyras. $1^{a}$ ed. 252 p. : il. ; 15x24 cm. ISBN: 84-85269-54-3. Depósito legal: M. 19797-1988. Palabras clave: fundamentos técnicos, historia, estrategia, táctica, judo, competición. Resumen: Tratado teórico de judo. La monografía esta dividida en 5 capítulos que analizan la técnica y táctica de la competición. El primero de ellos describe la evolución del judo en los últimos años y lo que esto ha conllevado respecto a la condición física, las reglas, los pesos, los estilos, el aprendizaje y las lesiones. El segundo capítulo analiza las técnicas de competición más comunes, apoyándose en dibujos y fotografías así como en la descripción de las categorías de peso donde más frecuentemente son utilizadas, el tipo de agarre, la entrada, la acción y dirección de la proyección y los puntos clave para su eficacia. El tercer capítulo presenta el entrenamiento físico y mental necesario para realizar las técnicas anteriores en competición con máxima eficacia. El siguiente capítulo aborda los aspectos tácticos de la competición y cuál debe ser el análisis correcto de los mismos para sacar el máximo partido de ellos; y por último presenta la historia del judo, desde su creación hasta su práctica deportiva y competitiva. Adjunta un apéndice con resultados de las competiciones europeas anuales.

177. Izquierdo García, Ángel Luis (1979). Judoka : para llegar a ser cinturón negro. Madrid: Taravilla. 1a ed. 72 p. : il. ; 17x24 cm. ISBN: No ISBN. Depósito legal: M. 35055-1979. Palabras clave: historia, fundamentos teóricos, fundamentos técnicos, programa técnico. Resumen: Manual teórico y técnico de judo. La obra consta de 23 capítulos. Los dos primeros capítulos relatan la formación del judo y su fundación como tal. El tercer capítulo presenta las características del lugar de entrenamiento o dojo, para luego explicar el significado de la palabra "judo". El quinto capítulo describe e ilustra la vestimenta del judoka y continúa con la explicación de la forma de saludar. El séptimo capítulo diferencia los dos métodos de judo, Kodokan y Kawaishi. Los siguientes ocho capítulos profundizan en la descripción de los fundamentos teóricos y técnicos del judo como son los agarres, los grados, los tipos de caídas y su ejecución, el desequilibrio, las características del randori y la competición, un conjunto de términos referidos al arbitraje de la competición y la definición de las katas. Los siguientes cinco capítulos exponen los contenidos técnicos de los cinturones amarillo, naranja, verde, azul y marrón respectivamente, describiendo de forma sucinta dichas técnicas e incluyendo su ilustración y esquema de movimiento. Para cinturón amarillo presenta las técnicas: de ashi barai, hiza guruma, o soto gari, o goshi, ippon seoi nage, hon kesa gatame, kata gatame, yoko shio gatame, kami shio gatame y tate shio gatame. Para cinturón naranja presenta: sasae tsuri komi ashi, o uchi gari, ko uchi gari, uki goshi, morote seoi nage, kuzure kesa gatame, ushiro kesa gatame, makura kesa gatame, kuzure yoko shio gatame y kuzure kami shio gatame. Para cinturón verde presenta: okuri ashi barai, koshi guruma, tsuri komi goshi, harai goshi, tai otoshi, okuri eri jime, hadaka jime. Para cinturón azul presenta: ko soto gari, uchi mata, hane goshi, kata guruma, tomoe nage, kata juji jime, gyaku juji jime, nami juji jime, kata ha jime, juji gatame y ude garami. Y para cinturón marrón presenta: ko soto gake, ashi guruma, harai tsuri komi ashi, utsuri goshi, uki otoshi, ude gatame, hiza gatame, waki gatame. Los tres últimos capítulos incluyen un breve resumen de los judokas más notables de la historia, los beneficios de la práctica del judo y un pequeño vocabulario.

178. Jazarin, J.L. (1996). El espíritu del judo : charlas con mi maestro. Madrid: Eyras. 1aㅡ ed. 256 p. ; 11x16,5 cm. ISBN: 84-85269-83-7. Depósito legal: M. 42879-1996. Palabras clave: filosofía. Resumen: Tratado teórico de judo. La obra es un ensayo reflexivo sobre la práctica del judo y sus aspectos más filosóficos. Narración cronológica de las charlas mantenidas por el autor con su maestro sobre las distintas preguntas que le iban surgiendo al autor sobre la práctica del judo, su tradición y filosofía, como el kuatsu, el zen y la espada, el no-pensamiento en la práctica, el estudio de la tradición, el significado de los cinturones, la relación cuerpo-mente, los paradigmas del judo, el hara, las categorías de peso en la competición o la vida y la muerte.

179. Juan Sancho, Gabriel (1992). Los 40 años del judo valenciano : XXV años de la Federación de Judo de la Comunidad Valenciana. Valencia: Gabriel Juan Sancho. 1aㅡ ed. 375 p. : il. ; 15x21,5 cm. ISBN: No ISBN. Depósito legal: V. 988-1992. Palabras clave: historia, judo, competición, maestros. Resumen: Tratado histórico de judo. Revisión histórica del nacimiento y evolución del judo en Valencia desde 1950. Describe cronológicamente la evolución de este arte marcial, adjuntando texto gráfico y tablas de 
clasificación de las distintas competiciones que se realizaron. Comienza con la descripción de los primeros intentos por crear un dojo y su consecución, para luego pasar a narrar la evolución de la Federación Valenciana de Judo. A continuación comenta el judo en Alicante y Castellón, ya que el autor no dispuso de tanta información de estas provincias. Continúa con las distintas competiciones, y sus resultados, que se promovieron durante aquella época, como son la liga nacional, los campeonatos de España por equipos de autonomías y los campeonatos de España organizados por la Federación Valenciana. Luego revisa los maestros extranjeros que visitaron Valencia para difundir el arte o competir. El siguiente capítulo narra la historia del judo femenino y cómo fue evolucionando rápidamente del mismo modo que el judo universitario. Los últimos capítulos son más breves, tratando de los árbitros, de la relación entre el judo y los medios de comunicación en el pasado y presente, cuáles fueron las familias que se dedicaron al judo, el periodo de exhibiciones y la historia de los deportes asociados a la federación de judo y su desarrollo hasta conseguir la emancipación. Concluye con la descripción de la Federación de Judo de la Comunidad Valenciana, un ensayo de los últimos 25 años trascurridos y las fichas de los campeones de al menos algún campeonato nacional.

180. Judo-Barcelona (1976). 25 años. Barcelona: Judo Barcelona. $1^{a}$ ed. 28 p. : il. ; 21x29,5 cm. ISBN: No ISBN. Depósito legal: no. Palabras clave: historia, clubes, competición, instalaciones. Resumen: Tratado histórico de judo. La obra relata la creación del gimnasio Judo Barcelona acompañada de numerosas ilustraciones y comenta sus instalaciones, un breve resumen de la biografía de sus profesores, visitantes destacados y el maestro Kawaishi, un listado de los alumnos más destacados, la biografía deportiva de sus campeones de España y competidores destacados, la historia de las diferentes competiciones de la época y un listado de los cinturones negros del club.

181. Kano, Jigoro (1989). Judo Kodokan. Madrid: Eyras. 1a ed. 264 p. : il. ; 18x25,5 cm. ISBN: 84-85269-65-9. Depósito legal: M. 40823-1989. Palabras clave: katas, fundamentos técnicos, rehabilitación, principios técnicos. Resumen: Manual técnico de judo. El libro esta dividido en 5 partes, presentando la primera los principios sobre los que se fundó el judo así como los aspectos formales de su práctica. La segunda parte analiza la técnica, con los movimientos básicos, la clasificación de las técnicas de proyección y control, su posterior explicación y los atemis. La tercera parte hace una breve descripción del randori, para continuar con la descripción de la ejecución de las katas y su secuencia fotográfica. La última parte incluye la kata Seiryoku Zen'yo Kokumin Taiiku y algunas técnicas de reanimación. Adjunta dos apéndices sobre la vida de Jigoro Kano y una guía del Kodokan respectivamente, así como un glosario e índice de términos utilizados.

182. Kashiwazaki, Katsuhiko (1992). Tomoe-nage : técnicas maestras de judo. Barcelona: Paidotribo. 1a ed. 134 p. : il. ; 15x21,5 cm. ISBN: 84-8019-004-3. Depósito legal: B. 12460-1992. Palabras clave: fundamentos técnicos, principios técnicos, entrenamiento, táctica. Resumen: Manual técnico y táctico de tomoe-nage. Después de reflexionar sobre la importancia y utilización personal de esta técnica, narra la historia de la misma y su utilización por los grandes maestros. El tercer capítulo describe la técnica, sus puntos clave y las variantes que puede adoptar. Continúa con la explicación de su variante más importante, el yoko-tomoe-nage. Los tres capítulos siguientes presentan las combinaciones, contraataques y defensas a las que puede dar lugar dicha técnica, ofreciendo siempre apoyo gráfico para sus explicaciones. El octavo capítulo ofrece una serie de combinaciones entre esta técnica y su continuidad con el trabajo en el suelo, y luego pasa al entrenamiento de tomoe-nage a través de los distintos métodos específicos del judo. Los dos últimos capítulos hacen una aplicación de la técnica a la defensa personal y comentan la realización del tomoe-nage en las competiciones más importantes respectivamente.

183. Kashiwazaki, Katsuhiko (1993). Shimewaza. Barcelona: Paidotribo. 1 a ed. 191 p. : il. ; 15x21,5 cm. ISBN: 84-8019-080-9. Depósito legal: B. 12867-1993. Palabras clave: fundamentos técnicos, rehabilitación, entrenamiento. Resumen: Manual técnico sobre las estrangulaciones de judo. Después de detallar la relación del autor con este grupo de técnicas y comentar la evolución de las mismas, hace una descripción técnica introductoria sobre las estrangulaciones. Los siguientes 6 capítulos están dedicados, cada uno de ellos, a una técnica de estrangulación, ofreciendo la descripción de su ejecución así como fotografías aclaratorias. El siguiente capítulo hace un compendio de aquellas estrangulaciones menos comunes para dedicar los últimos cuatro capítulos al entrenamiento general de las estrangulaciones, el estado de inconsciencia y las técnicas de reanimación, su aplicación en la defensa personal y su realización en algunas competiciones.

184. Kashiwazaki, Katsuhiko y Nakanishi, Hidetoshi (1995). Atacar en judo : guía de combinaciones y contraataques. Barcelona: Paidotribo. 1aㅡ ed. 162 p. : il. ; 15x21,5 cm. ISBN: 84-8019-181-3. Depósito legal: B. 28655-1995. Palabras clave: fundamentos técnicos. Resumen: Manual técnico avanzado de judo. Cada tema esta dedicado a una técnica junto con sus combinaciones y contraataques, con la explicación e ilustración de los movimientos. Las técnicas estudiadas son: seoi-nage, ippon seoi-nage, harai-goshi, uchimata, o-goshi, ouchi-gari, kouchi-gari, osoto-gari, kosoto-gari, hiza-guruma, okuriashi-barai, tai-otoshi, tomoe-nage e hikikomi-gaeshi. Los cuatro últimos capítulos ofrecen 
combinaciones de judo-suelo, cuando el oponente esta arrodillado, cuando estás tumbado sobre la espalda y cuando tienes el agarre del cinturón.

185. Kawaishi, Mikonosuke (1963). Judo : las siete katas. Barcelona: Bruguera. $1 \underline{a}$ ed. 302 p. : il. ; 14x21 cm. ISBN: No ISBN. Depósito legal: B. 14095-1963. (2a ed., 1966; 3aㅡ ed., 1968). Palabras clave: katas, historia. Resumen: Manual teórico y técnico de judo. La obra esta formada por siete capítulos, precedidos por un prólogo del autor que comenta la actitud de tori y uke en la ejecución de las katas, la ejecución correcta de las katas, su entrenamiento, y los contenidos de la monografía; una introducción que señala los requisitos para la práctica de la kata; y un prefacio de la versión inglesa de E.J. Harrison. El primer capítulo expone las características de la nage-no-kata, incluye un cuadro resumen de las series técnicas que la componen, y describe su ejecución completa acompañada de numerosas ilustraciones explicativas. El segundo capítulo narra la formación de la katame-no-kata y sus técnicas para luego describir su ejecución técnica acompañada de las fotografías explicativas. El tercer capítulo expone la historia de la gonosen-no-kata y describe su ejecución técnica por partes con los gráficos explicativos correspondientes. El cuarto capítulo relata el origen y evolución de la kime-no-kata, ofrece consejos para su práctica y entrenamiento correctos, enumera sus técnicas y describe su ejecución acompañada de las ilustraciones explicativas. El quinto capítulo explica el significado de la Itsutsu-nokata, los principios que integran, y describe su ejecución junto con sus ilustraciones y esquemas de movimiento explicativos. El sexto capítulo estudia la ju-no-kata, su composición, la lista de técnicas de cada serie junto con la descripción e ilustración de cada una de ellas. El último capítulo relata la historia de la koshiki-no-kata, describe su composición técnica y explica su ejecución por partes acompañada de su representación gráfica. Adjunta una conclusión que resume los consejos para la práctica correcta de las katas.

186. Kawaishi, Mikonosuke (1964). Mi método de judo. Barcelona: Bruguera. 1ae ed. 275 p. : il. ; 14x21,5 cm. ISBN: No ISBN. Depósito legal: B. 19617-1964. (2ª ed., 1967; 3aㅡ ed., 1973, 332 p., ISBN: 84-02-00380$\mathrm{X}$ ). Palabras clave: fundamentos teóricos, fundamentos técnicos, principios técnicos. Resumen: Manual teórico y técnico de judo. La obra esta dividida en dos partes, precedidas por la explicación de la estructura de los contenidos de la obra y algunas reglas de pronunciación. La primera parte explica los fundamentos técnicos y teóricos básicos del judo como son las posturas, las caídas, los agarres y los tipos de desequilibrios incluyendo su representación gráfica y esquemas de movimiento. También incluye la descripción de la ejecución técnica del tsukuri y kake de las principales proyecciones, agrupadas según la parte del cuerpo que produzca la proyección (movimientos de piernas, con la cadera, con los hombros, con los brazos y movimientos de sacrificio), acompañadas de sus ilustraciones explicativas y esquemas de movimiento. La segunda parte detalla los objetivos y principios de las inmovilizaciones, estrangulaciones y luxaciones para luego describir la ejecución de sus principales técnicas acompañadas de sus fotografías explicativas. Adjunta un resumen de los principios generales que rigen la competición de judo.

187. Kawaishi, Mikonosuke (1965). Mi método de defensa personal. Barcelona: Bruguera. $1^{\underline{a}}$ ed. 128 p. : il. ; 14x21,5 cm. ISBN: No ISBN. Depósito legal: B. 7352-1965. (2ª ed., 1967). Palabras clave: fundamentos técnicos, defensa personal, kyusho, aplicación marcial, armas. Resumen: Manual teórico y técnico de defensa personal. El libro esta dividido en dos partes. La primera parte presenta las principales posiciones básicas defensivas, comenta la táctica a utilizar ante un combate y describe e ilustra distintas técnicas de parada ante ataques de frente, varios métodos para soltar las muñecas, paradas ante los ataques laterales, paradas ante los ataques por detrás, defensas contra golpes de puño, defensas contra los puntapiés y golpes de rodilla y cabeza, defensas contra los golpes de palo, defensas contra armas blancas, defensas contra la amenaza de un revolver y varios agarres para inmovilizar al adversario, incluyendo sus esquemas de movimientos. La segunda parte describe e ilustra la localización de los principales puntos vitales del cuerpo humano, las distintas zonas de golpeo de la mano, presenta algunos ejercicios para fortalecer las manos, y explica la utilización, puntos de impacto y ejemplos de aplicación de los atemis con la mano, las yemas de los dedos, el codo, la cabeza, la rodilla y el pie.

188. Kawaishi, Mikonosuke (1967). Judo : las siete katas. Barcelona: Bruguera. $1^{a}$ ed. 286 p. : il. ; 10x17,5 cm. ISBN: No ISBN. Depósito legal: B. 37845-1966. (2 $2^{\underline{a}}$ ed., 1970; $3^{\underline{a}}$ ed., 1972; $4^{\underline{a}}$ ed., 1973, ISBN: 84-0200792-9; 5 a ed., 1974, ISBN: 84-02-00792-9; 6 ed., 1975, ISBN: 84-02-00792-9). Palabras clave: katas, historia. Resumen: Manual teórico y técnico de judo. La obra esta formada por siete capítulos, precedidos por un prólogo del autor que comenta la actitud de tori y uke en la ejecución de las katas, la ejecución correcta de las katas, su entrenamiento, y los contenidos de la monografía; una introducción que señala los requisitos para la práctica de la kata; y un prefacio de la versión inglesa de E.J. Harrison. El primer capítulo expone las características de la nage-no-kata, incluye un cuadro resumen de las series técnicas que la componen, y describe su ejecución completa acompañada de numerosas ilustraciones explicativas. El segundo capítulo narra la formación de la katame-no-kata y sus técnicas para luego describir su ejecución técnica acompañada de las fotografías explicativas. El tercer capítulo expone la historia de la gonosen-no-kata y describe su ejecución técnica por partes con los gráficos 
explicativos correspondientes. El cuarto capítulo relata el origen y evolución de la kime-no-kata, ofrece consejos para su práctica y entrenamiento correctos, enumera sus técnicas y describe su ejecución acompañada de las ilustraciones explicativas. El quinto capítulo explica el significado de la Itsutsu-nokata, los principios que integran, y describe su ejecución junto con sus ilustraciones y esquemas de movimiento explicativos. El sexto capítulo estudia la ju-no-kata, su composición, la lista de técnicas de cada serie junto con la descripción e ilustración de cada una de ellas. El último capítulo relata la historia de la koshiki-no-kata, describe su composición técnica y explica su ejecución por partes acompañada de su representación gráfica. Adjunta una conclusión que resume los consejos para la práctica correcta de las katas.

189. Kawaishi, Mikonosuke (1969). Mi método de defensa personal. Barcelona: Bruguera. $1^{\mathfrak{a}}$ ed. 222 p. : il. ; 18x10 cm. ISBN: No ISBN. Depósito legal: B. 23876-1969. (2 $2^{\underline{a}}$ ed., 1972; $3^{a}$ ed., 1974, ISBN: 84-0203399-7; 4 a ed., 1975, ISBN: 84-02-00807-0; 5a ed., 1976; 6a ed., 1984, ISBN: 84-02-00807-0). Palabras clave: fundamentos técnicos, defensa personal, kyusho, aplicación marcial, armas. Resumen: Manual teórico y técnico de defensa personal. El libro esta dividido en dos partes. La primera parte presenta las principales posiciones básicas defensivas, comenta la táctica a utilizar ante un combate y describe e ilustra distintas técnicas de parada ante ataques de frente, varios métodos para soltar las muñecas, paradas ante los ataques laterales, paradas ante los ataques por detrás, defensas contra golpes de puño, defensas contra los puntapiés y golpes de rodilla y cabeza, defensas contra los golpes de palo, defensas contra armas blancas, defensas contra la amenaza de un revolver y varios agarres para inmovilizar al adversario, incluyendo sus esquemas de movimientos. La segunda parte describe e ilustra la localización de los principales puntos vitales del cuerpo humano, las distintas zonas de golpeo de la mano, presenta algunos ejercicios para fortalecer las manos, y explica la utilización, puntos de impacto y ejemplos de aplicación de los atemis con la mano, las yemas de los dedos, el codo, la cabeza, la rodilla y el pie.

190. Kawaishi, Mikonosuke (1969). Mi método de judo. Barcelona: Bruguera. 1aㅡ ed. 332 p. : il. ; 10x17,5 cm. ISBN: No ISBN. Depósito legal: B. 20273-1969. (2ª ed., 1971; 3르 ed., 1973, ISBN: 84-02-00806-2; 4⿳亠丷a ed.,

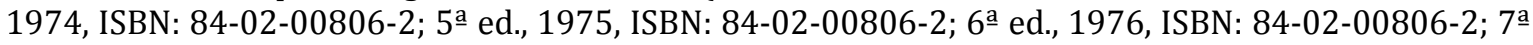
ed., 1977, ISBN: 84-02-00806-2). Palabras clave: fundamentos teóricos, fundamentos técnicos, principios técnicos. Resumen: Manual teórico y técnico de judo. La obra esta dividida en dos partes, precedidas por la explicación de la estructura de los contenidos de la obra y algunas reglas de pronunciación. La primera parte explica los fundamentos técnicos y teóricos básicos del judo como son las posturas, las caídas, los agarres y los tipos de desequilibrios incluyendo su representación gráfica y esquemas de movimiento. También incluye la descripción de la ejecución técnica del tsukuri y kake de las principales proyecciones, agrupadas según la parte del cuerpo que produzca la proyección (movimientos de piernas, con la cadera, con los hombros, con los brazos y movimientos de sacrificio), acompañadas de sus ilustraciones explicativas y esquemas de movimiento. La segunda parte detalla los objetivos y principios de las inmovilizaciones, estrangulaciones y luxaciones para luego describir la ejecución de sus principales técnicas acompañadas de sus fotografías explicativas. Adjunta un resumen de los principios generales que rigen la competición de judo.

191. Kawaishi, Mikonosuke (1975). Judo : las siete katas. Barcelona: Bruguera. 1aㅡ ed. 286 p. : il. ; 12x19,5 cm. ISBN: 84-02-04178-7. Depósito legal: B. 6395-1975. Palabras clave: katas, historia, fundamentos técnicos. Resumen: Manual teórico y técnico de judo. La obra esta formada por siete capítulos, precedidos por un prólogo del autor que comenta la actitud de tori y uke en la ejecución de las katas, la ejecución correcta de las katas, su entrenamiento, y los contenidos de la monografía; una introducción que señala los requisitos para la práctica de la kata; y un prefacio de la versión inglesa de E.J. Harrison. El primer capítulo expone las características de la nage-no-kata, incluye un cuadro resumen de las series técnicas que la componen, y describe su ejecución completa acompañada de numerosas ilustraciones explicativas. El segundo capítulo narra la formación de la katame-no-kata y sus técnicas para luego describir su ejecución técnica acompañada de las fotografías explicativas. El tercer capítulo expone la historia de la gonosen-no-kata y describe su ejecución técnica por partes con los gráficos explicativos correspondientes. El cuarto capítulo relata el origen y evolución de la kime-no-kata, ofrece consejos para su práctica y entrenamiento correctos, enumera sus técnicas y describe su ejecución acompañada de las ilustraciones explicativas. El quinto capítulo explica el significado de la Itsutsu-nokata, los principios que integran, y describe su ejecución junto con sus ilustraciones y esquemas de movimiento explicativos. El sexto capítulo estudia la ju-no-kata, su composición, la lista de técnicas de cada serie junto con la descripción e ilustración de cada una de ellas. El último capítulo relata la historia de la koshiki-no-kata, describe su composición técnica y explica su ejecución por partes acompañada de su representación gráfica. Adjunta una conclusión que resume los consejos para la práctica correcta de las katas.

192. Kimura, Masahiko (1976). El judo : conocimiento práctico y normas. Barcelona: Aedos. 1a ed. 180 p. : il. ; 20x20,5 cm. ISBN: 84-7003-216-X. Depósito legal: B. 22831-1976. Palabras clave: historia, fundamentos técnicos, principios técnicos. Resumen: Manual teórico y técnico de judo. La obra esta 
formada por 10 capítulos. El primer capítulo detalla la historia y evolución del judo para luego comentar los fundamentos del judo. El tercer capítulo presenta los principios técnicos de las técnicas de proyección, estudiando la posición del cuerpo, los modos de agarre, los movimientos del cuerpo y las caídas, junto con su ilustración. El cuarto capítulo describe la ejecución de las principales técnicas de mano como kata guruma, tai otoshi e ippon seoi nage, incluyendo las posibilidades de ataque, las defensas contra estas técnicas, las combinaciones y contraataques, sus variantes y la ilustración en primer plano de los detalles técnicos. El quinto capítulo estudia las técnicas de cadera harai goshi, hane goshi, tsurikomi goshi, o goshi, utsuri goshi, ura nage y koshi guruma, ofreciendo la secuencia fotográfica de cada técnica, las posibilidades de ataque, las defensas, combinaciones y contraataques. Siguiendo la misma estructura, el sexto capítulo analiza las técnicas de pierna como son: de ashi barai, okuri ashi barai, sasae tsuri komi ashi, harai tsuri komi ashi, hiza guruma, o soto gari, o uchi gari, ko uchi gari, ko soto gari, uchi mata y tomoe nage. El siguiente capítulo presenta la transición al trabajo en el suelo, las contras en el trabajo del suelo y algunas combinaciones de obitori gaeshi, resumiendo su ejecución e incluyendo la secuencia fotográfica de cada movimiento. El octavo capítulo estudia la ejecución técnica de las principales inmovilizaciones como son kesa gatame y sus variantes, kata gatame, kami shiho gatame, kuzure kami shiho gatame, tate shiho gatame y yoko shiho gatame, además de presentar las defensas contra estas técnicas, combinaciones, liberaciones y sus correspondientes ilustraciones. Los dos últimos capítulos describen e ilustran la ejecución técnica por partes, las defensas y combinaciones de las luxaciones y estrangulaciones más comunes, como son: ude garami, juji gatame, ude gatame, hiza guruma, juji jime y sus variantes, ryote jime, hadaka jime, okuri eri jime, yoko okuri jime, kata ha jime y sankaku jime. Adjunta un índice de términos japoneses.

193. Kishi, Yasu (1987). Jiu-jitsu. Barcelona: Editors. 1a ed. 152 p. : il. ; $12 x 19$ cm. ISBN: 84-7561-562-7. Depósito legal: B. 36911-1987. (2ª ed., 1988, ISBN: 84-7561-691-7; 3⿳⺈ ed., 1990, ISBN: 84-7561-691-7; 4 a ed., 1991, ISBN: 84-7561-691-7). Palabras clave: fundamentos técnicos, entrenamiento, armas. Resumen: Manual técnico de jiu-jitsu. El libro comienza con una breve introducción sobre la historia y lo que es el jiu-jitsu, para después comenzar a explicar algunas consideraciones generales respecto a la alimentación, la respiración, la higiene y algunas recomendaciones para la práctica. A continuación presenta las ocho fases preparatorias para la práctica del jiu-jitsu. Comienza con el detalle del método de entrenamiento en el jiu-jitsu y continúa con la descripción de los ejercicios para entrenar los pulmones, el corazón y los brazos en la segunda fase; las piernas en la tercera y el temperamento en la cuarta. Continúa con algunos sencillos golpes y agarres para en el siguiente capítulo presentar otros más complicados. Las dos últimas fases describen ejercicios de endurecimiento y para conseguir agilidad respectivamente. Luego pasa a detallar las respuestas ante situaciones de defensa personal para finalizar con un compendio de consideraciones generales sobre la utilización de la energía, la disciplina, los puntos sensibles del cuerpo, quién puede practicar este arte, algunos consejos prácticos y cuáles son las armas complementarias del jiu-jitsu.

194. Koike, Tadashi (1975). Judo : de cinturón blanco a cinturón amarillo. Barcelona: De Vecchi. 1ae ed. 80 p. : il. ; 14×20 cm. ISBN: 84-315-1266-0. Depósito legal: B. 17219-1975. (2ª ed., 1980). Palabras clave: fundamentos técnicos. Resumen: Manual técnico de judo para cinturón amarillo. La obra puede dividirse en dos partes, en donde la primera presenta los fundamentos del judo como el saludo, las posiciones, el agarre, los desplazamientos, el tai sabaki y las caídas. La segunda parte describe las técnicas de proyección, control y combinaciones de nivel de cinturón amarillo. Finaliza con una descripción de los tipos de entrenamiento y un diccionario.

195. Kolychkine Thomson, Andrés (1989). Judo : nueva didáctica. Barcelona: Paidotribo. 1aㅡ ed. 236 p. : il. ; 15x21,5 cm. ISBN: 84-86475-26-0. Depósito legal: B. 23999-1989. Palabras clave: historia, pedagogía, fundamentos teóricos, fundamentos técnicos, táctica, planificación del entrenamiento. Resumen: Tratado teórico y pedagógico del judo. El libro tiene 5 capítulos. El primer capítulo esta dedicado a la historia y objetivos del judo, y en el segundo se presentan los fundamentos pedagógicos del judo, desde su terminología e instalaciones hasta sus grados, actitudes, docentes, seguridad y organización deportiva. Los dos siguientes capítulos estudian el judo arriba y el judo abajo respectivamente, explicando de forma diferenciada la técnica y la táctica de las distintas técnicas que se explican. El último capítulo discute brevemente la práctica del judo por parte de los jóvenes y de las mujeres, cómo hacer la elección adecuada de las katas y una programación de trabajo. Adjunta un índice de técnicas y bibliografía.

196. Kudo, Kazuzo (1979). Judo en acción : técnicas de combate cuerpo a cuerpo en el suelo. Bilbao: Fher. 1a ed. 127 p. : il. ; 14x21 cm. ISBN: 84-243-1701-7. Depósito legal: BI. 1465-1979. (2ª ed., 1981; 3를. ed., 1983). Palabras clave: fundamentos técnicos, defensa personal policial, principios técnicos. Resumen: Manual teórico y técnico de judo. La obra esta formada por 5 partes. La primera parte presenta los fundamentos del judo explicando en qué consisten las técnicas de agarre, los movimientos del cuerpo, la ejecución de las técnicas, la forma de avanzar y la descripción e ilustración de los ejercicios de calentamiento. Las siguientes tres partes tienen la misma estructura, explicando los principios técnicos, reglas de entrenamiento e incluyendo la descripción de la ejecución técnica, el 
momento adecuado de realización, las advertencias, los puntos básicos y los escapes de las principales técnicas de sujeción, estrangulación y luxación del judo. La última parte describe la ejecución de diversas técnicas de preparación del agarre cuando el oponente se encuentra en diferentes posiciones en el suelo junto con su ilustración y el comentario de sus puntos clave.

197. Kudo, Kazuzo (1979). Judo en acción : técnicas de proyección. Bilbao: Fher. 1ae ed. 128 p. : il. ; 15x21 cm. ISBN: 84-243-1611-8. Depósito legal: BI. 68-1979. (2aa ed., 1981). Palabras clave: fundamentos teóricos, fundamentos técnicos, principios técnicos. Resumen: Manual teórico y técnico de judo. La obra esta compuesta por 5 capítulos precedidos por una definición del judo de Jigoro Kano y varios fotografías de los primeros campeones de judo. El primer capítulo explica los fundamentos del judo, como son las posiciones, el agarre, los movimientos del cuerpo, el empleo de la fuerza, el desequilibrio, los movimientos preparatorios y de ataque, los métodos de caída y los distintos entrenamientos de las proyecciones, incluyendo ilustraciones y esquemas de movimiento de cada uno de ellos. Los siguientes cuatro capítulos desarrollan la misma estructura para explicar las distintas técnicas presentadas incluyendo una breve descripción de cada técnica, los movimientos preparatorios, el ataque y algunas sugerencias, las defensas, las proyecciones alternas, la combinación de ataques y el contraataque, además de la secuencia fotográfica de cada apartado. Las técnicas incluidas dentro del segundo capítulo son las técnicas de brazos: tai-otoshi, seoi-nage, ippon-seoi-nage, kata-guruma, uki-otoshi, sumi-otoshi, sukui-nage, soto-makikomi, morote-gari y kuchiki-taoshi. El tercer capítulo analiza la ejecución de las técnicas de cadera harai-goshi, uki-goshi, tsuri-komi-goshi, sode-tsuri-komi-goshi, hane-goshi, hane-makikomi, uchimata, ogoshi, koshi-guruma, ushiro-goshi, utsuri-goshi y tsuri-goshi. El cuarto capítulo estudia las técnicas de piernas ouchi-gari, osoto-otoshi, osoto-gari, sasae-tsuri-komiashi, harai-tsuri-komi-ashi, okuri-ashi-barai, deashi-barai, suwame-gaeshi, kouchi-gari, kouchi-gake, kosoto-gari, kosoto-barai, kosoto-gake, nidan-kosoto-gari, nidan-kosoto-gake, hiza-guruma, ashiguruma y osoto-guruma. El último capítulo incluye la descripción técnica de tomoe-nage, ura-nage, sumi-gaeshi, uki-waza, yoko-gake, yoko-guruma, yoko-otoshi, tani-otoshi y no-waki. Adjunta apéndices sobre la ropa de entrenamiento, la cortesía, una clasificación de las técnicas de judo y bibliografía.

198. Lanz García, José Armando y Salsas Moreno, José (1977). Judo ne waza. Madrid: E.G.S. 1a ed. 88 p. : il. ; 17x24 cm. ISBN: 84-400-3444-X. Depósito legal: M. 26608-1977. Palabras clave: fundamentos técnicos. Resumen: Manual técnico de judo. El libro esta formado por 3 capítulos, precedidos por una introducción que comenta los objetivos de los autores. El primer capítulo describe e ilustra por partes varias técnicas de ataque a una posición defensiva en cuadrupedia, finalizando con una inmovilización, una estrangulación o una luxación. El segundo capítulo explica diferentes técnicas de ataque cuando uke se encuentra entre las piernas de tori para finalizar con una inmovilización, una estrangulación o una luxación, incluyendo la secuencia fotográfica de cada una de ellas. El tercer capítulo detalla la ejecución de distintas técnicas de entrada cuando tori se encuentra entre las piernas de uke para finalizar con una inmovilización. Incluye bibliografía.

199. Lasserre, Robert (1961). Atemis y jiu jitsu : manual práctico. Barcelona: Hispano Europea. 1a ed. 247 p. :

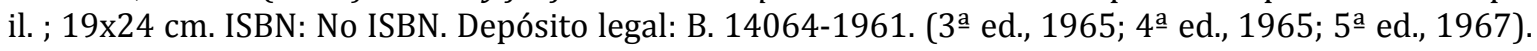
Palabras clave: fundamentos técnicos, defensa personal, kyusho, equipamiento, armas. Resumen: Manual teórico y técnico de judo. La obra esta formada por 2 partes. La primera parte estudia los atemis del judo, comentando su origen, en qué consiste el arte de atacar los puntos vitales (atewaza), la clasificación de sus técnicas, su inclusión dentro del judo, qué son y cómo se ejecutan los atemis, sus principios técnicos; describe e ilustra las zonas de golpeo de las manos y pies; describe un conjunto de ejercicios de preparación física o calentamiento; presenta los aparatos auxiliares para el endurecimiento de las manos y los pies además de incluir la descripción de varios ejercicios para su utilización; comenta brevemente la importancia del kiai y la mirada en el combate; clasifica las distintas presiones y pellizcos que se pueden realizar junto con sus características; y describe la localización y efecto de la manipulación de los diferentes puntos vitales además de incluir su representación gráfica. La segunda parte comenta la actitud fundamental y el espíritu ante el combate, describe los desplazamientos básicos, las formas de ataque, la táctica de combate ante varios adversarios, las distintas guardias, cómo se gira el cuerpo (tai-sabaki) en diferentes direcciones incluyendo el esquema de movimiento de los pies en cada uno de ellos y cómo se realiza el entrenamiento de la esquiva. Los siguientes capítulos describen e ilustran diferentes formas de defenderse contra ataques de frente (empujón al pecho, presa de solapa con una mano, presa de solapa con dos manos, presa de solapa invertida, presa a la manga o al brazo por debajo del codo, presa a la manga o al brazo por encima del codo, presa a la muñeca con una mano, presa a la muñeca invertida, presa a las muñecas con dos manos, presa a los cabellos, presa a la garganta con una mano, presa a la garganta con dos manos, cintura por delante bajo los brazos, cintura por delante sobre los brazos y presa a las piernas), contra ataques de lado (presa de cabeza, presa de cabeza, presa del brazo al bíceps, presa del brazo al codo, presa del brazo a la muñeca), contra ataques por detrás (presa de cabellos, presa de cuello, presa de cintura por detrás sobre los brazos, presa de cintura por detrás bajo los brazos, presa de brazos por detrás), defensas contra puñetazos (defensas antes del golpe, defensas 
contra golpes), defensas contra silletazos (silletazo de punta, silletazo de arriba a abajo, silletazo de costado), defensa contra bastonazos, defensas contra cuchilladas (de arriba a abajo, de abajo a arriba, golpe lateral, golpe de revés), defensas contra revolver (manos arriba de frente, manos arriba de espalda), y algunas formas de inmovilizar a un adversario.

200. Lasserre, Robert (1961). Judo : manual práctico. Según las enseñanzas del Kodokan, de Tokio. Barcelona: Hispano Europea. $1^{\mathfrak{a}}$ ed. 286 p. : il. ; 14x20,5 cm. ISBN: No ISBN. Depósito legal: B. 1834-1961. (3aa ed.,

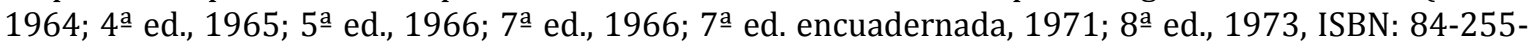
0311-6 / 84-255-0113-X (7aa ed. encuadernada) / 84-255-0288-8 (1a edición rústica); 9ạ ed., 1975, ISBN: 84-255-0288-8). Palabras clave: katas, historia, fundamentos técnicos, combate, competición, reglamentos. Resumen: Manual de enseñanza del judo. La obra presenta todos los aspectos fundamentales para comenzar a realizar judo. Comienza con unas notas teóricas sobre la historia y principios del judo así como la etiqueta y el lugar de entrenamiento, para continuar con la descripción detallada de las principales técnicas de tobillo, pierna, cadera, hombro, brazo, ma sutemi y yoko sutemi. La descripción de cada técnica explica su nombre y traducción, desequilibrio, oportunidad, tsukuri, kake, contrapresa y ataque sucesivo. Además presenta una ilustración sobre el movimiento de los pies. Concluye la obra con un breve comentario sobre las tres partes esenciales del judo (kata, randori y shiai), algunas recomendaciones para el practicante, el papel del tanden en el judo, el reglamento de los torneos así como algunas reflexiones sobre la victoria o la higiene.

201. López Domínguez, Mario (1981). Aplicación práctica del judo. Barcelona: Ramos-Majos. 1ae ed. 216 p. : il. ; 16x22 cm. ISBN: 84-7494-035-4. Depósito legal: B. 27834-1981. Palabras clave: fundamentos teóricos, fundamentos técnicos, defensa personal, competición, exámenes, reglamentos. Resumen: Manual técnico de judo y de aplicación a la defensa personal. La monografía esta dividida en 6 partes, precedidas por una breve historia y evolución del judo. La primera parte presenta los aspectos formales y una clasificación de las técnicas de judo pie y judo suelo. En la segunda parte comenta los grados, la ejecución de las caídas y algunas consideraciones generales para la participación total del cuerpo en el judo. Las dos siguientes partes describen las principales técnicas de pierna y cadera respectivamente, mientras que la quinta parte hace una aplicación, en situaciones de defensa personal, de algunas técnicas de proyección y estrangulación. La última parte describe el programa de exámenes para cinturón negro y para la adquisición de los grados. También incluye el reglamento internacional de competición y un vocabulario.

202. López Linares, Alejandro y cols. (2009). El judo como uno de los contenidos de la etapa de secundaria. Granada: Ada book. 1aㅡ ed. 168 p. ; 17x24 cm. ISBN: 978-84-92953-45-5. Depósito legal: no.

203. López Mayoral, Gerardo y Ceballos Ledesma, Jesús (1959). Judo y defensa personal. Zaragoza: Librería General. 1a ed. 135 p. : il. ; 19x27 cm. ISBN: No ISBN. Depósito legal: Z. 240-1959. Palabras clave: katas, historia, fundamentos técnicos, principios técnicos, defensa personal, entrenamiento, competición, reglamentos, sistemas de entrenamiento. Resumen: Manual teórico y técnico de judo. El libro esta dividido en 3 partes, precedidas por una introducción que expone los objetivos de los autores. La primera parte consta de 11 capítulos. El primer capítulo comenta los orígenes e historia del judo, su llegada a España, sus principios técnicos y sus ventajas para la práctica y el practicante. El segundo capítulo expone los métodos de entrenamiento del judo y presenta las características de la vestimenta, el lugar de entrenamiento, el saludo y el sistema de grados. El tercer capítulo enumera los objetivos del calentamiento y describe diferentes ejercicios. El cuarto capítulo describe los principios técnicos y ejecución de las posturas de judo, la forma de agarrarse, las caídas acompañadas de su representación gráfica y comenta las distintas formas de desequilibrar al adversario. El quinto capítulo expone la clasificación de las técnicas de judo y ofrece consejos para el entrenamiento de las mismas. El sexto capítulo describe la ejecución de las técnicas de nage-waza: uki-goshi, seoi-nage (ippon y morote), kata-guruma, tai-otoshi, uki-goshi, o-goshi, tsuri-komi-goshi, harai-goshi, hane-goshi, ushirogoshi, koshi-guruma, de-ashi-harai, ko-soto-gari, ko-soto-gake, okuri-ashi-harai, sasae-tsuri-komi-ashi, hiza-guruma, o-uchi-gari, ko-uchi-gari, uchi-mata, o-soto-gari, o-guruma, tomoe-nage, ura-nage, sumigaeshi, yoko-gake, yoko-guruma y uki-waza, incluyendo la secuencia gráfica de su ejecución. El séptimo capítulo explica la ejecución de las principales técnicas de katame-waza: kuzure-kesa-gatame, honkesa-gatame, kata-gatame, kami-shio-gatame, kuzure-kami-shio-gatame, yoko-shio-gatame, kuzureyoko-shio-gatame, ushiro-kesa-gatame, tate-shio-gatame, nami-juji-jime, kata-juji-jime, gyaku-jujijime, hadaka-jime, okuri-eri-jime, kata-ha-jime, ude-garami-gaeshi, ude-garami-hineri, ude-hishigi-jujigatame, ude-hishigi-ude-gatame, ude-hishigi-hiza-gatame, ude-hishigi-waki-gatame, ude-hishigi-haragatame y ashi-guruma, acompañadas de sus respectivas ilustraciones explicativas. El octavo capítulo describe las técnicas de defensa y salidas ante las inmovilizaciones, estrangulaciones y luxaciones presentadas anteriormente. El noveno capítulo enumera algunas de las combinaciones y contraataques principales tanto en el nage-waza como en el katame-waza. El décimo capítulo resume el reglamento de competición y el undécimo comenta los distintos paradigmas respecto a la progresión de aprendizaje de las técnicas de judo y presenta una tabla resumen de los contenidos y tiempo de permanencia en cada cinturón. La segunda parte consta de 3 capítulos, comentando el primero de ellos 
la aplicación del judo a la defensa personal y su utilización en las Fuerzas de Policía y Armadas. Los dos siguientes capítulos describen la ejecución de la kime-no-kata y la kodokan-goshin-jitsu-no-kata respectivamente incluyendo la secuencia gráfica de la ejecución de cada movimiento. La tercera parte incluye dos capítulos dedicados a la terminología general del judo y de la defensa personal. Adjunta un apéndice con el reglamento de competición.

204. Mansur, Francisco (2006). La "biblia" del brazilian jiu jitsu. Madrid: Budo International. 1a ed. 199 p. : il. ; 17x24 cm. ISBN: 84-96492-13-3. Depósito legal: M. 5483-2006. Palabras clave: fundamentos técnicos, defensa personal. Resumen: Manual técnico de jiu-jitsu. El libro esta formado por 19 partes, precedidas por un prólogo de Alfredo Tucci, una introducción sobre el objetivo y contenidos de la obra y un resumen de la historia del jiu-jitsu. El primer capítulo ilustra las posiciones de base de pie, arrodillado y agachado. El segundo capítulo incluye la secuencia fotográfica de las distintas técnicas de escape, mientras que el tercero presenta las caídas. El cuarto capítulo expone las posiciones de "montadas" y sus posibles defensas para continuar con las posiciones de guardia, el tirón hacia la guardia y las pasadas de guardia en el suelo y de pie. El sexto capítulo incluye la representación gráfica de las distintas técnicas de raspado arrodillado y de pie. El séptimo capítulo presenta la secuencia fotográfica de diversas técnicas de inmovilización. Los dos siguientes capítulos ilustran varias técnicas de estrangulación y de luxación aplicadas desde distintas posiciones. El décimo capítulo presenta algunas de las posiciones de pie en la guardia. Continua con las distintas montadas y su aplicación en diferentes posiciones. El duodécimo capítulo incluye 3 técnicas de posición de rodilla en la barriga. El capítulo decimotercero incluye la representación gráfica de varias técnicas de reposición de guardia en la pasada y de giro en la pasada de guardia. Los dos siguientes capítulos presentan algunas técnicas de estrangulación en forma de corbata y guillotina así como varias técnicas de proyección. El decimosexto capítulo incluye la ilustración de 3 técnicas de paso a la espalda de pie. El siguiente capítulo presenta la secuencia fotográfica de ciertas defensas a distintas inmovilizaciones. Los dos últimos capítulos incluyen la representación de algunas técnicas de control en la montada y control en guardia así como técnicas de triángulo en guardia y luxación al brazo.

205. Martell, Pierre (1987). Judo. Barcelona: Molino. 1a ed. 34 p. : il. ; 21x29 cm. ISBN: 84-272-2205-X. Depósito legal: B. 34110-1987. Palabras clave: historia, fundamentos técnicos, principios técnicos, defensa personal, entrenamiento. Resumen: Manual teórico y técnico de judo. La obra esta formada por 6 capítulos presentados bajo una estructura de viñetas. El primer capítulo relata el origen del judo, la vestimenta, sus principios técnicos y algunas nociones sobre la reanimación. El segundo capítulo explica por partes diferentes técnicas de judo en pie para luego describir el trabajo de judo en el suelo, con las principales inmovilizaciones, luxaciones y estrangulaciones. El cuarto capítulo expone las características de los distintos métodos de entrenamiento, para finalizar con la descripción de algunas técnicas de defensa personal ante las situaciones de agresión más comunes y un resumen de las reglas de competición.

206. Martínez Barrera, José Miguel (1987). Goshindo miura-ryu : escuela de corazón de sauce. Barcelona: Alas. 1a ed. 127 p. : il. ; 15x21,5 cm. ISBN: 84-203-0206-6. Depósito legal: B. 9158-1987. Palabras clave: historia, fundamentos técnicos, zen, maestros, meditación. Resumen: Manual teórico y técnico de jujutsu. El libro consta de tres partes, precedidas por una presentación que comenta la introducción del autor en el goshindo, su currículum profesional, sus títulos y certificados, algunas fotos practicando con el maestro Raymond Thomas y una dedicatoria. La primera parte incluye el árbol genealógico del estilo, su historia y evolución, la biografía de Raymond Thomas junto con varias de sus fotografías, el emblema de la escuela junto con su significado, resume el código del bushido, enumera las distintas artes budo japonesas y comenta el sistema de grados del estilo y sus formas de saludar. La segunda parte comenta la relación entre el goshindo y el zen, relata la historia del zen y expone los principios teóricos del zazen. La tercera parte nombra e ilustra los fundamentos técnicos del goshindo miura-ryu como son las patadas, formas de caer, las distintas técnicas de goshin-tai y goshin-tambo y presenta la secuencia fotográfica de la Ten No Kata So No Ichi, Ten No Kata So No Ni, Ten No Kata So No San, Ten No Kata So No Yon, Ten No Kata So No Go, Goshin-tai No Kata, Goshin-tambo No Kata y Goshin-bo No Kata. Finaliza con la explicación de los diferentes métodos y posturas de meditación en zazen.

207. Martínez-Villasante, Luis Gonzalo (1984). Programación sobre la enseñanza de judo-suelo (texto oficial). Madrid: Federación Española de Judo y Deportes Asociados. 1aed. 167 p. : il. ; 17x23,5 cm. ISBN: 84500-9949-8. Depósito legal: M. 16287-1984. Palabras clave: fundamentos técnicos, didáctica, psicología evolutiva, planificación del entrenamiento. Resumen: Manual teórico y técnico de judo. El libro esta compuesto por 7 capítulos. El primer capítulo relata el trabajo realizado por el autor para confeccionar la programación de la enseñanza del judo-suelo. El segundo capítulo comenta las características físicas, psíquicas y de crecimiento de los niños de entre 6 y 8 años, para luego presentar las posiciones kesa, kami, tate y yoko, comentar los principios técnicos de las inmovilizaciones, describir e ilustrar las técnicas hon-kesa-gatame, kami-shiho-gatame, yoko-shiho-gatame y tate-shiho gatame junto con sus salidas, y exponer las diferentes formas de voltear a uke o salir de su agarre. El tercer capítulo detalla las características físicas y psíquicas de los niños de 9-11 años, describe otras 
salidas de las posiciones hon-kesa-gatame, kami-shiho-gatame, yoko-shiho-gatame y tate-shihogatame, explica las variaciones técnicas de las principales inmovilizaciones, presenta otras formas de voltear y controlar al uke así como algunas combinaciones técnicas entre proyecciones e inmovilizaciones, todo ello acompañado de las fotografías explicativas. El cuarto capítulo comenta las características físicas y psíquicas de los niños de 12-13 años y presenta la programación de los contenidos técnicos acordes a dicha edad, como son las salidas de las variantes de las inmovilizaciones principales, el encadenamiento de distintas inmovilizaciones y otros encadenamientos entre las proyecciones e inmovilizaciones junto con sus ilustraciones. El siguiente capítulo analiza las características de los niños entre 14-16 años para describir los contenidos técnicos para dicha edad como las variantes de las inmovilizaciones principales, formas de voltear y controlar a uke, comenta los fundamentos de los diferentes tipos de estrangulaciones junto con la descripción técnica de katajuji-jime, gyaku-juji-jime, nami-juji-jime, hadaka-jime, okuri-eri-jime, kata-ha-jime, y comenta los fundamentos de las luxaciones además de explicar la ejecución de ude-garami, ude-gatame, jujigatame, hiza-gatame y waki-gatame. El sexto capítulo explica las características de los adolescentes de más de 17 años, detalla la ejecución de las técnicas adecuadas para este grupo de edad así como algunas variantes de las inmovilizaciones, otras formas de voltear e inmovilizar a uke, las variantes de las estrangulaciones y luxaciones básicas y la ejecución de algunas luxaciones realizadas desde posición de pie. El último capítulo presenta las técnicas de perfeccionamiento de las estrangulaciones y luxaciones básicas incluyendo una descripción técnica y sus ilustraciones explicativas así como algunas formas especiales de encadenamiento pie-suelo, de voltear y controlar a uke y un cuadro resumen del agrupamiento de las técnicas de estrangulamiento.

208. Marwood, Des (1995). Judo. Iniciación y perfeccionamiento. Barcelona: Paidotribo. 1a ed. 271 p. : il. ; 15x21,5 cm. ISBN: 84-8019-180-5. Depósito legal: B. 132-1995. (2ª ed., 2000; 3를. ed., 2002). Palabras clave: fundamentos técnicos. Resumen: Manual técnico de judo. Después de explicar los fundamentos técnicos y formales del judo, el primer capítulo describe las técnicas de proyección hasta cinturón negro, con una explicación general de cada técnica y una secuencia de dibujos tanto de la técnica como de los puntos clave e incluso de las combinaciones o contraataques que puede realizar el oponente. El segundo capítulo incluye un comentario sobre la kata, su importancia y entrenamiento, para continuar con la presentación, del mismo modo que en el primer capítulo, del estudio de las inmovilizaciones, las estrangulaciones y las luxaciones.

209. Mirallas Sariola, Jaume Antón (1995). Bases didácticas del judo : biomecánica para el estudio y el aprendizaje de la técnica y la táctica del judo. Barcelona: Jaume Antón Mirallas Sariola. 1aa ed. 156 p. : il. ; 14x20,5 cm. ISBN: 84-605-3104-X. Depósito legal: B. 6132-1995. (2ª ed., 1996). Palabras clave: fundamentos teóricos, fundamentos técnicos, didáctica, biomecánica, judo. Resumen: Tratado teórico de judo. La monografía esta formada por 3 capítulos, precedidos por una introducción que comenta los contenidos del libro y la evolución de su campo de estudio. El primer capítulo explica los fundamentos teóricos básicos de la biomecánica como sus áreas de aplicación, las áreas de la mecánica y sus leyes fundamentales. El segundo capítulo define los términos de sistema biomecánico, estabilidad, equilibrio, acción técnico-táctica, elementos técnico-tácticos; analiza estos elementos técnico-tácticos (posición, postura, presa, desplazamiento, contacto, control y caída) y sus variantes desde el punto de vista biomecánico; y describe las fases de la estructura cinética de la acción técnico-táctica en el judo. El último capítulo analiza la estructura básico-funcional de la técnica, la estructura funcional de la táctica así como la acción técnica y las acciones tácticas ofensivas (anticipación, retención, transformación) y defensivas (esquiva, afrontamiento) además de sus repercusiones didácticas en la enseñanza del judo. Adjunta anexos sobre las etapas de la vida del judoka, la estructura didáctica de la sesión de entrenamiento, la preparación psicológica del judoka, la estrategia en el combate, una tabla de magnitudes físicas, un glosario biomecánico y de judo y bibliografía.

210. Mirallas Sariola, Jaume Antón (1995). Introducción a la pedagogía del judo infantil. Barcelona: Jaume Antón Mirallas Sariola (con la colaboración de la Diputación Provincial de La Coruña y la Federación Gallega de Judo y D.A. 1a ed. 49 p. : il. ; 14x20,5 cm. ISBN: 84-920937-0-6. Depósito legal: B. 6132-1995. Palabras clave: fundamentos técnicos, táctica, didáctica, juegos. Resumen: Manual teórico de judo. La obra esta dividida en 7 capítulos, precedidos por una tabla con el contenido temático y horario del curso de judo realizado en La Coruña entre los días 8 y 10 de septiembre de 1995. El primer capítulo enumera los objetivos y ejercicios de cada etapa de la vida del judoka, incluyendo un esquema de los mismos. El segundo capítulo presenta la estructura y variables de la programación de la sesión de judo infantil junto con su esquema. El tercer capítulo describe las características de la didáctica del juego y sus principios mientras que el cuarto incluye la definición de los elementos básicos y técnicos del judo acompañados de sus esquemas explicativos. El quinto capítulo define la acción técnica de judo y sus fases para en el sexto capítulo definir la acción táctica y sus fases. El último capítulo analiza las acciones tácticas ofensivas y defensivas en judo. Adjunta bibliografía.

211. Morales Negrillo, Laura (2009). Educación física : fundamentos del judo. Almería: Tutorial Formación. $1^{\mathrm{a}}$ ed. 85 p.: il.; 14x20,5 cm. ISBN: 978-84-9934-353-2. Depósito legal: AL. 1122-2009. Palabras clave: 
fundamentos teóricos, historia, fundamentos técnicos. Resumen: Manual teórico y técnico de judo. El libro esta formado por 5 capítulos precedidos por una introducción que comenta las características educativas de los deportes de lucha. El primer capítulo enumera las consideraciones metodológicas para la aplicación del judo en el contexto de la Educación Física. El segundo capítulo narra la historia del judo incluyendo un cronograma. El tercer capítulo expone los beneficios derivados de la práctica continuada de judo. El cuarto capítulo describe las características del tatami, del judogi, las posiciones y desplazamientos básicos del judo, sus principios técnicos y las caídas incluyendo su representación gráfica. El último capítulo presenta el cuaderno del alumno en el que se explica el randori, el sistema de grados, las técnicas de inmovilización, las reglas básicas de la competición, el código moral del judoka, las máximas de Jigoro Kano, algunas curiosidades y un breve glosario específico. Adjunta bibliografía.

212. Morente Sánchez, Jaime (2009). El judo en el ámbito escolar. Granada: Impredisur. 1aㅡ ed. 170 p. ; $17 \times 24$ cm. ISBN: 978-84-7933-829-9. Depósito legal: no.

213. Morillo del Río, Enrique; García Barbero, Juan y García Barbero, Víctor (1983). Judo : fundamentos, caídas, proyecciones, inmovilizaciones. Programa hasta cinturón negro. San Sebastián de los Reyes: Interediciones J.M. 1aㅡ ed. 47 p. : il. ; 19x27 cm. ISBN: 84-7500-160-2. Depósito legal: M. 17081-1983. Palabras clave: fundamentos técnicos. Resumen: Manual técnico de judo. La monografía esta compuesta de 6 capítulos, dedicando el primero a los fundamentos técnicos del judo. Los siguientes capítulos, atendiendo a la clasificación de contenidos propuesta por la Federación Española de Judo, presenta las técnicas de proyección en el segundo capítulo y las técnicas de control en el tercero. El cuarto capítulo explica las katas y las técnicas que incluyen las dos primeras; mientras que el quinto hace un comentario general sobre el desarrollo de la competición para finalizar con el cuadro resumen del programa de la Federación Española de Judo y un vocabulario.

214. Moronta Peña, David (2008). David vs Goliyat. Madrid: David Moronta Peña. 1a ed. 294 p. : il. ; $16 \times 23$ cm. ISBN: 978-84-612-7781-0. Depósito legal: M. 57761-2008. Palabras clave: historia, competición, instituciones. Resumen: Diario de David Moronta Peña. El libro esta formado por 23 capítulos precedidos por los agradecimientos y una introducción que comenta la iniciativa de la obra. Los siguientes 22 capítulos narran el proceso de tramitación para la participación del autor en los Campeonatos de Europa de judo en la modalidad de kata por parejas, incluyendo una descripción de las decisiones tomadas durante el proceso, sus entrenamientos, viajes, campeonatos y reuniones además de la ilustración de las notas, documentos y cartas acreditativas de dichas acciones. El último capítulo presenta una descripción de la actividad profesional y privada del autor desde julio hasta diciembre de 2007. Adjunta apuntes del autor realizados durante el proceso de tramitación, su currículo deportivo y una dedicatoria.

215. Moronta Peña, David (2009). Judo alterna (alumn@s David Moronta) : 1998-1999 / 2008-2009. Madrid: David Moronta Peña. 1ạ ed. 99 p. : il. ; 21x15 cm. ISBN: 978-84-613-1726-4. Depósito legal: M. 199492009. Palabras clave: historia, clubes, fotografía. Resumen: Tratado histórico de judo. El libro esta formado por 7 capítulos precedidos por los agradecimientos y una introducción que narra la introducción del autor en la docencia. El primer capítulo incluye la ficha de entrenamiento y/o resultados de los alumnos del club Judo Alterna. El segundo capítulo presenta las fotografías de los distintos grupos de alumnos del autor. El tercer capítulo expone algunos de los documentos oficiales de la creación del club así como del material didáctico utilizado durante las clases. El cuarto capítulo incluye varias fotografías de campeonatos, salidas y viajes del club. El quinto capítulo presenta un glosario específico de judo. El sexto capítulo reflexiona sobre el entrenamiento de judo. El último capítulo expone algunas frases curiosas de las clases de judo.

216. Moronta Peña, David y Campos Andrés, Natalia (2006). Los fundamentos a través de las kata. Madrid: Vision Libros. $1^{\mathrm{a}}$ ed. 101 p. : il. ; 14x21 cm. ISBN: 84-9821-324-X. Depósito legal: M. 9239-2006. Palabras clave: katas, fundamentos técnicos, aforismos. Resumen: Manual técnico de los fundamentos de judo a través de la kata. El libro esta dividido en 7 capítulos, con los cuatro primeros dedicados a la explicación del saludo, las caídas, las posiciones básicas y los desplazamientos a través del entrenamiento de la kata. El quinto capítulo presenta la cronología de Kano respecto a su vida marcial, para continuar con una clasificación y nomenclatura de los fundamentos del judo. El último capítulo incluye el nombre y traducción de las técnicas del judo Kodokan. Fuera del índice encontramos dos capítulos, el primero de ellos cuenta una historia que reflexiona sobre la práctica del judo, mientras que el segundo recoge varios aforismos. Adjunta bibliografía.

217. Moronta Peña, David y Campos Andrés, Natalia (2008). Iniciación a las kata en judo. Parla: Natalia Campos Andrés. 1aㅡ ed. 101 p. : il. ; 14x21 cm. ISBN: 84-612-3733-3. Depósito legal: M. 24043-2008. (2a ed. aum., 2008). Palabras clave: katas, fundamentos técnicos, biografía, maestros, programa técnico. Resumen: Manual teórico y técnico de judo. La obra esta formada por 9 capítulos, precedidos por una introducción que comenta el objetivo de la obra y un prólogo que relata la armonización de las katas. El primer capítulo enumera e ilustra la ejecución de la rei-ho-no-kata. El segundo capítulo presenta la ukemi-no-kata con su secuencia fotográfica. El tercer capítulo ilustra la kamae-ne-no-kata con el nombre de cada posición y un ejemplo de progresión de esta kata. El cuarto capítulo presenta la 
shintai-no-kata con sus ilustraciones explicativas además de proponer el esquema de trabajo de la kumi-no-kata y la kuzushi-no-kata. El quinto capítulo incluye una breve descripción de la cronología de Jigoro Kano. Los dos siguientes capítulos incluyen un glosario de términos de kihon y técnicas básicas así como una clasificación de los contenidos técnicos del judo y de las técnicas en desuso. El octavo capítulo presenta una historia sobre la práctica y objetivos del judo. El último capítulo incluye aforismos sobre el entrenamiento, el judo y el combate. Adjunta bibliografía.

218. Muñoz, Oscar (1956). Aprenda a defenderse : moderno método de judo, boxeo y lucha libre americana. Barcelona: Bruguera. $1^{\underline{a}}$ ed. 124 p. : il. ; 10x15 cm. ISBN: No ISBN. Depósito legal: no. (2aㅡ ed., 1958). Palabras clave: fundamentos técnicos, principios técnicos, entrenamiento. Resumen: Tratado teórico y técnico de judo, boxeo y lucha libre americana. La obra esta dedicada principalmente al judo, incluyendo algunos conceptos y técnicas básicas del boxeo y la lucha. Comienza con la explicación del significado y objeto del judo, para continuar con una metáfora sobre los principios del judo, recalcar la importancia de las posturas y su correcta ejecución y detallar su vestimenta y grados. El sexto capítulo explica los principios de kuzushi, tsukuri y kake, detallando e ilustrando cada una de las fases y luego pasa a las caídas y su técnica correcta, la descripción y clasificación de todas las técnicas de judo, los tipos de entrenamiento y los programas técnicos para cada grado o cinturón. A partir del capítulo undécimo pasa a explicar dichos programas técnicos, desde el cinturón blanco hasta el marrón, explicando sólo algunas de las principales técnicas, dividiendo la explicación en las fases de kuzushi, tsukuri y kake. El último capítulo dedicado al judo explica algunas de las técnicas de sutemi para los mismos cinturones. La segunda parte del libro expone los fundamentos del boxeo, como son la guardia, los desplazamientos y esquivas, y la ejecución de los golpes básicos. Finaliza con la descripción e ilustración de algunas técnicas de luxación, inmovilizaciones, golpeos y zancadillas de la lucha libre americana.

219. Muzas, Mario; Frutos Molinero, José Luis de.; Galán, Eduardo y Soria, Francisco (2003). Método didáctico de judo infantil. Pontevedra: Diputación Provincial de Pontevedra y Federación Galega de Judo e D.A. 1 a ed. 108 p. : il. ; 21x20 cm. ISBN: No ISBN. Depósito legal: VG. 1086-2003. Palabras clave: historia, fundamentos teóricos, didáctica, competición. Resumen: Tratado teórico y técnico de judo. La obra esta formada por 3 partes, precedidas por un prólogo, agradecimientos a Anton Geesink y la figura del maestro, y la presentación de los presidentes de la Federación Española y la Federación Gallega de Judo respectivamente. La primera parte explica el significado del método didáctico, presenta los criterios de secuenciación de los contenidos y los contenidos técnicos de las etapas de aproximación, adaptación y enseñanza 1 y 2 incluyendo numerosas fotografías explicativas. La etapa de aproximación expone las características del pre-judo, las posiciones básicas y sus formas de llegar, la posición de las piernas y el grupo uki-goshi. La etapa de adaptación presenta las posiciones de control, el grupo kesa, las posiciones de tori sobre uke, la posición del cuerpo, los grupos o-goshi y koshi-guruma. La etapa de enseñanza 1 explica los puntos básicos de control, las posiciones estableinestable, distintas formas de atacar a uke, el grupo seoi-nage, seoi-otoshi y tsuri-komi-goshi. La etapa de enseñanza 2 describe las inmovilizaciones tate y kami-shiho-gatame, las salidas y defensas básicas, algunas técnicas de estrangulación y luxación, las características de los grupos harai, barai, gari y sutemi, además del entrenamiento gonosen y renraku, y las caídas. También incluye el gokyo y las competiciones adaptadas de técnica y deportiva. La segunda parte relata la historia del judo gallego, enumera sus pioneros y primeros clubes, su evolución, los campeones de España entre 1965-2002, los judokas olímpicos gallegos, los campeonatos de España realizados en Galicia, las iniciativas realizadas por el judo gallego e incluye una cronología ilustrada. La última parte enumera los maestros, altos grados y clubes de judo gallegos.

220. Nacenta Navarro, Antonio (1965). Judo. Barcelona: De Gasso Hnos. 1a ed. 378 p. : il. ; 13x19,5 cm. ISBN: No ISBN. Depósito legal: B. 29021-1965. (2ª ed., 1967; 3를. ed., 1973, ISBN: 84-332-0498-X; 4를. ed., 1976, ISBN: 84-332-0024-0). Palabras clave: fundamentos técnicos, entrenamiento, relatos, competición, exámenes, grados, programa técnico. Resumen: Manual teórico y técnico de judo. El libro esta dividido en 4 partes. La primera parte explica la naturaleza del judo, relata una anécdota sobre el judo en la milicia, incluye la entrevista realiza al maestro Matsumoto en las Olimpiadas de 1964, comenta las características y permanencia en cada cinturón según el autor e incluye un vocabulario básico. La segunda parte relata una competición de judo y el ambiente en torno a dicha competición, la primera clase de judo del autor, explica la vertiente deportiva del judo y su origen, expone los principios del judo en pie y el judo en el suelo junto con la clasificación de sus contenidos técnicos y comenta las normas de competición y algunas historias del autor como competidor. La tercera parte incluye la tabla de técnicas que componen el judo junto con la descripción e ilustración de las principales técnicas de proyección, inmovilización, estrangulación y luxación, ofrece algunos consejos para el principiante e incluye el programa de exámenes de grados hasta cinturón negro. La última parte narra la preparación y desarrollo del primer campeonato del autor, su participación en el 3er campeonato del mundo de París, su entrenamiento diario, su participación en el Stage internacional de Beauvallon en 1963 y su 
participación en un curso de entrenamiento intensivo, comentando algunos de los aspectos teóricos del entrenamiento y el judo.

221. Nakanishi, Hidetoshi (1994). Seoi-nage. Barcelona: Paidotribo. 1aㅡ ed. 259 p. : il. ; 15x21,5 cm. ISBN: 848019-114-7. Depósito legal: no. Palabras clave: fundamentos técnicos, principios técnicos, entrenamiento. Resumen: Manual técnico de seoi-nage. Después de comentar la evolución del seoinage y hacer una introducción de sus fundamentos técnicos, los cinco capítulos siguientes están dedicados al morote-seoi-nage, describiendo su ejecución con distintos agarres, sus defensas y entrenamiento. Los siguientes cuatro capítulos hacen lo mismo con la técnica ippon-seoi-nage además de incluir sus posibles combinaciones. El último capítulo ilustra la utilización de estas técnicas en la competición.

222. Nalda Albiac, José Santos (1983). Judo competición infantil : reglas oficiales de competición. Barcelona: Alas. 1a ed. 48 p. : il. ; 21x15,5 cm. ISBN: 84-203-0156-6. Depósito legal: B. 39364-1983. Palabras clave: competición, reglamentos. Resumen: Extracto de las reglas de competición de la Federación Internacional comentadas a modo de cómic, incluyendo la explicación de los términos de arbitraje utilizados, acompañados de su representación gráfica.

223. Nalda Albiac, José Santos (2003). Judo infantil : educación integral. Barcelona: Alas. 1a ed. 205 p. : il. ; 23x17 cm. ISBN: 84-203-0423-9. Depósito legal: B. 16104-2003. Palabras clave: fundamentos teóricos, didáctica, programa técnico. Resumen: Manual técnico-didáctico de judo. La monografía esta dividida en 4 partes y la primera presenta las bases teóricas del judo comentando sus valores, actitudes, hábitos así como la clasificación de sus técnicas, el papel del profesor, el desarrollo del niño y las ventajas del judo. La segunda parte explica los conceptos básicos del judo, como su significado y símbolo, el saludo, los roles del practicante, el agarre, los principios del movimiento, los tipos de entrenamiento, la estructura del judo y los grados. La tercera parte expone los programas de los distintos grados hasta cinturón marrón, explicando cuáles son las habilidades técnicas, principios técnicos, valores, habilidades motrices, actitudes y metodología que se deben desarrollar en cada grado. La última parte esta compuesta por un comentario sobre la evolución del judo infantil y el testimonio de un alumno.

224. Navarro de Palencia Pérez, José (1984). Programa de kata para monitores, entrenadores regionales y entrenadores nacionales (texto oficial). Madrid: Federación Española de Judo y Deportes Asociados. 1a ed. 96 p. : il. ; 17x24 cm. ISBN: 84-500-9864-5. Depósito legal: M. 12615-1984. Palabras clave: katas, fundamentos técnicos. Resumen: Manual teórico y técnico de judo. El libro esta dividido en 3 partes, precedidas por un capítulo introductorio que comenta las características de las katas, sus objetivos y sus principios técnicos. La primera parte describe la posición, forma de saludar y desplazarse en la nage-no-kata para luego explicar la ejecución de sus técnicas e incluir la secuencia fotográfica de cada una de ellas. La segunda parte describe e ilustra la ejecución de las técnicas de la katame-no-kata. La tercera parte presenta la descripción e ilustración de la kime-no-kata.

225. Nidan (1960). El judo y el jiu-jitsu. Madrid: Nidan. 1a ed. 52 p. : il. ; 19x27,5 cm. ISBN: No ISBN. Depósito legal: M. 7506-1960. Palabras clave: historia, fundamentos teóricos, táctica, fundamentos técnicos, principios técnicos, defensa personal, vestimenta, cortesía, judo, jujutsu, aplicación marcial, etiqueta, grados. Resumen: Manual teórico y técnico de judo. El libro consta de 21 capítulos. Los dos primeros capítulos presentan el judo y al autor del libro. El tercer capítulo narra la aparición del judo y su expansión a España. El cuarto capítulo comenta las diferencias entre el judo y el jiu-jitsu, para luego presentar el programa de judo como deporte y como defensa personal. Los dos siguientes capítulos describen las características del dojo y el judogi del practicante. El séptimo capítulo describe el sistema de grados y cómo obtener los mismos. Los tres siguientes capítulos muestran cómo sujetar al compañero durante las proyecciones, el significado de uke y tori, y la manera de saludar. El decimosegundo capítulo explica los principios de las caídas junto con la descripción e ilustración de su ejecución técnica. Los siguientes seis capítulos describen la postura en el judo y la defensa personal, explican los tipos de desequilibrios y fuerzas, los tipos de desplazamientos, la forma de caminar, el agarre y los principios de kuzuchi, tsukuri y kake, incluyendo la representación gráfica de cada uno de ellos. El decimonoveno capítulo describe las distintas fases de la técnica o-soto-gari, su ejecución en movimiento, su aplicación a la defensa personal así como algunos ejercicios para su entrenamiento. El vigésimo capítulo comenta los principios del jiu-jitsu ante una situación de defensa personal y sus principios de entrenamiento; para finalizar con la descripción de varias técnicas de defensa contra agarres a las manos, a la solapa y un empujón.

226. Nowoisky, Heinz (1993). Les bases biomecàniques del kuzushi : l'entrenament técnic del judo sobre un lloc de medició. Barcelona: Generalitat de Catalunya. Secretaria General de l'Esport. 1aㅡ ed. 28 p. : il. ; 21x29,5 cm. ISBN: No ISBN. Depósito legal: B. 5708-1993. Palabras clave: principios técnicos, biomecánica, capacidades físicas. Resumen: Tratado teórico de judo. La obra consta de dos estudios. El primer estudio esta dividido en 3 partes y estudia las bases biomecánicas del kuzushi. La primera parte analiza los fundamentos teóricos y biomecánicos del kuzushi y la ruptura del equilibrio, analiza las fases de la ejecución del tai-otoshi y las fuerzas implicadas en cada una de ellas y presenta los 
resultados obtenidos. La segunda parte interpreta y discute los resultados obtenidos para en la tercera parte presentar las conclusiones extraídas. El segundo estudio esta dividido en 5 partes y presenta un aparato de medición de la fuerza en judo. La primera parte comenta la importancia de un movimiento técnicamente correcto para el rendimiento en el judo. La segunda parte presenta las características del aparato de medición de la fuerza y sus posibles aplicaciones. La tercera parte expone los resultados obtenidos mientras que los dos últimos capítulos comentan sus campos de aplicación y posibilidades.

227. Olivares García, José (1965). Judo. Madrid: Doncel. 1a ed. 86 p. : il. ; $13 \times 18$ cm. ISBN: No ISBN. Depósito

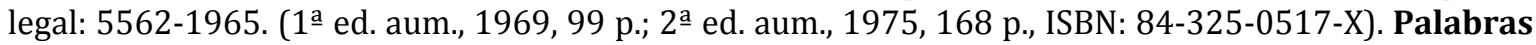
clave: historia, fundamentos técnicos, programa técnico, exámenes, grados. Resumen: Manual teórico y técnico de judo. El libro esta dividido en 7 capítulos. El primer capítulo narra el origen del jiu-jitsu y la creación del Kodokan. El segundo capítulo explica en qué consiste el judo, sus beneficios y principios técnicos, las características del dojo y el judogi, ilustra las formas de saludar, describe la ejecución de las distintas formas de caer y la posición fundamental junto con sus ilustraciones, y presenta el principio de los desequilibrios, el sistema de grados, el programa de judo y un resumen del reglamento de competición. El tercer capítulo describe la ejecución de diversos ejercicios de calentamiento para todo el cuerpo así como las normas de higiene básicas para su práctica. El cuarto capítulo incluye un glosario terminológico básico del judo. Los dos siguientes capítulos describen la ejecución por partes de las técnicas incluidas en el programa de cinturón amarillo y naranja respectivamente, incluyendo la representación gráfica de cada parte. El último capítulo presenta el tiempo de permanencia mínimo en cada grado y un extracto del reglamento para la concesión de grados.

228. Orlandi, Rinaldo (1977). Jiu jitsu moderno. Bilbao: Fher. 1aㅡ ed. 172 p. : il. ; $15 \times 21$ cm. ISBN: 84-2431371-2. Depósito legal: BI. 1321-1977. Palabras clave: fundamentos técnicos, defensa personal. Resumen: Manual de defensa personal a través del jiu-jitsu. Los primeros cuatro capítulos desarrollan la teoría que fundamenta la parte práctica del libro. Comienza hablando de la evolución histórica del judo y su interpretación para luego explicar la organización de los contenidos en sectores y algunos principios de física que se aplican en las técnicas presentadas. A continuación aparecen 5 sectores o capítulos, cada uno de ellos explicando e ilustrando 20 técnicas distintas y dispuestas en orden de dificultad creciente. Cada sector agrupa aquellas técnicas que comparten un mismo criterio y que preparan al practicante para alcanzar el entendimiento de los principios de la defensa personal. Al final de cada capítulo ofrece el planteamiento teórico que fundamenta las técnicas y algunas observaciones para la defensa personal.

229. Ortega Fernández, Rafael (1980). Bases en judo. Madrid: Rafael Ortega Fernández. 1aㅡ ed. 106 p. : il. ; 14x21 cm. ISBN: No ISBN. Depósito legal: M. 41260-1980. Palabras clave: fundamentos teóricos, fundamentos técnicos, principios técnicos, entrenamiento, preparación física. Resumen: Manual teórico y técnico de judo. La obra esta dividida en dos partes que desarrollan la misma estructura de contenidos, presentando distintos kumikata, algunas técnicas de proyección, el trabajo de encadenamiento, algunas técnicas en el suelo, el trabajo de contraataque, el entrenamiento de la agresividad y varios ejercicios de preparación física, intercalados con espacio para tomar notas. La primera parte describe y representa los agarres fundamentales del judo, las posiciones de equilibrio, la ejecución uki-goshi, o-goshi, goshi-guruma, ippon-seoi-nage, tsuri-komi-goshi, tai-otoshi, harai-goshi y uchi-mata, la forma de encadenar el trabajo de judo-pie con el de judo-suelo, la ejecución de las principales técnicas de inmovilización y sus variantes, algunas formas de volcar al adversario, la ejecución de ushiro-goshi como técnica de contraataque, un ejemplo de entrenamiento de la agresividad a través del randori y varios ejercicios de preparación física. La segunda parte describe e ilustra los agarres mixtos y formas de romper dichos agarres, las formas de caer en competición, las técnicas de barrido, ofrece algunos consejos sobre la competición contra adversarios de características morfológicas distintas y formas de encadenar el trabajo de judo-pie con el de judo-suelo, describe la ejecución de algunas técnicas de inmovilización avanzadas, los principios de las técnicas de luxación, la aplicación de las técnicas de-ashi-barai, te-uchi-mata y sukui-nage como técnicas de contraataque, y presenta un ejemplo de entrenamiento de la agresividad a través de varios ejercicios de randori y consejos para mejorar la condición física por medio del entrenamiento de los distintos ejercicios de judo.

230. Ortega Fernández, Rafael (1984). Judo moderno y eficaz. Madrid: Nueva Lente. 1a ed. 151 p. : il. ; 22x28,5 cm. ISBN: 84-7534-081-4. Depósito legal: M. 7537-1984. Palabras clave: fundamentos teóricos, fundamentos técnicos, competición. Resumen: Manual teórico y técnico de judo. El libro esta dividido en 8 capítulos. Los cinco primeros capítulos mantienen una misma estructura de contenidos en la que se explican el agarre, las técnicas de proyección, las técnicas de suelo y el entrenamiento. El primer capítulo define los papeles de tori y uke para luego describir e ilustrar el kumikata básico, la posición básica, las técnicas uki-goshi, o-goshi, las posiciones básicas en el suelo kesa, yoko, kami y tate, y explica el desarrollo del trabajo de randori. El segundo capítulo presenta las técnicas goshiguruma, kata-kesa-gatame, kuzure-kesa-gatame, makura-kesa-gatame, kuzure-makura-kesa-gatame, algunas técnicas de salida de las inmovilizaciones acompañadas de sus respectivas ilustraciones y 
detalla el trabajo de randori en el suelo y randori total. El tercer capítulo incluye la descripción e ilustración de algunos agarres especiales, las técnicas ippon-seoi-nage, tsuri-komi-goshi, tai-otoshi, harai-goshi, uchi-mata, ushiro-goshi, comenta el entrenamiento de renraku (encadenamientocombinación), explica algunas combinaciones en el suelo junto con distintas técnicas de salida de las inmovilizaciones y formas de volcar a uke. El cuarto capítulo expone los distintos agarres mixtos, las entradas en desplazamiento, las técnicas de-ashi-barai, ko-uchi-gari y o-uchi-gari, ilustra algunos encadenamientos en las técnicas de inmovilización, las bases de las estrangulaciones junto con las técnicas gyaku-juji-jime, kata juji-jime, nami-juji-jime, hadaka jime, okuri-eri-jime y kata ha jime, y las bases de las luxaciones junto con las técnicas ude garami y juji-gatame. El quinto capítulo describe la ejecución de o-soto-gari, ko-soto-gari, o-uchi-gari, ko-uchi-gari, okuri-ashi-barai, hiza-guruma, haraitsuri-komi-ashi, sasae-tsuri-komi-ashi junto con sus respectivas fotografías, expone algunos ejemplos de técnicas de contraataque y algunas formas de volcar a uke. El sexto capítulo ilustra la ejecución por partes de la adaptación de diferentes técnicas cuando tori es más alto que uke, cuando tori es más bajo que uke y cuando tori y uke son de la misma estatura pero utilizan un agarre mixto. Los dos siguientes capítulos explican la ejecución de algunas técnicas de competición y otras utilizadas en los campeonatos del mundo de 1979 y los Juegos Olímpicos de Moscú-80 junto con la forma de encadenar y contraatacar dichas técnicas, toda ellas ilustradas.

231. Oyaga Jimeno, Fermín (2007). Medio siglo del judo navarro : 1957-2007. Navarra: Miguel Rico \& Asociados. $1^{\mathrm{a}}$ ed. 336 p. : il. ; 21x29,5 cm. ISBN: 978-84-611-9884-9. Depósito legal: NA. 3028-2007. Palabras clave: historia, escuelas, judo, clubes, competición. Resumen: Revisión histórica de la implantación del judo en Navarra. Después de narrar el acercamiento del autor al judo, divide su introducción y desarrollo en Navarra en 3 periodos (introducción y asentamiento, difusión y expansión, apogeo y cénit). Cada periodo explica con detalle, y apoyo de abundante material gráfico, los hechos y personajes más significativos que fueron conformando la historia del judo en esta comunidad. A continuación ofrece material gráfico (fotos, recortes de periódico, panfletos, trípticos) sobre las efemérides de los campeonatos celebrados en Navarra, las distintas celebraciones que se realizaron en honor al judo, la publicidad que se ofrecía, los presidentes y altos grados que dirigieron el judo, la genealogía de las escuelas, el cuadro de honor de los distintos periodos del judo y de los clubes de Navarra en el 2007. Finaliza con el testimonio del autor y la relación de clubes navarros existentes en el 2007.

232. Páez-Centella García-Diego, César y Vilalta i Casas, Esther (1983). Judo infantil : pedagogia i tècnica. Esplugues de Llobregat: Generalitat de Catalunya, Institut Nacional d'Educació Física. 1aa ed. 164 p. : il. ; 15x21 cm. ISBN: 84-393-0236-3. Depósito legal: B. 37579-1983. Palabras clave: pedagogía, didáctica, competición, unidades didácticas. Resumen: Tratado teórico de judo. La obra esta formada por 10 capítulos. El primer capítulo presenta las etapas del desarrollo afectivo social y psico-motriz y sus características. El segundo capítulo expone la organización general de instalaciones y equipo para la práctica de judo. El tercer capítulo estudia las características y roles del profesor, el desarrollo de una clase atendiendo a las características del grupo, y la exposición del profesor. El cuarto capítulo expone la progresión de contenidos en relación al grado para luego enumerar las técnicas de suelo y de pie para cada curso o nivel. El sexto capítulo presenta el desarrollo práctico de tres unidades didácticas y cuatro sesiones. El séptimo capítulo comenta los diferentes sistemas de motivación del niño en la práctica del judo como el paso de grados, el juego, la competición, el sistema de carnés, el sistema de puntos, los murales y los cromos. El octavo capítulo detalla los tipos de competición y sus objetivos dentro de la labor pedagógica. El noveno capítulo analiza las ventajas de las exhibiciones, los concursos, los informes, los trofeos y otras actividades para el final del curso; y finaliza con la descripción de una actividad de pre-lucha para los niños de 6-7 años. Adjunta apéndices sobre la clasificación de los juegos, el desarrollo de distintos juegos, un modelo de informe, la normativa de las competiciones infantiles, un ejemplo de carta para los padres, vocabulario y bibliografía.

233. Páez-Centella García-Diego, César y Vilalta i Casas, Esther (1983). Judo infantil : pedagogia y técnica. Esplugues de Llobregat: Generalitat de Catalunya, Institut Nacional d'Educació Física. 1a ed. 164 p. : il. ; 15x21 cm. ISBN: 84-393-0228-2. Depósito legal: B. 37194-1983. Palabras clave: pedagogía, didáctica, competición, unidades didácticas. Resumen: Tratado teórico de judo. La obra esta formada por 10 capítulos. El primer capítulo presenta las etapas del desarrollo afectivo social y psico-motriz y sus características. El segundo capítulo expone la organización general de instalaciones y equipo para la práctica de judo. El tercer capítulo estudia las características y roles del profesor, el desarrollo de una clase atendiendo a las características del grupo, y la exposición del profesor. El cuarto capítulo expone la progresión de contenidos en relación al grado para luego enumerar las técnicas de suelo y de pie para cada curso o nivel. El sexto capítulo presenta el desarrollo práctico de tres unidades didácticas y cuatro sesiones. El séptimo capítulo comenta los diferentes sistemas de motivación del niño en la práctica del judo como el paso de grados, el juego, la competición, el sistema de carnés, el sistema de puntos, los murales y los cromos. El octavo capítulo detalla los tipos de competición y sus objetivos dentro de la labor pedagógica. El noveno capítulo analiza las ventajas de las exhibiciones, los 
concursos, los informes, los trofeos y otras actividades para el final del curso; y finaliza con la descripción de una actividad de pre-lucha para los niños de 6-7 años. Adjunta apéndices sobre la clasificación de los juegos, el desarrollo de distintos juegos, un modelo de informe, la normativa de las competiciones infantiles, un ejemplo de carta para los padres, vocabulario y bibliografía.

234. Pastor Albella, Tomás (1963). Manual de judo. Almazora: Escuela Judokan. 1ae ed. 60 p. : il. ; 21x28,5 cm. ISBN: No ISBN. Depósito legal: CS. 116-1963. Palabras clave: historia, fundamentos teóricos, fundamentos técnicos, principios técnicos, filosofía, entrenamiento, grados, sistemas de entrenamiento. Resumen: Manual teórico y técnico de judo. El libro consta de 20 capítulos, precedidos por una introducción que comenta la justificación de la aparición de la obra. El primer capítulo aclara la pronunciación de los términos japoneses. Los siguientes tres capítulos detallan la historia del judo, el significado de los términos judo y jiu jitsu, y el lugar donde se practican respectivamente. El quinto capítulo expone la actitud del judoka ante el entrenamiento y el compañero. Los dos siguientes capítulos describen la vestimenta del judo y la ejecución de las distintas formas de saludar respectivamente, incluyendo su representación gráfica. El octavo capítulo presenta el sistema de grados y cinturones. El siguiente capítulo describe e ilustra los diferentes tipos de desequilibrios del judo para continuar con la descripción e ilustración de las diferentes caídas. El décimo capítulo comenta los beneficios actitudinales del judo para el practicante. Los dos siguientes capítulos presentan las posturas del judo junto con su ilustración y el tiempo mínimo exigido para la obtención de los grados respectivamente. Continúa con la descripción de la ejecución del tai sabaki, las características de los entrenamientos de uchi komi, kata, randori y shiai; para finalizar con la explicación de los principios básicos y la utilización de la fuerza en el judo.

235. Pavia, J.J. y Fontan, J. (1961). La esgrima moderna ó el judo y la defensa personal. s.l.: Imprenta del Ministerio de la Marina. 1aㅡ ed. 276 p. : il. ; desc.xdesc. cm. ISBN: No ISBN. Depósito legal: D.O. núm. 111. Palabras clave: fundamentos técnicos, principios técnicos, defensa personal, vestimenta, cortesía, etiqueta, reglamentos. Resumen: Manual teórico y técnico de judo. El libro esta dividido en 5 partes precedidas de un preámbulo que comenta la enseñanza del judo dentro de las Fuerzas Armadas, un prólogo que señala la importancia de la defensa personal en la guerra y describe la historia y características del judo, un comentario autorizado y una dedicatoria. La primera parte consta de dos capítulos. El primer capítulo señala los objetivos de la obra, el decálogo del jugador deportivo y un cuadro de los valores físicos y morales de algunos deportes. El segundo capítulo narra la historia y evolución del judo, las características del dojo y su vestimenta, describe varios ejercicios de calentamiento, las caídas, las posturas, los desequilibrios, la forma de saludar y los agarres acompañados de su representación gráfica. La segunda parte consta de 3 capítulos. El primer capítulo clasifica los contenidos técnicos del judo e incluye su programación por cinturones. El segundo capítulo describe e ilustra las principales técnicas de proyección del judo. El tercer capítulo explica la ejecución de las técnicas básicas de inmovilización, estrangulación y luxación junto con sus ilustraciones. La tercera parte consta de 2 capítulos. El primer capítulo incluye la descripción e ilustración de la nage no kata. El segundo capítulo explica la ejecución de varias técnicas de combinación y contraataque acompañadas de sus ilustraciones. La cuarta parte consta de 2 capítulos. El primer capítulo describe e ilustra distintas técnicas de judo aplicadas a la defensa personal, las formas kime no kata y goshin jitsu, otras técnicas menos frecuentes y un cuadro resumen de las mismas. El segundo capítulo localiza los puntos vitales del cuerpo humano y expone los principios técnicos del combate cuerpo a cuerpo. La última parte consta de 3 capítulos. El primer capítulo explica los objetivos y características del kuatsu además de describir otras lesiones deportivas. El segundo capítulo incluye las reglas de competición del judo Kodokan junto con un glosario general y específico de judo. El último capítulo incluye un resumen del reglamento interior del departamento nacional de judo.

236. Peidro Payá, Luís (1995). El judo alcoyano : treinta años con el deporte. Alcoi: Judo Club Alcoi. 1a ed. 91 p. : il. ; 15x21 cm. ISBN: 84-605-4465-6. Depósito legal: A. 1112-1995. Palabras clave: historia, clubes, competición. Resumen: Tratado histórico de judo. La obra esta dividida en 5 capítulos ampliamente ilustrados. El primer capítulo narra los inicios del judo en Alcoy en la década de los años 60, sus instalaciones, su repercusión en la prensa y su profesorado. El segundo capítulo comenta la evolución del judo en la década de los años 70, con sus primeros logros federativos y deportivos, la creación de nuevos clubes, los problemas en los órganos de gobierno y los cambios de instalaciones. El tercer capítulo detalla la consolidación de los resultados deportivos de los competidores alcoyanos en judo, la creación de nuevas competiciones, la Federación de la Comunidad Valenciana y la desaparición del Club Jigotay. El cuarto capítulo narra los resultados deportivos del judo alcoyano en la década de los años 90 así como la organización de distintos campeones. El último capítulo comenta las competiciones, resultados y homenajes realizados por el $30^{\circ}$ aniversario de la implantación del judo en Alcoy. Adjunta un epílogo y un listado alfabético de judokas alcoyanos.

237. Pérez-Carrillo, Miguel J. (1967). Judo infantil. Barcelona: Hispano Europea. 1a ed. 76 p. : il. ; 14x20 cm. ISBN: No ISBN. Depósito legal: B. 39469-1967. (2ª ed., 1974, ISBN: 84-255-0121-0). Palabras clave: 
katas, fundamentos teóricos, fundamentos técnicos, programa técnico, principios técnicos, calentamiento. Resumen: Manual técnico de judo. La obra esta dividida en 7 partes, comenzando por la explicación de lo que es el judo y los roles de tori y uke. La segunda parte explica e ilustra algunos ejercicios de calentamiento antes de comenzar la clase de judo y el siguiente presenta los contenidos formales del judo, como son el dojo, la vestimenta, los grados, los agarres, el saludo, los desequilibrios, la postura, las caídas y algunos consejos sobre la enseñanza. Los siguientes tres capítulos describen tanto las inmovilizaciones como las proyecciones dividiendo estos contenidos según la edad de los niños en 3 periodos: de 5 a 7 años, de 8 a 10 años y de 11 a 13 años. Finaliza con la explicación e ilustración de los tres primeros grupos de técnicas de la nage-no-kata.

238. Pöhler, Ralf (1998). Iniciación al judo : del cinturón blanco al verde, las primeras competiciones. Barcelona: Hispano Europea. 1aㅡ ed. 128 p. : il. ; $13 \times 21$ cm. ISBN: 84-255-1211-5. Depósito legal: B. 4570-1998. Palabras clave: fundamentos teóricos, fundamentos técnicos, pedagogía, didáctica, entrenamiento, competición, planificación del entrenamiento, reglamentos. Resumen: Manual técnicodidáctico de judo. La monografía esta dividida en 10 lecciones que estructuran los contenidos de judo de forma progresiva, ofreciendo ejercicios y consejos para el monitor. Las dos primeras lecciones introducen al practicante en la historia general del judo y su situación actual en Alemania, la finalidad de la competición del judo y su reglamento respectivamente. La tercera lección presenta los primeros ejercicios para adquirir unas actitudes correctas en el entrenamiento además de presentar el tatami y la vestimenta. La cuarta lección ofrece un conjunto de ejercicios para ir avanzando en el trabajo de judo-suelo, proponiendo situaciones desde distintas posiciones de tori y uke, con fotografías para visualizar cada uno de ellos. Continúa con algunos ejercicios para la práctica de las proyecciones de rodillas y las caídas. La sexta lección comienza con las técnicas propias del judo, remarcando la acción de ceder ante los ataques. El siguiente capítulo centra su atención en el principio de acción-reacción e incluye el aprendizaje de varias técnicas. La octava lección comenta los diferentes ejercicios tradicionales como el tandoku-renshu, uchi-komi, yakusoku-geiko y randori, explicando algunos ejercicios básicos para desarrollar cada uno de ellos. La novena lección introduce al practicante en la competición, explicando cuál debe ser la preparación antes, durante y después de la competición e incluyendo un breve comentario sobre el reglamento. Finaliza con un comentario sobre el pase de cinturones, un breve manual de entrenamiento, el programa de contenidos de la Federación Alemana de Judo para el pase de cinturón y algunos criterios para la valoración técnica del practicante. Adjunta glosario.

239. Raga Díaz, Jorge (1992). Judo ¡Tú puedes! Gijón: Federación de Judo y Disciplinas Asociadas del Principado de Asturias. 1aㅡ ed. 15 p. : il. ; 21x14,5 cm. ISBN: No ISBN. Depósito legal: AS. 575-1992. Palabras clave: historia, vestimenta, clubes, grados, maestros. Resumen: Manual teórico y técnico de judo. La obra comenta a modo de cómic en qué consiste el judo, sus fundamentos históricos y de su fundador, la vestimenta y el sistema de grados. También presenta el alfabeto katakana y su forma de utilización. Adjunta un listado de los clubes de judo reafiliados en el año 1991.

240. Reay, Tony (1989). Judo : guía para jóvenes principiantes. Barcelona: Martínez Roca. 1aㅡ ed. 61 p. : il. ; 20x28 cm. ISBN: 84-270-1293-4. Depósito legal: B. 4537-1989. Palabras clave: historia, fundamentos teóricos, fundamentos técnicos, principios técnicos, vestimenta, competición, grados, instalaciones. Resumen: Manual teórico y técnico de judo. La obra esta formada por 8 capítulos, precedidos por una introducción que presenta la evolución de las artes marciales y los orígenes del judo, las características del judo infantil y el proceso de aprendizaje del judo en Japón. El primer capítulo describe la vestimenta del judo, su colocación y enumera las reglas del dojo. El segundo capítulo expone la ejecución correcta y progresión en el aprendizaje de las distintas caídas, describe el trabajo de proyecciones y de técnicas en el suelo, y presenta 3 ejercicios/juegos de judo. El tercer capítulo describe las características y particularidades de las proyecciones básicas (seoi-nage, o-uchi-gari, taiotoshi, osoto-gari, harai-goshi, tomoe-nage, sasae-tsurikomi-ashi, uchi-mata, morote-gari y ko-uchigari), incluyendo su secuencia fotográfica. El cuarto capítulo describe e ilustra las inmovilizaciones hon-kesa-gatame, kuzure-kesa-gatame, ushiro-kesa-gatame, makura-kesa-gatame, mune-gatame, honkami-shiho-gatame, kuzure-kami-shiho-gatame, kata-gatame, hon-tate-shiho-gatame, kuzure-tateshiho-gatame, hon-yoko-shiho-gatame, kuzure-yoko-shiho-gatame, y cómo escapar de ellas. Los dos siguientes capítulos comentan el sistema de graduación, los exámenes de grado y las reglas de competición. El séptimo capítulo explica los medios de trabajo para progresar en el entrenamiento y aprendizaje del judo, a través de las técnicas de combinaciones, las técnicas en el suelo, los agarres, la preparación mental y la defensa personal, además de incluir la secuencia fotográficas de varias técnicas de combinaciones. El último capítulo ofrece algunos consejos para padres e instructores sobre su papel en el aprendizaje de judo del niño. Adjunta una lista de direcciones de federaciones provinciales de judo y un glosario.

241. Renault, Jean-François (1976). El judo en diez lecciones. Bilbao: Cantábrica. 1aㅡ ed. 146 p. : il. ; 14x20 cm. ISBN: 84-221-0311-7. Depósito legal: BI. 3381-1976. (2aㅡ ed., 1985). Palabras clave: fundamentos teóricos, fundamentos técnicos, táctica, competición. Resumen: Manual teórico y técnico de judo. El 
libro esta formado por 10 capítulos. El primer capítulo relata la evolución del judo hasta la actualidad, ilustra como atar el cinturón, explica los tipos y momentos para saludar, describe e ilustra la ejecución de las diferentes caídas, comenta el trabajo de preparación física que debe seguir un judoka, y presenta la descripción e ilustración de las técnicas de proyección o goshi, tsuri komi goshi y las inmovilizaciones hon kesa gatame y kata gatame, destacando los puntos más importantes en su ejecución y el mejor momento para ser realizadas. El segundo capítulo explica la ejecución de las técnicas o soto gari, o uchi gari, hiza guruma y yoko siho gatame así como algunas formas de entrada cuando uke esta defensivo, señalando sus puntos más importantes, las mejores situaciones para su ejecución y las posibles combinaciones de técnicas, incluyendo su representación gráfica. El tercer capítulo detalla e ilustra la ejecución de las técnicas ippon seoi nage, ko uchi gari, sasae tsuri komi ashi y tate siho gatame, comentando los puntos clave de su ejecución, sus posibles combinaciones y momentos de ejecución, además de señalar los posibles enlaces entre el trabajo de judo en pie y judo en el suelo. El cuarto capítulo expone la ejecución técnica, puntos más importantes, momento de ejecución y posibles combinaciones de las técnicas harai goshi, uchi mata, de ashi barai, ushiro kesa gatame, kami siho gatame y varias formas de entrar a uke cuando está defensivo junto con sus ilustraciones respectivas. El quinto capítulo comenta cómo lograr el agarre deseado, varias formas de evitar el agarre del contrario, describe los distintos métodos de entrenamiento de judo y los principios técnicos y tácticos de las defensas. El sexto capítulo presenta las técnicas hane goshi, morote seoi nage, okuri ashi barai y algunas formas de entrar a uke cuando estamos de frente o sobre la espalda, señalando sus puntos más importantes, posibles combinaciones e incluyendo sus dibujos explicativos. El séptimo capítulo describe las técnicas tai otoshi, kata guruma, soto makikomi, juji gatame así como las defensas cuando uke atrapa nuestra pierna, destacando los puntos clave en su ejecución, sus combinaciones y oportunidades. El octavo capítulo continúa explicando los fundamentos técnicos del judo con las técnicas tomoe nage, ko soto gake, otra forma de entrar de frente a uke y una salida de pierna, además de explicar la forma de evitar un ippon en la competición. El noveno capítulo describe e ilustra las técnicas o soto otoshi, te guruma y la estrangulación por detrás además de explicar el entrenamiento de situaciones cerca del borde del tatami de competición. El último capítulo explica la ejecución de las técnicas harai tsuri komi ashi, utsuri goshi y sanka ku incluyendo sus respectivas ilustraciones y comenta la actitud del practicante de judo ante la competición. Adjunta un anexo de términos relacionados con las artes marciales y la competición.

242. Robebrt, Louis (1962). El judo y las técnicas de auto-defensa. Barcelona: Bruguera. 1aㅡ ed. 153 p. : il. ; 11x11,5 cm. ISBN: No ISBN. Depósito legal: B. 24893-1962. Palabras clave: fundamentos teóricos, fundamentos técnicos, defensa personal, jujutsu, grados, armas. Resumen: Manual teórico y técnico de judo. El libro consta de 10 capítulos, precedidos por un índice alfabético. El primer capítulo relata la historia del judo, comenta sus características y su aplicación práctica como método de defensa personal acompañado del kárate o el jiu-jitsu. El segundo capítulo explica el significado de la palabra judo, comenta las características del lugar de entrenamiento, el tatami, la vestimenta, describe las formas de saludar y explica el sistema de grados y exámenes. El tercer capítulo describe e ilustra la ejecución de las distintas formas de caer. El cuarto capítulo expone la clasificación técnica del judo, describe el agarre y presenta los contenidos técnicos desde cinturón amarillo hasta cinturón negro, describiendo e ilustrando algunas de las técnicas de proyección, inmovilización, estrangulación y luxación de cada cinturón. El quinto capítulo presenta la estructura de una clase de judo, explicando en qué consiste cada método de entrenamiento, la forma de marcar un punto y enumera las katas del judo. El siguiente capítulo explica en qué consiste el kuatsu, el kiai y cuál es la filosofía del judo. El séptimo capítulo localiza los puntos vitales del cuerpo humano, enumera las distintas partes utilizadas para golpear y describe el entrenamiento de los atemis básicos. El siguiente capítulo comenta las tres formas de defenderse o tácticas a utilizar en una situación de defensa personal y continúa describiendo la ejecución de las técnicas defensivas ante agarres a las muñecas, al cuello, a la cabeza, a la solapa, a la manga, a la cintura, patadas, ante un boxeador, ante ataques armados con un palo, un bastón, un cuchillo, un revolver o en ayuda de una tercera persona, acompañadas de su representación gráfica. El noveno capítulo presenta la ejecución de tres ejercicios para desarrollar los reflejos del practicante. El último capítulo comenta las peculiaridades del entrenamiento del judo femenino y el judo para niños, además de discutir las diferencias entre judo y jiu-jitsu. Adjunta una lista con los grados, el gokio y una tabla de anotación de los grados conseguidos y las fechas de interés.

243. Rodríguez Dabauza, Pedro (1986). Judo aplicado a la defensa personal. Madrid: Esteban Sanz Martínez. $1^{\text {a }}$ ed. 133 p. : il. ; 15x21 cm. ISBN: 84-85977-30-0. Depósito legal: M. 22147-1986. Palabras clave: fundamentos teóricos, pedagogía, principios técnicos, defensa personal, táctica, armas. Resumen: Manual teórico y técnico de judo. La obra esta dividida en 3 partes. La primera parte relata la historia del jiu-jitsu, analiza los fundamentos de la defensa personal como son la postura, la distancia, la fijación de la vista, el grito, la esquiva-desplazamiento-desequilibrio, la anticipación-sorpresa, y los atemis; enumera y localiza los puntos vulnerables básicos del cuerpo, describe la ejecución técnica de las distintas caídas, enumera los controles por luxación de muñeca y de cuello, y describe la ejecución 
técnica ante distintas situaciones de agarre a las muñecas, a las manos, a los brazos, al tronco, ante un agarre al pelo, una estrangulación al cuello, un empujón y una presa por detrás al cuello y brazos, incluyendo varias fotografías de la secuencia de movimientos. La segunda parte expone los métodos de reanimación ante distintos golpes, las diferentes guardias, las defensas, describe los controles por luxación de pierna, algunas formas de controlar al adversario en el suelo, describe e ilustra las defensas ante distintos ataques de puño y patadas, y defensas desde el suelo. La última parte describe la ejecución técnica de defensas contra ataques armados como botellas, palos, sillas, cuchillos y pistola, incluyendo la secuencia fotográfica de cada técnica, además de incluir formas de llevar a un agresor controlado, de atarle, la táctica de combate ante varios adversarios, las formas de entrenamiento ante dichas situaciones, el estudio de las técnicas de defensa personal a través del kata, y la metodología de enseñanza y cualidades del profesor de defensa personal.

244. Rodríguez Dabauza, Pedro (1986). Katame-waza : técnicas judo-suelo. Barcelona: Alas. 1ạ ed. 166 p. : il. ; 15x21,5 cm. ISBN: 84-203-0190-6. Depósito legal: B. 3279-1986. Palabras clave: fundamentos técnicos. Resumen: Manual técnico de judo-suelo. La primera parte del libro introduce los fundamentos del judo y del trabajo en el suelo, ejercicios para su desarrollo, entradas, y explica las técnicas básicas de control, estrangulación y luxación por medio de fotografías. La segunda parte explica y presenta gráficamente las distintas salidas ante el control del compañero así como algunas de las variantes de las técnicas de control, estrangulación y luxación. La última parte del libro aborda la explicación de las diferentes formas de entrar cuando el compañero esta en distintas posiciones en el suelo y las principales formas de llevar al suelo al compañero. También presenta brevemente algunos de los encadenamientos entre el judo-pie y el judo -suelo, entre las técnicas de judo-suelo, ciertas defensas ante la estrangulación y luxación, formas de soltar la pierna controlada por uke, las técnicas de recuperación, la descripción gráfica de la katame-no-kata y algunos contenidos teóricos sobre la enseñanza.

245. Rodríguez Dabauza, Pedro (1995). Ju-jitsu : el método progresivo de defensa personal actualizado. Volumen I. Barcelona: Paidotribo. 1ạ ed. 249 p. : il. ; 21x27,5 cm. ISBN: 84-8019-212-7. 84-8019-211-9 (ISBN de la obra completa). Depósito legal: B. 15501-1995. Palabras clave: historia, fundamentos teóricos, fundamentos técnicos, principios técnicos, defensa personal. Resumen: Manual técnico de jiu-jitsu. La obra esta compuesta de 2 partes, precedidas de una introducción donde se detalla el origen y evolución del jiu-jitsu y el nacimiento del budo. La primera parte explica los fundamentos del jiujitsu, desde sus aspectos formales sobre la vestimenta, el saludo y la conducta en el dojo hasta los principios dinámicos y los contenidos técnicos básicos. Describe los conceptos teóricos de distancia, ki, kiai, concentración, relajación, respiración, vista, puntos vulnerables; y los contenidos técnicos de posturas, desplazamientos, caídas, técnicas de proyección, técnicas de control, técnicas de sacrificio, técnicas de inmovilización, técnicas de estrangulación y tai sabaki. Esta parte también incluye el trabajo de goshin-jitsu, donde se ofrecen distintas posibles técnicas de defensa frente a situaciones de ataque con peligro y sin peligro ante distintos agarres y ante agarres producidos en el medio acuático. La segunda parte incluye las técnicas de kihon entre las que se incluyen las técnicas de reanimación, y las defensas contra atemis de puño, de pierna y ante situaciones en el suelo.

246. Rodríguez Dabauza, Pedro (1995). Ju-jitsu : el método progresivo de defensa personal actualizado. Volumen II. Barcelona: Paidotribo. 1aㅡ ed. 349 p. : il. ; 21x27,5 cm. ISBN: 84-8019-213-5 (corregido). 848019-211-9 (ISBN de la obra completa). Depósito legal: B. 15501-1995. Palabras clave: katas, pedagogía, defensa personal, primeros auxilios, arbitraje, competición, legislación, nutrición, preparación física. Resumen: Manual teórico y técnico de jiu-jitsu. La obra esta compuesta de dos partes, siendo la primera práctica y la segunda teórica. La primera parte incluye la descripción y representación de las posibles técnicas de jiu-jitsu ante situaciones de ataque con palo, con cuchillo, ante varios adversarios, y el estudio de las katas antiguas y modernas. La segunda parte incluye varias historias sobre los principios de las artes marciales, los métodos de enseñanza adecuados para cada tipo de entrenamiento, algunos ejemplos de exámenes, el compendio de cualidades del profesor de jiujitsu, una reflexión sobre las características del niño y la aplicación del jiu-jitsu en estas edades, la normativa y reglas de competición, las reglas del árbitro IJJF, el programa de contenidos para cada cinturón de la Federación Española de Judo y DA, una oda a las artes marciales, un plan de entrenamiento físico, consejos sobre alimentación, un resumen de las normas de actuación en primeros auxilios y la ley ante la defensa personal.

247. Rodríguez Dabauza, Pedro (1998). Kata judo-jujitsu : kodokan goshin jutsu, kime no kata. Barcelona: Alas. 1aㅡ ed. 155 p. : il. ; 17x23,5 cm. ISBN: 84-203-0390-9. Depósito legal: B. 39655-1998. Palabras clave: katas, historia, filosofía, didáctica, maestros. Resumen: Manual teórico y técnico de judo. El libro esta compuesto de 3 partes, precedidas por una introducción que comenta la importancia de las katas y su establecimiento, una biografía personal del autor y un prólogo sobre los contenidos y objetivos de la obra. La primera parte señala las características de la kodokan goshin jutsu no kata para luego describir brevemente la ejecución de sus técnicas acompañadas de su secuencia fotográfica y los puntos importantes de cada movimiento. La segunda parte comenta las características técnicas de la 
kime no kata para luego describir la ejecución técnica de su ceremonia y movimientos, acompañadas de la secuencia fotográfica de los mismos. La última parte narra el origen de las actividades de lucha, su desarrollo en Japón, los estudios de Jigoro Kano, la creación del judo Kodokan, la clasificación de sus técnicas, su expansión mundial y sus principios filosóficos y educativos.

248. Rodríguez Dabauza, Pedro (2000). Jiu jitsu de hoy : técnica de defensa personal del samurái de ayer.

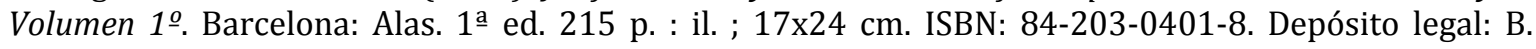
18747-2000. Palabras clave: katas, fundamentos técnicos, programa técnico, aplicación marcial, competición, exámenes, reglamentos. Resumen: Manual teórico y técnico de jiu jitsu. El libro esta formado por 14 capítulos, precedidos por los agradecimientos, los prólogos de Luis Báguena Salvador, Mario Deln Edel y Alejandro Blanco Bravo, una introducción que comenta la historia del jiu jitsu y su llegada a España, y el currículo profesional del autor. El primer capítulo explica los contenidos técnicos que incluye el jiu jitsu junto con la tabla de sus técnicas. El segundo capítulo presenta el programa oficial de jiu jitsu desde cinturón amarillo (5 kyo) hasta cinturón negro 5o dan. El tercer capítulo explica las características del dojo y las normas de conducta dentro del mismo. El cuarto capítulo describe la vestimenta del jiu jitsu junto con el significado de cada cinturón. Los siguientes 6 capítulos nombran e ilustran los contenidos técnicos desde cinturón amarillo (5o kyo) cinturón negro 1er dan, incluyendo esquemas de movimiento y comentarios de los contenidos técnicos más importantes. El capítulo decimoprimero enumera e ilustra por partes los movimientos de la E bo no kata. El decimosegundo capítulo comenta las características del jiu jitsu de competición e incluye un resumen de su reglamento de competición. El último capítulo presenta el esquema de un método de planificación física. Adjunta un glosario de budo y un epílogo.

249. Rodríguez Dabauza, Pedro (2000). Jiu jitsu de hoy : técnica de defensa personal del samurái de ayer. Volumen $2^{\stackrel{o}{*}}$. Barcelona: Alas. $1^{\mathrm{a}}$ ed. 169 p. : il. ; $17 \times 24$ cm. ISBN: 84-203-0403-4. Depósito legal: B. 44736-2000. ( $2^{\mathrm{a}}$ ed. corr. y aum., 2007, 189 p., ISBN: 978-84-203-0403-8). Palabras clave: katas, fundamentos técnicos, programa técnico, aplicación marcial, competición, exámenes, reglamentos, kuatsu. Resumen: Manual teórico y técnico de jiu jitsu. El libro esta formado por 7 capítulos, precedidos por los agradecimientos, los prólogos de Luis Báguena Salvador, Mario Den Edel y Alejandro Blanco Bravo, una introducción que comenta los contenidos de los dos volúmenes que componen la obra y el currículo profesional del autor. El primer capítulo presenta la tabla de contenidos técnicos desde cinturón negro $2^{\mathrm{o}}$ dan hasta $5^{\mathrm{o}}$ dan. Los siguientes 4 capítulos nombran e ilustran los contenidos técnicos de los exámenes a cinturón negro 2으, 3으, 4oㅡ y 5o dan respectivamente, incluyendo esquemas de movimiento y comentarios de los contenidos técnicos más importantes. El sexto capítulo presenta la ilustración de una técnica tanto de la kime no kata como de la kodokan goshin jutsu. El séptimo capítulo explica la historia del kuatsu o técnicas de reanimación, expone las consideraciones generales para su aplicación y describe e ilustra tres técnicas ante la falta de aire provocada por un golpe en el estómago, una estrangulación y un golpe en los testículos. Adjunta anexos con el reglamento de competición en las modalidades de dúo-kata y combate, las hojas de examen de $2^{\mathrm{o}}$ a $5^{\mathbf{o}}$ dan, el listado de niveles de maestría considerados en Oriente, un comentario sobre la ética del maestro y el índice del primer volumen de la obra.

250. Rodríguez Dabauza, Pedro (2002). Ju jitsu : budo goshin jutsu ryu. Técnicas avanzadas. Madrid: Pedro Rodríguez Dabauza. 1aㅡ ed. 397 p. : il. ; 17x24 cm. ISBN: 84-607-4786-7. Depósito legal: M. 24799-2002. Palabras clave: defensa personal, armas. Resumen: Manual teórico y técnico de jiu-jitsu. El libro esta formado por 13 capítulos, precedidos por una introducción que comenta los contenidos que deben impartirse en una ryu de jiu-jitsu y el currículum profesional del autor. Los tres primeros capítulos nombran e ilustran las técnicas de goshin jitsu ante distintos ataques con agarres, ataques con atemi y ataques con armas. El cuarto capítulo presenta la secuencia fotográfica del encadenamiento de varias técnicas. Los dos siguientes capítulos muestran la aplicación de las técnicas shiho nage y te gatame/sankyo ante distintos ataques con atemi y con armas. El séptimo capítulo describe e ilustra la ejecución de varias técnicas de goshin jitsu en el trabajo en el suelo. El octavo capítulo incluye dos historias sobre el aprendizaje del jiu-jitsu. El noveno capítulo enumera los principios de las técnicas antiguas de jiu-jitsu para en el siguiente presentar la secuencia fotográfica de algunas de las técnicas de ju-jutsu tradicional con katana y a manos libres ante ataques con atemi y con armas. Los dos siguientes capítulos ilustran por partes algunas defensas con cinturón o cuerda y la aplicación de técnicas de sutemi e inmovilización respectivamente. El último capítulo incluye numerosas fotografías sobre la práctica marcial del autor a lo largo de su vida.

251. Rouge, Jean-Luc (1992). Harai-goshi : técnicas maestras de judo. Barcelona: Paidotribo. 1aㅡ ed. 143 p. : il. ; 15x21,5 cm. ISBN: 84-8019-021-3. Depósito legal: B. 24001-1992. Palabras clave: historia, fundamentos técnicos, defensa personal, entrenamiento, táctica, competición. Resumen: Tratado técnico sobre harai-goshi. Después de comentar brevemente la importancia de esta técnica para el autor, comienza a relatar la historia de la técnica y su utilización por parte de grandes competidores y maestros en distintas situaciones. Continúa con la descripción de la técnica, con multitud de ilustraciones, y las distintas variantes que puede adoptar dependiendo de la posición de uke, su agarre 
o el movimiento de entrada. El siguiente capítulo presenta algunas de las combinaciones más frecuentes que se pueden realizar, con la explicación táctica y su momento correcto de realización para alcanzar el éxito. El quinto capítulo presenta el harai-goshi como una técnica de contraataque, por lo que después de explicar el ataque del contrario, matiza los pasos a tomar para realizar esta técnica y cuáles son los puntos claves en su realización. Los tres últimos capítulos son prácticos, tratando el entrenamiento físico a desarrollar para realizar correctamente la técnica, dos situaciones de defensa personal y la aplicación de dicha técnica en la competición real.

252. Rubio Galán, Isaac (1969). Principios básicos para iniciarse en judo : cinturón amarillo. Murcia: Tipografía San Francisco. 1aㅡ ed. 85 p. : il. ; 17x24,5 cm. ISBN: No ISBN. Depósito legal: MU. 1-1969. Palabras clave: historia, fundamentos teóricos, fundamentos técnicos. Resumen: Manual teórico y técnico de judo. El libro consta de 9 capítulos. El primer capítulo relata la historia y nacimiento del judo y el Kodokan. El segundo capítulo describe la estructura del dojo, el tatami y el judogi. El tercer capítulo ofrece diez consejos para la enseñanza del judo, presenta el programa técnico de enseñanza hasta cinturón negro, incluye un breve léxico específico y la clasificación de las técnicas de judo. El cuarto capítulo presenta la tabla de contenidos para cinturón amarillo. El quinto capítulo describe la ejecución de distintos ejercicios de calentamiento junto con su ilustración. El siguiente capítulo presenta la descripción técnica de las distintas formas de caer. El séptimo capítulo presenta los fundamentos técnicos del judo, como son la forma de saludar, la postura, el agarre, los desplazamientos y el principio de desequilibrio, incluyendo sus correspondientes fotografías explicativas. El octavo capítulo describe la ejecución por partes y los mejores momentos para realizar las técnicas de proyección del cinturón amarillo como o-soto-gari, de-ashi-barai, hiza-guruma, ko-soto-gake, o-uchigari, uki-goshi, tsuri-goshi, ippon-seoi-nage y morote-seoi-nage. El último capítulo describe e ilustra la ejecución de las técnicas hon-gesa-gatame, kata-gatame, kami-shiho-gatame, kuzure-kami-shihogatame, ushiro-gesa-katame, kata-juji-jime, giaku-juji-jime, nami-juji-jime y ude-garami.

253. Rubio Galán, Isaac (1970). Principios básicos para iniciarse en judo (programa para cinto negro). Murcia: Tipografía San Francisco. 1aㅡ ed. 170 p. : il. ; desc.xdesc. cm. ISBN: No ISBN. Depósito legal: no. (2a ed., 1971). Palabras clave: historia, fundamentos técnicos, principios técnicos, vestimenta, exámenes, programa técnico. Resumen: Manual teórico y técnico de judo. El libro esta formado por cinco partes. La primera parte relata el origen del judo, presenta las características del dojo y el tatami, la vestimenta del practicante, algunos consejos sobre su enseñanza, la clasificación de sus contenidos técnicos, un breve glosario y el programa técnico para el cinturón amarillo. Además incluye la descripción, acompañada de las ilustraciones explicativas, de una tabla de ejercicios de calentamiento, cómo ejecutar las caídas, los fundamentos técnicos básicos como son el saludo, la postura, el agarre, los desplazamientos y los desequilibrios, así como las técnicas básicas de nage-waza y katame-waza. Los dos siguientes capítulos explican las técnicas de nage-waza, katame-waza y estrangulación correspondientes a los cinturones naranja y verde respectivamente, mientras que los últimos dos capítulos presentan la descripción de las técnicas de nage-waza, katame-waza y luxación de los cinturones azul y marrón, acompañadas todas ellas de sus ilustraciones y de un breve comentario sobre su mejor momento de aplicación.

254. Rudek, Sandro (1964). Iniciación al judo : historia, principios y objeto del judo, posiciones fundamentales, caídas, proyecciones, inmovilizaciones, llaves, estrangulaciones, vocabulario. Barcelona: Sintes. $1^{\underline{a}}$ ed. 222 p. : il. ; 11x17,5 cm. ISBN: No ISBN. Depósito legal: B. 11.877-1964. Palabras clave: fundamentos técnicos. Resumen: Manual técnico de judo. La monografía esta dividida en 8 capítulos que conforman 2 partes. La primera parte es teórica y describe brevemente la historia del judo y los principios físicos, filosóficos y morales en los que se basa así como las reglas de competición y los exámenes del Kodokan para cada nivel; mientras que la segunda parte del libro, compuesta por los restantes seis capítulos abordan los fundamentos técnicos básicos del judo, aportando dibujos de ellos. Así, el tercer capítulo trata las caídas y el cuarto las posiciones. El quinto explica las proyecciones para continuar con las inmovilizaciones, las luxaciones y las estrangulaciones. Adjunta un vocabulario.

255. s.a. (1960). Judo en colaboración con el Budokwai y la Asociación Británica de Judo. Barcelona: Scientia. 1a ed. 30 p. : il. ; 20x13 cm. ISBN: No ISBN. Depósito legal: no. (2ª ed., 1963). Palabras clave: historia, fundamentos técnicos, competición, grados, reglamentos. Resumen: Manual teórico y técnico de judo. La obra consta de cuatro capítulos, precedidos por la explicación de los contenidos de la colección, el prólogo a la edición española por Juan A. Samaranch, el prólogo de G. Koizumi y la introducción de G.R. Gleeson que explica la historia del judo y los contenidos de la obra. El primer capítulo resume las reglas de competición del judo, como son la vestimenta, el lugar de competición, los árbitros, el desarrollo del combate, el sistema de puntuación, el tiempo y los actos prohibidos, incluyendo ilustraciones explicativas. El segundo capítulo describe e ilustra la ejecución de las técnicas sasae-tsurikomi-ashi y hane-goshi, explica la ejecución de una técnica de contraataque y comenta los contenidos técnicos del judo-suelo y algunos consejos para su enseñanza. El tercer capítulo presenta el sistema de grados y el sistema de promoción. El último capítulo incluye un glosario. 
256. s.a. (1967). Judo : del cinturón blanco al cinturón negro. Madrid: Samurái. 1a ed. 21 p. : il. ; 16×21,5 cm. ISBN: No ISBN. Depósito legal: M. 15068-1967. Palabras clave: fundamentos técnicos, programa técnico, instalaciones. Resumen: Tratado teórico de judo. La monografía presenta las características de los tatamis y tapices de judo, su historia y composición, la absorción de la onda de choque al efectuar las caídas sobre dichos tapices y algunos consejos para escoger el tipo de tatami más acorde con dicha práctica y lugar de entrenamiento. Además, incluye el programa técnico para cinturón negro junto con la ilustración y nombre de dichas técnicas.

257. s.a. (1971). Judo. Madrid: Delegación Nacional de Educación Física y Deportes (Federación Española de Judo) y Delegación Nacional de la Juventud (Sección de Actividades Deportivas). 1aㅡ ed. 27 p. : il. ; 12x17 cm. ISBN: No ISBN. Depósito legal: M. 25591-1971. Palabras clave: historia, fundamentos técnicos, programa técnico, salud. Resumen: Manual teórico y técnico de judo. El primer capítulo describe la historia y evolución del judo hasta su práctica deportiva. El segundo capítulo incluye 14 preguntas y respuestas sobre la práctica del judo y la participación del niño en la misma. El tercer capítulo enumera los beneficios del judo para el practicante y ofrece algunos consejos para su correcto desarrollo. El cuarto capítulo incluye una tabla con los diferentes grados y su edad correspondiente. El quinto capítulo presenta el programa técnica de iniciación en el judo con la ilustración por partes de los fundamentos técnicos del judo como las caídas y las principales técnicas de proyección e inmovilización.

258. s.a. (1975). Manual de judo infantil. Madrid: Imprenta Góngora. 1a ed. 32 p. : il. ; 15x21 cm. ISBN: No ISBN. Depósito legal: M. 18637-1975. Palabras clave: historia, arbitraje, salud. Resumen: El primer capítulo comenta brevemente el origen y evolución del judo. El segundo capítulo explica en qué consiste la práctica deportiva del judo, para en el tercer capítulo incluir 14 preguntas y respuestas sobre el judo y los niños. El cuarto capítulo enumera los beneficios del judo para los practicantes más jóvenes. El quinto capítulo describe cómo el practicante comienza la práctica del judo, sus contenidos y las diferencias con el kárate. El último capítulo incluye un resumen de las normas y gestos de arbitraje con sus ilustraciones.

259. s.a. (1977). Judo. Barcelona: Aura. 1aㅡ ed. 32 p. : il. ; 13x20 cm. ISBN: 84-214-0156-4. Depósito legal: B. 4404-1977.

260. s.a. (1987). Técnicas de combate: el judo como base de la defensa personal. Barcelona: Edicomunicación. $1^{\text {a }}$ ed. 146 p. : il. ; 13x19,5 cm. ISBN: 84-7672-095-5. Depósito legal: B. 12834-1987. Palabras clave: fundamentos teóricos, fundamentos técnicos, principios filosóficos, defensa personal, competición, maestros, programa técnico, reglamentos, armas. Resumen: Manual teórico y técnico de judo. La obra esta dividida en 3 partes, precedidas por un capítulo que explica la formación del judo moderno. La primera parte esta formada por 24 capítulos que explican la práctica del judo, describir el calentamiento, cómo colocarse el cinturón y el judogi, el significado del kiai, ofrecer algunos consejos sobre los primeros auxilios, describir la ejecución y tipos de saludo, la postura, la localización del centro de gravedad, las características del tatami, el método de entrenamiento uchi-komi, la adecuación del judo a las mujeres y los jóvenes, la ejecución del agarre, los desplazamientos, los principio de kuzushi y tsukuri, la ejecución de las caídas, el papel de tori y uke, enumerar las técnicas que componen el gokyo, el sistema de grados, las normas en el dojo y las katas de judo. La segunda parte esta formada por 26 capítulos. El primer capítulo nombra e ilustra las técnicas que componen la nage-no-kata para en el resto de capítulos describir e ilustrar la ejecución técnica, consejos para los cinturones negros, contrapresas y encadenamientos de las técnicas incluidas en el gokyo junto con la descripción técnica y salidas de las principales técnicas de inmovilización y estrangulación. La última parte esta formada por 10 capítulos que comentan los principios de las defensas contra armas blancas, los tipos de ataques y zonas de golpeo, describen la defensa contra varias situaciones de ataque con cuchillo, con revolver y con palo junto con su ilustración, explican la ejecución de varias presas para inmovilizar a un adversario, localizan los puntos vitales del cuerpo humano y los efectos de su manipulación, explican la ejecución de los atemis realizados con las diferentes partes de la mano, el puño, el codo, la cabeza, la rodilla y el pie, incluyen un extracto de los reglamentos mundiales de competición, algunos consejos antes del shiai, y expone las máximas de Jigoro Kano y un léxico específico.

261. s.a. (1988). Judo : historia, técnica, consejos. Barcelona: A-Z. 1ae ed. 63 p. : il. ; 13×18,5 cm. ISBN: No ISBN. Depósito legal: M. 1454-1988. Palabras clave: historia, fundamentos técnicos, programa técnico. Resumen: Manual teórico y técnico de judo. El libro esta dividido en 7 partes, precedidas por tres capítulos introductorios que relatan en forma de cómic la historia del judo, describen las formas de saludar y las normas de etiqueta, y presentan los fundamentos técnicos del judo. La primera parte expone los contenidos técnicos del cinturón blanco, describiendo la ejecución de o-goshi, ippon-seoinage, o-soto-gari, de-ashi-barai, hiza-guruma, uki-goshi, hon-kesa-gatame, kami-shiho-gatame, yokoshiho-gatame, ushiro-kesa-gatame y tate-shiho-gatame. La segunda parte incluye la descripción de las técnicas de cinturón amarillo tsuri-komi-goshi, harai-goshi, morote-seoi-nage, sasae-tsuri-komi-goshi, ko-uchi-gari, o-uchi-gari, kata-gatame, kusure-kesa-gatame, kusure-yoko-shiho-gatame, makura-kesa- 
gatame, kusure-kami-shiho-gatame, kusure-tate-shiho-gatame además de representar la posición de los judokas en el dojo. La tercera parte expone las técnicas incluidas en el cinturón naranja como son tai-otoshi, okuri-ashi-barai, koshi-guruma, hane-goshi, uchi-mata, ko-soto-gari y diferentes entradas a uke en el suelo. La cuarta parte describe e ilustra la ejecución de las técnicas kata-guruma, ashiguruma, tomoe-nage, ko-soto-gake, uki-otoshi, kata-juji-jime, morote-jime, hadaka-jime, ashi-gatamejime y sode-guruma pertenecientes al cinturón verde. La quinta parte presenta la ejecución y representación gráfica de las técnicas de cinturón azul o-soto-otoshi, o-guruma, soto-maki-komi, haraitsuri-komi-ashi, uki-waza, juji-gatame, ude-garami, ude-gatame, hiza-gatame, waki-gatame y hara gatame. La sexta parte incluye la descripción e ilustración de las técnicas yoko-otoshi, utsuri-goshi, yoko-guruma, ushiro-goshi, te-guruma, dos ejercicios de entradas cuando uke esta en el suelo y uno de liberación de las piernas. La última parte incluye un léxico básico.

262. s.a. (1988). Judo : programa de cinturón negro. A Coruña: Diputación de A Coruña. 1ạ ed. 70 p. : il. ; $15 \times 21 \mathrm{~cm}$. ISBN: No ISBN. Depósito legal: no. Palabras clave: fundamentos técnicos, programa técnico, principios técnicos, arbitraje, katas, reglamentos. Resumen: Manual teórico y técnico de judo. La obra esta dividida en 17 capítulos. El primer capítulo expone las normas de cortesía y describe las posturas básicas, el agarre, los desplazamientos, los principios técnicos, las formas de caer y los métodos de entrenamiento del judo. El segundo capítulo presenta los contenidos técnicos para el examen de cinturón negro además de explicar cómo se ata el cinturón. Los siguientes cinco capítulos enumeran e ilustran los contenidos técnicos para el cinturón amarillo, naranja, verde, azul y marrón. Los tres siguientes capítulos comentan las características de la nage-no-kata y representa su ejecución técnica, mientras que los tres siguientes capítulos muestran las técnicas de la katame-no-kata. El décimo cuarto capítulo incluye un resumen del reglamento de arbitraje mientras que el siguiente presenta un vocabulario específico de judo. Los dos últimos capítulos relatan la historia del judo así como su desarrollo en Galicia y enumeran a los judokas gallegos que han conseguido una medalla nacional.

263. s.a. (1991). Judo : llibret explicatiu. Judo : folleto explicativo. Barcelona: COOB'92. 1a ed. 33 p. : il. ; 10x21 cm. ISBN: 84-7868-062-4. Depósito legal: B. 26382-1991. Palabras clave: judo, competición, juegos, reglamentos. Resumen: Folleto explicativo del programa de competición del judo en los Juegos Olímpicos de Barcelona'92. El folleto esta dividido en 4 partes. La primera parte incluye una tabla con el calendario de todos los deportes olímpicos y de demostración participantes en los Juegos de la XXVa Olimpiada. La segunda parte detalla el organigrama del Comité Olímpico Internacional, el Comité Organizador Olímpico de Barcelona'92 y de las federaciones deportivas internacional, nacional y catalana de judo. La tercera parte presenta el calendario de competición del judo, sus pruebas, un resumen del reglamento general, de la organización y el reglamento de la competición, de las medallas y diplomas, de las instalaciones de competición y entrenamiento y del equipamiento. La última parte ofrece algunos datos generales sobre la ciudad de Barcelona y la aprobación de este texto. Adjunta varias hojas en blanco para tomar notas.

264. s.a. (1992). Judo : manual de equipo. Judo : team manual. Barcelona: COOB'92. División de Paralímpicos. $1^{\underline{a}}$ ed. 87 p. : il. ; 10x21 cm. ISBN: 84-7868-248-1. Depósito legal: B. 31022-1992. Palabras clave: competición, instalaciones, instituciones, juegos, reglamentos. Resumen: Folleto explicativo del programa de competición del judo en los Juegos Paralímpicos de Barcelona'92. El folleto esta dividido en 3 partes. La primera parte incluye la información general de la organización, órganos de control, programa general de los Juegos, pruebas programadas, países participantes, centro de información deportiva y la programación deportiva. La segunda parte incluye la información sobre la competición, detallando el reglamento, horario y lugar de la competición, las disposiciones generales, la organización técnica, el sistema de competición, el control de dopaje, las reuniones técnicas, el equipamiento de competición y entrenamiento, la ceremonia de proclamación de campeones, otra información de interés, centro de clasificaciones generales y funcionales, el mapa de las áreas paralímpicas, la instalación de competición y de entrenamiento y el mapa de las áreas de competición y entrenamiento. La tercera parte incluye la información a los competidores sobre el transporte, acreditación, alojamiento, asistencia médica, prensa, asistentes, área de espectadores reservada para los deportistas, alimentación y uniformes. Adjunta varias hojas en blanco para tomar notas.

265. San Bartolomé, Alfredo (1954). Método de judo del gimnasio Bushidokwai. Madrid: Imprenta Fernando Franco. 1aㅡ ed. 123 p. : il. ; 13×21,5 cm. ISBN: No ISBN. Depósito legal: no. Palabras clave: historia, fundamentos teóricos, fundamentos técnicos, grados. Resumen: Manual teórico y técnico de judo. El libro consta de 21 capítulos. El primer capítulo relata el contexto histórico y origen del judo. El segundo capítulo explica el principio de la palanca y expone varios ejemplos sobre la aplicación de la fuerza. El tercer capítulo expone los objetivos del judo, mientras que el cuarto describe las distintas posturas del judo junto con su representación gráfica. El quinto capítulo enumera el sistema de grados y describe la ejecución de los distintos tipos de agarre. Los dos siguientes capítulos explican la forma de avanzar y los principios de kuzushi, tsukuri y kake respectivamente, incluyendo gráficos y esquemas de movimiento de los mismos. El octavo capítulo describe e ilustra la ejecución de las distintas técnicas de caída, mientras que el noveno presenta la clasificación de los contenidos técnicos 
del judo y los define. El décimo capítulo describe los distintos métodos de entrenamiento del judo como son el randori, la kata y el butsukari. El siguiente capítulo describe la forma de saludar, su significado y ofrece algunos consejos para la práctica y el aprendizaje en judo. El decimosegundo capítulo expone el programa técnico por cinturones para luego explicar el programa para cinturón blanco en Japón. Los siguientes tres capítulos describen e ilustran los contenidos técnicos del cinturón blanco, amarillo y naranja respectivamente. El decimosexto capítulo expone las características de la fuerza necesarias para la práctica del judo, su objetivo y las ventajas e inconvenientes del entrenamiento habitual en el gimnasio. El siguiente capítulo describe el programa técnico del cinturón verde y explica la ejecución de la técnica okuri ashi barai. El decimoctavo capítulo analiza cómo debe ser el entrenamiento mental y espiritual del judo. El siguiente capítulo explica en qué consiste el programa técnico de los cinturones azul y marrón y cuál debe ser su entrenamiento. El vigésimo capítulo explica la importancia de la coordinación de los movimientos y el tai sabake para alcanzar una gran eficacia. El último capítulo comenta las características del entrenamiento de los sutemis para luego describir e ilustrar la ejecución de los mismos según el sistema de grados.

266. Sato, Nobuyuki (1992). Ashiwaza : técnicas maestras de judo. De-ashi-barai, okuri-ashi-barai, haraitsuri-komi-ashi, sasae-tsuri-komi-ashi. Barcelona: Paidotribo. 1a ed. 156 p. : il. ; 15x21,5 cm. ISBN: 848019-004-3. Depósito legal: no. Palabras clave: fundamentos técnicos, defensa personal, entrenamiento. Resumen: Manual técnico sobre los barridos de judo. Comienza la obra con la historia del autor con este grupo de técnicas, para continuar con el desarrollo de estas técnicas. El tercer capítulo presenta los principios de movimiento de estas técnicas para luego comenzar a describir e ilustrar la ejecución, combinaciones y variantes de: de-ashi-barai, sasae-tsuri-komi-ashi, harai-tsurikomi-ashi y okuri-ashi-barai. Después describe los tipos de entrenamiento para estas técnicas así como algunas defensas. El noveno capítulo ofrece la aplicación práctica en situaciones de defensa personal, y finaliza con el relato de la utilización de los barridos en la competición.

267. Saudi, Aine (1960). El judo al alcance de todos. Barcelona: Sintes. 1aㅡ ed. 232 p. : il. ; 12x18 cm. ISBN: No

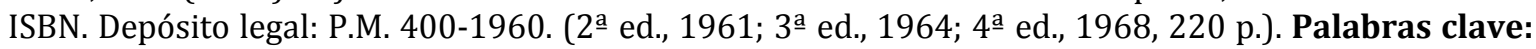
historia, fundamentos técnicos, vestimenta, competición, grados, reglamentos, kuatsu. Resumen: Manual técnico de judo. Después de comentar los orígenes y diferencias entre el judo y el jiu-jitsu, explica de forma general la vestimenta del practicante, el dojo, el saludo, la ejecución de las caídas, la clasificación de las técnicas, los tipos de kata, los grados, las técnicas de reanimación y el reglamento de combate. La siguiente parte describe e ilustra las técnicas más comunes de proyección, inmovilización, luxación y estrangulación. Cada técnica esta explicada e ilustrada por partes. Finaliza con el decálogo del judoka.

268. Sugai, Hitoshi (1993). Uchimata. Barcelona: Paidotribo. 1a ed. 182 p. : il. ; 15x21,5 cm. ISBN: 84-8019081-7. Depósito legal: B. 12868-1993. Palabras clave: fundamentos técnicos, principios técnicos, entrenamiento, táctica. Resumen: Manual de estudio teórico y práctico sobre uchimata. Después de comentar la historia personal con dicha técnica, el segundo capítulo aborda la historia de la misma, desde sus orígenes hasta su ejecución e importancia en la competición. El tercer capítulo describe la realización de uchimata y sus variantes contra distintos oponentes o en distintas situaciones. El cuarto capítulo presenta las combinaciones de técnicas que pueden acompañar a esta técnica para luego continuar con sus principales defensas y contraataques. El sexto capítulo explica el entrenamiento específico de la técnica tanto sus puntos clave como el entrenamiento con uno o varios compañeros. El último capítulo describe la utilización de esta técnica en distintos campeonatos con acompañamiento gráfico.

269. Taira, Shu (198-). Programa y texto para entrenadores regionales : nague-waza. Técnica de proyección. Madrid: Federación Española de Judo y Deportes Asociados. 1aㅡ ed. 96 p. : il. ; 15x20 cm. ISBN: No ISBN. Depósito legal: no. Palabras clave: fundamentos técnicos, entrenamiento, programa técnico, sistemas de entrenamiento. Resumen: Manual teórico y técnico de judo. La obra consta de 20 lecciones o capítulos precedidos por una introducción que explica el significado de los símbolos utilizados en la obra. El primer capítulo presenta los fundamentos teóricos del judo como el saludo, el kumikata, los desplazamientos y movimientos del cuerpo, los ukemi, los principios de kuzushi, tsukuri y kake, ofrece algunos consejos sobre la utilización de la fuerza y explica el método de entrenamiento uchikomi, las contratécnicas y los encadenamientos. El resto de lecciones describen la ejecución, puntos clave y entrenamiento de uchikomi de las 40 técnicas que comprenden el gokyo, incluyendo el esquema de movimiento de los pies. La segunda lección explica morote seoi nague, ippon seoi nague y kata guruma. La tercera lección presenta tai otoshi y sumi otoshi; mientras que la cuarta lección expone sukui nague y uki otoshi. Las siguientes cuatro lecciones describen la ejecución de las técnicas pertenecientes a koshi waza, incluyendo uki otoshi, o goshi, koshi guruma; tsuri goshi y tsuri komi goshi; harai goshi, hane goshi y koshi uchi mata; ushiro goshi y utsuri goshi. Las siguientes siete lecciones presentan el grupo de técnicas de ashi waza, como son: de ashi harai y okuri ashi harai; hiza guruma y sasae tsuri komi ashi; o soto gari y o soto guruma; o uchi gari y ko uchi gari; ko soto gari y ko soto gake; ashi uchi mata y harai tsuri komi ashi; ashi guruma y o guruma. Las últimas cinco lecciones exponen la ejecución 
de las técnicas de sutemi waza como tomoe-sumi gaeshi y ura nague; uki waza y yoko otoshi; tani otoshi y yoko wakare; yoko guruma y yoko gake; soto makikomi y hane makikomi.

270. Taira, Shu (2009). La esencia del judo. Gijón: Satori. 1a ed. 2 v. : 473 p. y 429 p. : il. ; 17x24 cm. ISBN: 978-84-936198-8-6. Depósito legal: AS. 6469-2009. Palabras clave: historia, fundamentos técnicos, principios técnicos, entrenamiento, programa técnico, sistemas de entrenamiento. Resumen: Tratado teórico y técnico de judo. La obra esta formada por dos volúmenes. El primer volumen consta de 3 capítulos. El primer capítulo describe la evolución del ju-jutsu al judo, la historia del judo, su difusión a nivel mundial, un resumen de su llegada a España así como una descripción de los resultados de los Campeonatos del Mundo y Juegos Olímpicos. El segundo capítulo expone los fundamentos técnicos del judo, los métodos de perfeccionamiento, la clasificación técnica del nage-waza junto con la descripción e ilustración de la ejecución de las técnicas que componen el gokyo, sus principios y puntos clave, los contraataques, combinaciones y defensas, el modo de perfeccionamiento y los ejercicios apropiados para desarrollar la técnica; y la ilustración de algunos ejemplos de técnicas de conexión. El tercer capítulo detalla los principios técnicos del osaekomi-waza, shime-waza y kansetsu-waza, explica la ejecución de sus técnicas acompañadas de sus ilustraciones además de distintas formas de ataque y técnicas de conexión en el judo suelo. También adjunta bibliografía y un glosario de términos japoneses. El segundo volumen presenta un sólo capítulo que explica la historia y formación de las kata, para luego explicar los principios técnicos, aspectos formales, descripción técnica, puntos clave y características técnicas de la nage-no-kata, katame-no-kata, kime-no-kata, ju-no-kata, kodokan goshinjutsu, itsutsu-no-kata y koshiki-no-kata. Adjunta apéndices sobre la biografía, maestros, raíces y fotografías del autor, bibliografía y un glosario de términos japoneses.

271. Taira, Shu; Herguedas, Justo y Román, Francisco I. (1992). Judo (I). España: Comité Olímpico Internacional. $1^{\mathrm{a}}$ ed. 410 p. : il. ; $17 \times 24 \mathrm{~cm}$. ISBN: 84-87094-16-3. 84-87094-03-1 (ISBN de la colección). Depósito legal: M. 27151-1992. Palabras clave: fundamentos técnicos, historia. Resumen: Manual técnico-didáctico e histórico de judo. La obra esta dividida en 3 capítulos, con el primero de ellos dedicado a describir la historia del judo y su difusión en España así como una descripción de los resultados obtenidos por los judocas españoles, el organigrama de la Federación Española, la vestimenta y su colocación, la evolución de las reglas de competición y los diferentes sistemas para organizar competiciones con sus ventajas e inconvenientes. El segundo capítulo desarrolla el estudio de las técnicas de proyección y su entrenamiento, con la explicación de cada técnica, sus principios y puntos clave, los contraataques, combinaciones y defensas, el modo de perfeccionamiento y los ejercicios apropiados para desarrollar la técnica. El tercer capítulo estudia las técnicas de control, comenzando por la explicación del kihon, ofreciendo una clasificación de todas ellas e incluyendo las inmovilizaciones, las estrangulaciones y las luxaciones. También incluye un glosario de términos.

272. Taira, Shu; Herguedas, Justo; Rodríguez Dabauza, Pedro y García García, José Manuel (1992). Judo (II). España: Comité Olímpico Español. 1aㅡ ed. 466 p. : il. ; 17x24 cm. ISBN: 84-87094-15-5. 84-97094-03-1 (ISBN de la colección). Depósito legal: M- 27151-1992. Palabras clave: katas, fundamentos teóricos, entrenamiento, defensa personal, educación, preparación física, programa técnico. Resumen: Tratado teórico y técnico de judo. Este tomo se encuentra dividido en 3 capítulos. El primero de ellos aborda el estudio de las katas de judo (nague-no-kata, katame-no-kata, kime-no-kata, ju-no-kata, goshinjutsukata, itsutsu-no-kata y koshiki-no-kata) con el máximo detalle, desde los aspectos formales que las rodean, hasta la ejecución y puntos esenciales de cada técnica del kata. El segundo capítulo estudia la aplicación del judo a la defensa personal, estando divididos los contenidos en los tres niveles de monitor, entrenador regional y entrenador nacional. En cada uno de ellos explica el kihon y las propias técnicas, siempre con apoyo gráfico y detalle de los puntos más importantes en su realización. El último presenta la teoría del entrenamiento y la preparación física, dividiendo los contenidos para los 3 niveles antes mencionados. Adjunta un glosario de términos japoneses.

273. Talens Coral, Francisco (1975). Judo : técnicas para la competición. Barcelona: Alas. 1aa ed. 47 p. : il. ; 15x21 cm. ISBN: 84-203-0347-X. Depósito legal: B. 42002-1975. Palabras clave: fundamentos técnicos, competición, reglamentos. Resumen: Manual teórico y técnico de judo. La obra esta formada por 3 partes, precedidas por un capítulo introductorio que señala las aportaciones del maestro Kawaishi al judo y la biografía del autor. La primera parte describe la ejecución de las principales técnicas de nage-waza como son o-uchi-gari, o-soto-gari, tsuri-komi-goshi, tai-otoshi, de-ashi-barai, hiza-guruma, ko-uchi-makikomi, ippon-seoinage, ko-soto-gake y harai-goshi junto con la secuencia fotográfica de su ejecución. La segunda parte presenta la descripción de las técnicas básicas de newaza como juji-gatame, okuri-eri-jime, ushiro-jime, tate-shiho-gatame, sankaku-jime, la forma de salir de ashi-garami y una forma de volcar al adversario que esta encima, incluyendo la secuencia fotográfica y los primeros planos de los detalles técnicos. La tercera parte incluye un extracto del reglamento de competición.

274. Tamayo Fajardo, Javier Antonio (2003). Iniciación al judo. Sevilla: Wanceulen. $1^{a}$ ed. 70 p. : il. ; 17x24 cm. ISBN: 84-95883-39-2. Depósito legal: SE. 955-2003. Palabras clave: educación, didáctica. Resumen: Tratado teórico sobre la inclusión del judo en la enseñanza Primaria. El primer capítulo 
resume la evolución histórica internacional del judo y su desarrollo en España, comenta las posibilidades de su inclusión dentro del programa educativo, y hace un resumen del reglamento de competición. El segundo capítulo describe las posibilidades educativas del judo y refleja tanto sus ventajas como inconvenientes. Luego presenta los contenidos técnicos y tácticos a tratar, explicando las técnicas brevemente y detallando en el siguiente capítulo la metodología para llevar a cabo este programa educativo. La última parte describe la puesta en práctica de una unidad didáctica sobre judo, con la explicación de los juegos que se van a incluir, las sesiones, así como los objetivos, metodología y evaluación a utilizar.

275. Teixidó Iglesias, Xavier (2009). Atemi giho : técnicas de golpeo en el jujutsu tradicional japonés. Barcelona: Alas. 1aㅡ ed. 132 p. : il. ; 14x21 cm. ISBN: 978-84-203-0465-6. 978-84-203-0464-9 (ISBN de la colección). Depósito legal: B. 43228-2009. Palabras clave: historia, fundamentos teóricos, fundamentos técnicos, principios técnicos, atemijutsu, kárate, preparación física, armas. Resumen: Manual teórico y técnico de jujutsu. El libro esta formado por 3 capítulos precedidos por una dedicatoria, los agradecimientos, un prólogo que comenta la práctica actual de las artes marciales, la biografía del autor y una introducción que señala los contenidos de la obra. El primer capítulo narra el origen e historia de las artes marciales japonesas, de la utilización sistematizada de los atemi y los sistemas de combate cuerpo a cuerpo, las primeras escuelas de artes marciales y su utilización de los atemi. El segundo capítulo expone los principios técnicos de los atemi, describe las formas de fortalecimiento y endurecimiento de las armas naturales del cuerpo junto con sus ilustraciones explicativas. El tercer capítulo define los grupos de trabajo del atemijutsu como son el kenpo, koppo, yawara e iaidori además de incluir la descripción e ilustración de algunas de sus técnicas. Adjunta bibliografía fundamental.

276. Teixidó Orga, Francisco (1954). Jiu-jitsu: método completo para la defensa y el ataque. Barcelona: Molino. 1aㅡ ed. 108 p. : il. ; 14x19 cm. ISBN: No ISBN. Depósito legal: no. Palabras clave: fundamentos técnicos, entrenamiento, preparación física. Resumen: Manual técnico de jiu-jitsu. El libro esta formado por 8 partes o etapas, precedidas de una introducción y un prefacio, donde explica la historia del jiu-jitsu, su papel educador en Japón y cómo desarrollar el entrenamiento propuesto. La primera etapa describe la ejecución de la presa de tenaza en el brazo, su principio técnico, sus efectos, compara el jiu-jitsu con el boxeo, la lucha libre y greco-romana, y presenta el entrenamiento del borde de la mano. La segunda etapa expone varios ejercicios para el entrenamiento de los pulmones y el corazón, de la fuerza-resistencia de los brazos y manos de forma individual, describe un ejercicio de lucha entre dos contendientes, y algunos ejercicios por parejas para el desarrollo de la fuerza de brazos, antebrazos y muñecas. La tercera etapa expone diferentes ejercicios para el desarrollo de la fuerzaresistencia de las piernas, tobillos, muslos, y propone el remo y la marcha como dos actividades complementarias para desarrollar esta parte del cuerpo. La cuarta etapa presenta los beneficios de un temperamento equilibrado, el ejercicio de presa a los riñones y su defensa como método para fortificar los músculos y el entrenamiento avanzado de endurecimiento del borde de las manos. La quinta etapa describe la ejecución de diferentes golpes y presas básicos como la presa de mano, la presa de dedos, golpes a la garganta con el canto de la muñeca, el "sígueme" policial, y la parada. La sexta etapa presenta un conjunto de golpes y presas avanzadas como son el hacer pasar al adversario por encima de la cabeza y el hombro, varias presas a la garganta y sus defensas, golpes a la base de la espina dorsal, una presa por encima del hombro, la manera de desarmar a un adversario, y la utilización de las mangas para inmovilizarle. La séptima etapa incluye ejercicios de torsión de las muñecas, presas al cuello, presas a la garganta, presa de muñecas por detrás, presa de tenaza en los tobillos, golpe de codo y las formas de evitar cada una de ellas. La última etapa explica distintos ejercicios para mejorar la agilidad del practicante como patadas, saltos, caídas, levantarse del suelo o volteos. La conclusión final incluye consejos prácticos sobre la práctica.

277. Thabot, Dominique (1999). Judo óptimo : análisis y metodología. Barcelona: INDE. $1^{a}$ ed. 128 p. : il. ; 17x24 cm. ISBN: 84-95114-89-5. Depósito legal: Z. 2509-1999. Palabras clave: pedagogía, didáctica, biomecánica, reglamentos, unidades didácticas. Resumen: Manual teórico y didáctico sobre el judo. La monografía esta dividida en 4 capítulos. El primero de ellos hace un análisis biomecánico y táctico del desequilibrio y la apertura de la guardia como factores de máxima eficacia en las proyecciones. El segundo capítulo analiza la práctica de judo para posteriormente trazar algunas líneas generales para su inclusión dentro del marco educativo. El siguiente capítulo presenta los aspectos formales para incluir una unidad didáctica sobre judo en la ESO, para en el último capítulo ofrecer el ejemplo de dicha unidad y otras consideraciones didácticas. Adjunta un apéndice en el que se detalla el reglamento de competición y arbitraje.

278. Thomas, Raymond (1971). Judo moderno : programa para cinturón blanco y amarillo. Barcelona: Alas. $1^{\mathrm{a}}$ ed. 72 p. : il. ; 11x18,5 cm. ISBN: No ISBN. Depósito legal: B. 43465-1971. (2ª ed., 1981, ISBN: 84203-0124-8). Palabras clave: historia, fundamentos técnicos, programa técnico, principios técnicos. Resumen: Manual teórico y técnico de judo. La obra esta formada por 11 capítulos. El primer capítulo define en qué consiste el judo y cuáles son sus principios para luego comentar su nacimiento y 
beneficios para el practicante. El cuarto capítulo describe e ilustra las diferentes caídas que existen en el judo. Los dos siguientes capítulos explican e ilustran los posibles desequilibrios en judo así como las seis posturas y la posición de las manos. El séptimo capítulo describe la ejecución de las técnicas incluidas en el programa de cinturón blanco, como son o goshi, ippon seoi nage, hiza guruma, de ashi barai, uki goshi, hon kesa gatame, yoko shiho gatame, ushiro kesa gatame, kame shiho gatame y tate shiho gatame, señalando las fases de kuzushi, tsukuri y kake además de los puntos clave, los principales errores, los movimientos defensivos a dichas técnicas, algunos de los encadenamientos y su ilustración. El octavo capítulo presenta las técnicas incluidas en el programa de cinturón amarillo, esto es, tsuri komi goshi, harai goshi, morote seoi nage, sasae tsuri komi ashi, ko uchi gari, o uchi gari, describiendo las fases de su ejecución, puntos clave, principales errores, movimientos defensivos, encadenamientos e ilustración. También incluye un comentario sobre el trabajo de defensa a desarrollar en este grado, enumera los principios de salida de las inmovilizaciones y presenta la ejecución técnica de kata-gatame, kuzure kesa gatame, kuzure yoko shiho gatame, makura kesa gatame, kuzure kami shiho gatame y kuzure tate shiho gatame. El noveno capítulo ofrece algunos consejos técnicos para la correcta práctica del judo. Los dos últimos capítulos explican la correcta utilización de la fuerza en judo y analiza su uso en las distintas situaciones de oposición. Adjunta un vocabulario específico.

279. Thomas, Raymond (1972). Judo moderno : nage no kata. Barcelona: Alas. 1aㅡ ed. 76 p. : il. ; 11x18,5 cm. ISBN: No ISBN. Depósito legal: B. 32116-1972. (2ª ed., 1975, ISBN: 84-203-0322-4; 3르 ed., 1977, ISBN: 84-203-0005-5; 4⿳亠丷厂 ed., 1980, ISBN: 84-203-0005-5; 5a ed., 1981, ISBN: 84-203-0005-5). Palabras clave: fundamentos teóricos, vestimenta, cortesía, etiqueta, fundamentos técnicos. Resumen: Manual teórico y técnico de judo. La obra esta formada por 9 capítulos. El primer capítulo diferencia el entrenamiento de randori y kata, para luego explicar el significado de las katas y las katas oficiales. El tercer capítulo detalla la actitud del practicante al ejecutar una kata. El cuarto capítulo expone las razones para estudiar las katas y los beneficios que desarrolla su práctica en los competidores. Los siguientes cuatro capítulos comentan los aspectos formales y técnicos relacionados con la ejecución de las katas como son el dojo, los desplazamientos, las posturas y la forma de saludar. El último capítulo describe la ejecución por partes de las técnicas incluidas dentro de la nage-no-kata, señalando el principio técnico y táctico que sigue cada una de ellas e incluyendo su representación gráfica y esquemas de movimiento.

280. Thomas, Raymond (1972). Judo moderno : programa para cinturón azul y marrón. Barcelona: Alas. 1áa ed. 76 p. : il. ; 11x18,5 cm. ISBN: No ISBN. Depósito legal: B. 16104-1972. (2ª ed., 1981, ISBN: 84-2030037-3). Palabras clave: fundamentos técnicos, programa técnico, principios técnicos, filosofía, entrenamiento, preparación física. Resumen: Manual teórico y técnico de judo. La obra esta formada por 6 capítulos. El primer capítulo describe la ejecución de las técnicas incluidas en el programa de cinturón azul, o guruma, o soto otoshi, soto maki komi, harai tsuri komi ashi, uki waza, ude-garami, juji gatame, ude gatame, hiza gatame, waki gatame, hara gatame, señalando las fases de kuzushi, tsukuri y kake además de los puntos clave, los principales errores, los movimientos defensivos a dichas técnicas, algunos de los encadenamientos y su ilustración. Continúa explicando e ilustrando la ejecución de dos entradas de frente, dos entradas de lado, una entrada por detrás y dos entradas cuando tori esta de espaldas. El segundo capítulo presenta las técnicas incluidas en el programa de cinturón marrón, esto es, yoko otoshi, utsuri goshi, yoko guruma, ushiro goshi, te guruma, junto con dos entradas de frente, una entrada de lado, una entrada por detrás y dos entradas cuando tori se encuentra de espaldas. El siguiente capítulo expone la ejecución de tres técnicas para liberar la pierna del agarre de uke acompañadas de su ilustración. El cuarto capítulo comenta el entrenamiento del trabajo de tatchi-waza y de ne-waza para la competición, describe los diferentes métodos de entrenamiento incluyendo ejemplos prácticos de los mismos, y explica el entrenamiento físico con pesas, el footing, los deportes complementarios y la relajación en dicho proceso de preparación para la competición. El siguiente capítulo detalla el principio del judo como filosofía de vida. El último capítulo resume los principios técnicos básicos en la ejecución de un movimiento de judo.

281. Thomas, Raymond (1972). Judo moderno : programa para cinturón naranja y verde. Barcelona: Alas. 1a ed. 76 p. : il. ; 11x18,5 cm. ISBN: No ISBN. Depósito legal: B. 4299-1972. (2ª ed., 1981, ISBN: 84-2030123-X). Palabras clave: historia, fundamentos teóricos, táctica, fundamentos técnicos, programa técnico, principios técnicos. Resumen: Manual teórico y técnico de judo. La obra esta formada por 6 capítulos. El primer capítulo describe la ejecución de las técnicas incluidas en el programa de cinturón naranja, tai otoshi, okuri ashi barai, koshi guruma, hane goshi, uchi mata, ko soto gari, kuzure yoko shiho gatame, kuzure makura kesa gatame, kuzure kami shiho gatame, kuzure tate shiho gatame, señalando las fases de kuzushi, tsukuri y kake además de los puntos clave, los principales errores, los movimientos defensivos a dichas técnicas, algunos de los encadenamientos y su ilustración. Continúa con el comentario sobre las posibles situaciones de entrada al trabajo de judo en el suelo, además de describir e ilustrar dos entradas de frente y una entrada de espaldas. El segundo capítulo presenta las técnicas incluidas en el programa de cinturón verde, esto es, kata guruma, tomoe nage, ko soto gake, 
uki otoshi y ashi guruma. También explica las generalidades de las estrangulaciones del método francés, incluye la descripción e ilustración de kata juji jime, morote jime, hadaka jime, sode guruma y ashi gatame jime así como la ejecución de otras dos entradas de frente, una entrada de lado, una entrada por detrás y dos entradas cuando tori esta de espaldas al suelo. El tercer capítulo describe cómo utilizar la técnica en el combate analizando diferentes situaciones tácticas y continúa explicando la correcta utilización de las caderas. Los dos siguientes capítulos comentan la capacidad de adaptabilidad (ken-tai) del practicante de judo a cualquier situación del combate incluyendo algunos ejemplos prácticos y la forma correcta de atacar. El último capítulo analiza la deportivización del judo, su proceso de transformación, sus consecuencias, los argumentos en contra de dicho proceso y los aspectos saludables del entrenamiento intensivo moderno. Adjunta un vocabulario específico.

282. Uzawa, Toshiyasu (1970). Tratado de judo. Madrid: Instituto Nacional de Educación Física de Madrid. $1^{\underline{a}}$ ed. 195 p. : il. ; 17x24,5 cm. ISBN: No ISBN. Depósito legal: 24971-1970. Palabras clave: fundamentos teóricos, fundamentos técnicos, reglamentos. Resumen: Manual técnico de judo. La obra esta dividida en 19 capítulos. Los primeros capítulos presentan los fundamentos del judo, comenzando por la historia y objetivos del judo y continuando con los aspectos formales y de etiqueta, esto es, el judogi, el saludo, las posturas, el agarre, el taisabaki, los principios biomecánicos y las caídas. Los siguientes cuatro capítulos estudian los aspectos prácticos, haciendo una clasificación de las técnicas, introducción a las kata, el randori y sus objetivos, y el método de entrenamiento general.

283. Uzawa, Toshiyasu (1981). Defensa personal. Valladolid: Miñón. 1a ed. 78 p. : il. ; 17x24 cm. ISBN: 84355-0548-0. Depósito legal: VA. 67-1981. Palabras clave: defensa personal, judo. Resumen: Manual de defensa personal a través del judo. El libro esta dividido en 4 capítulos, explicando el primero de ellos los fundamentos del judo para aplicar en la defensa personal, como son la postura, los desplazamientos, la actitud y las técnicas básicas. Los siguientes tres capítulos desarrollan las defensas contra ataques con agarre, ataques con distancia y ataques con arma. Cada situación esta explicada gráficamente y acompañada de una explicación para cada una de las fotografías. Se adjunta un apéndice de cómo llevar a un adversario controlado.

284. Uzawa, Toshiyasu (1981). Pedagogía del judo. Valladolid: Miñón. 1a ed. 160 p. : il. ; 17x23,5 cm. ISBN: 84-355-0553-7. Depósito legal: VA. 174-1981. Palabras clave: fundamentos técnicos, principios técnicos, entrenamiento, arbitraje, reglamentos. Resumen: Manual técnico de judo. Después de comentar la historia del judo y sus paradigmas, divide sus contenidos en 4 capítulos. El primero introduce los aspectos formales, los principios de la técnica, la clasificación de las técnicas y el entrenamiento de judo, mientras que el segundo presenta la ejecución de las técnicas del gokyo, divididas según cada kyo. El tercer capítulo describe la realización de las técnicas de control, estrangulación y luxación, para finalizar con un último capítulo de apéndices que explican una tabla de ejercicios de calentamiento, la esquiva en el suelo, el reglamento de arbitraje y el vocabulario del judo.

285. Valle, Fabián Vicente del (1950). Defensa personal : judo, jiu-jitsu, lucha, boxeo. Madrid: Imprenta Fernando Franco. 1aㅡ ed. 112 p. : il. ; $12 x 17$ cm. ISBN: No ISBN. Depósito legal: no. (2ª ed., 1950; 3aㅡ ed. corr. y aum., 1954). Palabras clave: fundamentos teóricos, defensa personal, táctica, kyusho, armas, fundamentos técnicos. Resumen: Manual teórico y técnico de defensa personal. La obra comienza explicando los aspectos generales de la defensa personal como las posibilidades de defensa de cualquier persona, las armas naturales del cuerpo, las aptitudes para afrontar una situación de defensa personal, el estudio de la situación y la táctica, los fundamentos técnicos de una guardia de defensa, la localización de los puntos vulnerables del cuerpo, y la clasificación de los distintos medios de ataque y defensa que existen. Los siguientes capítulos describen e ilustran las técnicas consideradas indispensables para aprender a defenderse, incluyendo golpes con la cabeza, las manos y los pies; llaves a las manos, brazo, cabeza, tronco, piernas, y presiones; presas; defensas contra un estrangulamiento, contra el ataque de dos hombres, de un hombre armado de cuchillo o pistola; algunos golpes especiales y cómo realizar un cacheo.

286. Vignati, Alejandro (1973). Judo Kadokan. Barcelona: Bruguera. 1a ed. 222 p. : il. ; $10 x 17$ cm. ISBN: 8402-03228-1. Depósito legal: B. 25805-1973. Palabras clave: katas, historia, fundamentos técnicos, ejercicios, calentamiento, competición, maestros, reglamentos, respiración. Resumen: Manual teórico y técnico de judo. La obra esta formada por dos partes, precedidos por un prólogo que comenta la formación del judo y sus contenidos. La primera parte esta compuesta por 4 capítulos. El primer capítulo describe el funcionamiento del sistema respiratorio, su importancia para el judoka y propone varios ejercicios para aprender a respirar correctamente. El segundo capítulo explica los beneficios de los ejercicios combinados y describe las características, objetivos y ejecución de doce ejercicios para el mantenimiento de la forma física. El tercer capítulo presenta los aspectos formales que rodean a la competición de judo, como son las características del tatami, la vestimenta, las autoridades y un breve resumen sobre el desarrollo del combate. El último capítulo de esta parte comenta el reglamento de competición junto con el sistema de grados y de examen. La segunda parte esta compuesta por 5 capítulos. El primer capítulo describe los fundamentos técnicos del judo, explicando las posturas fundamentales, los métodos para desequilibrar, cómo se ejecuta el agarre y las formas de caer, 
incluyendo numerosas fotografías explicativas. El segundo capítulo explica la ejecución técnica de las principales proyecciones de tewaza, ashiwaza y koshiwaza incluyendo su representación gráfica. El tercer capítulo describe e ilustra las técnicas básicas de inmovilización y luxación. El cuarto capítulo explica la ejecución técnica y recomendaciones prácticas de la primera serie de estrangulaciones del método Kawaishi junto con la mitad de las técnicas de la segunda serie. El último capítulo describe e ilustra las defensas contra agarres a diferentes partes del cuerpo, defensas desde el suelo, defensas contra ataques de arma blanca y pistola, explica las características y aplicación de los distintos golpes, y describe la ejecución técnica de los movimientos de la kime-no-kata según el sistema Kawaishi. Adjunta tres apéndices que describen la ejecución de algunas técnicas de luxación de brazo, pierna y cuello, ofrecen unas recomendaciones para el lector e incluyen un glosario.

287. Vilar-Sancho Aguirre, Luis (1982). Manual del judoka. Valencia: Luis Vilar-Sancho. $1 \underline{\text { a }}$ ed. 126 p. : il. ; 21x30,5 cm. ISBN: 84-300-6265-3. Depósito legal: V. 131-1982. Palabras clave: historia, fundamentos teóricos, fundamentos técnicos, biografía, competición, maestros. Resumen: Manual teórico y técnico de judo. El primer capítulo relata la historia del judo y la formación del Kodokan y el método Kawaishi. El segundo capítulo comenta los principios filosóficos y morales del judo, explica los grados, presenta la clasificación técnica del judo, el programa técnico hasta 3er dan y los métodos de entrenamiento. El tercer capítulo es una guía alfabética de la terminología específica del judo, incluyendo la explicación de los principios técnicos del judo, los términos específicos de la competición, la ejecución de las principales técnicas de proyección, inmovilización, luxación y estrangulación junto con su representación gráfica, la biografía de los grandes maestros y competidores y los resultados de algunos campeonatos. Adjunta bibliografía, índice de abreviaturas y un artículo periodístico sobre el judo valenciano (Diario de valencia. Viernes, 9 de enero de 1981).

288. Villamón Herrera, Miguel (dir.) (1999). Introducción al judo. Barcelona: Hispano Europea. 1a ed. 351 p. : il. ; 17x23 cm. ISBN: 84-255-1296-4. Depósito legal: B. 40344-1999. (2ª ed., 2005). Palabras clave: historia, fundamentos teóricos, pedagogía, principios técnicos, educación, filosofía, didáctica, entrenamiento, vestimenta, instituciones, iniciación deportiva, maestros, programa técnico, reglamentos, sistemas de entrenamiento. Resumen: Tratado teórico de judo. La obra esta formada por 3 partes. La primera parte consta de 3 capítulos dedicados a la conceptualización del judo como deporte de lucha, explicando el primero de ellos la evolución histórica de la lucha, el proceso de deportivización, la clasificación de los deportes de lucha y un compendio de las características de las luchas tradicionales existentes en España. El segundo capítulo comenta los fundamentos filosóficos de las artes marciales chinas y japonesas, la conceptualización de las artes marciales, la relación entre bujutsu-budo y jujutsu-judo y la influencia del bushido y el militarismo en las artes marciales y el judo. El tercer capítulo narra los antecedentes históricos y culturales del judo, la aportación de Jigoro Kano y la creación del Kodokan, su expansión internacional, la evolución del judo en España y en los INEF y facultades de Ciencias del Deporte. La segunda parte consta de 4 capítulos dedicados a la enseñanza del judo. El primer capítulo comenta las características de las etapas de iniciación al judo, analiza los distintos modelos de iniciación y el tratamiento de la competición en dicha etapa. El segundo capítulo analiza el papel de la familia como agente socializador y los motivos que llevan a los padres a introducir a sus hijos en la práctica del judo como son la socialización deportiva, la formación física, la competición, el autocontrol y la educación. El tercer capítulo describe las características pedagógicas del judo, las características de los distintos modelos de enseñanza del judo y propone un modelo de enseñanza escolar del judo aclarando las características pedagógicas, la progresión didáctica y el condicionante de las instalaciones. El cuarto capítulo describe las características físicas de los adultos derivadas del envejecimiento, los beneficios de la práctica física y del judo en el contexto recreativo en dicha edad, presenta los criterios de selección de las técnicas y medios de práctica para dicho grupo de practicantes y comenta las dificultades para valorar el esfuerzo en el judo de competición junto con los resultados de esfuerzo y coste energético del combate de judo y el judo recreativo. La última parte consta de 7 capítulos dedicados al tratamiento didáctico de sus contenidos. El primer capítulo analiza los aspectos actitudinales en la participación del judo para luego describir los aspectos normativos a través del análisis del reglamento de competición. Los dos siguientes capítulos presentan los aspectos conceptuales del judo, como son los principios del judo, sus métodos y evolución, y las distintas concepciones de técnica y táctica junto con las clasificaciones de los contenidos del judo. El quinto capítulo describe las características de los distintos sistemas de aprendizaje del judo. Los dos últimos capítulos incluyen un glosario y bibliografía.

289. Yamashita, Yasuhiro (1993). Osoto-gari : técnicas maestras de judo. Barcelona: Paidotribo. 1a ed. 134 p. : il. ; 15x21,5 cm. ISBN: 84-8019-019-1. Depósito legal: B. 20932-1993. Palabras clave: fundamentos técnicos, principios técnicos, defensa personal, entrenamiento, táctica. Resumen: Manual de estudio teórico y práctico sobre osoto-gari. Después de relatar el autor su aprendizaje y utilización de esta técnica, el segundo capítulo aborda la historia de la misma, desde sus orígenes hasta su ejecución e importancia en la competición. El tercer capítulo describe la realización de osoto-gari así como sus variantes con distintos oponentes o con distintos agarres. El cuarto capítulo presenta las 
combinaciones que pueden acompañar a esta técnica para luego continuar con las defensas y contraataques. El sexto capítulo explica los diferentes tipos de entrenamiento en solitario y con uno o varios compañeros para optimizar osoto-gari. El séptimo capítulo ofrece algunas propuestas para su aplicación en situaciones de defensa personal contra diversas formas de ataque y finaliza con la utilización del osoto-gari en la competición por parte de los grandes campeones de todos los tiempos.

290. Yerkow, Charles (1956). Judo katas. Barcelona: Hispano Europea. 1a ed. 161 p. : il. ; 13×19,5 cm. ISBN: No ISBN. Depósito legal: no. (2ª ed., 1959, 171 p.; 3aㅡ ed., 1963, 174 p.; $4^{\underline{a}}$ ed., 1964, 174 p.; $5^{\underline{a}}$ ed., 1966, 174 p.; $6^{a}$ ed., 1969, 174 p.; 7aㅡ ed., 1974, 174 p., ISBN: 84-255-0111-3). Palabras clave: katas, fundamentos técnicos. Resumen: Manual técnico de judo. El libro esta formado por 8 capítulos. El primer capítulo explica cómo se debe practicar el judo y en qué consiste este arte marcial. El segundo capítulo relata el origen del judo, sus objetivos, las formas de enseñanza, el sistema de grados, las normas de etiqueta y saludo, comenta el desarrollo y vocabulario de la competición, y la clasificación de sus técnicas. El tercer capítulo describe los fundamentos técnicos básicos del judo como son el agarre y las caídas, describiendo e ilustrando su ejecución. Los dos siguientes capítulos describen la ejecución de las técnicas incluidas en la nage-no-kata junto con sus ilustraciones, para luego hacer lo mismo con las principales técnicas de inmovilización, estrangulación y luxación en el trabajo de katame-waza (judo en el suelo). El séptimo capítulo reflexiona sobre los exámenes de grado y finaliza con un amplio compendio de términos de judo y su traducción.

291. Yokoyama, Sakujiro y Oshima, Eisuke (2009). Judo kyohan. Madrid: Budo International. $1^{\underline{a}}$ ed. 239 p. : il. ; 17x24 cm. ISBN: 978-84-92484-46-1. Depósito legal: M. 41369-2009. Palabras clave: fundamentos técnicos, principios técnicos. Resumen: Manual teórico y técnico de judo. El libro esta compuesto por 9 capítulos precedidos por un prefacio del autor que comenta los contenidos del libro y un prefacio del traductor que comenta sus dificultades. El primer capítulo relata brevemente la historia del judo kodokwan, expone sus objetivos. El segundo capítulo explica los fundamentos técnicos que componen el judo, sus principios técnicos, describe la posición shizentai, analiza las direcciones de desequilibrio, cómo romper la postura natural y en la postura de newaza, señala la importancia de la fuerza en judo y su aplicación y comenta la actitud física y mental ante el combate. El tercer capítulo ofrece algunos consejos para la práctica del judo. El cuarto capítulo explica los principios de tsukuri y kake, la práctica de randori y kata, los papeles de tori y uke, los principios técnicos de las caídas junto con su descripción e ilustración, la forma de desplazarse y la forma de agarre. El quinto capítulo expone la clasificación de las técnicas de nagewaza y algunos de sus nombres. El sexto capítulo explica la ejecución y características de las técnicas ukiotoshi, seoinage, kataguruma, ukigoshi, haraigoshi, tsurikomigoshi, ashibarai, tsurikomiashi, uchimata, tomoenage, uranage, sumigaeshi, yokogake, yokoguruma y ukiwaza acompañadas de sus ilustraciones explicativas. El séptimo capítulo presenta la descripción técnica, características, aplicación en randori e ilustración de las técnicas que componen el gokyo no waza, como son hizaguruma, sasae-tsurikomiashi, ukigoshi, taiotoshi, osotogari, deashibarai, yokootoshi, sumigaeshi, kosotogari, ogoshi, koshiguruma, seoinage, tomoenage, taniotoshi, okuriashibarai, haraigoshi, ushirogoshi, uranage, uchimata, obiotoshi, hanegoshi, ukiotoshi, ukiwaza, dakiwakare, kataguruma, hikikomigaeshi, tsurigoshi, sotomakikomi, utsurigoshi, osotootoshi, tawaragaeshi, yokoguruma, yokowakare, uchimakikomi, kouchigari, ashiguruma, haraitsurikomiashi, seoiotoshi, yamaarashi, osotoguruma y yokogake. El octavo capítulo presenta la ejecución de las técnicas de katamewaza como kamishihogatame, kuzure kamishihogatame, yoko-shihogatame, kesagatame, katagatame, namijuji, katajuji, gyakujuji, hadakajime, okurierijime, katahajime, udegarami, udehishigi, jumonjigatame, udegatame, hizagatame y ashigarami junto con sus ilustraciones explicativas. El noveno capítulo comenta la ejecución de las principales técnicas de atemiwaza.

\subsubsection{Kárate}

292. Aledo Bañuls, Enrique (1997). Karate shotokan : karate didáctico progresivo de alevín a junior. Denia: Club Karate Okinawa Denia Enrique Aledo Bañuls. 1aㅡ ed. 142 p. : il. ; $17 \times 24 \mathrm{~cm}$. ISBN: No ISBN. Depósito legal: A. 1791-1997. Palabras clave: fundamentos teóricos, fundamentos técnicos, programa técnico. Resumen: Manual teórico y técnico de kárate. El libro esta formado por 10 capítulos, precedidos por un prefacio que explica el objetivo de la obra, un breve resumen de la historia del kárate, un resumen de la biografía del autor y una dedicatoria. El primer capítulo explica en qué consiste el kárate, cuáles son las reglas de la sala de entrenamiento, el sistema de grados e incluye unas fichas para rellenar sobre nuestros primeros pasos en el kárate. El segundo capítulo describe las normas de higiene para el entrenamiento, las características de la vestimenta y la forma de atarse el cinturón y de ejecutar el saludo. El tercer capítulo explica por partes la ejecución de las posiciones y desplazamientos básicos incluyendo un esquema de movimiento de los pies así como las técnicas básicas de ataque con el puño, con las piernas y las defensas básicas. El cuarto capítulo ilustra las armas del karateka, enumera las principales técnicas de ataque y de defensa acompañadas de su 
ilustración. El quinto capítulo presenta el temario teórico básico junto con la traducción del vocabulario específico básico del kárate. El sexto capítulo explica las características técnicas de las principales katas del estilo shotokan y ofrece algunos consejos para su entrenamiento. El séptimo capítulo presenta la descripción ilustrativa de la ejecución de las principales katas acompañadas de sus esquemas de movimiento. El octavo capítulo incluye numerosas fotografías explicativas de distintas técnicas de defensa y ataque de kárate. El noveno capítulo nombra e ilustra las armas utilizadas en kárate y los símbolos de distintos escudos. El décimo capítulo ilustra numerosos ejercicios de estiramientos. Adjunta el programa de exámenes desde cinturón blanco hasta cinturón marrón, unas tablas para apuntar las observaciones de los exámenes, algunas ilustraciones marciales y varias hojas para tomar notas.

293. Aoki, Osamu y Sáenz Fernández, Félix (1979). Karate junior : 1. Cinturón blanco y cinturón amarillo. Bilbao: Fher. 1aㅡ ed. 46 p. : il. ; 17x24 cm. ISBN: 84-243-1719-X. Depósito legal: BI. 1934-1979. (2ª ed., 1981; 3a ed., 1987). Palabras clave: katas, kumite, fundamentos técnicos. Resumen: Manual técnico de kárate. El libro presenta los fundamentos técnicos para los cinturones blanco y amarillo de kárate, describiendo e ilustrando las posiciones (zenkutsu dachi, kokutsu dachi y kiba dachi), las zonas de golpeo de la mano y el pie, el golpe directo (tsuki), las defensas básicas (age uke, gedan barai, soto uke y uchi uke), los desplazamientos en zenkutsu dachi, la ejecución de diferentes técnicas en avance en zenkutsu dachi (oi-zuki, age uke, soto uke, gyaku zuki), cómo se realiza el giro de la cadera, las principales patadas (mae-geri y yoko-geri keage y kekomi), combinaciones de técnicas avanzando en zenkutsu dachi y la ilustración de las katas heian shodan y heian nidan.

294. Aoki, Osamu y Sáenz Fernández, Félix (1979). Karate junior : 2. Cinturón naranja y cinturón verde.

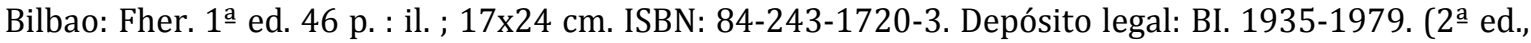
1981; 3a ed., 1987). Palabras clave: katas, kumite, fundamentos técnicos, combate. Resumen: Manual técnico de kárate. El libro presenta los fundamentos técnicos para los cinturones naranja y verde de kárate, describiendo e ilustrando las posiciones (neko ashi dachi, fudo dachi, shiko dachi y sanchin dachi), las zonas de golpeo de la mano y el pie, combinaciones técnicas de defensas y ataques con manos y pies, el entrenamiento de defensa y ataque con compañero, la ilustración de las katas heian sandan y heian yondan y la primera serie técnica del entrenamiento de kumite a tres pasos (sanbon) a diferentes alturas.

295. Aoki, Osamu y Sáenz Fernández, Félix (1979). Karate junior : 3. Cinturón azul y cinturón marrón. Bilbao: Fher. 1a ed. 46 p. : il. ; 17x24 cm. ISBN: 84-243-1737-8. Depósito legal: BI. 2297-1979. (2ª ed., 1981). Palabras clave: katas, kumite, fundamentos técnicos. Resumen: Manual técnico de kárate. El libro presenta los fundamentos técnicos para los cinturones azul y marrón de kárate. Describe e ilustra varias técnicas de defensa y de ataque con las manos y piernas, las secuencias técnicas del entrenamiento de ippon kumite ante distintos ataques, ilustra los movimientos de las katas heian godan y tekki shodan, expone los principios del jiyu ippon kumite y del jiyu kumite para finalizar presentando el makiwara y el saco como accesorios del entrenamiento.

296. Arakaki, Kiyoshi (2004). Los secretos del kárate de Okinawa : esencia y técnicas. Madrid: Tutor. 1aa ed. 138 p. : il. ; 21x28 cm. ISBN: 84-7902-438-0. Depósito legal: M. 1902-2004. Palabras clave: katas, fundamentos teóricos, fundamentos técnicos, biomecánica, kárate, escuelas. Resumen: Manual teórico y técnico de kárate. El libro esta dividido en 7 capítulos. El primer capítulo explica los principios biomecánicos del tsuki de kárate de los estilos shuri-te y naha-te así como algunas de sus variaciones más frecuentes, incluyendo ilustraciones demostrativas y el entrenamiento para perfeccionar dicha técnica. El segundo capítulo describe la ejecución técnica del golpe directo en desplazamiento, ofreciendo numerosos ejemplos prácticos de las leyes físicas que intervienen en el mismo, estudia el centro de gravedad, su aplicación en las posiciones de kárate y el entrenamiento para ser consciente del mismo. El tercer capítulo expone la forma de desplazarse en kárate, los principios biomecánicos que rigen dicho movimiento y ofrece varios ejemplos para comprobar este movimiento. El cuarto capítulo comenta las características de los diferentes tipos de katas, explica la correcta ejecución de la kata naifanchi por partes y con el apoyo gráfico, relata algunas curiosidades técnicas de la ejecución de la kata naifanchi por distintos maestros, la importancia de una correcta posición de shiko-dachi y del entrenamiento continuado para avanzar en el dominio técnico. El quinto capítulo analiza las teorías y características de las katas, ejemplifica los principios explicados con anterioridad sobre la kata taikyoku shodan, explica la ejecución del tsuki según el kung fu chino y la última etapa de aprendizaje de la kata. El sexto capítulo estudia el concepto de ki y su aplicación en el kárate además del control mental durante el entrenamiento. El último capítulo comenta la interpretación actual de las artes marciales y ofrece una idea general de todos los contenidos tratados con anterioridad. Adjunta un índice temático.

297. Armstead, John (1976). Kung-fu de Okinawa. Bilbao: Fher. 1aㅡ ed. 127 p. : il. ; $15 \times 21$ cm. ISBN: 84-2431235-X. Depósito legal: BI. 2853-1976. Palabras clave: historia, fundamentos técnicos, defensa personal, entrenamiento, escuelas, ética, preparación física, respiración. Resumen: Manual teórico y técnico de kung-fu. El libro esta dividido en 16 capítulos. El primer capítulo narra el origen del kung-fu, 
para en el segundo exponer las características de la escuela blanda y dura el kung-fu y su relación con el concepto yin-yang. El tercer capítulo presenta los principios fundamentales del kung-fu. El cuarto capítulo comenta la actitud mental del practicante durante el entrenamiento. El quinto capítulo describe los principales ejercicios de calentamiento acompañados de su correspondiente ilustración. El sexto capítulo comenta las características de la respiración utilizada en el kung-fu y describe su ejecución correcta incluyendo fotografías explicativas. El séptimo capítulo describe la ejecución e ilustra las posiciones fundamentales del kung-fu. Los siguientes cuatro capítulos describen la ejecución de las principales técnicas con la mano abierta, con la mano cerrada, las patadas y las paradas además de incluir sus respectivas fotografías explicativas. El duodécimo capítulo ilustra y nombra los diferentes métodos de entrenamiento para endurecer las manos y pies; mientras que el siguiente capítulo ilustra diferentes técnicas de rompimientos. Los dos siguientes capítulos comentan el concepto de chi y la importancia del condicionamiento físico para el entrenamiento. El último capítulo describe la ejecución de distintas técnicas defensivas ante los diversos ataques de un individuo armado o desarmado, y ante el ataque de varios adversarios desarmados, incluyendo las fotografías demostrativas.

298. Babiloni Guasch, José y Babiloni Saiz, Javier (2002). Karate kyokushinkai : programa paso de grados, niños. Valencia: José Babiloni. 1ํㅡ ed. 168 p. : il. ; 14x22 cm. ISBN: No ISBN. Depósito legal: V. 4309-2002. Palabras clave: katas, historia, fundamentos técnicos, programa técnico, biografía, fundamentos éticos, instalaciones, reglamentos, maestros. Resumen: Manual teórico y técnico de kárate. El libro esta formado por 19 capítulos precedidos por la hoja de identidad del libro y un resumen de los beneficios de la práctica del kárate. El primer capítulo explica la biografía del maestro Oyama, mientras que el segundo presenta el dojo kun. El tercer capítulo detalla el significado del kyokushinkai. El cuarto capítulo expone sus fundamentos éticos mientras que el quinto explica el comportamiento en el dojo. El sexto capítulo enumera la progresión de contenidos en el aprendizaje del kárate. El siguiente capítulo detalla el tiempo mínimo de permanencia en cada cinturón junto con su color. El octavo capítulo expone la procedencia de las katas del estilo kyokushinkai además de explicar su significado. El noveno capítulo incluye la terminología específica. Los siguientes 10 capítulos describen la ejecución de los contenidos técnicos desde $10^{\circ}$ kyu hasta cinturón negro acompañados de su representación gráfica.

299. Bargados Díaz, Félix (1999). Karate clase a clase : tomo 1. Oviedo: Servicio de Publicaciones. Universidad de Oviedo. $1^{a}$ ed. 174 p. : il. ; 17x24 cm. ISBN: 84-605-9394-0. Depósito legal: AS. 29771999. Palabras clave: fundamentos técnicos, entrenamiento, unidades didácticas. Resumen: Manual teórico y técnico de kárate. La obra consta de 69 sesiones prácticas ilustradas divididas en 15 capítulos, precedidos por una introducción, que explica el significado del término karate, los principios filosóficos que rigen su práctica y destaca los beneficios para el practicante, y unas notas aclaratorias que estructuran el desarrollo de una clase de kárate. El primer capítulo incluye 15 sesiones ilustradas de entrenamiento en las que se aprenden las técnicas básicas, las posiciones, los desplazamientos y la utilización de la cadera. El segundo capítulo presenta 11 sesiones para el aprendizaje de la kata heian shodan y el combate a un paso y a cinco pasos, acompañados de sus representaciones gráficas. El tercer capítulo expone el programa técnico para cinturón amarillo y los criterios de evaluación. El cuarto capítulo presenta 4 sesiones para trabajar el encadenamiento de dos técnicas tanto en estático como en movimiento. El quinto capítulo muestra 6 sesiones prácticas para el aprendizaje y desarrollo de las patadas básicas de kárate. El sexto capítulo incluye dos sesiones que trabajan las defensas a nivel medio interiores así como el sambon-kumite. El séptimo capítulo presenta 6 sesiones que entrenar el intercambio entre posicione largas y cortas. El octavo capítulo desarrolla el aprendizaje de la kata heian nidan. El siguiente capítulo incluye 4 sesiones para el entrenamiento del pie pivote y el giro de las caderas. Los dos siguientes capítulos presentan 7 y 3 sesiones para el entrenamiento de las defensas y de las técnicas de puño respectivamente. El decimosegundo capitulo expone 3 sesiones para el entrenamiento del desplazamiento sucesivo de los pies. Los tres últimos capítulos incluyen dos sesiones para el trabajo de intercambio de posiciones, una sesión para el trabajo de las articulaciones y dos sesiones que muestran el programa técnico para cinturón naranja y sus criterios de evaluación, respectivamente.

300. Bargados Díaz, Félix (2000). Karate clase a clase : tomo 2. s.l.: Félix Bargados. 1aㅡ ed. 388 p. : il. ; 17x24,5 cm. ISBN: No ISBN. Depósito legal: AS. 2588-2000. Palabras clave: fundamentos técnicos, entrenamiento, lesiones, unidades didácticas. Resumen: Manual técnico de kárate. La obra consta de 135 sesiones divididas en 33 capítulos, precedidos por una introducción que explica el significado del término karate, los principios filosóficos que rigen su práctica y destaca los beneficios para el practicante, y unas notas aclaratorias que estructuran el desarrollo de una clase de kárate. Las sesiones mantienen una misma estructura en la que se describen los ejercicios específicos para el aprendizaje de un fundamento técnico determinado, el repaso de algunos contenidos de la sesión anterior y varios ejercicios sobre la aplicación marcial de las técnicas explicadas, acompañadas de las representaciones gráficas correspondientes. Los capítulos abordan el entrenamiento de las defensas, las técnicas de 
puño y la respiración, las técnicas de pierna, el perfeccionamiento de la primera kata, el giro, otras defensas, el perfeccionamiento de la segunda kata, el desplazamiento simultáneo, el aprendizaje de la tercera kata, las defensa dobles, las técnicas de codos, otras técnicas de piernas, pisotones, el perfeccionamiento de la tercera kata, el aprendizaje de la cuarta kata, las técnicas de rodilla, las técnicas de combate convencional, el programa de contenidos técnicos del examen de cinturón verde además de sus criterios de evaluación, las defensas deslizantes, otra serie de técnicas de codo y de piernas, algunas técnicas de puño, encadenamientos, iniciación a las esquivas, las técnicas semilibres, el perfeccionamiento de la cuarta kata, las técnicas inversas, el aprendizaje de la quinta kata, otro conjunto de técnicas de combate convencional y las técnicas de manos atadas, las técnicas indirectas, las técnicas directas, las patadas semicirculares, el perfeccionamiento de la quinta kata, el repaso de las katas aprendidas, el programa de contenidos técnicos del examen de cinturón azul junto con los criterios de evaluación y la descripción de las lesiones más frecuentes en kárate.

301. Barioli, Cesare (1989). El gran libro del karate. Barcelona: De Vecchi. 1aㅡ ed. 252 p. : il. ; 17x23,5 cm. ISBN: 84-315-0805-1. Depósito legal: B. 29833-1989. Palabras clave: historia, fundamentos teóricos, escuelas, kárate, maestros. Resumen: Manual teórico y técnico de kárate. El libro esta compuesto por 2 partes. La primera parte incluye cuatro capítulos. El primer capítulo describe la historia y evolución del kárate y sus diferentes estilos en Asia. El segundo capítulo explica las características de los estilos shorin y shorei de kárate además de comentar la biografía de sus maestros más importantes. El tercer capítulo expone la expansión del kárate a Japón, la aportación de Gichin Funakoshi y sus herederos al kárate y relata la historia de los distintos estilos y sus maestros. El cuarto capítulo explica la práctica moderna del kárate, el entrenamiento en China, Okinawa y Japón, los elementos básicos que conforman la práctica, y el significado del kata y el combate. La segunda parte incluye cuatro capítulos. El primer capítulo narra la historia del estilo shotokan e incluye la descripción de varias secuencias técnicas y de la unsu-no-kata acompañadas de su secuencia fotográfica. El segundo capítulo relata el origen del estilo wado-ryu, la biografía del maestro Berengario Chiriaco y presenta la descripción e ilustración de varias técnicas del estilo y la seisan-no-kata. El tercer capítulo presenta una breve biografía del maestro Sei Iwasa junto con la descripción técnica de sus posiciones fundamentales y la kata tomari-bassai incluyendo su representación gráfica y esquemas de movimiento. El último capítulo describe el origen del estilo goju-ryu, la biografía del maestro Giancarlo Barbin junto con la descripción de sus características, la ilustración de las posiciones fundamentales del estilo, la kata sanchin y su aplicación marcial.

302. Barioli, César (Barioli, Cesare) (1967). Manual práctico de karate : la más terrible defensa personal. Barcelona: De Vecchi. 1a ed. 248 p. : il. ; 15x21,5 cm. ISBN: No ISBN. Depósito legal: 27738-1967. (2 ${ }^{\underline{a}}$ ed., 1970; 3a ed., 1973, ISBN: 84-315-0202-9). Palabras clave: katas, kumite, fundamentos técnicos, defensa personal. Resumen: Manual técnico de karate. La monografía presenta los fundamentos y técnicas básicas. Comienza relatando la historia del karate y cómo se organiza temporalmente una clase normal de karate, para comenzar en el siguiente capítulo con la descripción de las posiciones, los desplazamientos, las técnicas de brazo (seiken choku zuki y ura zuki), las técnicas de pierna (mae geri) y las defensas (gedan barai, age uke, ude uke). Los contenidos están ordenados bajo el criterio de dificultad y en cada técnica aparece su descripción, entrenamiento y aplicaciones acompañadas de fotografías y esquemas de movimiento. A continuación comenta brevemente tanto el entrenamiento de kumite y algunos ejercicios prácticos y la secuencia técnica de las katas: taikyoku shodan, taikyoku nidan, taikyoku sandan y heian shodan. La siguiente parte explica los principios de la defensa personal y ofrece algunas técnicas (empi uchi, mawashi geri) para dichas situaciones; seguido de dos capítulos muy breves que comentan la contracción muscular en la ejecución técnica y los requisitos para practicar el combate semilibre. La siguiente parte explica el entrenamiento técnico y las aplicaciones de los ataques circulares (teisho uchi, mawashi zuki), las paradas (tetsui uke, zuki uke) y las patadas (ushiro geri, fumikomi geri, tobi geri, hittsui geri). Los últimos apartados describen el trabajo de técnicas combinadas, las técnicas de lanzamiento, el combate libre y su reglamento. Adjunta glosario de términos japoneses.

303. Barioli, César (Barioli, Cesare) (1969). El karate : la más mortífera defensa personal. Barcelona: De Vecchi. $1^{a}$ ed. 160 p. : il. ; 13x19,5 cm. ISBN: No ISBN. Depósito legal: V. 2715-1969. (2 ${ }^{\underline{a}}$ ed., 1971; $3^{\underline{a}}$ ed., 1972; 3 a ed. y $1^{\underline{a}}$ reimp., 1975, ISBN: 84-315-0455-2; 4를. ed., 1977, ISBN: 84-315-0455-2). Palabras clave: kumite, fundamentos teóricos, fundamentos técnicos, principios técnicos, defensa personal, equipamiento, armas. Resumen: Manual teórico y técnico de kárate. El libro esta formado por 3 partes. La primera parte explica en qué consiste el kárate y su historia, cómo se construye un makiwara, cómo debe realizarse una sesión de entrenamiento, y cuáles son los principios de eficacia de un golpe de kárate. La segunda parte comienza exponiendo la forma de saludar y las distintas partes del puño que pueden ser utilizadas para golpear, para luego mostrar una estructura repetitiva de sus contenidos que describen los distintos ataques con los brazos y las piernas, los desplazamientos, el entrenamiento por parejas de dichas técnicas, el endurecimiento de las zonas corporales de golpeo, y las técnicas de proyección, luxación y estrangulación propias del kárate junto con un breve comentario del kiai, la 
progresión del entrenamiento de kumite y las pruebas de fuerza (shiwari). La tercera parte explica la localización de los puntos vitales del cuerpo, y describe e ilustra la defensa personal ante distintas agresiones con agarre, en distintas posiciones, y contra ataques armados de cuchillo, bastón y pistola.

304. Barioli, César (Barioli, Cesare) (1978). El karate : la más mortífera defensa personal. Barcelona: De Vecchi. $1^{a}$ ed. 164 p. : il. ; 14x20,5 cm. ISBN: 84-315-5355-3. Depósito legal: B.41434-1978. (2ª ed., 1983; 3a ed., 1987; 4a ed., 1989). Palabras clave: kumite, fundamentos teóricos, fundamentos técnicos, principios técnicos, defensa personal, equipamiento, armas. Resumen: Manual teórico y técnico de kárate. El libro esta formado por 3 partes. La primera parte explica en qué consiste el kárate y su historia, cómo se construye un makiwara, cómo debe realizarse una sesión de entrenamiento, y cuáles son los principios de eficacia de un golpe de kárate. La segunda parte comienza exponiendo la forma de saludar y las distintas partes del puño que pueden ser utilizadas para golpear, para luego mostrar una estructura repetitiva de sus contenidos que describen los distintos ataques con los brazos y las piernas, los desplazamientos, el entrenamiento por parejas de dichas técnicas, el endurecimiento de las zonas corporales de golpeo, y las técnicas de proyección, luxación y estrangulación propias del kárate junto con un breve comentario del kiai, la progresión del entrenamiento de kumite y las pruebas de fuerza (shiwari). La tercera parte explica la localización de los puntos vitales del cuerpo, y describe e ilustra la defensa personal ante distintas agresiones con agarre, en distintas posiciones, y contra ataques armados de cuchillo, bastón y pistola.

305. Barioli, César (Barioli, Cesare) (1978). Manual práctico de karate. Barcelona: De Vecchi. 1a ed. 223 p. : il. ; 14x20,5 cm. ISBN: 84-315-0635-0. Depósito legal: B. 19534-1978. (2ª ed., 1979). Palabras clave: katas, kumite, fundamentos técnicos, defensa personal. Resumen: Manual técnico de karate. La monografía esta dividida en 29 capítulos. Comienza relatando la historia del karate y cómo se organiza temporalmente una clase normal de karate, para comenzar en el siguiente capítulo con la descripción de las posiciones, los desplazamientos, las técnicas de brazo (seiken choku zuki y ura zuki), las técnicas de pierna (mae geri) y las defensas (gedan barai, age uke, ude uke). Los contenidos están ordenados bajo el criterio de dificultad y en cada técnica aparece su descripción, entrenamiento y aplicaciones acompañadas de fotografías y esquemas de movimiento. A continuación comenta brevemente tanto el entrenamiento de kumite y algunos ejercicios prácticos y la secuencia técnica de las katas: taikyoku shodan, taikyoku nidan, taikyoku sandan y heian shodan. La siguiente parte explica los principios de la defensa personal y ofrece algunas técnicas (empi uchi, mawashi geri) para dichas situaciones; seguido de dos capítulos muy breves que comentan la contracción muscular en la ejecución técnica y los requisitos para practicar el combate semilibre. La siguiente parte explica el entrenamiento técnico y las aplicaciones de los ataques circulares (teisho uchi, mawashi zuki), las paradas (tetsui uke, zuki uke) y las patadas (ushiro geri, fumikomi geri, tobi geri, hittsui geri). El último capítulo describe el trabajo de técnicas combinadas.

306. Barioli, César (Barioli, Cesare) (1985). Manual práctico de karate. Barcelona: Río Negro y De Vecchi. 1a ed. 191 p. : il. ; 13x19 cm. ISBN: 84-315-0150-2. Depósito legal: B. 20840-1985. Palabras clave: katas, kumite, fundamentos técnicos, defensa personal. Resumen: Manual técnico de karate. Comienza relatando las normas que rigen en el gimnasio y cómo se organiza temporalmente una clase normal de karate, para luego describir la ejecución técnica de las posiciones, los desplazamientos, las técnicas de brazo (seiken choku zuki y ura zuki), las técnicas de pierna (mae geri) y las defensas (gedan barai, age uke, ude uke). Los contenidos están ordenados bajo el criterio de dificultad y en cada técnica aparece su descripción, entrenamiento y aplicaciones acompañadas de fotografías y esquemas de movimiento. A continuación comenta brevemente tanto el entrenamiento de kumite y algunos ejercicios prácticos y la secuencia técnica de las katas: taikyoku shodan, taikyoku nidan, taikyoku sandan y heian shodan. La siguiente parte explica los principios de la defensa personal y ofrece algunas técnicas (empi uchi, mawashi geri) para dichas situaciones; seguido de dos capítulos muy breves que comentan la contracción muscular en la ejecución técnica y los requisitos para practicar el combate semilibre. La siguiente parte explica el entrenamiento técnico y las aplicaciones de los ataques circulares (teisho uchi, mawashi zuki), las paradas (tetsui uke, zuki uke) y las patadas (ushiro geri, fumikomi geri, tobi geri, hittsui geri). Los últimos apartados describen el trabajo de combinación de técnicas.

307. Barros García, José María; Santiago Alonso, Miguel y Vázquez Lazo, Juan Carlos (1998). Karate, a competición. Santiago de Compostela: Lea. 1aㅡ ed. 111 p. : il. ; 15x24 cm. ISBN: 84-89947-33-3. Depósito legal: C. 870-1998. Palabras clave: fundamentos técnicos, estrategia, táctica, arbitraje, competición, planificación del entrenamiento, preparación física. Resumen: Manual teórico y técnico de kárate. El libro esta formado por cinco capítulos. El primer capítulo define los conceptos de técnica, táctica y estrategia en la competición de kárate así como sus relaciones, la localización del kárate en la clasificación deportiva, la utilización de la competición dentro del proceso de iniciación deportiva y de rendimiento junto con sus objetivos tácticos. El segundo capítulo enumera los factores que inciden en la competición, las características de los diferentes competidores, la definición de las acciones técnicas y tácticas que integran la competición, junto con la descripción e ilustración de la ejecución de los distintos desplazamientos, las distancias entre los competidores, la clasificación y definición de las 
acciones defensivas y ofensivas, y la descripción técnica de varios ejemplos de defensas y esquivas. El tercer capítulo enumera los factores involucrados en la preparación de la competición y presenta un ejemplo de una programación anual junto con algunos ejemplos ilustrados de ejercicios de preparación de la competición. El cuarto capítulo profundiza en la preparación física del competidor, sus objetivos y medios así como la exposición de los medios, métodos, carácter del trabajo muscular, intensidad de la carga, magnitud de la resistencia a superar, número de repeticiones y duración del esfuerzo de los distintos métodos para desarrollar las diversas manifestaciones de la fuerza. El último capítulo resalta los aspectos más importantes del reglamento de arbitraje.

308. Barros García, José María y Santiago Alonso, Miguel (1997). Karate : manual básico. Santiago de Compostela: Lea. $1^{\mathfrak{a}}$ ed. 91 p. : il. ; $15 \times 24$ cm. ISBN: 84-88553-29-3. Depósito legal: C. 52-1997. Palabras clave: historia, fundamentos técnicos, entrenamiento, competición, reglamentos, sistemas de entrenamiento. Resumen: Manual teórico y técnico de kárate. El libro esta formado por 6 capítulos. El primer capítulo define el kárate y relata el origen y evolución del arte y su introducción en Galicia. El segundo capítulo describe brevemente las generalidades sobre el dojo, la vestimenta, los grados y los valores tradiciones; para en el siguiente capítulo presentar las áreas y zonas de golpeo y la definición de los elementos de eficacia de una técnica. El cuarto capítulo define, describe e ilustra la ejecución de las posiciones, los desplazamientos, las principales técnicas defensivas y ofensivas tanto de puño como de pierna. El quinto capítulo explica los diferentes métodos de entrenamiento del kárate como son el kihon, la kata y el kumite y sus variaciones. El último capítulo comenta las modalidades de competición de kárate y resume los aspectos más importantes del reglamento de competición. Adjunta un vocabulario básico de kárate, terminología de arbitraje, gestos de los árbitros y jueces de competición, y un gráfico del área de competición.

309. Basile, Augusto (1971). ABC del kárate. Barcelona: Molino. 1a ed. 166 p. : il. ; 14x19,5 cm. ISBN: No ISBN. Depósito legal: B. 7487-1971. Palabras clave: kumite, historia, fundamentos teóricos, táctica, fundamentos técnicos, principios técnicos, ejercicios, entrenamiento, calentamiento, competición, equipamiento, reglamentos. Resumen: Manual teórico y técnico del kárate. El libro esta dividido en 3 partes. La primera partes esta compuesta por 3 capítulos que comentan los orígenes del kárate, definen en qué consiste su práctica y exponen los principios del entrenamiento junto con la descripción y utilización de los aparatos de entrenamiento. La segunda parte esta formada por 4 capítulos. El primer capítulo explica la posición de partida "yoi" y su significado. El segundo capítulo describe la ejecución de las principales posiciones de kárate, resaltando sus principios técnicos e incluyendo su representación gráfica. El tercer capítulo presenta la descripción, ilustración y aplicación de las técnicas defensivas básicas. El cuarto capítulo describe la ejecución de las técnicas de ataque tanto de brazos como de piernas, ilustra su ejecución y resalta sus principios técnicos y principales errores a evitar. La tercera parte consta de 3 capítulos. El primer capítulo describe e ilustra los ejercicios básicos de calentamiento mientras que el segundo comenta cómo y cuándo debe realizarse la contracción muscular y cuáles son los inconvenientes que ocasiona una mala ejecución. El último capítulo comenta las características del combate deportivo, ofrece consejos para su práctica y describe las características del kihon-kumite y jiyu-ippon-kumite. Adjunta apéndices con una tabla anatómica de los puntos vitales del cuerpo, un listado de consejos útiles para el karateka, las reglas internacionales de arbitraje para las competiciones y un comentario de la Unión Europea de Kárate de dichas reglas.

310. Basile, Augusto (1971). Kárate : defensa para la mujer. Barcelona: Molino. 1a ed. 136 p. : il. ; 14x19,5 cm. ISBN: No ISBN. Depósito legal: B. 7490-1971. Número de registro: 11707-70. Palabras clave: historia, fundamentos técnicos, defensa personal. Resumen: Manual teórico y técnico de kárate. La obra esta compuesta de 4 partes. La primera parte esta formada por 3 capítulos que relatan de forma breve los orígenes del kárate, en que consiste su práctica, y los beneficios que reporta este arte a las mujeres. La segunda parte incluye 3 capítulos que describen e ilustran los golpes fundamentales que puede utilizar una mujer ante situaciones de defensa personal, algunas técnicas de defensa desde una posición sentada y contra ataques frontales. La tercera parte presenta las defensas contra distintos tipos de agarres, contra abrazos, contra ataques por la espalda, contra rateros que intentan sustraer el bolso y defensas desde el suelo. La última parte describe algunos ejercicios para tonificar y fortalecer el cuerpo. Adjunta cuatro apéndices sobre los principios de la defensa personal, la localización e importancia de conocer los puntos vitales, y el significado del kiai.

311. Basile, Augusto (1979). Karate kata 1 : pinan ni dan. Barcelona: Hispano Europea. 1 a ed. 87 p. : il. ; 14x21 cm. ISBN: 84-255-0514-3. Depósito legal: B. 3326-1979. Palabras clave: katas, fundamentos técnicos. Resumen: Manual técnico-didáctico de la kata pinan nidan. Después de explicar el método de entrenamiento de las katas y el significado y objetivo de las mismas, describe e ilustra la secuencia de movimientos de la kata pinan nidan. Además se incluyen los esquemas de movimiento de toda la secuencia técnica. El siguiente capítulo ofrece la secuencia completa del kata con su esquema de desplazamiento y con fotografías a vista de pájaro. Adjunta el reglamento de arbitraje de la federación española de karate. 
312. Basile, Augusto (1979). Karate kata 2 : pinan sho dan. Barcelona: Hispano Europea. 1aㅡ ed. 89 p. : il. ; 14x21 cm. ISBN: 84-255-0515-1. Depósito legal: B. 3327-1979. Palabras clave: katas, fundamentos técnicos. Resumen: Manual técnico-didáctico de la kata pinan sho dan. La obra esta dividida en 6 capítulos, siendo los 3 primeros de ellos explicativos de la importancia de la práctica de los kata, su utilidad y la finalidad del kata pinan sho dan junto con la explicación de sus posiciones y técnicas más significativas, respectivamente. El cuarto capítulo describe la realización de pinan sho dan, con explicaciones breves y concisas, fotografías desde diferentes ángulos y esquemas de movimiento. El siguiente capítulo presenta la kata con su esquema de desplazamiento y una vista de pájaro de sus técnicas. El último capítulo incluye el reglamento de arbitraje de kumite de la federación española de karate.

313. Basile, Augusto (1979). Karate kata 3 : pinan san dan. Barcelona: Hispano Europea. 1a ed. 95 p. : il. ; 14x21 cm. ISBN: 84-255-0516-X. Depósito legal: B. 3328-1979. Palabras clave: katas, fundamentos técnicos. Resumen: Manual técnico-didáctico de la kata pinan san dan. El libro esta dividido en 8 capítulos. Los cuatro primeros capítulos son de introducción al karate y así explican la importancia de la práctica de las kata y su utilidad, los principios técnicos en los que se debe basar la técnica de karate y el kiai. El quinto capítulo explica la finalidad del pinan san dan y sus movimientos técnicos más difíciles, para continuar con la descripción de la realización del kata, con explicaciones breves y concisas, fotografías desde diferentes ángulos y esquemas de movimiento. El siguiente capítulo presenta el esquema de desplazamiento de pinan san dan y una vista de pájaro de sus técnicas. El último capítulo incluye el reglamento de arbitraje de kumite de la federación española de karate.

314. Basile, Augusto (1979). Karate kata 4 : pinan yo dan. Barcelona: Hispano Europea. 1aㅡ ed. 103 p. : il. ; 14x21 cm. ISBN: 84-255-0517-8. Depósito legal: B. 3329-1979. Palabras clave: katas, fundamentos técnicos. Resumen: Manual técnico-didáctico de la kata pinan yo dan. La obra esta dividida en 10 capítulos, con los primeros cuatro dedicadas a la explicación de los fundamentos del karate y las kata, como son la importancia y utilidad de las kata, los principios técnicos de la técnica de karate y el kiai. El siguiente capítulo describe las técnicas más significativas del kata así la leyenda para seguir el ritmo de ejecución del kata. El sexto capítulo describe la realización del kata, con explicaciones breves y concisas, fotografías desde diferentes ángulos y esquemas de movimiento. Los dos capítulos siguientes presentan la aplicación de los movimientos del kata (bunkai), separando la ejecución del kata en dos secuencias respectivamente. El noveno capítulo presenta el esquema de desplazamiento durante la kata y los movimientos vistos desde arriba, y finaliza con la inclusión del reglamento de arbitraje de kumite de la federación española de karate.

315. Basile, Augusto (1979). Karate kata 5 : pinan go dan. Barcelona: Hispano Europea. $1^{a}$ ed. 101 p. : il. ; 14x21 cm. ISBN: 84-255-0518-6. Depósito legal: B. 3330-1979. Palabras clave: katas, fundamentos técnicos. Resumen: Manual técnico-didáctico de la kata pinan go dan. La obra esta dividida en 9 capítulos, con los primeros cuatro dedicadas a la explicación de los fundamentos del karate y las kata, como son la importancia y utilidad de las kata, los principios técnicos de la técnica de karate y el kiai. El quinto capítulo detalla los movimientos más importantes del kata y el ritmo de la kata. El siguiente capítulo describe la realización del kata, con explicaciones breves y concisas, fotografías desde diferentes ángulos y esquemas de movimiento; y continúa con un resumen gráfico de todo el kata. El octavo capítulo presenta el esquema de desplazamiento durante la kata y sus movimientos vistos desde arriba, y termina con el reglamento de arbitraje de kumite de la federación española de karate.

316. Bouzas Hermida, José Enrique (1979). Kata de kárate gankaku: kata de estudio avanzado para cinturones negros. Barcelona: Alas. 1aㅡ ed. 46 p. : il. ; 16x21 cm. ISBN: 84-203-0087-X. Depósito legal: B. 13577-1979. Palabras clave: katas, principios técnicos, aplicación marcial. Resumen: Manual teórico y técnico de kárate. El capítulo introductorio explica el significado de las katas así como las características de su práctica. El primer capítulo comenta los aspectos formales que deban acompañar a la ejecución de una kata además de sus principios técnicos y los errores comunes que suelen aparecer durante su ejecución. El segundo capítulo comenta el significado del ideograma gankaku, presenta su embusen y describe e ilustra los movimientos que componen la kata gankaku, incluyendo la aplicación marcial de sus movimientos más característicos. Adjunta un glosario de términos con su traducción.

317. Cáceres Madrid, José (2006). Manual de consulta para la práctica del karate do. Barcelona: Alas. 1a ed. 187 p. : il. ; 17x24 cm. ISBN: 84-203-0439-5. Depósito legal: B. 5595-2006. Palabras clave: kumite, fundamentos técnicos, principios técnicos, vestimenta, cortesía, aplicación marcial, etiqueta, katas. Resumen: Manual teórico y técnico de kárate. La obra esta formada por 13 capítulos precedidos por un prólogo que resume los principios y pilares del kárate, una nota aclaratoria del autor y las colaboraciones prestadas. El primer capítulo expone los principios para la práctica mientras que el segundo narra la historia del kárate. El tercer capítulo analiza los principios filosóficos del kárate. El cuarto capítulo define los conceptos de arte, marcial, kárate y do, además de comentar las normas de etiqueta y respeto, el sistema de grados, la indumentaria e incluir algunas reflexiones sobre la postura de atención, la mirada, el hara, la respiración, la tensión-relajación, la meditación, el ki y el kiai. El 
quinto capítulo detalla los beneficios de la práctica del kárate para el niño. El sexto capítulo ilustra las distintas zonas de golpeo, posiciones básicas, técnicas de defensa, golpes directos e indirectos, y técnicas de pierna del kárate además de exponer los principios técnicos de su ejecución. El séptimo capítulo comenta las características del trabajo con compañero de ten no kata, chi no kata, jiyu kumite y gin no kata además de incluir su secuencia fotográfica. El octavo capítulo explica el significado de las katas, detalla sus principios técnicos y significado, y presenta la secuencia fotográfica junto con su embusen y esquemas de movimiento de las katas taikioku shodan, heian shodan, heian nidan, heian sandan, heian yondan y heian godan. El noveno capítulo analiza los beneficios de la competición en kárate. El décimo capítulo comenta las características a tener en cuenta en la aplicación real de las técnicas de kárate además de incluir la ilustración de distintos ejemplos prácticos. El décimo primer capítulo incluye las preguntas y respuestas más frecuentes cuando un niño comienza la práctica del kárate. El décimo segundo capítulo presentan los 20 principios rectores del kárate, un organigrama de los estilos de kárate, algunas frases de sus grandes maestros y un diccionario de términos. El último capítulo ofrece un consejo para el continuo aprendizaje.

318. Camps Meseguer, Hermenegildo (1980). Tratado completo de karate : adaptado a todos los estilos y escuelas. Barcelona: Alas. 1aㅡ ed. 217 p. : il. ; $15 \times 21$ cm. ISBN: 84-203-0099-3. Depósito legal: B. 167621980. (2 ${ }^{\mathrm{a}}$ ed., 1982, 220 p.; $3^{\mathrm{a}}$ ed., 1984, 224 p.; $4^{\mathrm{a}}$ ed., 1985, 220 p.; $5^{\mathrm{a}}$ ed., 1987, 220 p.). Palabras clave: fundamentos técnicos. Resumen: Manual técnico de todos los estilos de karate. Después de hacer una breve introducción y presentar la nomenclatura específica del arte marcial, el primer capítulo clasifica y describe las posiciones de karate adjuntando varias fotografías de cada una de ellas y un esquema de la colocación de los pies. El segundo capítulo presenta los criterios generales para realizar correctamente los desplazamientos, los giros y la guardia, así como la descripción de desplazamientos y giros acompañada de los esquemas de movimiento de los pies. Los dos siguientes capítulos clasifican y describen la ejecución técnica de los ataques con brazos y piernas respectivamente, ofreciendo imágenes de su ejecución final. Del mismo modo, el quinto capítulo se centra en los bloqueos mientras que el último lo hace con los derribos o barridos en acción ofensiva y defensiva. También ofrece una serie de consejos básicos para la lucha en el suelo en situaciones de defensa personal. Adjunta diccionario técnico.

319. Camps Meseguer, Hermenegildo (1981). Karate: los 5 katas pinan. Barcelona: Alas. $1^{\underline{a}}$ ed. 110 p. : il. ; 15x21,5 cm. ISBN: 84-203-0122-1. Depósito legal: no. Palabras clave: katas, fundamentos técnicos. Resumen: Manual técnico-didáctico de las katas pinan. El primer capítulo explica el significado, el origen y la importancia, además de comentar la metodología de entrenamiento y ofrecer una clasificación de los mismos. A continuación, cada capítulo presenta una de las katas pinan (shodan, nidan, sandan, yodan y godan) con la descripción de sus secuencias de movimiento, fotografías, esquemas de movimiento, el sentido de los giros y su amplitud, y un compendio al final de cada capítulo con todas las fotografías que componen cada kata.

320. Camps Meseguer, Hermenegildo (1985). Historia y filosofía del kárate. Barcelona: Alas. 1aa ed. 350 p. : il. ; 15x21 cm. ISBN: 84-203-0182-5. Depósito legal: B. 21914-1985. (2a ed., 1990, 348 p.). Palabras clave: historia, fundamentos teóricos, artes marciales, budo, escuelas, relatos, fundamentos filosóficos, budismo, bushido, confucianismo, hinduismo, instituciones, maestros, religión, sintoísmo, taoísmo. Resumen: Tratado teórico de kárate. La obra esta formada por dos partes, precedidas por una presentación que comenta la evolución de las artes marciales y el kárate en particular, y un prefacio que explica las fuentes y metodología utilizada. La primera parte consta de 12 capítulos. El primer capítulo explica el significado y características del kárate, sus beneficios e introducción social. El segundo capítulo relata los sistemas de lucha en la antigüedad desde Egipto y Mesopotamia hasta Grecia y Roma, y los distintos tipos de lucha. El tercer capítulo comenta los sistemas de lucha de la India, los primeros textos escritos así como la relación entre el budismo y las técnicas de combate. El cuarto capítulo discute el origen de China, relata la llegada de Bodhidharma a China y al templo Shaolin junto con su entrenamiento, sus libros, la serie de ejercicios de las 18 manos de lohan y su posterior evolución al shaolin-ssu-chuan-fa, los últimos días de Bodhidharma, comenta la historia de ChangSang-Feng, explica la clasificación de las escuelas interna y externa y las características de las distintas artes marciales que las conforman. El quinto capítulo analiza el desarrollo de las artes marciales dentro de las sociedades secretas, las guerras nacionales e internacionales de China y su influencia sobre las artes marciales e incluye una breve explicación del chuan-fa a mediados del s. XX. El sexto capítulo comenta los diferentes sistemas de combate sin armas de Manchuria, Mongolia, Corea, Sudeste de Asia, Cambodia, Thailandia, Malasia, Indonesia y Filipinas junto con sus características. El séptimo capítulo presenta la localización de Okinawa, su comercio y relación con los países de su alrededor, comenta la posible llegada del chuan-fa a la isla, las características del tode originario de Okinawa, las circunstancias que desarrollaron el arte marcial, la influencia de la ocupación japonesa de la isla, relata la historia de los pioneros del kárate y el nacimiento del moderno kárate de Okinawa. El séptimo capítulo presenta la historia de las antiguas artes marciales de Japón como el sumo, el ju-jutsu, el ninjutsu, la influencia del chuan-fa chino, el judo, el aikido acompañadas de sus características además de 
comentar la introducción del kárate en Japón, las aportaciones de Funakoshi, y expone la historia, maestros y sucesores de los estilos shotokan, shito-ryu, goju-ryu, wado-ryu, y kyokushinkai. El noveno capítulo relata la entrada y circunstancias del chuan-fa y el kárate en Occidente a través de las islas Hawai y la costa occidental de los Estados Unidos. El décimo capítulo expone el espíritu marcial del pueblo japonés durante la Segunda Guerra Mundial, el descubrimiento del kárate por parte del pueblo americano en dicha guerra, la división del kárate en sus diferentes estilos y organizaciones, detalla la introducción del kárate en los Estados Unidos junto con los maestros y principales acontecimientos que posibilitaron dicha introducción, las posteriores evoluciones que sufrió el kárate, la reentrada del kárate en Hawai, la creación de sus distintas asociaciones y la discusión de la creación del full-contact y sus diferencias con el kárate. El capítulo decimoprimero relata la expansión del kárate en Europa, el papel del cine y las películas de artes marciales en dicho proceso, el renacimiento del arte marcial en China, describe la creación y fundamentos teóricos del shorinji-kempo, comenta la celebración de los primeros campeonatos internacionales de kárate. El decimosegundo capítulo analiza la personalidad de Bruce Lee y los fundamentos teóricos del Jeet Kune Do además de presentar su biografía y carrera profesional. La segunda parte consta de 5 capítulos. El primer capítulo comenta las características y fundamentos teóricos del taoísmo, confucianismo, hinduismo, budismo, las diferencias entre el budismo y el hinduismo, y el sintoísmo. El segundo capítulo presenta la práctica del zen, su relación con la religión, las condiciones para su práctica, sus objetivos, fundamentos teóricos y técnicos, además de incluir algunos datos históricos y un breve comentario sobre las distintas escuelas y sus características. El tercer capítulo explica el significado e historia de los términos bushido y budo, comenta la historia, características y funciones de los samuráis, describe sus prácticas marciales del kyudo, yabusame, iaido y kendo, y presenta la historia de los 47 ronin, la vida y aventuras de Miyamoto Musashi y la historia del último samurái. El cuarto capítulo analiza distintos aspectos internos y manifestaciones externas del kárate y las artes marciales como son el sexto sentido, la disciplina espiritual, la actitud mental, la energía interna, el control de la respiración, el ritmo, la mirada, el tameshiwari, el taky-shugyo, el kobudo, el kuatsu y shiatsu, el ceremonial y la simbología. El último capítulo presenta las conclusiones y reflexiones finales de la obra. Adjunta un índice, fé de erratas y un cuadro sinóptico de los orígenes y desarrollo del karate-do.

321. Camps Meseguer, Hermenegildo (1991). Karate superior : kumite para cinturones negros. Barcelona: Alas. 1a ed. 206 p. : il. ; 15x21 cm. ISBN: 84-203-0256-2. Depósito legal: B. 16177-1991. Palabras clave: kumite, fundamentos teóricos, táctica, fundamentos técnicos, principios técnicos, ejercicios, entrenamiento. Resumen: Manual teórico y técnico de kárate. La obra consta de 7 capítulos. El primer capítulo analiza y comenta las distintas facetas que componen el kárate como son la preparación física, la formación psicológica, la instrucción marcial, la expresión artística, la competición deportiva y la defensa personal. El segundo capítulo explica los fundamentos teóricos del kumite como es la descripción de las posiciones de combate, las guardias, la mirada, la respiración, el sentido de la oportunidad (timing), la distancia con el adversario y su ajuste, el trabajo de piernas y las estrategias y tácticas durante el combate. El tercer capítulo presenta varios ejercicios para el entrenamiento técnico individual, por parejas para el trabajo de gohon-kumite, sambon-kumite, ippon-kumite y ejercicios de reacción. El cuarto capítulo explica en qué consisten las técnicas de finta, de provocación, las esquivas, los derribos, y las técnicas de luxación, incluyendo la descripción y representación gráfica de varios ejercicios para el entrenamiento de las esquivas, los derribos y las técnicas de luxación. El quinto capítulo muestra distintos ejercicios para el trabajo de la táctica defensiva, en el suelo, "go no sen", la provocación, la ofensiva, la aplicación de mae-geri, mawashi-geri y ushiro-geri, el encadenamiento de patadas, el encadenamiento de técnicas de puño y pierna, y ejercicios para el entrenamiento de la táctica "sen no sen" (anticipación), incluyendo sus correspondientes ilustraciones explicativas. El sexto capítulo presenta la descripción e ilustración de cinco combinaciones técnicas de aplicación de las katas pinan (bunkai-kumite) y 10 combinaciones libres de yakusoku-kumite. El último capítulo explica los principios básicos para una correcta práctica de kumite. Adjunta un epílogo que señala las técnicas empleadas dentro de la defensa personal.

322. Camps Meseguer, Hermenegildo y Cerezo Arias, Santiago (2005). Estudio técnico comparado de los katas de karate. Barcelona: Alas. 1aㅡ ed. 684 p. : il. ; 21×29,5 cm. ISBN: 84-203-0432-8. Depósito legal: no. Palabras clave: historia, principios técnicos, filosofía, kárate, escuelas, programa técnico. Resumen: Tratado teórico y técnico de kárate. El libro esta formado por 15 capítulos. El primer capítulo explica el significado de los términos kárate y kata, y su relación para luego relatar el origen y la evolución de las artes marciales orientales. Los dos siguientes capítulos explican el desarrollo del kárate en la isla de Okinawa junto con sus maestros y la entrada del kárate en Japón y su diversificación en las distintas escuelas. El quinto capítulo describe el proceso evolutivo que sufrieron los katas hasta la actualidad y los cambios realizados por los diferentes maestros en su sistematización. El sexto capítulo presenta los aspectos filosóficos que impregnan a las artes marciales y su influencia sobre la práctica. Los dos siguientes capítulos exponen las diferentes clasificaciones que se pueden realizar de los katas y las características de los diferentes estilos y escuelas que interpretaron los katas 
primitivos y modernos. El noveno capítulo expone los criterios técnicos que debe reunir un kata para su correcta ejecución junto con las distintas denominaciones que reciben algunas técnicas, en distintos estilos. El décimo capítulo explica las características históricas de los katas Passai, Kushanku y Naifanchi, ilustra la ejecución técnica de estos katas en sus distintas versiones y bajo los estilos shotokan, shito ryu y wado ryu, y estudia las diferentes técnicas entre dichas versiones. Los dos siguientes capítulos explica las características técnicas de los katas procedentes de la línea naha-te y de las líneas tomari-te y shuri-te respectivamente, y presenta las versiones de los estilos goju ryu, shito ryu, uechi ryu y shotokan, analizando las diferencias técnicas entre ambas. El capítulo decimotercero describe brevemente la historia de los katas modernos clásicos Tensho, Ananko, Jurokko, Aoyagi, Miojo, Shinpa e Ishimine no Passai, adjuntando la secuencia fotográfica de cada kata por partes y con primeros planos de los detalles técnicos más significativos. El decimocuarto capítulo expone brevemente las características de los katas modernos didácticos de las cuatro escuelas principales de kárate y la Matsubayashi ryu e ilustra su ejecución técnica por partes, para finalizar con el análisis de los katas energéticos, su evolución y efectos sobre la salud, y el estudio comparado junto con la secuencia fotográfica de los katas más avanzados llamados Hakucho, Hafa, Papuren, Ni-paipo y Wando. Incluye textos históricos, por todo el libro, sobre el bubishi, el makiwara, los samurái, el budo y bujutsu, el bushido, el dojo kun y el material para el entrenamiento. Adjunta bibliografía.

323. Cho, Sihak Henry (1988). Taekwondo : karate coreano. Barcelona: Martínez Roca. $1^{\underline{a}}$ ed. 247 p. : il. ; 17x24 cm. ISBN: 84-270-1238-1. Depósito legal: B. 33694-1988. Palabras clave: historia, fundamentos técnicos. Resumen: Manual teórico y técnico de taekwondo. La obra esta formada por 9 partes. La primera parte esta compuesta por 4 capítulos que describen los antecedentes históricos y la evolución del taekwondo, sus similitudes con el kárate, y su desarrollo moderno. La segunda parte describe la ejecución de distintos ejercicios de calentamiento y las posturas básicas del arte, para en la tercera parte describir los fundamentos del combate libre, el movimiento de los pies y el desplazamiento del cuerpo. La cuarta parte presenta las técnicas de bloqueo, explicando su ejecución y aplicación contra diferentes ataques. La quinta parte explica la ejecución correcta de los ataques de puño, con mano abierta, con el codo y otras partes de la mano, así como su aplicación en distintas posiciones, situaciones y desplazamientos, y sus defensas. La siguiente parte estudia e ilustra la patada frontal junto con sus variantes y sus defensas. Las dos siguientes partes describen e ilustran como realizar, utilizar y defender las patadas laterales y circulares, incluyendo sus variantes y en distintas situaciones; para finalizar con el estudio de otras patadas como el golpe de rodilla, el pisotón y la patada de gancho.

324. Club de Karate Shotokan de Xixona (2004). Crónica de 20 años : 1984-2004. Alicante: Club de Karate Shotokan de Xixona. 1aㅡ ed. 335 p. : il. ; 21x30,5 cm. ISBN: No ISBN. Depósito legal: A. 169-2004. Palabras clave: historia, clubes, competición, eventos, instalaciones. Resumen: Tratado histórico de kárate. La obra esta formada por 19 capítulos que relatan brevemente la historia del club de kárate shotokan de Xixona dividida en cursos escolares, desde 1984-1985 hasta el curso 2002-2003, incluyendo numerosas fotografías de sus profesores, alumnos, competiciones, exhibiciones, cursos, exámenes y celebraciones, además de tablas con resultados y la aclaración de distintos conceptos relacionados con las artes marciales y la práctica del kárate.

325. Cónsul Peñalvert, Josep y Carrasco Millán, Mariano (2000). Iniciación al nanbudo : el arte marcial del tercer milenio. Barcelona: Alas. 1aㅡ ed. 186 p. : il. ; 17x24 cm. ISBN: 84-203-0400-X. Depósito legal: B. 35059-2000. Palabras clave: fundamentos técnicos, historia. Resumen: Manual teórico y técnico de nanbudo. La obra esta dividida en 3 partes. La primera aborda los contenidos históricos del nanbudo, desde la vida de su fundador hasta la creación del arte. La segunda parte comenta los aspectos formales, como son la vestimenta, el comportamiento en el dojo y los grados. Y la tercera parte y más extensa, se dedica a la división del nanbudo como arte marcial. De este modo, los contenidos prácticos se incluyen en 3 apartados distintos como son el arte de guerra (Bu Do Ho), el desarrollo de la energía (Ki Do Ho) y la parte filosófica del arte marcial (Noryoku Kai Hatsu Ho). En la parte de Bu Do Ho se describen e ilustran las técnicas básicas del arte marcial, como son las posiciones, las técnicas de puño, de pierna, de caída, de esquiva, las técnicas de combate (randori), las kata, la organización de la competición y el arbitraje. En la parte de Ki Do Ho explica los ejercicios para trabajar la energía corporal junto con sus fundamentos teóricos, como son el nanbu taiso (gimnasia corporal), nanbu tenchi undo (gimnasia de relajación y estiramiento ligamentario), nanbu shizen no ki undo (ejercicios respiratorios) y nanbu genki kata (katas). La última parte, Noryoku Kai Hatsu Ho, explica las siete fuerzas que se incluyen dentro de los ejercicios de meditación activa para desarrollar el sentido filosófico de aprehensión y comprensión del mundo. Adjunta apéndices sobre el desarrollo de una clase, el desarrollo del nanbudo en la actualidad, terminología, direcciones y bibliografía.

326. Delcourt, Jacques (1968). Técnica del karate : método completo hasta el grado de cinturón negro. Barcelona: Hispano Europea. 1a ed. 298 p. : il. ; 14x20,5 cm. ISBN: No ISBN. Depósito legal: 298791968. (2ª ed., 1973, ISBN: 84-255-0318-3; $3^{a}$ ed., 1975, ISBN: 84-255-0318-3; 4⿳亠丷厂 ed., 1982, ISBN: 84225-0396-5; 5aㅡ ed., ISBN: 84-225-0396-5, 6aㅡ ed., 1990, ISBN: 84-225-0396-5; 7a ed., 1992, ISBN: 84- 
225-0396-5; 8a ed., 1995, ISBN: 84-225-0396-5). Palabras clave: katas, fundamentos técnicos, competición, reglamentos. Resumen: Manual técnico de karate. La obra esta dividida en 5 partes. Comienza con una pequeña introducción sobre los orígenes, características y principios fundamentales que deben regir la práctica del karate. La segunda parte describe técnicamente y señala los errores a evitar en la ejecución de los ataques, paradas, y patadas más comunes, ofreciendo fotografías, ilustraciones y esquemas de movimiento de las mismas. La siguiente parte presenta la secuencia de movimientos de las katas Heian, explicando la ejecución de cada técnica y su significado (bunkai). Los dos últimos capítulos presentan el reglamento de competición y el programa de contenidos técnicos en los exámenes de grado, respectivamente. También incluye un breve glosario.

327. Di Marino, Stéfano y Ghetti, Roberto (2000). Lecciones de kárate : guía práctica fotográfica. Barcelona: De Vecchi. $1^{a}$ ed. 110 p. : il. ; 16x24 cm. ISBN: 84-315-2413-8. Depósito legal: B. 18540-2000. (2 ${ }^{\underline{a}}$ ed., 2001; $3^{a}$ ed., 2004). Palabras clave: katas, kumite, fundamentos técnicos. Resumen: Manual técnico de karate. El libro esta dividido en 7 capítulos. El primero narra la historia y evolución del karate hasta su formación actual. Los dos siguientes capítulos describen los aspectos formales y los tipos de técnicas existentes en el karate, y las partes del cuerpo que pueden ser utilizadas como arma, respectivamente. El cuarto capítulo explica las distintas posiciones y desplazamientos acompañando las explicaciones con material gráfico. A continuación detalla sucintamente la ejecución de las principales técnicas de puño, de pierna, de golpeo, de golpeo con el codo y con la rodilla, y las paradas. El sexto capítulo describe las técnicas que se incluyen dentro del trabajo de kihon kumite y termina con la descripción de los movimientos de las katas heian shodan y pinan shodan.

328. Díaz Martínez, Juan José (1979). Pedagogía del kárate infantil. Madrid: Copi. 1aa ed. 220 p. : il. ; 15x21,5 cm. ISBN: 84-85723-01-5. Depósito legal: M. 39589-1979. Palabras clave: fundamentos técnicos, pedagogía, didáctica. Resumen: Manual teórico, técnico y pedagógico de karate. La monografía esta compuesta por 12 capítulos, precedidos por un breve comentario sobre la historia del karate, su capacidad para educar físicamente y para desarrollar las capacidades físicas del practicante. El primer capítulo presenta el análisis del desarrollo evolutivo del niño y las características de sus sistemas vitales para luego ofrecer algunos ejercicios que desarrollen la flexibilidad, la velocidad, la agilidad y la destreza. El segundo capítulo ofrece un breve comentario sobre la teoría y clasificación de los juegos así como ejercicios para desarrollar en la clase. Los dos siguientes capítulos presentan de forma abreviada las teorías de la agresividad y los principios psicopedagógicos que deben ser tenidos en cuenta por el profesor o entrenador para educar al niño. El quinto capítulo resalta la importancia de la atención del niño dentro del aprendizaje y propone un método para aplicar en las clases de karate. Continúa con la explicación de la organización de la clase y la ordenación de los contenidos técnicos que el autor lleva a cabo en base a los cinturones. El octavo capítulo describe e ilustra los katas taykyoku para continuar con las caídas y con algunas proyecciones parecidas a las del judo. El penúltimo capítulo ofrece una serie de ejercicios por parejas que representan el trabajo ante situaciones de defensa personal y finaliza con el esquema de técnicas por grados. Adjunta bibliografía consultada.

329. Didier, Francis y Sitruk, Guy (1979). El karate en diez lecciones. Bilbao: Cantábrica. 1a ed. 199 p. : il. ; $13 \times 20 \mathrm{~cm}$. ISBN: 84-221-0379-6. Depósito legal: BI. 553-1979. (2 $2^{\mathrm{a}}$ ed., 1985). Palabras clave: fundamentos técnicos, competición. Resumen: Manual teórico y técnico de karate. El primer capítulo introduce al lector en el arte marcial, comentando sus características principales y algunas nociones básicas de vestimenta, comportamiento y saludo así como algunos ejercicios de calentamiento y flexibilidad. El segundo capítulo describe las partes del cuerpo que pueden ser utilizadas como arma dentro del karate, los mecanismos físicos y mentales que ha de desarrollar un practicante, y los puntos vitales del cuerpo humano. Los siguientes 7 capítulos presentan, ilustran y explican las posiciones básicas, los ataques directos e indirectos de puño, las técnicas de pie, los blocajes, la explicación de los diferentes tipos de trabajo de kumite junto con algunos ejemplos prácticos, el trabajo de encadenamiento de técnicas tanto en solitario como con compañero, y ejemplos de técnicas de barrido. El último capítulo, además de explicar el reglamento de la competición y su organización, también discute sus pros y contras e incluye un léxico. Adjunta un anexo con algunos de los clubes que existen en el territorio español.

330. Escoriza Archela, Antonio (2009). Zanshin : buscando el equilibrio en la competición. León: Antonio Escoriza Archela. 1a ed. 215 p. : il. ; 15x21 cm. ISBN: 978-84-613-6973-7. Depósito legal: LE. 18902009. Palabras clave: fundamentos teóricos, táctica, kárate, astrología, competición, personalidad. Resumen: Tratado teórico de kárate. El libro esta formado por 12 capítulos precedidos por un prólogo que explica el significado de los términos anshin y zanshin y una introducción que resume la biografía, inquietudes del autor y los contenidos de la obra. El primer capítulo explica brevemente las vertientes deportiva y tradicional del kárate, su historia, el significado del shiai kumite y el fundamento del libro. El segundo capítulo expone las características y significado de las cuatro actitudes primarias como son la pasión, el coraje, la constancia y la ilusión acompañadas de un relato explicativo. El tercer capítulo enumera las tres dimensiones que conforman al ser humano, explica las diferentes teorías del 
pensamiento antiguo sobre la conducta, detalla las características conductuales de los temperamentos colérico, sanguíneo, flemático y melancólico además de la relación entre temperamento, carácter y personalidad. El cuarto capítulo presenta las características de las tipologías constitucionales, los fundamentos teóricos de la programación neurolingüística además de los principios del liderazgo, los estilos de liderazgo de cada temperamento y la teoría del liderazgo situacional. El quinto capítulo relata la metodología de análisis de la carta astral. El sexto capítulo define los conceptos de estrategia y táctica así como su aplicación al kárate y la vida. El séptimo capítulo resalta la importancia del control ante una venta o un combate de kárate. El octavo capítulo explica las tácticas de la competición de kárate denominadas tu primero, presión, centro, línea, círculo, ataque y contraataque. El noveno capítulo expone la relación entre los temperamentos, los cuatro elementos básicos de tierra, agua, fuego y aire, y las tres dimensiones del ser humano además de un breve análisis de sus características. El décimo capítulo detalla las motivaciones de los distintos temperamentos mientras que el capítulo decimoprimero explica la aplicación de los elementos y signos zodiacales a la práctica y competición de kárate. El último capítulo describe las tácticas de competición más adecuadas para cada elemento. Adjunta la explicación del concepto "ichigo ichie" así como el currículo del autor y un resumen de las medallas conseguidas por sus alumnos.

331. Falsoni, Ennio (1972). El karate en 12 lecciones. Barcelona: De Vecchi. 1a ed. 191 p. : il. ; 17x24 cm. ISBN: No ISBN. Depósito legal: B. 32249-1972. (3ae ed., 1976, ISBN: 84-315-0921-X; 4르 ed., 1977, ISBN: 84-315-0921-X; 5aㅡ ed., 1979, ISBN: 84-315-0921-X; 6aㅡ ed., 1982, ISBN: 84-315-0921-X). Palabras clave: katas, kumite, fundamentos técnicos. Resumen: Manual técnico-didáctico de iniciación al karate. El libro esta dividido en 12 lecciones. La primera lección hace un resumen de los aspectos básicos de la práctica, como el saludo, la vestimenta, el calentamiento, cómo cerrar el puño y el kiai. A continuación comienzan las lecciones prácticas en las que se explica la ejecución de las diferentes técnicas, como las posiciones en la segunda lección, el choku-zuki en la tercera, el gyaku-zuki y su entrenamiento en el makiwara en la cuarta, o age-uke y gedan-barai en la quinta. La sexta lección comienza con la técnica shuto-uke y las patadas frontal y lateral. Continúa con la parada soto-ude-uke y el mawashi-geri, para en la octava lección describir secuencias de trabajo de kihon. A continuación presenta el trabajo de las patadas vistas anteriormente pero en movimiento así como ejercicios por parejas para entrenar dichas técnicas. Los dos últimos capítulos están dedicados al trabajo avanzado de kihon kumite y de la kata Heian shodan. Adjunta un apéndice en el que se explica brevemente el tameshiwari, la prevención de accidentes, la situación del karate a nivel mundial, las reglas de competición de la Unión Europea de Karate y un breve vocabulario.

332. Falsoni, Ennio (1986). El karate en 12 lecciones. Barcelona: De Vecchi. 1a ed. 191 p. : il. ; 17x23,5 cm. ISBN: 84-315-0292-4. Depósito legal: B. 24562-1986. (2aㅡ ed., 1988; $3^{a}$ ed., 1991). Palabras clave: katas, kumite, fundamentos técnicos. Resumen: Manual técnico-didáctico de iniciación al karate. El libro esta dividido en 12 lecciones. La primera lección hace un resumen de los aspectos básicos de la práctica, como el saludo, la vestimenta, el calentamiento, cómo cerrar el puño y el kiai. A continuación comienzan las lecciones prácticas en las que se explica la ejecución de las diferentes técnicas, como las posiciones en la segunda lección, el choku-zuki en la tercera, el gyaku-zuki y su entrenamiento en el makiwara en la cuarta, o age-uke y gedan-barai en la quinta. La sexta lección comienza con la técnica shuto-uke y las patadas frontal y lateral. Continúa con la parada soto-ude-uke y el mawashi-geri, para en la octava lección describir secuencias de trabajo de kihon. A continuación presenta el trabajo de las patadas vistas anteriormente pero en movimiento así como ejercicios por parejas para entrenar dichas técnicas. Los dos últimos capítulos están dedicados al trabajo avanzado de kihon kumite y de la kata Heian shodan. Adjunta un apéndice en el que se explica brevemente el tameshiwari, la prevención de accidentes, la situación del karate a nivel mundial, las reglas de competición de la Unión Europea de Karate y un breve vocabulario.

333. Federación Catalana de Kárate (1983). Preparación física para karate. Barcelona: Polux Internacional. $1^{\text {a }}$ ed. 127 p. : il. ; 17x24 cm. ISBN: 84-85867-02-5. Depósito legal: B. 27069-1983. Palabras clave: fundamentos teóricos, entrenamiento, ejercicios, capacidades físicas, cualidades físicas, lesiones, planificación del entrenamiento, preparación física, tests. Resumen: Tratado teórico y técnico de la preparación física en kárate. El libro esta formado por 6 capítulos, precedidos por una introducción que resume los contenidos del libro. El primer capítulo explica en qué consiste la preparación física, cuáles son sus objetivos, beneficios y resultados. El segundo capítulo define el concepto forma física, detalla los tipos de evaluación de la forma física que existen, describe diferentes tests o pruebas para evaluar la constitución, obesidad, resistencia, fuerza, flexibilidad y elasticidad del individuo, un cuestionario médico a realizar antes del entrenamiento y enumera algunos factores de riesgo que obligan a realizar un examen médico previo. El tercer capítulo define las capacidades y cualidades físicas básicas. El cuarto capítulo explica qué es el entrenamiento, cuáles son sus tipos, define las variables de un buen calentamiento incluyendo una tabla ilustrada de ejercicios, explica los fundamentos teóricos de los entrenamientos cardio-respiratorios, de flexibilidad y elasticidad, de fuerza y de pesas, incluyendo numerosos ejercicios acompañados de su representación gráfica además 
de otros ejercicios para el desarrollo de la velocidad, la velocidad de reacción, la agilidad, los multisaltos, los abdominales, de relajación, de enfriamiento y ejercicios específicos de pesas para el kárate. El quinto capítulo expone los fundamentos teóricos de la programación y planificación del entrenamiento. El último capítulo detalla las lesiones y patologías más frecuentes en la práctica del kárate, resalta las precauciones a tener en cuenta en la ejecución de ciertos ejercicios, define el concepto de fatiga, sus tipos y el sobreentrenamiento para finalizar enumerando las contraindicaciones para la práctica de ejercicio físico.

334. Federación Española de Kárate, Escuela Nacional de Entrenadores (1986). Preparación física específica para el kárate. s.l.: Federación Española de Kárate. 1aㅡ ed. 54 p. : il. ; 15x21 cm. ISBN: No ISBN. Depósito legal: M. 13493-1986. Palabras clave: fundamentos teóricos, entrenamiento, ejercicios, capacidades físicas, habilidades motrices, preparación física, sistemas de entrenamiento, tests. Resumen: Manual teórico y técnico de preparación física. El libro esta formado por 9 capítulos. El primer capítulo explica los sistemas energéticos del cuerpo humano. El segundo capítulo describe la ejecución de distintas pruebas de valoración funcional. El tercer capítulo explica las características de los distintos periodos que conforman la planificación del entrenamiento de un karateka. Los siguientes tres capítulos estudian los distintos métodos de entrenamiento de la resistencia, fuerza y velocidad aplicados al kárate, incluyendo la ilustración de algunos ejercicios específicos. El séptimo capítulo analiza los tipos de entrenamiento y movimientos en el trabajo de movilidad articular, incluyendo algunos de sus ejercicios ilustrados. Los dos últimos capítulos exponen el entrenamiento de la agilidad y el entrenamiento mental.

335. Fernández Solís, Luis (1989). Kárate de competición (entrenadores nacionales y regionales). Málaga: Luis Fernández Solís. 1a ed. 98 p. : il. ; 21x30 cm. ISBN: 84-404-5585-2. Depósito legal: no.

336. Fernández Solís, Luis (1994). La competición del karate : entrenamiento de campeones. Barcelona: Paidotribo. 1aㅡ ed. 267 p. : il. ; 15x21,5 cm. ISBN: 84-8019-112-0. Depósito legal: B. 072-1994. Palabras clave: competición, programa técnico. Resumen: Análisis técnico y táctico de la competición de karate. Los cinco primeros capítulos del libro están estructurados de la misma manera, comenzando con una clasificación de las acciones técnicas y su posterior explicación y ejemplificación gráfica. Las acciones tratadas son las defensas de brazos, los desplazamientos, los ataques de puño, las técnicas de piernas y los barridos. El sexto capítulo explica los sistemas de competición, tanto de ataque como de reacción. El séptimo capítulo clasifica y describe los aspectos de distancia, tensión y mirada en la competición, para en el octavo capítulo pasar a explicar los distintos trabajos de táctica y estrategia, y la utilización de la distancia y de la tensión como aspectos tácticos. El siguiente capítulo aborda los aspectos psicológicos del competidor, comentando algunos de los aspectos más importantes; y finaliza con una explicación breve de la metodología del entrenador en el entrenamiento.

337. Fernández-Bravo del Prado, Francisco Javier (2009). 1979-2009 : 30 años de historia. Ciudad Real: Club Shotokan-Ciudad Real. 1aㅡ ed. 95 p. : il. ; 14x21 cm. ISBN: No ISBN. Depósito legal: CR. 311-2009. Palabras clave: historia, clubes, competición, eventos, fotografía. Resumen: Tratado histórico de kárate. El libro relata la historia del club shotokan de kárate de Ciudad Real a través de un conjunto de fotografías de sus maestros, alumnos, competiciones, exhibiciones y hechos más significativos.

338. Ferré i Odena, Alberto (1979). Karate completo evolutivo para todos : amarillo-naranja. Alicante: Daimyo. $2^{\underline{a}}$ ed. 35 p. : il. ; 32x21 cm. ISBN: 84-300-0619-2. Depósito legal: A. 150-1979. Palabras clave: katas, kumite, historia, fundamentos técnicos, entrenamiento, unidades didácticas. Resumen: Manual teórico y técnico de kárate. La obra esta formada por 6 capítulos, precedidos por una introducción que describe la ejecución de varios ejercicios de calentamiento, relata la historia del kárate y explica en qué consiste y sus contenidos. Los siguientes cinco capítulos presentan los contenidos a desarrollar durante una sesión práctica de una hora de duración incluyendo numerosos gráficos explicativos. El primer capítulo describe como atarse el cinturón, la forma de saludar, la ejecución de tsuki-chudan, gedan barai y su entrenamiento en desplazamiento. El segundo capítulo explica la ejecución de uchiuke, gyaku-tsuki, oi-tsuki, mae-geri y su entrenamiento en desplazamiento. El tercer capítulo estudia las técnicas mawashi-geri, soto-uke, jodan-age-uke, las posiciones ko-kutsu-dachi y kiba-dachi, y algunas combinaciones de ippon-kumite. El cuarto capítulo explica las técnicas shuto-uke, yoko-geri y la aplicación del tai-sabaki. El quinto capítulo describe las técnicas mawashi-tsuki, uraken, tetsui-uchi, tetsui-uke, ushiro-geri, junto con sus correspondientes entrenamientos y dos técnicas de ipponkumite. El último capítulo explica en qué consisten las katas y cuál es su clasificación. Adjunta desplegables con la representación gráfica y explicación de las katas eian shodan y eian nidan.

339. Fraguas, José María (1984). Shito ryu karate do : katas superiores. Matsukade - Bassai-Dai - Niseshi Ro-Hai - Seienchin - Soochin - Seipai. Madrid: Esteban Sanz Martínez. 1ae ed. 138 p. : il. ; 15x21 cm. ISBN: 84-85977-13-0. Depósito legal: M. 31497-1984. Palabras clave: katas, historia, fundamentos técnicos, kárate. Resumen: Manual teórico y técnico de kárate. El libro esta compuesto de 9 capítulos, precedidos de una introducción que explica la práctica y beneficios del kárate. El primer capítulo relata la formación del estilo Shito Ryu y sus maestros hasta la actualidad, incluyendo un árbol genealógico de sus primeros representantes. El segundo capítulo explica el significado de las katas, su historia, el 
significado de sus movimientos y técnicas, los aspectos y características en su realización y la actitud mental. Los siguientes capítulos ilustran y presentan la secuencia técnica de las katas matsukade, bassai-dai, niseshi, (matsumura no) ro-hai, seienchin, soochin y seipai, así como el bunkai de las técnicas más características de las mismas.

340. Funakoshi, Gichin (1986). Karate-do : mi camino. Madrid: Eyras. 1aㅡ ed. 153 p. : il. ; 11x18 cm. ISBN: 8485269-46-2. Depósito legal: no. (2ª ed., 1989; 3aㅡ ed., 1992). Palabras clave: historia, biografía, relatos. Resumen: Autobiografía de Gichin Funakoshi. Compuesta por 7 capítulos, narra algunas de las anécdotas que fueron conformando la vida de Funakoshi y el karate moderno. El primer capítulo describe sus primeros años de vida y su introducción en el karate, para continuar con la historia y formación del karate hasta que fue presentado a la sociedad. El tercer capítulo presenta algunas historias sobre los principios morales que rigen el karate, para continuar con el relato de la presentación del karate a la sociedad japonesa, la aparición de los primeros libros y exhibiciones. El quinto capítulo describe algunas de las historias que rodearon al karate en sus inicios, cómo introdujo la cortesía dentro del karate y cómo ha sido su vida. El sexto capítulo comenta las seis reglas para practicar correctamente el kárate, cómo violó dichas reglas una vez en su vida, y cómo el karate puede ser practicado por cualquier persona. Finaliza con un breve comentario sobre la utilización de las distintas partes del cuerpo como arma, algunos recuerdos de su infancia y cómo finalmente llegó a convertirse en una actividad internacional. Adjunta un glosario de términos y un cuadro cronológico de Japón y de sus datos biográficos.

341. Funakoshi, Gichin (1987). Karate-do kyohan : el texto maestro. Madrid: Eyras. 1aㅡ ed. 257 p. : il. ; 18x25,5 cm. ISBN: 84-85269-43-7. Depósito legal: M. 29423-1987. Palabras clave: katas, kumite, fundamentos técnicos, principios técnicos, defensa personal, combate, entrenamiento, táctica, kyusho, sistemas de entrenamiento. Resumen: Manual teórico y técnico de kárate. El libro esta formado por 7 capítulos. El primer capítulo a modo de introducción explica en qué consiste el kárate, el significado y evolución de su definición, la ética del practicante de kárate, su historia y maestros, la clasificación de las katas del estilo shotokan, relata la presentación pública del kárate y expone los distintos paradigmas que puede adoptar su práctica. El segundo capítulo presenta las distintas zonas de golpeo del cuerpo así como la descripción de la utilización de las principales técnicas de defensa y ataque con los puños y piernas. El tercer capítulo describe varios ejercicios del entrenamiento básico junto con sus ilustraciones para en el cuarto capítulo exponer las características de cada una de las katas del estilo shotokan, los principios para progresar en el entrenamiento, las líneas de movimiento que siguen las katas y describir e ilustrar las katas taikyoku shodan, taikyoku nidan, taikyoku sandan, heian shodan, heian nidan, heian sandan, heian yodan, heian godan, bassai, kwanku, tekki shodan, tekki nidan, tekki sandan, hangetsu, jutte, empi, gankaku, jion, y la ten no kata omote, acompañadas del esquema de colocación de los pies en cada posición y la línea de ejecución. El quinto capítulo profundiza en los diferentes tipos de combate, aclarando el significado del combate, describiendo la ejecución técnica por compañeros de la ten no kata ura, comentando las características del trabajo de combate preestablecido a tres (sambom gumite) y a un paso (ippon gumite), señalando los principios técnicos del combate con las piernas, describiendo e ilustrando varias secuencias técnicas del combate iai (de rodillas) y algunas técnicas de proyección y exponiendo los principios tácticos ante ataques armados o en situaciones de defensa personal por parte de una mujer. El sexto capítulo localiza y define cada uno de los puntos vitales del cuerpo humano para finalizar con la exposición de las máximas del estudiante para utilizar el kárate adecuadamente. Adjunta un apéndice sobre cómo construir un makiwara y un glosario.

342. Funakoshi, Gichin (2002). Karate-do nyumon : el texto introductorio del gran maestro. Barcelona: Hispano Europea. $1^{\mathrm{a}}$ ed. 122 p. : il. ; 17x23 cm. ISBN: 84-255-1441-X. Depósito legal: B. 20320-2002. Palabras clave: katas, historia, fundamentos técnicos, principios técnicos, relatos. Resumen: Manual teórico y técnico de kárate. La obra esta formada por 13 capítulos. El primer capítulo relata una historia sobre el poder del kárate y comenta los prejuicios acerca del mismo. Los dos siguientes capítulos comentan la historia de las islas Ryukyu y los orígenes del kárate. El cuarto capítulo explica las razones para el cambio de significado de la palabra kárate junto con las causas sociales y políticas. Los dos siguientes capítulos presentan las biografías de Itosu y Azato junto con alguna de sus historias más significativas y su interpretación de la práctica del kárate. El séptimo capítulo enumera y comenta los principios del entrenamiento para luego explicar los diferentes trabajos existentes dentro del kárate y ofrecer unos consejos generales para su adecuado entrenamiento. Los dos siguientes capítulos describen la ejecución y utilización de los puños, los pies y las posiciones fundamentales con el apoyo de ilustraciones. Los dos siguientes capítulos describen el trabajo de la Ten no Kata Omote y Ura, explicando su ejecución técnica por partes e ilustrando cada uno de los movimientos. El último capítulo relata dos historias sobre Azato y el combate entre Matsumura y Uehara. Adjunta un índice alfabético.

343. Funakoshi, Gichin (2005). Los veinte principios rectores del kárate : el legado espiritual del gran

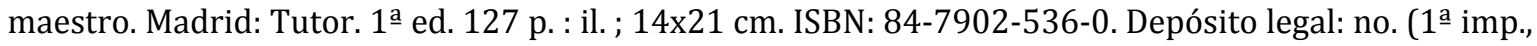
2006; 2a ed., 2008). Palabras clave: fundamentos teóricos, táctica, principios técnicos, principios filosóficos. Resumen: Tratado teórico de kárate. La obra esta formada por 20 capítulos, precedidos por 
una introducción que comenta las características de la obra original en japonés y un prólogo que señala el objetivo de la obra. Los 20 capítulos presentan los principios técnicos, tácticos, filosóficos y espirituales que rigen la práctica del kárate. Adjunta un epílogo que narra la historia del kárate y un comentario de los preceptos más significativos.

344. Funakoshi, Gichin (2006). Karate jutsu : las enseñanzas originales del gran maestro Funakoshi. Barcelona: Hispano Europea. 1aㅡ ed. 160 p. : il. ; 17x23 cm. ISBN: 978-84-255-1687-0. 84-255-1687-0. Depósito legal: B. 37292-2006. Palabras clave: katas, historia, fundamentos técnicos, principios filosóficos, salud. Resumen: Manual teórico y técnico de kárate. La obra consta de 4 partes precedidas por un prefacio que señala la importancia de la obra y la historia del original, un prólogo que aclara el objetivo de la obra, una introducción que analiza el valor de la obra y su estructura y el prefacio del autor que señala las causas para escribir la obra. La primera parte esta formada por 3 capítulos. El primer capítulo explica en qué consiste el kárate, sus estilos, las formas practicadas en la actualidad y cómo evolucionó el sistema de competición. El segundo capítulo analiza las aplicaciones y paradigmas que conforman la práctica del kárate. El tercer capítulo ofrece varios consejos sobre el entrenamiento. La segunda parte incluye la descripción de cómo cerrar el puño, las posiciones básicas y cómo fabricar un makiwara, explica las principales técnicas de mano y de pierna, los tipos de embusen y las técnicas de derribo. La tercera parte describe la ejecución técnica de las katas heian shodan, naihanchi shodan y koshokun acompañadas de su secuencia fotográfica además de enumerar la secuencia técnica de las katas heian nidan, heian sandan, heian yodan, heian godan, naihanchi nidan, naihanchi sandan, sehshan, passai, wanshu, chinto, jitte y jion. La última parte esta formada por dos capítulos. El primer capítulo expone los principios rectores del kárate y los métodos de escape. El segundo capítulo detalla la difusión del kárate en la sociedad. Adjunta notas aclaratorias.

345. Funakoshi, Gichin (2007). Karate-do : mi camino. Móstoles: Dojo. $1^{\underline{a}}$ ed. 153 p. : il. ; 11x18 cm. ISBN: 978-84-935400-0-5. Depósito legal: M. 2904-2007. Palabras clave: historia, biografía, relatos. Resumen: Autobiografía de Gichin Funakoshi. Compuesta por 7 capítulos, narra algunas de las anécdotas que fueron conformando la vida de Funakoshi y el karate moderno. El primer capítulo describe sus primeros años de vida y su introducción en el karate, para continuar con la historia y formación del karate hasta que fue presentado a la sociedad. El tercer capítulo presenta algunas historias sobre los principios morales que rigen el karate, para continuar con el relato de la presentación del karate a la sociedad japonesa, la aparición de los primeros libros y exhibiciones. El quinto capítulo describe algunas de las historias que rodearon al karate en sus inicios, cómo introdujo la cortesía dentro del karate y cómo ha sido su vida. El sexto capítulo comenta las seis reglas para practicar correctamente el kárate, cómo violó dichas reglas una vez en su vida, y cómo el karate puede ser practicado por cualquier persona. Finaliza con un breve comentario sobre la utilización de las distintas partes del cuerpo como arma, algunos recuerdos de su infancia y cómo finalmente llegó a convertirse en una actividad internacional. Adjunta un glosario de términos y un cuadro cronológico de Japón y de sus datos biográficos.

346. Funakoshi, Gichin (2008). To-te jitsu : el arte del puño de Okinawa. Madrid: Budo International. $1^{\underline{a}}$ ed. 319 p. : il. ; 17x24 cm. ISBN: 978-84-92484-01-0. Depósito legal: M. 18418-2008. Palabras clave: katas, historia, fundamentos técnicos, principios filosóficos, salud. Resumen: Manual teórico y técnico de kárate. La obra esta formada por 4 capítulos, precedidos por un prefacio que explica la evolución del kárate, la nota del editor inglés, un prólogo que comenta las características de la obra y una introducción que señala las causas para escribir la obra. El primer capítulo explica en qué consiste el kárate, sus estilos, las formas practicadas en la actualidad, cómo evolucionó el sistema de competición y ofrece varios consejos sobre el entrenamiento. El segundo capítulo incluye la descripción de cómo cerrar el puño, las posiciones básicas y cómo fabricar un makiwara acompañados de su representación gráfica, explica las principales técnicas de mano y de pierna, los tipos de embusen y las técnicas de derribo. El tercer capítulo describe la ejecución técnica de las kata bin-an shodan, naihanchi shodan y koshokun acompañadas de su secuencia fotográfica además de enumerar la secuencia técnica de las katas bin-an nidan, bin-an sandan, bin-an yodan, bin-an godan, naihanchi nidan, naihanchi sandan, seishan, passai, wanshu, chinto, jitte y jion. El último capítulo expone los principios rectores del kárate y los métodos de escape. El segundo capítulo detalla las aplicaciones y paradigmas que conforman la práctica del kárate, sus principios rectores y las causas de su popularidad, incluyendo los textos originales en japonés.

347. García Espada, Luis Alberto (1998). Karate do shito ryu. Madrid: Multideporte. 1aㅡ ed. 171 p. : il. ; 16x21,5 cm. ISBN: 84-87325-26-2. Depósito legal: M. 46943-1998. Palabras clave: katas, fundamentos teóricos, fundamentos técnicos, defensa personal. Resumen: Manual teórico y técnico de kárate. La obra esta formada por 20 capítulos. Los tres primeros capítulos comentan brevemente la filosofía del kárate, su historia y las características técnicas del estilo shito ryu junto con la definición de algunos términos de kárate. Los siguientes 6 capítulos ilustran las distintas posiciones, defensas, ataques directos, ataques circulares de brazo, ataques de codo y ataques de pierna del estilo shito ryu. Los siguientes diez capítulos presentan la secuencia fotográfica de los movimientos de las katas pinan 
(shodan, nidan, sandan, yondan y godan), juroku, bassai-dai, rohai, sanchin y seienchin junto con la técnica y posición adoptadas en cada movimiento. El último capítulo incluye la secuencia fotográfica de varias técnicas de defensa personal. Adjunto dos anexos sobre diferentes explicaciones técnicas y vocabulario.

348. García Espada, Luis Alberto (2008). Shito ryu karate do : historia, filosofía, katas y mtc. Madrid: Luis Alberto García Espada. 1aㅡ ed. 193 p. : il. ; 21x29,5 cm. ISBN: 978-84-612-1538-6. Depósito legal: M. 1601-2008. Palabras clave: katas, kumite, historia, entrenamiento, atemijutsu, fundamentos filosóficos, medicina tradicional china, sistemas de entrenamiento. Resumen: Manual teórico y técnico de kárate. La obra esta formada por 15 capítulos precedidos por los agradecimientos. Los cuatro primeros capítulos narran la historia del kárate, ilustran su árbol genealógico y los maestros que más influyeron en Mabuni Kenwa y relata la historia del estilo shito-ryu. El quinto capítulo explica en qué consisten los trabajo de kihon, hojo-undo, toshu hojo-undo y kigu hojo-undo acompañados de varias ilustraciones explicativas. El sexto capítulo comenta la historia y significado de las katas, enumera sus principios técnicos, el significado del bunkai, detalla las características de las katas shinsei, shinpa, juroku, shiho kosookun, matsukaze, aoyagi, miojo e hiji ate goho acompañadas de la secuencia fotográfica de su ejecución, y señala la importancia de las katas. El séptimo capítulo expone el objetivo del kumite, relata su historia y analiza sus principios técnicos y tácticos. El octavo capítulo explica en qué consiste el atemi-jutsu, comenta los cuatro niveles de aprendizaje, sus tipos y métodos de aplicación y los fundamentos teóricos del jintai kyusho-jutsu. El noveno capítulo presenta los fundamentos teóricos de la medicina tradicional china como la teoría del yin/yang, la teoría de los cinco elementos, los meridianos, los puntos y su manipulación para el tratamiento de ciertas dolencias. El décimo capítulo presenta los fundamentos filosóficos del estilo shito-ryu mientras que el siguiente narra la historia del zen, sus escuelas y práctica. El décimo segundo capítulo incluye el cuadro básico de los contenidos de shito-ryu mientras que el siguiente capítulo describe el trabajo de tenshin happo. El décimo cuarto capítulo explica el significado del dojo y sus normas de cortesía. El último capítulo incluye numerosas fotografías de Mabuni. Adjunta un anexo con el estudio de kaishu waza.

349. Gómez Vivar, Ángel (2003). Karate : defensa personal. Madrid: Esteban Sanz Martínez. 1aㅡ ed. 143 p. : il. ; 17x23,5 cm. ISBN: 84-85977-93-9. Depósito legal: M. 50370-2003. Palabras clave: fundamentos teóricos, fundamentos técnicos, principios técnicos, defensa personal, estrategia, táctica, preparación física, preparación psíquica. Resumen: Manual teórico y práctico sobre la aplicación del kárate a la defensa personal. La primera parte del libro, compuesta de 5 capítulos, explica la teoría de la defensa personal, esto es, la preparación física y mental ante una agresión, los tipos de agresores y sus características, el comportamiento táctico y estratégico ante una agresión y las consideraciones pertinentes a nuestra respuesta ante una agresión. La segunda parte del libro esta compuesta por 4 capítulos y cada uno de ellos describe textual y gráficamente los diferentes tipos de técnicas de kárate que se pueden aplicar a las situaciones antes descritas. El primer capítulo presenta las técnicas básicas de defensa, de ataque de puño, de codo, de pierna y las posiciones a adoptar, para continuar con nuestra actuación ante agarres, ante ataques de puño y pierna, y por último contra un arma (palo y cuchillo).

350. Gómez-Trigo Ochoa, Gerardo (2002). Karate para discapacitados. Libro segundo : las cuatro primeras katas (fascículo primero). Madrid: Gerardo Gómez-Trigo Ochoa. 1aㅡ ed. 33 p. : il. ; 15x21 cm. ISBN: 84932604-1-X. Depósito legal: M. 22145-2002. Palabras clave: formas. Resumen: Manual teórico de kárate. El libro esta formado por 4 partes precedidas por los agradecimientos y una presentación que relata la situación del autor y su práctica del kárate. Las cuatro partes incluyen la traducción de los términos utilizados para la explicación de cada kata, la descripción de su secuencia de movimientos, su descomposición en técnicas y el embusen. Las katas estudiadas son pinan shodan, sanchin, pinan nidan y gekisai dai ichi respectivamente. Adjunta bibliografía.

351. Gómez-Trigo Ochoa, Gerardo (2003). Karate para discapacitados. Libro segundo : katas. Fascículo primero B : cuatro katas disminuidas. Madrid: Gerardo Gómez-Trigo Ochoa. 1aㅡ ed. 39 p. ; 15x21,5 cm. ISBN: 84-932604-5-2. Depósito legal: M. 19267-2003. Palabras clave: formas. Resumen: Manual teórico de kárate. La obra esta formada por 4 partes precedidas por un prólogo que explica los contenidos de la obra. Las cuatro partes incluyen la traducción de los términos utilizados para la explicación de cada kata, la descripción de su secuencia de movimientos y su descomposición en técnicas y posiciones. Las katas estudiadas son pinan shodan, pinan nidan, sanchin y gekisai dai ichi disminuida respectivamente. Adjunta bibliografía.

352. Grupp, Joachim (2005). Katas de kárate shotokan : vol. 1. Madrid: Tutor. 1aㅡ ed. 222 p. : il. ; 17x24 cm. ISBN: 84-7902-490-9. Depósito legal: M. 911-2005. Palabras clave: katas, historia, kárate, aplicación marcial. Resumen: Manual teórico y técnico de kárate. La obra esta formada por 5 capítulos. El primer capítulo narra la historia del kárate shotokan, la formación del karate-do y las características de las katas del estilo shotokan. Los siguientes tres capítulos hacen una breve introducción, presentan la secuencia fotográfica de su ejecución, enumeran la secuencia de acciones e ilustran algunas de las aplicaciones de las katas Heian, de las katas Tekki, de las katas superiores básicas Bassai-Dai, Jion, 
Empi, Hangetsu y Kanku-Dai y de las katas superiores avanzadas Nijushiho, Bassai-Sho, Gojushiho Sho y Gojushiho Dai respectivamente. Adjunta un apéndice con bibliografía.

353. Grupp, Joachim (2007). Katas de kárate shotokan : vol. 2. Madrid: Tutor. 1aㅡ ed. 151 p. : il. ; 17x24 cm. ISBN: 978-84-7902-629-5. Depósito legal: M. 51457-2006. Palabras clave: katas, historia, kárate, aplicación marcial. Resumen: Manual teórico y técnico de kárate. La obra esta formada por 5 capítulos. El primer capítulo narra la historia del kárate shotokan, la formación del karate-do y las características de las katas del estilo shotokan. El segundo capítulo hace una breve introducción, presenta la secuencia fotográfica, enumera la secuencia de acciones e ilustra algunas de las aplicaciones de las katas superiores meikyo, sochin, jitte, kanku sho, gankaku, chinte, unsu, wankan y ji'in. El tercer capítulo nombra e ilustra las posiciones de kárate mientras que el cuarto incluye la secuencia fotográfica de algunas de las técnicas más comunes de las katas de kárate shotokan. El último capítulo adjunta bibliografía y los créditos de las fotografías.

354. Gutiérrez Martínez, Francisco (1999). Karate : un camino hacia uno mismo. Granada: Francisco Gutiérrez Martínez. 1ae ed. 238 p. : il. ; 17x24 cm. ISBN: 84-605-9838-1. Depósito legal: GR. 1517-1999. Palabras clave: katas, historia, fundamentos teóricos, entrenamiento, aplicación marcial, grados. Resumen: Manual teórico y técnico de kárate. El libro esta formado por 20 capítulos precedidos por un prólogo que comenta las formas de leer la obra y una introducción que comenta sus contenidos. Los primeros cuatro capítulos reflexionan sobre el comienzo de la práctica del kárate, las causas de abandono, la satisfacción con el entrenamiento, la transformación que implica su práctica. El quinto capítulo describe varios ejercicios para sentir la energía del cuerpo. El sexto capítulo narra la historia del kárate mientras que el séptimo incluye un cuadro sinóptico de los estilos de kárate, su esquema cronológico y una tabla con los estilos y sus maestros fundadores. El octavo capítulo enumera los cinturones negros de kárate presentes en Granada además de un esquema con el desarrollo del kárate shito-ryu en dicha ciudad y algunas fotografías de los alumnos. El noveno capítulo aclara el significado de los cinturones mientras que el siguiente presenta los fundamentos técnicos del kárate y los principios técnicos de su ejecución. El décimo primer capítulo analiza los principios técnicas de las katas así como el significado del bunkai y la relación de katas de shurite, nahate y otras. El siguiente capítulo analiza el significado de los símbolos de cada estilo de kárate, ilustrando los emblemas de shito-ryu de Mabuni, de shito-ryu de Granada y la evolución de estos símbolos. El décimo tercer capítulo incluye un vocabulario específico. Los últimos siete capítulos presentan la secuencia fotográfica de la ejecución y bunkai de las katas pinan shodan, pinan nidan, pinan sandan, pinan yondan, pinan godan, sishoochin y kururunfa.

355. Gutiérrez, Raúl (coord.); Rubio Pérez, Antonio y Palao, Luis Antonio (1984). Karate shito-ryu : 5 katas superiores. Barcelona: Alas. $1^{a}$ ed. 110 p. : il. ; 15x21,5 cm. ISBN: 84-203-0171-X. Depósito legal: B. 41809-1984. Palabras clave: katas, fundamentos teóricos, fundamentos técnicos, principios técnicos, aplicación marcial. Resumen: Manual teórico y técnico de kárate. El libro esta formado por 9 capítulos, precedidos por un prólogo y el currículo de los autores. El primer capítulo narra la biografía del maestro Mabuni y el origen del estilo shito-ryu. El segundo capítulo expone los principios técnicos de las katas, ofrece algunos consejos para su aprendizaje y clasifica las katas dependiendo de su origen además de comentar sus características técnicas. El tercer capítulo representa los puntos de triangulación de sanchin y analiza sus principios técnicos y errores. El cuarto capítulo comenta el origen y características de la kata sanchin y representa su ejecución técnica. Los siguientes cuatro capítulos explican la historia de las katas yuroku, kosookun-dai, rohai, seienchin incluyendo la secuencia fotográfica de su ejecución y de la aplicación de algunas de sus técnicas. El noveno capítulo incluye un breve comentario sobre las generalidades del kárate y el estilo shito-ryu, además de enumerar sus contenidos técnicos y representar gráficamente las distintas posiciones de los pies y las partes del cuerpo utilizadas para golpear.

356. Habersetzer, Roland (1970). El karate. Madrid: Espasa-Calpe. 1a ed. 64 p. : il. ; 13x17,5 cm. ISBN: No ISBN. Depósito legal: M. 12098-1970. Palabras clave: historia, fundamentos teóricos, fundamentos técnicos, defensa personal, combate. Resumen: Manual teórico y técnico de kárate. El libro esta compuesto por 14 capítulos. El primer capítulo comenta el origen del kárate y sus diferentes estilos. El segundo capítulo explica los fundamentos teóricos del kárate. Los siguientes cuatro capítulos describen e ilustran las áreas de golpeo utilizadas en kárate, la localización de los puntos vitales, la vestimenta y el material de entrenamiento (makiwara y saco de arena). El séptimo capítulo expone la ejecución del saludo ceremonial, para luego comentar los ejercicios preparatorios antes de una clase de kárate. Los dos siguientes capítulos enumeran los beneficios de la práctica del kárate y dónde practicarlo. El siguiente capítulo está dividido en dos partes que presentan sus fundamentos técnicos y algunos ejemplos del trabajo de combate con compañero. Los tres últimos capítulos comentan el significado e importancia de las katas, los diferentes tipos de combate y sus características, y exponen algunos ejemplos de la aplicación del kárate a situaciones de defensa personal. Adjunta un índice de términos japoneses. 
357. Habersetzer, Roland (1976). Karate-do : técnicas básicas, asaltos y competición. Barcelona: Hispano Europea. $1^{\underline{a}}$ ed. 584 p. : il. ; 13x19,5 cm. ISBN: 84-255-0434-1. Depósito legal: B. 32337-1976. (2aㅡ. ed., 1987; 3a ed., 1990; 4a ed., 1993, 576 p.). Palabras clave: kumite, fundamentos teóricos, entrenamiento, fundamentos técnicos, biomecánica, fisiología. Resumen: Manual teórico y técnico de karate. La obra esta dividida en 4 partes, precedidas ambas por una introducción sobre el origen, historia y aspectos formales del karate. La primera parte detalla los principios físicos, fisiológicos, psicológicos y espirituales que deben aplicarse al karate, además de los fundamentos técnicos y su correcta ejecución para obtener la máxima eficacia de movimiento. Aportando ejemplos de todos ellos, ilustraciones con sus esquemas de movimiento, y su método de entrenamiento, estudia la fuerza abdominal, las posturas, los desplazamientos, los golpes, las caderas y las técnicas de pie. La segunda parte describe las técnicas de ataque, contraataque, defensivas, las proyecciones y las luxaciones, explicando su correcta ejecución, sus puntos esenciales, su aplicación, su entrenamiento, sus variantes e ilustrando sus movimientos. La tercera parte explica los principios generales a todos los tipos de kumite, enumera e ilustra el trabajo de kihon kumite con sus consejos prácticos y secuencia gráfica de movimientos, para ahondar en el trabajo de jiyu-kumite. Así, describe las características de la guardia, los medios técnicos para el ataque y la defensa, y los aspectos formales de la competición como son el reglamento el arbitraje y el material protector. La última parte esta compuesta por los métodos de entrenamiento aportando la fundamentación teórica de la fisiología específica del karate, los ejercicios de calentamiento y de endurecimiento del cuerpo, los materiales que se utilizan para endurecer el cuerpo y el trabajo de técnicas encadenadas para el entrenamiento de los practicantes más avanzados. Adjunta apéndices sobre kuatsu, el programa de contenidos por grados, bibliografía y un glosario de términos japoneses.

358. Harrison, E. J. (1965). Manual de karate. Barcelona: Bruguera. 1a ed. 174 p. : il. ; 14x21 cm. ISBN: No ISBN. Depósito legal: B. 27115-1965. (2ª ed., 1967; $3^{\mathrm{a}}$ ed., 1968; $4^{\mathrm{a}}$ ed., 1974, 220 p., ISBN: 84-0200386-9). Palabras clave: katas, kumite, historia, fundamentos técnicos, entrenamiento, kyusho. Resumen: Manual técnico de karate. La obra esta dividida en 9 capítulos. El primer capítulo describe la historia y ventajas del karate tanto para viejos como para jóvenes y en el segundo detalla las partes de la mano que pueden utilizarse como armas. Los dos siguientes capítulos explican las posturas y posiciones, y las técnicas de pierna y pie respectivamente. Continua describiendo los aparatos auxiliares del entrenamiento y su utilización. A continuación presenta las katas como métodos fundamentales para el entrenamiento, ofreciendo algunos ejercicios básicos y la explicación de las katas: taikyouku shodan, pinan shodan, pinan nidan, pinan sandan, pinan yodan, pinan godan y dai nihon karate-do ten-no-kata. Finaliza con el detalle de algunos ejercicios de yakusoku kumite, un breve comentario sobre el trabajo en el resto de tipos de kumite y la localización y formas de ataque de los puntos vitales en el cuerpo. Adjunta un glosario.

359. Harrison, E. J. (1969). Manual de karate : la infalible técnica japonesa de autodefensa sin armas. Barcelona: Bruguera. 1aㅡ ed. 220 p. : il. ; 10x17,5 cm. ISBN: No ISBN. Depósito legal: B. 10614-1969. (2 $2^{\underline{a}}$ ed., 1971; ed. desc., 1972; $3^{\underline{a}}$ ed., 1973, ISBN: 84-02-00805-4; 5 $5^{\underline{a}}$ ed., 1974, ISBN: 84-02-00805-4; $6^{\underline{a}}$ ed., 1975, ISBN: 84-02-00805-4; 7aㅡ ed., 1976, ISBN: 84-02-00805-4, 8를. ed., 1983, ISBN: 84-02-008054). Palabras clave: katas, kumite, historia, fundamentos técnicos, entrenamiento, kyusho. Resumen: Manual técnico de karate. La obra esta dividida en 9 capítulos. El primer capítulo describe la historia y ventajas del karate tanto para viejos como para jóvenes y en el segundo detalla las partes de la mano que pueden utilizarse como armas. Los dos siguientes capítulos explican las posturas y posiciones, y las técnicas de pierna y pie respectivamente. Continua describiendo los aparatos auxiliares del entrenamiento y su utilización. A continuación presenta las katas como métodos fundamentales para el entrenamiento, ofreciendo algunos ejercicios básicos y la explicación de las katas: taikyouku shodan, pinan shodan, pinan nidan, pinan sandan, pinan yodan, pinan godan y dai nihon karate-do ten-no-kata. Finaliza con el detalle de algunos ejercicios de yakusoku kumite, un breve comentario sobre el trabajo en el resto de tipos de kumite y la localización y formas de ataque de los puntos vitales en el cuerpo. Adjunta un glosario.

360. Harrison, E. J. (1977). Manual de karate : la infalible técnica japonesa de autodefensa sin armas. Barcelona: Bruguera. 1a ed. 219 p. : il. ; 10x17,5 cm. ISBN: 84-02-05359-9. Depósito legal: B. 391451977. Palabras clave: katas, kumite, historia, fundamentos técnicos, entrenamiento, kyusho. Resumen: Manual técnico de karate. La obra esta dividida en 9 capítulos. El primer capítulo describe la historia y ventajas del karate tanto para viejos como para jóvenes y en el segundo detalla las partes de la mano que pueden utilizarse como armas. Los dos siguientes capítulos explican las posturas y posiciones, y las técnicas de pierna y pie respectivamente. Continua describiendo los aparatos auxiliares del entrenamiento y su utilización. A continuación presenta las katas como métodos fundamentales para el entrenamiento, ofreciendo algunos ejercicios básicos y la explicación de las katas: taikyouku shodan, pinan shodan, pinan nidan, pinan sandan, pinan yodan, pinan godan y dai nihon karate-do ten-no-kata. Finaliza con el detalle de algunos ejercicios de yakusoku kumite, un breve 
comentario sobre el trabajo en el resto de tipos de kumite y la localización y formas de ataque de los puntos vitales en el cuerpo. Adjunta un glosario.

361. Hasemeier, Alfred (1968). Técnica del kárate : manual de enseñanza. Las Fonts de Tarrasa: Sintes. 1ạ ed. 70 p. : il. ; $12 \times 18$ cm. ISBN: No ISBN. Depósito legal: B. 26893-1968. (2ª ed., 1973, ISBN: 84-302-05039). Palabras clave: historia, fundamentos teóricos, táctica, fundamentos técnicos, defensa personal, kyusho. Resumen: Manual teórico y técnico de kárate. El libro esta formado por 35 capítulos. El primer capítulo comenta brevemente la historia del kárate. Los siguientes cuarto capítulos localización los puntos vitales del cuerpo y comentan el sistema circulatorio sanguíneo y las formas utilizadas en el kárate para paralizar dicho sistema. Los dos siguientes capítulos describen e ilustran las partes del cuerpo utilizadas para golpear y cómo pueden endurecerse. El octavo capítulo describe la posición de guardia del karate. Los siguientes 19 capítulos presentan la descripción e ilustración de algunas de las técnicas básicas de kárate. Los dos siguientes capítulos muestran la aplicación de las técnicas explicadas anteriormente ante situaciones de defensa personal. Los últimos cuatro capítulos señalan los principios tácticos a recordar en una situación de defensa personal, comentan la importancia de la actitud y el comportamiento en la lucha defensiva, resumen los principios técnicos del kárate y apuntan cuatro condiciones para mantener la salud. El epílogo incluye consejos para progresar en la práctica.

362. Hasemeier, Alfred (1970). Curso de kárate : camino de campeones. Las Fonts de Tarrasa: Sintes. 1aㅡ. ed. 76 p. : il. ; $12 \times 18$ cm. ISBN: 84-302-0399-0. Depósito legal: B. 8455-1970. (2a ed., 1975). Palabras clave: historia, fundamentos técnicos, combate, competición, preparación física, reglamentos. Resumen: Manual teórico y técnico de kárate. El libro esta formado por 15 capítulos. El primer capítulo narra la evolución histórica del kárate. El segundo capítulo comenta las reglas de conducta en el deporte. El tercer capítulo presenta una tabla de ejercicios de fuerza y flexibilidad para cada parte del cuerpo mientras que el cuarto describe e ilustra varios de dichos ejercicios. El quinto capítulo presenta las posiciones fundamentales de kárate para luego exponer las principales técnicas de ataque con golpe directo, en arco, con los pies, y las técnicas defensivas tanto de brazos como de pies, incluyendo las fotografías explicativas de cada uno de ellos. El octavo capítulo ilustra y comenta algunos ejercicios para el endurecimiento de manos y pies. El noveno capítulo expone las diferentes alturas de ataque e ilustra la combinación de varias técnicas. Los dos siguientes capítulos enumeran los diferentes tipos de combate, comentan las características del jiyu-ippon-kumite y el jiyu-kumite y presentan varios ejemplos gráficos de los mismos. El duodécimo capítulo incluye un resumen del reglamento de competición, para finalizar con un listado de los términos utilizados en el combate y en el kárate. El epílogo resume los contenidos del libro y el método para progresar.

363. Hernández Martos, Alonso (1984). Técnicas y katas. Madrid: Polen. 1aㅡ ed. 162 p. : il. ; 15x22 cm. ISBN: 84-85423-34-8. Depósito legal: M. 8035-1984. Palabras clave: katas, fundamentos técnicos, programa técnico, exámenes, reglamentos. Resumen: Manual técnico de kárate. La obra esta formada por 10 capítulos. Los cinco primeros capítulos ilustran y nombran los contenidos técnicos para la obtención del cinturón amarillo, naranja, verde, azul y marrón respectivamente. El sexto capítulo incluye la secuencia fotográfica de las katas dai-ichi-dosa, dai-ni-dosa, dai-san-dosa, dai-yon-dosa de shito-ryu, mientras que el séptimo presenta las katas pinan shodan, pinan nidan, pinan sandan, pinan yodan y pinan godan. El octavo capítulo presenta las katas ananko y jitte a través de su ilustración. El noveno capítulo muestra la secuencia fotográfica de la ejecución de las katas toitsu kata heian shodan, toitsu kata heian nidan, toitsu kata heian sandan, toitsu kata heian yodan y toitsu kata heian godan. El décimo capítulo expone los requisitos para el examen de cinturón negro, detalla su desarrollo y señala los puntos más importantes en la ejecución de una kata.

364. Herráiz Embid, Salvador (1985). Karate wado fudochi. Azuqueca de Henares (Guadalajara): Salvador Herráiz Embid. 1a ed. 252 p. : il. ; 21x30 cm. ISBN: 84-398-5390-4. Depósito legal: GU. 436-1985. Palabras clave: katas, kumite, historia, fundamentos teóricos, táctica, fundamentos técnicos, principios técnicos, ejercicios, calentamiento, vestimenta, cortesía, kyusho, aplicación marcial, competición, etiqueta, instalaciones, instituciones, reglamentos. Resumen: Manual teórico y técnico de kárate. El libro esta formado por 28 capítulos precedidos por un prólogo que señala los objetivos del libro. Los dos primeros capítulos exponen los beneficios del kárate a nivel físico y comentan sus contenidos y objetivos. El tercer capítulo narra la historia de las artes marciales, del kárate y sus diferentes estilos. El cuarto capítulo profundiza en la historia del kárate wado ryu además de exponer sus características técnicas. El quinto capítulo presenta la organización institucional del wado ryu en Europa mientras que el sexto comenta las características del kárate deportivo, resume sus reglas de competición y la historia de la alta competición. El séptimo capítulo explica el significado del dojo, sus características, normas de comportamiento y sistema de grados. El octavo capítulo estudia los principios técnicos del kárate. El noveno capítulo comenta las características del calentamiento además de incluir la representación de algunos de sus ejercicios. El décimo capítulo ofrece varios para el entrenamiento de pesas aplicado al kárate. El décimo primer capítulo describe la ejecución de la guardia. Los dos siguientes capítulos enumeran e ilustran las armas naturales de golpeo y los puntos 
vitales del cuerpo humano así como la descripción de los efectos de los atemis. El décimo cuarto capítulo describe la ejecución de las posiciones de kárate acompañadas de su representación gráfica y esquemas de movimiento mientras que el décimo quinto presenta los desplazamientos. El siguiente capítulo explica la ejecución y aplicación del tai sabaki junto con su representación gráfica. Los dos siguientes capítulos exponen las características de las técnicas de mano y analizar las ventajas e inconvenientes en la utilización de las técnicas de brazo o pierna. Los siguientes cinco capítulos explican la ejecución y utilización de las principales técnicas de bloqueo, ataques de puño, ataques de pierna y barridos acompañadas de su representación gráfica. Los tres siguientes capítulos explican la posible aplicación de las torsiones y proyecciones, movimientos simultáneos y los principios técnicos de los encadenamientos. El vigésimo sexto capítulo enumera los principios técnicos y de entrenamiento de las katas, además de la descripción y secuencia fotográfica de la ejecución y aplicación marcial de las katas pinan nidan, pinan shodan, pinan sandan, pinan jondan pinan godan, naifhanchi, kushanku, bassai, wanshu, chinto y seisan. El siguiente capítulo expone los principios técnicos y tácticos del combate, ilustra varios ejercicios de kihon kumite, analiza el combate contra varios adversarios y el combate libre. El último capítulo un test de conocimientos generales sobre las artes marciales. Adjunta vocabulario específico y bibliografía.

365. Herráiz Embid, Salvador (1986). Wado ryu karate do. Guadalajara: Salvador Herráiz Embid. 1a ed. 113 p. : il. ; 15x21 cm. ISBN: No ISBN. Depósito legal: GU. 278-1986. Palabras clave: katas, kumite, historia, fundamentos técnicos, fundamentos filosóficos, instituciones, maestros, armas. Resumen: Manual teórico y técnico de kárate. El libro esta formado por 33 capítulos. Los tres primeros capítulos definen los términos kárate, rei y mokuso. El cuarto capítulo comenta los fundamentos filosóficos del kárate. El cuarto capítulo analiza la evolución del significado del término kárate. Los tres siguientes capítulos explican la actitud del aspirante a cinturón negro, las cualidades que debe exhibir un dan y las características del entrenamiento superior. El octavo capítulo explica la relación entre el kárate y el budo. El noveno capítulo explica la evolución y creación de los diferentes estilos de kárate además de representar algunas de sus diferencias técnicas. El décimo capítulo presenta los cuadros y mapas de los diferentes estilos y maestros de kárate. El décimo primer capítulo compara los principales estilos de kárate respecto a su kime. El décimo segundo capítulo incluye el cuadro de símbolos de los diferentes estilos de kárate. El décimo tercer capítulo narra la historia y características del wado ryu mientras que el siguiente relata la formación marcial de Ohtsuka. El décimo quinto capítulo expone la filosofía de Ohtsuka. El décimo sexto capítulo presenta el resumen del autor respecto a las ideas de Ohtsuka. Los siguientes tres capítulos presentan los contenidos técnicos del wado ryu junto con la ilustración de las katas rohai y jitte. El vigésimo capítulo comenta las características técnicas de las principales katas de wado ryu mientras que el siguiente detalla las organizaciones wado en el mundo y discute sus problemas. El vigésimo segundo capítulo señala la importancia de la concentración mental. Los dos siguientes capítulos detallan los objetivos del kiai y las katas. Continúa con la descripción de la utilización del saco, el makiwara y los rompimientos. El vigésimo sexto capítulo presenta algunas de las armas utilizadas en el kobudo y en el wado ryu. El siguiente capítulo comenta los tipos y características del kumite. Los dos siguientes capítulos exponen las cualidades de un profesor y analizan su labor docente. Los tres últimos capítulos analizan la importancia de la disciplina en el entrenamiento, los factores que intervienen en el progreso del aprendizaje en kárate y ofrece algunos consejos para la práctica de la musculación y las artes marciales.

366. Herráiz Embid, Salvador (1987). Wado ryu waza y Ohtsuka Hironori. Guadalajara: Salvador Herráiz Embid. 1ạ ed. 49 p. : il. ; 21x29,5 cm. ISBN: No ISBN. Depósito legal: GU. 124-1987. Palabras clave: historia, fundamentos técnicos, principios técnicos, biografía, entrevistas, maestros. Resumen: Manual teórico y técnico de kárate. El libro esta formado por dos partes. La primera parte comenta las características técnicas generales del wado ryu, sus katas, las diferentes formas de practicar el wado ryu, el trabajo de kihon kumite, incluye algunos apuntes sobre los fundamentos históricos y teóricos del kárate, algunos ejemplos de técnicas de esquiva y la representación gráfica de algunos contenidos. La segunda parte presenta la biografía de Hironori Ohtsuka junto con las entrevistas realizadas a Hironori Ohtsuka, Masatoshi Nakayama y Kishomaru Ueshiba.

367. Herráiz Embid, Salvador (1990). Historia y filosofía del karate do. Guadalajara: Salvador Herráiz Embid. $1^{\underline{a}}$ ed. 195 p. : il. ; 21x30 cm. ISBN: No ISBN. Depósito legal: GU. 189-1990. Palabras clave: historia, biografía, escuelas, instituciones, maestros. Resumen: Tratado histórico de kárate. El libro esta formado por 27 capítulos profusamente ilustrados precedidos por un prólogo resume los contenidos del libro y una introducción que comenta el origen de las artes marciales. Los cuatro primeros capítulos narran la historia de Grecia, India, China y Okinawa así como sus artes de combate. El quinto capítulo describe la biografía de Sokon Matsumura y su formación marcial mientras que el sexto comenta la división de estilo shorei y sus maestros. El séptimo capítulo relata la biografía de Miyagi, la formación del goju ryu y sus distintos maestros. El octavo capítulo presenta la formación marcial de Kenwa Mabuni mientras que el noveno comenta la creación del estilo shorin. El décimo capítulo detalla los principales maestros del estilo shorin ryu karate jitsu junto con su ideología sobre el kárate. El 
décimo primer capítulo describe la historia de Funakoshi, sus aportaciones al kárate y su introducción en Japón. El décimo segundo capítulo profundiza en las posteriores generaciones de maestros del estilo shotokan comentando sus principales aportaciones. El décimo tercer capítulo detalla la formación del maestro Ohtsuka mientras que el siguiente capítulo presenta la evolución del estilo shito ryu a través de sus principales maestros. El décimo quinto capítulo describe la biografía de Gogen Yamaguchi y algunos de sus estudiantes. El décimo sexto capítulo analiza algunas de las diferencias técnicas entre los principales estilos de kárate. El décimo séptimo capítulo enumera algunas de los estilos de kárate y sus fundadores. El décimo octavo capítulo comenta brevemente la historia del kárate, sus beneficios, sus aplicaciones y su práctica. El décimo noveno capítulo comenta la introducción del kárate en Europa junto con una entrevista a Henry Pleé. El vigésimo capítulo analiza la llegada del kárate a España. El vigésimo primer capítulo presenta las distintas organizaciones de kárate en Japón mientras que el siguiente describe el currículo de los maestros Sasakawa, Takagi y Delcourt y narra el escándalo de la WUKO además de las entrevistas realizadas a Sasakawa y Takagi. Los siguientes tres capítulos representan gráficamente la evolución geográfica del kárate, la evolución de las artes marciales y la relación entre los maestros de kárate. El vigésimo sexto capítulo presenta los escudos y símbolos de los principales estilos de kárate. El último capítulo incluye un archivo gráfico de los principales maestros de kárate.

368. Herráiz Embid, Salvador (1990). Historia y filosofía del karate do wado ryu. Guadalajara: Sociedad Deportiva Wado Ryu Alcarria Karatedo. 1aㅡ ed. 59 p. : il. ; 21x30 cm. ISBN: No ISBN. Depósito legal: GU. 190-1990. Palabras clave: historia, principios técnicos, principios filosóficos, biografía, instituciones, maestros. Resumen: Tratado histórico de kárate. La obra esta formada por 8 capítulos ilustrados. El primer capítulo relata la infancia de Hironori Ohtsuka y su formación en ju jitsu. El segundo capítulo detalla su aprendizaje marcial del to-de mientras que el tercero expone la presentación del wado ryu karate jitsu y sus características técnicas además de intercalar varios textos sobre las bases, principios, katas y fundamentos filosóficos del estilo wado ryu. El cuarto capítulo narra la expansión y primeros clubes de kárate wado ryu así como algunas anécdotas de sus estudiantes. El quinto capítulo comenta la expansión internacional del wado ryu y sus maestros. El sexto capítulo analiza la división del wado ryu mientras que el séptimo capítulo relata los últimos años del maestro Ohtsuka y su muerte. El último capítulo enumera los maestros encargados del estilo wado ryu en Europa y presenta la entrevista realiza a Patrice Belrhiti. Adjunta un listado de maestros japoneses del estilo wado ryu fuera de Japón y la afiliación de la asociación Wado Ryu A. Karatedo.

369. Herráiz Embid, Salvador (1991). Do : el espíritu del kárate. Historia y filosofía de los Grandes Maestros. Barcelona: Alas. 1a ed. 149 p. : il. ; 15x21,5 cm. ISBN: 84-203-0260-0. Depósito legal: no. Palabras clave: historia, fundamentos teóricos, escuelas, kárate, instituciones, maestros. Resumen: Tratado teórico de kárate. El libro esta formado por 26 capítulos. Los cuatro primeros capítulos relatan la historia y expansión del combate así como las formas de lucha, campeones y maestros de Grecia, India, China y Okinawa. El quinto capítulo relata la formación marcial de Sokon Matsumura y sus reglas de entrenamiento, para luego describir las aportaciones técnicas de Kanryo Higaona al estilo Naha Te, de Miyagi Chojun al Goju Ryu, de Kenwa Mabuni al Shito Ryu, de Anko Itosu al Shuri Te, y de los distintos maestros de Shorin Ryu Karate Jitsu como Chomo Anashiro, Chotoku Kyan, Kentsu Yabu, Choshin Chibana, Shoei Miyazato, Choki Motobu y Shoshin Nagamine. El undécimo capítulo describe la introducción del kárate en Japón por parte de Gichin Funakoshi así como sus aportaciones didácticas y sus reformas hacia el kárate moderno. El siguiente capítulo presenta a las generaciones posteriores del estilo shotokan junto con la descripción de las normas de etiqueta en kárate. Los tres siguientes capítulos describen la formación de los estilos wado ryu, shito ryu y goju ryu, sus características técnicas, entrenamiento y sus maestros. El decimosexto capítulo presenta las diferencias técnicas entre los distintos estilos y narra la formación histórica de las distintas ramas o estilos, para luego enumerar algunos de los estilos principales de kárate y su año de creación. El décimo-octavo capítulo detalla la base filosófica que impregna al kárate y los beneficios que proporciona su práctica espiritual. Los siguientes tres capítulos narran la introducción y expansión del kárate en Europa y España junto con sus predecesores, maestros e impulsores, así como las distintas organizaciones de kárate en Japón, su formación, evolución y maestros. Los últimos cinco capítulos reúnen cuadros sobre la evolución geográfica del kárate, la evolución de las artes, la relación entre los principales maestros, los escudos y símbolos de los distintos estilos y un breve archivo biográfico de los principales maestros.

370. Herráiz Embid, Salvador (1999). Karate : mucho más que un deporte. Barcelona: Film Ideal. 1aㅡ ed. 393 p. : il. ; 23x28 cm. ISBN: 84-95080-02-8. Depósito legal: B. 20255-1999. Palabras clave: katas, kumite, historia, fundamentos teóricos, fundamentos técnicos, armas, principios técnicos, principios filosóficos, kárate, aplicación terapéutica, aplicación marcial, instituciones, reglamentos. Resumen: Manual teórico y técnico de kárate. La obra esta dividida en 4 partes. La primera parte ofrece una imagen general de lo que es el kárate para luego exponer sus beneficios, los principios técnicos que rigen la práctica, los puntos vitales del cuerpo humano y las técnicas más adecuadas para alcanzarlos, los tipos de trabajos que existen, la descripción de las principales posiciones, desplazamientos, técnicas de puño 
(uke waza, tzuki waza, uchi waza) y pierna (keri waza) saltos, barridos, desequilibrios, torsiones y proyecciones acompañadas de sus ilustraciones y esquemas de movimiento, ejemplos del trabajo de encadenamiento de técnicas, comenta el significado de las katas y sus beneficios, ilustra las katas pinan en los estilos shito-ryu, wado-ryu y shotokan, expone los objetivos del trabajo de bunkai gumite y presenta algunos ejemplos de la katas pinan, comenta e ilustra los trabajos de I Dori (técnicas sentados de rodillas), Go No Sen (combinaciones ante ataques de brazo y piernas), Tanto Dori, (técnicas ante cuchillo), Daito Dori (técnicas ante espada), Ju Gumite (combate libre) Shiai Gumite (combate de competición), presenta un resumen del reglamento de competición, comenta las bases de la karaterapia e incluye un vocabulario. La segunda parte analiza la evolución histórica de las artes marciales predecesoras del kárate desde la antigüedad, su evolución en Okinawa y Japón junto con la aportación de sus grandes maestros y sus estilos, la evolución del kárate fuera de Oriente y la clasificación de los principales maestros y estilos en la historia mundial del kárate. La tercera parte estudia los aspectos espirituales que desarrolla la práctica del kárate para finalizar con el análisis de la historia de las distintas organizaciones y federaciones de kárate. Incluye 8 páginas con fotografías en color entre las páginas 92 y 93 y otras 8 entre la 220 y 221.

371. Herráiz Embid, Salvador (2000). ¿Evolución o transgresión? : karate y olimpismo... toda la verdad. Guadalajara: Sociedad Deportiva Wado Ryu Alcarria Karatedo. 1aㅡ ed. 119 p. : il. ; $17 x 24$ cm. ISBN: 84607-0612-5. Depósito legal: GU. 295-2000. Palabras clave: historia, instituciones. Resumen: Compendio documental histórico sobre la institucionalización del kárate y su entrada en el programa olímpico. La obra esta dividida en 7 capítulos y cada uno de ellos presenta los datos, entrevistas y conversaciones que ha recopilado el autor entorno a la institucionalización del karate bajo distintas federaciones internacionales, las personas que han formado parte de esta historia, las competencias de cada una de ellas y la inclusión del kárate dentro del programa olímpico. El texto esta acompañado por documentos y fotografías de los hechos narrados.

372. Herráiz Embid, Salvador (2004). El Rey Juan Carlos y el Príncipe Felipe : dos soldados en el romántico kárate español. Guadalajara: Club Deportivo Básico Wado Ryu Alcarria Karatedo. 1aㅡ ed. 300 p. : il. ; 17x24,5 cm. ISBN: 84-609-0673-6. Depósito legal: GU. 166-2004. Palabras clave: historia, artes marciales. Resumen: Ensayo histórico sobre la relación de la familia real española con las artes marciales, en especial el kárate. A través de ocho capítulos narra la aparición de las artes marciales en España, y la relación que mantienen concretamente el Rey Juan Carlos y el Príncipe Felipe con el kárate, dividiendo los contenidos en distintos periodos de tiempo. Incluye referencias a los grandes promotores del kárate en el territorio nacional así como los sucesos históricos y sociales que fueron conformando la práctica del kárate en nuestro país.

373. Herráiz Embid, Salvador; Conde Marina, Pedro; Tucci, Alfredo y el equipo de colaboradores de Cinturón Negro (2008). Los grandes maestros del karate-do y de la tradición de Okinawa. Madrid: Budo International. $1^{a}$ ed. 255 p. : il. ; 17x24 cm. ISBN: 978-84-92484-07-2. Depósito legal: M. 26524-2008. Palabras clave: biografía, entrevistas, maestros. Resumen: Tratado teórico de kárate. La obra esta formada por 19 capítulos ampliamente ilustrados. El primer capítulo narra los últimos años del maestro Funakoshi. El segundo capítulo presenta la biografía de Tak Kubota, su labor profesional y entrenamiento. El tercer capítulo enumera y comenta los veinte principios rectores del kárate. El cuarto capítulo incluye la biografía del maestro Egami y explica su aportación al kárate. El quinto capítulo presenta la última entrevista realizada a Gogen Yamaguchi. El sexto capítulo comenta la biografía de Nakayama e incluye una de sus entrevistas. El séptimo capítulo narra la llegada de las artes marciales a Occidente. El octavo capítulo comenta la vida de Hirokazu Kanazawa incluyendo algunas de sus anécdotas dentro del kárate. El noveno capítulo relata la formación marcial de Soshin Nagamine y su desarrollo profesional. El décimo capítulo describe el castillo de Shuri, su repercusión sobre algunos maestros de kárate y los contenidos del kárate y enumera los distintos maestros relacionados con el castillo. El décimo primer capítulo detalla la biografía de Seikichi Uehara, mientras que el siguiente comenta la vida de Seikichi Odo junto con una entrevista. El décimo tercer capítulo presenta la relación y aportaciones de Tetsuhiro Hokama al kárate expone el origen del estilo goju ryu y su evolución. El siguiente capítulo narra la biografía de Morio Higaonna hasta la creación de la Okinawan Goju Ryu Karatedo Federation. Los últimos tres capítulos incluyen las entrevistas realizadas a Ken Funakoshi, Taiji Kase y Goshi Yamaguchi.

374. Higaonna, Morio (1998). Karate-do tradicional : Okinawa goju ryu. Aplicaciones del kata 1. Volumen III. Barcelona: Paidotribo. 1aㅡ ed. 215 p. : il. ; 15x21,5 cm. ISBN: 84-8019-329-8. Depósito legal: B. 72-1998. (2aㅡ ed., 2006). Palabras clave: katas, fundamentos técnicos, aplicación marcial. Resumen: Manual técnico sobre la aplicación de las katas de goju-ryu. Después de explicar brevemente el carácter de las katas y su aplicación, desarrolla sus contenidos en 7 capítulos. Comienza con la explicación de los puntos clave y la representación gráfica de las katas sepai, kururunfa, sesan, suparimpei y tensho. Los dos últimos capítulos representan gráficamente las aplicaciones ante adversario de las katas gekisai dai ichi y gekisai dai ni. 
375. Higaonna, Morio (1998). Karate-do tradicional : Okinawa goju ryu. Aplicaciones del kata 2. Volumen IV. Barcelona: Paidotribo. 1aㅡ ed. 251 p. : il. ; 15x21,5 cm. ISBN: 84-8019-330-1. 84-8019-331-X (ISBN de la obra completa). Depósito legal: B. 73-1998. (2ª ed., 2006). Palabras clave: kumite, defensa personal, relatos, aplicación marcial. Resumen: Manual teórico y técnico de kárate. La obra esta formada por 12 partes. Las ocho primeras partes describen brevemente e ilustran por partes las aplicaciones (bunkai) de las partes más importantes de las katas saifa, seiyunchin, shisochin, sanseru, sepai, kururunfa, sesan y suparinpei. El noveno capítulo expone las características del trabajo de iri kumi o sparring libre, comenta su historia y presenta una secuencia fotográfica comentada de un ejemplo de dicho trabajo. Los dos siguientes capítulos comentan la estructura del shiai kumite o torneo de combate y el yakusoku kumite o combate preparado, para luego ilustrar una secuencia de combate y 3 combinaciones de trabajo preparado junto con su explicación. El último capítulo recopila varios relatos de los maestros Kanryo Higaonna y Chojun Miyagi.

376. Higaonna, Morio (1998). Karate-do tradicional : Okinawa goju ryu. Ejecuciones del kata. Volumen II. Barcelona: Paidotribo. 1aㅡ ed. 233 p. : il. ; 15x21,5 cm. ISBN: 84-8019-328-X. Depósito legal: B. 71-1998. (2aㅡ ed., 2005). Palabras clave: katas, fundamentos técnicos, kárate. Resumen: Manual técnico de las katas del estilo goju-ryu. La obra esta compuesta por 9 capítulos. El primer capítulo explica el significado de las katas y peculiaridades de éstas en el estilo goju-ryu. Continua con la explicación detallada de las características del estilo y en el tercer capítulo ofrece un análisis profundo de la kata sanchin del maestro Miyagi Chojun, profundizando en las posturas y movimientos, la respiración, el tono muscular, aspectos clave en su ejecución, la importancia de este kata y su modo de entrenamiento, sus efectos sobre el practicante y finaliza con la ejecución de la kata y la secuencia gráfica de dichos movimientos. Los siguientes capítulos describen los puntos clave en la ejecución de las katas gekisai dai ichi, gekisai dai ni, saifa, seiyunchin, shosochin y sanseru respectivamente, añadiendo gráficos explicativos y esquemas de los movimientos. Adjunta terminología.

377. Higaonna, Morio (1998). Karate-do tradicional : Okinawa goju ryu. Técnicas básicas. Volumen I. Barcelona: Paidotribo. 1ạ ed. 328 p. : il. ; 15x21,5 cm. ISBN: 84-8019-327-1. Depósito legal: B. 70-1998. (2a ed., 2003, 323 p.). Palabras clave: historia, kárate, equipamiento, entrenamiento, preparación física, fundamentos técnicos. Resumen: Tratado histórico y técnico sobre el karate goju-ryu. La obra esta dividida en 10 capítulos, con los cinco primeros dedicados a profundizar en la historia del karate y en concreto de la formación del estilo goju-ryu. Así, el primer capítulo centra su atención en el origen chino del kempo y su entrada en Okinawa, para continuar con las relaciones existentes entre esta isla y China durante la época siguiente. El tercer capítulo describe el desarrollo de la ciudad de Naha y su estilo de combate así como la vida de los maestros Higaonna Kanryo y Miyagi Chojun. El siguiente capítulo profundiza en el desarrollo del estilo goju-ryu y continúa con la presentación del árbol genealógico de los maestros del estilo. La siguiente parte del libro esta dedicada a los fundamentos técnicos, siendo el sexto capítulo introductorio del funcionamiento del cuerpo y los ejercicios preliminares. El séptimo capítulo describe los ejercicios complementarios para el acondicionamiento físico por medio de la utilización de diferentes instrumentos. El siguiente capítulo explica las técnicas fundamentales, tanto posturas y posiciones como las técnicas de mano, pie y los desplazamientos. El noveno capítulo ofrece una serie de ejercicios por parejas para fortalecer los antebrazos, con apoyo gráfico. Finaliza con la explicación de la kata Sanchin a través de descripciones del movimiento breves, fotografías y esquemas de movimiento. Adjunta un listado con las direcciones de las federaciones internacionales de Goju-ryu.

378. Hubert, John (1977). Karate : arte oriental de defensa. Madrid: Demiguel. 1aㅡ ed. 50 p. : il. ; 16x23,5 cm. ISBN: 84-400-2828-8. Depósito legal: M. 12664-1977. Palabras clave: fundamentos técnicos, defensa personal, entrenamiento, kyusho, aplicación marcial, equipamiento, nutrición, respiración, armas. Resumen: Manual teórico y técnico de kárate. El libro esta dividido en 6 partes, precedidas de una introducción que explica en qué consiste el kárate y sus características principales. La primera parte describe la posición de defensa básica. La segunda parte describe e ilustra las distintas zonas del cuerpo que se utilizan como armas como el pulgar y los dedos, las manos, los nudillos, el brazo, la muñeca, el codo, la cabeza, los pies, el talón y el empeine, la planta del pie, las rodillas, algunos golpes hacia atrás y patadas a la cabeza y la forma de aplicar sus golpes correspondientes. También incluye la localización de los puntos vitales del cuerpo humano, la descripción y representación gráfica de las principales paradas defensivas y contragolpes así como algunos ejemplos prácticos de defensa contra varios adversarios, contra el ataque de cuchillo y revolver, algunas técnicas de defensa específicas para las mujeres y los aparatos de fortalecimiento y endurecimiento del kárate. La tercera parte ofrece algunos consejos nutricionales así como aquellos alimentos a tomar y evitar. La cuarta parte resalta la importancia de los ejercicios corporales y mentales para la práctica del kárate. El quinto capítulo comenta la utilización del grito (kiai) en el combate y sus efectos sobre el adversario. La última parte propone algunos ejercicios respiratorios de yoga para aplicarlos a la preparación mental y física del practicante de kárate. 
379. Iñarra, Joxean (1998). Entrenatzaile eta irakasleentzako fitxa didaktikoak : karatea. San Sebastián: Deba Bailarako Euskara eta Kirol Zerbitzuak. 1a ed. 60 p. : il. ; 21x15 cm. ISBN: 84-920247-9-8. Depósito legal: SS. 817-1998. (2 $\underline{a}$ ed., 2000). Palabras clave: historia, fundamentos teóricos, fundamentos técnicos, principios filosóficos, didáctica, ejercicios, capacidades físicas. Resumen: Manual teórico y técnico de kárate. La obra consta de 16 capítulos. El primer capítulo comenta los orígenes del kárate. El segundo capítulo enumera los elementos básicos como el sistema de grados y los contenidos técnicos. El tercer capítulo describe la forma de saludar y la vestimenta del kárate. El siguiente capítulo presenta algunos ejercicios y juegos de calentamiento y vuelta a la calma. El quinto capítulo expone los consejos para la práctica del kárate. Los siguientes cinco capítulos describen la ejecución de las principales posiciones básicas, técnicas de defensa, técnicas de golpeo con la mano cerrada y abierta, y técnicas de pierna. El undécimo capítulo incluye la progresión didáctica en el aprendizaje de los golpes de puño con la descripción e ilustración de varios ejercicios. El siguiente capítulo describe la ejecución y variantes de algunos juegos para desarrollar la velocidad de reacción de las técnicas básicas del kárate tanto de los miembros inferiores como superiores. El capítulo decimotercero explica el significado de la kata y sus principios técnicos. Los tres últimos capítulos incluyen los 20 principios rectores del kárate, un diccionario específico y bibliografía.

380. Iwai, Kohaku (2003). El maestro Chooki Motobu y el karate de Okinawa. Madrid: Miraguano. 1a ed. 185 p. : il. ; $17 x 24$ cm. ISBN: 84-7813-263-5. Depósito legal: M. 45129-2003. Palabras clave: katas, historia, fundamentos teóricos, biografía, escuelas, maestros. Resumen: Tratado teórico de kárate. La obra esta formada por 4 partes. La primera parte presenta la interpretación del kárate realizada por Chooki Motobu, en la que explica los orígenes del kárate, los diferentes estilos y sus características, comenta la evolución de las katas, las reglas básicas del kenpo, cómo construir un puño, la colocación de la guardia, cómo construir un makiwara y su entrenamiento, instrumentos complementarios para el entrenamiento, los fundamentos del entrenamiento, explica e ilustra la kata Nai Fan Chi Sodan, el trabajo de kumite, enumera los distintos maestros de las Islas Ryukyu junto con sus técnicas favoritas e incluye algunos relatos sobre los antiguos artistas marciales. La segunda parte presenta diferentes secuencias de yakusoku kumite, explicando e ilustrando cada una de ellas por partes, señala algunos remedios para las lesiones más comunes e incluye una breve biografía de Chooki Motobu. La tercera parte narra la historia de las Islas Ryukyu, las características de sus periodos, su relación con China, su sistema social, las prohibiciones de armas, los poderes políticos de cada época y la evolución de su arte marcial hasta conformar el kárate-jutsu y karate-do por la aportación de los diferentes artistas marciales. La última parte profundiza en la historia de las artes marciales desarrolladas en las Islas Ryukyu, como son los estilos naha-te, shuri-te y tomari-te, los maestros de estos estilos, presenta las biografías de Gichin Funakoshi, Chooki Motobu, Chojun Miyagi, Kenwa Mabuni e Hiroki Otsuka, analiza las transformaciones sufridas por el kárate a su llegada a Japón, el nuevo sistema de entrenamiento, las escuelas y asociaciones creadas, la evolución del kárate como deporte junto con sus consecuencias y los diferentes tipos de kata del kárate-jutsu.

381. Kanazawa, Hirokazu (2007). Kárate para cinturón negro : curso intensivo. Madrid: Tutor. 1a ed. 232 p. : il. ; 21x28 cm. ISBN: 978-84-7902-684-4. Depósito legal: M. 47972-2007. Palabras clave: katas, kumite, fundamentos teóricos, fundamentos técnicos, entrenamiento, planificación del entrenamiento. Resumen: Manual técnico de kárate estilo shotokan . Esta dividido en 6 capítulos que progresan en dificultad para explicar la evolución técnica y de entrenamiento hasta llegar al cinturón negro, y comienza con un apartado introductorio que recoge los fundamentos del kárate, desde el empleo de las manos y los pies como armas hasta las posiciones, las técnicas y rutinas de respiración y el mokuso. Todos los capítulos están compuestos por 3 lecciones que desarrollan una misma estructura de presentación del entrenamiento y detallan los puntos a recordar en cada uno de los ejercicios propuestos. El primer capítulo desarrolla el entrenamiento de las técnicas de posiciones y ataques de puño y pierna de nivel básico y el segundo en la ampliación de estos fundamentos con ataques, posiciones y combinaciones de mayor dificultad. El tercer capítulo presenta la primera kata, combinaciones básicas de técnicas y ejercicios de kumite a un paso. El cuarto capítulo aumenta la dificultad de las combinaciones de técnicas, tanto de brazo como de pierna, describe la segunda kata y el trabajo de kumite libre a un paso. El quinto capítulo ofrece una serie de ejercicios de pierna de máxima dificultad, el trabajo de combate libre, algunos ejercicios de defensa personal, el entrenamiento con material (makiwara, saco de arena, nunchaku) y los ejercicios de tameshi-wari. El último capítulo presenta distintos programas de entrenamiento, con la combinación de los ejercicios presentados en los capítulos anteriores, y la descripción textual y gráfica de la kata Tekki Shodan. Adjunta un glosario de términos de kárate japoneses.

382. Kanazawa, Hirokazu (2009). Técnicas de combate de kárate. Manual completo de kumite. Madrid: Tutor. $1^{\underline{a}}$ ed. 198 p. : il. ; 21x28 cm. ISBN: 978-84-7902-753-7. Depósito legal: no. Palabras clave: kumite, fundamentos técnicos. Resumen: Manual teórico y técnico de kárate. El libro esta formado por 12 capítulos, precedidos por unas notas introductorios sobre algunas de las enseñanzas que recibió el autor del maestro Funakoshi, la clasificación de métodos de entrenamiento de kumite, el significado 
del saludo y el protocolo para realizar el saludo y el trabajo de gohon e ippon-kumite. El primer capítulo describe la ejecución técnica de las principales técnicas simples de ataque y defensa tanto en estático como en movimiento incluyendo la secuencia fotográfica de las mismas. Los dos siguientes capítulos describen la ejecución del trabajo de gohon kumite a nivel yodan y chudan y 4 técnicas de sanbon kumite acompañados de su secuencia fotográfica y un pequeño comentario sobre la actitud en cada técnica. Los dos siguientes capítulos describen e ilustran 3 técnicas de kiso kumite, 6 técnicas de kihon ippon kumite a nivel yodan, chudan y gedan y 3 técnicas de ippon kumite ante ataques de yokogeri y mawashi-geri. El sexto capítulo comenta los objetivos del trabajo de kaeshi ippon kumite, y describe e ilustra 8 de sus combinaciones técnicas. El siguiente capítulo explica los principios que rigen el jiyu ippon kumite y presenta la descripción e ilustración por partes de 6 combinaciones ante ataques a nivel yodan, chudan y gedan, y 3 técnicas ante yoko-geri, mawashi-geri, ushiro-geri, yodan kizamizuki y chudan gyaku-zuki. El octavo capítulo presenta el método de trabajo del okuri jiyu ippon kumite e incluye 6 ejemplos técnicos de dicho trabajo. El siguiente capítulo expone las características del jiyu kumite y sus tipos como son el shiai kumite y el kiogi kumite, además de incluir 22 ejemplos prácticos de este trabajo, con la descripción e ilustración de cada uno de ellos. El décimo capítulo explica los principios técnicos del trabajo de happo kumite e incluye un ejemplo del mismo con la descripción e ilustración de sus técnicas. El siguiente capítulo presenta el entrenamiento para el control de la técnica y describe e ilustra 6 ejemplos de diferentes técnicas. El último capítulo explica como doblar el do-gi incluyendo su secuencia fotográfica. Adjunta un glosario y un listado de los contactos de la SKIF.

383. Kishi, Yasu (1986). Karate. Barcelona: Editors. $1^{a}$ ed. 145 p. : il. ; 13x20 cm. ISBN: 84-7561-393-4. Depósito legal: B. 42780-1986. (2ª ed., 1988, ISBN: 84-7561-686-0; $4^{\mathrm{a}}$ ed., 1990, ISBN: 84-7561-686-0;

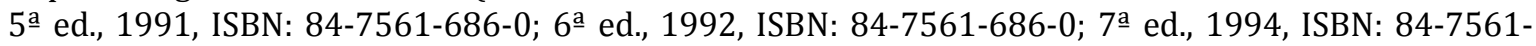
686-0). Palabras clave: katas, historia, fundamentos técnicos, ejercicios, combate, entrenamiento, kyusho. Resumen: Manual teórico y técnico de kárate y aikido. El libro esta formado por 23 capítulos, precedidos por una introducción que explica el significado de la palabra kárate. El primer capítulo describe las zonas de golpeo de la mano, el brazo y el codo así como su modo de utilización. Los siguientes cinco capítulos comentan las diferentes técnicas de mano, las principales posiciones, las zonas de golpeo del pie y un breve comentario de algunas de las técnicas de golpeo con los pies y manos. Los siguientes tres capítulos explican cómo endurecer las manos y los pies, además de los aparatos que se utilizan para ello y las formas de golpearlos. Los siete capítulos siguientes describen la ejecución de varias secuencias de técnica básica y las cinco katas pinan. A continuación se describen varias secuencias de combate preestablecido y la localización de los puntos vitales del cuerpo, incluyendo su representación gráfica. Los últimos tres capítulos comentan la forma de atacar los puntos vitales. Adjunta un glosario.

384. Kohata, Hiromichi (1985). Katas de gensei-ryu : karate-do. Asturias: Hiromichi Kohata. $1 \underline{\text { a }}$ ed. 48 p. : il. ; $17 \times 25$ cm. ISBN: No ISBN. Depósito legal: 0. 494-1985. Palabras clave: katas, historia, aplicación marcial. Resumen: Manual teórico y técnico de kárate. El libro consta de 6 capítulos precedidos por un prólogo que detalla las partes que componen el kárate y señala sus características. El primer capítulo explica el significado e historia de la escuela gensei-ryu además de su tabla genealógica y una breve biografía del autor. El segundo capítulo describe la ejecución de la kata gensei-shodan acompañada de sus ilustraciones y de los puntos importantes para su realización. El tercer capítulo detalla el significado de la kata ten-i-no-kata, sus características y expone la descripción e ilustración de su ejecución técnica así como sus puntos clave y la aplicación marcial de su técnica más característica. El cuarto capítulo comenta el significado y características de la kata chi-i-no-kata, incluye su descripción técnica junto con su secuencia fotográfica. El quinto capítulo señala el significado y características de la kata jin-i-no-kata, presenta la descripción de su ejecución técnica acompañada de su secuencia fotográfica e incluye la explicación de sus puntos más importantes además de la ilustración de su bunkai. El último capítulo expone la historia de la kata naifanchi, presenta su descripción técnica e ilustración, y señala algunas de las precauciones para su realización.

385. Koriko, Michouko (seud. de Repollés Aguilar, José) (1977). Kárate. Barcelona: Bruguera. 1a ed. 29 p. : il. ; 15x20,5 cm. ISBN: 84-02-04943-5. Depósito legal: B. 40206-1976. Palabras clave: historia, fundamentos técnicos, principios técnicos, defensa personal, ejercicios, entrenamiento, vestimenta, cortesía, kyusho, etiqueta, preparación física, armas. Resumen: Manual teórico y técnico de kárate. La obra esta compuesta por 5 capítulos. El primer capítulo narra la historia del kárate, describe su eficacia y la vestimenta, ofrece algunos consejos para el entrenamiento, enumera sus beneficios y sus armas naturales. El segundo capítulo localiza los puntos vitales del cuerpo humano incluyendo una breve descripción de los efectos de su manipulación, describe la estructura de un makiwara, presenta las características de otros aparatos de entrenamiento, explica las características de las posiciones fundamentales y enumera algunos de los principios técnicos del combate. El tercer capítulo describe la ejecución de las principales técnicas de mano, golpes de codo, golpes de rodilla y técnicas de pie, exponiendo sus principios técnicos y aplicaciones. El cuarto capítulo describe la ejecución técnica de las principales defensas, varios ejemplos de defensas contra ataques a la zona media y superior del 
cuerpo, y señala la importancia de la guardia y los desplazamientos además de explicar la ejecución de sus diferentes tipos. El último capítulo describe la ejecución de varias defensas ante distintas presas, patadas, el ataque de varias personas o estando sentado, además de exponer los principios de actuación ante ataques armados con palo, cuchillo y la amenaza de un arma de fuego.

386. Kozuki, Russell (1974). Karate : un camino hacia el poder. Bilbao: Mensajero. 1ae ed. 191 p. : il. ; 17x21,5 cm. ISBN: 84-271-0820-6. Depósito legal: BI. 252-1974. (2ª ed., 1978; $3^{\underline{a}}$ ed., 1981). Palabras clave: katas, fundamentos teóricos, fundamentos técnicos, principios técnicos, combate, aplicación marcial. Resumen: Manual teórico y técnico de kárate. La obra esta formada por 5 capítulos. El primer capítulo resume brevemente la historia del kárate y de la Asociación Japonesa de Kárate. El segundo capítulo explica los principios técnicos del kárate para luego profundizar en la descripción por partes e ilustración de sus fundamentos técnicos, incluyendo ejemplos de sus aplicaciones y esquemas de movimiento. El tercer capítulo presenta la descripción técnica de ejecución de las katas Heian con la ayuda de ilustraciones y esquemas de movimiento de los pies, la línea de ejecución (embusen), y la aplicación de los movimientos más significativos. El cuarto capítulo describe e ilustra los movimientos de la kata bassai-dai incluyendo el esquema de movimiento de los pies y el embusen. El último capítulo describe por partes la ejecución de algunas técnicas de combate libre e incluye sus ilustraciones. Adjunta un índice de materias.

387. Labarta, Concha y Pereda González, Pablo (2003). El arte de la mano vacía : leyendas de to-de. La Rioja: Junco Rojo. 1a ed. 305 p. : il. ; 15x19 cm. ISBN: 84-88261-48-9. Depósito legal: LR. 1-2003. Palabras clave: formas, historia, relatos, maestros. Resumen: Compendio de historias sobre el to-de. La monografía esta compuesta de 23 capítulos precedidos por 3 capítulos introductorios que explican la evolución del to-de hacia el kárate, el significado del embusen y la transmisión del conocimiento del tode. Cada capítulo incluye un relato sobre las formas del arte marcial to-de, narrados por Matsu Higa, su hijo, Otei Hiruma, Matsumura y Masashi, y que contienen las características del arte. Cada capítulo hace referencia a una kata. Ho, Sanchin, Ba-Fu no kata, Seienchin, Turuashi Ni, Kururunfa, Ryukin no kata, Kushanku, Turuashi Ichi, Siru no kata, suparimpei, seipai, pinan, tsuki no kata, Sanchin femenino, Kushanku no Matsu Otei, Mu, Huan Gar, Gorin Ichi no kata, Yabu, Goryu no kata ichi, Tanto no kata y Rohei.

388. Lasserre, Robert (1963). Karaté-do : manual práctico. Barcelona: Hispano Europea. 1a ed. 151 p. : il. ; 14x20,5 cm. ISBN: No ISBN. Depósito legal: B. 15723-1963. (2aㅡ ed., 1964; $4^{\underline{a}}$ ed., $1965 ; 5^{\underline{a}}$ ed., 1966; $6^{\underline{a}}$ ed., 1968; 7aㅡ ed., 1970; ed. desc., 1971; ed. desc., 1974; 8 ed., $^{\text {ed }}$ 1975, ISBN: 84-255-0117-2). Palabras clave: fundamentos técnicos. Resumen: Manual teórico y técnico de kárate. La obra esta formada por 38 capítulos. Los 6 primeros capítulos comentan la historia del kárate, cuales son sus características, sus ventajas y desventajas y algunas de las leyendas entorno al kárate. Los 3 siguientes capítulos describen e ilustran las armas corporales que utiliza el kárate, los accesorios para el entrenamiento y los principios a seguir para una práctica correcta. Los siguientes 7 capítulos presentan los fundamentos técnicos básicos como son la posición, las posturas básicas, la guardia, los desplazamientos, el giro del cuerpo y la clasificación de sus técnicas. Continúa con la descripción e ilustración de las técnicas de puño, la mano utilizada como un sable, los golpes de codo y los golpes con el pie además de su entrenamiento. El siguiente capítulo explica el entrenamiento de endurecimiento con el makiwara de las distintas zonas de golpeo. Los siguientes 6 capítulos describen la ejecución de las principales defensas y sus variantes para finalizar con la descripción de los distintos tipos de entrenamiento de kumite, la ilustración de los puntos vitales corporales, la descripción de varios ejercicios especiales para la preparación física, y la explicación de los grados y el espíritu del kárate.

389. Latorre Ramos, Jesús (2002). Karate shito kai : katas superiores Vol. I. Madrid: Asociación de Karate Shito Kai Sierra del Guadarrama. 1a ed. 159 p. : il. ; 16x24 cm. ISBN: 84-932463-1-X. Depósito legal: M. 5348-2002. Palabras clave: katas, kárate, aplicación marcial. Resumen: Manual técnico de kárate. El libro esta dividido en 6 capítulos. Cada capítulo comienza explicando el significado y características técnicas de la kata que presenta para luego presentar su secuencia fotográfica, el esquema de movimiento de los pies de cada una de las técnicas y su bunkai. Las katas estudiadas son: bassai dai, bassai syo, ishimine no bassai, matsumura no bassai, tomari no bassai y oyadomari no bassai.

390. Latorre Ramos, Jesús (2003). Karate shito kai : katas y kihon Vol. II. Madrid: Asociación de Karate Shito Kai Sierra del Guadarrama. 1aㅡ ed. 173 p. : il. ; 16x24 cm. ISBN: 84-932463-2-8. Depósito legal: M. 52726-2003. Palabras clave: katas, fundamentos técnicos, kárate, aplicación marcial. Resumen: Manual técnico de kárate. El libro esta dividido en 6 capítulos. El primer capítulo ilustra las partes del cuerpo con las que se golpea, las principales posiciones, golpes directos y circulares de brazos, defensas y las patadas, junto con una tabla clasificatoria de las katas shito kai. El segundo capítulo comenta las características de los kihon dosa (kihon dosa dai ichi, kihon dosa dai ni, kihon dosa dai san y kihon dosa dai jon), para luego presentar la secuencia fotográfica de las cuatro pre-katas junto con el esquema de movimiento de los pies. El siguiente capítulo compara y comenta las diferentes entre las katas pinan y heian e ilustra la ejecución de las katas pinan, su bunkai, la aplicación de sus movimientos más característicos al yakusoku kumite y la ejecución de la kata heian, acompañados 
siempre del esquema de movimiento de los pies. Las katas comparadas son pinan syodan y heian nidan, pinan nidan y heian syodan, pinan sandan y heian sandan, pinan jondan y heian jondan, y pinan godan con heian godan. Adjunta un diccionario y un glosario.

391. Lee, Sam (1998). Kárate. Arganda del Rey: Edimat. 1ạ ed. 189 p. : il. ; $13 \times 21$ cm. ISBN: 84-8403-061-X. Depósito legal: M. 27397-1998. Palabras clave: historia, fundamentos técnicos, combate, escuelas. Resumen: Manual teórico y técnico de kárate. El libro esta formado por 7 capítulos. El primer capítulo relata la historia del los sistemas de lucha, el origen del kárate y sus diferentes estilos. El segundo capítulo comenta las características y utilización de las diferentes partes del cuerpo usadas en el kárate para golpear acompañadas de sus respectivas fotografías. El tercer capítulo describe la ejecución de las posturas de espera, adelantadas, atrasadas y estables incluyendo su representación gráfica. Los tres siguientes capítulos detallan la ejecución técnica y utilización de los principales bloqueos, técnicas de ataque con los brazos y patadas. El último capítulo explica varias secuencias de ataque y defensa como aplicación de las técnicas presentadas con anterioridad, incluyendo la secuencia fotográfica de las mismas.

392. López Megía, Víctor (2008). La puerta hacia el karate-do : arte marcial y deporte. Sevilla: Wanceulen. 1a ed. 296 p. : il. ; 17x23,5 cm. ISBN: 978-84-9823-223-3. Depósito legal: SE. 3441-2008. Palabras clave: katas, kumite, historia, fundamentos teóricos, fundamentos técnicos, principios técnicos, entrenamiento, biografía, budo, escuelas, kobudo, fundamentos filosóficos, competición, maestros. Resumen: Manual teórico y técnico de kárate. El libro esta formado por 6 capítulos precedidos por la biografía y currículo del autor. El primer capítulo narra el origen de las artes de lucha, la historia del templo shaolín, el origen del karate, presenta el esquema del sistema social okinawense, presenta la biografía de los principales introductores de los estilos Shorin-ryu y Shorei-ryu, comenta las características de los distintos estilos de kárate y sus maestros, narra la biografía de los sucesores del Shorin-ryu y Shorei-ryu, explica los orígenes del kobudo y sus introductores además de detallar las características y utilización de sus armas, un análisis de la evolución de las artes marciales japonesas hasta la actualidad, analiza la obra titulada "Bubishi" y expone las características e historia de algunos aparatos complementarios para el entrenamiento. El segundo capítulo presenta varios aforismos sobre los fundamentos filosóficos del kárate, expone las reglas del dojo, el ken no taiyo hakku, el dojo kun, y explica los conceptos de maestro, do, budismo y zen. El tercer capítulo detalla el significado, historia, características y clasificación de las katas, explica el desarrollo de su competición y principios técnicos, ofrece varios consejos para la competición, presenta la lista oficial de katas de competición, analiza el origen y significado de las katas del estilo shito-ryu y presenta brevemente los fundamentos teóricos ocultos en las katas. El cuarto capítulo explica en qué consiste el kumite, cuáles son sus tipos, analiza la importancia del grito, la mirada, la finta y el engaño, comenta la competición de kumite y su reglamento, incluye varios extractos de la obra "el arte de la guerra" sobre el combate, analiza algunos sucesos bélicos históricos y enumera los principios técnicos y tácticos de la defensa personal. El quinto capítulo expone los principios técnicos del kárate, señala las cualidades físicas y psíquicas de un artista marcial, analiza los factores que intervienen en la eficacia de la técnica, señala importancia de la respiración correcta y describe su ejecución, explica la técnica de tai-sime, localiza los puntos vitales y señala los efectos de su manipulación. El último capítulo explica los objetivos de las guardias e ilustra sus posiciones junto con las zonas utilizadas para golpear, describe la ejecución y utilización de las principales técnicas de defensa, de ataque, posturas y técnicas de pierna acompañadas de sus ilustraciones correspondientes. Adjunta bibliografía.

393. López Reiz, Enrique (1973). Introducción al kárate. Madrid: Tebar Flores. 1ae ed. 108 p. : il. ; 16x23 cm. ISBN: 84-400-6800-X. Depósito legal: M. 34791-1973. Palabras clave: kumite, historia, fundamentos teóricos, fundamentos técnicos, principios técnicos, entrenamiento, salud. Resumen: Manual teórico y técnico de kárate. El libro consta de 37 capítulos. El primer capítulo expone el propósito del libro y narra los orígenes del kárate. El segundo capítulo comenta las características y fundadores de los distintos estilos de kárate. El tercer capítulo enumera los beneficios y los requisitos necesarios para su práctica mientas que el cuarto señala los puntos esenciales del entrenamiento. El quinto capítulo ofrece algunos datos sobre la efectividad del kárate. El sexto capítulo expone el desarrollo de una clase mientras que el séptimo presenta las armas naturales utilizadas en el kárate. El octavo capítulo muestra el cuadro general de los contenidos técnicos del kárate. El noveno capítulo describe brevemente e ilustra las posiciones básicas. Los siguientes 27 capítulos describen la ejecución técnica y señalan los principios técnicos y principales defectos de las técnicas oi-zuki, gyako-zuki, uraken, ushiro-empi, mae-empi, jodan-empi, yoko-empi, shuto-uchi exterior, shuto-uchi interior, mae-geri, yoko-geri-kekomi, mawashi-geri, ushiro-geri, gyako-mawashi-geri, mikazuki-geri, yoko-tobi-geri, maetobi-geri, gedan-barai, otoshi-uke, uchi-uke, soto-uke, morote-uke, shuto-uke, jodan-age-uke, juji-uke, haishu-uke y nukite. El último capítulo presenta los distintos métodos de kumite y ofrece algunos consejos para su práctica.

394. Mabuni, Kenei (1983). Técnicas de kárate. Madrid: Polen. $1^{\mathrm{a}}$ ed. 209 p. : il. ; $15 x 22$ cm. ISBN: 84-8542333-X. Depósito legal: M. 36475-1983. Palabras clave: katas, kumite, historia, fundamentos teóricos, 
fundamentos técnicos, principios técnicos, aplicación marcial. Resumen: Manual teórico y técnico de kárate. El libro esta formado por 26 capítulos precedidos por un breve comentario que explica en qué consiste el kárate. El primer capítulo narra la historia del kárate y las características del estilo shitoryu. El segundo capítulo expone las principales partes del cuerpo utilizadas para golpear explicando su ejecución. El tercer capítulo describe brevemente las posiciones básicas acompañadas de su ilustración. Los siguientes cuatro capítulos presentan las distintas técnicas de ataque con el puño, el codo, la pierna y las principales defensas ilustrando su ejecución en distintas situaciones. El octavo capítulo presenta la descripción de ejecución de la uke-no-kata junto con su secuencia fotográfica. El siguiente capítulo señala la importancia y entrenamiento de uke. El décimo capítulo describe e ilustra los cinco principios defensivos, mientras que el siguiente señala las características esenciales de las katas y clasifica las katas del estilo shito-ryu. El décimo segundo capítulo expone las características de las katas pinan mientras que los siguientes diez capítulos describen la ejecución y aplicación marcial de las katas pinan shodan, pinan nidan, pinan sandan, pinan yondan y pinan godan acompañadas de su secuencia fotográfica. El vigésimo tercer capítulo incluye la descripción e ilustración de varias secuencias técnicas de yakusoku kumite basadas en las katas pinan. Los tres últimos capítulos comentan las características de la kata passai-dai junto con la descripción e ilustración de su ejecución y aplicación marcial.

395. Mabuni, Kenwa y Nakasone, Genwa (2002). Invitación al karate-do (Karate do nyu mon). Madrid: Miraguano. $1^{\underline{a}}$ ed. 205 p. : il. ; $17 \times 24$ cm. ISBN: 84-7813-239-2. Depósito legal: M. 12749-2002. Palabras clave: katas, historia, fundamentos técnicos, principios técnicos, defensa personal, combate, aplicación marcial. Resumen: Manual teórico y técnico de kárate. La obra esta formada por 6 partes. La primera parte incluye 3 capítulos que estudian el espíritu japonés y su relación con las artes marciales, el origen del kárate, su relación con el kempo chino, y los contenidos morales incluidos dentro del kárate. La segunda parte incluye 2 capítulos que destacan los beneficios para la salud de la práctica del kárate a nivel fisiológico y de energía interna. La tercera parte esta formada por 5 capítulos que comentan el origen del kárate y sus relaciones con otras artes marciales, los distintos estilos y escuelas de kárate, los principios de las katas junto con su clasificación y significado, el entrenamiento de kumite, y la actitud del practicante ante el entrenamiento y el progreso del aprendizaje. La cuarta parte esta compuesta por 2 capítulos describen las distintas partes de golpeo de la mano y el brazo, las posturas y los instrumentos y métodos para el entrenamiento junto con sus efectos. La quinta parte describe la ejecución de la kata Heian Nidan acompañada de varios gráficos y esquemas de movimiento, los consejos para su entrenamiento, la descripción de su aplicación práctica (bunkai) y un conjunto de preguntas y respuestas sobre los puños, las patadas, la respiración y la teoría de la defensa. La última parte esta formada por 3 capítulos que explican ilustrativamente la kata Heian Sandan y su aplicación práctica, y comenta la resolución técnica de algunos problemas específicos sobre las defensas, el kumite, y varias situaciones de defensa personal. Adjunta fotografías del maestro Kenwa Mabuni, epílogo y resúmenes biográficos.

396. Mahillo Monte, Javier (1987). Iniciación al karate : filosofía y técnica. Santander: Javier Mahillo Monte. $1^{\text {a }}$ ed. 39 p. : il. ; 15x21,5 cm. ISBN: 84-398-8900-3. Depósito legal: SA. 115-1987. Palabras clave: historia, fundamentos técnicos, principios filosóficos, katas. Resumen: Manual teórico y técnico de kárate. La obra esta formada por 3 partes. La primera parte consta de 3 capítulos. El primer capítulo comenta las diferencias entre Oriente y Occidente, mientras que el segundo analiza la práctica del kárate en Occidente. El tercer capítulo narra el origen de las artes marciales y expone los principios filosóficos del kárate. La segunda parte consta de 6 capítulos. El primer capítulo enumera los contenidos técnicos del kárate y explica el significado del término shotokan. Los siguientes cinco capítulos nombra y representa gráficamente las principales técnicas defensivas, posiciones, técnicas de ataque directo con los brazos, técnicas de ataque indirecto con los brazos y técnicas de pierna. La tercera parte consta de cinco capítulos precedidos por un comentario sobre el significado de las katas y sus principios técnicos. Los siguientes cinco capítulos presentan el esquema de ejecución de las katas heian shodan, heian nidan, heian sandan, heian jodan y heian godan. Adjunta apéndices sobre las principales partes de la mano y el pie utilizadas para golpear y un vocabulario específico.

397. Martín García, José (1980). Karate do : escuela shito-riu. Madrid: Doble-R. 1a ed. 74 p. : il. ; 14×20,5 cm. ISBN: 84-85362-15-2. Depósito legal: M. 31181-1980. Palabras clave: historia, maestros, katas. Resumen: Manual teórico y técnico de kárate. La obra esta formada por 7 capítulos precedidos por una introducción que expone los contenidos de la obra, explica el significado de las katas y señala los principios técnicos de la escuela shito-riu. El primer capítulo narra la historia del karate-do mientras que el segundo expone la biografía de Gichin Funakoshi. Los siguientes cinco capítulos presentan la secuencia fotográfica de la ejecución de las katas pinan shodan, pinan nidan, pinan sandan, pinan jondan y pinan godan acompañadas de la posición y técnica de cada movimiento. Adjunta un consejo final para el progreso en el entrenamiento.

398. Martínez Serrano, José Fernando (2009). La huella del karate-do : alerta y vigilia. Madrid: Esteban Sanz Martínez. 1aㅡ ed. 117 p. : il. ; 15x24 cm. ISBN: 978-84-935390-8-5. Depósito legal: M. 47416-2009. 
Palabras clave: katas, historia, fundamentos teóricos, principios técnicos, vestimenta, cortesía, kárate, etiqueta. Resumen: Manual teórico y técnico de kárate. El libro esta formado por 10 capítulos precedidos por los agradecimientos y una introducción que señala los objetivos de la obra. El primer capítulo narra la historia del kárate y sus maestros, describe la isla de Okinawa e incluye algunas referencias históricas. El segundo capítulo explica en qué consiste la kata, cuál es su significado, relata su historia y comenta sus características técnicas. El tercer capítulo detalla la historia, significado características y fundamentos teóricos de las 5 katas pinan además de incluir la secuencia fotográfica de dichas katas. El cuarto capítulo expone la historia, evolución, fundamentos teóricos y principios técnicos del estilo shito-ryu junto con una tabla de las katas de dicho estilo. El quinto capítulo comenta la biografía del maestro Kyan Motobu además de incluir el árbol genealógico del kárate. El sexto capítulo explica la historia y características técnicas de las katas bassai-dai, gojyushiho, seienchin, sepai y sanseru. El séptimo capítulo presenta los beneficios derivados de la práctica de las katas comentando las sensaciones, sentimientos y experiencias que desarrollan. El octavo capítulo expone varios dojo-kun de kárate, describe el lugar de entrenamiento y los saludos e incluye algunos consejos sobre la competición de kumite. El noveno capítulo presenta un glosario de términos específicos de kárate. El décimo capítulo comenta las conclusiones finales del autor. Adjunta el currículo del autor, bibliografía y varias hojas para tomar notas.

399. Masniéres, Jean-Luc (1994). El karate: método fácil y práctico para aprender y perfeccionarse. Girona:

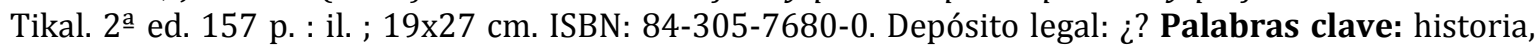
fundamentos técnicos, principios técnicos, entrenamiento, capacidades físicas, kyusho, competición, musculación, preparación física. Resumen: Manual teórico y técnico de kárate. La obra esta formada por 5 partes. La primera parte presenta las distintas vertientes que ha adoptado el kárate hasta la actualidad; detalla las características del progreso tradicional en el aprendizaje, explicando sus cuatro etapas; comenta las características del lugar de entrenamiento y las reglas de vestimenta y cortesía que rigen allí; describe la ejecución técnica de las posiciones y desplazamientos incluyendo gráficos explicativos y esquemas de movimiento de los pies; explica los principios físicos, técnicos y psíquicos que dotan a los movimientos de eficacia; y expone las armas del cuerpo junto con su aplicación habitual y los puntos vitales del cuerpo humano. La segunda parte describe las características y ejecución técnica de las principales defensas y ataques junto con un breve comentario sobre las luxaciones y las proyecciones, e incluyendo gráficos y esquemas de movimiento de todas las técnicas explicadas. La tercera parte analiza los métodos de entrenamiento propios del kárate (repeticiones técnicas, ejercicios predispuestos, asaltos convencionales y asaltos libres), explicando su correcta aplicación, sus objetivos y características además de incluir una progresión técnica de cada uno de ellos como ejemplo. La cuarta parte comenta las diferencias entre el combate real y el combate deportivo para luego exponer e interpretar el reglamento de competición. La última parte expone los principios del entrenamiento para mejorar la flexibilidad, aumentar la musculatura y endurecer el cuerpo junto con ejemplos prácticos de sus ejercicios y el desarrollo de dos planes de entrenamiento. Adjunta anexos sobre el sistema de graduación, los términos de arbitraje, y léxico específico del kárate.

400. Mayoral Sánchez, Francisco (1986). Técnica de karate-do : estilo shito-ryu. Madrid: Gráficas Carrascal. $1^{\text {a }}$ ed. 176 p. : il. ; 15x21 cm. ISBN: 84-398-7792-7. Depósito legal: M. 36210-1986. Palabras clave: historia, fundamentos técnicos, principios técnicos, aforismos. Resumen: Manual teórico y técnico de kárate. La obra esta formada por cuatro capítulos, precedidos por un conjunto de proverbios, el currículo del autor, un resumen de la historia del karate y una introducción que comenta sus principios técnicos. El primer capítulo describe la ejecución técnica de las posiciones junto con su ilustración. El segundo capítulo detalla las distintas zonas y formas del puño utilizadas para golpear así como la ejecución y errores principales de los ataques directos e indirectos de puño, mano y codo acompañados de su representación gráfica. El tercer capítulo presenta las zonas del pie y rodilla utilizadas para golpear además de describir la ejecución y principios técnicos de los principales ataques de pie y rodilla. El último capítulo describe la ejecución de las diferentes técnicas de defensa con brazo y pierna acompañadas de sus ilustraciones explicativas. Adjunta un vocabulario.

401. Mayoral Sánchez, Francisco (1996). Karate do shito-ryu. Madrid: Multideporte. 1aㅡ ed. 175 p. : il. ; $17 \times 24$ cm. ISBN: 84-87967-02-7. Depósito legal: M. 13149-1996. Palabras clave: historia, fundamentos técnicos, principios técnicos, kárate. Resumen: Manual teórico y técnico de kárate. La obra esta formada por 4 capítulos, precedidos por un conjunto de proverbios, el currículum vitae del autor, el árbol genealógico de los maestros de kárate, el comentario de la historia del kárate, y una introducción que describe los principios técnicos básicos que rigen el kárate. El primer capítulo detalla la importancia de una buena posición y los criterios que debe cumplir, para luego mostrar una imagen de cada una de las posiciones del estilo shito-ryu junto con su descripción técnica. El segundo capítulo localiza las formas y áreas del puño o brazo para utilizar como armas, y luego describe la ejecución técnica de los ataques directos e indirectos de puño, manos y codo, realizados en sus posiciones habituales, incluyendo una imagen de la preparación de la técnica y otra de su finalización. El tercer capítulo muestra las áreas de golpeo con el pie y la rodilla, su utilización habitual y pasa a ilustrar los 
ataques de pie y de rodilla más habituales, describiendo sus puntos clave y errores más frecuentes. El último capítulo incluye la explicación técnica e ilustración de la preparación y posición final de las defensas de brazo y de pierna. Adjunta un vocabulario.

402. McCarthy, Patrick (2001). Bubishi : la biblia del kárate. Madrid: Tutor. 1a ed. 217 p. : il. ; 17x24 cm. ISBN: 84-7902-245-0. Depósito legal: M. 27143-2001. (2ª ed., 2004; 3aㅡ ed., 2007, ISBN: 978-84-7902307-2). Palabras clave: historia, fundamentos técnicos, filosofía, kyusho, fitoterapia, medicina tradicional china. Resumen: Estudio de la obra china clásica Bubishi. El libro esta dividido en 4 partes, que se subdividen en una parte teórica y otra de artículos relacionados con cada tema. La primera parte estudia los orígenes del Bubishi, su transmisión, repercusión en el karate actual, y cómo se fue conformando la historia del karate. Los artículos de este primer capítulo están dedicados a los orígenes del estilo grulla blanca, la transmisión de conocimientos del maestro Wang, algunos consejos de etiqueta, los principios filosóficos de las artes marciales, las observaciones del maestro Wang sobre el sistema puño del monje y un pequeño comentario sobre la deidad Jiu Tian Feng Huo Yuan San Tian Dou. La segunda parte estudia la medicina y fitoterapia chinas y sus efectos. Los artículos de esta parte ofrecen tratamiento para distintas enfermedades y detallan algunos diagramas de fitoterapia y la composición de ungüentos, medicinas y píldoras. La tercera parte profundiza en los puntos vitales del cuerpo humano, su representación a lo largo de la historia y su correcta manipulación. Los artículos sobre puntos vitales describen la localización de los distintos puntos vitales, sus efectos al ser manipulados y el diagrama de los puntos vitales en la estatua del hombre de bronce. La última parte recoge los aspectos estratégicos que aparecen en el Bubishi y hace una reseña histórica de los estilos de gongfu de Fujian, para finalizar con los artículos sobre las técnicas de lucha de los quan del sistema puño del monje, de la lucha cuerpo a cuerpo, posturas de entrenamiento de manos y pies, las máximas de Sun Zi y los principios de la ley antigua. Adjunta bibliografía, términos chinos y japoneses e índices onomástico, toponímico y temático.

403. Menkyo, Soke (2002). Kárate fácil. Barcelona: Freelive. 1aㅗ ed. 63 p. : il. ; 16x24 cm. ISBN: No ISBN. Depósito legal: B. 8396-2001. Palabras clave: katas, kumite, historia, fundamentos teóricos, fundamentos técnicos, kyusho, competición, reglamentos. Resumen: Manual teórico y técnico de kárate. El libro esta dividido en 20 capítulos. El primer capítulo narra la historia del kárate y sus estilos. El segundo capítulo presenta la práctica del kárate mientras que el tercero ofrece varios consejos prácticos para realizar la primera sesión. El cuarto capítulo describe las distintas partes del cuerpo utilizadas para golpear. Los dos siguientes capítulos describen varios ejercicios de flexibilidad y fortalecimiento. El séptimo capítulo describe la ejecución de un golpe directo (tsuki) junto con su representación gráfica. Los dos siguientes capítulos explican la ejecución de las principales posturas y de mae-geri. El décimo capítulo explica el significado del kiai. Continúa explicando el desplazamiento en zenkutsu, la ejecución de los principales bloqueos acompañados de su secuencia gráfica y comentando las características de otras técnicas de kárate. El décimo cuarto capítulo localiza los puntos vitales del cuerpo humano. El siguiente capítulo comenta las características del ju-kumite y shikai. El décimo sexto capítulo resume las reglas de competición. El siguiente capítulo explica el significado y en qué consiste una kata además de incluir una clasificación de los mismos. Los tres últimos capítulos enumeran los principales errores en las técnicas básicas de kárate, un glosario de los contenidos técnicos básicos del kárate, el sistema de grados y un vocabulario específico.

404. Mitchell, David (2003). Karate : conocer el deporte. Madrid: Tutor. 1 a ed. 48 p. : il. ; 20x13,5 cm. ISBN: 84-7902-377-5. Depósito legal: M. 8161-2003. Palabras clave: historia, fundamentos teóricos, fundamentos técnicos, escuelas. Resumen: Manual teórico y técnico de kárate. La obra esta formada por 20 capítulos, precedidos de una introducción que relata brevemente la historia del kárate. Los seis primeros capítulos explican las características técnicas de los estilos de kárate más importantes, ofrecen algunos consejos de seguridad y de elección del club, y detallan la indumentaria para la práctica, los grados que existen y las normas de conducta que rigen en el dojo. El séptimo capítulo describe algunos ejercicios de calentamiento para ejecutar antes de la clase de kárate para luego describir la ejecución técnica de la colocación del puño, el golpe básico con el puño, los principios técnicos para conseguir golpear con potencia, la ejecución de golpes de puño y paradas en desplazamiento junto con las ilustraciones explicativas. Los cuatro siguientes capítulos describen otras técnicas de puño, mano abierta, codo, defensas, patadas y combinaciones de técnicas explicadas e ilustradas por partes. Los últimos cuatro capítulos exponen las características y objetivos del combate preestablecido, el combate libre, las katas y la competición. Adjunta un glosario e índice alfabético.

405. Molina Zapata, Fulgencio (1986). Goju-ryu karate do volumen 1. Murcia: Imprenta Boluda. 1a ed. 64 p. : il. ; 20x29 cm. ISBN: No ISBN. Depósito legal: MU. 641-1986. Palabras clave: historia, fundamentos teóricos, fundamentos técnicos, biografía, kyusho, maestros. Resumen: Manual teórico y técnico de kárate. La obra esta compuesta por 8 capítulos precedidos por un prólogo que expone los objetivos de la obra y el currículo del autor. El primer capítulo narra la historia del estilo goju-ryu junto con algunas fotos de sus maestros. Los dos siguientes capítulos presentan brevemente las biografías y aportaciones de Kanryo Higaonna y Chojun Miyagi al kárate incluyendo varias fotografías. El cuarto capítulo explica 
las características técnicas del estilo goju-ryu. El quinto capítulo relata la biografía de Gogen Yamaguchi. El sexto capítulo describe la ejecución técnica de las posiciones de kárate acompañadas de su representación gráfica y esquema de los pies. El séptimo capítulo localiza los puntos vitales del cuerpo humano. El último capítulo describe las distintas formas de golpear con las manos y los pies incluyendo su representación gráfica.

406. Molina Zapata, Fulgencio (1991). Karate do tradicional goju ryu. Murcia: Fulgencio Molina Zapata. 1a ed. 250 p. : il. ; 21x29,5 cm. ISBN: No ISBN. Depósito legal: MU. 246-1991. Palabras clave: katas, kumite, historia, fundamentos teóricos, fundamentos técnicos, biografía, maestros. Resumen: Manual teórico y técnico de kárate. El libro esta formado por 25 capítulos precedidos por un prólogo que comenta los objetivos y contenidos de la obra y una introducción que narra la historia del arte marcial de Okinawa. El primer capítulo relata el origen y evolución del Okinawa-te. Los siguientes tres capítulos presentan las biografías de Higashionna Kanryo, Miyagi Chojun y Yamaguchi Gogen. Los dos siguientes capítulos explican la teoría de los cinco animales y los tres elementos aplicadas a las artes marciales. El séptimo capítulo comenta el desarrollo del sistema goju kai y sus contenidos técnicos. El octavo capítulo explica los ejercicios preliminares de junbi undo. El noveno capítulo enumera las técnicas que componen el kihon waza ho además de incluir su representación gráfica. El décimo capítulo presenta las formas de desplazarse junto con sus esquemas de movimiento. Los siguientes cinco capítulos explican el trabajo de kihon ido, neko ashi ido, shido ido, moto dachi shido ido y neko ashi happo ido incluyendo la ilustración de varias de sus técnicas. El decimosexto capítulo detalla los fundamentos del kata ido además de ilustrar la ejecución de las vueltas en su realización acompañadas de sus esquemas de movimiento. Los tres siguientes capítulos narran el origen de las katas, describen la formación de las katas goju ryu y presenta una clasificación de las mismas. El vigésimo capítulo comenta los contenidos técnicos de las katas taikyoku y gekisai incluyendo la representación gráfica de dos de sus katas. El siguiente capítulo comenta el origen, características técnicas, fundamentos teóricos y principios técnicos de las katas Sanchin y Tensho presentando la secuencia fotográfica de su ejecución y aplicaciones. El vigésimo segundo capítulo incluye la representación gráfica de las katas saifa, seienchin, sanseiru, shisochin, seisan, seipai, kururunfa y suparunpei (pecchurin) explicando su significado y características técnicas. El siguiente capítulo comenta la evolución del entrenamiento de bunkai kumite además de incluir la secuencia fotográfica de algunas de sus técnicas. Los dos últimos capítulos explican los diferentes tipos de kumite y kakete acompañados de algunos ejemplos gráficos. Adjunta bibliografía.

407. Montanari, Enzo (1999). Karate desconocido : la parte desconocida del kárate tradicional. Madrid: Tutor. 1a ed. 127 p. : il. ; 21x28 cm. ISBN: 84-7902-243-4. Depósito legal: M. 43814-1999. (2 $2^{\mathrm{a}}$ ed., 2003). Palabras clave: historia, fundamentos teóricos, combate, kárate, kyusho, preparación física. Resumen: Tratado teórico y técnico de karate. La obra esta dividida en 10 capítulos, con los 6 primeros dedicados a los aspectos teóricos que fundamentan la historia y práctica del karate. El primer capítulo ofrece una explicación de las distintas razones que provocaron el secretismo del karate y continúa en el segundo con el relato de la historia del karate en la actualidad, sus vertientes, y un breve comentario del karate shotokan y su evolución. El tercer capítulo presenta algunas de las teorías chinas, como la teoría del yin-yang, de los meridianos o de los cinco animales y que fundamentan el estudio del kyusho jitsu que se explica en el siguiente capítulo, y que ilustra con todo detalle los puntos vitales del cuerpo humano. El quinto capítulo explica el funcionamiento de la proyección de potencia interna o Fah Jing y continúa con algunas aplicaciones del kyusho en su vertiente terapéutica. El séptimo capítulo comenta el arte de agarrar las manos o tuite jitsu para luego pasar a describir y mostrar algunas de las técnicas de kárate clásico y la aplicación del comienzo de las katas Bassai dai, Kanku dai, Empi, Jion, Jiin y Jitte. Los dos últimos capítulos hacen un análisis comparativo de las aplicaciones prácticas de las katas tekki shodan y naihanchi shodan y presenta algunos de los pasajes de Yi Chin Ching que estudian el acondicionamiento de la mano a través de la técnica de la "palma de arena de hierro".

408. Motobu, Choki (2008). Okinawa kempo karate jutsu. Madrid: Budo International. 1a ed. 143 p. : il. ; 17x24 cm. ISBN: 978-84-82484-18-8. Depósito legal: M. 47139-2008. Palabras clave: kumite, historia, fundamentos técnicos, rehabilitación, equipamiento. Resumen: Manual teórico y técnico de kárate. El libro esta dividido en 6 capítulos precedidos por un comentario sobre el contexto histórico del autor y el prólogo. El primer capítulo narra el origen del kárate, explica en qué consiste y comenta sus diferentes estilos. El segundo capítulo describe la posición básica del cuerpo. El tercer capítulo presenta las reglas menores del kempo junto con un comentario sobre la práctica del kumite. El cuarto capítulo explica cómo construir un makiwara y describe algunas de sus técnicas de entrenamiento. El quinto capítulo presenta la descripción e ilustración de algunas técnicas de kumite como las defensas ante distintos ataques. El último capítulo expone varios métodos y tratamientos ante las lesiones más habituales en la práctica del kárate.

409. Muñoz, Carlos (1975). El karate, la mejor arma de defensa y ataque. Barcelona: De Vecchi. 1 1 a reimp. 80 p. : il. ; 14x20,5 cm. ISBN: 84-315-0166-9. Depósito legal: M. 22075-1975. (3ª ed., 1978, 96 p.; 4를. ed., 
1982, 96 p.; 5a ed., 1986, 96 p.; 6ª ed., 1988, 96 p.). Palabras clave: fundamentos técnicos. Resumen: Manual de enseñanza de los aspectos básicos del kárate. Después de narrar los orígenes e historia del kárate, detalla e ilustra sus principios básicos (el saludo, los ejercicios de calentamiento y el modo de cerrar el puño), los aspectos técnicos de las posiciones fundamentales, de los principales golpes de puño y pierna así como de las técnicas de parada. Continúa con algunos ejemplos de ejercicios por parejas, recomendaciones para el progreso en el entrenamiento, ejercicios de kihon y de kumite. Finaliza con la descripción técnica ilustrada de la kata Heian Shodan y un vocabulario de términos japoneses.

410. Nakayama, Masatoshi (1975). Katas de karate : heian 1, tekki 1. Bilbao: Fher. 1a ed. 144 p. : il. ; $15 x 21$ cm. ISBN: 84-243-0815-8. Depósito legal: BI. 23-1975. (2a ed., 1979). Palabras clave: katas, fundamentos técnicos. Resumen: Manual técnico de kárate. La obra esta formada por 2 capítulos precedidos de una introducción que detalla los principios técnicos de las katas, los principios para su entrenamiento y aprendizaje, las características de las katas presentadas y algunos consejos para la lectura del libro. El primer capítulo incluye un diagrama con la colocación y desplazamiento de los pies durante la realización de la kata Heian 1, la descripción de la ejecución técnica de cada movimiento junto con el esquema de movimiento de los brazos y los pies, así como sus aplicaciones y las ilustraciones desde diferentes puntos de vista. El segundo capítulo mantiene la misma estructura de contenidos para estudiar la ejecución de la kata Tekki 1. Adjunta un breve glosario de términos japoneses y dos desplegables con la vista desde la parte alta de las katas Heian 1 y Tekki 1.

411. Nakayama, Masatoshi (1975). Katas de karate : heian 2, heian 3. Bilbao: Fher. 1a ed. 144 p. : il. ; $15 x 21$ cm. ISBN: 84-243-0816-6. Depósito legal: BI. 22-1975. (2ª ed., 1979). Palabras clave: katas, fundamentos técnicos. Resumen: Manual técnico de kárate. La obra esta formada por 2 capítulos precedidos de una introducción que detalla los principios técnicos de las katas, los principios para su entrenamiento y aprendizaje, las características de las katas presentadas y algunos consejos para la lectura del libro. El primer capítulo incluye un diagrama con la colocación y desplazamiento de los pies durante la realización de la kata Heian 2, la descripción de la ejecución técnica de cada movimiento junto con el esquema de movimiento de los brazos y los pies, así como sus aplicaciones y las ilustraciones desde diferentes puntos de vista de cada movimiento. El segundo capítulo mantiene la misma estructura de contenidos para estudiar la ejecución de la kata Heian 3. Adjunta un breve glosario de términos japoneses y dos desplegables con la vista desde la parte alta de las katas Heian 2 y Heian 3.

412. Nakayama, Masatoshi (1975). Katas de karate : heian 4. Bilbao: Fher. $1^{\text {a }}$ ed. 108 p. : il. ; $15 x 21 \mathrm{~cm}$. ISBN: 84-243-0817-4. Depósito legal: BI. 21-1975. (2 ${ }^{\mathrm{a}}$ ed., 1975). Palabras clave: katas, fundamentos técnicos. Resumen: Manual técnico de kárate. La introducción de la obra explica en qué consisten las katas, cuál es la actitud mental para ejecutarlas, detalla sus principios técnicos, las características de la kata Heian 4 y enumera distintos consejos prácticas para su correcta ejecución y la lectura del libro. El primer capítulo incluye un diagrama con la colocación y desplazamiento de los pies durante la realización de la kata Heian 4, la descripción de la ejecución técnica de cada movimiento junto con el esquema de movimiento de los brazos y los pies, así como sus aplicaciones y las ilustraciones desde diferentes puntos de vista de cada movimiento. Adjunta un breve glosario de términos japoneses y un desplegable con la vista desde la parte alta de la kata Heian 4.

413. Nakayama, Masatoshi (1975). Katas de karate : heian 5. Bilbao: Fher. $1^{a}$ ed. 119 p. : il. ; $15 x 21 \mathrm{~cm}$. ISBN: 84-243-0818-2. Depósito legal: BI. 20-1975. Palabras clave: katas, fundamentos técnicos. Resumen: Manual técnico de kárate. La introducción de la obra explica en qué consisten las katas, cuál es la actitud mental para ejecutarlas, detalla sus principios técnicos, las características de la kata Heian 5 y enumera distintos consejos prácticas para su correcta ejecución y la lectura del libro. El primer capítulo incluye un diagrama con la colocación y desplazamiento de los pies durante la realización de la kata Heian 5, la descripción de la ejecución técnica de cada movimiento junto con el esquema de movimiento de los brazos y los pies, así como sus aplicaciones y las ilustraciones desde diferentes puntos de vista de cada movimiento. Adjunta un breve glosario de términos japoneses y un desplegable con la vista desde la parte alta de la kata Heian 5.

414. Nakayama, Masatoshi (1976). La dinámica del kárate : posiciones y técnicas fundamentales de ataque (Libro primero). Bilbao: Fher. 1aㅡ ed. 176 p. : il. ; 18x25,5 cm. ISBN: 84-243-1198-1. Depósito legal: BI. 1581-1976. (2 $2^{\text {a }}$ ed., 1979). Palabras clave: historia, fundamentos técnicos, principios técnicos. Resumen: Manual técnico de kárate. La obra esta compuesta por 2 partes, precedidas de un capítulo dedicado al origen y evolución del karate y otro a los principios cinéticos de la práctica del karate. La primera parte desarrolla la explicación de las técnicas fundamentales, como las posiciones y sus consideraciones, la utilización y entrenamiento de la cadera, la estabilidad, y los modos de utilización de las manos y los pies como armas. La segunda parte explica la ejecución correcta de los ataques directos, indirectos y patadas, junto con las variantes de los movimientos principales y su entrenamiento. Esta explicación esta ilustrada con numerosas fotografías, desde diferentes puntos de 
vista e incluso con fotografía estroboscópica en algunos casos. Esta parte también incluye un breve glosario.

415. Nakayama, Masatoshi (1976). La dinámica del kárate : técnicas de parada y contraataque (Libro segundo). Bilbao: Fher. $1^{\mathrm{a}}$ ed. 152 p. : il. ; 18x25,5 cm. ISBN: 84-243-1197-3. Depósito legal: BI. 15821976. (2a ed., 1979). Palabras clave: fundamentos teóricos, entrenamiento, biomecánica, cine, fundamentos técnicos. Resumen: Manual técnico de kárate. La obra esta compuesta por 3 partes, precedidas de un capítulo dedicado al origen y evolución del karate y otro a los principios cinéticos de la práctica del karate. La primera parte estudia la técnica básica de movimiento de las paradas, sus distintos tipos así como su entrenamiento ante distintos ataques. La segunda parte, compuesta por 3 capítulos, describe la aplicación de las distintas defensas ante ataques a nivel alto, medio y bajo respectivamente, con sus ilustraciones y esquemas de movimiento. La última parte presenta el entrenamiento de las principales técnicas de ataque con brazos, piernas y paradas así como ejercicios físicos individuales y por parejas para el acondicionamiento general. También incluye un apéndice con el análisis cinético de algunos golpes y un glosario.

416. Nakayama, Masatoshi (1979). Karate superior 1 : compendio. Bilbao: Fher. $1^{\text {a }}$ ed. 144 p. : il. ; 15x22,5

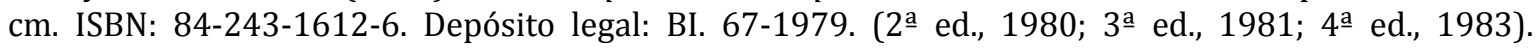
Palabras clave: fundamentos técnicos, katas. Resumen: Manual técnico de karate. La monografía comienza explicando el significado del karate y algunos aspectos teóricos previos, así como las partes del cuerpo con las que se golpea y cómo lo hacen, la ejecución de las posiciones, cómo se realizan los desplazamientos y algunos ejercicios preparatorios. El tercer capítulo describe los principios en los que se basan todas las técnicas de karate: la forma, la fuerza y velocidad, la concentración y relajación de la fuerza, el aumento de la energía muscular, el ritmo y tiempo, la cadera y la respiración; y continua con la explicación de las técnicas fundamentales de brazo y pierna junto con sus ilustraciones. El quinto capítulo ilustra todas las katas Heian, Tekki shodan y ofrece un breve comentario de Tekki nidan, Tekki sandan, Bassai dai, Kanku dai, Jyutte, Hangetsu, Empi, Gankaku y Jion. A continuación comenta los tipos de kumite que existen e ilustra las técnicas del gohon kumite y del ippon kumite. La última parte del libro hace un resumen histórico del karate, comenta cómo se desarrollan las competiciones, cómo se fortalece el cuerpo a través del entrenamiento con el makiwara y cuáles son los puntos vitales anatómicos. Adjunta un glosario.

417. Nakayama, Masatoshi (1979). Karate superior 2 : fundamentos. Bilbao: Fher. $1^{\mathfrak{a}}$ ed. 144 p. : il. ; 14x22,5

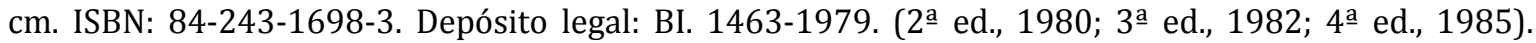
Palabras clave: fundamentos técnicos, biomecánica. Resumen: Manual técnico de karate. Después de explicar lo que es el karate, profundiza en los fundamentos técnicos del karate, ilustrando y esquematizando cada uno de los movimientos explicados. El segundo capítulo estudia la cadera, sus movimientos y ejecución correcta, los principales defectos y cómo se entrena. Continúa detallando la distintas posturas de karate, la colocación de cada parte del cuerpo para alcanzar una posición correcta, como son los desplazamientos desde estas posiciones y cuáles son sus métodos de entrenamiento. El cuarto capítulo divide los desplazamientos y cambios de dirección en fases, explicando con todo detalle cada una de ellas y cómo es su entrenamiento. Luego explica algunos detalles y principios técnicos comunes a todas las técnicas, como son la coordinación, el empleo de la muñeca y el tobillo, la torsión del antebrazo, la sincronización, el equilibrio, el radio de acción, la mirada, la dirección correcta, la velocidad y la fuerza. El sexto capítulo enumera los detalles técnicos que deben recordarse durante el entrenamiento de las paradas, los ataques directos e indirectos y las patadas, así como algunos principios comunes a todas ellas. Por último, ilustra la musculatura humana y ofrece un programa de entrenamiento de 12 semanas para las técnicas básicas. Adjunta un glosario.

418. Nakayama, Masatoshi (1979). Karate superior 3 : kumite 1. Bilbao: Fher. $1^{\mathrm{a}}$ ed. 143 p. : il. ; 15x22,5 cm.

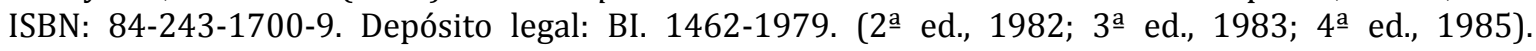
Palabras clave: kumite, fundamentos técnicos, táctica. Resumen: Manual técnico de karate. Comienza explicando el significado del karate y cuáles son los tipos de kumite junto con sus características. Los dos siguientes capítulos explican el significado de los principios Sen-no-sen y Go-no-sen, acompañados por secuencias fotográficas. Los siguientes capítulos muestran gráficamente distintas formas de atacar con la pierna, ataques indirectos y ataques de pierna en corta distancia, haciendo un pequeño comentario sobre su ejecución correcta. Los dos últimos capítulos se concentran en los derribos y en las combinaciones de ataque a dos niveles respectivamente y junto con numerosas fotografías. Adjunta un glosario.

419. Nakayama, Masatoshi (1980). Karate superior 4 : kumite 2. Bilbao: Fher. 1 a ed. 143 p. : il. ; 15x22,5 cm. ISBN: 84-243-1796-3. Depósito legal: BI. 202-1980. (2 $2^{a}$ ed., 1983; $3^{a}$ ed., 1985). Palabras clave: kumite, fundamentos técnicos. Resumen: Manual técnico de karate. La obra comienza explicando el significado del karate y los tipos de kumite, para luego profundizar en cómo debe ser la preparación para el combate. A continuación comenta algunas de las técnicas más avanzadas del combate, como son los derribos, el cambio de técnicas, las patadas en anticipación, los contraataques, las técnicas de 
última oportunidad, las técnicas continuadas y las paradas decisivas. Todas estas técnicas están ampliamente ilustradas. Adjunta un glosario.

420. Nakayama, Masatoshi (1980). Karate superior 5 : katas de heian y tekki. Bilbao: Fher. $1^{a}$ ed. 144 p. : il. ; 15x22,5 cm. ISBN: 84-243-1851-X. Depósito legal: BI. 1626-1980. (2ª ed., 1983; 3aㅡ ed., 1985). Palabras clave: katas, fundamentos técnicos. Resumen: Manual técnico de katas de karate. La obra comienza con la explicación de lo que es el karate y algunos detalles importantes comunes a las katas Heian y Tekki. A continuación, aparecen explicadas las secuencias de movimientos de cada una de las katas, señalando los detalles técnicos más importantes, aportando fotografías de cada movimiento, la línea de acción (embusen) y finalizando con un resumen de los aspectos más significativos de cada kata. Las katas presentadas son las 5 Heian y las 3 Tekki. Adjunta un glosario.

421. Nakayama, Masatoshi (1980). Karate superior 6 : katas, bassai y kanku. Bilbao: Fher. 1 a ed. 143 p. : il. ; 15x22,5 cm. ISBN: 84-243-1852-8. Depósito legal: BI. 1627-1980. (2ª ed., 1983; 3ª ed., 1985). Palabras clave: katas, fundamentos técnicos. Resumen: Manual técnico de karate. La obra explica la ejecución de las katas Bassai y Kanku. Comienza con una introducción sobre el significado del karate y los puntos importantes en la ejecución de éstas katas para en el primer capítulo pasar a explicar cada movimiento, ofrecer su secuencia fotográfica, su línea de acción y finalizar con un compendio de los puntos más importantes. El segundo capítulo se estructura de la misma manera y describe la ejecución de la kata Kanku. Adjunta un glosario.

422. Nakayama, Masatoshi (1983). Karate superior 7 : katas jitte, hangetsu y empi. Bilbao: Fher. 1a ed. 152 p. : il. ; 15x22 cm. ISBN: 84-243-2197-9. Depósito legal: no. Palabras clave: katas, fundamentos técnicos, aplicación marcial. Resumen: Manual teórico y técnico de kárate. La obra esta compuesta por 6 capítulos, precedidos por una introducción que comenta la evolución del kárate hasta su deportivización. El primer capítulo describe lo que es el kárate y cuáles son sus principios filosóficos y técnicos. El segundo capítulo describe el significado de las katas y su entrenamiento, la clasificación de las katas respecto al cinturón del practicante, los puntos más importantes durante su realización y el esquema del ritmo de las katas jitte, hangetsu y empi. Los tres siguientes capítulos siguen una misma estructura que comienza por la presentación e ilustración de la secuencia técnica de cada kata y a continuación detalla sus puntos más importantes y la aplicación práctica de los movimientos más significativos. La presentación de la secuencia técnica de las katas jitte, hangetsu y empi incluye la ilustración de cada movimiento dividido en fases y desde dos puntos de vista distintos, con una breve descripción del movimiento, una imagen cenital de la técnica y un esquema del movimiento de los pies y su orientación. El último capítulo incluye un glosario de términos.

423. Nakayama, Masatoshi (1983). Karate superior 8 : katas gankaku y jion. Bilbao: Fher. $1^{\mathfrak{a}}$ ed. 152 p. : il. ; 15x22 cm. ISBN: 84-243-2198-7. Depósito legal: no. Palabras clave: katas, principios técnicos, aplicación marcial. Resumen: Manual teórico y técnico de kárate. La obra esta compuesta por 5 capítulos, precedidos por una introducción que comenta la evolución del kárate hasta su deportivización. El primer capítulo describe lo que es el kárate y cuáles son sus principios filosóficos y técnicos. El segundo capítulo describe el significado de las katas y su entrenamiento, la clasificación de las katas respecto al cinturón del practicante, los puntos más importantes durante su realización y el esquema del ritmo de las katas gankaku y jion. Los dos siguientes capítulos presentan e ilustran desde varios puntos de vista la secuencia técnica de las katas gankaku y jion respectivamente, junto con la explicación de sus puntos más importantes y la aplicación práctica de los movimientos más significativos. El último capítulo presenta la ejecución completa de ambas katas comentando los principios técnicos y aplicación de algunos de sus movimientos. Adjunta un glosario de términos.

424. Nakayama, Masatoshi (2006). Karate superior 1 : compendio. Madrid: Tutor. $1 \underline{a}$ ed. 144 p. : il. ; $17 \times 24$ cm. ISBN: 84-7902-545-X. Depósito legal: M. 49253-2005. Palabras clave: katas, kumite, fundamentos técnicos. Resumen: Manual técnico sobre los fundamentos del karate. Esta dividido en 7 capítulos. Comienza aportando una visión general del karate-do y explica la utilización de manos y pies como armas, las características de las posiciones básicas, de los movimientos, y algunos de los ejercicios preparatorios. El tercer capítulo describe los principios biomecánicos que se aplican en el karate para continuar con los ejercicios de entrenamiento de las técnicas básicas de mano y pierna. El siguiente capítulo describe e ilustra las katas Heian y hace un breve comentario sobre las katas superiores. El sexto capítulo explica los tipos de combate que existen y finaliza con una descripción histórica del karate, de las competiciones, el entrenamiento con el makiwara y la representación de los puntos vitales del ser humano. Adjunta un glosario de términos japoneses y su traducción.

425. Nakayama, Masatoshi (2006). Karate superior 2 : fundamentos. Madrid: Tutor. 1aㅡ ed. 144 p. : il. ; $17 x 24$ cm. ISBN: 84-7902-546-8. Depósito legal: M. 49254-2005. Palabras clave: fundamentos técnicos, biomecánica. Resumen: Manual teórico y técnico. La obra tiene 6 capítulos ilustrados gráficamente. Después de definir el karate-do, explica el funcionamiento de las caderas, su aplicación dentro del karate, sus tipos de rotación, los puntos clave y los métodos de entrenamiento. El tercer capítulo estudia las posiciones, sus requisitos e importancia, los tipos de posiciones con sus características, sus puntos clave y métodos de entrenamiento. El cuarto capitulo explica la ejecución de los 
desplazamientos, cambios de dirección y tai-sabaki en karate junto con sus métodos de entrenamiento. Continúa con la descripción de los puntos clave comunes en las técnicas de brazo y pierna así como los principios biomecánicos de todas ellas. El último capítulo comenta los detalles técnicos del entrenamiento de las paradas, de los ataques directos e indirectos y de las patadas. También incluye una descripción de la musculatura esquelética así como un programa de entrenamiento para las técnicas básicas. Adjunta un glosario.

426. Nakayama, Masatoshi (2006). Karate superior 3 : kumite 1. Madrid: Tutor. $1^{\text {a }}$ ed. 143 p. : il. ; 17x24 cm. ISBN: 84-7902-547-6. Depósito legal: M. 49255-2005. Palabras clave: kumite, fundamentos técnicos, principios técnicos. Resumen: Después de comentar en la introducción la aparición del kárate deportivo y sus consecuencias sobre el karate-do, define lo que es el karate-do. El segundo capítulo explica detalladamente la práctica del kumite, sus tipos y significados, y cómo debe ser la preparación para el combate. Los dos siguientes capítulos explican los principios Sen no Sen y Go no Sen, ofreciendo numerosas fotografías sobre dichos principios y su aplicación mediante diferentes técnicas. El quinto capítulo y posteriores, describen las técnicas de combate más comunes de forma gráfica, comenzando con los tipos de patadas y continuando con los ataques indirectos, las técnicas de pierna a corta distancia, los derribos y los ataques combinados a dos niveles. Cada capítulo comienza con la descripción de las características de los maestros que demuestran estas técnicas. Adjunta un glosario.

427. Nakayama, Masatoshi (2006). Karate superior 4 : kumite 2. Madrid: Tutor. 1 a ed. 144 p. : il. ; $17 x 24$ cm. ISBN: 84-7902-548-4. Depósito legal: M. 49256-2005. Palabras clave: kumite, fundamentos técnicos, principios técnicos. Resumen: Manual técnico avanzado de kumite. La obra tiene 8 capítulos. El primero hace una introducción de lo que es el karate así como del contenido de los volúmenes 3 y 4, y sus objetivos. El segundo capítulo describe el kumite, sus fundamentos, sus tipos, los puntos esenciales y los principios de la práctica. A continuación y en capítulos diferentes describe brevemente y con un amplio conjunto de fotografías los barridos, la variedad técnica, las patadas con la pierna adelantada, las respuestas o contraataques, las técnicas por sorpresa y de última oportunidad y la combinación de técnicas en el combate. Cada capítulo comienza con un breve comentario sobre las características de los maestros que demuestran dichas técnicas.

428. Nakayama, Masatoshi (2006). Karate superior 5 : katas heian y tekki. Madrid: Tutor. $1^{a}$ ed. 143 p. : il. ; 17x24 cm. ISBN: 84-7902-595-6. 978-84-7902-595-3. Depósito legal: M. 28341-2006. Palabras clave: katas, fundamentos técnicos, combate. Resumen: Manual técnico de las katas Heian y Tekki. Después de definir lo que es el karate-do, pasa a describir cada uno de los movimientos de las katas heian shodan, heian nidan, heian sandan, heian yondan, heian godan, tekki shodan, tekki nidan y tekki sandan, remarcando los puntos más importantes en su realización. Ofrece ilustraciones del desarrollo de cada movimiento, el esquema de los movimientos y su línea de ejecución (embusen). Adjunta un glosario de términos.

429. Nakayama, Masatoshi (2006). Karate superior 6 : katas, bassai y kanku. Madrid: Tutor. 1aㅡ ed. 208 p. : il. ; $18 \times 23 \mathrm{~cm}$. ISBN: 84-7902-620-0. Depósito legal: no. Palabras clave: katas, fundamentos técnicos. Resumen: Manual técnico de karate. La obra explica la ejecución de las katas Bassai y Kanku. Comienza con una introducción sobre el significado del karate y los puntos importantes en la ejecución de éstas katas para en el primer capítulo pasar a explicar cada movimiento, ofrecer su secuencia fotográfica, su línea de acción y finalizar con un compendio de los puntos más importantes. El segundo capítulo se estructura de la misma manera y describe la ejecución de la kata Kanku. Adjunta un glosario.

430. Nakayama, Masatoshi (2006). Karate superior 7 : katas jitte, hangetsu y empi. Madrid: Tutor. $1^{\text {a }}$ ed. 143 p. : il. ; 17x24 cm. ISBN: 978-84-7902-628-8. 84-7902-628-6. Depósito legal: M. 51458-2006. Palabras clave: katas, fundamentos técnicos, aplicación marcial. Resumen: Manual teórico y técnico de kárate. La obra esta compuesta por 6 capítulos, precedidos por una introducción que comenta la evolución del kárate hasta su deportivización. El primer capítulo describe lo que es el kárate y cuáles son sus principios filosóficos y técnicos. El segundo capítulo describe el significado de las katas y su entrenamiento, la clasificación de las katas respecto al cinturón del practicante, los puntos más importantes durante su realización y el esquema del ritmo de las katas jitte, hangetsu y empi. Los tres siguientes capítulos siguen una misma estructura que comienza por la presentación e ilustración de la secuencia técnica de cada kata y a continuación detalla sus puntos más importantes y la aplicación práctica de los movimientos más significativos. La presentación de la secuencia técnica de las katas jitte, hangetsu y empi incluye la ilustración de cada movimiento dividido en fases y desde dos puntos de vista distintos, con una breve descripción del movimiento, una imagen cenital de la técnica y un esquema del movimiento de los pies y su orientación. El último capítulo incluye un glosario de términos.

431. Nakayama, Masatoshi (2008). Karate superior 8 : katas gankaku y jion. Madrid: Tutor. $1 \underline{\text { a }}$ ed. 144 p. : il. ; 17x24 cm. ISBN: 978-84-7902-690-5. Depósito legal: 51752-2007. Palabras clave: katas, principios técnicos, aplicación marcial. Resumen: Manual teórico y técnico de kárate. La obra esta compuesta por 5 capítulos, precedidos por una introducción que comenta la evolución del kárate hasta su 
deportivización. El primer capítulo describe lo que es el kárate y cuáles son sus principios filosóficos y técnicos. El segundo capítulo describe el significado de las katas y su entrenamiento, la clasificación de las katas respecto al cinturón del practicante, los puntos más importantes durante su realización y el esquema del ritmo de las katas gankaku y jion. Los dos siguientes capítulos presentan e ilustran desde varios puntos de vista la secuencia técnica de las katas gankaku y jion respectivamente, junto con la explicación de sus puntos más importantes y la aplicación práctica de los movimientos más significativos. El último capítulo presenta la ejecución completa de ambas katas comentando los principios técnicos y aplicación de algunos de sus movimientos. Adjunta un glosario de términos.

432. Ohtsuka, Hironori (2009). Wado-ryu karate. Madrid: Budo International. $1 \underline{\underline{a}}$ ed. 383 p. : il. ; 17x24 cm. ISBN: 978-84-82484-25-6. Depósito legal: M. 5040-2009. Palabras clave: fundamentos teóricos, fundamentos técnicos, principios técnicos, principios éticos, fundamentos filosóficos, katas. Resumen: Manual teórico y técnico de kárate. La obra esta dividida en 3 partes precedidas por las notas del traductor, un comunicado de la familia Ohtsuka y el prólogo del autor. La primera parte incluye la biografía del autor junto con sus reflexiones sobre el origen y el camino de las artes marciales, su evolución, el objetivo del entrenamiento y de las artes marciales, los requisitos para la práctica, sus principios técnicos y morales, los principios para el progreso en el entrenamiento, la actitud ante las situaciones de defensa personal y el combate además de incluir varias historias. La segunda parte describe la ejecución de las distintas técnicas de puño, mano abierta, patadas, posiciones, ataques de puño y formas de defensa incluyendo sus ilustraciones correspondientes. La tercera parte explica el orden de aprendizaje de las katas y describe la ejecución técnica de las katas pinan shodan, pinan nidan, pinan sandan, pinan jondan, pinan godan, kushanku, naifhanchi, seishan y chinto.

433. Oliva Seba, Antonio; Fernández Benzo, Julián y Vicent Ciscar, Antonio (1982). Formalización del kárate deportivo. Madrid: AIESEP. $1^{a}$ ed. 205 p. : il. ; 22x31,5 cm. ISBN: No ISBN. Depósito legal: no. Palabras clave: fundamentos teóricos, kárate, competición. Resumen: Análisis y sistematización de las acciones técnicas y tácticas de la competición de karate. El estudio esta dividido en 5 apartados y tiene como objetivo principal estudiar los combates individuales realizados en el Campeonato del mundo de 1980. El primer capítulo reproduce fielmente parte de la obra de Ennio Falsoni, "Karate en 12 lecciones", sobre "El karate: su nacimiento y desarrollo en Oriente". Continúa con un comentario sobre el desarrollo del karate deportivo y en concreto de la selección española en las competiciones internacionales. Los dos siguientes capítulos sistematizan el karate deportivo, tanto sus reglas como sus acciones y describe la metodología utilizada para la recogida de los datos. El último capítulo presenta los resultados obtenidos y discute aquellos aspectos más significativos. Adjunta anexos sobre los programas utilizados para recoger los datos, la presentación estadística de los datos y bibliografía.

434. Oliva Seba, Antonio; Torres Baena, Fernando y Navarro Mouchet, Jesús (2002). Combate supremo. Tarragona: Ángel Delgado Poco (Club Karate Musoken). 1a ed. 869 p. : il. ; 17x24 cm. ISBN: 84-6076024-3. Depósito legal: M. 48670-2002. Palabras clave: fundamentos teóricos, didáctica, combate, entrenamiento, praxiología, taoísmo. Resumen: Tratado teórico sobre el combate deportivo. El libro esta compuesto de 3 partes de 3 capítulos, cada una de ellas abordando una de las manifestaciones que conforman al individuo, el sentimiento, el movimiento y el pensamiento. La primera parte estudia el sentimiento, profundizando sus capítulos en el modo de afrontar la vida y sus acontecimientos, el proceso de desarrollo del ser humano y el guerrero a través del taoísmo y la teoría del yin-yang, y la importancia del concepto amor, como motor de la vida y las personas, dentro del desarrollo personal. La segunda parte expone la manifestación del movimiento explorando el origen y evolución del ser humano y la lucha como manifestación de su desarrollo, el descubrimiento de los 3 bloques del individuo (sentimiento, pensamiento y movimiento) y su formalización en la teoría SMP, junto con las características de cada bloque y la aplicación de la teoría DCE (dominante, complementario, equilibrador) sobre estos bloques para conformar los 9 arquetipos de luchadores. El tercer capítulo de esta parte define, clasifica y formaliza cada una de las partes y acciones del combate, dividiendo los contenidos en técnica, táctica y emótica. La última parte aborda el pensamiento, analizando el combate a través de la praxiología, exponiendo el desarrollo de varias unidades didácticas y adjuntando los congresos, posters, comunicaciones y proyectos en los que se han involucrado los autores. El segundo capítulo de esta parte ahonda en el concepto de entrenamiento, sus características y programación, su importancia dentro del desarrollo personal, las características del entrenador y describe dos ejercicios básicos para el entrenamiento (sol y sombra, supra-ipon) junto con sus ventajas e inconvenientes. El último capítulo reflexiona sobre el proceso de enseñanza-aprendizaje, las etapas de perfeccionamiento en las artes marciales, la relación intuición-razón dentro del proceso de aprendizaje, la metodología didáctica, las características de los niveles evolutivos y los estadios, para finalizar con una propuesta didáctica aplicada a los bloques racional, pasional y motórico. Adjunta una amplia bibliografía, un ensayo reflexivo sobre el futuro de las artes marciales, una breve biografía de los autores, el listado de colaboradores, la historia y funciones del CICAC y las cartas de agradecimiento de distintas federaciones. 
435. Pedregal Canga, Manuel (2003). Gensei ryu karate-do : cinco principios, tres dimensiones. Madrid: Esteban Sanz Martínez. 1aㅡ ed. 229 p. : il. ; 17x24 cm. ISBN: 84-85977-86-6. Depósito legal: M. 141972003. Palabras clave: katas, historia, fundamentos técnicos, principios técnicos, maestros. Resumen: Manual de introducción al estilo Gensei ryu de kárate. La primera parte describe el nacimiento y desarrollo del estilo y sus características así como a sus personajes más significativos. También define y explica gráficamente los 5 principios que prevalecen en el estilo. La segunda parte presenta el trabajo de kihon con unas consideraciones preliminares y la secuencia gráfica del trabajo. La tercera parte estudia las katas del estilo, con su secuencia gráfica y una explicación de los aspectos más importantes a considerar en su ejecución. La última parte presenta a los introductores del estilo en España, con su foto y una breve descripción bibliográfica. Adjunta bibliografía.

436. Pereda González, Pablo (1998). Meijin. Logroño: Garyu Ryu Karate-Do. 1aㅡ ed. 144 p. ; 14x20,5 cm. ISBN: 978-84-937275-3-6. Depósito legal: no. Palabras clave: historia, principios filosóficos, kárate, aplicación terapéutica. Resumen: Tratado teórico de kárate. El libro esta formado por 8 capítulos precedidos por varias cartas de agradecimiento y un prólogo que comenta los inicios del kárate para minusválidos. El primer capítulo describe la práctica del kárate en la antigüedad y en el seno familiar, el significado del kata y las características del dojo. El segundo capítulo relata los comienzos del autor en la universidad y el kárate además de incluir algunas leyendas sobre los principios de las artes marciales. El tercer capítulo describe su formación universitaria y marcial. El cuarto capítulo detalla los contactos y charlas del autor con distintos maestros de las artes marciales y con algunos de sus alumnos. El quinto capítulo explica la experiencia del autor como profesor de kárate, reflexiona sobre el significado de las katas, la competición, el honor, la templanza y el perdón. El sexto capítulo incluye una investigación sobre los atemis, un programa de entrenamiento para los tsukis y explica los contenidos de la escuela Garyu-ryu. El séptimo capítulo presenta los 20 principios del kárate. El último capítulo describe los logros del autor hasta conseguir el grado de Meijin. Adjunta la carta de agradecimiento de la familia Higa y un epílogo.

437. Pereda González, Pablo (2004). El mundo mágico de Matsu Higa. Tudela: Pablo Pereda González. 1ª ed. 379 p. ; 14x21 cm. ISBN: 84-609-0742-2. Depósito legal: NA. 1182-2004. Palabras clave: historia, fundamentos teóricos, to-de, maestros. Resumen: El libro consta de 13 capítulos. El primer capítulo narra la historia del to-de y okinawa-te, la evolución de las katas waishinzan, turuashi y katas tántricos, describe los entrenamientos del cuerpo energético y espiritual, expone las enseñanzas de Higa sobre la última kata, define la sofrología y la energía interna, y describe la práctica energética del kata sanchin junto con los niveles de consciencia organizados y patológicos. El segundo capítulo relata las visitas del autor a su abuela y el descubrimiento del manuscrito sobre To-de fechado en 1868. Los siguientes 10 capítulos narran la investigación desarrollada por el autor y los aprendizajes con los maestros Masashi, Akashi, Higa, Otei, Takuji, Nakamura, TsuMa, Nakashima, Kime y el gran Higa. El último capítulo incluye un epílogo como resumen de la obra.

438. Pereda González, Pablo (2005). Karaterapia : movimientos que curan. Método rehabilitación y terapia Dr. Pereda. La Rioja: Pablo Pereda González. 1aㅡ ed. 200 p. ; 16x23 cm. ISBN: 84-609-5226-6. Depósito legal: no. ( $2^{a}$ ed., 2006, 265 p.). Palabras clave: fundamentos teóricos, principios técnicos, aplicación terapéutica, enfermedades, investigación. Resumen: El libro esta formado por 10 capítulos precedidos por varios prólogos que señalan la importancia de la obra, la dedicatoria del autor, una introducción que comenta la historia, características y aplicaciones de la karaterapia y un capítulo que expone los contenidos del DVD que adjunta esta publicación. El primer capítulo explica los principios técnicos de la karaterapia, sus fundamentos técnicos, las características del kata y señala la importancia de la alineación vertebral y el papel de los ligamentos. El segundo capítulo detalla los problemas del sedentarismo, la escoliosis, la cifosis, la etiopatogenia, la lordosis, los lumbagos y las dorsalgias, expone sus tipos y características además de sus prácticas terapéuticas. El tercer capítulo define las distintas patologías de las extremidades, trastornos del crecimiento y detalla el plan de trabajo para tratar estos problemas. El cuarto capítulo compara la danza con la kata, expone los requisitos de las katas desde el punto de vista energético, describe algunas de las aplicaciones de la kata transterapia y el desarrollo de una sesión. El quinto capítulo analiza los beneficios del kata sanchin, sus estudios electrofisiológicos, y compara diversas técnicas mentales de meditación. El sexto capítulo explica en qué consiste la infraconsciencia, describe sus primeros estudios, las características de los consumidores de heroína, cocaína, alcohol y alucinógenos, y los principios de actuación para la aplicación de la karaterapia. El séptimo capítulo narra las experiencias del autor en la aplicación de la karaterapia y la kata sanchin. El octavo capítulo expone las aplicaciones de sanchin en medicina interna, como la rehabilitación respiratoria y angor pectoris además de detallar sus principios técnicos. El noveno capítulo comenta las aplicaciones de la karaterapia sobre alteraciones motoras y sus beneficios además de enumerar los contenidos técnicos de cinturón amarillo, naranja y verde de garyu ryu karate do. El último capítulo presenta el estudio de la sanuzella-zym sobre la capacidad física del hombre, la aplicación terapéutica de la kata en pacientes VIH y de hepatitis viral, y expone las recomendaciones, prácticas y tratamientos desde la karaterapia para el cáncer. Adjunta un suplemento que detalla los fundamentos teóricos 
hormonales de la karaterapia, describe las particularidades del entrenamiento con seropositivos, define los conceptos generales sobre paraplejias y parálisis cerebrales, además de incluir algunas de las preguntas más frecuentes sobre karaterapia y el programa completo de cinturón negro. También adjunta el currículo del autor.

439. Pereda González, Pablo (2005). Poema de amor : inspirado en la historia de Matsu y Otei. La Rioja: Pablo Pereda González. 1aㅡ ed. 52 p. : il. ; 21x29,5 cm. ISBN: 84-609-6667-4. Depósito legal: no. Palabras clave: amor, maestros, seppuku. Resumen: Poema de amor inspirado en el sepuku. El libro esta formado por 25 capítulos precedidos por una introducción que comenta la historia de la creación del poema. Los siguientes 25 capítulos narran los sentimientos de amor de Matsu Higa por Otei Hiruma acompañados de la ilustración de diversos trazos.

440. Pereda González, Pablo (2006). El mundo mágico de Otei Hiruma. Logroño: Tomari. 1a ed. 410 p. ; 14x20,5 cm. ISBN: 84-609-9056-7. Depósito legal: no. Palabras clave: ejercicios, to-de. Resumen: Tratado teórico de kárate. El libro esta formado por 7 capítulos precedidos por un prólogo que resume los katas presentados y su utilidad, las obras del autor, y narra el acceso del autor a los conocimientos de la bruja Kime. Los siguientes 7 capítulos narran la estancia del autor en Okinawa aprendiendo los conocimientos del to-de femenino por medio de Kime y su grupo de practicantes, y describen los ejercicios preparatorios para el contacto con Otei Hiruma así como dicho contacto.

441. Pereda González, Pablo (2006). Kime, el útero divino. Logroño: Pablo Pereda González. 1ae ed. 145 p. : il. ; 15x20,5 cm. ISBN: 84-611-2144-9. Depósito legal: no. Palabras clave: katas, historia, fundamentos teóricos, fundamentos técnicos, aplicación terapéutica. Resumen: Tratado teórico de kárate. El libro esta formado por 7 capítulos precedidos por una advertencia práctica, un prólogo que comenta las características y beneficios del trabajo del "útero divino" y un capítulo introductorio que señala los contenidos de la obra. El primer capítulo narra la historia del to-de, su evolución, sus objetivos y características. El segundo capítulo expone las repercusiones de los distintos tipos de movimiento sobre la consciencia y los requisitos de las danzas rituales. El tercer capítulo señala la historia y práctica del método del útero divino. El cuarto capítulo detalla los beneficios derivados de los ejercicios propuestos y los requisitos para su aplicación terapéutica. El quinto capítulo incluye las notas de campo sobre las prácticas de "útero divino" mientras que el sexto presenta su transcripción. El último capítulo incluye un breve epílogo.

442. Pérez Agustí, Adolfo (1988). El libro de oro del kárate. Madrid: Adolfo Pérez Agustí. 1a ed. 192 p. : il. ; 15x21,5 cm. ISBN: 84-404-2587-2. Depósito legal: M. 24531-1988. Palabras clave: historia, fundamentos teóricos, fundamentos técnicos, escuelas, aplicación marcial. Resumen: Manual teórico y técnico de kárate. El libro esta formado por 10 capítulos. El primer capítulo narra la historia de las artes marciales, del kárate y de los diferentes estilos shorin ryu, naha-te, tomari-te, shotokan, shitoryu, goju-ryu, kyokushinkai y wado-ryu, incluyendo una tabla con la génesis del kárate. El segundo capítulo presenta las distintas zonas de la mano, rodilla y pie utilizadas para golpear en kárate así como su aplicación. Los siguientes cuatro capítulos describen la ejecución y utilización de las diferentes posiciones de espera y las posturas adelantadas, retrasadas y estables del kárate acompañadas de sus ilustraciones correspondientes. El séptimo capítulo explica la ejecución y aplicación de las principales técnicas de bloqueo mientras que el octavo presenta las técnicas de ataque. El noveno capítulo muestra las principales patadas de kárate acompañadas de su representación gráfica. El último capítulo describe e ilustra la aplicación de algunas de las técnicas explicadas ante diversos ataques.

443. Pérez García, Fernando (2003). Kyokushin karate : tradición y evolución en busca de la eficacia. Móstoles: Arkano Books. 1aㅡ ed. 284 p. : il. ; 17x24 cm. ISBN: 84-89897-73-5. Depósito legal: M. 431072003. ( $2^{\underline{a}}$ ed., 2006). Palabras clave: katas, kumite, historia, fundamentos técnicos. Resumen: Manual técnico de karate estilo kyokushin. La obra esta dividida en 6 capítulos, comenzando el primero de ellos explicando la historia y filosofía de este estilo y algunas de las características que lo definen a nivel práctico. El segundo capítulo describe los elementos formales o de etiqueta del dojo, como son el saludo, el comportamiento, la terminología específica, los grados y su progresión. Continúa con una breve explicación de los objetivos del calentamiento e ilustra algunos de ellos junto con algunos ejercicios de acondicionamiento físico general. El siguiente capítulo ilustra los fundamentos, como son las posiciones, los ataques con brazos y piernas, los blocajes, y algunas técnicas básicas en movimiento, así como una descripción de las katas, el kumite y el aspecto mental del entrenamiento. El quinto capítulo explica sucintamente los objetivos, principios técnicos básicos, procedencia y significado de las katas y ofrece la secuencia de movimientos ilustrada de cada kata del estilo. El último capítulo profundiza en el kumite desde sus aspectos históricos y filosóficos hasta un resumen de las clasificaciones de los campeonatos del mundo, del reglamento, algunas nociones básicas sobre los rompimientos, las técnicas más frecuentes en la competición, los sistemas técnicas de combate junto con la táctica y estrategia, algunos elementos auxiliares para el entrenamiento y un comentario sobre la preparación física y psicológica del competidor. 
444. Perry, Paul J. (1993). Karate sin lesiones. Barcelona: Paidotribo. 1a ed. 188 p. : il. ; 15x21,5 cm. ISBN: 848019-075-2. Depósito legal: B. 3987-1993. Palabras clave: fundamentos técnicos, lesiones, medicina. Resumen: Estudio técnico de los movimientos de karate. La obra analiza los movimientos del calentamiento, los principales puñetazos, posturas, defensas, patadas y avances de karate, describiendo su ejecución correcta así como los defectos a evitar para no caer lesionado. Ofrece ilustraciones tanto de los movimientos correctos como incorrectos. El séptimo capítulo resalta los movimientos más importantes de las katas heian y tekki shodan con sus defectos; y finaliza con algunas consideraciones preventivas en el trabajo de kumite y el entrenamiento de la respiración.

445. Pflüger, Albrecht (2000). 25 shotokan katas : cuadros sinópticos de los katas de kárate para exámenes y competiciones. Barcelona: Paidotribo. 1aㅡ ed. 86 p. : il. ; 21x27,5 cm. ISBN: 84-8019-460-X. Depósito legal: no. (2 $2^{\underline{a}}$ ed., 2004; $3^{\underline{a}}$ ed., 2006). Palabras clave: katas, kárate. Resumen: Manual técnico de las katas del estilo shotokan de karate. La obra esta dividida en 13 capítulos. Los 11 primeros capítulos describen de forma breve la historia del karate, su llegada a Japón, el nacimiento de los diferentes estilos y su árbol genealógico, el cambio de significado de la palabra karate, la evolución del estilo shotokan, qué es un kata, los problemas que impiden el desarrollo del karate en la actualidad, los tipos de katas que existen, los criterios para evaluarlas y algunas recomendaciones para la correcta práctica de las katas. El siguiente capítulo comenta las características y algunos datos anecdóticos sobre cada una de las katas del estilo shotokan y representa gráficamente la ejecución de las mismas, sus esquemas de movimiento y la aplicación práctica de las técnicas más significativas de cada kata. Finaliza con un resumen de los principios del entrenamiento de las katas, un glosario y bibliografía.

446. Piñero Lazaro, Antonio (1974). Karate. Zaragoza: Antonio Piñero. $1^{\mathrm{a}}$ ed. 187 p. : il. ; 21x31 cm. ISBN: 84-400-7263-5. 84-400-7262-7. Depósito legal: Z. 176-1974. (2aㅡ ed., 1978). Palabras clave: katas, fundamentos técnicos, defensa personal. Resumen: Manual técnico de karate. La obra comienza con una explicación de los orígenes y significado del karate para continuar con la descripción e ilustración de algunos ejercicios de calentamiento para todo el cuerpo. El tercer capítulo se centra en los tipos de respiración y su realización para en los dos siguientes presentar tanto las partes de golpeo con la mano como con el pie. El sexto capítulo explica las posiciones de karate y ofrece una ilustración y esquema de los pies de cada una de ellas; y en un capítulo separado trata la repartición del peso en la posición de los pies de algunas posiciones. A partir del octavo capítulo comienza a presentar las técnicas propias del karate, tanto de kihon como de kata y kumite. Así, va ilustrando los golpes con las manos, con los pies y los blocajes, mostrando además de la forma correcta algunos de los principales errores técnicos. Después comienza con la explicación de las katas pinan, detallando la ejecución de cada movimiento de las mismas y acompañado con la línea de realización (embusen) y una secuencia fotográfica. Los siguientes tres capítulos se concentran en el estudio del kumite, comenzando con la explicación del trabajo de sambon e ippon-kumite y continuando con la descripción de tres posiciones o guardias para afrontar el estudio del combate libre. También incluye un conjunto de ilustraciones sobre acciones desarrolladas en combate libre. Finaliza la obra con la descripción de algunas técnicas de defensa personal general y específicas para la mujer, y fotografías sobre rompimientos. Adjunta un glosario.

447. Piñero Lazaro, Antonio (1984). Karate kyokushin. Zaragoza: Antonio Piñero. 1aㅗ ed. 285 p. : il. ; 21x30 cm. ISBN: 84-398-1967-6. Depósito legal: no.

448. Puig-Siscar (1966). Karate : el más terrible y eficaz arte de combate. Barcelona: Alas. 1aㅡ ed. 95 p. : il. ; 10x15,5 cm. ISBN: No ISBN. Depósito legal: B. 10660-1966. Palabras clave: fundamentos teóricos, entrenamiento, kyusho, arbitraje, competición, equipamiento, grados, preparación física, reglamentos. Resumen: Manual teórico y técnico de kárate. El libro esta formado por 9 capítulos precedidos por un prólogo que señala las cualidades del practicante de kárate. El primer capítulo comenta en qué consiste la preparación física del karateka y señala el papel del ataque en el combate. El segundo capítulo clasifica las zonas del cuerpo utilizadas para golpear además de incluir su gráfico. El tercer capítulo describe la estructura del makiwara y el saco así como su entrenamiento. El cuarto capítulo localiza los puntos vitales del cuerpo humano. El quinto capítulo incluye un diccionario de términos específicos del kárate. El sexto capítulo comenta la organización federativa del kárate y el sistema de grados además de señalar las características de temperamento, comportamiento y vestimenta que debe exhibir el karateka. El séptimo capítulo incluye un resumen de las reglas de competición. El octavo capítulo explica el desarrollo del examen de cinturón negro mientras que el noveno presenta un extracto del reglamento de arbitraje. Adjunta una nota con el programa de pase de grados de la sección de kárate de la FFJDA.

449. Puig-Siscar (1967). Técnica aplicada del karate. Barcelona: Alas. 1ae ed. 90 p. : il. ; 10x15,5 cm. ISBN: No ISBN. Depósito legal: B. 12953-1967. Palabras clave: kumite, ejercicios, entrenamiento, aplicación marcial, equipamiento, preparación física. Resumen: Manual teórico y técnico de kárate. El libro esta formado por 4 capítulos precedidos por un prólogo que comenta los contenidos de la obra. El primer capítulo ofrece varios consejos para el entrenamiento con el makiwara además de describir el entrenamiento de las manos y los pies acompañados de su representación gráfica. El segundo capítulo expone los principios técnicos de los saltos. El tercer capítulo detalla los principios técnicos de los 
ejercicios de acondicionamiento físico además de describir e ilustrar la ejecución de varios de ellos. El cuarto capítulo describe por partes la ejecución de 15 técnicas de kumite ante distintos ataques acompañadas de su representación gráfica.

450. Quirós Martínez, Juan Antonio (2002). Karate-do : posiciones, desplazamientos y defensas. Tomo I. Madrid: Asociación de la Prensa Hispanoamericana. 1ํㅡㄹ ed. 478 p. : il. ; 17x24 cm. ISBN: 84-931483-2-6. Depósito legal: no. Palabras clave: fundamentos técnicos. Resumen: Manual técnico de las posiciones, desplazamientos y defensas de karate. Después de hacer una introducción general al karate, desde su historia, significado y objetivos hasta el dojo, el saludo y los cinturones, comienza a explicar los conceptos básicos que aparecen en la práctica del karate, sus principios dinámicos, algunos fundamentos anatómicos y las partes del cuerpo con las que se golpea. El siguiente capítulo estudia las características de las posiciones, sus fundamentos y requisitos para ser correctas para luego pasar a describir cada una de ellas respecto a proporción, articulaciones, especialidad, colocación, variantes, momentos de posición, errores frecuentes y su práctica. El siguiente capitulo aborda el estudio de los desplazamientos, qué tipos hay, cuales son sus características, cómo se realiza cada uno de ellos dividiendo el movimiento en fases y la ejecución de movimientos especiales. Continua con la explicación de los principios de las defensas para luego pasar a describir cada una de las defensas existentes con sus variantes. Todas las explicaciones del libro están acompañadas de su representación fotográfica.

451. Quirós Martínez, Juan Antonio (2007). Tsuki waza : ataques directos. Tomo II. Madrid: Juan Antonio Quirós Martínez. 1a ed. 269 p. : il. ; 17x24 cm. ISBN: 978-84-611-8289-3. Depósito legal: M. 360412007. Palabras clave: principios técnicos, defensa personal, biomecánica. Resumen: Manual teórico y técnico de kárate. El libro esta formado por 50 capítulos precedidos por una presentación que comenta la progresión en el entrenamiento de kárate y cómo utilizar el libro. El primer capítulo define el término tsuki waza, expone sus principios técnicos y analiza sus fundamentos biomecánicos incluyendo numerosos gráficos explicativos. El segundo capítulo explica en qué consiste el seiken tsuki y la forma de armar el puño. El tercer capítulo define el kara tsuki-choku tsuki y expone el área de contacto, lugar de partida, recorrido, lugar de llegada, colocación del codo y hombro, puntos importantes, errores frecuentes y sus variantes incluyendo distintas ilustraciones explicativas. Los siguientes seis capítulos definen y explican el área de contacto, lugar de partida, recorrido, lugar de llegada, colocación del codo y hombro, puntos importantes, errores frecuentes y ejercicios de los ataques jun tsuki, giaku tsuki, maete tsuki, kizami tsuki y yoko tsuki, acompañados de sus ilustraciones explicativas. El décimo capítulo detalla el encadenamiento de varios tsukis incluyendo su secuencia fotográfica. El resto de capítulos explican el uso, área de contacto, lugar de partida, recorrido, lugar de llegada, colocación del codo y hombro, puntos importantes, errores frecuentes, ejercicios, variantes y aplicaciones de las técnicas mawashi tsuki, kagi tsuki, ura tsuki, age tsuki, age ura tsuki, otoshi tsuki, tate tsuki, ushiro age tsuki, ushiro furi tsuki, maete tsuki tai hineri, iai tsuki, gassho tsuki, iaiken tsuki, ippon ken, ippon ken tsuki, mawashi naname ippon ken, age ippon ken, ura ippon ken, nakadaka ippon ken, chukoken tsuki, kaisho, hiraken tsuki, tate nukite, hira nukite, ippon nukite, nihon nukite, boshinken tsuki, hirabasami, yubi basami, shotei tsuki, jodan shotei tsuki, chudan shotei tsuki, gedan shotei tsuki, otoshi shotei tsuki, kumade tsuki, tobi komi tsuki, la descripción técnica de las posiciones uki ashi dachi y han dachi, y las defensas gedan shotei tsuki y morote yoko barai, junto con sus respectivas ilustraciones y gráficos explicativos. Adjunta un glosario específico y la biografía del autor.

452. Regoli, Claudio A. (1989). Karate : manual completo ilustrado. Barcelona: De Vecchi. 1a ed. 158 p. : il. ; 17x23,5 cm. ISBN: 84-315-0687-3. Depósito legal: B. 689-1989. Palabras clave: katas, kumite, historia, fundamentos técnicos, principios técnicos, ejercicios, competición. Resumen: Manual teórico y técnico de kárate. La obra esta compuesta de 12 capítulos. El primer capítulo narra la historia y expansión del kárate hasta la actualidad. Los dos siguientes capítulos detallan las zonas del cuerpo que pueden ser utilizadas para golpear al adversario y la forma de utilizarlas además de localizar los puntos vulnerables del cuerpo humano y comentar su manipulación. Los siguientes cuatro capítulos describen la ejecución técnica de las principales posiciones, golpes con el puño, golpes con la pierna y defensas acompañadas por su ilustración desde diferentes puntos de vista. El octavo capítulo explica los métodos de entrenamiento del kihon gohon kumite y del kihon ippon kumite para luego presentar la ejecución de diez secuencias técnicas de éste último a modo de ejemplo, ilustradas en cada movimiento, y resaltar los principios técnicos que deben considerarse en su práctica. El siguiente capítulo expone las características de las katas del estilo shotokan para luego presentar la secuencia técnica de la kata bassai-dai, la aplicación de algunos de sus movimientos y la ilustración en varias direcciones de su ejecución. Los tres últimos capítulos comentan las formas de endurecer las manos, las pruebas de rotura de materiales y las características y objetivos de la competición deportiva. Adjunta un glosario.

453. Regoli, Claudio A. (1995). Karate : técnica de autodefensa, filosofía de vida. Barcelona: De Vecchi. 1aㅡ. ed. 158 p. : il. ; 16x23,5 cm. ISBN: 84-315-0687-3. Depósito legal: no. (2ª ed., 1998, ISBN: 84-315-1915-0). Palabras clave: katas, historia, fundamentos técnicos, principios técnicos, kyusho, competición. 
Resumen: Manual teórico y técnico de kárate. La obra esta formada por 12 capítulos. El primer capítulo relata la historia y desarrollo del kárate así como sus diferentes estilos. El segundo capítulo describe las distintas partes del cuerpo utilizadas para golpear acompañadas de sus ilustraciones. El tercer capítulo señala los principales puntos vulnerables del cuerpo humano. El cuarto capítulo explica la ejecución de las posiciones básicas del kárate junto con sus fotografías. Los siguientes 3 capítulos describen la ejecución técnica de los principales golpes con los brazos, con el pie y sus paradas acompañadas de sus ilustraciones explicativas. El octavo capítulo detalla las características de los distintos tipos de combate junto con la descripción de algunos ejemplos prácticos y su secuencia fotográfica, y los principios básicos de un golpe. El noveno capítulo define el significado de la kata, enumera las katas de los distintos estilos de kárate y describe la ejecución de la kata bassai-dai acompañada de su secuencia fotográfica. El décimo capítulo presenta la estructura del makiwara mientras que los dos últimos capítulos comentan el entrenamiento para las técnicas de rupturas y los tipos de competiciones deportivas. Adjunta un glosario.

454. Riera Alfonso, Alfonso (2008). Karate kata : forma evolutiva. s.l.: Alfonso Riera Alfonso. 1aㅡ ed. 283 p. : il. ; 19x27,5 cm. ISBN: 84-95655-38-1. Depósito legal: B. 30946-2008. Palabras clave: katas, historia, fundamentos teóricos, sistemas de entrenamiento. Resumen: Manual teórico y técnico de kárate. El libro esta compuesto por 39 capítulos. El primer capítulo explica el significado del kata. El segundo capítulo relata la historia del kárate y sus katas. El tercer capítulo señala las cualidades de un buen maestro. El cuarto capítulo expone el sentido y valor del dojo y el saludo. El quinto capítulo describe el principio de rectitud del artista marcial. El sexto capítulo reflexiona sobre la vertiente marcial y deportiva del kárate. El séptimo capítulo comenta los principios técnicos de las katas. Los siguientes 30 capítulos presentan las características, objetivos y ejecución de las formas denominadas forma del lado contrario y forma hacia atrás, forma en 4 direcciones y forma con-contra armas, forma espontánea y forma con apoyo mano, forma de desequilibrios y forma creada, forma de proyecciones y forma de controles, forma en el suelo y forma de rodamientos, forma de agarres y forma de estrangulaciones, forma sucesiva y forma con rompimiento, forma flexible y forma con guardias, forma de vaivén y forma en el sitio, forma rítmica y forma de desplazamientos, forma mental y forma con obstáculos, forma de mano abierta y forma de puño cerrado, forma de bloqueos, forma de patadas y forma de saltos, forma en corto y largo y forma doble y simultánea, forma sobre un pie y forma a favor-contra caderas, forma contra músculos y forma sentado, forma con ojos cerrados y forma sin kimono, forma continua y forma con un solo miembro, forma física y forma de formas, forma natural, forma evolutiva, forma sin forma, forma competitiva evolutiva y juka, contemplando la totalidad (kanku dai), sorprendiendo al enemigo (bassai dai), evoluciones de golondrina (empi), el monje del templo (jion), y el caballero de acero (tekki). Los dos últimos capítulos proponen algunas mejoras para el kárate actual y comentan las pruebas de examen bajo este sistema de enseñanza.

455. Riera Alfonso, Alfonso (2009). Kumite kata : formas de combate evolutivas. Barcelona: Alfonso Riera Alfonso. 1a ed. 290 p. : il. ; 19x27,5 cm. ISBN: 84-95655-42-1. Depósito legal: B. 37680-2009. Palabras clave: katas, fundamentos teóricos, principios técnicos, sistemas de entrenamiento. Resumen: Manual teórico y técnico de kárate. El libro esta formado por 36 capítulos. El primer capítulo discute la metodología de enseñanza actual de las katas. El resto de capítulos expone los fundamentos teóricos, metodología de entrenamiento de distintas katas y su forma de aplicación. Las katas presentadas se denominan forma de proyecto, forma del sol naciente, forma educativa, forma guerrera, forma magistral, forma secreta, forma anónima, forma de fondo, forma de transformación, forma creativa, forma de nube, forma de arte, forma de los sentidos, forma básica y superior, forma de los cinco elementos, forma de dureza y fortaleza, forma de mano llena, forma de puntos vitales, forma de participación, forma de números, forma inusual, forma de proporción, forma de reforma, forma de orden, forma de interpretación, forma de coordinación, forma de representación, forma de adaptación, forma de definición, forma bilateral, forma de protección, forma de armar, forma de posición, forma de movilidad y forma de unificación.

456. Rivero de la Corte, Francisco (1985). Karate-do shotokan : manual de karate. Cádiz: T. García. 1a ed. 110 p. : il. ; 15x21 cm. ISBN: 84-398-4100-0. Depósito legal: CA. 504-1985. Palabras clave: katas, kumite, fundamentos técnicos, entrenamiento, anatomía, arbitraje, competición, exámenes, lesiones, reglamentos. Resumen: Manual teórico y técnico de kárate. El libro esta formado por 8 capítulos precedidos por una dedicatoria, el prólogo que comenta el origen del kárate, y un comentario sobre las funciones del alumno y las normas del dojo. El primer capítulo presenta los términos japoneses y españoles de las posiciones, ataques directos e indirectos, bloqueos y patadas de kárate acompañados de su representación gráfica. El segundo capítulo expone el significado y principios técnicos de las katas además de enumerar la secuencia técnica de todas las katas heian y tekki shodan, incluyendo su representación gráfica. El tercer capítulo detalla dos trabajos de entrenamiento técnico y táctico de kumite, y describe la ejecución de las técnicas de sanbon kumite, kihon ippon kumite y jiju ippon kumite. El cuarto capítulo incluye los contenidos de katas y kumite para el pase de grados hasta cinturón negro. El quinto capítulo presenta un resumen del reglamento de competición junto con los 
términos específicos del arbitraje. El sexto capítulo señala los beneficios de la práctica de ejercicio físico, sus recomendaciones, enumera algunos entrenamientos para mejorar el rendimiento deportivo, define las principales lesiones deportivas, y representa los huesos y músculos del cuerpo humano. El séptimo capítulo incluye un glosario de términos japoneses mientras que el octavo relata una historia sobre el aprendizaje.

457. Rodríguez, José (1984). Karate : estudio de técnicas fundamentales. Barcelona: Alas. $1^{\text {a }}$ ed. 71 p. : il. ; 15x21,5 cm. ISBN: 84-203-0167-1. Depósito legal: B. 27229-1984. (2ª ed., 1987). Palabras clave: katas, kumite, historia, fundamentos teóricos, fundamentos técnicos. Resumen: Manual teórico y técnico de kárate. El libro esta formado por 11 capítulos precedidos por una introducción que comenta los objetivos de la obra. El primer capítulo explica en qué consiste el kárate y relata su origen. El segundo capítulo narra la historia del kárate shotokan mientras que el tercero señala la importancia de las posiciones y representa gráficamente las posiciones naturales. El cuarto capítulo muestra las armas naturales utilizadas en el kárate junto con la forma correcta de cerrar un puño. El quinto capítulo describe la ejecución técnica de las principales posiciones de kárate acompañadas de su correspondiente ilustración y esquema, la forma correcta de avanzar y dar la vuelta. El sexto capítulo explica la ejecución de oi-zuki en desplazamiento y posición natural así como de gyaku-zuki. El séptimo capítulo describe la ejecución de las técnicas defensivas básicas tanto en posición natural como avanzando incluyendo su representación gráfica. El octavo capítulo representa gráficamente algunas combinaciones técnicas avanzando para luego ilustrar su aplicación con un compañero. El noveno capítulo expone los principios técnicos en el trabajo de combinaciones por parejas. El décimo capítulo describe la ejecución de las principales técnicas de pierna acompañadas de su representación gráfica. El siguiente capítulo comenta el significado, origen y características de las katas además de incluir la representación gráfica de las katas heian shodan y heian nidan. Adjunta un glosario técnico y un epílogo.

458. s.a. (1977). Karate. Barcelona: Aura. 1aㅡ ed. 40 p. : il. ; $13 \times 20$ cm. ISBN: 84-214-0178-5. Depósito legal: no. (2 $2^{a}$ ed., 1991; $3^{\text {a }}$ ed., 1992). Palabras clave: katas, historia, fundamentos técnicos, vestimenta, escuelas, arbitraje, competición, grados. Resumen: Manual teórico y técnico de kárate. La obra esta formada por 9 capítulos, precedidos por una introducción que expone las generalidades del kárate y los objetivos de la obra. El primer capítulo relata brevemente la historia del kárate y sus estilos, mientras que el segundo presenta su vestimenta y sistema de grados. El tercer capítulo describe el desarrollo de una sesión de entrenamiento. El cuarto capítulo describe la ejecución técnica de las principales posiciones, partes utilizadas para golpear, golpes con la mano, paradas y patadas, acompañadas de su representación gráfica. El quinto capítulo comenta en qué consisten las katas y el sexto las pruebas de rompimiento. Los dos siguientes capítulos resumen el desarrollo de una competición y las normas de arbitraje. El último capítulo explica los principios técnicos de los principales estilos de kárate.

459. s.a. (1999). Karate kyokushinkai : programa paso de grados. Valencia: International Federation of Karate Spain. 1aㅡ ed. 43 p. : il. ; 9x18 cm. ISBN: No ISBN. Depósito legal: V. 969-1999. Palabras clave: fundamentos técnicos, programa técnico, fundamentos éticos, grados. Resumen: Manual teórico y técnico de kárate. El libro esta compuesto por 21 capítulos. El primer capítulo explica brevemente la historia del estilo kyokushinkai. Los dos siguientes capítulos presentan el dojo kun y los fundamentos éticos del kárate. El cuarto capítulo incluye la terminología específica del kárate. Los dos siguientes capítulos detallan el tiempo mínimo entre exámenes así como el sistema de grados. El séptimo capítulo comenta el significado del término kyokushinkai. El octavo capítulo enumera los principios del entrenamiento. Los siguientes 13 capítulos presentan el programa de contenidos técnicos por cinturones desde $10^{\circ}$ kyu hasta cinturón negro 3er dan. Adjunta un apéndice que señala los beneficios derivados de la práctica del kárate.

460. s.a. (2007). Viviendo el karate en la Comunidad de Madrid. Madrid: Federación Madrileña de Kárate. 1a ed. 99 p. : il. ; $17 \times 27$ cm. ISBN: No ISBN. Depósito legal: M. 10234-2007. Palabras clave: clubes, maestros, salud. Resumen: Manual teórico de kárate. El libro esta formado por 3 partes. La primera parte consta de 17 capítulos. El primer capítulo comenta las competiciones de kárate realizadas en la Comunidad de Madrid, mientras que el segundo apunta el origen del kárate. El tercer capítulo detalla los beneficios de su práctica. El cuarto capítulo expone los resultados deportivos del kárate madrileño y español. El quinto capítulo comenta la inclusión de la mujer en el kárate y los beneficios que le reporta su práctica. El sexto capítulo explica los principios éticos que rigen el kárate mientras que el séptimo detalla los beneficios de su práctica en cualquier edad. El octavo capítulo resalta los beneficios físicos y psíquicos de su práctica. El noveno capítulo expone los valores que transmite el kárate a niños y adolescentes. El décimo capítulo desarrolla los beneficios que aporta su práctica. El siguiente capítulo explica en qué consiste la competición de kumite y kata. El décimo segundo capítulo señala los aspectos sociales que desarrolla el kárate. El siguiente capítulo expone la implicación física que supone su práctica mientras que el décimo cuarto capítulo resalta su disciplina. El décimo quinto capítulo detalla cuándo y cómo practicar esta actividad. Los dos últimos capítulos exponen la organización 
institucional del kárate en Madrid y las ventajas de un club federado. La segunda parte incluye la biografía deportiva de distintos practicantes y maestros de kárate de la Comunidad de Madrid. La última parte incluye un listado con las direcciones de los centros que imparten esta actividad.

461. Sáenz Fernández, Félix (1992). Karate : didáctica y técnica. Bilbao: Fher. 1aㅡ ed. 174 p. : il. ; 15x22,5 cm. ISBN: 84-243-3060-9. Depósito legal: BI. 2217-1992. Palabras clave: kumite, fundamentos teóricos, fundamentos técnicos, pedagogía, principios técnicos, didáctica, entrenamiento, biomecánica, competición. Resumen: Manual teórico y técnico de kárate. El libro esta formado por 13 capítulos precedidos por un prólogo que comenta los contenidos del libro y una introducción que señala sus objetivos. El primer capítulo narra la evolución en los procesos de enseñanza del kárate y detalla los elementos constitutivos del proceso de enseñanza-aprendizaje. El segundo capítulo relata la historia del kárate y analiza sus componentes físico, técnico y mental. El tercer capítulo enumera los objetivos didácticos del kárate, las características de los diferentes sistemas de enseñanza junto con la explicación de algunas normas didácticas básicas, los tipos de evaluación existentes y las áreas de desarrollo influenciadas por la práctica del kárate. El cuarto capítulo define los términos de entrenador, profesor y maestro junto con sus objetivos y cualidades didácticas además de comentar sus formas de legitimación, sus requisitos teóricos y sus tareas. El quinto capítulo analiza los canales de información, los medios de enseñanza como son el cuerpo y la palabra junto con sus procedimientos pedagógicos y presenta las características de las ayudas complementarias y medios auxiliares. El sexto capítulo estudia las características de los grupos de aprendizaje, su organización, programación y requisitos así como los componentes y factores que intervienen en el proceso de individualización. El séptimo capítulo detalla el desarrollo de los paradigmas educativos, estudia los contenidos didácticos del kárate, las características y objetivos de las etapas de aprendizaje, de los sistemas de aprendizaje y un análisis de los factores que intervienen en el proceso de enseñanza-aprendizaje y en su estancamiento. El octavo capítulo expone los fundamentos teóricos del kárate, analiza la mecánica articular del cuerpo y los principios biomecánicos aplicados al kárate. El noveno capítulo analiza los reflejos y factores que intervienen en el equilibrio, presenta la ejecución de las posiciones básicas del kárate, enumera sus principales errores técnicos y presenta diferentes métodos de entrenamiento de las posiciones. El décimo capítulo define y clasifica las acciones técnicas del kárate, explica su progresión de enseñanza, puntos esenciales de su ejecución y algunos sistemas de entrenamiento. El décimo primer capítulo define los tipos de desplazamiento, explica su ejecución y consejos para su enseñanza. El décimo segundo capítulo enumera los tipos y características técnicas de los encadenamientos y combinaciones. El último capítulo expone los fundamentos teóricos del kumite, sus tipos de entrenamiento y proceso de enseñanza-aprendizaje y analiza las características pedagógicas de la competición. Adjunta bibliografía.

462. Sáenz Fernández, Félix (1998). Kárate : programación y métodos de enseñanza. Bilbao: Librifer. 1a ed. 175 p. : il. ; 15x22,5 cm. ISBN: 84-89914-43-5. Depósito legal: BI. 982-1998. Palabras clave: pedagogía, didáctica, planificación del entrenamiento. Resumen: Tratado teórico de kárate. La obra esta dividida en 12 capítulos precedidos por una introducción que resume los contenidos y objetivos de la obra. El primer capítulo define el concepto de planteamiento general de la enseñanza comentando sus objetivos, consideraciones previas, organización del trabajo, valoración de la enseñanza y áreas de influencia de dicho planteamiento. El segundo capítulo expone las necesidades, propósitos y directrices de la programación de la enseñanza así como un análisis de los criterios y factores básicos que influyen en la misma. El tercer capítulo define el concepto de unidad didáctica, explica su desarrollo práctico exponiendo algunos ejemplos prácticos de acuerdo a la clasificación de los contenidos técnicos del kárate y comenta las características de los diferentes tipos de clases existentes. El cuarto capítulo detalla las características generales, objetivos, estructura de entrenamiento y contenidos pertenecientes a cada nivel de aprendizaje. El quinto capítulo presenta una programación anual de enseñanza junto con la definición de los niveles de dificultad técnica, intensidad del trabajo, adecuación física, clima emocional y métodos de enseñanza. El sexto capítulo detalla las tareas y desarrollo de cuatro sesiones de kárate. El séptimo capítulo comenta las características de los métodos expositivos además de su estructura y un cuadro resumen de las características de cada método. Los siguientes cuatro capítulos detallan el concepto, planificación, organización, valoración, áreas de influencia, sistemas de trabajo y críticas de los métodos de enseñanza centralizada, enseñanza por trabajos, enseñanza mutua y aprendizaje individual. El último capítulo expone las características generales de los procesos creativos y profundiza en el desarrollo y aplicación de cada uno de ellos. Adjunta bibliografía.

463. Sáenz Fernández, Félix y Egea Cáceres, José Manuel (1998). Karate para todos. Bilbao: V.M.G. 1ํㅡㄹ. ed. 141 p. : il. ; 16x23,5 cm. ISBN: 84-923186-0-0. Depósito legal: BI. 1627-1998. Palabras clave: fundamentos técnicos. Resumen: Manual técnico de karate. La obra desarrolla los fundamentos técnicos del karate divididos en cinturones. Comienza con la explicación de la historia del karate y su desarrollo en España. Continúa con los aspectos formales y de indumentaria así como una explicación sencilla de los desplazamientos y las partes del cuerpo que pueden utilizarse como arma. Los siguientes capítulos 
están divididos por cinturones y cada uno de ellos explica los contenidos para dicho nivel de destreza. Describe el tipo de trabajo de kihon, kata y kumite que se debe realizar y aportando material gráfico. Adjunta un glosario, un índice didáctico y tablas para anotar los resultados de las competiciones.

464. Sáenz Fernández, Félix y Egea Cáceres, José Manuel (2000). Karate para todos. Bilbao: V.M.G. 1aㅡ ed. 142 p. : il. ; 17x24 cm. ISBN: 84-923186-2-7. Depósito legal: BI. 1536-1999. Palabras clave: fundamentos técnicos. Resumen: Manual técnico de karate. La obra desarrolla los fundamentos técnicos del karate divididos en cinturones. Comienza con la explicación de la historia del karate y su desarrollo en España. Continúa con los aspectos formales y de indumentaria así como una explicación sencilla de los desplazamientos y las partes del cuerpo que pueden utilizarse como arma. Los siguientes capítulos están divididos por cinturones y cada uno de ellos explica los contenidos para dicho nivel de destreza. Describe el tipo de trabajo de kihon, kata y kumite que se debe realizar y aportando material gráfico. Adjunta un glosario, un índice didáctico y tablas para anotar los resultados de las competiciones.

465. Sampayo, Carlos (1974). El kárate a su alcance. Barcelona: Bruguera. 1aㅡ ed. 216 p. : il. ; 10x17 cm. ISBN: 84-02-03652-X. Depósito legal: B. 18940-1974. Palabras clave: historia, fundamentos teóricos, fundamentos técnicos, ejercicios, combate, entrenamiento, kyusho, equipamiento. Resumen: Manual teórico y técnico de kárate. La obra esta formada por 25 capítulos precedidos por una introducción que explica el objetivo del kárate, los requisitos para su práctica, sus beneficios, el significado del término kárate, relata brevemente su origen, ofrece varios consejos para su práctica y comenta sus principios técnicos. El primer capítulo localiza los puntos vitales del cuerpo humano y explica su manipulación. El segundo capítulo describe la ejecución de distintos ejercicios de calentamiento. Los siguientes tres capítulos describen e ilustran los principales golpes de mano, codo y pie. El sexto capítulo describe varios ejercicios de defensa y ataque con el antebrazo. El séptimo capítulo señala la importancia de la posición en kárate para luego describir la ejecución de las posiciones fundamentales y del cuerpo, piernas y brazos. El décimo capítulo explica la ejecución de las distintas guardias así como algunos de sus ejercicios de entrenamiento. El siguiente capítulo expone la importancia de la muñeca y describe varios ejercicios de defensa. El décimo segundo capítulo detalla los principios del entrenamiento. Continúa describiendo la estructura y utilización de los diversos accesorios para el entrenamiento. El décimo cuarto capítulo describe las posiciones fundamentales de kárate. Los tres siguientes capítulos detallan el entrenamiento y ejercicios del puño, codo y pie. El décimo octavo capítulo explica los movimientos de giro (tai sabaki) incluyendo el esquema de movimiento de los pies. El siguiente capítulo describe la ejecución de varios ejercicios para el entrenamiento de la mano como sable junto con algunas de sus aplicaciones marciales. El vigésimo capítulo analiza los distintos tipos de combate, sus normas y presenta varios ejercicios por parejas para luego describir distintos ejercicios individuales. Continúa con el comentario del golpeo de los puntos vitales para finalizar con un comentario sobre los fundamentos morales del kárate, algunos consejos alimentarios y el significado de los grados. Adjunta apéndices con la ilustración de las armas naturales de cuerpo, un análisis de la utilización del kárate y la legislación, y un vocabulario específico.

466. Sampayo, Carlos (1977). El kárate a su alcance. Barcelona: Bruguera. 1ae ed. 216 p. : il. ; 10x17,5 cm. ISBN: 84-02-05086-7. Depósito legal: B. 7349-1977. Palabras clave: historia, fundamentos teóricos, fundamentos técnicos, ejercicios, combate, entrenamiento, kyusho, equipamiento. Resumen: Manual teórico y técnico de kárate. La obra esta formada por 25 capítulos precedidos por una introducción que explica el objetivo del kárate, los requisitos para su práctica, sus beneficios, el significado del término kárate, relata brevemente su origen, ofrece varios consejos para su práctica y comenta sus principios técnicos. El primer capítulo localiza los puntos vitales del cuerpo humano y explica su manipulación. El segundo capítulo describe la ejecución de distintos ejercicios de calentamiento. Los siguientes tres capítulos describen e ilustran los principales golpes de mano, codo y pie. El sexto capítulo describe varios ejercicios de defensa y ataque con el antebrazo. El séptimo capítulo señala la importancia de la posición en kárate para luego describir la ejecución de las posiciones fundamentales y del cuerpo, piernas y brazos. El décimo capítulo explica la ejecución de las distintas guardias así como algunos de sus ejercicios de entrenamiento. El siguiente capítulo expone la importancia de la muñeca y describe varios ejercicios de defensa. El décimo segundo capítulo detalla los principios del entrenamiento. Continúa describiendo la estructura y utilización de los diversos accesorios para el entrenamiento. El décimo cuarto capítulo describe las posiciones fundamentales de kárate. Los tres siguientes capítulos detallan el entrenamiento y ejercicios del puño, codo y pie. El décimo octavo capítulo explica los movimientos de giro (tai sabaki) incluyendo el esquema de movimiento de los pies. El siguiente capítulo describe la ejecución de varios ejercicios para el entrenamiento de la mano como sable junto con algunas de sus aplicaciones marciales. El vigésimo capítulo analiza los distintos tipos de combate, sus normas y presenta varios ejercicios por parejas para luego describir distintos ejercicios individuales. Continúa con el comentario del golpeo de los puntos vitales para finalizar con un comentario sobre los fundamentos morales del kárate, algunos consejos alimentarios y el significado de los grados. Adjunta apéndices con la ilustración de las armas naturales de cuerpo, un análisis de la utilización del kárate y la legislación, y un vocabulario específico. 
467. Sancho Illa, Armand (2000). Karate do kyokushinkai : volumen 1. Técnica, kata, aplicaciones y programa de grados. Barcelona: Alas. $1 \stackrel{\text { a }}{\text { ed. }} 315$ p. : il. ; 17x24 cm. ISBN: 84-203-0398-4. Depósito legal: B. 10962000. Palabras clave: historia, fundamentos técnicos, programa técnico, principios técnicos, ejercicios, entrenamiento, biomecánica, katas, preparación física. Resumen: Manual teórico y técnico de kárate. El libro esta formado por 5 partes. La primera parte incluye un prólogo que comenta los objetivos y contenidos del libro y la biografía del autor y colaboradores, narra los orígenes del kárate, la biografía de Masutatsu Oyama, relata el origen del kyokushinkai, sus grados, expone las normas de etiqueta en el dojo y señala las influencias de las katas kyokushinkai. La segunda parte comenta los principios físicos y técnicos del kárate así como la descripción e ilustración de diversos ejercicios de calentamiento y preparación física. La tercera parte explica la ejecución técnica de las posiciones y desplazamientos del estilo kyokushinkai acompañadas de sus ilustraciones explicativas. La cuarta parte enumera e ilustra las distintas partes del cuerpo utilizadas para golpear además de incluir la descripción, secuencia fotográfica y esquemas de movimiento de los principales ataques de brazo, técnicas de bloqueo y ataques con las piernas. La última parte presenta el programa de contenidos desde el $10^{\circ}$ hasta el 3er kyu ilustrando sus técnicas y describiendo la ejecución de sus katas. Adjunta un glosario.

468. Sancho Illa, Armand (2000). Kárate do kyokushinkai : volumen 2. Técnica superior, kata, kumite y defensa personal. Barcelona: Alas. 1a ed. 335 p. : il. ; 17x24 cm. ISBN: 84-203-0399-2. Depósito legal: B. 32957-2000. Palabras clave: katas, kumite, fundamentos técnicos, programa técnico, defensa personal, aplicación marcial, competición, legislación, reglamentos, armas. Resumen: Manual teórico y técnico de kárate. El libro esta formado por 5 partes. La primera parte incluye un prólogo que comenta los objetivos y contenidos del libro y la biografía del autor y colaboradores. La segunda parte enumera e ilustra las distintas partes del cuerpo utilizadas para golpear además de incluir la descripción, secuencia fotográfica y esquemas de movimiento de algunas técnicas avanzadas de ataques de brazo, técnicas de bloqueo y ataques con las piernas. La tercera parte presenta el programa de contenidos desde el $2^{\circ}$ kyu hasta el grado sandan, ilustrando sus técnicas y describiendo la ejecución de sus katas, bunkai y ejercicios de kumite. La cuarta parte incluye un extracto del reglamento de competición de kumite además de presentar la secuencia fotográfica de algunas de sus técnicas. La última parte comenta la legislación relativa a la defensa personal y las artes marciales y detalla la ejecución de varias técnicas de defensa personal ante agarres a la muñeca, empujones, abrazos, estrangulaciones y ataques con cuchillo acompañadas de su secuencia fotográfica.

469. Sauvage, Philippe (2005). Curso de kárate para niños : descubrir el kárate do. Barcelona: De Vecchi. 1a ed. 140 P. : il. ; $17 \times 24$ cm. ISBN: 84-315-3173-8. Depósito legal: B. 16044-2005. Palabras clave: fundamentos técnicos. Resumen: Manual técnico de kárate. La obra esta dividida en 4 partes, comenzando con una breve explicación de la historia del kárate, los diferentes estilos e instituciones nacionales más importantes. Continua con el detalle de los beneficios físicos y psicológicos de su práctica para, en la tercera parte, comenzar a describir el dojo y la vestimenta, el saludo, y los fundamentos técnicos. Las posiciones, desplazamientos y técnicas son descritas e ilustradas, explicando además como se realiza su entrenamiento. También incluye la secuencia gráfica de la ejecución de las katas Taikyoku shodan y Heian yodan, así como una explicación de los tipos de kumite existentes. La última parte presenta un calentamiento con algunos de los ejercicios para elevar el ritmo cardíaco y preparar las articulaciones y músculos.

470. Savine, Ives (1971). Karate. Barcelona: Rodegar. 1ae ed. 110 p. : il. ; $11 \times 17$ cm. ISBN: No ISBN. Depósito legal: B. 18119-1971. Palabras clave: kumite, historia, fundamentos teóricos, fundamentos técnicos, defensa personal, ejercicios, entrenamiento, kyusho, aplicación marcial, equipamiento, armas. Resumen: Manual teórico y técnico de kárate. La obra esta formada por 9 capítulos. El primer capítulo narra la historia del kárate, explica en qué consiste y sus beneficios y comenta cuáles son los requisitos para su práctica, dónde puede practicarse y su vestimenta. El segundo capítulo enumera las zonas utilizadas para golpear, ofrece algunos consejos para el entrenamiento, describe la estructura del makiwara y otros instrumentos secundarios y enumera los puntos vitales. El tercer capítulo describe la ejecución del saludo, las posturas básicas y su aplicación en combate, los distintos golpes de puño y las principales técnicas de ataque con el puño. El cuarto capítulo expone las zonas de la mano, el codo y el pie utilizadas para golpear así como algunas de sus técnicas. El quinto capítulo explica la ejecución de varias técnicas de defensa ante distintos ataques dirigidos a la parte alta y media del cuerpo. El sexto capítulo presenta la descripción de distintos secuencias de kumite. El séptimo capítulo explica en qué consisten el transhiki, fukushiki y jiyu kumite, sus principios tácticos, y describe la ejecución de varias técnicas de defensa personal ante distintas presas, estrangulaciones, agarres, el ataque de varios atacantes, patadas y la defensa en el suelo. El octavo capítulo presenta la descripción de varias técnicas de defensa personal ante lo ataques armados con bastón, cuchillo y pistola. El noveno capítulo ofrece consejos para el entrenamiento y la práctica. Adjunta un glosario de términos específicos de kárate.

471. Schlatt (2004). Diccionario de karate Shôtôkan. Ribarroja (Valencia): Kamikaze Karategui Española. 1a ed. 240 p. : il. ; 15x21 cm. ISBN: 84-607-9752-X. Depósito legal: V. 1357-2004. Palabras clave: katas, 
fundamentos técnicos, entrenamiento, fundamentos filosóficos, competición. Resumen: Tratado teórico de kárate. La obra esta formada por 24 capítulos precedidos por la biografía de los maestros Kase y Fujinaga, y un prólogo que comenta los contenidos de la obra. Todos los capítulos incluyen el ideograma japonés junto con su traducción al español. El primer capítulo explica la pronunciación de los términos japoneses mientras que el segundo presenta el sistema numérico. El tercer capítulo incluye los niveles y direcciones. El cuarto capítulo detalla los términos relacionados con los elementos del entrenamiento. El quinto capítulo explica en qué consiste la kata. El sexto capítulo expone los orígenes y características de las katas heian, tekki y taikyoku. El siguiente capítulo detalla el significado y características de las katas del estilo shotokan. Los siguientes cinco capítulos incluyen los términos relacionados con las instrucciones dadas durante el entrenamiento, los movimientos, posiciones, posturas y técnicas de kárate acompañados de sus ilustraciones. El décimo tercer capítulo describe el origen del término karate-do mientras que el siguiente narra la biografía del maestro Funakoshi. El décimo quinto capitulo incluye otros términos relacionados con la práctica mientras que el siguiente analiza el significado de los términos shu-ha-ri, oss, zanshin, keiko, kangeiko, bushido, gasshuku, kamae y kumite. Los dos siguientes capítulos presenta los términos relacionados con los aspectos formales del dojo así como sus normas. El décimo noveno capítulo muestra los veinte preceptos del kárate. Los dos siguientes capítulos comentan el origen de los diferentes estilos de kárate y muestran sus fundamentos filosóficos. Los tres últimos capítulos incluyen los términos relacionados con la competición, las partes del cuerpo y algunos de los aforismos del zen. Incluye el índice de términos presentados, bibliografía, otros libros de la editorial y una breve biografía del autor.

472. Serrano García, Miguel Ángel (1979). Programa de exámenes de karate-do. Madrid: Gopi. 1a ed. 155 p. : il. ; 16x22 cm. ISBN: 84-85723-00-7. Depósito legal: M. 36196-1979. Palabras clave: fundamentos técnicos, didáctica, exámenes. Resumen: Manual técnico de karate. La obra esta dividida en 6 partes, precedidas por la explicación del origen-desarrollo del karate y los principios biomecánicos que rigen el movimiento en este arte. Los primeros cinco capítulos estructuran los contenidos técnicos requeridos en los exámenes de grado blanco-amarillo, amarillo-naranja, naranja-verde, verde-azul y azul-marrón respectivamente. Cada capítulo describe los detalles técnicos de las posiciones, técnicas de brazo, técnicas de pierna, técnicas de defensa, combinaciones y katas requeridos para superar cada uno de los cinturones. Las descripciones están acompañadas de fotografías de cada técnica. El quinto capítulo también incluye la secuencia fotográfica de los movimientos de las katas tekki shodan y empi. El último capítulo ilustra algunos ejercicios de calentamiento y explica el entrenamiento con el saco y el makiwara. Adjunta un gráfico de los puntos vitales del cuerpo, un comentario sobre el espíritu del karate y nomenclatura.

473. Shotokan Karate-do de España (2002). Fraternidad 2002 : encuentro mundial shotokan. Málaga: Shotokan karate-do de España. 1a ed. 42 p. : il. ; 21x30 cm. ISBN: No ISBN. Depósito legal: MA. 14912002. Palabras clave: historia. Resumen: Tratado histórico de kárate. El libro esta dividido en 3 partes. La primera parte incluye una selección de fotografías correspondientes al día 21 de septiembre de 2002 sobre los entrenamientos y competición realizados a tenor del encuentro realizado. La segunda parte incluye algunas de las fotografías correspondientes al día 22 de septiembre de 2002 sobre la exhibición y festejos realizados. La última parte incluye las fotografías correspondientes al día 23 de septiembre de 2002 sobre los entrenamientos y acto de clausura.

474. Smit, Sanette (2001). Kárate : guía básica para conocer este arte marcial. Arganda del Rey: Edimat. 1a ed. 96 p. : il. ; desc.xdesc. cm. ISBN: 84-9764-135-3. Depósito legal: no. (2ª ed., 2002; 3a ed., 2003). Palabras clave: fundamentos técnicos, defensa personal, entrenamiento, competición. Resumen: Manual teórico y técnico de kárate. La monografía esta compuesta por 7 capítulos. El primero comenta brevemente los orígenes del kárate y sus estilos, y los beneficios de su práctica. El segundo capítulo introduce algunas notas para el comienzo de la práctica como la elección de la escuela y el maestro, las reglas del dojo, el sistema de grados y el método de entrenamiento. Después explica la utilización de los puños y los pies en el kárate, un conjunto de ejercicios de acondicionamiento físico general y calentamiento y las lesiones más frecuentes y su tratamiento. El cuarto capítulo describe la ejecución técnica de los puñetazos, paradas, patadas, posiciones y combinaciones de técnicas más habituales, además de explicar la importancia del equilibrio, la coordinación, la respiración, el hara, el entrenamiento con saco y con pesas para la práctica del kárate. El siguiente capítulo comenta los fundamentos del kata y el kumite, incluyendo algunos ejercicios de ambos, para después ofrecer una visión general de la competición en ambas disciplinas, el reglamento, el entrenamiento y los distintos competidores. El último capítulo profundiza en la aplicación del kárate ante situaciones de defensa personal, explicando sus premisas, sus objetivos y características y presentando varias situaciones y su resolución. Adjunta un listado de contactos y un glosario terminológico.

475. Tamano, Toshio (1992). Curso de kárate : el kárate Gojuryu. Barcelona: De Vecchi. 1ae ed. 142 p. : il. ; 17x24 cm. ISBN: 84-315-1005-6. Depósito legal: B. 1103-1992. Palabras clave: historia, fundamentos técnicos, textos, kárate. Resumen: Manual técnico y teórico de karate goju-ryu. La obra esta dividida en 3 partes. Comienza con la descripción detallada de la historia del karate goju-ryu, los maestros y sus 
sistemas de enseñanza. La segunda parte describe e ilustra las posiciones básicas, los golpes, las patadas, las paradas, los ejercicios preparatorios, la respiración en la kata sanchin, ejercicios de fortalecimiento, entrenamiento con instrumentos, ejercicios complementarios de ukemi waza, la kata saifa y los diferentes tipos de kumite. Además, explica la aplicación de todas las técnicas estudiadas. La última parte recopila una de las conferencias ofrecidas por Chojun Miyagi sobre la situación actual de este estilo.

476. Tamura, Ryo (1979). Artes marciales. Barcelona: Bruguera. 1a ed. 93 p. : il. ; 10x17,5 cm. ISBN: 84-0206330-6. Depósito legal: B. 9757-1979. Palabras clave: katas, kumite, historia, fundamentos técnicos, principios técnicos, defensa personal, ejercicios, calentamiento, kyusho, preparación física, armas. Resumen: Manual teórico y técnico de artes marciales. El libro esta formado por 21 capítulos. El primer capítulo narra el origen de las artes marciales. El segundo capítulo localiza los puntos vitales del cuerpo humano. El tercer capítulo explica la forma correcta de cerrar un puño y describe varios ejercicios para su endurecimiento. El cuarto capítulo explica la aplicación del shuto, su entrenamiento en el makiwara y otros golpes con la mano abierta. El quinto capítulo describe la ejecución de las principales patadas acompañadas de su representación gráfica. El sexto capítulo detalla los principios técnicos de las posiciones básicas de kárate y la posición de guardia incluyendo su representación gráfica. Los dos siguientes capítulos describen la ejecución de las principales técnicas de parada y los desplazamientos básicos acompañados de sus ilustraciones explicativas. El noveno capítulo explica el desarrollo y los ejercicios de una sesión de entrenamiento. El décimo capítulo describe e ilustra la ejecución de la kata heian shodan. El décimo primer capítulo comenta las características del entrenamiento por parejas y describe la ejecución de algunos de sus ejercicios. El décimo segundo capítulo señala los principios técnicos del sanbon kumite, ippon kumite y jiyu kumite además de explicar su desarrollo. El décimo tercer capítulo describe las defensas ante un empujón y varias presas de solapa y de muñeca. Los siguientes tres capítulos explican la ejecución de distintas técnicas de defensa personal ante puñetazos, patadas y ataques con bastón acompañados de su representación gráfica. El décimo séptimo capítulo comenta las generalidades del kung fu y presenta la descripción e ilustración de algunos de sus ejercicios de preparación física. Los últimos cuatro capítulos explican la ejecución de varias técnicas de defensa personal ante los ataques de bastón largo, cuchillo, silla y pistola incluyendo algunas ilustraciones explicativas.

477. Thomas, Raymond (1971). Karate : defensa personal. Atemis, kiai, técnicas de reanimación. Barcelona: Alas. 1a ed. 77 p. : il. ; 11x18 cm. ISBN: No ISBN. Depósito legal: B. 19072-1971. (3a ed., 1982). Palabras clave: fundamentos técnicos, principios técnicos, ejercicios, combate, entrenamiento, kyusho, kuatsu, armas, defensa personal. Resumen: Manual teórico y técnico de kárate. La obra esta formada por 21 capítulos. El primer capítulo presenta los objetivos del libro. El segundo capítulo explica los dos principios del combate mientras que el tercero analiza los distintos ataques. El cuarto capítulo señala la importancia de la actitud ante el combate mientras que el quinto describe la actitud física ante tal situación. El sexto capítulo analiza la respuesta ante un ataque. El séptimo capítulo ofrece algunos consejos para el entrenamiento de la defensa personal. El octavo capítulo localiza los puntos vitales del cuerpo humano. El noveno capítulo expone los principios técnicos ante un agarre además de describir la ejecución de varias técnicas de defensa personal ante los agarres al cuerpo o la ropa acompañados de su representación gráfica y esquemas de movimiento. El décimo capítulo explica la ejecución de varias técnicas de defensa ante los intentos de estrangulación incluyendo su ilustración. Los siguientes tres capítulos describen las técnicas de defensa ante las presas por delante, detrás y el flanco adjuntando su representación gráfica. Los dos siguientes capítulos describen la aplicación de varias técnicas de defensa personal ante puñetazos y patadas además de incluir sus gráficos explicativos. Los siguientes cuatro capítulos exponen los principios de actuación ante los ataques armados con bastón, cuchillo, silla y pistola además de incluir la descripción e ilustración de diversas técnicas. El vigésimo capítulo explica el significado del kiai y describe varios ejercicios de respiración y entrenamiento del kiai. El último capítulo explica los principios del kuatsu, ofrece algunos consejos prácticos y describe la ejecución de varias de sus técnicas ante los golpes más habituales de kárate.

478. Thomas, Raymond (1971). Karate : primeras nociones. Posturas, desplazamientos, paradas, ataques. Barcelona: Alas. 1aㅡ ed. 77 p. : il. ; 11x18,5 cm. ISBN: No ISBN. Depósito legal: B. 14622-1971. (2aㅡ. ed., 1978, ISBN: 84-203-0007-1; 3르 ed., 1980, ISBN: 84-203-0007-1; 4ª ed., 1982, ISBN: 84-203-0007-1). Palabras clave: fundamentos técnicos. Resumen: Manual teórico y técnico de kárate. El libro esta compuesto por 12 capítulos. El primer capítulo explica en qué consiste el aprendizaje y entrenamiento del kárate, para en el segundo describir los contenidos que presenta la obra y cuál es la estructura de una clase de kárate. El tercer capítulo describe el calentamiento a realizar antes de cualquier clase de kárate. Los siguientes nueve capítulos presentan, a modo de lección, los fundamentos técnicos básicos como son las posturas, los desplazamientos, las paradas y los ataques. La primera lección describe e ilustra fudo-dachi, sanchin-dachi, tsuki-jodan, tsuki-gedan, zenkutsu-dachi y gedan-barai. La segunda lección comenta el término de kihon y presenta ago-uchi, mawashi-uchi y oie-tsuki. La tercera lección incluye uraken-shomen, uraken-sayu, gyaku-tsuki y kin-geri. La cuarta lección presenta los diferentes 
partes de la mano que se pueden utilizar para golpear junto con su ilustración, y describe la ejecución de uraken-hizo-uchi, kokutsu-dachi y ude-uke-uchi. La quinta lección describe las técnicas shutogammen, shuto-sakotsu-uchi-komi y ude-uke-soto. La sexta lección presenta shuto-hizo, mae-geri y las partes del pie utilizadas para golpear. La siguiente lección expone la ejecución de las técnicas kibadachi, shiko-dachi y yoko-geri. Las dos últimas lecciones presentan las técnicas neko-ashi-dachi, hijijodan-ate, kihon-sanbon y los conceptos yame y mate. Adjunta un glosario de términos específicos de kárate y su traducción.

479. Thomas, Raymond (1971). Kárate femenino : técnicas y defensa personal especializadas. Barcelona: Alas. 1aㅡ ed. 77 p. : il. ; 11x18,5 cm. ISBN: No ISBN. Depósito legal: B. 24229-1971. (3ae ed., 1975, ISBN: 84203-0327-5). Palabras clave: fundamentos técnicos, defensa personal. Resumen: Manual técnico de kumite y defensa personal para las mujeres. El libro esta compuesto por 6 lecciones de introducción al kumite para las mujeres, en las que se desarrollan ejercicios de gohon, sambon, ippon-kumite y defensa personal adaptados a la mujer. La última parte presenta situaciones de defensa personal ante agarres, abrazos y cuando se esta sentado. Finaliza con la utilización que pueden recibir algunos de los objetos que se portan en la vida diaria como armas. Adjunta un glosario.

480. Thomas, Raymond (1971). Kárate práctico : ippon-kumité, sanbon-kumité, gohon-kumité, ju-kumité. Barcelona: Alas. 1a ed. 78 p. : il. ; 11x18,5 cm. ISBN: No ISBN. Depósito legal: B. 14623-1971. (2aㅡ. ed., 1978, ISBN: 84-203-0008-X; 3a ed., 1980, ISBN: 84-203-0008-X; 4⿳亠丷厂 ed., 1982, ISBN: 84-203-0008-X). Palabras clave: katas, kumite, fundamentos técnicos. Resumen: Manual teórico y técnico de kárate. La monografía esta formada por 10 capítulos. El primer capítulo comenta las características de los diferentes tipos de kumite para después incluir nueve lecciones. La primera lección describe el trabajo técnico de una clase de kárate para luego explicar una secuencia técnica tanto de gohon-kumite como de ippon-kumite. La segunda lección describe una secuencia de sanbon-kumite, gohon-kumite e ipponkumite. La tercera lección presenta la ejecución de una serie de gohon e ippon-kumite, explica el entrenamiento de kihon y describe la ejecución de age-uke. La cuarta lección explica una nueva serie de sanbon, gohon e ippon-kumite además de la ejecución técnica de mawashi-geri. La quinta lección desarrolla una nueva secuencia técnica de sanbon, gohon e ippon-kumite así como la explicación técnica de mawashi-shuto-uke. La sexta lección presenta una serie técnica de sanbon, gohon e ipponkumite y explica la ejecución de shuto-uke. La séptima lección comenta la segunda forma de ejecutar el cambio de dirección e incluye la descripción de una serie de kihon-sanbon, gohon e ippon-kumite. Las dos últimas lecciones explican el desarrollo del jyu-kumite y describen la ejecución técnica de la tenno-kata junto con su ilustración, respectivamente. Adjunta un glosario de términos específicos de kárate con su traducción y un resumen de las reglas de competición.

481. Thomas, Raymond (1971). Karate superior : katas, entrenamiento para la competición. Barcelona: Alas. $1^{a}$ ed. 77 p. : il. ; 11x18,5 cm. ISBN: No ISBN. Depósito legal: B. 19073-1971. (3ª ed., 1982, ISBN: 84203-0033-0). Palabras clave: historia, katas. Resumen: Manual teórico y técnico de kárate. La obra esta formada por 11 capítulos. El primer capítulo explica en qué consisten las katas. El segundo capítulo narra la historia del kárate y sus diferentes escuelas. El tercer capítulo ofrece varios consejos para la práctica de las katas mientras que el cuarto incluye su clasificación. Los siguientes 7 capítulos comentan las características de las katas taikyoku-no-kata-shodan, shihozuki-shodan, shihozuki-nidan, shihozuki sandan, pinan-shodan, pinan-nidan y pinan-sandan, incluyendo la descripción y representación gráfica de su ejecución. Adjunta un breve glosario específico.

482. Thomas, Raymond (1971). Perfeccionamiento del kárate : katas adelantadas, katas superiores. Barcelona: Alas. 1aㅡ ed. 77 p. : il. ; 11x18,5 cm. ISBN: No ISBN. Depósito legal: B. 24228-1971. (2ª ed., 1978, ISBN: 84-203-0036-5). Palabras clave: katas. Resumen: Manual técnico de kárate. El primer capítulo describe e ilustra las katas pinan yodan, pinan godan. El segundo capítulo presenta le ejecución de yang-tsu no kata junto con su representación gráfica. El tercer capítulo incluye la descripción e ilustración de la kata sanchin-no-kata. Los dos últimos capítulos presentan las katas tekki-shodan-no-kata y saifa-no-kata. Finaliza con un epílogo que comenta los contenidos de los siguientes libros de la colección.

483. Thomas, Raymond (1975). Kata bassai-dai : kata superior para cinturones negros. Barcelona: Alas. 1a ed. 79 p. : il. ; 17x12 cm. ISBN: 84-203-0348-8. Depósito legal: B. 54186-1975. (2ª ed., 1981). Palabras clave: katas, pedagogía, principios teóricos, entrenamiento, aplicación marcial. Resumen: Manual teórico y técnico de kárate. La obra esta compuesta por 4 capítulos. El primer capítulo explica cómo deben practicarse las katas. El segundo capítulo expone el significado de la kata bassai-dai y sus características técnicas. El tercer capítulo describe e ilustra la secuencia técnica de la kata bassai-dai, incluyendo el esquema de movimiento de los pies junto con la aplicación de alguna de sus técnicas. El último capítulo explica las diferencias entre las katas antiguas y modernas, y señala cómo debe ser su correcto aprendizaje.

484. Thomas, Raymond (1975). Kata bassai-sho : kata superior para cinturones negros. Barcelona: Alas. 1a ed. 63 p. : il. ; 17x11,5 cm. ISBN: 84-203-0351-X. Depósito legal: B. 54187-1975. (2ª ed., 1982, ISBN: 84203-0351-8). Palabras clave: katas, historia, fundamentos teóricos, aplicación marcial. Resumen: 
Manual teórico y técnico de kárate. La obra esta compuesta por 2 capítulos. El primer capítulo detalla el origen de la kata bassai-sho y los principios técnicos que la caracterizan. El segundo capítulo presenta la secuencia técnica de la kata bassai-sho, incluyendo sus ilustraciones, esquema de movimiento de los pies y la aplicación de alguna de sus técnicas.

485. Thomas, Raymond (1975). Kata kanku-dai : kata superior para cinturones negros. Barcelona: Alas. 1a ed. 93 p. : il. ; 17x11,5 cm. ISBN: 84-203-0350-X. Depósito legal: B. 54188-1975. (2ª ed., 1982, 96 p.). Palabras clave: katas, historia, fundamentos teóricos, aplicación marcial. Resumen: Manual teórico y técnico de kárate. La obra esta formada por 2 capítulos. El primer capítulo comenta la historia y el significado de las katas kanku. Y el segundo capítulo describe e ilustra la ejecución de las técnicas de la kata kanku-dai junto con el esquema de las posiciones, el movimiento de los pies y la aplicación práctica de ciertas técnicas.

486. Thomas, Raymond (1975). Kata tekki-shodan : kata superior para cinturones negros. Barcelona: Alas. $1^{\underline{a}}$ ed. 64 p. : il. ; 17x12 cm. ISBN: 84-203-0349-6. Depósito legal: B. 54189-1975. (2ª ed., 1981). Palabras clave: katas, historia, fundamentos teóricos, aplicación marcial, preparación física, salud. Resumen: Manual teórico y técnico de kárate. La obra esta formada por 8 capítulos. Los dos primeros capítulos explican en qué consisten las katas de kárate y cuál es su significado. El tercer capítulo comenta la correcta ejecución del kata, para luego exponer la historia de los katas. El quinto capítulo comenta la estructura y beneficios de las katas para luego explicar las características de las katas tekki. El siguiente capítulo describe e ilustra la secuencia de movimientos de la kata tekki-shodan y la aplicación práctica de algunas de sus técnicas, incluyendo un esquema de los movimientos de los pies. Los dos últimos capítulos presentan algunos ejercicios especiales de preparación física para el entrenamiento de ésta kata y ofrecen consejos para el entrenamiento general de las katas.

487. Thomas, Raymond (1976). Kata en-pi : kata superior para cinturones negros. Barcelona: Alas. 1 a ed. 64 p. : il. ; 17x12 cm. ISBN: 84-203-0357-7. Depósito legal: B. 6353-1976. Palabras clave: katas, principios técnicos, aplicación marcial. Resumen: Manual teórico y técnico de kárate. La obra esta compuesta por 2 capítulos, precedidos por un prólogo que explica el significado de la kata en-pi. El primer capítulo señala las características técnicas que debe reunir una kata. El segundo expone la descripción e ilustración técnica de la kata en-pi, incluyendo el esquema de movimiento de los pies junto con la aplicación de alguna de sus técnicas.

488. Thomas, Raymond (1976). Kata hangetsu : kata superior para cinturones negros. Barcelona: Alas. 1aㅡ. ed. 64 p. : il. ; 17x11,5 cm. ISBN: 84-203-0354-2. Depósito legal: B. 738-1976. Palabras clave: katas, historia, aplicación marcial. Resumen: Manual teórico y técnico de kárate. La obra esta compuesta por 2 capítulos, precedidos de un prólogo que expone el significado de la kata y sus características técnicas. El primer capítulo detalla los objetivos de las katas y la importancia de la respiración correcta en la ejecución de la kata. El segundo capítulo presenta la descripción e ilustración de la secuencia técnica de la kata hangetsu junto con el esquema de movimiento de los pies y la aplicación práctica de alguno de sus movimientos.

489. Thomas, Raymond (1976). Kata jitte : kata superior para cinturones negros. Barcelona: Alas. 1a ed. 64 p. : il. ; 17x11,5 cm. ISBN: 84-203-0357-7. En el ISBN: 84-203-0356-9. Depósito legal: B. 6553-1976. Palabras clave: katas, kumite, historia, aplicación marcial. Resumen: Manual teórico y técnico de kárate. La obra esta compuesta por 3 capítulos, precedidos de un prólogo que señala el origen y características de la kata jitte. El primer capítulo explica cómo deben ejecutarse las katas además de la actitud y ceremonia en su realización. El segundo capítulo describe e ilustra la secuencia técnica de la kata jitte acompañada del esquema de movimiento de los pies y la aplicación práctica de alguno de sus movimientos. El último capítulo explica la importancia del kumite para comprender el significado de la kata y cuáles son los beneficios para el practicante.

490. Thomas, Raymond (1976). Kata kanku-sho : kata superior para cinturones negros. Barcelona: Alas. 1a ed. 79 p. : il. ; 17x11,5 cm. ISBN: 84-203-0353-4. Depósito legal: B. 739-1976. Palabras clave: katas, aplicación marcial. Resumen: Manual teórico y técnico de kárate. El prólogo de la obra comenta la importancia de las katas, la clasificación de las mismas y las características de la kata kanku-sho. Después describe e ilustra la ejecución técnica de la kata kanku-sho, incluyendo el esquema de movimiento de los pies, las posiciones y la aplicación práctica de ciertas técnicas.

491. Thomas, Raymond (1977). Kárate femenino : técnicas y defensa personal especializadas. Barcelona: Alas. $1^{a}$ ed. 76 p. : il. ; desc.xdesc. cm. ISBN: 84-203-0035-7. Depósito legal: B. 5726-1977. Palabras clave: fundamentos técnicos, defensa personal. Resumen: Manual técnico de kumite y defensa personal para las mujeres. El libro esta compuesto por 6 lecciones de introducción al kumite para las mujeres, en las que se desarrollan ejercicios de gohon, sambon, ippon-kumite y defensa personal adaptados a la mujer. La última parte presenta situaciones de defensa personal ante agarres, abrazos y cuando se esta sentado. Finaliza con la utilización que pueden recibir algunos de los objetos que se portan en la vida diaria como armas. Adjunta un glosario.

492. Thompson, Chris (2009). Kárate : técnica, entrenamiento y competición. Badalona: Paidotribo. 1aa ed. 160 p. : il. ; 22x28,5 cm. ISBN: 978-84-8019-130-2. Depósito legal: no. Palabras clave: historia, 
fundamentos teóricos, fundamentos técnicos, ejercicios, entrenamiento, competición, reglamentos. Resumen: Manual teórico y técnico de kárate. El libro esta formado por 3 partes. La primera parte consta de 6 capítulos que comentan cómo escoger un club de kárate, la historia del kárate desde la India hasta la actualidad, la historia y características de los principales estilos de kárate, en qué consisten los fundamentos técnicos del kárate, qué significado tiene el cinturón negro y cómo conseguirlo, y describe brevemente las reglas de la competición shobu ippon y WKF además de los posibles objetivos de un gasshuku. La segunda parte consta de 9 capítulos que presentan los fundamentos técnicos del kárate. Los dos primeros capítulos explican las normas de etiqueta y describen e ilustran los ejercicios de calentamiento y estiramientos. El tercer capítulo presenta los fundamentos técnicos del kárate, desde sus posiciones y zonas de golpeo hasta las principales defensas y ataques con los brazos y piernas, acompañadas de sus ilustraciones. El cuarto capítulo comenta cómo entrenar con el makiwara y describe varios ejercicios de tameshiwari (rompimientos). El quinto capítulo ilustra las distintas zonas de ataque al adversario, y describe la ejecución de 2 técnicas de escape, 1 técnica de hente waza y 5 ejercicios de yakusoku gumite con sus respectivas ilustraciones. El sexto capítulo explica el significado del kata, sus beneficios y su entrenamiento además de describir e ilustrar cada movimiento de la kata Jion. Los tres últimos capítulos de esta parte comentan la inclusión de las técnicas de proyección en kárate, el entrenamiento de jiyu kumite, describen 9 secuencias de jiyu kumite y una aplicación del kárate en la defensa personal. La última parte consta de 4 capítulos que presentan la vertiente deportiva del kárate. Los dos primeros capítulos describen la indumentaria, las categorías, un resumen de las reglas WKF de competición, y la descripción e ilustración de las órdenes y señales de los árbitros. Los dos últimos capítulos comentan brevemente las normas de competición en kata y los grados y cinturones en kárate. Adjunta 5 apéndices que explican como atar el cinturón, dos glosarios de términos japoneses, las katas de competición de la WKF, las señales de lucha con los banderines y un índice alfabético.

493. Trimble, Aidan y Hazard, Dave (1995). Karate básico. Barcelona: Paidotribo. 1a ed. 218 p. : il. ; 15x21,5 cm. ISBN: 84-8019-111-2. Depósito legal: B. 071-1994. Palabras clave: fundamentos técnicos. Resumen: Manual técnico de karate. La obra esta dividida en 8 capítulos, comenzando con un breve relato de la historia del karate shotokan y su formación. Continua con la descripción técnica de la respiración en el kimé y el kiai, para luego continuar con la utilización de las caderas y sus criterios técnicos. Los siguientes capítulos presentan las principales posturas (zenkutsu, kokutsu, kiba), puñetazos (choku, gyaku, oi, kizami-zuki), bloqueos (age, soto, uchi, shuto-uke, gedan-barai), patadas (mae, yoko, mawashi, ushiro-geri) y golpes (shuto, nukite, uraken, empi-uchi) de karate, ofreciendo una descripción técnica de cada uno de ellos e ilustraciones. Adjunta ilustraciones del sistema muscular, de los puntos vulnerables y un glosario.

494. Valera, Dominic y Piñero Lazaro, Antonio (1979). Kárate : técnicas de competición. Zaragoza: Antonio Piñero. 1aㅡ ed. 119 p. : il. ; 19x21,5 cm. ISBN: 84-300-1076-9. Depósito legal: Z. 708-1979. Palabras clave: kumite, fundamentos técnicos. Resumen: Manual técnico de técnicas de competición de karate. Después de comentar el origen del karate, su desarrollo por el mundo y el espíritu del karateka, explica la importancia de los ejercicios de calentamiento al comienzo de la clase y de relajamiento muscular al finalizar y presenta un conjunto de ejercicios de acondicionamiento físico general y de flexibilidad. El siguiente capítulo explica cuales son los puntos vitales en competición e ilustra los mismos para luego pasar a describir brevemente y de forma gráfica algunos ataques de puño en el trabajo por parejas. Los tres siguientes capítulos describen algunos de los ataques de pierna, desequilibrios y barridos más comunes. Adjunta un glosario.

495. Velilla Fuentes, Santiago (2007). El c'hi : kuatsu-chikung con la práctica armónica del kárate-do. (Camisa de hierro y médula) (Para conservar la salud física y espiritual). Zaragoza: Shirima-Velilla. 1aㅗ ed. 211 p. : il. ; 17x24 cm. ISBN: 978-84-611-9778-1. Depósito legal: Z. 3369-2007. Palabras clave: qigong, historia, fundamentos teóricos, fundamentos técnicos, ejercicios, kuatsu. Resumen: Manual teórico y técnico de kárate. El libro esta formado por 16 capítulos precedidos por los agradecimientos, un prólogo que comenta la labor profesional del autor, varias felicitaciones y una introducción que comenta la formación marcial del autor y analiza la práctica del kárate. El primer capítulo incluye el currículo del autor. El segundo capítulo ilustra los orígenes del kárate, narra sus antecedentes, las armas utilizadas durante la época y un esquema de los principales estilos y escuelas de kárate. El tercer capítulo comenta las armas utilizadas en Okinawa. El cuarto capítulo explica la relación entre el zen y las artes marciales. El quinto capítulo incluye el dojo kun del autor. El sexto capítulo describe la estructura del makiwara e ilustra las principales partes del cuerpo utilizadas para golpear. El séptimo capítulo explica la concepción taoísta del universo y la teoría de los cinco elementos. El octavo capítulo aplica la teoría de los cinco elementos al estilo shirima de kárate. El noveno capítulo expone los conceptos de frecuencias vibracionales y presenta la práctica armónica del karate. El décimo capítulo representa la mutación del ki, la práctica armónica y la armonización de la salud según el método shirima incluyendo numerosas fotografías explicativas. El capítulo decimoprimero define los objetivos del seitai katsugen-undo y describe su práctica. El decimosegundo capítulo describe la ejecución de los 
ejercicios de la pequeña circulación, las 8 piezas del brocado, algunos ejercicios de chikung para la salud, para las artes marciales, el masaje chikung de precalentamiento y de los ejercicios del chikung camisa de hierro acompañados de sus ilustraciones explicativas. El capítulo decimotercero incluye la ilustración de las katas heian o pinan y una tabla de aplicación terapéutica del kata. El decimocuarto capítulo expone los fundamentos teóricos del estilo shirima de kárate. El siguiente capítulo detalla las características técnicas de los dos tipos de chikung además de incluir algunas reflexiones sobre el kata sanchin. El decimosexto capítulo presenta los fundamentos teóricos del kuatsu además de incluir algunas ilustraciones de la anatomía muscular y ósea del ser humano. Adjunta fotografías de diferentes artistas marciales y un comentario final sobre la evolución del kárate.

496. Williams, Bryn (1978). Karate. Barcelona: Aura. 1a ed. 38 p. : il. ; 20x13,5 cm. ISBN: 84-214-0178-5. Depósito legal: B. 9921-1978. Palabras clave: fundamentos teóricos, fundamentos técnicos. Resumen: Manual técnico de karate. El libro presenta de manera introductoria, los aspectos históricos del kárate, la vestimenta y los cinturones, información básica sobre los clubes de karate, la descripción de algunas posiciones, desplazamientos, las partes del cuerpo utilizadas como arma, la ejecución de algunos golpes con la mano, bloqueos y patadas. También hace unos breves comentarios sobre el origen de las katas, el rompimiento de maderas, las competiciones, extracto del arbitraje de competición y las diferencias principales entre los estilos de karate.

497. Yamaguchi, Gogen (1995). El karate-do de Gogen Yamaguchi. El karate-do del "Gato" : autobiografía del

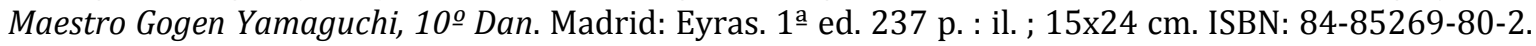
Depósito legal: M. 17520-1995. Palabras clave: historia, biografía, kárate, zen, yoga, katas. Resumen: Biografía del autor y manual técnico de karate goju-ryu. La obra esta dividida en 2 partes, la primera de ellas narra la vida y hechos de Gogen Yamaguchi, desde su niñez hasta entendimiento completo del camino, ilustrando algunos de sus momentos más importantes. Narra cómo fue creciendo en su vida personal y marcial, cómo influyeron los hechos sociales de aquella época en su entendimiento y entrenamiento en las artes marciales, cómo era su vida diaria o cuáles fueron los sistemas y principios que fueron conformando el karate goju-ryu. El último capítulo recoge las conclusiones de todos sus años de estudio y explica la filosofía de la escuela Goju-ryu a través de los secretos de las artes marciales, el shinto y el yoga. Mientras que la segunda parte ofrece una parte técnica en la que se describen e ilustran tres tipos de ejercicios propios de la Goju-ryu, las katas sanchin, tensho y sisoochin, cómo utilizar el tessen, el sai y el kusari; algunas nociones prácticas sobre el yoga y sus ejercicios, consejos sobre la meditación zen y una breve explicación del Bubishi. Incluye un epílogo.

\subsubsection{Kendo, Kenjutsu e Iaido}

498. Akeshi, Sueyoshi (2007). Iaido : el arte japonés de desenvainar. Madrid: Budo International. $1^{\mathfrak{a}}$ ed. 111 p. : il. ; 17x24 cm. ISBN: 978-84-935919-1-5. Depósito legal: M. 38961-2007. Palabras clave: fundamentos técnicos, combate, entrenamiento, vestimenta. Resumen: Manual teórico y técnico de iaido. La obra esta formada por 7 capítulos. El primer capítulo presenta el arte del iaido, los principios de la acción y de la práctica y la descripción de los distintos entrenamientos especiales dentro del iaido. El segundo capítulo enumera las partes de la katana e ilustra la etiqueta y saludos correctos. El tercer capítulo ilustra las formas de agarre de la katana y las formas de envainar la katana, para luego pasar a las técnicas básicas como nuki tsuke, gundari, sumi gaeshi, tomoe nuki y toshiaki. El quinto capítulo presenta la secuencia gráfica de algunos movimientos para el entrenamiento como tatsu no otoshi go, suri ashi, kaeru tobi, y estiramientos. Los dos últimos capítulos presentan de forma gráfica distintas combinaciones y el trabajo de ataques y defensas por parejas para evitar el desarme respectivamente.

499. Akeshi, Sueyoshi (2008). Iaido avanzado : el arte japonés de desenvainar. Madrid: Budo International. $11^{a}$ ed. 111 p. : il. ; 17x24 cm. ISBN: 978-84-92484-20-1. Depósito legal: M. 52213-2008. Palabras clave: fundamentos técnicos, principios técnicos, aplicación marcial. Resumen: Manual teórico y técnico de iaido. El libro esta formado por 16 capítulos precedidos por un prólogo que presenta al autor. El primer capítulo comenta los contenidos del libro mientras que el segundo analiza los principios técnicos de la escuela mugen kai. Los siguientes trece capítulos incluyen la secuencia fotográfica de las katas tatsu no otoshi go, inazuma nuke, jumonji kuzushi, mugai kesa, tsunami gaeshi, hangetsu nuki, kama itachi, shishi giri, tomoe o nuke, kamigane nuki, gundari, nuki tsake y toshiaki junto con su aplicación marcial. El último capítulo presenta la ilustración de varias series técnicas ante distintas presas de muñecas.

500. Fleitas González, Pedro (1994). La espada japonesa. Telde: Seigan. 1aㅡ ed. 33 p. : il. ; 12x16 cm. ISBN: 8488738-08-0. 84-88738-01-3 (ISBN de la colección). Depósito legal: GC. 1170-1994. Palabras clave: historia, fundamentos teóricos, fundamentos técnicos. Resumen: Tratado teórico de la espada. La obra esta formada por 3 capítulos. El primer capítulo describe los tipos de hojas y sus partes acompañadas de su representación gráfica. El segundo capítulo narra brevemente la historia de las espadas 
japonesas y su evolución. El tercer capítulo comenta la utilización de la espada en las escuelas Bujinkan, describe la forma de portar la espada y empuñarla, explica la dirección de los cortes y sus principios técnicos y presenta la ceremonia de examen de 5o dan. Adjunta la descripción e ilustración de una serie técnica para evitar el ataque con espada.

501. Galán, Francisco Javier y Royo, Francisco (1994). Ken : introducción básica a la esgrima japonesa. Barcelona: Alas. 1aㅡ ed. 62 p. : il. ; 29x21 cm. ISBN: 84-203-0363-1. Depósito legal: B. 12566-1994. Palabras clave: katas, historia, fundamentos técnicos, ejercicios, combate. Resumen: Manual de teórico y técnico de kenjutsu. El primer capítulos relata la historia y desarrollo del kenjutsu, de sus maestros más destacados y los aspectos técnicos generales del kenjutsu. Los dos capítulos siguientes describen la etiqueta y el ceremonial de inicio con numerosas ilustraciones de los mismos. A continuación describe la forma de agarre del bokken, las posturas básicas, los desplazamientos, las guardias y las distancias, incluyendo gráficos e ilustraciones explicativas. El siguiente capítulo comenta las formas y métodos para golpear así como la combinación de técnicas adjuntando las ilustraciones de las mismas. El último capítulo explica la práctica del kumitachi e incluye la secuencia fotográfica y breve descripción de siete ejercicios de kumitachi. Adjunta varias fotografías.

502. Nalda Albiac, José Santos (1985). Ken-jutsu. Barcelona: Alas. 1ạ ed. 150 p. : il. ; 15x21,5 cm. ISBN: 84203-0185-X. Depósito legal: B. 31579-1985. Palabras clave: katas, historia, fundamentos teóricos, fundamentos técnicos, principios técnicos, combate, entrenamiento, vestimenta, cortesía, competición, sistemas de entrenamiento, armas. Resumen: Manual teórico y técnico de kenjutsu. El libro esta formado por 18 capítulos precedidos por la presentación del libro y un prólogo que señala los objetivos del libro. El primer capítulo narra la historia de los samurái y desarrollo del kenjutsu. El segundo capítulo explica la estructura del bokken y su forma de agarrarlo. El tercer capítulo explica las normas de respeto hacia las armas mientras que el cuarto describe la forma de saludar. El quinto capítulo explica la ejecución de las distintas formas de kamae mientras que el sexto describe los diferentes tipos de desplazamiento acompañados de su representación gráfica. El séptimo capítulo explica el significado y objetivos kiai. El octavo capítulo define los tipos de distancia. El noveno capítulo localiza los puntos de ataque del kenjutsu. El décimo capítulo describe la ejecución de los principales golpes del kenjutsu incluyendo su representación gráfica. El décimo primer capítulo comenta los principios técnicos del suburi junto con la representación gráfica de algunos de sus ejercicios. El décimo segundo capítulo presenta la ejecución de las paradas básicas junto con sus principios técnicos. El décimo tercer capítulo detalla los tipos de esquiva junto con su representación y esquemas de movimiento. El décimo cuarto capítulo presenta diversas técnicas de kaeshi waza (contraataque) acompañadas de sus gráficos explicativos. El décimo quinto capítulo describe el desarrollo de una clase de kenjutsu incluyendo sus ejercicios prácticos. El décimo sexto capítulo representa gráficamente una kata de kenjutsu acompañada de sus esquemas de movimiento. El décimo séptimo capítulo ofrece varios consejos para el entrenamiento de la táctica. El décimo octavo capítulo enumera las ventajas de la competición como método de entrenamiento y señala sus requisitos y factores.

503. Nalda Albiac, José Santos (1986). Iaido : todas las bases y los katas exigidos para cinto negro. Barcelona: Alas. $1^{\underline{a}}$ ed. 136 p. : il. ; 15x21 cm. ISBN: 84-203-0202-3. Depósito legal: no. Palabras clave: fundamentos técnicos, escuelas, iaido, katas. Resumen: Manual técnico de iaido. Comienza con una introducción sobre el origen y significado del iaido seguido de los principios para la práctica. El tercer capítulo explica los tipos de sable que existen, sus partes, el cuidado de mantenimiento que requieren y el respeto que se debe tener hacia ellos. Después pasa a explicar las formas de saludar y de entrar al dojo junto con la estructura de una kata, cuáles son sus fases y cómo se realiza cada una de ellas. Los dos siguientes capítulos estudian las katas de los estilos Muso Shinden Ryu y Sete Iai, tanto su historia como la ejecución de sus técnicas. Explican cada una de sus técnicas e ilustran dichos movimientos adjuntando los esquemas de movimiento. El último capítulo presenta los ejercicios básicos previos a la realización de las técnicas y cómo se realiza el aprendizaje de estos fundamentos. También incluye algunos ejercicios de percepción y respuesta inmediata.

504. Nalda Albiac, José Santos (1993). Iaido : la calma en acción. Barcelona: Alas. 1a ed. 143 p. : il. ; 17x24 cm. ISBN: 84-203-0279-1. Depósito legal: B. 17359-1993. (3a ed., 2005, 190 p.). Palabras clave: fundamentos técnicos, escuelas, iaido, katas. Resumen: Manual técnico de iaido. Comienza con una introducción sobre el origen y significado del iaido seguido de los principios para la práctica. El tercer capítulo explica los tipos de sable que existen, sus partes, el cuidado de mantenimiento que requieren y el respeto que se debe tener hacia ellos. Después pasa a explicar las formas de saludar y de entrar al dojo junto con la estructura de una kata, cuáles son sus fases y cómo se realiza cada una de ellas. Los dos siguientes capítulos estudian las katas de los estilos Muso Shinden Ryu y Sete Iai, tanto su historia como la ejecución de sus técnicas. Explican cada una de sus técnicas e ilustran dichos movimientos adjuntando los esquemas de movimiento. El último capítulo presenta los ejercicios básicos previos a la realización de las técnicas y cómo se realiza el aprendizaje de estos fundamentos. También incluye algunos ejercicios de percepción y respuesta inmediata. 
505. Nalda Albiac, José Santos (2000). Nito jutsu : la escuela de los dos sables. Barcelona: Alas. 1a ed. 143 p. : il. ; $17 \times 23,5$ cm. ISBN: 84-203-0404-2. Depósito legal: B. 43048-2000. Palabras clave: katas, fundamentos técnicos, defensa personal, armas, estrategia, táctica, escuelas, maestros. Resumen: Manual teórico y técnico de kenjutsu. La monografía esta compuesta de15 capítulos. Los dos primeros capítulos detallan la biografía de Miyamoto Musashi y su escuela, y las nociones básicas de las ryu y sus símbolos. El tercer capítulo describe, clasifica e ilustra las distintas posiciones de guardia junto con el ritual del saludo y la forma de empuñar los dos sables. Los siguientes cinco capítulos enumeran y explican los ataques fundamentales con los dos sables, las técnicas de bloqueo y los ataques encadenados, ilustrando y describiendo su ejecución. Los dos siguientes capítulos profundizan en el concepto de sen no sen (iniciativa en el ataque), sus requisitos y características incluyendo varios ejemplos prácticos ilustrados de esta técnica. El undécimo capítulo explica el significado del kata y sus requisitos para luego describir e ilustrar la kata nito jutsu. Los dos siguientes capítulos presentan la aplicación del arte de los dos sables contra el jo jutsu y los principios de defensa contra varios adversarios. Finaliza con el estudio de la estrategia en el combate y su forma de entrenamiento, y el programa de contenidos de una clase de entrenamiento de nito jutsu ryu 2000 y sus consejos prácticos.

506. Navarro Parra, José (2009). Manual de kenjutsu : teoría y práctica. Una guía para todos los artistas marciales. Barcelona: Alas. 1aㅡ ed. 153 p. : il. ; 17x23,5 cm. ISBN: 978-84-203-0466-3. Depósito legal: B. 44736-2009. Palabras clave: katas, fundamentos teóricos, fundamentos técnicos, principios técnicos, vestimenta. Resumen: Manual teórico y técnico de kenjutsu. El libro esta formado por 11 capítulos precedidos por un breve comentario sobre la práctica del kenjutsu, un prólogo que comenta los contenidos del libro, el relato del primer contacto de un practicante con el kenjutsu, un comentario sobre la estructura del libro y los agradecimientos. El primer capítulo expone las normas de conducta de los estudiantes de kenjutsu y describe la forma de saludar, envainar y desenvainar el bokken acompañados de su secuencia fotográfica. El segundo capítulo incluye las normas generales sobre la práctica. El tercer capítulo detalla los fundamentos teóricos en el manejo del bokken. El cuarto capítulo explica el significado del kamae y describe sus distintos tipos en el kenjutsu junto con sus ilustraciones. El quinto capítulo enumera los principios técnicos del kenjutsu e incluye la descripción de los puntos importantes y principales errores de sus técnicas básicas (suburis) acompañadas de sus ilustraciones. El sexto capítulo explica la aplicación de las técnicas básicas contra un oponente. Los dos siguientes capítulos presentan la descripción y secuencia fotográfica de varias técnicas combinadas así como su aplicación práctica. El noveno capítulo detalla los fundamentos teóricos de las técnicas defensivas del kenjutsu junto con la explicación de varias técnicas y su secuencia fotográfica. El décimo capítulo expone el significado de las katas e incluye la secuencia fotográfica de la kiri no kata. El último capítulo explica el concepto de makoto y su entrenamiento. Adjunta un glosario específico.

507. Panchamé Munté, John (1977). El Kendo. La esgrima japonesa : técnicas y katas. Barcelona: Alas. 1a ed. 61 p. : il. ; 15x21,5 cm. ISBN: 84-203-0062-4. Depósito legal: B. 35920-1977. (2ª ed., 1987). Palabras clave: fundamentos técnicos, katas. Resumen: Manual teórico y técnico de kendo. La monografía comienza explicando el origen del kendo y ofreciendo una visión introductoria del mismo y sus peculiaridades. Así explica las partes del shinai, el katana, el bokken, la armadura y el ceremonial. Después ofrece una serie de ejercicios para realizar como calentamiento y en el siguiente capítulo explica las reglas de competición. Los siguientes capítulos describen los fundamentos técnicos del kendo, como son el agarre del shinai, las guardias, los desplazamientos y el suburi. A continuación describe los ocho golpes fundamentales del kendo y sus paradas, explicando su ejecución y adjuntando fotografías de los mismos. El siguiente capítulo esta dedicado a las combinaciones técnicas y finaliza con la secuencia gráfica de la ceremonia de saludo, y las katas ipponme, nihonme y sambonme.

508. Regoli, Claudio A. (1995). El kendo : técnicas, entrenamiento, reglas. Barcelona: De Vecchi. $1^{a}$ ed. 175 p. : il. ; 17x24 cm. ISBN: 84-315-1503-1. Depósito legal: B. 43734-1995. (2ª ed. corr. y aum., 1999, ISBN: 84-315-2186-4). Palabras clave: fundamentos teóricos, táctica, fundamentos técnicos, principios técnicos, ejercicios, combate, entrenamiento, vestimenta, cortesía, arbitraje, competición, etiqueta, reglamentos. Resumen: Manual teórico y técnico de kendo. El libro esta dividido en 8 capítulos precedidos por un prólogo que comenta las características del kendo. El primer capítulo detalla los aspectos formales de la práctica del kendo, como el dojo y la vestimenta, además de describir e ilustrar la forma de colocarse el uniforme y la armadura. El segundo capítulo explica la ejecución del saludo, cómo empuñar, las posiciones con el arma, las guardias y los desplazamientos incluyendo sus fotografías explicativas además de comentar los niveles de distancia. El tercer capítulo analiza la forma de golpear en el kendo y explica la ejecución de los diferentes tipos de golpes acompañados de su representación gráfica. El cuarto capítulo comenta el significado del término zanshin y su ejecución en el combate. El quinto capítulo explica la ejecución de los distintos ejercicios básicos de entrenamiento del kendo incluyendo varias fotografías explicativas. El sexto capítulo presenta los fundamentos teóricos y principios tácticos de la práctica del kendo. El séptimo capítulo incluye la descripción e ilustración de las principales acciones de ataque, contraataque, dobles y situaciones particulares del 
kendo así como un comentario sobre sus diferentes métodos de entrenamiento. El último capítulo presenta los reglamentos de competición y arbitraje del kendo. Adjunta un glosario específico.

509. Ríos, Carmelo H. (1982). Samurái : la vía del sable. Estudio sobre el arte del sable japonés iaido, historia, filosofía, técnica, esoterismo, katas. Barcelona: Alas. 1aㅡ ed. 128 p. : il. ; 15x21,5 cm. ISBN: 84-203-01310. Depósito legal: B. 16792-1982. (2a ed., 1986). Palabras clave: katas, fundamentos teóricos, fundamentos técnicos, filosofía, escuelas. Resumen: Manual teórico y técnico del sable japonés. La obra comienza con cuatro capítulos introductorios dedicados a explicar la relación entre las artes marciales y la tradición y el budo, y los orígenes mitológicos del sable y su simbología. Continua con un análisis detallado de las partes del ken y sus diferentes tipos, para luego pasar a relatar el origen de la vía del sable, el nacimiento de la escuela katori shinto ryu, los principios del iaido y del bushido, el significado y ceremonia del hara-kiri, el significado del do y el ki, y algunas nociones básicas sobre el kiai. Los siguientes capítulos profundizan en los contenidos más prácticos del arte, explicando el concepto maai, el concepto mushin, el sentido de la anticipación, el arte de mirar, los sonidos, los mudra, los mandala, el proceso de meditación, y la purificación mental. La segunda parte del libro, ilustra y explica con brevedad las guardias del iaido y las katas kusa-nagi-no-ken, nuki-uchi-no-ken, saken y happo-ken, junto con su esquema de ejecución.

510. Royo, Francisco y Diago Marco, Marta (Rei Grup) (1995). Ken : el arte que cautiva. Barcelona: Alas. 1a ed. 140 p. : il. ; 17x24 cm. ISBN: 84-203-0367-4. Depósito legal: B. 2159-1995. Palabras clave: katas, fundamentos teóricos, fundamentos técnicos, ejercicios, kendo, kyudo, aplicación terapéutica, armas. Resumen: Manual teórico y técnico de kendo. El libro esta formado por 2 partes precedidas por una presentación de la obra, una introducción que comenta la formación marcial del autor, un comentario sobre los contenidos de la obra anterior y una comparación entre Occidente y Oriente. La primera parte consta de 10 capítulos. El primer capítulo explica el significado del dojo mientras que el segundo expone las cualidades y labor de un maestro. El tercer capítulo expone la relación entre el ken y el zen. El cuarto capítulo comenta las características rituales del kenjutsu. El quinto capítulo señala la importancia de la constancia y la perseverancia para el manejo del ken. El sexto capítulo reflexiona sobre el aprendizaje de la técnica y de la vía de las artes marciales. El séptimo capítulo comenta la práctica de las artes marciales por las mujeres. El octavo capítulo define los conceptos de ki, kiai y mokuso. El noveno capítulo explica los fundamentos teóricos del kenjutsu. El décimo capítulo analiza la aplicación del arte de la guerra en la actualidad. La segunda parte consta de 10 capítulos. El primer capítulo enumera los principios técnicos del ju-jitsu contra los ataques de bokken-katana. El segundo capítulo describe brevemente varias técnicas de calentamiento y estiramiento acompañadas de sus ilustraciones. El tercer capítulo expone las bases anatómicas del kenjutsu y kyudo incluyendo numerosas ilustraciones explicativas, comenta las características y ejecución de la ken-kyu-no-kata y señala los beneficios derivados de la práctica del kendo y kyudo así como su aplicación para el tratamiento de ciertas enfermedades. El cuarto capítulo relata brevemente la historia del kendo y comenta su indumentaria. El quinto capítulo señala los objetivos del iaijutsu, su indumentaria e incluye la secuencia fotográfica de la kata 2 de iaijutsu. El sexto capítulo explica el significado de la katana. El séptimo capítulo describe la forma de conservar el iaito o katana. El octavo capítulo enumera los principios técnicos de los uchi kata suburis. El noveno capítulo describe la ejecución de distintos kumitachis junto con sus ilustraciones. El último capítulo incluye un glosario específico.

511. Thomas, Raymond (1972). Kendo : reglas fundamentales para su práctica. Barcelona: Alas. 1a ed. 76 p. : il. ; 11x18,5 cm. ISBN: No ISBN. Depósito legal: B. 32115-1972. Palabras clave: historia, fundamentos teóricos, armas, fundamentos técnicos, principios técnicos, bushido, competición, reglamentos, samurái, sistemas de entrenamiento. Resumen: Manual teórico y técnico de kendo. La obra esta formada por 6 capítulos precedidos por un prólogo que explica en qué consiste este arte marcial. El primer capítulo narra la historia del ken-jitsu mientras que el segundo expone la biografía de Miyamoto Musashi. El tercer capítulo enumera los principios del código del samurái. El cuarto capítulo expone las reglas fundamentales del kendo. El quinto capítulo describe la estructura de las espadas y armadura utilizadas en el kendo, el desarrollo del kendo deportivo, su sistema de grados, la forma de vestirse y las normas de cortesía. El sexto capítulo detalla los puntos vulnerables atacados en kendo para luego presentar las reglas de competición y la descripción de las guardias, posiciones, desplazamientos, ejercicios básicos, golpes, paradas, combinaciones y métodos de entrenamiento básicos del kendo. Adjunta un glosario de términos específicos.

512. Wa Rei Ryu (Rei Grup) (1997). El sable : alma del samurái. Barcelona: Alas. 1a ed. 157 p. : il. ; 17x24 cm. ISBN: 84-203-0385-2. Depósito legal: B. 28945-1997. Palabras clave: historia, artes marciales, filosofía, iaido, kenjutsu, bushido, samurái, armas. Resumen: Tratado histórico y filosófico sobre el sable japonés, su práctica y practicantes. El primer capítulo presenta el significado del sable y del samurái dentro de la sociedad japonesa, enfatizando sus actitudes. El segundo capítulo centra su atención en los significados atribuidos al sable y su utilización, como en el seppuku, en oriente y occidente. A continuación describe el desarrollo de las artes de combate en oriente y occidente, explicando los factores que fueron moldeando en cada sociedad. El cuarto capítulo detalla el origen y 
desarrollo del samurái, su papel social y las causas que provocaron su estatus social. Continúa con el origen del sable, su modo de fabricación, las escuelas más importantes de fabricación, cómo se fue evolucionando hacia armas cada vez más efectivas, y cuál era el papel e importancia del sable para el samurái. El sexto capítulo presenta el Iai, sus orígenes y cuáles son sus diferencias técnicas y filosóficas respecto al kenjutsu. El séptimo capítulo describe textual y gráficamente las distintas guardias a adoptar y cuál es su interpretación filosófica, para en el octavo narrar el sentimiento de respeto que se tiene por el arma, y en concreto el sable, en las artes marciales. Continúa describiendo la estrategia en el combate y la aportación de algunos maestros, como Musashi y Yagyu, y la obra Las treinta y seis estrategias. El décimo capítulo ensalza los aspectos saludables del kenjutsu, ahondando en su fisiología y en la estructura de sus movimientos para mejorar la capacidad física del practicante. El siguiente capítulo fundamenta e interpreta el bushido para finalizar con la descripción de los últimos samuráis, su modo de vida y cómo dicho modo de vida no podría ser reproducido en la actualidad.

513. Wa Rei Ryu (2005). Ken : introducción básica a la esgrima japonesa. Barcelona: Alas. $1^{a}$ ed. 139 p. : il. ; 17x24 cm. ISBN: 84-203-0436-0. Depósito legal: B. 23351-2005. Palabras clave: historia, fundamentos técnicos, ejercicios, escuelas, kenjutsu, zen. Resumen: Manual de introducción al kenjutsu. Después de presentar la escuela de kenjutsu creada por el autor, comenta brevemente su historia, algunos esgrimistas famosos y las diferentes escuelas. Los dos capítulos siguientes describen la etiqueta y el ceremonial de inicio con apoyo gráfico. A continuación ofrece las consideraciones que se deben respetar en el entrenamiento del kihon, para luego describir en capítulos independientes, de forma clara y concisa, la forma de agarre del bokken, la postura básica, los desplazamientos, las guardias, las distancias, las formas y métodos de golpear y los encadenamientos. Hace especial hincapié en la importancia de la distancia como un factor determinando del éxito en el combate. Prosiguiendo en el desarrollo del kenjutsu, describe los aspectos a considerar en el trabajo con una pareja y ofrece algunos ejercicios para trabajar de esta manera. Finaliza con un capítulo dedicado a reproducir la entrevista con el monje Tenko (que guió al autor) y un epílogo sobre la introducción del zen en la cultura japonesa.

514. Wa Rei Ryu y Kanben Rei Ryu (2001). El wakizashi : guardián del honor del samurái. Barcelona: Alas. 1á ed. 159 p. : il. ; 17x24 cm. ISBN: 84-203-0411-5. Depósito legal: B. 37205-2001. Palabras clave: historia, fundamentos técnicos, kenjutsu, zen, esgrima, medicina, psicología, armas, seppuku. Resumen: Tratado histórico y técnico del wakizashi. Después de introducirnos en la cultura de Japón y sus características, el primer capítulo presenta la espada corta y su historia, relacionada con la del samurái, a través de los distintos periodos, para continuar con su importancia dentro del suicidio ritual. Además hace un repaso histórico del significado del suicidio en las distintas culturas y desde la ciencia, para finalizar con el significado atribuido dentro del código samurái. Los siguientes dos capítulos describen la esgrima occidental y su posible relación, similitudes y diferencias técnicas y filosóficas, con la escuela de Musashi así como la vida de este artista marcial; y el papel del wakizashi en ambos aspectos. El quinto capítulo describe el kamae y la práctica con pareja de la escuela Wa Rei Ryu, ofreciendo ilustraciones sobre ambas y los principios en los que se basan. Los siguientes tres capítulos, bajo un enfoque filosófico, reflexionan sobre el arte de la no violencia, en contraposición a las actitudes de la sociedad actual; la aportación de la psicología zen a las artes marciales y cuál es el espíritu que debe prevalecer en el practicante; y la aplicación de la sofrología al kenjutsu y en concreto a la consciencia en el seppuku. El noveno capítulo ofrece la situación actual del kenjutsu y cuáles son los posibles caminos de futuro que puede tomar; para concluir con un breve comentario sobre el wakizashi de una sempai.

\subsubsection{Kobudo y otras armas japonesas}

515. Basile, Augusto (1977). Nunchaku : técnicas de base y de defensa. Bilbao: Fher. 1ạ ed. 117 p. : il. ; $14 \times 21$ cm. ISBN: 84-243-1370-4. Depósito legal: BI. 1322-1977. Palabras clave: fundamentos técnicos. Resumen: Manual teórico y técnico sobre el manejo del nunchaku. La obra esta dividida en 9 capítulos. Comienza con una explicación de lo que es el kobudo y cómo se desarrollo, para luego pasar a la historia del nunchaku en particular. El tercer capítulo describe las partes del nunchaku y los diferentes modelos que existen; para luego ofrecer algunos detalles de su entrenamiento. El quinto capítulo describe e ilustra algunos de los ejercicios básicos en el manejo del nunchaku para continuar con la explicación de las posiciones de guardia. Los tres últimos capítulos comentan las fotografías que ilustran algunas de las técnicas de defensa, contraataque, paradas y defensas contra un adversario.

516. Ferré i Odena, Alberto (1979). Nunchaku : técnicas de combate contra kárate, armas y varios adversarios, senken no kata. $2^{\circ}$ tomo. Alicante: Daimyo. $2^{\underline{a}}$ ed. 34 p. : il. ; 31x21 cm. ISBN: 84-300-04122. Depósito legal: A. 26-1979. Palabras clave: katas, fundamentos técnicos, defensa personal, ejercicios, aplicación marcial, armas. Resumen: Manual técnico de nunchaku. La obra esta formada por 12 capítulos precedidos por un saludo inicial de la dirección y un prefacio que presenta la obra. El 
primer capítulo expone algunos ejercicios de calentamiento para luego representar gráficamente la ejecución de la técnica de gran círculo y el movimiento circular en ocho (furi-uchi). Los siguientes siete capítulos incluyen la descripción técnica y representación gráfica de varias técnicas de defensa del nunchaku contra un puñetazo y una patada de kárate, el ataque con puñal, un palo y una espada, así como contra varios adversarios al mismo tiempo. El décimo primer capítulo incluye la secuencia fotográfica y descripción técnica de la senken no kata, para finalizar con la ilustración de dos páginas del cuento titulado "La mano de Naha".

517. Ferré i Odena, Alberto (1979). Nunchaku : técnicas superiores para uno o dos nunchakus, jin no kata. $1^{\circ}$ tomo. Alicante: Daimyo. 1aㅡ. ed. 34 p. : il. ; 21x31 cm. ISBN: 84-300-0386-X. Depósito legal: A. 17-1979. (2a ed., 1979, 31 p.; $3^{a}$ ed., 1980). Palabras clave: historia, fundamentos técnicos, ejercicios, katas. Resumen: Manual teórico y técnico de nunchaku. El libro esta formado por 12 capítulos, precedidos por la presentación de la estructura el nunchaku. El primer capítulo comenta los contenidos que conforman la colección, mientras que el segundo narra la historia del nunchaku. El tercer capítulo ilustra los diferentes ejercicios educativos de manejo del nunchaku para luego representar los ataques acompañados de sus esquemas de movimiento. Los tres siguientes capítulos describen la ejecución de las posturas, guardias y blocajes fundamentales en el manejo del nunchaku incluyendo sus fotografías explicativas. El octavo capítulo explica la ejecución de varios ejercicios preparatorios junto con su representación gráfica para luego describir e ilustrar varias secuencias de encadenamientos y bloqueos y contraataques. El décimo primer capítulo explica varios ejercicios con dos nunchakus para finalizar con la descripción y representación gráfica de la jin-no-kata. Adjunta un cómic titulado "la mano de naha".

518. Ferré i Odena, Alberto (dir.) (1974). Nunchaku : defensa y ataque. Alicante: Daimyo. 1a ed. 42 p. : il. ; 31x22 cm. ISBN: 84-400-8126-X. Depósito legal: A. 437-1974. (4ae ed., 1979). Palabras clave: historia, fundamentos técnicos, defensa personal, ejercicios, calentamiento. Resumen: Manual teórico y técnico de nunchaku. El libro esta formado por 9 capítulos. El primer capítulo narra la historia de la utilización del nunchaku así como sus características técnicas. El segundo capítulo describe varios ejercicios de calentamiento acompañados de sus ilustraciones correspondientes. Los siguientes tres capítulos explican e ilustran la ejecución de las principales posturas, guardias y blocajes en el manejo del nunchaku. El sexto capítulo detalla las principales técnicas de ataque con el nunchaku acompañadas de su secuencia fotográfica de ejecución y esquemas de movimiento. El séptimo capítulo incluye la descripción e ilustración de la aplicación de varias técnicas con nunchaku a situaciones de defensa personal. El último capítulo comenta el significado de la kata, presenta su esquema de movimiento y describe su ejecución técnica junto con su secuencia fotográfica y esquema de movimiento de los pies.

519. Gutiérrez, Raúl (1984). Nunchaku : la más completa guía para los instructores modernos. Barcelona:

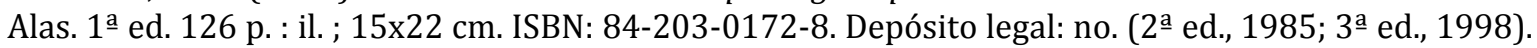
Palabras clave: katas, historia, fundamentos teóricos, armas, fundamentos técnicos, principios técnicos, defensa personal, competición. Resumen: Manual teórico y técnico de nunchaku. La obra esta formada por 18 capítulos, precedidos por una introducción que comenta los objetivos de la obra y presenta el nunchaku. El primer capítulo narra la historia del nunchaku. El segundo capítulo representa la estructura y partes del nunchaku, sus medidas y las diferentes formas de agarre. El tercer capítulo ilustra los distintos tipos de nunchaku que existen mientras que el cuarto señala las características de los diferentes tipos de nunchaku para el entrenamiento. El quinto capítulo ilustra varios ejercicios de preparación física con el nunchaku. El sexto capítulo clasifica las artes del kobudo y comenta el origen y características del sai, nunchaku, kama, tonfa y tekos, junto con los contenidos técnicos presentes en una kata con nunchaku. Los dos siguientes capítulos presentan la ocultación del nunchaku y las diferentes formas de portarlo. El noveno capítulo ilustra las posiciones y guardias fundamentales en el manejo del nunchaku junto con la localización de los puntos vitales. El décimo capítulo señala la importancia y beneficios de una correcta respiración mientras que el siguiente representa los diferentes ángulos de maniobra en el manejo del nunchaku junto con sus esquemas de movimiento. El décimo segundo capítulo describe brevemente la ejecución de la kata "tigre solitario" acompañada de su secuencia fotográfica. El siguiente capítulo analiza la aplicación del nunchaku en situaciones de defensa personal señalando sus ventajas e inconvenientes. El décimo cuarto capítulo señala los principios técnicos de utilización del nunchaku por parte de los oficiales de la ley mientras que el siguiente describe e ilustra 17 técnicas de defensa personal con el nunchaku. Los tres últimos capítulos explican en qué consiste el nunchaku de competición, cuál es el objetivo de la Federación Francesa de Nunchaku de Competición y las categorías de aprendizaje del nunchaku.

520. Hayashi, Kenji (1976). El bo : defensa, ataque, kihon-kumite, kata. Barcelona: Alas. $1^{a}$ ed. 46 p. : il. ; 15x21 cm. ISBN: 84-203-0052-7. Depósito legal: B. 54932-1976. (2ª ed., 1980; 3ae ed., 1985). Palabras clave: kumite, fundamentos teóricos, fundamentos técnicos. Resumen: Manual teórico y técnico de bo. El libro esta formado por 6 capítulos. El primer capítulo relata el origen del bo y su estructura. El segundo capítulo ilustra sus dos formas de agarre y las diferentes guardias. El tercer capítulo incluye las fotografías de las defensas básicas del bo mientras que el cuarto presenta los ataques 
fundamentales. El quinto capítulo muestra la secuencia fotográfica de varias técnicas de kihon-kumite. El último capítulo enumera la secuencia técnica de la kata bo jitsu de sakugawa acompañada de su representación gráfica.

521. Hayashi, Kenji (1976). El sai : posiciones, defensas, ataques y contraataques, bloqueos, kata. Barcelona: Alas. 1aㅡ ed. 48 p. : il. ; 15x21 cm. ISBN: 84-203-0009-8. Depósito legal: B. 23663-1976. (2ª ed., 1982; 3aㅡ ed., 1987). Palabras clave: historia, fundamentos teóricos, armas, fundamentos técnicos, aplicación marcial. Resumen: Manual teórico y técnico del sai. El libro esta formado por 8 capítulos. El primer capítulo comenta los orígenes del sai mientras que el segundo presenta la biografía del autor. El siguiente capítulo enumera los tipos de sai, sus partes y describe las distintas formas de cogerlo junto con su ilustración explicativa. El cuarto capítulo nombra e ilustra las posiciones fundamentales para luego presentar los principales ataques, bloqueos y ataques y defensas contra katana. El octavo capítulo incluye la secuencia fotográfica de una kata con sai.

522. Hentona, Choyu (1981). Nunchaku : kata asabana I. Madrid: Choyu Hentona. 1a ed. 32 p. : il. ; 16x23,5 cm. ISBN: 84-300-3248-7. Depósito legal: M. 2005-1981. Palabras clave: fundamentos técnicos. Resumen: Manual técnico de nunchaku. La obra consta de dos partes, precedidas por el comentario del significado del símbolo de la escuela Okinawa-Kobudo. La primera parte describe la ejecución de los fundamentos técnicos básicos del manejo de nunchaku como son las principales guardias, defensas y ataques, acompañadas de sus ilustraciones explicativas. También comenta la historia y significado de la kata asabana I junto con la breve descripción y secuencia fotográfica de su ejecución.

523. Hirota, Yoshiho (1975). Nunchaku práctico : técnicas para la autodefensa contra armas. Barcelona: Alas. $1^{\text {a }}$ ed. 47 p. : il. ; 15x21 cm. ISBN: 84-203-0332-1. Depósito legal: B. 20901-1975. (2ª ed., 1977, ISBN:

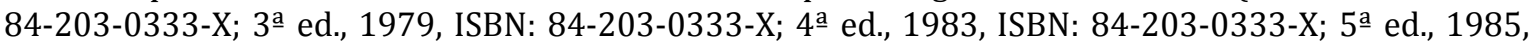
ISBN: 84-203-0333-X). Palabras clave: historia, defensa personal, kárate, aplicación marcial, armas. Resumen: Manual teórico y técnico de nunchaku. La obra esta formada por 3 capítulos precedidos por un prólogo y la biografía del autor. El primer capítulo narra la historia del nunchaku junto con sus fundamentos teóricos. El segundo capítulo ilustra las posiciones fundamentales básicas mientras que el tercero compara gráficamente el kárate con el manejo del nunchaku. El tercer capítulo presenta la secuencia fotográfica de la aplicación marcial de varias técnicas de nunchaku contra ataques armados y desarmados.

524. Isidro Casas, José Luis (2006). El bo : manual del palo japonés. El palo largo japonés. Madrid: Budo International. $1^{\underline{a}}$ ed. 111 p. : il. ; $17 \times 24$ cm. ISBN: 84-96492-38-9. Depósito legal: M. 35673-2006. Palabras clave: historia, fundamentos técnicos, aikido, budo, kobudo, armas. Resumen: Manual teórico y técnico de bo jutsu. El libro esta formado por 29 capítulos. El primer capítulo relata el encuentro entre Miyamoto Musashi y Muso Gonnoshuke y la historia del bo. Los dos siguientes capítulos exponen los distintos trabajos con el bo en el aikido y en el kobudo. El cuarto capítulo ofrece consejos prácticos y reglas para manejar y agarrar el bo, mientras que el quinto incluye un breve glosario. A partir del sexto capítulo se ilustran los fundamentos técnicos del bo jutsu, ofreciendo la secuencia fotográfica y esquemas de movimiento de: ukemi waza, kamae no bo, atemi no bo waza, maki uchi, yodan tsuki, tsuto uke, kokyu uchi, shoto nagashi, harai, gedan tsuki, yodan tsuki, las katas shodan no bo, nidan no bo, sandan no bo y yodan no bo, bo no waza, irimi-nage, shionage, ikkyo ura, ikkyo omote, nikyo, udekime-nage, sotokaiten-nage y kokyu-nage.

525. Morales Nogales, Francisco Javier y Andreu Cortés, Juan (1981). Tres armas orientales : nunchakus, tonfa y bo. Barcelona: Francisco Javier Morales Nogales y Juan Andreu Cortés. $1^{\mathfrak{a}}$ ed. 241 p. : il. ; 13×21 cm. ISBN: 84-300-3720-9. Depósito legal: B. 36674-1981. Palabras clave: fundamentos teóricos, fundamentos técnicos, principios técnicos. Resumen: Manual teórico y técnico de armas. El libro esta formado por 3 partes precedidas de un prólogo que señala los objetivos de la obra y una introducción que describe la estructura de los nunchaku, el tonfa y el bo. La primera parte ofrece varios consejos para la práctica y entrenamiento con los nunchaku, describe e ilustra sus fundamentos técnicos y enumera la secuencia de movimientos de cinco katas prefabricadas. La segunda parte expone las características del tonfa, describe e ilustra sus fundamentos técnicos y enumera la secuencia de movimientos de dos katas prefabricadas. La última parte comenta las características del bo, señala sus principios técnicos, describe e ilustra la ejecución de sus fundamentos técnicos y enumera la secuencia de movimientos de tres katas prefabricadas.

526. Nalda Albiac, José Santos (1984). Tambo Jutsu. Barcelona: Alas. 1aㅡ ed. 127 p. : il. ; $15 \times 21$ cm. ISBN: 84203-0164-7. Depósito legal: B. 16376-1984. Palabras clave: katas, fundamentos teóricos, fundamentos técnicos, defensa personal, ejercicios, combate, cortesía, aplicación marcial, armas. Resumen: Manual teórico y técnico de tambo jutsu. El libro esta formado por 16 capítulos precedidos por un prólogo que señala el origen e importancia del arte. El primer capítulo explica la estructura y medidas del tambo mientras que el segundo describe cómo se empuña. El tercer capítulo explica las distintas formas de saludar incluyendo su representación gráfica. El cuarto capítulo ilustra las diferentes guardias para luego mostrar diferentes ejercicios de manejo del tambo. El quinto capítulo clasifica y representa gráficamente los golpes con el tambo incluyendo sus esquemas de movimiento. 
El sexto capítulo explica la ejecución de las defensas básicas con y contra tambo, mientras que el séptimo muestra una kata. Los siguientes cuatro capítulos presentan la representación gráfica de algunas de las defensas con tambo, kárate contra tambo, tambo contra kárate y defensas contra tambo. El décimo segundo capítulo explica algunas técnicas para recuperar el tambo acompañadas de sus ilustraciones correspondientes. Los siguientes tres capítulos presentan la aplicación del tambo en la defensa contra ataques con cuchillo, ante distintas presas y agarres, y algunas técnicas de luxación y conducción, junto con su representación gráfica y esquemas de movimiento. El último capítulo exponen los contenidos de cuatro clases de tambo-jutsu.

527. Nalda Albiac, José Santos (1986). Jo-jutsu. Barcelona: Alas. 1a ed. 144 p. : il. ; 15x21,5 cm. ISBN: 84-2030193-3. Depósito legal: B. 27062-1986. Palabras clave: historia, fundamentos teóricos, armas, fundamentos técnicos, principios técnicos, ejercicios, calentamiento, vestimenta, katas. Resumen: Manual teórico y técnico de jojutsu. El libro esta formado por 14 capítulos a modo de cómic precedidos por un prólogo que comenta los contenidos del libro y una presentación del mismo. El primer capítulo narra el origen del jojutsu mientras que el segundo expone la estructura y características del jo. El tercer capítulo describe la forma de saludar y las normas de etiqueta dentro del dojo. El cuarto capítulo presenta varios ejercicios de calentamiento mientras que el quinto describe cómo se empuña el jo. El sexto capítulo representa las distintas guardias con el jo. El séptimo capítulo describe la ejecución de los ataques básicos simples acompañados de su representación gráfica para luego continuar con las paradas y los ataques combinados. El décimo capítulo expone los fundamentos teóricos de las técnicas de combate y presenta la descripción e ilustración de varias de ellas. El siguiente capítulo explica los principios yin/yang junto con la secuencia gráfica de distintas técnicas a mano vacía ante el ataque con el jo (jo dori). Los últimos tres capítulos presentan la secuencia gráfica de ejecución de la kata de jo fundamental, la kata de los 31 golpes y la kata de jo contra ken acompañadas de sus esquemas de movimiento.

528. Nalda Albiac, José Santos (1988). Nagi-nata : programa completo para cinto negro. Barcelona: Alas. $1^{\text {a }}$ ed. 127 p. : il. ; 15x21,5 cm. ISBN: 84-203-0225-2. Depósito legal: B. 35642-1988. Palabras clave: fundamentos técnicos. Resumen: Manual técnico de nagi-nata. Comienza con una introducción sobre la historia de la nagi-nata y las características de los distintos tipos. A continuación expone el desarrollo de una clase tradicional y describe el agarre del nagi-nata. Pasa a explicar, ilustrar y esquematizar algunas de las técnicas incluidas en el programa moderno de nagi-nata, parte de las katas y cómo se debe desarrollar el entrenamiento y el combate.

529. Planellas Vidal, Pau-Ramon (1985). Tanto-jitsu : técnicas básicas. Barcelona: Alas. 1a ed. 48 p. : il. ; 15x21,5 cm. ISBN: 84-203-0189-2. Depósito legal: B. 43844-1985. Palabras clave: historia, fundamentos teóricos, principios técnicos, defensa personal, estrategia, táctica. Resumen: El primer capítulo señala la utilización del tanto dentro del bujitsu y sus contenidos técnicos. El segundo capítulo describe e ilustra las diferentes posiciones de guardia (kamae) además de algunos ejercicios para mejorar el manejo del tanto. El tercer capítulo comenta la utilización especial del tanto debido a la peligrosidad del mismo para luego explicar las diferentes estrategias y principios tácticos a tener en cuenta. El quinto capítulo relata el uso que tenía el tanto dentro del suicidio ritual para finalizar con la descripción e ilustración de distintas secuencias técnicas con el tanto.

530. Planellas Vidal, Pau-Ramon (1989). Tonfa policial. Barcelona: Alas. 1a ed. 144 p. : il. ; $16 \times 24$ cm. ISBN: 84-203-0241-4. Depósito legal: B. 36841-1989. (2 ${ }^{a}$ ed., 1998, 176 p.). Palabras clave: historia, fundamentos teóricos, táctica, fundamentos técnicos, principios técnicos, defensa personal, kárate, aplicación marcial. Resumen: Manual teórico y técnico de tonfa. El libro esta formado por 13 capítulos precedidos por una breve biografía del autor y sus asesores y una introducción que detalla la formación de los agentes de seguridad. El primer capítulo describe e ilustra una técnica de tambo tradicional. El segundo capítulo narra el origen del tonfa y los diferentes nombres que recibe. El tercer capítulo compara gráficamente las técnicas del tonfa con las de kárate. El cuarto capítulo explica la estructura y utilización del sai, jutte y manrikigusari, detalla la evolución de los métodos utilizados por la policía japonesa e incluye numerosas fotografías sobre la utilización de dichas armas. El quinto capítulo comenta la adopción de algunas armas policiales en Occidente junto con la descripción e ilustración de algunas técnicas de defensa personal con el tambo y hambo. El sexto capítulo analiza la metodología del tonfa policial mientras que el séptimo explica su estructura. El octavo capítulo define y describe las distintas posiciones de sujeción del tonfa, las técnicas de giro, percusión, bloqueo, presión, palanca, estrangulación y enganche junto con la ilustración de algunas de ellas. El noveno capítulo describe e ilustra la ejecución de sus técnicas fundamentales como son el cambio de posición del tonfa en ataque, combinación de golpe directo y golpe de giro, combinación de bloqueo y estrangulación, y presión con el tonfa y barrido. El décimo capítulo expone los principios tácticos del manejo del tonfa policial. Los siguientes cuatro capítulos describen la ejecución de algunas técnicas de defensa personal con el tonfa ante diversos ataques, varias técnicas de detención, conducción de detenidos y de defensa de una tercera persona, acompañadas de su secuencia fotográfica. Adjunta un epílogo que expone los objetivos y carencias de la obra. 
531. Sakay, Yoshihito (1976). El tonfa : bloqueos, ataques, defensa, kata. Barcelona: Alas. 1 a ed. 48 p. : il. ; 15x21 cm. ISBN: 84-203-0358-5. Depósito legal: B. 8097-1976. (3ª ed., 1985). Palabras clave: historia, kárate. Resumen: Manual teórico y técnico de tonfa. El libro esta formado por 5 capítulos. El primer capítulo narra el origen del tonfa junto con la biografía del autor. El segundo capítulo compara gráficamente las técnicas de kárate y con tonfa. El tercer capítulo ilustra sus posiciones fundamentales de ataque mientras que el cuarto presenta algunas de las técnicas de defensa contra el bo. El quinto capítulo nombra e ilustra la ejecución de las técnicas de la kata yaraguwa tonfa jitsu.

532. Tamano, Toshio (1992). Curso de nunchaku : arma del karate tradicional kobudo de Okinawa. Barcelona: De Vecchi. 1aㅡ. 149 p. : il. ; 17x24 cm. ISBN: 84-315-1091-9. Depósito legal: B. 381371992. (2a ed., 1999, ISBN: 84-315-2207-0). Palabras clave: katas, kumite, fundamentos técnicos. Resumen: Manual técnico de manejo del nunchaku. La obra esta dividida en 4 partes. La primera de ellas aborda la historia y desarrollo del manejo del nunchaku y del kobudo así como la descripción de la estructura del nunchaku. La segunda parte explica las técnicas fundamentales del manejo, como son las posiciones fundamentales, el agarre, las técnicas de rotación, los ataques y las paradas, ofreciendo descripciones claras e ilustradas. La tercera parte describe e ilustra la ejecución de la secuencia de movimientos de la primera kata básica (Nunchaku Shorei No Kata Dai Ichi) y la kata Toyama No Nunchaku. Finaliza con la explicación de los diferentes trabajos existentes de combate, que se realizan siempre contra un ataque de bo. Explica el manejo fundamental del bo y luego el trabajo y grupos de técnicas del Nunchaku Kiso Kumite Dai Ichi, del Nunchaku Kiso Kumite Dai Ni, y del Nunchaku Bunkai Kumite.

533. Thomas, Raymond (1974). El manejo del nunchaku : posiciones, paradas, ataques, kata. Barcelona: Alas. $1^{a}$ ed. 93 p. : il. ; 12x16,5 cm. ISBN: 84-203-0306-2. Depósito legal: B. 32297-1974. (2ª ed., 1984; $3^{a}$ ed., 1986). Palabras clave: historia, fundamentos teóricos, armas, fundamentos técnicos, principios técnicos, ejercicios, entrenamiento, calentamiento, katas. Resumen: Manual teórico y técnico de nunchaku. El libro esta compuesto por 13 capítulos precedidos por un prólogo que señala los objetivos del libro. El primer capítulo relata la historia del manejo de los nunchaku. El segundo capítulo describe la estructura del nunchaku incluyendo su representación gráfica. El tercer capítulo señala algunas de las utilidades del nunchaku. El cuarto capítulo detalla las características del entrenamiento con el nunchaku mientras que el quinto detalla sus contenidos técnicos. El sexto capítulo describe la ejecución de diversos ejercicios de calentamiento para continuar explicando la ejecución de las posturas básicas acompañadas de su representación gráfica. El séptimo capítulo expone los principios técnicos de los desplazamientos. Los siguientes tres capítulos explican las características de las guardias, paradas y contraataques con el nunchaku además de incluir la descripción e ilustración de sus técnicas básicas. El décimo primer capítulo explica en qué consiste un kata para luego ofrecer varios consejos prácticos y finalizar con la explicación de la ejecución de la nunchaku-no-kata y su representación gráfica.

\subsubsection{Kyudo}

534. Acker, William R. B. (1999). Kyudo : el arte japonés del tiro con arco. Barcelona: Obelisco. 1aㅡ ed. 77 p. : il. ; 13x21 cm. ISBN: 84-7720-689-9. Depósito legal: B. 12070-1999. Palabras clave: fundamentos técnicos, principios técnicos. Resumen: Manual teórico y técnico de kyudo. El libro esta formado por 14 capítulos, precedidos por un prefacio que describe la llegada del autor a Japón, el propósito del libro. El primer capítulo señala la importancia de una postura correcta en el tiro con arco y expone sus principios técnicos. El segundo capítulo describe el estado de preparación yugamae así como el material necesario para la práctica. El tercer capítulo explica como debe asirse el arco mientras que el cuarto señala la colocación de los hombros. El quinto capítulo detalla el significado del término monomi (mirar el blanco) así como sus principios técnicos. El sexto capítulo define el término dozukuri además de presentar sus principios técnicos. El séptimo capítulo describe los dos tipos de respiración mientras que el octavo estudia la ejecución de la retirada y sus principios técnicos. El noveno capítulo enumera las cinco cruces mientras que el décimo capítulo resumen los puntos clave al sostener en la retirada completa. El capítulo decimoprimero explica como se debe apuntar y los diferentes tipos de apuntar. El decimosegundo capítulo describe las sensaciones del practicante ante el disparo. Los dos últimos capítulos describen la estructura y características del arco y la flecha respectivamente. Adjunta un glosario de términos japoneses.

535. Augusto, Jordan y Galende, Juliana (2007). Kyudo, el silencio y la flecha : técnica, arte y zen en el tiro con arco japonés. Madrid: Budo International. 1aㅡ ed. 95 p. : il. ; 17x24 cm. ISBN: 978-84-96492-81-3. Depósito legal: M. 13066-2007. Palabras clave: fundamentos teóricos, fundamentos técnicos, filosofía, vestimenta, cortesía, etiqueta. Resumen: Tratado teórico de kyudo. Después de comentar en la introducción los objetivos del libro pasa a describir los orígenes e historia del arco y la flecha a través de las distintas civilizaciones. El tercer capítulo explica cuáles son los problemas que afectan a nuestro 
cuerpo y ofrece algunos ejercicios para contrarrestar dichos problemas y preparar al cuerpo para la práctica del kyudo. Continúa con la explicación del papel del cuerpo en la arquería, el equilibrio, la descripción cinemática y algunos problemas derivados de la práctica, y la relación entre cuerpo, energía (ki) y el disparo. El sexto capítulo profundiza en las formas de kyu-jutsu y en los accesorios que rodean a ésta práctica, describiendo el arco, las flechas, el guante, el uniforme, la diana, el dojo y el makiwara. El siguiente capítulo describe la secuencia ceremonial para realizar un disparo, explicando las características de cada fase. Los dos siguientes capítulos profundizan en los aspectos filosóficos que rodean al tiro con arco japonés, como son el zen y el mushin o teoría del vacío, explicando la mentalidad que se debe adoptar en la práctica. El último capítulo explica los rudimentos básicos de la meditación zen para preparar la mente y el pensamiento en la práctica.

536. Herrigel, Eugen (2005). Zen en el arte del tiro con arco. Madrid: Gaia Ediciones. 1 a ed. 176 p. : il. ; $13 \times 19$ cm. ISBN: 84-8445-127-5. Depósito legal: no. (2ª ed., 2008, ISBN: 978-84-8445-127-3). Palabras clave: fundamentos técnicos, pedagogía, filosofía, kyudo, zen. Resumen: Tratado filosófico de kyudo. La obra consta de 8 capítulos intercalados con numerosos aforismos a modo de resumen. El primer capítulo narra los fundamentos filosóficos del arte del tiro con arco. El segundo capítulo comenta las razones por las que el autor quiso estudiar el arte del tiro con arco y el zen, así como su llegada a Japón y el comienzo de sus clases. El tercer capítulo detalla los contenidos de la primera clase de tiro con arco, como la respiración y las fases del disparo. El cuarto capítulo explica los aspectos actitudinales ante la práctica para luego comentar los principios filosóficos del arte y las características necesarias del alumno. El sexto capítulo profundiza en la relación maestro y discípulo, los aspectos pedagógicos del arte, y las principales dificultades en la progresión hacia la maestría. El siguiente capítulo comenta la preparación para rendir un examen de maestría y el significado que tiene dicho examen en el proceso de enseñanza-aprendizaje y de la relación entre maestro y discípulo. El octavo capítulo incluye la interpretación del autor del tratado "La mente sin grilletes" del maestro Takuan sobre el arte de la espada y un pasaje del Hagakure sobre la maestría. Adjunta notas y varios apéndices sobre la ejecución técnica en los 8 estadios del kyudo, el credo del guerrero, la explicación de las citas e ilustraciones de esta edición y un resumen de la biografía del autor.

537. Nalda Albiac, José Santos (1988). Kyudo. Barcelona: Alas. 1a ed. 128 p. : il. ; 15x21,5 cm. ISBN: 84-2030220-1. Depósito legal: B. 11884-1988. Palabras clave: fundamentos técnicos. Resumen: Manual introductorio de kyudo. Los primeros capítulos explican el origen y características del tiro con arco, de su práctica montado a caballo y de los principios zen que impregnan al kyudo. El cuarto capítulo describe las características del material que rodea a este arte marcial y continua con la explicación de la técnica correcta de agarrar el arco y las flechas y ejecutar un disparo. Finaliza con la explicación de las normas de etiqueta y ceremonial del kyudo, así como los rituales de tiro de la escuela Osagawara, el estilo Heki-ryu y el estilo moderno.

\subsubsection{Kyusho y Kuatsu}

538. Bosch Espinal, José y Benaiges Gomá, Jaime (1980). Puntos mortales secretos: su descripción y ataque. Barcelona: Polux Internacional. 1a ed. 456 p. : il. ; 16x22,5 cm. ISBN: 84-85867-00-9. Depósito legal: B. 35827-1980. Palabras clave: historia, fundamentos teóricos, principios técnicos, principios éticos, artes marciales, kyusho, anatomía, equipamiento, entrenamiento, fisiología, legislación, lesiones, preparación física. Resumen: Manual teórico y técnico de kyusho. El libro esta formado por 3 partes precedidas por la presentación del libro, un prólogo que comenta la importancia del mismo, un resumen de los contenidos del libro y una introducción que comenta el estudio de los atemis por las diferentes artes marciales junto con su representación gráfica de los puntos vitales. La primera parte consta de 7 capítulos. El primer capítulo narra la historia y expansión de las artes marciales. El segundo capítulo comenta la historia y características técnicas de las principales escuelas que estudian los atemis como son el jiu-jitsu, kárate, kenpo kárate, kung-fu, muay thai, pentjak silat, shorinji kempo, tae-kwon-do y viet-vo-dao. El tercer capítulo define el concepto atemi y analiza sus factores de eficacia como su superficie de impacto, velocidad, dureza del arma, concentración de la fuerza, precisión, fuerza muscular, fuerza de reacción y espíritu de la acción. El cuarto capítulo describe la estructura del makiwara, los sacos, los cajones con material granular y otros aparatos además de explicar su entrenamiento de endurecimiento acompañado de la ilustración de algunas de sus técnicas. El quinto capítulo define los tipos de técnicas defensivas ante una agresión y detalla el objetivo, ejecución y principios técnicos de los pellizcos y presiones así como un breve comentario de otras técnicas. El sexto capítulo define las características generales de las armas naturales del cuerpo humano y analiza su forma de utilización acompañada de su representación gráfica. El séptimo capítulo explica el significado del kiai, describe la anatomía y fisiología del oído, relata los orígenes históricos del kiai, y describe su correcta ejecución, efectos y aplicaciones. La segunda parte consta de 3 capítulos. El primer capítulo describe la anatomía y fisiología del sistema locomotor, circulatorio, respiratorio y nervioso 
incluyendo numerosos gráficos explicativos. El segundo capítulo expone los efectos de la manipulación de los puntos vitales, describe la localización dichos puntos vitales, sus efectos y las armas utilizadas para su manipulación acompañadas de numerosas fotografías y gráficos explicativos. El tercer capítulo describe y clasifica los efectos de los golpes, explica los efectos causados por los ataques en los puntos vitales para luego definir las características, tipos y causas que pueden provocar los síncopes, shock, desmayo, lesiones traumáticas de la médula espinal, conmoción y contusión cerebral, traumatismos craneoencefálicos, contusión y dolor. La tercera parte consta de 3 capítulos. El primer capítulo comenta la legislación referente a la defensa personal. El segundo capítulo incluye un diccionario abreviado. El tercer capítulo ofrece algunos consejos éticos y técnico-prácticos para la defensa personal. Adjunta una conclusión final.

539. Clark, Rick (2002). Puntos de presión en combate : una guía al núcleo secreto de las artes marciales asiáticas. Madrid: Tutor. 1aㅡ ed. 208 p. : il. ; 17x24 cm. ISBN: 84-7902-372-4. Depósito legal: M. 509922002. Palabras clave: katas, fundamentos teóricos, fundamentos técnicos, kyusho, aplicación marcial, medicina, medicina tradicional china. Resumen: Manual teórico y técnico sobre los puntos vitales. El libro esta formado por cinco capítulos y un prefacio que comenta la importancia de la manipulación de los puntos vitales en las artes marciales o los cuerpos de seguridad. El primer capítulo analiza los principios técnicos y tácticos presentes en las artes marciales que practica el autor, para en el segundo capítulo desarrollar varias explicaciones de la medicina occidental y la medicina tradicional china sobre la manipulación de los puntos vitales del cuerpo y sus efectos. El tercer capítulo analiza las posibles direcciones de un ataque, los tipos de ataque que pueden encontrarse en el bunkai de una kata ante un solo adversario desarmado y las técnicas de defensa personal que pueden encontrarse en las katas. Continúa con la descripción de la ejecución técnica y la localización del punto vital manipulado de las técnicas de defensa personal que aparecen en las katas kusanku, pinan y naihanchi además de las técnicas de proyección, proyección para agarres y técnicas especiales que aparecen en distintas katas. El quinto capítulo presenta la localización de los puntos vitales del cuerpo. Adjunta un apéndice con distintas listas de puntos vitales y una bibliografía.

540. Lasserre, Robert (1964). Kiai y kuatsu : técnicas secretas de reanimación. Barcelona: Hispano Europea. $1^{a}$ ed. 176 p. : il. ; 14x20,5 cm. ISBN: No ISBN. Depósito legal: B. 22456-1964. (2ª ed., 1967; 3a ed., 1967). Palabras clave: historia, fundamentos teóricos, fundamentos técnicos, rehabilitación, ejercicios, lesiones, kuatsu. Resumen: Manual teórico y técnico de kiai y kuatsu. La obra esta compuesta de 2 partes, precedidas por varios capítulos introductorios que presentan el origen del kiai y el kuatsu, algunas nociones sobre el sistema nervioso y su relación con el circulatorio, la descripción clínica del síncope, sus causas y mecanismos, y algunos consejos para distinguir la muerte aparente de la muerte real. La primera parte del libro analiza las cualidades del practicante del kuatsu, describe la ejecución de las técnicas tradicionales para el tratamiento de las epistaxis (hemorragia nasal), las palpitaciones, la sofocación y el hipo, analiza las leyes que fundamentan las técnicas de kuatsu, explica su modo de actuar sobre el cuerpo, la metodología en su aplicación junto con algunos consejos prácticos, describe e ilustra la localización de los puntos de kuatsu, explica como examinar a un sujeto sin peligro; y describe las indicaciones, la posición del sujeto y el practicante, la propia técnica y la respiración de varios métodos de kuatsu. Luego incluye la descripción de diferentes kuatsu para los traumatismos en los testículos, en el corazón y en el cerebro, para realizar la respiración artificial, el tratamiento de los ahogados así como las técnicas de los So-kuatsu, Shinzo-kuatsu, Kikai-So-Kuatsu y Aiire-So-kuatsu. La segunda parte del libro estudia el origen del kiai, su significado, sus consecuencias, la explicación fisiológica del síncope debido al kiai, su relación con el kuatsu, describe dos técnicas de aplicación del kiai como técnica de reanimación, analiza las etapas del entrenamiento del kiai, los principios para el entrenamiento del kiai y las propiedades físicas y mecánicas del kiai.

541. Nalda Albiac, José Santos y Justes López, Arturo (1999). La práctica del kuatsu : el arte de resucitar. Barcelona: Alas. $1^{\text {a }}$ ed. 128 p. : il. ; 17x24 cm. ISBN: 84-203-0394-1. Depósito legal: B. 575-1999. Palabras clave: fundamentos teóricos, fundamentos técnicos, rehabilitación, anatomía, aplicación terapéutica, fisiología, lesiones. Resumen: Manual técnico sobre técnicas de reanimación. Los cuatro primeros capítulos del libro hacen una pequeña introducción sobre la anatomía humana, las principales lesiones del karate, judo y aikido, el significado del kuatsu y algunos conceptos de la reflexoterapia. El siguiente capítulo comenta el procedimiento y principios para realizar correctamente las técnicas de kuatsu y dar paso a las técnicas específicas para cada problema. Los siguientes capítulos presentan las técnicas específicas para las lipotimias y taquicardias, explicando las causas que las producen, la descripción de las técnicas a emplear y su ilustración. El octavo capítulo describe las manipulaciones sobre la zona dorsal para activar los procesos cardiorrespiratorios y el noveno los criterios de elección ante diversas situaciones. Continúa con la explicación de algunos de los problemas más habituales en el entrenamiento y pasa a explicar las técnicas específicas para los traumatismos craneales, traumatismos en los testículos, y el kuatsu integral para aquellas situaciones más peligrosas donde las técnicas anteriores no han surtido ningún efecto. En los siguientes capítulos explica los tipos y tratamientos para las hemorragias, las heridas en la piel, las lesiones musculares, las lesiones 
articulares, las luxaciones y las fracturas. Finaliza con un breve comentario sobre algunos remedios para las lesiones más leves, el tratamiento para accidentes diversos y los efectos del alcohol y el tabaco sobre el practicante.

542. Nalda Albiac, José Santos y Justes López, Arturo (2008). La práctica del kuatsu : el arte de resucitar. Barcelona: Alas. 1a ed. 253 p. : il. ; 17x23,5 cm. ISBN: 978-84-203-0394-9. Depósito legal: B. 559482008. Palabras clave: fundamentos teóricos, fundamentos técnicos, rehabilitación, anatomía, aplicación terapéutica, fisiología, lesiones. Resumen: Manual teórico y técnico de kuatsu. El libro esta formado por 41 capítulos. El primer capítulo explica la historia y los orígenes de las técnicas de reanimación, para en el segundo comentar su utilización dentro de las artes marciales, la importancia concedida dentro del judo y la llegada de estas técnicas a Europa. Los siguientes 7 capítulos presentan los contenidos básicos y fisiología de la anatomía humana y los sistemas circulatorio, respiratorio, carotídeo, nervioso y endocrino, incluyendo numerosas fotografías explicativas. El décimo capítulo define la vertebroterapia y comenta los efectos de los distintos masajes dependiendo de su zona de aplicación vertebral. Los dos siguientes capítulos, definen el síncope y las estrangulaciones, exponiendo sus clases, características, síntomas y fases. El decimocuarto capítulo define el kuatsu, su objetivo, sus clases y ámbitos de aplicación, para en el siguiente comentar brevemente los diferentes tipos que existen y los criterios para su elección. Los siguientes 13 capítulos expone los criterios técnicos generales de actuación de las técnicas de reanimación y describen e ilustran dichas técnicas ante hemorragias nasales, hipo, pinchazos en el costado, asma, sofoco, espasmo diafragmático, palpitaciones, bradicardia, shock traumático primario, lipotimia, estrangulaciones, traumatismos en el cuello o la cabeza, en el tórax o el abdomen, y en los genitales. El capítulo vigésimo noveno define las clases de asfixia y los atragantamientos, y describe e ilustra la maniobra de Heimlich. Los dos siguientes capítulos explican la ejecución y precauciones del masaje cardíaco y la reanimación RCP, para luego detallar la actuación en la reanimación de ahogados. El trigésimo tercer capítulo enumera las lesiones más comunes en el judo, kárate y aikido así como las medidas preventivas para evitarlas y las pautas generales de actuación. Los siguientes 7 capítulos describen las características y formas de actuación ante los diferentes tipos de hemorragias, heridas en la piel, lesiones musculares, lesiones articulares, luxaciones en las artes marciales, fracturas óseas, incluyendo ilustraciones explicativas. El último capítulo resume la utilización de algunos remedios naturales en el tratamiento de las lesiones.

543. Pantazi, Evan (2005). Kyusho-jitsu : los puntos vitales del cuerpo humano en las artes marciales. Madrid: Budo International. 1a ed. 175 p. : il. ; 17x24 cm. ISBN: 84-96492-00-1. Depósito legal: M. 22798-2005. Palabras clave: fundamentos técnicos, defensa personal, entrenamiento. Resumen: Manual teórico y técnico de kyusho-jitsu. La obra esta formada por 24 capítulos. Los dos primeros capítulos presentan el arte marcial y su historia, describiendo su práctica y entrenamiento y sus fundamentos. Los siguientes 4 capítulos profundizan en los fundamentos del kyusho-jitsu, explicando los niveles en la manipulación de los puntos de presión, la interpretación de la Medicina Tradicional China y la Medicina Moderna Occidental sobre dichos puntos, y la concepción oriental sobre la energía o chi. Los tres siguientes capítulos comentan la aplicación del kyusho-jitsu sobre los brazos, describe su progresión de entrenamiento y comenta el potencial de las principales patadas. Continúa describiendo la teoría del yin-yang y la aplicación de sus principios a la práctica de entrenamiento. Los tres siguientes capítulos estudian los puntos de la cabeza, su manipulación, y los distintos métodos para incidir sobre ellos. Los dos siguientes capítulos detallan el trabajo sobre el tronco y describe el trabajo de reanimación de la respiración, la conciencia y la circulación. El decimoquinto capítulo comenta los aspectos legales asociados al empleo de la fuerza y el kyusho-jitsu. Los siguientes capítulos estudian las estrangulaciones, describe la progresión de aprendizaje, expone el proceso de aprendizaje del kyusho en los niños, y comenta los puntos vitales estudiados en el Bubishi. Finaliza con 4 capítulos dedicados a la aplicación del gancho en situaciones de defensa personal, los ataques a los puntos de las piernas, los puntos vitales de la cara interna del brazo y 7 series instruccionales que estudian la manipulación de varios puntos vitales, de diferentes formas en función de la disfunción corporal deseada o dependiendo del grado de control necesario.

544. Pantazi, Evan (2006). Kyusho-jitsu : claves esenciales de los puntos vitales. Madrid: Budo International. $1^{a}$ ed. 111 p. : il. ; 16x24 cm. ISBN: 84-96492-27-3. Depósito legal: M. 25151-2006. Palabras clave: fundamentos teóricos, fundamentos técnicos, rehabilitación, kyusho, anatomía, aplicación marcial, bioenergética, fisiología, respiración. Resumen: Manual teórico y técnico de kyusho. El libro esta formado por 9 capítulos. El primer capítulo expone los estudios desarrollados entorno al kyusho en la actualidad, los contenidos de dichas investigaciones y sus conclusiones hasta el momento. El segundo capítulo presenta el sistema numérico de la acupuntura, el término chino, la localización anatómica, el método de ataque y los efectos de la manipulación de los principales puntos vitales de la espalda y el tronco. El tercer capítulo explica el funcionamiento del sistema respiratorio y su importancia para el mantenimiento de la vida junto con la localización, el método de ataque y efectos de sus puntos kyusho, y comenta su manipulación para sanar deficiencias respiratorios. El cuarto capítulo describe la localización, manipulación y efectos de ciertos puntos vitales para derribar al adversario así como sus 
fundamentos teóricos. El quinto capítulo expone los mecanismos de manipulación de tendones y músculos. El sexto capítulo comenta los conceptos básicos de la ciencia bio-energética, los campos electromagnéticos del ser humano, describe varios ejercicios para manipular la energía del cuerpo y explica sus beneficios para el kyusho. El séptimo capítulo ofrece los consejos para aprender la manipulación de los puntos vitales como método de curación y describe la ejecución de dos ejercicios para curar el dolor de cabeza. El octavo capítulo comenta la aplicación y características de la manipulación de los puntos vitales a la lucha cuerpo a cuerpo (grappling), ilustrando algunos ejemplos prácticos. El último capítulo relata el proceso de evolución técnica y teórica que ha sufrido este arte durante los últimos años, incluyendo la secuencia fotográfica de varias técnicas.

545. Pantazi, Evan (2008). Kyusho jitsu : puntos vitales para el placer sexual. Madrid: Budo International. 1 $\mathbf{a}^{\mathrm{a}}$ ed. 79 p. : il. ; 17x24 cm. ISBN: 978-84-936306-7-6. Depósito legal: M. 13336-2008. Palabras clave: kyusho, sexo. Resumen: Manual teórico y técnico de kyusho. El libro esta compuesto por 7 capítulos precedidos por un prólogo que señala la pertinencia de los contenidos y una introducción que comenta los fundamentos del kyusho. El primer capítulo describe el entrenamiento de los músculos pubicoccígeos así como sus efectos en hombres y mujeres. El segundo capítulo comenta las características de los puntos de presión y el significado de determinadas posturas. El tercer capítulo describe varias técnicas de excitación. El cuarto capítulo explica la manipulación y efectos de determinados puntos para potenciar el coito. El quinto capítulo explica la ejecución de varios ejercicios para manipular la energía propia y de nuestra pareja. El sexto capítulo comenta la localización, manipulación y efectos de determinados puntos para provocar la transferencia de energía. El último capítulo señala los beneficios y aplicación de la manipulación de los puntos vitales.

546. Pantazi, Evan (2009). Kyusho jitsu : programa de "puntos vitales" para los Cuerpos de Seguridad y Fuerzas de Orden Público. Madrid: Budo International. 1aㅡ ed. 143 p. : il. ; 17x24 cm. ISBN: 978-8492484-28-7. Depósito legal: M. 9583-2009. Palabras clave: fundamentos teóricos, kyusho, aplicación marcial. Resumen: Manual teórico y técnico de kyusho. El libro esta compuesto por 12 capítulos precedidos por dos prólogos que comentan la efectividad del kyusho y una introducción que expone las características del programa de kyusho para las fuerzas de seguridad. Los siguientes doce capítulos localizan los principales 12 puntos vitales del cuerpo humano, explican su manipulación, la forma de colocar las esposas, realizar un derribo y la liberación de un agarre además de incluir la secuencia fotográfica de algunas de sus aplicaciones prácticas.

547. Planellas Vidal, Pau-Ramon (1995). Jintai kyusho : los puntos vulnerables del cuerpo humano. Barcelona: Alas. $1^{\mathrm{a}}$ ed. 190 p. : il. ; 17x24 cm. ISBN: 84-203-0369-0. Depósito legal: B. 24722-1995. Palabras clave: fundamentos técnicos, kyusho, relatos, aplicación terapéutica, armas. Resumen: Manual teórico y técnico sobre los kyusho. El libro esta formado por 4 capítulos. El primer capítulo relata varias historias sobre la manipulación de los puntos vitales desde tiempos antiguos para luego comentar su utilización por las diferentes artes marciales. El segundo capítulo presenta las diferentes armas, como el jutte, el tessen, el tanbo y el yubi-bo, que pueden ser utilizadas para manipular los puntos vitales del cuerpo, detallando su estructura y las escuelas que las utilizan. El tercer capítulo profundiza en el estudio de los ataques a los puntos vitales mediante golpes, presiones, aplastamientos y pinzamientos, tanto con armas como sin ellas, describiendo e ilustrando la ejecución de cada uno de ellos. El último capítulo enumera y clasifica los puntos vitales del cuerpo dependiendo de su localización (yodan, chudan, gedan) para luego describir su localización, los diferentes nombres que reciben, las consecuencias de su manipulación y los ataques más comunes y efectivos a cada uno de ellos.

548. Strohm, Franz Eberhard Eckard (2002). Kuatsu : técnica oriental de reanimación. Controles y primeros auxilios en casos de dolor, lesión o muerte. Barberá del Vallés: Abraxas. 1aㅡ ed. 188 p. : il. ; 13x21 cm. ISBN: 84-95536-56-0. Depósito legal: B. 38506-2002. Palabras clave: fundamentos teóricos, fundamentos técnicos, kyusho, primeros auxilios, enfermedades. Resumen: Manual teórico y técnico de kuatsu. El libro esta formado por 11 capítulos. El primer capítulo ofrece una idea general sobre qué es el kuatsu para luego exponer las bases anatómicas del sistema circulatorio, esquelético y nervioso. El tercer capítulo explica brevemente los métodos de kuatsu y los compara con la medicina tradicional occidental. El cuarto capítulo describe e ilustra las distintas técnicas de kuatsu para recuperar la actividad respiratoria, la actividad cardiaca o la consciencia tras golpes, estrangulaciones, ahogamientos y atragantamientos. El siguiente capítulo describe algunas de las técnicas especiales del kuatsu para detener una hemorragia, eliminar el dolor de cabeza y la sinusitis, colocar la laringe, controlar las nauseas y vómitos y atenuar los efectos de las torceduras. El sexto capítulo explica los principios técnicos para masajear los puntos ki del cuerpo para luego describir su localización y efectos. Los últimos tres capítulos presentan el mudra del corazón, las tablas resumen con la localización, aplicación y objetivos de los puntos ki y un cuadro del uso de los puntos ki.

\subsubsection{Ninjutsu}


549. Camín Jarnés, Gabriel (1990). Técnicas de kyus. Zaragoza: Escuela Aragonesa de Ninjutsu. 1a ed. 72 p. : il. ; 21x30 cm. ISBN: 84-404-6875-X. Depósito legal: Z. 1419-1990.

550. Castillo Escalona, Francisco (2007). Nin jutsu : guía práctica para monitores, instructores y maestros. Coslada: Incipit Editores. $1^{a}$ ed. 109 p. : il. ; 17x24 cm. ISBN: 978-84-8198-749-2. Depósito legal: M. 52038-2007. Palabras clave: fundamentos técnicos, principios técnicos. Resumen: Manual teórico y técnico de ninjutsu. La obra esta formada por 8 capítulos. El primer capítulo presenta el sistema de graduación en ninjutsu. El segundo capítulo expone los principios fundamentales del ninjutsu junto con la descripción de una clase y un organigrama del entrenamiento. El tercer capítulo nombra las caídas, rodamientos, movimientos del cuerpo, desplazamientos y andamientos del ninjutsu incluyendo algunas fotografías explicativas. El cuarto capítulo presenta los contenidos técnicos del dakentai jutsu, como son las técnicas de puños, posturas y las técnicas de kihon-happo acompañadas de su secuencia fotográfica. El quinto capítulo detalla los contenidos técnicos del jutai jutsu incluyendo su representación gráfica. El sexto capítulo detalla las técnicas básicas de hambo jutsu-kukushin ryu mientras que el séptimo expone las técnicas del shuriken jutsu acompañadas de numerosas ilustraciones. El último capítulo representa las guardias y cortes básicos del iai-jutsu.

551. Challant, Ken y Bonomelli, Roberto (1991). Ninja : las técnicas secretas, la práctica. Barcelona: De Vecchi. $1^{\underline{a}}$ ed. 199 p. : il. ; 17x23,5 cm. ISBN: 84-315-0998-8. Depósito legal: B. 41149-1991. (2ª ed., 1994; 3a ed., 1998, ISBN: 84-315-1898-7). Palabras clave: historia, fundamentos técnicos, estrategia, táctica, escuelas, armas. Resumen: Manual teórico y técnico de ninjutsu. El libro esta formado por 12 capítulos, precedidos de una introducción que comenta algunas de las características de los ninjas. El primer capítulo narra el origen e historia del ninjutsu desde China hasta la escuela Yagyu. El segundo capítulo aclara algunos conceptos sobre las artes marciales para después presentar la práctica del ninjutsu en la actualidad, sus paradigmas y escuelas, la aparición del ninjutsu en el cine y su explosión social. Los dos siguientes capítulos exponen las características de los trajes y vestimentas ninja así como los principios tácticos y estratégicos que rigen su comportamiento. El sexto capítulo describe e ilustra los fundamentos técnicos del ninjutsu como son los desplazamientos, las caídas y las posiciones de guardia, para luego comentar la aplicación de las técnicas especiales en el agua, en la escalada y las acciones en tierra. El noveno capítulo explica la estructura, utilización, técnica empleada y principios del entrenamiento en el manejo de la espada, el bokken, los bastones, las armas con cadena, el kongo, el tonki, los shaken, los shuriken y las cuerdas, incluyendo numerosas fotografías de sus fundamentos técnicos. Los tres últimos capítulos describen las peculiaridades del combate sin armas del ninjutsu junto con algunos ejemplos ilustrados, y comentan brevemente el papel de la mujer dentro del ninjutsu y los conocimientos de medicina del ninja.

552. Collado Valencia, José Manuel (1993). Nin jutsu : las escuelas tradicionales. Valladolid: José Manuel Collado. $1^{a}$ ed. 216 p. : il. ; 20x29 cm. ISBN: No ISBN. Depósito legal: VA. 710-1997. Palabras clave: historia, fundamentos teóricos, fundamentos técnicos. Resumen: Manual teórico y técnico de ninjutsu. El libro esta formado por 5 capítulos precedidos por un prólogo que comenta las etapas de aprendizaje del ninjutsu así como los contenidos de la obra. El primer capítulo expone los principios de aprendizaje y técnicos del ninjutsu. El segundo capítulo analiza la tradición del ninjutsu explicando las características de los contenidos del entrenamiento de sus guerreros, las escuelas del ninjutsu así como los fundamentos teóricos y filosóficos del ninjutsu. El tercer capítulo explica los fundamentos técnicos de las diferentes escuelas de ninjutsu. El cuarto capítulo detalla los principios tácticos y estratégicos de las escuelas Togakure, Kumogakure y Gyokushin. El último capítulo describe los fundamentos teóricos y técnicos de los kuji kiri junto con su ilustración y aplicaciones. Adjunta un índice con la relación de escuelas y técnicas.

553. Collado Valencia, José Manuel (1995). Nin jutsu : escuelas tradicionales. Madrid: Esteban Sanz Martínez. $1^{\underline{a}}$ ed. 369 p. : il. ; 17x24 cm. ISBN: 84-85977-572. Depósito legal: M. 10731-1995. Palabras clave: historia, fundamentos teóricos, fundamentos técnicos. Resumen: Manual teórico y técnico de ninjutsu. El libro esta dividido en 2 partes precedidas por una introducción que comenta la historia del ninjutsu y los contenidos de la obra. La primera parte consta de 11 capítulos. Los primeros 10 capítulos describen la progresión de aprendizaje hasta cinturón negro, con recomendaciones sobre el programa y proceso de entrenamiento, la definición terminológica de los fundamentos técnicos y las armas utilizadas. El último capítulo explica los elementos que integran el entrenamiento mental. La segunda parte consta de 4 capítulos. El primer capítulo analiza la tradición del ninjutsu explicando las características de los contenidos del entrenamiento de sus guerreros, las escuelas del ninjutsu así como los fundamentos teóricos y filosóficos del ninjutsu. El segundo capítulo describe los fundamentos técnicos de las diferentes escuelas de ninjutsu. El tercer capítulo detalla los principios tácticos y estratégicos de las escuelas Togakure, Kumogakure y Gyokushin. El último capítulo expone los fundamentos teóricos y técnicos de los kuji kiri junto con su ilustración y aplicaciones. Adjunta un índice con la relación de escuelas y técnicas.

554. Esteve Calero, Alex (2002). Bujinkan budo taijutsu : caminando por la esencia del arte marcial. Barcelona: Alex Esteve Calero. $1^{\mathrm{a}}$ ed. 285 p. : il. ; 17x24,5 cm. ISBN: 84-85278-30-5. Depósito legal: B. 
37812-2002. Palabras clave: historia, fundamentos teóricos, principios técnicos, biografía, vestimenta, cortesía, escuelas, ninjutsu, fundamentos filosóficos, entrevistas, etiqueta, grados, instituciones, maestros. Resumen: Manual teórico y técnico de ninjutsu. El libro esta formado por 4 capítulos precedidos por una presentación que explica el significado del libro, los agradecimientos, un comentario sobre el significado del término buyû y una introducción que señala los objetivos del libro. El primer capítulo presenta la asociación Bujinkan Dojo, los preceptos para la admisión en dicha asociación, el código del dojo, su sistema de grados, describe la ejecución y significado de la prueba shinden gokui, expone las normas de vestimenta y cortesía e incluye las biografías de Masaaki Hatsumi y Toshitsugu Takamatsu. El segundo capítulo comenta la organización de las tradiciones marciales, señala la importancia de la escritura en la transmisión de las artes marciales y la formación del budoka, destaca el principio de autoprotección de las artes marciales, comenta la historia y características de las escuelas Togakure Ryu Ninpo, Gyokko Ryu Kosshijutsu, Koto Ryu Koppojutsu, Takagi Yoshin Ryu Jutaijutsu, Gyokushin Ryu Ninpo, Kumogakure Ryu Ninpo, Shindenfudo Ryu Dakentaijutsu, Gikan Ryu Koppojutsu, Kukishinden Ryu Happo Bikenjutsu, describe la estructura de la armadura japonesa junto con numerosas ilustraciones y relata brevemente la historia de Japón. El tercer capítulo incluye la entrevista realizada a Hatsumi Sensei por el autor. El cuarto capítulo presenta las reflexiones de 18 shihan sobre el término nagare, la actitud de un artista marcial, la actitud hacia el entrenamiento del pasado, las técnicas guerreras divinas y las espadas japonesas, la vía del guerrero como estilo de vida, el kata, la relación entre el hombre y las armas, la percepción, el kuzushi, el análisis de la gogyo no kata, el ukemi, el kuden, la mujer en las artes marciales, la lucha, los fundamentos teóricos y principios del Rokushakubo, el kiai, los principios técnicos del tanto jutsu y la interpretación de las enseñanzas del Soke Hatsumi. También incluye un comentario sobre el sentido de las artes marciales y de la vida. Adjunta un glosario específico y bibliografía.

555. Fleitas González, Pedro (1990). Hambo jutsu : sistema de combate ninja con bastón medio. Barcelona: Alas. 1a ed. 108 p. : il. ; 15x21,5 cm. ISBN: 84-203-0253-8. Depósito legal: B. 39128-1990. Palabras clave: fundamentos teóricos, armas, fundamentos técnicos, ejercicios, combate, aforismos, aplicación marcial. Resumen: Manual teórico y técnico de ninjutsu. La obra esta compuesta por 17 capítulos precedidos por el currículo del autor y una introducción que comenta los contenidos técnicos de la obra. El primer capítulo enumera los preceptos ninja mientras que el segundo incluye la entrevista realizada al autor sobre los conceptos básicos del ninjutsu. El tercer capítulo explica las características de los diferentes bastones utilizados por el ninja, cómo cogerlo, golpear y bloquear incluyendo sus fotografías explicativas. El cuarto capítulo analiza los factores de distancia timing en el manejo del hambo. Los dos siguientes capítulos describen e ilustran las posiciones básicas y movimientos básicos en el manejo del hambo. El séptimo capítulo ilustra algunos de los ejercicios de adiestramiento para el manejo del hambo. Los siguientes cinco capítulos explican brevemente la ejecución de las técnicas básicas, técnicas de estrangulamiento, de proyección, técnicas contra varios adversarios y técnicas contra el ataque con sable acompañadas de su secuencia fotográfica. El siguiente capítulo explica las características de la shinobigatana además de incluir la descripción e ilustración de algunas de sus técnicas. El último capítulo incluye las fotografías de Hatsumi realizando varias técnicas con hambo. Adjunta bibliografía.

556. Fleitas González, Pedro (1990). Ninpo taijutsu : manual de técnicas básicas de lucha sin armas. Barcelona: Alas. 1aㅡ ed. 143 p. : il. ; 15x21,5 cm. ISBN: 84-203-0246-5. Depósito legal: B. 11597-1990. Palabras clave: fundamentos técnicos, ninjutsu, escuelas, Japón, programa técnico. Resumen: Manual teórico y técnico de ninjutsu. El primer capítulo explica la situación geográfica de Japón, su estructura social y sistema educativo, sus épocas y tradiciones. El segundo capítulo narra la historia y formación del ninjutsu como arte marcial para después detallar su práctica. El cuarto capítulo presenta el programa de estudios de la Bujinkan y un breve resumen de sus contenidos. Continúa con la descripción del sistema de grados y los contenidos técnicos del arte. El sexto capítulo ilustra las caídas, los rodamientos, las posiciones, los desplazamientos, los bloqueos, los ataques de puño y pierna, la secuencia de movimientos de la Sanshin no kata, las 8 técnicas básicas (kihon happo) y algunas de sus variaciones y algunas de las técnicas de jutai jutsu (proyecciones, controles, estrangulaciones, luxaciones, etc.). El séptimo capítulo presenta distintos modelos en el desarrollo de una clase de ninjutsu y finaliza explicando la teoría de los 5 elementos, sus relaciones, unas breves nociones didácticas y un compendio de pensamientos de Hatsumi Sensei. Adjunta vocabulario y bibliografía.

557. Fleitas González, Pedro (1992). Ninjutsu : técnicas superiores. Telde: Pedro Fleitas González. 1aㅡ ed. 121 p. : il. ; 16x21,5 cm. ISBN: 84-604-4243-8. Depósito legal: GC. 1038-1992. Palabras clave: historia, fundamentos técnicos, ninjutsu, escuelas, aplicación marcial, grados. Resumen: Manual teórico y técnico de ninjutsu. El libro esta formado por 10 capítulos precedidos por una introducción que destaca la labor pedagógica del autor. El primer capítulo presenta la organización del ninjutsu mientras que el segundo explica su sistema de graduación. El tercer capítulo narra la historia del ninjutsu. El cuarto capítulo enumera los objetivos y misiones del ninja. El quinto capítulo explica brevemente la ejecución y aplicación práctica de las técnicas de kamae de la escuela gyokko ryu 
koshijutsu acompañadas de sus ilustraciones. El sexto capítulo describe e ilustra la ejecución de las técnicas de kihon happo de la koshi kihon sanpo no kata y la hoshu kihon goho no kata. El séptimo capítulo presenta la descripción y secuencia fotográfica de las técnicas y variantes de u jaku, renyo y koku de la gyokko ryu koshijutsu. El octavo capítulo explica la ejecución de las técnicas de kyoto, do gaeshi y katame dori así como sus variantes de la escuela takagi yoshin ryu jutaijutsu acompañadas de sus ilustraciones correspondientes. Los dos últimos capítulos incluyen la descripción y secuencia fotográfica de las técnicas hisaku, o gyaku, ura nami y sus variantes de la escuela koto ryu así como la migi kata ude tonso no gata de la escuela togakure ryu ninjutsu. Adjunta bibliografía.

558. Fleitas González, Pedro (1994). Pensamientos del Dr. Masaaki Hatsumi. Telde: Seigan. 1a ed. 33 p. ; 12x15,5 cm. ISBN: 84-88738-07-2. 84-88738-01-3 (ISBN de la colección). Depósito legal: GC. 2421994. Palabras clave: filosofía. Resumen: Compendio de aforismos sobre el combate, el ninjutsu, el budo y la técnica.

559. Fleitas González, Pedro (1994). Taijutsu : combate $\sin$ armas. Telde: Seigan. 1a ed. 39 p. : il. ; 12x15,5 cm. ISBN: 84-88738-02-1. 84-88738-01-3 (ISBN de la colección). Depósito legal: GC. 90-1994. Palabras clave: fundamentos teóricos, fundamentos técnicos, principios técnicos, ejercicios, calentamiento, ninjutsu, escuelas. Resumen: Manual teórico y técnico de taijutsu. El libro esta formado por 7 capítulos. El primer capítulo explica los objetivos de los ejercicios de junan taiso además de describir la ejecución de varios de ellos. El segundo capítulo define el término taijutsu y sus principios técnicos. El tercer capítulo expone los métodos de combate que componen el taijutsu. El cuarto capítulo comenta el principio de mushotoku o acción sin objetivo. Los dos siguientes capítulos detallan los beneficios del taijutsu. El séptimo capítulo enumera los fundadores y contenidos de las nueve escuelas que componen el sistema Bujinkan.

560. Fleitas González, Pedro (1995). Refinamiento espiritual. Telde: Seigan. 1aㅡ ed. 52 p. : il. ; 12x15,5 cm. ISBN: 84-88738-11-0. ISBN de la colección: 84-88738-01-3. Depósito legal: GC. 5-1995. Palabras clave: fundamentos teóricos, pedagogía, fundamentos filosóficos, budismo, sintoísmo. Resumen: Manual teórico de ninjutsu. El libro esta formado por cinco capítulos precedidos por una introducción que comenta los contenidos de la obra. Los dos primeros capítulos exponen las características y fundamentos teóricos del budismo y el shintoismo. El tercer capítulo explica los elementos mínimos que deben componer el kamizama de un dojo. El cuarto capítulo comenta los aspectos principales para alcanzar el refinamiento espiritual. El último capítulo explica el significado de la frase "shikin haramitsu daikomyo" que detalla el principio de aprendizaje de la escuela Bujinkan dojo.

561. Fleitas González, Pedro (1996). Budo taijutsu : artes marciales Bujinkan. Telde: Seigan. 1a ed. 90 p. ; 15x20,5 cm. ISBN: 84-88738-20-X. Depósito legal: GC. 2-1996. Palabras clave: historia, fundamentos teóricos, escuelas, relatos, entrevistas, armas. Resumen: Tratado teórico de ninjutsu. El libro esta dividido en 2 partes. La primera parte consta de 3 capítulos. El primer capítulo explica en qué consiste el budo taijutsu, que es el ryu, el dojo y describe el proceso de evolución del ser humano. El segundo capítulo presenta el primer soke, fecha de creación, soke actual, características técnicas, principales enseñanzas y conceptos históricos de las 9 escuelas que conforman la Bujinkan Dojo. El tercer capítulo expone las características y estructura de los utensilios y armas utilizados en la Bujinkan Dojo. La segunda parte consta de un capítulo que narra algunas experiencias personales del autor, varios relatos relacionados con el ninjutsu e incluye un listado con los guerreros históricos del ninjutsu y de las denominaciones del guerrero ninja. Adjunta bibliografía.

562. Fleitas González, Pedro (1996). Guía de la shidoshikai. Telde: Seigan. $1^{a}$ ed. 40 p. : il. ; 11x15 cm. ISBN: 84-88738-19-6. Depósito legal: no. Palabras clave: vestimenta, cortesía, ninjutsu, escuelas, clubes, etiqueta, instalaciones, instituciones. Resumen: Guía informativa de la asociación shidoshikai. El libro esta dividido en 5 capítulos. El primer capítulo expone el objetivo y escuelas de la Bujinkan Dojo, la biografía de los maestros Takamatsu y Hatsumi, la estructura y organización del bushinden, sus reglas de comportamiento, guías de participación, las características de los certificados y licencias expedidos por la Bujinkan Dojo acompañados por su ilustración y su sistema de grados. El segundo capítulo presenta un listado con los datos de los miembros de la shidoshikai divididos por comunidades autónomas. EL tercer capítulo incluye el calendario de actividades de la asociación para el año 2005. El cuarto capítulo muestra los datos de contacto de los miembros de la Bujinkan Dojo. El último capítulo presenta la propaganda de los establecimientos especializados en material relacionado con la asociación.

563. Fleitas González, Pedro (2003). Budo taijutsu : artes marciales Bujinkan Dojo. Barcelona: Shinden. 1aㅡ ed. 73 p. : il. ; 18x24 cm. ISBN: 84-933469-0-X. Depósito legal: SE. 3935-2003. (2ª ed., 2005, ISBN: 8488738-20-X). Palabras clave: historia, fundamentos teóricos, escuelas, relatos, entrevistas, armas. Resumen: Tratado teórico de ninjutsu. El libro consta de 5 capítulos. El primer capítulo explica en qué consiste el budo taijutsu, que es el ryu, un dojo y describe el proceso de evolución del ser humano. El segundo capítulo presenta el primer soke, fecha de creación, soke actual, características técnicas, principales enseñanzas y conceptos históricos de las 9 escuelas que conforman la Bujinkan Dojo. El tercer capítulo expone las características y estructura de los utensilios y armas utilizados en la 
Bujinkan Dojo acompañados de sus ilustraciones explicativas. El cuarto capítulo narra algunas experiencias personales del autor, varios relatos relacionados con el ninjutsu e incluye un listado con los guerreros históricos del ninjutsu y de las denominaciones del guerrero ninja. El quinto capítulo incluye distintos extractos de las entrevistas del autor con sus buyu respecto a las artes marciales, el ninjutsu y sus fundamentos teóricos. Adjunta bibliografía.

564. Fleitas González, Pedro (2008). Dragón blanco, white dragon. Telde: Seigan. 1a ed. 377 p. : il. ; 20x26 cm. ISBN: 84-88738-33-1. Depósito legal: GC. 794-2008. Palabras clave: fundamentos teóricos, fundamentos técnicos, ninjutsu, escuelas, aforismos, entrevistas, maestros. Resumen: Manual teórico y técnico de ninjutsu. El libro esta formado por 3 capítulos precedidos por los agradecimientos. El primer capítulo incluye numerosos aforismos sobre las enseñanzas transmitidas por el maestro Hatsumi junto con la breve descripción y secuencia fotográfica de diversas técnicas de ninjutsu. El segundo capítulo presenta las entrevistas realizadas a los maestros Sveneric Bogsater, Jack Hoban, Mariette Van Der Vliet, Francisco Roldán Belmonte, Carlos Morales Paez, Guillermo Lugo, Peter King, Juan Manuel Serrano, Arnaud Cousergue y Moti Nativ, sobre sus inicios en las artes marciales, sus principios del entrenamiento, sus experiencias y sus comentarios sobre el desarrollo de las artes marciales bujinkan, además de presentar algunas secuencias fotográficas del maestro Hatsumi. El tercer capítulo narra la historia de la kukishinden ryu happo hiken, sus contenidos y principios técnicos así como el comentario de algunas vivencias, una entrevista realizada al propio autor y la descripción e ilustración de las principales posiciones, golpes, técnicas básicas, keiko sabaki gata, shoden no kata, chuden no kata y okuden no kata de la escuela junto con las posiciones y técnicas básicas de sanshaku bo jutsu y jo jutsu. Adjunta bibliografía.

565. Hatsumi, Masaaki (1992). 5 escuelas tradicionales de ninpo tai jutsu (bases para su estudio). Málaga: Pedro Martín Alarcón. 1aㅡ ed. 139 p. : il. ; 15x21 cm. ISBN: No ISBN. Depósito legal: MA. 1437-1992. Palabras clave: historia, fundamentos técnicos, principios éticos, ninjutsu, escuelas, zen. Resumen: Manual teórico y técnico de ninjutsu. El libro esta formado por 19 capítulos precedidos por los agradecimientos, el currículo del autor y una introducción que explica la metodología de la obra y sus objetivos. El primer capítulo explica en qué consiste el zen y cita los trabajos de Takuan y Musashi como ejemplos. El segundo capítulo discute la imagen del ninja en la sociedad occidental y expone los principios morales del ninja. El tercer capítulo explica el significado y utilización del ki a través de diversos aforismos. El cuarto capítulo enumera y comenta los principios para el progreso en el entrenamiento. El quinto capítulo narra la historia de las escuelas de ninjutsu junto con sus características. El sexto capítulo presenta los fundamentos técnicos del ninjutsu denominados tensho. Los siguientes cinco capítulos presentan la historia, contenidos técnicos y descripción de sus fundamentos técnicos de las escuelas togakure ryu, gyoko ryu, takagi ryu, koto ryu y kukishinden ryu. El décimo segundo capítulo detalla las etapas de la meditación sobre los tres centros básicos. El siguiente capítulo expone las características e historia de los nueve símbolos de kuji kiri para continuar detallando la ejecución, significado y poderes de las posiciones rin, pyo, toh, sha y kai. El último capítulo incluye diversos koanes del ninjutsu. Adjunta bibliografía.

566. Hatsumi, Masaaki (1993). Bujin : divino guerrero. Telde: Seigan. 1aㅡ ed. 117 p. : il. ; 16x21 cm. ISBN: 84604-5111-9. Depósito legal: GC. 299-1993. (2⿳亠口冋 ed., 2006, 151 p., ISBN: 84-88738-31-5). Palabras clave: historia, fundamentos técnicos, entrenamiento, relatos, maestros, armas. Resumen: Manual teórico y técnico de ninjutsu. El libro esta compuesto por 9 capítulos. El primer capítulo incluye la entrevista de Masaaki Hatsumi con Ryotaro Koyama sobre sus relaciones personales con el Maestro Takamatsu. El segundo capítulo relata la historia de los ninjas a través de varios relatos y una extracto de una película. El tercer capítulo presenta los diferentes tipos de entrenamiento que se incluyen en el ninjutsu (ninja hachimon), describiendo varias de sus técnicas. El cuarto capítulo detalla la estructura del bastón shinobi y explica las técnicas de pesca con caña y varias defensas por partes y de forma ilustrativa. El quinto capítulo comenta las ocho puertas o disciplinas que debe dominar el verdadero ninja y el entrenamiento desarrollado en la Togakure Ryu. El sexto capítulo expone el artículo escrito por el Sensei Toshitsugu Takamatsu sobre su vida y entrenamiento marcial desde pequeño. El séptimo capítulo incluye un relato sobre el desarrollo de las armas y diversas fotografías sobre la utilización del palo. El octavo capítulo presenta los 10 katas o shoshin no kata, describiendo e ilustrando su ejecución. El último capítulo relata la vida de los samuráis y el kihon happo de Nagato Toshiro.

567. Hatsumi, Masaaki (1996). Ninja submission. Telde: Seigan. 1a ed. 59 p. : il. ; 21x29,5 cm. ISBN: 8488738-22-6. Depósito legal: GC. 480-1996. Palabras clave: historia, fundamentos técnicos, armas. Resumen: Manual teórico y técnico de ninjutsu. La obra esta formada por 7 capítulos precedidos por un comentario sobre lo que significa e implica el ninpo, describe la ejecución de una técnica sorpresiva, como agarrar una espada real desenvainada, las utilidades de un arma secreta, una técnica de luxación con el shukoh, como perturbar al enemigo, y un conjunto de cuadros pintados por el autor (shinobie). El primer capítulo relata el encuentro y entrenamiento del autor bajo la tutela de su Maestro Takematsu, así como algunos de sus aprendizajes sobre la actitud de entrenamiento, la kata, y el verdadero budo. El segundo capítulo explica el origen de las nueve escuelas que agrupa el autor bajo la 
Bujinkan Dojo así como la biografía de Takamatsu Toshitsugu. El tercer capítulo enumera los aspectos técnicos de las distintas posiciones de guardia (kamae), el cambio de la postura (taiehn jutsu) y el desarrollo técnico de la forma de los cinco caminos para practicar la forma básica de ataque (go gyo no kata). El cuarto capítulo describe la ejecución técnica de las ocho formas básicas (kihon happo), para luego pasar a las ocho formas básicas del combate. El sexto capítulo describe como someter y controlar a un enemigo y finaliza con un breve comentario sobre la disciplina de entrenamiento y adiestramiento.

568. Hatsumi, Masaaki (1996). Sô jutsu : técnicas con lanza. Telde: Seigan. 1a ed. 146 p. : il. ; 21x29,5 cm. ISBN: 84-88738-24-2. Depósito legal: GC. 1258-1996. Palabras clave: fundamentos técnicos, katas. Resumen: Manual teórico y técnico de ninjutsu. El libro esta formado por 4 capítulos precedidos por una breve biografía del autor, numerosas ilustraciones sobre la historia de Japón, los maestros de ninjutsu y textos, un prefacio que destaca la personalidad del autor y otro prefacio que enumera las tradiciones que desarrollaron el sojutsu y los tipos de lanzas. El primer capítulo describe e ilustra las técnicas de kaisetsu gata, como son el saludo, kanpo, shiho waza, hicho ho, hitotsu ai ho, ichiju santo, hatsu ai (hassai), hiso (hi yari), tenchi kaku y happo yaku. El segundo capítulo presenta la descripción y secuencia fotográfica de las técnicas que componen la gokui gata como son ichimonji, kiku sui, maki cho, oni sashi, hi ryu, toppuku, kage no cho, mitsudama y nanamai ha. El tercer capítulo explica la ejecución de las técnicas incluidas en la menkyo kaiden hencho gata como son yoko taoshi, ryuto, tomoe, nugi nuki, arashi, shinmyo, taki otoshi, yoko nage, tachi nage y nichi getsu. El último capítulo detalla la ejecución de las técnicas contenidas en la keiko gata denominadas ryo kasumi, so taihen.

569. Hatsumi, Masaaki (1996). Traducciones de los vídeos del gran maestro. Telde: Seigan. $1^{\underline{a}}$ ed. 118 p. : il. ; 21x29,5 cm. ISBN: 84-88738-21-8. Depósito legal: no. Palabras clave: fundamentos técnicos, maestros. Resumen: Compendio de traducciones. El libro expone en cada capítulo las traducciones de las explicaciones técnicas de los videos del Maestro Hatsumi titulados: Kotto Ryu Koppojutsu, Takagi Yoshin Ryu Jutaijutsu, Gyokko Ryu Kosshijutsu, Kukishinden Ryu Yoroi Kumi Uchi, Kukishinden Ryu Hanbojutsu-Shikomizue, Togakure Ryu Ninpo Taijutsu, Shinden Fudo Ryu Dakentai Jutsu, Jutte Jutsu, Rokushaku Bojutsu, Shinken Shiraha Dome, Muto Dori, incluyendo el nombre de cada técnica, el diálogo y quién demuestra dicha técnica.

570. Hatsumi, Masaaki (1998). Tetsuzan : montaña de hierro. Telde: Seigan. 1aㅡ ed. 94 p. : il. ; 17x25 cm. ISBN: 84-88738-26-9. Depósito legal: GC. 596-1998. Palabras clave: fundamentos técnicos, principios técnicos, entrenamiento, series TV, entrevistas, exámenes, maestros, periodismo. Resumen: El primer capítulo expone los agradecimientos del autor, la labor profesional durante este año y comenta la celebración del $30^{\circ}$ aniversario de Hatsumi Sensei al frente de la Bujinkan Dojo. El segundo capítulo narra los exámenes de 5o dan y el primer entrenamiento del año 1989 y comenta los contenidos de la serie de TV "Jiraiya y el mundo de guerra ninja". El tercer capítulo comenta el significado del kihon happo. El cuarto capítulo explica el significado de la prueba de 5o dan y describe varias técnicas ante una estrangulación, un ataque por detrás, y la ejecución y aplicación de ichimonji no kamae, omote gyaku dori y jumonji no kamae. El quinto capítulo incluye la entrevista de Hatsumi con Koizumi y la descripción e ilustración de las técnicas uragyaku-dori, muso-dori, musha-dori, ganseki-nage, omote oni-kudaki y fundo koshi-guruma. El sexto capítulo presenta la reflexiones de Toshiro Nagato sobre las enseñanzas del soke y el entrenamiento en la Bujinkan además de explicar e ilustrar las técnicas koshiguruma. El séptimo capítulo comenta el entrenamiento de las patadas, describe algunos ejercicios de calentamiento, la ejecución de la patada en el hielo y una técnica de shinobi kogatana acompañados de sus respectivas ilustraciones. El octavo capítulo detalla los principios técnicos del futari dori además de describir e ilustrar su ejecución. El noveno capítulo relata la historia de Takamatsu sensei con un tsujigiri (asesino callejero) además de detallar la ejecución de las técnicas niningiri nokata y onikudadki gyaku otoshi nage. El décimo capítulo comenta los contenidos de la serie de TV "Jiraiya", la transmisión de los conocimientos a través del densho y el progreso en el entrenamiento. Los dos últimos capítulos incluyen los artículos escritos por Shizuo Koizumi en sus entrevistas con Takamatsu sensei respecto al ninjutsu, sus entrenamientos, exhibiciones, principios y algunas de sus anécdotas biográficas.

571. Hatsumi, Masaaki (2000). Ninpo : sabiduría de vida. Telde: Seigan. 1aㅡ ed. 163 p. : il. ; $15 \times 24$ cm. ISBN: 84-88738-29-3. Depósito legal: no.

572. Hatsumi, Masaaki (2005). El ninja moderno. Telde: Seigan. 1a ed. 191 p. : il. ; 14x21 cm. ISBN: 8488738-30-7. Depósito legal: GC. 665-2005. Palabras clave: fundamentos teóricos, principios filosóficos, ejercicios, relatos, fisioterapia. Resumen: Manual teórico y técnico de ninjutsu. El libro esta formado por 5 capítulos precedidos por la nota del traductor, la carta el maestro Hatsumi a Pedro Fleitas, una introducción que comenta los contenidos del libro y un prólogo que narra el contacto del autor con el budo. El primer capítulo reflexiona sobre los principios de las artes marciales y relata varias anécdotas sobre su espíritu. El segundo capítulo expone el significado de los héroes, ofrece algunos consejos para dedicarse al arte, señala la importancia de darse cuenta de los puntos ciegos y comenta los objetivos del budo, el significado de la sonrisa y del sudor en el entrenamiento. El tercer 
capítulo expone los fundamentos filosóficos del budo, comenta la experiencia cinematográfica del autor, define los conceptos de ninpo y ninjutsu, explica la utilización de los elementos agua, madera, fuego, metal y tierra por parte del ninja, relata la introducción del autor y del maestro Takamatsu en las artes marciales y el viaje de retorno a Togakure. El cuarto capítulo explica el significado del término "rashamen", relata varias anécdotas, comenta algunas de los amuletos para la guerra y las artes de las kunoichi. El quinto capítulo ofrece algunos consejos prácticos para mantener una buena salud, señala la importancia de la alimentación en la guerra, expone la dieta ninja y algunos remedios contra el envenenamiento, la aplicación del ninjutsu en la prevención de accidentes, un método para explorar y masajear el cuerpo, y describe la ejecución del ejercicio "hichibuku" y otros ejercicios de masaje y estiramiento para compensar las irregularidades de la médula espinal.

573. Hatsumi, Masaaki (2007). Stick fighting avanzado. Barcelona: Shinden. 1a ed. 208 p. : il. ; 20x26,5 cm. ISBN: 978-84-96894-02-0. Depósito legal: B. 24439-2007. Palabras clave: katas, historia, fundamentos técnicos, principios técnicos, bojutsu, ninjutsu, escuelas, jojutsu, maestros, programa técnico. Resumen: Manual teórico y técnico de ninjutsu. El libro esta formado por 2 capítulos. El primer capítulo analiza el término bushido y su significado, su relación con el budo, narra la aparición del bo, explica en qué consiste el bo-jutsu, sus tipos y su evolución histórica, y narra la historia de la escuela Kukishin-ryu de bo-jutsu. El segundo capítulo comienza explicando los materiales utilizados en la construcción del bo y sus características para luego describir la ejecución del saludo, las guardias, y las técnicas ukemi, ashi barai, shiho bofuri gata y men uchiharai gata incluyendo la secuencia fotográfica de las técnicas por partes, explica los principios técnicos de la utilización del bo, describe e ilustra las 25 técnicas del gokyo gokai ihen sabaki gata, describe e ilustra la secuencia técnica de las técnicas jumonji, roppo, kyuho, hiryu, tsukeiri, udekake, kote gaeshi y tachi otoshi de jo-jutsu, presenta la secuencia fotográfica de 3 técnicas de bo nuke ( 2 técnicas de kubinuke y 1 de nage bo) y ofrece varias ilustraciones del manejo del bo por parte de Takamatsu Toshitsugu Sensei. Incluye un apéndice con el texto original japonés.

574. Hatsumi, Masaaki (2009). Técnicas samurái de combate sin armas. Barcelona: Shinden. $1 \underline{a}$ ed. 239 p. : il. ; 20x26,5 cm. ISBN: 978-84-96894-13-6. Depósito legal: no. Palabras clave: fundamentos teóricos, fundamentos técnicos. Resumen: Manual teórico y técnico de ninjutsu. El libro esta formado por 8 capítulos precedidos por una introducción que comenta la historia del Budo Taijutsu y expone algunas aclaraciones terminológicas. El primer capítulo explica las características del kihon happo y su entrenamiento además de describir las técnicas que componen el kosshi sanpo y torite goho acompañadas de varias fotografías explicativas. El segundo capítulo expone los fundamentos teóricos del sanshin no kata y describe la ejecución de sanshin no kata, taihen ukemi gata y taihenjutsu mutodori gata junto con varias ilustraciones. El tercer capítulo presenta las estrategias del gyokko-ryu kosshi jutsu y explica las técnicas que componen el joryaku, churyaku y geryaku, además de numerosas ilustraciones. El cuarto capítulo incluye la descripción de las técnicas que componen koto-ryu koppo jutsu kurai dori, shoden gata, hekito gata, chuden gata, okuden gata y kaiden gata junto con algunas recomendaciones para el entrenamiento de los puños, la práctica de estas técnicas y diversas fotografías. El quinto capítulo enumera los contenidos del ninpo taijutsu y describe las técnicas que componen taijutsu ukemi gata, shinobi gaeshi gata y hiden gata. El sexto capítulo expone la aplicación del taijutsu en la actualidad y presenta la descripción de las técnicas que componen omote gata, ura gata, eri jime gata, sabaki gata, tai no kata, muto-dori gata, daisho sabaki gata, shirabe gata y moguri gata. El séptimo capítulo expone las características de la práctica de Shinden Fudo-ryu y la ejecución de ten no kata, chi no kata y shizen shigoku no kata. El último capítulo comenta las enseñanzas del kukishin-ryu y describe la ejecución de las técnicas kukishin-ryu happo biken no jutsu, shoden gata, chuden gata, sabaki gata, okuden y shirabe moguri gata den junto con numerosas ilustraciones técnicas y de Takamatsu sensei. Adjunta un apéndice con el texto original japonés.

575. Hatsumi, Masaaki; Mendoza, Ruy San de y Mendoza, Ana de (1992). Combat ninja. Málaga: U.C.N. 1a ed. 110 p. : il. ; 15x21 cm. ISBN: No ISBN. Depósito legal: MA. 1154-1992. Palabras clave: historia, fundamentos teóricos, táctica, fundamentos técnicos, pedagogía, principios técnicos, entrenamiento, escuelas, ninjutsu, instalaciones, armas. Resumen: Manual teórico y técnico de ninjutsu. El libro esta formado por 26 capítulos precedidos por el currículo de los autores. El primer capítulo narra el origen y evolución del ninjutsu junto con su árbol genealógico y algunas fotografías de sus maestros. El segundo capítulo presenta la organización de la Bujinkan Dojo de Japón mientras que el tercero explica la celebración del daikomiosai. El cuarto capítulo incluye el programa técnico y de entrenamiento de la Bujinkan dojo. El quinto capítulo comenta la metodología y progresión en el aprendizaje de las técnicas mientras que el sexto expone sus principios técnicos. El séptimo capítulo describe las etapas de progresión. El octavo capítulo enumera el sistema de grados del ninjutsu. El noveno capítulo detalla las características del trabajo con armas. El décimo capítulo expone los principios técnicos del combate. El décimo primer capítulo presenta la relación entre las cinco manifestaciones naturales y la práctica del ninjutsu. El décimo segundo capítulo enumera las técnicas de taihen-jitsu, dakentai-jitsu y jutai-jitsu que conforman el tai jitsu junto con algunas ilustraciones explicativas. El décimo tercer capítulo 
describe las técnicas de kihon happo y de san shin no kata. Los siguientes tres capítulos presentan los contenidos técnicos del tanto jutsu, hambo jutsu y tambo jutsu acompañados de la ilustración de algunas de sus técnicas. Los siguientes tres capítulos describen los contenidos técnicos del nipo ken jutsu, iai ninpo y kusari fundo jutsu. El vigésimo capítulo explica el significado del sakki test. El siguiente capítulo enumera las técnicas contenidas en los videos técnicos de Japón. El vigésimo segundo capítulo presenta los contenidos técnicos de la estrategia denominada go gyo y explica sus principios técnicos. El vigésimo tercer capítulo comenta la utilización y entrenamiento con los shuriken y los shaken, ilustrando sus distintas formas de lanzamiento y sus tipos. El vigésimo cuarto capítulo expone las consideraciones pedagógicas para desarrollar un programa infantil de ninjutsu. El vigésimo quinto capítulo enumera las técnicas de entrenamiento mental en ninjutsu. El último capítulo relata la celebración del III Tai Kai del maestro Hatsumi en España incluyendo numerosas fotografías.

576. Hatsumi, Masaaki y Chambers, Quintin (1994). Stick fighting : técnicas de defensa personal con bastón. Telde: Seigan. 1a ed. 148 p. : il. ; 15x21 cm. ISBN: 84-88738-08-0. Depósito legal: GC. 1125-1994. Palabras clave: fundamentos teóricos, fundamentos técnicos, defensa personal, armas. Resumen: Manual técnico de defensa personal. La obra esta formada por 8 secciones, precedidas por un capítulo que comenta los fundamentos de la defensa personal con bastón. La primera sección estudia los movimientos básicos de defensa, describiendo su ejecución e incluyendo varias fotografías, gráficos y esquemas de movimiento de los pies. La segunda sección analiza las técnicas de defensa contra ataques de puño, describiendo su ejecución, comentando los aspectos más importantes e ilustrando la técnica por partes. El resto de secciones mantiene la misma estructura, explicando las técnicas de defensa con bastón contra ataques de piernas, contra agarres de muñeca, contra agarres de manga y solapa, contra agarres por detrás, contra agarres del bastón y las inmovilizaciones. Adjunta un glosario.

577. Hayes, Stephen (1990). Los ninja : sus artes y secretos de combate. Madrid: Eyras. $1^{\mathrm{a}}$ ed. 133 p. : il. ; 15x24 cm. ISBN: 84-85269-66-7. Depósito legal: M. 6288-1990. Palabras clave: historia, fundamentos teóricos, táctica, armas. Resumen: Manual teórico de ninjutsu. El libro esta formado por 7 capítulos. Comienza con la explicación de los orígenes del ninjutsu, desde su formación como arte marcial hasta sus clanes, entrenamiento, actividad en la vida social, etapas durante la historia y su estado actual. El segundo capítulo relata el encuentro entre el autor y Hatsumi Sensei. Los siguientes capítulos describen el aprendizaje técnico del autor bajo las órdenes de distintos maestros, así en el tercer capítulo describe las técnicas de puño y las posiciones de combate. El cuarto capítulo expone las distintas armas empleadas por los ninja, como cadenas, cuerdas, palos, bastones, armas ocultas, la espada ninja, hojas para lanzar, y su correcta utilización. El quinto capítulo profundiza en las técnicas de invisibilidad propias del ninjutsu como el sentido del engaño, sus desplazamientos, el reconocimiento del terreno, la invisibilidad en la noche, y el arte del disfraz. El sexto capítulo expone las tácticas y estrategias de combate del ninjutsu; y finaliza con el estudio y análisis psicológico que desarrollaban los ninja de sus oponentes y de sí mismos.

578. Hombre Dopazo, Juan (1992). Ninja training. España: Juan Hombre Dopazo. 1a ed. 264 p. : il. ; 17x24 cm. ISBN: 84-604-4102-4. Depósito legal: M. 32009-1992. Palabras clave: historia, fundamentos teóricos, armas, fundamentos técnicos, fundamentos filosóficos, entrevistas, maestros. Resumen: Manual teórico y técnico de ninjutsu. El libro esta dividida en 3 partes precedidas por una dedicatoria y la presentación de la escuela Mutekatsu Ryu. La primera parte presenta los fundamentos teóricos de la escuela Mutekatsu Ryu, incluye una breve biografía personal y las entrevistas realizadas a Stephen K. Hayes, Masaaki Hatsumi, Shoto Tanemura, Tetsuya Higuchi e Inomura Ueno Uchida, además de comentar los orígenes, evolución histórica y características del shinobijutsu. La segunda parte narra la historia y periodos del ninjato (espada del ninja), describe su estructura y sus partes, resume los periodos de la historia de las espadas japonesas, comenta el significado de la espada, las partes del entrenamiento, la importancia de una mente en calma, enumera los contenidos técnicos del iai-to, relata el origen del kiai, describe la ejecución de las dos técnicas básicas de desenvaine y los cinco desenvaines realizados desde la posición de seiza acompañados de su secuencia fotográfica, explica el significado de la limpieza del ninjato junto con la descripción e ilustración de dicho proceso, comenta la realización de la prueba la espada denominada wakaru gyo y el significado de la benevolencia y el honor para el guerrero bugenki. La tercera parte describe los contenidos técnicos del arte de la evasión y el escape (inton taihenjutsu), las características de las técnicas de ukemi, kaiten y tobi, enumera las técnicas elementales de taihenjutsu, describe la ejecución de las 7 técnicas básicas de taihenjutsu acompañadas de su representación gráfica, señala la importancia de shinobi seiza, explica la ejecución de las técnicas avanzadas de taihenjutsu junto con sus ilustraciones explicativas además de las tácticas avanzadas de intonpon.

579. Hombre Dopazo, Juan (2006). Ichi shinobi densho : el primer libro de enseñanza. Madrid: Juan Hombre Dopazo. $1^{a}$ ed. 240 p. : il. ; 17x24 cm. ISBN: 84-609-9353-1. Depósito legal: M. 13220-2006. Palabras clave: historia, fundamentos teóricos, fundamentos técnicos, relatos, fundamentos filosóficos, programa técnico. Resumen: Manual teórico y técnico de ninjutsu. El libro esta formado por 16 capítulos precedidos por un prefacio que incluye la entrevista realizada al soke Kawakami por el autor. 
El primer capítulo comenta la situación actual del ninjutsu. El segundo capítulo narra la historia y desarrollo del ninjutsu. El tercer capítulo explica en qué consiste el ninjutsu mientras que el cuarto comenta sus fundamentos teóricos. El quinto capítulo expone los contenidos del shinobi densho (enseñanza tradicional del ninjutsu japonés). El sexto capítulo explica la enseñanza actual del ninjutsu mientras que el séptimo desarrolla y explica el programa de enseñanza del autor. El octavo capítulo detalla los fundamentos filosóficos del ninjutsu. El noveno capítulo explica los fundamentos teóricos relacionados con la formación y el aprendizaje, el saludo y la meditación. El décimo capítulo relata un cuento sobre la virtud de la paciencia. El siguiente capítulo relata la primera leyenda del ninjutsu. El decimosegundo capítulo presenta los principios tácticos y estratégicos del ninjutsu extraídos de "El libro de la guerra". El capítulo decimotercero incluye la descripción y secuencia fotográfica de varios ejercicios de manejo de la katana, de las principales técnicas de shinobi gakure kenjutsu (arte de esconderse de la espada), shinobi nawayoway jutsu (arte de trampas con las cuerdas), shinobi kusarigamajutsu (arte de la hoz con cadena), shinobi gakure no jutsu (arte de combate escondido). El decimocuarto capítulo enumera el resto de disciplinas incluidas dentro del ninjutsu. Los dos últimos capítulos presentan las normas de cortesía y de compromiso del ninja.

580. Hombre Dopazo, Juan (2007). Japan ninjutsu : bakemono no jutsu. España: Juan Hombre Dopazo. 1a ed. 161 p. : il. ; 17x24 cm. ISBN: 978-84-611-5664-1. Depósito legal: M. 37826-2007. Palabras clave: historia, fundamentos técnicos, ninjutsu. Resumen: Manual teórico y técnico de ninjutsu. La obra esta formada por 3 capítulos. El primer capítulo expone los contenidos teóricos, principios tácticos y entrenamiento del genjutsu (arte oscuro) para en el segundo capítulo describir e ilustrar 10 técnicas de genbojutsu (arte oscuro con palo). El último capítulo explica y comenta los contenidos del bakemono no jutsu o arte del impedido, y sus dos disciplinas, el hensho jutsu o arte de los disfraces y el gisho jutsu o arte de la personificación, interpretación y maquillaje. Adjunta información de contacto del curso de formación de instructores de la Japan Ninjutsu Federation.

581. Hombre Dopazo, Juan (2007). Japan ninjutsu : iga ryu koga ryu ninjutsu. España: Juan Hombre Dopazo. $11^{a}$ ed. 161 p. : il. ; 17x24 cm. ISBN: 978-84-611-5663-4. Depósito legal: M. 37825-2007. Palabras clave: historia, entrenamiento, ninjutsu, escuelas, relatos, cultura, armas. Resumen: Manual teórico y técnico de ninjutsu. La obra esta formada por 12 capítulos, precedidos de una introducción que narra las leyendas sobre los orígenes del ninjutsu, comenta sus contenidos teóricos y las organizaciones dedicadas a la enseñanza del verdadero ninjutsu. El primer capítulo comenta la aparición de las distintas organizaciones de ninjutsu que existen en la actualidad, sus orígenes y las críticas a cada una de ellas. El segundo capítulo expone 9 datos sobre las prácticas y asociaciones que intentan incluirse dentro del ninjutsu. El tercer capítulo enumera las familias ninja de Koga y su evolución histórica además de incluir la historia de Hideyoshi para unificar el archipiélago. El cuarto capítulo relata las historias y familias ninja que ocuparon la región de Iga, para continuar con breves relatos sobre la utilización de los shinobi por parte de los daimyo y la historia ninja de los señoríos Fukui, Owari, Hirozen, Kishiwada, Takatsuki, Hikone, Iga-ryu, Sendai, Kaga y Koriyama. El sexto capítulo profundiza en los principios técnicos y tácticos del ninja para realizar una acción nocturna y aplicación en el asalto a una fortaleza. El séptimo capítulo clasifica los tipos de espía que existen, su papel en la guerra e incluye un extracto del libro SONSHI como manual de estrategia del ninja y una historia sobre la fuerza de voluntad y perseverancia del ninja. Los tres siguientes capítulos analizan el ninjutsu como arte marcial, como forma de vida y como camino espiritual, indicando los beneficios de la práctica y su entrenamiento en estos aspectos. Los dos últimos capítulos ilustran el Yashiki (casa del ninja) y las armas del ninja. Adjunta información de contacto del curso de formación de instructores de la Japan Ninjutsu Federation.

582. Hombre Dopazo, Juan (2007). Japan ninjutsu : kuji goshin ho. España: Juan Hombre Dopazo. 1aㅡ ed. 160 p. : il. ; 17x24 cm. ISBN: 978-84-611-5665-8. Depósito legal: M. 37827-2007. Palabras clave: historia, fundamentos teóricos, fundamentos técnicos, entrenamiento. Resumen: Manual teórico y técnico de ninjutsu. La obra esta formada por 10 capítulos. El primer capítulo explica la relación entre respiración y mudras, los tipos de respiración, los beneficios de la respiración y los efectos de los mudras. El segundo capítulo describe la ejecución técnica de los mudras mágicos destinados al bienestar y la sabiduría. Continúa profundizando en la teoría del kuji goshin ho, su teoría y secretismo, el significado de cada mudra junto con una ilustración de su realización y mantra. El quinto capítulo desarrolla el entrenamiento ninja del primer mudra (rin) desde su teoría y fundamentos teóricos hasta sus beneficios. El sexto capítulo presenta al dios Fudo Myoo, su significado, cualidades y aportaciones al ninja y expone la ceremonia que realiza el autor en dedicación a este dios. El siguiente capítulo explica la importancia del pensamiento positivo para el ninja y recopila varios métodos de protección del ninja, como son haya kuji y juji no ho. El octavo capítulo estudia la historia de la utilización del kiai, los tipos de kiai que existen, sus efectos y su entrenamiento. El noveno capítulo describe la estructura del cerebro y del sistema endocrino para luego explicar el poder de la mente y la visualización para curar junto con un ejercicio práctico. Finaliza con un comentario sobre las supersticiones y falsas creencias 
que rodean a los ninja. Adjunta información de contacto del curso de formación de instructores de la Japan Ninjutsu Federation.

583. Hombre Dopazo, Juan (2007). Japan ninjutsu : kunoichi. España: Juan Hombre Dopazo. 1a ed. 161 p. : il. ; 17x24 cm. ISBN: 978-84-611-8944-1. 978-84-6115-656-6 (ISBN de la obra completa). Depósito legal: M. 38025-2007. Palabras clave: historia, fundamentos técnicos, ninjutsu, estrategia, fitoterapia. Resumen: Manual teórico y técnico de ninjutsu. La obra esta formada por 7 capítulos, precedidos de una introducción que explica los estados de una kunoichi. El primer capítulo describe el origen de las kunoichi y su papel social; para continuar con las enseñanzas filosóficas que recibían. El tercer capítulo presenta los principios del kyojitsu o arte de la subversión incluyendo los consejos prácticos para su aplicación. El cuarto capítulo ilustra y describe en fases la ejecución de 2 ejercicios de kihon y 9 técnicas de kyojitsu. El quinto capítulo analiza 9 estrategias de combate de las kunoichi y su utilización en distintas situaciones. El sexto capítulo expone la leyenda de Harumi Jiro y el último capítulo comenta el estudio de la farmacia (ninyagen jutsu) y las plantas como disciplina complementaria del ninja. Adjunta información de contacto del curso de formación de instructores de la Japan Ninjutsu Federation.

584. Hombre Dopazo, Juan (2007). Japan ninjutsu : muto gakure kenjutsu. España: Juan Hombre Dopazo. 1a ed. 161 p. : il. ; 17x24 cm. ISBN: 978-84-611-5662-7. Depósito legal: M. 21420-2007. Palabras clave: fundamentos técnicos, armas. Resumen: Manual teórico y técnico de ninjutsu. La obra esta formada por 3 capítulos. El primer capítulo expone las características del muto gakure no jutsu (arte de esconderse y desaparecer ante un enfrentamiento contra katana), la sencillez para su eficacia, las actitudes ante el enfrentamiento y consejos prácticos. El segundo capítulo describe e ilustra cinco ejercicios de acondicionamiento físico general, habilidad y familiarización contra los ataques con katana. El tercer capítulo incluye 19 series de técnicas de defensa contra katana, describiendo brevemente su ejecución e incluyendo su secuencia fotográfica. Adjunta información de contacto del curso de formación de instructores de la Japan Ninjutsu Federation.

585. Hombre Dopazo, Juan (2007). Japan ninjutsu : ninjato. España: Juan Hombre Dopazo. 1a ed. 163 p. : il. ; 17x24 cm. ISBN: 978-84-611-5658-0. 978-84-611-5656-6 (ISBN de la obra completa). Depósito legal: M. 4369-2007. Palabras clave: fundamentos técnicos, armas. Resumen: Manual teórico y técnico de ninjutsu. La obra esta formada por 5 capítulos. El primer capítulo comenta y diferencia la utilización del ninjato frente a la katana, para continuar con su descripción estructural, el entrenamiento con el bokken en sustitución del ninjato y la forma de agarrar y coger el ninjato. El tercer capítulo describe e ilustra la ejecución de los cortes y ataques básicos, la primera serie coordinada de movimientos y los escapes o rodamientos. El cuarto capítulo explica la ejecución de cinco técnicas de combate contra un corte hacia abajo, contra un corte interior, contra un corte exterior, contra un ataque directo y contra un doble corte, adjuntando una secuencia de fotografías de cada una de ellas. El último capítulo define los propósitos del kata y sus distintos tipos e ilustra la secuencia técnica de la koga ninjato no kata. Adjunta el programa de formación de los instructores de la Japan Ninjutsu Federation y los requisitos para realizar un entrenamiento en Japón.

586. Hombre Dopazo, Juan (2007). Japan ninjutsu : ongyo ton jutsu. España: Juan Hombre Dopazo. 1a ed. 161 p. : il. ; 17x24 cm. ISBN: 978-84-611-5661-0. Depósito legal: M. 21419-2007. Palabras clave: fundamentos técnicos, aplicación marcial, principios filosóficos, filosofía. Resumen: Manual teórico y técnico de ninjutsu. La obra esta formada por 3 capítulos. El primer capítulo explica el significado de las cinco actitudes que rigen el entrenamiento del ninja. El segundo capítulo describe los cinco espíritus o estados espirituales que se alcanzan con el desarrollo del entrenamiento. El último capítulo presenta 16 técnicas avanzadas de cinturón azul contra ataques desarmados que son comentadas brevemente y con una secuencia fotográfica. Adjunta información de contacto del curso de formación de instructores de la Japan Ninjutsu Federation.

587. Hombre Dopazo, Juan (2007). Japan ninjutsu : shinobi gakure no jutsu. España: Juan Hombre Dopazo. 1a ed. 165 p. : il. ; 17x24 cm. ISBN: 978-84-611-5657-3. 978-84-611-5656-6 (ISBN de la obra completa). Depósito legal: M. 4370-2007. Palabras clave: fundamentos teóricos, fundamentos técnicos, educación, programa técnico. Resumen: Manual teórico y técnico de ninjutsu. La obra esta formada por 10 capítulos, precedidos por una entrevista al gran maestro Jinichi Kawakami. El primer capítulo explica los orígenes y tareas del ninja en su época de máxima esplendor, para luego exponer en qué consiste el ninjutsu. El tercer capítulo enumera los contenidos de las enseñanzas tradicionales del ninjutsu y continúa con la descripción de la situación actual del ninjutsu. El quinto capítulo describe el programa de aprendizaje que sigue la Japan Ninjutsu Federation, sus criterios de enseñanza y los valores que se necesitan para entrar a formar parte de esta asociación. El sexto capítulo presenta varias técnicas con el uso de cuerdas así como algunas técnicas de ataque y distracción. El séptimo capítulo explica detenidamente las enseñanzas y estrategias enseñadas en la Japan Ninjutsu Federation como son la examinación, espontaneidad, vigor, peligro, imitación, rezar, tenacidad, por ti mismo, y confianza, y la narración de una de las primeras leyendas sobre los ninja. Los dos siguientes capítulos exponen las reglas de cortesía de la escuela y la enumeración de las disciplinas o estrategias que 
componen el programa del ninjutsu. El último capítulo explica las reglas de compromiso de la asociación. Adjunta el programa del curso de instructores.

588. Hombre Dopazo, Juan (2007). Japan ninjutsu : shinobi ken jutsu. España: Juan Hombre Dopazo. 1a ed. 161 p. : il. ; 17x24 cm. ISBN: 978-84-611-5660-3. Depósito legal: M. 21418-2007. Palabras clave: fundamentos técnicos, ninjutsu, principios filosóficos, filosofía, textos, entrevistas. Resumen: Manual teórico y técnico de ninjutsu. La obra esta formada por 4 capítulos, precedidos de una introducción que expone el sistema de graduación del ninjutsu y las costumbres propias del autor durante el entrenamiento. El primer capítulo incluye makimonos (pergaminos) ninja del Soke Kawakami. El segundo capítulo expone los 5 principios espirituales que rigen el ninjutsu y controlan el cuerpo, el corazón, el espíritu, la mente y el alma, y sus aportaciones al entrenamiento del ninja. El tercer capítulo incluye charlas y anécdotas del autor con sus alumnos respecto a la actitud ante el entrenamiento. El último capítulo presenta diez técnicas de shinobi ken, ilustradas en fases y con una breve descripción del movimiento. Adjunta información de contacto del curso de formación de instructores de la Japan Ninjutsu Federation.

589. Hombre Dopazo, Juan (2007). Japan ninjutsu : tengu nana arashi. España: Juan Hombre Dopazo. 1a ed. 161 p. : il. ; 17x24 cm. ISBN: 978-84-611-5659-7. 978-84-611-5656-6 (ISBN de la obra completa). Depósito legal: M. 11835-2007. Palabras clave: fundamentos técnicos, estrategia. Resumen: Manual teórico y técnico de ninjutsu. La obra esta formada por 5 capítulos, precedidos de una introducción que explica las distintas organizaciones y escuelas de ninjutsu así como las 3 fases en el aprendizaje del mismo: nindo, ninpo y ninjutsu. El primer capítulo relata los orígenes de los tengu, sus características, significado y leyendas dentro del ninjutsu. El segundo capítulo narra la leyenda del tengu oscuro en su lucha contra el dragón rojo. El tercer capítulo describe los principios técnicos y tácticos de eficacia del tengu, como la fuerza de impacto, las 4 fases tácticas del combate, la habilidad de esconderse, el kime y sus fases de desarrollo. El cuarto capítulo describe brevemente e ilustra los contenidos técnicos básicos del combate tengu: ushiro tengu tobi, mae tengu tobi, tengu mae nagare, tengu ushiro nagare, tengu arare nagare, tengu furonin nagare y tengu uchi uke. El último capítulo describe 7 técnicas del programa de verde, incluyendo una secuencia fotográfica de cada una de ellas, como son: ichi tengu arashi, ni tengu arashi, san tengu arashi, yon tengu arashi, go tengu arashi, roku tengu arashi y nana tengu arashi. Adjunta el programa de formación de los instructores de la Japan Ninjutsu Federation y los requisitos para realizar un entrenamiento en Japón.

590. Javy-San (1988). Ninjutsu : técnicas básicas. Barcelona: Javy-San. 1aㅡ ed. 148 p. : il. ; 15x21,5 cm. ISBN: No ISBN. Depósito legal: B. 9170-1988. Palabras clave: fundamentos teóricos, fundamentos técnicos, kyusho, armas. Resumen: Manual teórico y técnico de ninjutsu. El libro esta formado por 21 capítulos precedidos por una dedicatoria y un prefacio que comenta los objetivos de la obra. El primer capítulo localiza los puntos vitales del cuerpo humano, mientras que el segundo ilustra el organigrama del entrenamiento sin armas. El tercer capítulo ilustra los golpes de puño. El cuarto capítulo presenta distintos ejercicios de calentamiento, flexibilidad, elasticidad y acrobacias acompañados de su representación gráfica. Los siguientes cuatro capítulos enumeran e ilustran las principales técnicas de taihen-jutsu (posiciones), soku-yaku (técnicas de piernas), dakentai-jutsu (métodos de golpeo) y shime-waza (estrangulaciones). El noveno capítulo comenta el entrenamiento de la kunoichi además de presentar una breve descripción e ilustración de distintas técnicas de ha-jutsu (escapes). El décimo capítulo comenta la estructura y características del hanbo junto con la descripción y representación gráfica de algunas de sus técnicas. El capítulo decimoprimero presenta varias técnicas de bo-jutsu mientras que el siguiente capítulo comenta el entrenamiento de tanto-jutsu e incluye la ilustración de algunas de sus técnicas. El capítulo decimotercero comenta las características de la espada del ninja y muestra diversas técnicas de iaido. Los dos siguientes capítulos presentan la secuencia fotográfica de varias técnicas de kusarifundo contra el ataque con katana y la defensa personal a mano vacía contra una amenaza de pistola. El decimosexto capítulo comenta los contenidos técnicos del entrenamiento de gotonpo (entrenamiento en la naturaleza) incluyendo algunas ilustraciones explicativas. El decimoséptimo capítulo muestra algunas técnicas de inton-jutsu. El siguiente capítulo expone las características del shuriken y su entrenamiento acompañado de la ilustración de algunas de sus técnicas. El decimonoveno capítulo muestra las principales técnicas de kuji-kiri mientras que el siguiente capítulo comenta los principios del entrenamiento del ninja. El último capítulo explica las técnicas de supervivencia del ninja como son la construcción de una tienda, el dominio del fuego, la alimentación y la calefacción, el agua, la creación de trampas, las señales de auxilio, la construcción de métodos de orientación, como seguir una ruta, la marcha y las técnicas de rapel.

591. Kim, Ashida (1992). Técnicas mentales ninja. Barcelona: Martínez Roca. 1aㅡ ed. 147 p. : il. ; 14×21,5 cm. ISBN: 84-270-1603-4. Depósito legal: B. 6544-1992. Palabras clave: katas, fundamentos teóricos, fundamentos técnicos, filosofía, ejercicios, textos, medicina, maestros. Resumen: Manual teórico y técnico de ninjutsu. La obra esta dividida en 9 capítulos, precedidos de una introducción que comenta los objetivos del libro y los beneficios de los ejercicios mostrados. El primer capítulo estudia los requisitos y características para convertirse en un buen ninja. El segundo capítulo presenta un extracto 
del texto de medicina titulado Nei Ching sobre la medicina china para en el tercer capítulo explicar en que consisten las técnicas de chi kung y algunos consejos para su práctica. El cuarto capítulo profundiza en el significado de los nueve niveles de poder del kuji-kiri adjuntando la ilustración de cada uno de ellos y describe los pasos en el aprendizaje de los mismos. El quinto capítulo desarrolla la teoría de los cinco elementos comentando las propiedades de cada uno de ellos y describiendo su ejecución técnica. El sexto capítulo expone tres ejemplos del control del cuerpo que debe desarrollar el ninja como son el control del cuerpo, el tameshiwara (arte de la fracturación) y la garra de dragón. El séptimo capítulo comenta en qué consiste, cuáles son los objetivos y cómo se ponen en práctica las capacidades mentales del ninja como son la lectura de la mente, la hipnosis, la sugestión, el requerimiento, el control de opciones y la hipnosis en combate. El octavo capítulo comienza explicando el significado de la kata y los principios técnicos que deben considerarse durante su realización para luego exponer las características de los cinco principios básicos de la forma del camino perdido (mi lu kata) y describir e ilustrar sus movimientos y su aplicación. El último capítulo comenta los fundamentos de los maestros ocultos, su papel en el entrenamiento y el ejercicio más básico para comunicarse con ellos. El epílogo resume las características del ninja.

592. Lee, San (1998). Ninja. Madrid: Edimat. 1aㅡ ed. 188 p. : il. ; 14x21 cm. ISBN: 84-8403-110-1. Depósito legal: no.

593. Lee, San (1999). El libro de oro del ninja II. Arganda del Rey: Edimat. 1ae ed. 190 p. : il. ; $13 \times 21$ cm. ISBN: 84-8403-089-X. Depósito legal: M. 25287-1999. Palabras clave: historia, fundamentos teóricos, fundamentos técnicos, principios teóricos, entrenamiento, estrategia, táctica, ninjutsu, escuelas, fitoterapia, armas. Resumen: Manual teórico y técnico de ninjutsu. El libro esta formado por 18 capítulos. El primer capítulo comenta la finalidad del ninjutsu según Takamatsu. El segundo capítulo expone la entrevista realizada al maestro Bo F. Munthe en su visita a España sobre su comienzo en las artes marciales, aspectos generales del ninjutsu y la finalidad de su visita. El tercer capítulo comenta el origen de la escuela Togakure, las metas y fases del entrenamiento de ninjutsu, el papel del soke y la comunidad de practicantes, el refinamiento técnico y táctico a través del tiempo con un ejemplo de algunos ejercicios del estado de iluminación y describe e ilustra las posturas tradicionales de guardia y la forma de andar del ninja. Los dos siguientes capítulos exponen las características, objetivos, principios y formas de entrenamiento del método defensivo y el entrenamiento efectivo del ninjutsu. El sexto capítulo expone los principios del entrenamiento ninja y la táctica en el combate y describe el ataque a un centinela, la importancia de la voz y la tríada de conocimiento, intención y acción para el éxito en el combate. El siguiente capítulo expone la utilización de hierbas y plantas para curar enfermedades y los efectos de ciertos venenos naturales. Continua con el estudio del arte de la invisibilidad y cuáles son los métodos, disfraces e identidades para pasar desapercibido así como varios ejercicios para practicarlo. El noveno capítulo presenta algunas de las armas que utiliza el ninja para en los siguientes capítulos profundizar en las características y utilización de la cerbatana, los shuriken, el ninja to (espada tradicional ninja), el tumi (pequeño arco), la kusarigama (cadena y hoz), los shukos (garfios), el hambo (palo) y el shinobi zue, junto con varias técnicas de aplicación de cada una de ellas. El último capítulo explica las 4 fases para progresar en las técnicas de golpeo (dakentai) e incluye varias fotografías y gráficos explicativos.

594. Levy, Joel (2008). Ninja, el guerrero sombra. Madrid: Paraninfo Cengage Learning. $1 \underline{\underline{a}}$ ed. 208 p. : il. ; 16x24 cm. ISBN: 978-84-283-3027-5. Depósito legal: no. Palabras clave: historia, fundamentos teóricos, táctica, principios técnicos, entrenamiento, relatos, equipamiento, armas. Resumen: Tratado teórico de ninjutsu. El libro esta formado por cinco capítulos precedidos de una introducción que aclara el significado de la palabra ninja y su diferencia con el samurái, y un cronograma de Japón. El primer capítulo relata el origen de los ninja, el establecimiento de las ryu y la evolución histórica del papel del ninja en las guerras del Japón. El segundo capítulo describe las características y utilización del equipamiento del ninja, desde las armas hasta las herramientas. El tercer capítulo explica la educación recibida por un ninja, las disciplinas que componen el ninjutsu moderno, describe el tipo de entrenamiento físico y sus distintos métodos, la preparación psicológica y los principales fundamentos técnicos como son los puñetazos y posturas. El cuarto capítulo presenta la jerarquía de los ninja, el funcionamiento de una operación ninja, sus principios técnicos y tácticos, las tácticas utilizadas para infiltrarse en un castillo y las características de la arquitectura ninja. El último capítulo incluye varias historias sobre ninjas, expone la evolución del fenómeno cultural ninja y discute la existencia de los ninja a través de las controversias surgidas de la historia japonesa. Adjunta un epílogo, un glosario, bibliografía e índice.

595. López Crespo, Juan Antonio (1986). Ninja : historia y técnicas de los guerrilleros feudales. Barcelona: Alas. 1a ed. 95 p. : il. ; 15x21,5 cm. ISBN: 84-203-0194-9. Depósito legal: B. 22717-1986. Palabras clave: historia, fundamentos teóricos, fundamentos técnicos, entrenamiento, kyusho. Resumen: Manual teórico y técnico de ninjutsu. El libro esta compuesto por 5 capítulos. El primer capítulo analiza los kanji del ninja y explica su historia y características como guerrero. El segundo capítulo comenta la interrelación entre el aspecto religioso, marcial y político para la formación del ninja. El tercer capítulo 
enumera y localiza los puntos vitales del cuerpo humano y describe brevemente su manipulación. El cuarto capítulo explica la formación teórica, técnica y el método de entrenamiento que seguían los practicantes para convertirse en ninjas, para en el quinto capítulo clasificar los contenidos técnicos del ninjutsu, las disciplinas practicadas, describir e ilustrar algunas de sus técnicas (ataques desarmados, defensa contra cuchillo, ataque usando la funda del sable, defensa a manos limpias contra sable, nociones de kenjutsu, técnicas de percusión y derivas de ataques, bojutsu y cuchillo mariposa).

596. Martín Alarcón, Pedro (1995). Bujinkan ninpo taijutsu : sistema de graduación de 10o a 1er kyu. Málaga: Asociación Daysu. 1aㅡ ed. 184 p. : il. ; 14x21 cm. ISBN: 84-605-5327-2. Depósito legal: MA. 539-1995.

Palabras clave: historia, fundamentos teóricos, fundamentos técnicos, principios técnicos. Resumen: Manual teórico y técnico de ninjutsu. El libro esta compuesto por 26 capítulos precedidos por una introducción que comenta el estudio del ninpo taijutsu. El primer capítulo explica en qué consiste el ninpo taijutsu además de señalar sus beneficios. El segundo capítulo narra los orígenes del arte mientras que el tercero detalla sus normas de cortesía y etiqueta. El cuarto capítulo expone el significado y características del dojo. El quinto capítulo presenta el sistema de grados y su significado. Los dos siguientes capítulos enumeran los fundamentos técnicos que componen el trabajo sin armas y con armas del bujinkan ninpo. El octavo capítulo detalla los principios técnicos para el examen de grados kyu. Los siguientes nueve capítulos enumeran las técnicas que componen los exámenes de grado desde 9 o hasta 1er kyu. El decimoctavo capítulo describe las posturas que integran la kamae no kata además de incluir su representación gráfica. Los dos siguientes capítulos explican los principios técnicos de las posiciones y desplazamientos. Los dos siguientes capítulos nombran e ilustran las técnicas de luxación y proyección del ninpo taijutsu. Los últimos cuatro capítulos ilustran y describen brevemente la ejecución del kihon jo jutsu, kihon tanbo jutsu, kihon tanto jutsu y kihon kama jutsu. Adjunta un glosario específico.

597. Martín Alarcón, Pedro (2005). Gyokko ryu kosshi jutsu. Málaga: Asociación Deportiva y Cultural CLUB DAYSU. $1 \underline{a}$ ed. 178 p. : il. ; 14x21 cm. ISBN: No ISBN. Depósito legal: no. Palabras clave: katas, historia, fundamentos teóricos, fundamentos técnicos, principios técnicos, kyusho. Resumen: Manual teórico y técnico de ninjutsu. El libro esta formado por 23 capítulos precedidos por una introducción que comenta las características y beneficios de las artes Bujinkan y un preámbulo que señala las 9 tradicionales marciales del maestro Hatsumi. Los dos primeros capítulos narran los orígenes de las escuelas del ojo del tigre y la escuela joya del tigre. El tercer capítulo comenta la relación entre el budo y el zen. El cuarto capítulo describe la estructura de la escuela. El quinto capítulo expone las características del acondicionamiento físico. Los dos siguientes capítulos describen los principios y fundamentos técnicos de las guardias y desplazamientos. El octavo capítulo explica la forma de atacar los puntos y huesos del cuerpo. Los siguientes cinco capítulos describen brevemente las formas básicas, formas de despertar las presas, la forma de las ocho bases y el arte de la movilidad. Los siguientes tres capítulos exponen los principios técnicos de las técnicas de proyección, los desequilibrios y las caídas. El decimoséptimo capítulo enumera las técnicas que componen el arte de proyectar de la escuela Gyokko. El decimoctavo capítulo detalla el significado de las tres estrategias que componen el kosshijutsu de la gyokko ryu. Los siguientes tres capítulos explican la ejecución de las técnicas que componen las estrategias secretas de jo ryaku no maki juni gata, chu ryaku no maki hachi gata y ge ryaku no maki hachi gata. El vigésimo segundo capítulo expone los fundamentos teóricos de la manipulación de los puntos vitales además de nombrar, localizar y explicar los efectos de su golpeo. El último capítulo presenta los principales rituales y simbología del budo.

598. Martín Alarcón, Pedro (2005). Koto ryu koppo jutsu : el arte de los métodos de los huesos de la Escuela del Tigre Derribado. Málaga: Asociación Deportiva y Cultural CLUB DAYSU. 1ae ed. 186 p. : il. ; 14x21 cm. ISBN: No ISBN. Depósito legal: no. Palabras clave: katas, historia, fundamentos teóricos, fundamentos técnicos, principios técnicos, kyusho. Resumen: Manual teórico y técnico de ninjutsu. El libro esta formado por 25 capítulos precedidos por un prólogo que señala los beneficios de la práctica de artes marciales. Los dos primeros capítulos describen los orígenes de la escuela koto ryu y su genealogía. El tercer capítulo enumera su estructura técnica. El cuarto capítulo señala la importancia del acondicionamiento físico mientras que el quinto comenta los objetivos, tipos y principios del calentamiento. El sexto capítulo describe las distintas formas de caminar del ninjutsu. El séptimo capítulo detalla los principios técnicos de los golpeos y sus tipos. El octavo capítulo describe la ejecución de las principales técnicas de golpeo de la koto ryu. El noveno capítulo enumera las técnicas incluidas en la tori gata no daiji. El décimo capítulo explica los principios técnicos de los golpeos. El siguiente capítulo presenta los contenidos y técnicas que componen el taihenjutsu. Los siguientes cinco capítulos explican los principios técnicos de las posiciones, los desplazamientos, las técnicas de proyección, los desequilibrios y las caídas. El decimoséptimo capítulo enumera los contenidos del nage jutsu. Los siguientes cinco capítulos describen las técnicas que componen la shoden no kata juhachi gata, hekito no kata hachi gata, chuden no kata juni gata, okuden no kata juni gata y kaiden no kata juni gata. El capítulo vigésimo tercero expone los fundamentos teóricos de la manipulación de los puntos 
vitales además de nombrar, localizar y explicar los efectos de su golpeo. Los dos últimos capítulos comentan el entrenamiento en la oscuridad y los principios técnicos del entrenamiento avanzado.

599. Martín Alarcón, Pedro (2009). Ninjutsu budo : leyenda, tradición e historia. Málaga: Asociación Daysu. 1a ed. 132 p. : il. ; 14×21 cm. ISBN: No ISBN. Depósito legal: no. Palabras clave: historia, fundamentos teóricos, principios técnicos, vestimenta, cortesía, etiqueta. Resumen: Manual teórico y técnico de ninjutsu. El libro esta compuesto por 17 capítulos precedidos por una introducción que comenta la relación maestro-alumno y el proceso de enseñanza-aprendizaje en el budo taijutsu. El primer capítulo define brevemente el ninjutsu mientras que el segundo relata su origen. El tercer capítulo expone los fundamentos teóricos y principios técnicos del ninjutsu. El cuarto capítulo describe la vestimenta utilizada por los ninjas. Los dos siguientes capítulos describen las características del dojo además de las reglas de cortesía y etiqueta. El séptimo capítulo expone el sistema de grados, describe su ceremonial y el significado de los cinturones. Los siguientes tres capítulos describen los principios físicos, fisiológicos, psicológicos y la relación cuerpo-mente-espíritu. El capítulo decimoprimero explica los principios técnicos del ninjutsu. El decimosegundo capítulo señala los distintos tipos de atemi y los factores que influyen en su eficacia. El capítulo decimotercero comenta las características del ninjutsu. Los dos siguientes capítulos describen la utilización del kiai y los puntos vitales. El decimosexto capítulo detalla los distintos métodos de respiración así como algunos ejercicios para su desarrollo. El último capítulo reflexiona sobre la capacidad de intuición del ninja.

600. Pérez Agustí, Adolfo (1986). El libro de oro del ninja. Madrid: Adolfo Pérez Agustí. 1a ed. 181 p. : il. ; 15x21,5 cm. ISBN: 84-398-6587-2. Depósito legal: M. 15548-1986. Palabras clave: historia, fundamentos teóricos, fundamentos técnicos, principios técnicos, estrategia, escuelas, samurái, armas. Resumen: Manual teórico y técnico de ninjutsu. El libro esta formado por 22 capítulos precedidos por una introducción que explica los objetivos y entrenamiento del ninja. El primer capítulo enumera las distintas escuelas de ninjutsu mientras que el segundo presenta al maestro Masaaki Hatsumi e incluye una entrevista. El tercer capítulo describe e ilustra las distintas posturas de kamae. El cuarto capítulo explica la comprensión del enemigo utilizada por el ninja. El quinto capítulo expone algunas de las estrategias utilizadas por el ninja. El sexto capítulo detalla las tácticas de espionaje. El séptimo capítulo describe las técnicas básicas de penetración en el campamento enemigo. El octavo capítulo comenta algunos de los trucos utilizados por el ninja para no ser descubierto. El noveno capítulo comenta las características de las kunoichi, su preparación marcial, sus armas y sus obligaciones. El décimo capítulo expone la representación, significado y utilización de los kuji-kiri. El capítulo decimoprimero comenta las características de las armas del cuerpo utilizadas para golpear. El decimosegundo capítulo presenta la figura de Sho Kosugi como experto luchador. El capítulo decimotercero incluye la secuencia fotográfica de varias técnicas sin armas (dakentai). El decimocuarto capítulo detalla las diferentes técnicas de esconderse y aprovechar la naturaleza utilizadas por el ninja (gotompo). Los dos siguientes describen e ilustran la estructura de las armas básicas y especiales del ninja además de comentar brevemente su historia. El decimoséptimo capítulo incluye la secuencia fotográfica de algunas de las técnicas de espada del ninjutsu. Los siguientes cuatro capítulos ilustran diversas técnicas con shuriken, hambo, tanto y kusarigama. El último capítulo describe los ejercicios de los cinco elementos.

601. Pérez Agustí, Adolfo (1987). El libro de oro del Ninja II. Madrid: Adolfo Pérez Agustí. 1aㅡ ed. 190 p. ; 15x21 cm. ISBN: 84-398-8751-5. Depósito legal: no. Palabras clave: historia, fundamentos teóricos, fundamentos técnicos, principios teóricos, entrenamiento, estrategia, táctica, ninjutsu, escuelas, fitoterapia, armas. Resumen: Manual teórico y técnico de ninjutsu. El libro esta formado por 18 capítulos. El primer capítulo comenta la finalidad del ninjutsu según Takamatsu. El segundo capítulo expone la entrevista realizada al maestro Bo F. Munthe en su visita a España sobre su comienzo en las artes marciales, aspectos generales del ninjutsu y la finalidad de su visita. El tercer capítulo comenta el origen de la escuela Togakure, las metas y fases del entrenamiento de ninjutsu, el papel del soke y la comunidad de practicantes, el refinamiento técnico y táctico a través del tiempo con un ejemplo de algunos ejercicios del estado de iluminación y describe e ilustra las posturas tradicionales de guardia y la forma de andar del ninja. Los dos siguientes capítulos exponen las características, objetivos, principios y formas de entrenamiento del método defensivo y el entrenamiento efectivo del ninjutsu. El sexto capítulo expone los principios del entrenamiento ninja y la táctica en el combate y describe el ataque a un centinela, la importancia de la voz y la tríada de conocimiento, intención y acción para el éxito en el combate. El siguiente capítulo expone la utilización de hierbas y plantas para curar enfermedades y los efectos de ciertos venenos naturales. Continua con el estudio del arte de la invisibilidad y cuáles son los métodos, disfraces e identidades para pasar desapercibido así como varios ejercicios para practicarlo. El noveno capítulo presenta algunas de las armas que utiliza el ninja para en los siguientes capítulos profundizar en las características y utilización de la cerbatana, los shuriken, el ninja to (espada tradicional ninja), el tumi (pequeño arco), la kusarigama (cadena y hoz), los shukos (garfios), el hambo (palo) y el shinobi zue, junto con varias técnicas de aplicación de cada una de ellas. El último capítulo explica las 4 fases para progresar en las técnicas de golpeo (dakentai) e incluye varias fotografías y gráficos explicativos. 
602. Pérez Agustí, Adolfo (2008). El manejo de las armas ninja. Madrid: Masters. 1aㅡ ed. 217 p. : il. ; $16 \times 23$ cm. ISBN: 978-84-96319-65-3. Depósito legal: M. 18691-2008. Palabras clave: historia, fundamentos técnicos, principios técnicos, armas. Resumen: Manual teórico y técnico de ninjutsu. El libro esta formado por 4 capítulos precedidos por una introducción que señala las ventajas del ninjutsu. El primer capítulo discute el origen de las artes marciales, describe las características técnicas del ninjutsu y sus armas, y comenta su aparición en el cine y la televisión. El segundo capítulo relata la historia del ninjutsu junto con la biografía de algunos ninjas famosos. El tercer capítulo comenta los contenidos técnicos del ninjutsu, las habilidades especiales del ninja y expone los principios técnicos del arte de la invisibilidad, el sigilo, la invulnerabilidad y el camuflaje. El último capítulo describe la estructura, características, utilidad y manejo de las armas del ninja clasificadas en espadas, garras, armas arrojadizas, bastones, bastones articulados, armas de enganche, armas punzantes, cadenas, armas de hoja y hoz, pinchos, arcos y armas arrojadizas, otras armas menos conocidas y armas de las kunoichi, acompañados de numerosas ilustraciones y la secuencia fotográfica de algunas de sus técnicas. Adjunta la secuencia fotográfica de distintas técnicas.

603. Planellas Vidal, Pau-Ramon (1988). Ninjutsu-no-sho : el arte secreto. Barcelona: Alas. $1^{\mathrm{a}}$ ed. 152 p. : il. ; 15x21 cm. ISBN: 84-203-0217-1. Depósito legal: B. 11883-1988. Palabras clave: historia, fundamentos técnicos, vestimenta, escuelas, fundamentos filosóficos, armas. Resumen: Manual teórico y técnico de ninjutsu. El libro esta formado por 18 capítulos precedidos por una introducción que comenta los objetivos de la obra. El primer capítulo analiza la terminología japonesa y el significado del término ninjutsu. El segundo capítulo narra la historia del ninjutsu y su evolución. El tercer capítulo enumera las diferentes escuelas de ninjutsu y sus fundadores. El cuarto capítulo expone los fundamentos filosóficos del ninjutsu. El quinto capítulo describe la vestimenta utilizada por el ninja en distintas situaciones. El sexto capítulo explica en qué consiste el taijutsu y cuáles son sus contenidos técnicos acompañadas de varias ilustraciones explicativas. El séptimo capítulo describe las técnicas de caídas, rodamientos y volteretas junto con la secuencia fotográfica de algunas de sus técnicas. El octavo capítulo clasifica las armas utilizadas por el ninja para luego describir las características, estructura y utilización de las principales armas y utensilios del ninja como son el ninja-to, hanbo, tanto, yari, kusari-fundo, shinobi-nawa, shuriken-jutsu, fukiya, yumi y shuko junto con diversas fotografías explicativas de sus técnicas. Adjunta un diccionario específico y un epílogo.

604. Rojas Torres, Pedro (1987). Ninjutsu : el arte supremo. noveno, octavo y séptimo kyu. Malgrat de Mar (Barcelona): Asociación Española de Ninjutsu. 1aㅡ ed. 84 p. : il. ; 16×24 cm. ISBN: No ISBN. Depósito legal: GI. 64-1987. Palabras clave: historia, fundamentos técnicos, formas. Resumen: Manual teórico y técnico de ninjutsu. El libro esta formado por 7 capítulos precedidos por una dedicatoria, los agradecimientos, un prólogo que comenta los méritos profesionales del autor y una introducción que señala la formación del autor en ninjutsu. El primer capítulo define el ninjutsu y explica brevemente su historia. El segundo capítulo incluye una tabla cronológica del ninjutsu en Europa. El tercer capítulo presenta el uniforme y las graduaciones del ninjutsu. El cuarto capítulo describe brevemente la ejecución de las técnicas de taihen jutsu como son los ukemis, los desplazamientos (ninja aruki) y la forma de las posiciones (kamae no kata) acompañadas de su secuencia fotográfica. El quinto capítulo ilustra las principales técnicas de daken tai jutsu además de incluir la secuencia fotográfica de la san shin no kata y koshi kihon san po no kata. El sexto capítulo incluye numerosas fotografías de las visitas de diferentes maestros y los cursos realizados, mientras que el último presenta los diplomas conseguidos por el autor.

605. Rosuro Sensei y Pérez Agustí, Adolfo (2006). El arte secreto del ninja. Madrid: Masters. 1a ed. 197 p. : il.; 14x21 cm. ISBN: 84-96319-46-6. Depósito legal: B. 3407-2006. Palabras clave: historia, fundamentos técnicos, estrategia, táctica, ninjutsu. Resumen: Tratado técnico de introducción al ninjutsu. El libro esta formado por 8 capítulos. Después de dedicar el primer capítulo a la historia del arte marcial desde sus orígenes hasta sus maestros y escuelas, el segundo capítulo explica brevemente los fundamentos técnicos (guardias y armas del cuerpo). El tercer capítulo presenta los orígenes, características y obligaciones de la kunoichi (mujer ninja). El cuarto capítulo profundiza en las técnicas superiores como el kuji kiri o la invisibilidad, esto es, los sonidos y gestos utilizados para conseguir realidad vibratoria, y las artes para escapar, esconderse y disfrazarse (invisibilidad). El quinto capítulo describe las estrategias psicológicas que utilizaba el ninja para conseguir engañar al enemigo y derrotarlo; además analiza las acciones específicas de espionaje, infiltración, penetración y trucos. El siguiente capítulo expone someramente algunas de las técnicas que utilizaba el ninja para aprovechar los elementos de la naturaleza para esconderse. A continuación ofrece una descripción de las armas y accesorios que utilizaba el ninja así como su historia y modo de utilización. El último capítulo describe el entrenamiento técnico y táctico, y las consideraciones generales que debe adoptar el practicante.

606. Ruy-San (seud. de Mendoza, Ruy San de) (1985). Ninjas : arte secreta. Historia, arte, tradición y técnica de los ninjas de Japón. Madrid: Esteban Sanz Martínez. 1ae ed. 233 p. : il. ; 14x20,5 cm. ISBN: 84-8597724-6. Depósito legal: M. 34513-1985. Palabras clave: historia, fundamentos técnicos, instituciones, maestros. Resumen: Manual teórico y técnico de ninjutsu. La obra esta compuesta por 10 capítulos. El 
primer capítulo narra la llegada del autor a Japón y su contacto con el maestro Hatsumi. El segundo capítulo relata la historia del ninjutsu, sus familias y linaje hasta la actualidad. El tercer capítulo describe varias armas ninja, para luego ilustrar las posturas de base, las posturas defensivas y las posturas de ataque del ninjutsu. El quinto capítulo ilustra las distintas técnicas de combate sin armas, desde las caídas y saltos hasta las técnicas de manos, de puntapié, presión en los puntos vitales, técnicas de retorno y luxaciones. El sexto capítulo localiza gráficamente los puntos vitales del cuerpo humano incluyendo su nombre japonés. El séptimo capítulo detalla los ryus estudiados por el nimpo hasta formar los contenidos del ninjutsu, explicando dichos contenidos. El octavo capítulo presenta imágenes de algunas de las proezas de los ninjas para continuar con el relato de una historia sobre las capacidades del ninja, imágenes del museo Yuma-Mura que perpetúa la existencia de los ninjas en Japón, sus contenidos, fotografías del autor y otros instructores, algunas técnicas especiales y la colección de libros dedicados al ninjutsu por el autor. El último capítulo describe los contenidos que se incluirán en los 9 volúmenes sobre el ninjutsu Tokagure. Adjunta un glosario.

607. Ruy-San (seud. de Mendoza, Ruy San de) (1987). Ninjas : tanto. Madrid: Samurái. 1a ed. 92 p. : il. ; 15x21 cm. ISBN: No ISBN. Depósito legal: M. 8681-1987. Palabras clave: fundamentos teóricos, fundamentos técnicos, armas. Resumen: Manual teórico y técnico de ninjutsu. El libro esta formado por 9 capítulos precedidos por una introducción que comenta los objetivos de la obra y la filosofía del ninjutsu. El primer capítulo incluye algunas reflexiones del autor sobre su propia vida. El segundo capítulo comenta la historia del cuchillo y su utilización en Japón. El tercer capítulo presenta el combate de sangre en Brasil además de ilustrar algunas fundas para portarlo. El cuarto capítulo detalla la utilización del cuchillo por parte de los comandos o fuerzas especiales incluyendo varias ilustraciones. El quinto capítulo expone la historia y características del cuchillo bali-song de Filipinas. El sexto capítulo comenta las formas básicas de entrenamiento con el tanto shinobi además de ilustrar sus fundamentos técnicos. El séptimo capítulo enumera algunas de las consideraciones prácticas para desarrollar el entrenamiento con cuchillos reales e ilustra diversas técnicas de aplicación práctica. El octavo capítulo ilustra algunas de las técnicas empleadas por las kunoichi con el tanto. El noveno capítulo incluye algunas de las aportaciones del maestro Hatsumi al ninjutsu junto con algunas de sus fotografías. Adjunta varios anexos con los programas técnicos de la Bujinkan Ninja Society que incluyen la representación gráfica de sus técnicas. También adjunta información sobre las publicaciones y videos de la editorial Samurái Producciones.

608. s.a. (2005). Nueva guía Shidoshikai : guía completa de la Bujinkan Dôjô. España y América Latina. Barcelona: Shinden. $1^{\mathrm{a}}$ ed. 41 p. : il. ; $12 \times 17$ cm. ISBN: No ISBN. Depósito legal: B. 40412-2005. Palabras clave: vestimenta, cortesía, ninjutsu, escuelas, clubes, etiqueta, instalaciones, instituciones. Resumen: Guía informativa de la asociación shidoshikai. El libro esta dividido en 5 capítulos. El primer capítulo expone el objetivo y escuelas de la Bujinkan Dojo, la biografía de los maestros Takamatsu y Hatsumi, la estructura y organización del bushinden, sus reglas de comportamiento, guías de participación, las características de los certificados y licencias expedidos por la Bujinkan Dojo acompañados por su ilustración y su sistema de grados. El segundo capítulo presenta un listado con los datos de los miembros de la shidoshikai divididos por comunidades autónomas. EL tercer capítulo incluye el calendario de actividades de la asociación para el año 2005. El cuarto capítulo muestra los datos de contacto de los miembros de la Bujinkan Dojo. El último capítulo presenta la propaganda de los establecimientos especializados en material relacionado con la asociación.

609. Thelen, Yves (1989). Ninja : los samuráis de la sombra. Barcelona: Martínez Roca. $1 \underline{\text { a }}$ ed. 184 p. : il. ; 14x21,5 cm. ISBN: 84-270-1317-5. Depósito legal: B. 18154-1989. Palabras clave: historia, fundamentos técnicos, principios técnicos, fundamentos filosóficos. Resumen: Manual teórico y técnico de ninjutsu. El libro esta formado por 4 capítulos precedidos por una introducción que comenta las características del ninjutsu y un glosario de términos japoneses. El primer capítulo narra los orígenes del ninjutsu, comenta las diferentes escuelas y sus contenidos técnicos, señala los principios esenciales del ninjutsu, explica el significa del dojo y ofrece varios consejos sobre el entrenamiento. El segundo capítulo explica en qué consiste el atemi jutsu, presenta los principales fundamentos técnicos del kárate, detalla el trabajo de kihon, el arte de la proyección, la inmovilización, la luxación, los pellizcos y la estrangulación junto con la clasificación de sus fundamentos técnicos, expone los principios técnicos del entrenamiento con armas, comenta las características del entrenamiento con shuriken, el arte de la invisibilidad, las técnicas de escalada y descenso en rappel, y el nadador de combate acompañados de numerosas ilustraciones explicativas. El tercer capítulo comenta las cualidades del ninja como son el dominio de sí mismo, la meditación, el vacío mental y el sexto sentido. El último capítulo expone los fundamentos filosóficos del ninjutsu, analizando el lenguaje, el yo y el vacío, y la relación del zen con el budo y el ninjutsu, y discute el futuro del ninjutsu. Adjunta bibliografía.

\subsubsection{Sumo}


610. Paz Gútiez, Eduardo de (2006). Sumo : la lucha de los dioses. Barcelona: Shinden. $1^{a}$ ed. 165 p. : il. ; $18 \times 26$ cm. ISBN: 84-933469-5-0. Depósito legal: B. 18352-2006. Palabras clave: historia, fundamentos teóricos, entrenamiento, competición, reglamentos. Resumen: Tratado histórico y técnico sobre el sumo. El primer capítulo centra su atención en la historia y evolución del sumo hasta la actualidad. El segundo profundiza en los gimnasios de sumo, cómo es la vida en ellos, cuáles son las actividades que realizan los sumotoris y cómo se puede visitar este lugar y dónde se encuentran. El tercer capítulo relata el desarrollo y organización de una competición y una exhibición de sumo. El siguiente capítulo expone la organización de la Nihon Sumo Kyokai, su personal y cuáles son sus tareas. El quinto capítulo describe las formas de vida tras la retirada de los sumotoris de la competición. El sexto capítulo lista a los campeones de sumo de todos los tiempos haciendo especial hincapié sobre los yokozuna modernos y cómo se endurecieron las normas para acceder a éste grado. El siguiente capítulo describe las técnicas permitidas y prohibidas dentro de la competición, para finalizar con la exposición de la expansión del sumo en otros países con la ayuda de los medios de comunicación e internet. Adjunta un glosario de términos y bibliografía.

\subsubsection{Taijutsu y Yawarajutsu}

611. Federación Española de Lucha, Departamento Nacional de Yawara-jitsu (197-). Vademecum del yawaraka. Madrid: Federación Española de Lucha. $1^{a}$ ed. 40 p. : il. ; 12x17 cm. ISBN: No ISBN. Depósito legal: no. Palabras clave: historia, fundamentos teóricos, fundamentos técnicos, programa técnico. Resumen: Manual teórico y técnico de yawara-jitsu. El libro esta formado por tres capítulos, precedidos por una tabla para apuntar los grados conseguidos. El primer capítulo expone las características del uniforme de entrenamiento para luego relatar la historia del yawara-jitsu. El tercer capítulo incluye los programas de contenidos por cinturones junto con un breve diccionario y los títulos de enseñanza. Adjunta dos apéndices con la secuencia fotográfica de las cinco katas básicas y la kata yawara respectivamente.

612. Fraga, José Luis (1988). Mi método de tai jitsu : técnica y entrenamiento de cinturón blanco al verde. Manual oficial de la Yoseikan. Barcelona: Alas. 1a ed. 156 p. : il.; 15x21,5 cm. ISBN: 84-203-0221-X. Depósito legal: B. 20904-1988. Palabras clave: katas, fundamentos teóricos, armas, fundamentos técnicos, principios técnicos, biomecánica, cortesía, kyusho, zen, instalaciones, meditación. Resumen: Manual teórico y técnico de tai-jitsu. El libro esta formado por 25 capítulos precedidos por un prólogo que comenta las características del tai-jitsu yoseikan. El primer capítulo expone los principios técnicos del tai-jitsu. Los dos siguientes capítulos detallan la estructura del dojo y sus reglamentos. El cuarto capítulo describe la ejecución de las dos formas de saludar acompañadas de su representación gráfica. El quinto capítulo explica en qué consiste el método zazen y describe su ejecución técnica. El sexto capítulo localiza los puntos vitales del cuerpo humano y comenta los efectos de su manipulación. El séptimo capítulo presenta las distintas zonas utilizadas para golpear en el tai-jitsu junto con su representación gráfica. El octavo capítulo describe la ejecución de las distintas formas de caer junto con sus ilustraciones explicativas. Los dos siguientes capítulos describen la ejecución de las posiciones fundamentales y guardias acompañadas de sus fotografías correspondientes. El décimo primer capítulo explica la estabilidad y equilibrio de las posiciones de tai-jitsu además de sus movimientos de compensación. Los dos siguientes capítulos describen los diferentes tipos de desplazamientos y el taisabaki junto con sus esquemas de movimiento e ilustraciones. El décimo cuarto capítulo detalla la importancia y utilización del giro de la cadera en las técnicas de golpeo para luego describir e ilustrar las principales técnicas de defensa. El décimo sexto capítulo detalla el proceso de la respiración, sus funciones y propone varios de sus ejercicios. Los dos siguientes capítulos exponen los principios técnicos y ejecución de los puñetazos y patadas básicos del tai-jitsu acompañados de su ilustración. El décimo noveno capítulo enumera los principios técnicos de los cuatro métodos para resolver los agarres. El vigésimo capítulo presenta los contenidos técnicos del tai-jitsu para en los siguientes tres capítulos describir e ilustrar la ejecución de las defensas por atemi, luxación y proyección ante los agarres los ocho tipos distintos de agarres de muñeca incluyendo su secuencia fotográfica. El vigésimo cuarto capítulo explica el significado de las katas, enumera sus principios técnicos y las katas del taijitsu además de comentar las generalidades, objetivos y movimientos de las dos primeras katas acompañadas de su secuencia fotográfica. El último capítulo expone los efectos físicos y psíquicos del kiai, su utilización en las artes marciales, su fisiología y los factores que influyen en su efectividad.

613. Muñiz González, Joaquín (2004). Tai-jitsu defensa personal : Metodología técnica y pedagogía didáctica. Programa de cinturón negro por grados (Volumen 1). Oviedo: Club Tai-Jitsu Asturias. 1aㅡ ed. 477 p. : il. ; 17x24 cm. ISBN: 84-607-9855-0 (Del Volumen 1). Depósito legal: AS. 98-2004. Palabras clave: historia, fundamentos técnicos, didáctica, entrenamiento, unidades didácticas. Resumen: Manual técnico de tai-jitsu. El libro esta dividido en 5 partes, con la primera de ellas abordando la historia y contextualización del mismo. La segunda parte explica sus principios de entrenamiento y enseñanza 
así como el protocolo y vestimenta. La tercera parte, después de estructurar la práctica del tai-jitsu y describir los contenidos técnicos, pasa a descomponer sus contenidos en grados o cinturones. Así, explica las técnicas de cada grado con una secuencia gráfica y un breve comentario. La cuarta parte aborda la normativa de exámenes, la clasificación de los contenidos técnicos y la formalización de la competición, desde su historia y justificación hasta su actuación pedagógica o el papel de los padres. La última parte esta compuesta por el desarrollo de una unidad didáctica de tai-jitsu y el vocabulario. Adjunta bibliografía y una biografía del autor.

614. Pérez-Carrillo, Miguel J. (1982). Yawara-Jitsu : defensa personal científica. Técnicas básicas y kata no 1 : agresiones de frente con una mano. Barcelona: Hispano Europea. 1a ed. 351 p. : il. ; 13x19,5 cm. ISBN: 84-255-0633-6. Depósito legal: B. 33885-1982. Palabras clave: fundamentos técnicos, defensa personal, katas. Resumen: Manual de yawara-jitsu. La obra esta dividida en 20 capítulos. Comienza con la explicación del origen y características del yawara-jitsu para pasar inmediatamente a un conjunto de ejercicios de precalentamiento y flexibilidad que además están ilustrados. A continuación explica la ejecución correcta de las caídas y de las guardias como contenidos básicos antes de comenzar a explicar las técnicas propias de este arte. Desde el quinto capítulo, centrando en el estudio de los golpes de puño y pierna, agrupa las distintas respuestas que se pueden adoptar tras ciertos ataques. Así, explica, ilustra y matiza los puntos clave y principales defectos de las variantes defensivas que puede adoptar el practicante ante distintas agresiones: agarre del cuello con una mano, agarre de solapa con una mano, agarre de muñeca con una mano, agarre de muñeca en diagonal con una mano, agarre de muñeca alta con una mano, agarre de muñeca alta en diagonal, agarre de brazo con una mano, agarre de brazo en diagonal, agarre de pelo con una mano, empujón al pecho, directo a la cara y amenaza de puñal al vientre. La obra finaliza con la explicación de cómo conducir a un detenido, como realizar un control en el suelo y la realización de la primera kata básica.

615. Pérez-Carrillo, Miguel J. (1986). Yawara-Jitsu : defensa personal científica. Técnicas dobles y kata no 2. Madrid: Federación Española de Lucha. 1a ed. 301 p. : il. ; 13x20 cm. ISBN: 84-505-4151-4. Depósito legal: M. 30093-1986. Palabras clave: fundamentos técnicos, defensa personal, katas. Resumen: Manual técnico de yawara-jitsu. El primer capítulo profundiza en los diferentes golpes que existen y su objetivo para continuar con la explicación de las distintas defensas que se pueden realizar ante situaciones de agresión. Todas las defensas están explicadas e ilustradas y se componen de al menos dos acciones, un primer golpe para facilitar la ejecución de la siguiente acción que será una luxación, una proyección, una estrangulación u otro atemi; o por el contrario, un bloqueo o esquiva seguido de cualquier acción de ataque. Así, presenta defensas contra: agarre de cuello con dos manos, agarre de solapas con ambas manos, agarre de muñecas con ambas manos, agarre de muñecas altas, agarre de brazos con ambas manos, agarre de brazos altos, agarre de una muñeca con dos manos, agarre de muñeca alta con dos manos, abrazo al cuerpo por encima de los brazos, abrazo al cuerpo por debajo de los brazos, golpe circular a la cabeza, gancho al mentón, patada de frente a los genitales, ataque con una botella o palo corto, amenaza de puñal al cuello, puñalada baja al vientre, puñalada alta al pecho y amenaza de frente con pistola o revolver. Los dos últimos capítulos explican los controles en el suelo, los movimientos de esquiva y la segunda kata básica.

616. Pérez-Carrillo, Miguel J. (1986). Yawara-Jitsu : manual de defensa contra agresiones armadas. Con armas: blancas, de fuego y contundentes. Barcelona: Alas. $1^{\mathrm{a}}$ ed. 189 p. : il. ; 15x21,5 cm. ISBN: 84-2030146-9. Depósito legal: B. 16983-1986. Palabras clave: fundamentos técnicos, defensa personal, armas. Resumen: Manual técnico de yawara-jitsu. Comienza con una breve introducción sobre el trabajo que se va a desarrollar en el libro, esto es, las defensas contra amenazas y ataques, explicando sintéticamente cuales son las técnicas que hay que utilizar para finalmente reducir al atacante. Desde el segundo capítulo y hasta el decimocuarto, describe e ilustra las defensas contra las siguientes amenazas de puñal: al cuello, al pecho, al vientre, cuello desde un lateral, al costado por delante y por detrás del brazo, a la nuca y por la espalda; y de pistola: de frente, desde un lateral y por la espalda. También presenta situaciones de amenaza con un arma larga de frente y por la espalda. Y finaliza con las defensas ante ataques de palo corto, puñal y agresiones especiales con una silla, una cadena, nunchakus o un revolver mientras estas sentado.

617. Planellas Vidal, Pau-Ramon (1983). El tai jitsu : método superior de defensa personal. Barcelona: Alas. 1a ed. 93 p. : il. ; 15x21,5 cm. ISBN: 84-203-0153-1. Depósito legal: B. 33479-1983. Palabras clave: fundamentos técnicos, principios técnicos, defensa personal, armas. Resumen: Manual teórico y técnico de tai jitsu. El libro esta formado por 17 capítulos precedidos por un introducción que comenta el origen de las artes de combate y un preámbulo que explica en qué consiste el tai jitsu y cuáles son sus principios técnicos. El primer capítulo detalla los fundamentos marciales del tai jitsu mientras que el segundo analiza la aplicación de los principios de equilibrio y no resistencia a la práctica, señala las características del kiai, la distancia, las esquivas y las técnicas auxiliares. El tercer capítulo describe la ejecución de las ocho técnicas fundamentales de atemi y sus variantes acompañadas de su representación gráfica para continuar con la presentación de algunas esquivas con paradas, ejemplos de paradas, esquivas y bloqueos, tate-tzuki, oi-tzuki, ataques con el canto de la mano, nakadaka ken, 
golpes con la mano y patadas. Los siguientes cinco capítulos explican la ejecución de diversas técnicas de defensa personal ante estrangulaciones, agarres al cuerpo y al cuello, presas, proyecciones, ataques con palo y ataques por la espalda incluyendo su secuencia fotográfica. El último capítulo expone los contenidos técnicos del tai jitsu. Adjunta un epílogo.

\subsection{China}

\subsubsection{Baguazhang}

618. García García, Carlos (2005). Baguazhang : el poder del círculo mágico. Barcelona: Alas. 1ae ed. 415 p. : il. ; 17x24 cm. ISBN: 84-203-0437-9. Depósito legal: B. 47022-2005. Palabras clave: historia, fundamentos teóricos, fundamentos técnicos, principios técnicos, ejercicios, entrenamiento, escuelas, fundamentos filosóficos, maestros, meditación, música, taoísmo. Resumen: Manual teórico y técnico de baguazhang. La obra esta dividida en 16 partes precedidas por los agradecimientos, el prólogo y una biografía del autor. La primera parte expone los fundamentos de la filosofía tradicional china como son la teoría yin/yang, las cinco energías, los tres tesoros, el concepto de qi y su origen, la energía de espíritu, la teoría del bagua. La segunda parte describe las características de las diferentes escuelas taoístas y sus maestros a lo largo de la historia. La tercera parte narra el origen y desarrollo del qigong y sus vertientes. La cuarta parte comenta los orígenes del baguazhang, sus maestros y transmisión e incluye los estudios históricos sobre el mismo realizados por Kan Won Ku. La quinta parte detalla la biografía de los alumnos y alumnos de segunda generación del maestro Dong Hai Chuan, como son Yin Fu, Chen Ting Hua, Li Cun Yi, Ma Wuei Qi, Ma Gui, Liu Feng Chun, Chang Chan Kuei, Liu De Kuan, Liang Zhen Pu, Gao Yi Sheng, Li Ziming, Sun Lu Tang y Fu Zhen Song. La sexta parte describe el proceso de transmisión del baguazhang a través de las diferentes generaciones y maestros. La séptima parte enumera los fundamentos técnicos del baguazhang y explica sus características. La octava parte incluye la descripción técnica, características y beneficios de algunos ejercicios de calistenia acompañados de sus ilustraciones. La novena parte describe la ejecución técnica del trabajo de desplazamiento o zhuangbu. La décima parte explica la ejecución de los 12 principios o técnicas básicas del baguazhang, algunos ejercicios para su entrenamiento y aplicación marcial así como algunos métodos de entrenamiento especiales del baguazhang. La décimo primera parte expone la ejecución técnica del esquema de trabajo Xiao Kaimen Quan, la relación de cada movimiento con los órganos internos y la aplicación marcial de algunos de estos movimientos, incluyendo la secuencia fotográfica de los mismos. La siguiente parte explica los principios técnicos y fundamentos teóricos de los métodos de trabajo Xi Sui Jin (lavado de médula) y Fajing (proyección de energía). La décimo tercera parte señala la relación entre las ocho palmas y los trigramas así como la descripción técnica del círculo de las ocho palmas básicas y algunas de sus aplicaciones marciales, acompañadas de su secuencia fotográfica. La siguiente parte analiza los conceptos de la meditación taoísta, ofrece consejos para su práctica, enumera los 18 pasos propedéuticos para la meditación tao y describe las prácticas meditativas. Las dos últimas partes incluyen las 84 canciones secretas del baguazhang así como un glosario de términos chinos respectivamente.

619. Monzó Landeira, Germán y Chan, Susana (1982). Pa kua chang : loong yin pa kua chang. Barcelona: Alas. $1^{\text {a }}$ ed. 48 p. : il. ; 17x23,5 cm. ISBN: 84-203-0142-6. Depósito legal: B. 39009-1982. (2ª ed., 1986). Palabras clave: formas, fundamentos teóricos, baguazhang. Resumen: Manual teórico y técnico de Pa Kua Chang. La introducción de la obra relata el origen de los diferentes estilos internos para luego explicar someramente el significado del chi y las características del Pa Kua Chang. Continua con el comentario de los trigramas y sus significados, para en la siguiente parte comenzar con la representación gráfica y la descripción técnica de la forma de dragón de Pa Kua Chang, la aplicación a la defensa personal de algunas de estas técnicas y la 1a parte de la forma Pa Kua Chang.

620. Vilá Oliveras, Jordi (1993). Baguazhang : un estilo interno de wu-shu. Barcelona: Alas. $1^{a}$ ed. 48 p. : il. ; 17x24 cm. ISBN: 84-203-0275-9. Depósito legal: B. 2171-1993. Palabras clave: historia, fundamentos técnicos, ejercicios, combate, entrenamiento, táctica, fundamentos filosóficos, aplicación marcial. Resumen: Manual teórico y técnico de baguazhang. El libro esta formado por 2 partes. La primera parte consta de 2 capítulos. El primer capítulo narra la historia del baguazhang junto con algunas de sus leyendas y la ilustración de los principales maestros del arte. El segundo capítulo explica el origen filosófico del arte. La segunda parte consta de 7 capítulos. El primer capítulo expone los principios internos del baguazhang, sus generalidades y sus niveles de entrenamiento con sus ejercicios. El segundo capítulo detalla los principios técnicos de los desplazamientos junto con su representación gráfica. El tercer capítulo analiza la táctica y técnica del combate. El cuarto capítulo describe la ejecución del ejercicio dan huanzhang (cambio de palma simple) así como algunas de sus aplicaciones marciales, acompañadas de su secuencia fotográfica. El quinto capítulo ilustra la aplicación marcial del desplazamiento en círculo. Los dos últimos capítulos comentan la importancia del trabajo interior e 
incluye unas palabras finales respectivamente. Adjunta varios apéndices con la relación entre los 8 trigramas y el baguazhang, los trigramas y sus atributos, los nombres de las 8 formas y las palabras clave del estilo.

\subsubsection{Choy Lee Fut}

621. García López, Gaspar Jorge (1981). Choy li fut. Barcelona: Alas. 1a ed. 47 p. : il. ; 17x23,5 cm. ISBN: 84203-0107-8. Depósito legal: B. 1466-1981. (2a ed., 1984; 3a ed., 1987). Palabras clave: historia, defensa personal, aplicación marcial, programa técnico. Resumen: Manual teórico y técnico de Choy Li Fut. La primera parte del libro narra la historia del arte, las distintas generaciones y sus maestros, y describe brevemente los diferentes tipos de entrenamiento dentro del arte, enumerando sus principales ejercicios. La segunda parte incluye una secuencia fotográfica de técnicas de aplicación práctica en el combate entre dos practicantes y en la defensa personal, adjuntando una breve explicación del movimiento de cada uno de ellos.

622. García López, Gaspar Jorge (2007). Choy lee fut kung fu : la herencia de los maestros. Albacete: Magnus Enterprises. 1a ed. 158 p. : il. ; 21x30 cm. ISBN: 978-84-611-6740-1. Depósito legal: M. 24304-2007. Palabras clave: formas, fundamentos teóricos, fundamentos técnicos, ejercicios, ética. Resumen: Manual teórico y técnico de choy lee fut. El libro esta compuesto por 6 capítulos precedidos por los agradecimientos y una introducción que comenta los objetivos de la obra. El primer capítulo explica en qué consiste el choy lee fut, relata su historia y evolución, describe sus niveles de entrenamiento, los beneficios derivados de su práctica, propone un programa de entrenamiento y presenta las cuatro reglas tradicionales del aprendizaje. El segundo capítulo comenta los beneficios del control de la mente, el cuerpo, la respiración y la relajación, describe e ilustra la ejecución de varios ejercicios de control de la respiración, de concentración y meditación, expone los principios técnicos del choy lee fut y presenta varios ejercicios de qigong. El tercer capítulo explica los fundamentos teóricos del choy lee fut como la canción de las 18 palabras secretas, las seis puertas, las cinco energías, el sistema direccional y algunos conceptos básicos del combate. El cuarto capítulo señala la importancia de los caballos dentro del choy lee fut, comenta sus fundamentos técnicos y analiza los desplazamientos y aplicaciones de las formas Ng Lun Ma, Ng Lun Chui y Sei Mun Kiu Jou San Ma junto con sus esquemas de movimiento. El quinto capítulo describe la ejecución de las distintas técnicas de puño, pierna y defensas del choy lee fut acompañadas de sus ilustraciones. El último capítulo explica el significado del saludo y el código de conducta del choy lee fut. Adjunta la secuencia fotográfica de las formas del choy lee fut y un glosario.

623. González Rincón, Juan Sebastián (1999). Cuchillos mariposa de choy li fut : guía de choy li fut kungfu. Barcelona: Alas. 1a ed. 125 p. : il. ; 17x24 cm. ISBN: 84-203-0395-X. Depósito legal: B. 12272-1999. Palabras clave: formas, historia, fundamentos técnicos, principios técnicos, defensa personal, ejercicios, entrenamiento, aplicación marcial, armas. Resumen: Manual teórico y técnico de choy li fut. El libro esta formado por 7 capítulos precedidos de los agradecimientos, la biografía del autor y una introducción que comenta los objetivos de las artes marciales. El primer capítulo narra el origen, evolución y maestro de choy li fut. El segundo capítulo expone las ventajas del entrenamiento con armas dobles y comenta la historia y características de los doble sables de hoja ancha, los cuchillos mariposa, las dobles espadas rectas, las dobles dagas, las dobles espadas de gancho, las dobles hachas, los dobles látigos de cadena, los dobles palos de dos secciones y otras armas menos significativas. El tercer capítulo detalla las fases y niveles de entrenamiento, sus principios técnicos y describe la ejecución de las distintas posiciones "ma" acompañadas de su ilustración. El cuarto capítulo describe la ejecución de varios ejercicios de manejo de los cuchillos acompañados de su secuencia fotográfica. El quinto capítulo relata la historia de los cuchillos mariposa y enumera sus técnicas en función de la distancia de combate. El sexto capítulo incluye la descripción técnica y secuencia fotográfica de la forma bot gwa sahren-do. El último capítulo presenta la descripción e ilustración de varias técnicas de defensa de los cuchillos mariposa contra palo y sable ancho. Adjunta un listado de las formas de choy li fut, un epílogo y bibliografía.

624. Moreira, Carlos y Valencia, Pedro (1992). Hung-sing-choy-li-fat y la palma de hierro. Barcelona: Alas. 1a ed. 158 p. : il. ; desc.xdesc. cm. ISBN: 84-203-0270-8. Depósito legal: B. 29118-1992. Palabras clave: historia, fundamentos teóricos, fundamentos técnicos, principios técnicos, ejercicios, cultura, equipamiento, preparación física, armas. Resumen: Manual teórico y técnico de choy li fat. El libro esta formado por 15 capítulos precedidos por una introducción que comenta los problemas de transliteración, una dedicatoria y una breve biografía de los autores. El primer capítulo narra la historia y evolución del choy li fat junto con la biografía de algunos de sus maestros más destacados. El segundo capítulo describe la estructura del altar del choy li fat y su significado. El tercer capítulo expone las características generales del estilo choy li fat mientras que el cuarto analiza las características del estilo hung shing choy li fat de Fat Sam. El quinto capítulo analiza los principios 
técnicos del estilo de Fat Sam además de describir sus fundamentos técnicos acompañados de sus ilustraciones y esquemas de movimiento. El sexto capítulo ilustra algunas de las posturas típicas de las técnicas de los cinco animales más populares. Los siguientes tres capítulos presentan varias ilustraciones del ritual de entrada de las formas, de la forma titulada la palma de buda y del estilo borracho. El décimo capítulo presenta la secuencia fotográfica de la aplicación de varias técnicas de combate y de defensa personal. El capítulo decimoprimero presenta la ilustración de las principales armas tradicionales del choy li fat. El decimosegundo capítulo presenta la ilustración de varios ejercicios de fortalecimiento de la camisa de hierro. El siguiente capítulo comenta el origen de la práctica de la palma de hierro, señala la importancia de las hierbas medicinales para su práctica y ofrece algunos consejos prácticos. El decimocuarto capítulo ilustra los distintos tipos de muñecos de madera existentes. El último capítulo explica el significado del león y su danza, sus características técnicas y su equipación. Adjunta bibliografía.

625. Tarragó Tomás, Ferrán (1990). Choy-li-fut : el potente y dinámico kung fu del sur. Barcelona: Alas. 1a ed. 127 p. : il. ; 15x21 cm. ISBN: 84-203-0247-3. Depósito legal: B. 15713-1990. Palabras clave: formas, historia, fundamentos técnicos, entrenamiento, maestros. Resumen: Manual teórico y técnico de choyli-fut. El libro esta formado por 18 capítulos. El primer capítulo narra la historia del choy-li-fut y su creador, así como los herederos e instructores hasta la $3^{a}$ generación. Continua con la diferenciación de las dos ramas del choy-li-fut y la biografía de los grandes maestros: Ho Ngau, Chan Hon Hung, Lau Kwok Hung, Doc Fai Wong, Ngan Yu Ting, Chan Kit Fong, Fong Yuk Shu, chan Yon Fa, Chang Kwo Wai, Wu Wan Cheuk, Gaspar García, Chan Yiu Wun, Chan Kin Man, Lee Koon Hung, Lau Bun y To Sum. El quinto capítulo describe la metodología en la enseñanza del choy-li-fut junto con sus características técnicas, para continuar con la ilustración y descripción de las posturas básicas, la utilización de la cadera, la aplicación del concepto yin-yang en el entrenamiento y la respiración. El noveno capítulo clasifica las técnicas defensivas y describe las principales técnicas junto con su ilustración. Los tres capítulos siguientes presentan las técnicas de puño y mano, los codos y las rodillas, y las patadas. El decimocuarto capítulo describe e ilustra la secuencia de movimientos de la forma superior Kau Da Kuen, para dedicar los últimos cuatro capítulos a enumerar los saludos o aperturas, las formas del estilo choy-li-fut, los 10 principios fundamentales del entrenamiento y una tabla cronológica de China. adjunta bibliografía.

626. Wong, Doc-Fai y Rico Artigas, Pedro (1997). El muñeco de madera del choy li fut : el enfrentamiento definitivo para el combate. Zaragoza: Pedro Rico Artigas y Doc-fai Wong. 1aㅡ ed. 123 p. : il. ; $17 \times 24 \mathrm{~cm}$. ISBN: 84-605-6265-4. Depósito legal: Z. 1204-1997. Palabras clave: historia, fundamentos teóricos, armas, fundamentos técnicos, ejercicios, entrenamiento, aplicación marcial, medicina tradicional china, preparación física. Resumen: Manual teórico y técnico de choy li fut. El libro esta formado por cinco capítulos precedidos por una introducción que comenta los objetivos del libro y resume sus contenidos, la biografía de los autores, y el árbol genealógico del choy li fut. El primer capítulo narra la historia del choy li fut y sus maestros. El segundo capítulo describe la estructura del muñeco de madera ching jong y enumera las ventajas de su utilización. El tercer capítulo expone los requisitos técnicos previos para comenzar el entrenamiento con el muñeco de madera, describe algunos ejercicios de preparación física, ofrece algunos consejos prácticos para el calentamiento y desarrollo de las sesiones de entrenamiento, define las características de la medicina tradicional china y señala la importancia del chi kung y el tai chi chuan para desarrollar la fuerza interna. El cuarto capítulo presenta las características técnicas, la descripción de ejecución y aplicación marcial de las principales técnicas de choy li fut utilizadas en el entrenamiento con el muñeco de madera acompañadas de sus correspondientes ilustraciones. El quinto capítulo incluye la descripción técnica y secuencia fotográfica de la forma del muñeco de madera del choy li fut. Adjunta un epílogo y glosario específico.

\subsubsection{Jeet Kune Do}

627. Bernasconi C., Bruno (1996). Conceptos del jeet kune do : el método de combate de Bruce Lee. Telde: Seigan. 1a ed. 90 p. : il. ; 14x20,5 cm. ISBN: 84-88738-23-4. Depósito legal: GC. 1066-1996. Palabras clave: fundamentos teóricos, fundamentos técnicos, principios técnicos, vestimenta, cortesía, etiqueta, historia, instituciones. Resumen: Manual teórico y técnico de jeet kune do. El libro esta formado por 29 capítulos precedidos por los agradecimientos y una introducción que comenta los objetivos del libro. El primer capítulo explica la esencia de las artes marciales. El segundo capítulo detalla los fundamentos del zen, presenta los ocho requisitos del budismo y explica el significado del arte sin arte. El tercer capítulo describe la formación marcial de Bruce Lee. El cuarto capítulo enumera los contenidos técnicos del jeet kune do. El quinto capítulo explica en qué consiste la práctica del jeet kune do, sus fundamentos teóricos, características técnicas y principios del entrenamiento. El sexto capítulo comenta el principio de libertad del jeet kune do, mientras que el séptimo capítulo enumera sus principios técnicos. El octavo capítulo explica las funciones de la Jeet Kune Do Society y la IMB 
Academy. El noveno capítulo analiza la organización actual del jeet kune do junto con un listado de sus instructores oficiales. El décimo capítulo detalla los objetivos de los seminarios de jeet kune do, su desarrollo y sus normas de comportamiento. El décimo primer capítulo presenta los distintos sistema de graduación del jeet kune do. El décimo segundo capítulo enumera las reglas generales del Instituto Jun Fan Gung Fu mientras que el siguiente ilustra los distintos certificados entregados por Bruce Lee. El décimo cuarto capítulo incluye una tabla de terminología específica del jeet kune do. El décimo quinto capítulo describe la vestimenta y material utilizados junto con su representación gráfica. El décimo sexto capítulo expone las generalidades del entrenamiento junto con los objetivos del calentamiento. El décimo séptimo capítulo presenta una guía de desarrollo de las habilidades técnicas del jeet kune do además de comentar los factores involucrados en el entrenamiento. Los tres siguientes capítulos comentan las características de la posición de guardia, la actitud ante el combate, y los objetivos y características de las esquivas y el engaño. El vigésimo primer capítulo enumera las distintas técnicas de pierna del jeet kune do así como sus principios técnicos. El vigésimo segundo capítulo expone las características y principios técnicos de los principales puñetazos del jeet kune do. El vigésimo tercer capítulo analiza las paradas y los dos siguientes capítulos las distancias de combate y los desvíos respectivamente. El vigésimo sexto capítulo señala la importancia de la movilidad en el combate. El vigésimo séptimo capítulo detalla los principios técnicos de los desplazamientos. El siguiente capítulo describe la ejecución las cinco formas de ataque de Bruce Lee. El último capítulo expone los principales errores o enfermedades del jeet kune do. Adjunta un comentario sobre el Club Bruce Lee El Pequeño Dragón.

628. Corriente Basús, Federico (1982). Estudios sobre el tao del jeet kunedo. Barcelona: Alas. 1ae ed. 189 p. : il. ; 15x21 cm. ISBN: 84-203-0133-7. Depósito legal: B. 16793-1982. (2ª ed., 1987). Palabras clave: fundamentos técnicos, principios técnicos, ejercicios, táctica, sistemas de entrenamiento. Resumen: Manual teórico y técnico de jeet kune do. El primer capítulo comenta el origen y localización de las primeras artes marciales además de analizar las características del boxeo, el judo y jujitsu, el karate, taekwondo, kung fu y similares y el jeet kune do. El segundo capítulo explica en que consisten el entrenamiento, el calentamiento y los ejercicios de mantenimiento así como la descripción de algunos ejercicios de resistencia y las zonas objetivo en un combate. El tercer capítulo analiza las cualidades físicas y mentales de un luchador y cómo intervienen cada una de ellas en el combate. Los dos siguientes capítulos describen la ejecución correcta de la posición de guardia, los desplazamientos y las esquivas del jeet kune do, incluyendo fotografías explicativas. El sexto capítulo presenta la ejecución de las técnicas de mano, sus errores más frecuentes, su momento correcto de utilización y las defensas contra dichas técnicas junto con varias ilustraciones, mientras que el séptimo capítulo desarrolla la misma estructura de contenidos estudiando las principales técnicas de pie y las paradas. El octavo capítulo expone diferentes métodos para el entrenamiento de la potencia y la velocidad. El siguiente capítulo presenta la descripción de varias técnicas superiores y de lucha contra el estilo clásico junto con sus ilustraciones para finalizar con el análisis de los defectos de las posiciones clásicas de combate, la táctica en el ataque, la forma de preparar el ataque, la utilización de los ataques simples, el ataque compuesto, las fintas, las contras y la táctica respecto a las características de los luchadores.

629. Lee, Bruce (1990). El tao del jeet kune do. Madrid: Eyras. 1a ed. 208 p. : il. ; 21x27,5 cm. ISBN: 8485269-69-1. Depósito legal: M. 40697-1990. Palabras clave: fundamentos teóricos, principios técnicos, filosofía. Resumen: Manual teórico de jeet kune do. La monografía comienza con un conjunto de comentarios sobre el zen, el arte, los principios del jeet kune do, la práctica y la forma de enfrentarse al aprendizaje. Después desarrolla 8 capítulos a través de aforismos que detallan, en primer lugar, los fundamentos físicos y técnicos que impregnan el jeet kune do, ofreciendo esquemas y dibujos de cada uno de ellos. Continua con el análisis de las cualidades físicas y su correcta aplicación dentro de la práctica; el análisis de la ejecución técnica de los golpes, patadas y agarres del jeet kune do incorporando numerosos dibujos de cada una de ellas. Los dos siguientes capítulos profundizan en acciones secundarias que complementan el trabajo anterior, como son las fintas, las paradas, las manipulaciones, la distancia, el juego de piernas y la evasión. El sexto capítulo reflexiona sobre el ataque y los aspectos teóricos que lo fundamentan, incluyendo aforismos sobre los distintos tipos de ataques. Finaliza ofreciendo algunos consejos prácticos sobre el proceso de aprendizaje y la actitud ante el jeet kune do.

630. Lee, Bruce y Uyehara, M. (1991). El método de combate de Bruce Lee : técnicas de defensa personal. Madrid: Eyras. 1aㅡ ed. 125 p. : il. ; 15x24 cm. ISBN: 84-85269-70-5. Depósito legal: M. 14734-1991. Palabras clave: fundamentos técnicos, defensa personal. Resumen: Manual técnico de defensa personal. El libro esta dividido en 7 capítulos. Cada capítulo presenta la ejecución técnica ante distintas situaciones de ataque, ofreciendo una explicación técnica del movimiento por partes e ilustraciones así como un comentario de la acción. El primer capítulo ofrece varios ejemplos de situaciones de defensa personal ante ataques por sorpresa, y continua con defensas contra asaltantes desarmados, contra agarres, contra presas y abrazos de estrangulamientos, contra asaltantes armados, contra varios asaltantes y la defensa desde una posición vulnerable. 
631. Lee, Bruce y Uyehara, M. (1992). El método de combate de Bruce Lee : entrenamiento básico. Madrid: Eyras. 1a ed. 125 p. : il. ; 15x24 cm. ISBN: 84-85269-72-1. Depósito legal: M. 1563-1992. Palabras clave: fundamentos técnicos, entrenamiento, capacidades físicas. Resumen: Manual técnico de acondicionamiento para las artes marciales. La obra esta compuesta de cinco capítulos todos ellos ilustrados. El primer capítulo expone algunos ejercicios para desarrollar la resistencia, la flexibilidad y los abdominales y realizar el calentamiento del cuerpo. El segundo capítulo describe los principios técnicos de la posición de guardia además de ofrecer algunos consejos para evaluar dicha posición y explicar el desarrollo de un equilibrio correcto. El tercer capítulo estudia los desplazamientos, sus principios técnicas básicos, sus tipos y los aspectos clave de cada uno de ellos. El cuarto capítulo profundiza en el entrenamiento de la potencia de los puñetazos y patadas, explicando sus principios y distintos ejercicios para desarrollarla. Finaliza con el desarrollo del entrenamiento de velocidad, explicando distintos ejercicios, la progresión en dicho entrenamiento, su aplicación a las técnicas del jeet kune do y sus principales errores.

632. Lee, Bruce y Uyehara, M. (1993). El método de combate de Bruce Lee : la habilidad en las técnicas. Madrid: Eyras. 1aㅡ ed. 127 p. : il. ; 15x24 cm. ISBN: 84-85269-77-2. Depósito legal: M. 4896-1993. Palabras clave: fundamentos técnicos, combate, táctica, kyusho. Resumen: Manual técnico de jeet kune do. El libro esta formado por 6 capítulos precedidos por una introducción que señala los objetivos de la obra. El primer capítulo comenta la importancia de la habilidad en el movimiento y analiza la distancia, los desplazamientos y el paso lateral y su utilización en el jeet kune do. El segundo capítulo compara el golpe directo con la mano adelantada en el sistema clásico y el jeet kune do, analiza los principios técnicos y principales errores de los puñetazos además de incluir numerosos ejemplos prácticos y fotografías explicativas. El tercer capítulo describe la ejecución de las principales patadas del jeet kune do junto con algunos ejercicios para su entrenamiento. El cuarto capítulo explica los principios técnicos de las paradas y su aplicación ante varios ataques y distintos agresores. El quinto capítulo localiza los puntos vitales y comenta su forma de ataque junto con varias fotografías explicativas. El sexto capítulo ofrece varios consejos para la práctica con sparring, comenta sus principales acciones técnicas, errores y acciones tácticas acompañadas de su secuencia fotográfica.

633. Lee, Bruce y Uyehara, M. (1994). El método de combate de Bruce Lee : técnicas avanzadas. Madrid: Eyras. 1a ed. 126 p. : il. ; 15x24 cm. ISBN: 84-85269-78-0. Depósito legal: M. 16409-1994. Palabras clave: fundamentos técnicos, táctica. Resumen: Manual teórico y técnico de wushu. La obra esta formada por cinco capítulos. Los dos primeros capítulos describen e ilustran la ejecución técnica y sus variantes, dependiendo de la situación del oponente, de las técnicas ofensivas de mano como son el jab de dedo con la mano adelantada, el directo con la mano adelantada, el golpe al cuerpo, el directo de izquierda, el directo de izquierda al cuerpo, el jab con la mano adelantada, el golpe de gancho y el uppercut. El siguiente capítulo describe la ejecución técnica y señala las ventajas de los ataques con patadas como la patada con la pierna adelantada sobre la espinilla y la rodilla, la patada lateral con la pierna adelantada, la patada circular, la patada con giro y la patada de gancho, incluyendo además numerosas fotografías explicativas. El cuarto capítulo comenta los principios para aplicar la defensa y contra, y describe la utilización del jab de dedo, el directo con la mano adelantada, la patada a la espinilla o la rodilla, la patada lateral de parada, la patada circular y la patada en giro como contraataques y medios para detener el ataque o el avance del contrario. El último capítulo reflexiona sobre las cualidades que debe tener un buen luchador y las tácticas a adoptar ante distintos competidores y situaciones de combate.

634. Little, John (2006). Bruce Lee : el tao del gung fu. Comentarios de Bruce Lee sobre el camino marcial. Badalona: Paidotribo. 1aㅡ ed. 224 p. : il. ; 15x21,5 cm. ISBN: 84-8019-904-0. Depósito legal: no. (1aㅗ reimp., 2007). Palabras clave: fundamentos técnicos, principios técnicos, taoísmo. Resumen: Manual teórico y técnico de gung fu. La monografía esta compuesta de 4 partes. La primera narra los orígenes del gung fu y sus escuelas, la teoría del yin-yang y su aplicación correcta en el gung fu. La segunda parte describe los principios técnicos sobre los que se fundamente el gung fu para después estudiar los aspectos teórico-prácticos del puñetazo directo de wing chun, las técnicas de bloqueo/ataque, el chi sao, las patadas, la defensa personal, el programa de entrenamiento y los materiales del gung fu. La tercera parte ahonda en el taoísmo, sus principios y cómo son aplicados en la filosofía y práctica del gung fu. Finaliza con un compendio de historias sobre algunos estilos de artes marciales chinas, una breve biografía de algunos maestros de gung fu, discusiones de Bruce Lee sobre la práctica y principios del gung fu, y un conjunto de preguntas y respuestas que profundizan en el arte. Adjunta tres apéndices, el primero de ellos relata el historial marcial de Bruce Lee en distintas épocas, el segundo incluye algunos términos de gung fu, y el tercero recopila cartas y recortes sobre gung fu.

635. Little, John (2008). Be water, my friend : la filosofía de Bruce Lee que te ayudará a entender el mundo que te rodea y a descubrir tu guerrero interior. Madrid: La esfera de los libros. $1^{\underline{a}}$ ed. 343 p. : il. ; 16x23,5 cm. ISBN: 978-84-9734-715-0. Depósito legal: M. 7083-2008. Palabras clave: fundamentos teóricos, biografía, filosofía, jeet kune do. Resumen: Tratado filosófico de jeet kune do. La obra esta compuesta por 3 partes. La primera parte incluye 5 capítulos en los que se plasma la esencia de las artes marciales 
y los principios filosóficos en los que Bruce Lee fundamentó el jeet kune do, a través del pensamiento de varios filósofos, anécdotas, historias y reflexiones personales. La segunda parte incluye 5 capítulos en los que describe la actitud del practicante de artes marciales ante el mundo, la vida y el entrenamiento, reflexionando sobre la capacidad para adaptarse a los problemas diarios, las relaciones entre las personas, el racismo en el mundo, los desafíos presentes en la vida diaria o el entrenamiento y la relación entre cuerpo y mente. La última parte esta compuesta por 7 capítulos en los que narra la filosofía del jeet kune do, los beneficios del arte para el practicante, los principios que rigen la práctica, un extracto de la entrevista del autor con Brandon Lee, algunos aforismos de Bruce Lee, el propósito educador de cada una de las películas de Bruce Lee, y un consejo final para la práctica correcta del jeet kune do. Adjunta 4 apéndices sobre el eco-zen, el tao del wu hsin, los principales trabajos de Bruce Lee, y una cronología de su vida.

636. Little, John (comp.) (2006). Bruce Lee : jeet kune do. Sobre el camino marcial. Barcelona: Paidotribo. 1a ed. 456 p. : il. ; 15x21,5 cm. ISBN: 84-8019-860-5. Depósito legal: no. Palabras clave: fundamentos teóricos, fundamentos técnicos, principios técnicos, filosofía, didáctica, entrenamiento, planificación del entrenamiento. Resumen: Manual teórico y técnico de jeet kune do. El libro esta dividido en 6 partes. La primera parte presenta un conjunto de reflexiones de Bruce Lee respecto al combate, los luchadores, su técnica, su táctica y su desarrollo, además de analizar las ventajas y desventajas de las principales artes marciales. La segunda parte relata el origen y desarrollo del jeet kune do, sus características, sus principios y estrategias, presenta la clasificación y explicación de sus contenidos técnicos básicos y ejemplos gráficos de los mismos, sus principios técnicos y tácticos, y describe la ejecución correcta de una postura de guardia y del juego de piernas. La tercera parte analiza los principios técnicos generales de las técnicas de brazo para luego profundizar en los principios técnicos y situaciones en las que utilizar el puñetazo con el puño adelantado (directo), el gancho, el dorso del puño, la cruz y otros golpes menos habituales así como algunas reflexiones sobre el boxeo y la esgrima y su aplicación al jeet kune do. La cuarta parte estudia los principios técnicos y tácticos de las técnicas de pierna como la patada con la pierna adelantada contra la espinilla/rodilla, la patada de costado, la patada con gancho y otras patadas menos frecuentes. La quinta parte expone los métodos de enseñanza de Bruce Lee para luego presentar los contenidos técnicos de un programa de entrenamiento de 12 lecciones, un programa de entrenamiento privado de 10 lecciones y su programa de acondicionamiento físico general, junto con diversos comentarios metodológicos en la enseñanza del jeet kune do y sus técnicas. La última parte expone las reflexiones de Bruce Lee sobre la filosofía del jeet kune do y la actitud del practicante ante el entrenamiento. Adjunta gráficos, esquemas y anotaciones de Bruce Lee durante todo el libro.

637. Mercado Aguado, Felipe (2007). El camino del puño interceptor : jeet kune do. Barcelona: Alas. 1a ed. 209 p. : il. ; 17x23,5 cm. ISBN: 978-84-203-0445-8. Depósito legal: B. 49818-2007. Palabras clave: historia, fundamentos teóricos, fundamentos técnicos, biografía, maestros. Resumen: Manual teórico y técnico de jeet kune do. El libro esta formado por 8 capítulos precedidos por los agradecimientos, y un prefacio que comenta la labor del autor. El primer capítulo expone los fundamentos teóricos del jeet kune do desde las propias palabras de Bruce Lee junto con algunos de sus escritos. El segundo capítulo incluye la biografía de Dan Inosanto y Ted Wong con varias ilustraciones. El tercer capítulo relata los comienzos del autor en el aprendizaje del jeet kune do. El cuarto capítulo comenta las cualidades físicas del practicante de jeet kune do y ofrece consejos para su entrenamiento además de incluir la descripción de algunos ejercicios de acondicionamiento físico con pesas acompañados de sus ilustraciones. El quinto capítulo explica brevemente los fundamentos del wing chun, el thai boxing, el kali-eskrima-arnis y el jun fan trapping y su inclusión en el programa de jeet kune do además de incluir la descripción y representación gráfica de algunas de sus técnicas. El sexto capítulo describe los fundamentos técnicos del jeet kune do junto con sus ilustraciones y esquemas de movimiento además de explicar las diferentes formas de ataque del jeet kune do y analizar las distancias de combate, las características y táctica ante un oponente y los beneficios del combate. El séptimo capítulo presenta las conclusiones del autor tras sus años de entrenamiento en jeet kune do. El último capítulo incluye un glosario específico de jeet kune do. Adjunta un apéndice con los certificados y acreditaciones del autor.

638. Pérez Agustí, Adolfo (2004). Bruce Lee y el tao del Jeet Kune Do. Madrid: Masters. 1 a ed. 223 p. : il. ; 14x21 cm. ISBN: 84-96319-15-6. Depósito legal: SE. 4084-2004. (2 ${ }^{\underline{a}}$ ed., 2006). Palabras clave: fundamentos teóricos, táctica, principios técnicos, biografía, jeet kune do, entrevistas, maestros. Resumen: Ensayo sobre la biografía del artista marcial y síntesis de El tao del Jeet Kune Do. Los cuatro primeros capítulos presentan la biografía detallada de Bruce Lee, narrando su infancia y adolescencia y su primer contacto con las artes marciales; cómo se convirtió en una ídolo y alcanzó la televisión y el cine; cómo se desarrolló su vida cinematográfica y cómo se produjo su muerte. El quinto capítulo ofrece las entrevistas realizadas a su madre, su esposa y al propio Bruce. El sexto capítulo expone brevemente la vida y muerte de su hijo y ofrece el extracto de una de sus entrevistas. El siguiente capítulo ahonda en la filmografía de Bruce, con una ficha de cada película así como un breve comentario sobre su papel en ella. El octavo capítulo presenta la situación actual del Jeet Kune Do, sus 
instructores, su transmisión y cuáles son las características que lo impregnan hoy en día. El último capítulo describe las características técnicas y tácticas del Jeet Kune Do así como los principios que deben regir su práctica.

639. Richardson, Burton (2006). Tras las huellas de Bruce Lee : jeet kune do sin límites. Madrid: Budo International. 1a ed. 127 p. : il. ; 17x24 cm. ISBN: 84-96492-18-4. Depósito legal: M. 11245-2006. Palabras clave: principios técnicos, combate, entrenamiento, armas. Resumen: Manual teórico y técnico de jeet kune do. El libro esta formado por 18 capítulos. El primer capítulo explica algunas de las formas de ponerse en pie desde diferentes posiciones en el suelo. El segundo capítulo explica la evolución de las artes marciales a través de las competiciones. El tercer capítulo describe los beneficios del entrenamiento con sparring. El cuarto capítulo detalla el afán de superación proporcionado por las artes marciales. El quinto capítulo ofrece varios consejos para la progresión en el aprendizaje y el entrenamiento. El sexto capítulo reflexiona sobre la vertiente deportiva y de combate de las artes marciales. El séptimo capítulo señala la importancia del entrenamiento para alcanzar buenos resultados. El octavo capítulo analiza la importancia del entorno en una pelea y propone dos ejercicios para entrenar bajo dichas circunstancias. El noveno capítulo explica algunos métodos de entrenamiento para aprender a reaccionar ante un ataque sorpresa. El décimo capítulo señala la importancia del entrenamiento en distintas situaciones para adquirir experiencia en el combate mientras que el siguiente capítulo expone los principios del jeet kune do unlimited. El décimo segundo capítulo explica las directrices del jeet kune do unlimited junto con la descripción del examen para instructores. El décimo tercer capítulo señala la importancia de pelear contra un compañero que no coopera para progresar en el entrenamiento. El décimo cuarto capítulo analiza las características del planteamiento del jeet kune do original y de los conceptos del jeet kune do así como sus ventajas. Los dos siguientes capítulos señalan la importancia de absorber las cosas buenas de otros estilos después de comprobarlas y de las nuevas tecnologías para el progreso del arte marcial y del entrenamiento. El décimo séptimo capítulo analiza los cinco métodos de ataque de Bruce Lee para finalizar con un comentario sobre el entrenamiento con armas de fuego. Adjunta secuencias fotográficas de técnicas de jeet kune do por todo el texto.

640. Tackett, Tim (2008). Jeet kune do : el arte de Bruce Lee. Madrid: Budo International. 1a ed. 127 p. : il. ; $17 \times 24$ cm. ISBN: 978-84-936306-3-8. Depósito legal: M. 7915-2008. Palabras clave: fundamentos teóricos, fundamentos técnicos, pedagogía, principios técnicos, ejercicios, instituciones. Resumen: Manual teórico y técnico de jeet kune do. El libro esta compuesto por 14 capítulos precedidos por un prólogo que comenta los contenidos del libro. El primer capítulo comenta el currículo de los profesores de "el grupo de los miércoles por la noche" y sus objetivos pedagógicos. El segundo capítulo explica los contenidos técnicos y efectividad del jeet kune do. El tercer capítulo expone los fundamentos teóricos de los sistemas denominados "conceptos del jeet kune do", "jeet kune do original" y "nucleus" además de relatar la historia y evolución del jeet kune do. El cuarto capítulo explica los contenidos técnicos del jeet kune do e ilustra su posición básica. El quinto capítulo describe la ejecución de las cinco formas de ataque acompañadas de su secuencia fotográfica. El sexto capítulo detalla los principios técnicos de la defensa en el jeet kune do para continuar con el contraataque. El octavo capítulo señala la importancia de la distancia en el jeet kune do y el juego de pies además de incluir la descripción e ilustración de algunos de sus ejercicios. Los siguientes tres capítulos comentan los trabajos de trapping (manos que atrapan), el ritmo discontinuo y la velocidad, describiendo varios ejemplos de su entrenamiento. El décimo segundo capítulo enumera los requisitos físicos de las artes marciales. El décimo tercer capítulo explica el proceso de enseñanza del jeet kune do mientras que el último capítulo expone el principio de progresión del jeet kune do.

641. Vunak, Paul (1992). Jeet kune do. Madrid: Multideporte. 1a ed. 149 p. : il. ; 17x24 cm. ISBN: 84-8796750-7. Depósito legal: M. 10343-1992. Palabras clave: fundamentos teóricos, fundamentos técnicos, principios técnicos, filosofía, ejercicios, combate, entrenamiento. Resumen: Manual teórico y técnico de jeet kune do (JKD). El libro esta compuesto por 5 capítulos precedidos de una introducción que comenta las características generales del jeet kune do y el objetivo del libro. El primer capítulo explica los conceptos del jeet kune do, esto es, cuales son sus atributos, la filosofía del combate y sus principios, su variada formación marcial, los principios técnicos para avanzar en el entrenamiento y la descripción e ilustración de varias secuencias técnicas de combate por partes. El segundo capítulo comenta los principios mentales del JKD en combate, los fundamentos técnicos que integran este arte y la descripción e ilustración por partes de otro conjunto de secuencias técnicas. El tercer capítulo expone las características de los niveles de entrenamiento dentro del JKD e incluye un nuevo conjunto de secuencias técnicas explicadas e ilustradas por partes. El cuarto capítulo detalla las características del trabajo de chi-sao para luego exponer otros ejercicios de combate por parejas. El último capítulo enumera los 10 principios del trabajo isométrico y describe e ilustra cinco ejercicios como ejemplo.

642. Zamudio Cabeza, Juan José (2005). Jeet kune do : el arte ofensivo de la defensa. Barcelona: Alas. 1aㅡ ed. 168 p. : il. ; 17x24 cm. ISBN: 84-203-0279-1. Depósito legal: B. 8744-2005. (2ª ed., 2008, ISBN: 978-84203-0433-5). Palabras clave: historia, fundamentos teóricos, principios técnicos, filosofía, 
entrenamiento, estrategia, táctica, equipamiento, maestros, sistemas de entrenamiento. Resumen: Manual teórico y técnico de jeet kune do. El libro esta compuesto de 7 capítulos, precedidos por una introducción que relata la vida de Bruce Lee y el origen del jeet kune do además de su desarrollo en España. El primer capítulo describe los fundamentos técnicos del jeet kune do, como son la guardia, los diferentes tipos de desplazamientos, los puntos vitales que se buscan, la utilización de la visión periférica, las características y tipos de esquivas junto con algunos ejercicios para desarrollar esta habilidad, los principales golpes de ataque y la teoría de las cuatro esquinas. El segundo capítulo explica las diferentes distancias que existen en un combate, comenta sus características, ventajas e inconvenientes y propone distintos ejercicios para entrenar dichas situaciones con sus correspondientes ilustraciones. El tercer capítulo expone las características del entrenamiento técnico, de la condición física y para el combate callejero, para luego describir y explicar los beneficios de los distintos métodos y aparatos para los distintos tipos de entrenamiento. El cuarto capítulo profundiza en los principios técnicos del jeet kune do, la teoría de los cinco caminos de ataque junto con algunos ejemplos ilustrados, las características de los diferentes tipos de luchadores, las normas de conducta en la sala de entrenamiento y explica el entrenamiento con sparring. El quinto capítulo comenta la importancia del miedo en las situaciones de defensa personal y el posible ritual que precede a cualquier combate. El sexto capítulo presenta la filosofía del jeet kune do a través de un diálogo entre maestro y alumno. El último capítulo narra brevemente la biografía de las personas más importantes a nivel mundial de jeet kune do. Adjunta la biografía del autor junto con numerosas fotografias, una recopilación de fotos de Bruce Lee y un glosario terminológico.

643. Zamudio Cabeza, Juan José (2009). Footwork : la esencia del combate en jeet kune do. Barcelona: Alas. $1^{a}$ ed. 157 p. : il. ; 14x21 cm. ISBN: 978-84-203-0460-1. Depósito legal: B. 38781-2009. Palabras clave: fundamentos técnicos, ejercicios, entrenamiento, filmografía, maestros. Resumen: Manual teórico y técnico de jeet kune do. La obra esta formada por 13 capítulos precedidos por un prólogo que comenta el desarrollo profesional de autor y los agradecimientos. El primer capítulo comenta las características de las posiciones natural, de preparado y de guardia bai jong junto con su descripción técnica e ilustración. El segundo capítulo señala las características del juego de pies del jeet kune do y enumera los tipos de desplazamientos. El tercer capítulo describe la ejecución y aplicación de los diferentes tipos de desplazamientos acompañados de su ilustración explicativa y ejercicios para su desarrollo. El cuarto capítulo analiza la utilización de los desplazamientos para medir y controlar la distancia con el adversario. El quinto capítulo incluye la descripción de varios desplazamientos en la defensa contra ataques de puño y de pierna junto con su secuencia fotográfica. El sexto capítulo expone algunos de los desplazamientos que funcionan como engaños ante el adversario. El séptimo capítulo explica en qué consisten los atrapes, cuál es su método de entrenamiento y su utilización con los desplazamientos. El octavo capítulo enumera algunas combinaciones de puños y patadas con los desplazamientos además de incluir la descripción e ilustración de algunas de ellas. El noveno capítulo comenta la efectividad del jeet kune do. El décimo capítulo enumera e ilustra el entrenamiento complementario para los golpes de puño y el tren superior, los desplazamientos y la movilidad, los atrapes y agarres y las patadas, además de incluir un plan de entrenamiento semanal. El siguiente capítulo narra la biografía de Bruce Lee junto con algunas de sus fotografías. El decimosegundo capítulo expone la aparición del jeet kune do y Bruce Lee en los medios de comunicación a través de sus películas. El último capítulo incluye numerosas fotografías del autor con practicantes y en distintos cursos.

\subsubsection{Qigong}

644. Blawyn, Elrond; Blawyn, Juliana; Blawyn, Sophia y Jones, Suzanne (2009). Rejuvenece tu cuerpo. Barcelona: Robinbook. 1a ed. 251 p. : il. ; 12x19,5 cm. ISBN: 978-84-7927-991-2. Depósito legal: B. 3552-2009. Palabras clave: qigong, fundamentos teóricos, fundamentos técnicos, ejercicios, yoga, meditación, personalidad. Resumen: Manual teórico y técnico de tai chi y qigong. La obra esta dividida en 3 partes, precedidas por una introducción que comenta los contenidos de la obra. La primera parte explica los conceptos de energía, respiración y chakras, describiendo sus tipos y algunos de sus ejercicios prácticos, comenta las ayudas internas y externas para la meditación, la técnica de visualización y algunas técnicas de meditación. La segunda parte expone las características de los sistemas de chi kung del dragón rojo, t'ai chi chi kung, t'ai chi con rodillo, los activadores de los chakras, la isometría india y el yoga incluyendo la descripción técnica de sus ejercicios y acompañados de su representación gráfica. La tercera parte ofrece una propuesta de programa diario de meditación, algunos ejercicios de estiramiento, expone los beneficios del ejercicio físico, detalla la relación entre el flujo de energía y la salud, y resalta la importancia del chakra del corazón para alcanzar el máximo crecimiento espiritual. Adjunta bibliografía.

645. Boillat de Corgemont Sartorio, Marc (2003). Salud y bienestar con el chi kung : pal tan kum, sib chil nil gong dong jak. Barcelona: Alas. $1^{\mathfrak{a}}$ ed. 141 p. : il. ; 17x24 cm. ISBN: 84-203-0427-1. Depósito legal: B. 
47045-2003. Palabras clave: qigong, historia, fundamentos teóricos, fundamentos técnicos. Resumen: Tratado teórico y práctico sobre dos secuencias específicas de chi kung. El primer capítulo reflexiona de forma breve sobre la práctica en general, la tradición y los esquemas de movimiento y su importancia en el aprendizaje, y sobre la relación entre maestro-alumno y su didáctica. La segunda parte presenta las generalidades del chi kung, desde su historia hasta sus tipos. La tercera parte ahonda en los fundamentos de esta práctica marcial, analizando sus principios y factores, la función de la mente, y profundizando en la respiración. El último capítulo describe textual y gráficamente dos secuencias de movimiento poco comunes, Pal Tan Kum (Chi kung externo, marcial) y Sib Chil Nil Gong Dong Jak (Chi kung interno, meditativo). Presenta teorías sobre sus orígenes y comenta cómo fueron aprendidas por el autor. Finaliza con una explicación teórica del número 17 y su importancia para el ser humano.

646. Boillat de Corgemont Sartorio, Marc (2004). Prevención y vitalidad con el chi kung : estudio de la forma pal tan kum desde la óptica terapéutica y energética. Barcelona: Alas. 1ae ed. 141 p. : il. ; 17x24 cm. ISBN: 84-203-0431-X. Depósito legal: B. 48601-2004. Palabras clave: qigong, fundamentos teóricos, principios técnicos, ejercicios, fisioterapia, medicina tradicional china. Resumen: Manual teórico de chi kung en el que se analiza la secuencia Pal Tan Kum de Chi kung desde la medicina tradicional china y en el ámbito energético. Comienza con un capítulo introductorio que refleja el carácter de la práctica original del chi kung para continuar con otro dedicado a la persona de Pingyang Jin, experto en Chi kung médico que fundamenta el posterior análisis de la secuencia de movimientos. El tercer capítulo revisa los conceptos fundamentales de la medicina tradicional china que se aplicaran más tarde, y a continuación presenta la secuencia Pal Tan Kum señalando el trabajo energético que produce cada movimiento y posición. El siguiente capítulo profundiza en el automasaje, matinal y al anochecer, cómo método para mejorar el flujo del chi, ofreciendo una serie detallada de ilustraciones y explicaciones además de las directrices fundamentales para su correcta ejecución. Por último, reproduce de forma gráfica los puntos y meridianos de energía en el cuerpo humano. Adjunta bibliografía.

647. Cáliz Lillo, Ignacio (2006). Chi kung : el arte de la respiración. Madrid: Librería Argentina. 1 a ed. 117 p. : il. ; 17x24 cm. ISBN: 84-89836-90-6. Depósito legal: M. 18124-2006. Palabras clave: fundamentos teóricos, ejercicios, respiración. Resumen: Manual teórico y técnico de chikung. El libro esta formado por 14 capítulos precedidos por un prólogo que comenta brevemente la biografía del autor, un prefacio que señala los beneficios derivados de la práctica del chikung y una introducción que comenta los contenidos del libro. El primer capítulo relata brevemente la historia del chikung. El segundo capítulo expone los beneficios del chikung mientras que el tercero presenta algunas máximas taoístas. El cuarto capítulo describe el proceso de respiración. El quinto capítulo define el concepto de chi mientras que el sexto comenta la energía de los meridianos. El séptimo capítulo describe el recorrido de los meridianos del cuerpo junto con su representación gráfica mientras que el octavo incluye los vasos extraordinarios. El noveno capítulo presenta la anatomía de la columna vertebral acompañada de su representación gráfica. El décimo capítulo clasifica los músculos involuntarios y explica sus características. Los siguientes cuatro capítulos describen la ejecución de varios ejercicios de chikung, dos ejercicios especiales para personas enfermas en cama, y distintos ejercicios sentados y de pie junto con sus secuencias fotográficas. Adjunta una conclusión y un apéndice sobre los mudras.

648. Cáliz Lillo, Ignacio (2008). Chi kung : movimiento energético para la salud corporal. Madrid: Librería Argentina. $1^{\mathrm{a}}$ ed. 121 p. : il. ; 17x24 cm. ISBN: 978-84-85895-60-1 (Libro). Depósito legal: M. 420252008 (Libro). ISBN: 97884-85895-63-2 (Libro+DVD). Depósito legal: M. 42027-2008 (Libro+DVD). Palabras clave: formas, fundamentos teóricos, principios técnicos, ejercicios. Resumen: Manual teórico y técnico de qigong. El libro esta formado por 2 partes, precedidas por una introducción que explica los objetivos de la obra. La primera parte explica los fundamentos teóricos y principios técnicos del qigong como son los beneficios de la práctica, la posición, la teoría del yin-yang, la teoría de los cinco elementos, los chakras, la teoría de los meridianos, el sistema linfático, la mente del practicante, la alimentación, los métodos de respiración, el equilibrio interior y exterior, la sonrisa interior, la meditación, la homeopatía, los miedos, consejos para la aplicación de los ejercicios de qigong con personas con problemas de esquizofrenia, la 8 reglas para practicar el qigong, y la teoría de la energía. La segunda parte describe la ejecución de los 18 ejercicios de qigong, su meridiano, color, alimento, música, chakra, glándula, estado mental y elemento, acompañados de sus ilustraciones explicativas.

649. Calpe Rufat, Isabel (2003). Qi gong : práctica corporal y pensamiento chino. Barcelona: Kairós. 1aㅡ ed. 190 p. : il. ; 14×22 cm. ISBN: 84-7245-541-6. Depósito legal: no. (2a ed., 2009). Palabras clave: fundamentos teóricos, principios técnicos, entrenamiento, filosofía, budismo, salud, taoísmo. Resumen: Tratado teórico y técnico de qi gong. La monografía esta compuesta por 8 capítulos, precedidos por un capítulo introductorio que relata el contacto de la autora con el qi gong, el significado de qi gong oriental y occidental, el trabajo de una maestra china en occidente y la relación entre cuerpo, mente y espíritu. El primer capítulo relata la historia del qi gong, la influencia del taoísmo y budismo, y la evolución de su práctica a través de las diferentes épocas por las que pasó hasta su llegada a Occidente. El segundo capítulo explica el significado del qi en la cosmología china, la 
teoría del yin-yang, las 5 manifestaciones del qi y las 8 direcciones. El tercer capítulo estudia y aplica los principios del qi al ser humano, describiendo el cuerpo energético, los 3 dantian y los 3 tesoros. El cuarto capítulo expone los principios corporales del qi gong, las etapas del trabajo corporal y la descripción de la ejecución técnica de posiciones, movimientos, respiración y mudras de qi gong. El quinto capítulo explora la naturaleza y la sesión de entrenamiento como campos de manifestación del qi, además de las enseñanzas del maestro. El sexto capítulo presenta los principios de las medicinas taoísta y budista, informa de las causas de la enfermedad desde el taoísmo y budismo, describe los procesos terapéuticos y los beneficios de la práctica del qi gong. El séptimo capítulo recopila los testimonios de 9 personas sobre los cambios experimentados con la práctica del qi gong; para finalizar con la aplicación del qi gong y sus conceptos filosóficos a la vida. Adjunta notas e índice de ilustraciones.

650. Chang, Weizhen (1993). Yijinjing : ejercicios para el fortalecimiento de los tendones. Madrid: Miraguano. 1a ed. 126 p. : il. ; 13x19 cm. ISBN: 84-7813-117-5. Depósito legal: M. 32560-1993. Palabras clave: ejercicios, fundamentos técnicos. Resumen: Manual teórico y técnico de qigong. El libro esta formado por 31 capítulos precedidos por un prólogo que explica en qué consiste el yijinjing, sus beneficios y las fuentes del texto. El primer capítulo ofrece algunos consejos prácticos para el desarrollo de los ejercicios de yijinjing. El segundo capítulo explica la ejecución de distintos ejercicios preparatorios junto con su representación gráfica. El tercer capítulo describe la ejecución de la posición inicial del yijinjing mientras que el resto de capítulos presentan la descripción técnica, observaciones y efectos de los 28 ejercicios que componen el yijinjing junto con sus ilustraciones explicativas y esquemas de movimiento.

651. Chen, Guang Fu (1995). Chicong estética : técnicas milenarias chinas para la conservación y la recuperación de la belleza a través de la salud. Barcelona: Los libros de la frontera. $1^{a}$ ed. 55 p. : il. ; 17x23 cm. ISBN: 84-8255-001-2. Depósito legal: B. 19851-1995. Palabras clave: fundamentos teóricos, fundamentos técnicos, ejercicios. Resumen: Manual teórico y técnico de chicong. El libro esta formado por 4 capítulos. El primer capítulo explica en qué consiste el chicong, cuáles son sus beneficios para la salud, enumera sus tipos, comenta los principios técnicos de la respiración, la posición y la mente durante la práctica y señala sus elementos más importantes. El segundo capítulo describe la ejecución de los movimientos básicos de chicong para la relajación y el fortalecimiento acompañados de su representación gráfica. El tercer capítulo incluye la explicación e ilustración de la ejecución de los ejercicios de chicong para la belleza y para quitar grasas. El cuarto capítulo presenta la descripción técnica e ilustración de varios ejercicios de chicong estética en movimiento. Adjunta dos apéndices con el comentario de la teoría del yin-yang y su relación con la teoría de los cinco elementos.

652. Chia, Mantak (1991). Despierta la energía curativa a través del tao : el secreto taoísta para hacer circular la energía interna. Villaviciosa de Odón: Mirach. 1 a ed. 219 p. : il. ; 15x21,5 cm. ISBN: 84-8747610-4. Depósito legal: B. 7199-1991. Palabras clave: fundamentos teóricos, fundamentos técnicos, ejercicios, entrenamiento, aplicación terapéutica. Resumen: Manual teórico y técnico de chikung. El libro esta dividido en 5 partes precedidas por un prefacio que comenta los contenidos del libro y su relevancia, una introducción que explica en qué consiste la energía curativa del tao, una breve biografía del autor y un comentario sobre la medicina occidental y el yoga taoísta. La primera parte consta de 3 capítulos. El primer capítulo explica el significado del chi y en qué consiste el método taoísta. El segundo capítulo ofrece varios consejos prácticos para hacer circular el chi. El tercer capítulo expone la teoría de la sonrisa interior, sus beneficios y describe su ejecución para los distintos órganos. La segunda parte consta de 4 capítulos. El primer capítulo localiza los puntos de energía del canal frontal y describe sus ejercicios. El segundo capítulo presenta la circulación del chi por el canal gobernante, sus centros de energía y su aplicación terapéutica. El tercer capítulo describe la ejecución final para completar la órbita microcósmica. El cuarto capítulo explica los ejercicios destinados para hacer circular la energía a los brazos y las piernas. La tercera parte consta de 3 capítulos. El primer capítulo detalla como elaborar un programa de entrenamiento mientras que el segundo comenta los efectos derivados de la práctica de los ejercicios de chikung. El tercer capítulo incluye algunas preguntas y respuestas frecuentes sobre la circulación microcósmica. La cuarta parte consta de 3 capítulos. El primer capítulo incluye tres artículos sobre los beneficios derivados de la circulación de la energía según la medicina, la historia del taoísmo y las artes curativas, y el relato de la búsqueda de la energía curativa taoísta por parte de un doctor. El segundo capítulo incluye varias experiencias personales de los practicantes de este método. El tercer capítulo presenta la entrevista realizada a tres practicantes del yoga taoísta. La quinta parte consta de 3 capítulos. El primer capítulo comenta los niveles del yoga taoísta. El segundo capítulo incluye las siete fórmulas de los siete libros del tao. El tercer capítulo comenta las características de las prácticas taoístas complementarias. Adjunta dos apéndices con una tabla de los centros de energía y un comentario sobre cómo afecta el yoga taoísta al sistema hormonal.

653. Chia, Mantak (1994). Chi kung : camisa de hierro. Málaga: Sirio. 1ạ ed. 357 p. : il. ; $13 \times 21 \mathrm{~cm}$. ISBN: 847808-160-7. Depósito legal: B. 37990-1994. (2aㅡ ed., 1996; 6ª ed., 2001; 8a ed., 2006). Palabras clave: fundamentos teóricos, fundamentos técnicos, principios técnicos, ejercicios, anatomía, fisiología. 
Resumen: Tratado teórico y técnico de chikung. El libro esta dividido en 7 capítulos precedidos por los agradecimientos, la biografía del autor y algunos consejos sobre cómo utilizar el libro. El primer capítulo comenta el objetivo del sistema del tao curativo, narra la historia del chikung de la camisa de hierro, describe sus beneficios, el origen de la respiración de la camisa de hierro, explica los fundamentos teóricos del chikung de la camisa de hierro y comenta las características de los ejercicios presentados en el libro. El segundo capítulo expone la fisiología de la respiración abdominal y la respiración inversa, describe su ejecución acompañada de su representación gráfica, comenta la estructura de los diafragmas urogenital y pélvico, explica la ejecución del proceso de respiración condensada y señala sus principios técnicos, incluye la descripción e ilustración de varios ejercicios preliminares, un resumen de la respiración camisa de hierro, la relación entre la función respiratoria y las bombas sacra y craneal, la descripción de la órbita microcósmica, el poder del perineo y expone algunas precauciones para la práctica. El tercer capítulo explica la ejecución, principios técnicos y desarrollo de la postura del caballo con una pared y el abrazo del árbol así como la ejecución de la práctica del enraizamiento, la recogida del chi tras la práctica y sus diferentes posturas acompañadas de su representación gráfica y esquemas de movimiento. El cuarto capítulo comenta la importancia del alineamiento estructural y describe la aplicación de los principios del alineamiento a la práctica del chikung camisa de hierro. El quinto capítulo explica la relación entre el chikung y la quiropráctica, la relación del tejido conjuntivo con los huesos, músculos, tendones y meridianos de acupuntura, y describe el recorrido de los 12 meridianos del cuerpo junto con su ilustración. El sexto capítulo ofrece varios consejos para la práctica del chikung además de proponer una rutina diaria. El último capítulo incluye el relato de diversas experiencias con el chikung camisa de hierro.

654. Chia, Mantak (1995). Nei kung de la médula ósea. Málaga: Sirio. 1aed. 333 p. : il. ; 13x21 cm. ISBN: 847808-161-5. Depósito legal: B. 5361-1995. (4⿳亠丷a ed., 2001). Palabras clave: fundamentos teóricos, fundamentos técnicos, ejercicios, entrenamiento, planificación del entrenamiento, preparación física. Resumen: Tratado teórico y técnico de chikung. El libro esta formado por 6 capítulos precedidos por un aviso sobre los contenidos descritos, los agradecimientos, la biografía del autor, una introducción que comenta las características de las prácticas taoístas y un prefacio que señala los beneficios derivados de la práctica del nei kung de la médula ósea. El primer capítulo explica las funciones y beneficios del nei kung de la médula ósea y las características de sus prácticas. El segundo capítulo detalla los beneficios de la respiración ósea y la compresión ósea además de describir la ejecución de ambos métodos acompañados de su representación gráfica. El tercer capítulo comenta las características de los tres enfoques taoístas sobre la energía sexual junto con la descripción de la ejecución del ejercicio de la cerradura de poder, la compresión genital, el masaje preliminar, el masaje de la energía sexual y el ejercicio del huevo interno junto con sus ilustraciones explicativas. El cuarto capítulo expone los métodos y equipo de golpeo del nei kung de la médula ósea junto con la descripción e ilustración de sus ejercicios. El quinto capítulo describe los beneficios del levantamiento de pesas chi, el equipo y sus preparativos, sus ejercicios y fases del entrenamiento, acompañados de numerosas ilustraciones. El sexto capítulo comenta los principios del entrenamiento del nei kung de la médula ósea, describe un programa de entrenamiento con sus diferentes disciplinas y ofrece algunos consejos prácticos. Adjunta dos apéndices con la descripción e ilustración de ejercicios complementarios y la localización de los puntos y meridianos.

655. Chia, Mantak (2001). Despierta la energía curativa a través del tao : el secreto taoísta para hacer circular la energía interna. Madrid: Equipo Difusor del Libro. 1aㅡ ed. 219 p. : il. ; 15x21,5 cm. ISBN: 8495593-00-9. Depósito legal: B. 41111-2001. Palabras clave: fundamentos teóricos, fundamentos técnicos, ejercicios, entrenamiento, aplicación terapéutica. Resumen: Manual teórico y técnico de chikung. El libro esta dividido en 5 partes precedidas por un prefacio que comenta los contenidos del libro y su relevancia, una introducción que explica en qué consiste la energía curativa del tao, una breve biografía del autor y un comentario sobre la medicina occidental y el yoga taoísta. La primera parte consta de 3 capítulos. El primer capítulo explica el significado del chi y en qué consiste el método taoísta. El segundo capítulo ofrece varios consejos prácticos para hacer circular el chi. El tercer capítulo expone la teoría de la sonrisa interior, sus beneficios y describe su ejecución para los distintos órganos. La segunda parte consta de 4 capítulos. El primer capítulo localiza los puntos de energía del canal frontal y describe sus ejercicios. El segundo capítulo presenta la circulación del chi por el canal gobernante, sus centros de energía y su aplicación terapéutica. El tercer capítulo describe la ejecución final para completar la órbita microcósmica. El cuarto capítulo explica los ejercicios destinados para hacer circular la energía a los brazos y las piernas. La tercera parte consta de 3 capítulos. El primer capítulo detalla como elaborar un programa de entrenamiento mientras que el segundo comenta los efectos derivados de la práctica de los ejercicios de chikung. El tercer capítulo incluye algunas preguntas y respuestas frecuentes sobre la circulación microcósmica. La cuarta parte consta de 3 capítulos. El primer capítulo incluye tres artículos sobre los beneficios derivados de la circulación de la energía según la medicina, la historia del taoísmo y las artes curativas, y el relato de la búsqueda de la energía curativa taoísta por parte de un doctor. El segundo capítulo incluye varias experiencias 
personales de los practicantes de este método. El tercer capítulo presenta la entrevista realizada a tres practicantes del yoga taoísta. La quinta parte consta de 3 capítulos. El primer capítulo comenta los niveles del yoga taoísta. El segundo capítulo incluye las siete fórmulas de los siete libros del tao. El tercer capítulo comenta las características de las prácticas taoístas complementarias. Adjunta dos apéndices con una tabla de los centros de energía y un comentario sobre cómo afecta el yoga taoísta al sistema hormonal.

656. Chia, Mantak (2002). Terapia cósmica I : chi kung cósmico. Málaga: Sirio. 1aㅡ ed. 301 p. : il. ; 17x24 cm. ISBN: 84-7808-392-8. Depósito legal: MA. 266-2002. Palabras clave: qigong, fundamentos teóricos, fundamentos técnicos, ejercicios, acupuntura, aplicación terapéutica. Resumen: Manual teórico y técnico de chi kung. El libro esta dividido en 9 capítulos. El primer capítulo presenta el chi kung de la terapia cósmica dentro del sistema del tao universal, sus prácticas, las etapas del dominio del chi y las cuatro secciones de la terapia cósmica. El segundo capítulo describe la ejecución de los distintos ejercicios preparatorios para el chi kung cósmico. El tercer capítulo expone la teoría del chi kung cósmico y describe las prácticas del mismo como son la respiración verdadera, la activación de las seis direcciones y los tres fuegos, abrir el tercer ojo y la apertura de los tres tan tien. El cuarto capítulo describe la teoría, características y la ejecución técnica de las prácticas de una sesión curativa general. El quinto capítulo explica los conceptos básicos de la teoría de la sanación cósmica, para en el sexto capítulo detallar las técnicas utilizadas dentro de una sesión individual de sanación, sus principios y práctica, junto con el tratamiento de diversas dolencias. El séptimo capítulo ofrece algunos consejos prácticos para realizar la exploración manual del diagnóstico chi kung y describe los síntomas que se pueden apreciar en la exploración de los órganos internos. El octavo capítulo explica la teoría del chi kung de la sanación cósmica junto con la descripción de los ejercicios preparatorios, para luego describir e ilustrar sus cuatro secuencias como son: abriéndonos al chi celeste, terrestre y cósmico; abrir el puente y los canales reguladores; apertura de los canales funcional y gobernador; y activación de los canales yin-yang y del cinturón del chi; además de la secuencia combinada Palma de Buda I. El último capítulo explica las prácticas básicas del tao universal, describiendo la ejecución de la sonrisa interior cósmica y los seis sonidos curativos. Adjunta una guía que detalla la ubicación, funciones e indicaciones terapéuticas de los puntos de acupuntura utilizados en el chi kung cósmico y bibliografía.

657. Chia, Mantak (2004). El elixir del chi kung : creación de la píldora terrenal dorada. Móstoles: Neo Person. $1^{a}$ ed. 150 p. : il. ; desc.xdesc. cm. ISBN: 84-95973-03-0. Depósito legal: M. 6066-2004. (2ª ed., 2005; 3a ed., 2005). Palabras clave: fundamentos teóricos, ejercicios, anatomía. Resumen: Manual teórico y técnico de chi kung. La obra consta de cuatro capítulos, precedidos por la biografía del autor, agradecimientos y consejos para la práctica de los ejercicios presentados en la obra. El primer capítulo explica la composición y función de la saliva, los distintos tipos de elixir y describe la ejecución de varios ejercicios para incrementar la saliva acompañados de su representación gráfica y esquemas de movimiento. El segundo capítulo presenta la anatomía del pelo para luego describir la teoría y práctica de los doce ejercicios que combinan el pelo y la saliva, expone la conexión entre los distintos órganos externos e internos y cómo absorber el excedente de energía a través de ellos acompañados de su representación gráfica y esquemas. El tercer capítulo describe la ejecución técnica de las prácticas que usan las energías del pelo, de los órganos de los sentidos y de la saliva para fortalecer el cuerpo incluyendo su representación gráfica y esquemas de movimiento. El último capítulo localiza los doce canales corporales del chi y la sangre además de incluir la descripción e ilustración de algunos ejercicios para estimular el flujo de chi. Adjunta un apéndice sobre la distribución del pelo en el cuerpo y bibliografía.

658. Chia, Mantak (2004). Tan tien chi kung : la fuerza vacía, el poder del perineo y el segundo cerebro. Móstoles: Neo Person. $1^{\mathfrak{a}}$ ed. 189 p. : il. ; 14x21 cm. ISBN: 84-95973-02-2. Depósito legal: M. 60732004. ( $2^{a}$ ed., 2005). Palabras clave: fundamentos teóricos, fundamentos técnicos, principios técnicos, filosofía, ejercicios, entrenamiento, meditación, respiración. Resumen: Manual teórico y técnico de chi kung. La obra esta formada por 7 capítulos precedidos por la biografía del autor, agradecimientos y una introducción que presenta los contenidos de la obra. El primer capítulo explica el funcionamiento del tan tien chi kung, el poder de la sonrisa interna, la relación entre el tan tien inferior y el cerebro así como los efectos de la respiración natural. El segundo capítulo expone los beneficios de la postura agachada y describe su práctica por parejas acompañada de varias ilustraciones explicativas. El tercer capítulo comenta la relación entre la persona y el cosmos así como el papel del tan tien chi kung dentro de dicha relación y los efectos sobre el organismo del chikung de la danza y de los huesos. El cuarto capítulo expone las características del tan tien, describe la ejecución de la respiración del tigre y el dragón, ejercicios para el fortalecimiento del perineo, para aumentar la presión del chi en el tan tien y en sus siete áreas, y para liberar la tensión del diafragma, junto con sus ilustraciones y esquemas de movimiento. El quinto capítulo describe la ejecución técnica de los ejercicios de calentamiento del tan tien chi kung así como las posturas del tan tien chi kung acompañadas de su representación gráfica, esquemas y líneas de movimiento. El sexto capítulo comenta los efectos del tan tien chi kung sobre el movimiento del chi y como método de autosanación, relajación, autorrealización, reactivación y 
regeneración. El último capítulo explica cómo el tan tien chi kung puede actuar como meditación energética activa.

659. Chia, Mantak (2009). La sonrisa interior : incrementar el chi con el cultivo de la alegría. Barcelona: Obelisco. $1^{\underline{a}}$ ed. 77 p. : il. ; 16x24 cm. ISBN: 978-84-9777-524-3. Depósito legal: C0. 292-2009. Palabras clave: fundamentos teóricos, fundamentos técnicos, principios técnicos, taoísmo, aplicación terapéutica. Resumen: Manual teórico y técnico de qigong. El libro esta formado por 6 capítulos precedidos por unas recomendaciones prácticas sobre la aplicación de los contenidos del libro. El primer capítulo explica en qué consiste el tao universal, sus niveles de entrenamiento, los fundamentos teóricos del taoísmo, el chi y sus aplicaciones. El segundo capítulo comenta los objetivos del tao universal y sus principios técnicos. El tercer capítulo señala los beneficios de la sonrisa interior además de describir la ejecución de sus distintos ejercicios acompañados de su representación gráfica. El cuarto capítulo expone brevemente los fundamentos teóricos y técnicos de la meditación de la órbita microcósmica. El quinto capítulo presenta las virtudes del taoísmo y explica como realizar la transformación del estrés. El sexto capítulo ofrece algunos consejos para la vida diaria y la salud. Adjunta los agradecimientos, la biografía del autor, presenta el centro de enseñanza del tao universal y un índice analítico.

660. Chia, Mantak y Chia, Maneewan (1995). Despierta la luz curativa del tao. Villaviciosa de Odón: Mirach. $1^{\text {a }}$ ed. 410 p. : il. ; desc.xdesc. cm. ISBN: 84-8747-661-9. Depósito legal: no. Palabras clave: fundamentos teóricos, fundamentos técnicos, ejercicios, meditación. Resumen: Manual técnico de chikung. El libro esta dividido en 15 capítulos precedidos por una introducción que señala los beneficios y fundamentos del tao curativo. El primer capítulo expone los fundamentos teóricos de la alquimia interior mientras que el segundo explicado la teoría del chi. El tercer capítulo detalla las virtudes internas y su relación con el chi. El cuarto capítulo describe la ejecución de los ejercicios preparatorios para las meditaciones incluyendo su representación gráfica y señalando sus principios técnicos. Los dos siguientes capítulos exponen los fundamentos teóricos de los puntos de la órbita microcósmica así como los ejercicios para su apertura. El séptimo capítulos explica la ejecución de los ejercicios de la órbita microcósmica y su relación con la energía de la tierra. El octavo capítulo detalla la ejecución de los ejercicios de la fuerza cósmica junto con sus ilustraciones. Los tres siguientes capítulos explican los fundamentos teóricos y ejercicios de la apertura del corazón, la energía sexual y el chi celeste además de su relación con la órbita microcósmica y la representación gráfica de los ejercicios. El duodécimo capítulo incluye un resumen de los puntos más importantes de cada ejercicio. El siguiente capítulo presenta los fundamentos teóricos y ejercicios de la órbita macrocósmica y sus ilustraciones. Los dos últimos capítulos incluyen consejos para la práctica diaria y la aplicación terapéutica de los ejercicios de la luz curativa para distintos problemas y enfermedades.

661. Chia, Mantak y Chia, Maneewan (2002). Despierta la luz curativa : instrucciones y teoría. Móstoles: Neo Person. $2^{a}$ ed. 92 p. ; 10x18,5 cm. ISBN: 84-88066-69-4. Depósito legal: M. 5247-2002. Palabras clave: fundamentos teóricos, fundamentos técnicos, ejercicios, meditación. Resumen: Manual técnico de chikung. El libro esta dividido en dos partes. La primera parte consta de un capítulo que presenta el guión del vídeo 1 sobre los fundamentos teóricos de la órbita microcósmica, sus indicaciones, su aplicación y su ejecución. La segunda parte consta de 6 capítulos que presentan el guión del vídeo 2 . Los tres primeros capítulos detallan los fundamentos teóricos y ejecución de los ejercicios de apertura del corazón y vinculación del amor con la energía sexual, conexión con la energía de la madre tierra, y vinculación con el yo superior y la energía cósmica del yo superior. Los tres últimos capítulos exponen los beneficios derivados de la meditación, su relación con el desarrollo espiritual y describe los ejercicios de despejar el canal funcional y conectar los tres tan tien, despejar el canal gobernador y conectarlo con el chi universal, y conectar con la coronilla y el entrecejo y unión de los dos canales.

662. Chia, Mantak y Oellibrandt, Dirk (2003). Terapia cósmica II : cosmología taoísta y sanación universal. Málaga: Sirio. 1a ed. 333 p. : il. ; desc.xdesc. cm. ISBN: 84-7808-403-7. Depósito legal: no. Palabras clave: qigong, fundamentos teóricos, fundamentos técnicos, ejercicios, aplicación terapéutica, meditación. Resumen: Manual teórico y técnico de chi kung. El libro esta dividido en 10 capítulos precedidos por los agradecimientos y una nota de precauciones antes de comenzar la práctica. El primer capítulo presenta explica los fundamentos de la cosmología taoísta. El segundo capítulo detalla las relaciones entre la cosmología taoísta y la teoría del chi. El tercer capítulo describe las prácticas básicas y ejercicios de preparación del sistema del tao universal. El tercer capítulo expone la astrología taoísta y describe la estructura del universo. El cuarto capítulo incluye un resumen con los puntos más importantes y aplicaciones de los fundamentos teóricos sobre la astrología taoísta. El quinto capítulo describe la relación entre el desarrollo de la humanidad y el universo, y las relaciones entre ambos sistemas. El séptimo capítulo expone la relación entre el sistema solar y la fisiología humana además de la teoría de los cinco elementos y la utilización de la energía cósmica en Oriente y Occidente. El octavo capítulo presenta la estructura del cráneo y la relación entre el cuerpo y la energía universal incluyendo varias ilustraciones explicativas. El noveno capítulo detalla cómo utilizar la energía cósmica en la vida diaria. El décimo capítulo incluye los fundamentos teóricos y técnicos para preparar y 
realizar los ejercicios de sanación universal. El decimoprimer capítulo describe e ilustra los ejercicios de meditación planetaria y estelar. Adjunta un apéndice con información sobre la organización Du Mai y bibliografía.

663. China Sports Magazine (comp.) (1989). Los prodigios del qigong : un ejercicio chino para el bienestar, la salud y la longevidad. Madrid: Mandala. 1a ed. 139 p. : il. ; 21x28 cm. ISBN: 84-86961-08-4. Depósito legal: M. 6737-1989. Palabras clave: historia, principios técnicos, ejercicios, qigong, relatos, aplicación terapéutica. Resumen: Manual teórico y técnico de qigong. La obra esta dividida en 3 partes. La primera parte esta formada de 3 capítulos que detallan la historia y evolución del qigong hasta la actualidad, la aparición de las primeras imágenes de daoyin junto con su interpretación e ilustración, las investigaciones realizadas en torno al qigong y la manifestación de sus beneficios, y los cambios fisiológicos causados por la práctica y tratamiento con el qigong. La segunda parte consta de 12 capítulos. El primer capítulo describe la ejecución técnica de algunos ejercicios de qigong para la relajación, el fortalecimiento y de preparación interior, un programa de entrenamiento, las formas de actuar del qigong, sus principios técnicos y un comentario sobre sus posibles efectos secundarios. Los 3 siguientes capítulos presentan la ejecución técnica e ilustración de los ejercicios baduanjin (ejercicios de brocado en ocho figuras), los ejercicios yijinjing (ejercicios de calentamiento de los tendones) y los ejercicios de qigong taiji. El quinto capítulo comenta las características de los ejercicios de qigong wuqin o wuqinxi y sus beneficios para la salud. Los siguientes tres capítulos describen la ejecución técnica del ejercicio de respiración del ganso salvaje, la serie de 20 figuras recopilada por Wang Ziping para la salud y la longevidad, y el boxeo de las siete estrellas, incluyendo la ilustración de sus movimientos y el esquema de movimiento de sus pies. El noveno capítulo expone la ejecución y principios técnicos de un ejercicio de qigong. Los siguientes tres capítulos explican la ejecución de diferentes ejercicios para favorecer la salud, curar la gastroptosis y la otitis; presenta la ejecución de los ejercicios para curar la emisión seminal y sus consejos prácticos, y expone la descripción técnica de 8 posturas de pie para mantenerse en forma junto con su ilustración. La tercera parte contiene 10 capítulos. El primer capítulo expone los beneficios de la práctica del qigong para luego exponer la formación del maestro Ma Chun en la investigación del qigong y sus experiencias en la curación. Los siguientes siete capítulos presentan los beneficios que tuvo la práctica del qigong sobre distintas enfermedades de varios pacientes para finalizar con algunas anécdotas sobre la aplicación del qigong dayan sobre ciertas patologías.

664. Choy, Howard (1988). 18 manos de lohan chi-kung. Barcelona: Alas. 1aㅡ ed. 48 p. : il. ; 17x24 cm. ISBN: 84-203-0223-6. Depósito legal: B. 28669-1988. Palabras clave: historia, fundamentos teóricos, principios técnicos, salud. Resumen: Manual teórico y técnico de chi kung. La obra esta formada por 12 capítulos, precedidos por una nota del traductor y una introducción que comenta los contenidos de la obra. El primer capítulo relata el origen del lohan kung mientras que el segundo presenta el linaje del estilo. Los siguientes cuatro capítulos muestran la relación entre el lohan kung y el choy-lee-fut, el kung-fu, el tai-chi y la forma de los cinco animales, incluyendo varios gráficos. El séptimo capítulo enumera las beneficios del lohan kung para la salud, para luego exponer la teoría del yin/yang y los meridianos. El décimo capítulo detalla los principios técnicos de la práctica del lohan kung. El siguiente capítulo muestra la secuencia fotográfica del ejercicio de lohan kung acompañada de una breve explicación de cada posición. El último capítulo explica la función de la posición "derribar cadena montañosa con palmas". Adjunta bibliografía.

665. Chuen, Lam Kam (1993). El camino de la energía : dominar el arte chino de la fuerza interna con el ejercicio chi kung. Barcelona: Integral. 1aㅡ ed. 192 p. : il. ; 17x24 cm. ISBN: 84-7901-067-3. Depósito legal: B. 29925-1993. Palabras clave: fundamentos técnicos, principios técnicos, ejercicios, entrenamiento, aplicación terapéutica, enfermedades. Resumen: Manual técnico de chi kung. El libro esta dividido en cuatro partes, precedidas por una introducción que explica el concepto de energía, las características del sistema Zhan Zhuang, y la circulación de chi. La primera parte consta de 3 capítulos que describen las dos primeras posturas del sistema Zhan Zhuang, varios ejercicios para entrenar la respiración y relajación y la tabla de sensaciones y reacciones derivadas de la práctica del chi kung, acompañados de su representación gráfica, esquemas de movimiento e incluyendo consejos prácticos y poemas. La segunda parte consta de dos capítulos, describiendo los ejercicios de ba duan jin por partes y con la ayuda de gráficos explicativos el primero de ellos y otras tres posturas del sistema Zhan Zhuang acompañadas del esquema para practicar la secuencia completa, sus principios técnicos y su representación gráfica. La tercera parte consta de dos capítulos. El primer capítulo describe la ejecución técnica de las posiciones sexta, séptima, octava y novena junto con sus correspondientes variaciones, incluyendo los consejos para su práctica y su ilustración. El segundo capítulo presenta la descripción técnica, consejos prácticos y beneficios de varios ejercicios para centrar la energía y aumentar la resistencia mental. La última parte consta de 3 capítulos que aplican las posiciones de Zhan Zhuang a las situaciones de la vida diaria, a las diferentes edades o etapas de la vida, y ante algunas situaciones de enfermedad leve, describiendo e ilustrando su ejecución y ofreciendo consejos y sugerencias para la práctica. Adjunta índice y bibliografía. 
666. Chuen, Lam Kam (1997). Chi kung : el camino de la energía. El arte chino de la fuerza interna. Barcelona: Integral. $1^{\mathrm{a}}$ ed. 192 p. : il. ; desc.xdesc. cm. ISBN: 84-7901-317-6. Depósito legal: B. 48146-1997. (2aㅡ ed., 1999; 4a ed., 2002). Palabras clave: fundamentos técnicos, principios técnicos, ejercicios, entrenamiento, aplicación terapéutica, enfermedades. Resumen: Manual técnico de chi kung. El libro esta dividido en cuatro partes, precedidas por una introducción que explica el concepto de energía, las características del sistema Zhan Zhuang, y la circulación de chi. La primera parte consta de 3 capítulos que describen las dos primeras posturas del sistema Zhan Zhuang, varios ejercicios para entrenar la respiración y relajación y la tabla de sensaciones y reacciones derivadas de la práctica del chi kung, acompañados de su representación gráfica, esquemas de movimiento e incluyendo consejos prácticos y poemas. La segunda parte consta de dos capítulos, describiendo los ejercicios de ba duan jin por partes y con la ayuda de gráficos explicativos el primero de ellos y otras tres posturas del sistema Zhan Zhuang acompañadas del esquema para practicar la secuencia completa, sus principios técnicos y su representación gráfica. La tercera parte consta de dos capítulos. El primer capítulo describe la ejecución técnica de las posiciones sexta, séptima, octava y novena junto con sus correspondientes variaciones, incluyendo los consejos para su práctica y su ilustración. El segundo capítulo presenta la descripción técnica, consejos prácticos y beneficios de varios ejercicios para centrar la energía y aumentar la resistencia mental. La última parte consta de 3 capítulos que aplican las posiciones de Zhan Zhuang a las situaciones de la vida diaria, a las diferentes edades o etapas de la vida, y ante algunas situaciones de enfermedad leve, describiendo e ilustrando su ejecución y ofreciendo consejos y sugerencias para la práctica. Adjunta índice y bibliografía.

667. Chuen, Lam Kam (1999). El poder curativo del chi : ejercicios para hacer fluir la energía, serenar la mente y fortalecer el cuerpo. Barcelona: Integral. 1aㅡ ed. 159 p. : il. ; 16x23,5 cm. ISBN: 84-7901-444-X. Depósito legal: no. Palabras clave: fundamentos teóricos, fundamentos técnicos. Resumen: Manual teórico y técnico de chi kung. El libro esta compuesto de 5 partes, precedidas de una introducción que comenta la energía que esta presente en el ser humano y su relación con la salud y la enfermedad, y los estados de ánimo. La primera parte introduce el término chi y presenta varios ejercicios para movilizar el chi a través del cuerpo, describiendo su ejecución, los principales errores, sus beneficios y sensaciones. La segunda parte expone distintos ejercicios para restablecer el flujo de chi por medio de movimientos de tai chi. La tercera parte describe e ilustra la ejecución de ciertas posiciones para aumentar el volumen y el flujo del chi, señalando sus aspectos fundamentales y ofreciendo consejos prácticos para avanzar adecuadamente durante el entrenamiento. Los ejercicios de la cuarta parte presentan técnicas de masaje basados en la teoría de los cinco elementos, además de explicar el poder curativo de cada una de ellas. La última parte aplica los ejercicios básicos explicados en la primera parte del libro a estados de disminución de las reservas de energía, pudiendo realizarlos en cama, sentado o apoyado. Adjunta un breve relato sobre la historia del Zhan Zhuang y el autor, índice materias y agradecimientos.

668. Chuen, Lam Kam (1999). El poder curativo del chi kung : ejercicios para hacer fluir la energía, serenar la mente y fortalecer el cuerpo. Barcelona: Integral. 1a ed. 159 p. : il. ; desc.xdesc. cm. ISBN: 84-7871-3069. Depósito legal: no. (2a ed., 2005). Palabras clave: fundamentos teóricos, fundamentos técnicos. Resumen: Manual teórico y técnico de chi kung. El libro esta compuesto de 5 partes, precedidas de una introducción que comenta la energía que esta presente en el ser humano y su relación con la salud y la enfermedad, y los estados de ánimo. La primera parte introduce el término chi y presenta varios ejercicios para movilizar el chi a través del cuerpo, describiendo su ejecución, los principales errores, sus beneficios y sensaciones. La segunda parte expone distintos ejercicios para restablecer el flujo de chi por medio de movimientos de tai chi. La tercera parte describe e ilustra la ejecución de ciertas posiciones para aumentar el volumen y el flujo del chi, señalando sus aspectos fundamentales y ofreciendo consejos prácticos para avanzar adecuadamente durante el entrenamiento. Los ejercicios de la cuarta parte presentan técnicas de masaje basados en la teoría de los cinco elementos, además de explicar el poder curativo de cada una de ellas. La última parte aplica los ejercicios básicos explicados en la primera parte del libro a estados de disminución de las reservas de energía, pudiendo realizarlos en cama, sentado o apoyado. Adjunta un breve relato sobre la historia del Zhan Zhuang y el autor, índice materias y agradecimientos.

669. Clyman, Gary J. (2002). Los elementos prácticos del chi-kung : el método Clyman. Romanones: Tao. 1ạ ed. 155 p. : il. ; 15x21,5 cm. ISBN: 84-921280-9-7. Depósito legal: M. 51808-2001. Palabras clave: fundamentos teóricos, fundamentos técnicos, principios técnicos, principios teóricos, entrenamiento. Resumen: Manual teórico y técnico de chi-kung. La obra esta dividida en 4 capítulos. El primer capítulo explica en qué consiste el chi-kung, cuales son sus objetivos y beneficios, relata su historia y resume las etapas de aprendizaje que aparecen en el libro. El segundo capítulo presenta los principios básicos del chi-kung así como la definición, objetivos y beneficios de los elementos técnicos que componen el método Clyman de chi-kung. El tercer capítulo presenta el esquema de contenidos de las 6 lecciones que componen el curso de aprendizaje, los principios técnicos para la práctica y expone la descripción de los contenidos técnicos de las 6 lecciones, describiendo los ejercicios técnicos de cada 
una de ellas. La primera lección incluye los ejercicios de calentamiento, la respiración condensadora, el entrenamiento de las vías energéticas básicas, la meditación de arriba y abajo, la meditación de flujo hacia dentro y afuera, la meditación del círculo del tai-chi y el ejercicio de relajación en la posición de sellado. La segunda lección incluye el ejercicio del aire exterior, el ejercicio del aire interior y la tabla de práctica de las lecciones 1 y 2 . La tercera lección incluye las técnicas en posición sentado con entrenamiento mental, el puño de saludo, la meditación de la bola de energía del tai-chi, el abaniqueo lateral, el abaniqueo frontal, la proyección por ambas manos hacia abajo y afuera, la proyección por ambas manos hacia arriba y afuera, la meditación con las manos en las rodillas y la tabla de práctica de las lecciones 1,2 y 3. La tercera lección incluye la descripción de la órbita microcósmica, mientras que la quinta lección presenta la construcción de la tabla básica de chi-kung. La sexta lección incluye la ampliación de la tabla básica, la meditación del cielo y la tierra, la meditación del cielo y la tierra con afirmaciones, la meditación del cielo y la tierra con visualizaciones, la proyección de tu voluntad/impregnación del universo, la condensación por capas, y un resumen de la duración total de la tabla ampliada, los beneficios del chi-kung y algunos consejos para seguir avanzando en el entrenamiento. El último capítulo expone varias rutinas de entrenamiento para aquellas personas que disponen de poco tiempo de práctica. Adjunta un apéndice con una lista de afirmaciones y bibliografía.

670. Cohen, Kenneth S. (2004). El camino del qigong. Barcelona: La liebre de marzo. 1a ed. 479 p. : il. ; 17x24 cm. ISBN: 84-87403-70-0. Depósito legal: B. 3409-2004. Palabras clave: formas, qigong, historia, fundamentos teóricos, principios técnicos, ejercicios, sexo, entrenamiento, aplicación terapéutica, fisioterapia, meditación, nutrición, planificación del entrenamiento, relajación, respiración, armas. Resumen: Manual teórico y técnico de qigong. La obra esta compuesta por cuatro secciones, precedidas por los agradecimientos, un prólogo que analiza la obra, la pronunciación de las palabras chinas y una nota del autor. La primera sección consta de cinco capítulos. El primer capítulo detalla en qué consiste el qigong, sus categorías y aplicaciones. El segundo capítulo relata los orígenes del qigong, sus influencias externas y su historia reciente. El tercer capítulo define los conceptos de qi, jing y shen. El cuarto capítulo presenta varios estudios que relacionan el qi con la bioelectricidad, la bioquímica y la bioluminiscencia. El quinto capítulo resume los resultados obtenidos tras la aplicación del qigong sobre la presión sanguínea, el sistema circulatorio, el aparato digestivo, el cerebro, la salud mental, el aparato respiratorio, el asma y el sistema inmunitario. La segunda sección consta de cuatro capítulos. El primer capítulo ofrece consejos sobre el lugar y la hora de la práctica del qigong, comentando sus fundamentos teóricos. El segundo capítulo comenta los principios técnicos de la postura qigong. El tercer capítulo expone las características, principios y beneficios del fang song gong (relajación activa) junto con la descripción de varios de sus ejercicios. El cuarto capítulo señala la importancia de la respiración, describe algunos métodos para autoevaluar nuestra forma de respiración y comenta las características, beneficios y forma de ejecución de los distintos tipos o métodos de respiración. La tercera sección consta de ocho capítulos. El primer capítulo detalla las características generales de la meditación de pie, comenta la historia de la postura de pie además de describir los principios y ejecución de la meditación de pie y caminando. El segundo capítulo señala los tipos de meditación qigong junto con sus características generales para luego detallar la ejecución y objetivos de distintos métodos. El tercer capítulo explica la ejecución de los ejercicios de qigong dinámico denominados los ocho brocados, el lavado de médula, el juego de los cinco animales, la regla taiji y el balanceo de brazos, acompañados de su representación gráfica junto con un resumen de las características de los estilos xing yi quan, bagua zhang y taiji quan. El cuarto capítulo presenta la descripción técnica de cuatro series de masaje autocurativo. El quinto capítulo analiza la relación entre las emociones y el cuerpo, las características de la posición qigong y su influencia sobre las emociones y expone los fundamentos teóricos de la medicina tradicional china sobre la relación órgano-emoción. El sexto capítulo describe el proceso de curación a través de la transmisión de qi, los requisitos para su práctica, sus métodos, su forma de diagnóstico y las estrategias de tratamiento. El séptimo capítulo ofrece varias propuestas de programas de entrenamiento. El octavo capítulo enumera y comenta los beneficios de la práctica del qigong así como algunas señales de una práctica incorrecta. La última sección consta de cuatro capítulos. El primer capítulo presenta las reglas para mantener una dieta equilibrada según la teoría qigong y la nutrición occidental. El segundo capítulo narra la historia del té, define sus propiedades terapéuticas y explica cómo preparar un té. El tercer capítulo narra los antecedentes del daoísmo y el qigong sexual y describe sus fundamentos teóricos y técnicas. El cuarto capítulo expone las etapas de aprendizaje del qigong. Adjunta apéndices con la cronología de las dinastías chinas, el concepto de dan tian, los problemas de la investigación científica sobre qigong, un resumen de los beneficios del qigong interno, un glosario de términos utilizados en qigong, notas aclaratorias y bibliografía.

671. Deming, Li (comp.) (1989). Wuqinxi, ejercicios para el fortalecimiento físico a la manera de los cinco animales. Madrid: Miraguano. $1^{a}$ ed. 91 p. : il. ; 13x19 cm. ISBN: 84-7813-046-2. Depósito legal: M. 37309-1989. Palabras clave: fundamentos técnicos, ejercicios, wushu, salud. Resumen: Manual teórico y técnico de wushu. El libro esta formado por 5 capítulos. El primer capítulo relata la historia de la formación de los ejercicios wuqinxi además de señalar las características y principios técnicos de 
dichos ejercicios. El segundo capítulo esta dividido en 5 partes, describiendo e ilustrando las tres primeras partes la ejecución técnica de los 10 ejercicios de calentamiento, las cuatro series de cinco ejercicios basados en cada animal (tigre, ciervo, mono, oso, grulla) y dos ejercicios de relajación final, y finalizando con la explicación de las características de cada animal y los aspectos técnicos más importantes de cada ejercicio de wuqinxi. El tercer capítulo presenta el pentagrama de las melodías principales para escuchar mientras se realizan los ejercicios de wuqinxi, y señala las características, objetivos y efectos de estas melodías sobre el practicante. El cuarto capítulo expone varios casos clínicos sobre la aplicación beneficiosa de los ejercicios de wuqinxi y los efectos que tienen sobre el sistema muscular, cardiovascular, digestivo, ocular y los nervios. El último capítulo describe e ilustra la ejecución de un ejercicio de wuqinxi simplificado de cada animal.

672. Ding, Li (1992). Técnicas de canalización de la energía vital : qigong meridiano. Madrid: Miraguano. 1a ed. 254 p. : il. ; 13×19 cm. ISBN: 84-7813-088-8. Depósito legal: M. 2709-1992. Palabras clave: historia, fundamentos teóricos, principios técnicos. Resumen: Manual teórico y técnico de qigong. La monografía esta formada por 3 capítulos. El primer capítulo explica la historia del qigong, su práctica y beneficios, sus fundamentos, la aplicación del qigong meridiano para regular la mente, la respiración y la energía, consejos y precauciones para su práctica, así como algunas notas para distintas enfermedades. El segundo capítulo explica los ejercicios para hacer entrar la energía en el dantian y de exhalación e inhalación como forma de calentamiento, incluyendo varios dibujos y esquemas de movimiento de cada técnica. El tercer capítulo estudia los 14 meridianos, describiendo su recorrido, la ubicación de sus puntos importantes, los efectos de su entrenamiento y la ejecución técnica de sus movimientos acompañada de varios gráficos, esquemas de movimiento y los puntos clave de dicha ejecución. Los meridianos presentados son: el meridiano del pulmón Taiyin de la mano, el meridiano del intestino grueso Yangming de la mano, el meridiano del estómago Yangming del pie, el meridiano del bazo Taiyin del pie, el meridiano del corazón Shaoyin de la mano, el meridiano del intestino delgado Taiyang de la mano, el meridiano de la vejiga Taiyang del pie, el meridiano del riñón Shaoyin del pie, el meridiano del pericardio Jueyin de la mano, el meridiano de Sanjiao Shaoyang de la mano, el meridiano de la vesícula biliar Shaoyang del pie, el meridiano del hígado Jueyin del pie, el meridiano Ren y el meridiano Du. Adjunta una breve biografía del autor.

673. Dong, Liu (2001). Qi gong, la vía del sosiego : principios filosóficos y aplicaciones terapéuticas. Barcelona: Kairós. 1aㅡ ed. 182 p. : il. ; 14x22 cm. ISBN: 84-7245-474-6. Depósito legal: B. 112-2001. (2ae ed., 2002). Palabras clave: fundamentos teóricos, fundamentos técnicos, principios técnicos, filosofía, ejercicios. Resumen: Tratado técnico y práctico sobre este arte marcial. Esta dividido en dos partes, la primera presenta la teoría sobre la que se fundamenta la práctica del qi gong, mientras que la segunda describe algunos ejercicios para su aplicación terapéutica. La primera parte profundiza en la filosofía china y su aplicación al qi gong. De esta manera, comienza describiendo las tres joyas del cielo, la tierra y el ser humano, para continuar con las tres armonizaciones del qi gong, los tres niveles de pensamiento, la apertura de los tres puntos, las tres reuniones internas y externas, la píldora de la inmortalidad, el agua de los tres cuencos que influye sobre la eficacia del qigong, las tres perfecciones del Jin-Qi-Shen, las tres prevenciones para la práctica y las tres prácticas de qi gong. La segunda parte presenta distintas tablas de ejercicios con aplicación terapéutica, como son el cuerpo de jade, la muchacha de jade, la hoja de jade, el sueño del Buda, y el Yi Jin Xi Sui Jing. Cada capítulo presenta una breve introducción de la tabla de ejercicios, sus usos terapéuticos, la preparación previa, los movimientos mediante gráficos y las recomendaciones para realizar correctamente dichos movimientos.

674. Fenton, Peter (2002). Shaolin nei jin qi gong : salud tradicional en un mundo moderno. Barberá del Vallés: Humanitas. 1aㅡ ed. 228 p. : il. ; 15x21,5 cm. ISBN: 84-7910-357-4. Depósito legal: B. 26535-2002. Palabras clave: formas, historia, fundamentos teóricos, ejercicios, anatomía, aplicación terapéutica, enfermedades, meditación. Resumen: Manual teórico y técnico de qigong. La obra esta formada por cinco capítulos. El primer capítulo expone las propiedades del qi, su presencia en la naturaleza, sus funciones, relata los orígenes del qigong y las particularidades del estilo shaolin nei jin qi gong. El segundo capítulo algunos de los hábitos que impiden la práctica correcta del qigong para luego describir e ilustrar cuatro ejercicios de calentamiento así como los cuatro ciclos básicos del estilo, incluyendo sus esquemas de movimiento. El tercer capítulo explica las aplicaciones terapéuticas del qigong, su metodología de tratamiento, relata el caso de Anton Mesmer y sus métodos de curación, y describe el tratamiento para el insomnio, dolores de cabeza, problemas de hígado y vesícula biliar, hipertensión, dolencias cardíacas, asma febril, resfriado asmático, problemas estomacales y prevenir el cáncer. El cuarto capítulo detalla los beneficios de la meditación y describe varios de sus ejercicios. El último capítulo describe el recorrido del qi por el cuerpo a través de los doce canales y explica su utilización, incluyendo su representación gráfica. Adjunta bibliografía y un índice de términos.

675. Fernández, Víctor (2008). Chikung de las ocho joyas. Barcelona: Terapias Verdes. 1a ed. 75 p. : il. ; $13 \times 19$ cm. ISBN: 978-84-96707-35-1. Depósito legal: B. 55796-2007. Palabras clave: historia, fundamentos teóricos, medicina tradicional china, fundamentos técnicos, principios técnicos, ejercicios, respiración. Resumen: Manual teórico y técnico de chikung. El libro esta formado por 8 
capítulos. El primer capítulo define la práctica del chikung mientras que el segundo describe el origen y evolución de los ejercicios ba duan jing. El tercer capítulo describe las características, efectos y ejecución de los ocho ejercicios que componen el ba duan jing acompañados de su representación gráfica. El cuarto capítulo expone los beneficios de su práctica continuada, mientras que el quinto enumera sus principios técnicos. El sexto capítulo comenta brevemente la teoría de los cinco elementos. El séptimo capítulo analiza el mecanismo de la respiración y sus tipos. El último capítulo comenta las características y función de los órganos internos de la medicina tradicional china.

676. Fernández, Víctor (2008). Chikung de los cinco animales. Barcelona: Terapias Verdes. $1^{\text {a }}$ ed. 75 p. : il. ; 13x19 cm. ISBN: 978-84-96707-36-8. Depósito legal: B. 55797-2007. Palabras clave: historia, fundamentos teóricos, fundamentos técnicos, principios técnicos, principios teóricos, entrenamiento, ejercicios. Resumen: Manual teórico y técnico de chikung. El libro esta formado por 7 capítulos. El primer capítulo define la práctica del chikung mientras que el segundo narra la historia del método wuqinxi, sus fundamentos teóricos. El tercer capítulo expone los beneficios derivados de la práctica de los ejercicios wuqinxi. El cuarto capítulo describe las características de los cinco animales (oso, ciervo, mono, grulla y tigre) que componen el método wuqinxi, los efectos de su práctica y la ejecución de sus ejercicios. El quinto capítulo presenta los principios técnicos para la práctica de los ejercicios wuqinxi. El sexto capítulo expone y comenta las 24 reglas para el progreso y desarrollo dentro de la práctica del chikung. El séptimo capítulo analiza el significado del símbolo yin-yang y explica su aplicación en el tai chi chuan y chikung.

677. Fernández, Víctor (2008). Chikung iniciación. Barcelona: Terapias Verdes. 1aㅡ ed. 78 p. : il. ; 13x19 cm. ISBN: 978-84-96707-34-4. Depósito legal: B. 55374-2007. Depósito legal del DVD: B. 48539-2007. Palabras clave: fundamentos técnicos, principios técnicos, historia, ejercicios, entrenamiento. Resumen: Manual teórico y técnico de chikung. El libro esta formado por 8 capítulos. El primer capítulo define el concepto de chikung, señala los requisitos para su aprendizaje y el objetivo de su práctica. El segundo capítulo explica en qué consiste el chikung, sus estilos y objetivos. El tercer capítulo relata la historia del chikung. El cuarto capítulo comenta los principios del entrenamiento mientras que el quinto señala las diferencias entre el chikung y el tai chi chuan. El sexto capítulo enumera y comenta los principios técnicos de la práctica el chikung. El séptimo capítulo expone las reacciones normales y anormales derivadas de la práctica continuada del chikung así como sus contraindicaciones. El último capítulo describe la ejecución de varias ejercicios básicos de chikung para mantener la vitalidad y los ejercicios wuji, lian yi, los ocho trigramas, ejercicio de contacto cielotierra, el tigre vuelca la montaña, el ave fénix abre sus alas, el dragón y el tigre se juntan, la respiración macrocósmica y limpiar con la bola de chi. El DVD de 58 minutos de duración aproximadamente, esta formado por 4 capítulos precedidos por una introducción que explica las características del chikung y sus diferencias respecto al tai chi. Los siguiente cuatro capítulos presentan la ejecución de la posición básica, la meditación wuchi, ejercicios de chikung de calentamiento para cada día y otros ejercicios. Adjunta créditos.

678. Ferraro, Dominique (2003). Qigong para niños : ejercicios sencillos y técnicas respiratorias para mantener a los niños en óptimo estado de salud. Barcelona: Oniro. $1^{\mathrm{a}}$ ed. 142 p. : il. ; 18x23,5 cm. ISBN: 84-9754-087-5. Depósito legal: B. 33138-2003. Palabras clave: fundamentos teóricos, ejercicios, aplicación terapéutica, enfermedades, fisioterapia. Resumen: Manual práctico de qigong aplicado en la infancia y adolescencia. Los cuatro primeros capítulos presentan los aspectos teóricos que rodean a este método, desde los beneficios del qigong, hasta las razones por las que suelen enfermar los niños, algunas recomendaciones prácticas antes de aplicar este método y cómo se debe realizar la preparación para los ejercicios. El quinto capítulo describe los ejercicios secuencialmente con apoyo gráfico. Presenta: el juego de los cinco animales, los sonidos terapéuticos y ejercicios de concentración mental y memoria. El capítulo sexto analiza teóricamente las causas y problemas visuales que aparecen en el niño y ofrece algunos consejos prácticos además de la ejercitación qigong. A continuación propone los ejercicios más convenientes para tratar este problema, comenzando con ejercicios para relajar el cuerpo y que circule la energía hasta los ojos y ejercicios estáticos de visualización y meditación, y continuando con el automasaje, ejercicios de los tres sonidos y finaliza con los consejos prácticos para la aplicación de todos ellos. El último capítulo centra su atención sobre el masaje pediátrico, tanto en la prevención y tonificación como en el terapéutico para los problemas físicos más comunes en la infancia. Adjunta bibliografía y compendio de abreviaturas.

679. Ferraro, Dominique y Zhou, Ma Xu (2001). Mejore su vista con el qigong : claves de esta milenaria gimnasia terapéutica china. Barcelona: Oniro. 1a ed. 159 p. : il. ; 13x21 cm. ISBN: 84-95456-59-1. Depósito legal: B. 19066-2001. Palabras clave: fundamentos teóricos, ejercicios, qigong, enfermedades, fisioterapia, medicina tradicional china, salud. Resumen: Manual teórico y técnico de qigong. La obra esta formada por 7 capítulos. El primer capítulo expone los principales causantes del deterioro progresivo de la vista, los consejos prácticos para conservar una buena vista y ante la utilización del ordenador o la televisión, ofrece recomendaciones dietéticas para mantener la salud de los ojos, y explica como funciona el qigong, su fundamentación en la medicina tradicional china y las 
patologías que puede curar el método de la autora. El segundo capítulo explica las formas en que la medicina tradicional china tonifica los órganos y las energías del cuerpo para luego proponer un programa de entrenamiento y describir e ilustrar las indicaciones, los sonidos, posturas y respiraciones de los distintos ejercicios para relajar el cuello, los hombros y la espalda, y hacer fluir la energía por todo el cuerpo, movilizar los ojos y desarrollar la visualización y meditación. El tercer capítulo describe la ejecución de los ejercicios de automasaje para los ojos y de digitopuntura para tonificarlos. El cuarto capítulo presenta los efectos de los sonidos terapéuticos y la teoría de los cinco elementos para luego describir la ejecución técnica de los ejercicios de los tres sonidos y los tres ideogramas. El quinto capítulo expone las técnicas de acupresión para el tratamiento de varias patologías oftalmológicas como la miopía, presbicia, estrabismo, ambliopía, hipermetropía, astigmatismo, escotoma y opacidad corneal, glaucoma y catarata. El sexto capítulo estudia la anatomía y funciones ojo desde la medicina tradicional china así como las causas más frecuentes que deterioran su salud y las maneras de prevenir dichas enfermedades. El último capítulo describe la localización, acción, síntomas y enfermedades de los puntos de acupresión relacionados con los ojos así como la ilustración de los meridianos de energía. Adjunta glosario de términos médicos y chinos y bibliografía.

680. Fratkin, Jake y Requena, Yves (1995). Iniciación al qi gong : ejercicios chinos de salud y longevidad. Introducción y viaje a China. Madrid: Asociación de Medicinas Complementarias e Instituto Internacional de Qi Gong. 1aㅡ ed. 88 p. : il. ; 11x20 cm. ISBN: 84-88346-14-X. Depósito legal: M. 372121995. Palabras clave: fundamentos teóricos, fundamentos técnicos, ejercicios, salud. Resumen: Manual teórico y técnico de qigong. El libro esta formado por 27 capítulos. El primer capítulo define el concepto de qigong, enumera sus estilos, describe la práctica del qigong en la actualidad, sus principios, sus diferencias respecto al taijiquan, sus beneficios para la salud, su aplicación en distintas situaciones y como método curativo. El segundo capítulo incluye la entrevista realizada al Dr. Yves Requena sobre su viaje a China. El tercer capítulo propone distintos ejercicios de qigong según el momento del día, mientras que el cuarto señala los efectos del masaje sobre las distintas partes del cuerpo. El quinto capítulo ilustra diferentes ejercicios para la apertura de las articulaciones del cuerpo. El sexto capítulo explica e ilustra la ejecución del ejercicio de qigong con las manos abiertas. El séptimo capítulo describe el dibujo del símbolo del taiji. Los siguientes cuatro capítulos describen la ejecución de los ejercicios de las 8 piezas de brocado, el masaje final de qigong, ejercicios aeróbicos de qigong y qigong de fortalecimiento de los músculos, acompañados de sus ilustraciones explicativas. El decimosegundo capítulo detalla la ejecución de varios ejercicios de estiramiento mientras que el siguiente capítulo muestra algunos ejercicios para la longevidad. El decimocuarto capítulo enumera algunas causas de los problemas de alteración de la energía para luego señalar los puntos de acupuntura para desmagnetizar el cuerpo acompañados de su ilustración. Los siguientes nueve capítulos describen la ejecución de los ejercicios de qigong denominados: agua celeste, relajación progresiva de los órganos y desintoxicación, respiración condensada en las 2 puertas con movimiento de las manos, respiración condensada de las 6 puertas, respiración cósmica, órbita microcósmica simple, órbita microcósmica con retención de la respiración, qigong de los 8 vasos maravillosos y órbita macrocósmica para los dedos de las manos y de los pies. El vigésimo quinto capítulo enumera los niveles energéticos mientras que el siguiente capítulo describe e ilustra la ejecución del ejercicio el misterio de las 7 puertas. El último capítulo presenta la órbita microcósmica de los puntos de acupuntura acompañados de su ilustración. Adjunta bibliografía, videografía, información sobre el Instituto Internacional de Qigong y lista de contactos.

681. Gandini, Maurizio (1996). El qi gong : los secretos chinos de salud, longevidad, vitalidad. Barcelona: De Vecchi. 1aㅡ ed. 149 p. : il. ; 17x24 cm. ISBN: 84-315-1560-0. Depósito legal: B. 17955-1996. Palabras clave: fundamentos técnicos, ejercicios, qigong, fisioterapia. Resumen: Manual teórico y técnico de qigong. El libro esta compuesto de 4 partes precedidas por las indicaciones generales para realizar correctamente los ejercicios que se presentan a continuación. La primera parte comenta las características del qigong estático para luego describir la ejecución y los principios técnicos de los ejercicios sostener la bola, abrazar la bola, abrazar el dan dian, montar el tigre y repeler el dragón junto con las ilustraciones por partes de sus movimientos. La segunda parte comenta los beneficios y describe la ejecución técnica tanto de los movimientos preliminares como del movimiento completo de los ejercicios de qigong dinámico llamados separar las aguas, forma del tigre, forma del oso, forma del mono, forma de la serpiente y forma de la grulla, incluyendo la ilustración de sus movimientos. La tercera parte presenta la teoría de los cinco elementos y su relación con la práctica de los seis sonidos para luego exponer cada uno de los sonidos (hígado, corazón, bazo, pulmones, riñones y triple fuego) con sus movimientos y beneficios para la salud. La última parte comenta los beneficios del automasaje y describe la ejecución del automasaje para los ojos, incluyendo la ilustración de los puntos para el automasaje y de cada movimiento.

682. González Rincón, Juan Sebastián (1996). Las 9 perlas del chi kung (qigong). Barcelona: Alas. 1aㅡ ed. 123 p. : il. ; 17x24 cm. ISBN: 84-203-0378-X. Depósito legal: B. 16261-1996. Palabras clave: historia, fundamentos teóricos, ejercicios, qigong, fundamentos filosóficos, medicina tradicional china, 
respiración. Resumen: Manual teórico y técnico de qigong. El libro esta formado por 9 capítulos precedidos por una breve biografía del autor, los agradecimientos, un prólogo que comenta el objetivo de la obra y una introducción que presenta las características de la obra. El primer capítulo explica el concepto de qi. El segundo capítulo narra la historia del qigong y sus vertientes, mientras que los dos siguientes capítulos comentan la influencia del taoísmo y el budismo sobre el qigong respectivamente. El quinto capítulo expone los principios y fundamentos teóricos de la medicina tradicional china acompañados de sus ilustraciones explicativas. El sexto capítulo presenta las características de los tres tesoros del qigong. El séptimo capítulo detalla los síntomas positivos y negativos derivados de la práctica del qigong así como sus contraindicaciones. El octavo capítulo explica los efectos de la respiración y sus tipos. El último capítulo describe la ejecución de distintos ejercicios de qigong estático y dinámica acompañados de su secuencia fotográfica. Adjunta un epílogo, una entrevista con el maestro Saotome y bibliografía.

683. González Rincón, Juan Sebastián (2004). Qigong : caminando hacia la armonía. Barcelona: Índigo. 1a ed. 176 p. : il. ; 18x26 cm. ISBN: 84-96381-17-X. Depósito legal: B. 2135-2005. Palabras clave: historia, fundamentos teóricos, principios técnicos, ejercicios, taijiquan, aplicación terapéutica, fisioterapia, meditación, respiración. Resumen: Manual teórico y técnico de qigong. El libro esta compuesto por 21 capítulos precedidos por los agradecimientos, un prólogo que señala la importancia de la obra y una introducción que comenta las características generales del qi. El primer capítulo narra los orígenes históricos del qigong. El segundo capítulo explica la teoría del qi y su significado. El tercer capítulo comenta las características del taoísmo, budismo y qigong. El cuarto capítulo describe la relación entre el qigong y las artes marciales. El quinto capítulo comenta la aplicación terapéutica y beneficios del tai chi chuan. El sexto capítulo expone los conceptos básicos para la práctica del qigong. El séptimo capítulo detalla las características de los tres tesoros del qigong. El octavo capítulo señala las características de la columna vertebral y describe las posturas de la meditación de pie. El noveno capítulo localiza el dantien y explica su significado. El décimo capítulo expone los efectos de la respiración y describe sus distintos tipos acompañados de su representación gráfica. El capítulo decimoprimero describe el papel de la mente (yi) y el espíritu (shen) en la práctica del qigong. El siguiente capítulo señala las indicaciones y contraindicaciones del qigong. El capítulo decimotercero ofrece algunos consejos para la práctica y describe sus efectos. El resto de capítulos describen la ejecución y funciones de los ejercicios para generar el qi, para conducir el qi, para autorregular el qi, para la relajación general del qi, para los ejercicios de meditación denominadas "adorando a buda", "buda medita" y "absorber la energía del sol" y del automasaje en las piernas acompañados de su representación gráfica. Adjunta bibliografía.

684. Hu, Bin (1994). Relajación y respiración : fundamentos de terapia Qigong. Madrid: Miraguano. 1a ed. 151 p. : il. ; 13x19 cm. ISBN: 84-7813-127-2. Depósito legal: M. 25656-1994. Palabras clave: fundamentos teóricos, fundamentos técnicos, principios técnicos, historia, ejercicios, aplicación terapéutica. Resumen: Manual teórico y técnico de qigong. La obra esta formada por 15 capítulos precedidos por una introducción que señala las características del qigong. El primer capítulo narra la historia del qigong y sus diferentes estilos. El segundo capítulo expone los fundamentos teóricos y conceptos del qigong. El tercer capítulo describe los beneficios y efectos terapéuticos del qigong. El cuarto capítulo señala la importancia de una correcta postura en la práctica del qigong y describe la ejecución de sus principales posturas acompañadas de su ilustración. El quinto capítulo presenta los distintos métodos de relajación mental del qigong además de comentar sus beneficios, principios y fases y ofrecer algunas recomendaciones para su práctica. El sexto capítulo detalla la función, objetivo y tipos de respiración junto con la explicación de los principios, ejecución y fases para su práctica. El séptimo capítulo expone las distintas clasificaciones del qigong desde el punto de vista de su aplicación y del método de ejercicio. El octavo capítulo analiza la situación actual de los estudios de qigong mientras que el noveno señala sus indicaciones y contraindicaciones. El décimo capítulo describe la ejecución de distintos ejercicios de qigong acompañados de su representación gráfica. El capítulo decimoprimero expone los puntos esenciales para la práctica mientras que el decimosegundo enumera los efectos normales y las reacciones anormales derivadas de dicha práctica. El siguiente capítulo comenta los momentos menos idóneos para la práctica del qigong. El decimocuarto capítulo comenta las aplicaciones terapéuticas del qigong en el tratamiento de distintas enfermedades mientras que el último capítulo señala la importancia de la perseverancia en su práctica. Adjunta una breve biografía del autor.

685. Leonelli, Núria (2006). Chi kung : fisioterapia para el bienestar emocional y mental. Barcelona: Fapa. 1a ed. 62 p. : il. ; 14×22 cm. ISBN: 84-9733-422-1. Depósito legal: B. 1967-2006. Palabras clave: formas, qigong, fundamentos teóricos, principios técnicos, ejercicios, medicina tradicional china, meditación. Resumen: Manual teórico y técnico de chi kung. La obra esta dividida en 4 capítulos precedidos por una introducción que comenta las características e historia de la medicina tradicional china y su relación con el qigong. El primer capítulo expone los conceptos básicos del qigong como son la teoría de la energía vital (chi), la teoría yin/yang, las características de las terapias de la medicina tradicional 
china, la historia y evolución de la práctica y su expansión mundial. El segundo capítulo describe los conceptos básicos de la medicina tradicional china que se aplican en el qigong como son los tres tesoros o energías básicas (esencia, energía vital y espíritu), el significado y relación de cada órgano con las emociones, la teoría de los cinco elementos y el movimiento de la energía, la red de meridianos y los tres centros energéticos. El tercer capítulo comenta los principios técnicos del qigong y su aplicación práctica además de comentar las características y ejecución técnica de la meditación Zhan Zhuang y explicar la historia de los ejercicios de los 8 tejidos de seda (baduanjin) junto con la descripción de su ejecución técnica e ilustraciones, su funcionamiento y beneficios para la salud. El último capítulo detalla los experimentos y conclusiones extraídas por el grupo de investigadores científicos del qigong.

686. Ly, Antoine (2007). Qigong dinámico. Madrid: Tutor. 1a ed. 94 p. : il. ; 18x23,5 cm. ISBN: 978-84-7902650-9. 84-7902-650-2. Depósito legal: M. 17080-2007. Palabras clave: formas, qigong. Resumen: Tratado teórico y técnico de qigong. Esta dividido en cinco capítulos principales. El primero de ellos nos introduce el qigong desde su evolución hasta sus fuentes teóricas o los maestros de transmisión de la presente versión. El segundo capítulo explica las tres regulaciones del qigong, esto es, del cuerpo físico, del corazón y del aliento. El tercer capítulo describe los ejercicios preparatorios antes de la práctica y el cuarto los fundamentos pedagógicos y las tres posturas fundamentales. El último capítulo describe textual y gráficamente la secuencia de movimientos de las ocho piezas del brocado del general Yue Fei. Adjunta glosario y bibliografía.

687. MacRitchie, James (1998). Chi kung : el cultivo de la energía personal. Móstoles: Arkano Books. 1aa ed. 157 p. : il. ; 14x21 cm. ISBN: 84-89897-05-0. Depósito legal: no. (2ª ed., 1999; 3aㅡ ed., 2005). Palabras clave: qigong, historia, fundamentos teóricos, ejercicios, aplicación terapéutica. Resumen: Ensayo introductorio al chikung desde la teoría y la práctica. El libro esta compuesto por seis capítulos y cada uno de ellos se divide en un acercamiento a la fundamentación teórica de esta práctica y en un ejercicio introductorio básico. El primer capítulo presenta lo que es el chikung, cuáles son las razones para practicarlo, las características principales de los diferentes chikung así como de sus dos categorías y el primer ejercicio, la sonrisa curativa, con la explicación de su objetivo y su secuencia de movimientos. El segundo capítulo centra el enfoque histórico sobre China, el taoísmo y el propio chikung así como los orígenes de las principales formas y el chikung en el occidente actual. También incluye el ejercicio La lluvia de energía. Tras reconocer que para entender el chikung es necesario conocer los sistemas y principios de la medicina y filosofía chinas, el tercer capítulo explica la anatomía y fisiología de la energía, centrándose en las estructuras básicas y aplicando los principios del tao, los cinco procesos elementales, y las leyes y principios básicos del sistema de meridianos. Aquí presenta el tercer ejercicio denominado Enfoca el centro de tu energía. El cuarto capítulo explica las distintas aplicaciones del chikung, concretamente en la forma física, las artes marciales, la salud y la curación, el sexo, la longevidad, las capacidades humanas extraordinarias, el desarrollo espiritual y la inmortalidad, y presentar el ejercicio Llamando a la puerta de la vida. El quinto capítulo presenta otros sistemas de energía corporal y cómo éstos se relacionan o diferencian del chikung, ahondando principalmente en el reciente "contacto terapéutico". El ejercicio que presenta este capítulo es Recarga de energía. El último capítulo refiere las consideraciones prácticas a tener en cuenta durante la realización del chikung, sus distintos propósitos (limpiar, generar, incrementar, acumular, refinar, circular, almacenar, conservar, descargar) y ofrece el último ejercicio, La energía curativa en tus manos. Por último, aparece un resumen de las recomendaciones prácticas y un glosario.

688. Mertens, Wilhelm y Oberlack, Helmut (2006). Qigong : relajante, tranquilizador y revitalizador. Arganda del Rey: Edimat. 1aㅡ ed. 80 p. : il. ; 16x20 cm. ISBN: 84-9764-824-2. Depósito legal: M. 7254-2006. Palabras clave: formas, qigong, fundamentos teóricos, fundamentos técnicos, ejercicios. Resumen: Manual teórico y técnico de qigong. La obra esta formada por 4 partes. La primera parte explica el significado de la salud en Occidente y Oriente, presenta la teoría del yin/yang, el significado del qi, la teoría de los cinco elementos, el significado del qigong y su relación con el tai chi así como los contenidos del libro y algunos consejos para practicar los ejercicios presentados. La segunda parte expone los principios técnicos para la práctica de cualquier ejercicio y describe la ejecución de las posiciones básicas del qigong y varios ejercicios para conocer y sentir el dantian, dominar la respiración, prepararse para el esfuerzo, relajarse y aumentar la permeabilidad, acompañados de su secuencia fotográfica, consejos y los puntos importantes de la ejecución. La tercera parte incluye la descripción técnica e ilustración de los ejercicios de las ocho joyas y de tai chi-qigong acompañados de consejos prácticos. La última parte describe la ejecución técnica de varios ejercicios para finalizar la práctica del qigong acompañada de su ilustración, consejos y resultados. Adjunta un glosario y bibliografía recomendada.

689. Muñoz Costas, Josep (2009). Qigong para regular órganos y emociones. Madrid: Tao. 1ạ ed. 165 p. : il. ; 15x21 cm. ISBN: 978-84-935889-0-8. Depósito legal: M. 11789-2009. Palabras clave: fundamentos teóricos, fundamentos técnicos, ejercicios, entrenamiento, fisioterapia. Resumen: Manual teórico y técnico de qigong. La obra esta formada por 10 capítulos precedidos por una aclaración de la 
transcripción de las palabras chinas. El primer capítulo explica la concepción china del chi, las diferentes escuelas de qigong, los beneficios de la práctica y la explicación de los principios energéticos. El segundo capítulo expone la teoría de los cinco elementos junto con la influencia de las emociones. El tercer capítulo describe la función, consecuencias del desequilibrio, emoción y dieta aparejada a los cinco órganos principales. El cuarto capítulo comenta los tipos de qi, los meridianos, los beneficios de la práctica del qigong, sus contraindicaciones y sus tipos. El quinto capítulo ofrece algunos consejos para la práctica de los ejercicios de qigong estático, describe las diferentes posiciones y propone una secuencia de entrenamiento. El sexto capítulo describe la ejecución de algunos ejercicios de calentamiento así como los ejercicios de qigong dinámico para armonizar el desequilibrio energético de los cinco órganos principales, incluyendo su representación gráfica y esquemas de movimiento. El séptimo capítulo explica la relación entre los órganos y los sentidos además de incluir la descripción de los ejercicios de masaje de cada sentido acompañados de su representación gráfica. El octavo capítulo describe la ejecución de varios ejercicios para cultivar la salud y la sonrisa interior. El noveno capítulo examina la actitud ante el entrenamiento para finalizar con la propuesta de varias sesiones prácticas encaminadas hacia la armonización general, el trabajo de un sólo órgano, restablecer el equilibrio de un órgano y tonificar Adjunta una conclusión final.

690. Padilla Corral, José Luis (1999). Qigong : en la sanación del espíritu. Cuenca: Tien C.B. 1ae ed. 262 p. : il. ; 16x22,5 cm. ISBN: No ISBN. Depósito legal: AB. 229-1999. Palabras clave: fundamentos teóricos, ejercicios, fundamentos filosóficos, aplicación terapéutica. Resumen: Manual teórico y técnico de qigong. El libro esta formado por 7 capítulos precedidos por una introducción que comenta los objetivos de la obra. El primer capítulo explica en qué consiste el qigong. El segundo capítulo analiza el término qigong ideogramáticamente para presentar sus objetivos y principios. El tercer capítulo comenta los elementos filosóficos básicos del qigong. El cuarto capítulo describe la ejecución, principios técnicos y efectos de los ejercicios del qigong planetario, de la decisión, de la precisión, del equilibrio, de la permanencia, de la contemplación y una combinación de estos tres últimos, acompañados de su representación gráfica y esquemas de movimiento. El quinto capítulo detalla los objetivos del qigong de lo interno y expone los fundamentos teóricos de sus ejercicios denominados "tratado de lo interno" y "la proyección de la luz". El sexto capítulo explica los fundamentos teóricos de la aplicación terapéutica del qigong para luego describir el tratamiento general del dolor, de enfermedades crónicas, los ejercicios del tratamiento preventivo, de enfermedades sistémicas, del sufrimiento y del estrés. El último capítulo describe la ejecución de los 6 movimientos de qi gong li, su aplicación como intermediario del cielo y la tierra. Adjunta un comentario final.

691. Pang, Ming; Jin, Xiaoguang y Marcello, Joseph (2005). Secretos de la energía inteligente : la ciencia del zhineng qigong. Teoría, principios y práctica. Madrid: Gaia Ediciones. $1 \underline{a}$ ed. 405 p. : il. ; $17 \times 24 \mathrm{~cm}$. ISBN: 84-8445-062-7. Depósito legal: M. 13921-2005. Palabras clave: fundamentos teóricos, fundamentos técnicos, principios técnicos, ejercicios. Resumen: Tratado teórico y práctico de qigong. El libro esta dividido en 4 partes precedidas por tres prefacios que presentan los estudios universitarios de zhineng qigong, los contenidos y objetivos de la obra. La primera parte expone y comenta los fundamentos teóricos y principios del zhineng qigong. La segunda parte consta de 4 capítulos. El primer capítulo expone el programa de enseñanza y la difusión mundial del método zhineng qigong. El segundo capítulo define los conceptos de qi y qigong, los tipos de qigong, sus rasgos comunes, su historia y sus beneficios para la salud además de presentar los fundamentos teóricos y conceptos de la ciencia del qigong y las peculiaridades del zhineng qigong. El tercer capítulo presenta los principios técnicos y consejos para la práctica del zhineng qigong. El cuarto capítulo analiza la relación entre el qigong y la medicina tradicional china así como con algunas facultades especiales. La tercera parte consta de 8 capítulos. Los seis primeros capítulos describen la ejecución de los métodos par elevar y verter el chi, la forma de fusión de los tres centros en posición erecta, el método de cuclillas frente a la pared, la terapia de extracción del chi y llenado con chi, el método de extensión del chi y el método de establecimiento de un campo de chi. El séptimo capítulo incluye la secuencia fotográfica de algunos de estos ejercicios. El octavo capítulo ofrece algunos consejos para el progreso en la práctica del zhineng qigong. La última parte comenta las características de las prácticas complementarias al qigong, algunos consejos nutricionales y medicinales, cómo realizar la limpieza de los meridianos y del flujo linfático y un comentario sobre algunas técnicas contemporáneas de purificación de la linfa sanguínea y otras prácticas de sustentación vital. Adjunta un epílogo, dos apéndices sobre el centro vital del hombre, bibliografía, un glosario y la biografía de los autores.

692. Pericás Álvarez, Francisco (2002). Chikung : energía vital. Ejercicios para la salud. Barcelona: Alas. 1a ed. 123 p. : il. ; $17 \times 24$ cm. ISBN: 84-203-0413-1. Depósito legal: B. 6608-2002. Palabras clave: fundamentos teóricos, fundamentos técnicos, ejercicios, fisioterapia, respiración. Resumen: Manual teórico y técnico de chikung. El libro esta compuesto por 4 capítulos precedidos por una dedicatoria, una introducción que señala el objetivo de la obra y una breve biografía del autor. El primer capítulo discute los factores involucrados en la vida espiritual y comenta los métodos de autoobservación, relajación y meditación para transformar la personalidad. El segundo capítulo expone los fundamentos 
teóricos de la energía así como la relación de las teorías del yin/yang, de los colores y del aura con dicha energía. El tercer capítulo describe los tipos de respiración, las propiedades de los aceites esenciales, algunas técnicas de automasaje, distintos ejercicios de mantenimiento y para abrir los chakras acompañados de sus ilustraciones. El cuarto capítulo incluye la descripción e ilustración de los ejercicios de chikung denominados la posición del árbol, los ocho brocados, abrazar la esfera, el pájaro vuela alto, aguantar el árbol, desplegar las alas, esconder las alas, empujar la luna, empujar el cielo, ejercicio del corazón y el mono encorvado. Adjunta el árbol familiar del estilo yuen shaolin.

693. Pintat Mateu, Neus (2009). Qi gong : desenvolupa les teves qualitats essencials. Barcelona: Publicacions de l'Abadia de Montserrat. 1a ed. 140 p. : il. ; $15 \times 21 \mathrm{~cm}$. ISBN: 978-84-9883-148-1. Depósito legal: B. 23950-2009. Palabras clave: fundamentos teóricos, qigong. Resumen: Manual teórico y técnico de qigong. El libro esta compuesto por 10 capítulos precedidos por un prólogo que comenta los objetivos de la obra y los agradecimientos. El primer capítulo expone los objetivos y efectos terapéuticos del qigong. El segundo capítulo comenta los orígenes de la medicina tradicional china. El tercer capítulo presenta la teoría del yin/yang mientras que el cuarto describe la teoría de los cinco elementos. El quinto capítulo muestra las relaciones energéticas de los órganos y el cuerpo. Los siguientes cinco capítulos describen las características, relaciones energéticas, cualidades esenciales, emociones y actitudes perturbadoras, forma física, test de la constitución, test del elemento y ejercicios de qigong de los elementos madera, fuego, tierra, metal y agua respectivamente incluyendo ilustraciones explicativas. Adjunta bibliografía.

694. Pintat Mateu, Neus (2009). Qi gong : harmonia de cos, ment i esperit. Barcelona: Publicacions de l'Abadia de Montserrat. 1ạ ed. 98 p. : il. ; $15 \times 21 \mathrm{~cm}$. ISBN: 978-84-9883-147-4. Depósito legal: B. 23951-2009. Palabras clave: fundamentos teóricos, ejercicios, qigong, medicina tradicional china, respiración. Resumen: Manual teórico y técnico de qigong. El libro esta formado por 4 capítulos precedidos por un prólogo que expone las cualidades de la medicina tradicional china. El primer capítulo comenta las características de la medicina tradicional china, sus métodos, y sus fundamentos teóricos y filosóficos. El segundo capítulo expone los métodos del qigong y sus principios técnicos. El tercer capítulo describe la ejecución de los diferentes tipos de respiración. El cuarto capítulo describe la ejecución de los ejercicios de qigong dinámicos como la postura básica, la postura del árbol, los ocho brocados, el sistema zhan zhuang, la órbita microcósmica externa y el triple calentador junto con sus ilustraciones explicativas. El quinto capítulo incluye la descripción e ilustración de los distintos ejercicios de interiorización del qigong. Adjunta bibliografía.

695. Prat Banús, José María (1985). Chi-kung : el arte secreto chino de la respiración para la salud física y mental. Barcelona: Alas. $1^{a}$ ed. 128 p. : il. ; $15 \times 21$ cm. ISBN: 84-203-0176-0. Depósito legal: B. 138151985. (2 ${ }^{\mathrm{a}}$ ed., 1986). Palabras clave: historia, fundamentos teóricos, principios técnicos, ejercicios, artes marciales, escuelas, aplicación terapéutica, budismo, respiración, taoísmo. Resumen: Manual teórico y técnico de chikung. El libro esta formado por 14 capítulos precedidos por una introducción que comenta el estudio del chikung en la actualidad. El primer capítulo explica el proceso de la respiración en las plantas y los animales. El segundo capítulo describe la fisiología del aparato respiratorio en el ser humano. El tercer capítulo describe el movimiento respiratorio, sus fases, su control y su relación con los estados mentales. El cuarto capítulo define el concepto de chikung y sus funciones, narra su historia y su relación con el taoísmo y budismo. El quinto capítulo expone la teoría del yin-yang y aplicación en el chikung. El sexto capítulo comenta los efectos físicos y mentales derivados de la práctica del chikung, sus efectos durante la propia práctica, sus contraindicaciones y los principios del entrenamiento. El séptimo capítulo describe la aplicación del chikung en las artes marciales. El octavo capítulo analiza los requisitos para la práctica del chikung como son la relajación, la tranquilidad y la concentración durante la práctica del chikung, durante la vida diaria, en relación al tantien y al movimiento. El noveno capítulo describe la ejecución de la práctica de chikung de pie, sentado y tumbado acompañada de su representación gráfica. El décimo capítulo explica el control de la respiración durante los ejercicios de chikung, enumera sus principios técnicos y presenta una planificación de la práctica. El capítulo decimoprimero detalla las características de los métodos I Ching Ching, Pa Tuan Chin (ocho piezas de seda) y Wu Chin Si (juego de los cinco animales) mientras que el siguiente capítulo presenta los fundamentos de los estilos tai chi chuan, pa kua chang y hsing i chuan. El capítulo decimotercero comenta la influencia de los cambios de la naturaleza sobre el individuo y ofrece algunos consejos respecto a la sexualidad mientras que el último capítulo describe la ejecución de los 24 ejercicios estacionales para tratar esos cambios acompañados de su representación gráfica.

696. Prouzet, Aimé (2001). La autocuración con el qi gong. Barcelona: Paidotribo. 1 a ed. 270 p. : il. ; 15x21,5 cm. ISBN: 84-8019-564-9. Depósito legal: no. Palabras clave: formas, historia, fundamentos teóricos, fundamentos técnicos, ejercicios, qigong, fundamentos filosóficos, aplicación terapéutica, medicina tradicional china, meditación, unidades didácticas. Resumen: Manual teórico y técnico de qigong. La obra esta formada por cinco partes. La primera parte consta de 2 capítulos, precedidos por un comentario sobre la actuación del qigong sobre el cuerpo, sus vertientes y contenidos técnicos. El 
primer capítulo relata la historia del qigong mientras que el segundo expone los fundamentos filosóficos y las bases de la medicina tradicional china que configuran la práctica del qigong. La segunda parte consta de tres capítulos, precedidos por un comentario sobre cómo realizar los ejercicios prácticos. El primer capítulo presenta le ejecución técnicas de las posturas básicas acompañadas de sus respectivas ilustraciones. El segundo capítulo describe los distintos tipos de respiración y sus características. El tercer capítulo señala los efectos fisiológicos de las técnicas de visualización así como su aplicación junto con el qigong. La tercera parte consta de tres capítulos, precedidos por un comentario sobre los objetivos del qigong externo. El primer capítulo enumera los objetivos de los masajes para luego presentar la descripción de las técnicas de masaje aplicadas a la cabeza, las extremidades, los ojos, las orejas, los dientes, el tórax, los órganos digestivos y los riñones, acompañados de gráficos e ilustraciones explicativas. El segundo capítulo incluye la descripción de distintos ejercicios de movilización de las articulaciones del cuerpo junto con su ilustración. El tercer capítulo enumera los principios técnicos para la práctica de las series de ejercicios, describe la ejecución de los ejercicios de apertura y finalización de dichas series así como los ejercicios ba duan jin tanto de pie como sentando, los ejercicios yi jin jing, la forma de los cinco animales, la marcha del gato, el movimiento del arquero y el andar terapéutico, acompañados de su secuencia fotográfica. La cuarta parte consta de 3 capítulos, precedidos por un comentario sobre los objetivos del qigong interno. El primer capítulo explica el funcionamiento del qigong interno mientras que el segundo describe los principios técnicos, características, beneficios y ejecución de las técnicas denominadas la postura del árbol, los sonidos de curación, la sonrisa interior y el song jin gong, acompañados de su representación gráfica. El tercer capítulo expone la ejecución técnica de los ejercicios de meditación denominados circulación microcósmica, circulación macrocósmica, la rueda y el dominio de la raíz del qi comentando sus características y beneficios. La última parte consta de dos capítulos. El primer capítulo expone los principios para la práctica del qigong así como el desarrollo de varias sesiones tipo. El segundo capítulo explica brevemente la aplicación del qigong por parte de un terapeuta junto con una tabla de enfermedades y sus correspondientes técnicas terapéuticas. Adjunta la descripción e ilustración del ritual de los cinco tibetanos y bibliografía.

697. Reid, Daniel (1999). El libro del chi-kung : principios teóricos y aplicaciones prácticas. Barcelona: Urano. $1^{\underline{a}}$ ed. 382 p. : il. ; 13x21,5 cm. ISBN: 84-7953-311-0. Depósito legal: B. 11706-1999. Palabras clave: historia, fundamentos teóricos, principios técnicos, ejercicios, entrenamiento, escuelas, fisiología, salud, taoísmo. Resumen: Tratado teórico y técnico de chikung. La monografía esta dividida en 12 capítulos, precedidos por una introducción que explica los términos y conceptos básicos de la filosofía taoísta que impregnan la práctica del chikung como son el chi, el tao, la polaridad yin y yang, la teoría de los cinco elementos, los meridianos, los tipos de energía humana, las formas de movilizar el chi y el tao del cultivo de la vida. El primer capítulo narra la evolución histórica del chikung en China analizando cada una de sus etapas. El segundo capítulo expone las características de las principales escuelas de pensamiento del chikung junto con sus principios técnicos y las clasificaciones que se pueden realizar de su práctica atendiendo al equilibrio entre quietud y movimiento, la postura adoptada y el objetivo de mejora. El tercer capítulo explica las características de los tres poderes (cielo, tierra y humanidad), el funcionamiento del campo de energía humano y los ciclos rítmicos de la naturaleza y el cosmos, y su interpretación por el chikung. El cuarto capítulo presenta los tres tesoros (esencia, energía y espíritu), el funcionamiento del nei-gung (alquimia interna) junto con sus etapas de entrenamiento, explica los beneficios que reporta la práctica del chikung sobre la esencia, la energía y el espíritu (cuerpo, respiración y mente) y expone la relación chikung con la psiconeuroinmunología. El quinto capítulo detalla los beneficios y mecanismos fisiológicos que produce la práctica del chikung sobre el sistema nervioso central, inmunológico, circulatorio, digestivo, respiratorio, además de explicar sus efectos sobre el equilibrio acido/alcalino, los radicales libres, el Parkinson, las parálisis, las fracturas de columna, el sida, el cáncer, y comentar algunas de sus aplicaciones terapéuticas y utilización en hospitales y centros de investigación. El sexto capítulo expone la relación entre chi y respiración, las cuatro etapas de la respiración, las tres contracciones, los tipos de respiración; explica los distintos métodos para dirigir la energía con el cuerpo, la mente, a través de los sonidos, la luz y los colores, los aromas, el tacto, y la energía sexual, incluyendo algunos ejemplos prácticos. El séptimo capítulo describe las características y la ejecución técnica de las cuatro posturas y las siete maneras de respirar del chikung. El octavo capítulo expone los principios técnicos del chikung, las pautas generales para su ejecución y las precauciones para su práctica. El noveno capítulo detalla la historia, peculiaridades y características técnicas del tai chi chuan, pa tuan chin (ocho piezas de brocado), hsing yi, pa kua chang, wu chin hsi, shao lin chuan, liu yin chueh, chan chuang y hsiao chou tien. El décimo capítulo ofrece algunos consejos para la práctica del chikung y describe algunos ejercicios de las formas estáticas y dinámicas de chikung, incluyendo gráficos explicativos. El capítulo decimoprimero explica las señales y sensaciones que se experimentan en la práctica así como algunas desviaciones de las mismas y su corrección. El último capítulo expone la aplicación del chikung a la vida diaria como en 
la respiración, la alimentación, la actividad sexual y los pensamientos. Adjunta un epílogo y direcciones internacionales de interés.

698. Requena, Yves (1993). Qi gong : gimnasia china para la salud y la longevidad. Barcelona: La liebre de marzo. $1^{a}$ ed. 381 p. : il. ; 16×24 cm. ISBN: 84-87403-08-5. Depósito legal: B. 2860-1993. (2⿳亠口冋 ed., 1995; ed. desc., 1997; ed. desc., 1999; 3a reimp., 2002). Palabras clave: historia, fundamentos teóricos, ejercicios, escuelas, wushu, enfermedades, fisiología, fisioterapia, meditación. Resumen: Manual teórico y técnico de qigong. La obra esta formada por 6 partes. La primera parte relata los orígenes del qigong, su evolución histórica junto con las aportaciones realizadas por las distintas escuelas de pensamiento, su clasificación y evolución técnica, y su introducción en el mundo occidental. La segunda parte consta de 6 capítulos que estudian las bases fisiológicas del qigong, sus características y patologías, como son el qi, los distintos tipos de energías y sus características; la sangre y los líquidos orgánicos; la teoría yin-yang y de los cinco elementos; los cinco órganos, las seis entrañas, y los doce meridianos; los 8 meridianos curiosos; y el origen de las enfermedades según la medicina china. La tercera parte esta formada por siete capítulos que profundizan en la práctica del qigong. Describe los diferentes estilos y la clasificación de los ejercicios de qigong, analiza los principios básicos para la práctica como son la conducción de la energía mediante el pensamiento, la respiración y los movimientos, describe e ilustra las posturas del qigong junto con su utilización, ventajas e inconvenientes, describe los distintos ejercicios de respiración que plantea el qigong así como su utilización, describe e ilustra los ejercicios de qigong para la apertura de las articulaciones, la respiración cósmica, el símbolo del taiji, las 8 piezas de seda, las 8 piezas de bordado, los 5 animales, los animales de longevidad, ejercicios de estiramiento y la circulación macrocósmica, presenta los diferentes ejercicios de masaje y de visualización y meditación. La cuarta parte esta compuesta por 5 capítulos que presentan las investigaciones más recientes en la aplicación terapéutica del qigong, los ejercicios para tratar algunas enfermedades como la hipertensión y el cáncer, los resultados clínicos de la aplicación terapéutica del qigong, los seis sonidos terapéuticos y el entrenamiento para emitir energía a través de las manos. La quinta parte explica las características, fundamentos y objetivos de los ejercicios de meditación y las técnicas sexuales taoístas para alcanzar la sabiduría y la inmortalidad. La última parte incluye 3 capítulos que ofrecen consejos para la práctica correcta del qigong, presenta programas de entrenamiento y la definición de algunos conceptos tratados por el qigong. Adjunta un índice de términos chinos, bibliografía, la dirección del instituto europea de qigong en España y otras obras del autor.

699. Requena, Yves (1996). La gimnasia de la eterna juventud : guía fácil de qi gong. El arte de desarrollar nuestra energía vital. Barcelona: Robinbook. 1aㅡ ed. 235 p. : il. ; 13x21,5 cm. ISBN: 84-7927-192-2. Depósito legal: B. 40893-1996. Palabras clave: formas, qigong, fundamentos teóricos, fundamentos técnicos, ejercicios, fisioterapia, respiración. Resumen: Manual teórico y técnico de qigong. La obra esta formada por cuatro partes. La primera parte presenta los aspectos teóricos de esta práctica, explicando en qué consiste el qigong, sus orígenes, la teoría del yin-yang, la teoría de los cinco elementos, la localización de los meridianos, la teoría de la energía vital, cómo captar la energía de la tierra y el cielo, la localización de los centros de energía, los aspectos que componen el qigong (movimiento, respiración y concentración) y algunos de sus ejercicios, el estudio en profundidad del primer ejercicio explicado y los tres enfoques que componen la práctica del qigong. La segunda parte expone la importancia de los masajes y de la utilización de las manos al comienzo de la sesión de qigong, para luego describir los ejercicios de masaje sobre las propias manos, el rostro, la frente, el cuero cabelludo, los ojos, la nariz, los labios, las orejas, el palacio del viento, la nuca, el palacio de los centros vitales, el "gran lo" de la energía, el "ming men", el "dan tian", los brazos y las piernas, incluyendo sus efectos y un gráfico explicativo de cada ejercicio, para finalizar con algunos consejos prácticos. La tercera parte explica los aspectos técnicos del ejercicio de "abrazar el árbol" por partes y comenta sus beneficios osteopáticos, energéticos y sus resultados físicos, así como un gráfico resumen de los aspectos técnicos de esta postura. La última parte describe la ejecución del ejercicio de las ocho piezas del brocado incluyendo varios gráficos y esquemas de movimiento explicativos, los efectos de cada posición, las precauciones y algunos consejos prácticos, y finaliza con la enumeración de los beneficios de las ocho piezas de brocado, la forma de practicar este ejercicio, el trabajo de respiración junto con su teoría, su entrenamiento y los diferentes ejercicios de visualización, los consejos prácticos generales para una sesión de qigong, y el programa de 3 sesiones de entrenamiento.

700. Requena, Yves (2006). La gimnasia de la gente feliz : qi gong. Barcelona: Kairós. 1a ed. 137 p. : il. ; 19x23,5 cm. ISBN: 84-7245-614-5. Depósito legal: B. 5123-2006. Palabras clave: fundamentos teóricos, ejercicios, bellas artes, enfermedades, salud. Resumen: Manual teórico y técnico de qigong. El libro esta compuesto de 7 capítulos, precedidos por una introducción que propone un test para evaluar los aspectos yin y yang del lector, explica el significado del chi, el equilibrio de la energía, en qué consiste el qigong, describe brevemente 6 maneras de estimular la energía vital, y compara el tai chi chuan, el yoga y el qigong. El primer capítulo comenta los beneficios de la práctica del qigong como prevención y tratamiento de enfermedades además de describir la ejecución, acompañada de 
fotografías explicativas, de diversos ejercicios de qigong para el tratamiento de las alergias, cervicalgias, cistitis, dolor de vientre, depresión, dorsalgias, embarazo, espasmofilia, estreñimiento, fatiga, fragilidad respiratoria, hipertensión arterial, inmunidad, insomnio, libido, lumbalgias, menopausia, migrañas, osteoporosis, síndrome premenstrual, trastornos hormonales, vista, y algunos consejos para mejorar los tratamientos. Los siguientes 4 capítulos explican la ejecución y efectos de varios ejercicios de qigong para las diferentes estaciones del año, para deportistas, para estilizar la silueta, para realizar con los hijos, en el trabajo o en el colegio, para desarrollar la creatividad en la pintura y la escultura, en la música, el canto, el arte dramático y la danza. El sexto capítulo presenta la descripción de varios ejercicios para realizar en la naturaleza y absorber su energía. El último capítulo expone las características del qigong como medio para alcanzar la felicidad. Adjunta un índice general $\mathrm{y}$ un listado de direcciones donde practicar qigong.

701. Requena, Yves (2007). Movimientos para la felicidad : wu dang qi gong. Barcelona: La liebre de marzo. 1aㅡ ed. 191 p. : il. ; 17x24 cm. ISBN: 978-84-87403-94-1. Depósito legal: B. 1465-2007. Palabras clave: formas, historia, fundamentos teóricos, fundamentos técnicos, ejercicios, aplicación terapéutica, meditación. Resumen: Manual teórico y técnico de qigong. El libro esta formado por 4 partes. La primera parte comenta las características y beneficios terapéuticos del wu dang qigong así como su historia. La segunda parte esta formada por 8 capítulos. El primer capítulo explica los fundamentos teóricos de las 6 posturas estáticas del wu dang. Los siguientes 6 capítulos incluyen la descripción técnica de la ejecución de las 6 posturas estáticas junto con sus efectos y el relato de algún caso real. El último capítulo ofrece varios consejos para la práctica de las 6 posturas estáticas y la secuencia de 15 movimientos. La tercera parte describe la ejecución de la secuencia de 15 movimientos del wu dang qigong acompañada de sus ilustraciones explicativas, el comentario de sus efectos y distintos comentarios. La cuarta parte esta formada por 3 capítulos. El primer capítulo explica los fundamentos teóricos de la pequeña circulación celeste. El segundo capítulo incluye la descripción de los ejercicios que componen la meditación de la pequeña circulación celeste mientras que el último capítulo detalla sus efectos energéticos, fisiológicos y psicológicos. Adjunta índice y bibliografía.

702. Rodríguez, José (2007). Chi-kung. Alcobendas: Libsa. 1a ed. 192 p. : il. ; 17x24,5 cm. ISBN: 84-662-13155. Depósito legal: no. Palabras clave: qigong, historia, fundamentos teóricos, fundamentos técnicos, ejercicios, entrenamiento, fisioterapia, meditación. Resumen: Manual teórico y técnico de qigong. La obra esta dividida en 4 partes. La primera parte explica en qué consiste el chikung, relata su historia, comenta las características técnicas de los diferentes estilos, destaca sus beneficios y la importancia de la respiración para la vida diaria, y comenta cómo se desarrolla una sesión y la evolución en la práctica. La segunda parte expone los conceptos básicos del chikung como son el chi, la teoría del yin/yang, la teoría de los cinco elementos, describe cómo funciona el sistema respiratorio y cómo son los tipos de respiración. La tercera parte, compuesta por 9 capítulos, comienza detallando los consejos previos antes de la práctica para luego describir e ilustrar por partes los distintos ejercicios de automasaje chikung para todo el cuerpo. Continúa con la descripción del trabajo de estiramiento de los 12 meridianos tendino-musculares, sus principios y el ciclo horario del chi, además de localizar cada uno de los meridianos, describir sus síntomas y los movimientos para estirar cada uno de ellos, con la ayuda de ilustraciones y destacando sus puntos más importantes. Después expone los objetivos del baño de energía y describe e ilustra los distintos ejercicios que existen. También comenta las características de las distintas posiciones de trabajo de enraizamiento de la energía, comentando su ejecución técnica y la respiración y meditación que acompaña a cada una de ellas. El siguiente capítulo expone las recomendaciones generales de la práctica de la secuencia de 8 ejercicios taoístas, destaca los beneficios, la respiración, la concentración y la ejecución técnica de cada uno de ellos, acompañados de la secuencia de fotografías de su ejecución. Los dos últimos capítulos de esta parte describen las distintas posturas de meditación, los ejercicios de estiramiento y relajación para finalizar la sesión de chikung, y comentan las recomendaciones específicas para la práctica de la mujer durante la menstruación, el embarazo y la osteoporosis. La última parte expone la filosofía que impregna al chikung, explicando la vía del equilibrio en todos los aspectos de la vida diaria.

703. s.a. (1991). Qigong taoísta del templo Yuquan Yuan : meditación, curación y larga vida. Madrid: Mandala. $1^{a}$ ed. 124 p. : il. ; 13x20,5 cm. ISBN: 84-86961-33-5. Depósito legal: M. 22054-1991. (2ª ed., 2004, ISBN: 84-86961-32-7). Palabras clave: principios técnicos, ejercicios, qigong, enfermedades, salud. Resumen: Manual técnico de qigong. El libro incluye la traducción de dos textos del templo Yuquan Yuan precedidos por una presentación que comenta la llegada de la autora a China, un comentario sobre la práctica del qigong, cuáles son sus beneficios y un resumen de los contenidos del libro. El primer texto esta formado por 3 partes precedidas por un prólogo que señala los objetivos del libro. La primera parte describe varios ejercicios de qigong. La segunda parte presenta doce imágenes acompañadas de un texto explicativo que reflexionan sobre los principios del qigong. La tercera parte describe la ejecución de los ejercicios fundamentales de qigong así como de otros específicos para el tratamiento de la diarrea, forúnculos, problemas circulatorios, falta de eyaculación y pulso débil, pérdidas involuntarias de semen, dolores musculares, dolor de espalda, flexibilidad de huesos y 
circulación sanguínea, inapetencia sexual, dolor de tripas, ictericia, dolor de piernas, reuma o enfriamiento, dolor de hombros, dolor de estómago, vientre hinchado, parálisis, dolor de cabeza, erecciones involuntarias, problemas con el intestina delgado, mareo, pies dormidos, problemas con la glándula gástrica, epidemia, malestar general, depresiones y dolor de riñones. El segundo texto señala las diferencias entre el qigong para hombres y para mujeres además de describir la ejecución de las seis fases del qigong femenino y algunos ejercicios para tratar el dolor menstrual, la falta de menstruación, la leucorrea y la metrorragia.

704. Schillings, Astrid y Hinterthür, Petra (1995). Qi gong : la grulla voladora. Ejercicios de meditación en movimiento. Barcelona: Martínez Roca. $1^{a}$ ed. 282 p. : il. ; 14x21,5 cm. ISBN: 84-270-1949-1. Depósito legal: B. 473-1995. Palabras clave: formas, historia, fundamentos teóricos, principios técnicos, filosofía, ejercicios, medicina tradicional china, taoísmo. Resumen: Manual teórico y técnico de qigong. La monografía esta dividida en 4 partes. La primera parte esta formada por cinco capítulos que explican, respectivamente, qué es el qigong y cuál es su utilización, relata brevemente su historia, explica el significado de la grulla y sus movimientos dentro de la mitología, presenta la localización de los 12 meridianos y los 8 canales adicionales junto con su ilustración y efectos sobre la salud, y presentan la teoría yin/yang y de los cinco elementos. La segunda parte incluye 8 capítulos que presentan los horarios de flujo del qi como pautas orientativas para la práctica del qigong, exponen algunas indicaciones para el aprendizaje, la vida diaria y la práctica, describen la ejecución técnica de las cinco primeras formas acompañadas de sus ilustraciones, comentan las particularidades de la sexta forma (práctica quiescente orientada por Qi) incluyendo la descripción de su ejecución, exponen las personas que no deben practicar el qigong, las formas de respiración del qigong y describen la ejecución de diversos ejercicios terapéuticos para distintas patologías junto con sus secuencias fotográficas y esquemas de movimiento. La tercera parte esta formada por 4 capítulos. El primer capítulo expone la interpretación de la medicina tradicional china sobre la salud y la enfermedad. El segundo capítulo comenta las actitudes y disposiciones del practicante avanzado en la ejecución del qigong de la grulla, los efectos internos y externos del ejercicio. El tercer capítulo analiza las mutaciones de la energía y los principios hasta alcanzar la iluminación. El cuarto capítulo estudia los estados espontáneos de crisis derivados de la transmutación de la energía. La cuarta parte incluye los anexos sobre las biografías de Zhao Jin Xiang y Cheung Chun Wa, notas y bibliografía.

705. Sheng, Keng Yun (1998). Chi kung en movimiento : sanar por la respiración. Barcelona: Obelisco. 1a ed. 138 p. : il. ; 13x21 cm. ISBN: 84-7720-624-4. Depósito legal: B. 6816-1998. Palabras clave: fundamentos teóricos, fundamentos técnicos, principios técnicos, ejercicios, aplicación terapéutica, respiración. Resumen: Manual teórico y técnico de chikung. El libro esta dividido en 2 partes precedidas por un prefacio que comenta los contenidos del libro, los agradecimientos, la nota del editor y una introducción que expone la biografía de la autora. La primera parte consta de 7 capítulos. El primer capítulo expone los principios del entrenamiento de chikung. El segundo capítulo enumera las funciones y efectos derivados de su práctica. El tercer capítulo detalla los 17 tipos de respiración chikung. El cuarto capítulo describe e ilustra los ejercicios básicos de respiración y forma de caminar del chikung. El quinto capítulo explica la ejecución del ejercicio de agacharse y ponerse de pie acompañado de sus ilustraciones. El sexto capítulo enumera los principios técnicos del chikung en movimiento e incluye la descripción e ilustración del chikung en movimiento del lado izquierdo y derecho, de caminar intercambiando y en movimiento uniforme de tres pasos. El último capítulo explica los ejercicios para ejercitar las piernas junto con su secuencia fotográfica. La segunda parte consta de 9 capítulos. Los primeros siete capítulos señalan los beneficios y describen la ejecución de los ejercicios de chikung en movimiento de un paso, de dos pasos, de tres pasos, en movimiento rápido, más rápido, más rápido de todos y el antiguo chikung en movimiento chino tradicional de cinco pasos incluyendo sus ilustraciones explicativas. El octavo capítulo describe las reacciones normales y anormales derivadas de la práctica del chikung. El último capítulo relata la historia de la niña y la tortuga. Adjunta un glosario de términos específicos y dos apéndices con los puntos de acupuntura y canales de energía así como varios testimonios sobre los efectos terapéuticos del chikung.

706. Sheng, Keng Yun (2002). Manual de longevidad : kung de la grulla volando. Ejercicios ch'i kung para vivir más y mejor. Barberá del Vallés: Humanitas. 1a ed. 204 p. : il. ; 15x21,5 cm. ISBN: 84-7910-355-8. Depósito legal: B. 26532-2002. Palabras clave: qigong, principios técnicos, ejercicios, relatos, acupuntura, anatomía, salud. Resumen: Manual teórico y técnico de chikung. El libro esta formado por dos partes. La primera parte esta formada por 3 capítulos que explican en qué consiste el chikung, cuáles son los beneficios derivados de su práctica, y comenta los principios técnicos de sus métodos. La segunda parte esta formado por 8 capítulos. El primero expone las características del Kung de la longevidad de la Grulla Volando junto con sus beneficios para la salud, para en los siguientes 5 capítulos describir en fases la ejecución técnica de 5 ejercicios de chikung, comentar sus efectos y beneficios sobre la salud e incluir la serie fotográfica de cada uno de ellos. Los dos últimos capítulos relatan las historias del maestro Bien Chiu y el general, y de la serpiente en la copa. Adjunta un 
glosario, la descripción e ilustración de la localización de los puntos de acupuntura y canales de energía e índice de términos.

707. Soon-Yeong, Yap y Hiew, Chok C. (2008). Sanación CFQ : la energía como medicina. Chikung de la libertad cósmica : sanar el cuerpo, transformar la consciencia. Madrid: Mandala. $1^{\underline{a}}$ ed. 431 p. : il. ; 16x23,5 cm. ISBN: 978-84-8352-086-4. Depósito legal: M. 22882-2008. (2ª ed., 2009, ISBN: 978-848352-172-4). Palabras clave: historia, fundamentos teóricos, principios técnicos, ejercicios, aplicación terapéutica, medicina, medicina tradicional china, meditación, salud. Resumen: Tratado teórico de chikung. El libro esta dividido en 4 partes precedidas por un prefacio que detalla sus objetivos y contenidos, los agradecimientos y un prólogo que explica el origen del chikung y el método de curación del autor. La primera parte consta de 5 capítulos. El primer capítulo relata la biografía del autor y sus primeros contactos con el chikung. El segundo capítulo comenta la historia del chikung y enumera sus principios. El tercer capítulo explica los niveles de consciencia, define los conceptos básicos del chikung y detalla las limitaciones de la medicina tradicional china. El cuarto capítulo presenta la forma de diagnóstico de la medicina tradicional, expone la relación entre la tensión corporal y la enfermedad, el proceso de sanación y presenta algunos ejemplos de los resultados del método de sanación CFQ. El quinto capítulo enumera los problemas que se pueden tratar con el método CFQ, sus limitaciones, resalta la importancia de la nutrición para la salud y comenta la evolución espiritual del método CFQ. La segunda parte consta de 4 capítulos. El primer capítulo detalla el concepto de meridianos, los principios técnicos de los ejercicios de chikung dinámico junto con la descripción e ilustración de sus 7 movimientos, resalta los beneficios y efectos de los ejercicios de CFQ y ofrece algunos consejos para su práctica. El segundo capítulo comenta el origen y objetivos de la meditación, enumera los grupos de personas que no deberían practicar la meditación CFQ, describe los conceptos básicos de la meditación y su desarrollo. El tercer capítulo describe la ejecución de varios ejercicios complementarios de los meridianos, sus efectos y puntos esenciales. El cuarto capítulo expone y comenta el sutra del corazón. La tercera parte consta de 4 capítulos. El primer capítulo comenta los requisitos para convertirse en sanador, los tipos de sanadores que existen, las limitaciones del tratamiento CFQ, describe el desarrollo de una sesión meditativa directa del CFQ. El segundo capítulo analiza la aplicación del método $\mathrm{CFQ}$ a los niños, sus técnicas, su práctica y su aplicación a determinados trastornos. El tercer capítulo comenta las características de los trastornos psicológicos y los estados de consciencia así como la aplicación de algunos ejercicios del método CFQ para tratarlos. El cuarto capítulo presenta los problemas y enfermedades aparejados a la edad de jubilación y la aplicación de los ejercicios CFQ para su tratamiento y el rejuvenecimiento. La cuarta parte consta de 5 capítulos. El primer capítulo expone las causas de la parálisis, el tratamiento convencional y mediante el método CFQ y algunos remedios CFQ para las heridas. El segundo capítulo explica las causas del derrame cerebral, los principios de sanación, describe el programa de rehabilitación del CFQ y los errores más frecuentes. El tercer capítulo comenta las características del estado de coma, su tratamiento convencional y mediante el CFQ. El cuarto capítulo analiza los factores involucrados en el cáncer, el tratamiento de la medicina occidental y alternativa, y describe el remedio CFQ y sus limitaciones. El último capítulo resume los contenidos del libro. Adjunta bibliografía.

708. Speziale, Ana María y Fernández de Castro, Ángel (2008). Zhu dao qigong : el camino del bambú. Madrid: Tao. $1 \underline{\text { a }}$ ed. 198 p. : il. ; 15x21 cm. ISBN: 978-84-934084-8-4. Depósito legal: M. 5728-2008. Palabras clave: fundamentos teóricos, fundamentos técnicos, principios teóricos, entrenamiento, ejercicios, respiración. Resumen: Manual teórico y técnico de qigong. El libro esta formado por 12 capítulos precedidos por una dedicatoria, los agradecimientos y un prólogo que comenta la aparición de este libro. El primer capítulo comenta las características generales del zhu dao qigong. El segundo capítulo explica en qué consiste el qigong, cuales son sus tipos, los efectos y beneficios derivados de su práctica y los objetivos de su entrenamiento. El tercer capítulo señala la importancia de la respiración, describe la fisiología de la respiración y sus tipos así como su relación con el qi. El cuarto capítulo define el concepto de qi. El quinto capítulo narra la formación marcial de la autora y las características técnicas del estilo zhu dao qigong. Los dos siguientes capítulos detallan la forma de escoger un bambú y los principios técnicos de la preparación para la práctica. El octavo capítulo describe la ejecución y beneficios de los ejercicios del zhu dao qigong así como de sus ejercicios respiratorios acompañados de sus ilustraciones. Los dos siguientes capítulos explican los principios del entrenamiento y las virtudes que representa el bambú. El capítulo decimoprimero presenta las cualidades del bambú y su presencia en la naturaleza. El último capítulo incluye varias poesías sobre el bambú. Adjunta bibliografía consultada, un glosario específico, un listado de libros publicados por Ediciones Tao, un listado de direcciones sobre el Zhu dao qigong e información de la editorial.

709. Stevanovitch, Vlady (1993). Las técnicas energéticas. Barcelona: Robinbook. 1a ed. 277 p. : il. ; 17x24 cm. ISBN: 84-7927-076-4. Depósito legal: B. 29553-1993. Palabras clave: fundamentos teóricos, ejercicios, entrenamiento. Resumen: Manual teórico y técnico de chikung. La obra consta de 3 partes, precedidas por una introducción que comenta las dificultades del estudio del chi. La primera parte esta formada por 7 capítulos. El primer capítulo explica en qué consisten las técnicas de relajación 
mediante la autosugestión para luego describir la ejecución de varias de sus técnicas. El segundo capítulo expone la importancia de una postura correcta y presenta varios ejercicios para su corrección. El tercer capítulo detalla el significado del tan tien y detalla varios ejercicios para percibir el tan tien. El cuarto capítulo señala la relación entre chi y respiración, y presenta distintos ejercicios para captar los tipos de respiración. El quinto capítulo ofrece consejos para la práctica del chikung además de describir dos ejercicios para desarrollar la pequeña circulación energética. El sexto capítulo detalla diferentes ejercicios para desarrollar la percepción y toma de consciencia de las manos. El último capítulo incluye varios ejercicios destinados a la manipulación del chi. La segunda parte esta formada por 6 capítulos. El primer capítulo señala los diferentes entrenamientos existentes con el chi. Los siguientes cinco capítulos describen la ejecución técnica de distintos ejercicios para transferir el chi, captar la energía solar, ejercicios de chi belt, sublimar la energía yang y desarrollar la esfera de energía. La última parte esta formada por cinco capítulos. Los dos primeros capítulos exponen varios ejercicios de la técnica de la serpiente así como la manipulación del chi en los huesos. El tercer capítulo analiza la relación del chi y el sexo, mientras que el cuarto discute la utilización del chi en la guerra y las artes marciales. El último capítulo describe la última fase del entrenamiento del chi junto con algunos de sus ejercicios para alcanzar el vacío mental. Adjunta un epílogo y una conclusión final.

710. Stevanovitch, Vlady; Yudelove, Eric Steven; Yang, Jwing-Ming; Requena, Yves y Hooton, Claire (2001). Chi kung : ejercicios taoístas para la salud. Madrid: América Ibérica. 1a ed. 95 p. : il. ; 11x20 cm. ISBN: No ISBN. Depósito legal: M. 969-2001. Palabras clave: qigong, fundamentos teóricos, fundamentos técnicos, ejercicios, taijiquan, fisioterapia. Resumen: Manual teórico y técnico de chikung. El libro esta compuesto por 7 capítulos precedidos por un prólogo que comenta los objetivos del taoísmo y su relación con el chikung. El primer capítulo explica en qué consiste el chi y sus aplicaciones. El segundo capítulo detalla los fundamentos teóricos del chikung, sus principios básicos y sus aplicaciones terapéuticas. El tercer capítulo describe la ejecución de los seis sonidos curativos acompañados de su representación gráfica. El cuarto capítulo comenta las características de las dos categorías del chikung así como sus principios técnicos. El quinto capítulo describe la ejecución del ejercicio de las ocho piezas de brocado acompañado de su representación gráfica y esquemas de movimiento. El sexto capítulo incluye la descripción e ilustración de varias técnicas de automasaje taoísta para el rejuvenecimiento. El último capítulo expone los fundamentos teóricos y principios técnicos del tai chi chuan.

711. Sun, Junqing (1999). Un método para la salud: wudang chikung. Un modo de vivir y alcanzar la felicidad. Madrid: Narcea. 1aㅡ. ed. 239 p. : il. ; 13×19,5 cm. ISBN: 84-277-1283-9. Depósito legal: V. 601-1999. (2 $2^{\mathrm{a}}$ ed., 2007, 273 p., ISBN: 978-84-934080-3-9). Palabras clave: fundamentos teóricos, fundamentos técnicos, ejercicios, escuelas, aplicación terapéutica. Resumen: Manual teórico y técnico de chikung. El libro esta formado por 9 capítulos precedidos por una presentación que comenta el contacto de la traductora con el autor junto con una pequeña biografía del autor, y una introducción que comenta los contenidos de la obra. El primer capítulo expone la historia y fundamentos teóricos del yangsheng chikung además de describir la ejecución y efectos de los ejercicios de concentración en el dantian y los fundamentos técnicos del daoyin chikung acompañados de su representación gráfica. El segundo capítulo explica la ejecución de los ejercicios que componen el daoying chikung mediante la respiración con todo el cuerpo y el método de salud golpeando y frotando el cuerpo, incluyendo sus esquemas de movimiento y representación gráfica. El tercer capítulo incluye la descripción e ilustración de los ejercicios que componen el método daoyin de respiración natural y para hacer circular el chi junto con sus ilustraciones. Los siguientes tres capítulos presentan la ejecución y efectos de los fundamentos técnicos de otros métodos de chikung, el wudang fuming chikung para recuperar la vista y el método para curar enfermedades acompañados de su ilustración explicativa. El séptimo capítulo presenta la clasificación de las escuelas de chikung y sus fundamentos teóricos. El octavo capítulo explica en qué consiste el tao, la teoría del yin/yang y su aplicación al wudang chikung, y las características de los niveles del wudang chikung. El noveno capítulo comenta las causas de la depresión y la esquizofrenia además de presentar su tratamiento y algunos ejemplos de casos. Adjunta un epílogo y un glosario básico.

712. Sun, Junqing (2006). Wubaomen chi-kung : el ABC del chi-kung. Romanones: Tao. 1a ed. 293 p. : il. ; 15x21 cm. ISBN: 84-934080-1-8. Depósito legal: M. 14754-2006. Palabras clave: historia, fundamentos teóricos, fundamentos técnicos, principios técnicos, ejercicios, aplicación terapéutica, fisioterapia. Resumen: Manual teórico y técnico de chikung. El libro esta dividido en 2 partes, precedidas por unas notas aclaratorias sobre la transcripción de las palabras chinas y un prólogo. La primera parte esta formada por 3 capítulos. El primer capítulo explica el concepto, características y funciones del chi y el chikung. El segundo capítulo describe las técnicas de masaje de un método de chikung para mejorar la circulación del chi y la sangre así como un comentario sobre algunas costumbres que favorecen la salud. El tercer capítulo narra los orígenes e historia del chikung. La segunda parte esta formada por 6 capítulos. El primer capítulo expone los fundamentos teóricos de la práctica del chikung, explicando sus principios técnicos y consejos prácticos. El segundo capítulo 
comenta las características, procedimiento de ejecución, recomendación y efectos de los diferentes ejercicios que conforman el método yangsheng chikung. El tercer capítulo describe la ejecución técnica, recomendaciones y efectos de nueve ejercicios de chikung para adelgazar; mientras que el cuarto capitulo presenta varios ejercicios de suiyi chikung para realizar en la vida diaria. El quinto capítulo comenta la aplicación del chikung en la curación de algunas enfermedades y expone la ejecución de distintos métodos. El último capítulo presenta los fundamentos teóricos del chikung y comenta las características y objetivos de los cinco tipos principales de chikung.

713. Sun, Quing y García Sáez de Samaniego, José Ignacio (1986). Qigong (chicun) : la grulla. Madrid: Sun Qing. 1aㅡ ed. 68 p. : il. ; 21×29,5 cm. ISBN: No ISBN. Depósito legal: M. 34010-1986. Palabras clave: fundamentos teóricos, fundamentos técnicos, principios técnicos, ejercicios, qigong. Resumen: Manual teórico y técnico de qigong. El libro esta formado por 11 capítulos precedidos por una introducción que explica la teoría del qi, en qué consiste el qigong y cuál es su historia, las características del qigong de la grulla y resume los principios técnicos del entrenamiento y sus beneficios para la salud. Los primeros diez capítulos presentan la descripción e ilustración de las cinco tablas de ejercicios pertenecientes al qigong dinámico tituladas "las seis comunicaciones y recuperación doble del qi", "erguido sobre la tierra, en contacto con el cielo", "la cabeza de la grulla y del dragón y el paso de la barre del qi", "la grulla toca el agua" y "revolución circular y regreso al uno", además de comentar sus fundamentos teóricos y efectos sobre el organismo. El capítulo decimoprimero describe los principios técnicos de los métodos de regulación del cuerpo, del espíritu y de la respiración además de incluir la descripción e ilustración del ejercicio del "poste erguido" perteneciente al qigong estático.

714. Tawm, Kim (1995). Ejercicios secretos de los monjes taoístas. Málaga: Sirio. 1aa ed. 97 p. : il. ; 13x21 cm.

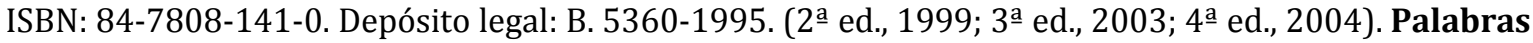
clave: filosofía, ejercicios, sexo, nutrición, taoísmo. Resumen: Manual teórico y técnico de qigong. La obra esta formada por 10 capítulos, precedidos por un prefacio que comenta los contenidos de la obra y una introducción que señala algunos consejos para la práctica. Los seis primeros capítulos describen la ejecución técnica de los ejercicios básicos, los ejercicios preparatorios para el ayuno, los ejercicios universales, el ejercicio de los tres secretos y los ejercicios basados en los efectos de los cinco sonidos. Los dos siguientes capítulos enumeran las recomendaciones de orden sexual y dietético respectivamente, mientras que el noveno capítulo incluye un extracto de las causas y efectos de la Ley del Karma. El último capítulo incluye las respuestas sobre ciertas curiosidades de los lectores.

715. Tzu, Kuo Shih (1995). La terapia qi gong : el arte chino de curar mediante la energía. Madrid: Edaf. 1a ed. 110 p. : il. ; 17x24 cm. ISBN: 84-7640-950-8. Depósito legal: M. 22173-1995. Palabras clave: historia, fundamentos teóricos, fundamentos técnicos, investigación, sistemas de entrenamiento. Resumen: Manual teórico y técnico de qigong. El libro esta dividido en 3 partes precedidas por un prefacio que comenta los contenidos de la obra y presenta la biografía del autor. La primera parte consta de un capítulo precedido por una introducción que explica en qué consiste el qigong, cuáles son sus características y sus funciones. El capítulo narra la historia del qigong y sus maestros. La segunda parte consta de 3 capítulos que detallan los fundamentos teóricos y técnicos de los tres métodos principales del qigong como son la regulación del cuerpo, la regulación de corazón/mente y la regulación de la respiración. La tercera parte incluye varios estudios sobre la relación entre el qigong y la medicina tradicional china, y un compendio de estudios científicos modernos sobre los métodos del qigong. Adjunta un listado de nombres y títulos, un glosario de términos chinos y reconocimientos.

716. Tzu, Kuo Shih (2003). Terapia qi gong. Barcelona: RBA. 1a ed. 159 p. : il. ; $13 \times 19$ cm. ISBN: 84-4732810-4. Depósito legal: M. 14647-2003. (2ª ed., 2007, ISBN: 978-84-473-5384-2). Palabras clave: historia, fundamentos teóricos, fundamentos técnicos, investigación, sistemas de entrenamiento. Resumen: Manual teórico y técnico de qigong. El libro esta dividido en 3 partes precedidas por un prefacio que comenta las diferentes prácticas de qigong e incluye la biografía del autor. La primera parte consta de 2 capítulos. El primer capítulo explica en qué consiste el qigong, cuáles son sus características y sus funciones. El segundo capítulo narra el origen y desarrollo histórico del qigong. La segunda parte consta de 3 capítulos que señalan las características, beneficios, fundamentos teóricos, principios técnicos y ejecución de los 3 métodos del qigong como son la regulación del cuerpo, la regulación del cuerpo/mente y la regulación de la respiración. La última parte incluye varios estudios sobre la relación entre el qigong y la medicina tradicional china, y un compendio de estudios científicos modernos sobre los métodos del qigong. Adjunta un listado de nombres y títulos, un glosario de términos chinos y reconocimientos.

717. Van Nghi, Nguyen (1980). Chi kung : gimnasia medical china. Madrid: Cabal. 1a ed. 111 p. : il. ; 13x19 cm. ISBN: 84-7034-037-9. Depósito legal: M. 13977-1980. Palabras clave: fundamentos teóricos, fundamentos técnicos, calentamiento, aplicación terapéutica, enfermedades. Resumen: Manual teórico y técnico de chikung. La obra esta dividida en 2 partes, precedidas por un preámbulo que comenta la influencia de la medicina oriental en occidente. La primera parte clasifica los tipos de gimnasia energética que existen para luego explicar y describir cada una de ellas en mayor profundidad, estudiando las características, ejercicios, ventajas e inconvenientes de la gimnasia estática, compuesta 
por los principios de la gimnasia postural, la educación de la voluntad y el control respiratorio, y de la gimnasia dinámica, incluyendo la representación gráfica y los esquemas de cada uno de los ejercicios presentados. La segunda parte expone la forma de aplicación de la gimnasia terapéutica a enfermedades como la úlcera duodenal, la hipertensión arterial, el asma, el síndrome depresivo, la ptosis gástrica, la colitis crónica y la tuberculosis pulmonar, describiendo las fases preparatorios y los ejercicios propiamente dichos para cada una de ellas.

718. Van Nghi, Nguyen (2009). Chi kung : gimnasia terapéutica china. Madrid: Mandala. 1a ed. 110 p. : il. ; 13x20,5 cm. ISBN: 978-84-8352-129-8. Depósito legal: M. 1768-2009. Palabras clave: fundamentos teóricos, fundamentos técnicos, calentamiento, aplicación terapéutica, enfermedades. Resumen: Manual teórico y técnico de chikung. La obra esta dividida en 2 partes, precedidas por un preámbulo que comenta la influencia de la medicina oriental en occidente. La primera parte clasifica los tipos de gimnasia energética que existen para luego explicar y describir cada una de ellas en mayor profundidad, estudiando las características, ejercicios, ventajas e inconvenientes de la gimnasia estática, compuesta por los principios de la gimnasia postural, la educación de la voluntad y el control respiratorio, y de la gimnasia dinámica, incluyendo la representación gráfica y los esquemas de cada uno de los ejercicios presentados. La segunda parte expone la forma de aplicación de la gimnasia terapéutica a enfermedades como la úlcera duodenal, la hipertensión arterial, el asma, el síndrome depresivo, la ptosis gástrica, la colitis crónica y la tuberculosis pulmonar, describiendo las fases preparatorios y los ejercicios propiamente dichos para cada una de ellas.

719. Wilson, Stanley (1997). Qi gong para principiantes : ocho movimientos sencillos que te ayudarán a lograr una salud óptima. Málaga: Sirio. $1^{a}$ ed. 166 p. : il. ; 17x24 cm. ISBN: 84-7808-347-2. Depósito legal: no. ( $2^{\underline{a}}$ ed., 2001; $3^{\underline{a}}$ ed., 2005). Palabras clave: formas, qigong, fundamentos teóricos, principios técnicos, escuelas, aplicación terapéutica, meditación, fundamentos técnicos. Resumen: Manual teórico y técnico de qigong. El libro esta compuesto de 9 capítulos. El primer capítulo explica lo que es el qigong, su historia, la teoría de los cinco elementos y los tres tesoros que fundamentan su práctica. El segundo capítulo profundiza en el sistema Pal Dan Gum, su historia y las similitudes y diferencias que tiene con el tai chi chuan. El tercer capítulo resalta la importancia de la respiración en la vida, sus tipos y explica como regularla, utilizar la respiración abdominal y son beneficios. El cuarto capítulo analiza los tres principios del entrenamiento corporal como son la postura, la relajación y permanecer enraizados. El siguiente capítulo estudia el entrenamiento mental para la práctica del Pal Dan Gum, explicando la práctica de la atención y los seis ladrones y demonios de la mente como métodos para vaciar la mente. El sexto capítulo presenta los consejos para comenzar la práctica del Pal Dan Gum, los puntos clave a recordar durante la ejecución y la descripción e ilustración de los 8 movimientos del Pal Dan Gum. El séptimo capítulo ofrece sugerencias para progresar en el entrenamiento y adecuarla a nuestras posibilidades. El octavo capítulo define el concepto de salud óptima y cuales son los principios que convierten al Pal Dan Gum en un arte de sanación; para finalizar con la descripción de dos ejercicios de meditación para centrarse en el dan tien y equilibrar los chakras. Adjunta bibliografía y una biografía del autor.

720. Wong, Kiew Kit (1996). El arte del chi-kung : cómo aprovechar al máximo la energía vital. Barcelona: Urano. $1^{\text {a }}$ ed. 319 p. : il. ; 15x22,5 cm. ISBN: 84-7953-118-5. Depósito legal: B. 2387-1996. (2⿳亠口冋 ed.,

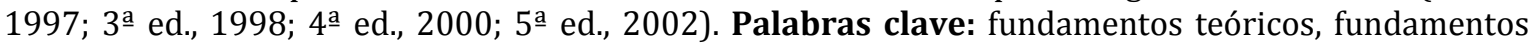
técnicos, filosofía, qigong, artes marciales, salud. Resumen: Manual teórico y técnico de chi-kung. El libro esta compuesto de 6 partes. La primera parte esta compuesta de 3 capítulos en los que narra algunas de las anécdotas más significativas del chi-kung respecto a sus poderes curativos, el origen de su práctica, y el paradigma actual del chi-kung, incluyendo al final de cada capítulo la descripción de un ejercicio. La segunda parte esta formada por 4 capítulos que detallan los beneficios físicos y de salud derivados de la práctica del chi-kung, explicando los fundamentos teóricos de la medicina tradicional china respecto a la energía y ejercicios para aumentar la longevidad y controlar el estrés. La tercera parte expone, a través de 5 capítulos, la aplicación del chi-kung sobre los deportistas, la actividad sexual y como medio para rejuvenecer, incluyendo ejemplos de su aplicación y ejercicios específicos para cada ámbito. La cuarta parte esta formada por 3 capítulos que describen las características básicas de las artes marciales y cómo puede utilizarse el chi-kung dentro de ellas para maximizar las habilidades de lucha. Además, incluye varios ejercicios para fortalecer el cuerpo, mejorar la respiración y el flujo del chi. La quinta parte esta compuesta de 4 capítulos dedicados a describir los beneficios que puede aportar la práctica del chi-kung sobre la actividad mental o académica, relatar algunos ejemplos de dichos beneficios, cómo focalizar el chi para aumentar la creatividad y cómo se puede realizar la transmisión de chi a distancia. La última parte esta compuesta de 2 capítulos que exponen el marco conceptual para explicar los sorprendentes beneficios del chi-kung y la posible aplicación del chi-kung en la búsqueda de Dios. Adjunta notas bibliográficas, un glosario e índice.

721. Wong, Kiew Kit (1998). Chi-kung para la salud y la vitalidad : una aproximación práctica al arte de la energía. Barcelona: Urano. 1aㅡ ed. 246 p. : il. ; 15x22,5 cm. ISBN: 84-7953-199-1. Depósito legal: no. (2 $2^{\underline{a}}$ ed., 2000; $3^{\mathrm{a}}$ ed., 2002). Palabras clave: fundamentos teóricos, fundamentos técnicos, principios 
técnicos, entrenamiento, artes marciales, aplicación marcial, medicina tradicional china, planificación del entrenamiento, respiración, salud. Resumen: Tratado teórico de chi-kung. El libro esta formado por 18 capítulos. El primer capítulo explica las cuatro dimensiones del chi-kung, su historia y sus fundamentos teóricos. El segundo capítulo expone los objetivos generales y específicos de los diferentes tipos de chi-kung así como los requisitos esenciales en el entrenamiento. Los siguientes tres capítulos describen la ejecución de las 10 formas o ejercicios de chi-kung del Instituto Shaolin Wahnam, incluyendo su representación gráfica y sus beneficios. El sexto capítulo comenta los consejos para entrenar correctamente y obtener los máximos beneficios en la práctica del chi-kung así como los principales errores a evitar. El séptimo capítulo explica los fundamentos teóricos del ejercicio del Flujo de Chi Inducido, su ejecución y ofrece algunos consejos prácticos para su correcta realización; para en el siguiente capítulo comentar los tres elementos del chi-kung (forma, energía y mente), así como las distintas clasificaciones que existen del chi-kung. El noveno capítulo detalla las características de los diferentes tipos de respiración, el trabajo por etapas para aprender a realizar la respiración abdominal y las características de los meridianos de energía. El décimo capítulo presenta los fundamentos de la meditación, sus etapas, sus objetivos y dos ejercicios para realizar la meditación de pie y sentado junto con algunos consejos prácticos. El siguiente capítulo analiza los efectos secundarios de una mala práctica, los síntomas y sus causas y cómo corregir dichos efectos. El decimosegundo capítulo expone la situación actual del chi-kung y describe la historia, características y aportaciones de las distintas modalidades de chi-kung como el Waitankung, el Taiji de los Dieciocho Pasos, el Chi-kung Shaolin Damo y la práctica del Sifu Yap. El siguiente capítulo expone los aspectos generales de la medicina tradicional china, su relación con el chi-kung y las enfermedades, para continuar con la explicación de la psicología y psiquiatría según la medicina china y su tratamiento del estrés a través del chi-kung. Los dos siguientes capítulos describen la aplicación teórica y práctica del chi-kung en el deporte, las artes marciales y el rendimiento de la mente. Los dos últimos capítulos exponen distintos programas de entrenamiento de chi-kung y las preguntas y respuestas más frecuentes sobre esta práctica. Adjunta notas, glosario, lecturas recomendadas, direcciones útiles e índice analítico.

722. Yang, Jwing-Ming (1994). Las ocho piezas del brocado : mejorar y conservar la salud. Villaviciosa de Odón: Mirach. 1a ed. 93 p. : il. ; 18x23,5 cm. ISBN: 84-87476-59-7. Depósito legal: M. 26216-1994.

Palabras clave: historia, fundamentos teóricos, fundamentos técnicos, principios técnicos, ejercicios. Resumen: Manual teórico y técnico de chikung. El libro esta formado por 5 capítulos precedidos por los reconocimientos, una breve biografía del autor, un prólogo que señala los beneficios derivados de la práctica del chikung y un prefacio que comenta los contenidos de los futuros libros del autor. El primer capítulo define los términos de chi y chikung, narra la historia del chikung y del ejercicio de las ocho piezas del brocado, comenta los fundamentos teóricos del chi, las características de las diferentes categorías de chikung, expone los fundamentos teóricos y características de las categorías wai dan (elixir externo) y nei dan (elixir interno) del entrenamiento chikung y detalla cómo utilizar la presente obra. El segundo capítulo expone la teoría de los tres tesoros y su relación, y comenta los principios técnicos para el entrenamiento chikung. El tercer capítulo comenta las características del ejercicio de las ocho piezas del brocado en posición sedente para luego presentar las palabras secretas de cada pieza, la descripción de su ejecución y la explicación de sus fundamentos teóricos y beneficios acompañados de su ilustración explicativa. El cuarto capítulo describe los principios técnicos, ejecución, fundamentos teóricos y beneficios de los ejercicios que componen las ocho piezas del brocado de pie junto con su representación gráfica. El último capítulo incluye la conclusión del libro. Adjunta un apéndice con la traducción de algunos términos chinos.

723. Yang, Jwing-Ming (1994). Qigong para la artritis : el método chino de curación y prevención. Villaviciosa de Odón: Mirach. 1ํㅡㄹ ed. 166 p. : il. ; 18x23,5 cm. ISBN: 84-87476-50-3. Depósito legal: M. 18840-1994. Palabras clave: historia, fundamentos teóricos, fundamentos técnicos, principios técnicos, principios teóricos, entrenamiento, ejercicios, aplicación terapéutica, medicina, medicina tradicional china. Resumen: Manual teórico y técnico de qigong. El libro esta formado por 5 capítulos precedidos por los reconocimientos, una breve biografía del autor, dos prólogos que comentan los objetivos y contenidos de la obra, y un prefacio que explica en qué consiste la artritis y cuáles son los beneficios del qigong. El primer capítulo explica en qué consiste el qigong, narra brevemente su historia, comenta las características de sus diferentes categorías, detalla sus fundamentos teóricos y principios del entrenamiento, y cómo utilizar este libro. El segundo capítulo presenta la artritis desde el punto de vista de la medicina occidental y china, analiza la estructura de las articulaciones, las distintas formas de artritis y problemas relacionados, comenta algunas de sus causas, y propone otros medios para su prevención y curación. El tercer capítulo expone las características de los tratamientos chinos para la artritis como el masaje, la acupuntura, las hierbas, la presión, los ejercicios de qigong, analiza comparativamente la prevención que hace la medicina occidental y la medicina china y señala los beneficios que aporta la práctica del qigong para la artritis en contraposición con los métodos occidentales. El cuarto capítulo expone los principios del entrenamiento de qigong para la artritis, describe la ejecución de varios ejercicios de qigong para fortalecer los órganos internos, de diversas 
técnicas de masaje y presión de cavidades acompañados de su representación gráfica así como la explicación y características de los ejercicios de qigong específicos para tratar la artritis junto con su secuencia fotográfica y esquemas de movimiento. El último capítulo incluye un breve comentario final. Adjunta dos apéndices con un glosario y una traducción de términos chinos.

724. Yang, Jwing-Ming (1995). Chi kung del cambio músculo/tendón y lavado médula/cerebro : el secreto de la juventud. Villaviciosa de Odón: Mirach. 1ae ed. 309 p. : il. ; 18x23,5 cm. ISBN: 84-87476-74-0. Depósito legal: M. 40342-1995. Palabras clave: historia, fundamentos teóricos, fundamentos técnicos, principios técnicos, ejercicios, sistemas de entrenamiento. Resumen: Tratado teórico de qigong. El libro esta dividido en 4 partes precedidas por la biografía de Li Qing-Yun, las notas de traducción, un prólogo que comenta las investigaciones del autor, dos prefacios que comentan los contenidos de la obra y la biografía del autor. La primera parte consta de 4 capítulos. El primer capítulo comenta las categorías de qigong, señala los objetivos de las prácticas yi jin jing y xi sui jing, sus influencias sobre la religión, las artes marciales y la medicina en China y en la actualidad y un resumen de los contenidos de la obra. El segundo capítulo narra la historia del qigong. El tercer capítulo señala las características y diferencias entre el qigong budista y taoísta. El cuarto capítulo define los conceptos de kan y li, describe su forma de regulación y los tipos de respiración. La segunda parte consta de 2 capítulos. El primer capítulo expone los fundamentos teóricos de la práctica yi jin jing (qigong del cambio músculo/tendón), sus objetivos, ventajas y desventajas, sus tipos de prácticas, describe los principios técnicos de las prácticas wai zhuang y nei zhuang, señala las diferencias entre el yi jin jing y la camisa de hierro y detalla los fundamentos teóricos de su teoría del entrenamiento. El segundo capítulo comenta los principios técnicos del entrenamiento del yi jin jing, ofrece algunos consejos sobre la práctica, describe el equipo y técnicas del entrenamiento yi jin jing wai dan y yi jin jing nei dan acompañados de sus ilustraciones explicativas y representaciones gráficas e incluye un programa de entrenamiento. La tercera parte consta de 2 capítulos. El primer capítulo expone los conceptos básicos y fundamentos teóricos de la práctica xi sui jing (qigong del lavado médula/cerebro), sus tipos de prácticas, detalla los fundamentos teóricos de su teoría del entrenamiento y enumera las etapas del entrenamiento de wai dan y nei dan en la práctica xi sui jing. El segundo capítulo comenta los requisitos de los practicantes del xi sui jing, incluye sus poemas originarios comentados, describe las técnicas de entrenamiento del xi sui jing wai dan y xi sui jing nei dan acompañados de sus ilustraciones explicativas y representaciones gráficas así como los ejercicios de purificación del qi y transformación en shen, de lavado de médula y conquista del cabello, de perfeccionamiento del shen y devolución a la nada, y de aplastar la nada. La cuarta parte incluye un conjunto de preguntas y respuestas sobre la esencia, el qi y el espíritu así como la conclusión final de la obra. Adjunta varias recetas de hierbas para la práctica del yin jin jing y del xi sui jing y un glosario de términos específicos.

725. Yang, Jwing-Ming (1995). La raíz del chi-kung chino : los secretos del entrenamiento chi kung. Villaviciosa de Odón: Mirach. 1aㅡ ed. 309 p. : il. ; 18x23,5 cm. ISBN: 84-87476-62-7. Depósito legal: M. 10724-1995. Palabras clave: fundamentos teóricos, principios técnicos, ejercicios, entrenamiento, anatomía, fisiología, medicina tradicional china. Resumen: Tratado teórico y técnico de chikung. La obra consta de 4 partes. La primera parte contiene 6 capítulos. El primer capítulo comenta la evolución del chikung en diferentes culturas, define el chi y el chikung y comenta los contenidos incluidos en el libro. El segundo capítulo relata la historia del chikung a través de las diferentes dinastías. El tercer capítulo explica los conceptos básicos del chikung como son los tres tesoros (Jing, Chi y Shen), las diferencias conceptuales entre Yi y Xin, los dantian y el movimiento del chi. El cuarto capítulo comenta las características del chi y su relación con el cuerpo humano, los tipos de chi, su relación con la energía bioelectromagnética, la influencia de los campos electromagnéticos sobre el cuerpo humano y el flujo de chi. El quinto capítulo presenta la relación entre el chikung y las religiones orientales y describe las características de las categorías del chikung. El sexto capítulo profundiza en los fundamentos de las teorías y métodos de entrenamiento Wai Dan (elixir externo) y Nei Dan (elixir interno). La segunda parte esta formada por 8 capítulos. El primer capítulo explica cómo aumentar y desarrollar el chi explicando varios ejercicios para conseguirlo y describe la teoría y relación entre los elementos agua y fuego. El segundo capítulo expone la teoría de la relajación, cuáles son sus principios y posturas, y describe las posiciones y características de las distintas posiciones para enraizarse al suelo y encontrar el equilibrio. El tercer capítulo comenta la relación entre la salud y la respiración, explica como regular la respiración y los diferentes métodos que existen en el chikung. El cuarto capítulo describe los diferentes métodos para regular la mente emocional. El quinto capítulo detalla los diferentes ejercicios para regular la esencia y convertirla en chi. El sexto capítulo describe los diferentes métodos y ejercicios para regular el chi. El séptimo capítulo expone cómo regular el espíritu con la descripción de varios ejercicios. El octavo capítulo enumera y comenta las diversas sensaciones que suele experimentar el practicante de chikung, describe algunas de las posibles desviaciones que puede conllevar la práctica del chikung proponiendo además ejercicios para controlarlas y comenta las 24 reglas del chikung. La tercera parte consta de 3 capítulos que repasan la teoría del chi y de los cinco elementos y describen la localización y características de los doce canales primarios y los ocho vasos 
extraordinarios de chi, incluyendo su representación gráfica. La última parte esta formada por 2 capítulos a modo de conclusión que reúnen las preguntas que se hizo el autor durante el estudio del chikung y que aún siguen asaltándole y un resumen general de la obra junto con los principios técnicos que nunca debería olvidar el practicante. Esta última parte también incluye dos apéndices con un glosario y un índice temático.

726. Yang, Jwing-Ming (1995). Masaje qigong chino : masaje general. Villaviciosa de Odón: Mirach. 1aㅡ ed. 294 p. : il. ; 18x23,5 cm. ISBN: 84-87476-72-4. Depósito legal: M. 40343-1995. Palabras clave: fundamentos teóricos, fundamentos técnicos, principios técnicos, fisioterapia, medicina tradicional china, qigong. Resumen: Manual teórico y técnico de qigong. La obra esta dividida en 2 partes precedidas por los reconocimientos, una breve biografía del autor, dos prólogos que comentan la figura del autor y analizan la medicina occidental y la medicina tradicional china, y un prefacio que presenta los conceptos básicos del qigong. La primera parte consta de 3 capítulos. El primer capítulo ofrece varias definiciones de los conceptos de qi y qigong, clasifica y explica las características de los diferentes tipos de masaje qigong, comenta la historia del masaje qigong junto con los grupos sociales que desarrollaron esta técnica y cómo utilizar esta obra. El segundo capítulo profundiza en los fundamentos teóricos del masaje qigong, explicando la estructura y funcionamiento de los sistemas circulatorio, nervioso y linfático según la medicina occidental, los conceptos generales del cuerpo de qi según la medicina china como son la localización y características de los doce meridianos y los ocho vasos extraordinarios de qi, un breve comentario sobre el cuerpo mental, las puertas y conexiones superficiales y profundas del qi que existen en el cuerpo humano junto con su utilización y ofrece un listado de consejos antes de comenzar a realizar el masaje qigong. El tercer capítulo presenta las diferentes partes del cuerpo utilizadas en el masaje qigong, la descripción de la ejecución de 50 técnicas básicas de masaje junto con sus ilustraciones y comenta los cinco criterios para progresar en el aprendizaje del masaje qigong. La segunda parte consta de 3 capítulos. El primer capítulo expone los objetivos generales del masaje qigong, la teoría y medios del masaje al cuerpo mental, cuerpo físico y cuerpo de qi y explica el procedimiento, recorrido y fuerza para dar un masaje qigong. El segundo capítulo explica algunos principios técnicos y metodológicos antes de comenzar el masaje qigong para luego describir la estructura anatómica, la teoría, las puertas y las técnicas de masaje que se aplican a la cabeza, la espalda, la parte de atrás de las extremidades, el pecho y el abdomen, y la parte delantera de las extremidades, incluyendo numerosas fotografías explicativas. El último capítulo expone los objetivos del automasaje junto con sus ventajas e inconvenientes, describe la ejecución de las técnicas básicas del automasaje a las diferentes partes del cuerpo como a los órganos internos, acompañadas de sus ilustraciones y esquemas de movimiento. Adjunta un glosario y traducción de términos chinos e índice onomástico.

727. Yang, Jwing-Ming (2000). Guía fácil de qi gong. Barcelona: Robinbook. 1aㅡ ed. 206 p. : il. ; 13x20 cm. ISBN: 84-7927-435-2. Depósito legal: B. 9367-2000. (2 ad., 2008). Palabras clave: historia, fundamentos teóricos, entrenamiento, fundamentos técnicos, ejercicios. Resumen: Manual teórico y técnico de qigong. El libro esta compuesto por 5 capítulos precedidos por los agradecimientos, la explicación de la romanización de las palabras chinas, un breve comentario sobre la biografía del autor y los prefacios a la primera y segunda edición que comentan los contenidos de la presente obra y el resto de volúmenes que componen la colección y la actualización de los nuevos contenidos de la segunda edición. El primer capítulo explica la teoría del qi, en qué consiste la práctica del qigong, narra su historia y la de las ocho piezas del brocado, comenta los principios del qi, las categorías de qigong, las características de sus métodos de entrenamiento y ofrece algunos consejos sobre cómo utilizar el libro. El segundo capítulo expone la teoría de los tres tesoros y explica los principios del entrenamiento para la práctica del qigong. El tercer capítulo comenta las características del ejercicio de las ocho piezas del brocado en posición sedente para luego presentar las palabras secretas de cada pieza, la descripción de su ejecución y la explicación de sus fundamentos teóricos y beneficios acompañados de su ilustración explicativa. El cuarto capítulo describe los principios técnicos, ejecución, fundamentos teóricos y beneficios de los ejercicios que componen las ocho piezas del brocado de pie junto con su representación gráfica y esquemas de movimiento. El último capítulo incluye la conclusión del libro. Adjunta un apéndice con la traducción de algunos términos chinos y bibliografía.

728. Yang, Jwing-Ming (2000). Un método chino para prevenir y curar la artritis. Málaga: Sirio. $1^{a}$ ed. 174 p. : il. ; 17x24 cm. ISBN: 84-7808-310-3. Depósito legal: B. 3669-2000. (2ª ed., 2009, ISBN: 978-84-7808623-8). Palabras clave: historia, fundamentos teóricos, fundamentos técnicos, principios técnicos, principios teóricos, entrenamiento, ejercicios, aplicación terapéutica, medicina, medicina tradicional china. Resumen: Manual teórico y técnico de qigong. El libro esta formado por 5 capítulos precedidos por los reconocimientos, una breve biografía del autor, dos prólogos que comentan los objetivos y contenidos de la obra, y un prefacio que explica en qué consiste la artritis y cuáles son los beneficios del qigong. El primer capítulo explica en qué consiste el qigong, narra brevemente su historia, comenta las características de sus diferentes categorías, detalla sus fundamentos teóricos y principios del entrenamiento, y cómo utilizar este libro. El segundo capítulo presenta la artritis desde el punto de 
vista de la medicina occidental y china, analiza la estructura de las articulaciones, las distintas formas de artritis y problemas relacionados, comenta algunas de sus causas, y propone otros medios para su prevención y curación. El tercer capítulo expone las características de los tratamientos chinos para la artritis como el masaje, la acupuntura, las hierbas, la presión, los ejercicios de qigong, analiza comparativamente la prevención que hace la medicina occidental y la medicina china y señala los beneficios que aporta la práctica del qigong para la artritis en contraposición con los métodos occidentales. El cuarto capítulo expone los principios del entrenamiento de qigong para la artritis, describe la ejecución de varios ejercicios de qigong para fortalecer los órganos internos, de diversas técnicas de masaje y presión de cavidades acompañados de su representación gráfica así como la explicación y características de los ejercicios de qigong específicos para tratar la artritis junto con su secuencia fotográfica y esquemas de movimiento. El último capítulo incluye un breve comentario final. Adjunta dos apéndices con un glosario y una traducción de términos chinos.

729. Yang, Jwing-Ming (2001). Qigong : salud y artes marciales. Ejercicios y meditación. Málaga: Sirio. 1aㅡ ed. 218 p. : il. ; 17x24 cm. ISBN: 84-7808-384-7. Depósito legal: MA. 1334-2001. Palabras clave: historia, fundamentos teóricos, fundamentos técnicos, principios técnicos, ejercicios, aplicación marcial, salud. Resumen: Manual teórico y técnico de qigong. La obra esta formada por 5 capítulos. El primer capítulo relata la historia y evolución del qigong chino, los conceptos y principios generales necesarios para entender su práctica, y describe brevemente la historia y teoría de los estilos marciales de entrenamiento de qigong, esto es, taijiquan, baguazhang, xingyiquan y liu he ba fa. El segundo capítulo comenta los principios técnicos del método wai dan (elixir externo), la historia del método wai dan de Da Mo junto con la descripción técnica de sus movimientos y sus ilustraciones, así como la ejecución e ilustración de otros ejercicios derivados del método de Da Mo como son la secuencia de las palmas extendidas, las formas activas, la ocho piezas de brocado en pie y las formas pasivas del método wai dan, incluyendo sus esquemas de movimiento. El tercer capítulo presenta la historia del método nei dan (elixir interno), sus principios generales, los métodos budistas y taoístas de meditación, además de la descripción técnica e ilustración de los ejercicios para generar y hacer fluir el qi, y de los masajes y ejercicios para después de la meditación. El cuarto capítulo explica la relación del qigong con la salud y las 4 técnicas chinas de diagnóstico de la enfermedad, describe los conceptos, teorías y principios básicos de la acupuntura, y presenta la teoría y técnicas del masaje y la fricción incluyendo ilustraciones de las mismas. El último capítulo estudia la relación entre qigong y artes marciales, describiendo los principios técnicos de la opresión de las cavidades, la obstrucción de las venas y la respiración, y la metodología del entrenamiento de camisa e hierro. Adjunta un glosario de términos chinos, un índice temático y la bibliografía de consulta adicional en cada capítulo.

730. Yang, Jwing-Ming (2003). Dolor de espalda : cómo curar y prevenir el dolor de espalda con chi kung. Móstoles: Arkano Books. 1aㅡ ed. 278 p. : il. ; 17x24 cm. ISBN: 84-89897-72-7. Depósito legal: M. 280192003. Palabras clave: fundamentos teóricos, fundamentos técnicos, ejercicios, fisioterapia, medicina, medicina tradicional china. Resumen: Manual teórico y técnico de chikung. El libro esta dividido en 7 capítulos, precedidos por unas notas aclaratorias sobre la romanización de los términos chinos, la biografía del autor y dos testimonios sobre el dolor de espalda y la curación a través del chikung. El primer capítulo define los conceptos de chi y chikung desde la medicina occidental y la medicina tradicional china, narra la historia del chikung, comenta las características de los tipos de chikung y sus escuelas, expone los fundamentos teóricos y principios del entrenamiento chikung y cómo utilizar el libro. El segundo capítulo describe la anatomía, sistema nervioso y la red bioeléctrica de la espalda junto con la descripción de los doce meridianos y los ocho vasos y sus respectivas ilustraciones. El tercer capítulo analiza las posibles causas del dolor de espalda y su sintomatología. El cuarto capítulo explica cómo diagnostica la medicina occidental el dolor de espalda y cuál es su tratamiento y medidas preventivas. El quinto capítulo describe las técnicas de diagnóstico del dolor de espalda de la medicina china y la función y beneficios del chikung para su alivio. El sexto capítulo describe los cinco procedimientos reguladores para un entrenamiento de chikung así como la descripción e ilustración de los ejercicios de chikung junto con la teoría y técnicas de masaje para el dolor de espalda, acompañados de sus esquemas de movimiento. El último capítulo resume el objeto de la obra a modo de conclusión. Adjunta un apéndice con un glosario de términos chinos y su traducción.

731. Yang, Jwing-Ming (2003). La raíz del chi kung chino : secretos del entrenamiento en chi kung. Málaga: Sirio. 1a ed. 410 p. : il. ; 17x24 cm. ISBN: 84-7808-393-6. Depósito legal: B. 1483-2003. (2ª ed., 2006). Palabras clave: fundamentos teóricos, principios técnicos, ejercicios, entrenamiento, anatomía, fisiología, medicina tradicional china. Resumen: Tratado teórico y técnico de chikung. La obra consta de 4 partes. La primera parte contiene 6 capítulos. El primer capítulo comenta la evolución del chikung en diferentes culturas, define el chi y el chikung y comenta los contenidos incluidos en el libro. El segundo capítulo relata la historia del chikung a través de las diferentes dinastías. El tercer capítulo explica los conceptos básicos del chikung como son los tres tesoros (Jing, Chi y Shen), las diferencias conceptuales entre Yi y Xin, los dantian y el movimiento del chi. El cuarto capítulo comenta las características del chi y su relación con el cuerpo humano, los tipos de chi, su relación con la energía 
bioelectromagnética, la influencia de los campos electromagnéticos sobre el cuerpo humano y el flujo de chi. El quinto capítulo presenta la relación entre el chikung y las religiones orientales y describe las características de las categorías del chikung. El sexto capítulo profundiza en los fundamentos de las teorías y métodos de entrenamiento Wai Dan (elixir externo) y Nei Dan (elixir interno). La segunda parte esta formada por 8 capítulos. El primer capítulo explica cómo aumentar y desarrollar el chi explicando varios ejercicios para conseguirlo y describe la teoría y relación entre los elementos agua y fuego. El segundo capítulo expone la teoría de la relajación, cuáles son sus principios y posturas, y describe las posiciones y características de las distintas posiciones para enraizarse al suelo y encontrar el equilibrio. El tercer capítulo comenta la relación entre la salud y la respiración, explica como regular la respiración y los diferentes métodos que existen en el chikung. El cuarto capítulo describe los diferentes métodos para regular la mente emocional. El quinto capítulo detalla los diferentes ejercicios para regular la esencia y convertirla en chi. El sexto capítulo describe los diferentes métodos y ejercicios para regular el chi. El séptimo capítulo expone cómo regular el espíritu con la descripción de varios ejercicios. El octavo capítulo enumera y comenta las diversas sensaciones que suele experimentar el practicante de chikung, describe algunas de las posibles desviaciones que puede conllevar la práctica del chikung proponiendo además ejercicios para controlarlas y comenta las 24 reglas del chikung. La tercera parte consta de 3 capítulos que repasan la teoría del chi y de los cinco elementos y describen la localización y características de los doce canales primarios y los ocho vasos extraordinarios de chi, incluyendo su representación gráfica. La última parte esta formada por 2 capítulos a modo de conclusión que reúnen las preguntas que se hizo el autor durante el estudio del chikung y que aún siguen asaltándole y un resumen general de la obra junto con los principios técnicos que nunca debería olvidar el practicante. Esta última parte también incluye dos apéndices con un glosario y un índice temático.

732. Yang, Jwing-Ming (2004). Masaje qigong chino : masaje general. Málaga: Sirio. 1a ed. 396 p. : il. ; 17x24 cm. ISBN: 84-7808-410-X. Depósito legal: B. 9377-2004. Palabras clave: fundamentos teóricos, fundamentos técnicos, principios técnicos, fisioterapia, medicina tradicional china, qigong. Resumen: Manual teórico y técnico de qigong. La obra esta dividida en 6 capítulos. El primer capítulo ofrece varias definiciones de los conceptos de qi y qigong, clasifica y explica las características de los diferentes tipos de masaje qigong, comenta la historia del masaje qigong junto con los grupos sociales que desarrollaron esta técnica y cómo utilizar esta obra. El segundo capítulo profundiza en los fundamentos teóricos del masaje qigong, explicando la estructura y funcionamiento de los sistemas circulatorio, nervioso y linfático según la medicina occidental, los conceptos generales del cuerpo de qi según la medicina china como son la localización y características de los doce meridianos y los ocho vasos extraordinarios de qi, un breve comentario sobre el cuerpo mental, las puertas y conexiones superficiales y profundas del qi que existen en el cuerpo humano junto con su utilización y ofrece un listado de consejos antes de comenzar a realizar el masaje qigong. El tercer capítulo presenta las diferentes partes del cuerpo utilizadas en el masaje qigong, la descripción de la ejecución de 50 técnicas básicas de masaje junto con sus ilustraciones y comenta los cinco criterios para progresar en el aprendizaje del masaje qigong. El cuarto capítulo expone los objetivos generales del masaje qigong, la teoría y medios del masaje al cuerpo mental, cuerpo físico y cuerpo de qi y explica el procedimiento, recorrido y fuerza para dar un masaje qigong. El quinto capítulo explica algunos principios técnicos y metodológicos antes de comenzar el masaje qigong para luego describir la estructura anatómica, la teoría, las puertas y las técnicas de masaje que se aplican a la cabeza, la espalda, la parte de atrás de las extremidades, el pecho y el abdomen, y la parte delantera de las extremidades, incluyendo numerosas fotografías explicativas. El último capítulo expone los objetivos del automasaje junto con sus ventajas e inconvenientes, describe la ejecución de las técnicas básicas del automasaje a las diferentes partes del cuerpo como a los órganos internos, acompañadas de sus ilustraciones y esquemas de movimiento. Adjunta un glosario y traducción de términos chinos e índice onomástico.

733. Yang, Jwing-Ming (2004). Qigong : el secreto de la juventud. Tratados del cambio de músculo/tendón y lavado de médula/cerebro, de Da Mo. Málaga: Sirio. 1aㅡ ed. 395 p. : il. ; 17x24 cm. ISBN: 84-7808-411-8. Depósito legal: B. 4943-2004. Palabras clave: historia, fundamentos teóricos, fundamentos técnicos, principios técnicos, ejercicios, sistemas de entrenamiento. Resumen: Tratado teórico de qigong. El libro esta dividido en 4 partes precedidas por la biografía de Li Qing-Yun, las notas de traducción, un prólogo que comenta las investigaciones del autor, dos prefacios que comentan los contenidos de la obra y la biografía del autor. La primera parte consta de 4 capítulos. El primer capítulo comenta las categorías de qigong, señala los objetivos de las prácticas yi jin jing y xi sui jing, sus influencias sobre la religión, las artes marciales y la medicina en China y en la actualidad y un resumen de los contenidos de la obra. El segundo capítulo narra la historia del qigong. El tercer capítulo señala las características y diferencias entre el qigong budista y taoísta. El cuarto capítulo define los conceptos de kan y li, describe su forma de regulación y los tipos de respiración. La segunda parte consta de 2 capítulos. El primer capítulo expone los fundamentos teóricos de la práctica yi jin jing (qigong del cambio músculo/tendón), sus objetivos, ventajas y desventajas, sus tipos de prácticas, describe los principios 
técnicos de las prácticas wai zhuang y nei zhuang, señala las diferencias entre el yi jin jing y la camisa de hierro y detalla los fundamentos teóricos de su teoría del entrenamiento. El segundo capítulo comenta los principios técnicos del entrenamiento del yi jin jing, ofrece algunos consejos sobre la práctica, describe el equipo y técnicas del entrenamiento yi jin jing wai dan y yi jin jing nei dan acompañados de sus ilustraciones explicativas y representaciones gráficas e incluye un programa de entrenamiento. La tercera parte consta de 2 capítulos. El primer capítulo expone los conceptos básicos y fundamentos teóricos de la práctica xi sui jing (qigong del lavado médula/cerebro), sus tipos de prácticas, detalla los fundamentos teóricos de su teoría del entrenamiento y enumera las etapas del entrenamiento de wai dan y nei dan en la práctica xi sui jing. El segundo capítulo comenta los requisitos de los practicantes del xi sui jing, incluye sus poemas originarios comentados, describe las técnicas de entrenamiento del xi sui jing wai dan y xi sui jing nei dan acompañados de sus ilustraciones explicativas y representaciones gráficas así como los ejercicios de purificación del qi y transformación en shen, de lavado de médula y conquista del cabello, de perfeccionamiento del shen y devolución a la nada, y de aplastar la nada. La cuarta parte incluye un conjunto de preguntas y respuestas sobre la esencia, el qi y el espíritu así como la conclusión final de la obra. Adjunta varias recetas de hierbas para la práctica del yin jin jing y del xi sui jing y un glosario de términos específicos.

734. Yang, Jwing-Ming (2006). La respiración embriónica : meditación qigong. Málaga: Sirio. 1 a ed. 510 p. : il. ; $17 \times 24$ cm. ISBN: 84-7808-497-5. Depósito legal: B. 17486-2006. Palabras clave: historia, fundamentos teóricos, fundamentos técnicos, ejercicios, textos, sistemas de entrenamiento. Resumen: Tratado teórico de qigong. El libro esta dividido en 3 partes precedidas por los agradecimientos, las notas de traducción, una dedicatoria, la biografía del autor, un prólogo que comenta las características de la obra y un prefacio que expone las características generales del qigong y resume los contenidos del libro. La primera parte consta de 2 capítulos. El primer capítulo expone los conceptos básicos y fundamentos teóricos del qigong, sus tipos, sus etapas de perfeccionamiento, sus procesos de regulación, las características del qigong del cambio músculo/tendón y del lavado de médula/cerebro y la definición de la respiración embriónica. El segundo capítulo explica el significado del dao, del qigong y presenta los fundamentos teóricos de la respiración embriónica así como el significado y objetivos de la meditación. La segunda parte consta de 2 capítulos. El primer capítulo incluye las traducciones y comentarios de los antiguos documentos sobre el concepto general de la respiración embriónica, el dan tian, la regulación de la respiración, la mente y el espíritu y los métodos de entrenamiento. El segundo capítulo presenta los resúmenes de los puntos más importantes de los antiguos documentos. La tercera parte consta de 2 capítulos. El primer capítulo describe los ejercicios de preparación, práctica y recuperación de la respiración embriónica acompañados de sus ilustraciones explicativas y representaciones gráficas. El último capítulo incluye la conclusiones finales de la obra. Adjunta un glosario de términos específicos y un índice temático.

735. Yang, Peter y Prat Banús, José María (2004). Chi kung cristiano (chi tu chi kung). Barcelona: Publicacions de l'Abadia de Montserrat. $1^{a}$ ed. 277 p. : il. ; 13x19 cm. ISBN: 84-8415-603-6. Depósito legal: B.20070-2004. (2 ${ }^{\mathrm{a}}$ ed., 2008). Palabras clave: entrevistas, fundamentos teóricos, taijiquan, qigong. Resumen: La obra esta dividida en 8 capítulos. El primer capítulo presenta el lugar de entrenamiento "El Rincón del Silencio" y explica la visita del autor y sus lecturas durante la misma. El segundo capítulo incluye una entrevista realizada a Peter Yang sobre su experiencia. Los siguientes cinco capítulos presentan las sucesivas entrevistas del autor con Peter Yang para profundizar en los temas relacionados con el tan tien, el símbolo yin-yang, la práctica y principios del chi kung y el tai chi y el papel del zen. El último capítulo presenta la entrevista realizada a Peter Yang sobre los contenidos expuestos en una convivencia que estudiaba el amor divino-amor humano.

736. Yang, Shaoqing (1986). Jingang qigong : ejercicios de respiración con movimientos de todo el cuerpo. Madrid: Miraguano. 1a ed. 108 p. : il. ; 13×19,5 cm. ISBN: 84-85639-68-5. Depósito legal: M. 162691986. (2 ${ }^{a}$ ed., 1990). Palabras clave: historia, fundamentos técnicos, principios técnicos, ejercicios. Resumen: Manual teórico y técnico de qigong. La obra esta formada por 3 capítulos, precedidos por un prólogo que comenta la historia del qigong y la vertiente jingang qigong. El primer capítulo explica las características y beneficios de la práctica del jingang qigong. El segundo capítulo expone los principios técnicos de la práctica y el entrenamiento. El último capítulo describe la ejecución técnica de los movimientos de los 15 ejercicios que componen el jingang qigong, acompañados de su representación gráfica y esquemas de movimiento.

\subsubsection{Taijiquan}

737. Alonso, Rafael y Medrano, Antonio (1999). Tai chi xin yi de shaolin : salud y armonía para el cuerpo y la mente. Majadahonda: Yatay. 1aㅡ ed. 151 p. : il. ; 15x21 cm. ISBN: 84-921582-8-X. Depósito legal: M. 27790-1999. Palabras clave: historia, principios técnicos, filosofía, salud. Resumen: Tratado histórico y filosófico de tai chi chuan. La obra esta dividida en 5 capítulos, comenzando por la definición de los 
conceptos básicos de la filosofía china que impregnan esta práctica, chi, yin-yang, wu hsing y pa kua. El segundo capítulo describe la evolución histórica del kung fu y de sus vertientes externa e interna así como del templo shaolin. Continua explicando las características del trabajo realizado en el tai chi estilo xin yi, los principios que deben seguirse en la práctica de las secuencias de movimientos, los ejercicios con espada, el empuje de manos, el chi kung, los sistemas de grados y las competiciones; y la difusión de este estilo. El cuarto capítulo desarrolla en profundidad los 8 principios sobre los que se basa toda la práctica del xin yi, estos son, xiao, xin, jie, zhong, yi, chi, li, yu. Finaliza con la descripción de los beneficios para la salud que reporta la práctica del tai chi xin yi.

738. Arlandes, Gerard (2006). Taichi para Occidente : una guía para comprender la energía vital y mejorar nuestro bienestar. Barcelona: RBA. 1aㅡ ed. 174 p. : il. ; 19x24,5 cm. ISBN: 84-7871-631-9. Depósito legal: B. 16291-2006. Palabras clave: formas, historia, fundamentos teóricos, fundamentos técnicos, filosofía, ejercicios, entrenamiento, calentamiento, taijiquan, aplicación terapéutica, cultura, fisioterapia, medicina tradicional china, respiración. Resumen: Manual teórico y técnico de tai chi. El libro esta formado por 3 partes. La primera parte esta compuesta de 3 capítulos sobre la cultura china. El primero muestra las características culturales e históricas de la sociedad china como son su aparición, la escritura, la lógica del pensamiento chino, la familia, el estado y el poder, los funcionarios, y su influencia sobre el tai chi. El segundo expone la filosofía que impregna a la sociedad china, explicando la teoría del qi, la teoría del yin/yang, la teoría de las cinco fases cambiantes, la importancia del libro I Ching (Libro de las mutaciones), los conceptos básicos del taoísmo, confucianismo y budismo así como su influencia sobre el taichichuan. El tercer capítulo de la primera parte desarrolla los conceptos y principios básicos (cinco elementos, sustancias vitales, órganos, meridianos y puntos) que rigen la medicina tradicional china. La segunda parte estudia la representación y manifestación del cuerpo en la cultura china a través de 3 capítulos. El primero de ellos comenta el significado del cuerpo tanto en Occidente como en Oriente y la transformación del cuerpo mediante la respiración. El segundo capítulo define en qué consiste y cuales son los objetivos de la gimnasia china para luego comentar los principios y fundamentos técnicos de la misma y compararla con la gimnasia occidental. El tercer capítulo expone las características del taichichuan, su historia y el significado de la palabra taichi, sus objetivos y beneficios para el practicante. La última parte esta formada por 6 capítulos que abordan el estudio de la práctica. El primer capítulo comenta la interpretación que hacen las técnicas corporales chinas de la respiración, para en el segundo capítulo pasar a describir la ejecución técnica de los ejercicios de automasaje para todo el cuerpo, incluyendo gráficos explicativos. Los dos siguientes capítulos describen e ilustran distintos ejercicios previos para preparar el cuerpo antes de la práctica de taichi, tanto de calentamiento como de alineación del cuerpo, realizados de pie y en el suelo, y la secuencia corta de Pekín (forma de 24 movimientos) explicada por partes y con la ayuda de observaciones y esquemas de movimiento. El quinto capítulo enumera y explica los principios del entrenamiento para progresar en la práctica y el último capítulo detalla la aplicación del tai chi a problemas de la vida diaria como el estrés, el dolor de espalda y cervicales, los problemas de rodillas y el insomnio. Adjunta bibliografía, videografía y páginas web.

739. Benner, Hans (2002). Tai chi : el equilibrio de la energía controlada. Barcelona: Art Enterprise. 1aㅡ ed. 89 p. : il. ; 10x21 cm. ISBN: 84-96046-15-X. Depósito legal: B. 38363-2002. Palabras clave: fundamentos técnicos, entrenamiento, filosofía, salud. Resumen: Manual teórico y técnico de tai chi. La obra esta formada por 5 capítulos. El primer capítulo explica la práctica del tai chi, sus fundamentos filosóficos, sus beneficios físicos y mentales, y describe el funcionamiento y características del sistema circulatorio y digestivo así como el papel del tai chi sobre ellos. El segundo capítulo explica la fisiología del sistema respiratorio, los tipos de respiración, la explicación del chi, su aplicación práctica y las cuatro extensiones del tai chi. El tercer capítulo presenta los principios de aplicación práctica del tai chi como son la teoría de los cinco elementos, el estudio de los meridianos y sus funciones, las trece posturas, y algunos consejos para avanzar en el entrenamiento. El cuarto capítulo explica los principios para iniciarse en la práctica del tai chi, los movimientos de la cabeza, el equilibrio del cuerpo, la relajación del cuerpo, el equilibrio de la mente y el cuerpo y la coordinación de los movimientos. El último capítulo describe la ejecución de varios ejercicios de calentamiento antes de presentar la secuencia de ejercicios breves de Cheng Man-Ching, el trabajo por parejas y sus características.

740. Boillat de Corgemont Sartorio, Marc (2008). Tai chi chuan : el camino de vuelta. Ciencia, psicología, filosofía y experiencia. Barcelona: Alas. 1a ed. 349 p. : il. ; 17x23,5 cm. ISBN: 978-84-203-0451-9. Depósito legal: B. 50437-2008. Palabras clave: historia, fundamentos teóricos, pedagogía, principios técnicos, didáctica, fundamentos filosóficos. Resumen: La obra esta formada por 7 partes, precedidas por una introducción que comenta los contenidos y objetivos de la obra, y los agradecimientos. La primera parte explica el significado del tai chi chuan, ofrece algunos consejos para elegir a un maestro, analiza la relación entre la mente y la salud, define los distintos niveles de consciencia, y analiza los estados negativos contra los que luchan las artes internas. La segunda parte señala las características del método científico, su relación entre la filosofía, y analiza las emociones y los sentimientos así como su influencia sobre el comportamiento. La tercera parte narra la historia del tai chi y sus distintas 
leyendas. La cuarta parte analiza la didáctica en la práctica del tai chi, las características del instructor, los niveles de progresión, y analiza el proceso de normalización que han sufrido las artes marciales chinas. La quinta parte aplica la filosofía y fundamentos teóricos del tai chi a la persona y expone los principios rectores de la vida. La sexta parte enumera los principios técnicos del tai chi chuan y ofrece algunos consejos para controlar el cuerpo, la mente y el espíritu. La séptima parte comenta los fundamentos pedagógicos del maestro Shin Dae Woung, las características de su versión del tai chi chuan y sus principios técnicos, además de incluir la descripción de la ejecución de la primera forma de tai chi chuan dae woung acompañada de su secuencia fotográfica. Adjunta anexos con una selección de artículos y pasajes del maestro Tiziano Grandi y un conjunto de consideraciones para tener una existencia tai chi.

741. Bonet Escandell, Ferrán (2008). Tai chi kung fu UMA : espíritu, labor y efecto, de una herramienta de "sanación". Oliva: Centre UMA. 1a ed. 164 p. : il. ; 14x21 cm. ISBN: 978-84-612-4790-5. Depósito legal: V. 2680-2008. Palabras clave: pedagogía, didáctica, fundamentos filosóficos. Resumen: Tratado teórico de tai chi. La obra esta formada por ocho capítulos precedidos por un prefacio, un prólogo que explica los objetivos del tai chi, varias dedicatorias y agradecimientos, y una introducción que señala las características del tai chi UMA. El primer capítulo presenta los objetivos del tai chi UMA. El segundo capítulo explica los procesos de desarrollo y transformación para luego comentar los factores de salud y la práctica del tai chi kung fu UMA. El cuarto capítulo expone la organización del Centre UMA, incluye varios ensayos sobre las artes marciales, la educación y la ética, y destaca las cualidades de su práctica. El quinto capítulo analiza los principios didácticos y filosóficos del tai chi UMA. El sexto capítulo describe el programa de enseñanza, los planteamientos filosóficos, docente y técnicos, los contenidos técnicos, procedimentales y actitudinales, los elementos constitutivos, el método de enseñanza y el estilo didáctico del tai chi kung fu UMA. El séptimo capítulo enumera los ámbitos de aplicación del tai chi UMA y narra una puesta en práctica del tai chi con niños. El último capítulo reflexiona sobre los hábitos que favorecen la salud y el futuro de los practicantes. Adjunta un currículum profesional del autor y una lista de contactos.

742. Brown, Marjorie Ann (1998). El tai chi : disciplina del cuerpo y el espíritu. Barcelona: Astri. 1a ed. 126 p. : il. ; desc.xdesc. cm. ISBN: 84-469-0666-X. Depósito legal: no. (2ª ed., 2001; 3ae ed., 2002). Palabras clave: qigong, formas, historia, ejercicios, combate, calentamiento, fundamentos filosóficos, aplicación terapéutica. Resumen: Manual teórico y técnico de tai chi. La obra esta dividida en 10 capítulos, precedidos por un prólogo que comenta las diferencias entre los términos tai chi y tai chi chuan. El primer capítulo relata la historia del tai chi, mientras que el segundo relaciona los movimientos del tai chi con la filosofía. El tercer capítulo analiza los beneficios de la práctica del tai chi. El cuarto capítulo describe la ejecución de algunos ejercicios de chi gong acompañados de su representación gráfica y esquemas de movimiento. El quinto capítulo comenta la aplicación del tai chi como técnica de meditación. Los tres siguientes capítulos describen la ejecución técnica de distintos ejercicios de iniciación o calentamiento, de movilidad y energía, y los movimientos de la forma. El noveno capítulo expone la ejecución de los cuatro movimientos y cuatro ángulos que conforman los ejercicios del gran desplazamiento (ta-lau) y la técnica de dispersión de manos acompañados de su representación gráfica. El último capítulo incluye la entrevista realizada a D. Juan Sebastián González Rincón.

743. Bryant, Graham y James, Lorraine (2005). Programa de iniciación al taichi. Madrid: Tutor. 1ae ed. 64 p. : il. ; 21x30,5 cm. ISBN: 84-7902-515-8. Depósito legal: B. 15546-2005. (3a imp., 2008). Palabras clave: formas, fundamentos técnicos. Resumen: Manual teórico y técnico de tai chi. La obra esta compuesta de 5 capítulos, precedidos de una introducción en la que se explica lo que es el tai chi, su historia y la forma simplificada. El primer capítulo enumera los beneficios del tai chi para su practicante y continúa con algunas cuestiones prácticas para su realización. El tercer capítulo explica los fundamentos del tai chi, detallando la postura, la respiración, la posición de apertura, del arco, el paso vacío y la mano de tai chi. El cuarto capítulo describe e ilustra algunos ejercicios generales de calentamiento detallando los beneficios físicos de cada uno de ellos. El último capítulo muestra la secuencia de movimientos de la forma simplificada de tai chi, explicando e ilustrando cada movimiento por partes y adjuntando esquemas de movimiento. Adjunta una breve biografía de los autores y dvd. El DVD de 42 minutos de duración aproximadamente comenta las características del tai chi chuan para luego describir algunos ejercicios de calentamiento y la ejecución de la forma de 10 movimientos. Sus contenidos están disponibles en castellano e inglés.

744. Bunnag, Tew (1990). El arte del t'ai chi ch'uan : meditación en movimiento. Barcelona: La liebre de marzo. $1 \underline{\underline{a}}$ ed. 104 p. : il. ; 17x21 cm. ISBN: 84-87403-00-X. Depósito legal: no. (2ª ed., 1993; 3 a ed., 1995; 4⿳亠 ed., 1995; 8 ${ }^{a}$ reimp., 2007). Palabras clave: fundamentos teóricos, fundamentos filosóficos. Resumen: Tratado teórico de tai chi chuan. La monografía esta dividida en 3 partes. La primera describe los principios filosóficos en los que se basa el tai chi, como son el tao, el yin-yang, el ch'i y la teoría de los cinco elementos. En la segunda parte, se teoriza sobre la propia práctica y la ejecución de los movimientos, explicando las características de las formas o series de movimientos, las características de las distintas etapas de aprendizaje, cuáles son los ejercicios y las características de 
los distintos entrenamientos marciales (liberando fuerza, empuje de manos, combate libre), los niveles del trabajo con la energía (chi kung), y los objetivos de la meditación. La última parte incluye distintos anexos sobre los orígenes históricos del tai chi, las escuelas y estilos, y una cronología pertinente al texto. Adjunta un índice de figuras.

745. Bunnag, Tew (1992). T'ai ch'i chuan : camino de curación. Barcelona: La liebre de marzo. 1ae ed. 127 p. :

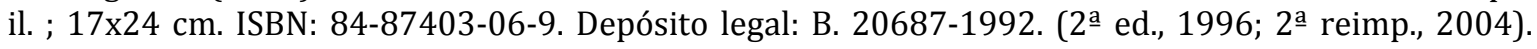
Palabras clave: qigong, fundamentos teóricos, ejercicios, aplicación terapéutica, fisioterapia, meditación. Resumen: Manual teórico y técnico de tai chi chuan. El libro esta dividido en 4 partes precedidas por un prólogo que comenta los efectos terapéuticos del tai chi chuan y una introducción que analiza la situación actual del tai chi chuan en la sociedad. La primera parte presenta los fundamentos teóricos del tai chi chuan explicando el concepto de chi, los meridianos, la composición del chi humano, los tipos de chi, su relación con el tai chi, los puntos utilizados en la práctica del tai chi, la teoría de los cinco elementos y su relación con el tai chi. La segunda parte expone las características de las distintas prácticas del tai chi y sus beneficios, las prácticas de chikung y la meditación. La tercera parte explica los principios del entrenamiento para la práctica del tai chi como método sanador, ofrece algunos consejos para seguir una dieta básica, la forma de comer y vivir correctamente, expone los fundamentos teóricos y técnicos de la práctica curativa y detalla la aplicación del tai chi como práctica curativa. La última parte incluye los apéndices con la enumeración de los clásicos del tai chi, la influencia budista del tai chi, las características de los órganos internos según la medicina tradicional china, los ocho meridianos extraordinarios, la relación entre el ching y la longevidad, la relación entre el libro I Ching y el tai chi, la descripción de varias técnicas de automasaje acompañadas de su secuencia fotográfica y la explicación de los seis estadios de la enfermedad.

746. Bunnag, Tew (2006). La esencia del t'ai chi ch'uan. Barcelona: La liebre de marzo. 1aㅡ ed. 116 p. : il. ; 14x21 cm. ISBN: 84-87403-88-3. Depósito legal: b. 8826-2006. Palabras clave: historia, principios técnicos, fundamentos filosóficos, meditación. Resumen: Manual teórico de tai chi. La obra esta formada por 7 capítulos precedidos por una introducción que comenta la labor literaria del autor. El primer capítulo explica la situación actual del tai chi además de su evolución hasta este momento y sus beneficios para el practicante. El segundo capítulo relata los orígenes del tai chi chuan desde la figura de Chang San Feng y el Budismo. El tercer capítulo detalla la práctica del tai chi chuan como arte marcial explicando sus características y principios técnicos. El cuarto capítulo expone los fundamentos filosóficos del tai chi chuan y los ideales para el practicante de artes marciales. El quinto capítulo analiza los ocho peligros que acechan al practicante de artes marciales en su camino espiritual. El sexto capítulo describe el papel de la oración en las prácticas meditativas y en el tai chi chuan. El último capítulo explica en qué consiste la meditación sedente y sus tres prácticas, así como la relación entre la meditación y las artes marciales.

747. Bunnag, Tew (2009). L'essència del tai-txi-txuan. Barcelona: Viena. 1a ed. 124 p. : il. ; 14x21,5 cm. ISBN: 978-84-8330-534-8. Depósito legal: B. 9384-2009. Palabras clave: historia, principios técnicos, fundamentos filosóficos, meditación. Resumen: Manual teórico de tai chi. La obra esta formada por 7 capítulos precedidos por una introducción que comenta la labor literaria del autor. El primer capítulo explica la situación actual del tai chi además de su evolución hasta este momento y sus beneficios para el practicante. El segundo capítulo relata los orígenes del tai chi chuan desde la figura de Chang San Feng y el Budismo. El tercer capítulo detalla la práctica del tai chi chuan como arte marcial explicando sus características y principios técnicos. El cuarto capítulo expone los fundamentos filosóficos del tai chi chuan y los ideales para el practicante de artes marciales. El quinto capítulo analiza los ocho peligros que acechan al practicante de artes marciales en su camino espiritual. El sexto capítulo describe el papel de la oración en las prácticas meditativas y en el tai chi chuan. El último capítulo explica en qué consiste la meditación sedente y sus tres prácticas, así como la relación entre la meditación y las artes marciales.

748. Cabiles, Evelyn A. (2008). Taichí con pelota y abanico : instrucciones paso a paso para su desarrollo personal. s.l.: Grupo Buho. 1aㅡ ed. 202 p. : il. ; 15x21 cm. ISBN: 978-84-936657-1-5. Depósito legal: SE. 5761-2008. Palabras clave: qigong, formas, historia, ejercicios, taijiquan, escuelas, fisioterapia. Resumen: Manual teórico y técnico de taichí. El libro esta formado por dos partes, precedidas por varios capítulos introductorios que comentan en qué consiste el taichí, la historia de sus escuelas, sus características técnicas, las técnicas de visualización, la creación de una forma de taichí, resaltan la importancia de un calentamiento y una práctica correcta, ofrecen algunos consejos para el entrenamiento, explican los problemas asociados a la modernidad y describen el método de respiración abdominal. La primera parte describe la ejecución de distintos ejercicios de chikung con pelota y una técnica de masaje acompañados de sus ilustraciones para luego presentar la secuencia fotográfica y descripción de la forma de 20 movimientos de taichí con pelota. La segunda parte relata brevemente la historia del abanico, describe su estructura, explica su utilización como medio de defensa personal y dentro del taichí además de incluir la secuencia fotográfica de la forma de 30 
movimientos del taichí con abanico, acompañada de unas breves explicaciones técnicas. Adjunta varias cartas de agradecimiento, la biografía de la autora y bibliografía.

749. Cáliz Lillo, Ignacio (1990). Tratado taoísta : tai-chi qigong. Madrid: Mandala. 1aㅡ ed. 173 p. : il. ; 21x28,5 cm. ISBN: 84-86961-20-3. Depósito legal: M. 19006-1990. (2ª ed., 2004; 3ํㅡㄹ. ed., 2009, ISBN: 978-848352-133-5). Palabras clave: qigong, historia, fundamentos teóricos, fundamentos técnicos, principios técnicos, filosofía, ejercicios, taijiquan, escuelas, respiración. Resumen: Manual teórico y técnico de tai chi. La obra esta formada por 5 capítulos. El primer capítulo comenta los orígenes históricos y legendarios del tai chi chuan. El segundo capítulo estudia la filosofía que impregna el tai chi junto con la teoría de los ocho diagramas, del hecho supremo, del pa-kwa y del yin-yang. El tercer capítulo estudia los fundamentos teóricos del tai chi chuan como la teoría de la energía, la armonía con el tao, describe las energías meridianas, la localización de los 12 meridianos junto con su ilustración, la localización y acción de los vasos gobernadores, la teoría de los cinco elementos, la localización y funcionamiento de los chakras y las glándulas del cuerpo, la teoría de la energía sexual, destaca la importancia de la respiración y comenta los beneficios del chi-kung y los principios del entrenamiento en la práctica del tai chi chuan. El cuarto capítulo analiza los principios técnicos de la práctica del tai chi chuan. El último capítulo describe la ejecución técnica de los ejercicios de qigong para activar el flujo del qi y la tabla de taichi de la escuela yang incluyendo la secuencia fotográfica de cada uno de ellos.

750. Cáliz Lillo, Ignacio (1998). Tai chi. Madrid: Mandala. 1a ed. 139 p. : il. ; 10x14,5 cm. ISBN: 84-95052-105. Depósito legal: M. 39066-1998. (2aㅡ ed., 2003). Palabras clave: formas, historia, fundamentos teóricos, fundamentos técnicos, principios técnicos, combate, taijiquan, escuelas, taoísmo. Resumen: Manual teórico y técnico de taijiquan. El primer capítulo explica en qué consiste el tai chi para luego narrar los orígenes del arte marcial y el taoísmo como su base filosófica. El cuarto capítulo explica la teoría de la energía (chi) de la medicina tradicional china y las características de sus diferentes tipos. El quinto capítulo presenta los doce meridianos del cuerpo humano, los siete centros de energía (chakras) y las glándulas. El sexto capítulo describe el trabajo de la respiración y sus características. El último capítulo expone las reglas y consejos para la práctica del tai chi, sus principios técnicos, ilustra la forma de 24 movimientos de la escuela Yang y describe la práctica del empuje de manos (thu shu).

751. Cáliz Lillo, Ignacio (2003). Manual chino de tai chi. Madrid: Dilema. 1aㅡ ed. 154 p. : il. ; 14×20,5 cm. ISBN: 84-96079-30-9. Depósito legal: SE. 1849-2003. Palabras clave: formas, fundamentos técnicos. Resumen: Manual teórico y técnico de tai chi. El libro esta formado por 8 partes, precedidas de dos capítulos que explican la historia y beneficios físicos de la práctica del tai chi. A continuación, las 8 partes describen e ilustran la ejecución de las 24 posturas del tai chi simplificado. Además de describir la ejecución de cada movimiento en partes, incluye esquemas de movimiento y detalla los puntos esenciales de cada posición. El epílogo consta de dos relatos sobre los beneficios del tai chi sobre la salud y de otro sobre el pueblo origen del tai chi chuan.

752. Cáliz Lillo, Ignacio (2004). Tai chi : "el fluido de luz". Madrid: Librería Argentina. 1aa ed. 123 p. : il. ; 13x21 cm. ISBN: 84-89836-52-3. Libro + DVD: 84-89836-58-2. Libro + Video: 84-89836-51-5. Depósito legal: M. 16847-2004. Palabras clave: formas, fundamentos técnicos, principios técnicos, taijiquan, escuelas, fundamentos teóricos. Resumen: Manual teórico y técnico de taijiquan. El libro esta formado por 15 capítulos. Los primeros cuatro capítulos relatan la historia del tai chi junto con sus características y comentan los principios técnicos y recomendaciones prácticas para comenzar a practicar el tai chi. Los dos siguientes capítulos exponen la teoría de la energía y los meridianos, para después comentar los 10 principios técnicos del tai chi. El noveno capítulo describe e ilustra la ejecución técnica de la tabla de tai chi Yang. El décimo capítulo presenta la teoría de los cinco elementos para finalizar con el comentario de algunos detalles técnicos en la realización del tai chi, las normas que deben regir la vida de un practicante de tai chi, los principios técnicos del trabajo de empuje de manos y las conclusiones finales del libro. El DVD comenta en qué consiste el tai chi, sus contenidos técnicos, sus fundamentos teóricos, sus principios técnicos, sus objetivos y beneficios además de presentar la ejecución de la forma de 24 movimientos del estilo yang de tai chi desde la vista frontal y posterior, ejercicios de chikung individuales y por parejas, ejercicios de empuje de manos, la forma larga del estilo yang de tai chi junto con los detalles técnicos de brazos y piernas, y la descripción de los movimientos de la forma de 24 movimientos del estilo yang de tai chi acompañada de su posterior visualización completa y de los detalles de brazos y piernas. Los contenidos están disponibles en inglés, castellano, alemán, italiano y francés. Adjunta el enlace a la página web de Budo International.

753. Cáliz Lillo, Ignacio (2007). Tai chi Yang : preparación para el examen de cinturón negro 1er Dan de tai chi. Federación Madrileña de Kárate. Madrid: Librería Argentina. 1aㅡ ed. 271 p. : il. ; $17 \times 24 \mathrm{~cm}$. ISBN: 978-84-85895-33-5. 978-84-85895-34-2 (Libro+DVD). Depósito legal: M. 20392-2007 (Libro). M. 20393-2007 (Libro+DVD). Palabras clave: formas, fundamentos teóricos, fundamentos técnicos, principios técnicos, combate, aplicación marcial, exámenes. Resumen: Manual teórico y técnico de tai chi. La obra esta dividida en 2 partes, precedidas de una introducción que comenta la 
institucionalización del tai chi en España y los objetivos del libro. La primera parte esta compuesta por 7 capítulos que narran las experiencias del autor con el tai chi, los principios técnicos del tai chi junto con algunos consejos para la práctica, los aspectos taoístas que impregnan el tai chi, relata la historia de Chang San-Feng como creador del tai chi, explican las características de los diferentes estilos de tai chi así como los conceptos teóricos sobre la anatomía, los meridianos del cuerpo y la fisiología del cuerpo humano. La segunda parte esta compuesta por 12 capítulos. Los 7 primeros capítulos enumeran los requisitos de los practicantes para alcanzar el cinturón negro 1er dan de tai chi, explican cómo debe realizarse la presentación ante el tribunal de grados y cuáles son los contenidos técnicos y teóricos que deben realizarse, ilustran las posiciones de piernas y pies, las posiciones de brazos y manos, las técnicas de patadas, y el ejercicio del abrazo del árbol. El siguiente capítulo describe los niveles de ejercicios dentro del empuje de manos (tu-shu), sus principios técnicos e ilustra sus técnicas básicas. El noveno capítulo describe e ilustra 3 técnicas de defensa o aplicación marcial ante diferentes agarres y ataques. Los dos siguientes capítulos describen e ilustran la tabla de 24 movimientos de Pekín y la tabla con palo. El último capítulo expone algunos consejos prácticos para la ejecución del examen. Incluye apéndices sobre la respiración, el chi, los trece puntos y algunos aforismos.

754. Cáliz Lillo, Ignacio (2009). Tai chi : "el fluido de luz". Curso completo en teoría y práctica. Madrid: Librería Argentina. 1a ed. 108 p. : il. ; desc.xdesc. cm. ISBN: 978-84-85895-74-8. Depósito legal: M. 35700-2009. Palabras clave: formas, fundamentos técnicos, principios técnicos, taijiquan, escuelas, fundamentos teóricos. Resumen: Manual teórico y técnico de taijiquan. El libro esta formado por 15 capítulos. Los primeros cuatro capítulos relatan la historia del tai chi junto con sus características y comentan los principios técnicos y recomendaciones prácticas para comenzar a practicar el tai chi. Los dos siguientes capítulos exponen la teoría de la energía y los meridianos, para después comentar los 10 principios técnicos del tai chi. El noveno capítulo describe e ilustra la ejecución técnica de la tabla de tai chi Yang. El décimo capítulo presenta la teoría de los cinco elementos para finalizar con el comentario de algunos detalles técnicos en la realización del tai chi, las normas que deben regir la vida de un practicante de tai chi, los principios técnicos del trabajo de empuje de manos y las conclusiones finales del libro. El DVD comenta en qué consiste el tai chi, sus contenidos técnicos, sus fundamentos teóricos, sus principios técnicos, sus objetivos y beneficios además de presentar la ejecución de la forma de 24 movimientos del estilo yang de tai chi desde la vista frontal y posterior, ejercicios de chikung individuales y por parejas, ejercicios de empuje de manos, la forma larga del estilo yang de tai chi junto con los detalles técnicos de brazos y piernas, y la descripción de los movimientos de la forma de 24 movimientos del estilo yang de tai chi acompañada de su posterior visualización completa y de los detalles de brazos y piernas. Los contenidos están disponibles en inglés, castellano, alemán, italiano y francés. Adjunta el enlace a la página web de Budo International.

755. Cáliz Lillo, Ignacio (prólogo) (1986). Manual chino de tai-chi. Madrid: Las Mil y Una Ediciones. 1a ed. 95 p. : il. ; 13x20,5 cm. ISBN: 84-85805-29-1. Depósito legal: M. 43029-1986. Palabras clave: formas, historia, aplicación terapéutica. Resumen: Manual teórico y técnico de taichi. La obra esta compuesta de 6 capítulos. El primer capítulo relata el origen legendario del taichi, su evolución en distintas escuelas y las características técnicas comunes a todas ellas. El segundo capítulo explica los beneficios que reporta la práctica del taichi sobre el sistema nervioso, el sistema cardiovascular y respiratorio y el metabolismo. El tercer capítulo describe la ejecución técnica de las 24 posturas de la forma simplificada, señala los detalles técnicos más importantes e incluye las ilustraciones y esquemas de movimiento de cada una de ellas. Los últimos tres capítulos relatan dos casos particulares de enfermedades curadas a través de la práctica del taichi y la descripción del pueblo y habitantes de Chenjiagou como cuna y maestros del taijiquan.

756. Cangelosi, Paolo (2008). Tai chi Yang : la forma y sus aplicaciones. Madrid: Budo International. 1a ed. 232 p. : il. ; 17x24 cm. ISBN: 978-84-936119-7-2. Depósito legal: M. 1532-2008. Palabras clave: formas, historia, fundamentos teóricos, fundamentos técnicos, principios técnicos, entrenamiento, escuelas, fundamentos filosóficos, aplicación marcial. Resumen: Manual teórico y técnico de tai chi. El libro esta formado por 10 capítulos precedidos por el prólogo que resume los contenidos del libro. El primer capítulo expone la biografía del autor. El segundo capítulo relata el origen del tai chi y sus diferentes estilos. El tercer capítulo comenta los fundamentos filosóficos del tai chi mientras que el cuarto explica el concepto de chi, su relación con el tai chi y la dinámica de las energía en sus técnicas. El quinto capítulo expone las características técnicas del estilo yang de tai chi y sus principios técnicos y del entrenamiento. El sexto capítulo ilustras las principales posiciones de brazos y piernas del tai chi. El séptimo capítulo enumera las posiciones de la forma de tai chi. El octavo capítulo incluye la secuencia fotográfica de la ejecución de la forma de tai chi del estilo yang, mientras que el noveno representa las ocho acciones o principios denominados "ba jing". El último capítulo presenta la secuencia fotográfica de la forma de tai chi junto con sus aplicaciones marciales.

757. Carrillo Vigueras, Jesús (2006). Técnicas de afrontamiento del estrés : tai chi. s.l.: Sindicato de Enfermería de Murcia. 1aㅡ ed. 96 p. : il. ; 21x29,5 cm. ISBN: No ISBN. Depósito legal: no. (2ª ed., 2007; $3^{\underline{a}}$ ed., 2008, ISBN: 978-84-612-8155-8). Palabras clave: fundamentos teóricos, fundamentos técnicos, 
principios técnicos, ejercicios, qigong, taijiquan, enfermedades, fisioterapia, relajación, respiración. Resumen: Manual teórico y técnico de tai chi chuan. El libro esta formado por 13 capítulos. El primer capítulo define el concepto de estrés y sus fases. El segundo capítulo describe las respuestas fisiológicas, cognitivas y de conducta frente al estrés. El tercer capítulo expone las consecuencias físicas, psicológicas y conductuales derivadas del estrés. El cuarto capítulo explica los objetivos de las diferentes técnicas de prevención y tratamiento del estrés. El quinto capítulo expone los objetivos del chikung y del tai chi así como los fundamentos teóricos del chikung. El sexto capítulo define el concepto de tai chi chuan y sus fundamentos teóricos. El séptimo capítulo explica los diez principios técnicos esenciales del tai chi chuan. El octavo capítulo presenta los distintos enfoques de la relajación, sus objetivos, los requisitos para su práctica y describe algunos de los métodos para alcanzar la relajación. El noveno capítulo detalla la relación entre qigong y respiración, describe varios ejercicios respiratorios y explica la concentración y relajación desarrolladas por el qigong. El décimo capítulo describe la ejecución y objetivos de los ejercicios de ba duan jin acompañados de sus ilustraciones. El capítulo decimoprimero explica la historia y características de la tabla de tai chi de 24 movimientos de Beijing además de describir su ejecución técnica y aplicación práctica junto con sus ilustraciones y esquemas de movimiento. El decimosegundo capítulo incluye las instrucciones técnicas de Kuo Lieng Ying y Cheng Man-Ching sobre la práctica de la forma. El último capítulo comenta los objetivos y características de las técnicas de automasaje y describe distintos ejercicios para el masaje de todo el cuerpo junto con sus ilustraciones. Adjunta bibliografía.

758. Chang, Dsu Yao y Fassi, Roberto (2008). El gran libro del t'ai chi ch'üan. Barcelona: De Vecchi. 1a ed. 383 p. : il. ; 17x24 cm. ISBN: 978-84-315-3889-7. Depósito legal: no. Palabras clave: formas, historia, fundamentos teóricos, táctica, fundamentos técnicos, principios técnicos, textos, taijiquan, escuelas, aplicación marcial. Resumen: Tratado teórico y técnico de tai chi chuan. El libro esta formado por 14 capítulos. El primer capítulo explica en qué consiste el tai chi chuan, comenta las características de las artes marciales tradicionales chinas, relata los orígenes históricos del tai chi chuan, explica las características de cada estilo junto con su situación actual y las bases filosóficas y religiosas que impregnan y fundamentan a esta práctica. También incluye una descripción del programa de estudio del tai chi chuan del maestro Chang Dsu Yao. Los dos siguientes capítulos exponen brevemente la teoría taoísta sobre las tres energías o tesoros que recorren el cuerpo, sus transformaciones y niveles así como las características de la energía ching (esencia). El cuarto capítulo presenta la teoría del chi (energía interna), sus tipos y características, expone los conceptos de medicina tradicional china relacionados con el chi así como su aplicación y relación con el tai chi chuan. El siguiente capítulo expone los tipos y características del shen (energía espiritual y mental), su circulación y transformación así como su relación con el tai chi chuan. El sexto capítulo presenta los conceptos de wai li (fuerza externa) y nei chin (fuerza interna), las manifestaciones que puede adoptar la fuerza interna junto con la ilustración de algunos ejemplos, la aplicación de la fuerza interna en la práctica del tai chi chuan y describe un ejercicio práctica para entender y combinar los diferentes tipos de fuerza interna (chin). El siguiente capítulo profundiza en la explicación de los principios técnicos clásicos del tai chi chuan. El octavo capítulo describe la ejecución de los cinco pasos y ocho técnicas que componen las 13 técnicas dinámicas del tai chi chuan incluyendo el trigrama de cada uno de ellos. El siguiente capítulo describe e ilustra la ejecución de las posiciones del tai chi chuan junto con la explicación técnica de las posturas y respiración durante la práctica. El décimo capítulo incluye la descripción e ilustración por partes de las 108 posturas que componen la forma larga del estilo yang del tai chi chuan junto con la grafía china del nombre de cada técnica. El siguiente capítulo explica y comenta los principios técnicos y tácticos en el combate de tai chi chuan. El decimosegundo capítulo resalta los beneficios de conocer las aplicaciones marciales de las técnicas de tai chi chuan para luego describir e ilustrar por partes la aplicación marcial de cada una de las posturas de la forma larga del estilo yang. El último capítulo incluye la traducción y comentario de los textos clásicos del tai chi chuan, como son la "Teoría del tai chin chuan", "Tratado clásico del tai chi chuan", "Explicación de la práctica física y mental de las trece técnicas dinámicas", "Las cuatro palabras secretas", "Los diez principios fundamentales del tai chi chuan", "Las cinco palabras secretas", "Los puntos esenciales de la práctica del ejercicio fundamental y de los combates del tai chi chuan", "Poesías secretas del antiguo libro de Ch'ien Lung", "La poesía de las ocho palabras", "La teoría de la comprensión de la mente", "La teoría de la importancia del uso del cuerpo entero", "Enunciación de los diecisiete puntos importantes", El escrito de los cinco puntos", "La poesía de los golpes", "La poesía de la esencia (de las trece técnicas dinámicas y sus aplicaciones)", "El secreto de liberar (la fuerza interna)", "Los puntos fundamentales del tai chi chuan", "La poesía de la aplicación (de las técnicas)" y "La poesía del verdadero significado". Adjunta las conclusiones del maestro Chang Dsu Yao sobre la práctica del tai chi chuan. Los apéndices incluyen un glosario con la transcripción de los ideogramas chinos, bibliografía y breve biografía de los autores.

759. Chen, Sheng Yu y Cáceres, Diego (2006). Tai-chi Chen : la forma "Yí Lu" y sus aplicaciones marciales. Madrid: Budo International. $1^{\underline{a}}$ ed. 190 p. : il. ; 17x24 cm. ISBN: 84-96492-54-0. Depósito legal: M. 
46087-2006. Palabras clave: formas, fundamentos teóricos, principios técnicos, aplicación marcial. Resumen: Manual teórico y técnico de tai chi. El libro esta formado por cuatro capítulos. El primer capítulo narra la historia del estilo Chen de tai chi así como sus fundamentos teóricos y características técnicas. El segundo capítulo presenta la biografía del maestro Chen, los principios técnicos del estilo y el listado de posiciones que componen la forma de 81 movimientos del maestro Hong. El tercer capítulo presenta la secuencia fotográfica de la ejecución de la primera forma del estilo Chen denominada "Yi Lu" junto con algunos primeros planos de los detalles técnicos más significativos. El último capítulo incluye la representación gráfica de la aplicación marcial de la forma y algunas de sus variantes.

760. Chen, William C. C. (2001). Tai chi chuan : el camino de la armonía. Madrid: Espasa-Calpe. 1a ed. 218 p. : il. ; $12 \times 21$ cm. ISBN: 84-239-2469-6. Depósito legal: M. 30229-2001. Palabras clave: formas, fundamentos teóricos, fundamentos técnicos, biografía, maestros. Resumen: Manual teórico y técnico de tai chi chuan. La obra esta formada por 2 partes. La primera parte comenta la biografía del autor, cuáles son las características del tai chi chuan y sus beneficios, cómo se puede definir el término maestro y cómo se desarrolla la velocidad y el equilibrio a través del entrenamiento de tai chi chuan. La segunda parte explica el entrenamiento que siguió el autor para aprender la aplicación práctica del tai chi chuan, las razones para crear su tabla de 60 movimientos, la forma de interpretar la parte práctica del libro y presenta la descripción de la ejecución técnica de dichos movimientos acompañada por las ilustraciones y esquemas de movimiento de cada uno de ellos. El epílogo relata una anécdota del autor en Nueva York.

761. Chen, William C. C. (2006). La práctica del tai chi : guía para una buena salud física y mental. Pozuelo de Alarcón: Espasa-Calpe. $1^{a}$ ed. 218 p. : il. ; 12x21 cm. ISBN: 84-670-2261-2. Depósito legal: M. 244062006. Palabras clave: formas, fundamentos técnicos, taijiquan, escuelas. Resumen: Manual teórico y técnico de tai chi chuan estilo Chen. La obra se divide en 2 partes, con la primera de ellas dedicada a un acercamiento teórico de lo que es el tai chi, cuales son sus características, que significa la palabra maestro dentro de las artes marciales, y cómo se entrena la rapidez y el equilibrio. La segunda parte explica los principios del entrenamiento en el tai chi para luego describir e ilustrar los 60 movimientos del estilo chen. Ofrece una descripción amplia de cada movimiento, un esquema de movimiento y el tipo de respiración en cada fase del movimiento. Finaliza con un epílogo en el que narra un pequeño incidente en Nueva York.

762. Cheng, Man-Ching (1991). Tai-chi : el arte de la armonía. Los trece capítulos sobre tai chi chuan del maestro Cheng. Madrid: CEA-GAR. 1를. ed. 127 p. : il. ; 13x21 cm. ISBN: 84-604-0393-9. Depósito legal: M. 34211-1991. Palabras clave: fundamentos teóricos, principios técnicos, textos, fundamentos filosóficos. Resumen: Tratado teórico de tai chi chuan. La obra esta formada por 13 capítulos comentados y anotados, precedidos por los agradecimientos, las notas del traductor a la edición inglesa, la biografía del autor y su prólogo. El primer capítulo explica en qué consiste el tai chi. El segundo capítulo expone los fundamentos teóricos del tai chi. El tercer capítulo describe la concentración del chi y sus beneficios. El cuarto capítulo detalla la transformación del temperamento aparejada a la práctica del tai chi chuan. El quinto capítulo compara la práctica del tai chi chuan con el nadar y expone sus principios técnicos. El sexto capítulo explica el significado del corazón y la espina dorsal además de su relación. El séptimo capítulo comenta los principios físicos implicados en la práctica. El octavo capítulo ofrece algunos consejos para cultivar el chi. Los dos siguientes capítulos exponen los beneficios y el fortalecimiento de los órganos internos al hundir el chi en el tan tien así como la aplicación del tai chi chuan para la curación de la tuberculosis. El décimo primer capítulo describe las fases de desarrollo en la práctica del tai chi chuan y sus características. El siguiente capítulo expone la teoría de los cinco elementos y su relación con los fundamentos técnicos del tai chi chuan, mientras que el último capítulo presenta los doce principios del tai chi chuan. Adjunta un epílogo, una poesía y una breve biografía de Ángel Fernández de Castro.

763. Cheng, Man-Ching (1996). Instrucciones avanzadas de Cheng Man-Ch'ing para la forma del tai-chi : con una selección de escritos sobre meditación, el I Ching, medicina y las artes de la poesía, la caligrafía y la pintura china. Romanones: Tao. 1a ed. 207 p. : il. ; $13 \times 20$ cm. ISBN: 84-921280-0-3. Depósito legal: M. 4758-1996. (2a ed., 2003). Palabras clave: formas, principios técnicos, principios teóricos, entrenamiento, ejercicios, combate, caligrafía, meditación, pintura, poesía. Resumen: Manual teórico y técnico de tai chi. La obra esta formada por 3 partes precedidas de la nota a la edición inglesa que resume los contenidos de la obra y la nota del traductor. La primera parte consta de 15 capítulos. Los tres primeros capítulos incluyen los prólogos de Ch'en Wei-ming, Teng K'o-yü y del autor respectivamente. El cuarto capítulo comenta la historia, beneficios y fundamentos teóricos del tai chi. El quinto capítulo explica los principios técnicos del tai chi según Yang Cheng-fu. El sexto capítulo expone las tres clases de valentía. El séptimo capítulo analiza los principales errores en la práctica del tai chi mientras que el octavo resume los aprendizajes del autor. Los siguientes cuatro capítulos incluyen las preguntas y respuestas sobre "El tratado de tai-chi chüan", "Las trece posturas", "La canción de las trece posturas" y "La canción del empuje de manos". El décimo tercer capítulo ofrece 
varios consejos para la práctica sin profesor. Los dos siguientes capítulos incluyen los epílogos a los libros de "Los trece capítulos" y "'Nuevo Método". La segunda parte consta de 4 capítulos. El primer capítulo describe la ejecución de la forma de 37 movimientos acompañada de su representación gráfica. El segundo capítulo explica la ejecución de los 4 principios del empuje de manos incluyendo su ilustración, mientras que el tercero detalla los principios del ejercicio ta-lü. El cuarto capítulo comenta en qué consiste el ejercicio de san-shou. La tercera parte consta de 4 capítulos. El primer capítulo comenta la relación entre la meditación y la salud además de incluir la descripción de varios ejercicios y exponer sus principios del entrenamiento. El segundo capítulo presenta el prólogo del autor al libro I Ching. El tercer capítulo ofrece distintos consejos para la fecundidad. El último capítulo comenta las características y principios de la poesía, caligrafía y pintura.

764. Cheng, Man-Ching (2000). Tai-chi chuan : el arte de la armonía. Valencia: Ahimsa. $1^{a}$ ed. 93 p. : il. ; 13x21 cm. ISBN: 84-931254-1-5. Depósito legal: no. Palabras clave: fundamentos teóricos, fundamentos filosóficos, aplicación marcial, aplicación terapéutica. Resumen: Tratado teórico de tai chi chuan. La monografía esta compuesta por 13 capítulos, precedidos por un prólogo que explica los orígenes del tai chi chuan y del maestro Chang San Feng. El primer capítulo presenta los principios técnicos y filosóficos del tai chi chuan, para luego explicar la importancia del chi, su concentración junto con la mente en el tan tien y su aplicación. El cuarto capítulo analiza los efectos del tai chi chuan sobre el temperamento y continúa haciendo una analogía entre la natación y el tai chi chuan. El sexto capítulo estudia la relación entre el corazón y la espina dorsal y resalta la importancia de mantener la columna erguida para evitar la enfermedad. El séptimo capítulo expone varios principios físicos sobre la fuerza y la energía para aplicarlos a la técnica del tai chi chuan. El octavo capítulo ofrece algunos consejos para realizar ejercicios de tai chi chuan y concentrar la mente y el chi en el tan tien durante la vida diaria. El noveno capítulo enumera las razones por las que la práctica del tai chi chuan fortalece los órganos internos y continúa con el relato de la curación del autor de la tuberculosis. El undécimo capítulo explica las fases de entrenamiento del tai chi chuan y sus características para finalizar con dos capítulos dedicados a explicar los principios filosóficos de la mutua producción y destrucción cíclica de las artes marciales, y la interpretación de las 12 enseñanzas sobre la correcta práctica del tai chi chuan. Adjunta notas.

765. Cheng, Man-Ching (2001). Los trece capítulos de tai-chi chüan del maestro Cheng : el arte de la armonía. Romanones: Tao. 1aㅡ ed. 124 p. : il. ; 14x21 cm. ISBN: 84-921280-4-6. Depósito legal: M. 14465-2001. (2 ${ }^{\underline{a}}$ ed., 2001; $3^{\mathrm{a}}$ ed., 2004). Palabras clave: fundamentos teóricos, principios técnicos, textos, fundamentos filosóficos. Resumen: Tratado teórico de tai chi. La obra esta formada por 13 capítulos precedidos por los agradecimientos, las notas del traductor sobre la escritura de la obra, la biografía del maestro Cheng Man-ch'ing y el prólogo del autor. El primer capítulo explica en qué consiste el tai chi. El segundo capítulo expone los fundamentos teóricos del tai chi. El tercer capítulo describe la concentración del chi y sus beneficios. El cuarto capítulo detalla la transformación del temperamento aparejada a la práctica del tai chi chuan. El quinto capítulo compara la práctica del tai chi chuan con el nadar y expone sus principios técnicos. El sexto capítulo explica el significado del corazón y la espina dorsal además de su relación. El séptimo capítulo comenta los principios físicos implicados en la práctica. El octavo capítulo ofrece algunos consejos para cultivar el chi. Los dos siguientes capítulos exponen los beneficios y el fortalecimiento de los órganos internos al hundir el chi en el tan tien así como la aplicación del tai chi chuan para la curación de la tuberculosis. El décimo primer capítulo describe las fases de desarrollo en la práctica del tai chi chuan y sus características. El siguiente capítulo expone la teoría de los cinco elementos y su relación con los fundamentos técnicos del tai chi chuan, mientras que el último capítulo presenta los doce principios del tai chi chuan. Adjunta la nota del editor español y la bibliografía recomendada.

766. Chuen, Lam Kam (1994). Tai chi : paso a paso. Barcelona: Integral. $1 \underline{\underline{a}}$ ed. 143 p. : il. ; 24x19 cm. ISBN: 84-7901-097-5. Depósito legal: no. (2ª ed., 1996; $3^{\mathrm{a}}$ ed., 1998; 4⿳亠丷厂 ed., 2002; $5^{\mathrm{a}}$ ed., 2005). Palabras clave: fundamentos técnicos, ejercicios. Resumen: Manual técnico de tai chi. La obra esta compuesta por dos partes. La primera parte incluye cuatro capítulos que recopilan, describen e ilustran diferentes ejercicios y programas de entrenamiento para relajar y tonificar el cuerpo, desarrollar la fuerza interna y el control muscular, mejorar el equilibrio, y profundizar en los aspectos anteriores a través del trabajo con un compañero. La segunda parte presenta la forma del pequeño circulo, explicando cada paso por partes y con esquemas de movimiento, y ofreciendo algunos consejos prácticos para mejorar el aprendizaje y entrenamiento de la misma. Adjunta direcciones de interés y bibliografía.

767. Chuen, Lam Kam (1997). Tai chi : una obra indispensable para fortalecer y aumentar la energía interna, flexibilidad y resistencia. Barcelona: Integral. 1aㅡ ed. 144 p. : il. ; 19x25 cm. ISBN: 84-7901-292-7. Depósito legal: no. Palabras clave: fundamentos técnicos, ejercicios. Resumen: Manual técnico de tai chi. La obra esta compuesta por dos partes. La primera parte incluye cuatro capítulos que recopilan, describen e ilustran diferentes ejercicios y programas de entrenamiento para relajar y tonificar el cuerpo, desarrollar la fuerza interna y el control muscular, mejorar el equilibrio, y profundizar en los aspectos anteriores a través del trabajo con un compañero. La segunda parte presenta la forma del 
pequeño circulo, explicando cada paso por partes y con esquemas de movimiento, y ofreciendo algunos consejos prácticos para mejorar el aprendizaje y entrenamiento de la misma. Adjunta direcciones de interés y bibliografía.

768. Chuen, Lam Kam (2005). Tai chi : para mantenerse joven. Barcelona: Integral. 1aㅡ ed. 127 p. : il. ; 18x23,5 cm. ISBN: 84-7871-263-1. Depósito legal: no. Palabras clave: formas, qigong, fundamentos técnicos, ejercicios. Resumen: Manual técnico de tai chi. La obra esta compuesta de 6 capítulos. Comienza con una introducción donde explica brevemente los fundamentos del arte y describe los beneficios que reporta para la salud. Los siguientes capítulos describen la ejecución y resaltan los puntos clave de 5 grupos de ejercicios. El primer grupo esta compuesto por 10 ejercicios básicos para calentar y estirar el cuerpo; luego incluye los movimientos de la esfera dorada, dedicados al movimiento de la energía interna; continua con las técnicas de los ocho tesoros preciosos, que tienen como objetivo la apertura de los recorridos corporales de la energía; y finaliza con un capítulo dedicado a ocho de los movimientos clásicos del tai chi para aumentar la energía corporal y otro capítulo con un conjunto de ejercicios de enfriamiento. Todos los ejercicios están acompañados de ilustraciones con los esquemas de movimiento.

769. Connor, Danny (1994). La practica del tai chi y tai chi qigong. Madrid: Edaf. 1a ed. 183 p. : il. ; 18x25,5 cm. ISBN: 84-7640-832-3. Depósito legal: M. 18670-1994. (2 $2^{\mathrm{a}}$ ed., 1995). Palabras clave: formas, fundamentos teóricos, qigong. Resumen: Manual teórico y técnico de tai chi. La obra esta dividida en 11 capítulos. Los cuatro primeros capítulos explican brevemente lo que es el tai chi, el encuentro del autor con este arte marcial, la historia del tai chi y sus escuelas, y un ensayo donde se expone la filosofía del tai chi en términos de defensa personal y movimiento corporal. El quinto capítulo describe e ilustra la ejecución de los 24 pasos del tai chi simplificados, destacando los aspectos técnicos más importantes en cada fase del movimiento. A continuación profundiza en los principios técnicos de la práctica de empuje de manos (tuishou) y ofrece dos ejercicios para desarrollar con un compañero. El séptimo capítulo presenta un ensayo sobre el discernimiento mental en la práctica de las trece acciones y sus principios técnicos, para en los dos capítulos siguientes, detallar las teorías chinas que fundamentan la práctica del tai chi, como los tipos de meditación existentes y la teoría de los cinco elementos, y exponer los beneficios de su práctica. El décimo capítulo relata las características del tai chi como método de defensa personal para finalizar con un capítulo dedicado a explicar los fundamentos del qigong y describir los 18 movimientos individuales del tai chi qigong, detallando la ejecución, los puntos más importantes y los beneficios para la salud de cada ejercicio.

770. Copping, Rupert (1982). Tai chi chuan : camino hacia la armonía. Granada: Ganímedes. 1aㅡ ed. 122 p. : il. ; 16x21,5 cm. ISBN: No ISBN. Depósito legal: no. Palabras clave: formas, fundamentos teóricos, fundamentos técnicos, principios técnicos, defensa personal. Resumen: Manual teórico y técnico de tai chi chuan. El libro esta formado por 6 capítulos precedidos por un prólogo que narra la historia del tai chi. El primer capítulo explica las cuatro vertientes que adopta la práctica del tai chi chuan. El segundo capítulo expone los principios técnicos del tai chi mientas que el tercero describe e ilustra la ejecución de las 36 posturas del tai chi incluyendo sus esquemas de movimiento. El cuarto capítulo comenta los fundamentos teóricos y objetivos de la práctica de empuje de manos y describe la ejecución de su primera práctica acompañada de su ilustración. El quinto capítulo detalla los principios técnicos del tai chi utilizado como sistema de defensa personal además de incluir la descripción e ilustración de algunos ejemplos prácticos. El último capítulo incluye un resumen del libro "Tai chi chuan ching". Adjunta una hoja desplegable con el esquema de movimiento del tai chi chuan.

771. Crompton, Paul (1991). El tai chi : su conocimiento y práctica. Madrid: Edaf. 1ạ ed. 191 p. : il. ; 14x20,5 cm. ISBN: 84-7640-508-1. Depósito legal: M. 25213-1991. (2ª ed., 1996; 6ª ed., 2001; 7ำ ed., 2002; $8^{\underline{a}}$ ed., 2004). Palabras clave: qigong, fundamentos teóricos, combate, artes marciales, poesía, respiración, armas. Resumen: Manual teórico y técnico de tai chi. La obra esta formada por 11 capítulos. El primer capítulo expone las diferentes teorías existentes respecto al origen del tai chi. El segundo capítulo expone las características, similitudes y diferencias en las ocho posturas y cinco pasos entre los diferentes estilos, comenta la historia de otras posturas adicionales y expone la relación entre los movimientos de la forma larga del estilo yang y el tiempo utilizado, la fase dominante, la dirección, y los órganos yin y yang. El tercer capítulo describe el trabajo del empuje de manos y combate y los principios que rigen la práctica. El cuarto capítulo presenta las armas más habituales utilizadas en el tai chi, como son la espada y la lanza, comentando su historia y evolución, sus características, sus requisitos y métodos de trabajo, y las diferencias terminológicas utilizadas en sus posiciones y acciones. El quinto capítulo comenta las diferencias y similitudes entre el tai chi chuan y otras artes marciales como el pakua, chin-na, aikido o judo, como medio para profundizar en el entendimiento de la práctica. El sexto capítulo explica el chi kung o cultivo de la energía interior, definiendo su práctica y detallando la utilización que puede tener en esferas como la medicina, las artes marciales, las artes ocultas, las artes escénicas y los caminos religiosos. Continúa con algunas notas aclaratorias sobre la historia del I Ching, la teoría de los cinco elementos y la teoría del yin-yang, para luego detallar su relación con el tai chi. El octavo capítulo incluye varios poemas dedicados al tai 
chi y su método de práctica. Los tres últimos capítulos incluyen consejos herbales para el tratamiento terapéutico, un comentario sobre la importancia de la respiración junto con su fisiología y forma de entrenamiento, y el estado actual del tai chi. Adjunta bibliografía, glosario e índice de nombres.

772. Crompton, Paul (1997). Tai chi : guía práctica de los efectos terapéuticos de esta disciplina. Barcelona: Oniro. 1aㅡ ed. 64 p. : il. ; desc.xdesc. cm. ISBN: 84-922523-3-2. Depósito legal: no. (1aㅡ reimp., 2002). Palabras clave: formas, historia, fundamentos teóricos, fundamentos técnicos, aplicación terapéutica. Resumen: Manual teórico y técnico de tai chi. El libro esta formado por 4 capítulos precedidos por una introducción que comenta brevemente la historia, características, familias y contenidos técnicos del tai chi. El primer capítulo explica los fundamentos teóricos del tai chi. El segundo capítulo describe la ejecución de varios ejercicios introductorios del tai chi acompañados de su secuencia fotográfica y notas explicativas. El tercer capítulo explica la ejecución técnica de la forma simplificada de Pekín junto con su representación gráfica y esquemas de movimiento. El cuarto capítulo comenta los efectos terapéuticos derivados de la práctica del tai chi además de exponer las características de un buen maestro, direcciones de interés y bibliografía. Adjunta un índice terminológico y agradecimientos.

773. Crompton, Paul (2000). Tai chi : introducción práctica. Bilbao: Mensajero. 1a ed. 188 p. : il. ; 12x19 cm. ISBN: 84-271-2306-X. Depósito legal: BI. 395-2000. Palabras clave: formas, fundamentos teóricos, fundamentos técnicos, principios técnicos, salud. Resumen: Manual teórico y técnico de tai chi. La obra esta compuesta de 8 capítulos, precedidos por una introducción sobre la historia del tai chi, su formación, y vertientes prácticas. El primer capítulo explora las raíces filosóficas del tai chi, el taoísmo, la teoría del yin-yang y el budismo. El segundo capítulo explica los principios teóricos que fundamentan la práctica del chi kung, su funcionamiento y clasifica las diferentes prácticas de chi kung. El tercer capítulo describe la aplicación de las leyes de la física sobre la ejecución técnica del tai chi, para después analizar sus principios técnicos. El quinto capítulo presenta 9 ejercicios introductorios describiendo su ejecución y sus beneficios posteriores para la práctica del tai chi. El sexto capítulo narra la historia sobre la formación de la escuela yang y su forma de 48 movimientos, además de describir e ilustrar dicha secuencia de movimientos y otros ejercicios para trabajar las piernas y los pies. El séptimo capítulo detalla la práctica y términos empleados en el trabajo de empuje de manos y los métodos básicos para realizar dicho trabajo. El último capítulo expone el contacto del autor con el tai chi y un comentario sobre la relevancia social del tai chi. Adjunta bibliografía.

774. Crompton, Paul (2003). Tai chi en casa : guía práctica para ejecutar los principales movimientos y secuencias que le permitirán conseguir el bienestar físico y mental. Barcelona: Parramón. 1aa ed. 96 p. : il. ; 17x25 cm. ISBN: 84-342-3054-2. Depósito legal: B. 36960-2003. (2ª ed., 2005). Palabras clave: formas, historia, combate, calentamiento, taijiquan, escuelas. Resumen: Manual teórico y técnico de tai chi. La obra esta formada por 4 capítulos, precedidos de una introducción que explica cómo utilizar este libro y relata la historia del tai chi. El primer capítulo explica brevemente los conceptos básicos internos y externos del tai chi, como son el chi, el yin y yang, los dantien, la postura, la relajación y tensión, el abrir y cerrar y la postura del arco. El segundo capítulo describe e ilustrar por partes varios ejercicios de estiramiento como preparación para la práctica del tai chi. El tercer capítulo describe la ejecución técnica por partes de la forma de 24 movimientos de Pekín acompañada de ilustraciones, esquemas de movimiento y señalando la visualización en cada postura y algunas notas prácticas. El último capítulo comenta los principios técnicos del empuje de manos y presenta la descripción e ilustración de varios de sus ejercicios. Adjunta la ilustración de la forma completa así como un índice de términos.

775. Dang, Tri Thong (1999). Tai chi para principiantes. Barcelona: Obelisco. $1^{\mathfrak{a}}$ ed. 75 p. : il. ; 13x21 cm. ISBN: 84-7720-703-8. Depósito legal: B. 18730-1999. (2ª ed., 2002; 3를. ed., 2004; $4^{\mathrm{a}}$ imp., 2007, ISBN: 978-84-7720-703-0). Palabras clave: formas, historia, fundamentos técnicos. Resumen: Manual técnico de tai chi. La obra presenta en su introducción en qué consiste el tai chi, cuál es su origen según las leyendas, cuáles son sus beneficios y cómo manejar el libro. La parte principal de la obra describe la ejecución técnica de la forma simplificada de tai chi con la ayuda de gráficos explicativos y esquemas de movimiento de los brazos y pies. La conclusión resalta los principios técnicos más importantes para la práctica correcta.

776. Daniele, Flavio (2008). Ciencia, tao y arte del combate. Barcelona: Shinden. 1aㅡ ed. 137 p. : il. ; 16x23 cm. ISBN: 978-84-96894-10-5. Depósito legal: B. 32850-2008. Palabras clave: fundamentos teóricos, filosofía, qigong, escuelas. Resumen: Tratado teórico de taijiquan. La obra esta dividida en 2 partes. La primera parte describe las relaciones entre el hombre y la naturaleza, el corazón y el cerebro, la estructura y funcionamiento del cerebro, las representaciones que hacemos del mundo, de la realidad y la importancia del lenguaje, la secuencia sonido-movimiento-luz, el papel del movimiento creativo y la evolución del ser humano a través del sonido, el movimiento y la representación mental. La segunda parte desarrolla los contenidos teóricos del taijiquan, analizando el significado de sus movimientos, los 3 universos que componen el ser humano y sus características, y los estadios y fases de transformación de las energías que componen la práctica del taijiquan. Adjunta información sobre la escuela nei dan. 
777. Despeux, Catherine (1993). Taiji quan : arte marcial, técnica de larga vida. Sant Boi de Llobregat: Ibis. 1a ed. 292 p. : il. ; 18x22,5 cm. ISBN: 84-8027-014-4. Depósito legal: B. 11034-1993. Palabras clave: historia, fundamentos teóricos, principios técnicos, escuelas, taijiquan. Resumen: Manual teórico y técnico de taijiquan. La obra esta compuesta por 8 capítulos. El primer capítulo narra el origen de las escuelas esotéricas y exotéricas, sus diferencias, las escuelas Chen, Yang, Wu, de Guo Weizhen y de Sun Lutang junto con sus fundadores y descendientes, así como la situación actual. El segundo capítulo explica el significado del principio "taiji", su aplicación en el cuerpo y la aplicación de los principios taiji sobre el taijiquan. El tercer capítulo describe las características del taijiquan como arte para mejorar la salud, sus principios y cuáles son sus etapas de aprendizaje. El cuarto capítulo profundiza en el paradigma marcial del taijiquan, describiendo las modalidades de fuerza interior desarrollada por cada escuela, y sus fundamentos estratégicos y de los puntos vitales del cuerpo. El quinto capítulo recopila extractos de diversos tratados sobre taijiquan para explicar los principios técnicos en los que se fundamenta este arte. El siguiente capítulo expone algunos consejos prácticos para comenzar la práctica del taijiquan y realizar adecuadamente cada movimiento. El séptimo capítulo describe e ilustra distintos ejercicios de la escuela Yang, como el encadenamiento de movimientos, el empuje de manos, el gran desplazamiento y la dispersión de las manos, explicando el papel de cada practicante y la utilización de cada técnica. El último capítulo presenta el encadenamiento de 64 movimientos de la escuela Chen, ilustrando cada movimiento y explicando su significado. Adjunta bibliografía, textos chinos de los tratados sobre taijiquan, nombres chinos de las escuelas Yang, Chen y de la dispersión de las manos, e índice de los nombres de personas y de los términos chinos.

778. Drewe, James (2006). T'ai chi. Barcelona: Círculo de Lectores. 1aa ed. 128 p. : il. ; 15x21 cm. ISBN: 84672-1850-9. Depósito legal: no. Palabras clave: formas, fundamentos teóricos, fundamentos técnicos, taijiquan, escuelas. Resumen: Manual teórico y técnico de tai chi chuan. El libro esta dividido en 4 partes, precedidas de una introducción que comenta brevemente en qué consiste la práctica del tai chi chuan, cuáles son sus beneficios y aplicaciones, comenta los principios técnicos de la práctica y de sus fundamentos técnicos como la posición de las manos, las posturas y posiciones de pie y explica como utilizar este libro. La primera parte describe la ejecución de varios ejercicios preparatorios y de calentamiento antes de la práctica incluyendo la secuencia fotográfica de los mismos y su dirección. Las siguientes tres partes describen e ilustran la secuencia de movimientos de la forma abreviada de 24 movimientos del estilo Yang en tres partes, desde la figura 1 hasta la 8, desde la figura 9 hasta la 16 y desde la figura 17 hasta la 24, señalando además las características de cada movimiento y su dirección. Adjunta un índice terminológico.

779. Fengming, Wang (2008). Taichi tueishou : aplicaciones y fuerza interna en el empuje de manos del taichichuan. Barcelona: Alas. 1a ed. 379 p. : il. ; 17x23,5 cm. ISBN: 978-84-203-0449-6. Depósito legal: B. 46852-2008. Palabras clave: fundamentos teóricos, fundamentos técnicos, principios técnicos, ejercicios, entrenamiento, kyusho, relatos, acupuntura, aplicación marcial, sistemas de entrenamiento. Resumen: Manual teórico y técnico de tai chi chuan. El libro esta formado por 12 capítulos precedidos por un comentario sobre la romanización de los términos chinos, una breve biografía del autor y una introducción que resume la historia del tai chi chuan y su transmisión. El primer capítulo resume los contenidos de la obra y los principios para el aprendizaje del empuje de manos. El segundo capítulo expone los fundamentos y principios teóricos del empuje de manos del tai chi chuan. El tercer capítulo explica los principios técnicos de la práctica del empuje de manos junto con algunas ilustraciones explicativas. El cuarto capítulo describe la ejecución y beneficios de diversos ejercicios de calentamiento para todo el cuerpo acompañados de sus ilustraciones. El quinto capítulo presenta la descripción del movimiento, intención, puntos, beneficios y notas de los ejercicios de cultivo interno del chi incluyendo su secuencia fotográfica. El sexto capítulo comenta las características básicas y aplicaciones de las trece fuerzas del taichi además de la explicación e ilustración de su práctica individual y en pareja. El séptimo capítulo detalla las etapas de aprendizaje del empuje de manos y describe el movimiento, características y puntos clave de los ejercicios que componen los siete métodos de aplicaciones en el empuje de manos junto con sus ilustraciones explicativas. El octavo capítulo detalla las características y fundamentos técnicos de los diferentes tipos de potencia interna del tai chi chuan. El noveno capítulo presenta la descripción e ilustración de algunas técnicas de luxación, agarres y contras del tai chi chuan, mientras que el décimo capítulo presenta las técnicas de piernas. El capítulo decimoprimero comenta los fundamentos teóricos de la manipulación de los puntos de presión, la manipulación de los puntos de acupuntura y la ilustración de algunas de sus técnicas. El último capítulo incluye las anécdotas de algunas maestros del tai chi chuan.

780. Fernández de Castro, Ángel (1989). Tai-chi chuan : el cerebro abdominal. Madrid: CEA-GAR. 1ㅡa ed. 218 p. : il. ; 14x20 cm. ISBN: 84-404-4036-7. Depósito legal: M. 7232-1989. (2a ed., 2000, 195 p.; 3aㅡ ed., 2004, 195 p., ISBN: 84-932547-4-6). Palabras clave: formas, fundamentos teóricos, fundamentos técnicos, principios técnicos, defensa personal, textos, taijiquan, escuelas, entrevistas, maestros, meditación, salud. Resumen: Manual teórico y técnico de tai chi. La obra esta formada por 11 capítulos, precedidos de una introducción que relata cómo Yang Lu-ch'an conoció el taichi y creó el 
estilo yang, comenta las características del tai chi dentro de las artes marciales chinas y el origen del tai chi a manos de Chang San-feng. El primer capítulo explica el significado del yin y yang así como la circulación del chi por el cuerpo. El segundo capítulo describe las características técnicas de los ejercicios de base, el empuje de manos y el trabajo de san-shou del tai chi; para en el siguiente capítulo exponer los pilares que conforman la práctica del tai chi como son la meditación, la salud y la defensa personal, sus características y relaciones, comentar las diferencias y similitudes que existen entre la práctica del tai chi y el yoga, y explicar las calificaciones que recibe el chi así como los ocho kuan. El cuarto capítulo presenta los beneficios y objetivos de la suavidad en la práctica del tai chi para luego describir los 11 principios técnicos que deben considerarse durante el entrenamiento. El quinto capítulo explica la ejecución correcta de las técnicas de pies, las posiciones y los movimientos, la utilización de los músculos de las caderas, los principios de la respiración y su aplicación al movimiento. El sexto capítulo enumera las cuatro secciones técnicas que componen el trabajo de empuje de manos (tui-shou), describe sus principios técnicos y la ejecución técnica de algunas de sus formas junto con algunos movimientos de defensa personal. El siguiente capítulo presenta los 11 principios técnicos del tai chi según el maestro Yang Ch'eng-fu; para continuar con un conjunto de preguntas y respuestas hechas al maestro Cheng Man-Ch'ing sobre la práctica y entrenamiento del tai chi. El noveno capítulo incluye un resumen de los textos clásicos del tai chi, agrupados en 7 apartados, que explican los principios técnicos y tácticos de su práctica. El siguiente capítulo enumera las reglas prácticas, los principios del cuerpo y los diez puntos esenciales que hay que conocer antes de comenzar la práctica, detalla los principios de progresión para el entrenamiento y comenta el significado del término wu-wei. El último capítulo enumera el nombre y orden de las posturas de la forma del estilo Yang simplificada por el maestro Cheng Man-ch'ing, además de describir e ilustrar la ejecución técnica de cada una de ellas. Adjunta un conjunto de preguntas de evaluación sobre la práctica de la forma, un gráfico de las zonas reflejas que se estimulan con el tai chi, un epílogo, el currículum del autor y bibliografía recomendada.

781. Fernández de Castro, Ángel (1994). La técnica del tai-chi. Madrid: Libsa. 1 a ed. 96 p. : il. ; 17x24 cm. ISBN: 84-7630-359-9. Depósito legal: no. (2a ed., 1996). Palabras clave: qigong, historia, principios técnicos, ejercicios, textos, fundamentos filosóficos. Resumen: Manual teórico y técnico de tai chi. La obra esta formada por 5 capítulos, precedidos por un prólogo que resume los contenidos del libro. El primer capítulo narra los orígenes del tai chi chuan. El segundo capítulo comenta las influencias filosóficas del tai chi chuan, mientras que el tercero resume las aportaciones y contenidos de los Clásicos del tai chi chuan. El cuarto capítulo describe en qué consiste el chikung, cuál es su historia, su relación con el tai chi, sus beneficios, describe la ejecución de varios ejercicios estáticos y los ocho ejercicios de seda acompañados de su representación gráfica, y enumera los principios técnicos para su práctica. El quinto capítulo señala los principios técnicos de la práctica del tai chi chuan, destacando la importancia de la columna vertebral. Adjunta un anexo con una investigación sobre los orígenes del tai chi chuan, y notas finales.

782. Fernández de Castro, Ángel (2002). Enciclopedia del tai-chi : el universo interior. Romanones: Tao. 1 a ed. 721 p. : il. ; 17x24,5 cm. ISBN: 84-932547-0-3. Depósito legal: M. 49407-2002. Palabras clave: formas, historia, fundamentos teóricos, principios técnicos, filosofía, taijiquan, escuelas, maestros. Resumen: Tratado teórico y técnico de tai chi. La obra esta formada por 8 capítulos. El primer capítulo relata los orígenes filosóficos del tai-chi para luego comentar sus orígenes históricos. El tercer capítulo expone las características del chi-kung, su entrenamiento y sus principios. El cuarto capítulo reúne los textos clásicos y las aportaciones hechas al tai chi por sus principales maestros a cada estilo además de incluir el gráfico de las formas del templo wu-tang, la forma de ch'i chi-kuang, las formas de las familias Chen, Yang y Wu, la forma de ch'ang nai-chou y la forma simplificada Yang, y los árboles genealógicos de las familias Chen, Yang y Wu. El quinto capítulo reúne y explica los 13 principios de Yang Ch'eng-fu sobre la práctica del tai chi, los puntos esenciales para progresar en la práctica y otros consejos. El sexto capítulo comenta los 3 aspectos que componen la práctica del tai chi, como son la meditación, la salud, y la defensa personal, y explica las características de su trabajo. El séptimo capítulo detalla los principios técnicos del movimiento para finalizar con un comentario sobre la forma de practicar el tai chi. Adjunta dos apéndices con la ilustración de los meridianos energéticos y una tabla con la cronología de las dinastías chinas respectivamente. También incluye una conclusión final, una biografía del autor, un glosario, las fuentes consultas y la bibliografía recomendada.

783. Fernández de Castro, Ángel (2004). Historia y anécdotas de maestros de tai-chi de la familia Yang. Romanones: Tao. 1aㅡ ed. 97 p. : il. ; 15x21 cm. ISBN: 84-932547-2-X. Depósito legal: M. 49362-2003. Palabras clave: historia, textos, maestros. Resumen: Tratado teórico de taichi. La obra esta dividida en 7 capítulos. El primer capítulo expone brevemente los orígenes del taichi para en el segundo capítulo narrar la historia del estilo Yang junto con la de su fundador Yang Lu-ch'an. Los dos siguientes capítulos presentan la historia y evolución del estilo yang a través de los hijos de Yang Lu-ch'an y de Yang Ch'eng-fu. El quinto capítulo expone la historia de otros maestros destacados del estilo Yang en la 
difusión del estilo. El sexto capítulo analiza el origen y transmisión de los textos clásicos de la familia Yang, para en el último capítulo comentar las características y contenidos de estos clásicos.

784. Fernández de Castro, Ángel (2004). Los orígenes del tai-chi. Romanones: Tao. 1a ed. 103 p. : il. ; 15x21 cm. ISBN: 84-932547-3-8. Depósito legal: M. 49360-2003. Palabras clave: historia, biografía, textos, taijiquan, escuelas, relatos, maestros. Resumen: Tratado histórico de tai chi. La obra esta compuesta por 8 capítulos. El primer capítulo, a modo de introducción, comenta la aparición de las primeras prácticas y libros preocupados por la salud. El segundo capítulo narra la creación del tai chi. El tercer capítulo cuenta la historia de Chang San-Feng como creador del tai chi así como otras leyendas relacionadas con el mismo. El cuarto capítulo analiza la historia de Chang San-Feng a través del estudio y comparación de diferentes investigadores entre los documentos y textos encontrados así como los textos transmitidos por Chang San-Feng. El quinto capítulo analiza la obra de Huang Tsung-hsi sobre las bases de la Escuela Interna y su relación con el tai-chi. Los tres últimos capítulos presentan las fuentes principales de información sobre el origen de la escuela interna, como son el "Epitafio para Wang Cheng-nan", "El arte de la Escuela Interna" y "La biografía de Chang Sung-hsi" respectivamente. Adjunta la bibliografía consultada y una breve biografía del autor.

785. Fernández de Castro, Ángel (2005). Enciclopedia abreviada del tai-chi. Romanones: Tao. $1^{\mathfrak{a}}$ ed. 357 p. : il. ; 17x21,5 cm. ISBN: 84-932547-6-2. Depósito legal: M. 46420-2004. Palabras clave: formas, historia, fundamentos teóricos, principios técnicos, filosofía, taijiquan, escuelas, maestros. Resumen: Tratado teórico y técnico de tai chi. La obra esta formada por 8 capítulos. El primer capítulo relata los orígenes filosóficos del tai-chi para luego comentar sus orígenes históricos. El tercer capítulo expone las características del chi-kung, su entrenamiento y sus principios. El cuarto capítulo reúne los textos clásicos y las aportaciones hechas al tai chi por sus principales maestros a cada estilo además de incluir el gráfico de las formas del templo wu-tang, la forma de ch'i chi-kuang, las formas de las familias Chen, Yang y Wu, la forma de ch'ang nai-chou y la forma simplificada Yang, y los árboles genealógicos de las familias Chen, Yang y Wu. El quinto capítulo reúne y explica los 13 principios de Yang Ch'eng-fu sobre la práctica del tai chi, los cinco puntos para progresar en la práctica y otros consejos. El sexto capítulo comenta los 3 aspectos que componen la práctica del tai chi, como son la meditación, la salud, y la defensa personal, y explica las características de su trabajo. El séptimo capítulo detalla los principios técnicos del movimiento para finalizar con un comentario sobre la forma de practicar el tai chi. Adjunta bibliografía.

786. Fernández de Castro, Ángel (2005). Historia de maestros de tai-chi de la familia Ch'en. Romanones: Tao. $1^{\underline{a}}$ ed. 119 p. : il. ; 15x21 cm. ISBN: 84-932547-7-0. Depósito legal: M. 46419-2004. Palabras clave: historia, maestros. Resumen: Tratado teórico de tai chi chuan. La obra esta formada por 9 capítulos precedidos de una introducción que comenta brevemente la cronología de los escritos clásicos sobre tai chi. El primer capítulo estudia las diversas teorías sobre el origen del tai chi para luego exponer la leyenda de Chang San-feng, y discutir su historicidad en el tercer capítulo. Los siguientes capítulos presentan la biografía y trabajos del general Ch'i Chi-kuang, la transmisión del estilo Chen a través de sus diferentes maestros y generaciones, y la discusión de la historicidad de Wang Tsung-yüeh y Chiang Fa. Los dos últimos capítulos comentan los escritos de Chang Nai-chou y discuten los orígenes y biografía de Yang Lu-ch'an. Adjunta bibliografía.

787. Fernández de Castro, Ángel (2005). Los clásicos del tai-chi : su historia y sus autores. Romanones: Tao. 1a ed. 267 p. : il. ; $15 \times 21$ cm. ISBN: 84-932547-8-9. Depósito legal: M. 34578-2005. Palabras clave: principios técnicos, textos. Resumen: Tratado teórico de tai chi chuan. La obra esta formada por 29 capítulos, que presentan los principios aportados por cada maestro y texto clásico a la práctica del tai chi chuan y su evolución. El primer capítulo relata la leyenda de Chang San-feng para luego exponer la historia y escritos teóricos sobre los principios de la práctica del tai chi chuan de Wang Cheng-nan, el arte de la Escuela Interna, el maestro Ch'en Wang-t'ing, el maestro Wang Tsung-yüeh, el maestro Yang Lu-ch'an, Wu Ch'eng-ch'ing, el maestro Wu Ju-ch'ing, el maestro Wu Yü-hsiang, la transmisión del estilo Hao, el maestro Li I-yü, la tradición literaria de la familia Yang, el maestro Yang Pan-hou, el maestro Yang Ch'eng-fu, los escritos de otros maestros Yang, el maestro Cheng Man-ch'ing, otros escritos teóricos de maestros del siglo XX, otros escritos teóricos básicos del tai chi, el escrito del maestro Kuo Feng-ch'ih y la aportación del maestro Wu Chien-chüan.

788. Fernández de Castro, Ángel (2005). ¿Qué es el tai-chi? Romanones: Tao. 1aㅡ ed. 157 p. : il. ; 15x21 cm. ISBN: 84-934080-0-X. Depósito legal: M. 34575-2005. Palabras clave: historia, fundamentos teóricos, principios técnicos, textos, maestros. Resumen: Tratado teórico de tai chi. La obra esta formada por 8 capítulos. Los dos primeros capítulos analizan los orígenes filosóficos e históricos del tai chi respectivamente. El tercer capítulo explica el significado del chi, los tipos de chikung y su entrenamiento. El cuarto capítulo analiza la historia del tai chi a través de sus maestros y aportaciones al arte marcial, presentando la leyenda de Chang San-feng, la transmisión del estilo Chen, Hao, Yang y $\mathrm{Wu}$, las biografías de los maestros Ch'en Wang-t'ing, Yang Lu-ch'an, Wu Yü-hsiang y Ch'en Si-t'ong, y las biografías y escritos teóricos de Yang Ch'eng-fu, Wu Chien-ch'üan y Cheng Man-ch'ing. El quinto capítulo expone los principios del tai-chi descritos por Yang Ch'eng-fu, para luego explicar los tres 
pilares del tai chi, como son la meditación, la salud y la defensa personal, y compararlo con el yoga. El séptimo capítulo explica los principios mecánicos del cuerpo en el tai chi para finalizar con un comentario sobre las recomendaciones para la práctica correcta. Adjunta el currículo del autor y bibliografía.

789. Fernández de Castro, Ángel (2006). La relación entre I Ching y tai-chi. Romanones: Tao. 1 a ed. 141 p. : il. ; 15x21 cm. ISBN: 84-932547-0-0. Depósito legal: M. 35437-2006. Palabras clave: formas, historia, filosofía, textos, taoísmo. Resumen: Tratado teórico de taijiquan. El libro esta formado por tres capítulos. El primer capítulo narra el origen histórico y legendario del tai chi para en el siguiente capítulo presentar la primera aparición del término tai chi en una obra (I Ching) y su significado. El último capítulo estudia la relación entre las posiciones del tai chi y sus principios filosóficos basados en las obras "I Ching" y "Tao Te Ching", describiendo la ejecución técnica de la forma de tai chi, interpretando sus movimientos desde la filosofía taoísta presente en el I Ching, e ilustrando las posiciones y los hexagramas de cada movimiento. Adjunta el currículo del autor.

790. Fernández de Castro, Ángel (trad.) (1993). Las piedras de toque del tai-chi : las transmisiones secretas de la familia Yang. Madrid: CEA-GAR. 1aa ed. 182 p. : il. ; 13x20 cm. ISBN: 84-604-5430-4. Depósito legal: M. 3762-1993. Palabras clave: fundamentos teóricos, táctica, principios técnicos, historia, defensa personal, textos, taijiquan, escuelas. Resumen: Manual teórico y técnico de tai chi. La obra consta de 8 capítulos, precedidos por un prólogo, las notas del traductor y una introducción que discute el origen del tai chi, su fundador y transmisiones. El primer capítulo expone las consideraciones de Yang Ch'engfu para la práctica del tai chi chuan. El segundo capítulo enumera los diez principios técnicos mientras que el tercer capítulo incluye la exposición de la transmisión oral del tai chi chuan. El cuarto capítulo presenta los manuscritos de la familia Yang recopilados por Li Ying-ang acompañados de varias ilustraciones. El quinto capítulo incluye las nueve transmisiones secretas sobre el tai chi chuan mientras que el sexto muestra los manuscritos de la familia Yang recopilados por Shen Chia-chen. El séptimo capítulo detalla la aplicación de los principios técnicos y tácticos del tai chi chuan a la defensa personal junto con algunas anécdotas de sus maestros. El último capítulo incluye el prólogo e introducción del libro titulado "T'ai-chi ch'üan t'i-yung ch'üan-shu" de Yang Ch'eng-fu.

791. Font Roig, Fidel (1993). Tai-chi chuan : estudio sobre una técnica del wu-shu. Barcelona: Paidotribo. 1a ed. 176 p. : il. ; 15x21,5 cm. ISBN: 84-8019-064-7. Depósito legal: B. 3342-1993. (2aㅡ ed., 1997; 3를. ed., 2002). Palabras clave: fundamentos teóricos, fundamentos técnicos, principios técnicos, historia, didáctica. Resumen: Manual teórico y práctico de taichi chuan. Esta dividido en 3 partes y la primera comienza por la explicación de los aspectos teóricos del wushu, el taichi y sus diferentes estilos así como sus principios filosóficos y técnicos para poder progresar en la práctica. La segunda parte incluye una explicación de los fundamentos técnicos del arte como la colocación de pies, manos y actitud del cuerpo; y continúa con la descripción de las técnicas de manos, los desplazamientos, las patadas y sus combinaciones. A continuación describe las series de trabajo de los cuatro estilos de taichi chuan y ofrece un breve comentario sobre el combate y sus conceptos básicos. La última parte desarrolla un planteamiento didáctico sobre el taichi chuan.

792. Friedrich, Andreas W. (2006). Tai chi chuan: meditación en movimiento. Arganda del Rey: Edimat. 1aㅡ ed. 80 p. : il. ; 16×20 cm. ISBN: 84-9764-822-6. Depósito legal: M. 7257-2006. Palabras clave: formas, historia, fundamentos teóricos, fundamentos técnicos, principios técnicos, taijiquan, escuelas. Resumen: Manual teórico y técnico de tai chi chuan. La obra esta dividida en 4 partes. La primera parte consta de 2 capítulos. El primer capítulo explica en qué consiste el tai chi chuan, su relación con la teoría del yin/yang y define los conceptos de chi y yi. El segundo capítulo expone los principios técnicos del tai chi, ofrece algunos consejos para su práctica y describe cómo utilizar la obra. La segunda parte describe la ejecución de las posiciones básicas del tai chi, incluyendo su ilustración y señalando los puntos más importantes y algunos consejos, mientras que la tercera parte estudia los ejercicios preparatorios. La última parte presenta la descripción de la forma simplificada del estilo yang, acompañada de su secuencia fotográfica, los puntos más importantes y consejos para su correcta realización. Adjunta un glosario y una lista de libros recomendados.

793. Fu, Zhongwen (2008). Tai chi chuan : (tai ji quan) : manual del estilo Yang. Madrid: Tutor. 1a ed. 244 p. : il. ; $17 \times 24$ cm. ISBN: 978-84-7902-713-1. Depósito legal: no. Palabras clave: formas, fundamentos teóricos, principios técnicos, combate, textos, taijiquan, escuelas. Resumen: Manual teórico y técnico de tai chi chuan. La obra consta de 3 capítulos precedidos por una introducción que comenta la versión inglesa del libro y las cuestiones sobre la traducción, y un capítulo introductorio que incluye los prólogos de la obra de Fu Zhongwen y Gu Liuxin. El primer capítulo presenta el "Tratado sobre la practica del taijiquan" y "Los diez puntos esenciales de la teoría del taijiquan" de Yang Chengfu sobre los fundamentos y principios teóricos del taijiquan. El segundo capítulo comienza explicando cómo interpretar los contenidos del libro para luego describir la ejecución técnica de la forma de taijiquan del estilo yang, los puntos importantes de cada postura e incluir la ilustración de cada una de ellas. El tercer capítulo describe brevemente los diferentes trabajos del empuje de manos (tui shou) como son con paso fijo (Ding Bu Tuishou), con paso activo (Huo Bu Tuishou), y los métodos de pasos de Dalu, Lie 
y Zhou, incluyendo algún gráfico explicativo de las posiciones y el esquema de movimientos de los pies. Adjunta un apéndice sobre los Clásicos del taijiquan que comienza con las aclaraciones del autor inglés sobre las dificultades de la traducción, la presentación de las traducciones de los textos "El tratado de taijiquan" de Wang Zongyue, la "Canción de las trece posturas" de autor desconocido, "La aclaración mental de las trece posturas" de Wu Yuxiang, "El clásico del taijiquan" de Wu Yuxiang y "La canción del empuje de manos" de Wang Zongyue junto con sus originales en chino. También adjunta un glosario y bibliografía.

794. Galante, Lawrence (1993). Tai chi : el fundamento supremo. Barberá del Vallés: Humanitas. 1a ed. 207 p. : il. ; 21x26,5 cm. ISBN: 84-7910-137-7. Depósito legal: B. 3353-1993. Palabras clave: historia, filosofía, defensa personal, taijiquan, escuelas. Resumen: Manual teórico y técnico de tai chi chuan. El libro esta compuesto de 14 capítulos. Los 11 primeros capítulos tienen un enfoque teórico bajo el cual explican lo que significa tai chi chuan, los orígenes e historia de cada escuela, los principios básicos que se encuentran recogidos en los "Clásicos del Tai Chi", la filosofía que impregna esta práctica, los principios espirituales que deben estar presentes durante la ejecución de los movimientos, la relación entre el tai chi y otros sistemas orientales como el yoga y el zen, la relación del tai chi con la psicología occidental, los sistemas ocultos, la salud, la defensa personal, y por último la explicación teórica de los principios dinámicos del tai chi chuan. Los últimos tres capítulos se centran en la parte técnica del arte, ofreciendo consideraciones para el entrenamiento en solitario y describiendo e ilustrando las técnica del tai chi del estilo yang junto con las aplicaciones a la defensa personal de las principales posturas. La secuencia fotográfica de la serie de movimiento adjunta esquemas de movimiento de cada parte del cuerpo, un gráfico con la situación de los pies y la repartición del peso corporal, y la respiración de cada movimiento. El último capítulo también incluye la forma de manos que empujan y la técnica Ta Lu. En la conclusión del libro aparecen algunas aplicaciones auxiliares para la defensa personal. Adjunta bibliografía general y específica.

795. García Romeral, Luis (2008). Tai chi : la ordenación del caos. Madrid: Tutor. 1aㅡ ed. 189 p. : il. ; 17x24 cm. ISBN: 978-84-7902-685-1. Depósito legal: M. 51753-2007. Palabras clave: qigong, formas, fundamentos técnicos, principios técnicos, filosofía, ejercicios, taijiquan, escuelas. Resumen: Manual teórico y técnico de tai chi. La obra esta formada por 9 capítulos. El primer capítulo indica brevemente los fundamentos filosóficos que dieron lugar al tai chi. El siguiente capítulo expone la historia del tai chi, clasifica las artes marciales, los estilos internos y los estilos de tai chi, presenta la biografía de los grandes maestros de tai chi, comenta la indumentaria para la práctica y los grados del tai chi. El tercer capítulo explica el concepto de tan thien, la actitud física y mental para la práctica y describe la ejecución de varios ejercicios preparatorios para la práctica del tai chi, acompañados de ilustraciones. El cuarto capítulo presenta el concepto de chi, los meridianos, y la práctica del chikung para luego explicar y presentar por partes la ejecución técnica de seis ejercicios de chikung. El quinto capítulo profundiza en los fundamentos del tai chi, describiendo la forma correcta de realizar el saludo, las técnicas fundamentales de posiciones, paradas, técnicas con la palma de la mano, técnicas de puño, técnicas de pierna, técnicas de codo y técnicas de caída, y las formas de respirar. El sexto capítulo estudia la meditación y señala los principios técnicos para ejecutar correctamente sus ejercicios. El siguiente capítulo incluye la descripción de la secuencia técnica y fotográfica de la forma de 10 movimientos estilo Yang y la forma circular de 12 movimientos estilo Cheng Man Ching. Los dos últimos capítulos comentan sucintamente la práctica del empuje de manos (tui shou) y la utilización de las armas. Adjunta un glosario.

796. González Rincón, Juan Sebastián (1992). Guía práctica del tai chi chuan : la magia del movimiento. Barcelona: Índigo. 1aㅡ ed. 121 p. : il. ; 18x26 cm. ISBN: 84-86668-51-4. Depósito legal: B. 9237-1992. Palabras clave: formas, historia, fundamentos técnicos, filosofía, taijiquan, escuelas, aplicación marcial, salud. Resumen: Manual teórico y técnico de tai chi chuan. La monografía esta compuesta de 10 capítulos. Los cinco primeros capítulos estudian los aspectos teóricos del tai chi chuan, como su origen, maestros y estilos; los fundamentos taoístas presentes en su práctica; la teoría de la energía chi y su relación con la salud; el aspecto marcial del tai chi chuan y su práctica como forma de meditación. El sexto capítulo ofrece algunos consejos técnicos antes de comenzar la práctica y continua con la enumeración e interpretación de los 10 principios del tai chi chuan. Los dos siguientes capítulos describen e ilustran la ejecución de los ejercicios de calentamiento previos a la práctica del tai chi chuan y la forma de 37 movimientos del estilo Yang. El último capítulo presenta la aplicación marcial de algunos de los movimientos de la forma incluyendo fotografías de la misma.

797. González Rincón, Juan Sebastián (1993). Los ocho capítulos del tai chi chuan. Barcelona: Alas. 1a ed. 109 p. : il. ; 17x24 cm. ISBN: 84-203-0280-5. Depósito legal: B. 25115-1993. (2ª ed., 1999, 125 p.). Palabras clave: formas, historia, filosofía, combate, taijiquan, escuelas. Resumen: Manual teórico y técnico de tai chi chuan. La obra esta formada por 8 capítulos precedidos por los agradecimientos, la biografía del autor y una breve introducción. El primer capítulo explica en qué consiste el tai chi chuan y cuales son sus beneficios terapéuticos. El segundo capítulo relata la historia y filosofía del pueblo chino para luego exponer la leyenda del tai chi chuan, su origen histórico y cuál es su situación actual. Los siguientes 
tres capítulos narran el origen de los estilos Chen, Yang, Wu y Sun, las distintas ramas, las aportaciones de sus maestros y sus sistemas de entrenamiento. El sexto capítulo describe e ilustra el desarrollo técnico de las forma simplificada de 24 movimientos del estilo Yang, para luego explicar las aplicaciones marciales a través del trabajo del empuje de manos, describiendo e ilustrando algunas de sus técnicas y enumerando los principios técnicos de dicha práctica. El último capítulo incluye preguntas y respuestas sobre la práctica, la técnica, los beneficios, y otras cuestiones de interés sobre el tai chi chuan. Adjunta un epílogo y bibliografía.

798. Gorostidi Berrondo, Juan (2004). Cuadernos de tai chi chuan : no 2-3. El trabajo corporal 2. El diagrama postural. San Sebastián: Juan Gorostidi. 1aㅡ ed. 110 p. : il. ; 21x30 cm. ISBN: 84-609-0312-5. Depósito legal: SS. 228-2004. Palabras clave: fundamentos teóricos, pedagogía, taijiquan, fundamentos filosóficos, bibliografía, psicología evolutiva. Resumen: Tratado teórico de tai chi chuan. El libro esta formado por 5 capítulos precedidos por una editorial que señala los problemas de publicación. El primer capítulo explica la evolución del sentido de identidad del ser humano, los paradigmas de la medicina moderna y los movimientos alternativos a la misma sobre el ámbito de lo corporal y sus limitaciones, la paradoja corporal y algunas perspectivas de trabajo. El segundo capítulo reflexiona sobre el papel del profesor en el proceso de enseñanza. El tercer capítulo expone la evolución desde la posición bípeda hasta la erguida junto con sus ventajas e inconvenientes, y analiza la posición natural y las tres matrices dinámicas y posturales. El cuarto capítulo expone las características de las fases de producción bibliográfica sobre tai chi chuan incluyendo un comentario de algunas de las aportaciones literarias más significativas. El último capítulo incluye un ensayo sobre la importancia de la vida. Adjunta información sobre la aparición de los contenidos en internet.

799. Gorostidi Berrondo, Juan (2008). Levantar la mirada. Tai chi chuan, fundamentos para una práctica contemporánea. Barcelona: La liebre de marzo. 1aㅡ ed. 521 p. ; 17x24 cm. ISBN: 978-84-92470-02-0. Depósito legal: B. 36613-2008. Palabras clave: historia, fundamentos teóricos, pedagogía, combate, entrenamiento, fundamentos filosóficos, enfermedades, medicina, salud. Resumen: Tratado teórico de tai chi chuan. El libro esta dividido en 3 áreas, precedidas de una introducción que señala los objetivos de la obra y la colección, y 4 capítulos introductorios. El primer capítulo presenta las causas que han originado el libro y las reflexiones del autor. El segundo capítulo analiza el origen del tai chi chuan y su evolución hasta legitimarse así como las causas que posibilitaron su expansión en Occidente. El tercer capítulo presenta lo exótico como liberador de tensiones, en contraposición con la vida cotidiana, rutinaria y sus limitaciones. El cuarto capítulo explica la metodología utilizada y los contenidos de la obra así como la explicación/definición de varios conceptos básicos. La primera área consta de 9 capítulos. El primer capítulo explica la evolución de la relación del hombre con su cuerpo y con el trabajo. El segundo capítulo compara la evolución del pensamiento humano con las etapas de la humanidad y los sentimientos de identidad además de explicar los 4 tipos de identidad. El tercer capítulo comenta el origen del deporte, los valores asociados al mismo desde la sociedad y analiza sus valores educativos. También incluye una aclaración sobre la cuantificación del tai chi como deporte. El cuarto capítulo expone las características de los modelos de corrección postural y del trabajo corporal, analiza la relación de las distintas teorías sobre la relación cuerpo-mente, la psicologización del cuerpo y comenta los problemas del trabajo corporal en el tai chi chuan. El quinto capítulo explica en qué consiste una sesión de tai chi y cuáles son los fundamentos teóricos de su trabajo corporal. El sexto capítulo comenta las características que debe poseer el lugar de entrenamiento, la función del profesor al comienzo de la sesión de entrenamiento y los fundamentos teóricos de los ejercicios iniciales o de calentamiento de la sesión. El séptimo capítulo explica las características de los 4 modelos dinámicos de progresión de la dificultad técnica de los ejercicios de tai chi. El octavo capítulo describe la posición natural y los tres patrones de movimiento además de su relación con la sensibilización corporal que provocan. El último capítulo describe las características de la forma de Pekín así como algunas de sus variables y su interpretación. Adjunta un excurso que analiza la obra de Sacks y la relaciona con el trabajo corporal. La segunda área consta de 8 capítulos precedidos por una introducción que reflexiona sobre los conceptos de salud, enfermedad, terapia y energía además de presentar sus contenidos. El primer capítulo relata la historia de la medicina en Occidente y su implantación, incluyendo un análisis crítico de la concepción del cuerpo y la enfermedad en las distintas épocas. El segundo capítulo define los conceptos de dolencia y enfermedad, analiza la relación médico-paciente, el proceso de medicalización sufrido en la sociedad y las causas de la enfermedad. El tercer capítulo analiza las alternativas existentes a la medicina moderna, principalmente la medicina tradicional china, y define el concepto de "qi". El cuarto capítulo explica las leyes que relacionan e interaccionan entre cuerpo, mente y emoción así como el objetivo del trabajo corporal del tai chi chuan. El quinto capítulo detalla las características del enfoque energético y sus problemas de aplicación, define el concepto de entrenamiento desde el enfoque energético, expone las consecuencias de la aceleración y lentificación de movimientos sobre la concentración del practicante, relata la historia y evolución de las formas de tai chi chuan, sus beneficios junto con su interpretación y aplicación en la actualidad, y comenta la relación entre las formas del tai chi chuan y el aprendizaje. El sexto capítulo comenta el sistema de 
analogías empleado en el tai chi chuan explicando y criticando el significado de las 3 analogías sobre los tres tesoros, la órbita microcósmica y la órbita macrocósmica. El séptimo capítulo expone las características de los ejercicios de taichi-qigong, los ejercicios de canalización, los criterios o fases para facilitar las vivencias derivadas de estos ejercicios y los ejercicios zhan zhuang gong/bao yi. El octavo capítulo critica la aproximación psicosomática y su discurso así como los problemas de fusión entre la medicina de Oriente y de Occidente. La tercera área consta de 8 capítulos precedidos por una introducción que reflexiona sobre el propósito de las artes marciales y la cualidad mortal del ser humano. El primer capítulo analiza las nuevas formas de guerra y terrorismo así como las hipótesis del terrorismo. El segundo capítulo reflexiona sobre las causas de la guerra, la formación de un soldado y la necesidad de la guerra. El tercer capítulo analiza las características de las distintas aproximaciones a las artes marciales, su carácter, utilidad, relación con la realidad y significado. También enumera las condiciones del contacto marcial. El cuarto capítulo analiza el trabajo de exteriorización de la fuerza, el desarrollo de la espacialidad en el ser humano y ofrece algunos consejos prácticos para el entrenamiento y aprendizaje del "fa jin". El quinto capítulo expone las paradojas referentes al contacto marcial, las características del contacto marcial en el tai chi chuan y los enfoques de los distintos sistemas de entrenamiento marcial y del tai chi chuan respecto al contacto marcial. El sexto capítulo describe las distintas formas de contacto del tai chi chuan junto con sus principios técnicos. El séptimo capítulo analiza las peculiaridades de un combate de boxeo. El último capítulo reflexiona sobre la distancia entre los sublime y lo ridículo. Adjunta un interludio que presenta los contenidos de las siguientes obras de la colección. También adjunta un índice temático, índice de términos orientales, índice onomástico y bibliografía.

800. Gorostidi Berrondo, Juan (dir.) (2001). Cuadernos de tai chi chuan : no 0. El contexto del tai chi chuan. San Sebastián: Juan Gorostidi. 1aㅡ ed. 46 p. : il. ; 21x30 cm. ISBN: 84-607-1629-5. Depósito legal: SS. 1428-2000. Palabras clave: fundamentos teóricos, clubes, educación. Resumen: Tratado de tai chi chuan. El libro esta dividido en tres partes precedidas por una introducción que presenta los objetivos de la publicación. La primera parte explica la evolución de la práctica del tai chi chuan y sus enfoques actuales, analiza algunos tópicos relaciones con la práctica del tai chi chuan y define sus aplicaciones prácticas. La segunda parte expone los objetivos y contenidos de los cuadernos de tai chi chuan. La tercera parte incluye el programa del primer nivel para la formación de profesores de tai chi chuan además de un breve comentario de sus contenidos.

801. Gorostidi Berrondo, Juan (dir.) (2002). Cuadernos de tai chi chuan : no 1. El trabajo corporal 1. La entrada al entrenamiento. San Sebastián: Juan Gorostidi. $1^{\underline{a}}$ ed. 70 p. : il. ; $21 \times 30$ cm. ISBN: 84-6073824-8. Depósito legal: SS. 14-2002. Palabras clave: fundamentos teóricos, entrenamiento, fundamentos filosóficos. Resumen: Tratado de tai chi chuan. El libro esta formado por 4 capítulos precedidos por la editorial que comenta los contenidos de la obra. El primer capítulo explica las distintas representaciones del cuerpo a lo largo de la historia, su alienación, el sentido del trabajo corporal en el tai chi chuan, sus principios de aprendizaje y la teoría de la polaridad aplicada al tai chi chuan. El segundo capítulo incluye varias reflexiones de practicantes de tai chi chuan sobre el significado del cuerpo y el trabajo corporal. El tercer capítulo analiza las variables de lugar, acogida del profesor a los alumnos y los principales ejercicios que componen la propia actividad del tai chi chuan, y su influencia sobre el practicante, el entrenamiento y el aprendizaje. El último capítulo presenta y analiza la obra de Sacks titulada "Con una sola pierna" sobre la alienación del cuerpo. Adjunta información sobre la colaboración y suscripciones.

802. Grandi, Tiziano (2004). El dedo y la luna : el dao del profesor Zheng Man Qing. Barcelona: La liebre de marzo. 1a ed. 189 p. : il. ; 17x24 cm. ISBN: 84-87403-76-X. Depósito legal: B. 46030-2004. Palabras clave: principios teóricos, filosofía, taijiquan, aplicación marcial, aplicación terapéutica. Resumen: Tratado teórico de taijiquan. La obra esta formada por 3 partes que reflejan las enseñanzas de Zheng Man Qing a sus alumnos entre 1942 y 1975. La primera parte explica el enfoque terapéutico del taijiquan, detallando los tres tesoros, la importancia de la cintura y a meditación, ofreciendo algunos ejercicios para desarrollar el qi y consejos sobre nutrición y sexo. La segunda parte ahonda en su enfoque marcial, describiendo el trabajo con la espada de taiji, los principios y fundamentos teóricos de la práctica de empuje de manos y consejos para su práctica. La tercera parte presenta el enfoque espiritual del taiji quan, profundizando en cada uno de los principios filosóficos y técnicos que conforman esta práctica y ofreciendo consejos prácticos de los mismos. También incluye los trece tratados sobre el taiji quan. Adjunta las reflexiones del autor sobre el taiji quan.

803. Hanche, Christian F. (2002). Tai chi : tranquilidad en movimiento. Arganda del Rey: Edimat. 1a ed. 96 p. : il. ; $20 \times 27$ cm. ISBN: 84-9764-139-6. Depósito legal: no. Palabras clave: historia, fundamentos teóricos, fundamentos técnicos, ejercicios, combate, vestimenta, salud. Resumen: Manual teórico y técnico de taijiquan. El libro esta formado por 6 capítulos, precedidos de una introducción que comenta de forma general en qué consiste el taijiquan. El primer capítulo relata el origen y fundamentos filosóficos que dieron origen al taijiquan, la historia de los diferentes estilos, la vestimenta y armas que se suelen portar durante su práctica y la teoría del chi. El segundo capítulo 
comenta los requisitos previos para la práctica como la actitud, la respiración y los principios técnicos, y describe los ejercicios de calentamiento y la postura de preparación incluyendo fotografías explicativas. El tercer capítulo describe la ejecución técnica de varios ejercicios para realizar de pie como: sujeción del tronco, subida y bajada de manos, bola de tai chi, separación de la crin de un caballo salvaje, rechazo del mono, patada con bola de chi ball así como los ejercicios básicos de pasos y movimientos, acompañados todos ellos de la secuencia fotográfica de su ejecución. El siguiente capítulo define los aspectos marciales del tai chi y del trabajo por parejas, para luego detallar el funcionamiento del cuerpo y sus articulaciones en un combate y describir la ejecución de varios ejercicios de trabajo por parejas con sus respectivas ilustraciones explicativas. El quinto capítulo señala los beneficios de la práctica del tai chi sobre la postura, las articulaciones, los músculos, el sistema cardiovascular y el estado de bienestar. El último capítulo incluye un listado de contactos útiles de sociedades y asociaciones de tai chi chuan. Adjunta un índice.

804. Heyoten, Louis Wan der (1990). Energía, serenidad y alegría de vivir con el tai chi chuan. Barcelona: De Vecchi. 1aㅡ ed. 143 p. : il. ; 17x23,5 cm. ISBN: 84-315-0893-0. Depósito legal: B. 10549-1990. Palabras clave: historia, fundamentos teóricos, ejercicios, respiración, formas, entrenamiento, taijiquan, escuelas. Resumen: Manual teórico y técnico de tai chi chuan estilo yang. La obra esta dividida en 2 partes, una teórica y otra práctica. La parte teórica se compone de 3 capítulos que explican lo que es el tai chi chuan, sus características y beneficios, los principios para la práctica; las teorías y conceptos que fundamentan el tai chi chuan; y el significado del chi, su importancia en la práctica y algunos ejercicios para su desarrollo. La parte práctica incluye 5 capítulos que detallan la posición de las manos, presentan 5 ejercicios de movimientos respiratorios, explican e ilustran las secuencias de las dos perlas maravillosas, detallan el significado y simbolismo del gran encadenamiento y por último, describen la ejecución de la secuencia de movimientos del gran encadenamiento (tierra, hombre y cielo). Adjunta un epílogo.

805. Heyoten, Louis Wan der (2001). El ABC del tai chi chuan. Barcelona: Kairós. 1a ed. 226 p. : il. ; 14x22 cm. ISBN: 84-7245-482-7. Depósito legal: B. 113-2001. (2 ${ }^{\underline{a}}$ ed., 2005). Palabras clave: formas, historia, fundamentos teóricos, principios técnicos, principios filosóficos, psicología, aplicación marcial, respiración, salud. Resumen: Manual teórico y técnico de tai chi chuan. La obra esta dividida en 2 partes, la teoría y la práctica respectivamente. La primera parte comenta en qué consiste la práctica del tai chi chuan para luego explicar su historia, su fundamentación filosófica, sus beneficios, la importancia de la teoría del yin-yang para entender el tai chi chuan, las recomendaciones para la práctica correcta, los principios técnicos en su ejecución y su adaptación dependiendo de la estación del año, la descripción de varios ejercicios para sensibilizar y fortalecer las manos. La segunda parte explica la ejecución técnica de la forma simplificada de tai chi chuan junto con la secuencia fotográfica de cada técnica, expone algunos ejercicios por parejas e ilustra la aplicación marcial de varias de sus técnicas, describe la realización de distintos ejercicios para aprender a respirar adecuadamente y para utilizar algunos movimientos de tai chi chuan con un objetivo terapéutico, y finaliza comentando la simbología incluida en la práctica y los distintos estados de consciencia o mundos que se pueden alcanzar a través de la misma.

806. Hilt, Michael (2005). Tai chi. L'Hospitalet: Hispano Europea. $1^{\mathrm{a}}$ ed. 32 p. : il. ; $16 \times 19$ cm. ISBN: 84-2551605-6. Depósito legal: B. 36571-2005. Palabras clave: principios técnicos, ejercicios. Resumen: Manual teórico y técnico de tai chi. La obra esta formada por 2 partes, precedidas por unas aclaraciones conceptuales sobre el chi y los meridianos. La primera parte expone brevemente los principios del tai chi, sus fundamentos, beneficios, quién puede practicarlo y en que consiste el chi kung. La segunda parte explica la ejecución de los 12 ejercicios del tao por partes, posición inicial y realización, acompañando el texto con varias ilustraciones del movimiento.

807. Hine, John (1993). Yang tai chi chuan. Barcelona: Paidotribo. $1^{\mathfrak{a}}$ ed. 443 p. : il. ; 15x21,5 cm. ISBN: 848019-079-5. Depósito legal: B. 8835-1993. Palabras clave: qigong, formas, historia, fundamentos teóricos, defensa personal, combate, taijiquan, escuelas, meditación. Resumen: Manual teórico y técnico de tai chi chuan estilo yang. El libro esta compuesto por 15 capítulos. Los siete primeros capítulos son teóricos y en ellos se explica lo que es el tai chi y el chi, cuál es la relación e importancia del chi para las artes marciales, las características de las 3 artes marciales internas, la historia del tai chi chuan, los efectos del tai chi sobre la salud y cuáles son los principios básicos para una práctica correcta. A continuación describe e ilustra algunos ejercicios para calentar, las posturas básicas del tai chi y explica la secuencia completa de la forma solitaria del tai chi estilo yang. Esta secuencia esta acompañada de numerosas fotografías de cada movimiento, incluyendo el esquema de movimiento de las partes corporales. Continúa con un capítulo dedicado al trabajo de empuje de manos, clasificando sus diferentes entrenamientos y detallando las características de su entrenamiento, y otro capítulo dedicado a la meditación y algunos ejercicios. Finaliza con una explicación del entrenamiento en chi kung junto con la descripción de algunos de sus ejercicios, las aplicaciones de ciertos movimientos de tai chi para la defensa personal y la secuencia de movimientos de la forma de tai chi de la espada de doble filo. 
808. Hooton, Claire (1997). Guía fácil de tai chi : técnicas simples para alcanzar la paz interior. 10 minutos para la salud y el bienestar. Barcelona: Robinbook. 1a ed. 174 p. : il. ; 13x20 cm. ISBN: 84-7927-216-3. Depósito legal: B. 26135-1997. (2 ${ }^{\underline{a}}$ ed., 1998). Palabras clave: formas, fundamentos técnicos, principios técnicos, entrenamiento, taijiquan, escuelas. Resumen: Manual teórico y técnico de tai chi. El libro esta formado por 5 capítulos, precedidos por una introducción que narra el contacto de la autora con el tai chi, y los orígenes y formación de esta práctica. El primer capítulo estudia los principios técnicos del tai chi, describe e ilustra la postura 70/30 y presenta las posiciones de la mano. El segundo capítulo describe e ilustra las primeras 20 posturas de la forma simplificada del estilo Yang, analizando cada postura en distintas posiciones del movimiento y con ilustraciones de las mismas desde dos puntos de vista distintos. El tercer capítulo describe los 12 errores más comunes cuando se comienza a aprender el tai chi para luego ofrecer algunas pautas para profundizar en la práctica del tai chi, y finaliza con la secuencia fotográfica continua de las primeras 20 posturas explicadas. Adjunta bibliografía.

809. Hsi, Rainer (2003). Manual práctico de tai-chi chüan. Madrid: Ojos de Papel. 1ª ed. 127 p. : il. ; 13x19,5 cm. ISBN: 84-96138-01-1. Depósito legal: no. Palabras clave: qigong, historia, fundamentos teóricos, principios técnicos, textos, maestros. Resumen: Manual teórico y técnico de tai chi. El libro esta formado por 10 capítulos precedidos por una introducción que comenta los objetivos de la obra. El primer capítulo narra la historia del tai chi y la familia Chen así como sus fundamentos filosóficos. El segundo capítulo expone las características del tai chi. El tercer capítulo enumera los principios técnicos para la práctica. El cuarto capítulo incluye los aforismos extraídos de los textos originales del maestro Wang Tsun-Yueh. Los dos siguientes capítulos presentan los principios técnicos del tai chi según los distintos maestros y poemas. El séptimo capítulo describe la ejecución de las 21 posturas del tai chi acompañadas de su representación gráfica. El octavo capítulo explica el desarrollo de 3 ejercicios complementarios tras la práctica del tai chi junto con sus ilustraciones. El noveno capítulo expone los fundamentos teóricos y beneficios del chikung. El último capítulo señala la importancia de la columna vertebral y describe su correcta colocación.

810. Huang, Al Chungliang (1994). La esencia del t'ai chi. Málaga: Sirio. $1^{\mathrm{a}}$ ed. 281 p. : il. ; 13x20,5 cm. ISBN: 84-7808-051-1. Depósito legal: B. 2815-1994. (2aed., 1999; 3a ed., 2002). Palabras clave: historia, fundamentos teóricos, filosofía, ejercicios, textos, caligrafía. Resumen: Tratado teórico de t'ai chi. La monografía esta compuesta por 9 capítulos, que recogen y amplían las sesiones realizadas durante un seminario del maestro Huang en Esalen en 1971. Los cinco primeros capítulos describen los contenidos y anécdotas desarrollados durante los cinco primeros días del seminario, incluyendo contenidos teóricos, filosóficos, históricos, consejos prácticos y ejercicios para sentir la energía y perfeccionar el t'ai chi. El sexto capítulo describe la sesión dedicada a los ejercicios de caligrafía y la explicación de su relación con el t'ai chi. Los siguientes capítulos presentan la interpretación de los diez grabados zen de bueyes y el Tao te King. El último capítulo relata el último día del seminario en el que se recuerda todo lo trabajado anteriormente. Adjunta una breve biografía del autor.

811. Lam, Tin-Yu (2006). Tai chi : fácil y rápido para todo momento. Ejercicios sencillos para realizar en casa, en el trabajo y durante los viajes. Móstoles: Gaia Ediciones. 1a ed. 144 p. : il. ; 16x20 cm. ISBN: 84-8445119-4. Depósito legal: no. Palabras clave: fundamentos teóricos, principios filosóficos, ejercicios, relajación. Resumen: Manual teórico y técnico de tai chi. La obra esta formada por 6 capítulos, precedidos de una introducción que comenta brevemente sus orígenes y la leyenda de Chang San-feng. El primer capítulo explica en qué consiste la práctica del tai chi y cuáles son los principios filosóficos taoístas que rigen su práctica, explicando el yin-yang, el chi, el shen, el i, el sum y el estilo de vida según el tai chi. El segundo capítulo explica e ilustra la ejecución de distintos ejercicios de tai chi para realizar al comienzo del día tanto en la cama como de pie. Los siguientes tres capítulos exponen diferentes ejercicios para realizar en los viajes, en el trabajo y como medio de relajación, explicando cada movimiento por partes y acompañado de ilustraciones. El último capítulo ofrece un encadenamiento de los movimientos anteriores para cuando se dispone de más tiempo de práctica, describiendo e ilustrando la ejecución técnica de los mismos.

812. Leonelli, Núria (2004). Tai chi chuan: calidad de vida, arte de longevidad. Barcelona: Fapa. 1a ed. 62 p. : il. ; 14x21,5 cm. ISBN: 84-9733-351-9. Depósito legal: B. 29340-2004. Palabras clave: formas, fundamentos teóricos, principios técnicos, ejercicios, calentamiento, taijiquan, escuelas, aplicación marcial, meditación, salud. Resumen: Manual teórico y técnico de tai chi chuan. El libro esta dividido en 4 capítulos, precedidos de una introducción que comenta brevemente la práctica del tai chi chuan. El primer capítulo describe los beneficios del tai chi chuan para el practicante. El segundo capítulo explica los fundamentos teóricos y filosóficos que se aplican en el tai chi chuan, como son la filosofía taoísta, los conceptos de la medicina tradicional china de los tres tesoros y el sistema de meridianos, y las características de las artes marciales chinas junto con la historia del tai chi chuan. El tercer capítulo explica los 13 principios técnicos para la práctica del tai chi chuan. El último capítulo esta dividido en cuatro partes, que describen e ilustran los ejercicios de la meditación Zhan Zhuang, los ejercicios 
básicos de calentamiento Liangong Shi Ba Fa, la forma básica Yang de 8 movimientos junto con sus consejos para la práctica, y los ejercicios de aplicación marcial de dicha forma.

813. Liang, Shou-Yu y Wu, Wen-Ching (1995). Guía del taijiquan de 24 y 48 posiciones y sus aplicaciones. Villaviciosa de Odón: Mirach. 1aㅡ ed. 212 p. : il. ; 18x23,5 cm. ISBN: 84-87476-63-5. Depósito legal: M. 5338-1995. Palabras clave: formas, historia, fundamentos teóricos, fundamentos técnicos, principios técnicos, taijiquan, escuelas, aplicación marcial. Resumen: Manual teórico y técnico de taijiquan. El libro esta formado por cinco capítulos precedidos por los agradecimientos, la biografía de los autores, dos prólogos que explican en qué consiste la práctica del taijiquan y dos introducciones que señalan los beneficios del taijiquan y exponen los objetivos del libro. El primer capítulo expone los fundamentos teóricos del taijiquan como son la teoría del yin/yang, la teoría de los cinco elementos, el concepto de energía y su circulación, y relata la historia del taijiquan y de la familia Yang. El segundo capítulo comenta los principios técnicos para la práctica del taijiquan y presenta las normas sobre la respiración, dirigir la mente y equilibrar la energía. El tercer capítulo explica la ejecución de varios ejercicios de calentamiento y de qigong además de las posiciones estáticas, en movimiento y formas de la mano del taijiquan acompañadas de su representación gráfica. El cuarto capítulo enumera las posiciones del taijiquan de 24 posiciones, representa su esquema de movimiento y describe la ejecución de sus técnicas, sus puntos clave y aplicación marcial junto con su secuencia fotográfica. El quinto capítulo presenta la tabla de movimientos de la forma de 48 posiciones del taijiquan además de presentar la descripción e ilustración de su ejecución. Adjunta una conclusión final, un apéndice con la traducción de las posiciones de las formas de 24 y 48 posiciones, la traducción de los términos chinos, bibliografía y un índice de términos.

814. Liang, Shou-Yu y Wu, Wen-Ching (2003). Taijiquan : 24 y 48 posiciones y sus aplicaciones marciales. Málaga: Sirio. $1^{a}$ ed. 253 p. : il. ; 17x24 cm. ISBN: 84-7808-408-8. Depósito legal: B. 46629-2003. Palabras clave: formas, historia, fundamentos teóricos, principios técnicos, defensa personal, ejercicios, qigong. Resumen: Manual teórico y técnico de taijiquan. La obra esta formada por 5 capítulos. El primer capítulo comenta en qué consiste la práctica del taijiquan para luego exponer sus fundamentos teóricos y explicar la teoría del yin y yang, la teoría de los cinco elementos y el concepto de qi, relata la historia y creación del taijiquan junto con un breve comentario sobre la historia de la familia Yang. El segundo capítulo expone las normas o principios para el movimiento del cuerpo, el control de la respiración, la mente y la energía para practicar el taijiquan adecuadamente. El tercer capítulo describe varios ejercicios de calentamiento y estiramientos, distintos ejercicios de qigong para facilitar el flujo de energía por el cuerpo y los fundamentos técnicos básicos (posiciones estáticas, en movimiento y formas de la mano) de las formas de 24 y 48 movimientos, ilustrando cada uno de ellos e incluyendo su esquema de movimiento. El cuarto capítulo presenta el desarrollo de la forma de 24 movimientos, detallando su ejecución técnica, los puntos clave de cada posición y su aplicación, dividiendo cada movimiento en partes junto con sus ilustraciones y esquemas de movimiento. El quinto capítulo describe la ejecución técnica de la forma de 48 movimientos, señalando los puntos clave de la ejecución, sus aplicaciones prácticas e incluyendo distintas fotografías y esquemas de movimiento de cada movimiento dividido en partes. Adjunta apéndices con la traducción de los movimientos de las formas de 24 y 48 movimientos, y un glosario con la traducción de términos chinos. También adjunta bibliografía e índice onomástico.

815. Liao, Waysun (2002). Clásicos del tai chi : introducción a la filosofía y la práctica de una antiquísima tradición china. Barcelona: Oniro. 1aㅡ ed. 218 p. : il. ; 15x23 cm. ISBN: 84-95456-89-3. Depósito legal: B. 48075-2001. Palabras clave: historia, principios técnicos, ejercicios, textos, fundamentos filosóficos, taijiquan, fundamentos teóricos, formas. Resumen: Manual teórico y técnico de tai chi. El libro esta compuesto por 7 capítulos precedidos por un prólogo que comenta los contenidos de la obra. El primer capítulo relata el origen del tai chi y sus fundamentos filosóficos. El segundo capítulo explica el concepto de chi, describe varios ejercicios para captar el chi, desarrollar la respiración condensada y aumentar la percepción del chi interno acompañados de su representación gráfica. El tercer capítulo expone los principios físicos de los golpes de tai chi, describe la ejecución de varios ejercicios de transferencia de poder interno y la práctica en pareja, explica su aplicación a las artes marciales además de enumerar sus principios. Los siguientes tres capítulos incluyen los clásicos del tai chi de los maestros Chang San-Feng, Wong Chung-yua y Wu Yu-hsiang comentados. El último capítulo incluye las cinco virtudes y las ocho verdades del tai chi, los principios técnicos para la práctica y la descripción de la ejecución técnica de la forma de 37 movimientos del maestro Cheng acompañada de su representación gráfica y esquemas de movimiento.

816. Lie, Foen Tjoeng (1995). Tai chi chuan : manual práctico para desarrollar el cuerpo, relajar la mente y elevar el espíritu. Girona: Tikal. 1a ed. 132 p. : il. ; 15x21 cm. ISBN: 84-305-7958-3. Depósito legal: no. Palabras clave: formas, historia, fundamentos teóricos, fundamentos técnicos, principios técnicos. Resumen: Manual teórico y técnico de tai chi chuan. El libro esta formado por 5 capítulos precedidos por un prólogo que comenta los contenidos de la obra. El primer capítulo narra el origen y desarrollo del tai chi chuan y describe las características técnicas de los diferentes estilos. El segundo capítulo 
representa el árbol genealógico del tai chi chuan. El tercer capítulo describe los efectos fisiológicos y psicológicos derivados de la práctica del tai chi chuan. El cuarto capítulo comenta las características técnicas del tai chi chuan, sus principios técnicos y ofrece algunos consejos para su práctica. El último capítulo describe la ejecución y puntos más importantes de la forma de 26 movimientos de la escuela de Pekín de tai chi chuan incluyendo su secuencia fotográfica. Adjunta un índice terminológico.

817. Lien-Ying, Kuo (1999). T'ai chi ch'uan, aspectos marciales : el arte del boxeo de sombras kuo lien-ying. Barcelona: La liebre de marzo. 1ํㅡㄹ ed. 198 p. : il. ; 14x21 cm. ISBN: 84-87403-44-1. Depósito legal: B. 35389-1999. Palabras clave: fundamentos teóricos, filosofía, entrenamiento. Resumen: Recopilación e interpretación de los escritos antiguos de T'ai Chi llevada a cabo por el Sr. Kuo. El libro es la traducción e interpretación de su trabajo. Explica en profundidad los aspectos marciales del arte para alcanzar la plenitud y armonía. Esta dividido en 6 capítulos y la introducción presenta algunos aspectos teóricos que forman la base del T'ai Chi. El primer capítulo fundamenta los principios de la lucha T'ai Chi y explica su aplicación correcta. A continuación detalla las 3 fases que debe completar el practicante para estudiar, investigar y entender el T'ai Chi íntegramente. El tercer capítulo describe los 3 pasos para investigar la práctica del empuje de manos y las normas que deben prevalecer en dicha práctica. El cuarto capítulo explica el trabajo a realizar para desarrollar las energías de las 8 puertas y de los 5 pasos. El siguiente capítulo describe la secuencia de aprendizaje del T'ai Chi y fija la atención en los aspectos técnicos claves para alcanzar un correcto aprendizaje. El último capítulo presenta las normas para la aplicación del T'ai chi en combate, sus patrones de movimiento, su táctica y estrategia, la manera de valorar los progresos así como algunos textos que reflexionan sobre la forma de ejercitarse, los principios del arte o su origen. Adjunta notas aclaratorias.

818. Lluch, Salvador (1987). Guía práctica del tai-chi. Barcelona: Obelisco. 1aㅡ ed. 85 p. : il. ; 10x19,5 cm. ISBN: 84-7720-019-X. Depósito legal: B. 12435-1987. (2ª ed., 1989; 3ํㅡㄹ. ed., 1993, ISBN: 84-7720-308-3; $4^{\mathrm{a}}$ ed., 1994, ISBN: 84-7720-308-3; 5 a ed., 1995, ISBN: 84-7720-308-3). Palabras clave: formas. Resumen: Manual técnico de tai chi. Después de comentar en el prólogo los fundamentos teóricos en los que se basa el tai chi, introduce algunos consejos generales para la práctica y comienza a describir la serie de 80 movimientos de tai chi, dividiendo cada movimiento y las explicaciones de la ejecución técnica en las fases de inspiración y espiración. Cada movimiento esta representado gráficamente.

819. Lorini, Walter (1999). Lecciones de tai-chi. Barcelona: De Vecchi. 1aㅡ. ed. 111 p. : il. ; $16 \times 24$ cm. ISBN: 84-

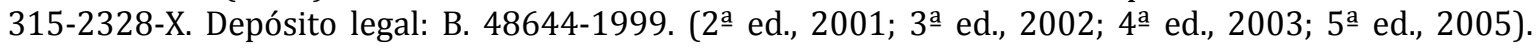
Palabras clave: formas, historia, fundamentos técnicos, taijiquan, escuelas. Resumen: Manual teórico y técnico de tai chi. La obra esta compuesta de 5 capítulos. El primer capítulo explica la historia del tai chi a través de sus distintos periodos, distingue las características de los diferentes estilos de tai chi y presenta la teoría yin y yang junto con los 8 tipos de fuerzas del tai chi. El segundo capítulo detalla una serie de ejercicios preparatorios a modo de calentamiento y expone los principios técnicos de las posturas estáticas y en movimiento. El siguiente capítulo desarrolla la teoría de la respiración y el chi y propone una serie de ejercicios para su entrenamiento. Después pasa a un apartado de preguntas frecuentes sobre el tai chi para en el último capítulo presentar la secuencia de 24 movimientos del tai chi estilo yang. Comienza por explicar la simbología utilizada y un esquema general de los 24 movimientos para luego describir cada uno de ellos, adjunta varias fotografías, un esquema de movimiento de las manos y otro de los pies que incluye la distribución del peso corporal.

820. Lowenthal, Wolfe (1996). No hay secretos : el profesor Cheng Man-ch'ing y su tai-chi chüan. Romanones: Tao. $1^{a}$ ed. 176 p. : il. ; 13x20 cm. ISBN: 84-921280-1-1. Depósito legal: M. 10137-1996. (2ª ed., 2000; $3^{a}$ ed., 2003; 4a ed., 2006). Palabras clave: pedagogía, principios técnicos, principios filosóficos, entrenamiento, biografía, relatos, fisioterapia, meditación. Resumen: Compendio teórico de tai chi chuan. La obra esta formada por 37 capítulos, precedidos por un prólogo que comenta las cualidades del profesor Cheng y una introducción que presente su forma de ser. La obra relata las historias y reflexiones del autor en su entrenamiento con el profesor Cheng, analizando los principios técnicos y filosóficos del tai chi chuan, su práctica y métodos de entrenamiento, analizando las tres clases de valentía, los métodos de aprendizaje del profesor Cheng, describiendo la ejecución de masajes para todo el cuerpo, y reflexionando sobre la meditación y el crecimiento espiritual. Adjunta un epílogo a la edición española.

821. Lowenthal, Wolfe (1997). La puerta a lo milagroso : exploraciones adicionales en el tao de Cheng ManCh'ing. Romanones: Tao. 1a ed. 153 p. : il. ; 13×20 cm. ISBN: 84-921280-2-X. Depósito legal: M: 99671997. (2 ${ }^{\underline{a}}$ ed., 2004,155 p.). Palabras clave: historia, principios técnicos, filosofía, combate, entrenamiento, maestros. Resumen: Manual teórico de tai chi. La obra consta de 27 capítulos. El primer capítulo es introductorio y presenta la obra. El segundo capítulo explica el concepto de chi según los antiguos maestros. El tercer capítulo expone la biografía del maestro Yang Ch'eng-fu y su relación con Cheng. El cuarto capítulo expone el concepto de chi y armonía del profesor Cheng. Los dos siguientes capítulos detallan los principios técnicos que rigen la práctica del empuje de manos y el movimiento de la cintura respectivamente. Continúa definiendo los principios técnicos de la espada y las características de su entrenamiento. El noveno capítulo explica la doctrina del medio aplicada al tai 
chi por el profesor Cheng. El décimo capítulo relata la biografía del autor y su introducción en las artes marciales. Los siguientes cuatro capítulos exponen el pensamiento político y filosófico del profesor Cheng a través de las experiencias y anécdotas del autor. El décimo quinto capítulo detalla los tres tesoros en la práctica del tai chi y continúa con los principios técnicos, los papeles tácticos y las tres puertas del empuje de manos. El décimo noveno capítulo explica el significado del saludo mientras que el vigésimo capítulo analiza la relación entre el tai chi y el tao. Los tres siguientes capítulos reflexión sobre los conceptos de equilibrio y responsabilidad, la relación corazón-mente y el principio de adherirse. El vigésimo cuarto capítulo estudia la aplicación del tai chi a la defensa personal y ofrece algunos consejos prácticos. Los tres últimos capítulos exponen los principios técnicos referidos a la columna vertebral, las piernas y las patadas según el maestro Yang. Adjunta una nota del editor y bibliografía recomendada.

822. Marín Ferrer, Bibiana (2004). Tai chi xin yi : hacia el equilibrio del cuerpo y la mente. Salamanca: Témpora. $1^{\text {a }}$ ed. 112 p. : il. ; 17x24 cm. ISBN: 84-95906-89-9. Depósito legal: S. 130-2004. Palabras clave: formas, fundamentos teóricos, fundamentos técnicos, principios técnicos, maestros, relajación, respiración, salud. Resumen: Manual teórico y técnico de taijiquan. El libro esta formado por 10 capítulos. El primer capítulo ofrece una idea general de en qué consiste el tai chi además de explicar las características generales de las formas Chen, Yang, Wu, Sun, la historia del Tai Chi Xin Yi de Shaolin y algunos consejos para su práctica. El segundo capítulo define la terminología utilizada en el tai chi, relata la biografía del maestro Xia Zi Cai, su llegada a España, los objetivos que persigue dicho estilo y cómo se practica en la actualidad. El tercer capítulo detalla los beneficios de la práctica del tai chi sobre los sistemas respiratorio, circulatorio, digestivo, motor, nervioso, reproductor y sobre el metabolismo. Los siguientes tres capítulos profundiza en los conceptos y principios de la teoría de la energía, la respiración y la relajación; estudiando el sistema energético humano, sus meridianos y puntos; los estados, clases, posturas y ejercicios para desarrollar la respiración, y los estados y posturas para alcanzar la relajación. El séptimo capítulo presenta la estructura de los contenidos del Tai Chi Xin Yi, cuáles son los principios de su práctica, y describe e ilustra la ejecución de las posturas principales junto con algunos de los ejercicios de calentamiento. El octavo capítulo describe por partes la ejecución técnica de la forma de 24 movimientos con la ayuda de ilustraciones, esquemas de movimiento y notas explicativas. Los dos últimos capítulos describen la respiración y mirada durante la forma de 24 movimientos, enumeran las posiciones de la forma de 78 movimientos y explica brevemente el trabajo con la espada dentro del sistema Tai Chi Xin Yi y sus principios técnicos. Adjunta vocabulario, músicas y bibliografía.

823. Maza, Rafael de la y Fernández de Castro, Ángel (2008). El taijiquan de Sun Lutang. Madrid: Tao. 1aㅡ ed. 213 p. : il. ; 15x21 cm. ISBN: 978-84-934080-7-7. Depósito legal: M. 50110-2007. Palabras clave: formas, historia, principios técnicos, principios teóricos, entrenamiento, biografía, textos, taijiquan, escuelas. Resumen: Manual teórico y técnico de taijiquan. El libro esta compuesto por 6 capítulos precedidos por los agradecimientos, el árbol genealógico del hsingyiquan y del baguazhang y un prólogo que resume los contenidos del libro. El primer capítulo comenta brevemente las características del estilo Sun de taiji así como del xingyiquan, baguazhang, taijiquan y liu he ba fa. El segundo capítulo incluye la biografía de Sun Lutang mientras que el tercero enumera los principios técnicos y de entrenamiento del estilo Sun. El cuarto capítulo enumera las 97 posturas que componen la forma del estilo Sun mientras que el quinto describe su ejecución técnica e incluye su ilustración. El sexto capítulo presenta los clásicos del taiji. Adjunta una conclusión.

824. McFarlane, Stewart (1998). Manual completo de t'ai chi. Barcelona: Ediciones B. $1^{\underline{a}}$ ed. 120 p. : il. ; 22x28,5 cm. ISBN: 84-406-7886-X. Depósito legal: no. Palabras clave: formas, fundamentos técnicos, combate, maestros. Resumen: Manual teórico y técnico de tai chi. La obra esta compuesta de 3 partes, precedidas de un capítulo que explica cómo utilizar el libro y una introducción que comenta el estilo presentado, los beneficios de su práctica, los orígenes del tai chi y sus maestros. La primera parte explica los fundamentos del tai chi, describe e ilustra la ejecución de varios ejercicios de flexibilidad y estiramiento así como los principios técnicos para evitar los tres grandes problemas del aprendizaje del tai chi como son evitar la tensión, alinear bien la postura y hundirse en la postura. La segunda parte presenta un ejercicio preparatorio para la práctica del tai chi y luego detalla la secuencia de movimientos de la forma de Cheng Man-ch'ing incluyendo varias ilustraciones del movimiento por partes, los puntos claves de cada posición, y la repartición del peso y orientación de los pies. La última parte presenta el trabajo avanzado por parejas o empuje de manos y sus aplicaciones, describiendo e ilustrando cada ejercicio por fases y resaltando los puntos clave. Adjunta un breve glosario, algunos consejos para elegir un curso de tai chi, y un índice.

825. Miñana Patiño, Francisco Javier (2000). Taiji quan (tai chi chuan) : el universo taoísta. Valencia: Javier Miñana. $1^{\underline{a}}$ ed. 359 p. : il. ; 14x21,5 cm. ISBN: 84-607-1460-8. Depósito legal: V. 4746-2000. (2ª ed., 2002, ISBN: 84-95052-78-4). Palabras clave: historia, principios técnicos, ejercicios, entrenamiento, medicina tradicional china, taoísmo. Resumen: Ensayo teórico y práctico sobre este arte marcial. Dividido en 4 partes, la primera de ellas es un poema dedicado a la esencia de todas las cosas. La 
segunda parte explica la teoría relacionada con el arte marcial, desde los elementos históricos del taoísmo y los orígenes, generaciones, maestros y transmisión del taijiquan, hasta la explicación de la numerología taoísta y el análisis de los aspectos más significativos de la medicina tradicional china, el qi, el sistema del triple calentador, los meridianos y las funciones de los órganos. La tercera parte indica las características principales de los diferentes tipos de qi gong así como de los enfoques del taiji quan, para luego explicar las etapas en el entrenamiento, las condiciones para su práctica y lo que supone el cultivo interno del qi. Por último, detalla los principios del movimiento a través de los dos tipos de potencia que existen en el taiji quan, las formas de interpretar la práctica y el entrenamiento teniendo en cuenta las trece bases del taiji quan. La cuarta parte centra su atención en el Yijing, sus características principales, la formación del universo, la forma de consultar este libro, el significado y características detalladas de los trigramas, así como las interpretaciones del bagua de Fuxi y Wen. Adjunta los programas de entrenamiento de los distintos niveles de profesores de taiji quan y bibliografía.

826. Moegling, Barbara y Moegling, Klaus (1995). Tai chi : aprenda a armonizar cuerpo y mente. Girona: Tikal. $1^{\underline{a}}$ ed. 116 p. : il. ; $15 \times 21 \mathrm{~cm}$. ISBN: 84-305-8039-5. Depósito legal: no. Palabras clave: fundamentos teóricos, fundamentos técnicos, fundamentos filosóficos. Resumen: Manual teórico y técnico de tai chi. El libro esta formado por 8 capítulos precedidos por un prólogo que presenta los contenidos de la obra. El primer capítulo explica la teoría del yin/yang y su aplicación al ejercicio físico y deporte. El segundo capítulo define el concepto de salud desde las perspectivas occidental y oriental además de detallar los requisitos para el mantenimiento de la misma. El tercer capítulo describe un ejercicio de relajación para luego explicar el significado, características y ejecución de varios ejercicios para la sensibilización de la respiración, los pies, las manos, la espalda, el abdomen y la voz, acompañados de sus ilustraciones. El cuarto capítulo comenta las características del tai chi chuan, su historia, describe las posiciones básicas del método de brocados acompañadas de su representación gráfica y ofrece los consejos técnicos para su práctica. El quinto capítulo explica la ejecución de los 8 movimientos del Pa Tuan Chin (método de brocados) incluyendo su secuencia fotográfica. El sexto capítulo comenta los fundamentos filosóficos del tai chi chuan además de incluir la descripción e ilustración de la serie de ejercicios titulada "Entre el cielo y la tierra". El séptimo capítulo detalla el significado del budismo zen y la influencia de la meditación sobre el deporte. El último capítulo resume los contenidos del libro y expone los requisitos para seguir profundizando en el tai chi chuan.

827. Moreno García, Jorge (2006). Tai chi chuan para todos. Barcelona: Morales i Torres Editores. 1a ed. 261 p. : il. ; 15x23 cm. ISBN: 84-96106-56-X. Depósito legal: B. 6923-2006. Palabras clave: qigong, formas, historia, fundamentos teóricos, pedagogía, principios técnicos, ejercicios, yoga, meditación, respiración, fundamentos técnicos. Resumen: Manual teórico y técnico de tai chi chuan. La obra esta formada por 12 capítulos. El primer capítulo presenta la práctica del tai chi chuan, sus principios filosóficos, sus orígenes, sus personajes más influyentes y los diferentes estilos que existen con sus creadores y características básicas. El segundo capítulo estudia las cualidades del profesor y el alumno de tai chi chuan dentro del proceso de enseñanza, comenta los niveles de aprendizaje de la práctica y la relación que tiene con la educación física y la salud, e incluye un resumen de las instrucciones del maestro Yang Cheng-fu sobre los principios técnicos de la práctica y una reflexión sobre los componentes del proceso de enseñanza y aprendizaje del tai chi chuan. El tercer capítulo expone los distintos significados que puede adoptar la práctica del tai chi chuan, los principios que rigen la misma y los beneficios que reporta su entrenamiento continuado. El cuarto capítulo presenta la teoría de la energía (qi), los puntos más importantes dentro del trabajo de la energía así como un resumen de la relación entre órganos y emociones. El quinto capítulo introduce la práctica del chi kung, explica el origen y características de los ejercicios de "as 8 joyas" y describe su ejecución técnica con el apoyo de varias ilustraciones de cada posición. El sexto capítulo estudia el proceso del sistema respiratorio, los tipos de respiración y los beneficios de la respiración profunda. El séptimo capítulo explica la ejecución de varios ejercicios de calentamiento de todo el cuerpo antes de comenzar la práctica del tai chi chuan, sus puntos clave y describe una serie de ejercicios de tai chi chuan que ayudan al aprendizaje posterior del resto de movimientos, incluyendo siempre varias fotografías de cada ejercicio. El octavo capítulo enumera las posturas básicas del tai chi chuan, la teoría de los cinco elementos, y detalla e ilustra la ejecución de la forma de 12 movimientos. El noveno capítulo profundiza en el estudio de la relajación, sus características y requisitos previos, y describe varios de sus ejercicios; para luego pasar a la meditación, sus tipos y posiciones. El undécimo capítulo presenta la forma de 32 movimientos con espada, describiendo la ejecución técnica de cada movimiento y apoyándose en la secuencia fotográfica correspondiente. Finaliza con el comentario sobre la relación del tai chi chuan con el yoga, y comenta los ocho pasos en el aprendizaje del yoga y los beneficios de las posturas hatha yoga. Adjunta bibliografía.

828. Muñoz Martín, Ignacio (2004). Iniciación ao tai chi. Santiago de Compostela: Lea. $1^{a}$ ed. 124 p. : il. ; 15x24 cm. ISBN: 84-95444-55-0. Depósito legal: C. 1415-2004. Palabras clave: formas, historia, fundamentos técnicos, principios técnicos, escuelas, programa técnico, salud. Resumen: Manual 
teórico y técnico de tai chi. La obra esta compuesta por 10 capítulos precedidos por una presentación que explica la situación del tai chi en Galicia. El primer capítulo explica en qué consiste el tai chi, narra sus orígenes y las características de las diferentes escuelas así como de otros estilos internos, y describe su proceso de deportivización. El segundo capítulo comenta los principios fisiológicos y biomecánicos del tai chi así como sus beneficios. El tercer capítulo describe la técnica de relajación de Jacobson, la técnica de control de la respiración además del objetivo, posicional inicial y desarrollo de los ejercicios de los ocho brocados de seda. El cuarto capítulo explica la ejecución de las posiciones básicas, desplazamientos, técnicas de brazo, técnicas de pie y técnicas de puño del tai chi chuan. El quinto capítulo detalla la ejecución del estudio de las técnicas de tai chi por parejas. El sexto capítulo expone las armas utilizadas en el tai chi, comenta los beneficios de su entrenamiento y enumera la estructura y técnicas de la espada. El séptimo capítulo expone el origen de las formas de tai chi junto con su clasificación y comenta las características de las formas que componen el programa unificado del gobierno chino. El octavo capítulo explica el origen y objetivos de la forma simplificada además de incluir su descripción e ilustración. El noveno capítulo detalla la práctica del tai chi chuan bajo diferentes paradigmas y muestra la programación de sus contenidos dentro del ámbito de la iniciación. El último capítulo relata la historia del tai chi en Galicia y enumera los presidentes y directores más significativos, los lugares de práctica y un breve tesauro de tai chi.

829. Muñoz Martín, Ignacio (2006). Primeiros pasos do tai chi. Santiago de Compostela: Lea. 1a ed. 124 p. : il. ; 15x24 cm. ISBN: 84-95444-75-5. Depósito legal: C. 3112-2006. Palabras clave: formas, historia, fundamentos teóricos, fundamentos técnicos, combate. Resumen: Manual teórico y técnico de tai chi chuan. El libro esta compuesto por 10 capítulos. El primer capítulo define el tai chi chuan, relata sus orígenes y el de los principales estilos tradicionales junto con sus características, y un breve comentario sobre otros estilos internos de artes marciales chinas. El segundo capítulo comenta los fundamentos fisiológicos y biomecánicos implicados en el tai chi chuan. El tercer capítulo expone los objetivos del acondicionamiento físico del tai chi chuan, los principios de la relajación muscular junto con la descripción técnica de distintos ejercicios para cada parte del cuerpo, detalla los principios técnicos del control de la respiración y sus principales errores y presenta el trabajo de los 8 brocados de seda, los objetivos de cada posición y su ejecución. El cuarto capítulo describe la ejecución de las técnicas básicas del tai chi chuan, incluyendo las posiciones, los desplazamientos, las técnicas de brazo y de pie y la colocación de las manos. Los siguientes dos capítulos comentan los objetivos del trabajo por parejas del tai chi chuan y presentan los ejercicios del nivel básico de iniciación junto con sus puntos clave y las armas utilizadas en el tai chi chuan. El séptimo capítulo clasifica las formas de tai chi chuan y relata el origen y estructura de las formas de 24, 36 y 48 movimientos del tai chi chuan así como la forma de 32 movimientos con espada. El siguiente capítulo analiza el origen, objetivos y características de la forma simplificada del tai chi chuan, y expone los objetivos y los elementos técnicos que componen sus secciones. Los dos últimos capítulos exponen las características de los distintos enfoques o ámbitos que puede abarcar el tai chi chuan, los elementos que componen un programa de iniciación y presenta la historia del tai chi chuan en Galicia, sus personalidades más importantes y la dirección de centros que imparten este arte.

830. Oberlack, Helmut (2004). Tai chi chuan : armonía para el cuerpo, la mente y el alma. L'Hospitalet: Hispano Europea. $1^{\mathrm{a}}$ ed. 95 p. : il. ; 17x23 cm. ISBN: 84-255-1548-3. Depósito legal: B. 341466-2004. Palabras clave: formas, fundamentos teóricos, fundamentos técnicos, principios técnicos, ejercicios, entrenamiento, capacidades físicas, calentamiento, taijiquan, escuelas. Resumen: Manual teórico y técnico de tai chi chuan. La obra esta formada por 8 capítulos. El primer capítulo explica los conceptos de yin y yang, relata la historia del tai chi chuan y la aparición de los estilos, comenta los principios técnicos de la práctica, los beneficios que produce y los casos en los que no se aconseja la práctica del tai chi chuan. El segundo capítulo expone los consejos prácticos antes de comenzar el entrenamiento. El tercer capítulo describe las bases técnicas de los movimientos de tai chi chuan como son la posición básica del cuerpo, el desplazamiento del peso, la rotación, los movimientos de brazos, las posiciones de las manos, los pasos y las posiciones de los pies. Los siguientes tres capítulos comentan los principios técnicos respecto a la mente, la conexión dentro-fuera y la respiración. El séptimo capítulo describe la ejecución de distintos ejercicios de calentamiento, estiramiento y respiratorios para realizar antes de la forma de tai chi chuan, incluyendo su representación gráfica. El último capítulo ofrece algunos consejos prácticos para desarrollar el entrenamiento y describe la ejecución técnica de la forma abreviada del estilo yang junto con sus ilustraciones. Adjunta un índice alfabético.

831. Paniagua Tébar, José Luis (2006). Tai chi para mayores y jóvenes... Madrid: Librería Argentina. 1aa ed. 153 p. : il. ; 17x24 cm. ISBN: 84-85895-03-8. Depósito legal: M. 24339-2006. Palabras clave: formas, historia, ejercicios, aplicación terapéutica, respiración, salud. Resumen: Manual teórico y técnico de tai chi. La obra esta formada por 8 capítulos. El primer capítulo explica el concepto de salud, sus factores, los hábitos saludables e insalubres la relación cuerpo-mente-emociones-espíritu. El segundo capítulo comenta las características del wushu y el tai chi chuan, su historia y escuelas, y sus contenidos técnicos. El tercer capítulo describe la ejecución de las posiciones básicas del tai chi chuan, el 
desarrollo de una clase práctica, los ejercicios preparatorios de la secuencia y la secuencia reducida del tai chi chuan, junto con sus ilustraciones y esquemas de movimiento. El cuarto capítulo expone la importancia de la respiración en la práctica, sus fases y la descripción de varios ejercicios de estiramiento para todo el cuerpo acompañados de su representación gráfica. El quinto capítulo detalla la ejecución de distintos ejercicios para el tratamiento del bloqueo cervical, pélvico y la ciática. El sexto capítulo expone las fases y características del aprendizaje motor además de ofrecer algunos consejos al practicante. El séptimo capítulo describe el recorrido de los meridianos, mientras que el último capítulo presenta la ejecución técnica de los ejercicios baduanjin acompañados de su representación gráfica. Adjunta varios apéndices sobre alimentación, una tabla con las hormonas básicas y su función, las propiedades del própolis junto con su utilización y efectos, una tabla de remedios caseros para distintas afecciones y la descripción de un conjunto de ejercicios correctores con su secuencia fotográfica.

832. Parry, Robert (1999). Tai chi : guías de progreso para la vida. Barcelona: Paidotribo. 1a ed. 173 p. : il. ; 15x21,5 cm. ISBN: 84-8019-414-6. Depósito legal: B. 10435-1999. (2ª ed., 2000). Palabras clave: fundamentos técnicos, taijiquan, escuelas. Resumen: Tratado teórico y técnico de tai chi. La obra esta dividida en 8 capítulos, con el primero de ellos introduciendo las características del arte.. El segundo capítulo describe los principios para el correcto aprendizaje y continúa detallando algunos consejos prácticos y sugerencias para realizar adecuadamente los movimientos y posturas. Los dos siguientes capítulos describen los movimientos de dos secuencias de la escuela yang, ofreciendo imágenes y esquemas de cada movimiento. El sexto capítulo hace un análisis más detallado de aquellas posturas con mayor dificultad, para continuar detallando los aportes beneficiosos del taichi sobre el cuerpo. El último capítulo ofrece algunos consejos para encontrar un maestro, comenta la relación yin-yang, el chi kung, la teoría de los cinco elementos y los aspectos taoístas que impregnan el tai chi. Adjunta un esquema ilustrado de la secuencia presentada así como una lista de lecturas adicionales y las direcciones de dos asociaciones de tai chi en Londres.

833. Parry, Robert (2000). Manual de tai chi : guía paso a paso del estilo Yang simplificado. Barcelona: Círculo de Lectores. $1^{\underline{a}}$ ed. 144 p. : il. ; 22x28,5 cm. ISBN: 84-226-8409-8. Depósito legal: no. (2 ${ }^{\underline{a}}$ ed., 2001). Palabras clave: qigong, formas, fundamentos teóricos, fundamentos técnicos, ejercicios, combate, fundamentos filosóficos. Resumen: Manual teórico y técnico de tai chi. El libro esta dividido en 2 partes precedidas por una introducción que comenta los contenidos de la obra. La primera parte esta compuesta por 8 capítulos que describen la ejecución de los ejercicios de calentamiento y la secuencia completa de la forma Yang de 160 movimientos acompañados de su secuencia fotográfica y esquemas de movimiento. La segunda parte esta compuesta por 3 capítulos. El primer capítulo explica los beneficios derivados de la práctica del tai chi y los fundamentos teóricos del chi. El segundo capítulo describe la ejecución del tai chi en parejas junto con su secuencia fotográfica y beneficios. El tercer capítulo expone los fundamentos teóricos y filosóficos del tai chi como el taoísmo y la teoría de los cinco elementos además de incluir la descripción de algunos ejercicios de chikung y ofrecer algunos consejos para su práctica. Adjunta direcciones de interés, índice y agradecimientos.

834. Parry, Robert (2005). El tai chi de la salud y la vitalidad : guía completa para practicar la forma Yang. Barcelona: Grijalbo. 1aㅡ ed. 144 p. : il. ; 20x26 cm. ISBN: 84-253-3920-0. Depósito legal: no. Palabras clave: formas, fundamentos técnicos, principios técnicos. Resumen: Manual teórico y técnico de tai chi. El libro esta formado por 4 capítulos, precedidos de una introducción que explica los beneficios del tai chi y las razones para su práctica. El primer capítulo detalla la historia de la familia Yang, los principios del tai chi y el flujo de energía, la teoría del yin-yang y los beneficios sobre la salud. El segundo capítulo describe las condiciones para practicar el tai chi, los principios técnicos de sus movimientos, un conjunto de ejercicios de calentamiento y las instrucciones para revisar el libro. Los dos siguientes capítulos describen los movimientos de la forma abreviada yang, incluyendo ilustraciones, esquemas del movimiento y sus beneficios directos. Adjunta un sumario con las imágenes de toda la forma abreviada yang, y un índice.

835. Parry, Robert (2005). Tai chi : objetivo vida equilibrada. Barcelona: Amat. 1a ed. 198 p. : il. ; $13 \times 20 \mathrm{~cm}$. ISBN: 84-9735-200-9. Depósito legal: B. 30958-2005. Palabras clave: qigong, formas, fundamentos teóricos, principios técnicos, entrenamiento, taijiquan, escuelas, medicina tradicional china, nutrición, salud. Resumen: Manual teórico y técnico de tai chi. La obra consta de 9 capítulos. El primer capítulo define el término tai chi y en qué consiste su práctica, relata sus orígenes e historia, comenta el proceso de aprendizaje, los beneficios derivados de la práctica y el significado del chi. El segundo capítulo explica como determinar la velocidad de ejecución propia en el tai chi, ofrece algunos consejos sobre la práctica y describe la ejecución de varios ejercicios de calentamiento antes de comenzar la forma de tai chi. El tercer capítulo presenta y explica los principios técnicos del tai chi y sus posturas básicas. Los dos siguientes capítulos describen por partes la ejecución técnica de la forma de tai chi del estilo yang acompañada de un gráfico, el esquema de la posición y la coordinación de la respiración y los movimientos. El sexto capítulo profundiza en las características, beneficios y significado de las posturas o movimientos de la forma de tai chi. El séptimo capítulo analiza los beneficios de la práctica 
del tai chi sobre el organismo desde el punto de vista de la medicina tradicional china, ofrece diversos consejos nutricionales y comenta algunas de las causas externas e internas que producen las enfermedades. El octavo capítulo incluye preguntas y respuestas frecuentes respecto a la práctica del tai chi y los extractos de cartas que presentan las anécdotas de varios practicantes. El último capítulo expone cómo encontrar un buen profesor, la relación entre yin y yang, las características del chi kung, la teoría de los cinco elementos, la aplicación del taoísmo al tai chi e incluye la secuencia gráfica completa de la forma presentada. Adjunta un glosario y bibliografía.

836. Pawlett, Raymond (2000). Tai chi : introducción práctica. Arganda del Rey: Edimat. 1ae ed. 112 p. : il. ; 22x28,5 cm. ISBN: 84-8403-658-8. Depósito legal: no. Palabras clave: fundamentos teóricos, fundamentos técnicos, principios técnicos, formas. Resumen: Manual teórico y técnico de tai chi. El libro esta formado por 9 capítulos precedidos por una introducción que comenta las características del tai chi y un resumen de sus orígenes. El primer capítulo presenta los conceptos de yin-yang mientras que el siguiente explica el concepto de chi. El tercer capítulo enumera los principios técnicos del tai chi o diez esencias además de comentar su entrenamiento. El cuarto capítulo analiza los principios técnicos del tai chi junto con varias ilustraciones explicativas. El quinto capítulo describe e ilustra varios ejercicios de calentamiento. El sexto capítulo presenta los fundamentos técnicos del tai chia acompañados de sus fotografías. El siguiente capítulo detalla la ejecución de la forma simplificada de tai chi junto con la descripción de la aplicación de sus movimientos, los puntos a tener en cuenta y la visualización. Los dos últimos capítulos incluyen la secuencia fotográfica de toda la forma y las conclusiones finales. Adjunta un índice terminológico.

837. Peck, Alan (2001). Tai chi : introducción a la técnica y sus beneficios. Barcelona: Oniro. 1 a ed. 121 p. : il. ; $13 \times 21 \mathrm{~cm}$. ISBN: 84-95456-77-X. Depósito legal: B. 33656-2001. Palabras clave: fundamentos teóricos, fundamentos técnicos, principios técnicos, entrenamiento. Resumen: Manual teórico de tai chi chuan. La obra esta compuesta de 9 capítulos. El primer capítulo comenta los orígenes e historia del tai chi chuan, junto con su significado. El segundo capítulo describe las características prácticas del tai chi chuan, explicando los diferentes estilos que existen y sus similitudes, los requisitos físicos previos para realizar tai chi chuan, apunta algunas de la razones más frecuentes para comenzar su práctica, comenta los beneficios físicos y mentales aportados por su práctica continuada, expone el concepto de chi, los principios fundamentales del tai chi chuan, sus compatibilidades con otras actividades físicas y la vida moderna, y su vertiente meditativa. El tercer capítulo comenta los diferentes trabajos que existen en el tai chi chuan, como son los ejercicios preparatorios y sus características, la forma corta junto con la descripción de las primeras posturas, la práctica con armas y el trabajo de empuje de manos, incidiendo en sus principios técnicos. El cuarto capítulo ofrece consejos para iniciarse en la práctica del tai chi chuan, indicando cómo escoger a un maestro o un estilo, la ropa necesaria para el entrenamiento, los problemas que pueden aparecer y un breve comentario sobre la historia y maestros de cada estilo. Los dos siguientes capítulos explican los principios más avanzados del tai chi chuan, comentando las características de los niveles de aprendizaje y los aspectos sobre la defensa personal, y los consejos para un aprendizaje eficaz. El séptimo capítulo expone la teoría del chi y su aplicación dentro del tai chi chuan, detallando sus beneficios y su forma de trabajo. El octavo capítulo recopila algunos extractos de los Clásicos del tai chi chuan para explicar sus principios prácticos. El último capítulo resume los principios o consejos prácticos más importantes para un principiante. Adjunta un glosario.

838. Pla-Xiberta, Feliciano (2002). Tai chi curativo. Barcelona: Integral. 1aㅡ ed. 126 p. : il. ; 11x17 cm. ISBN: 84-7901-832-1. Depósito legal: B. 12903-2002. (2a ed., 2003). Palabras clave: formas, historia, principios técnicos, ejercicios, taijiquan, escuelas, meditación, respiración. Resumen: Manual teórico y técnico de tai chi. El libro esta formado por cinco partes precedidas por una poesía, la dirección de contacto del autor y una introducción que incluye una dedicatoria, la biografía del autor, los objetivos del libro y una fábula sobre el origen del tai chi. La primera parte presenta la práctica habitual del tai chi en China, relata el origen del tai chi y las características de cada escuela, explica el significado del símbolo del tai chi, comenta los beneficios de la práctica del tai chi, incluye la tabla de 80 movimientos aparecida en el manual El arte del Tai Chi-Chuan, describe la ejecución de la respiración abdominal, comenta las características del chi y su entrenamiento, su relación con la salud y los principios técnicos de la práctica. La segunda parte describe la ejecución de distintos ejercicios para apreciar las tensiones del cuerpo, aprender a respirar correctamente, descansar sentado, echado y de pie, reaprender a andar, reforzar las rodillas, brazos, enumera sus principios técnicos, expone el método de aprendizaje Liang-Mo y explica la simbología utilizada para representar los movimientos explicados. La tercera parte describe la ejecución de la serie de la Tierra del estilo Yang incluyendo su representación gráfica y esquemas de movimiento. La cuarta parte explica cómo practicar la forma sentado y el empuje de manos, narra algunas de las experiencias del autor, su método de enseñanza, la relación del tai chi con la caligrafía, explica el flujo del chi y ofrece algunos consejos nutricionales. La última parte expone los principios técnicos de Yang Cheng-fu sobre la práctica del tai chi, un compendio de sus secretos según el autor, la filosofía del tai chi, algunos párrafos para la meditación, un conjunto de aforismos sobre el 
tai chi, enumera los beneficios de su práctica, un gráfico de la forma yang descrita anteriormente y un breve glosario.

839. Qu, Lei Lei (2005). El sencillo arte del tai chi : guía paso a paso para estar en forma y lograr la armonía entre el cuerpo y la mente. Barcelona: Amat. 1a ed. 127 p. : il. ; 19x26 cm. ISBN: 84-9735-212-2. Depósito legal: B. 46534-2005. Palabras clave: formas, fundamentos técnicos, principios técnicos, ejercicios, calentamiento, taijiquan, escuelas, fisioterapia. Resumen: Manual teórico y técnico de tai chi. El libro esta formada por dos partes, precedidas por un prólogo que comenta las características y beneficios del tai chi, una introducción que explica los conceptos de yin/yang y chi, y relata la historia del chi gong y el tai chi chuan. La primera parte consta de 3 capítulos. El primer capítulo expone los principios técnicos del tai chi. El segundo capítulo describe la ejecución de las técnicas básicas del tai chi acompañadas de sus ilustraciones. El tercer capítulo detalla la ejecución de distintos ejercicios de calentamiento y estiramiento de todo el cuerpo junto con su representación gráfica. La segunda parte describe la ejecución técnica de forma de 24 movimientos del estilo yang de tai chi incluyendo su secuencia fotográfica y señalando los puntos más importantes. Adjunta un anexo con la descripción e ilustración de varios ejercicios de masaje para los ojos.

840. Rico, Alberto (1981). Tai-chi-chuan. Barcelona: Alas. 1aㅡ ed. 48 p. : il. ; 17x24 cm. ISBN: 84-203-0113-2. Depósito legal: B. 17313-1981. (2ª ed., 1986). Palabras clave: historia, principios técnicos, ejercicios, combate, meditación. Resumen: Manual teórico y técnico de kung fu. La obra esta formada por 11 capítulos, precedidos por una introducción que señala la creación del Instituto de Tai-Chi en Barcelona y sus objetivos. El primer capítulo explica en qué consiste el tai chi mientras que el segundo capítulo narra su historia. El tercer capítulo señala las diferentes escuelas que existen. El cuarto capítulo define el concepto de ki. El quinto capítulo expone las fases de la meditación taoísta, sus técnicas y principios. Los dos siguientes capítulos enumeran los diez principios técnicos del tai chi y las ocho cualidades de la energía. El octavo capítulo describe brevemente la ejecución de los ejercicios de puesta de manos con una y dos manos. El siguiente capítulo describe la ejecución de los ejercicios del gran desplazamiento incluyendo su representación gráfica. El décimo capítulo presenta la descripción técnica e ilustración de la técnica de dispersión de manos. El último capítulo explica la ejecución de otros ejercicios complementarios a la práctica. Adjunta bibliografía y un organigrama histórico del tai chi chuan.

841. Robinson, Ronnie (2006). Tai chi en casa : una guía paso a paso para mejorar tu salud y bienestar. Barcelona: RBA. 1aㅡ ed. 144 p. : il. ; 23x28 cm. ISBN: 84-7871-555-X. Depósito legal: no. Palabras clave: formas, fundamentos técnicos, principios técnicos, ejercicios, combate, taijiquan, escuelas, meditación. Resumen: Manual teórico y técnico de tai chi. La obra esta formada por 6 capítulos. El primer capítulo explica en qué consiste el tai chi, cuales son sus orígenes, los distintos estilos que existen, qué es el chi y en qué consiste el chi kung y cuáles son los beneficios de la práctica del tai chi. El segundo capítulo comenta los 10 principios técnicos del tai chi, y profundiza en la liberación de la tensión corporal, la importancia de una postura correcta, el enraizamiento de las posiciones, el trabajo de escucha de la energía (ting jing), y ofrece algunos consejos para comenzar la práctica, hacer tai chi en casa y para avanzar en el aprendizaje. El tercer capítulo describe la ejecución de varios ejercicios de calentamiento generales y específicos del chi kung, ilustrando cada ejercicio por partes que incluyen esquemas de movimiento y un gráfico con el reparto de peso en los pies. El cuarto capítulo presenta las posiciones de manos, brazos, pies y piernas además de los pasos básicos, para luego describir el desarrollo técnico de la forma simplificada de Cheng Man Ching, acompañado de ilustraciones y esquemas de los movimientos y la repartición del peso. El quinto capítulo expone varios ejercicios de empuje de manos por parejas tanto a una mano como a dos, describiendo brevemente su ejecución, ilustrando sus secuencias técnicas y ofreciendo un esquema de la posición de los pies. El último capítulo comenta la vertiente meditativa del tai chi y las características de su práctica, y describe un ejercicio de meditación en movimiento y otro en estático.

842. Rochford, Matthew (2004). Total tai chi. Madrid: Pearson Educación. 1aㅡ ed. 192 p. : il. ; 24×28,5 cm. ISBN: 84-205-4320-9. Depósito legal: no. Palabras clave: formas, fundamentos técnicos, taijiquan, escuelas. Resumen: Manual técnico de tai chi chuan. Esta dividido en 4 partes. La primera aborda la historia del tai chi y su división en estilos. También presenta brevemente las características de los diferentes estilos así como los beneficios para el practicante, los ejercicios de calentamiento, los estiramientos y los movimientos de las ocho energías. La segunda parte explica los fundamentos técnicos sobre los que se basa la práctica del tai chi y algunos de los ejercicios para brazos y pies, con la representación gráfica y esquemas de movimiento de los mismos. La tercera esta dedicada al estudio de la forma del estilo Yang simplificado de ocho posturas, la forma de dieciséis posturas y el trabajo en pareja, con la explicación de cada movimiento y el apoyo gráfico desde diferentes puntos de vista y con el esquema de movimiento. La última parte integra unas rutinas de ejercicios de tai chi para la mañana, la tarde, la noche, y para realizar en la oficina. Además describe un ejercicio de meditación guiada, algunos consejos sobre el entrenamiento del tai chi, cómo descubrir a un buen maestro, y cuáles son algunas de las fuentes bibliográficas e institucionales sobre tai chi. Adjunta un índice. 
843. Rodríguez, José (2008). Tai chi para todos. Alcobendas: Libsa. 1a ed. 192 p. : il. ; 17x24,5 cm. ISBN: 97884-662-1463-6. Depósito legal: no. Palabras clave: formas, fundamentos teóricos, fundamentos técnicos, combate, taijiquan, escuelas, aplicación marcial, aplicación terapéutica, taoísmo. Resumen: Manual teórico y técnico de tai chi chuan. El libro esta formado por 7 capítulos, precedidos de una introducción que comenta los contenidos del libro y en qué consiste el tai chi chuan. El primer capítulo presenta la base filosófica del tai chi chuan como es el taoísmo y la teoría del yin y yang, relata su historia y evolución y la forma de progresar en este arte. El segundo capítulo define el concepto de salud, la estimulación del tai chi chuan sobre el sistema energético del practicante, la aplicación de la teoría de los cinco elementos a la práctica del tai chi chuan y un conjunto de poemas que recogen el conocimiento y principios del tai chi chuan. El tercer capítulo comenta los principios técnicos del tai chi chuan, las distintas formas de ejecución y la incorporación progresiva de la meditación a la práctica. El cuarto capítulo describe e ilustra los fundamentos técnicos del tai chi chuan, como son las posiciones básicas, las técnicas de pasos, la formas de manos y los movimientos combinados junto con sus esquemas de movimiento además de comentar el trabajo de la respiración y la proyección de fuerza (Fa Chin). Los dos siguientes capítulos comentan las características principales y describen la ejecución técnica de la forma de 10 movimientos del estilo yang y la forma de 18 movimientos del estilo chen respectivamente, explicando cada movimiento por partes acompañado de varias ilustraciones y esquemas de movimiento y señalando el movimiento energético. El último capítulo describe las características de las trece posturas del tai chi chuan (8 puertas y 5 pasos), del wu wei (arte de ceder), describe la ejecución de varios ejemplos prácticos de la aplicación de los movimientos de tai chi chuan como arte marcial junto con sus ilustraciones, y presenta las diferentes armas del tai chi chuan junto con sus beneficios.

844. Roy, Ángel V. (2003). Apreciando la vida : el maestro de tai-chi. Zaragoza: Kábala. $1^{\mathrm{a}}$ ed. 170 p. : il. ; $13 \times 21 \mathrm{~cm}$. ISBN: No ISBN. Depósito legal: Z. 1426-2003. Palabras clave: historia, fundamentos teóricos, pedagogía, principios técnicos, fundamentos filosóficos. Resumen: Manual teórico y técnico de tai chi. El libro esta formado por 48 capítulos precedidos por un prólogo que comenta los objetivos de la obra. Los primeros 28 capítulos comentan las características del tai chi, sus fundamentos teóricos y filosóficos además de comentar algunos de sus principios técnicos. Los siguientes 18 capítulos narran la historia del tai chi, el significado de su símbolo, sus tipos, su vertiente marcial, sus principios técnicos y sus principios de enseñanza-aprendizaje. El penúltimo capítulo narra el desarrollo y experiencias de un curso de verano sobre tai chi. El último capítulo comenta los objetivos y describe la ejecución de la forma del pequeño tai chi acompañada de su representación gráfica.

845. Ruiz Varea, Agustín y Díez Coello, Carlos Antonio (2007). Tai-chi : primer ciclo. Valencia: Ediciones VJ. $1^{a}$ ed. 58 p. : il. ; 14x21 cm. ISBN: 978-84-611-6630-5. Depósito legal: V. 1928-2007. (2ª ed., 2008, ISBN: 978-84-612-7051-4). Palabras clave: fundamentos teóricos, fundamentos técnicos, principios técnicos, ejercicios, cualidades físicas, fisioterapia. Resumen: Manual teórico y técnico de tai chi. El libro esta formado por 24 capítulos precedidos por una introducción que señala los objetivos de la obra. El primer capítulo expone brevemente la teoría del yin/yang para luego enumerar las tres joyas y los principios técnicos para la práctica. El cuarto capítulo describe la posición de partida y sus objetivos. El quinto capítulo ofrece algunos consejos para el calentamiento. Los dos siguientes capítulos explican en qué consiste el chikung y las funciones del qi. El octavo capítulo ilustra la teoría de los cinco elementos. Los siguientes cuatro capítulos describen la posición del árbol, comentan la historia del baduanjin y su clasificación, y explican la ejecución de algunos de los ejercicios de la seda sentado y de pie acompañados de su representación gráfica. El décimo tercer capítulo detalla algunos ejercicios de automasaje para luego presentar los distintos tipos de respiración y sus ejercicios de entrenamiento. Los siguientes seis capítulos describen la ejecución de las posiciones, ataques y defensas básicas acompañados de sus ilustraciones. El vigésimo primer capítulo muestra algunos ejercicios para mejorar el equilibrio mientras que los últimos tres capítulos describen e ilustran el trabajo del paseo de la grulla y la aplicación de las 24 técnicas, enumera los meridianos de la medicina tradicional china y comenta las características y utilidad de los distintos puntos del cuerpo.

846. s.a. (1996). Tai-chi : guía práctica. Barcelona: Obelisco. 1ae ed. 104 p. : il. ; $11 \times 17$ cm. ISBN: 84-7720491-8. Depósito legal: no. (2ª ed., 1998; $3^{\underline{a}}$ ed., 1998; $6^{\underline{a}}$ ed., 2002). Palabras clave: fundamentos teóricos, fundamentos técnicos, principios técnicos, fundamentos filosóficos, formas. Resumen: Manual teórico y técnico de tai chi. El libro esta formado por un prólogo que comenta las características del tai chi junto con sus fundamentos teóricos y filosóficos y una parte principal que explica los principios técnicos de la práctica del tai chi y describe la ejecución de la secuencia de 80 movimientos del tai chi acompañados de su representación gráfica.

847. s.a. (1997). Ejercicios tradicionales chinos para mantenerse en forma. Barcelona: Ceac : libros cúpula. 1a ed. 116 p. : il. ; 15x23 cm. ISBN: 84-329-1387-1. Depósito legal: B. 30333-1997. Palabras clave: formas, historia, fundamentos técnicos, ejercicios, qigong, taijiquan, fisioterapia. Resumen: Manual teórico y técnico de tai chi chuan. La monografía esta formada por 5 capítulos. El primer capítulo expone la importancia de los ejercicios físicos en China desde la antigüedad hasta nuestros días, 
presenta los ejercicios daoyin y sus beneficios junto con la ejecución y figuras de los mismos, explica los ejercicios yijinjing, sus características y una serie práctica de 10 secuencias de movimientos que incluyen la descripción de la posición inicial, el movimiento y sus beneficios, para finalizar con la explicación de la ejecución técnica de dos versiones de los ejercicios baduanjin. El segundo capítulo narra la evolución del tai chi chuan, sus principios técnicos, describe la secuencia de movimientos de la forma simplificada de tai chi chuan (24 movimientos) dividiendo cada movimiento en partes, incluyendo varios gráficos de los mismos y señalando los errores más comunes, y expone los resultados de varias pruebas médicas sobre la práctica del tai chi chuan. El tercer capítulo introduce la práctica del qigong, describe la posición, respiración y forma de alcanzar la serenidad de 3 de sus ejercicios, enumera sus beneficios, ofrece consejos para su práctica y prevención de los efectos secundarios, describe el trabajo combinado de taiji qigong así como la aplicación médica del qigong. El cuarto capítulo expone la historia del masaje terapéutico en China y detalla la ejecución de ejercicios para prevenir los resfriados, la frotación del estómago, el masaje terapéutico para el síndrome de Ménière y ejercicios para los ojos, incluyendo varios gráficos de cada ejercicio y la explicación por partes del movimiento. Finaliza con un compendio de consejos para alargar la vida.

848. Sapin, Jean-Claude (1986). Tai chi chuan : meditación en movimiento. Desarrollo del cuerpo a través de la mente. Barcelona: Martínez Roca. 1aㅡ ed. 217 p. : il. ; 13x19,5 cm. ISBN: 84-270-1047-8. Depósito

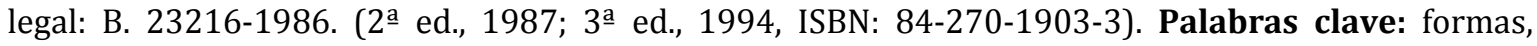
fundamentos técnicos, artes marciales, taijiquan, escuelas, psicología, taoísmo. Resumen: Manual teórico y técnico de tai chi chuan. La monografía esta compuesta de 2 partes, precedidas de un capítulo donde explica las 3 vertientes del tai chi chuan, esto es, marcial, gimnástica y de meditación. La primera parte contiene 2 capítulos que describen la parte práctica del tai chi chuan. El primero de ellos explica los conceptos fundamentales, los principios técnicos para la práctica, el trabajo de manos y el trabajo de los pies en las posiciones y los golpes. El segundo de ellos describe e ilustra la ejecución de la secuencia de 64 movimientos de la forma Yang, explicando cada fase del movimiento y sus aspectos clave. La segunda parte esta compuesta de 4 capítulos que detallan la relación del tai chi chuan con la tradición oriental. El primero de ellos relata las fases de transformación de la meditación taoísta y ejercicios del tai chi chuan relacionados. El segundo de ellos detalla los principios marciales del tai chi chuan, los principios técnicos de las posiciones y técnicas, el programa de entrenamiento y secuenciación de los ejercicios y varios trabajos de empuje de manos. El tercero de ellos narra la génesis taoísta y finaliza con las tres nociones esenciales que guían la práctica del tai chi chuan, como son la noción de centro, de simultaneidad y de vacuidad. Adjunta dos anexos sobre los contenidos técnicos de cada grado y unos consejos para utilizar el libro como manual de aprendizaje.

849. Serra, José Luis (2009). Taiji quan : de los Chen a los Sun. Barcelona: Alas. $1 \stackrel{a}{a}$ ed. 137 p. : il. ; 17x23,5 cm. ISBN: 978-84-203-0455-7. Depósito legal: B. 29619-2009. Palabras clave: formas, historia, fundamentos técnicos, principios técnicos, ejercicios, taijiquan, escuelas, fundamentos filosóficos, anatomía, genealogía, maestros, fundamentos teóricos. Resumen: Manual teórico y técnico de taijiquan. La obra esta formada por 10 capítulos precedidos por una introducción que comenta las características de las artes marciales chinas y el currículo del autor. El primer capítulo relata el origen del taijiquan y presenta la biografía y aportaciones de los principales maestros de la familia chen. El segundo capítulo describe las características y orígenes de los principales estilos de taijiquan así como una comparación de los estilos chen y yang. El tercer capítulo presenta los fundamentos filosóficos del taijiquan. El cuarto capítulo enumera los contenidos técnicos del taijiquan y describe las características y tipos de entrenamiento del quan jia, tui shou, las arnas tradicionales, el qigong y el san shou, incluyendo la ilustración de algunos ejemplos prácticos. El quinto capítulo describe los principios técnicos del taijiquan. El sexto capítulo define la práctica del chansi gong, los dos tipos de fuerza implicados, expone la ejecución de dos de sus ejercicios acompañados de su secuencia fotográfica, y comenta los principios técnicos del ejercicio fa jing y la respiración. El séptimo capítulo define los conceptos de qi y dan tian además de la circulación de la energía por el cuerpo. Los dos siguientes capítulos describen la ejecución técnica de las formas de 19 movimientos del estilo chen y de 13 movimientos del estilo yang acompañadas de su secuencia fotográfica. El último capítulo incluye las palabras del maestro Chen Xiao Wang respecto a los cinco niveles de habilidad en el taiji quan. Adjunta un anexo con bibliografía.

850. Serrano Aguilar, Mario René (2006). Principios fundamentales del tai chi. s.l.: Mario René Serrano Aguilar. $1^{\underline{a}}$ ed. 120 p. : il. ; 17x24 cm. ISBN: No ISBN. Depósito legal: CU. 386-2006. Palabras clave: formas, fundamentos teóricos, fundamentos técnicos, principios técnicos, ejercicios, textos, taijiquan, escuelas, maestros, medicina tradicional china, respiración. Resumen: Manual teórico y técnico de tai chi. La obra esta formada por 4 partes precedidas por ocho capítulos introductorios. El primer capítulo explica el significado de los conceptos wushu y kung-fu, mientras que el segundo presenta la clasificación de sus estilos junto con un comentario de sus características técnicas. El tercer capítulo explica los conceptos de energía y los tres tesoros. El cuarto capítulo expone los fundamentos teóricos del tai chi junto con los beneficios de su práctica para la salud. El quinto capítulo narra los orígenes del 
taiji quan. El sexto capítulo muestra las características técnicas de los estilos de tai chi mientras que el séptimo adjunta el árbol genealógico del mismo. El octavo capítulo detalla la aplicación marcial del taiji quan. La primera parte esta formada por ocho capítulos. El primer capítulo explica la relación del qigong y el taiji quan con los fundamentos teóricos de la medicina tradicional china como son la teoría de los cinco elementos y del yin/yang y la descripción de las trece posturas de Zhang Shan Feng. El segundo capítulo enumera los tipos de respiración, propone varios ejercicios para desarrollar la respiración abdominal y detalla sus beneficios. Los dos siguientes capítulos detallan en qué consiste la práctica del qigong, cuáles son sus principios técnicos y beneficios. El quinto capítulo señala la utilización de la posición zhan zhuang gong y describe su ejecución. Los dos últimos capítulos enumera los puntos clave en la ejecución de los ejercicios de baduanjin, incluye su descripción técnica acompañada de una ilustración y señala sus beneficios. La segunda parte esta formada por tres capítulos. Los dos primeros capítulos presentan los ocho meridianos extraordinarios y los doce canales energéticos describiendo su función y trayecto. El tercer capítulo recopila algunos de los textos de Chang San-feng, Chen Wang Ting, Wang Zuen Yue, Wu Yu-xiang, Li Yi-yu, Yang Chengfu y el maestro Cheng sobre los principios técnicos del tai chi. La tercera parte esta formada por dos capítulos. El primer capítulo nombra e ilustra las posiciones básicas de los pies, desplazamientos y técnicas de mano del tai chi mientras que el segundo incluye un glosario. La última parte esta formada por 3 capítulos que enumeran las técnicas contenidas en las formas de 16 y 24 movimientos del estilo yang y la forma de 18 movimientos del estilo chen de tai chi. Adjunta tres apéndices con la secuencia fotográfica de la ejecución de las formas de 16 movimientos del estilo yang y de 18 movimientos del estilo chen así como bibliografía.

851. Serrato Rodríguez, Juan Carlos (2002). Cuerpo, mente y taiji quan. Madrid: Juan Carlos Serrato Rodríguez. $1^{\mathrm{a}}$ ed. 320 p. : il. ; 14x21 cm. ISBN: 84-607-5799-4. Depósito legal: no.

852. Shing, Yen-Ling (1995). Estilo chen de tai chi chuan : treinta y seis y cincuenta y seis movimientos. Volumen III. Barcelona: Paidotribo. 1aㅡ ed. 334 p. : il. ; 15x21,5 cm. ISBN: 84-8019-201-1. 84-8019-2208 (ISBN de la obra completa). Depósito legal: B. 15538-1998. (2 $2^{\mathrm{a}}$ ed., 2004). Palabras clave: formas, fundamentos teóricos, fundamentos técnicos, principios técnicos, principios teóricos, entrenamiento, taijiquan, escuelas. Resumen: Manual teórico y técnico de tai chi chuan. El libro esta formado por 2 partes, precedidas por una introducción que consta de 4 capítulos. Los dos primeros capítulos de la introducción señalan las características técnicas del estilo chen de tai chi chuan para en los dos siguientes exponer los principios técnicos que rigen su práctica, describir los fundamentos técnicas como son las posturas, las técnicas de mano y los desplazamientos junto con sus ilustraciones explicativas, y comentar los principios del entrenamiento para progresar. La primera parte del libro esta formada por dos capítulos. El primero enumera y nombra las posiciones de la forma de los 36 movimientos para luego describir la ejecución técnica por partes y el objetivo de cada uno de ellos además de incluir la secuencia fotográfica de los mismos. La segunda parte enumera las posiciones de la forma de 56 movimientos del estilo chen y presenta la descripción de su ejecución técnica acompañada de las fotos aclaratorias de cada movimiento.

853. Shing, Yen-Ling (1995). Tai chi chuan : los ejercicios básicos. Volumen I. Barcelona: Paidotribo. 1a ed. 259 p. : il. ; 15x21,5 cm. ISBN: 84-8019-202-X. Depósito legal: B. 15506-1995. (2ª ed., 1998; 3ª ed., 2003; 4a ed., 2006). Palabras clave: formas, fundamentos técnicos. Resumen: Manual teórico y técnico sobre el tai chi chuan. Esta compuesto por nueve capítulos. Comienza señalando algunas de las características que distinguen al tai chi chuan de otras prácticas, y en el segundo capítulo describe algunas de las consideraciones a tener en cuenta en el entrenamiento. El siguiente capítulo explica brevemente la colocación correcta del cuerpo para realizar cualquier movimiento y continua detallando los beneficios de su práctica. El quinto capítulo comenta brevemente algunos aspectos para avanzar en el entrenamiento. Los dos siguientes capítulos presentan gráficamente las posturas y movimientos básicos del tai chi chuan. Los dos últimos capítulos describen textual y gráficamente los 24 movimientos simplificados y los 48 movimientos de tai chi chuan respectivamente. Adjunta un breve glosario.

854. Shing, Yen-Ling (1995). Tai chi con espada : la palma de los ocho diagramas. Volumen II. Barcelona: Paidotribo. $1^{\mathrm{a}}$ ed. 259 p. : il. ; 15x21,5 cm. ISBN: 84-8019-203-8. Depósito legal: B. 15537-1995. (2ª ed., 2004). Palabras clave: formas, fundamentos técnicos, taijiquan, armas. Resumen: Tratado técnico del tai chi con espada. La obra esta dividida en 2 partes. La primera de ellas, compuesta por 4 capítulos, hace una introducción técnica a la esgrima china y al tai chi con espada, y describe las técnicas, posturas y movimientos de piernas básicos en dicha técnica. Finaliza esta parte con la descripción y representación gráfica de la forma de treinta y dos movimientos simplificados de tai chi con espada. La segunda parte comenta brevemente la historia de la palma de los ocho diagramas, explica las características de sus movimientos, los niveles y secuencias de entrenamiento, y los movimientos básicos. El último capítulo describe los movimientos de la palma básica de los ocho diagramas.

855. Soto Caride, José Ricardo (2009). Unidades didácticas de tai-chi : condición física fácil y saludable. Barcelona: Alas. 1ํㅡ ed. 166 p. : il. ; 17x23,5 cm. ISBN: 978-84-203-0461-8- Depósito legal: B. 42850- 
2009. Palabras clave: fundamentos teóricos, educación, didáctica, unidades didácticas. Resumen: Manual teórico y técnico de tai chi. El libro esta formado por 6 capítulos precedidos por una dedicatoria, los agradecimientos, una advertencia sobre los contenidos de la obra y un prólogo que señala los contenidos de la colección. El primer capítulo presenta 11 los objetivos y contenidos de la obra. El segundo capítulo expone los niveles curriculares del sistema educativo. El tercer capítulo explica en qué consiste el tai chi chuan, narra brevemente su historia, expone los beneficios derivados de su práctica, sus demandas fisiológicas, analiza los principios técnicos para su práctica, describe la ejecución de sus posiciones básicas acompañadas de su representación gráfica, comenta los principios técnicos de la respiración, y explica la ejecución y efectos de varias técnicas de visualización. El cuarto capítulo comenta la vinculación de las unidades didácticas de tai chi chuan con el currículo oficial, su interdisciplinariedad, su adaptación al centro y las personas, la metodología de enseñanza-aprendizaje utilizada junto con la ficha de varias tareas jugadas y las listas de control utilizadas en la evaluación específica. El quinto capítulo presenta las unidades didácticas de tai chi chuan para primaria o 1o ciclo de secundaria, para $2^{\mathrm{o}}$ ciclo de secundaria, para bachillerato y la ilustración de algunas series con implementos para ser usadas como ayudas didácticas. El último capítulo incluye unas consideraciones finales sobre la utilización de las artes marciales y sus profesionales. Adjunta bibliografía y un anexo con las especificaciones para el uso de las series como actividad física saludable.

856. Su, Yu-Chang (1995). El tejido invisible: manual de tai chi chuan. Palma de Mallorca: Prensa Universitaria. 1a ed. 467 p. : il. ; 16x24 cm. ISBN: 84-86876-78-8. Depósito legal: P.M. 382-1995. Palabras clave: qigong, historia, fundamentos técnicos, filosofía, combate. Resumen: Manual teórico y técnico sobre tai chi chuan. La obra esta dividida en 14 capítulos. Los cinco primeros capítulos fundamentan teóricamente la práctica del tai chi chuan, desde los conceptos básicos de filosofía china que impregnan esta práctica hasta la visión que tiene dicha filosofía del hombre como ser energético, el origen e historias del tai chi chuan que dieron lugar a los distintos estilos, sus maestros y la propia filosofía del tai chi chuan, que es la aplicación de la filosofía china antes descrita a los movimientos. Los dos siguientes capítulos presentan las posiciones, puños, palmas y patadas del tai chi chuan así como sus 13 principios, es decir, sus movimientos y técnicas fundamentales, junto con fotografías que aclaran cada gesto. El octavo capítulo describe la secuencia de movimientos del esquema Yang simplificado de 36 movimientos además de incluir apoyo gráfico de cada uno de ellos. Continua con la ilustración de algunas técnicas de "manos pegajosas" y la aplicación de este trabajo a la primera parte del esquema simplificado anterior. El décimo capítulo ilustra las aplicaciones de los movimientos de tai chi chuan en situaciones de combate. A continuación expone las fases para controlar la energía propia y del oponente y describe algunos de los ejercicios de cada fase. Los dos siguientes capítulos ofrecen consejos para la práctica correcta del tai chi chuan así como la explicación e ilustración de los ejercicios de calentamiento y finales. Finaliza con la descripción de algunos ejercicios seleccionados para el trabajo de la energía del primer nivel, es decir, de los 5 elementos, apoyándose en numerosas fotografías.

857. Su, Yu-Chang (2005). Yang taichi chuan. Madrid: Vision Libros. 1a ed. 75 p. : il. ; $14 \times 21 \mathrm{~cm}$. ISBN: 849770-959-4. Depósito legal: SE. 2181-2005. Palabras clave: formas, taijiquan, escuelas. Resumen: Manual técnico de taichi chuan. El primer capítulo incluye el nombre en chino, español e inglés de las posturas de la forma de 36 movimientos del estilo yang de taichi chuan. El segundo capítulo explica cómo interpretar la información contenida en la obra para luego presentar la secuencia fotográfica de la forma de 36 movimientos y la descripción esquemática de su ejecución.

858. Sutton, Nigel (1999). El guerrero interno : enseñanzas del maestro Lau Kim Hong sobre la aplicación marcial del arte del tai chi chuan. s.l.: s.n. 1aㅡ ed. 117 p. ; 8x12 cm. ISBN: No ISBN. Depósito legal: no. Palabras clave: fundamentos teóricos, principios técnicos. Resumen: Tratado teórico de tai chi chuan. La obra esta compuesta por 2 capítulos precedidos por una dedicatoria, los agradecimientos, una nota explicativa y una breve biografía del maestro Lau Kim Hong. La introducción expone la biografía y entrenamiento desarrollado por el maestro Lau Kim Hong junto con algunas de sus reflexiones sobre los objetivos y características del tai chi chuan y varios consejos sobre la práctica del tai chi chuan y su entrenamiento. El segundo capítulo analiza las características y principios técnicos del tai chi chuan.

859. Sutton, Nigel (1999). La vía interna : enseñanzas del tai chi chuan de Cheng Man Ching. s.l.: s.n. 1a ed. 109 p. ; 8x11,5 cm. ISBN: No ISBN. Depósito legal: no. Palabras clave: fundamentos teóricos, principios técnicos, entrenamiento. Resumen: Tratado teórico de tai chi chuan. La obra expone los fundamentos teóricos, principios técnicos, de aprendizaje y de entrenamiento del tai chi chuan.

860. Tapia Rodríguez, Javier (2008). Tai chi para camareros y camareras. Barcelona: Grup Sociologies. $1^{\text {a }}$ ed. 160 p. ; $11 \times 18$ cm. ISBN: 978-84-936347-5-9. Depósito legal: B. 18254-2008. Palabras clave: fundamentos teóricos, fundamentos técnicos, ejercicios, meditación, relajación. Resumen: Manual teórico y técnico de tai chi. El libro esta compuesto por 8 capítulos precedidos por un prólogo que comenta las características del tai chi y los objetivos de la obra, y una introducción que expone las características del trabajo de camarero y señala los objetivos del tai chi, sus requisitos y sus fundamentos teóricos. El primer capítulo describe algunos ejercicios para comenzar la jornada de 
trabajo. El segundo capítulo describe los modos de respiración y su aplicación a los movimientos. El tercer capítulo propone varios ejercicios de estiramiento para todo el cuerpo. El cuarto capítulo expone los fundamentos teóricos del zen y presenta varios ejercicios para sentir, absorber y proyectar la energía. El quinto capítulo explica el objetivo de la rutina de las 8 puertas además de incluir su descripción técnica. El sexto capítulo detalla la ejecución de varios ejercicios para ganar confianza en uno mismo. El séptimo capítulo describe varios ejercicios y técnicas de relajación y meditación. El último capítulo presenta distintos ejercicios para aumentar la autoestima así como algunos consejos prácticos dependiendo de la fecha de nacimiento, ejercicios de fortalecimiento, los fundamentos del chikung y de los cinco animales.

861. Tarragó Tomás, Ferrán (1990). Tai chi chuan : un camino hacia la salud y la armonía. Barcelona: Obelisco. $1^{a}$ ed. 213 p. : il. ; $20 \times 27$ cm. ISBN: 84-7720-184-6. Depósito legal: B. 44014-1990. (2 ${ }^{\underline{a}}$ ed., 1994, ISBN: 84-7720-324-5; 3aㅡ ed., 1995, ISBN: 84-7720-324-5; 4⿳⺈ ed., 2003, ISBN: 84-7720-324-5). Palabras clave: formas, fundamentos teóricos, fundamentos técnicos, principios técnicos, taijiquan, escuelas, taoísmo. Resumen: Manual teórico y técnico de tai chi chuan. La obra esta dividida en 2 partes. La primera parte desarrolla los fundamentos teóricos de la práctica del tai chi chuan. Comienza con la definición del tai chi chuan, en la que explica sus características y expansión territorial. Continua describiendo los orígenes e historia de la práctica, su filosofía, el significado del símbolo del tai chi chuan y de sus movimientos, la energía o chi y su relación con el tai chi chuan. Después expone la aplicación del taoísmo sobre la práctica del tai chi chuan, así como su asociación con el I-Ching y el Pakua. El siguiente capítulo profundiza en la teoría de los cinco elementos y cuál es su relación con los movimientos el tai chi chuan. A continuación describe los beneficios físicos y mentales de la práctica del tai chi chuan para luego explicar la respiración y meditación taoístas, su correcta ejecución y beneficios para el practicante. Finaliza la primera parte con la descripción técnica de los movimientos de base del tai chi chuan, desde la posición de las manos hasta las posiciones, patadas, los 10 principios esenciales para la práctica correcta y la ejecución y propiedades de los 8 tesoros (Pa tuan chin). La segunda parte describe e ilustra la secuencia de movimientos de la escuela de Pekín, dividiendo sus 84 movimientos en 6 secciones, y explicando cada movimiento por partes, con distintas fotografías e incluyendo la explicación del movimiento, la situación del cuerpo, la fase y la respiración. Adjunta bibliografía recomendada.

862. Tarragó Tomás, Ferrán (2009). Tai chi chuan para la tercera edad. Barcelona: Obelisco. 1aㅡ ed. 172 p. : il. ; 15x23,5 cm. ISBN: 978-84-9777-592-2. Depósito legal: B. 37406-2009. Palabras clave: formas, historia, fundamentos teóricos, fundamentos técnicos, didáctica, ejercicios, taijiquan, escuelas, aplicación terapéutica, unidades didácticas. Resumen: Manual teórico y técnico de tai chi chuan. El libro esta formado por 5 partes precedidas por los agradecimientos, un prólogo que comenta los objetivos y metodología de la obra, y una introducción que explica la formación del estilo presentado. La primera parte explica en qué consiste el tai chi chuan y sus características, narra su historia, expone sus fundamentos teóricos y comenta el significado del chi. La segunda parte detalla los fundamentos de la respiración y meditación taoístas, y enumera los principios técnicos del tai chi chuan. La tercera parte describe los beneficios derivados de la práctica del tai chi chuan además de incluir el testimonio de varios alumnos de la tercera edad. La cuarta parte presenta los objetivos de la programación del tai chi chuan para las personas de la tercera edad, las características de estos practicantes y de su profesor, analiza las variables a controlar dentro de dicha programación, comenta el desarrollo práctico de una sesión y los recursos materiales necesarios. La quinta parte describe la ejecución de varios ejercicios de calentamiento general así como los movimientos de base del tai chi chuan, el pa tuan chin (los ocho brocados) y la forma de 13 movimientos del estilo yang. Adjunta bibliografía recomendada y la biografía del autor.

863. Tcheng-Tsiun (seud. de Thomas, Raymond) (1973). Tai chi : yoga chino. Barcelona: Alas. $1^{a}$ ed. 93 p. : il. ; 12x16,5 cm. ISBN: 84-203-0278-3. Depósito legal: 10711-1973. (2ª ed., 1989). Palabras clave: formas, historia, fundamentos técnicos, principios técnicos, meditación, respiración. Resumen: Manual teórico y técnico de tai chi. La obra consta de 11 capítulos, precedidos por un prólogo que explica las vertientes que adopta el tai chi. El primer capítulo expone los dos métodos de practica del tai chi para en el segundo aclarar en qué consiste su práctica. El tercer capítulo relata brevemente la historia del tai chi chuan. El cuarto capítulo analiza el significado del símbolo del tai chi para en los dos siguientes capítulos explicar los conceptos de chi, respiración y concentración así como su aplicación a la práctica. El séptimo capítulo ofrece varios consejos para la práctica mientras que el octavo enumera sus principios técnicos. El noveno capítulo describe la ejecución técnica de la primera serie de tai chi, dividiendo su estudio en 13 lecciones e incluyendo la representación gráfica de cada postura. El décimo capítulo presenta la descripción e ilustración de la mitad de la segunda serie del tai chi en 9 lecciones ilustradas. El último capítulo expone la aplicación marcial de algunos movimientos de tai chi.

864. Tcheng-Tsiun (seud. de Thomas, Raymond) (1982). Yoga chino : Tai chi. $2^{a}$ parte. Barcelona: Alas. $1^{\underline{a}}$ ed. 93 p. : il. ; 12x16,5 cm. ISBN: 84-203-0136-1. Depósito legal: B. 30531-1982. Palabras clave: fundamentos técnicos, principios técnicos, artes marciales, relatos. Resumen: Manual teórico y técnico 
de tai chi. La obra consta de 5 capítulos. El primer capítulo describe e ilustra la ejecución técnica de la segunda serie de movimientos de tai chi divididos en 16 lecciones, como continuación de aquellos presentados en la 1aㅡ obra del autor. El segundo capítulo explica el significado del símbolo del tai chi así como sus fundamentos filosóficos. El tercer capítulo relata una historia sobre los métodos de enseñanza chinos. El cuarto capítulo describe la práctica de las artes marciales chinas en dicho país en la actualidad y comenta las características del tai chi chuan, el tui shou y el ta lu. El quinto capítulo analiza los 10 principios técnicos fundamentales para la práctica del tai chi chuan. Adjunta notas del autor.

865. Tcheng-Tsiun (seud. de Thomas, Raymond) (1983). Yoga chino : Tai chi. $3^{a}$ parte. Barcelona: Alas. $1^{\mathrm{a}}$ ed. 94 p. : il. ; $12 \times 17$ cm. ISBN: 84-203-0144-2. Depósito legal: B. 6746-1983. Palabras clave: fundamentos técnicos. Resumen: Manual teórico y técnico de tai chi. La obra describe la ejecución de los movimientos de la tercera serie de tai chi acompañados de su representación gráfica, dividiéndolos en 21 lecciones prácticas.

866. Tsao, Jesse (2003). Taichi en casa : ejercicios combinados para practicar en un espacio reducido. Madrid: Edaf. 1aㅡ ed. 239 p. : il. ; 20x25,5 cm. ISBN: 84-414-1358-4. Depósito legal: M. 37631-2003. Palabras clave: formas, fundamentos técnicos. Resumen: Manual teórico y técnico de tai chi. La obra esta compuesta por 5 capítulos, precedidos de una introducción donde explica el objetivo de la obra y los requisitos para desarrollar sus ejercicios. El primer capítulo profundiza en los fundamentos del tai chi, explicando la ejecución de las técnicas de brazos y piernas, las posiciones, los pasos y patadas y la emisión de energía, incluyendo fotografías de cada una de ellas. Los siguientes cinco capítulos dividen la secuencia de 74 posturas, describiendo e ilustrando cada una de ellas y resaltando sus puntos clave y aplicaciones para la defensa personal. Además, cada movimiento esta descrito por partes y con esquemas de movimiento. Adjunta una breve biografía del autor.

867. Verdugo, Esther (2003). Tai chi : el arte marcial de los monjes taoístas. Madrid: Libsa. 1 a ed. 191 p. : il. ; 17x25 cm. ISBN: 84-662-0926-3. Depósito legal: no. (2 $2^{\underline{a}}$ ed., 2004; $3^{a}$ ed., 2005). Palabras clave: qigong, formas, historia, fundamentos técnicos, textos, taijiquan, escuelas, respiración. Resumen: Manual teórico y técnico de tai chi. La obra esta formada por 9 capítulos. El primer capítulo comenta la historia del tai chi y la doctrina taoísta, los diferentes estilos, los fundamentos generales del libro y el concepto chi. El segundo capítulo resume los contenidos de los libros clásicos de tai chi como son el tratado de tai chi chuan de Chang San Feng, el maestro Wang Tsung-Yueh, los cinco principios secretos del maestro Li I-Yu, la transmisión secreta de los cuatro caracteres, la canción de las trece posturas, los diez puntos importantes del maestro Yang Chen-Fu y los seis puntos esenciales del maestro Wu Chien Ch'uan. El tercer capítulo presenta las ocho posturas del tai chi explicando el significado y principios técnicos de cada una de ellas. El cuarto capítulo analiza la meditación, describiendo sus objetivos y posiciones, detallando algunos de sus ejercicios para conseguir sentir la energía, la quietud mental y controlar las emociones. El quinto capítulo describe los ejercicios de Dao Yin para estirar los músculos y dirigir la circulación del Chi, y presenta la práctica del chi kung, las distintas escuelas junto con sus características, los métodos de respiración y los ejercicios para desarrollar cada uno de ellos y los síntomas y beneficios que provoca el entrenamiento continuado en esta práctica. El sexto capítulo describe la ejecución de las posiciones básicas del chi kung y cómo debe realizarse la preparación para realizar los ejercicios, la correcta respiración, la mente y los músculos. El séptimo capítulo comenta el origen de los ejercicios del brocado de seda, los puntos clave para su realización, detalla la ejecución de sus ejercicios por fases y resalta los puntos más importantes. El octavo capítulo estudia el significado del juego de los cinco animales exponiendo las características y objetivos de cada uno de ellos, para finalizar con la descripción de los principios técnicos de la forma Yang de 24 movimientos y la explicación de sus movimientos por partes, atendiendo al movimiento de cada parte del cuerpo por separado e incluyendo gráficos de cada posición. Adjunta un índice de posturas.

868. Wang, Maestro (2007). Tai chi para la vida diaria. Santa Perpetua de Mogoda: Abraxas. 1a ed. 185 p. : il. ; 13x21 cm. ISBN: 978-84-96196-83-4. Depósito legal: B. 11897-2007. Palabras clave: fundamentos técnicos, ejercicios, formas, meditación, relajación, respiración, taijiquan, fundamentos teóricos. Resumen: Manual teórico y técnico de tai chi. La obra esta formada por 9 capítulos precedidos por un prólogo que comenta las características y beneficios del tai chi, y una introducción que presenta los contenidos del libro así como los fundamentos, ventajas y objetivos del tai chi. El primer capítulo describe e ilustra los ejercicios de calentamiento antes de la práctica de tai chi. El segundo capítulo explica los tipos de respiración, su ejecución y su aplicación respecto al trabajo realizado. El tercer capítulo comenta las características de la flexibilidad para luego describir e ilustrar distintos ejercicios de estiramiento para los brazos. El cuarto capítulo explica desde distintos puntos de vista el concepto de energía o chi, y propone algunos ejercicios para sentirlo, absorber energía por los pies y las manos y proyectarla. El quinto capítulo presenta las características de la rutina de las 8 puertas y la descripción de su secuencia técnica. El sexto capítulo comenta los principios filosóficos del combate para luego presentar 3 ejercicios de confianza. El séptimo capítulo describe l preparación y ejecución de los ejercicios de relajación junto con la meditación. El octavo capítulo ofrece algunos consejos para 
desarrollar la autoestima, presenta varios de sus ejercicios y su planificación respecto al tipo de trabajo realizado. El último capítulo comenta el vocabulario y terminología utilizada en el tai chi. Adjunta un apéndice con la descripción de varios ejercicios de tensión y relajación para todo el cuerpo.

869. Wespin, Dominique de (1987). Prácticas chinas para la salud. Madrid: Edaf. 1ạ ed. 194 p. : il. ; 14x20,5 cm. ISBN: 84-7640-162-0. Depósito legal: 23677-1987. Palabras clave: formas, fundamentos teóricos, fundamentos técnicos, principios técnicos, ejercicios, taijiquan, aforismos, anatomía, aplicación terapéutica, fisioterapia. Resumen: Manual teórico y técnico de tai chi chuan. La obra consta de 8 capítulos precedidos por un prefacio, unos consejos sobre la lectura del libro y la experiencia de la autora en China. El primer capítulo describe la teoría yin/yang, el concepto de energía, su flujo a través de los meridianos y puntos, los principios para la práctica, incluye unas laminas anatómicas sobre el flujo de la energía, y describe varios ejercicios preliminares de tai chi y masaje. El segundo capítulo define el concepto de respiración, su relación con el cuerpo y el espíritu, sus principios técnicos y adjunta la descripción e ilustración de varias técnicas de respiración divididas en cinco lecciones. El tercer capítulo comenta la historia y beneficios del masaje chino además de describir e ilustrar diversos ejercicios de automasaje en la cara y con una caña de bambú. El cuarto capítulo analiza la estructura de la columna vertebral y su influencia sobre la salud para luego explicar el tratamiento de las vértebras cervicales, dorsales y lumbares a través de la descripción de distintas técnicas de automasaje. El quinto capítulo detalla el papel y efectos del tao inn, explica sus medios y principios técnicos y describe el autotratamiento de todo el cuerpo. El sexto capítulo narra la historia del tai ki tchuan, explica el significado de dicho término, expone sus principios técnicos junto con algunos consejos prácticos y describe la ejecución de varios ejercicios preparatorios. El séptimo capítulo explica la posición y movimientos de las distintas posiciones del tai ki tchuan. El último capítulo narra la semejanza entre la existencia humana y las estaciones; detalla las reglas fundamentales para la vida y ofrece algunos consejos para el comportamiento ideal durante todo el día. Adjunta un conjunto de aforismos para comprender China, una conclusión final, notas del autor y un índice de nombres.

870. Wile, Douglas (1999). Clásicos perdidos del tai-chi, de finales de la dinastía Ch'ing. Romanones: Tao. 1a ed. 211 p. ; $13 \times 20$ cm. ISBN: 84-921280-3-8. Depósito legal: M. 18255-1999. Palabras clave: historia, textos. Resumen: Tratado teórico de tai chi chuan. La obra esta formada por 4 capítulos precedidos de una introducción que comenta los orígenes y textos de partida para cada uno de los aspectos que configuran la práctica. El primer capítulo describe el contexto histórico y social del tai chi chuan en el siglo XIX, estudiando la economía, las relaciones internacionales de China, la rebelión interna, las condiciones de la llanura del norte de China para la formación de las artes marciales, las características de la élite cultural y las corrientes intelectuales, una revisión de la bibliografía de Wu Yü-hsiang y una discusión sobre la participación de las familias Wu y Li en la formación del tai chi chuan. El segundo capítulo analiza los textos clásicos de tai chi chuan, desde su formación hasta su transmisión, explicando brevemente el contenido de cada uno de ellos y su importancia. El tercer capítulo presenta el análisis y traducción de los nuevos textos clásicos de Wu Ch'eng-ch'ing, Wu Ju-ch'ing, Li I-yü y de los cuarenta capítulos de la familia Yang. El último capítulo señala y explica el papel de estos nuevos textos para entender algunas cuestiones polémicas sobre los autores de los textos clásicos, las distintas ediciones de los textos, los personajes históricos y ciertas anomalías de los propios textos. Adjunta un apéndice con la genealogía y cronología de la familia $\mathrm{Wu}$, un glosario y bibliografía.

871. Wile, Douglas (2001). Las piedras de toque del tai-chi : las transmisiones secretas de la familia Yang. Romanones: Tao. 2a ed. 171 p. : il. ; 15x21,5 cm. ISBN: 84-921280-7-0. Depósito legal: M. 19116-2001. Palabras clave: fundamentos teóricos, táctica, principios técnicos, historia, defensa personal, textos, taijiquan, escuelas. Resumen: Manual teórico y técnico de tai chi. La obra consta de 8 capítulos, precedidos por un prólogo, las notas del traductor y una introducción que discute el origen del tai chi, su fundador y transmisiones. El primer capítulo expone las consideraciones de Yang Ch'eng-fu para la práctica del tai chi chuan. El segundo capítulo enumera los diez principios técnicos mientras que el tercer capítulo incluye la exposición de la transmisión oral del tai chi chuan. El cuarto capítulo presenta los manuscritos de la familia Yang recopilados por Li Ying-ang acompañados de varias ilustraciones. El quinto capítulo incluye las nueve transmisiones secretas sobre el tai chi chuan mientras que el sexto muestra los manuscritos de la familia Yang recopilados por Shen Chia-chen. El séptimo capítulo detalla la aplicación de los principios técnicos y tácticos del tai chi chuan a la defensa personal junto con algunas anécdotas de sus maestros. El último capítulo incluye el prólogo e introducción del libro titulado "T'ai-chi ch'üan t'i-yung ch'üan-shu" de Yang Ch'eng-fu.

872. Wile, Douglas (2001). Los precursores del tai-chi chüan : la creación de un arte marcial interno. Romanones: Tao. $1^{a}$ ed. 210 p. : il. ; 15x21,5 cm. ISBN: 84-921280-5-4. Depósito legal: M. 6621-2001. Palabras clave: historia, taijiquan. Resumen: Tratado teórico de tai chi chuan. La obra consta de 5 capítulos precedidos por una nota explicativa sobre la transcripción utilizada. El primer capítulo comenta los contenidos del libro y los orígenes del tai chi chuan. El segundo capítulo narra la biografía de Ch'i Chi-kuang y expone los aspectos esenciales del "Clásico del Boxeo". El tercer capítulo analiza la biografía y estudios de Huang Tsung-hsi e incluye la traducción de los textos titulados "Epitafio para 
Wang Cheng-nan" de Huang Tsung-hsi, "El arte de la escuela interna" de Huang Pai-chia y "La biografía de Chang Sung-hsi" de Ts'ao Ping-jen. El cuarto capítulo discute la biografía de Ch'ang Nai-chou y sus escritos, y presenta su obra "Los escritos sobre artes marciales". El último capítulo explica el contexto social y político del resurgimiento del tai chi chuan en el siglo XX. Adjunta la nota del editor español y bibliografía.

873. Wile, Douglas (2007). Extractos biográficos y escritos de Zheng Manquing sobre taijiquan y qigong. Romanones: Tao. 1aㅡ ed. 163 p. : il. ; 15x21 cm. ISBN: 978-84-934080-6-0. Depósito legal: M. 446512007. Palabras clave: historia, principios técnicos, principios teóricos, principios filosóficos, biografía, nutrición, salud. Resumen: Manual teórico de artes marciales chinas. La obra esta formada por dos capítulos. El primer capítulo incluye la introducción del traductor que analiza la provincia y ciudad natal de Zheng Manqing, su contexto intelectual, relata la biografía del autor, recopila la traducción de la biografía de Wu Guozhong, algunos relatos sobre la vida de Zheng Manquing y distintos fragmentos y entrevistas aparecidos en la prensa de Taiwán, analiza su educación y algunas características de su pensamiento plasmadas en su obra. El segundo capítulo reúne los artículos y comentarios de Zheng Manquing, y los apuntes de sus alumnos, sobre los principios técnicos, teóricos y filosóficos del taijiquan y su práctica.

874. Wong, Kiew Kit (1998). El arte del tai chi chuan : guía completa de principios y práctica. Barcelona: Martínez Roca. 1aㅡ ed. 318 p. : il. ; 15x23,5 cm. ISBN: 84-270-2357-X. Depósito legal: B. 24532-1998. (2a ed., 2000; $4^{\underline{a}}$ ed., 2003; $5^{\underline{a}}$ ed., 2004). Palabras clave: qigong, formas, historia, fundamentos teóricos, fundamentos técnicos, principios técnicos, ejercicios, combate, entrenamiento, táctica, textos, taijiquan, escuelas, fundamentos filosóficos, salud, taoísmo, armas. Resumen: Manual teórico y técnico de tai chi chuan. La obra esta formada por 21 capítulos. El primer capítulo expone las características marciales del tai chi chuan además de compararlo con el resto de artes y prácticas marciales. El segundo capítulo expone la teoría del yin/yang así como su aplicación a la práctica del tai chi chuan. El tercer capítulo narra los orígenes del tai chi chuan y los diferentes estilos junto con sus maestros. El cuarto capítulo presenta los consejos prácticos incluidos en el "canto de los secretos para el entrenamiento" de Wu Yuxiang, la "fórmula de los cinco caracteres" de Li Yi-yu y los "diez puntos importantes del tai chi chuan" de Yang Deng-fu. El quinto capítulo enumera las trece técnicas del tai chi y describe la ejecución de la postura de los tres círculos, un ejercicio para desarrollar el aplomo y equilibrio, las cuatro técnicas primarias y las cuatro técnicas secundarias de manos acompañadas de su representación gráfica y esquemas de movimiento, además de discutir los problemas de rodilla supuestamente asociados con la práctica del tai chi. El sexto capítulo presenta los tipos de entrenamiento chi kung que existen además de explicar y representar algunos de sus ejercicios. El séptimo capítulo incluye la descripción e ilustración de la forma simplificada de 24 movimientos y la forma de 48 movimientos de tai chi. El octavo capítulo enumera los principios técnicos del trabajo de manos junto con la descripción de algunos ejercicios básicos y avanzados de dicho trabajo acompañados de su representación gráfica. El noveno capítulo comenta los requisitos necesarios para aplicar el tai chi a una situación de combate además de exponer la aplicación marcial de la forma simplificada de 24 movimientos de tai chi junto con sus ilustraciones explicativas y esquemas de movimiento. Los dos siguientes capítulos describen la ejecución técnica y desarrollo de nuevas secuencias de combate de tai chi chuan acompañadas de sus representaciones gráficas. El décimo segundo capítulo detalla la concepción china sobre la salud, analiza los factores que intervienen sobre la salud y enumera los efectos del tai chi chuan sobre la misma. Los siguientes seis capítulos señalan las características distintivas, nombran los movimientos y representan la ejecución de las formas de los estilos de tai chi chuan Wudang, estilo Chen, estilo Yang, estilo Wu de Wu Yu-xiang, estilo de Wu Chuan-you y estilo Sun. El décimo noveno capítulo explica el porqué apenas se utilizan las armas en el tai chi chuan, algunas de sus funciones y analiza el uso de la espada, la cimitarra y el báculo, incluyendo la representación de algunos de sus ejercicios. El vigésimo capítulo incluye el "tratado sobre el tai chi chuan" junto con las notas explicativas del autor. El último capítulo analiza la relación entre el tai chi chuan y el taoísmo. Adjunta notas aclaratorias.

875. Yang, Jwing-Ming (1995). Guía de taijiquan. Villaviciosa de Odón: Mirach. 1ae ed. 120 p. : il. ; 18x24 cm. ISBN: 84-87476-63-5. Depósito legal: no.

876. Yang, Jwing-Ming (2001). Tai chi chuan : aplicaciones marciales : estilo Yang avanzado de tai chi chuan. Móstoles: Arkano Books. 1aㅡ ed. 413 p. : il. ; 17x24 cm. ISBN: 84-89897-38-7. Depósito legal: M. 410892000. (2 ${ }^{a}$ ed., 2002). Palabras clave: fundamentos técnicos, principios técnicos, formas, combate, estrategia, taijiquan, escuelas, aplicación marcial. Resumen: Manual teórico y técnico de tai chi chuan. El libro esta compuesto por 6 capítulos. El primer capítulo explica en qué consiste la práctica del tai chi chuan y sus diferentes métodos de entrenamiento, cuáles son los principios que debe seguir el practicante para convertirse en un buen practicante de tai chi y cómo utilizar este libro. El segundo capítulo analiza los objetivos de las secuencias técnicas en las artes marciales, los principios generales de las técnicas de tai chi, y analiza la ejecución y la aplicación marcial de las principales técnicas del tai chi chuan del estilo yang con la ayuda de numerosas ilustraciones y esquemas de movimiento y comentando el significado e interpretación de cada postura. El tercer capítulo comenta los puntos clave 
en el entrenamiento del empuje de manos, los métodos de entrenamiento de los sonidos Hen-Ha y sus principios técnicos, las características generales y ejercicios básicos del entrenamiento con balón de tai chi, expone los conceptos estratégicos, los principios técnicos y los ejercicios básicos del empuje de manos junto con la secuencia fotográfica y el esquema de movimiento de cada uno de ellos, y describe e ilustra las aplicaciones marciales de los ejercicios antes explicados. El cuarto capítulo expone las reglas y principios generales del conjunto de lucha tai chi, describe los movimientos de cada forma, analiza su movimiento y estrategia y sus posibles aplicaciones marciales, con el apoyo de numerosas ilustraciones y esquemas de movimiento. El quinto capítulo comenta la estrategia y los aspectos morales ante una pelea real, describe diferentes ejercicios para entrenar en el combate real, expone los principios en la sincronización del ataque y la teoría del Jin en un combate y presenta poemas y canciones sobre la estrategia del combate. El último capítulo realiza un resumen y conclusión de las ideas generales presentadas en el libro. Adjunta apéndices que enumeran las posturas del estilo yang de tai chi, el conjunto de lucha tai chi y un glosario de términos chinos junto con su traducción.

877. Yang, Jwing-Ming (2008). Taijiquan, estilo Yang clásico : método completo y qigong. Móstoles: Arkano Books. $1^{\mathfrak{a}}$ ed. 376 p. : il. ; 17x24 cm. ISBN: 978-84-96111-37-0. Depósito legal: M. 753-2008. Palabras clave: fundamentos técnicos, qigong, taijiquan, escuelas. Resumen: Tratado teórico y técnico del taijiquan del estilo Yang. Esta dividido en cinco capítulos, abordando el primero de ellos la historia de las artes marciales chinas, del taijiquan y del estilo Yang, para luego aportar la base teórico del taijiquan, desde su concepto hasta sus contenidos, su proceso de enseñanza y algunos consejos prácticos para mejorar. El segundo capítulo presenta las definiciones del qi y el qigong así como las categorías del qigong, los principios básicos de su teoría de entrenamiento y su aplicación al taijiquan como parte del qigong marcial. El tercer capítulo define los fundamentos del taijiquan y describe sus ocho puertas y cinco desplazamientos. El cuarto capítulo presenta la teoría del taijiquan del estilo yang, comenzando por cómo practicar la secuencia de movimientos, cuáles son sus posturas básicas, los ejercicios yin y yang del qigong de taijiquan para finalizar con la descripción de cada uno de los movimientos de la secuencia del estilo Yang, con apoyo gráfico y diagrama de los movimientos que se realizan en cada uno de ellos. El último capítulo está dedicado a la conclusión final u objetivo del libro. Adjunta dos apéndices, el primero de ellos con el listado de nombres de los movimientos del estilo Yang y el segundo con una glosario de términos chinos y su traducción.

878. Yang, Jwing-Ming (2008). Teoría del taiji y fuerza marcial : taijiquan avanzado del estilo Yang. Móstoles: Arkano Books. 1aㅡ. ed. 312 p. : il. ; 17x24 cm. ISBN: 978-84-96111-36-3. Depósito legal: M. 752-2008. Palabras clave: fundamentos técnicos, taijiquan, escuelas. Resumen: Tratado teórico y técnico sobre el taijiquan y la fuerza marcial o Jin. Esta dividido en 4 capítulos, presentando el primero de ellos la teoría sobre la historia del taiji y del estilo Yang, qué es el taijiquan, cómo se entrena y cuáles son sus verdaderos objetivos. El segundo capítulo aborda el qi y las posturas del taijiquan, desde un punto de vista teórico y práctico, con la explicación detallada de cómo hacer circular el qi, cuáles son sus movimientos y las posturas correctas y sus reglas. El tercer capítulo desarrolla y ahonda en el Jin o fuerza marcial, desde su definición y clasificación básicas hasta la teoría general del jin de taiji. Continua con la descripción de la acumulación del jin en las posturas y partes del cuerpo y los diferentes tipos de Jin y sus aplicaciones principales y secundarias, con apoyo gráfico y esquemas de movimiento. El último capítulo presenta la conclusión final y se adjuntan dos apéndices sobre poemas y canciones de taiji y un glosario de términos chinos.

879. Yang, Peter (1996). Tai-chi zen : manual de un fiel al tao. Barcelona: Alas. $1^{\mathfrak{a}}$ ed. 143 p. : il. ; 17x24 cm. ISBN: 84-203-0376-3. Depósito legal: B. 1725-1996. Palabras clave: formas, fundamentos teóricos, principios técnicos, taijiquan, escuelas, música. Resumen: Manual teórico y técnico de tai chi. La obra esta formada por 3 capítulos precedidos por una introducción que resume los contenidos del libro y un preámbulo que incluye una poesía y la presentación del autor junto con sus notas biográficas y convivencias. El primer capítulo enumera los principios del tai chi zen, describe su forma de respiración, el método de respiración de los 2000 días, narra los orígenes del tai chi, ofrece varios consejos para su práctica y aprendizaje, explica sus principios técnicos y beneficios, define varios conceptos relacionados con las artes marciales, incluye varias historias y aforismos, y describe la ejecución de algunos ejercicios de calentamiento acompañados de su representación gráfica. El segundo capítulo enumera las condiciones, principios y reglas para la práctica del tai chi, y describe la ejecución de la tabla de 80 movimientos del estilo Yang acompañada de su representación gráfica, esquemas de movimiento y orientación. El tercer capítulo incluye la letra de varias canciones. Adjunta un certificado de calificación e información de contacto de los grupos que practican el tai chi zen de la escuela de Peter Yang.

880. Yang, Peter y Prat Banús, José María (1978). Tai chi : equilibrio y armonía para todas las edades. Barcelona: Alas. 1aㅡ ed. 128 p. : il. ; 15x21,5 cm. ISBN: 84-203-0070-5. Depósito legal: B. 13031-1978. (2ª ed., 1979; $3^{\mathrm{a}}$ ed., 1984; $4^{\mathrm{a}}$ ed., 1985; 5a ed., 1987). Palabras clave: formas, historia, principios técnicos, filosofía, taijiquan, escuelas, salud. Resumen: Manual teórico y técnico de tai chi. La obra esta dividida en 2 partes. La primera parte consta de 10 capítulos. El primer capítulo expone la biografía del 
maestro Peter Yang, mientras que el segundo describe los problemas de la sociedad actual y los beneficios derivados de la práctica del tai chi. El tercer capítulo explica en qué consiste el tai chi. El cuarto capítulo señala la importancia de la respiración y comenta los efectos del tai chi sobre la salud y las enfermedades. El quinto capítulo comenta la vertiente marcial del tai chi chuan y describe cuál es la aplicación de sus movimientos. El sexto capítulo expone los fundamentos filosóficos de tai chi mientras que el séptimo narra la historia del tai chi y sus diferentes escuelas. Los tres últimos capítulos enumera los requisitos previos para la práctica, describe la forma adecuada de respirar y señala las 10 reglas de oro o principios técnicos. La segunda parte presenta la descripción técnica y secuencia fotográfica de la forma de 80 movimientos de la escuela Yang. Adjunta notas del autor, bibliografía y el pentagrama de "La ciencia de la salud".

881. Yu, Tricia (2003). Taichi : mente y cuerpo. Barcelona: Círculo de Lectores. 1a ed. 160 p. : il. ; 19x24 cm. ISBN: 84-672-0323-4. Depósito legal: no. (3a ed., 2004). Palabras clave: formas, fundamentos técnicos, taijiquan, escuelas, fundamentos teóricos. Resumen: Manual teórico y técnica de tai chi. La obra esta dividida en 2 partes, precedidas de una introducción en la que se explica el origen y objetivos del taichi, los requisitos previos antes de comenzar a practicar, los diferentes tipos de respiración y su aplicación en el taichi, y un conjunto de ejercicios para percibir el qi y calentar antes de la práctica. La primera parte describe e ilustra la ejecución técnica de los ejercicios preparatorios antes de la realización de la forma del estilo Yang. Los ejercicios están agrupados en 3 partes, al igual que los movimientos de la forma Yang, y son explicados en ilustrados por partes, incluyendo esquemas de movimiento y los puntos más importantes de cada posición. La segunda parte expone la secuencia de movimientos de la forma del estilo Yang, dividiéndola en 3 partes y explica cada movimiento por partes, a través de varias fotografías y con esquemas de movimiento de las extremidades. Finaliza con algunos ejercicios individuales, por parejas y grupo para cultivar el qi. Adjunta un glosario, contactos de interés y un índice.

882. Yu, Tricia (2003). Taichi : mente y cuerpo. Madrid: Tursen S.A. / H. Blume. $1^{\mathrm{a}}$ ed. 160 p. : il. ; 19x24 cm. ISBN: 84-89840-47-4. Depósito legal: no. Palabras clave: formas, fundamentos técnicos, taijiquan, escuelas, fundamentos teóricos. Resumen: Manual teórico y técnica de tai chi. La obra esta dividida en 2 partes, precedidas de una introducción en la que se explica el origen y objetivos del taichi, los requisitos previos antes de comenzar a practicar, los diferentes tipos de respiración y su aplicación en el taichi, y un conjunto de ejercicios para percibir el qi y calentar antes de la práctica. La primera parte describe e ilustra la ejecución técnica de los ejercicios preparatorios antes de la realización de la forma del estilo Yang. Los ejercicios están agrupados en 3 partes, al igual que los movimientos de la forma Yang, y son explicados en ilustrados por partes, incluyendo esquemas de movimiento y los puntos más importantes de cada posición. La segunda parte expone la secuencia de movimientos de la forma del estilo Yang, dividiéndola en 3 partes y explica cada movimiento por partes, a través de varias fotografías y con esquemas de movimiento de las extremidades. Finaliza con algunos ejercicios individuales, por parejas y grupo para cultivar el qi. Adjunta un glosario, contactos de interés y un índice.

883. Yunzben, Ma (trad.) (1986). Taijiquan : Taichi en 88 movimientos. Madrid: Miraguano. 1aㅡ ed. 237 p. : il. ; 13x19,5 cm. ISBN: 84-85639-76-6. Depósito legal: M. 35152-1986. (2ª ed., 1989; $3^{\text {a }}$ ed., 1999; 4를. 2005). Palabras clave: formas, fundamentos técnicos, principios técnicos. Resumen: Manual técnico del taijiquan. En su introducción expone brevemente las características de la práctica del taijiquan y relata los puntos básicos para su aprendizaje y práctica. A continuación expone los 88 movimientos de los que consta, aportando una breve explicación, los puntos esenciales de los ejercicios, e ilustraciones que representan tanto la posición inicial y final del ejercicio como la trayectoria descrita por los miembros en movimiento.

884. Zhang, Fuxing (1997). El libro del tai chi : las tres variantes de la danza de armonía china. Barcelona: Martínez Roca. $1^{\text {a }}$ ed. 222 p. : il. ; 14x21,5 cm. ISBN: 84-270-2209-3. Depósito legal: B. 15741-1997. (2aㅡ ed., 1998; 3a ed., 2001; 4⿳亠口了 ed., 2002). Palabras clave: formas, historia, fundamentos técnicos, principios técnicos, combate, escuelas. Resumen: Manual teórico y técnico de tai chi chuan. La monografía esta formada por 6 capítulos precedidos por un comentario sobre los maestros de tai chi chuan del autor y la práctica que realiza. El primer capítulo detalla el origen y filosofía del tai chi chuan, las diferentes escuelas, y los beneficios de su práctica. El segundo capítulo analiza las cuatro características o principios del tai chi chuan, como son la suavidad, delicadeza y lentitud; la continuidad y regularidad; la circularidad, y la armonía y totalidad, así como su correcta aplicación al movimiento. El tercer capítulo explica los aspectos fundamentales en la práctica del tai chi chuan para progresar, como el trabajo consciente, la relajación, la coordinación, el dominio del centro de gravedad, la respiración, la ritmicidad, el progreso gradual, y la paciencia, resistencia y perseverancia. Los dos siguientes capítulos presentan la secuencia de movimientos de la forma de tai chi simplificado y de tai chi estándar, describiendo cada movimiento por partes, adjuntando varias fotografías y esquemas de movimiento, señalando los puntos clave y un diagrama de los pasos de cada forma. El último capítulo 
expone e ilustra varios ejercicios del empuje de manos dentro de los movimientos básicos, con paso fijo y con paso móvil. Adjunta un índice temático.

885. Zhaoming, Shao (2009). La energía del tai chi con una forma completa de ocho movimientos. Madrid: Tutor. $1^{a}$ ed. 64 p. : il. ; 21x30,5 cm. ISBN: 978-84-7902-797-1. Depósito legal: B. 39626-2009. Palabras clave: historia, fundamentos teóricos, fundamentos técnicos, qigong, escuelas, taijiquan, escuelas, aplicación marcial, meditación. Resumen: Manual teórico y técnico de tai chi. El libro esta formado por 12 capítulos precedidos por una introducción que comenta los contenidos del libro. El primer capítulo narra la historia del tai chi y sus diferentes estilos, su aplicación marcial, sus accesorios y sus armas. El segundo capítulo expone el significado del símbolo del yin/yang y el significado del tai chi. El tercer capítulo explica el concepto del qi y del dan tian. El cuarto capítulo describe los diferentes tipos de respiración mientras que el quinto enumera los beneficios derivados de la práctica del tai chi y comenta los requisitos necesarios para la práctica. El sexto capítulo describe e ilustra algunos ejercicios de calentamiento mientras que el séptimo presenta distintos ejercicios de qigong. El octavo capítulo explica los fundamentos técnicos del tai chi para luego presentar la descripción técnica y secuencia fotográfica de la forma de 8 movimientos de tai chi del estilo yang. El décimo capítulo incluye varios ejercicios de enfriamiento junto con su representación gráfica para finalizar con un ejercicio de meditación de pie y las conclusiones finales. Adjunta la biografía del autor y los agradecimientos. Incluye un DVD de 55 min. de duración con 10 capítulos que incluyen la introducción, los ejercicios de calentamiento, los ejercicios de qigong, los fundamentos del tai chi y sus posturas, la forma de los 8 movimientos de tai chi, los ejercicios de enfriamiento, la meditación de pie, las aplicaciones marciales, los accesorios y armas del tai chi y la conclusión, explicados en español e inglés.

\subsubsection{Wing Chun}

886. Chiang, Lee (1981). Wing chun-kung fu. Barcelona: Alas. 1aㅡ ed. 48 p. : il. ; 17x23,5 cm. ISBN: 84-2030117-5. Depósito legal: B. 26691-1981. (2ª ed., 1985). Palabras clave: historia, fundamentos técnicos, principios técnicos, anatomía, wing chun, fundamentos teóricos. Resumen: Manual teórico y técnico de wing chun. La obra consta de 19 capítulos. El primer capítulo presenta la biografía del autor. El segundo capítulo narra la historia y evolución del wing chun. El tercer capítulo define el concepto de chi, mientras que el cuarto localiza el punto del tan tien y describe un ejercicio de respiración. El quinto capítulo enumera los fundamentos técnicos que componen el wing chun así como sus principios técnicos, para en el sexto capítulo describir la ejecución de sus posturas junto con su ilustración. El séptimo capítulo incluye varias fotografías explicativas de las técnicas de bloqueo correctas e incorrectas dentro del wing chun acompañadas de una pequeña explicación. El octavo capítulo expone la ejecución técnica de las dos patadas básicas acompañadas de su representación gráfica y una aplicación de las mismas. El siguiente capítulo expone los diferentes bloqueos según la guardia adoptada. Los dos siguientes capítulos detallan la teoría del centro del cuerpo y de mirar siempre al oponente adjuntando algunas fotografías ilustrativas. El décimo segundo capítulo incluye la descripción de una serie de lop sao (técnica de atrapar los brazos) para luego exponer la teoría del codo inmóvil. El siguiente capítulo explica en qué consiste la práctica del chi sao para continuar con un comentario sobre el trabajo con el muñeco de madera (yang jong) y un esquema de su construcción. Los últimos seis capítulos incluyen la secuencia fotográfica de varias técnicas de ataque y defensa acompañadas de una breve descripción.

887. Chun, Yip y Connor, Danny (1995). Wing chun : técnica y filosofía (el estilo de kung fu más practicado del mundo). Barcelona: Paidotribo. 1a ed. 161 p. : il. ; 15x21,5 cm. ISBN: 84-8019-204-6. Depósito legal: B. 1573-1995. (2 ${ }^{\underline{a}}$ ed., 1999; $2^{\underline{a}}$ ed. y $1^{\underline{a}}$ reimp., 2006; $3^{\underline{a}}$ ed., 2006, ISBN: 978-84-8019-204-0). Palabras clave: formas, fundamentos técnicos, combate, textos, maestros. Resumen: Manual teórico y técnico de wing chun. La obra esta compuesta por 10 capítulos. Los dos primeros capítulos narran la entrevista mantenida por el autor y el maestro, y cómo comenzaron a estudiar juntos. El tercer capítulo profundiza en los orígenes del wing chun, para luego relatar la biografía de Yip Man y su filosofía. El quinto capítulo explica los principios técnicos del chi sau. Los siguientes tres capítulos describen la secuencia de movimientos de las tres formas del wing chun (Siu Lim Tao, Chum Kiu, Biu Tze) junto con sus ilustraciones. Los dos últimos capítulos incluyen preguntas y respuestas a Yip Chun sobre la práctica del wing chun, y la Doctrina del Medio de Confucio.

888. Gutiérrez, Víctor (2005). Wing tsun : el tao de la acción. Madrid: Budo International. $1^{a}$ ed. 223 p. : il. ; $17 \times 24$ cm. ISBN: 84-96492-02-8. Depósito legal: M. 39136-2008. Palabras clave: fundamentos teóricos, táctica, fundamentos técnicos, programa técnico, pedagogía, principios técnicos, defensa personal, entrenamiento, salud, sistemas de entrenamiento. Resumen: Manual teórico y técnico de wing chun. El libro esta formado por 4 partes. La primera parte contiene tres capítulos exponiendo el primero de ellos los principios técnicos del wing chun y su aplicación en combate. El segundo capítulo describe los principios del entrenamiento y sus métodos, así como su aplicación al deporte, la defensa 
personal y la rehabilitación. El tercer capítulo relaciona el chi sao con la meditación. La segunda parte consta de cinco capítulos. El primero analiza las estrategias globales de las artes marciales para luego explicar los principios técnicos y tácticas de las defensas. El tercer capítulo analiza los principios de aprendizaje del chi sao, mientras que el cuarto expone las fases de aprendizaje y entrenamiento junto con la ilustración de algunas series técnicas y sus aplicaciones. El quinto capítulo estudia los principios técnicos de efectividad de los movimientos de wing chun. La tercera parte incluye cinco capítulos. El primer capítulo analiza los factores psicológicos, físicos y técnicos implicados en una situación de defensa personal. Los dos siguientes capítulos explican los principios de actuación ante una situación de defensa personal ante varios ataques y contra individuos armados respectivamente. El cuarto capítulo presenta el programa de contenidos del método de enseñanza lat sao. El quinto capítulo expone los principios tácticos del combate cuerpo a cuerpo y en el suelo así como la progresión técnica del programa de aprendizaje y un comentario de los beneficios del trabajo de chi gerk. La última parte esta formada por cinco capítulos. El primer capítulo narra la leyenda de la monja Ng Nui. El segundo capítulo comenta las diferencias biológicas entre hombres y mujeres, y analiza los motivos de las mujeres para no practicar artes marciales y no alcanzar un alto rendimiento. El tercer capítulo estudia los factores que influyen en el deterioro funcional del cuerpo para luego presentar los beneficios asociados a la práctica del wing chun. El cuarto capítulo analiza los conocimientos marciales de Bruce Lee . El último capítulo analiza el futuro del wing chun. Adjunta un apéndice que resume las características de los tres niveles de progresión técnica del wing chun y describe los indicadores y métodos de entrenamiento del nivel avanzado.

889. Gutiérrez, Víctor (2006). Re-evolution : los secretos del wing tsun. Madrid: Budo International. 1a ed. 143 p. : il. ; 16x24 cm. ISBN: 84-96492-35-4. Depósito legal: M. 29589-2006. Palabras clave: fundamentos técnicos, principios técnicos, defensa personal policial, wing chun. Resumen: Manual teórico y técnico de wing tsun. La obra esta formada por 15 capítulos. El primer capítulo analiza la situación actual del wing tsun y discute sus principios técnicos. El segundo capítulo reflexiona sobre la adaptación del wing tsun a la época actual. El tercer capítulo explica el concepto de "quédate pegado". El cuarto capítulo presenta el sistema re-evolution del autor y las razones para su creación. El quinto capítulo explica los principios técnicos de wing tsun ante un grappler. El sexto capítulo expone las fases de entrenamiento con el muñeco de madera así como su aplicación en el combate real. El séptimo capítulo comenta las características de los niveles de aprendizaje del wing tsun y profundiza en los contenidos del nivel avanzado. El octavo capítulo expone la relación entre la meditación y el chi sao. El noveno capítulo expone los éxitos y problemas del wing tsun en la actualidad. El décimo capítulo analiza las características del wing tsun que se adaptan a las necesidades de las fuerzas de orden pública para en el siguiente capítulo presentar el programa SAFE de defensa policial operativa, sus objetivos, características y principios. El décimo segundo capítulo analiza las peculiaridades de los niños para adaptar el entrenamiento de wing tsun. El siguiente capítulo expone los principios de actuación y hábitos ante situaciones de defensa personal y las medidas de actuación en diversas situaciones. El décimo cuarto capítulo presenta algunos ejemplos del sistema re-evolution sobre la aplicación de las técnicas de chi-sao al combate real acompañadas de su secuencia fotográfica. El último capítulo incluye la comparación gráfica de algunas secciones del wing tsun clásico con el reevolution.

890. Kernspecht, Keith Ronald (1996). El arte del combate : estrategia, táctica, fisiología, psicología, filosofía e historia de la defensa personal sin armas. Bilbao: Organización Española de Wing Tsung. $1^{\mathrm{a}}$ ed. 346 p. : il. ; 14x21 cm. ISBN: 84-605-5910-6. Depósito legal: M. 45661-1996. Palabras clave: fundamentos teóricos, fundamentos técnicos, principios técnicos, defensa personal, táctica. Resumen: Manual teórico y técnico de wing chun. El libro esta compuesto por 18 capítulos precedidos por un prólogo que comenta los principios biomecánicos del wing chun y una introducción que señala los objetivos del libro. El primer capítulo analiza los principios fundamentales que debe tener un buen sistema de defensa personal y las técnicas de defensa de los métodos tradicionales. El segundo capítulo comenta las características de los 4 tipos de defensa del wing chun junto con una breve explicación de las consideraciones jurídicas de la defensa personal. El tercer capítulo expone los fundamentos teóricos de las distintas de combate, los desplazamientos y los ataques de puño. El cuarto capítulo describe la ejecución de los puñetazos en cadena. El quinto capítulo analiza la posición óptima de los brazos en la defensa. El sexto capítulo detalla los principios de combate del wing chun mientras que el séptimo presenta su aplicación a los fundamentos técnicos del wing chun acompañados de su representación gráfica. El octavo capítulo expone las ventajas del wing chun junto con la descripción e ilustración de las fases de un combate total. El noveno capítulo presenta la aplicación del sistema wing chun para mujeres junto con la explicación de distintos ejercicios de entrenamiento ilustrados y una entrevista con el autor. El décimo capítulo expone los principios físicos aplicados en el wing chun junto con algunos consejos para la defensa personal real. El siguiente capítulo presenta los fundamentos del budismo, taoísmo y confucianismo y su aplicación al wing chun. El decimosegundo capítulo describe el proceso de enseñanza-aprendizaje del wing chun, presenta una tabla que analiza las diferencias del 
sistema Leung Ting y los estilos tradicionales e información general sobre la historia y organización del wing chun. El siguiente capítulo relata la historia de las artes de combate. Los dos siguientes capítulos representan el árbol genealógico del sistema wing chun y la cronología de las artes de combate. El decimosexto capítulo incluye algunas preguntas y respuestas frecuentes sobre el sistema wing chun. Los dos últimos capítulos señalan las ventajas del wing chun sobre otros estilos e incluyen las opiniones de diferentes expertos. Adjunta la biografía del autor y un comentario sobre la profesionalización de los instructores de wing chun.

891. Ortíz Perea, José (1995). Wing-chun : estudio teórico y práctico. Barcelona: Alas. 1aa ed. 122 p. : il. ; $17 \times 24$ cm. ISBN: 84-203-0368-2. Depósito legal: B. 24723-1995. Palabras clave: fundamentos técnicos, principios técnicos, historia, ejercicios, entrenamiento, equipamiento, sistemas de entrenamiento. Resumen: Manual teórico y técnico de wing chun. La obra consta de 4 capítulos precedidos por un prólogo y una introducción que explica en qué consiste el wing chun y sus características. El primer capítulo señala cuáles son los contenidos del wing chun. El segundo capítulo describe la ejecución de los fundamentos técnicos del wing chun acompañados de su ilustración además de comentar sus principios técnicos. El tercer capítulo explica en qué consiste la práctica del chi sao y sus distintos ejercicios, además de describir su ejecución técnica e incluir sus ilustraciones explicativas. El último capítulo comenta las características, objetivos y beneficios del entrenamiento con el muñeco de madera e incluye la secuencia fotográfica de su forma estándar. Adjunta un anexo que relata el origen e historia del wing chun.

892. Pascual Martín, Santiago (2002). El arte del wing chun : ciencia, filosofía, técnica. Barcelona: Alas. 1a ed. 211 p. : il. ; 16×24 cm. ISBN: 84-203-0412-3. Depósito legal: B. 6597-2002. Palabras clave: formas, historia, fundamentos teóricos, fundamentos técnicos, principios técnicos, armas. Resumen: Manual teórico y técnico de wing chun. La obra consta de 6 capítulos, precedidos por un capítulo introductorio que narra la historia del origen del arte. El primer capítulo presenta algunas historias y anécdotas sobre el proceso de enseñanza y la relación profesor-alumno en el wing chun así como algunos consejos prácticos para escoger a un buen sifu. El segundo capítulo expone los contenidos técnicos del wing chun, sus características, principios técnicos y métodos de entrenamiento además de la secuencia fotográfica de las tres formas a mano vacía. El tercer capítulo expone los beneficios del chi sao, describe su estructura de aprendizaje e incluye la descripción e ilustración de los movimientos básicos de las diferentes prácticas que lo conforman. El cuarto capítulo relata la historia del muñeco de madera (Muk Yan Jong), sus métodos de entrenamiento, enumera las principales técnicas utilizadas, describe sus características físicas, ilustra algunos de sus movimientos y secuencias técnicas, comenta las características y beneficios del entrenamiento con armas del wing chun analizando las cuatro partes del entrenamiento con palo (kwan), sus técnicas y movimientos, el manejo de los cuchillos (baat jam do) junto con algunas ilustraciones explicativas. El quinto capítulo expone los principios técnicos de combate del wing chun además de algunos aforismos. El último capítulo incluye la terminología técnica básica.

893. Prat Banús, José María (1984). Wing tsun kuen kung fu : aplicaciones prácticas. Barcelona: Alas. 1aa ed. 47 p. : il. ; 17x24 cm. ISBN: 84-203-0162-0. Depósito legal: B. 14613-1984. Palabras clave: historia, fundamentos técnicos, aplicación marcial. Resumen: Manual teórico y técnico de Wing Tsun Kuen. El primer capítulo aborda la historia del boxeo chino para terminar explicando el origen del Wing Tsun Kuen y sus maestros. El segundo capítulo explica los fundamentos técnicos del Wing Tsun Kuen, la clasificación de sus técnicas, y algunos comentarios sobre las formas y el aprendizaje del estilo. La tercera parte incluye 8 ejercicios de aplicaciones prácticas del Wing Tsun Kuen, describiendo su ejecución y acompañados de series fotográficas.

894. Prat Banús, José María (1988). Chiy tou wing chun kuen : el completo sistema Wing Chun. Barcelona: Alas. 1a ed. 174 p. : il. ; 15x21,5 cm. ISBN: 84-203-0216-3. Depósito legal: B. 9859-1988. Palabras clave: formas, historia, fundamentos teóricos, táctica, principios técnicos, principios éticos, combate, entrenamiento, fundamentos filosóficos, equipamiento, maestros, armas. Resumen: Manual teórico y técnico de wing chun. La obra esta compuesta por dos partes precedidas por los agradecimientos, un prólogo que presenta la creación de la obra y una introducción que explica el desarrollo de la cultura china, presenta el estilo wing chun kuen, sus diez mandamientos, las influencias recibidas por el autor y un comentario sobre los contenidos y objetivos de la obra. La primera parte consta de 12 capítulos. El primer capítulo presenta los fundamentos teóricos del wing chun mientras que el segundo incluye sus principios del entrenamiento. El tercer capítulo ofrece varios consejos sobre la práctica de siu lim tao además de sus principios técnicos. Los dos siguientes capítulos comentan las características técnicas de las formas cham kiu y bil jee junto con sus objetivos y principios técnicos. El sexto capítulo explica las características y desarrollo del método chi sau junto con sus fundamentos teóricos y técnicos. El séptimo capítulo explica en qué consiste el entrenamiento con el muñeco de madera, sus fundamentos y requisitos técnicos junto con una secuencia gráfica de su entrenamiento. Los dos siguientes capítulos presentan las características, fundamentos y principios técnicos en el manejo del palo largo y los cuchillos mariposa. El décimo capítulo explica los principios tácticos del combate. El décimo primer 
capítulo expone los principios filosóficos y morales del wing chun, mientras que el último capítulo comenta algunas generalidades del wing chun, su enseñanza. La segunda parte consta de 2 capítulos. El primer capítulo incluye numerosas fotografías de los exponentes que componen la familia del wing chun kung fu. El segundo capítulo incluye un epílogo.

895. Ting, Leung (1985). Wing tsun kuen kung fu 1. Madrid: Esteban Sanz Martínez. 1aa ed. 181 p. : il. ; 21x28 cm. ISBN: 84-85977-27-0. Depósito legal: M. 34514-1985. Palabras clave: formas, historia, fundamentos técnicos, entrenamiento, aplicación marcial, grados, instituciones. Resumen: Manual teórico y técnico de wing tsun. La obra esta formada por 10 capítulos. El primer capítulo presenta a los principales maestros del arte junto con varios prólogos. El segundo capítulo relata la historia del wing tsun. El tercer capítulo detalla la biografía del autor incluyendo numerosas fotografías. El cuarto capítulo describe la organización de la Wing Tsun Martial Arts Association, sus objetivos, sistema de grados y títulos. El quinto capítulo narra la expansión del wing tsun por Europa. El sexto capítulo comenta las características del sistema de entrenamiento del wing tsun y sus contenidos técnicos, como son las formas de boxeo, el chi sau, el entrenamiento de fuerza, los ejercicios complementarios, las técnicas del muñeco de madera y las armas. El séptimo capítulo describe el entrenamiento y aprendizaje de la forma siu-nin-tau además de incluir su descripción y secuencia fotográfica. El octavo capítulo presenta la aplicación de las técnicas de la forma siu-nin-tau junto con su explicación. Los dos últimos capítulos presentan la ejecución de la forma chum-kiu y la aplicación marcial de sus técnicas respectivamente, incluyendo la secuencia fotográfica y un comentario explicativo de ambas.

896. Ting, Leung (1986). Wing tsun kuen kung fu 2. Madrid: Esteban Sanz Martínez. 1a ed. 181 p. : il. ; 21x28,5 cm. ISBN: 84-85977-26-2. Depósito legal: M. 40011-1986. Palabras clave: formas, historia, ejercicios, combate, aplicación marcial, equipamiento, maestros, armas. Resumen: Manual teórico y técnico de wing tsun. La obra consta de 9 capítulos. El primer capítulo narra el origen e historia del wing tsun para en el segundo capítulo relatar la biografía de Yip Man. El tercer capítulo expone los principios técnicos y de entrenamiento del wing tsun y un comentario sobre los ejercicios de chi-sau. El cuarto capítulo describe la ejecución de las técnicas de chi-sau. El quinto capítulo presenta la ejecución de la forma biu-tze así como su aplicación incluyendo numerosas fotografías explicativas. El sexto capítulo comenta las características del entrenamiento de muk-yan chong, presenta al maestro Yip Man demostrando algunas de sus técnicas y explica la aplicación marcial de algunas de sus técnicas acompañadas de su representación gráfica. Los dos siguientes capítulos muestran las técnicas básicas del luk-dim-poon-kwan (palo largo) y baat-cham-dao (cuchillos mariposa) respectivamente y acompañadas de una breve explicación. El último capítulo describe la ejecución de diversos ejercicios complementarios con el saco de pared, el muñeco, con diversos instrumentos como muelles y pesas y sin aparatos. También incluye el texto original y la traducción del manuscrito de Yip Man sobre el origen del wing tsun.

\subsubsection{Wushu / Kung Fu}

897. Aguilar, Huang (2006). Shaolin : viaje al corazón del templo. Madrid: Budo International. 1a ed. 223 p. : il. ; $17 \times 24$ cm. ISBN: 84-96492-23-0. Depósito legal: M. 18111-2006. Palabras clave: historia, principios técnicos, filosofía, entrevistas, maestros, armas. Resumen: Manual teórico y técnico de kung fu. La obra esta formada por 19 capítulos. El primer capítulo explica la organización y funcionamiento actual del templo shaolín. El segundo capítulo comenta las características especiales de los monjes guerreros. El tercer capítulo detalla los mecanismos del chi kung, sus tipos y sus efectos. El cuarto capítulo narra la historia del templo shaolín y su proceso de apertura en la actualidad. El quinto capítulo presenta la entrevista realizada a Shi Suxi, abad del templo shaolín. El sexto capítulo relata los orígenes del zen junto con algunos consejos para su práctica. El séptimo capítulo incluye la entrevista realizada a Shi Wang Heng. El octavo capítulo expone las reglas para la admisión de nuevos estudiantes en el templo shaolín, cómo se realizaba la transmisión de las enseñanzas y cuál es la situación actual. El noveno capítulo detalla los problemas en la normalización de las formas de wushu tanto en occidente como en oriente. El décimo capítulo presenta la leyenda del tai chi, relata sus orígenes y describe sus contenidos técnicos. El siguiente capítulo aclara la organización del tai chi y los problemas derivados de su enseñanza a los occidentales. El décimo segundo capítulo expone las características de la espada shaolín y su entrenamiento. Continúa con una entrevista realizada a Shi De Yang. El décimo cuarto capítulo narra la experiencia del autor dentro del templo shaolín para luego relatar la historia del templo shaolín. Los dos siguientes capítulos describen la utilización del palo y las piernas dentro del estilo de kung fu shaolín, su utilización, ventajas e inconvenientes. Los dos últimos capítulos explican en qué consiste el tui shou y cuáles son sus orígenes, junto con un comentario sobre la lucha cuerpo a cuerpo shaolín y el combate.

898. Alcántara Castilla, Fermín (2006). Lama quán pà (hop-gar wushu / kung fu), el kung fu de los monjes guerreros del Tíbet : bases y fundamentos. Madrid: Mandala. 1aㅡ ed. 191 p. : il. ; $14 \times 21 \mathrm{~cm}$. ISBN: 978-84- 
8352-017-8. Depósito legal: SE 43-2007. Palabras clave: formas, historia, fundamentos teóricos, fundamentos técnicos, programa técnico, respiración. Resumen: Tratado de introducción histórica y técnica al Lama Quàn Pài. Después de dedicar los dos primeros capítulos a detallar la historia y características de este estilo de lucha de los monjes tibetanos, paso a describir los aspectos técnicos (colocación de las manos, posiciones, técnicas de pierna y puño, ejercicios de habilidad y guardias). Aportando ilustraciones que representan estos aspectos técnicos, también expone las 3 formas de boxeo, la forma de mano larga y la forma de mano corta. Finaliza con la explicación de la respiración energética y sus características técnicas y mentales. Adjunta un árbol genealógico del estilo, el programa de enseñanza de la escuela del autor, una extensa biografía del autor y su estudiante más destacado, y bibliografía.

899. Bagué, Esteban y Alcocer, Enrique (1989). Boxeo de Wong-Lon : tang-lang-pai (mantis religiosa). Barcelona: Alas. $1^{a}$ ed. 48 p. : il. ; 16x24 cm. ISBN: 84-203-0233-3. Depósito legal: B. 5468-1989. Palabras clave: fundamentos teóricos, fundamentos técnicos, formas. Resumen: Manual técnico de Tang-Lang-Pai wushu. La obra comienza explicando lo que es el wushu y cuáles son sus orígenes, además de describir el origen de las técnicas así como la propia historia del estilo Tang-Lang-Pai, la clasificación de sus técnicas, sus armas y el papel del tao en su práctica. Continua con algunos consejos prácticos sobre el método de entrenamiento en dicho estilo y pasa a describir brevemente e ilustrar las posiciones, las patadas, los puñetazos, la primera forma de mantis (I Tang-Lang-Kun-Tao), y varias técnicas de mantis en el trabajo con compañero.

900. Bagué, Esteban y Vallés, Yolanda (1988). Pak mei kuen : kung fu. Barcelona: Alas. 1aa ed. 48 p. : il. ; 17x24 cm. ISBN: 84-203-0231-7. Depósito legal: B. 43402-1988. Palabras clave: formas, historia, fundamentos teóricos, fundamentos técnicos, aplicación marcial. Resumen: Manual teórico y técnico de kung fu. La obra esta dividida en 7 capítulos, precedidos por una breve biografía del autor y un prefacio que comenta las generalidades del pak mei y el objetivo de la obra. El primer capítulo comenta brevemente la historia de los cinco monjes de shaolín. El segundo capítulo expone las características de los estilos hung-gar o hung-kuen, wing chun y pak mei. El tercer capítulo narra la evolución del estilo pak mei hasta la actualidad, mientras que el cuarto explica en qué consiste el pak mei. Los dos siguientes capítulos muestran las ilustraciones y secuencia fotográfica de las posiciones básicas y la forma de kung fu pak mei denominada gou boo teaw (empujón de nueve pasos) respectivamente, acompañadas de una breve explicación de su ejecución técnica. El último capítulo presenta la ilustración de diversas aplicaciones de las técnicas del estilo acompañadas de un breve comentario.

901. Barioli, Cesare (1990). Kung-fu. Barcelona: Río Negro. 1ạ ed. 125 p. : il. ; 13x19 cm. ISBN: 84-87390-250. Depósito legal: 16441-1990. Palabras clave: historia, fundamentos técnicos, principios técnicos, filosofía, baguazhang, shorinji kempo, taijiquan, wushu, escuelas. Resumen: Manual teórico y técnico de wushu. La obra esta formada por 6 capítulos. El primer capítulo introduce la práctica del kung-fu comentando sus características principales y su evolución a través de los distintos periodos, las distintas escuelas y su expansión a las zonas más próximas e influencia sobre otras artes marciales. El segundo capítulo describe e ilustra la ejecución técnica de 12 figuras de los monjes budistas. El tercer capítulo profundiza en la práctica del tai chi chuan, comentando su filosofía de origen, su historia, los principios que rigen su práctica, su metodología de entrenamiento y describe la ejecución técnica junto con sus gráficos de los 15 primeros movimientos del ejercicio individual. El siguiente capítulo relata la formación del pa-kwa ch'uan y su linaje, los principios técnicos de su práctica, describe algunos de sus ejercicios individuales junto con sus gráficos y esquemas de movimiento así como de la aplicación práctica de algunos movimientos de sus formas. El quinto capítulo expone los fundamentos del t'ang lang ch'uan y describe la ejecución técnica de la forma para la preparación del principiante junto con sus ilustraciones. El último capítulo presenta la historia y filosofía del shorin-ji kempho, su práctica, la descripción de sus bases técnicas y metodología de entrenamiento, describe las técnicas de la utilización positiva de la fuerza (posiciones, desplazamientos, utilización del cuerpo, paradas, golpes, patadas y forma de entrenamiento) y la utilización negativa de la fuerza (utilización del cuerpo, llaves de muñeca, proyecciones, inmovilizaciones y ejercicios por parejas).

902. Barioli, César (Barioli, Cesare) (1975). El kung-fu. Barcelona: De Vecchi. 1aㅡ ed. 125 p. : il. ; 14x20,5 cm.

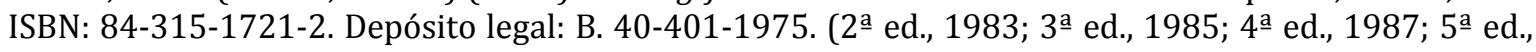
1989). Palabras clave: historia, fundamentos técnicos, principios técnicos, filosofía, baguazhang, shorinji kempo, taijiquan, wushu, escuelas. Resumen: Manual teórico y técnico de wushu. La obra esta formada por 6 capítulos. El primer capítulo introduce la práctica del kung-fu comentando sus características principales y su evolución a través de los distintos periodos, las distintas escuelas y su expansión a las zonas más próximas e influencia sobre otras artes marciales. El segundo capítulo describe e ilustra la ejecución técnica de 12 figuras de los monjes budistas. El tercer capítulo profundiza en la práctica del tai chi chuan, comentando su filosofía de origen, su historia, los principios que rigen su práctica, su metodología de entrenamiento y describe la ejecución técnica junto con sus gráficos de los 15 primeros movimientos del ejercicio individual. El siguiente capítulo relata la formación del pa-kwa ch'uan y su linaje, los principios técnicos de su práctica, describe algunos de sus 
ejercicios individuales junto con sus gráficos y esquemas de movimiento así como de la aplicación práctica de algunos movimientos de sus formas. El quinto capítulo expone los fundamentos del t'ang lang ch'uan y describe la ejecución técnica de la forma para la preparación del principiante junto con sus ilustraciones. El último capítulo presenta la historia y filosofía del shorin-ji kempho, su práctica, la descripción de sus bases técnicas y metodología de entrenamiento, describe las técnicas de la utilización positiva de la fuerza (posiciones, desplazamientos, utilización del cuerpo, paradas, golpes, patadas y forma de entrenamiento) y la utilización negativa de la fuerza (utilización del cuerpo, llaves de muñeca, proyecciones, inmovilizaciones y ejercicios por parejas).

903. Blanco Dopazo, Fernando (1993). Chi shing tang lang chuen : boxeo de la mantis religiosa siete estrellas. Barcelona: Alas. 1aㅡ ed. 48 p. : il. ; 17x24 cm. ISBN: 978-84-203-0296-6. 84-203-0296-1 (corregido). Depósito legal: B. 10935-1993. Palabras clave: historia, escuelas. Resumen: Manual teórico y técnico de Chi Shing Tang Lang Chuen. El primer capítulo detalla los diferentes estilos y subsistemas que existen del boxeo de la mantis y continua con la enumeración de los maestros de la mantis religiosa siete estrellas por todo el mundo. Los siguientes capítulos explican las características del estilo y ofrecen un resumen de sus contenidos técnicos. A continuación aparecen algunas secuencias técnicas, representadas gráficamente, para finalizar con un comentario sobre las diferencias entre este estilo y otros de la mantis, el método de realizar los pateos, y un relato sobre la historia de Lee Kwan Shan.

904. Cangelosi, Paolo (2006). La esencia del kung fu. Madrid: Budo International. 1a ed. 239 p. : il. ; 17x24 cm. ISBN: 84-96492-41-9. Depósito legal: M-41779-2006. Palabras clave: historia, fundamentos teóricos, filosofía, combate, calentamiento, baguazhang, taijiquan, escuelas, wing chun, wushu, meditación, armas. Resumen: Tratado teórico de wushu. El libro esta formado por 14 capítulos, precedidos por una introducción que comenta la biografía marcial del autor. El primer capítulo describe los fundamentos filosóficos y teóricos del pa kua, explicando los principios técnicos de su práctica y la interpretación que hace el pa kua del chi o energía. El segundo capítulo relata los orígenes e historia del hung gar, describe las características e historia de sus formas, y comenta el entrenamiento del autor con su maestro de hung gar. El tercer capítulo enumera los trece principios del estilo yang de tai chi chuan así como sus raíces filosóficas. El cuarto capítulo describe el trabajo de meditación que realiza el autor a través del tai chi chuan, ofrece unas breves nociones históricas del tai chi chuan y comenta los distintos métodos de entrenamiento de la gran forma (kung chia). El siguiente capítulo presenta la teoría de los cinco elementos y la relación entre los mismos. El sexto capítulo estudia las características y utilización de los principios técnicos y tácticos del kung fu de combate en estilo libre. El siguiente capítulo relata la historia y evolución del estilo tang lang, sus características técnicas, las peculiaridades de la forma Mo Soi Kune, la relación entre el tang lang y la astrología, y los consejos prácticos para realizar los ejercicios de acondicionamiento de este estilo. El octavo capítulo comenta la historia del estilo borracho, sus características, sus técnicas fundamentales, sus fundamentos filosóficos, la descripción de la forma Lu Bau Gu Fei y de algunos ejercicios tradicionales de acondicionamiento, y la descripción e ilustración de varias secuencias técnicas con compañero. El noveno capítulo detalla la historia, evolución y expansión del pa kua, los maestros y características de sus distintas escuelas, y describe las características técnicas de la forma Pa Men Chan. El décimo capítulo comenta la historia del tao yin o forma de gimnasia interna, sus distintos métodos de entrenamiento, describe el trabajo de los Pa Tuan Chin, Yun Chun y los 3 sistemas de Chi Kung. El siguiente capítulo expone las características técnicas del estilo chen de tai chi chuan, sus orígenes y evolución histórica, describe el trabajo tui shou (empuje de manos) y varias secuencias técnicas de defensa personal. El duodécimo capítulo explica la historia, características y clasificación de las armas del kung fu y describe la forma Nam Pak Siu Lam. El siguiente capítulo comenta el contacto del autor con el wing chun, su entrenamiento, y un análisis de las características técnicas del sistema. El último capítulo explica la utilización de las armas en los diferentes estilos de kung fu, en particular de la espada recta, además de sus principios técnicos.

905. Cangelosi, Paolo (2009). Hung gar kung fu : la forma Gong Gee Fook Fu Kune y sus aplicaciones. Madrid: Budo International. 1aㅡ ed. 143 p. : il. ; 17x24 cm. ISBN: 978-84-92484-40-9. Depósito legal: M. 252182009. Palabras clave: formas, historia, fundamentos teóricos, fundamentos técnicos, aplicación marcial, instituciones, sociedad. Resumen: Manual teórico y técnico de kung fu. El libro esta dividido en 8 capítulos precedidos por un prólogo que resume los contenidos del libro. El primer capítulo narra el origen e historia del hung gar kung fu. El segundo capítulo incluye numerosas fotos del autor con los distintos maestros del estilo. El tercer capítulo comenta la práctica de los nueve puentes del dragón de hierro (loon kou tiuet kiu), el papel de las sociedades secretas y narra el desarrollo de la revolución bóxer. El cuarto capítulo comenta la historia de la forma gong gee fook fu kune y sus características técnicas. Los dos siguientes capítulos incluyen la secuencia fotográfica de la primera y segunda parte respectivamente de la forma gong gee fook fu kune. El séptimo capítulo ilustra la aplicación marcial de la forma mientras que el último capítulo presenta las armas o zonas utilizadas para golpear del hung gar kung fu. 
906. Casal Piñeiro, Julio (2005). El kung-fu aplicado a la defensa personal policial : conceptos básicos. s.l.: Alfer. $1^{a}$ ed. 94 p. : il. ; 15x21 cm. ISBN: 84-689-3729-0. Depósito legal: VG. 936-2005. Palabras clave: historia, fundamentos técnicos, principios técnicos, defensa personal, combate, estrategia, armas. Resumen: Manual teórico y técnico de kung- fu. La obra consta de 19 capítulos precedidos por una presentación que explica qué es la defensa personal policial y cuáles sus beneficios, comenta el origen del kung-fu y los principios técnicos para ejecutar una técnica correctamente. Los cuatro primeros capítulos describen la ejecución de algunos bloqueos a la zona alta, media y baja del cuerpo así como otros realizados con las piernas, incluyendo sus correspondientes ilustraciones. El quinto capítulo presenta la descripción e ilustración de algunas técnicas de ataque con los puños y la mano abierta, para luego presentar algunas técnicas de patada. El séptimo capítulo describe por partes varias técnicas de codazo y rodillazo acompañadas de su representación gráfica, mientras que el octavo presenta dos técnicas de barrido. El noveno capítulo muestra algunas de las técnicas de defensa más comunes desde el suelo para en el décimo describir e ilustrar dos técnicas de defensa y derribo frente a una patada circular. Los dos siguientes capítulos explican la ejecución de una presa de cuello y la defensa ante un cabezazo. El décimo tercer capítulo incluye la descripción técnica de varias técnicas de luxación a la muñeca, al codo y al hombro junto con su ilustración. Los tres siguientes capítulos explican los principios técnicos de la posición de guardia, la distancia de seguridad y cómo identificar a varias personas a la vez. Los dos siguientes capítulos explican la defensa ante un ataque con un palo y con una pistola respectivamente además de adjuntar sus ilustraciones explicativas. El último capítulo comenta las estrategias físicas y psicológicas a emplear durante un combate.

907. Casarella, Antonello (2001). Lecciones de kungfú wushu : guía práctica fotográfica. Barcelona: De Vecchi. 1aㅡ ed. 111 p. : il. ; 17x24 cm. ISBN: 84-315-2674-2. Depósito legal: B. 20230-2001. (2a ed., 2004). Palabras clave: historia, fundamentos técnicos, combate, escuelas. Resumen: Manual teórico y técnico de wushu. La monografía esta dividida en 10 capítulos. Los dos primeros capítulos explican los orígenes e historia del wushu así como las bases filosóficas que impregnan dicha práctica. Continúa con una descripción de los diferentes estilos y sus habituales clasificaciones respecto a su localización (Norte-Sur), su dureza (blandos-duros) y su carácter (externos-internos). También describe brevemente los principales estilos de wushu y sus características. En el cuarto capítulo explica los diferentes objetivos que se pueden perseguir en la práctica del wushu; para luego pasar a explicar la parte técnica común a casi todos los estilos. Comienza con la descripción e ilustración del saludo, los ejercicios preparatorios, las posiciones más comunes de manos y piernas, los pasos o desplazamientos así como las técnicas de pierna y brazo (puño, palma, codo y parada). Las fotografías incluyen además un esquema del movimiento realizado por cada parte del cuerpo. El siguiente capítulo presenta algunas combinaciones de técnicas así como su aplicación en el combate contra un compañero, adjunta ilustraciones y esquemas de movimiento de cada una de ellas. Finaliza con 4 capítulos bastante breves que explican los agarres propios del wushu, algunos ejercicios para mejorar la sensibilidad o percepción de los movimientos del adversario, las técnicas del sanda o wushu deportivo y una descripción de la utilización de armas dentro del wushu.

908. Chang, Dsu Yao y Fassi, Roberto (2000). Enciclopedia del kung fu shaolin : volumen 1. Madrid: Tutor. 1a ed. 125 p. : il. ; $17 \times 24$ cm. ISBN: 84-7902-282-5. Depósito legal: M. 46889-2000. Palabras clave: historia, fundamentos teóricos, fundamentos técnicos, ejercicios, calentamiento, fundamentos filosóficos, grados. Resumen: Manual teórico y técnico de wushu. La obra esta formada por 12 capítulos. El primer capítulo expone la interpretación del wushu del maestro Chang. Los dos siguientes capítulos explican el significado de kung-fu y de shaolin, para luego relatar la historia de las artes marciales chinas y del templo shaolin junto con su evolución. El cuarto capítulo comenta los fundamentos técnicos que se incluyen dentro del estilo shaolin, ilustrando algunas de sus técnicas más importantes, así como las armas que se manejan y los estilos derivados. El quinto capítulo presenta el programa técnico de examen para los diferentes grados; y después explica la importancia de la respiración y el chi, junto con sus tipos y utilización, en el entrenamiento de shaolin. El séptimo capítulo expone los fundamentos filosóficos que modelaron las artes marciales chinas, como son la teoría yin-yang, la teoría de los cinco elementos, el confucianismo, el taoísmo y el budismo. El octavo capítulo describe e ilustra las formas de saludar y la terminología utilizada para ello, mientras que el noveno presenta los 8 ejercicios de gimnasia o calentamiento con sus correspondientes ilustraciones. El décimo capítulo describe la ejecución técnica de las posiciones, ilustrando e incluyendo un esquema de la colocación de los pies en cada una de ellas. Los dos últimos capítulos explican las características de la lengua china, su pronunciación y matices así como algunos de los términos utilizados en las artes marciales. Adjunta dos apéndices con un breve diccionario chino-español y la adaptación del programa de examen en España.

909. Chang, Dsu Yao y Fassi, Roberto (2000). Enciclopedia del kung fu shaolin : volumen 2. Madrid: Tutor. $1^{\mathrm{a}}$ ed. 139 p. : il. ; $17 \times 24$ cm. ISBN: 84-7902-283-3. Depósito legal: M. 46890-2000. Palabras clave: formas, fundamentos técnicos, ejercicios, combate. Resumen: Manual técnico de wushu. La obra esta compuesta por 6 capítulos. El primer capítulo describe la ejecución técnica de las principales técnicas 
de ataque con los brazos y piernas, las paradas y las técnicas de caída del shaolín junto con la secuencia fotográfica de las mismas. El segundo capítulo presenta los dos primeros ejercicios (Lien Pu Ch'üan Ti I Lu, Lien Pu Ch'üan Ti Ehr Lu) de forma del estilo simplificado Lien Pu Ch'üan, explicando la ejecución técnica de cada posición, su nombre chino y el nombre chino de la figura y la traducción al castellano, incluyendo sus correspondientes ilustraciones. Los dos siguientes capítulos describen e ilustran, siguiendo la misma estructura del capítulo anterior, la primera forma de shaolín clásico (Shaolin Ch'üan Ti I Lu) y los dos primeros ejercicios de las técnicas de pierna (T'ui Fa Ti I Lu, T'ui Fa Ti Ehr Lu). El quinto capítulo describe la ejecución técnica de los dos primeros combates preordenados (Po Chi Ti I T'ao, Po Chi Ti Ehr T'ao) incluyendo la secuencia fotográfica de sus posiciones. El último capítulo presenta la descripción técnica de la primera forma de palo corto (Pang Fa Ti I Lu) acompañada de las ilustraciones de cada movimiento. Adjunta un compendio de los ideogramas y nombres chinos de las técnicas presentadas en este volumen.

910. Chang, Dsu Yao y Fassi, Roberto (2000). Enciclopedia del kung fu shaolin : volumen 3. Madrid: Tutor. 1a ed. 130 p. : il. ; $17 \times 24$ cm. ISBN: 84-7902-284-1. Depósito legal: M. 46888-2000. Palabras clave: formas, combate, fundamentos técnicos, defensa personal. Resumen: Manual técnico de wushu. La obra esta compuesta por 4 capítulos. El primer capítulo presenta la ejecución técnica, posición y nombre en chino y castellano de cada postura de la segunda, tercera, cuarta y quinta formas (Shaolin Ch'üan Ti Ehr Lu, Shaolin Ch'üan Ti San Lu, Shaolin Ch'üan Ti Szu Lu, Shaolin Ch'üan Ti Wu Lu) de shaolín clásico, acompañadas de sus correspondientes ilustraciones. El segundo capítulo describe e ilustra la ejecución técnica de las formas tercera, cuarta y quinta de los combates preordenados (Po Chi Ti San T'ao, Po Chi Tu Szu T'ao, Po Chi Ti Wu T'ao) además de incluir los consejos prácticos para desarrollar correctamente el combate libre (Tzu Yu Po Chi). El tercer capítulo describe la ejecución técnica de las 10 técnicas que componen el primer combate fundamental con agarres (Chi Na Po Chi Ti I T'ao) adjuntando la ilustración de cada posición. El último capítulo presenta la ejecución técnica, posición adoptada y nombre en chino y castellano de las posturas de la segunda forma de palo corto (Pang Fa Ti Ehr Lu) junto con la ilustración de las mismas. Adjunta los comentarios finales del maestro Chang para la práctica y los ideogramas y nombres chinos de las técnicas presentadas en este volumen.

911. Chen, Jaime y Padrón, Miguel (1981). Boxeo Liu-He-Men : shaolin del norte. Barcelona: Alas. 1aㅡ ed. 47 p. : il. ; 16x23,5 cm. ISBN: 84-203-0121-3. Depósito legal: B. 37108-1981. (2ª ed., 1986). Palabras clave: historia, fundamentos técnicos, ejercicios. Resumen: Manual técnico de kung-fu. La obra consta de 7 capítulos. El primer capítulo comenta los orígenes del kung-fu, clasifica las diferentes modalidades en cuatro grupos, como son el régimen de conservación, el boxeo chino, la lucha y la técnica con armas, e incluye la representación gráfica de algunos de sus contenidos. El segundo capítulo explica las características del boxeo chino, sus contenidos técnicos, y las características técnicas de los cinco estilos de lucha del boxeo shaolín. El tercer capítulo presenta la reproducción gráfica de la serpiente. El cuarto capítulo enumera los requisitos de un maestro. El quinto capítulo detalla la biografía de Chen Ning. El siguiente capítulo nombra e ilustra algunos ejercicios de calentamiento, las guardias y posturas, algunas de las técnicas del estilo de la serpiente, el dragón, el águila, varias patadas, el manejo del kune y el nunchaku de tres secciones y distintos ejercicios de elasticidad y flexibilidad. El séptimo capítulo señala la importancia de la coordinación para la práctica del kung-fu.

912. Chutang, Ling (1986). Kung-fu. Barcelona: Editors. 1aㅡ ed. 151 p. : il. ; $14 \times 21$ cm. ISBN: 84-7561-390-X. Depósito legal: B. 42777-1986. (2ª ed., 1988; 3를. ed., 1988, 84-7561-685-2; 4⿳a ed., 1990, ISBN: 84-7561820-0; $6^{\underline{a}}$ ed., 1992, ISBN: 84-7561-685-2; 7a ed., 1994, ISBN: 84-7561-685-2). Palabras clave: fundamentos técnicos, kárate, taijiquan. Resumen: Tratado técnico de kung-fu. Tras describir brevemente los fundamentos del kung-fu, como la respiración, los métodos de entrenamiento, la anatomía humana, la acción muscular y el origen de la técnica en los primeros cinco capítulos, continua con la descripción de las posturas basadas en el taichichuan. El séptimo capítulo presenta otra serie de posturas que recuerdan a las del kárate. Los siguientes 3 capítulos describen los golpes con puño y pie más comunes, para continuar con secuencias de trabajo de defensa, explicadas y representadas gráficamente, ante distintos ataques. Finaliza con una propuesta de trabajo para los desplazamientos y consejos finales para el entrenamiento.

913. Chutang, Ling (1996). Kung-fu. Barcelona: Ultramar. 1a ed. 194 p. : il. ; 15x23 cm. ISBN: 84-7386-704-1. Depósito legal: B. 24924-1996. Palabras clave: fundamentos técnicos, kárate, taijiquan. Resumen: Tratado técnico de kung-fu. Tras describir brevemente los fundamentos del kung-fu, como la respiración, los métodos de entrenamiento, la anatomía humana, la acción muscular y el origen de las técnicas de kung-fu en los primeros cinco capítulos, continua con la descripción de la ejecución técnica de las posturas basadas en el taichichuan. El séptimo capítulo presenta otras posturas relacionadas con las de kárate. Los siguientes 3 capítulos describen los diferentes golpes con puño y pie, para continuar con secuencias de trabajo de defensa, explicadas y representadas gráficamente, ante distintos ataques. Finaliza con una propuesta de trabajo para los desplazamientos, algunas recomendaciones alimenticias para conseguir agilidad y consejos finales para el entrenamiento. 
914. Conches Guillén, Aurelio David (1989). Kung fu chang chuan : el estilo originario del wu shu. Posiciones, defensas y ataques, formas, técnicas y entrenamiento. Barcelona: Hispano Europea. 1a ed. 216 p. : il. ; 17x23 cm. ISBN: 84-255-0811-8. Depósito legal: B. 15800-1989. Palabras clave: formas, historia, fundamentos teóricos, fundamentos técnicos, entrenamiento, escuelas, kyusho. Resumen: Manual teórico y técnico de wushu. La obra esta formada por 12 capítulos, precedidos de una introducción que explica la formación del estilo chang chuan y presenta su árbol genealógico. El primer capítulo relata el origen del wushu, su renovación a manos de Chueh Yuan y los estilos de wushu que existen en la actualidad.. El segundo capítulo presenta la práctica del wushu, desarrolla el programa habitual de entrenamiento, expone los hábitos o consejos para la práctica, el significado del cinturón o grado, el desarrollo del chi, el rompimiento de objetos y la descripción de varios ejercicios para endurecer las manos, incluyendo gráficos y esquemas de movimiento. El tercer capítulo narra el contacto de Germán Monzó con el chang chuan y su introducción en España. El cuarto capítulo describe la ejecución de diversos ejercicios de calentamiento junto con gráficos y esquemas de movimiento de los mismos. Los siguientes 4 capítulos describen e ilustran los fundamentos técnicos del chang chuan, como son las posiciones, las defensas, los ataques de puños y manos, y los ataques de pies y piernas, incluyendo gráficos de las zonas con las que golpear. El noveno capítulo comenta las características y principios que deben regir la práctica de las formas, enumera las distintas formas del estilo, y describe e ilustra la secuencia de movimientos de las 3 partes del principio básico del chang chuan y de la forma de los 18 pasos, incluyendo esquemas de movimiento de ambas. El décimo capítulo expone las técnicas de animales que posee el estilo junto con sus características y ofrece varias ilustraciones con dichas técnicas. Los dos últimos capítulos presentan la localización de los puntos vitales y el manejo de las distintas armas que se incluyen en el chang chuan. Adjunta un vocabulario básico y técnico.

915. Conches Guillén, Aurelio David (1989). Pei p'ai chuan : el kung fu secreto del norte de China. Barcelona: Alas. 1a ed. 48 p. : il. ; 16x24 cm. ISBN: 84-203-0235-X. Depósito legal: B. 8606-1989. Palabras clave: historia, wushu, escuelas, maestros. Resumen: Manual teórico sobre el Pa Chi Chuan (Boxeo de los 8 últimos). La obra describe la historia sobre la formación del estilo Pa Chi Chuan, narrando la vida y obra de los distintos maestros que conformaron este arte y detallando algunos de sus ejercicios. Esta primera parte esta complementada con fotografías e ilustraciones sobre los contenidos tratados. La segunda parte incluye un cuadro genealógico del estilo Pa Chi Chuan, detalles técnicos, y dos relatos del autor.

916. Conches Guillén, Aurelio David (1989). Pei p'ai chuan chin-na : agarres, presas y luxaciones. Barcelona: Alas. $1^{a}$ ed. 48 p. : il. ; 17x23,5 cm. ISBN: 84-203-0236-8. Depósito legal: B. 17794-1989. Palabras clave: historia, fundamentos teóricos, fundamentos técnicos, defensa personal, principios técnicos. Resumen: Manual teórico y técnico de chin-na. La obra esta dividida en 2 partes. La primera comenta el origen e historia de este arte de combate, explicando cuales son los principios básicos del entrenamiento y ofreciendo algunos consejos para progresar en el mismo. En la segunda parte se presentan varias ilustraciones y secuencias fotográficas en las que se describen algunos de los más comunes agarres, presas y luxaciones del arte. Adjunta la biografía de Yang Jwing Ming y un relato del autor.

917. Conches Guillén, Aurelio David (1990). Tan tuei kung fu (1 ${ }^{a}$ parte). Barcelona: Alas. $1^{a}$ ed. 48 p. : il. ; 17x24 cm. ISBN: 84-203-0251-1. Depósito legal: B. 31259-1990. Palabras clave: formas, historia, fundamentos técnicos. Resumen: Manual teórico y técnico sobre Tan Tuei. La primera parte de la obra describe el origen y clasificación del Tan Tuei como ejercicios preparatorios dentro del Chang Chuan, y los maestros de este estilo. También describe cuáles son sus características y beneficios para el practicante. La segunda parte ilustra y describe las aplicaciones de las 5 primeras líneas del Tan Tuei, incluyendo los esquemas de movimiento de las partes corporales.

918. Conches Guillén, Aurelio David (1990). Tan tuei kung fu : rutinas básicas de chang chuan (2 $2^{a}$ parte). Barcelona: Alas. 1aㅡ ed. 48 p. : il. ; 17x24 cm. ISBN: 84-203-0252-X. Depósito legal: B. 36006-1990. Palabras clave: formas, fundamentos técnicos, defensa personal. Resumen: Manual técnico de Tan Tuei. La obra explica las 10 rutinas existentes dentro del estilo Chang Chuan y que se encuentran resumidas en el poema de diez líneas del Tan Tuei Jiao Men Chang Chuan. Después de explicar cada una de estas líneas, ofrecer algunos consejos para su práctica, y describir las cinco técnicas principales, ilustra los movimientos de las secciones sexta, séptima, octava, novena y décima. Además de incluir los esquemas de movimiento de cada sección corporal describe las aplicaciones de éstas técnicas contra un adversario.

919. Conches Guillén, Aurelio David (1991). Pachi tang lang chuen : boxeo de las mantis de los ocho supremos. Barcelona: Alas. 1a ed. 256 p. : il. ; 17x24 cm. ISBN: 84-203-0259-7. Depósito legal: no.

920. Conches Guillén, Aurelio David (1992). Chin-na shu : el auténtico arte de agarrar y controlar en el kung-fu. Barcelona: Alas. 1a ed. 191 p. : il. ; 17x23,5 cm. ISBN: 84-203-0271-6. Depósito legal: B. 371841992. (2 a ed., 1993). Palabras clave: historia, fundamentos técnicos, principios técnicos, defensa personal, ejercicios, entrenamiento. Resumen: Manual teórico y técnico de kung fu. La obra esta formada por 20 capítulos. El primer capítulo explica los contenidos de la obra a modo de introducción 
y la transcripción de los términos chinos. El segundo capítulo detalla los diferentes estilos de artes marciales chinos y sus características. El tercer capítulo señala la importancia y beneficios de las artes marciales. El cuarto capítulo expone las cinco fases en el aprendizaje de las técnicas chin-na incluyendo la secuencia fotográfica de una técnica en dichas fases. El quinto capítulo relata la historia, objetivos, requisitos, contenidos técnicos, principios técnicos del chin-na así como los estilos y maestros con los que se relaciona directamente. Los siguientes cuatro capítulos narran la biografía del general Yueh Fei, el maestro Han Chin-Tang, el maestro Su Yu-Chang y el maestro Yang Jwing-Ming. Los dos siguientes capítulos presentan la teoría del chin-na aplicada a las cuatro categorías de técnicas como son: desplazar el hueso, dividir el músculo, cortar la respiración o el riego sanguíneo y presión a los puntos vitales, además de localizar los puntos vitales del cuerpo humano. El décimo segundo capítulo ilustra algunos de los ejercicios fundamentales de calentamiento junto con algunos consejos previos a la práctica. Los siguientes ocho capítulos muestran la secuencia fotográfica acompañada de la descripción de diversas técnicas de chin-na ejecutadas ante agarres, intentos de arrebatar el revólver, ataques de puño, patadas, ataques de palo, ataques con arma blanca y armas de fuego. Adjunta una breve biografía del autor y conclusión.

921. Cuturello, Ignazio y Ghezzi, Giuseppe (1996). Kung fu shaolín. Barcelona: De Vecchi. 1a ed. 222 p. : il. ; 17x24 cm. ISBN: 84-315-1637-2. Depósito legal: B. 39749-1996. Palabras clave: formas, historia, fundamentos técnicos, principios técnicos, aplicación marcial, maestros. Resumen: Manual teórico y técnico de wushu. El libro esta formado por 6 capítulos. El primer capítulo narra la biografía de Chang Dsu Yao, describe el estilo shaolín, incluye la clasificación de las artes marciales chinas, detalla la historia del estilo shaolín, explica los diferentes tipos de energía y fuerza, y describe su técnica de respiración. El segundo capítulo describe brevemente los fundamentos técnicos del shaolín, como las posiciones fundamentales, las técnicas de puño, las técnicas con la palma de la mano, las técnicas con el codo, las técnicas de defensa, las técnicas de pierna y las técnicas de caída, acompañadas de su representación gráfica. El tercer capítulo explica la ejecución técnica de la forma de las ocho direcciones (pa chi ch'üan fa) incluyendo su representación gráfica y esquemas de movimiento. El cuarto capítulo muestra la aplicación práctica de algunas de las técnicas de la forma de las ocho direcciones explicando e ilustrando su ejecución técnica. El quinto capítulo comenta las armas utilizadas en el estilo shaolín, las características técnicas del sable y presenta la ejecución de la primera forma con sable ( $\tan$ tao ti i lu) incluyendo su descripción técnica, su ilustración fotográfica, el nombre chino de la posición y la figura, y su traducción al español. El último capítulo expone la descripción técnica, ilustraciones y nombres chinos con su traducción, de los movimientos de la sexta forma de shaolín.

922. Dean, Richard (1982). Taodo hou ch'uan kung fu. Barcelona: Alas. 1 a ed. 48 p. : il. ; 17x24 cm. ISBN: 84203-0143-4. Depósito legal: B. 43981-1982. (2a ed., 1985). Palabras clave: formas, historia, fundamentos teóricos, aplicación marcial, armas. Resumen: Manual teórico y técnico de kung fu. La obra esta formada por 10 capítulos, precedidos por un breve comentario sobre la formación marcial del autor junto con algunas fotografías y un prólogo sobre la creación del estilo y los objetivos de la obra. El primer capítulo narra la historia del estilo del mono, mientras que el segundo comenta sus características técnicas. El tercer capítulo describe los requisitos del practicante del taodo hou chuan. El cuarto capítulo presenta la principal forma del estilo, el mono de hierro, comentando sus peculiaridades técnicas. El quinto capítulo presenta el método de entrenamiento de la soga del rey mono junto con algunas de sus fotografías. El sexto capítulo incluye la secuencia fotográfica de la aplicación marcial del mono de hierro. Los dos siguientes capítulos comentan las características técnicas de la forma del mono astuto y su aplicación marcial respectivamente. El noveno capítulo explica la ejecución del estilo del mono borracho para luego presentar algunas secuencias técnicas y la aplicación marcial de la danza del mono borracho. El último capítulo expone las armas utilizadas en el estilo del mono junto con algunas fotografías de las técnicas utilizadas en la forma con palo del mono astuto.

923. Dean, Richard (1983). Boxeo de la garra del águila : shuang hsing shaolin. Barcelona: Alas. 1 a ed. 47 p. : il. ; 17x23,5 cm. ISBN: 84-203-0150-7. Depósito legal: B. 21414-1983. Palabras clave: formas, historia, fundamentos técnicos, aplicación marcial, armas. Resumen: Manual teórico y técnico de kung fu. La obra esta formada por 6 capítulos, precedidos por un comentario de la formación marcial del autor y una introducción que detalla los contenidos del arte del shuang hsing shaolin. El primer capítulo enumera las 18 llaves del mundo para el boxeo de la garra del águila así como los ocho secretos o principios técnicos. El segundo capítulo describe la ejecución de las posturas básicas del estilo y una técnica avanzada de ataque acompañadas de sus fotografías explicativas. El tercer capítulo presenta la forma de la garra del águila (ying chao ping ch'uan) con una breve explicación de sus movimientos y su secuencia fotográfica. Los dos siguientes capítulos ilustran algunas técnicas del boxeo del águila borracha y la aplicación marcial de algunas de sus técnicas junto con un breve comentario técnico. El sexto capítulo comenta las características y beneficios de las ocho armas utilizadas en el shuang hsing shaolin acompañadas de la representación gráfica de algunas de sus técnicas. 
924. Dean, Richard (1984). Shuan hsing shaolin. Barcelona: Alas. 1a ed. 48 p. : il. ; 17x24 cm. ISBN: 84-2030163-9. Depósito legal: no.

925. Dean, Richard (1985). Taodo hou ch'uan kung fu : $2^{\underline{a}}$ parte. Boxeo del mono. Barcelona: Alas. $1^{\underline{a}}$ ed. 48 p. : il. ; 16x24 cm. ISBN: 84-203-0186-8. Depósito legal: B. 35754-1985. Palabras clave: formas, fundamentos técnicos, defensa personal, aplicación marcial. Resumen: Manual teórico y técnico de kung fu. El libro esta formado por 4 capítulos, precedidos por un breve currículum del autor y un prólogo que presenta los contenidos del libro. El primer capítulo describe las características técnicas del taodo hou chuan (estilo del mono), la utilización del chi, enumera las formas del estilo del mono acompañadas de algunas fotografías ilustrativas y el esquema de movimientos de la forma de las pequeñas flores de ciruelo "xiao mei hua quan". El segundo capítulo describe la ejecución técnica de la aplicación de algunos movimientos del estilo del mono a la defensa personal incluyendo su secuencia fotográfica. El tercer capítulo adjunta un glosario terminológico del taodo hou chuan. El cuarto capítulo enumera las formas con armas del estilo y las posiciones de las mismas. Adjunta un listado de estudios sobre el estilo del mono.

926. Dean, Richard (1987). Ta sheng yuan : el kung fu ninja de los Lin Kuei. Los secretos de los guerreros del mono. Barcelona: Alas. $1^{a}$ ed. 80 p. : il. ; 15x21,5 cm. ISBN: 84-203-0210-4. Depósito legal: B. 347641987. Palabras clave: formas, historia, fundamentos técnicos, principios técnicos, defensa personal, aplicación marcial, meditación, armas. Resumen: Manual teórico y técnico de kung fu. La obra esta compuesta por 10 capítulos, precedidos por un prefacio y una breve biografía profesional del autor. El primer capítulo narra la historia de los Lin Kuei, para en el segundo capítulo exponer las características del ta sheng yuan. El tercer capítulo presenta los contenidos teóricos y técnicos que componen el estilo ta sheng yuan. El cuarto capítulo comenta la práctica de la meditación ta sheng chi kung. El quinto capítulo expone los principios técnicos para desarrollar la meditación taoísta. El séptimo capítulo ilustra algunas de las posiciones y técnicas básica del ta sheng yuan junto con un comentario sobre su utilización. El octavo capítulo representa gráficamente la forma de la pelota de hierro además de comentar sus beneficios. El noveno capítulo describe la ejecución de varias técnicas de lucha y defensa personal acompañadas de su secuencia fotográfica. El último capítulo detalla las antiguas armas utilizadas en el arte, cita las más utilizadas en la actualidad e incluye las fotografías de algunas de sus técnicas. Adjunta una conclusión final.

927. Dean, Richard (1988). Wu dang kung fu. Barcelona: Alas. 1aㅡ ed. 48 p. : il. ; 17x24 cm. ISBN: 84-2030218-X. Depósito legal: no.

928. DI SOM y equipo de instructores (1983). Cuadernos didácticos para instructores de kung-fu 1 : preparación física. Vigo: Instituto Di Som. 1ํㅡㄹ ed. 27 p. : il. ; 21x28,5 cm. ISBN: No ISBN. Depósito legal: VG. 153-1983. Palabras clave: ejercicios, entrenamiento, planificación del entrenamiento, preparación física, preparación psíquica. Resumen: Manual teórico y técnico de kung-fu. El libro esta formado por 7 capítulos, precedidos por un comentario sobre los beneficios del ejercicio físico. El primer capítulo explica la relación entre cuerpo, mente y espíritu. El segundo capítulo comenta en qué consisten los ejercicios aeróbicos, calisténicos, isométricos, isotónicos e isocinéticos, cuáles son sus beneficios e ilustra algunos de ellos. El tercer capítulo representa algunas de las series de ejercicios para el entrenamiento de la fuerza, la flexibilidad, el fortalecimiento de manera individual y por parejas y el endurecimiento, acompañadas de sus esquemas de movimiento. El cuarto capítulo describe las características y tipos de calentamiento. El quinto capítulo define la preparación física de las capacidades de tolerancia, resistencia, velocidad y fuerza junto con algunos métodos para desarrollarlas, la preparación afectiva y la preparación psicológica. El sexto capítulo ofrece algunos consejos prácticos para elaborar un programa de entrenamiento, mientras que el último capítulo expone la importancia de la respiración en cualquier actividad deportiva.

929. DI SOM y Gallego, Javier (1983). Cuadernos didácticos para instructores de kung-fu 2 : didáctica, pedagogía y psicología. Vigo: Instituto Di Som. 1aㅡ ed. 44 p. : il. ; 21x28,5 cm. ISBN: No ISBN. Depósito legal: VG. 202-1983. Palabras clave: fundamentos teóricos, pedagogía, didáctica, unidades didácticas. Resumen: Manual teórico de kung-fu. La obra consta de 11 capítulos. El primer capítulo explica el concepto de personalidad, sus tipos y cuáles son los métodos para su exploración. El segundo capítulo analiza enumera los tipos de motivaciones, los niveles de aspiración del individuo y define los conceptos de actitud, interés y valor. El tercer capítulo expone la teoría de la frustración y del conflicto, los mecanismos de defensa y las técnicas para solucionar los conflictos provenientes de la frustración. El cuarto capítulo analiza los factores implicados en el aprendizaje, los tipos de aprendizaje, sus principios y condicionantes. El quinto capítulo presenta los tipos, características y factores de la atención junto con la explicación de los niveles de conciencia. El sexto capítulo muestra los elementos del proceso de comunicación y comenta los posibles tipos de comunicación. El séptimo capítulo enumera las características de las técnicas didácticas junto con los principios educativos. El octavo capítulo expone la función de las ayudas pedagógicas y sus tipos. El noveno capítulo explica en qué consisten las unidades didácticas, cuáles son los elementos que las integran y presenta el desarrollo de una unidad didáctica dedicada a los bloqueos con 10 sesiones de entrenamiento. Los dos últimos 
capítulos explican las características, principios y forma de actuación de las técnicas no-directivas así como la definición de programación, sus tipos, elementos y un ejemplo práctico.

930. Díez Coello, Carlos Antonio (2003). Kung-fu : escuelas Kuen-Lun \& Long Tan. Valencia: Carlos Antonio Díez Coello. $1^{\underline{a}}$ ed. 150 p. : il. ; 14x20,5 cm. ISBN: 84-607-8896-2. Depósito legal: V. 4205-2003. (2aㅡ ed., 2008, 145 p., ISBN: 978-84-612-7050-7). Palabras clave: fundamentos técnicos, programa técnico, defensa personal, ejercicios, entrenamiento. Resumen: Manual técnico de kung-fu. La obra consta de 5 capítulos, que presentan la descripción e ilustración de los contenidos técnicos del primer, segundo, tercer, cuarto y gran círculo de bronce, además de destacar las características psicológicas del practicante en cada etapa y ofrecer algunos consejos para el profesor. Los anexos incluyen la descripción técnica de los movimientos incluidos en los cinco taos básicos, las aplicaciones marciales de dichos taos, comenta los principios de la defensa personal además de describir la ejecución de algunas de sus técnicas, e incluye la representación gráfica de las posiciones, puñetazos, golpes de mano, codazos y rodillazos básicos del kung-fu.

931. Equipo de Especialistas Júpiter (1990). Manual práctico de kung-fu. Barcelona: De Vecchi. 1aㅡ ed. 125 p. : il. ; 14x20,5 cm. ISBN: 84-315-0664-4. Depósito legal: B. 19666-1990. (2a ed., 1995; 3a ed., 1996). Palabras clave: historia, fundamentos técnicos, escuelas. Resumen: Manual teórico y técnico de kung fu. La obra esta compuesta por cinco capítulos, precedidos por una introducción que narra la historia del kung fu. El primer capítulo comenta las diferencias existentes entre las escuelas interna y externa, sus principios técnicos, comenta la expansión del kung fu por el Extremo Oriente, las escuelas de kárate, la formación del taekwondo y la expansión a América y Europa. El segundo capítulo comenta los principios técnicos del supremo último puño además de incluir la descripción y representación gráfica de su forma. El tercer capítulo describe la ejecución técnica de las 12 técnicas que componen la lucha de los ocho hexagramas del pa kwa acompañados de su representación grafica. El cuarto capítulo expone la ejecución de los contenidos técnicos básicos del estilo de la mantis religiosa junto con su ilustración. El último capítulo presenta los fundamentos técnicos básicos del kung-fu del templo shaolín adjuntando su representación gráfica y esquemas de movimientos.

932. Esteve Orozco, Jesús (1985). Sang pu : mi arte marcial. Madrid: J. Gómez. 1ae ed. 118 p. : il. ; 21x30 cm. ISBN: No ISBN. Depósito legal: M. 12313-1985. Palabras clave: formas, fundamentos teóricos, fundamentos técnicos, programa técnico, ejercicios, calentamiento, vestimenta, competición, reglamentos. Resumen: Manual teórico y técnico de kung fu. El libro esta dividido en 2 partes precedidas por un capítulo introductorio que narra el origen y desarrollo del estilo sang pu. La primera parte consta de 18 capítulos. Los seis primeros capítulos explican el significado del emblema del estilo, detallan la vestimenta, protecciones y sala de entrenamiento, comentan las características técnicas generales del estilo y presentan su sistema de grados. Los dos siguientes capítulos describen brevemente la ejecución del saludo y los ejercicios de calentamiento además de incluir su representación gráfica. Los dos siguientes capítulos nombran e ilustran los contenidos técnicos del cinturón amarillo y naranja respectivamente. El décimo primer capítulo expone el trabajo de coordinación junto con un listado de las series técnicas básicas. Los siguientes tres capítulos presentan los contenidos técnicos de los cinturones verde, azul y marrón respectivamente mientras que el siguiente incluye la secuencia fotográfica de la forma de sang pu. Los dos últimos capítulos enumera los contenidos técnicos del programa de cinturón negro, los requisitos previos para el examen, la ilustración de varias técnicas de contraataque y los requisitos para conseguir el 1er dan. La segunda parte consta de 10 capítulos. El primer capítulo comenta el entrenamiento y contenidos técnicos desde 1er hasta 5o dan mientras que los tres siguientes capítulos desarrollan los ejercicios y contenidos de la rama de boxeo de piernas, la rama de puños y la rama de bloqueos. El quinto capítulo expone la actitud mental del practicante ante la práctica y algunos principios tácticos del combate. Los dos siguientes capítulos incluyen el reglamento de competición y los gestos técnicos de arbitraje del sang pu. Los dos últimos capítulos exponen algunos de los fundamentos filosóficos del sang pu a través de varios aforismos y la presentación de los colaboradores en la obra.

933. Esteve Orozco, Jesús (1986). Sang pu : mi arte marcial. 3 y 4. Madrid: Rato. 1 a ed. 42 p. : il. ; 21×29,5 cm. ISBN: No ISBN. Depósito legal: M. 1104-1986. Palabras clave: formas, ejercicios, combate, juegos. Resumen: Manual técnico de sang pu. El libro esta formado por 11 capítulos. El primer capítulo explica la ejecución de los gestos ofensivos con el talón, la espinilla y el codo acompañados de su representación gráfica. El segundo capítulo detalla la ejecución de la segunda parte del trabajo de sincronización. El tercer capítulo clasifica los tipos de barridos y comenta sus características. El cuarto capítulo expone los combates de grado. El quinto capítulo presenta la descripción técnica e ilustración de la forma tao-piao. El sexto capítulo enumera varios ejercicios de coordinación de golpes de puño y pierna. El séptimo capítulo explica la ejecución de las distintas formas de caer junto con su representación gráfica. El octavo capítulo comenta los objetivos, características y desarrollo del ejercicio denominado "soltura y pegada". El noveno capítulo expone los combates de grado. El décimo capítulo expone las características y desarrollo de los juegos de acondicionamiento del golpe y del 
encuentro incluyendo su ilustración. El capítulo decimoprimero presenta la descripción técnica e ilustración de la forma tao-shu.

934. Esteve Orozco, Jesús (1986). Sang pu : mi arte marcial. 5 y 6. Madrid: Rato. 1 a ed. 24 p. : il. ; 21x29,5 cm. ISBN: No ISBN. Depósito legal: M. 5551-1986. Palabras clave: formas, fundamentos técnicos, combate, juegos. Resumen: Manual técnico de sang pu. El libro esta formado por 9 capítulos. El primer capítulo enumera los ejercicios de coordinación para cinturón marrón, mientras que el segundo explica la ejecución de las caídas con giro acompañadas de su ilustración. El tercer capítulo detalla el combate de grado. El cuarto capítulo explica los juegos de acondicionamiento a la contra, al contragolpe y a la retirada. El quinto capítulo presenta la descripción e ilustración de la forma yung-wu-tao. El sexto capítulo comenta las características de los cinco combates de grado para aspirar al cinturón negro. El séptimo capítulo describe algunas de las técnicas de contraataque del sang pu. El octavo capítulo detalla los juegos de acondicionamiento de reflejos y de percepción junto con su representación gráfica. El noveno capítulo señala la importancia de la actitud mental en el combate.

935. Esteve Orozco, Jesús (1986). Sang pu : mi arte marcial. 7. Madrid: Rato. 1ae ed. 44 p. : il. ; 21x29,5 cm. ISBN: No ISBN. Depósito legal: M. 22405-1986. Palabras clave: fundamentos técnicos, programa técnico, pedagogía, combate, competición, exámenes, reglamentos. Resumen: Manual técnico de sang pu. El libro esta formado por 13 capítulos. El primer capítulo expone el programa de contenidos hasta cinturón negro. El segundo capítulo expone la pedagogía del entrenador de sang pu y sus objetivos. Los dos siguientes capítulos exponen los contenidos técnicos para alcanzar el $2^{\circ}$ y $3 \mathrm{er}$ dan. El quinto capítulo ilustra las 12 técnicas del combate cuerpo a cuerpo. Los dos siguientes capítulos enumeran los contenidos técnicos para alcanzar el 4o y 5o dan. El octavo capítulo incluye el reglamento oficial de competición del sang pu. Los siguientes 5 capítulos explican el desarrollo de los exámenes desde 1er hasta 5으. dan.

936. Federación Española de Kárate, Departamento Nacional de Kung-Fu (1984). Cuaderno didáctico para instructores de kung-fu. Madrid: Federación Española de Kárate. Departamento Nacional de Kung-Fu. $1^{\text {a }}$ ed. 51 p. : il. ; 20x29,5 cm. ISBN: No ISBN. Depósito legal: M. 22586-1984. Palabras clave: fundamentos teóricos, pedagogía, didáctica, ejercicios, entrenamiento, psicología, primeros auxilios, anatomía, preparación física, preparación psíquica. Resumen: Manual teórico y técnico de kung-fu. El libro esta dividido en 3 áreas. La primera área presenta los contenidos de preparación física, comentando en qué consisten los ejercicios aeróbicos, calisténicos, isométricos, isotónicos e isocinéticos, describe las características y tipos de calentamiento, define la preparación física de las capacidades de tolerancia, resistencia, velocidad y fuerza junto con algunos métodos para desarrollarlas, la preparación afectiva y la preparación psicológica, ofrece algunas sugerencias par el entrenamiento, explica el proceso de agotamiento y la composición de los nutrientes. La segunda área presenta los contenidos relacionados con la didáctica, pedagogía y psicología, explicando los conceptos de personalidad y motivación; la teoría de la frustración y del conflicto; los tipos de aprendizaje; los tipos, características y factores de la atención; los elementos del proceso de comunicación; enumera las características de las técnicas didácticas; expone la función de las ayudas pedagógicas; y resume los tipos de programación. La tercera área presenta los contenidos de anatomía y fisiología, presentando la organización del cuerpo humano, las características generales de los sistemas esquelético, muscular, nervioso, circulatorio y respiratorio, y describiendo los síntomas y tratamiento de las principales lesiones del kung-fu.

937. Fernández Novas, José Antonio y Ortega Álvarez, Pablo (2005). El sandá aplicado a la defensa personal policial. Vigo: José A. Fernández Novas y Pablo Ortega Álvarez. 1ae ed. 72 p. : il. ; 14x20,5 cm. ISBN: No ISBN. Depósito legal: VG. 859-2005. Palabras clave: fundamentos teóricos, fundamentos técnicos, principios técnicos, defensa personal, ejercicios, armas. Resumen: Manual teórico y técnico de kung fu. El libro esta formado por 11 capítulos. El primer capítulo explica en qué consiste el sandá y cuál es su historia. El segundo capítulo explica la aplicación marcial del sandá. El tercer capítulo clasifica los tipos de defensa personal y detalla las ventajas del sandá. El cuarto capítulo define el concepto defensa personal mientras que el quinto comenta las características, fundamentos y actuación de la defensa personal integral, la defensa personal policial y la defensa personal especial. El sexto capítulo enumera los principios técnicos de la defensa personal policial. El séptimo capítulo explica las armas naturales utilizadas en la defensa personal junto con un comentario de los principios de actuación en la defensa contra armas o contra varios agresores. El octavo capítulo muestra el desarrollo de una sesión de acondicionamiento físico. El noveno capítulo enumera los elementos físicos, técnicos, psicológicos, tácticos y habilidades que intervienen en una situación de defensa personal. El décimo capítulo expone los factores a evaluar en una situación de defensa personal mientras que el último capítulo detalla los contenidos técnicos que componen la defensa personal policial. Adjunta un cuadro resumen con las características de la defensa personal integral, policial y especial así como la descripción técnica e ilustración de distintos ejercicios de calentamiento, la defensa contra varios agresores, ataques de puño, agarres al pelo con inmovilización, agarres al pecho con inmovilización, golpes descendentes, 
técnicas con tonfa, técnicas con la defensa, técnicas contra cuchillo, esposamientos y técnicas con pistola.

938. Ferrán (seud. Mariano Luna, Fernando Rafael) (1981). Boxeo de la mantis religiosa : tang lang pai. Barcelona: Alas. 1aㅡ ed. 47 p. : il. ; 17x23,5 cm. ISBN: 84-203-0108-6. Depósito legal: B. 6454-1981. (2 $2^{\underline{a}}$ ed., 1984; $3^{a}$ ed., 1987). Palabras clave: fundamentos técnicos. Resumen: Manual teórico y técnico de boxeo de la mantis religiosa. La obra comienza explicando el significado del kung-fu y sus diferentes estilos, para luego introducir algunos conceptos generales sobre el proceso mental de aprendizaje, el significado del chi y la fuerza interna, las características de la escuela de la mantis religiosa, los beneficios de ésta práctica para la salud y algunos consejos sobre el entrenamiento. A continuación presenta una serie de ejercicios para el calentamiento y pasa a detallar cómo se realizan correctamente los desplazamientos, las patadas y las técnicas de manos, ilustrando los esquemas de movimiento de cada técnica. Finaliza con breves capítulos dedicados a la mejora de la capacidad de salto, el endurecimiento de las zonas de golpeo, el esquema de los movimientos básicos y el programa técnico del examen de grados en Tang-Lang-Pai.

939. Font Roig, Fidel (1992). Wu-shu : técnica y arte. Barcelona: Paidotribo. $1^{\mathrm{a}}$ ed. 303 p. : il. ; 15x21,5 cm. ISBN: 84-8019-015-9. Depósito legal: B. 13433-1992. Palabras clave: historia, fundamentos teóricos, fundamentos técnicos, filosofía, combate, entrenamiento, planificación del entrenamiento. Resumen: Manual teórico y técnico de wushu. La obra esta dividida en 3 partes La primera de ellas explica los aspectos teóricos del wushu, como son su historia, sus estilos y enfoques, la filosofía del arte, y algunos conceptos fundamentales relacionados con la tradición. La segunda parte presenta los contenidos prácticos del wushu, comenzando con la explicación de los principios de movimiento, los tipos de trabajo existentes y los tipos de entrenamiento. Después presenta las técnicas de puño, de palma, de garra, las patadas, las posiciones, los desplazamientos, el entrenamiento de las técnicas de puño, de las patadas y de las combinaciones, aunque sin describir su ejecución. Esta parte también incluye un planteamiento metodológico para realizar una clase, las armas de wushu con sus características y su entrenamiento, un compendio teórico sobre las técnicas de combate, test para evaluar las condiciones del practicante, un estudio de los problemas y soluciones más frecuentes durante el combate, un planteamiento de aprendizaje para el combate en niveles, una secuencia fotográfica de un combate de sanda, el planteamiento del combate con armas, un grupo de unidades didácticas para entrenar el combate y la estructura de una clase con armas. La tercera parte incluye una programación de contenidos de iniciación al wushu. Adjunta un glosario.

940. Fraguas, José María (1985). 11 estilos de Shao Lin. Madrid: Esteban Sanz Martínez. 1a ed. 146 p. : il. ; 15x21 cm. ISBN: 84-85977-19-X. Depósito legal: M. 11229-1985. Palabras clave: historia, fundamentos teóricos, baguazhang, choy lee fut, taijiquan, wing chun, wushu, fundamentos técnicos, xinyiquan, escuelas. Resumen: Manual teórico de kung-fu. El libro esta compuesto de 12 capítulos precedidos de una breve biografía del autor y parte de una entrevista. El primer capítulo narra la formación y construcción de los templos shao lin, su fundador y los estilos de combate que crearon sus monjes. El segundo capítulo relata la historia del estilo de la mantis religiosa, sus características y principios, sus movimientos y las teorías sobre las que se fundamentan, y su evolución técnica hasta la actualidad. El tercer capítulo profundiza en el estilo choy-li-fut, desde su fundación y características técnicas hasta sus tipos de puñetazos, las amas que utiliza, las características de sus formas, la danza del león, las técnicas de piernas y las técnicas de mano. El cuarto capítulo presenta el sistema interno del pa kua, sus ejercicios, su historia y orígenes, los beneficios físicos, psíquicos y espirituales que reporta su práctica, sus principios técnicos y armas. El quinto capítulo expone las características de la práctica del tai chi chuan, su historia y teorías, compara el tai chi chuan con el yoga, detalla los diferentes estilos taoístas de tai chi chuan, sus ejercicios, los 10 principios fundamentales de la práctica del tai chi chuan y su explicación. El sexto capítulo narra la historia del wing chun y sus maestros más importantes, explica las características de las tres formas de trabajo a mano vacía (siu lim tao, chum kiu, bil jee) y la secuencia de aprendizaje de estos contenidos técnicos. El séptimo capítulo expone las características técnicas del estilo de la garra del águila, relata su historia y formas de entrenamiento, la secuencia de aprendizaje de sus técnicas, y los siete principios del estilo. El octavo capítulo presenta el estilo del mono y sus diferentes variantes, así como la historia de su formación, la secuenciación de sus técnicas y las 36 palabras clave y cinco puntos que forman la base del sistema. El noveno capítulo expone las principales características del hung gar, la aportación técnica de los cinco animales (dragón, serpiente, tigre, grulla, leopardo), la ejecución correcta de las principales posturas del sistema y la interpretación de los cinco elementos dentro de la práctica del hung gar. El décimo capítulo explica el sistema interno Hsing I, sus escuelas e historia, las características técnicas del sistema representadas por los cinco elementos y los doce animales, así como los principios para la práctica correcta. El undécimo capítulo estudia el estilo de la grulla blanca, sus diferentes ramas y características, su formación, los cuatro principios del combate y sus desplazamientos. El último capítulo explica el significado del chang chuan o puño largo, su historia, su contenido técnico y los principios y puntos principales del estilo. 
941. Fraguas, José María y Rossell Sellart, Tony (1986). Hung-gar kung-fu : el tigre y la grulla de shao-Lin. Madrid: Esteban Sanz Martínez. 1aㅡ ed. 157 p. : il. ; 15x21 cm. ISBN: 84-85977-28-9. Depósito legal: M. 13025-1986. Palabras clave: qigong, formas, historia, fundamentos teóricos, fundamentos técnicos, ejercicios, aplicación marcial, maestros, armas. Resumen: Manual teórico y técnico de kung fu. La obra esta formada por 14 capítulos, precedidos por una breve biografía de los autores. El primer capítulo narra la historia del hung gar kung fu mientras que el segundo presenta la biografía del maestro Wong Ping Pui y su llegada a España, incluyendo varias fotografías demostrativas. El tercer capítulo comenta brevemente las características técnicas de los cinco animales de shao-lin junto con su representación gráfica. Los siguientes seis capítulos describen la ejecución de las posiciones básicas, guardias, bloqueos, técnicas de brazo y de pierna y algunos ejercicios del hung gar kung fu acompañados de sus correspondientes ilustraciones explicativas. El décimo capítulo incluye la secuencia fotográfica y nombre de los movimientos que componen la forma fu-pao, mientras que el siguiente capítulo muestra la aplicación práctica de algunas de sus técnicas. El décimo segundo capítulo expone la secuencia fotográfica de la forma a dos hombres ching-nin-kuen-doy-dar. El siguiente capítulo detalla los fundamentos teórico del chikung externo e interno, sus principios técnicas y explica la ejecución de varios ejercicios de chikung interno acompañados de su representación gráfica. El último capítulo ilustra algunas de las armas utilizadas en el estilo hung gar.

942. Fraguas, José María y Rossell Sellart, Tony (1988). Los secretos del kung-fu : shao-lin. Madrid: Esteban Sanz Martínez. 1aㅡ ed. 207 p. : il. ; 15x21 cm. ISBN: 84-85977-47-5. Depósito legal: M. 19834-1988. Palabras clave: formas, historia, principios técnicos, defensa personal, aplicación marcial, maestros. Resumen: Manual teórico y técnico de kung fu. La obra esta formada por 13 capítulos, precedidos por una breve biografía de los autores. El primer capítulo narra a historia del hung gar así como el papel representado por Chih Shan Chan. El segundo capítulo relata la formación de la sociedad secreta hung. El tercer capítulo comenta la vida de Hung Tsi Kuan y Luk-A-Tsai y sus aportaciones al estilo hung gar. Los tres siguientes capítulos explican la biografía de los maestros Wong Chi Ying, Wong Fei Hung y Lam Sai Wing, además de incluir algunas de sus anécdotas. El séptimo capítulo expone los principios y contenidos técnicos del estilo. Los tres siguientes capítulo comentan las características técnicas y beneficios de las formas tid sin kuen, fu hok seun ying kuen y kung chi fook fu kuen, adjuntando su representación gráfica, esquemas de movimiento y una breve explicación de su ejecución. El décimo primer capítulo incluye la secuencia fotográfica de algunas aplicaciones prácticas de las técnicas del estilo mientras que el siguiente muestra las técnicas básicas del hung gar contra agarres. El último capítulo presenta a los maestros John Leong, Ching Wong, Vernon Rieta y Bucksam Kong ejecutando algunas de las técnicas del hung gar.

943. Gérome, Pierre H. A. (trad.) (1974). Kung fu. Barcelona: Telstar. 1aㅡ ed. 44 p. : il. ; 24x34 cm. ISBN: 847237-058-5. Depósito legal: no.

944. González, Argimiro (1982). Kuen-tao kung-fu. Barcelona: Alas. 1a ed. 110 p. : il. ; 15x21,5 cm. ISBN: 84203-0135-3. Depósito legal: B. 28719-1982. (2ª ed., 1987). Palabras clave: formas, historia, ejercicios, calentamiento, textos, vestimenta, grados, armas. Resumen: Manual teórico y técnico de kung fu. La obra consta de 17 capítulos precedidos por el currículo del autor y una introducción que explica el significado de los términos wushu y kuoshu. El primer capítulo narra la historia del médico Hua Tuo y la creación de los ejercicios de wuqinxi junto con la representación gráfica de los mismos. El segundo capítulo relata el origen del monasterio shaolin. El tercer capítulo enumera las destrucciones sufridas por el tempo shaolin. El cuarto capítulo comenta la importancia del libro "I ching" sobre el kung fu mientras que el quinto detalla los escritos del Wu Chi relacionados con el origen del tai chi chuan. Los dos siguientes capítulo explican la vestimenta antigua y el uniforme actual del kung fu acompañados de su representación gráfica. El octavo capítulo explica las zonas del golpeo utilizadas en el kung fu para luego representar distintos ejercicios de calentamiento. El décimo capítulo explica el significado y características de los kuens para continuar comentando las peculiaridades de los kuens presentados en el libro. Los siguientes cuatro capítulos presentan la secuencia fotográfica y esquemas de movimiento de los kuens denominados fung chuan yi lu, ng chuan, li ban kien y si pak. El décimo sexto capítulo enumera los grados en kung fu. El último capítulo enumera y clasifica las distintas armas chinas acompañadas de su representación gráfica. Adjunta bibliografía y la presentación de la Sociedad Shaolin-Chi Kuoshu.

945. Gualinga Yasacama, Arturo (1986). Fighter kung-fu kao. Las Palmas de Gran Canaria: Arturo Gualinga Yasacama. $1^{\underline{a}}$ ed. 53 p. ; 21x31,5 cm. ISBN: No ISBN. Depósito legal: GC. 417-1986. Palabras clave: fundamentos técnicos, vestimenta. Resumen: Manual técnico de kung-fu. La obra esta formada por 6 capítulos, precedidos por una introducción que explica la experiencia marcial del autor y los contenidos de la obra. El primer capítulo describe la vestimenta utilizada mientras que el segundo expone los contenidos de los ejercicios de calentamiento. El tercer capítulo describe la ejecución de dos técnicas de bloqueo. El cuarto capítulo describe la ejecución de cuatro técnicas mientras que el cuarto capítulo incluye la descripción de las técnicas del dragón, del tigre, del leopardo, de la serpiente, de la grulla, del león, del elefante, del caballo, del mono y del gato incluyendo sus características. El último 
capítulo presenta la descripción de la ejecución técnica de las 10 fases que componen el kuen y comenta sus peculiaridades.

946. Gutiérrez, Raúl (1981). Los 5 estilos del boxeo del mono. Barcelona: Alas. 1 a ed. 48 p. : il. ; 17x24 cm. ISBN: 84-203-0115-9. Depósito legal: no. (2ª ed., 1986, 45 p.). Palabras clave: historia, fundamentos técnicos, biografía, aplicación marcial, maestros. Resumen: Manual teórico y técnico de kung fu. El libro esta formado por 8 capítulos precedidos por los agradecimientos, el currículo del autor y una introducción que comenta la popularización del estilo del mono. El primer capítulo presenta la biografía de Chan Sau Chung y comenta las características de los cinco estrategias de lucha del estilo del mono. El segundo capítulo expone la biografía de Chan Siu Chuen. El tercer capítulo comenta brevemente la evolución del estilo del mono acompañada de su esquema. El cuarto capítulo detalla la biografía y entrenamiento marcial de John Fanning incluyendo una entrevista. El quinto capítulo ilustra las posiciones típicas del estilo del mono mientras que el sexto describe brevemente la ejecución de algunas de sus técnicas acompañadas de su secuencia fotográfica. Los dos últimos capítulos explican la aplicación práctica de algunas técnicas del estilo del mono y el estilo del mono borracho al combate acompañadas de sus ilustraciones correspondientes.

947. Gutiérrez, Raúl (1982). Shaolin-ch'uan-fa : templo de artes marciales chinas. Barcelona: Alas. 1aㅡ ed. 48 p. : il. ; 16x23,5 cm. ISBN: 84-203-0132-9. Depósito legal: B. 16791-1982. (2ª ed., 1986). Palabras clave: historia, fundamentos teóricos, fundamentos técnicos, religión. Resumen: Manual teórico y técnico de kung fu. La obra esta formada por 10 capítulos. El primer capítulo narra el origen del kung fu mientras que el segundo presenta otras versiones históricas. El tercer capítulo relata la vida del fundador del budismo. El cuarto capítulo expone los fundamentos religiosos del templo ch'uan-fa. El quinto capítulo plantea los fundamentos teóricos en la enseñanza del templo ch'uan-fa. El sexto capítulo enumera y representa las posiciones y guardias básicas del estilo mientras que el séptimo presenta los bloqueos o desviaciones. Los tres siguientes capítulos nombran los golpes de mano, patadas y acrobacias respectivamente acompañados de su ilustración y esquemas de movimiento. El último capítulo incluye una carta de reconciliación dirigida al Dios Su.

948. Gutiérrez, Raúl (1984). El estilo del Tigre Blanco "Ba-Fu". Barcelona: Alas. 1aa ed. 48 p. : il. ; 17x23,5 cm. ISBN: 84-203-0158-2. Depósito legal: B. 980-1984. (2a ed., 1986). Palabras clave: fundamentos técnicos, ejercicios, entrenamiento, preparación física, formas. Resumen: Manual teórico y técnico de kung fu. La obra esta formada por 6 capítulos, precedidos por un capítulo introductorio que aclara los distintos términos referidos a las artes marciales y las vertientes del kung fu. El primer capítulo presenta los contenidos técnicos del estilo del tigre blanco. El segundo capítulo describe los métodos y ejercicios de entrenamiento para desarrollar la palma de hierro incluyendo numerosas fotografías explicativas, mientras que el segundo expone sus diversas formas de golpear. El tercer capítulo relata una anécdota sobre la fortaleza proporcionada por el entrenamiento de la piel de acero. El cuarto capítulo describe el proceso de entrenamiento con el saco de arena para el endurecimiento así como sus ejercicios ilustrados. El quinto capítulo detalla el entrenamiento con el muñeco de madera, mientras que los dos siguientes capítulos describen la ejecución de otros ejercicios complementarios y el endurecimiento con las argollas de caña acompañados de distintas fotografías explicativas. El sexto capítulo incluye la secuencia fotográfica de la $1^{\underline{a}}$ forma del tigre blanco denominada "el tigre se retuerce" acompañada de una breve explicación técnica.

949. Gutiérrez, Raúl (1985). El estilo del Tigre Blanco "Ba-Fu" : parte 2. Barcelona: Alas. 1ạ ed. 48 p. : il. ; 17x23,5 cm. ISBN: 84-203-0188-4. Depósito legal: B. 41742-1985. Palabras clave: principios técnicos, entrenamiento, aplicación marcial, equipamiento, formas. Resumen: Manual teórico y técnico de kung fu. La obra esta formada por 5 capítulos. El primer capítulo comenta las características técnicas de los estilos del norte y del sur de China, así como el origen y principios técnicos del estilo tigre blanco. El segundo capítulo explica el entrenamiento de las manos con el saco, los principios del entrenamiento con el saco de velocidad y el saco pesado además de incluir varias fotografías del autor. El tercer capítulo analiza los factores y principios involucrados en los rompimientos. El cuarto capítulo presenta la secuencia fotográfica de la ejecución de la segunda forma del tigre blanco denominada "el tigre da manotazos" acompañada de sus esquemas de movimiento. El quinto capítulo detalla los beneficios de la práctica de los rompimientos.

950. Hang, Enrich (1974). Kung-fu. Barcelona: A.T.E. (Asesoría Técnica de Ediciones). 1a ed. 174 p. : il. ; 13x19,5 cm. ISBN: 84-85047-25-7. Depósito legal: B. 6764-1974. Palabras clave: defensa personal, entrenamiento, filosofía, meditación, respiración. Resumen: Manual teórico de wushu. La obra esta compuesta de 9 capítulos. Después de una breve introducción, dedica dos capítulos a explicar la filosofía del "kung-fu" a través de diversos relatos históricos y el mundo zen. Continúa con la explicación de lo que significa concentrarse y expone una serie de ejercicios de concentración. Luego ofrece algunos consejos sobre la meditación, cómo debe realizarse la respiración y algunos ejercicios para fortalecer la musculatura y entrenar las articulaciones. Finaliza con dos capítulos prácticos dedicados a algunas situaciones de defensa personal contra ataques armados y las zonas corporales que pueden ser utilizadas como armas en el kung-fu. Adjunta conclusiones y epílogo. 
951. Itier, Roger (2007). El gran libro del kung fu wushu. Barcelona: De Vecchi. $1^{a}$ ed. 351 p. : il. ; $17 \times 24$ cm. ISBN: 978-84-315-3382-3. Depósito legal: no. Palabras clave: historia, fundamentos técnicos, filosofía, combate, entrenamiento, taijiquan, wushu, escuelas, armas. Resumen: Manual teórico y técnico de wushu. La monografía esta compuesta de dos partes precedidas de una introducción en donde se detallan las reformas que se están realizando para incluir el wushu en los JJ.00. de China. La primera parte es teórico e incluye la historia y evolución del arte, su filosofía, el significado de la palabra wushu, una clasificación de sus estilos y escuelas, los fundamentos del saludo, la estructura y organización de la sala de entrenamiento, la jerarquía existente en las artes marciales chinas y su representación, la vestimenta utilizada y cuáles son las distintas materias que integran el entrenamiento en las artes marciales chinas. La segunda parte es práctica y en ella se explican e ilustran los fundamentos técnicos del boxeo largo, sus principios dinámicos y de entrenamiento, algunos ejercicios fundamentales, ejercicios de combinaciones de técnicas del boxeo largo, los fundamentos del boxeo del sur, una breve introducción sobre la historia del taijiquan, el desarrollo de las teorías y fundamentos técnicos que integran el taijiquan, una introducción al sanda, los fundamentos del sanda, la aplicación del wushu en niños, las características de las armas y algunas de sus combinaciones técnicas. Los anexos incluyen vocabulario específico de los estilos presentados, bibliografía y direcciones útiles.

952. Izquierdo, Pedro y Conches Guillén, Aurelio David (1986). Mao chao chuan : boxeo de la garra del gato. Barcelona: Alas. 1aㅡ ed. 48 p. : il. ; 17x24 cm. ISBN: 84-203-0192-2. Depósito legal: B. 13263-1986. Palabras clave: formas, historia, fundamentos técnicos, defensa personal, armas. Resumen: Manual teórico y técnico de kung fu. La obra esta formada por 6 capítulos, precedidos por una breve biografía de David Conches y una introducción que narra la historia del estilo de la garra del gato. El primer capítulo incluye una entrevista realizada a Pedro Izquierdo. El segundo capítulo expone los contenidos técnicos del estilo junto con algunas ilustraciones. El segundo capítulo comenta los principios tácticos ante una situación de defensa personal. Los dos siguientes capítulos describen la actuación ante una situación de defensa personal contra un ataque con cuchillo y otro con palo respectivamente, incluyendo su secuencia fotográfica. El quinto capítulo muestra algunas de las técnicas del estilo con armas mientras que el sexto detalla la ejecución técnica de la primera parte de la forma de la garra del gato acompañada de su secuencia fotográfica. Adjunta una conclusión final.

953. Liang, Yin Chuan y Pérez Agustí, Adolfo (2005). El tao del kung-fú : bases para el entrenamiento. Madrid: Masters. 1aㅡ ed. 236 p. : il. ; 14x21 cm. ISBN: 84-96319-25-3. Depósito legal: B. 46632-2005. Palabras clave: qigong, historia, fundamentos teóricos, fundamentos técnicos, entrenamiento, escuelas, armas. Resumen: Manual sobre los diferentes estilos que componen el kung-fu y sus aspectos más significativos. Después de narrar y detallar el origen del kung-fu, sus vertientes norte y sur y sus entrenamientos en la actualidad, presenta en el segundo capítulo el entrenamiento tradicional, basado en los movimientos de los animales, y a continuación en los entrenamientos especiales, esto es, el endurecimiento, los ejercicios de pateo, el entrenamiento de la palma en el agua y troncos de bambú, los postes de madera, el kung-fu sobre teteras, el muñeco de madera y sus diferentes tipos, y otros equipos. El cuarto capítulo detalla las características de los estilos internos (tai chi, pa-kua, hsing-i, wushu), sus técnicas y entrenamiento. El siguiente capítulo describe el chi kung, su historia, sus técnicas y sus ejercicios. El sexto capítulo aborda la descripción histórica, técnica, de entrenamiento y principios de los estilos externos (ch'ang ch'uan, hung gar, wing chun, choy li fut, mantis religiosa, boxeo de la grulla blanca, el estilo del mono, los ocho inmortales borrachos, pak mei, boxeo del dragón). A continuación describe las armas chinas y las armas dobles así como los principios que se deben aplicar en cada una de ellas. El undécimo capítulo trata los golpes de mano, ofreciendo una breve descripción y su ilustración; para terminar con 3 capítulos prácticos sobre ejercicios para mejorar el manejo de los pies, las patadas y las posiciones.

954. Longyun, Cai y Shankang, Shao (1989). Wushu : estilo borracho. Madrid: Miraguano. $1^{\mathfrak{a}}$ ed. 174 p. : il. ; $13 \times 19$ cm. ISBN: 84-7813-051-9. Depósito legal: M. 40596-1989. Palabras clave: historia, fundamentos técnicos, principios técnicos. Resumen: Manual teórico y técnico de kung fu. El libro esta formado por 2 capítulos precedidos por una introducción que comenta las características generales y ventajas del estilo zuijiuquan (boxeo del borracho). El primer capítulo describe la ejecución técnica y puntos esenciales de las 14 habilidades de zuijiuquan acompañados de su representación gráfica y esquemas de movimiento. El segundo capítulo expone los principios técnicos del zuijiuquan. Adjunta una breve biografía de los autores.

955. Moriel Rivera, Santiago (1992). Ju-dien-chuan : el estilo secreto de la mariposa (1 $1^{\underline{a}}$ parte). Barcelona: Alas. 1aㅡ ed. 48 p. : il. ; 17x24 cm. ISBN: 84-203-0273-2. Depósito legal: B. 37182-1992. Palabras clave: wushu, escuelas. Resumen: Manual teórico y técnico de ju-dien-chuan de la familia Weey. La obra comienza explicando el origen de este estilo, sus características, sus maestros y su introducción en España. Los tres siguientes capítulos explican la aplicación del tao al estilo, caracterizado en las posiciones, las peculiaridades del trabajo de piernas en el ju-dien-chuan y la relación de éste con el ch'i. A continuación enumera las posiciones y golpes para luego ilustrar algunas de ellas. Finaliza con la 
representación gráfica y la descripción de la secuencia de movimientos de la 1aㅡ forma tradicional, puño de mariposa (shao lin be jian chuan).

956. Nieto, Marco (2009). El ABC del wushu : manual autodidáctico sobre las artes marciales chinas. Barcelona: Alas. 1ae ed. 91 p. : il. ; 17x23,5 cm. ISBN: 978-84-203-0462-5. Depósito legal: B. 40442-2009. Palabras clave: formas, fundamentos técnicos. Resumen: Manual teórico y técnico de wushu. El libro esta dividido en 4 capítulos precedidos por los agradecimientos. El primer capítulo explica el significado del término wushu y su caligrafía, y comenta su historia. El segundo capítulo comenta las características de la fonética china. El tercer capítulo describe la ejecución técnica, puntos esenciales, errores comunes, métodos de entrenamiento y principios técnicos de las maneras de colocar las manos, los pasos básicos, las técnicas de manos y las técnicas de piernas. El cuarto capítulo presenta la descripción técnica, los puntos esenciales, los principales errores y las técnicas para corregirlos de los movimientos que componen las formas wubuquan (boxeo de los cinco pasos) y chuji changquan yi lu (primera forma elemental del boxeo largo). Adjunta la bibliografía consultada.

957. Pabst, Manfred (1986). Kung fu : teoría y práctica del estilo clásico y moderno. Bilbao: Mensajero. 1a ed. 155 p. : il. ; 16x21 cm. ISBN: 84-271-1451-6. Depósito legal: BU. 134-1986. Palabras clave: historia, fundamentos técnicos, principios técnicos, textos, jeet kune do, wing chun, wushu, escuelas. Resumen: Manual teórico y técnico de wushu. La obra esta formada por 3 partes. La primera parte comenta los orígenes filosóficos del wushu, su desarrollo como boxeo shaolin, su expansión territorial, su práctica actual en China, el desarrollo y características de los estilos de wushu, y un resumen de las características y fundamentos del jeet kune do como sistema moderno de wushu. La segunda parte describe los principios técnicos del jeet kune do en un primer capítulo y a continuación presenta la ejecución técnica e ilustra los fundamentos técnicos del wing chun y jeet kune do, desde las posiciones y formas móviles hasta ejemplos de aplicación, ejercicios para desarrollar estos fundamentos, técnicas de contraataque con los brazos, las técnicas defensivas, las técnicas de pierna, y la explicación de los principios de los ejercicios de lucha junto con varios ejemplos de las acciones en contra, técnicas contra ataques de pierna, combinaciones contra ataques dobles, combinaciones ofensivas, y la técnica de las manos que atrancan. La tercera parte estudia los estilos clásicos de wushu como la tai mantis y el wan chuan. Comenta su fundamentación teórica, las posiciones y formas de movimiento junto con sus esquemas e ilustraciones, ejercicios con compañero para entrenar los ataques y defensas, técnicas desde el suelo, combinaciones de técnicas de puño y pierna y su aplicación práctica, y la descripción técnica de dos formas breves con compañero.

958. Padrón, Miguel (1983). Boxeo de la grulla blanca : bai hok pai (2ª parte). Barcelona: Alas. $1^{\underline{a}}$ ed. 47 p. : il. ; 17x24 cm. ISBN: 84-203-0151-5. Depósito legal: 27487-1983. (2ª ed., 1986). Palabras clave: historia, wushu, escuelas. Resumen: Manual teórico y técnico de bai hok pai. La obra comienza con la narración de la creación del estilo, la historia del kung-fu, cómo se organizaban las escuelas y los exámenes y cómo fue la reorganización del sistema en la dinastía Ming. El siguiente capítulo compara el boxeo largo de la grulla blanca con el wing tsun, el bai hok pai con el hung gar, el bai hok pai con el kenpo "fushin" y la adaptación del tai chi al boxeo de la grulla blanca. Finaliza con la representación gráfica de un tao superior de Bai Hok Pai, técnicas superiores, combinaciones y encadenamientos del Bai Hok Pai y técnicas de aplicación a la defensa personal. Finaliza con un breve comentario sobre el sistema de combate tradicional y el del full-contact dentro del boxeo de la grulla blanca y cinco fotografías típicas de Honan.

959. Padrón, Miguel (1985). Boxeo de la grulla blanca : bai hok pai. Barcelona: Alas. $1 \underline{\text { a }}$ ed. 47 p. : il. ; 17x24 cm. ISBN: 84-203-0114-0. Depósito legal: B. 35016-1985. Palabras clave: formas, historia, fundamentos técnicos, principios técnicos, defensa personal, aplicación marcial. Resumen: Manual teórico y técnico de kung fu. La obra esta formada por 12 capítulos, precedidos por el relato del mito de la grulla blanca. El primer capítulo comenta el origen del estilo bak hok pai, mientras que el segundo narra la historia de los cinco animales. El tercer capítulo describe las características técnicas de las formas de los cinco animales para luego enumerar las principales características técnicas del bak hok pai. El quinto capítulo expone la biografía de los maestros Chu-Huen-Tak y Miguel Padrón. El sexto capítulo describe las armas naturales del cuerpo y su utilización, incluyendo su representación gráfica. El séptimo capítulo enumera e ilustra las posiciones básicas del estilo mientras que los dos siguientes capítulos presentan las patadas y los barridos. El décimo capítulo describe brevemente e ilustra algunas de las técnicas de defensa del estilo bak hok pai contra varios ataques de puño y patadas. El siguiente capítulo describe la ejecución técnica de una parte de la forma yeng-ching-yi junto con su secuencia fotográfica. El último capítulo ilustra distintas técnicas del manejo del bastón largo de bambú (pa-kua-kua).

960. Parra, Isidoro (1987). Chang chuan kung fu : boxeo largo del norte de China. Parte 2. Barcelona: Alas. 1a ed. 48 p. : il. ; 17x24 cm. ISBN: 84-203-0207-4. Depósito legal: no.

961. Pérez Agustí, Adolfo (1982). Ming chuan kung fu : en busca de la auténtica defensa personal. Barcelona: Alas. $1^{\mathrm{a}}$ ed. 48 p. : il. ; 17x23,5 cm. ISBN: 84-203-0141-8. Depósito legal: B. 37537-1982. (2aㅡ ed., 1986). Palabras clave: formas, fundamentos técnicos, defensa personal, ejercicios, entrenamiento, aplicación 
marcial, preparación física. Resumen: Manual teórico y técnico de kung fu. La obra esta formada por 5 capítulos, precedidos por una reflexión del autor sobre la finalidad de las artes marciales. El primer capítulo explica en qué consiste el ming chuan, sus contenidos técnicos junto con un comentario biográfico de los maestros John Fanning, Amado y Adolfo Pérez. El segundo capítulo explica los distintos ejercicios de entrenamiento adoptados del monasterio de shaolin. El tercer capítulo describe brevemente la ejecución de algunas técnicas de ming chuan aplicadas a la defensa personal o al combate junto con su secuencia fotográfica. El cuarto capítulo expone algunos de los métodos de endurecimiento corporal del estilo acompañados de su representación gráfica. El quinto capítulo describe la ejecución técnica de la forma del tigre del estilo ming chuan incluyendo su secuencia fotográfica. Adjunta varias fotografías de John Fanning entrenando.

962. Pérez Agustí, Adolfo (1985). El libro de oro del kung-fu. Fuenlabrada: Adolfo Pérez Agustí. 1ạ ed. 174 p.: il. ; 15x21,5 cm. ISBN: 84-398-5300-9. Depósito legal: M. 39519-1985. Palabras clave: historia, fundamentos técnicos, baguazhang, choy lee fut, kyusho, taijiquan, wing chun, wushu, xinyiquan, escuelas, armas. Resumen: Manual teórico y técnico de kung-fu. El libro esta formado por 4 partes, precedidas de dos capítulos que narran el origen del kung-fu y su aplicación terapéutica. La primera parte presenta la historia y contenidos de los estilos internos del kung-fu como son el tai chi chuan, pakua, hsing-i, wushu e ilustra las técnicas con paraguas y la defensa con sillas. La segunda parte explora los estilos externos incluyendo la historia y entrenamientos del ch'ang ch'uan; la historia, posiciones y endurecimiento del hung gar; la historia, maestros y contenidos técnicos del wing chun; los orígenes del choy-li-fut; la ilustración del arte de trepar; la formación de la mantis religiosa y sus técnicas; los principios e ilustraciones técnicas de la grulla blanca, el estilo del mono, el ming ch'uan, el boxeo del dragón; así cómo una breve descripción de otros estilos. La tercera parte ilustra las diferentes armas chinas, los orígenes del bastón chino, varias ilustraciones técnicas con bastón, y la descripción de las armas dobles en kung-fu. La última parte incluye varios gráficos sobre las posiciones fundamentales del kung-fu, la ilustración de los puntos vitales y su manipulación, la descripción del ataque en yunque, el endurecimiento de antebrazos y abdomen, la explicación de los golpes con la mano y sus partes, la biografía y carrera profesional de Bruce Lee y diplomas del autor.

963. Pérez Agustí, Adolfo (1998). Kung-fu. Arganda del Rey: Edimat. 1a ed. 190 p. : il. ; 13x21 cm. ISBN: 848403-057-1. Depósito legal: M. 16370-1998. Palabras clave: historia, fundamentos técnicos, biografía, baguazhang, choy lee fut, taijiquan, wing chun, wushu, xinyiquan, escuelas, maestros, taoísmo. Resumen: Manual teórico y técnico de kung-fu. El libro esta formado por 10 capítulos ilustrados, precedidos por una introducción que relata el origen del kung-fu. El primer capítulo comenta la relación entre el taoísmo y el kung-fu y describe algunos métodos y ejercicios para mejorar la salud a través de la respiración. El segundo capítulo expone el origen y características del tai chi, el tai chi chuan, el pa kua y el hsing i. El tercer capítulo relata el origen del wushu y describe sus contenidos técnicos. El cuarto capítulo analiza el origen de los estilos del norte de wushu, los niveles de enseñanza así como la historia y contenidos técnicos del hung gar, wing chun y choy li fut. El quinto capítulo comenta los orígenes, características y contenidos técnicos del tang lang, la mantis religiosa, el boxeo de la grulla blanca, el estilo del mono, el ming chuan y el boxeo del dragón. El sexto capítulo analiza la utilización histórica del bastón como arma, mientras que el séptimo capítulo presenta las armas dobles del kung-fu. El octavo capítulo ilustra las posiciones fundamentales de kung-fu además de localizar los puntos vitales y describir su manipulación y efectos. El noveno capítulo describe la ejecución técnica de los golpes de mano básicos mientras que el último capítulo resume la vida de Bruce Lee. Adjunta diplomas del autor.

964. Pericás Álvarez, Francisco (1986). Yo kung fu. Barcelona: Alas. 1a ed. 48 p. : il. ; 17x24 cm. ISBN: 84203-0195-7. Depósito legal: B. 23988-1986. Palabras clave: formas, historia, fundamentos técnicos, combate, entrenamiento. Resumen: Manual teórico y técnica de kung fu. El libro esta formado por 10 capítulos, precedidos por un prólogo y una biografía del autor. El primer capítulo presenta la biografía del fundador del estilo Yo Kung Fu, la creación de dicho estilo, los contenidos de la obra y ofrece algunos consejos para el entrenamiento y el combate. Los siguientes cuatro capítulos incluyen la ilustración y breve descripción de los fundamentos técnicos del estilo, como son las técnicas básicas de puño, posiciones, bloqueos y técnicas de pierna. El sexto capítulo presenta la secuencia fotográfica de la forma del puño duro de shaoling con el nombre de sus técnicas. El siguiente capítulo explica algunos ejercicios para mejorar la concentración mientras que el octavo capítulo presenta la representación de las posiciones básicas según el programa de cinturones. El noveno capítulo relata el origen e historia del kung fu. Finaliza con un comentario sobre la importancia de la respiración, los tipos de combate practicados en el yo kung fu, la preparación y estrategia ante un combate, y ofrece algunos consejos para el entrenamiento.

965. Prat Banús, José María (1979). Kung fu-wu shu : camino de vida. Barcelona: Alas. $1^{\text {a }}$ ed. 125 p. : il. ; 15x21 cm. ISBN: 84-203-0090-X. Depósito legal: B. 23247-1979. (2ª ed., 1983; 3ae ed., 1987). Palabras clave: qigong, historia, fundamentos teóricos, fundamentos técnicos, entrenamiento, cortesía, escuelas, acupuntura, fundamentos filosóficos, fitoterapia, medicina tradicional china, moxibustión, armas. 
Resumen: Manual teórico y técnico de kung fu. El libro esta formado por 4 capítulos precedidos por una dedicatoria, el currículo del autor, un conjunto de proverbios chinos, los agradecimientos y una introducción que explica el significado de los términos kung fu y wushu. El primer capítulo narra la historia del kung fu y sus estilos detallando sus fundamentos teóricos, técnicos y filosóficos así como su expansión territorial y evolución. El segundo capítulo expone y comenta las reglas de comportamiento del kung fu de la escuela budista y taoísta. El tercer capítulo estudia la relación entre la medicina china y el kung fu además de comentar las características de los ejercicios gimnásticos, los ejercicios de respiración, el masaje curativo, la moxibustión, la acupuntura y la herboterapia aplicados al kung fu junto con la descripción de algunos de sus ejercicios y tratamientos. El cuarto capítulo relata la historia de las armas chinas, expone su clasificación y comenta las características, fundamentos técnicos y entrenamiento con el bastón, el palo largo, el bastón de tres secciones, el kwan tao, la espada, el látigo metálico bin, las armas arrojadizas, la daga, la lanza y el tridente acompañados de numerosas ilustraciones explicativas. Adjunta una tabla cronológica de las dinastías chinas y bibliografía.

966. Prat Banús, José María (1980). Hung gar kung fu. Barcelona: Alas. 1a ed. 47 p. : il. ; 17x24 cm. ISBN: 84303-0100-0. Depósito legal: no. (2 ${ }^{\mathrm{a}}$ ed., 1981; 3a ed., 1985). Palabras clave: formas, historia, fundamentos técnicos, maestros. Resumen: Manual teórico y técnico de kung fu. El libro esta formado por 16 capítulos precedidos por un prólogo que expone los objetivos de la colección. El primer capítulo narra el origen del hung gar y comenta las características del kung fu según el maestro Wong. El segundo capítulo detalla las enseñanzas del maestro Wong en España además de relatar una historia sobre las proezas de los maestros de hung gar. El tercer capítulo explica los contenidos técnicos del hung gar, enumera sus formas y sus características técnicas. El cuarto capítulo presenta los contenidos teóricos y técnicos del hung gar. El quinto capítulo comenta las formas que contienen los diez animales del hung gar junto con un esquema de la evolución del estilo y sus maestros. Los siguientes diez capítulos explican el significado y características técnicas del dragón, el tigre, la serpiente, el leopardo, la grulla, el león, el elefante, el caballo, el mono y el gato junto con la descripción y secuencia fotográfica de la ejecución de una de sus técnicas. El último capítulo describe e ilustra otras técnicas del estilo hung gar.

967. Prat Banús, José María (1982). Chui pa hsien : el boxeo de los ocho inmortales borrachos. 1a parte. Barcelona: Alas. $1^{\mathfrak{a}}$ ed. 48 p. : il. ; 16x23,5 cm. ISBN: 84-203-0127-2. Depósito legal: B. 3142-1982. (2 $2^{\mathrm{a}}$ ed., 1986). Palabras clave: historia, fundamentos técnicos, biografía, choy lee fut, relatos, maestros. Resumen: Manual teórico y técnico de kung fu. La obra esta formada por 8 capítulos, precedidos por una biografía del autor y una introducción que comenta los contenidos del libro. El primer capítulo comenta los contenidos técnicos del estilo mientras que el segundo analiza el origen del estilo de los borrachos. El tercer capítulo presenta el mito de los ocho inmortales así como la descripción de cada uno de ellos. El cuarto capítulo describe la ejecución de varios ejercicios de la posición de borracho acompañados de su ilustración explicativa. El quinto capítulo comenta el arte de los chui pa hsien dentro del hung gar. El sexto capítulo expone la biografía del maestro Chan Dau y enumera las formas que creó. El séptimo capítulo analiza la ejecución de los chui pa hsien dentro del choy li fut, mientras que el octavo muestra la creación del estilo Lu Jer Shen Kuen.

968. Prat Banús, José María (1982). Chui pa hsien : el boxeo de los ocho inmortales borrachos. $2^{\underline{a}}$ parte. Barcelona: Alas. 1aㅡ ed. 48 p. : il. ; 16x23,5 cm. ISBN: 84-203-0128-0. Depósito legal: B. 3143-1982. (2ª ed., 1986). Palabras clave: historia, fundamentos técnicos, aplicación marcial. Resumen: Manual teórico y técnico de kung fu. La obra esta formada por 9 capítulos. El primer capítulo describe la ejecución de la forma de los borrachos de Lu Jer, incluyendo su representación gráfica. El segundo capítulo narra el origen del estilo Hsuang Tung Kuen. El tercer capítulo comenta la biografía de Wang Lang, creador del estilo de la mantis religiosa. El cuarto capítulo explica el origen del estilo del águila y la forma de los borrachos de dicho estilo. El quinto capítulo describe el arte de la grulla blanca y sus formas además de incluir la representación gráfica de algunas de sus técnicas y su aplicación marcial. El sexto capítulo expone los contenidos técnicos del estilo Tai Shing así como su forma de los borrachos. El séptimo capítulo analiza otros estilos con técnica de los borrachos. El octavo capítulo describe varios ejercicios de acondicionamiento físico antes de practicar la técnica de los borrachos, mientras que el último capítulo ilustra algunas de las técnicas de los 8 inmortales borrachos dentro del estilo Tao Kuen así como su aplicación marcial. Adjunta un epílogo.

969. Prat Banús, José María (1982). Lung yin kuen kung-fu : el arte del boxeo del dragón. Barcelona: Alas. 1ạ ed. 48 p. : il. ; 17x23,5 cm. ISBN: 84-203-0134-5. Depósito legal: 21206-1982. Palabras clave: historia, fundamentos técnicos, formas. Resumen: Manual teórico y técnico de Lung Yin Kuen. Comienza con una introducción donde explica el significado del dragón tanto en Occidente como en Oriente. El primer capítulo narra la historia del estilo, de sus maestros y sus familias. El segundo capítulo explica las diferentes partes técnicas del estilo y sus contenidos, junto con su entrenamiento, para finalizar en el tercer capítulo con la representación y descripción técnica de la forma Mor Kiu del estilo del dragón.

970. Prat Banús, José María (1985). Lama pai kung-fu : el boxeo de los monjes lamas tibetanos. $1^{a}$ parte. Barcelona: Alas. 1ํㅡㄹ ed. 47 p. : il. ; 17x23,5 cm. ISBN: 84-203-0179-5. Depósito legal: B. 16348-1985. 
Palabras clave: historia, fundamentos técnicos, maestros, religión, formas. Resumen: Manual teórico y técnico de kung fu. El libro esta formado por 2 capítulos precedidos por una introducción que comenta la formación del autor en este arte. El primer capítulo comenta las características, religión, historia y prácticas esotéricas del Tibet, y describe las técnicas de lung-mo, tum-mo y pho-wa de los monjes lamas. El segundo capítulo narra la historia del kung fu lama, su evolución, expansión y maestros junto con una tabla cronológica del clan lama y su comentario. Adjunta la secuencia fotográfica de la forma "el águila busca su presa".

971. Prat Banús, José María (1985). Lama pai kung-fu : el boxeo de los monjes lamas tibetanos. 2a parte. Barcelona: Alas. 1aㅡ ed. 47 p. : il. ; 17x24 cm. ISBN: 84-203-0180-9. Depósito legal: B. 20198-1985. Palabras clave: fundamentos técnicos, ejercicios, entrenamiento, sistemas de entrenamiento. Resumen: Manual teórico y técnico de kung fu. El libro esta formado por 2 capítulos precedidos por una introducción que presenta una historia sobre el poder de los lamas. El primer capítulo expone los contenidos técnicos del lama kung fu, describe la ejecución de una secuencia de combate del clan lama, las principales técnicas de puño del lama hop ga, las series técnicas del bac hoc pai y el método de entrenamiento de "los cuatro postes sencillos" acompañadas de sus ilustraciones explicativas. El segundo capítulo detalla las características del mui fa chong (postes de la flor de ciruelo), algunas de sus historias y el entrenamiento del clan lama, incluyendo numerosos gráficos explicativos.

972. Prat Banús, José María (1987). Ch'a chia chuan : el boxeo de la familia Ch'a (Parte 1aa). Barcelona: Alas. $1^{a}$ ed. 48 p. : il. ; 16x24 cm. ISBN: 84-203-024-X (Falta un número). 84-203-0204-X. Depósito legal: B. 180-1987. Palabras clave: historia, escuelas, wushu. Resumen: Manual teórico y técnico de Ch'a Chia Chuan. Comienza con una introducción dedicada al paradigma de las artes marciales actuales y la importancia de la no-agresividad en las mismas para luego pasar a describir las características de las 10 primeras escuelas del monasterio shaolin. Se explican las características del estilo, su historia y maestros más destacados y se adjunta representaciones gráficas de algunos de sus movimientos. Finaliza la obra con un organigrama de las principales escuelas de pugilismo y la comparación de las características principales de estas escuelas.

973. Prat Banús, José María (1987). Ch'a chia chuan : el boxeo de la familia Ch'a (Parte 2ª). Barcelona: Alas. 1a ed. 48 p. : il. ; 17x24 cm. ISBN: 84-203-0205-8. Depósito legal: B. 5927-1987. Palabras clave: historia, fundamentos técnicos, maestros. Resumen: Manual teórico y técnico de Ch'a Chia Chuan. La obra comienza relatando las relaciones entre china y los países árabes, para detallar en el segundo capítulo el significado del estilo Ch'a Kuen, cómo se produjo su transmisión y formación, sus características y las diferencias con los estilos del sur. El tercer capítulo explica el entrenamiento del pugilismo chino musulmán en Occidente, sus tres niveles y características. Continúa narrando la historia del trabajo tam tui, la biografía del maestro Lau Fei y finaliza con la descripción técnica de una forma de Ch'a Kuen, dividiendo en 4 secciones sus 77 movimientos totales y adjunta una secuencia gráfica de los mismos.

974. Prat Banús, José María y Monzó Landeira, Germán (1984). Chang chuan kung fu : boxeo largo del norte de China. Barcelona: Alas. 1aㅡ ed. 48 p. : il. ; 17x24 cm. ISBN: 84-203-0160-4. Depósito legal: B. 43031984. ( $2^{\mathrm{a}}$ ed., 1986). Palabras clave: historia, fundamentos técnicos, formas. Resumen: Manual teórico y técnico de Chang Chuan. El primer capítulo relata la historia del monasterio shaolin y la formación de sus diferentes estilos marciales. El segundo capítulo profundiza en la creación del estilo Chang Chuan, para continuar con la explicación de las posiciones y golpeos fundamentales del estilo. El último capítulo describe la ejecución técnica de la forma norteña Kung Li Chuan, presentando gráficamente sus movimientos e incluye otras técnicas de puño, defensas, patadas y saltos propios del estilo también representados gráficamente.

975. Prat Banús, José María y Reyna, Salvador (1980). Shaolin norte. Barcelona: Alas. 1a ed. 47 p. : il. ; 17x23,5 cm. ISBN: 84-203-0103-5. Depósito legal: B. 31873-1980. (2aㅡ ed., 1984; 3a ed., 1987). Palabras clave: historia, fundamentos técnicos, defensa personal, formas, aplicación marcial. Resumen: Manual teórico y técnico de shaolin norte. El primer capítulo presenta la vida del maestro Salvador Reyna y las características técnicas del estilo shaolin norte. El segundo capítulo describe las posturas del estilo y ofrece fotografías de las mismas, para en el tercero presentar la forma "Lim Pu Chuan" y la aplicación de algunos de sus movimientos a la defensa personal. El último capítulo detalla la ejecución técnica de la forma "Tam Tui", cinco de las subformas que integran la misma, y las aplicaciones a la defensa personal que se pueden hacer de ellas. Además, incluye fotografías de cada movimiento.

976. Regoli, Claudio A. (1989). Kung-fu : manual completo ilustrado. Barcelona: De Vecchi. 1 a ed. 159 p. : il. ; 17x23,5 cm. ISBN: 84-315-0817-5. Depósito legal: B. 31172-1989. (2ª imp., 1994; $3^{\text {a }}$ imp., 1996; $4^{\underline{a}}$ imp., 1999, ISBN: 84-315-2208-9). Palabras clave: historia, fundamentos técnicos, principios técnicos, baguazhang, choy lee fut, taijiquan, wing chun, xinyiquan, wushu, escuelas, armas. Resumen: Manual teórico y técnico de kung-fu. La obra esta formada por 3 partes, precedidas por dos capítulos introductorios que presentan las armas utilizadas en los distintos estilos de kung-fu y comentan el concepto de chi, el arte del tien hsueh, las técnicas de chin na y los dioses del kung fu. La primera parte 
consta de 4 capítulos que estudian la historia, características y principios técnicos de los estilos externos del norte como el shaolin shu, la mantis religiosa, el estilo del gran mono y el estilo del borracho, acompañados de numerosas ilustraciones de sus técnicas. La segunda parte consta de 3 capítulos que presentan las características y principios técnicos de los estilos externos del sur como el hung gar o hung kuen, el choy lee fut y el wing chun junto con la ilustración de algunos de sus fundamentos técnicos. La última parte consta de 3 capítulos que comentan la técnica de los estilos internos tai chi chuan, pa kwa chuan y el hsing i chuan, adjuntando algunas fotografías comentadas de sus técnicas básicas.

977. Rossell Sellart, Tony (1981). Hung gar kung fu : técnicas de aplicación práctica. Kung-chi-kuen (kata). Barcelona: Alas. 1aa ed. 48 p. : il. ; 17x23,5 cm. ISBN: 84-203-0110-8. Depósito legal: B. 9651-1981. (2a ed., 1984; 3a ed., 1987). Palabras clave: formas, fundamentos técnicos, ejercicios, calentamiento, respiración. Resumen: Manual teórico y técnico de kung fu. El libro esta formado por 10 capítulos. El primer capítulo señala la importancia de la respiración y describe uno de sus ejercicios de forma ilustrada. El segundo capítulo describe e ilustra varios ejercicios de calentamiento. Los siguientes seis capítulos describen la ejecución técnica y características de los fundamentos técnicos del hung gar kung fu, como son las posiciones de los pies, las guardias, las formas de ataque y defensa con las manos, las formas de ataque y defensa con los pies, las formas de bloqueo y algunas de sus técnicas combinadas. El noveno capítulo explica brevemente la ejecución de los primeros movimientos de la forma kung-chi-kuen acompañada de su secuencia fotográfica. El último capítulo ofrece algunas ilustraciones del maestro Lam Sai Wing ejecutando las viejas técnicas del hung gar.

978. Rossell Sellart, Tony (1986). El arte del boxeo de hung hei kung : técnicas superiores del hung kuen. Barcelona: Alas. 1aㅡ ed. 46 p. : il. ; 17x23,5 cm. ISBN: 84-203-0138-8. Depósito legal: B. 16986-1986. Palabras clave: formas, historia, maestros, armas. Resumen: Manual teórico y técnico de kung fu. El libro esta formado por 4 capítulos precedidos por una introducción que comenta los contenidos del libro. El primer capítulo narra el linaje de maestros de Hung-Gar de los tiempos actuales. El segundo capítulos presenta la descripción y secuencia fotográfica de una forma a dos hombres. El tercer capítulo comenta las características de las forma tid-shin-kuen e incluye su explicación e ilustración. El cuarto capítulo explica las características de las principales armas del hung-gar como son sam-chikuan, tich-ching-chi, gor-bin, tridente, kwan-tao, tou y wah-lum acompañadas de varias ilustraciones explicativas.

979. Rossell Sellart, Tony y Fraguas, José María (1987). Las armas del kung-fu. Madrid: Esteban Sanz Martínez. $1^{a}$ ed. 125 p. : il. ; 15x21 cm. ISBN: 84-85977-35-1. Depósito legal: M: 15347-1987. Palabras clave: fundamentos técnicos, defensa personal, armas. Resumen: Manual teórico y técnico de kung-fu. El libro esta compuesto de 13 capítulos, precedidos de una breve biografía de los autores y una introducción. El primer capítulo relata las características y utilización de las principales armas del kung-fu, para luego profundizar en las armas dobles, sus características, utilización y algunas de las técnicas más frecuentes. Los dos siguientes capítulos ilustran y nombran las posiciones de una forma de kwan-do y otra forma de sable así como algunas posiciones de su manejo. Los siguientes capítulos ilustran una forma de sam-chi-kuan, algunas de sus maniobras, una forma de cern-do (dos sables) y una forma de lanza. Los últimos 4 capítulos presentan las formas de dos personas en el combate de lanza contra palo largo, kwan-do contra sam-chi-kuan, sable contra doble sable y un compendio de técnicas con los cuchillos de mariposa.

980. Rossell Sellart, Tony y Serrano, Manuel (2008). Hung gar kung fu : parte 2. Madrid: Esteban Sanz Martínez. 1a ed. 339 p. : il. ; 15x21 cm. ISBN: 978-84-935390-3-0. Depósito legal: M. 29847-2008. Palabras clave: historia, ejercicios, combate, maestros, preparación física, formas. Resumen: Manual técnico de kung fu. La obra esta dividida en 12 capítulos. El primer capítulo presenta diversas ilustraciones de los autores practicando el hung gar kung fu. El segundo capítulo incluye varias fotografías del maestro Wong Ping Pui aplicando diversas técnicas y durante sus entrenamientos. El tercer capítulo comenta la historia de los grandes maestros del hung gar kung fu, como son Wong Fei Hung, Mok Gwei Lan, Tang Fong, Lam Sai Wing, Chan Hon Chung, Lam Jo, Yuen Ling, Chiu Kau, Ho Lap Tin y Chao Wing Tak. El cuarto capítulo ilustra algunas de las posiciones del hung gar kung fu y sus ejercicios de endurecimiento y fortalecimiento. El quinto capítulo enumera distintos ejercicios por parejas acompañados de su secuencia fotográfica. El sexto capítulo presenta la ejecución de la forma Mo Fa Kuen a través de la ilustración de sus movimientos para en el siguiente capítulo mostrar algunas de sus aplicaciones marciales. El octavo capítulo explica el significado de la forma Lau Gar Kuen además de incluir la secuencia gráfica de su ejecución. El siguiente capítulo demuestra la aplicación de algunas de las técnicas de la forma Lau Gar Kuen. Los dos siguientes capítulos explican el significado de la forma Fu Hok Seung Yin Kuen e ilustran su ejecución además de la aplicación marcial de algunas de sus técnicas. El último capítulo describe la función, características y principios técnicos de la forma Tid Sin Kuen junto con su representación gráfica. Adjunta un apéndice con la secuencia fotográfica de la forma Kung Chi Fook Fu Kuen realizada por el maestro Lam Sai Wing. 
981. s.a. (1964). Kung-fu : método secreto de lucha china. Barcelona: Policolor Offset. 1 a ed. 58 p. : il. ; 21x27,5 cm. ISBN: No ISBN. Depósito legal: B. 26096-1964. Palabras clave: fundamentos técnicos, defensa personal. Resumen: Manual técnico de kung-fu. Después de representar las armas naturales del cuerpo, como son los codos, rodillas, pies y la parte posterior de la cabeza, describe situaciones de defensa personal en las que se deben utilizar dichas armas. Cada situación esta estructurada de la misma manera, describiendo la situación, la defensa, la contra y el resultado final. Además, cada situación esta ilustrada en sus distintas fases. Describe situaciones de uno contra uno, contra varios agresores, contra agarres, revólveres y botellas.

982. s.a. (1978). Kung-fu. Madrid: Demiguel. 1aㅡ ed. 36 p. : il. ; 17x24,5 cm. ISBN: No ISBN. Depósito legal: B. 36700-1978. Palabras clave: defensa personal, aplicación marcial, armas. Resumen: Manual técnico de kung fu. La obra esta formada por 3 partes, precedidas por una introducción que comenta la aplicación marcial del kung fu a una situación de defensa personal. La primera parte incluye la representación gráfica de los puntos vitales del cuerpo humano. La segunda parte describe la ejecución de las posiciones defensivas y diversas técnicas de defensa contra el ahogamiento con una sola mano o dos manos, el empujón en el pecho, el abrazo en el pecho, la estrangulación tanto de pie como en el suelo, distintas llaves de mano, de brazo y de cuello, contra ataques con cuchillo desde diferentes direcciones, contra un palo, técnicas de golpes, presas al cuerpo y de cuello, defensas contra un boxeador y defensas desde el suelo, acompañadas de su representación gráfica y esquemas de movimiento. La última parte presenta la descripción técnica de algunas técnicas avanzadas ante una presa por la espalda, los ataques directos a la cara y una patada. Adjunta un epílogo.

983. s.a. (1987). Manual autodidáctico de las artes marciales chinas. Madrid: Miraguano. 1a ed. 95 p. : il. ; 19x25 cm. ISBN: 84-85639-82-0. Depósito legal: M. 10892-1987. Palabras clave: historia, fundamentos técnicos, ejercicios, entrenamiento. Resumen: El primer capítulo narra la historia del wushu y su evolución hasta la actualidad. El segundo capítulo clasifica los distintos estilos de wushu en tres: boxeo de sombra o ejercicios con manos vacías, ejercicios con armas y ejercicios de combate, incluyendo una breve descripción de los ejercicios de sombra más practicados junto con una ilustración de los mismos. El tercer capítulo presenta brevemente e ilustra los distintos ejercicios con armas así como los ejercicios de combate. El cuarto capítulo ilustra algunas de las escuelas actuales de entrenamiento de wushu y la historia del monasterio shaolin y su entrenamiento. El último capítulo describe la ejecución técnica de los ejercicios esenciales de wushu, divididos en 8 partes como son: ejercicios de hombros y brazos, ejercicios de piernas, ejercicios de cintura, ejercicios de formas y golpes de mano, ejercicios de pasos y manejo de los pies, ejercicios de salto, ejercicios de equilibrio y ejercicios de combinación. Explica la posición inicial, los movimientos por partes y los puntos esenciales además de varios gráficos con sus esquemas de movimiento.

984. Serrato Rodríguez, Juan Carlos (1988). Wushu zha quan. Madrid: Juan Carlos Serrato Rodríguez. 1a ed. 125 p. : il. ; 14x21 cm. ISBN: 84-404-3388-3. Depósito legal: M. 39995-1988. Palabras clave: formas, historia, fundamentos técnicos, biografía, competición, instituciones, maestros, reglamentos. Resumen: Manual teórico y técnico de wushu. El libro esta formado por 12 capítulos precedidos por las dedicatorias del maestro Wu Bing y Zen Yu Jiu, y una introducción que explica en qué consiste el wushu. El primer capítulo comenta el estado actual de las artes de wushu, su organización, institucionalización y expansión internacional. El segundo capítulo explica las características religiosas de la nación Hui. El tercer capítulo narra la historia del pueblo Hui y su desarrollo de las artes marciales. El cuarto capítulo expone las diferentes escuelas de wushu creadas por el pueblo Hui. El quinto capítulo presenta la localidad de Cangxian como el hogar del wushu y destaca la labor de distintos maestros del pueblo Hui en la expansión del wushu. Los dos siguientes capítulos narran las biografías y anécdotas de los maestros Wang Ziping y Zhang Wenguang. El octavo capítulo describe la ejecución de las técnicas básicas de manos y posiciones incluyendo su representación gráfica. El noveno capítulo presenta la descripción técnica de la forma yongzhanquan (boxeo para el valiente) y la aplicación marcial de algunas de sus técnicas acompañadas de su representación gráfica y esquemas de movimiento. El décimo capítulo explica la ejecución de la forma de boxeo zha junto con sus gráficos y esquemas de movimiento explicativos. El décimo primer capítulo detalla los criterios de calificación en la competición de wushu además de describir el campo y armas de competición. El último capítulo incluye una planilla para la construcción de formas libres.

985. Serrato Rodríguez, Juan Carlos (1992). El nan quan : el wu shu del sur de China. Madrid: Juan Carlos Serrato Rodríguez. 1aㅡ ed. 182 p. : il. ; 14x21,5 cm. ISBN: 84-604-2633-5. Depósito legal: M. 15229-1992. Palabras clave: formas, historia, fundamentos técnicos, principios técnicos, entrenamiento, escuelas, competición, reglamentos. Resumen: Manual teórico y técnico de kung fu. El libro esta formado por 4 secciones precedidas por los agradecimientos. La primera sección explica brevemente la historia del wushu y del nan quan junto con sus características técnicas y las de los estilos de Guang dong. La segunda sección detalla los contenidos técnicos del nan quan y ofrece varios consejos prácticos sobre el entrenamiento. La tercera sección describe e ilustra la ejecución de las técnicas básicas de nan quan, sus combinaciones y algunos ejercicios de puños y piernas para su perfeccionamiento. La última 
sección explica la ejecución técnica y puntos esenciales de cada uno de los movimientos de las formas de los cinco animales de shaolin, la primera, segunda y tercera formas elementales de nan quan y la forma superior del nan quan denominada tigre y grulla, incluyendo su secuencia fotográfica, representación gráfica y esquemas de movimiento. Adjunta una sección que presenta un diccionario chino-español y el reglamento internacional de formas obligatorias de competición.

986. Sierra de Cardenas, Antonio Vicente (2000). Kung fu : el tao del guerrero marcial. Valencia: Pau Cho I. 1ae ed. 163 p. : il. ; 21x29 cm. ISBN: 84-931283-1-7. Depósito legal: no.

987. Soler, Gabriel (2008). Hung gar kuen kung fu : Chau Wing Tak heredero de Tang Fong en Hong Kong. Barcelona: Gabriel Soler Cueli. $1^{a}$ ed. 437 p. : il. ; 16x23 cm. ISBN: 978-84-612-3596-4. Depósito legal: B. 27437-2008. Palabras clave: formas, historia, fundamentos técnicos, biografía, cultura, genealogía, maestros, medicina. Resumen: Manual teórico y técnico de hung gar kung fu. La obra esta formada por 20 capítulos ampliamente ilustrados, precedidos por los agradecimientos, varios prólogos y una introducción que comenta los contenidos del libro. El primer capítulo narra la historia del hung gar kung fu para en el segundo ilustrar su árbol genealógico. Los tres siguientes capítulos detallan la biografía de los maestros Wong Fei Hung, Tang Fong y Chau Wing Tak. El sexto capítulo incluye varias ilustraciones del gimnasio de Chau Wing Tak durante los años 60. El siguiente capítulo narra los inicios del hung gar en España. El octavo capítulo comenta el origen del león del norte y del sur, los objetivos de la danza del león, compara las características de los diferentes leones del sur y las competiciones. El siguiente capítulo ilustra las posiciones básicas del hung gar para luego incluir una relación de las formas que se practicaban en el gimnasio de Chai Wing Tak. Los dos siguientes capítulos presentan la ilustración de algunas de las secuencias técnicas de las formas a mano vacía denominadas kung chi hung kuen, siu lam fook fu kuen, fu hoc shion yen kuen, siu lam fu pao kuen, ng yen kuen y wu tip cheong; y de las formas con armas denominadas yeong ng loon pa kua kuan, hang che kuan, siu lam chac shen tay kwan tou, siu lam mui fa tiu tou, chen pen tay pa, long fu cho tin, wuan tau tang, mang kam yiu che, chen long yim yüt tou, puun long shion gau, fu leng gau, shion chap chay y lau yip tou. El décimo tercer capítulo describe la composición de diferentes medicamentos de uso tópico y oral específicos de la práctica del kung fu. Los últimos siete capítulos incluyen diversas fotografías de Hong Kong, practicantes y amigos, alumnos del autor, del maestro Gabriel, de exhibiciones, de cursillos y de algunos métodos de entrenamiento.

988. Soler, Gabriel y Rossell Sellart, Tony (2009). El gran maestro Chiu Chi Ling y las diferentes familias del hung gar kung fu. Barcelona: Gabriel Soler Cueli. 1aㅡ ed. 281 p. : il. ; 16x23 cm. ISBN: 978-84-613-29342. Depósito legal: B. 29926-2009. Palabras clave: historia, fundamentos técnicos, biografía, maestros. Resumen: Manual teórico y técnico de hung gar kung fu. La obra esta formada por 24 capítulos profusamente ilustrados, precedidos por los agradecimientos y varios prólogos. El primer capítulo describe brevemente la biografía del maestro Lam Sai Wing, mientras que el segundo incluye varias fotografías de Chiu Kow y Shiu Ying. Los siguientes cuatro capítulos presentan la biografía de Chiu Chi Ling, su participación en el cine, su aparición en artículos de prensa y publicaciones, y los seminarios impartidos. El octavo capítulo incluye la secuencia fotográfica de varias series técnicas de la rama tang fong. Los tres siguientes capítulos incluyen la descripción de Wong Feu Hung por parte de la maestra Mok Kwai, su biografía y cómo Lee Chang Woo fue alumno directo de esta maestra. Los siguientes diez capítulos presentan la biografía y aportación de los maestros Lam Jo, Chan Hon Chung, Back Sam Kong, Tang Fong, Ho Lap Tin, Yuen Ling, Lau Kai Tung, Wong Cho y Chau Wing Tak. El vigésimo segundo capítulo explica la llegada del hung gar a Europa, el papel del maestro Wong Ping Pui y varias fotografías de los cursillos impartidos por el maestro Chiu Chi Ling por Europa. El siguiente capítulo detalla la historia de la forma ng loon pa kua kuan para finalizar con la ilustración de distintas técnicas de palo con el muñeco de madera y su aplicación práctica.

989. Su, Yu-chang (2006). Pachi tanglang chuan. Madrid: Vision Libros. $1^{\underline{a}}$ ed. 321 p. : il. ; 17x24 cm. ISBN: 84-9821-435-1. Depósito legal: M. 32558-2006. Palabras clave: formas, historia, fundamentos técnicos, principios técnicos, combate, wushu, escuelas, maestros. Resumen: Manual teórico y técnico de kung fu. La obra consta de 12 capítulos. El primer capítulo expone las peculiaridades de las artes marciales de los estilos del norte y del sur, los estilos internos y externos, los nombres que adoptan, y narra los orígenes históricos de las artes marciales chinas y su presencia en la actualidad. El segundo capítulo comenta las referencias documentales que existen sobre el pachi chuen, relata sus orígenes históricos, además de sus maestros y sucesores, como Li Shu-Wen, Liu Yuen Chiao y Su Yu-Chang. El tercer capítulo detalla en qué consiste el pachi chuan así como los principios que rigen su entrenamiento. El cuarto capítulo señala y comenta las etapas de aprendizaje del pachi chuen, y describe la ejecución técnica de las formas Ting Tzu Pa Pu Suh y Kaimen Chuen acompañadas de su secuencia fotográfica. El quinto capítulo presenta la descripción técnica e ilustración de los fundamentos técnicos del pachi chuen. El sexto capítulo detalla las formas de manejo de la energía, los dos sistemas o teorías que fundamentan dichas prácticas, las 12 técnicas básicas y el chikung de pachi. El séptimo capítulo presenta la filosofía del maestro Su Yu-Chang sobre la práctica del pachi tanglang chuen. El siguiente capítulo describe las características, contenidos técnicos y entrenamiento del estilo 
pikua chuen además de adjuntar varias ilustraciones de sus técnicas. El noveno capítulo comenta las características técnicas del estilo tanglang (mantis), sus orígenes y maestros modernos, la biografía del maestro Su Yu-Chang. El décimo capítulo analiza las diferencias técnicas de los distintos estilos de tangland. El siguiente capítulo comenta brevemente los contenidos técnicos y principios del combate del tanglang chuen y presenta la ilustración de sus técnicas básicas, especiales y de combate. El último capítulo incluye la representación y utilización de las técnicas características del tanglang chuen además de la secuencia fotográfica del esquema Hsiao huyuen. Adjunta un anexo con el árbol genealógico del pachi chuan y el tanglang chuan.

990. Su, Yu-chang y Conches Guillén, Aurelio David (1990). Pachi tang lang chuen. Barcelona: Alas. 1aㅡ ed. 48 p. : il. ; 17x24 cm. ISBN: 84-203-0248-1. Depósito legal: no. Palabras clave: formas, fundamentos técnicos, fundamentos teóricos. Resumen: Manual teórico y técnico de kung fu. El libro esta dividido en 4 capítulos precedidos por las biografías del autor y el maestro Su Yu Chang. El primer capítulo comenta las características y beneficios del pachi tang lang chuen, su historia y maestros así como sus contenidos técnicos y fundamentos teóricos. El segundo capítulo expone la secuencia de movimientos que componen la forma Li Pi Chuen. El tercer capítulo incluye la secuencia fotográfica de la secuencia continua de defensas. El cuarto capítulo describe brevemente e ilustra algunas de las secuencias técnicas del pachi tang lang.

991. Tang, Peter P. (1979). Kung fu : manual práctico. Barcelona: Hispano Europea. 1 a ed. 173 p. : il. ;

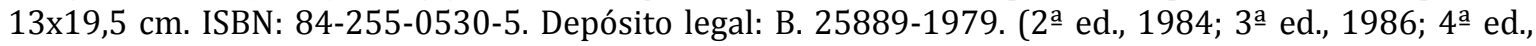
1991). Palabras clave: fundamentos técnicos, wushu, escuelas, preparación física. Resumen: Manual técnico de boxeo chino (chuan shu). La obra esta dividida en 6 capítulos y precedida de un prefacio en donde se narra la evolución de las artes marciales y ofrece algunos consejos al alumno autodidacta, al alumno que toma clases de kung fu y al maestro. El primer capítulo describe e ilustra las partes de la mano y pie con las que se golpe así como las posturas que se utilizan en este arte. Después pasa a representar 3 secuencias de movimientos de ataque y defensa, que están compuestas por 32 movimientos. Cada secuencia esta dividida en 4 partes para facilitar su aprendizaje y están ordenadas en orden creciente de dificultad. Además de las ilustraciones de cada movimiento también aparecen los esquemas de movimiento de los brazos y piernas. El quinto capítulo es un compendio de razones para endurecer la mano, métodos para realizar dicho endurecimiento, para aprovechar el tiempo y entrenar, y para aprender a romper maderas. El último capítulo explica las leyes físicas que se aplican en las artes marciales y que se relacionan con los aspectos técnicos de las mismas.

992. Tarragó Tomás, Ferrán (1985). Siu lam kung fu. Barcelona: Alas. $1^{a}$ ed. 48 p. : il. ; 16x23,5 cm. ISBN: 84203-0184-1. Depósito legal: B. 31776-1985. Palabras clave: formas, historia, fundamentos teóricos, fundamentos técnicos, combate, competición, reglamentos, armas. Resumen: Manual teórico y técnico de kung fu. El libro esta formado por 9 capítulos precedidos por una breve descripción de la formación marcial del autor. El primer capítulo narra la historia del northern siu-lam junto con la representación de su árbol genealógico. El segundo capítulo presenta el programa pedagógico de la rama sheung-mo del siu-lam. El tercer capítulo enumera las principales armas utilizadas en este estilo además de otras armas derivadas. El cuarto capítulo incluye la entrevista realizada al maestro Huinh-dai sobre los fundamentos teóricos del siu-lam. El quinto capítulo enumera las principales posturas y guardias con armas acompañadas de su ilustración. El sexto capítulo describe la ejecución de algunas técnicas básicas de puño acompañadas de su secuencia fotográfica. El séptimo capítulo explica la ejecución de la forma básica de dos hombres acompañada de sus ilustraciones explicativas. El octavo capítulo ilustra diversas técnicas de combate acompañadas de una breve explicación de su ejecución. El noveno capítulo incluye el reglamento de kung fu de la federación internacional de siu-lam.

993. Tarragó Tomás, Ferrán (1987). Wah lum tan tui. Barcelona: Alas. 1a ed. 48 p. : il. ; 17x24 cm. ISBN: 84203-0212-0. Depósito legal: no.

994. Tcheng-Tsiun (seud. de Thomas, Raymond) (1973). Kung fu : kárate chino. Barcelona: Alas. 1a ed. 92 p. : il. ; $12 \times 16$ cm. ISBN: 84-203-0289-9. Depósito legal: B. 43623-1973. (2ª ed., 1978; 3르 ed., 1980; 5aㅡ ed., 1989). Palabras clave: historia, fundamentos técnicos, ejercicios, entrenamiento, respiración. Resumen: Manual teórico y técnico de kung fu. El libro esta compuesto por 22 capítulos, precedidos por un prólogo que comenta los contenidos e importancia de la obra. El primer capítulo narra la historia del kung fu. El segundo capítulo comenta el origen de las técnicas para luego comentar los grados en kung fu. El cuarto capítulo comenta los métodos de entrenamiento para continuar con los métodos respiratorios, sus principios fundamentales, explicar el significado del chi y describir la ejecución de una técnica respiratoria. El décimo capítulo describe la ejecución de las posturas básicas acompañadas de su representación gráfica. Los siguientes seis capítulos explican la ejecución de los principales golpes de puño, patadas, defensas, presas y defensas contra uno o varios atacantes acompañadas de su ilustración. El décimo séptimo capítulo explica un ejercicio para la mejora de los desplazamientos acompañados de los esquemas de movimiento. Los últimos cinco capítulos comentan la importancia de la relajación muscular para el aprendizaje, la utilización de la fuerza muscular, el 
movimiento circular en la práctica del kung fu, el estudio de las armas y varios consejos para el entrenamiento.

995. Tcheng-Tsiun (seud. de Thomas, Raymond) (1974). Kung fu : kárate chino. Teoría y práctica. Barcelona: Alas. 1a ed. 92 p. : il. ; 11x16,5 cm. ISBN: 84-203-0293-7. Depósito legal: B. 12565-1974. (2a ed., 1977; $3^{3}$ ed., 1978; 4⿳亠丷a ed., 1980; $5^{a}$ ed., 1985). Palabras clave: formas, historia, fundamentos teóricos, textos, zen. Resumen: Manual teórico y técnico de kung fu. La obra esta formada por 8 capítulos, precedidos por un prólogo que comenta los contenidos de la obra. El primer capítulo comenta el origen del kung fu y su relación con el libro titulado "I Ching". El segundo capítulo explica el objetivo de los diferentes métodos de enseñanza. El tercer capítulo describe las armas naturales del cuerpo ilustrando su ejecución y relación con los animales. El cuarto capítulo describe la ejecución técnica de los 18 movimientos acompañados de su representación gráfica. El quinto capítulo comenta los movimientos positivos y negativos para en el sexto ofrecer varios consejos prácticos. Los dos siguientes capítulos exponen los orígenes del zen y su significado respectivamente, para finalizar con una comparación del kung fu con el kárate.

996. Toba, Rafael (1996). Introducción ó kun fu : método qwan ki do. Santiago de Compostela: Lea. 1aㅡ ed. 106 p. : il. ; $15 \times 24$ cm. ISBN: 84-88553-12-9. Depósito legal: C. 1906-1996. Palabras clave: katas, fundamentos técnicos, principios técnicos, defensa personal, competición. Resumen: Manual teórico y técnico de wushu. El libro esta formado por 9 capítulos. El primer capítulo detalla el origen de las formas de lucha y las artes marciales de Vietman, en particular del método Qwan Ki Do y su introducción en España. El segundo capítulo expone las normas de higiene, vestimenta y cortesía como los conocimientos previos al entrenamiento así como el pase de grados. El tercer capítulo explica brevemente las consideraciones generales que debe tener el profesor al comenzar el entrenamiento con sus niños, describe algunos ejercicios de calentamiento general y específico y las diferentes clases de juegos que pueden utilizarse durante las clases. El cuarto capítulo enumera los criterios técnicos de las posiciones, los desplazamientos, las guardias, los bloqueos y las técnicas de puño, además de ilustrar las principales técnicas de estos movimientos. El quinto capítulo profundiza en los contenidos técnicos más avanzados como son las patadas, las proyecciones, los barridos y las tijeras, describiendo su ejecución y su progresión de aprendizaje con los niños, ilustrando cada movimiento por partes. El sexto capítulo comenta los factores psicológicos involucrados en la defensa personal para niños y describe la ejecución de varias técnicas contra agarres a los brazos, agarres en movimiento, y las diferentes formas de caer y rodar por el suelo. El séptimo capítulo comenta la clasificación de los quyen (kata) y presenta la secuencia fotográfica de los quyen de las posturas, los desplazamientos y los golpes de puño. Los dos últimos capítulos comentan brevemente las reglas de competición y arbitraje y un resumen de los beneficios que ofrece la práctica del qwan ki do al adolescente.

997. Tung, Timothy (1982). Wushu! : gimnasia china para la salud de la familia. Barcelona: Círculo de Lectores. $1^{\mathrm{a}}$ ed. 144 p. : il. ; 20x26 cm. ISBN: 84-226-1482-0. Depósito legal: no. (2ª ed., 1983). Palabras clave: formas, fundamentos técnicos, principios técnicos, ejercicios, aplicación terapéutica, medicina, qigong, combate, taijiquan, fisioterapia. Resumen: Manual teórico y técnico de wushu. La obra esta compuesta de 3 partes, precedidas de una introducción que relata la historia y práctica del wushu. La primera parte explica los principios que rigen la práctica de las formas externas de ejercicio e incluye la descripción de la ejecución técnica de los ejercicios de seda (baduanjin), ejercicios para el primer año de vida, ejercicios de patio de juegos, ejercicios de granjeros (yijinjing), ejercicios para el tiempo de descanso, y los cinco ejercicios de juego animal (wuqinxi). Los ejercicios son divididos en partes, incluyendo un gráfico y esquema del movimiento, recordando los puntos clave y detallando los efectos físicos. La segunda parte comienza explicando los principios técnicos que aparecen en las formas internas de ejercicio para luego ofrecer una noción general y exponer la forma simplificada de taichi con contrincante imaginario, el taichi con espada y el dueto taichi (tuishou), incluyendo la descripción de cada movimiento por partes, sus gráficos y esquemas de movimiento. La última parte presenta e ilustra ejercicios para prevenir enfermedades, incluyendo las 18 terapias, ejercicios respiratorios o qigong, ejercicios oculares, ejercicios de automasaje y baños. Todos los ejercicios son explicados por partes, adjunta un gráfico y esquema de movimiento de los mismos, así como sus beneficios. Finaliza con una tabla que resume los efectos físicos y puntos a recordar de los ejercicios vistos anteriormente.

998. Tung, Timothy (1983). Wushu! : gimnasia china para la salud de la familia. Madrid: Debate. $1^{\mathrm{a}}$ ed. $144 \mathrm{p}$.

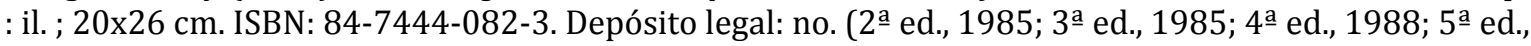
1990; 6a ed., 1993). Palabras clave: formas, fundamentos técnicos, principios técnicos, ejercicios, aplicación terapéutica, medicina, qigong, combate, taijiquan, fisioterapia. Resumen: Manual teórico y técnico de wushu. La obra esta compuesta de 3 partes, precedidas de una introducción que relata la historia y práctica del wushu. La primera parte explica los principios que rigen la práctica de las formas externas de ejercicio e incluye la descripción de la ejecución técnica de los ejercicios de seda (baduanjin), ejercicios para el primer año de vida, ejercicios de patio de juegos, ejercicios de granjeros (yijinjing), ejercicios para el tiempo de descanso, y los cinco ejercicios de juego animal (wuqinxi). Los 
ejercicios son divididos en partes, incluyendo un gráfico y esquema del movimiento, recordando los puntos clave y detallando los efectos físicos. La segunda parte comienza explicando los principios técnicos que aparecen en las formas internas de ejercicio para luego ofrecer una noción general y exponer la forma simplificada de taichi con contrincante imaginario, el taichi con espada y el dueto taichi (tuishou), incluyendo la descripción de cada movimiento por partes, sus gráficos y esquemas de movimiento. La última parte presenta e ilustra ejercicios para prevenir enfermedades, incluyendo las 18 terapias, ejercicios respiratorios o qigong, ejercicios oculares, ejercicios de automasaje y baños. Todos los ejercicios son explicados por partes, adjunta un gráfico y esquema de movimiento de los mismos, así como sus beneficios. Finaliza con una tabla que resume los efectos físicos y puntos a recordar de los ejercicios vistos anteriormente.

999. Vilá Oliveras, Jordi (1986). Boxeo shaolin mantis del norte. Barcelona: Alas. 1 a ed. 48 p. : il. ; 17x24 cm. ISBN: 84-203-0200-7. Depósito legal: B. 32118-1986. Palabras clave: formas, historia, fundamentos teóricos, fundamentos técnicos, principios técnicos, combate, escuelas, maestros. Resumen: Manual teórico y técnico de kung fu. El libro esta formado por 6 capítulos precedidos por una introducción que comenta los objetivos del libro y los agradecimientos. El primer capítulo narra la biografía de Wang Lang y la creación de su estilo de kung fu. El segundo capítulo relata la transmisión del estilo Tang Lang a sus herederos directos. El tercer capítulo comenta las características técnicas de los diferentes estilos que conforman el estilo de la mantis. El cuarto capítulo expone los fundamentos teóricos del estilo mantis del norte, mientras que el quinto capítulo presenta sus 13 principios técnicos. El sexto capítulo ofrece algunos consejos prácticos y presenta la descripción y representación gráfica de la técnica de siete estrellas (chi hsing fa) junto con sus esquemas de movimiento, los fundamentos técnicos del estilo, sus principales tácticas específicas, siete técnicas de combate y el esquema básicos de movimientos. Adjunta un apéndice con un resumen del estilo mantis.

1000. Vilá Oliveras, Jordi (1987). Guía práctica del wu-shu. Barcelona: Obelisco. 1ae ed. 117 p. : il. ; 11x21 cm. ISBN: 84-7720-018-1. Depósito legal: B. 12436-1987. Palabras clave: historia, fundamentos técnicos, principios técnicos, ejercicios, combate, entrenamiento, vestimenta, cortesía, escuelas, etiqueta, sistemas de entrenamiento. Resumen: Manual teórico y técnico de wushu. El libro esta formado por 17 capítulos precedidos por un prólogo que señala la labor del autor, una introducción que comenta los objetivos de la obra y un capítulo que explica el modo de empleo de esta guía. El primer capítulo narra brevemente la historia del kung fu. El segundo capítulo comenta las diferentes ramas del wushu. El tercer capítulo expone los métodos de entrenamiento del wushu mientras que el cuarto detalla el propósito de su práctica. El quinto capítulo comenta la vestimenta, lugar de práctica y tiempo de entrenamiento del wushu. Los siguientes tres capítulos describen la ejecución de diversos ejercicios de calentamiento, de reordenamiento de las articulaciones y de apoyo acompañados de su representación gráfica y esquemas de movimiento. El noveno capítulo expone las características de los dos tipos de fuerza existentes en el wushu para luego detallar el entrenamiento mental. El capítulo decimoprimero enumera los principios técnicos de las posiciones de los pies además de incluir la descripción e ilustración de las principales posiciones. Los dos siguientes capítulos incluyen la descripción e ilustración de las principales técnicas de brazos y de ataques con los pies respectivamente. El decimocuarto capítulo comenta las características del entrenamiento del boxeo contra la sombra. El siguiente capítulo detalla la ejecución técnica del entrenamiento de combate a dos personas. Los dos últimos capítulos exponen la aplicación y principios de la defensa personal así como la evolución de los objetivos del wushu a través del tiempo. Adjunta una conclusión final y un apéndice sobre las reglas de pronunciación del idioma chino moderno.

1001. Wong, Kiew Kit (2007). Kung-fu shaolín : los secretos del kung-fu para la autodefensa, la salud y la iluminación. Badalona: Paidotribo. 1aㅡ ed. 306 p. : il. ; 15x21,5 cm. ISBN: 978-84-8019-930-8. Depósito legal: no. Palabras clave: historia, fundamentos técnicos, filosofía, formas, escuelas, meditación, preparación física. Resumen: Manual teórico y técnico de kung-fu. El libro esta formado por 16 capítulos y comienza explicando los 4 aspectos que diferencian los estilos de kung-fu así como los beneficios que produce su práctica. El segundo capítulo profundiza en la evolución historia del kung-fu haciendo especial hincapié en las dinastías Han, Tang, Song, Yuan, Ming y el periodo moderno. El tercer capítulo explora las raíces históricas del kung-fu shaolín, cómo fueron desarrollándose los distintos estilos, describe las características, historia y principios técnicos del changquan, del estilo mono y del taijiquan, además de comentar brevemente los criterios de clasificación de las artes marciales en suave-duro e interno-externo. El cuarto capítulo describe las características generales de los estilos Bagua, Xingyi, kung-fu de los cinco ancestros y el kung-fu de la mantis religiosa, y explica los rasgos distintivos del kung-fu shaolín del sur, su divulgación y sus principales estilos. El quinto capítulo expone los beneficios, importancia y requisitos de un entrenamiento dirigido por objetivos incluyendo algunos ejemplos. El sexto capítulo narra la formación de las técnicas de kung-fu, el significado de las formas, para luego describir e ilustrar las formas de mano shaolín, las posiciones y los patrones básicos junto con su fundamentación teórica. El séptimo capítulo progresa en los contenidos técnicos del kungfu, exponiendo los principios del combate efectivo, el trabajo en las cuatro direcciones y contra un 
oponente imaginario, así como la ejecución de técnicas específicas contra patadas, técnicas de derribo y de sujeción. El siguiente capítulo expone los requisitos para formar secuencias de patrones y de secuencias para formar series, incluyendo varios ejemplos de ambos trabajos junto con su ilustración y esquemas de movimiento, y unos consejos prácticos para crear nuestras propias series. El noveno capítulo describe las características de los cinco animales que inspiraron los movimientos del kung-fu y describe la ejecución de la serie de los cinco animales presentando dibujos y esquemas de movimiento de la misma. El décimo capítulo presenta una serie de combinación basada en la serie de cinco animales del capítulo anterior, describiendo los puntos más importantes de cada patrón y presentando su esquema de movimiento. El siguiente capítulo describe varios ejercicios de fortalecimiento corporal como son el arte de un dedo lanzando zen, el arte de los treinta puñetazos, el arte qin-na y zarpa de tigre, después de explicar la relación entre fuerza y técnica. El decimosegundo capítulo profundiza en la táctica y estrategia del combate, explicando varios ejemplos para progresar en el combate. El siguiente capítulo describe las características y utilidades de las armas clásicas del kung-fu así como las propiedades de su utilización para el entrenamiento. Continua con los fundamentos teóricos del chi kung y sus variantes, describiendo e ilustrando varios de sus ejercicios, para finalizar con un capítulo dedicado a los aspectos espirituales y morales que impregnan la práctica del kung-fu y otro relacionado con la meditación, sus vías y progresión de entrenamiento, su filosofía, y los objetivos que persigue. Adjunta notas.

1002. Wong, Ping Pui y Prat Banús, José María (1977). Kung fu : historia, filosofía, técnicas, kata. Barcelona: Alas. 1aㅡ ed. 117 p. : il. ; 15x21 cm. ISBN: 84-203-0061-6. Depósito legal: B. 30298-1977. (2ª ed., 1979; $3^{\mathrm{a}}$ ed., 1984; $4^{\mathrm{a}}$ ed., 1987). Palabras clave: katas, historia, fundamentos técnicos, filosofía, defensa personal, escuelas, wushu, armas. Resumen: Manual teórico y técnico de kung fu. El libro esta formado por 8 capítulos. El primer capítulo comenta la creación de la obra y sus contenidos. El segundo capítulo explica los problemas terminológicos relacionados con la práctica del kung fu y su posible solución. El tercer capítulo incluye una tabla cronológica con los hechos históricos, culturales, religiosos y del kung fu más significativos. El cuarto capítulo narra la leyenda del origen del kung fu en el templo shaolín, los diferentes estilos y su expansión. El quinto capítulo comenta las influencias filosóficas y religiosas que han tenido el taoísmo, budismo, zen, teoría del yin/yang y el libro "I Ching" sobre la práctica del kung fu. El sexto capítulo comenta la clasificación de los estilos de kung fu para luego comentar las características de las escuelas interna (nei chia) y externa (wai chia). El séptimo capítulo describe la expansión del kung fu por Asia. El último capítulo localiza los puntos vitales del cuerpo, comenta los contenidos del estilo Hung Kuen de kung fu, su tabla genealógica y describe e ilustra las principales posiciones y guardias, defensas, técnicas de manos, de piernas y combinaciones, la kata Fook Fu Kuen, y varias técnicas de defensa personal cuerpo a cuerpo, contra ataque de cuchillo y de bastón.

1003. Wong, Robert (seud. de Repollés Aguilar, José) (1973). Kung fu. Barcelona: Rodegar. $1^{a}$ ed. 175 p. : il. ; 11x18 cm. ISBN: 84-332-0602-8. Depósito legal: no. (2aㅡ ed., 1975; 3a ed., 1977). Palabras clave: historia, fundamentos teóricos, fundamentos técnicos, principios técnicos, defensa personal, ejercicios, cine, zen, meditación, respiración, armas. Resumen: Manual teórico y técnico de kung fu. El libro esta dividido en 3 partes precedidas por una introducción que comenta los contenidos de la obra. La primera parte consta de 3 capítulos. El primer capítulo narra la historia del kung fu y comenta las características y contenidos del libro "I Ching". El segundo capítulo explica en qué consiste el zen, sus fundamentos teóricos, describe su práctica y beneficios. El tercer capítulo incluye la opinión de varios directores de cine sobre las películas de kung fu y la serie protagonizada por David Carradine. La segunda parte consta de 5 capítulos. El primer capítulo expone las características de la capacidad de concentración además de describir la ejecución de varios ejercicios para su desarrollo. El segundo capítulo detalla el proceso de respiración, ofrece algunos consejos para respirar correctamente, describe la práctica de la respiración abdominal y señala los principios para el progreso en el aprendizaje del kung fu. El tercer capítulo presenta el lugar de competición y vestimenta del kung fu, su sistema de grados, localiza los puntos vitales del cuerpo humano y comenta las distintas partes del cuerpo utilizadas para golpear y su posible utilización. El cuarto capítulo analiza las diferencias entre el kung fu y el kárate, enumera los métodos de entrenamiento del kung fu, explica sus fundamentos técnicos, los principios del entrenamiento con armas y describe las características de los aparatos auxiliares de entrenamiento. El quinto capítulo describe e ilustra la ejecución de las posturas y desplazamientos básicos del kung fu además de señalar la importancia de los movimientos circulares y comenta algunas de las escenas de las películas de kung fu. La tercera parte consta de 3 capítulos. El primer capítulo expone los principios del entrenamiento y de actuación para la defensa personal y describe varias defensas contra los ataques dirigidos al rostro y al cuerpo acompañados de su representación gráfica. El segundo capítulo explica la ejecución de distintas técnicas de defensa personal ante los agarres por detrás a la cintura, los hombros, la cabeza, ataques por la espalda, defensa contra varios agresores, presas de muñecas, golpes de rodillas y defensas desde el suelo, además de incluir su ilustración. El tercer capítulo detalla la ejecución de varias defensas contra 
distintos ataques armados con cuchillo, bastón y armas de fuego junto con sus ilustraciones explicativas.

1004. Xinde, Wang (1988). Técnicas elementales de captura en wushu. Madrid: Miraguano. $1^{a}$ ed. 116 p. : il. ; 13x19,5 cm. ISBN: 84-85639-96-0. Depósito legal: M. 5587-1988. Palabras clave: fundamentos técnicos, principios técnicos, ejercicios, entrenamiento, aplicación marcial, sistemas de entrenamiento. Resumen: Manual teórico y técnico de wushu. El libro esta formado por 3 partes precedidas por un prefacio que comenta brevemente la historia del wushu. La primera parte explica los 8 principios técnicos de la técnica de captura del wushu. La segunda parte consta de 5 capítulos. El primer capítulo explica las características el método de entrenamiento zhuanggong (técnicas de la estaca) además de describir la ejecución, puntos esenciales y objetivos varios de sus ejercicios acompañados de su representación gráfica. El segundo capítulo (habilidades de los brazos) expone las características del método de entrenamiento denominado bigong, explica la ejecución y puntos esenciales de sus ejercicios e ilustra sus movimientos. El tercer capítulo (habilidades de los dedos) señala la importancia del método zhigong junto con la descripción e ilustración de sus ejercicios. El cuarto capítulo presenta la ejecución, propósito, puntos esenciales y explicaciones ulteriores de los ejercicios que componen el método de entrenamiento yangong (habilidad de los ojos). El quinto capítulo describe dos ejercicios para el desarrollo de la habilidad para las caídas y volteretas, incluyendo su representación gráfica. La tercera parte consta de 3 capítulos. El primer capítulo explica los objetivos y ejecución de varias técnicas de captura por las muñecas, señalando los puntos importantes de cada parte del movimiento junto con sus ilustraciones explicativas. El segundo capítulo presenta la descripción de varias aplicaciones de la técnica de captura con entrelazamiento menor, así como su defensa y contraataque acompañadas de su representación gráfica y esquemas de movimiento. El tercer capítulo describe la ejecución de la técnica de captura de entrelazamiento mayor junto con su ilustración. Adjunta un epílogo que comenta los contenidos técnicos de la Escuela Natural jingang-chuan de wushu.

1005. Xinde, Wang (1992). 64 métodos de ataque con las piernas : wushu estilo Shaolín. Madrid: Miraguano. $1^{\mathrm{a}}$ ed. 327 p. : il. ; 13×19 cm. ISBN: 84-7813-102-7. Depósito legal: M. 34149-1992. Palabras clave: historia, fundamentos técnicos, principios técnicos. Resumen: Manual teórico y técnico de wushu. El libro esta formado de 3 capítulos. El primer capítulo expone la historia y formación de la escuela Jingang-Chan, sus diferencias con la escuela shaolin, sus principios fundamentales y contenidos. El segundo capítulo interpreta los aspectos esenciales del estilo, como son las cinco habilidades externas (movimientos de los ojos, de los pasos, de las piernas, del cuerpo y de las manos), cinco habilidades internas (coraje, sagacidad, fuerza, maestría y temple) y cuatro principios, e incluye la representación y enumeración de los principales puntos vitales del cuerpo humano. El último capítulo esta dividido en 3 partes que agrupan los métodos de ataque con una sola pierna (30 técnicas), los métodos de ataque con las piernas saltando ( 9 técnicas) y los métodos combinados de ataque con las piernas (25 técnicas). Cada técnica incluye una descripción general de sus puntos de ataque, la explicación por partes acompañada de varias figuras con sus esquemas de movimiento, los puntos esenciales de su ejecución y los puntos clave durante el combate real. Adjunta una biografía del autor.

1006. Yuntai, Xi y Gaozhong, Li (1988). Wushu : el boxeo estilo mono. Madrid: Miraguano. 1aㅡ ed. 106 p. : il. ; 13x19,5 cm. ISBN: 84-7813-015-2. Depósito legal: M. 33395-1988. Palabras clave: fundamentos técnicos, principios técnicos. Resumen: Manual teórico y técnico de wushu. El libro esta compuesto por 10 capítulos, comenzando con una breve explicación del estilo mono. El segundo capítulo presenta los orígenes del estilo mono, para continuar con la descripción de sus característica beneficiosas para la salud, las cinco reglas o principios que rigen su práctica, y la importancia de la semejanza espiritual del practicante con el mono para entrenar adecuadamente. Los dos siguientes capítulos ofrecen consejos para desarrollar un entrenamiento adecuado y cómo afrontar el estudio del estilo mono a través de los diagramas e ilustraciones de este libro. El octavo capítulo presenta los 49 ejercicios del boxeo estilo mono, describiendo e ilustrando su ejecución técnica. Finaliza con dos breves capítulos en los que se explican algunos de los términos utilizados en el boxeo estilo mono y las seis tácticas ofensivas y defensivas recomendables para el estudiante. Adjunta un apéndice con el diagrama de los 49 ejercicios del boxeo estilo mono.

1007. Zhenbang, Ma (1989). Diez ejercicios de proyección de piernas. Madrid: Miraguano. $1^{\underline{a}}$ ed. 151 p. : il. ; $13 \times 19$ cm. ISBN: 84-7813-030-6. Depósito legal: M. 2844-1989. Palabras clave: historia, principios técnicos, entrenamiento. Resumen: Manual teórico y técnico de wushu. El libro esta formado por 8 capítulos. Los dos primeros capítulos narran el origen de los diez ejercicios de proyección de piernas y el árbol genealógico de sus maestros. El tercer capítulo explica los principios técnicos que rigen la práctica para luego exponer los principios del entrenamiento y la progresión técnica derivada del mismo. Los dos siguientes capítulos exponen cómo aprender los diez ejercicios mediante la lectura del libro y cómo se llama cada uno de los ejercicios. El séptimo capítulo describe la posición de las manos y la ejecución de los diferentes pasos así como sus puntos críticos. El último capítulo describe la ejecución técnica de los movimientos que componen cada uno de los diez ejercicios de proyección de 
piernas, señala los puntos clave de su ejecución e ilustra cada una de sus posiciones además de incluir los esquemas de movimiento de las manos y pies. Adjunta una breve biografía del autor.

1008. Ziping, Wang (1985). Wushu : veinte ejercicios para la longevidad. Madrid: Miraguano. 1 a ed. 79 p. : il. ; 13x19,5 cm. ISBN: 84-85639-56-1. Depósito legal: M. 38740-1985. (2ae ed., 1988; 3a ed., 2004). Palabras clave: fundamentos técnicos, ejercicios. Resumen: Manual técnico de wushu. La obra esta formada por 20 capítulos que describe cada uno de ellos la posición de preparación y los movimientos de distintos ejercicios, así como los puntos clave u observaciones y sus funciones. Además, cada capítulo incluye un gráfico con los esquemas de movimiento. Adjunta dos apéndices que explican un ejercicio de reordenamiento de las partes del cuerpo tras la práctica de los ejercicios comentados anteriormente y algunas observaciones generales para la correcta práctica de los ejercicios descritos como la duración, la alimentación, la vestimenta, la preparación mental y el estado de ánimo.

1009. Zumou, Yuan y Serra, José Luis (1992). Shuai jiao : combate chino tradicional. Técnicas superiores. Barcelona: Alas. 1a ed. 110 p. : il. ; 15x21,5 cm. ISBN: 84-203-0263-5. Depósito legal: B. 6337-1992. Palabras clave: historia, fundamentos teóricos, fundamentos técnicos, principios técnicos, vestimenta, cortesía, aplicación marcial. Resumen: Manual teórico y técnico de kung fu. El libro esta formado por 10 capítulos precedidos por una breve biografía de los autores. El primer capítulo explica en qué consiste el shuai jiao mientras que el segundo relata su historia. El tercer capítulo presenta los principios técnicos del shuai jiao. El cuarto capítulo detalla su vestimenta mientras que el quinto explica cómo atarse el cinturón. El sexto capítulo describe la ejecución del saludo acompañada de su representación gráfica. El séptimo capítulo expone los principios técnicos de la posición de guardia. El octavo capítulo clasifica los tipos de caídas, enumera sus principios técnicos y representa gráficamente su ejecución. El noveno capítulo explica brevemente los tipos de agarres del shuai jiao junto con sus ilustraciones explicativas. El último capítulo incluye la descripción y secuencia fotográfica de la ejecución de las principales técnicas de shuai jiao, su ejercicio tradicional y su aplicación en un combate de wushu contra técnicas de puño, patada u otras proyecciones. Adjunta un epílogo.

\subsubsection{Xinyiquan y Yiquan}

1010. Diepersloot, Jan (2004). El tao del yiquan : los guerreros de la quietud. Barcelona: La liebre de marzo. $1^{\text {a }}$ ed. 181 p. : il. ; $17 \times 24$ cm. ISBN: 84-87403-73-5. Depósito legal: B. 17501-2004. Palabras clave: historia, fundamentos teóricos, principios técnicos, ejercicios, entrenamiento, taijiquan, xinyiquan, maestros, sistemas de entrenamiento. Resumen: Tratado teórico de yiquan. El libro esta formado por 4 partes. La primera parte esta compuesta por 3 capítulos que relatan la estructura social de la India en la época pre-budista, la formación de buda, la historia del budismo y su relación con las artes marciales, la expansión del budismo a China durante las dinastías Tang y Song, la historia del xingyiquan y su fundador el general Yueh Fei, las interpretaciones budistas y taoístas de sus contenidos técnicos, el papel de las artes marciales durante las dinastías Yuan, Ming y Qing, y un resumen de las etapas y entrenamiento del xingyiquan de Guo Yunshen. La segunda parte esta compuesta por 2 capítulos que comentan la biografía de Wang Xiangzhai, su aprendizaje de las artes marciales, su estancia en el monasterio Shaolín, los sucesos que marcaron su investigación marcial, la creación de la rama Yiquan del sistema Xingyiquan, sus viajes y desafíos por China, la evolución de sus sistema, y un compendio de escritos de Wang Xiangzhai sobre los orígenes históricos de las artes marciales, su interpretación del entrenamiento, la posición zhanzhuang, el desarrollo de la fuerza, el uso de la energía y las críticas a los sistemas xingyiquan, taijiquan y baguazhang. La tercera parte esta compuesta por 4 capítulos que exponen los principios técnicos del yiquan, desde el contacto del autor con el maestro Han y los conceptos teóricos del arte hasta los principios técnicos que rigen el movimiento, la descripción e ilustración de distintos ejercicios para conocer los movimientos elementos, desarrollar la fuerza y cómo utilizar dicha fuerza con conciencia a través de varios ejercicios. La última parte esta compuesta de 3 capítulos exponen la interpretación que hacen varios maestros de la fuerza vacía, el encuentro del autor con Sam Tam y los principios técnicos y de entrenamiento de su sistema marcial. Adjunta notas explicativas.

1011. Liang, Shou-Yu y Yang, Jwing-Ming (1995). Hsing yi chuan : teorías y aplicaciones. Villaviciosa de Odón: Mirach. $1 \underline{a}$ ed. 270 p. : il. ; 18x23,5 cm. ISBN: 84-87476-73-2. Depósito legal: M. 40344-1995. Palabras clave: qigong, formas, historia, fundamentos teóricos, fundamentos técnicos, principios técnicos, ejercicios, biografía, textos, artes marciales, aplicación marcial. Resumen: Manual teórico y técnico de hsing yi quan. La obra esta formada por 8 capítulos precedidos por la biografía de los autores, un prólogo que comenta los contenidos técnicos del hsing yi y los prefacios de los autores que comentan el origen de la publicación. El primer capítulo comenta las diferencias entre los estilos internos y externos, la teoría del chi, las características técnicas de las principales artes marciales internas, explica en qué consiste el hsing yi chuan, sus beneficios, relata su historia, la biografía del mariscal Yeuh Fei y expone los contenidos técnicos del hsing yi chuan. El segundo capítulo incluye y comenta los 
documentos que forman la base del hsing yi chuan. El tercer capítulo describe 12 ejercicios de hsing yi chi kung acompañados de su representación gráfica y esquemas de movimiento. El cuarto capítulo ofrece algunos consejos para la práctica de los movimientos básicos del hsing yi además de describir la ejecución de su postura estática básica así como los cinco movimientos básicos junto con su aplicación marcial y los textos que presentan sus principios técnicos. El quinto capítulo incluye los documentos que presentan los principios técnicos de la secuencia de las cinco fases para luego explicar su ejecución técnica junto con su secuencia fotográfica. El sexto capítulo presenta la descripción e ilustración de la ejecución de la forma de "hsing yi chuan" y algunas de sus aplicaciones marciales. El séptimo capítulo describe la ejecución de la forma por parejas "ann shenn pau" acompañada de su secuencia fotográfica y esquemas de movimiento. El octavo capítulo incluye la conclusión del libro. Adjunta dos apéndices con las diez tesis importantes de Yeuh Fei comentadas y un glosario de términos chinos.

1012. Liang, Shou-Yu y Yang, Jwing-Ming (2004). Xingyu quan : teoría, aplicaciones, tácticas de lucha y espíritu. Málaga: Sirio. 1aㅡ ed. 344 p. : il. ; 17x24 cm. ISBN: 84-7808-409-6. Depósito legal: B. 2542-2004. Palabras clave: formas, historia, fundamentos técnicos, principios técnicos, qigong, combate, textos, xinyiquan, maestros, música, poesía. Resumen: Manual teórico y técnico de Xingyiquan. El libro esta formado por 8 capítulos precedidos por una explicación sobre la latinización de las palabras chinas y la biografía de los autores. El primer capítulo expone las diferencias entre los estilos internos y externos de artes marciales, define el qi y su relación con la salud y las artes marciales chinas, presenta las diferencias existentes entre los sistemas taijiquan, xingyiquan, baguazhang y liu he ba fa para luego destacar las características del xingyiquan y estudiar en qué consiste dicho sistema, cuál es su historia, relata la biografía del mariscal Yue Fei y enumera los contenidos técnicos del xingyiquan. El segundo capítulo presenta la traducción e interpretación de los poemas, canciones y textos que contienen la explicación de los fundamentos técnicos del xingyiquan, resume la teoría general de los estilos internos y expone los principios técnicos de la práctica. El tercer capítulo describe por partes e ilustra la secuencia de entrenamiento del xingyiquan qigong incluyendo los esquemas de movimiento de las manos y la finalidad de cada movimiento. El cuarto capítulo describe las características e interpretaciones de los patrones básicos de movimiento del xingyiquan (San Ti Shi, Pi Quan, Zuan Quan, Beng Quan, Pao Quan, Heng Quan) para luego describir su ejecución técnica y aplicación en combate. El quinto capítulo enumera los consejos para la práctica de la secuencia de las cinco fases entrelazadas, presenta sus canciones e interpretaciones, estudia la relación entre las cinco fases y describe e ilustra dicha secuencia técnica con la ayuda de esquemas de movimiento de brazos y piernas. El sexto capítulo profundiza en el entrenamiento del xingyiquan comentando y presentando la ejecución técnica de la combinación de la secuencia de las doce formas y la secuencia de los cinco puños creada por el maestro Zheng Huai-Xian junto la descripción e ilustración de algunas de sus aplicaciones marciales. El séptimo capítulo describe la ejecución del trabajo de combate An Shen Pao incluyendo la ilustración y esquemas de movimiento de cada posición. El último capítulo resume los objetivos del libro. Adjunta dos apéndices sobre las diez tesis importantes de Yue Fei sobre los principios del xingyiquan y un glosario de términos chinos además de un índice temático.

1013. Prat Banús, José María (1984). Hsing i chuan kung fu : boxeo de la forma de la mente. Barcelona: Alas. 1a ed. 48 p. : il. ; 17x24 cm. ISBN: 84-203-0169-8. Depósito legal: B. 32076-1984. Palabras clave: formas, fundamentos técnicos, filosofía. Resumen: Manual teórico y técnico de Hsing I Chuan. El primer capítulo describe la teoría que fundamenta el arte, como son la teoría de los cinco elementos, su historia, los grandes maestros y la explicación de los principios dinámicos del sistema. El segundo capítulo presenta y explica las cinco formas y las cinco acciones del sistema; y en el tercero comenta la historia de Sun Lu Tang y las enseñanzas de un discípulo suyo en España. Finaliza con la descripción y representación fotográfica de dos series técnicas de Hsing I Chuan.

1014. Tang, Cheong Shing (2008). El camino del yiquan. Barcelona: Alas. $1^{a}$ ed. 379 p. : il. ; $17 \times 23,5$ cm. ISBN: 978-84-203-0448-9. Depósito legal: B. 18779-2008. Palabras clave: historia, fundamentos teóricos, fundamentos técnicos, principios técnicos, didáctica, ejercicios, combate, entrenamiento, maestros, programa técnico, armas. Resumen: Manual teórico y técnico de yiquan. El libro esta dividido en 18 capítulos, precedidos por una introducción que explica la mentalidad del artista marcial ante la práctica y describe las etapas de entrenamiento del yiquan como la teoría de los cinco elementos. El primer capítulo narra el origen histórico del yiquan, la biografía de su fundador (Wang Xiang Zhai), la creación del arte, sus ramas, comenta algunas anécdotas del fundador, explica su filosofía de las artes marciales, relata la biografía de los maestros You Peng Xi, Liang Zi Peng y Bruce Lee, comenta el entrenamiento marcial de Bruce Lee y expone la relación entre el yiquan y el jeet kune do. El segundo capítulo relata el primer contacto y entrenamiento del autor con el yiquan. El tercer capítulo incluye varios fragmentos y una anécdota de Wang Xiang Zhai sobre los principios del yiquan. El cuarto capítulo describe el sistema de entrenamiento del yiquan, sus métodos, sus contenidos técnicos, enumera los movimientos incluidos en cada contenido técnico junto con su nombre chino y presenta los contenidos de cada etapa de entrenamiento. El quinto capítulo comenta las características del sistema de Liang, presenta sus contenidos técnicos, describe la ejecución, puntos clave, consejos del 
maestro Liang y variantes de las técnicas Dun Yao (hundir la cintura), Tuo Yao (arrastrar la cintura), Cuo Yao (arrastrar la cintura por parejas) y las posturas estáticas de Liang junto con sus ilustraciones correspondientes, comenta las características del ejercicio de postración además de describir su ejecución y entrenamiento, e incluye un conjunto de ilustraciones de las posiciones de los maestros de Hong Kong. El sexto capítulo detalla los requisitos generales para el entrenamiento de las posturas estática, ilustra las posiciones de los pies, ofrece algunas pautas para antes del entrenamiento y describe la ejecución, beneficios, aspectos a mejorar, sensaciones y visualización de los cinco ejercicios de relajación, las ocho posturas frontales y las posturas marciales. También incluye algunos ejercicios para comprobar dichas posturas y algunas fotografías de los maestros de yiquan realizándolas. El séptimo capítulo describe los distintos ejercicios para comprobar la correcta ejecución de las posturas estáticas, comentando sus características y objetivos e ilustrando su ejecución. El octavo capítulo explica en qué consiste el trabajo de pies (Mo Ca Bu), ilustra su ejecución, describe los diferentes patrones de pasos e incluye un programa de entrenamiento para una clase. El noveno capítulo comenta los principios de los ejercicios fali (proyectar la fuerza), describe e ilustra sus ejercicios y presenta un programa para su entrenamiento. El décimo capítulo relata el origen del entrenamiento Fa Sheng (emisión de sonidos), sus beneficios y tipos, comenta las características de cada tipo y explica su ejecución. El siguiente capítulo presenta el trabajo de empuje de mano (Tui Shou), nombrando e ilustrando sus diferentes técnicas tanto en los ejercicios con un sólo brazo o con dos, e incluye su reglamento de competición. El decimosegundo capítulo representa las diferentes técnicas de puño del yiquan, demostradas por algunos maestros de yiquan, comenta los principios de entrenamiento y presenta una programación del mismo. El siguiente capítulo explica en qué consiste el combate de yiquan (Duan Shou), las cualidades necesarias y sus principios del entrenamiento, ilustra las técnicas de patadas así como los ejercicios para desarrollarlas, comenta los principios tácticos del combate y los compara con la obra de Sun Tzu. El decimocuarto capítulo comenta las características de las técnicas avanzadas de yiquan acompañadas de sus respectivas fotografías. El decimoquinto capítulo relata el origen de la danza del puño, su desarrollo, presenta sus movimientos y detalla sus etapas de aprendizaje. El decimosexto capítulo enumera los movimientos y requisitos del entrenamiento con la espada (Pi Jian) y con el palo, incluyendo algunas fotografías explicativas. El penúltimo capítulo incluye las tablas de progresión y la estructura de contenidos del yiquan así como algunas recomendaciones para mantener la salud. El último capítulo expone algunos consejos didácticos para adecuar las clases a cada practicante. Adjunta una conclusión que comenta la forma de progresar y aprender.

\subsubsection{Armas}

1015. Conches Guillén, Aurelio David (1989). Pei shao lin chien : espada chien del norte. Barcelona: Alas. 1a ed. 96 p. : il. ; 15x21 cm. ISBN: 84-203-0239-2. Depósito legal: B. 31693-1989. Palabras clave: historia, fundamentos teóricos, armas, fundamentos técnicos, principios técnicos, entrenamiento, formas. Resumen: Manual teórico y técnico de espadas chinas. La obra esta formada por 7 capítulos precedidos por los agradecimientos. El primer capítulo explica el objetivo de la obra junto con el currículo del autor. El segundo capítulo comenta los tipos de espadas que existen y su utilización e incluye varios proverbios sobre su manejo. El tercer capítulo relata los orígenes y evolución de la espada china. El cuarto capítulo explica los fundamentos teóricos y principios técnicos del manejo de la espada, comenta su proceso de entrenamiento y presenta la práctica con espada dentro del sistema Chang Chuan junto con la biografía de Chi Gi Kuan. El quinto capítulo enumera los principios para seleccionar una espada, las técnicas básicas del sistema San Ts'ai Chien junto con la descripción e ilustración de algunas de ellas así como la explicación del objetivo y ejecución de varias secuencias técnicas de espada contra sable y lanza y un comentario sobre las características de algunas espadas especiales y su estructura. El sexto capítulo describe e ilustra la ejecución de la forma de la espada de la flor (mei hua chien) mientras que el último representa gráficamente la secuencia de movimientos de la forma chang chuanshao lin chien junto con los esquemas de movimiento. Adjunta una conclusión que resume la historia y entrenamiento con armas en las artes marciales.

1016. García García, Carlos (2003). Miaodao : el sable de espiga de arroz. Barcelona: Alas. 1a ed. 204 p. : il. ; 17x24 cm. ISBN: 84-203-0422-0. Depósito legal: B. 7980-2003. Palabras clave: formas, historia, fundamentos teóricos, fundamentos técnicos, ejercicios, combate, entrenamiento, calentamiento, biografía, textos, escuelas, maestros, preparación física, sistemas de entrenamiento, armas. Resumen: Manual teórico y técnico de miaodao. La obra consta de 16 capítulos precedidos por un prefacio que comenta los contenidos de la obra, una breve biografía del autor, un prólogo que señala la transmisión de la cultura y una introducción que expone las generalidades del miaodao. El primer capítulo narra la biografía del general Qi Jiguang. El segundo capítulo presenta la clasificación de las armas chinas junto con su representación gráfica. El tercer capítulo expone el desarrollo histórico del forjado de sables y espadas junto con un listado de los diferentes tipos de sable. El cuarto capítulo narra el origen del 
miaodao. El quinto capítulo comenta las características de las principales escuelas de sable y espada de dos manos. El sexto capítulo comenta las características de los registros de Cheng Chongton y el maestro Wu Shu y del libro Mooye Dobo Tongji acompañados de algunas de sus ilustraciones. El séptimo capítulo expone la historia del Instituto Central de Guoshu de Nanjing y el estudio del miaodao y comenta las características de la forma de Guo Ruixiang junto con su ilustración. El octavo capítulo expone la biografía del maestro Liu Yunqiao y su estudio del miaodao. El noveno capítulo explica el significado del término miaodao, la estructura del sable y del sable de bambú y las formas de empuñar el miaodao junto con sus ilustraciones explicativas. El décimo capítulo describe e ilustra las posiciones básicas del miaodao mientras que el siguiente capítulo incluye sus técnicas básicas y guardias. El décimo segundo capítulo expone los métodos del cuerpo, de la energía y del espíritu. El siguiente capítulo señala la importancia de la respiración y describe un ejercicio de respiración abdominal natural. El décimo cuarto capítulo describe la ejecución de varios ejercicios de calentamiento y endurecimiento acompañados de su secuencia fotográfica. El décimo quinto capítulo explica la ejecución de dos ejercicios para recoger la energía acompañados de su representación gráfica. El último capítulo comenta la teoría de los cinco elementos y compara los movimientos del miaodao con dichos elementos. Adjunta un capítulo adicional que incluye la descripción técnica y secuencia fotográfica de las formas de las cuatro líneas del miaodao (si lu miaodao) y de pareja de miaodao (si lu miaodao dui lian). Adjunta un apéndice con la descripción e ilustración de diferentes técnicas de combate con el miaodao y cuatro anexos con las aclaraciones del sistema pinyin, tablas históricas y dinastías, medidas tradicionales chinas y un glosario de términos chinos.

1017. Iborra Montells, Antonio (1993). Yug-do : bastón chino. La vía del guerrero solar. Barcelona: Alas. 1 a ed. 127 p. : il. ; 17x24 cm. ISBN: 84-203-0277-5. Depósito legal: B. 10934-1993. Palabras clave: fundamentos técnicos, pedagogía, principios técnicos, principios filosóficos, ejercicios. Resumen: Manual teórico y técnico de yug-do. El libro esta formado por 7 capítulos precedidos por un prólogo y una introducción que comenta los objetivos del libro, los antecedentes históricos del arte y las características del guerrero solar. El primer capítulo ofrece varios consejos para la fabricación del bastón y la práctica. El segundo capítulo expone los contenidos técnicos del yug-do, explica en qué consiste el chi-kung y describe la ejecución del saludo ( $1^{\circ}$ paso), la consciencia de la inmovilidad y el ejercicio fundamental (2o paso), detallando sus principios técnicos. El tercer capítulo explica la actitud y la ejecución de la danza de los 22 movimientos (3er paso). El cuarto capítulo detalla varios ejercicios individuales y por parejas para adquirir la consciencia durante el movimiento rápido (4ํㅜ paso). El quinto capítulo comenta las características del nivel de consciencia de lo que no se mueve ( 5 o paso), los contenidos técnicos para alcanzar dicho nivel junto con la descripción de los principios y ejecución de las asanas con bastón. El sexto capítulo presenta los distintos ejercicios de consciencia creativa como el bastón creativo, la danza por parejas, la danza de los elementos, el baile del mar, la expresión corporal, la danza en grupo, junto con un comentario de sus aplicaciones. El último capítulo señala las características del séptimo paso, la consciencia de los sagrado, y comenta la aplicación de este nivel a la vida cotidiana y en relación con el dinero, el sexo y la nutrición. Adjunta un epílogo que resume las fases del proceso, bibliografía y música para la práctica con el bastón.

1018. Prat Banús, José María (1982). Método y manejo de las espadas chinas. Barcelona: Alas. 1a ed. 95 p. : il. ; 21x15,5 cm. ISBN: 84-203-0139-6. Depósito legal: B. 33553-1982. Palabras clave: formas, historia, fundamentos técnicos, combate, relatos, aplicación marcial. Resumen: Manual teórico y técnico de espada. La introducción comenta los orígenes de las armas marciales chinas y los beneficios que reporta su entrenamiento. Los dos primeros capítulos narran el origen de la espada china, su forja, y la historia del maestro forjador Pu Yuan. El tercer capítulo relata la historia de Chuang-Tzu con el Rey Wen sobre los espadachines y la utilización de la espada. Los cuatro últimos capítulos describen la ejecución técnica de las posiciones fundamentales en el manejo de la espada, los principales ataques, los movimientos de la forma de la espada Wen Wen Tao y la aplicación de esta forma en la lucha, acompañado de la ilustración de cada movimiento.

1019. Prat Banús, José María y Girona, Francisco (1995). Taburete chino : una introducción a las armas del kung-fu. Barcelona: Alas. 1ạ ed. 156 p. : il. ; 17x24 cm. ISBN: 84-203-0375-5. Depósito legal: B. 449011995. Palabras clave: formas, historia, fundamentos teóricos, táctica, fundamentos técnicos, principios técnicos, aplicación marcial, armas. Resumen: Manual teórico y técnico de armas chinas. El libro esta formado por 6 capítulos precedidos por los agradecimientos, la presentación de la obra y una introducción sobre los contenidos y objetivos de la obra. El primer capítulo incluye una clasificación de las armas chinas, la definición de algunos términos específicos y comenta los problemas relacionados con el aprendizaje de su manejo. El segundo capítulo presenta los objetivos del entrenamiento con el taburete y su estructura. El tercer capítulo describe las técnicas básicas de su manejo mientras que el cuarto describe sus tácticas de combate, incluyendo la representación de algunas de sus técnicas. El quinto capítulo describe la ejecución técnica de una forma de manejo del taburete incluyendo la ilustración de cada movimiento. El último capítulo incluye la secuencia fotográfica de varias series 
técnicas de taburete contra palo largo, palo corto y doble cimitarra, adjuntando un breve comentario de los movimientos.

1020. Rossell, A. (1977). Nunchaku de tres secciones : san chieh pang. Barcelona: Alas. $1 \underline{\underline{a}}$ ed. 48 p. : il. ; $15 \times 21,5$ cm. ISBN: 84-203-0060-8. Depósito legal: B. 27907-1977. (2ª ed., 1982). Palabras clave: historia, fundamentos técnicos, ejercicios. Resumen: Manual teórico y técnico de nunchaku. La obra consta de 9 capítulos. El primer capítulo comenta el origen y utilización del nunchaku. El segundo capítulo detalla su construcción, mientras que el tercero incluye la descripción e ilustración de varios ejercicios de calentamiento. El cuarto capítulo describe la ejecución de varios ejercicios de familiarización con el nunchaku de tres secciones acompañados de su representación gráfica. Los dos siguientes capítulos explican la ejecución de las posturas básicas de defensa y ataque, y los bloqueos básicos respectivamente junto con sus ilustraciones explicativas. El séptimo capítulo expone e ilustra la aplicación del nunchaku en situaciones de defensa personal contra bo largo, cuchillo, katana y ataques de pies y manos. El siguiente capítulo muestra la ejecución técnica de una kata con el nunchaku de tres secciones para finalizar con unos breves consejos prácticos para el entrenamiento.

1021. Serrato Rodríguez, Juan Carlos y Jiménez Ramírez, Luis (1992). Manual del palo chino. Madrid: Juan Carlos Serrato Rodríguez y Luis Jiménez Ramírez. 1aㅡ ed. 142 p. : il. ; 15x21 cm. ISBN: 84-604-1589-9. Depósito legal: M. 3270-1992. Palabras clave: formas, historia, fundamentos técnicos, principios teóricos, entrenamiento, combate. Resumen: Manual teórico y técnicos de palo chino. El libro esta formado por 6 capítulos precedidos por una introducción que comenta las características del palo chino y su práctica. El primer capítulo narra la historia del palo chino. El segundo capítulo ofrece algunos consejos prácticos para el entrenamiento y progresión con el palo chino. El tercer capítulo enumera las técnicas básicas y superiores de manejo del palo, describe la estructura del palo chino y las distintas formas de agarre, además de explicar la ejecución de las técnicas básicas acompañadas de su representación gráfica y esquemas de movimiento. El cuarto capítulo presenta la descripción e ilustración de las técnicas superiores del manejo del palo chino junto con sus esquemas de movimiento. El quinto capítulo explica la ejecución técnica de la forma básica de palo incluyendo su representación gráfica y esquemas de movimiento. El último capítulo clasifica las formas con compañero, expone sus principios de entrenamiento y presenta la secuencia fotográfica de varias técnicas de combinación de palo por un extremo y desarme del adversario, combinación de palo por dos extremos y combinaciones superiores. Adjunta un breve glosario de armas largas del wushu.

\subsection{Corea}

\subsubsection{Hapkido}

1022. Balbastre Gimeno, Rafael (2003). Sin moo hapkido : historia, filosofía y técnicas. Valencia: Asociación Española de Sin Moo Hapkido. 1aㅡ ed. 211 p. : il. ; 17x24 cm. ISBN: 84-607-8338-3. Depósito legal: V. 3107-2003. Palabras clave: historia, fundamentos técnicos, principios técnicos, defensa personal, vestimenta, cortesía, etiqueta, armas, fundamentos teóricos. Resumen: Manual teórico y técnico de hapkido. La obra esta compuesta por 18 capítulos precedidos por una introducción que comenta los contenidos de la obra, el currículo del autor y algunas fotografías de distintos cursos. El primer capítulo comenta los contenidos y principios técnicos del hapkido así como del sin moo hapkido. El segundo capítulo narra la historia y evolución de las artes marciales de Corea. El tercer capítulo presenta y comenta las 9 reglas del sin moo hapkido. El cuarto capítulo describe e ilustra las distintas guardias, técnicas de esquiva y caídas. Los dos siguientes capítulos presenta la ilustración de las principales técnicas de ataque con los puños y patadas básicas. El séptimo capítulo explica le ejecución de algunas patadas especiales acompañadas de su representación gráfica. Los tres siguientes capítulos presentan la descripción de varias técnicas de defensa ante diversos agarres de muñeca, a la ropa y al cuerpo respectivamente junto con su secuencia fotográfica. El décimo primer capítulo explica la ejecución de las defensas y contraataques contra distintos ataques de puño junto con sus ilustraciones explicativas. Los dos siguientes capítulos detallan la ejecución de varias técnicas de defensa personal sentado y tumbado respectivamente ante distintos ataques y agarres acompañados de sus representaciones gráficas. El décimo cuarto capítulo muestra algunas de las técnicas de defensa personal ante varios ataques con cuchillo. El décimo quinto enumera e ilustra las técnicas de inmovilización del sin moo hapkido. El décimo sexto capítulo explica los tipos de ki, su utilización en las artes marciales, describe un ejercicio de respiración denominado danjon bop y detalla la utilización del kiai en distintas artes marciales. El décimo séptimo capítulo detalla la forma de ejecutar el saludo, las normas dentro y fuera del do-chang, el sistema de grados y las reglas de higiene. El último capítulo relata la historia del hanbok y el significado del dobok. Adjunta un diccionario específico y agradecimientos. 
1023. Carbonell Vicen, André (1988). Hapkido : defensa personal dinámica. Primera parte. Barcelona: Alas. $1^{\text {a }}$ ed. 123 p. : il. ; 16x21,5 cm. ISBN: 84-203-0222-8. Depósito legal: B. 30357-1988. (2ª ed., 1999; 3ª ed. corr. y aum., 2009, 132 p., ISBN: 978-84-203-0453-3). Palabras clave: historia, fundamentos técnicos, programa técnico, defensa personal, ejercicios, kyusho, exámenes. Resumen: Manual teórico y técnico de hapkido. La obra esta formada por 8 capítulos, precedidos por una introducción que explica en qué consiste el hapkido e incluye la fotografía de varios maestros, y una carta del autor. El primer capítulo narra la historia mientras que el segundo compara los contenidos del hapkido con los del taekwondo y el aikido, describe distintos ejercicios de calentamiento y respiración, localiza los puntos vitales, expone los principios técnicos de las posiciones básicas junto con su ilustración, e ilustra las distintas formas de caer. El tercer capítulo muestra la ejecución de las técnicas que componen el programa técnico para el examen de cinturón amarillo, mientras que el cuarto describe brevemente la ejecución de diversas técnicas de defensa personal acompañadas de su secuencia fotográfica y esquemas de movimiento. El quinto capítulo nombra e ilustra las técnicas contenidas en el programa de examen para cinturón verde. Los dos últimos capítulos describen la ejecución de algunas técnicas de defensa personal y de la aplicación en la calle respectivamente, acompañadas de su secuencia fotográfica y esquemas de movimiento. Adjunta un glosario y un epílogo.

1024. Carbonell Vicen, André (1989). Hapkido : defensa personal dinámica. Segunda parte. Barcelona: Alas. 1 ạ ed. 159 p. : il. ; 15x21,5 cm. ISBN: 84-203-0240-6. Depósito legal: B. 36092-1989. Palabras clave: historia, fundamentos técnicos, programa técnico, defensa personal, kyusho, maestros. Resumen: Manual teórico y técnico de hapkido. El libro esta formado por 15 capítulos precedidos por los agradecimientos, una introducción que explica en qué consiste el hapkido, una dedicatoria y una carta del autor que comenta los contenidos de la obra. El primer capítulo resume los contenidos del libro "Muyedobo tongyi" junto con la presentación de los textos originales. El segundo capítulo relata la evolución de las artes marciales coreanas y sus relaciones con la China. El tercer capítulo narra los orígenes del daito ryu aikijutsu mientras que el cuarto presenta la biografía de Sogaku Takeda. El quinto capítulo explica el origen de los taekyun y describe sus características técnicas. El sexto capítulo comenta la biografía del fundador del hapkido, Choi Yong Sul. Los dos siguientes capítulos comentan el origen de las artes marciales, las influencias de Corea y el desarrollo de sus artes marciales. El noveno capítulo expone en qué consisten las técnicas de kwanjol sul (luxaciones) y en qué artes marciales se pueden encontrar dichas técnicas. El décimo capítulo define el término de ki. El capítulo decimoprimero describe e ilustra la ejecución de distintas técnicas de defensa personal del hapkido incluidas en el cinturón azul, ante varios agarres de las muñecas; del cuello, los hombros y las muñecas por detrás, ante un abrazo de frente y por la espalda, presenta la secuencia fotográfica de la ejecución de algunas técnicas de control en el suelo, de proyecciones y de combinaciones de patadas. El decimosegundo capítulo presenta la secuencia fotográfica de la ejecución de los contenidos técnicos de defensa personal del cinturón rojo, ante agarres al pelo, intentos de agarres, puñetazos, ilustra la ejecución de distintas llaves, proyecciones y ataques. El capítulo decimotercero define el concepto de estrangulación para luego explicar la ejecución de algunas técnicas de estrangulación acompañadas de su secuencia fotográfica. El decimocuarto capítulo detalla la manipulación de los puntos de presión e ilustra el ataque sobre los principales puntos de presión. El último capítulo incluye la representación gráfica del entrenamiento de las patadas especiales con el saco y la manopla. Adjunta un glosario específico y un epílogo.

1025. Carbonell Vicen, André (1992). Hapkido : defensa personal dinámica. Tercera parte. Barcelona: Alas. 1 ā ed. 127 p. : il. ; 15x21,5 cm. ISBN: 84-203-0266-X. Depósito legal: B. 16112-1992. Palabras clave: historia, fundamentos técnicos, principios técnicos, defensa personal, vestimenta, cortesía, etiqueta, armas. Resumen: Manual teórico y técnico de hapkido. La obra esta formada por 13 capítulos precedidos por una explicación del significado del símbolo del hapkido y una introducción que comenta los principios de la defensa personal y las pautas para su entrenamiento. El primer capítulo expone las normas de respeto, el saludo y la vestimenta en el hapkido. El segundo capítulo relata la historia del hapkido y sus maestros más destacados. El tercer capítulo expone la biografía del maestro Ji Han Jae. El cuarto capítulo detalla la aplicación de las técnicas de luxación dentro del estilo, mientras que el quinto compara los estilos duros y blandos de artes marciales. Los dos siguientes capítulos describen la ejecución de una defensa contra un agarre de muñeca y de las distintas caídas acompañadas de sus ilustraciones correspondientes. El octavo capítulo enumera los usos del kihap mientras que el noveno explica los principios técnicos de las patadas y describe varios de sus ejercicios. El décimo capítulo representa gráficamente la ejecución de algunas patadas con salto. Los tres últimos capítulos exponen los principios de actuación ante un ataque con cuchillo y describen la ejecución de distintas técnicas de defensa personal ante ataques con cuchillo, proyecciones y estrangulamientos y presas de cuello. Adjunta un epílogo y un glosario.

1026. Choe, Hui Son (2003). Hapkido : el arte marcial coreano de defensa personal. Técnicas básicas. Kibon gui sul. Madrid: Tutor. $1^{\text {a }}$ ed. 157 p. : il. ; 21x28 cm. ISBN: 84-7902-401-1. Depósito legal: M. 42778-2003. (2ª ed., 2007, ISBN: 978-84-7902-401-7). Palabras clave: historia, fundamentos técnicos, ejercicios, 
preparación física, combate. Resumen: Manual teórico y técnico de hapkido. La obra esta formada por 5 capítulos precedidos de una introducción que narra la historia del hapkido y explica sus características generales como arte marcial. El primer capítulo describe e ilustra algunos de los ejercicios de preparación física (jon bi undong) junto con algunos ejercicios de respiración (dan jon), la importancia del grito (kihap) y el método correcto para caer (nakbop). El segundo capítulo detalla la ejecución de las técnicas básicas (kibon sul) de hapkido, dividiendo cada una de ellas en partes y adjuntando ilustraciones y esquemas de movimiento de las mismas. Incluye la descripción de 11 técnicas de Bu Chae, 12 de Hwejon, 7 de Yun Hang, 7 de Palkumchi, 8 de Sonmok Kokki, 9 de Donchigui y 2 de Mokchorugui. El tercer capítulo detalla la resolución técnica de 5 situaciones de defensa (hoshinsul) contra un ataque de patada y otras 5 situaciones contra una estrangulación, ilustrando cada secuencia técnica en partes e incluyendo esquemas de movimiento así como primeros planos de los detalles más técnicos. El cuarto capítulo presenta y explica distintas combinaciones (yun kyeal gui sul) de las técnicas básicas explicadas en el segundo capítulo para finalizar con la breve descripción de 5 técnicas de patada (balchagui sul) y su ilustración en el último capítulo.

1027. Choe, Hui Son (2004). Hapkido : el arte marcial coreano de defensa personal. Técnicas básicas 2. Madrid: Tutor. 1aㅡ ed. 206 p. : il. ; 21x28 cm. ISBN: 84-7902-469-0. Depósito legal: M. 35144-2004. Palabras clave: fundamentos técnicos, principios técnicos, defensa personal femenina, aplicación marcial, armas. Resumen: Manual teórico y técnico de hapkido. La obra esta formada por 12 capítulos precedidos por un prólogo que comenta los objetivos de la obra e incluye la biografía del autor. El primer capítulo explica el respeto y la práctica en las artes marciales, la defensa personal en el hapkido, la importancia de la concentración en el entrenamiento, la distancia en el combate, los principios para realizar un rompimiento, la ejecución de un ejercicio de concentración y los principios técnicos de la defensa personal. El segundo capítulo describe la ejecución de diversas técnicas de defensa (kibon maki) acompañadas de su representación gráfica mientras que el tercero presenta las patadas básicas. El cuarto capítulo explica los desplazamientos básicos del hapkido junto con su aplicación práctica acompañados de sus fotografías explicativas. El quinto capítulo incluye la descripción y secuencia fotográfica de varias técnicas de defensa personal contra diferentes agarres. Los dos siguientes capítulos explican la ejecución de algunas técnicas de proyección y sus defensas, acompañadas de sus ilustraciones correspondientes. El octavo capítulo presenta la explicación técnica de la ejecución de varios movimientos de ataque junto con su representación gráfica. Los siguientes cuatro capítulos incluyen la descripción y secuencia fotográfica de diversas técnicas de defensa personal contra ataques armados, con bastón corto, contra dos atacantes y algunas técnicas especiales de defensa personal femenina.

1028. Choe, Hui Son (2005). Hapkido : el arte marcial coreano de defensa personal. Guía de estudio para cinturón negro. Madrid: Tutor. 1르 ed. 188 p. : il. ; 21x28 cm. ISBN: 84-7902-525-5. Depósito legal: M. 33114-2005. Palabras clave: fundamentos técnicos, defensa personal. Resumen: Manual técnico de hapkido. El libro esta dividido en dos capítulos, precedidos de una breve biografía del autor, su metodología de entrenamiento y su filosofía. La primera parte explica brevemente las técnicas básicas de defensa personal, incluyendo una secuencia por partes de cada técnica, los esquemas de movimiento de manos y pies, y resaltando los puntos más importantes. Las técnicas que se incluyen son Bu Chae, Hwejon, Yun Hang, Palkumchi y Sonmok Kokki. La segunda parte profundiza en las técnicas avanzadas de defensa personal, explicando por partes e ilustrando la correcta ejecución de las técnicas de proyección, las defensas contra dichas técnicas, las defensas contra estrangulaciones y combinaciones de técnicas.

1029. Choi, Won Chul y Choi, Sang Ho (1976). Hapkido : defensa personal coreana. Barcelona: Alas. $1^{\text {a }}$ ed. 159 p. : il. ; 15x21 cm. ISBN: 84-203-0049-7. Depósito legal: B. 39659-1976. (2ª ed., 1983). Palabras clave: defensa personal, ejercicios, calentamiento, armas. Resumen: Manual teórico y técnico de hapkido. La obra esta formada por 5 partes, precedidas por un breve comentario sobre la historia del hapkido, un prólogo y una introducción que comenta los objetivos de la obra. La primera parte nombra e ilustra varios ejercicios de preparación y las volteretas. La segunda parte describe brevemente la ejecución de las técnicas de defensa contra distintas presas de muñeca, presas sobre la ropa, presas alrededor del cuerpo y cogidas del cuello acompañadas de su secuencia fotográfica. La tercera parte incluye la descripción e ilustración de algunas de las principales inmovilizaciones del hapkido desde distintas posiciones. La cuarta parte detalla diversas técnicas de acompañamiento, ataque y defensa, y defensa con paraguas acompañadas de sus fotografías explicativas. La quinta parte ilustra los puntos de ataque con los palos además de incluir la descripción e ilustración de algunas de sus técnicas agrupadas según el tamaño de los palos.

1030. Pellegrini, John (2009). Combat hapkido : el arte de la defensa personal. Madrid: Budo International. $1^{a}$ ed. 223 p. : il. ; 17x24 cm. ISBN: 978-84-92484-42-3. Depósito legal: M. 37333-2009. Palabras clave: fundamentos técnicos, principios técnicos, defensa personal, kyusho, armas. Resumen: Manual teórico y técnico de hapkido. El libro esta formado por 12 capítulos precedidos por un prólogo que comenta las cualidades del autor. El primer capítulo comenta la formación marcial del autor, los principios 
técnicos del hapkido, sus características técnicas, las peculiaridades del hapkido de combate del autor y las razones para dicha evolución. El segundo capítulo expone los beneficios de las artes marciales como sistemas de defensa personal, explica las adaptaciones realizadas al sistema de enseñanza del hapkido para transformarlo en un sistema de autodefensa y enumera sus objetivos. Los dos siguientes capítulos presentan las secuencias fotográficas de las principales técnicas de piernas y brazos del hapkido de combate. El quinto capítulo presentan la ilustración de varias técnicas de defensa ante diversos ataques de piernas, mientras que el siguiente capítulo muestra distintas técnicas contra ataques de puño. Los dos siguientes capítulos ilustran varias técnicas de hapkido contra diferentes agarres de muñecas y de solapa. El noveno capítulo presenta la secuencia fotográfica de varias técnicas de defensa personal de hapkido que finalizan con luxaciones. El décimo capítulo presenta varias técnicas de hapkido contra el ataque armado con un palo, un cuchillo y una pistola. El capítulo decimoprimero ilustra los principales puntos de presión del cuerpo humano mientras que el último capítulo varias técnicas de hapkido de defensa en el suelo.

1031. Rueda Castaño, José Luis (2009). Korea y el hapkido. Barcelona: Alas. 1aㅡ ed. 360 p. : il. ; 17x23,5 cm. ISBN: 978-84-203-0458-8. Depósito legal: SE. 4179-2009. Palabras clave: historia, fundamentos teóricos, fundamentos técnicos, guerra, vestimenta, cortesía, etiqueta, instituciones. Resumen: Manual teórico y técnico de hapkido. El libro esta dividido en 2 partes precedidas por una introducción que comenta los objetivos del libro, una dedicatoria y los agradecimientos. La primera parte consta de 13 capítulos. El primer capítulo comenta la situación actual de Korea desde 1950. El segundo capítulo comenta las características de Korea en datos. El tercer capítulo detalla el proceso de reunificación de Korea. El cuarto capítulo expone las características sociales y peculiaridades de la vida en Korea. El quinto capítulo ofrece información relacionado con el viaje a Korea y cómo moverse en este país. El sexto capítulo comenta los lugares de interés turístico. El séptimo capítulo explica el significado de la bandera de Korea. El octavo capítulo presenta los fundamentos teóricos de las religiones más importantes de Korea. El noveno capítulo narra la historia de Korea y sus épocas mientras que el décimo detalla la ocupación japonesa. Los tres últimos capítulos describen el fin de la colonización, los nuevos problemas tras la rendición japonesa y la guerra de Korea tras la Segunda Guerra Mundial. La segunda parte consta de 28 capítulos precedidos por una introducción que comenta los contenidos de la segunda parte. El primer capítulo explica en qué consiste la práctica del hapkido y sus orígenes marciales. El segundo capítulo expone los principios técnicos del hapkido. El tercer capítulo incluye la biografía de Choi Young Chul. Los siguientes cuatro capítulos comenta las características de la ropa de entrenamiento, las normas de higiene, el sistema de grados, las normas de cortesía y la forma de saludar. El octavo capítulo explica los objetivos y describe los programas de calentamiento general y específico mientras que los dos siguientes capítulos incluyen la ejecución de ejercicios de estiramientos y ejercicios complementarios. El capítulo decimoprimero comenta los factores que influyen sobre una correcta alimentación mientras que el siguiente ofrece algunos consejos sobre el descanso. El capítulo decimotercero expone los beneficios derivados de la práctica del hapkido en sus distintas vertientes. El decimocuarto capítulo explica la relación entre alumno, instructor y padres. Los dos siguientes capítulos comentan los puntos vitales del cuerpo humano y su manipulación así como los contenidos técnicos que componen el hapkido. El decimoséptimo capítulo comenta las características y entrenamiento con las armas del hapkido. El siguiente capítulo incluye un glosario específico del hapkido. Los tres siguientes capítulos analizan las actitudes ante el entrenamiento, las características de los diferentes tipos de competición y la importancia de la respiración y la condición física. Los siguientes tres capítulos incluyen los fundamentos teóricos de la anatomía humana, ofrecen algunos consejos básicos sobre los primeros auxilios y describen las lesiones más comunes en el hapkido. El vigésimo quinto capítulo describe la ejecución de varios ejercicios con pesas para el hapkido mientras que los últimos tres capítulos comentan las características de algunas organizaciones de hapkido en España, curiosidades y anécdotas y un vocabulario general. Adjunta bibliografía y el listado de colaboradores.

1032. Ruiz Garro, Guzmán (2000). Hapkido : arte marcial coreano. Bilbao: Guzmán Ruiz Garro. 1ae ed. 259 p. : il. ; 21x29,5 cm. ISBN: No ISBN. Depósito legal: BI. 1620-2000. Palabras clave: historia, fundamentos técnicos, principios técnicos, defensa personal. Resumen: Manual teórico y técnico de hapkido. El libro esta formado por 17 capítulos precedidos por los agradecimientos. El primer capítulo expone las generalidades de Corea y su historia, la biografía de Choi Yong Sul y las características de las artes marciales coreanas. El segundo capítulo comenta los beneficios de una respiración correcta e ilustra algunas de sus técnicas. El tercer capítulo describe la ejecución de las diferentes caídas acompañadas de sus ilustraciones explicativas. El cuarto capítulo comenta la anatomía de la mano y los principios de la manipulación digital junto con la ilustración de algunas de sus técnicas. El quinto capítulo presenta la ilustración de las principales técnicas de bloqueo y ataque del hapkido. El sexto capítulo enumera las distintas zonas de la mano utilizadas para golpear junto con su representación gráfica y la terminología técnica básica del hapkido. El séptimo capítulo explica la ejecución de varias salidas contra diversos agarres de muñeca acompañadas de su secuencia fotográfica mientras que el octavo presenta varias 
técnicas de defensa personal ante varios agarres a la solapa El noveno capítulo representa las zonas del pie utilizadas para golpear, las principales patadas, sus principios técnicos y su terminología específica. El décimo capítulo incluye la descripción e ilustración de diferentes técnicas de defensa personal ante agarres al cinturón, la muñeca y el cuello. Los dos siguientes capítulos exponen los principios biomecánicos de las proyecciones y los controles en el suelo para luego explicar la ejecución de algunas de ellas junto con su representación gráfica. El capítulo décimotercero presentan algunas técnicas de defensa personal ante agarres de hombros, del cuerpo y de las muñecas. Los cuatro último capítulos explican las técnicas de estrangulamiento del hapkido, las técnicas de contra y defensa contra dos atacantes, la defensa con el dan bong y algunas técnicas de zwa sul y wa sul. También incluyen terminología específica y el reglamento para el pase de grados de 1er a 5o dan. Adjunta fotografías del autor y bibliografía.

1033. Ruiz Garro, Guzmán (2005). Hapkido : el arte de la defensa personal. Puntos vitales, técnica digital, suelo. Bilbao: Guzmán Ruiz Garro. 1aㅡ ed. 244 p. : il. ; 17x24 cm. ISBN: No ISBN. Depósito legal: BI. 1026-2005. Palabras clave: fundamentos teóricos, fundamentos técnicos, kyusho, anatomía, fisiología. Resumen: Manual teórico y técnico de hapkido. El libro esta formado por 11 capítulos precedidos por una dedicatoria y un comentario sobre los contenidos de la obra. El primer capítulo comenta las particularidades del alfabeto coreano denominado Hangeul. El segundo capítulo expone la teoría del yin/yang, de los meridianos y de la transmisión de la información explicando sus conceptos básicos. El tercer capítulo incluye un comentario sobre el arte de los puntos vitales. El cuarto capítulo describe e ilustra las partes de la mano utilizadas para golpear. El quinto capítulo explica la localización de los puntos de presión en los meridianos del cuerpo acompañados por su ilustración. El sexto capítulo detalla la localización de los principales puntos vitales así como los posibles efectos derivados de su manipulación junto con su representación gráfica y sus denominaciones coreanas. El séptimo capítulo explica la anatomía y fisiología del sistema nervioso, el sistema muscular y óseo, y el sistema respiratorio así como un análisis de principales lesiones de las artes marciales. El octavo capítulo describe la estructura de un cuchillo y algunos tipos de guardia acompañados de sus ilustraciones explicativas. Los dos siguientes capítulos comentan la estructura, anatomía y fisiología de la mano además de explicar la manipulación de la misma y sus efectos junto con la secuencia fotográfica de algunas de sus técnicas tanto de pie como en el suelo. El último capítulo presenta la descripción y secuencia fotográfica de los fundamentos técnicos del hapkido en el suelo. Adjunta bibliografía y fotografías del autor y sus alumnos.

1034. Torrent Rodrigo, Francisco Javier (2009). El pequeño libro del hapkido. Palma de Mallorca: Bubok Publishing. $1^{a \underline{a}}$ ed. 265 p. : il. ; 17x23,5 cm. ISBN: 978-84-9916-228-7. Depósito legal: P.M. 1996-2009. Palabras clave: historia, fundamentos teóricos, fundamentos técnicos, programa técnico, entrenamiento, biomecánica, vestimenta, cortesía, artes marciales, etiqueta. Resumen: Manual teórico y técnico de hapkido. El libro esta dividido en 3 partes precedidas por los agradecimientos y un prefacio que comenta los objetivos de la obra. La primera parte consta de 7 capítulos. El primer capítulo narra el origen de las artes marciales. El segundo capítulo comenta la relación entre la religión y las artes marciales. El tercer capítulo analiza la presencia de las artes marciales en Corea. El cuarto capítulo describe brevemente la historia del taekwondo, kárate, daito ryu aiki jujutsu, hapkido y kwon bup. El quinto capítulo detalla el desarrollo del hapkido y su llegada a España. El sexto capítulo explica las características de los samuráis, del ki, los fundamentos teóricos de la acupuntura, los efectos fisiológicos del masaje, el proceso de la respiración, y discute la existencia de canales energéticos en el cuerpo, los efectos del kihap (grito) y la relación entre los puntos vitales y los puntos de la acupuntura. El séptimo capítulo comenta el secretismo que rodean a las artes marciales. La segunda parte consta de 4 capítulos. El primer capítulo explica las nociones básicas de física y biomecánica aplicables a las artes marciales como la fuerza, peso, momento de fuerza, momento de inercia, presión, rozamiento, trabajo, potencia, energía, rendimiento, palancas, elasticidad, las fuerzas como vectores, centro de gravedad y la mecánica de rotación. El segundo capítulo explica los principios fundamentales del entrenamiento y su planificación, analiza los principios técnicos de los puñetazos, el agarre, el entrenamiento de los abdominales, las patadas, la importancia de la elasticidad y el entrenamiento con la electroestimulación. El tercer capítulo define los conceptos y características de la disfunción somática, las agujetas, la mialgia post-ejercicio, la fatiga y la lesión de tejidos. El cuarto capítulo expone los fundamentos teóricos sobre la nutrición. La tercera parte consta de 11 capítulos. Los primeros cuatro capítulo presentan las guías de examen para cinturón amarillo, verde, azul y rojo, mientras que el quinto señala algunas variantes técnicas. El sexto capítulo muestra el programa de contenidos para el examen de cinturón negro 1er dan. El séptimo capítulo explica las normas de cortesía y vestimenta del hapkido, mientras que el octavo detalla las características fonéticas y gramaticales del coreano junto con un pequeño vocabulario. El noveno capítulo incluye numerosas imágenes del autor. Los dos últimos capítulos presentan las referencias bibliográficas y los créditos fotográficos. 


\subsubsection{Taekwondo}

1035. Aso, Rafael y Xifró, Emilio (1981). Trabajo especial de piernas para la práctica del taekwon-do. Barcelona: Alas. 1aㅡ ed. 80 p. : il. ; 15x21,5 cm. ISBN: 84-203-0106-X. Depósito legal: B. 1005-1981. (2 ed., 1985; $3^{a}$ ed., 1987). Palabras clave: fundamentos técnicos, principios técnicos, ejercicios, entrenamiento, calentamiento, anatomía, competición, equipamiento. Resumen: Manual teórico y técnico de taekwondo. El libro consta de 12 capítulos, precedidos por una introducción que comenta en qué consiste el taekwondo y cuáles son sus contenidos técnicos. El primer capítulo expone la teoría del yin/yang. El segundo capítulo describe distintos ejercicios de calentamiento para las diferentes partes del cuerpo, detallando los músculos implicados e incluyendo su correspondiente ilustración. El tercer capítulo explica los principios biomecánicos que se aplican en el taekwondo. Los dos siguientes capítulos nombran e ilustran algunas de las técnicas de puño y defensas. El sexto capítulo propone varios ejercicios de fortalecimiento con el dan ryon gu mientras que el séptimo centra su atención en el saco. Los dos siguientes capítulos ofrecen algunos consejos para el cuidado de las piernas, su descripción anatómica y resaltan la importancia del juego de pies en el combate. El décimo capítulo describe las características de las patadas directas acompañadas de su ilustración mientras que el décimo primero analiza las patadas semi-circulares y circulares. El siguiente capítulo explica las diferencias entre la práctica del taekwondo como arte marcial y como deporte para luego describir la ejecución de diversas técnicas de ataque, contraataque, combate a tres pasos (sam bo deryon) y combate a un paso (il bo deryon) incluyendo su secuencia fotográfica.

1036. Camino Olea, Antonio Miguel (1991). Taekwondo : planificación del entreno competitivo. Barcelona: Alas. $1^{a}$ ed. 150 p. : il. ; 15x21,5 cm. ISBN: 84-203-0254-6. Depósito legal: no. Palabras clave: historia, fundamentos teóricos, entrenamiento, competición, táctica, lesiones, nutrición, preparación física, preparación psíquica. Resumen: Tratado teórico de taekwondo. La obra esta formada por 8 capítulos. El primer capítulo narra la historia y evolución del taekwondo desde la antigüedad hasta la actualidad. El segundo capítulo detalla los periodos del entrenamiento y sus características generales, para luego describir la preparación física del deportista y estudiar las características y métodos de calentamiento, los principios y tipos de entrenamiento, la descripción del trabajo durante el periodo de acondicionamiento físico básico, la definición de las cualidades físicas y los medios para desarrollarlas, los tipos de sobreentrenamiento que existen, los sistemas de entrenamiento aplicados al taekwondo y los métodos para relajarse. El siguiente capítulo analiza la preparación psicológica del deportista a través de las características psicológicas de los competidores, cómo realizar la motivación antes del combate y cuáles son los trastornos y obstáculos afectivos más frecuentes ante la competición. Los dos siguientes capítulos analizan la preparación técnica y táctica del competidor, desde los fundamentos técnicos, la corrección de errores y los utensilios para su mejora hasta los principios teóricos para preparar el trabajo táctico con compañero y en combate. El siguiente capítulo comenta las causas, diagnostico y tratamiento de las lesiones más frecuentes dentro de la competición de taekwondo junto con algunos conceptos generales y consejos de alimentación. El último capítulo incluye fotos del autor en distintos eventos.

1037. Carbonell Vicen, André (1985). Taekwondo : técnicas para la competición moderna. Barcelona: Alas. 1a ed. 112 p. : il. ; 15x21 cm. ISBN: 84-203-0174-4. Depósito legal: B. 4704-1985. (2ª ed., 1986). Palabras clave: historia, fundamentos teóricos, fundamentos técnicos, entrenamiento, competición. Resumen: Manual teórico y técnico de taekwondo. La obra consta de 35 capítulos precedidos por una introducción que comenta los inicios de la competición de taekwondo. Los tres primeros capítulos comentan brevemente en qué consiste el taekwondo, cuál es su historia y cómo se desarrolla el kyorugui moderno (combate de taekwondo deportivo). Los tres siguientes capítulos ilustran la vestimenta, las protecciones y el principal material de entrenamiento del taekwondo para luego presentar algunos consejos y programas de dietética respeto al momento de la temporada de competición, comentar algunas nociones teóricas sobre el calentamiento, la flexibilidad, las cualidades de un buen competidor, la preparación física, la resistencia y sus sistemas de entrenamiento, la rapidez y la potencia. Los siguientes 18 capítulos comentan brevemente e ilustran las posiciones, los desplazamientos, los pasos libres, las técnicas de pie, las técnicas de pie en ataque, la aplicación de las patadas yop chagui, tuit chagui, furyo chagui, neryo chagui, dollyo chagui, miro chagui, mom dollyo furyo chagui, las técnicas de manos, las defensas, el trabajo con el saco, con el espejo y la manopla, y algunas de las combinaciones técnicas. Los dos últimos capítulos exponen los posibles comportamientos tácticos en combate y las funciones del coach.

1038. Carretero Alonso, Pablo (1987). Camino práctico de las artes marciales : tae kwon-do. Gijón: Nórdina. $1^{\text {a }}$ ed. 259 p. : il. ; 21x31 cm. ISBN: 84-86015-78-2. Depósito legal: 0. 207-1987. Palabras clave: fundamentos técnicos, entrenamiento, grados. Resumen: Manual teórico y técnico de taekwondo. La obra esta formada por 8 capítulos cada uno de los cuales describe los contenidos técnicos de cada nivel o kup, desde el $8^{ }$hasta el $1^{\circ}$ kup, apoyándose en numerosas fotografías de las técnicas desde 
diferentes ángulos. El primer capítulo describe la ejecución de las posiciones, cómo se forma un puño, el saludo, y las técnicas básicas de defensa y ataque con los puños y piernas. Los siguientes 4 capítulos explican los contenidos técnicos del 7o al $4^{\circ}$ kup, incluyendo técnicas de manos, de piernas, combinación de técnicas y trabajo por parejas de dichas técnicas, describiendo su ejecución e ilustrando cada técnica por partes. Los tres últimos capítulos describen e ilustran los contenidos técnicos más avanzados, tanto de ataque de puño, de pierna, sus combinaciones y la aplicación en el trabajo por parejas, del 3er, $2^{-}$y 1er kup. Adjunta una tabla con la relación de kup y pumse, un esquema de las fases de trabajo de las cualidades físicas, y un índice de palabras.

1039. Cartwright, Robert (1974). Korean karate. Barcelona: Picazo. 1aㅡ ed. 189 p. : il. ; 12x16,5 cm. ISBN: 84361-0110-3. Depósito legal: B. 19051-1974. Palabras clave: pumses, historia, fundamentos técnicos, principios técnicos, defensa personal, ejercicios, combate, calentamiento, kárate, equipamiento, entrenamiento, preparación física, formas. Resumen: Manual teórico y técnico de taekwondo. El libro esta formado por 10 capítulos. El primer capítulo analiza el origen del kárate. El segundo capítulo explica en qué consiste el taekwondo mientras que el tercero expone sus principios técnicos. El cuarto capítulo describe la ejecución de diversos ejercicios de calentamiento junto con su representación gráfica. El quinto capítulo explica la ejecución de las posiciones, golpes, patadas y bloqueos básicos del taekwondo. El sexto capítulo explica en qué consisten las formas junto con la descripción e ilustración de las formas kuk mu I, kuk mu II, pyong an I, pyong an II, pyong an III, pyong an IV, pyong an V, chul gi I y pal sek acompañadas de sus esquemas de movimiento. El séptimo capítulo comenta las características de las situaciones de defensa personal, ofrece algunos consejos prácticos y la descripción de las defensas contra las presas, agarres al cuerpo o la vestimenta, ataques con cuchillo, bastón y pistola. El octavo capítulo explica un programa de preparación física, la estructura de los diferentes aparatos de entrenamiento, y ofrece varios consejos para la práctica de los rompimientos. El noveno capítulo detalla la ejecución de las guardias del combate en estilo libre junto con algunas de sus técnicas acompañadas de su representación gráfica. El décimo capítulo resume los contenidos del libro. Adjunta un apéndice con la localización de los puntos vitales del cuerpo humano.

1040. Choi, Won Chul (1974). Kárate taekwondo : técnicas para la competición. Barcelona: Alas. $1^{a}$ ed. 46 p. :

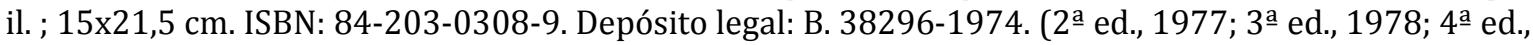
1981). Palabras clave: fundamentos técnicos, combate, competición. Resumen: Manual técnico de taekwondo. La obra consta de 4 partes, precedidas por una ficha biográfica del autor. Las dos primeras partes ofrecen consejos para el entrenamiento del practicante así como para antes y durante la competición. La tercera parte incluye una tabla con los nombres en castellano, coreano y japonés de las principales patadas del taekwondo. La última parte presenta la secuencia fotográfica del desarrollo de un combate, nombrando las técnicas utilizadas en cada secuencia.

1041. Choi, Won Chul (1981). Taekwondo : técnicas de combate. Barcelona: Alas. 1a ed. 48 p. : il. ; 15x22 cm. ISBN: 84-203-0308-9. Depósito legal: no. (2 $2^{\underline{a}}$ ed., 1990). Palabras clave: fundamentos técnicos, combate, competición. Resumen: Manual técnico de taekwondo. La obra consta de 4 partes, precedidas por una ficha biográfica del autor. Las dos primeras partes ofrecen consejos para el entrenamiento del practicante así como para antes y durante la competición. La tercera parte incluye una tabla con los nombres en castellano, coreano y japonés de las principales patadas del taekwondo. La última parte presenta la secuencia fotográfica del desarrollo de un combate, nombrando las técnicas utilizadas en cada secuencia.

1042. Chong, Soo-Park (1988). El taekwon-do : curso moderno ilustrado. Barcelona: De Vecchi. 1a ed. 158 p. : il. ; 17x23,5 cm. ISBN: 84-315-0598-2. Depósito legal: B. 29487-1988. (2ª ed., 1990; $3^{a}$ ed., 1992; $4^{a}$ ed., 1994; 5a ed., 1996; 6a ed., 1998). Palabras clave: pumses, fundamentos técnicos, reglamentos. Resumen: Manual teórico y técnico de taekwondo. El libro esta formado por 8 capítulos. El primero explica sucintamente la historia del taekwondo a través de las distintas dinastías hasta la actualidad. El segundo capítulo describe la utilización de las manos y pies como armas de golpeo, las posiciones básicas y la ejecución de los principales puñetazos, patadas y defensas. El tercer capítulo presenta e ilustra la secuencia técnica de las siguientes pum se: tekuk il chang, tekuk i chang, tekuk sam chang, tekuk sa chang, tekuk o chang, tekuk yuk chang, tekuk chil chang y tekuk pal chang, incluyendo un esquema de sus desplazamientos. El cuarto capítulo explica la ejecución de los steps y su utilización en el combate, presentando el esquema de movimiento de cada uno de ellos. El quinto capítulo comenta los aspectos prácticos y de entrenamiento de los rompimientos en taekwondo para en el siguiente capítulo resaltar los elementos fundamentales del combate y exponer los más significativos. Finaliza con la presentación del reglamento de arbitraje y el vocabulario específico del taekwondo.

1043. Chong, Soo-Park (1998). El taekwon-do. Barcelona: De Vecchi. 1a ed. 158 p. : il. ; 17x24 cm. ISBN: 84315-1876-6. Depósito legal: B. 46693-1998. (2 ${ }^{\underline{a}}$ ed. corr. y aum., 1999). Palabras clave: pumses, fundamentos técnicos, reglamentos. Resumen: Manual teórico y técnico de taekwondo. El libro esta formado por 8 capítulos. El primero explica sucintamente la historia del taekwondo a través de las distintas dinastías hasta la actualidad. El segundo capítulo describe la utilización de las manos y pies como armas de golpeo, las posiciones básicas y la ejecución de los principales puñetazos, patadas y 
defensas. El tercer capítulo presenta e ilustra la secuencia técnica de las siguientes pum se: tekuk il chang, tekuk i chang, tekuk sam chang, tekuk sa chang, tekuk o chang, tekuk yuk chang, tekuk chil chang y tekuk pal chang, incluyendo un esquema de sus desplazamientos. El cuarto capítulo explica la ejecución de los steps y su utilización en el combate, presentando el esquema de movimiento de cada uno de ellos. El quinto capítulo comenta los aspectos prácticos y de entrenamiento de los rompimientos en taekwondo para en el siguiente capítulo resaltar los elementos fundamentales del combate y exponer los más significativos. Finaliza con la presentación del reglamento de arbitraje y el vocabulario específico del taekwondo.

1044. Colmenero Firvida, Carlos (1997). Taekwondo : mi libro. Bilbao: V.M.G. 1a ed. 141 p. : il. ; $17 \times 24$ cm. ISBN: 84-605-6514-9. Depósito legal: BI. 1205-1997. Palabras clave: pumses, fundamentos técnicos, programa técnico. Resumen: Manual teórico y técnico de taekwondo. El libro esta formado por 10 capítulos precedidos por la explicación de la práctica del taekwondo, su historia, sus beneficios físicos y psíquicos, la descripción de la forma de atarse el cinturón y saludar y las partes del cuerpo que se utilizan para golpear. Los 10 capítulos presentan los contenidos técnicos para los cinturones blancoamarillo, amarillo, amarillo-naranja, naranja, naranja-verde, verde, verde-azul, azul, azul-marrón y marrón, como son las posiciones, defensas, ataques de puño, técnicas de pierna y pumse correspondientes a cada uno de ellos e incluyendo la ficha de examen para el paso de cinturón junto con la representación grafica y sus esquemas de movimiento. Adjunta cromos para pegar.

1045. Colmenero, Manuel (1991). Taekwondo. Arbitraje. s.l.: s.n. 1aㅡ ed. desc.; desc.xdesc. cm. ISBN: No ISBN. Depósito legal: no.

1046. Departament de Cultura de la Generalitat de Catalunya (1992). Diccionari de taekwondo. Barcelona: Enciclopedia Catalana. 1aㅡ ed. 131 p. ; 13x19,5 cm. ISBN: 84-7739-241-2. Depósito legal: B. 9598-1992.

Palabras clave: fundamentos teóricos, fundamentos técnicos, combate, instalaciones, instituciones. Resumen: Diccionario de taekwondo. La obra esta formada por 5 partes precedidas por una introducción que señala las características históricas del taekwondo, su institucionalización, la descripción y objetivos de la presente obra, su metodología de trabajo, los criterios seguidos respecto a los términos coreanos, el contenido del diccionario, la forma de consulta y el equipo de trabajo. La primera parte incluye las abreviaturas y símbolos utilizados mientras que la segunda muestra el árbol del campo estudiado. La tercera parte presenta el diccionario, incluyendo el número de orden, el término, la categoría gramatical, las equivalencias, la definición, y algunos casos los sinónimos y notas aclaratorias. Los términos incluidos se refieren a las instalaciones, personal, equipo, combate y organización del taekwondo. La cuarta parte incluye los índices en alfabéticos en castellano, francés e inglés. La última parte muestra la bibliografía.

1047. Fargas Fernández, Ireno (1990). Taekwondo : alta competición. Barcelona: Totalpress. 1aㅡ ed. 214 p. : il. ; 21x30,5 cm. ISBN: 84-404-7659-0. Depósito legal: B. 34296-1990. (2ª ed., 1995). Palabras clave: fundamentos técnicos, ejercicios, entrenamiento, psicología, competición, dopaje, equipamiento, nutrición, reglamentos. Resumen: Manual teórico y técnico de taekwondo. La obra esta compuesta por 5 capítulos precedidos por el historial deportivo y fotografías del autor. El primer capítulo comenta las características de un calentamiento, describe los principios técnicos de la posición de combate, los desplazamientos, las esquivas y los bloqueos acompañados de la secuencia fotográfica de cada uno de ellos. El segundo capítulo comenta las características de los ataques directos con la pierna atrasada, con la pierna adelantada, después de un giro, en distancias largas con paso, ataques dobles con corrección de la misma pierna, ataque con corrección de movimiento en salto con las dos piernas, ataques con apoyo y la técnica en el cuerpo a cuerpo incluyendo numerosas fotografías de algunas de sus técnicas más representativas. El tercer capítulo explica los diferentes tipos de contraataques para luego mostrar la secuencia fotográfica de las posibles contras ante los ataques de bandal-chagui, dolliochagui, tuit-chagui, neryo-chagui, yop-chagui, miro-chagui, mondollio-chagui, a los ataques de puño y a los contraataques. El cuarto capítulo expone los sistemas de trabajo en el entrenamiento con paos, con saco, con manoplas y con gomas elásticas incluyendo algunas fotografías de los mismos. El último capítulo presenta el reglamento oficial de competición, las características de las protecciones, las funciones del coach, los requisitos del entrenamiento psicológico, los principios de concentración y algunas técnicas para mejorar el rendimiento, un comentario sobre las normas generales de alimentación en el taekwondo, una tabla de sustancias dopantes y los resultados mundiales hasta la actualidad.

1048. Fargas Fernández, Ireno (1993). Taekwondo. Madrid: Comité Olímpico Español. 1aㅡ ed. 371 p. : il. ; 17x24 cm. ISBN: 84-87094-23-6. 84-87094-03-1 (de la colección). Depósito legal: M. 14075-1993. Palabras clave: historia, fundamentos técnicos, biomecánica, competición, reglamentos. Resumen: Tratado teórico y técnico de taekwondo. La obra esta dividida en 13 capítulos. Comienza con la explicación de la historia del taekwondo y su introducción en España, además de ofrecer una visión general de los resultados obtenidos en los distintos campeonatos y copas del Mundo y de Europa. El segundo capítulo presenta los movimientos básicos del taekwondo y explica las guardias, los desplazamientos, las esquivas, los bloqueos y el trabajo cuerpo a cuerpo. Continúa con la ilustración 
por partes de las técnicas básicas de combate y un análisis biomecánico de las 5 técnicas más utilizadas en la competición. El quinto capítulo desarrolla la técnica y táctica del combate, ilustrando las distintas combinaciones y contraataques posibles; para luego pasar a describir los diferentes sistemas de entrenamiento y ofrecer algunos ejemplos de ellos. El séptimo capítulo estudia la preparación física del competidor y su planificación, detallando el entrenamiento de cada cualidad física, el control del entrenamiento y la planificación a lo largo de toda la temporada. Continua con la presentación del reglamento y materiales de competición para en los últimos capítulos centrarse en el estudio de los aspectos psicológicos de la alta competición, ofrecer métodos para mejorar la capacidad psicológica del deportista, explicar el papel del entrenador, comentar las exhibiciones de taekwondo, ofrecer algunas recomendaciones sobre la alimentación en el taekwondo y presentar el programa de examen para el pase de dan. Adjunta bibliografía.

1049. Federación Española de Taekwondo y Tucci, Alfredo (2008). Taekwondo poomsae : los poomsaes básicos 1-8. Madrid: Budo International. 1aㅡ ed. 151 p. : il. ; 17x24 cm. ISBN: 978-84-92484-10-2. Depósito legal: M. 40701-2008. Palabras clave: pumses. Resumen: Manual teórico y técnico de taekwondo. La obra consta de 9 capítulos, precedidos por un prólogo, una introducción y el currículum deportivo de los protagonistas del libro. El primer capítulo explica el significado e importancia de los poomsae, expone el nombre castellano, coreano, el ideograma, el significado y la línea de entrenamiento asociada a los poomsaes básicos además de incluir un vocabulario fundamental. El resto de capítulos muestra la secuencia fotográfica de los movimientos de los poomsaes básicos, desde el taeguk $1^{\circ}$ jang hasta el taeguk $8^{\circ}$ jang.

1050. Federación Española de Taekwondo y Tucci, Alfredo (2008). Taekwondo poomsaes : los poomsaes superiores 9-17. Madrid: Budo International. 1a ed. 183 p. : il. ; 17x24 cm. ISBN: 978-84-92484-13-3. Depósito legal: M. 54426-2008. Palabras clave: pumses. Resumen: Manual teórico y técnico de taekwondo. La obra consta de 11 capítulos, precedidos por un prólogo, una introducción y el currículum deportivo de los protagonistas del libro. El primer capítulo explica el significado e importancia de los poomsae, expone el nombre castellano, coreano, el ideograma y el significado asociado a los poomsaes superiores. El segundo capítulo incluye un vocabulario fundamental. El resto de capítulos muestra la línea de entrenamiento y la secuencia fotográfica de los movimientos de los poomsaes superiores como koryo, keumgang, taebek, pyongwon, sipjin, jiitae, chonkwon, hansu e ilyio.

1051. Federación Mundial de Tae Kwon-Do y Choi, Won Chul (1977). Tae kwon-do : nuevos pumse. Barcelona: Choi Won Chul. 1aㅡ ed. 241 p. : il. ; 17x24 cm. ISBN: 84-400-3231-5. Depósito legal: B. 25925-1977. Palabras clave: pumses, historia, fundamentos técnicos, arbitraje, reglamentos. Resumen: Manual teórico y técnico de tae kwon-do. La obra esta divida en 3 partes. La primera parte es teórica y comienza con la definición y significado del tae kwon-do, narra su historia y explica los principios dinámicos en los que se basan sus técnicas. La segunda parte presenta la práctica del libro, en la que primeramente describe las armas naturales del cuerpo y los criterios técnicos de su ejecución, para luego presentar los distintos pumse tanto básicos (Taeguk Chang del 1 al 8) como superiores (Koryo, Kumgang, Taebek, Pyongwon, Sipchin, Chitae, Chunkwon, Jansu, Ilillo). Finaliza con el reglamento de arbitraje de tae kwon-do y los términos utilizados por el árbitro.

1052. Kim, Boo Hyang (1989). Tae kwon-do : fundamentos y pumse. Barcelona: Kim Boo Hyang. 1a ed. 233 p. :

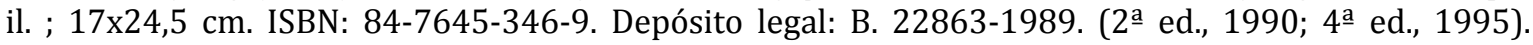
Palabras clave: pumses, historia, fundamentos teóricos, fundamentos técnicos, biomecánica, cortesía, kyusho, arbitraje, competición, reglamentos. Resumen: Manual teórico y técnico de taekwondo. El libro esta formado por 8 capítulos precedidos por varias fotografías de los Juegos Olímpicos de Seul'88, la presentación del libro y una introducción. El primer capítulo explica en qué consiste el taekwondo y comenta sus normas de cortesía. El segundo capítulo narra la historia y evolución del taekwondo y discute su relación con el kungfu y kárate. El tercer capítulo explica los principios físicos presentes en el taekwondo. El cuarto capítulo localiza los puntos vitales del cuerpo humano, presenta las zonas utilizadas para golpear, describe las posiciones, técnicas de defensa y técnicas de ataque básicas acompañadas de su representación gráfica, ilustraciones y esquemas de movimiento. El quinto capítulo explica el significado de los pumse y sus principios técnicos, junto con la descripción, principios técnicos, secuencia de movimientos, esquema de movimiento y representación gráfica de los pumse fundamentales como taeguk il chang, taeguk I chang, taeguk sam chang, taeguk sa chang, taeguk o chang, taeguk yuk chang, taeguk chil chang y taeguk pal chang, y superiores como koryo, kumgang, taebek, pyongwon, sipchin, chitae, chonkwon, jansu y ilio. El sexto capítulo incluye un resumen del reglamento de arbitraje y competición mientras que el séptimo presenta la nomenclatura y traducción de los fundamentos técnicos de taekwondo. El último capítulo incluye la bibliografía.

1053. Kim, Boo Hyang y Caballero Molina, Antonio (2003). Tae kwon-do siglo XXI : principios fundamentales. Santa Coloma de Gramanet: Kim Boo Hyang y Antonio Caballero. 1르 ed. 158 p. : il. ; 16x23 cm. ISBN: No ISBN. Depósito legal: B. 30932-2003. Palabras clave: pumses, fundamentos técnicos, principios técnicos, principios éticos, combate, vestimenta, cortesía, competición, reglamentos. Resumen: Manual teórico y técnico de taekwondo. El libro esta compuesto por ocho capítulos precedidos por un 
comentario sobre la expansión del taekwondo, un prólogo que destaca las virtudes del libro y una presentación que señala su objetivo. El primer capítulo explica el significado del término taekwondo, enumera los beneficios del taekwondo para cada edad, sus principios éticos, las normas de cortesía y educación junto con la descripción del saludo y la forma de atar el cinturón, y comenta las generalidades de su práctica. El segundo capítulo presenta la situación, clima, bandera e idioma de corea, su historia y narra el origen del taekwondo. El tercer capítulo localiza los puntos vitales del cuerpo humano, representa y nombra las zonas utilizadas para golpear, describe e ilustra sus posiciones básicas, comenta las características de las técnicas de jirugi, chigui, chirugui, pum, chagui y cha olio magqui incluyendo su representación gráfica. El cuarto capítulo explica el desarrollo de las técnicas de il bo kye rugui además de detallar sus principios técnicos e incluir la descripción y representación gráfica de algunas de sus técnicas. El quinto capítulo describe los diferentes tipos de caída para luego presentar algunas de las técnicas de yak sok kye rugui junto con su representación gráfica. El sexto capítulo expone los fundamentos teóricos de los pumse, sus principios técnicos además de incluir un breve comentario, la explicación de los movimientos y la representación gráfica de los pumse tae guk il chang, tae guk i chang, tae guk sam chang, tae guk sa chang, tae guk o chang, tae guk yuk chang, tae guk chil chang, tae guk pal chang, koryo y kumgang. El séptimo capítulo incluye el reglamento de competición mientras que el último recoge un diccionario con los términos utilizados.

1054. Kim, Gwabg il (2003). Taekwon-do : defensa personal. Yaksok kiorugui. Vitoria: Kim Gwang Il. 1aㅡ ed. 232 p. : il. ; 21x29,5 cm. ISBN: 84-607-8333-2. Depósito legal: VI. 323-2003. Palabras clave: historia, fundamentos técnicos, combate. Resumen: Manual teórico y técnico de taekwon-do. Comienza con la explicación del origen e historia del taekwon-do, adjuntando numerosas fotografías, y de la descripción de los puntos vitales del cuerpo humano y las partes del mismo que pueden ser utilizadas para golpear. Luego pasa a la descripción de los fundamentos de taekwon-do, esto es, las posiciones, las técnicas de ataque con las manos, con los pies y las defensas, detallando su correcta ejecución y mostrando gráficamente las distintas partes de cada movimiento y técnica. El siguiente capítulo explica los principios generales del yaksok kiorugui (combate concertado) tanto a 3 pasos como a 2 y a un paso. Finaliza con algunos ejemplos de defensa personal, las técnicas de endurecimiento del cuerpo y los rompimientos, y las normas de competición de taekwon-do. Adjunta la biografía deportiva del autor, un vocabulario específico, el reglamento para exámenes de grado y el programa técnico del examen para "pum".

1055. Lee, Kyu Hong (1995). Taekwondo : fundamento, básica y pumse. Sant Esteve Sesrovires: Lee Kyu Hong. $1^{\mathrm{a}}$ ed. 205 p. : il. ; 21x29,5 cm. ISBN: 84-605-2397-7. Depósito legal: B. 26149-1995. (2ª ed., 1999, 244 p.). Palabras clave: pumses, historia, fundamentos técnicos, exámenes, reglamentos. Resumen: Manual teórico y técnico de taekwondo. La obra esta compuesta por 7 capítulos, precedidos por la narración de la historia del taekwondo y un comentario sobre la práctica. El primer capítulo presenta la descripción de la ejecución técnica de las posiciones fundamentales y algunas posiciones especiales, señalando los errores más comunes y su aplicación acompañadas de su representación gráfica y esquema de movimiento. El segundo capítulo localiza los puntos vitales del cuerpo y expone las distintas partes del cuerpo que pueden ser utilizadas para golpear incluyendo su representación gráfica. El tercer capítulo describe la ejecución técnica de los movimientos de defensa de brazos, su aplicación y presenta la secuencia fotográfica de su ejecución. El cuarto capítulo expone la ejecución técnica, aplicación, zona utilizada para el golpeo y secuencia fotográfica de las principales técnicas de pierna. El quinto capítulo presenta la descripción técnica, secuencia fotográfica y entrenamiento en desplazamiento de las principales técnicas de brazo. Los dos últimos capítulos incluyen la tabla de movimientos, posiciones y pum de los pumse básicos y superiores respectivamente además de presentar la secuencia fotográfica de sus movimientos y su línea de ejecución. Adjunta el reglamento para el examen de grados desde 1er hasta $4^{\circ}$ dan.

1056. Lee, Kyong Myong (2000). Taekwondo dinámico. Barcelona: Hispano Europea. $1^{\mathrm{a}}$ ed. 159 p. : il. ; 13x21 cm. ISBN: 84-255-1346-4. Depósito legal: B. 29933-2000. (2aㅡ ed., 2003). Palabras clave: pumses, historia, fundamentos técnicos, filosofía, instituciones. Resumen: Manual teórico y técnico de taekwondo. La monografía esta compuesta por cinco partes. La primera aborda los aspectos históricos del taekwondo, el significado de los pumses, y su organización e institucionalización. La segunda parte explica el significado filosófico de la práctica del taekwondo así como de la vestimenta y el cinturón, para continuar en la tercera parte con el detalle de los principios dinámicos del movimiento, el significado del tao y la aplicación de la respiración y el ki al entrenamiento del taekwondo. La cuarta parte describe e ilustra los fundamentos técnicos del arte, desde las posiciones hasta las defensas, patadas, puñetazos, golpeos y empujes; para finalizar el quinto capítulo con la presentación de la secuencia de movimientos de los pumses básicos, taeguk 1 al 8 chang, y superiores, koryo, kumgang y taebek. Los pumses representan gráficamente cada movimiento, incluyen un gráfico con las líneas de desarrollo de cada pumse y una tabla detallando el movimiento, la posición y la técnica de mano. Adjunta vocabulario específico y bibliografía. 
1057. Lee, Kyong Myong (2001). Taekwondo kyorugi : la competición. Entrenamiento. Condición física. Técnica. Táctica. Combates. Barcelona: Hispano Europea. 1aㅡ ed. 159 p. : il. ; $13 \times 21$ cm. ISBN: 84-2551376-6. Depósito legal: B. 7653-2001. Palabras clave: historia, fundamentos técnicos, entrenamiento, competición, preparación física. Resumen: Manual teórico y técnico del taekwondo de competición. El libro esta compuesto por seis partes. La primera parte presenta algunos de los contenidos relacionados con la competición, como son las reglas de cortesía, los factores determinantes de la competición, la actitud mental durante la competición, el desarrollo de la propia competición y un resumen de sus reglas. La segunda parte describe los fundamentos técnicos de la competición, como son las posiciones de guardia, las técnicas de golpeos, pasos, defensa y finta más utilizadas, junto con su entrenamiento. La tercera parte estudia el entrenamiento técnico-táctico, ofreciendo multitud de ejercicios y con distintos medios como puede ser el entrenamiento con un compañero o con implementos complementarios. La cuarta parte hace un repaso de las cualidades físicas y sus métodos y medios de entrenamiento, proponiendo ejercicios y sesiones de entrenamiento para mejorar cada cualidad. La siguiente parte destaca algunas ideas generales sobre la táctica general y detalla las acciones tácticas a tener en cuenta en la competición; para finalizar con un compendio de aspectos asociados a la competición como son la actitud del competidor y el entrenador, el control del peso, la recogida de información, el entrenamiento psicológico, los masajes, las lesiones, y el listado de competiciones internacionales, y que son tratados someramente. Adjunta apéndices sobre la organización de una competición, un listado de enmiendas de las reglas de competición, terminología específica y bibliografía.

1058. Lee, Sam (1998). Tae-kwon-do. Arganda del Rey: Edimat. 1aㅡ ed. 190 p. : il. ; $13 \times 21$ cm. ISBN: 84-8403329-5. Depósito legal: M. 27396-1998. Palabras clave: fundamentos técnicos, ejercicios, entrenamiento, capacidades físicas, preparación física. Resumen: Manual teórico y técnico de taekwondo. La obra esta formada por 20 capítulos precedidos por una introducción que señala la importancia de las técnicas de pierna en las artes marciales y el objetivo del libro. Los once primeros capítulos describen la ejecución y zona de impacto de la patada frontal, circular, lateral, trasera, trasera en coz, descendentes, en abanico, abanico de $360^{\circ}$, en salto, en tijereta, oblicua, de grulla y algunas de sus variantes acompañadas de sus ilustraciones explicativas. El siguiente capítulo ilustra la aplicación de diversas patadas en situaciones de defensa personal. El décimo tercer capítulo describe e ilustra dos técnicas de barrido mientras que el siguiente explica la ejecución de cinco combinaciones de patadas. El décimo quinto capítulo expone distintos ejercicios de musculación específicos para las patadas más importantes. El décimo sexto capítulo enumera los principios técnicos de los estiramientos junto con la descripción e ilustración de varios ejercicios. El siguiente capítulo presenta varios ejercicios para mejorar la flexibilidad de la cadera, mientras que los últimos tres capítulos describen algunos ejercicios avanzados de entrenamiento con el saco, combinaciones con el punching y un ejercicio con el cinturón.

1059. Lee, Won Il (1975). Taekwon-do : entreno, posiciones fundamentales, katas obligatorias. Barcelona: Alas. $1^{\underline{a}}$ ed. 143 p. : il. ; 16x21 cm. ISBN: 84-203-0336-4. Depósito legal: B. 31739-1975. (2ª ed., 1977; 3를. ed., 1978; $4^{\mathrm{a}}$ ed., 1979; $5^{\mathrm{a}}$ ed., 1981; $6^{\underline{a}}$ ed., 1984). Palabras clave: katas, historia, fundamentos técnicos, ejercicios, combate, calentamiento, kyusho, respiración. Resumen: Manual teórico y técnico de taekwondo. El libro esta formado por 10 capítulos. El primer capítulo narra la historia del taekwondo además de incluir el currículo del autor. El segundo capítulo localiza los puntos vitales del cuerpo humano. El tercer capítulo incluye la ilustración de varios ejercicios de calentamiento mientras que el cuarto nombra y representa las zonas utilizadas para golpear. El quinto capítulo explica gráficamente la respiración reglamentaria. El sexto capítulo nombra e ilustra algunas de las técnicas del taekwondo ejecutadas en sus correspondientes posiciones. El séptimo capítulo incluye la línea de ejecución y la secuencia fotográfica de las ejecución de todas las hyong-kata. El octavo capítulo presenta numerosas fotografías sobre el entrenamiento y técnicas especiales del taekwondo. El noveno capítulo representa varias secuencias de combate mientras que el último ilustra la forma de doblar el kimono (dobok).

1060. Lee, Won Il (1979). Tae kwon do : técnicas superiores. Barcelona: Hispano Europea. $1^{\mathfrak{a}}$ ed. 192 p. : il. ; 13x19,5 cm. ISBN: 84-255-0525-9. Depósito legal: B. 4527-1979. (2ª ed., 1982; $3^{a}$ ed., 1985; $4^{\mathrm{a}}$ ed., 1988; 5a ed., 1990; 6a ed., 1992). Palabras clave: historia, fundamentos técnicos, ejercicios, entrenamiento, preparación física. Resumen: Manual teórico y técnico de taekwondo. El libro esta formado por 8 capítulos. El primer capítulo comenta en qué consiste el taekwondo, para luego describir su historia y evolución. El segundo capítulo enumera los beneficios de la práctica del taekwondo, incluyo un glosario de términos específicos y describe algunos ejercicios de calentamiento acompañados de su ilustración. El tercer capítulo incluye la descripción e ilustración de distintos ejercicios de endurecimiento y fortalecimiento de las manos y pies; mientras que el cuarto capítulo ilustra algunas posiciones y ejercicios fundamentales. El quinto capítulo nombra las diferentes patadas del taekwondo junto con algunos ejercicios específicos acompañados de su representación gráfica. El sexto capítulo incluye la secuencia fotográfica de 20 técnicas de defensa contra un ataque alto y a la zona media del cuerpo y 5 defensas contra una patada. El séptimo capítulo expone un resumen de las 
reglas de competición mientras que el último capítulo describe la ejecución de 10 técnicas de combate junto con su secuencia fotográfica.

1061. Lee, Won Il (1981). Tae kwon-do : defensa personal. Madrid: Cabal. 1aㅡ ed. 173 p. : il. ; $13 \times 19$ cm. ISBN: 84-7034-063-8. Depósito legal: M. 32529-1981. Palabras clave: pumses, fundamentos técnicos, defensa personal, entrenamiento, juegos, sistemas de entrenamiento, armas. Resumen: Manual teórico y técnico de taekwondo. El libro esta formado por 15 capítulos precedidos por la dedicatoria. El primer capítulo explica el significado de la defensa personal. Los siguientes tres capítulos ilustran las posiciones para los rompimientos, las distintas zonas del puño utilizadas para golpear y los golpes con las yemas de los dedos. El sexto capítulo presenta algunas de las técnicas ejecutadas en la posición apcubi mientras que los tres siguientes capítulos ilustran diversas técnicas en las posiciones duit cubi, chuchum sogui y otras posiciones menos frecuentes. El décimo capítulo muestra todas las posiciones con diferentes patadas de taekwondo. El capítulo decimoprimero enumera las técnicas de los pumses tae kuk del 1 al 8 acompañados de su representación gráfica. El siguiente capítulo presenta los sistemas de entrenamiento para los practicantes infantiles, jóvenes, mayores y mujeres. El capítulo decimotercero describe la ejecución de varios juegos infantiles y adultos incluyendo su representación gráfica. Los dos últimos capítulos describen la ejecución de numerosas técnicas de defensa personal ante agarres, ataques de puño y pierna, y ataques armados. Adjunta un diccionario y un breve glosario específico.

1062. Losito, Giuseppe (2000). Lecciones de tae kwon do. Barcelona: De Vecchi. 1a ed. 111 p. : il. ; 17x24 cm. ISBN: 84-315-2358-1. Depósito legal: B. 4433-2000. (2ª ed., 2001; 3aㅡ ed., 2004). Palabras clave: fundamentos técnicos. Resumen: Manual teórico y técnico de tae kwon do. La obra esta dividida en 2 partes y la primera introduce las nociones fundamentales de este arte, como su historia, los grados, la terminología específica, la explicación de las posiciones y algunos consejos prácticos para el combate. La segunda parte integra los contenidos técnicos desde el cinturón amarillo al negro. Todos estos capítulos tienen la misma estructura de técnicas fundamentales de cada cinturón y sus correspondientes formas. Todas las técnicas descritas dividen el movimiento en partes, describiendo su ejecución y presentando una ilustración y un esquema del movimiento. El último capítulo incluye el programa de examen para el cinturón negro.

1063. Majoral Cabrera, Cristina; Aribau, Elisa; Drobnic Martinez, Franchek y Pujol Amat, Pere (1995). La visio i el taekwondo : influencia de la visio en el rendiment esportiu en taekwondistes d'elit. Barcelona: Joan Verdaguer Codina. 1a ed. 19 p. : il. ; 14x20 cm. ISBN: ISBN en trámite. Depósito legal: B. 6130-1995. Palabras clave: taekwondo, investigación, vista. Resumen: Estudio científico de la visión en el taekwondo. La obra se estructura en introducción, sujetos y metodología, resultados, conclusiones, bibliografía y apéndice. La introducción resalta los estudios y trabajos realizados sobre la visión y el taekwondo. El primer apartado explica la composición del grupo de sujetos, un breve comentario sobre los aparatos utilizados para medir la visión y el listado de pruebas que se realizaron. El segundo apartado presenta los resultados de las pruebas de agudeza visual y estática, el estado refractario, la percepción de profundidad, la velocidad y amplitud de enfoque, la motilidad ocular, la amplitud de fusión, la binocularidad, el deslumbramiento, la relación entre la mano con la que escriben y la dominancia ocular, la lateralidad, la memoria visual y velocidad de percepción visual, el rendimiento visual y adaptación de la superficie de acuvisión a la figura del taekwondista. El tercer apartado detalla las conclusiones del estudio, matizando que es imprescindible realizar un análisis visual de los deportes de élite para obtener los máximos resultados. Adjunta bibliografía y un apéndice con los datos del test de acuvisión.

1064. Malota Lulgjuraj, Peter (1992). Tae kwon do : fundamentos, métodos de entrenamiento, combate. Madrid: Multideporte. $1^{\underline{a}}$ ed. 168 p. : il. ; 17x24 cm. ISBN: 84-87967-01-9. Depósito legal: M. 273391992. Palabras clave: historia, fundamentos técnicos, ejercicios, combate, planificación del entrenamiento, preparación física. Resumen: Manual teórico y técnico de taekwondo. La obra esta formada por 17 capítulos precedidos por los agradecimientos, una dedicatoria, el currículo del autor y una introducción que comenta los contenidos de la obra. El primer capítulo narra la historia del taekwondo mientras que el segundo incluye las preguntas y respuestas más frecuentes al comienzo de su práctica. El tercer capítulo describe e ilustra diversos ejercicios de preparación física. Los siguientes seis capítulos describen brevemente la ejecución de las principales técnicas de mano y pie, posiciones, bloqueos, técnicas de brazo, combinaciones de defensa y contraataque y técnicas piernas acompañadas de sus ilustraciones correspondientes. El décimo capítulo expone diversos ejercicios para el entrenamiento de las técnicas de pierna incluyendo su representación gráfica mientras que los tres siguientes capítulos explica la ejecución de algunas técnicas avanzadas, patadas en combinación y patadas en salto junto con su secuencia fotográfica. El décimo cuarto capítulo muestra algunos de los ejercicios con manoplas para luego presentar distintos ejercicios del entrenamiento con escudo y varias técnicas de combate. El último capítulo incluye las tablas semanales de preparación física para los niveles principiante, intermedio y avanzado. 
1065. Martínez Suárez, Xoán Carlos (1997). Iniciación al taekwondo. Madrid: Esteban Sanz Martínez. 1aa ed. 94 p. : il. ; 15x24 cm. ISBN: 84-88553-27-7. Depósito legal: no. Palabras clave: pumses, fundamentos teóricos, entrenamiento, cortesía, taekwondo, instituciones, psicología evolutiva, juegos. Resumen: Manual teórico y técnico de taekwondo. El libro esta compuesto por 14 capítulos. El primer capítulo explica las características de las etapas de desarrollo psicomotriz del niño junto con el papel del educador en cada una de estas etapas. Los dos siguientes capítulos describen las dos formas de saludo del taekwondo y el desarrollo de una clase, para luego incluir un breve vocabulario básico de taekwondo. Los siguientes cinco capítulos presentan los contenidos técnicos básicos del taekwondo, describiendo e ilustrando cómo cerrar un puño y golpear con el canto de la mano, las posiciones, las defensas baja, media y alta, el golpe directo, y las patadas frontal, lateral y circular. El décimo capítulo describe los tipos de kibon e ilustra algunas secuencias técnicas. El siguiente capítulo enumera los pumses correspondientes a cada grado e ilustra la secuencia técnica del Taeguk Il Chang. Los dos siguientes capítulos detallan la estructura de una sesión de entrenamiento, ofreciendo ejemplos del trabajo en cada una de las partes de la sesión, y compilan las fichas de descripción de diversos juegos con distinta orientación. El último capítulo relata la historia de la Federación Gallega de Taekwondo y resume los resultados nacionales e internacionales conseguidos por dicha federación. Adjunta varias ilustraciones técnicas.

1066. Martínez Suárez, Xoán Carlos (1997). Iniciación ó taekwondo. Santiago de Compostela: Lea. 1 ạ ed. 94 p. : il. ; 15x24 cm. ISBN: 84-88553-27-7. Depósito legal: C. 51-1997. Palabras clave: pumses, fundamentos teóricos, entrenamiento, cortesía, taekwondo, instituciones, psicología evolutiva, juegos. Resumen: Manual teórico y técnico de taekwondo. El libro esta compuesto por 14 capítulos. El primer capítulo explica las características de las etapas de desarrollo psicomotriz del niño junto con el papel del educador en cada una de estas etapas. Los dos siguientes capítulos describen las dos formas de saludo del taekwondo y el desarrollo de una clase, para luego incluir un breve vocabulario básico de taekwondo. Los siguientes cinco capítulos presentan los contenidos técnicos básicos del taekwondo, describiendo e ilustrando cómo cerrar un puño y golpear con el canto de la mano, las posiciones, las defensas baja, media y alta, el golpe directo, y las patadas frontal, lateral y circular. El décimo capítulo describe los tipos de kibon e ilustra algunas secuencias técnicas. El siguiente capítulo enumera los pumses correspondientes a cada grado e ilustra la secuencia técnica del Taeguk Il Chang. Los dos siguientes capítulos detallan la estructura de una sesión de entrenamiento, ofreciendo ejemplos del trabajo en cada una de las partes de la sesión, y compilan las fichas de descripción de diversos juegos con distinta orientación. El último capítulo relata la historia de la Federación Gallega de Taekwondo y resume los resultados nacionales e internacionales conseguidos por dicha federación. Adjunta varias ilustraciones técnicas.

1067. McKissock, John W. G. (2008). Taekwon-do : programa de examen hasta cinturón negro. ITF. Barcelona: Alas. 1므 ed. 107 p. : il. ; 17x23,5 cm. ISBN: 978-84-203-0450-2. Depósito legal: B. 33872-2008. Palabras clave: fundamentos teóricos, fundamentos técnicos, programa técnico, competición. Resumen: Manual teórico y técnico de taekwondo. El libro esta formado por 4 partes precedidas por una introducción que comenta los contenidos del libro y la historia del taekwondo. La primera parte describe la ejecución de las posiciones de taekwondo acompañadas de su ilustración y representación gráfica, ilustra las zonas utilizadas para golpear, explica el movimiento sinusoidal, la teoría del poder, los principios técnicos del movimiento, las características de las formas tul, los tipos de combate y la defensa personal. El segundo capítulo explica el significado de los términos do y maestro, detalla las normas de cortesía, los fundamentos morales, los objetivos del kihap, presenta los juramentos del estudiante y del instructor junto con las normas del dojang. El tercer capítulo expone las características y desarrollo de los cinco tipos de competición, como son tul, combate, técnica especial, test de potencia y combate tradicional. El cuarto capítulo presenta los contenidos técnicos por cinturones hasta el cinturón negro, comenta el desarrollo del examen de cinturón negro y una breve terminología. Adjunta un apéndice con una conclusión final y la biografía del autor.

1068. Mitchell, David (1994). Taekwondo en una semana. Madrid: Pirámide. 1ạ ed. 112 p. : il. ; $13 \times 20$ cm. ISBN: 84-368-0832-0. Depósito legal: M. 23967-1994. Palabras clave: fundamentos técnicos, combate, entrenamiento, reglamentos. Resumen: Manual teórico y técnico de taekwondo. El libro esta formado por 7 capítulos precedidos de una introducción que comenta los aspectos generales del taekwondo como su historia, sus tipos, los grados, consejos para elegir un club, los gastos derivados de su práctica, y las normas de etiqueta. Los 7 capítulos corresponden con los días de la semana y tienen la misma estructura: explicación e ilustración de las técnicas junto con sus principales errores y soluciones y un apartado de ejercicios específicos. Así, el primer capítulo (lunes) describe esquemáticamente la ejecución de las técnicas básicas: cómo cerrar el puño, puñetazo directo, puñetazo reverso, puñetazo rápido (jab), puñetazo reverso rápido, combinación de puñetazo rápido-puñetazo reverso, bloqueo hacia arriba, bloqueo bajo, patada frontal, patada frontal de empujón y patada circular, incluyendo varias fotografías y la solución de sus principales errores. También incluye un programa de entrenamiento aeróbico. El segundo capítulo (martes) estudia e ilustra la técnica del puñetazo de 
revés, puñetazo en martillo, ataque con la base de la mano, bloqueo medio hacia dentro, bloqueo medio hacia afuera, patada lateral, patada hacia atrás, patada con cambio de pierna, patada de salto, junto con sus errores y forma de corrección, así como varios ejercicios de fortalecimiento. El tercer capítulo (miércoles) presenta y describe la técnica, errores y corrección del golpe de mano en filo de sable, golpe de mano en filo de sable reversa, mano en punta de espada, ataque de codo, bloqueo de mano en filo de sable, bloqueo en aspa, patada frontal de acometida, patada de media luna, patada de media luna reversa, patada de media luna reversa con giro, patada circular reversa con giro, patada lateral con salto, patadas múltiples, junto con algunas técnicas de estiramiento. El cuarto capítulo (jueves) explica e ilustra la técnica de las patadas en el aire, las técnicas de combinación de patada de empujón-patada circular, patada de empujón-patada de acometida, patada circular-patada circular reversa, patada lateral-patada hacia atrás, y algunos ejercicios para aumentar la elasticidad. El quinto capítulo (viernes) continua con las técnicas de combinación: puñetazo rápido-puñetazo reversa-patada circular, patada frontal-patada de acometida-puñetazo rápido-puñetazo reverso, patada frontal-patada lateral en el aire, patada circular-patada circular reversa en el aire con giro, patada lateral-patada hacia atrás en el aire, técnicas de contraataque: bloqueo hacia arriba-puñetazo reverso, bloqueo de codo-mano en filo de sable con giro, bloqueo medio hacia dentro-ataque de codo, bloqueo medio hacia fuera-patada circular reversa, bloqueo medio con la mano en filo de sable-patada lateral con la planta del pie, bloqueo bajo-patada de media luna, bloqueo bajo-patada circular reversa. Además incluye la explicación de la preparación para las pruebas de rompimiento y el entrenamiento en endurecimiento de gran intensidad. El sexto capítulo (sábado) incluye técnicas de combate organizado de antemano avanzado como el detener con puñetazos el ataque del oponente, detener con patadas el ataque del oponente, bloqueo bajo reverso-patada circular reversa, desvío del antebrazo-patada circular reversa y la patada circular reversa con giro, finalizando con los consejos prácticos para las pruebas de rompimiento, el entrenamiento de velocidad y el entrenamiento técnico. El último capítulo (domingo) presenta las reglas de competición y algunos consejos para ganar en la misma. Adjunta un glosario.

1069. Mitchell, David (1995). Taekwondo. Barcelona: Paidotribo. 1aㅡ ed. 264 p. : il. ; 15x21,5 cm. ISBN: 848019-240-2. Depósito legal: B. 33381-1995. Palabras clave: fundamentos teóricos, educación, fundamentos técnicos, pumses, combate, aplicación marcial, preparación física. Resumen: Manual teórico y técnico de taekwondo. Comienza con la narración de los orígenes del taekwondo para continuar con un comentario de los aspectos generales del taekwondo como son el lugar de práctica, la actitud en clase, los contenidos técnicos y los grados. El tercer capítulo explica los principios dinámicos para realizar una técnica con fuerza y potencia y el cuarto capítulo comienza a explicar los fundamentos técnicos del taekwondo, en concreto la ejecución de las posiciones y giros. El quinto capítulo presenta las técnicas de golpeo, tanto con la mano, el codo, la rodilla, la espinilla y el pie, que se pueden utilizar en el taekwondo. Los tres capítulos siguientes presentan las técnicas de ataque fundamentales, las paradas y algunas de las combinaciones más comunes, ilustrando y explicando cada técnica por partes. El noveno capítulo comenta cómo debe realizarse la práctica de las formas y cuáles son sus significados para dedicar los siguientes tres capítulos a explicar cómo se desarrolla el entrenamiento de combate preparado, de combate libre y la competición. Estos capítulos aportan consejos para mejorar el entrenamiento y explican los aspectos formales y organizativos de la competición. El siguiente capítulo profundiza en los rompimientos, cuál es el entrenamiento previo, materiales más adecuados, y cuáles son los objetivos. Después pasa a comentar las cualidades físicas y cómo desarrollarlas, proponiendo además una tabla de ejercicios. Los últimos capítulos están dedicados a la reflexión sobre la seguridad dentro de las clases de taekwondo, debido a los tipos de entrenamiento, características de los practicantes y características de la sala de entrenamiento; la enumeración de los términos utilizados en taekwondo y la representación gráfica de los taegeuks.

1070. Panchamé Munté, John (1978). Método moderno de taekwondo : para niños y adultos con juegos, pumses, técnicas, etc. Barcelona: Alas. 1a ed. 126 p. : il. ; $15 \times 21$ cm. ISBN: 84-203-0072-1. Depósito legal: B. 20066-1978. ( $2^{\mathrm{a}}$ ed., 1981; $3^{\mathrm{a}}$ ed., 1986). Palabras clave: pumses, ejercicios, entrenamiento, calentamiento, juegos. Resumen: Manual técnico de taekwondo. El libro esta formado por dos partes, comentando la primera de ellas las características del niño y la adaptación del taekwondo a estas edades, describiendo distintos juegos de calentamiento e incluyendo la ilustración de distintas técnicas del taekwondo infantil. La segunda parte consta de 4 capítulos. El primer capítulo explica brevemente en qué consiste el entrenamiento del taekwondo, cuáles son sus beneficios para el practicante y describe varios ejercicios individuales y por parejas para calentar. El segundo capítulo ilustra algunas de las técnicas más comunes del taekwondo, mientras que el tercero comenta el entrenamiento necesario para realizar un rompimiento. El cuarto capítulo explica qué es un pumse, resalta la importancia de la relajación para la práctica y detalla los movimientos, posiciones y pum desde el taeguk 1 chang hasta el taeguk 8 chang, incluyendo la secuencia fotográfica de su ejecución.

1071. Panchamé Munté, John (1981). Taekwon-do : pumses y técnicas superiores. Barcelona: Alas. 1aㅡ ed. 173 p. : il. ; 15x21 cm. ISBN: 84-203-0112-4. Depósito legal: B. 15731-1981. (2ª ed., 1984; 3aㅡ ed., 1986). Palabras clave: pumses, historia, entrenamiento, preparación física. Resumen: Manual teórico y 
técnico de taekwondo. La obra esta dividida en 2 partes. La primera parte incluye ocho capítulos, comenzando por explicar la historia y formación del taekwondo y las cualidades de un buen taekwondoka. Después ofrece unos nociones generales sobre el calentamiento, las cualidades físicas y los circuitos de entrenamiento para finalizar esta parte con propuestas de entrenamiento para desarrollar la flexibilidad, la fuerza, la resistencia y la velocidad. La segunda parte de la obra comprende las técnicas superiores, en la que se representan gráficamente las técnicas fundamentales y de rompimientos, se explica el significado del pumse, y se describen y representan los pumses superiores, koryo, kumgang, taebek, pyongwon, sipchin, chitae, chunkwon, jansu e ilillo. Finaliza con algunas fotografías sobre las técnicas con katana, los rompimientos y el listado de las técnicas de taekwondo más utilizadas.

1072. Panchamé Munté, John (1983). Arbitraje de tae kwon-do : reglamento de la federación mundial. Barcelona: Hispano Europea. 1르 ed. 220 p. : il. ; 13x21,5 cm. ISBN: 84-255-0647-6. Depósito legal: B. 11336-1983. Palabras clave: historia, taekwondo, instituciones, arbitraje, competición, reglamentos. Resumen: Tratado teórico de taekwondo. La obra esta formada por 7 capítulos. El primer capítulo detalla la cronología de hechos más importantes de la historia de la Federación Mundial de Tae KwonDo. El segundo capítulo analiza la figura del árbitro, describiendo sus características y cualidades para ser un buen árbitro. El tercer capítulo incluye la terminología específica del arbitraje, para luego ilustrar los puntos vitales del cuerpo humano. El quinto capítulo expone las reglas de competición adjuntando fotografías explicativas. El sexto capítulo incluye las preguntas y respuestas más frecuentes sobre el reglamento de competición y finaliza con el listado de los resultados de los principales campeonatos mundiales y fotografías de los mismos.

1073. Park, Pil-Won (2006). Curso de taekwondo : la técnica del chagui. Barcelona: De Vecchi. 1a ed. 159 p. : il. ; 17x24 cm. ISBN: 84-315-3357-9. Depósito legal: B. 7290-2006. Palabras clave: historia, fundamentos técnicos, principios técnicos, combate. Resumen: Manual teórico y técnico de taekwondo. El libro esta formado por 4 capítulos precedidos por una presentación que comenta los orígenes modernos del taekwondo, la genealogía e Kwan, el significado del taekwondo y la explicación de las técnicas de golpe con los pies (chagui). El primer capítulo comenta las distintas zonas de golpeo del pie y la pierna junto con sus efectos y utilización. El segundo capítulo comenta las características y principios técnicas de las principales posiciones, técnicas de bloqueo y ataques con los brazos, ilustrando cada técnica. El tercer capítulo analiza las características, ejecución técnica y posiciones habituales en la realización de las patadas simples y con giro, las patadas asociadas a otra técnica, las patadas con salto, y el encadenamiento de varias patadas. El último capítulo explica el combate yaksok kyorugi, sus características e ilustra una serie técnica, explica las normas del combate chihap kyorugi junto con la presentación gráfica de las patadas en contraataque más frecuentes y las características del combate jayu kyorugi. Adjunta un glosario y un esquema de los principales movimientos.

1074. Pons Botella, Mario (1990). Taekwon-do : técnica fundamental y superior. Barcelona: Alas. 1a ed. 157 p. : il. ; 15x21,5 cm. ISBN: 84-203-0250-3. Depósito legal: B. 28749-1990. Palabras clave: pumses, historia, fundamentos teóricos, fundamentos técnicos, ejercicios, combate, biografía, vestimenta, cortesía, etiqueta, maestros, preparación física. Resumen: Manual teórico y técnico de taekwondo. El libro esta formado por 17 capítulos precedidos por los agradecimientos, una dedicatoria y la biografía del autor. El primer capítulo narra la historia del taekwondo en España mientras que el segundo capítulo relata el origen y evolución del taekwondo. El tercer capítulo explica los principios éticos del taekwondo. El cuarto capítulo expone el comentario del General Choi sobre la historia del taekwondo. El quinto capítulo presenta la biografía del General Choi. El sexto capítulo detalla las características y significado de las formas tuls. Los dos siguientes capítulos explican el sistema de graduación del taekwondo y la forma de saludar en clase. El noveno capítulo presenta la aplicación del principio de acción-reacción en las técnicas de taekwondo. Los dos siguientes capítulos ilustran las distintas alturas de ataque y las partes de las manos y los pies utilizadas para golpear. Los siguientes dos capítulos ilustran las técnicas fundamentales y las técnicas superiores del taekwondo desde cinturón blanco hasta 3er dan. El décimo cuarto capítulo incluye la secuencia fotográfica de las principales técnicas de pierna del taekwondo mientras que el siguiente describe brevemente la ejecución de varias técnicas de combate programado junto con sus ilustraciones. El penúltimo capítulo explica los fundamentos teóricos de la preparación física en el taekwondo junto con varias propuestas de entrenamiento. El último capítulo incluye la representación gráfica de diversos ejercicios de calentamiento y estiramientos.

1075. Pons Botella, Mario (1991). Taekwon-do : formas tul tradicionales. 18 hyong originales del taekwondo. Barcelona: Alas. 1aㅡ ed. 169 p. : il. ; 15x21,5 cm. ISBN: 84-203-0261-9. Depósito legal: B. 44080-1991. Palabras clave: pumses, historia. Resumen: Manual teórico y práctico de taekwondo. El libro esta formado por 21 capítulos, precedidos de una sucinta biografía de autor y sus colaboradores. Los 3 primeros capítulos presentan brevemente la historia del taekwondo y su formación como arte marcial, la historia de las formas del taekwondo y su evolución técnica, el significado e interpretación de cada forma y el listado de graduaciones junto con sus formas correspondientes. Los siguientes capítulos 
explican el significado de la forma, ilustran su secuencia de movimientos y enumeran las técnicas de cada movimiento. Las formas presentadas son las 18 formas tul tradicionales: Chon-Ji, Dan-Gun, DoSan, Won-Hyo, Yul-Gok, Joong-Gun, Toe-Gye, Hwa-Rang, Choong-Moo, Kwang-Gae, Po-Eun, Ge-Baek, Eumi-Am, Choong-Jang, Juche, Sam-Il, Yoo-Sin, y Choi-Yong.

1076. s.a. (1988). Taekwondo : técnicas homologadas por la Federación de Taekwondo. W.T.F. Barcelona: Alas. 1aㅡ ed. 64 p. : il. ; 21x26,5 cm. ISBN: 84-203-0228-7. Depósito legal: B. 39248-1988. Palabras clave: pumses, fundamentos técnicos, juegos. Resumen: Manual técnico de taekwondo. La obra esta formada por 12 capítulos precedidos por un capítulo introductorio que nombra en castellano y coreano los distintos golpes de puño acompañados de su representación gráfica. El primer capítulo explica el significado del término taekwondo para luego describir en qué consiste el pumse y cuáles son sus principios técnicos. El tercer capítulo describe brevemente los fundamentos técnicos del taekwondo incluyendo su representación gráfica y nombre en coreano. Los siguientes ocho capítulos presentan la línea de entrenamiento, la descripción e ilustración de los ocho pumses tae guk, incluyendo el hexagrama y nombre coreano de cada uno de ellos. El último capítulo resalta los valores educativos del taekwondo e incluye la descripción de varios juegos.

1077. s.a. (1992). Taekwondo : llibret explicatiu. Taekwondo : folleto explicativo. Barcelona: C00B'92. $1^{\mathrm{a}}$ ed. 37 p. : il. ; 10x21 cm. ISBN: 84-7868-090-X. Depósito legal: B. 26354-1992. Palabras clave: historia, taekwondo, competición, juegos, reglamentos. Resumen: Folleto explicativo del programa de competición del taekwondo en los Juegos Olímpicos de Barcelona'92. El folleto esta dividido en 4 partes. La primera parte incluye una tabla con el calendario de todos los deportes olímpicos y de demostración participantes en los Juegos de la XXVa Olimpiada. La segunda parte detalla el organigrama del Comité Olímpico Internacional, el Comité Organizador Olímpico de Barcelona'92 y de las federaciones deportivas internacional, nacional y catalana de taekwondo. La tercera parte presenta el calendario de competición del taekwondo, sus pruebas, un resumen del reglamento general, de la organización y el reglamento de la competición, de las medallas y diplomas, de las instalaciones de competición y entrenamiento y del equipamiento. La última parte ofrece algunos datos generales sobre la ciudad de Barcelona, un breve comentario sobre la historia del taekwondo y la aprobación de este texto. Adjunta varias hojas en blanco para tomar notas.

1078. s.a. (1992). Taekwondo : manual d'equip. Taekwondo : manual de equipo. Barcelona: C00B'92. $1^{\mathrm{a}}$ ed. 59 p. : il. ; 10x21 cm. ISBN: 84-7868-187-6. Depósito legal: B. 26859-1992. Palabras clave: competición, instalaciones, instituciones, juegos, reglamentos. Resumen: Folleto explicativo del programa de competición del taekwondo en los Juegos Olímpicos de Barcelona'92. El folleto esta dividido en 3 partes. La primera parte incluye la información general de la organización, órganos de control, programa general de los Juegos, pruebas programadas, países participantes, centro de información deportiva y la programación deportiva. La segunda parte incluye la información sobre la competición, detallando el reglamento, horario y lugar de la competición, la normativa, la organización técnica, el sistema de competición, el control de pesaje y dopaje, el equipamiento de competición y entrenamiento, la ceremonia de proclamación de campeones y las características del lugar de competición y entrenamiento. La tercera parte incluye la información a los competidores sobre el transporte, acreditación, equipamientos deportivos protecciones de competición, material de entrenamiento, asistencia médica, entrevistas, asistentes, área de espectadores reservada para los deportistas, y mapas del Palau Blaugrana y alrededores.

1079. s.a. (1992). Taekwondo : reglament oficial. Barcelona: Enciclopedia Catalana. 1 a ed. 65 p. : il. ; $13 \times 19,5$ cm. ISBN: 84-7739-284-6. Depósito legal: B. 27217-1992. Palabras clave: competición, reglamentos. Resumen: Manual teórico de taekwondo. La obra presenta el reglamento oficial de competición del taekwondo dividido en 25 capítulos además de incluir las ilustraciones sobre los gestos señales de los árbitros. Los contenidos del reglamento son: propósito, aplicación, área de competición, los competidores, las categorías de peso, la clasificación y métodos de competición, la duración del combate, el sorteo, el pesaje, el desarrollo del combate, las zonas y técnicas permitidas, los puntos válidos, la puntuación y publicación, los actos prohibidos, la decisión de superioridad, las decisiones, caídas, medidas en caso de caída, procedimientos para suspender el combate, árbitros y jueces, juez de zona, controladores, designación de los oficiales, otras cuestiones no específicas de las reglas y protestas.

1080. Sagarra Pérez de Óbanos, Josetxo (2009). Taekwondo junior : guía para conocer este arte marcial. Barcelona: Alas. 1ํㅡ ed. 92 p. : il. ; 17x23,5 cm. ISBN: 978-84-203-0467-0. Depósito legal: B. 45860-2009. Palabras clave: fundamentos teóricos, fundamentos técnicos, programa técnico, vestimenta, cortesía, competición, etiqueta, reglamentos. Resumen: Manual teórico y técnico de taekwondo. El libro esta formado por 15 capítulos precedidos de una dedicatoria, una presentación de la obra y un prólogo que comenta sus objetivos. El primer capítulos explica en qué consiste el taekwondo y cuáles son sus valores. El segundo capítulo narra su historia y código de honor. El tercer capítulo comenta las características de las principales artes marciales. El cuarto capítulo detalla la vestimenta del taekwondo, su significado y el sistema de grados. El quinto capítulo expone el significado del doyang y 
sus normas de comportamiento. El sexto capítulo describe la ejecución del saludo. El séptimo capítulo reflexiona sobre la figura del maestro. El octavo capítulo ofrece varios consejos para adquirir unos buenos hábitos de vida. El noveno capítulo describe varios ejercicios para desarrollar las habilidades específicas del taekwondo además de explicar el significado del zen, los rompimientos y el kiap. El décimo capítulo detalla el significado de los pumses y enumera sus principios técnicos. El capítulo decimoprimero resume el reglamento de competición. El siguiente capítulo incluye un breve glosario de coreano. El capítulo decimotercero presenta el programa de contenidos para el examen de cinturón negro junto con su ilustración. Los dos últimos capítulos incluyen las entrevistas a 3 maestros de taekwondo y las conclusiones finales.

1081. Serra Ortells, Vicente (1986). Taekwondo, un camino. Castellón: Imprenta Centelles. 1ạ ed. 87 p. : il. ; desc.xdesc. cm. ISBN: No ISBN. Depósito legal: no.

1082. Stepan, Charles A. (2002). Tae kwon do : guía básica para conocer este arte marcial. Arganda del Rey: Edimat. 1aㅡ ed. 96 p. : il. ; 20x27 cm. ISBN: 84-9764-137-X. Depósito legal: no. (2aㅡ ed., 2003). Palabras clave: fundamentos técnicos, defensa personal, aplicación marcial, competición. Resumen: Manual técnico y teórico de tae kwon do. La monografía esta dividida en 7 capítulos. Comienza con una pequeña introducción sobre los orígenes del taekwondo y el dojang, para luego explicar sus elementos básicos como las características deseables del profesor, el traje y cinturones, las reglas generales del dojang y sus términos más frecuentes. El tercer capítulo ofrece algunos consejos actitudinales y técnicos ante la primera clase y el cuarto describe las posiciones básicas del taekwondo y los errores más frecuentes en la posición de combate y el combate libre. El quinto capítulo explica los beneficios del entrenamiento con combinación de técnicas incluyendo algunos ejemplos ilustrados de técnicas de manos y el 1er pumse. El sexto capítulo describe la ejecución técnica de las principales patadas del taekwondo y sus errores, junto con una explicación somera del arte del rompimiento, su historia, los materiales utilizados, y la ejecución de algunos de ellos. Finaliza con un análisis de la competición deportiva y la aplicación de algunas técnicas de taekwondo en la defensa personal. Adjunta un glosario de términos y un listado de contactos.

1083. Verdaguer Codina, Joan; Drobnic Martinez, Franchek; Pujol Amat, Pere; Majoral Cabrera, Cristina y Aribau Montón, Elisa (1995). La visión y el taekwondo : influencia de la visión en el rendimiento deportivo de los taekwondistas de élite. Barcelona: Joan Verdaguer Codina. 1aㅡ ed. 19 p. : il. ; 14x19,5 cm. ISBN: 84-920506-1-6. Depósito legal: B. 6131-1995. Palabras clave: taekwondo, investigación, vista. Resumen: Estudio científico de la visión en el taekwondo. La obra se estructura en introducción, sujetos y metodología, resultados, conclusiones, bibliografía y apéndice. La introducción resalta los estudios y trabajos realizados sobre la visión y el taekwondo. El primer apartado explica la composición del grupo de sujetos, un breve comentario sobre los aparatos utilizados para medir la visión y el listado de pruebas que se realizaron. El segundo apartado presenta los resultados de las pruebas de agudeza visual y estática, el estado refractario, la percepción de profundidad, la velocidad y amplitud de enfoque, la motilidad ocular, la amplitud de fusión, la binocularidad, el deslumbramiento, la relación entre la mano con la que escriben y la dominancia ocular, la lateralidad, la memoria visual y velocidad de percepción visual, el rendimiento visual y adaptación de la superficie de acuvisión a la figura del taekwondista. El tercer apartado detalla las conclusiones del estudio, matizando que es imprescindible realizar un análisis visual de los deportes de élite para obtener los máximos resultados. Adjunta bibliografía y un apéndice con los datos del test de acuvisión.

1084. Wo, Lu Tao (1986). Taekwondo. Barcelona: Editors. 1aㅡ ed. 158 p. : il. ; 12x19 cm. ISBN: 84-7561-389-6. Depósito legal: B. 42776-1986. (2ª ed., 1988, ISBN: 84-7561-690-9; 4ª ed., 1990, ISBN: 84-7561-690-9; $5^{\mathrm{a}}$ ed., 1991, ISBN: 84-7561-690-9; 6 $6^{\mathrm{a}}$ ed., 1992, ISBN: 84-7561-690-9; 7aㅡ ed., 1993, ISBN: 84-7561690-9; 8a ed., 1994, ISBN: 84-7561-690-9). Palabras clave: pumses, fundamentos técnicos, principios técnicos, ejercicios, entrenamiento, kyusho, formas. Resumen: Manual teórico y técnico de taekwondo. La obra esta dividida en 9 capítulos. El primer capítulo comenta los orígenes y expansión del kárate. El segundo capítulo expone las características del taekwondo. El tercer capítulo explica los principios técnicos y su aplicación en el taekwondo. El cuarto capítulo incluye la descripción e ilustración de algunos ejercicios de calentamiento. El quinto capítulo describe la ejecución técnica de los golpes, patadas y bloqueos básicos además de presentar su representación gráfica. El sexto capítulo describe la ejecución de las formas kuk mu I, kuk mu II, pyong an I, pyong an II, pyong an III, pyong an IV, pyong an V, chul gi I, pal sek acompañadas de su representación gráfica, línea de ejecución y esquema de movimiento. El séptimo capítulo expone los principios para la aplicación marcial de las técnicas de taekwondo, describe la aplicación de varias técnicas ante ataques armados acompañados de su representación gráfica. El octavo capítulo describe algunos métodos de entrenamiento y endurecimiento físico además de comentar los principios técnicos para la ejecución de rompimientos, junto con algunas ilustraciones. La última parte localiza y enumera los puntos vitales del cuerpo humano. 


\subsubsection{Armas}

1085. López Merz, Francisco (1989). Jipanghi-sul : arma tradicional coreana. Barcelona: Alas. $1^{a}$ ed. 80 p. : il. ; 15x21,5 cm. ISBN: 84-203-0242-2. Depósito legal: B. 38608-1989. Palabras clave: historia, fundamentos técnicos, defensa personal. Resumen: Manual teórico y técnico de Ji-panghi Sul. El primer capítulo narra el nacimiento del ji-panghi y los diversos usos que se le dieron; para luego describir las partes del ji-panghi y los principios para su manejo. El tercer capítulo ilustra los puntos vitales del cuerpo e introduce los diferentes tipos de golpes con el ji-panghi. El siguiente capítulo describe e ilustra algunas de las técnicas de defensa contra distintos agarres, agresiones sin armas, contra patadas y contra agresiones con armas. Finaliza con un breve comentario sobre el uso actual del bastón y sus características.

\subsection{Filipinas}

\subsubsection{Kali, Eskrima, Arnis}

1086. Diego, Antonio y Ricketts, Christopher (2003). Los secretos del kalis ilustrísimo : el arte de combate filipino. Madrid: Tutor. 1a ed. 248 p. : il. ; $17 \times 24$ cm. ISBN: 84-7902-384-8. Depósito legal: M. 96982003. Palabras clave: historia, fundamentos teóricos, armas, fundamentos técnicos, principios técnicos, combate, estrategia. Resumen: Manual teórico y técnico de kalis. La obra esta compuesta por 4 partes. La primera parte comenta la historia del kalis, del fundador del estilo de la familia Ilustrisimo, y la biografía y contacto de los autores con el arte, la sistematización de sus técnicas y la práctica en la actualidad. El segundo capítulo de esta parte expone la estructura del sistema, los tipos de entrenamiento que utiliza, la progresión en los contenidos técnicos y sus métodos de entrenamiento. La segunda parte consta de 3 capítulos que describen los fundamentos técnicos del kalis, comenzando por la longitud y agarre del arma, las distancias de combate, las guardias y los desplazamientos, y los 12 ángulos de ataque. La tercera parte ofrece una descripción técnica ilustrada de las 13 técnicas defensivas de combate fundamentales y su aplicación contra distintas armas, y los métodos de desarme empleando palo contra palo, manos vacías contra cuchillo y pañuelo contra cuchillo. La última parte presenta la simbología corporal de la lucha, resalta la importancia de la fortaleza espiritual ante el combate, y analiza los principios y estrategias de combate. Adjunta un glosario y lecturas recomendadas.

1087. Mercado Aguado, Felipe (2003). Kali-eskrima-arnis : la eficacia de las armas filipinas. Barcelona: Alas. $1^{\text {a }}$ ed. 110 p. : il. ; $17 \times 24$ cm. ISBN: 84-203-0421-2. Depósito legal: B. 5440-2003. Palabras clave: historia, fundamentos teóricos, arnis, eskrima, kali, fundamentos técnicos. Resumen: Manual teórico y técnico de kali, eskrima, arnis. La primera parte de la obra introduce los aspectos teóricos que fundamentan el arte filipino, como son los maestros, la historia de las Filipinas y sus artes marciales, la historia de sus armas, algunos conocimientos básicos del cuerpo humano y los principios técnicos en los que se basa. La segunda parte desarrolla algunas de las técnicas básicas del arte, tanto de ataque como de defensa con y sin armas, explicando cada una de ellas por partes y a través de ilustraciones. La tercera parte incluye terminología específica del kali-eskrima-arnis.

1088. Mercado Aguado, Felipe y Andaluz Domínguez, Michael (1994). Kali : el arte de combate filipino. Barcelona: Alas. 1aㅡ ed. 125 p. : il. ; 17x24 cm. ISBN: 84-203-0290-2. Depósito legal: B. 6751-1994. Palabras clave: fundamentos técnicos, historia. Resumen: Manual teórico y técnico de kali. La obra comienza relatando el origen racial de las islas filipinas y sus continuas guerras para luego pasar a detallar la biografía de los grandes maestros escrimadores. El tercer capítulo describe los diversos estilos, sistemas y métodos de lucha de Filipinas así como las 12 categorías en la enseñanza del kali. Continúa con la descripción de los principios básicos de este arte y su simbología, para en el séptimo capítulo comenzar a describir una parte del amplio trabajo técnico que compone el kali. Así, presenta los agarres, las guardias, los golpes y bloqueos, el movimiento de los pies, los ángulos de ataque, los desarmes, las proyecciones y palancas, las combinaciones y las técnicas con diferentes armas, explicando cada una de ellas por partes y por medio de ilustraciones. Finaliza con la explicación de la simbología utilizada en el kali y terminología básica.

1089. Prat Banús, José María (1983). Arnis y escrima : artes marciales de las Islas Filipinas. Barcelona: Alas. 1aㅡ ed. 111 p. : il. ; 15×21 cm. ISBN: 84-203-0162-0. Depósito legal: B. 14613-1983. Palabras clave: historia, fundamentos teóricos, fundamentos técnicos, ejercicios, entrenamiento, aplicación marcial, sistemas de entrenamiento. Resumen: Manual teórico y técnico de arnis y escrima. El libro esta formado por 6 capítulos precedidos por una breve biografía del autor y una introducción que señala los objetivos del libro. El primer capítulo relata el origen de las artes marciales filipinas incluyendo numerosas fotografías. El segundo capítulo estudia la simbología técnica, de desplazamientos y mágica/religiosa de las artes marciales filipinas acompañadas de su representación gráfica. El tercer 
capítulo describe la ejecución de algunos ejercicios de manejo del bastón filipino, las zonas de golpeo sobre el cuerpo, algunas técnicas de defensa, el tajo corto, el arko, un ejercicio de combinación de las técnicas aprendidas, la aplicación al trabajo por parejas y la comparación gráfica entre el wing tsun y la escrima incluyendo sus ilustraciones correspondientes. El cuarto capítulo narra la introducción de Dan Inosato en la escrima y los métodos de entrenamiento y aprendizaje de la escrima. El quinto capítulo explica brevemente la ejecución de algunas técnicas por parejas de la Philippine Martial Arts Society junto con su secuencia fotográfica. El sexto capítulo incluye un conjunto de preguntas y respuestas sobre las generalidades de las artes marciales filipinas. Adjunta un apéndice que explica el significado de la caza de cabezas.

1090. Villanueva Domínguez, Gabriel (2004). Budo y kali. Madrid: Gabriel Villanueva Domínguez. 1aㅡ ed. 72 p. : il. ; 21x29,5 cm. ISBN: No ISBN. Depósito legal: M. 37823-2004. Palabras clave: fundamentos teóricos, armas, historia, pedagogía, fundamentos técnicos, sistemas de entrenamiento, aplicación marcial. Resumen: Manual teórico y técnico de budo y kali. El libro esta dividido en 2 partes precedidas por una dedicatoria, un prólogo que comenta los contenidos y objetivos de la obra, y un capítulo introductorio que describe las artes marciales filipinas y japonesas y narra la creación de la presente obra. La primera parte consta de 14 capítulos. El primer capítulo presenta los objetivos de la investigación. El segundo capítulo analiza las armas naturales de algunas artes marciales. El tercer capítulo describe e ilustra algunas de las armas que han estado presentes en el Museo del Ejército de Madrid junto con sus fotografías. El cuarto capítulo comenta las características de las principales armas filipinas mientras que los dos siguientes capítulos describen las armas filipinas tradicionales y modernas respectivamente. Los dos siguientes capítulos capítulos exponen las características de las armas y armaduras japonesas. Los últimos seis capítulos detallan las características e influencias de las armas y artes hindúes, tibetanas, chinas, polinesias, islámicas y occidentales. La segunda parte consta de 17 capítulos. El primer capítulo explica las distintas vertientes que adoptan las artes marciales en la actualidad. El segundo capítulo narra la historia y evolución de las artes marciales japonesas así como sus principales escuelas. El tercer capítulo relata la historia y características de las artes marciales filipinas mientras que el cuarto explica su difusión mundial. El quinto capítulo describe la introducción y difusión de las artes marciales filipinas en España junto con varias fotografías de sus maestros. El sexto capítulo expone los principios metodológicos de cualquier arte marciales mientras que los dos siguientes capítulos presentan los sistemas de entrenamiento del budo y del kali respectivamente. El noveno capítulo enumera los principios técnicos del budo y del kali. El décimo capítulo analiza las distancias de combate del kali y de las artes budo además de sus principales movimientos. El decimoprimer capítulo explica el concepto del ocho. El siguiente capítulo señala las características comunes que comparten el ninjutsu y el kali. El decimotercer capítulo analiza la eficacia de las artes budo y del kali. El siguiente capítulo ofrece recomendaciones para la práctica con armas. El decimoquinto capítulo explica las posibles soluciones ante un ataque con cuchillo desde el punto de vista del kali y de las artes marciales japonesas. El decimosexto capítulo analiza los principios técnicos de aplicación de las técnicas de luxación, proyección y control en las artes marciales japonesas y en el kali. El último capítulo describe e ilustra 16 aplicaciones de la técnica kote gaeshi, señalando sus puntos importantes e incluyendo su secuencia fotográfica. Adjunta un relato, notas sobre la terminología en las artes marciales y bibliografía.

\subsection{Tailandia}

\subsubsection{Muay Thai}

1091. De Cesaris, Marco (2000). Boxeo tailandés, muay thai. Madrid: Tutor. $1^{\text {a }}$ ed. 168 p. : il. ; $17 x 24$ cm. ISBN: 84-7902-260-4. Depósito legal: M. 18912-2000. (2ª ed., 2003; 3aㅡ ed., 2005). Palabras clave: historia, fundamentos técnicos, entrenamiento. Resumen: Manual teórico y técnico de muay thai. La monografía esta dividida en 12 capítulos. Los cinco primeros capítulos tienen un enfoque teórico desde el que se estudia el origen e historia del muay thai, el ceremonial del combate, la expansión de este arte por Tailandia y el resto del mundo, los más famosos campeones, los aspectos formales del combate referidos a equipamiento y reglas, y unas consideraciones generales sobre las técnicas de combate, esto es, una clasificación de las técnicas y sus características, la guardia, la distancia de combate, los puntos vitales, los desplazamientos y el timing. A continuación aparecen 4 capítulos dedicados a la parte práctica del arte, clasificando en cada capítulo los golpes de puño, las patadas, los golpes de codo y los golpes de rodilla. Además, en cada capítulo específico se explica la ejecución de cada golpe, se ilustran dichos movimientos junto con sus esquemas de movimiento y se describe el entrenamiento de cada tipo de golpe. Los últimos tres capítulos abordan aspectos generales del entrenamiento, como el papel de cada persona, el material específico, técnicas complementarias para mejorar el entrenamiento; una cronología sobre algunos hechos destacados con la expansión del Muay Thai por el 
resto del mundo; y la organización del Muay Thai en el mundo, describiendo el papel de las federaciones, los ministerios y los árbitros. Adjunta un glosario.

1092. De Cesaris, Marco (2005). Muay thai boran : el arte marcial tailandés. Madrid: Budo International. 1a ed. 207 p. : il. ; $17 \times 24$ cm. ISBN: 84-96492-03-6. Depósito legal: M. 38443-2005. Palabras clave: formas, historia, fundamentos técnicos, principios técnicos, combate, entrenamiento, muay thai, competición, entrevistas. Resumen: Manual teórico y técnico de muay thai. El libro esta formado por 26 capítulos, precedidos por los prólogos de Alfredo Tucci, el presidente honorífico y el presidente de la AITMA. El primero capítulo incluye la entrevista realizada al maestro Woody respecto al redescubrimiento del muay thai tradicional. Los tres siguientes capítulos incluyen la entrevista realizada al maestro Paosawath sobre las distintas vertientes del muay thai boran, el análisis histórico del desarrollo del muay thai y la situación actual del mismo. El quinto capítulo expone los principios técnicos de las patadas mientras que el sexto explica las características y métodos de entrenamiento de los contenidos técnicos del muay thai, como son los rodillazos, proyecciones, codazos y luxaciones. El séptimo capítulo expone las características técnicas de la patada directa para luego exponer la aplicación del muay thai al boxeo occidental. El noveno capítulo describe el trabajo de piernas y sus tipos, mientras que el décimo presenta los contenidos técnicos del mono blanco del muay boran. El siguiente capítulo comenta la unión entre el muay boran y el brazilian jiu jitsu para la creación de un sistema de combate más completo denominada cross fighting; para continuar con la descripción del muay kaard chiek o boxeo a manos vendadas. El décimo segundo capítulo presenta la creación de la academia de muay boran, sus objetivos, organización y contenidos técnicos. El siguiente capítulo expone la clasificación técnica del muay boran junto con los principios técnicos que rigen la competición de Mae Mai. Los dos siguientes capítulos resaltan la importancia de las low kicks en la defensa personal así como los principales objetivos y armas naturales utilizadas por el muay boran en dichas situaciones. El décimo séptimo capítulo enumera las características técnicas del thai close combat. Los tres siguientes capítulos detallan el correcto entrenamiento con los paos, el entrenamiento dentro de un kai muay o campo de entrenamiento de muay thai, y el entrenamiento de power muay thai para las competiciones de vale-tudo. Los dos siguientes capítulos comentan las características del muay chaiya y sus técnicas así como la leyenda de Diesel Noi. Continúa con una explicación de los antiguos métodos de entrenamiento del muay boran, la descripción y secuencia fotográfica de sus formas, y la explicación del combate muay kard chiek junto con un extracto de sus normas de competición y la secuencia fotográfica de algunas de sus combinaciones técnicas.

1093. De Cesaris, Marco (2007). Muay thai boran : técnicas avanzadas. Madrid: Budo International. 1a ed. 255 p. : il. ; 17x24 cm. ISBN: 978-84-96492-87-5. Depósito legal: M. 20673-2007. Palabras clave: fundamentos teóricos, fundamentos técnicos, ejercicios, entrenamiento, historia. Resumen: Manual teórico y técnico de muay thai. El libro esta formado por 14 capítulos. El primero capítulo expone los principios del entrenamiento mientras que el segundo describe e ilustra los fundamentos técnicos avanzados del muay thai. El tercer capítulo presenta varios ejercicios para fortalecer las partes del cuerpo. El cuarto capítulo detalla varias secuencias de ataque incluyendo su representación gráfica. El quinto capítulo relata la historia y orígenes del muay boran. El sexto capítulo presenta las técnicas de esquiva y defensa junto con sus ilustraciones. Los dos siguientes capítulos incluyen la descripción e ilustración de los codazos y rodillazos del muay boran mientras que el noveno capítulo presenta las técnicas de agarre. El décimo capítulo resume los principios técnicos y tácticos del combate. El siguiente capítulo incluye varios programas y ejercicios con el saco incluyendo su representación gráfica. Los dos últimos capítulos relatan los fundamentos teóricos del arte muay luesee y sus aplicaciones así como la organización e información de la Academia Internacional del Muay Boran.

1094. Juní Cadenet, Jesús (1985). Muay thai : boxeo thailandés. Técnicas y prácticas del kick boxing. Barcelona: Alas. 1aㅡ ed. 110 p. : il. ; 15x22 cm. ISBN: 84-203-0178-7. Depósito legal: B. 15338-1985. (2ª ed., 1988; $3^{a}$ ed., 1998, 126 p.). Palabras clave: historia, fundamentos técnicos. Resumen: Manual teórico y técnico de muay-thai. La obra esta compuesta de 2 partes. La primera explica los aspectos históricos, filosóficos y rituales del Muay-Thai junto con algunas historias sobre el enfrentamiento de luchadores thai contra otros expertos marciales y una breve introducción a la esgrima thai. La segunda parte es práctica y explica las técnicas de entrenamiento, comenzando con los ejercicios de calentamiento, condición física, y pesas; los fundamentos técnicos de los desplazamientos, los golpes de puño y codo, los golpes de pierna y rodilla, las proyecciones y el combate cuerpo a cuerpo, y algunas combinaciones de técnicas; el entrenamiento con el saco y los paos; las reglas de competición y terminología thailandesa. Esta segunda parte esta ilustrada ampliamente. Adjunta un relato de un combate de MuayThai.

1095. Mongksan (2006). Muay thai dee : historia y técnicas del arte marcial de Thailandia. Barcelona: Alas. 1 a ed. 218 p. : il. ; 17x23,5 cm. ISBN: 84-203-0440-9. Depósito legal: B. 26400-2006. Palabras clave: historia, fundamentos técnicos, muay thai. Resumen: Tratado teórico y técnico sobre muay thai. La obra esta dividida en 12 capítulos. Comienza con una explicación teórica de los aspectos históricos del arte marcial. Así, comenta los principales acontecimientos de las épocas Sukhothai y Ayutthaya; los 
reyes que pasaron por el trono en las distintas épocas junto con una breve biografía de los más importantes; las anécdotas de algunos héroes y heroínas; las implicaciones religiosas que impregnan la práctica; la simbología del arte a través de sus ceremonias; y una breve descripción de los sistemas antiguos de lucha que han dado lugar al muay thai. El séptimo capítulo explica brevemente, con ayuda gráfica, las técnicas que el ministerio de cultura tailandés aprobó como oficiales junto con los rituales y terminología. El siguiente capítulo narra los principales acontecimientos sociales desde el año 1782 hasta la actualidad. Los dos últimos capítulos están dedicados a explorar brevemente algunas de las tradiciones antiguas que se relacionan con el muay thai y entrevistas a los maestros españoles con mayor renombre.

\subsection{Malasia (y entorno)}

\subsubsection{Pencak Silat}

1096. Berrenechea, Juan Ignacio (1986). Introducción al pencak silat. Barcelona: Alas. 1a ed. 191 p. : il. ; $15 x 21$ cm. ISBN: 84-203-0193-0. Depósito legal: B. 17818-1986. Palabras clave: fundamentos técnicos, formas, competición. Resumen: Manual técnico de pencak silat. El libro comienza con la explicación de los orígenes del pencak silat, sus principales estilos en la actualidad y sus características. Continua con la descripción de la preparación física específica, los tipos de respiración y concentración, ilustrando los ejercicios tanto individuales como por parejas. Los siguientes capítulos profundizan en los aspectos técnicos del arte, como son sus posiciones fundamentales, el uso de las manos, los pies, la cabeza, la rodilla y la espinilla como armas naturales del cuerpo y cómo se realizan los golpes más habituales con cada una de estas regiones corporales. Continúa con la descripción e ilustración de los principales blocajes así como los kembang o katas básicos (harimau satu, harimau dwa, harimau tiga, harimau empat, harimau lima) y superiores (tari laga dwa). Los siguientes capítulos abordan en menor profundidad otros aspectos técnicos secundarios del pencak silat como el endurecimiento de las manos, la competición, sus técnicas especiales y las armas indonesias. Adjunta un breve comentario sobre los puntos vitales y un vocabulario.

\subsection{Vietnam}

\subsubsection{Vovinam Viet Vo Dao}

1097. Levet, Patrick (1999). Vovinam viet vo dao : el verdadero arte marcial vietnamita. Volumen $1^{\circ}$ : técnicas básicas. Barcelona: Alas. 1a ed. 192 p. : il. ; 17x23,5 cm. ISBN: 84-203-0387-9. Depósito legal: B. 201961999. Palabras clave: historia, fundamentos técnicos, principios técnicos, defensa personal, combate, entrenamiento, fundamentos filosóficos, competición, grados, reglamentos, sistemas de entrenamiento. Resumen: Manual teórico y técnico de vovinam viet vo dao. El libro esta formado por 2 partes precedidas por un prólogo que señala los objetivos del libro, los agradecimientos, la biografía y currículo del autor, la biografía del maestro Nguyen Van Chieu y un comentario sobre los viajes del autor a los países asiáticos y su contacto con viet nam. La primera parte consta de 9 capítulos. El primer capítulo narra la historia y evolución del vovinam. El segundo capítulo expone los fundamentos filosóficos del vovinam. El tercer capítulo comenta brevemente los contenidos técnicos del vovinam mientras que el cuarto analiza sus principios técnicos y describe sus métodos de caída. El quinto capítulo expone los métodos de entrenamiento del vovinam junto con un comentario sobre las enseñanzas psicológicas del arte marcial y algunos consejos prácticos. El sexto capítulo comenta las formas de modernización del vovinam. El séptimo capítulo enumera las cualidades de un verdadero maestro del arte. El octavo capítulo explica los niveles de maestría del vovinam, sus sistema de grados y el significado de cada uno de ellos. El noveno capítulo detalla las características básicas de los cinco tipos de competiciones del vovinam. La segunda parte nombra e ilustra los fundamentos técnicos del vovinam viet vo dao, como son las posiciones, blocajes, cantos de la mano, codazos, puñetazos, patadas, las principales estrategias de combate, defensas contra puñetazos y patadas, técnicas ofensivas de pierna, defensas contra cuchillo, algunas técnicas de la lucha tradicional vietnamita, defensa personal, llaves de brazo y técnicas de sable. También incluye un extracto del reglamento de combate. Adjunta dos apéndices con la historia de la escritura en viet nam, la fonética y pronunciación de su lenguaje y un glosario básico.

\subsection{Tibet}

\subsubsection{Boabom}


1098. Asanaro (2005). El arte secreto del seamm-jasani : 58 movimientos del antiguo Tíbet para la eterna juventud. Madrid: Edaf. 1aㅡ ed. 223 p. : il. ; 17x19 cm. ISBN: 84-414-1587-0. Depósito legal: M. 69122005. Palabras clave: fundamentos teóricos, fundamentos técnicos, principios técnicos, ejercicios, aplicación terapéutica, meditación, relajación, respiración. Resumen: Manual teórico y técnico de seamm-jasani. El libro esta compuesto por 8 capítulos precedidos por una introducción que narra una historia sobre la transmisión del arte. El primer capítulo presenta los fundamentos teóricos del seamm-jasani, su historia y algunos consejos sobre la alimentación. El segundo capítulo analiza los efectos de la era industrial sobre la salud. El tercer capítulo expone los contenidos que componen el curso de Jass-U y sus objetivos así como del Seamm-Jasani y sus características. El cuarto capítulo expone los beneficios derivados de la práctica del seamm-jasani. El quinto capítulo explica la estructura de los contenidos de la obra y ofrece varios consejos para la práctica de los ejercicios propuestos. El sexto capítulo presenta un programa de aprendizaje del arte además de algunas recomendaciones para antes y después de una clase. El séptimo capítulo describe los primeros 35 movimientos fundamentales que componen el curso de Jass-U acompañados de sus representaciones gráficas y esquemas de movimiento. El último capítulo incluye la descripción e ilustración de los 3 pasos de meditación así como de 20 movimientos de relajación activa. Adjunta la conclusión de la historia sobre la transmisión del arte, algunos comentarios de los practicantes y un resumen de la actividad profesional del autor.

1099. Asanaro (2007). Los mil caminos del boabom : el despertar del poder interior a través del arte de defensa del Tibet oculto. Badalona: Paidotribo. 1aㅡ ed. 344 p. : il. ; 15x21,5 cm. ISBN: 978-84-8019-921-6. Depósito legal: no. Palabras clave: fundamentos teóricos, fundamentos técnicos, principios técnicos, fundamentos filosóficos, salud. Resumen: Manual teórico y técnico de boabom. El libro esta dividido en 3 partes precedidas de una introducción que comenta los contenidos de la obra. La primera parte consta de 8 capítulos que a modo de relato exponen los fundamentos teóricos, fundamentos filosóficos y contenidos técnicos del boabom. La segunda parte consta de 5 capítulos. El primer capítulo expone los objetivos del boabom, comenta las consideraciones previas antes de su práctica e incluye la tabla de aprendizaje del boabom. El segundo capítulo describe la ejecución de los ejercicios que componen el Jass-U del boabom, sus principios técnicos y errores frecuentes acompañados de su representación gráfica. El tercer capítulo incluye la descripción e ilustración de las posiciones iniciales, técnicas de mano, técnicas de desplazamiento, técnicas de pie, formas de reacción y meditación así como sus aplicaciones y principales errores. El cuarto capítulo expone las características de las formas de reacción y describe la ejecución de sus secuencias de movimiento acompañadas de su representación gráfica. El quinto capítulo presenta el final del relato incluido en la primera parte sobre la enseñanza del boabom. La tercera parte consta de 3 capítulos. El primer capítulo expone la estructura y etapas del boabom. El segundo capítulo incluye las reflexiones de varios practicantes sobre los beneficios del boabom y seamm-jasani. El tercer capítulo incluye un estudio sobre la influencia de las artes boabom en sus estudiantes. Adjunta una breve biografía de los autores.

\subsection{Otras (Full Contact, Kick Boxing, etc.)}

1100. Albuixech, Juan José (1992). Manual completo para la práctica del kick-boxing. Barcelona: Alas. 1aa ed. 190 p. : il. ; 17x24 cm. ISBN: 84-203-0274-0. Depósito legal: B. 40347-1992. (2ª ed., 1993). Palabras clave: fundamentos técnicos, entrenamiento, biografía, competición, historia, instituciones, maestros. Resumen: Manual teórico y técnico de kick-boxing. El libro esta compuesto por 17 capítulos precedidos por una dedicatoria, un prólogo que señala los méritos del autor y los agradecimientos. El primer capítulo describe la ejecución de la guardia y presenta la ilustración de algunos ejemplos de la competición. El segundo capítulo analiza el sistema de combate de Bill Wallace ilustrando tres aplicaciones de su guardia de perfil. El tercer capítulo explica la ejecución de los golpes fundamentales acompañados de su representación gráfica y algunos ejemplos de su entrenamiento. El cuarto capítulo describe la ejecución de las principales patadas de kick-boxing y su entrenamiento acompañados de sus ilustraciones explicativas. El quinto capítulo analiza el low-kick, su ejecución, su defensa y algunas de sus aplicaciones junto con su representación, para luego presentar la ejecución de las técnicas de bloqueo y esquivas. El séptimo capítulo explica los cinco desplazamientos básicos mientras que el octavo señala las zonas permitidas para golpear. El noveno capítulo describe las principales federaciones de kick-boxing y sus competiciones. El décimo capítulo expone la forma de vendar las manos incluyendo gráficos explicativos. El siguiente capítulo incluye tres entrevistas sobre las lesiones, entrenamiento y competición del kick-boxing. El décimo segundo capítulo detalla el desarrollo de una clase de kick-boxing y sus métodos de entrenamiento. El siguiente capítulo incluye varias fotografías de la competición de kick-boxing. El décimo cuarto capítulo presenta la biografía de los principales campeones del kick-boxing. Los tres últimos capítulos presentan la clasificación europea de full- 
contact de 1992, los contenidos técnicos para el pase de grados y el reglamento de arbitraje de kickboxing. Adjunta la biografía del autor y un listado de gimnasios recomendados.

1101. Albuixech, Juan José (1994). Mejora tu kick boxing : incluye el entreno específico en el saco. Barcelona: Alas. 1aㅡ. ed. 174 p. : il. ; 17x24 cm. ISBN: 84-203-0313-5. Depósito legal: B. 9684-1994.

1102. Alonso, Marcelo (2008). Leyendas del vale-tudo : la historia y los protagonistas de los combates sin reglas. Madrid: Budo International. $1^{a}$ ed. 255 p. : il. ; 17x24 cm. ISBN: 978-84-92484-04-1. Depósito legal: M. 22630-2008. Palabras clave: historia, fundamentos técnicos, biografía, vale tudo, entrevistas. Resumen: Manual teórico y técnico de vale tudo. El libro esta formado por 21 capítulos ampliamente ilustrados y precedidos por un prólogo que comenta los contenidos del libro. El primer capítulo narra la historia y evolución del brazilian jiu-jitsu, algunos de sus combates más famosos. El segundo capítulo relata varios de los enfrentamientos entre el jiu-jitsu y la lucha libre. Los siguientes doce capítulos presentan las entrevistas realizadas a Marco Ruas, Ismael Wallid, Rodrigo Minotauro, los hermanos Minotauro, Joao Alberto Barreto, Wanderlei Silva, Rudimar Fedrigo, Ivan Gomes, Antonio Inoki, José "Pelé" Landy Ze Mario Sperry y Rei Zulu sobre sus vidas y competiciones. El décimo quinto capítulo comenta la historia, características y organización de la empresa Brazilian Top Team. El siguiente capítulo incluye las entrevistas realizadas a Wanderlei Silva y Rodrigo Minotauro después de sus últimas derrotas. Los últimos cinco capítulos presentan la descripción y secuencia fotográfica de varias series técnicas de vale tudo explicadas por Vitor Belfort, Ze Mario Sperry, Rodrigo Minotauro, Marcelo Garcia, Fabio Gurgel y Wanderlei Silva.

1103. Brieva Ortega, Javier (1985). Historia, filosofía y técnicas del shorinji kempo. Barcelona: Alas. $1^{\underline{a}}$ ed. 208 p. : il. ; 15x21,5 cm. ISBN: 84-203-0175-2. Depósito legal: B. 11662-1985. (2a ed. corr. y aum., 1990). Palabras clave: katas, historia, fundamentos técnicos, filosofía, defensa personal. Resumen: Manual teórico y técnico de shorinji kempo. La obra comienza con varios capítulos dedicados a la parte histórica del arte, comentando los objetivos del shorinji kempo, sus orígenes e historia en España y quién fue Doshin So. Después profundiza en los aspectos filosóficos del arte, con la explicación de la filosofía del shorinji kempo, el zen, la religión, y el kongo-zen. Los siguientes 3 capítulos aplican esta filosofía al shorinji kempo, con la descripción de la meditación y una reflexión sobre su relación con sus practicantes y cuáles son sus objetivos actuales. A continuación comienza con una parte práctica donde ilustra los ejercicios preparatorios, las técnicas básicas del shorinji kempo, describe algunas de las terapias que utiliza como el seiho y el kappo, localiza los puntos vitales del cuerpo humano, y profundiza en algunas teorías complementarias a la práctica del shorinji kempo, como son la medicina oriental, la acupuntura, la dieta, cómo actuar ante determinadas lesiones y los efectos de la práctica del shorinji kempo sobre la mente humana. Los últimos capítulos son de aplicación del shorinji kempo con enfoques específicos a su práctica por parte de una mujer, la ilustración de las katas, algunos consejos sobre la defensa personal, la aplicación de shorinji kempo a los niños, algunas consideraciones sobre las posiciones de guardia, la descripción de prácticas complementarias y el papel del sensei en el entrenamiento. Adjunta un diccionario terminológico.

1104. Calamonte Zorzo, Diego (1986). Técnica de full contact : "entrenamiento". Madrid: Esteban Sanz Martínez. $1^{a}$ ed. 103 p. : il. ; $15 \times 21$ cm. ISBN: 84-85977-29-7. Depósito legal: M. 13024-1986. Palabras clave: historia, fundamentos técnicos, reglamentos. Resumen: Manual teórico y técnico de full-contact. El libro esta compuesto por 15 capítulos, precedidos de una breve introducción y currículo deportivo del autor. El primer capítulo comenta el nacimiento del full-contact sucintamente y continúa con unas nociones generales sobre el calentamiento e ilustraciones de sus ejercicios. El tercer capítulo explica e ilustra las distintas posiciones de guardia, para continuar en los siguientes capítulos con los desplazamientos, las principales técnicas de puño, los blocajes, las técnicas de pierna, las técnicas de cuerpo a cuerpo, los barridos y desequilibrios, los encadenamientos y los ejercicios de elasticidad. Al comienzo de cada capítulo ofrece una idea general y los consejos para el entrenamiento de estos fundamentos. El duodécimo capítulo detalla los beneficios del entrenamiento con el saco y otros materiales, ilustrando algunos de sus ejercicios principales. Los dos últimos capítulos exponen el reglamento de competición, las reglas del coach, y algunos consejos para el desarrollo del combate.

1105. Campo y Cañas, Francisco Jesús del (1981). Full contact : principales bases del full contact Jag's Power. Logroño: Ochoa. $1^{a}$ ed. 93 p. : il. ; 15x[21] cm. ISBN: 84-7359-113-5. Depósito legal: no. Palabras clave: fundamentos teóricos, entrenamiento, fundamentos técnicos, competición, preparación física, reglamentos. Resumen: Manual teórico y técnico de full contact. El primer capítulo narra la historia de la creación del full contact en Estados Unidos y su introducción y expansión en España. Continúa con la ilustración de diferentes ejercicios de estiramientos del tren inferior y de fortalecimiento de los brazos para en el tercer capítulo presentar las fotografías de las distintas guardias que existen. Los dos siguientes capítulos comentan. Lo el trabajo de puños y piernas para exponer las ilustraciones de las principales técnicas de puño y de patadas. El sexto capítulo incluye fotografías de ejercicios con compañero para mejorar la flexibilidad, fortalecer el cuerpo y ejecutar técnicas de ataque. El siguiente capítulo ofrece recomendaciones sobre el entrenamiento al aire libre y continúa con los consejos prácticos para el endurecimiento de las manos y pies. Los últimos capítulos exponen las características 
de las tres modalidades de competición dentro del full contact, las categorías de pesos, los puntos prohibidos y penalizados por el reglamento, el papel de los jueces dentro de la competición y las fechas de las veladas en que ha participado el club Jag's Power.

1106. Casado, José A. (1984). Full contact : un deporte desconocido. Preparación física, técnicas y estrategia del combate. Barcelona: Alas. 1aㅡ ed. 160 p. : il. ; 15x21,5 cm. ISBN: 84-203-0168-X. Depósito legal: B. 30713-1984. (2 ${ }^{\mathrm{a}}$ ed., 1986; $3^{\mathrm{a}}$ ed., 1989). Palabras clave: historia, fundamentos técnicos, principios técnicos, combate, entrenamiento, estrategia, táctica, reglamentos. Resumen: Manual teórico y técnico de full-contact. El primer capítulo presenta este arte marcial, describe el trabajo que se realiza en una clase, resume el reglamento de competición, describe los métodos de trabajo del endurecimiento, resistencia, velocidad, potencia, coordinación, flexibilidad y elasticidad incluyendo ejercicios ilustrados. El segundo capítulo expone el desarrollo del trabajo del corazón y de la musculatura por medio de las pesas, proponiendo distintos ejercicios ilustrados. El tercer capítulo detalla las características de los distintos aparatos y métodos de entrenamiento como el saco, la comba, la sombra y otros utensilios propios del gimnasio. El cuarto capítulo describe el desarrollo de los distintos trabajos con sparring e incluye un esquema de la preparación de una temporada. El quinto capítulo relata la evolución histórica del full-contact, para luego ilustrar las posiciones, defensas, bloqueos y esquivas, ataques de puño, combinaciones y técnicas de pierna fundamentales, comentando las características de cada trabajo y finalizar con las consideraciones tácticas y estratégicas dentro del combate.

1107. Casero Abellán, Rogelio (1997). Shorinji kempo : el legado de los monjes guerreros de Shaolín. Barcelona: Alas. $1^{\text {a }}$ ed. 170 p. : il. ; $17 \times 24$ cm. ISBN: 84-203-0382-8. Depósito legal: B. 489-1997. Palabras clave: historia, fundamentos teóricos, táctica, fundamentos técnicos, principios técnicos, principios filosóficos, exámenes. Resumen: Manual teórico y técnico de shorinji kempo. El libro esta compuesto por 6 capítulos precedidos por los agradecimientos, una dedicatoria, el prólogo que comenta los objetivos del libro y el currículo del autor. El primer capítulo narra la historia del shorinji kempo, describe el desarrollo de una clase, clasifica sus contenidos técnicos y comenta sus características, presenta su sistema de grados y un sistema alternativo de contenidos hasta 3 o kyu, detalla el significado de su forma de saludar y emblema, relata la historia del shorinji kempo en España e incluye un directorio de gimnasios dedicados al shorinji kempo en España. El segundo capítulo muestra el esquema de las bases hasta $3^{\circ}$ kyu, el esquema de las técnicas hokei para 3o kyu y aclara la presentación de las series fotográficas del libro. El tercer capítulo expone las normas de comportamiento en el dojo, narra la biografía de Kaiso (fundador del estilo) y los objetivos del shorinji kempo, define los término bu y budo, expone los fundamentos filosóficos de las artes marciales y los fundamentos teóricos del shorinji kempo, presenta sus enseñanzas, describe los beneficios y ejecución de la meditación chinkon, enumera las técnicas ofensivas y defensivas junto con sus principios técnicos además de los propios principios tácticos del shorinji kempo. El cuarto capítulo presenta la descripción e ilustración de las distintas guardias, posiciones de los pies, movimientos del cuerpo, desplazamientos, técnicas de golpeo, puñetazos, patadas, defensas y posturas defensivas. El quinto capítulo explica brevemente la ejecución de las técnicas contenidas en las formas tenchiken dai-ikkei, giwaken dai-ikkei y ryuoken dai-ikkei junto con su secuencia fotográfica. El sexto capítulo muestra la ejecución de las principales técnicas hokei del shorinji kempo junto con una breve explicación además de presentar el examen de $3^{\circ}$ kyu. Adjunta un glosario específico, bibliografía e índice alfabético de técnicas hokei.

1108. Casero Abellán, Rogelio (2000). Shorinji kempo : el legado del Shaolín. Técnicas avanzadas. Granada: Dojo Sport. 1a ed. 225 p. : il. ; 17x23,5 cm. ISBN: 84-607-0318-5. Depósito legal: GR. 86-2000. Palabras clave: formas, fundamentos teóricos, fundamentos técnicos, principios técnicos, aplicación terapéutica, exámenes. Resumen: Manual teórico y técnico de shorinji kempo. El libro esta compuesto por 19 capítulos precedidos por los agradecimientos, un prólogo que comenta los contenidos del libro y la narración del aprendizaje de So Doshin en China. El primer capítulo enumera los contenidos técnicos para el $2^{\circ}$ kyu mientras que el segundo explica los fundamentos teóricos para el $2^{\circ}$ kyu como son los objetivos del shorinji kempo, los principios del entrenamiento, las etapas en el aprendizaje del kempo y detalla sus principios técnicos y morales. Los siguientes cuatro capítulos describen la ejecución de las bases, formas de ejecución individual, técnicas hokei y los contenidos del examen para $2^{\mathrm{o}}$ kyu acompañados de sus ilustraciones explicativas. El séptimo capítulo enumera los contenidos técnicos para el 1er kyu. El octavo capítulo explica los fundamentos teóricos para 1er kyu como son los principios de duro y blando, los fundamentos de la práctica en pareja, el sistema de grados, el estudio de la distancia y la oportunidad en el combate, los cinco elementos del atemi, las partes utilizadas para golpear, los elementos clave de los desplazamientos, el verdadero significado del hokei y el randori. Los siguientes cuatro capítulos presentan la descripción e ilustración de la ejecución de las bases, formas de ejecución individual, formas de ejecución en pareja, técnicas hokei y los contenidos del examen para 1er kyu. El décimo tercer capítulo enumera los contenidos técnicos para el 1er dan. El décimo cuarto capítulo explica los fundamentos teóricos para 1er dan como son los objetivos del kongo 
zen y los tipos de iniciativa en el combate. Los siguientes cuatro capítulos explica la ejecución de las bases, formas de ejecución individual, formas de ejecución en pareja, técnicas hokei y los contenidos del examen para 1er dan junto con sus ilustraciones explicativas. El último capítulo explica los principios del método terapéutico seiho, su forma de exploración, la descripción e ilustración de sus ejercicios de relajación y presenta el esquema de contenidos técnicos hasta 1er dan. Adjunta un esquema general de las técnicas hokei hasta $1^{10}$ dan, bibliografía y un índice alfabético de técnicas hokei.

1109. Cave, Eddie (2002). Kick boxing : guía básica para conocer este arte marcial. Arganda del Rey: Edimat. $1^{\underline{a}}$ ed. 96 p. : il. ; 20x27 cm. ISBN: 84-9764-136-1. Depósito legal: no. Palabras clave: fundamentos técnicos, defensa personal, competición. Resumen: Manual histórico y técnico de kickboxing. La monografía esta dividida en 5 capítulos. Comienza narrando la evolución del kickboxing y su expansión por Europa, así como su desarrollo histórico y los beneficios que reporta, sobre todo a las mujeres. El segundo capítulo describe los fundamentos técnicos del kickboxing, como es la guardia, el juego de pies y la distancia, así como la ejecución técnica de los principales golpes de puño, los ganchos, la combinación de golpes de puño, las defensas, las patadas, los golpes de rodilla y de codo, los barridos, y las combinaciones de golpes y patadas. En el tercer capítulo incluye ejercicios de acondicionamiento físico general para el kickboxer, consejos alimenticios, mentales y de la práctica con sparring para afrontar el entrenamiento. El cuarto capítulo describe las diferentes disciplinas que existen de kickboxing, junto con sus reglas, equipación, tácticas en el combate y la preparación del examen de grado. Finaliza con algunas situaciones de defensa personal contra uno o varios atacantes y contra distintas armas. Adjunta glosario, listado de contactos y créditos.

1110. Di Marino, Stefano (2003). Lecciones de kickboxing. Barcelona: De Vecchi. $1^{a}$ ed. 109 p. : il. ; 17x24 cm. ISBN: 84-315-2948-2. Depósito legal: B. 17639-2003. (2 $2^{\mathrm{a}}$ ed., 2009). Palabras clave: historia, fundamentos teóricos, fundamentos técnicos, ejercicios. Resumen: Manual teórico y técnico de kickboxing. La obra esta dividida en 8 capítulos. El primer capítulo comenta la práctica del kickboxing desde el punto de vista marcial y deportivo, su evolución histórica y la indumentaria y equipo para su práctica. El segundo capítulo expone los principios del calentamiento y describe la ejecución de diversos ejercicios de calentamiento para todo el cuerpo junto con sus ilustraciones. El tercer capítulo explica los principios técnicos del kickboxing, las características técnicas de la posición de guardia y los desplazamientos acompañados de varias ilustraciones y la descripción de un ejercicio preparatorio y el significado del saludo. El cuarto capítulo comenta las características y principios de los fundamentos técnicos del kickboxing para luego describir e ilustrar las principales técnicas de brazo, las técnicas de patada y dos ejercicios para mejorar la técnica de las patadas. El quinto capítulo expone los principios técnicos y tácticos de la defensa y describe las características de los bloqueos, fintas y coberturas junto con la explicación de la ejecución técnica e ilustración de varias técnicas y un ejercicio complementario. El sexto capítulo comenta el proceso de aprendizaje del kickboxing y el papel del entrenador, los guantes de entrenamiento y los paos en dicho proceso, incluyendo la descripción e ilustración de un ejercicio con compañero y guantes y dos tablas o programas de entrenamiento. El siguiente capítulo explica el desarrollo de la competición de kickboxing y presenta la ejecución de once ejercicios de combinaciones de técnicas de puño junto con sus ilustraciones. El último capítulo describe la ejecución de 4 ejercicios de combinaciones de piernas y 18 ejercicios de combinaciones de patadas y puñetazos. Adjunta una conclusión final con consejos para la evolución en el kickboxing.

1111. Falsoni, Ennio (1994). Kickboxing : curso de full-contact. Barcelona: De Vecchi. 1aㅡ ed. 156 p. : il. ; $17 \times 24$ cm. ISBN: 84-315-1346-2. Depósito legal: B. 39912-1994. (2ª ed., 1998). Palabras clave: historia, fundamentos técnicos, ejercicios, entrenamiento, planificación del entrenamiento, preparación física, reglamentos. Resumen: Manual teórico y técnico de full-contact. La obra esta compuesta de 17 capítulos. La introducción relata el origen del full-contact como evolución del kárate, los primeros campeones de la disciplina y su llegada a Europa. El primer capítulo describe los aspectos fundamentos de la preparación física del deportista junto con los principales ejercicios de acondicionamiento físico general y de movilidad articular tanto individuales como por parejas, acompañados de sus ilustraciones. Los tres siguientes capítulos presentan los fundamentos técnicos del full-contact, describiendo e ilustrando la ejecución de la guardia fundamental, las principales patadas (frontal, lateral, circular, de gancho, directa desde atrás y desde atrás con gancho en el aire), las técnicas de puño (directo de izquierda, directo de derecha, gancho y ascendente) y las defensas (esquivar con el tronco, bloquear y desvíos) así como su aplicación ante diferentes situaciones y sus principios técnicos. El siguiente capítulo describe distintas acciones técnicas básicas del trabajo por parejas para continuar con el trabajo de los contraataques, las técnicas combinadas y las fintas, incluyendo la ilustración de cada acción. Los tres siguientes capítulos describen los métodos de entrenamiento más habituales como son el shadow kickboxing, el combate vinculado y el combate libre, exponiendo sus principios y reglas. A continuación detalla el entrenamiento con las manoplas, el entrenamiento con pesas y con el saco, proponiendo algunas rutinas y ejercicios ilustrados. Los últimos cuatro capítulos comentan las peculiaridades del combate dentro del cuadrilátero, la preparación mental que debe acompañar al 
luchador, presenta una programación de los contenidos técnicos en distintos niveles y desarrolla el reglamento de competición de kickboxing.

1112. Fraguas, José María y García Soldado, Ángel (1987). Kajukenbo : el arte de defensa personal de las islas Hawai. Madrid: Esteban Sanz Martínez. 1aㅡ ed. 168 p. : il. ; 15x21 cm. ISBN: 84-85977-34-3. Depósito legal: M. 15346-1987. Palabras clave: historia, defensa personal, maestros, fundamentos técnicos. Resumen: Manual teórico y técnico de kajukenbo. El libro esta compuesto de 15 capítulos. El primer capítulo presenta la historia el fundador del kajukenbo, Adriano D. Emperado, una entrevista, y la ilustración y explicación de dos técnicas por parte del fundador. Continua explicando el significado del término gung fu y recopila distintas fotografías del kajukenbo en España. El cuarto capítulo explica el significado del emblema del kajukenbo y prosigue con la enumeración de las reglas y normas en el arte del kajukenbo. Los dos siguientes capítulos ilustran el saludo y el ritual de colocación del cinturón en partes así como los diferentes desplazamientos y sus esquemas de movimiento. El octavo capítulo presenta gráficamente varias técnicas contra distintos agarres y continúa con la secuencia fotográfica de la primera forma básica. El décimo capítulo presenta algunas de las técnicas del kajukenbo contra ataques de puño. El siguiente capítulo presenta la secuencia fotográfica de la forma intermedia, y continua con distintas técnicas contra ataques de bastón. El capítulo decimotercero incluye la secuencia fotográfica de la forma naihanchin $\mathrm{n}$ o 1 , para finalizar con la ilustración de varias técnicas de defensa contra ataques con cuchillo y contra tres adversarios.

1113. García Soldado, Ángel (1996). Kajukenbo. Madrid: Eyras. 1aㅡ ed. 159 p. : il. ; $15 \times 24$ cm. ISBN: 84-8526982-9. Depósito legal: M. 19401-1996. Palabras clave: historia, maestros, fundamentos técnicos. Resumen: Manual teórico y técnico de kajukenbo. El libro esta compuesto de 25 capítulos, con los 13 primeros bajo una orientación teórica. Dichos capítulos narran la historia y evolución del kajukenbo así como la biografía y aportaciones de las personas más influyentes sobre el arte, esto es, Kensu Yabu y Choki Motobu, James Mitose, Adriano Directo Emperado, Clarence Chang, Woodrow McCandless, Brother Abe Kamahoahoa, Ella Emperado Baniaga, Leone Manini Cuarisma, Sid Asunción, Marino Tiwanak, León "Manini" Cuarisma, Joseph Halbuna, Aleju "Al" Reyes, Tony Ramos, Charles Gaylord, Carlos Bunda, Ángel García Casado; y la línea de introducción del kajukenbo en España junto con un amplio repertorio gráfico de todas estas personas. Los siguientes capítulos estudian los aspectos técnicos del arte, comenzando con la presentación del reglamento K.S.D.I., los principios básicos de los golpes y su ejecución, la ilustración de los desplazamientos, y la descripción e ilustración de algunas de las técnicas de kajukenbo agrupadas bajo distintos alfabetos y según sus profesores.

1114. González López, Luis (1987). El libro del cinturón negro : kenpo karate. Madrid: Esteban Sanz Martínez. $1^{\text {a }}$ ed. 248 p. : il. ; 15x21 cm. ISBN: 84-85977-37-8. Depósito legal: M. 18558-1987. Palabras clave: historia, fundamentos técnicos, defensa personal, kárate, reglamentos. Resumen: Manual técnico de kenpo. Después de hacer una introducción sobre las razones por las que el practicante se acerca a las artes marciales y cuales son sus objetivos, comienza en el tercer capítulo con una síntesis técnica e histórica del kenpo, relatando su expansión así como destacando los elementos técnicos y mentales característicos de esta arte marcial y la secuencia de contenidos hasta cinturón negro. El cuarto capítulo estudia el saludo y los símbolos que rodean a este arte para luego pasar a la descripción e ilustración de 30 técnicas de defensa personal del kenpo karate. El siguiente capítulo recopila los principios de técnicos aplicables al kenpo para continuar con algunos consejos prácticos a seguir en las situaciones de defensa personal. El último capítulo enumera a los pioneros del kenpo karate en España. Adjunta información sobre el autor y dos apéndices, el primero dedicado a enumerar y comentar algunos criterios para mejorar el entrenamiento en artes marciales; y el segundo que incluye la normativa de examen para cinturón negro de kenpo.

1115. Gutiérrez, Raúl y Hernández Beltrán, Sergio (2007). Kosho-ryu fu-shih kenpo : la primera ley del puño. Madrid: s.n. 1a ed. 398 p. : il. ; 22x30 cm. ISBN: 978-84-611-6383-0. Depósito legal: M. 16423-2007. Palabras clave: katas, fundamentos técnicos, principios técnicos, principios filosóficos, combate, biografía, entrevistas, maestros, meditación. Resumen: Manual teórico y técnico de kenpo kárate. La obra esta formada por 11 capítulos ampliamente ilustrados precedidos por el prólogo, los agradecimientos, el currículo del co-autor y varias introducciones. El primer capítulo explica el origen del kenpo, comenta sus características y contenidos técnicos. El segundo capítulo expone las biografías de James Masayoshi Mitose y Thomas Barro Mitose, narra la introducción del kenpo en España, comenta el currículo filmográfico del autor acompañado de numerosas fotografías y presenta el programa de contenidos del sistema fu-shih kenpo. El tercer capítulo detalla los principios del kosho shorei-ryu kenpo, su sistema de grados, explica el significado de su emblema y discute la historia de los grados y los diferentes sistemas. El cuarto capítulo incluye las entrevistas realizadas a Arnold M. Golub, Bruce Juchnik y Bob Rose. El quinto capítulo explica la biografía de Choki Motobu y analiza su posible relación con James Mitose. El sexto capítulo narra los contactos del autor con Ed Parker, Jay T. Will, Jeff Speakman e incluye un comentario sobre la práctica marcial de Elvis Presley. El séptimo capítulo explica el origen del fu-shih kenpo, el significado de su emblema, sus fundamentos teóricos, principios técnicos y filosóficos. El octavo capítulo describe cómo practicar la meditación zazen. El noveno 
capítulo explica el significado y tipos de katas para luego presentar los movimientos y secuencia fotográfica del saludo del fu-shih kempo y las katas dachi, nejo-buto-nidan, saru-buto-shodan, puntos vitales y naihanchi junto con una tabla de las katas de cada estilo de kárate y kenpo. El décimo capítulo expone las características, ventajas y desventajas de las diferentes prácticas de combate del kárate y el kenpo junto con la interpretación del combate del nihon kenpo. El último capítulo describe e ilustra varias series técnicas de kosho-ryu y fu-shih kenpo. Adjunta seis apéndices con el listado de principales estilo de kenpo, una carta de Adriano Emperado, la terminología utilizada en el kenpo, el programa oficial de kosho shorei ryu fu shih kenpo, un comentario sobre el iai-do y las fuentes de información consultadas.

1116. Gutiérrez, Raúl (1979). Kenpo karate : una filosofía y yo. Historia, principios y técnicas del karate chino. Barcelona: Alas. 1aa ed. 126 p. : il. ; 15x21,5 cm. ISBN: No ISBN. Depósito legal: no. (2ª ed., 1983, ISBN: 84-203-0083-7; 3a ed., 1987, ISBN: 84-203-0083-7). Palabras clave: katas, kumite, historia, fundamentos teóricos, fundamentos técnicos, defensa personal, entrenamiento, fundamentos filosóficos, astrología. Resumen: Manual teórico y técnico de kenpo kárate. El libro esta compuesto por 18 capítulos, precedidos por un prefacio que comenta los objetivos perseguidos por la obra, una introducción del autor que detalla su currículum profesional y unas notas aclaratorias sobre el título, portada y contenido de la obra. El primer capítulo narra la historia del kárate y la creación del kenpo karate. El segundo capítulo explica en qué consiste el kenpo karate mientras que el tercero detalla sus principios técnicos y de entrenamiento. Los siguientes tres capítulos describen la forma de saludar, cómo atarse el cinturón y algunos ejercicios de calentamiento acompañados de su representación gráfica. El séptimo capítulo explica brevemente la ejecución de las posiciones básicas del kenpo karate junto con su ilustración, para continuar con los golpes de puño, las patadas y los blocajes. El décimo primer capítulo comenta el origen de las katas, su significado, ofrece 15 consejos para su correcta ejecución, y describe la ejecución de la kata "te no ugoki" acompañada de su secuencia fotográfica. El décimo segundo capítulo explica el sistema de grados, tiempo de permanencia y examen para cada cinturón. Los siguientes tres capítulos analizan la figura del sensei, el significado e importancia del hara, el ki y el kiai, así como un comentario sobre el significado de cada animal del horóscopo chino. Los últimos tres capítulos describen e ilustran distintas técnicas de defensa personal en aplicación del kihon-kumite, las características del trabajo de combate libre, los principios técnicos en el arte de golpear, la descripción e ilustración de algunas técnicas de competición y de defensa personal femenina.

1117. Gutiérrez, Raúl (1985). Kenpo karate : (kosho-shorei ryu kenpo). Madrid: Esteban Sanz Martínez. 1a ed. 247 p. : il. ; 15x21 cm. ISBN: 84-85977-23-8. Depósito legal: M. 18517-1985. Palabras clave: historia, fundamentos técnicos, defensa personal. Resumen: Manual teórico y técnico de kenpo kárate. La obra esta compuesta por 22 capítulos, precedidos por un prólogo que además sirve de introducción a los contenidos del libro. Los dos primeros capítulos relatan la historia del kenpo, sus instructores y su introductor en las islas hawaianas, incluyendo numerosas fotografías. El tercer capítulo describe la filosofía de esta práctica para después explicar el significado del emblema Kosho-Shorei Ryu Kenpo. El quinto capítulo presenta una carta en la que se explica la evolución del sistema kenpo kárate y luego detalla el sistema de grados, presenta ilustraciones sobre las guardias, las posturas más comunes y las armas del sistema. El sexto capítulo narra la historia de las katas, su significado y algunos consejos prácticos para su correcta ejecución. Los dos siguientes capítulos, ilustran las katas neko-buto-shodan y neko-buto-geri, incluyendo las aplicaciones prácticas de cada uno de sus movimientos. Continua con la presentación del conjunto de katas naihanchi (tekki), desde su historia, significado y principios técnicos, hasta la ilustración de los movimientos de las katas naihanchi shodan, naihanchi, nidan y naihanchi sandan. De la misma manera, los siguientes capítulos introducen y presentan las katas enpi no kata, saru-buto-shodan, saru-buto-nidan, saru-buto-sandan y sus respectivas aplicaciones, además del esquema y dibujos de saru-buto-yodan. Los tres últimos capítulos describen el significado de la aplicación a las situaciones de defensa personal del kenpo kárate e ilustra distintas técnicas contra ataques con y sin arma del sistema kenpo y kenpo fu-shih.

1118. Gutiérrez, Raúl (1985). Kenpo karate fu-shih : para la defensa personal policial y agentes seguridad. Barcelona: Alas. $1^{\mathrm{a}}$ ed. 128 p. : il. ; 15x21,5 cm. ISBN: 84-203-0177-9. Depósito legal: B. 16926-1985. (2a ed., 1987). Palabras clave: fundamentos teóricos, táctica, fundamentos técnicos, principios técnicos, defensa personal, ejercicios, capacidades físicas, armas. Resumen: Manual teórico y técnico de kenpo kárate. La obra esta formada por 16 capítulos precedidos por un prólogo que señala los contenidos de la obra y la preparación profesional del autor además de un breve comentario de su biografía. El primer capítulo enumera y representa las principales armas naturales del cuerpo humano para luego describir la situación actual de violencia, el papel de los cuerpos de seguridad y definir el término defensa policial, su práctica y riesgos. El segundo capítulo incluye el programa de contenidos de la Asociación Española de Kárate y artes Marciales mientras que el tercero describe un programa de ejercicios de flexibilidad. El cuarto capítulo expone las recomendaciones prácticas para el esposamiento o cacheo de un sospechoso. El quinto capítulo muestra los ángulos de equilibrio. El sexto 
capítulo enumera e ilustra distintas armas ocultas y camufladas. El séptimo capítulo describe la ejecución de las técnicas básicas de defensa personal, los principios de actuación ante distintos ataques, la defensa personal femenina y el entrenamiento con armas. Los dos siguientes capítulos presentan la ejecución e ilustración de dos técnicas de defensa personal ante un agarre de solapa. El décimo capítulo localiza los puntos vitales del cuerpo humano mientras que el siguiente incluye la descripción de las 10 técnicas de defensa personal según el programa kenpo-karate Fu Shih acompañadas de su secuencia fotográfica. Los cuatro últimos capítulos describen brevemente diversas técnicas de defensa personal ante técnicas de retención del y contra el arma, agarres, puñetazos y patadas, y defensas con el bastón.

1119. Gutiérrez, Raúl (1986). Full-contact : todo sobre el sistema de Bill Wallace. Madrid: Esteban Sanz Martínez. 1 a ed. 258 p. : il. ; 15x21 cm. ISBN: 84-85977-31-9. Depósito legal: M. 14519-1986. Palabras clave: historia, fundamentos teóricos, táctica, fundamentos técnicos, principios técnicos, ejercicios, entrenamiento, anatomía, entrevistas, preparación física, reglamentos. Resumen: Manual teórico y técnico de full-contact. El libro esta formado por 33 capítulos precedidos por un prólogo que analiza el origen y situación actual del full-contact y el currículo del autor. El primer capítulo presenta la figura de Bill Wallace mientras que el segundo explica el trabajo realizado para componer este libro. El tercer capítulo narra el encuentro entre el autor y Bill Wallace. El cuarto capítulo incluye numerosas fotografías del autor y su carrera profesional. El quinto capítulo describe la anatomía y fisiología de los principales grupos musculares para luego explicar la ejecución de numerosos ejercicios de calentamiento y acondicionamiento físico para todo el cuerpo, detallando sus beneficios fisiológicos y para las artes marciales así como las principales observaciones. Los siguientes ocho capítulos exponen la utilización de las técnicas de mano, patadas y métodos de entrenamiento de Bill Wallace acompañadas de numerosas ilustraciones explicativas. Los siguientes cinco capítulos definen los conceptos de flexibilidad, elasticidad y elongación, y explican los principios técnicos de su entrenamiento junto con algunas consejos prácticos. El décimo noveno capítulo incluye una mesa redonda sobre elasticidad junto con diversas fotografías de los métodos de entrenamiento de la flexibilidad de Bill Wallace. Los siguientes cinco capítulos definen los términos de resistencia, endurecimiento, velocidad, potencia y tipos de musculación, comentan sus objetivos y métodos de entrenamiento acompañados de algunas fotografías del curso impartido por Bill Wallace en Madrid. El siguiente capítulo incluye la entrevista realizada por Adolfo Pérez a Bill Wallace a su llegada a España. Los siguientes tres capítulos presentan un comentario sobre el seminario impartido por Wallace en España junto con distintas fotografías de Wallace realizando técnicas de puño y pierna en varios entrenamientos y campeonatos. El vigésimo noveno capítulo expone el reglamento de competición de la Asociación Española de Kárate y Artes Marciales S.U.S.K.A. El siguiente capítulo incluye un ensayo del autor sobre la competición de full-contact y algunas de sus secuencias técnicas. Los tres últimos capítulos exponen los principios técnicos y tácticos de las patadas de Bill Wallace además de las secuencias fotográficas de Bill Wallace y el autor realizando series en combinación de patadas.

1120. Gutiérrez, Raúl (1986). Kenpo karate : cinco katas fundamentales y sus aplicaciones. Barcelona: Alas. 1a ed. 128 p. : il. ; 15x21 cm. ISBN: 84-203-0199-X. Depósito legal: B. 30552-1986. Palabras clave: katas, historia, cortesía, aplicación marcial. Resumen: Manual teórico y técnico de kenpo kárate. El libro esta formado por 12 capítulos precedidos por los agradecimientos, el currículo del autor y un prólogo que resume los contenidos del libro. El primer capítulo relata el origen del kenpo kárate y su desarrollo. El segundo capítulo explica en qué consiste el kenpo y cuáles son sus características técnicas. El tercer capítulo comenta el significado de las katas junto con una breve explicación de las características de las katas presentadas. El cuarto capítulo detalla el significado del saludo y de los movimientos de las manos tanto en las artes marciales como en el kenpo karate, además de incluir la descripción de su ejecución. El quinto capítulo nombra e ilustra las posiciones fundamentales para luego presentar las patadas y maniobras de pie más comunes. Los siguientes cinco capítulos incluyen la descripción y secuencia fotográfica de la ejecución de las katas 3 a forma corta, formas bloqueos, finger set o puntos vitales, forma cuchillos y forma del tigre, incluyendo la representación de la aplicación marcial de sus técnicas más importantes. El último capítulo explica el significado del emblema de la IKKA. Adjunta un apéndice que comenta la labor profesional del autor.

1121. Iborra Montells, Antonio (2002). Yug-do, el arte marcial del bambú. Barcelona: Océano Ambar. $1^{\text {a }}$ ed. 189 p. : il. ; $17 \times 24$ cm. ISBN: 84-7556-133-0. Depósito legal: B. 42032-XLIV. Palabras clave: fundamentos teóricos. Resumen: Manual teórico de yug-do. La obra esta dividida en 3 partes, cada una de ellas explicando las características del bambú y su aplicación sobre el cuerpo, la mente y el espíritu.

1122. Iglesias, Alejandro (2009). Mixed martial arts : shoot. La autodefensa del siglo XXI. Madrid: Budo International. 1aㅡ ed. 175 p. : il. ; 17x24 cm. ISBN: 978-84-92484-35-5. Depósito legal: M. 16754-2009. Palabras clave: historia, fundamentos técnicos, programa técnico. Resumen: Manual teórico y técnico de artes marciales mixtas. El libro esta formado por 23 capítulos precedidos por dos prólogos que comentan la creación del sistema shoot y señala el papel del autor en dicha creación, y un prefacio que resume los contenidos del libro. El primer capítulo narra la historia y evolución del sistema shoot 
mientras que el segundo presenta su programa técnico. El tercer capítulo comenta la aplicación del método científico para la creación del sistema shoot y las ventajas de las nuevas tecnologías para dedicarse a la enseñanza de las artes marciales. El cuarto capítulo incluye las opiniones de distintos practicantes sobre el entrenamiento de shoot. El quinto capítulo compara las técnicas de las low kick. El sexto capítulo comenta la utilización de las paredes para realizar una proyección del oponente. El séptimo capítulo señala los detalles ofensivos y defensivos de la posición mediomontada. El octavo capítulo expone las ventajas de la técnica de escapa denominada "la pala" además de describir e ilustrar su ejecución técnica. Los dos siguientes capítulos comentan la utilidad de las técnicas "el garfio" y "el agarre cruzado" además de incluir la descripción de su ejecución acompañada de su secuencia fotográfica. Los dos siguientes capítulos explican la ejecución de la estrangulación simple y la estrangulación 68 junto con sus ilustraciones explicativas. El resto de capítulos incluyen la secuencia fotográfica de la ejecución de diversas técnicas desde las posiciones de guardia ofensiva, guardia defensiva, medio montada, cruzada, montada, en línea, la espalda, el clinch y desde la posición de llaves de pierna.

1123. Lee, Sam (1998). Full contact. Arganda del Rey: Edimat. $1^{a}$ ed. 189 p. : il. ; $13 \times 21$ cm. ISBN: 84-8403058-X. Depósito legal: M: 16379-1998. Palabras clave: fundamentos técnicos, principios técnicos, ejercicios, entrenamiento, kyusho, anatomía, capacidades físicas, competición, dopaje, fisiología, musculación, nutrición. Resumen: Manual teórico y técnico de full contact. El libro esta formado por 36 capítulos precedidos por una presentación que comenta las características del full contact y los agradecimientos. El primer capítulo expone las dificultades de un peleador frente a un combate. El segundo capítulo ofrece algunos consejos prácticos para el entrenamiento y el combate. El tercer capítulo describe la ejecución de los golpes de puño acompañadas de su representación gráfica y esquemas de movimiento, mientras que el cuarto expone sus principios técnicos. El quinto capítulo enumera los principios para progresar en el entrenamiento. El sexto capítulo localiza los puntos vitales del full contact. El séptimo capítulo describe la anatomía y fisiología del sistema muscular. El octavo capítulo comenta la composición y efectos de las anfetaminas y la marihuana. El noveno capítulo ofrece distintos consejos prácticos para evitar el cansancio durante el combate mientras que el décimo presenta algunos trucos para despistar al adversario. Los dos siguientes capítulos comentan los efectos del entrenamiento de fuerza y explica algunos de sus métodos. El capítulo decimotercero expone las generalidades de los distintos modos de entrenamiento. El decimocuarto capítulo describe e ilustra algunos errores técnicos frecuentes en los combates. El decimoquinto capítulo describe la función de las proteínas, desmiente algunas falsedades y comenta su presencia en los alimentos. El decimosexto capítulo detalla la función de la grasa y ofrece algunos consejos dietéticos. El decimoséptimo capítulo describe los efectos de la carencia de algunas vitaminas. El decimoctavo capítulo ofrece diversos consejos prácticos para relajar la musculatura durante los combates. El decimonoveno capítulo describe e ilustra distintos ejercicios de flexibilidad y musculación para el entrenamiento de las patadas. Los dos siguientes capítulos presentan la descripción e ilustración de numerosos ejercicios de musculación para todo el cuerpo. El vigésimo segundo capítulo incluye distintos ejercicios para mejorar la elasticidad corporal acompañados de su representación gráfica. El vigésimo tercer capítulo enumera a los campeones del mundo EPKA de 1985, mientras que los siguientes 13 capítulos incluyen diversas fotografías y comentarios de Dominique Valera, Dan Macaruso, Jeft Smith, Jean Yves Thériault, Zènaf, Bill Wallace, Roger Paschi, Fred Rogers, Benny Urquídez, Don Wilson, Joe Lewis, Ramón Gallego y Mariano Morante. Adjunta la ilustración de sus fundamentos técnicos durante todo el libro.

1124. Mahillo Monte, Javier (1988). Iniciación al kick-boxing : filosofía y técnica. Pamplona: Javier Mahillo Monte. $1^{a}$ ed. 30 p. : il. ; 15x20,5 cm. ISBN: 84-404-3234-8. Depósito legal: NA. 1298-1988. Palabras clave: historia, fundamentos técnicos. Resumen: Manual teórico y técnico de kick-boxing. La obra esta dividida en 3 partes. La primera parte relata la historia del muay-thai y la creación del kick-boxing, los objetivos de las artes marciales y la filosofía del practicante de artes marciales. La segunda parte clasifica las técnicas básicas del kick-boxing para luego definir, describir e ilustrar la posición de guardia, las principales técnicas defensivas, las técnicas de puño, las técnicas de pierna, los barridos y los desequilibrios. La última parte incluye la localización de las partes del cuerpo que se utilizan para golpear y los principales puntos vitales del cuerpo.

1125. Miguel Santos, Javier de y Escrig, Joaquín (1998). La ley del kenpo kenjukabo. Barcelona: Alas. 1a ed. 158 p. : il. ; 17x24 cm. ISBN: 84-203-0388-7. Depósito legal: B. 7395-1998. Palabras clave: katas, historia, fundamentos teóricos, fundamentos técnicos, principios técnicos, principios teóricos, principios filosóficos, defensa personal, kyusho, wushu, escuelas, armas. Resumen: Manual teórico y técnico de kenpo kárate. La obra esta formada por 6 capítulos precedidos por varios capítulos introductorios que comentan el origen del kenpo kárate en España, incluyen un homenaje al maestro Raúl Gutiérrez y una breve biografía de los autores, narran la historia del kenpo y el origen del kenjukabo, sus objetivos, el significado del término y su emblema, detallan las características técnicas de los cinco estilos originarios del pugilismo de shaolin, y describe los principios técnicos, teóricos y filosóficos del kenjukabo. El primer capítulo muestra el árbol genealógico del kenpo kenjukabo 
mientras que el segundo localiza los puntos vitales del cuerpo, representa las zonas utilizadas para golpear e ilustra las posiciones, desplazamientos, direcciones, bloqueos, esquivas, ataques de mano y pie, caídas, proyecciones, barridos y llaves de control básicos del kenjukabo acompañados de su clasificación. El tercer capítulo clasifica las técnicas del kenjukabo e incluye la secuencia fotográfica de diversas técnicas de defensa personal ante ataques de puño, con cuchillo, con palo, estrangulaciones, patadas y agarres. El cuarto capítulo explica el significado de las formas, la utilidad e importancia de los rompimientos, describe el acondicionamiento físico necesario, sus principios técnicos, las zonas corporales más utilizadas y la preparación de la prueba. El quinto capítulo describe los objetivos del calentamiento y los estiramientos además de ofrecer algunos consejos prácticos. El último capítulo incluye las direcciones y emblemas de las sedes de kenjukabo en España. Adjunta bibliografía recomendada.

1126. Mitose, James M. (1986). ¿Qué es la defensa personal? (kempo jiu-jitsu). Madrid: Esteban Sanz Martínez. $1^{\text {a }}$ ed. 109 p. : il. ; 15x21 cm. ISBN: 84-85977-32-7. Depósito legal: M. 22148-1986. Palabras clave: historia, fundamentos técnicos, defensa personal femenina, fundamentos filosóficos, genealogía, armas. Resumen: Manual teórico y técnico de kenpo jiu-jitsu. El libro esta compuesto por 2 partes precedidas por la presentación de la International Kosho-Shorei Association y una nota introductoria que señala el origen del kenpo. La primera parte consta de 20 capítulos. El primer capítulo narra la biografía de James M. Mitose. El segundo capítulo presenta el libro y sus objetivos. El tercer capítulo narra los acontecimientos más importantes de la kosho-shorei kenpo mientras que el cuatro ilustra su árbol genealógico. El quinto capítulo relata el origen y evolución del kenpo-karate en España mientras que el sexto recopila numerosas fotografías de dicho proceso. El séptimo capítulo incluye las cartas y certificados de Raúl Gutiérrez. Los dos siguientes capítulos presentan la carta de la kosho-shorei y la descripción de un seminario intensivo de entrenamiento. El décimo capítulo incluye la introducción de Arnold M. Golub a la edición inglesa de la obra. Los dos siguientes capítulos narran la historia de Daruma, presentan el escudo del kosho ryu kempo y su significado, describen la ejecución de su saludo. El décimo tercer capítulo detalla los objetivos del libro. Los siguientes tres capítulos explican en qué consiste el kempo jiu-jitsu, el go shinjutsu, el kenpo y sus ventajas. El décimo octavo capítulo relata varias historias sobre el kenpo para ilustrar sus fundamentos filosóficos. Los dos últimos capítulos incluyen varias fotografías de distintos maestros de kenpo y las cartas de agradecimiento recibidas por el autor. La segunda parte consta de 8 capítulos a modo de lecciones. El primer capítulo describe la ejecución de varios ejercicios de fortalecimiento de los puños para continuar con las patadas, incluyendo su representación gráfica. Los tres siguientes capítulos explican la ejecución de varias técnicas de defensa ante golpes, patadas, agarres y estrangulaciones acompañadas de sus secuencias fotográficas. El sexto capítulo presenta la descripción e ilustración de varias defensas ante diversos ataques finalizando con una llave, golpe o proyección. El séptimo capítulo detalla la ejecución técnica de distintas defensas ante los ataques armados con cuchillo, espada, palo y pistola incluyendo su representación gráfica. El último capítulo presenta algunas técnicas de defensa personal específicas para la mujer ante agarres, abrazos, ataques con cuchillo y pistola acompañadas de su secuencia fotográfica.

1127. Pérez Agustí, Adolfo (1986). El libro de oro del full contact. Madrid: Adolfo Pérez Agustí. $1^{a}$ ed. 180 p. : il. ; 16x22 cm. ISBN: 84-398-5701-2. Depósito legal: M. 1734-1986. Palabras clave: fundamentos técnicos, ejercicios, entrenamiento, capacidades físicas, dopaje, musculación, nutrición, sistemas de entrenamiento. Resumen: Manual teórico y técnico de full contact. El libro esta formado por 23 capítulos precedidos por una presentación que comenta las características generales del full contact e intercalados por la descripción y secuencia fotográfica de los fundamentos técnicos del full contact. El primer capítulo señala las dificultades del practicante de full contact. Los siguientes tres capítulos describe las características del entrenamiento técnico, cómo ejecutar un golpe de puño y cómo corregir la pegada acompañados de su representación gráfica. El quinto capítulo comenta el entrenamiento de las habilidades de combate junto con la secuencia fotográfica de algunas técnicas. El sexto capítulo localiza los principales puntos vulnerables del cuerpo humano. El séptimo capítulo explica brevemente el funcionamiento del sistema muscular. El octavo capítulo comenta los efectos de algunas drogas. Los dos siguientes capítulos detallan como combatir el cansancio en un combate y algunas tácticas de engaño. El capítulo decimoprimero expone algunos métodos y ejercicios para mejorar la fuerza, mientras que el siguiente propone diversos métodos de entrenamiento de la resistencia. El capítulo decimotercero comenta los principales errores técnicos junto con su representación gráfica. Los siguientes tres capítulos informan sobre las características de las proteínas, la importancia de la grasa y las carencias vitamínicas. El decimoséptimo capítulo ofrece algunos consejos prácticos para relajar la musculatura durante el combate. Los siguientes tres capítulos proponen algunos ejercicios de entrenamiento de las patadas, ejercicios de musculación con aparatos y otras formas de musculación acompañadas de sus ilustraciones explicativas. El vigésimo segundo capítulo incluye la descripción e ilustración de distintos ejercicios de flexibilidad mientras que el último capítulo presenta varias fotografías de los campeones del mundo EPKA de 1985. 
1128. Perreca, Giorgio y Malori, Daniele (1999). Kick boxing : preparación, técnicas, combate. Madrid: Tutor. $1{ }^{a}$ ed. 158 p. : il. ; $17 \times 24$ cm. ISBN: 84-7902-245-0. Depósito legal: M. 46664-1999. (2ª ed., 2003; $3^{\text {a }}$ ed., 2005). Palabras clave: historia, fundamentos técnicos, ejercicios, entrenamiento, capacidades físicas, táctica, equipamiento, nutrición. Resumen: Manual teórico y técnico de kick boxing. El libro esta formado por 6 partes, precedidas por una introducción que describe brevemente la historia del kick boxing. La primera parte describe los ejercicios preparatorios para el fortalecimiento de las tibias y los muslos antes de comenzar el entrenamiento técnico. La segunda parte explica los fundamentos técnicos de la posición de guardia y de las patadas a las piernas del adversario, ilustrando dichas técnicas. La tercera parte comenta brevemente la ejecución de los bloqueos, las amortiguaciones y cómo defenderse de una patada baja incluyendo fotografías explicativas. La cuarta parte explica el trabajo de estiramientos con la ilustración de numerosos ejercicios, describe los beneficios del trabajo con pao y saco, detalla como utilizar el saco y cuáles son las combinaciones técnicas más frecuentes, incluyendo la secuencia fotográfica de varias técnicas del trabajo con pao y con el saco. La quinta parte expone el comportamiento táctico ante un adversario más alto y más bajo para luego ilustrar las principales tácticas de defensa y contraataque por partes. La última parte explica la producción de energía por medio del metabolismo, el proceso de eliminación de toxinas, la estructura de los alimentos y las características de cada grupo alimenticio, para luego proponer los principios de un correcto plan dietético y exponer 3 tipos de dietas, además de incluir la tabla de valor nutricional de los alimentos. Adjunta bibliografía y fotografías de los autores.

1129. Perreca, Giorgio y Malori, Daniele (2000). Full contact : técnicas y preparación para el combate. Madrid: Tutor. $1^{a}$ ed. 167 p. : il. ; 17x24 cm. ISBN: 84-7902-246-9. Depósito legal: M. 47663-1999. (2aㅡㄹ. ed., 2002;

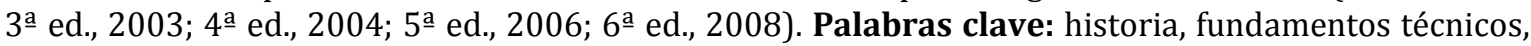
entrenamiento, cualidades físicas, instituciones, preparación física. Resumen: Manual teórico y técnico de full contact. La obra esta compuesta de 2 partes, precedidas de una introducción donde se narra la historia del full contact y la creación de sus instituciones, las cualidades psico-físicas del practicante, los grados y la carrera profesional. La primera parte detalla la preparación física del practicante, comenzando por la representación de los ejercicios de calentamiento, los diferentes métodos de entrenamiento de las cualidades físicas y programas de entrenamiento de las mismas. La segunda parte esta integrada por la preparación técnica, ilustrando las técnicas fundamentales del full contact, sus combinaciones y el entrenamiento con el maestro. Además incluye programas de entrenamiento con el pao y el punching ball, y breves comentarios sobre el entrenamiento endógeno, los traumatismos en el deporte, su prevención y tratamiento, y consejos dietéticos junto con varios menús orientativos.

1130. Prat Banús, José María (1983). Lua y kenpo. Artes marciales islas Hawaii. Barcelona: José María Prat Banús. $1^{a}$ ed. 250 p. : il. ; 15x21 cm. ISBN: 84-300-9546-2. Depósito legal: no.

1131. Seabourne, Tom (2000). Curso completo de cardiokickboxing : una forma segura y eficaz de llevar una vida sana y activa. Móstoles: Arkano Books. $1^{a}$ ed. 156 p. : il. ; 17x24 cm. ISBN: 84-89897-37-9. Depósito legal: M. 41089-2000. Palabras clave: fundamentos técnicos, entrenamiento, kickboxing. Resumen: Manual técnico y de entrenamiento en cardiokickboxing. El libro esta dividido en 16 capítulos. Comienza explicando algunas nociones antes de comenzar el entrenamiento como porqué practicar cardiokickboxing, cuales son las pautas generales antes de comenzar el entrenamiento, algunos consejos iniciales y la preparación de mente y cuerpo para comenzar un programa de entrenamiento. Los siguientes 6 capítulos describen e ilustran los ejercicios previos de estiramiento, las posiciones, los puñetazos y golpes, las patadas, los bloqueos y los desplazamientos específicos del cardiokickboxing. El noveno capítulo estudia la intensidad del ejercicio, cómo modificarla, algunos métodos para hacerlo y una nociones fisiológicas básicas sobre el ritmo cardiaco y el metabolismo. Continua con la explicación de los tipos de fibras musculares y la explicación de las contracciones y la potencia en los movimientos de cardiokickboxing. El capítulo decimoprimero ofrece un ejemplo de entrenamiento en casa ofreciendo algunos consejos prácticos para dicho entrenamiento que se suelen olvidar habitualmente y continua con ejemplos de combinaciones de técnicas, algunos ejercicios especiales y entrenamiento con sacos, todos ellos ilustrados. Los dos últimos capítulos profundizan en el entrenamiento del cardiokickboxing en cualquier lugar, algunos consejos prácticos generales e ideas que no se deben olvidar en la práctica, y en la prevención y tratamiento de las lesiones más frecuentes. Adjunta tres apéndices en los que se incluyen 3 programas de cardiokickboxing, algunas preguntas y respuestas sobre la práctica, y la enumeración de los músculos que intervienen en cada una de las técnicas. También adjunta un glosario.

1132. Vidal, Shihan (2009). Kenpo kai kihon keiko. s.l.: Shihan Vidal. 1aㅡ ed. 201 p. : il. ; 20x28 cm. ISBN: 97884-92428-12-0. Depósito legal: AB. 13-2009. Palabras clave: katas, fundamentos técnicos, principios técnicos, principios filosóficos, defensa personal, ejercicios, combate, entrenamiento, calentamiento, vestimenta, cortesía, competición, etiqueta, grados, reglamentos. Resumen: Manual teórico y técnico de kenpo kai. La obra esta dividida en 4 capítulos precedidos por una introducción que resume los contenidos de la obra. El primer capítulo relata el origen del kenpo kai y su llegada a Europa, la 
biografía de su presidente, sus objetivos, sus principios técnicos y filosóficos, los principios de su entrenamiento, explica el significado de su emblema, expone su sistema de grados, define el concepto de ki y estudia los tipos de kiai y su ejecución. El segundo capítulo presenta las normas de cortesía y etiqueta en el dojo, describe e ilustra la forma de colocarse el keikogi y el obi, las distintas formas de saludar y explica el ceremonial de comienzo y final de la clase. El tercer capítulo describe la ejecución de algunos ejercicios de calentamiento acompañados de su representación gráfica, destaca los principios técnicos de las técnicas de kihon, kihon no renshu y kihon dosa incluyendo la secuencia fotográfica de su ejecución, describe e ilustra la ejecución de dos katas, cuatro técnicas de juho, enumera los principios técnicos de los rompimientos junto con el entrenamiento necesario para el endurecimiento de las distintas partes del cuerpo, y localiza los puntos vitales y explica los efectos de su golpeo. La última parte comenta el desarrollo de una competición de kenpo kai además de incluir su reglamento. Adjunta apéndices con fotografías sobre las competiciones, algunas técnicas prohibidas, las técnicas que puntúan, la competición de katas, algunas técnicas de competición y vocabulario utilizado en kenpo kai.

\subsection{Miscelánea}

\subsubsection{Artes Marciales Chinas}

1133. Amador Mouchet, Enrique y Nong, Chong (2001). Taijiquan - qigong. Madrid: Enrique Amador y Chong Nong. 1 a ed. 78 p. : il. ; 16x20 cm. ISBN: 84-607-2133-7. Depósito legal: 14758-2001. Palabras clave: formas, historia, fundamentos teóricos, principios técnicos, ejercicios, qigong, cortesía, escuelas, respiración. Resumen: Manual teórico y técnico de taijiquan y qigong. La obra esta formada por 9 capítulos, precedidos por los agradecimientos y una breve biografía de los autores. El primer capítulo aclara algunos errores relacionados con los términos wushu, kung fu, taijiquan y qigong además de incluir un pequeño glosario. El segundo capítulo explica el significado de los términos qigong y qi, sus tipos y características. El tercer capítulo expone en qué consiste el taijiquan, su relación con las teorías del yin/yang y de los cinco elementos, narra sus orígenes y la fundación de los diferentes estilos, así como sus características comunes y su forma de popularización. El cuarto capítulo enumera los principios básicos para la práctica del taijiquan y el qigong. El quinto capítulo explica cómo debe hacerse la respiración. El sexto capítulo describe la ejecución del saludo y cuál es su significado. El séptimo capítulo describe las posiciones y formas de la mano básicas acompañadas de sus ilustraciones explicativas, mientras que el octavo capítulo explica la ejecución de diversos ejercicios de yangsheng qigong incluyendo su secuencia fotográfica. El último capítulo muestra la descripción y secuencia gráfica de la forma simplificada de 24 movimientos de taijiquan. Adjunta la dirección de contacto de la Escuela Wuhun y bibliografía.

1134. Blawyn, Elrond; Blawyn, Juliana; Blawyn, Sophia y Jones, Suzanne (1995). Ejercicios energéticos. Barcelona: Robinbook. 1a ed. 272 p. : il. ; 10x16 cm. ISBN: 84-7927-116-7. Depósito legal: B. 32551995. (2 ${ }^{a}$ ed., 2006, 251 p., ISBN: 84-7927-824-2). Palabras clave: qigong, fundamentos teóricos, fundamentos técnicos, ejercicios, yoga, meditación, personalidad. Resumen: Manual teórico y técnico de tai chi y qigong. La obra esta dividida en 3 partes, precedidas por una introducción que comenta los contenidos de la obra. La primera parte explica los conceptos de energía, respiración y chakras, describiendo sus tipos y algunos de sus ejercicios prácticos, comenta las ayudas internas y externas para la meditación, la técnica de visualización y algunas técnicas de meditación. La segunda parte expone las características de los sistemas de chi kung del dragón rojo, t'ai chi chi kung, t'ai chi con rodillo, los activadores de los chakras, la isometría india y el yoga incluyendo la descripción técnica de sus ejercicios y acompañados de su representación gráfica. La tercera parte ofrece una propuesta de programa diario de meditación, algunos ejercicios de estiramiento, expone los beneficios del ejercicio físico, detalla la relación entre el flujo de energía y la salud, y resalta la importancia del chakra del corazón para alcanzar el máximo crecimiento espiritual. Adjunta bibliografía.

1135. Calvo Caballero, Ángel (2003). Al hilo del tai-chi. Barcelona: Ángel Calvo Caballero. $1^{\mathrm{a}}$ ed. 126 p. : il. ; 14x21 cm. ISBN: No ISBN. Depósito legal: B. 39087-2003. Palabras clave: qigong, principios técnicos, ejercicios, taijiquan, personalidad, salud. Resumen: Manual teórico y técnico de artes marciales chinas. La obra esta formada por cuatro capítulos precedidos por un preámbulo que relata la formación marcial del autor, una introducción que describe la práctica del tai chi, y un comentario sobre los consejos prácticos para realizar los ejercicios mostrados en el libro. El primer capítulo analiza la importancia de la salud física y mental, la capacidad de transformación, el proceso de aprendizaje y el papel del cuerpo en dicho proceso además de describir distintos ejercicios para desarrollar estos aspectos. El segundo capítulo comenta los beneficios de la relajación y atención mental, la relación cuerpo-mente y el concepto de energía, incluyendo distintos ejercicios de chikung. El tercer capítulo explica en qué consiste la práctica del tai chi, sus objetivos y sus principios técnicos describiendo 
algunos de sus ejercicios. El último capítulo expone los beneficios del tai chi y el chikung, ofrece algunos consejos dietéticos y analiza el comportamiento humano desde los parámetros del placer y la voluntad.

1136. Canneti, Rafael (2008). Energía vital en el hombre : yoga, tai-chi, chi-kung, meditación. Fuenlabrada: Entrelíneas. 1aㅡ ed. 100 p. : il. ; 14x21 cm. ISBN: 978-84-9802-838-6. Depósito legal: M. 57438-2008. Palabras clave: fundamentos teóricos, fundamentos técnicos, ejercicios, fundamentos filosóficos. Resumen: Manual teórico y técnico de artes marciales chinas. El libro esta dividido en cuatro partes precedidas por una introducción que comentan las características y beneficios para la salud de las técnicas presentadas en la obra. La primera parte narra los antecedentes del yoga, define su práctica, comenta los requisitos para la práctica, describe varias asanas acompañadas de sus respectivas ilustraciones, comenta el concepto de energía vital, de serpiente kundalini y compara la interpretación de la energía en China e India. La segunda parte explica en qué consiste el tai chi chuan, cuáles son sus fundamentos teóricos, narra su historia, explica el empleo de la respiración en la práctica, ofrece algunas recomendaciones generales para la práctica de sus ejercicios, explica sus principios técnicos, expone sus fundamentos filosóficos y describe la ejecución de varias posturas acompañadas de su representación gráfica. La tercera parte detalla la práctica del chikung, comenta sus beneficios para la salud, explica sus fundamentos teóricos, describe la ejecución de varios de sus ejercicios junto con su ilustración explicativa y analiza la simbología relacionada con la energía vital. La cuarta parte expone las características de la meditación, ofrece algunas recomendaciones para su práctica y describe las dos primeras fases para comenzar con su práctica. Adjunta un glosario de términos específicos.

1137. Chia, Mantak y Li, Juan (1997). La estructura interna del tai chi : tai chi chi kung I. Málaga: Sirio. 1a ed.

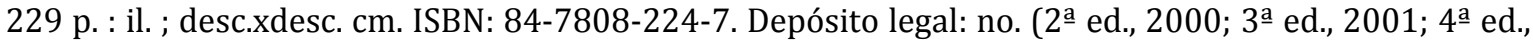
2003; 5 a ed., 2005). Palabras clave: historia, fundamentos teóricos, fundamentos técnicos, principios técnicos, formas. Resumen: Manual teórico y técnico de tai chi. La obra esta compuesta de 2 partes. La primera parte incluye los orígenes del tai chi chi kung, explica los beneficios de su práctica, sus principios básicos, presenta algunos ejercicios de calentamiento, describe la forma de los 13 movimientos incluyendo ilustraciones y esquemas de movimiento de cada técnica, y detalla los consejos técnicos necesarios para desarrollar la secuencia en casa. La segunda parte profundiza en los principios técnicos del tai chi, explicando las formas yin-yang, el arraigo en las técnicas, el movimiento del chi por el cuerpo y la activación de los tendones, incluyendo ejercicios para desarrollar cada aspecto. Los siguientes cinco capítulos describen las distintas formas de tai chi dependiendo de sus objetivos, como son la forma para desarrollar el tan tien, la forma curativa, la forma de la respiración cutánea y ósea, la forma de la estructura integrada y las aplicaciones marciales. El último capítulo narra la aplicación del tao sobre el tai chi. Adjunta dos apéndices sobre las preparaciones energéticas para el tai chi chi kung y la fisiología del tai chi.

1138. Ding, Li y Sutomo, Bambang (comp.) (1991). Taiji qigong : ejercicios de energía interna. Madrid: Miraguano. 1aㅡ ed. 169 p. : il. ; 13x19 cm. ISBN: 84-7813-073-X. Depósito legal: M. 1408-1991. Palabras clave: fundamentos técnicos, salud. Resumen: Manual teórico y técnico de taijiquan. El libro esta formado por 3 partes, precedidas de dos capítulos que explican cómo practicar correctamente la secuencia de movimientos y los beneficios que deben desprenderse de su práctica prolongada. Las 3 partes dividen la secuencia de 28 pasos del taiji qigong. Cada paso o movimiento esta explicado bajo la misma estructura: teoría, método y funciones. La teoría explica los fundamentos sobre los que se adquieren los beneficios del movimiento. El método describe la ejecución técnica del movimiento y las funciones detallan los beneficios de cada posición. Además, cada paso esta representado gráficamente junto con esquemas de movimiento. Adjunta una breve biografía del autor y del compilador.

1139. Fernández Casanova, Víctor Manuel (2007). Taichi chuan y chikung : el camino para reconectar con tu energía interior. Madrid: Dilema. 1aㅡ ed. 353 p. : il. ; 16x23 cm. ISBN: 978-84-9827-082-2. Depósito legal: M. 37265-2007. Palabras clave: qigong, formas, historia, fundamentos teóricos, ejercicios, biografía, taijiquan, escuelas, sexo, aplicación terapéutica, maestros, medicina tradicional china, meditación, planificación del entrenamiento, respiración. Resumen: Manual teórico y técnico de taichi chuan y chikung. La obra esta dividida en dos partes precedidas por un prólogo que explica los beneficios del taichi chuan y el chikung y señala los contenidos y objetivos de la obra. La primera parte consta de 20 capítulos. El primer capítulo explica los contenidos de la obra. El segundo capítulo describe el papel del pensamiento y las emociones sobre el ser humano y explica el proceso para desarrollar la alquimia de pensamiento. El tercer capítulo detalla el proceso de alquimia de la energía y las características de sus diferentes fases. El cuarto capítulo define el concepto de energía y explica las características de los tres tesoros. El quinto capítulo describe la estructura energética del cuerpo según la medicina tradicional china, las funciones de sus elementos y las capas del aura. El sexto capítulo ofrece algunos consejos prácticos para la práctica de la meditación y describe la ejecución de un ejercicio para tomar consciencia de nuestra estructura energética. El séptimo capítulo detalla los tipos de respiración, sus efectos sobre el organismo y enumera los principios técnicos para respirar correctamente. El octavo capítulo señala la función de la meditación en el proceso de alquimia del 
pensamiento, explica su aplicación al taichi chuan y al chikung, ofrece algunos consejos prácticos para su ejecución junto con la descripción de un ejercicio de iniciación, comenta la función de la oración y su aplicación al taichi chuan y al chikung, explica la práctica conjunta de meditación y oración, y presenta algunos mantras y oraciones. El noveno capítulo explica la práctica de la sonrisa interior y los sonidos curativos, detalla sus beneficios y expone sus principios técnicos. El décimo capítulo describe la ejecución del ejercicio de la sonrisa exterior y los campos morfogenéticos. El capítulo decimoprimero expone el significado del símbolo yin/yang, su origen y la aplicación de sus principios sobre el taichi chuan y el chikung. El decimosegundo capítulo comenta las características generales del taichi chuan, narra su historia, explica sus contenidos técnicos, el desarrollo de su práctica y sus beneficios. El capítulo decimotercero presenta los distintos estilos de chikung, sus aplicaciones, relata su historia y sus normas para la práctica. El decimocuarto capítulo analiza las diferencias entre el taichi chuan y el chikung. El décimo quinto capítulo incluye la biografía y aportaciones de Lao Tse, Chuang Tzu, Chang San Feng, el ancestro Lü, Bodhidarma, el monje Choy Fok, Yang Chen Fu, Chen Fake y Hu Yuezhen. El decimosexto capítulo analiza la figura del maestro. El decimoséptimo capítulo explica la función del sexo en el crecimiento personal interior, analiza su relación con el chikung y ofrece diversos consejos sobre el deseo y relaciones sexuales. El decimoctavo capítulo analiza las causas del sufrimiento humano y describe la ejecución de un ejercicio de meditación para eliminar el sufrimiento. El decimonoveno capítulo explica la función de la religión para alcanzar la lucidez interior y la salud mental-emocional. El vigésimo capítulo explica la función de la práctica del taichi chuan y el chikung ante la muerte y señala el proceso de la muerte según la concepción budista. La segunda parte consta de 19 capítulos. El primer capítulo describe los efectos de la práctica del taichi chuan y el chikung, explica las características del lugar de práctica, de la ejecución de sus formas, y enumera los principios básicos para comenzar su práctica. El segundo capítulo expone los principios técnicos básicos del taichi chuan y el chikung. El tercer capítulo describe la ejecución del ejercicio de contacto cielo-tierra. El cuarto capítulo detalla el recorrido de la respiración macrocósmica. El quinto capítulo explica la ejecución de una serie de ejercicios de chikung. El sexto capítulo detalla la ejecución técnica del ejercicio de limpiar el cuerpo con la bola de qi. El séptimo capítulo comenta la historia y características del automasaje chino y describe sus ejercicios prácticos. El octavo capítulo describe la ejecución de un ejercicio de chikung curativo. El noveno capítulo presenta las seis fases del Wu Ji, describe la ejecución de sus ejercicios y enumera sus beneficios. Los dos siguientes capítulos explican el desarrollo de los ejercicios de manos de nube y ejercicios shen de chikung incluyendo su representación gráfica. El decimosegundo capítulo comenta las características y objetivos del sistema chansijing, explica el principio de pie-cadera-mano y presenta la descripción de su práctica. El capítulo decimotercero comenta la historia y características de los ejercicios ba duan jin además de describir e ilustrar la ejecución de sus ocho ejercicios. El decimocuarto capítulo expone las características, beneficios y órganos relacionados con los ejercicios wu qin xi o juego de los cinco animales incluyendo su representación gráfica. El decimoquinto capítulo señala los objetivos y tipos del sistema puño de la mente (I Chuan Chikung) además de señalar los beneficios de sus ejercicios. El decimosexto capítulo narra la historia de los 18 luohan, señala sus beneficios, las características de sus formas y describe los efectos de las posturas de la forma sub bak luohan sau acompañadas de su representación gráfica. El decimoséptimo capítulo comenta las características y ventajas de la forma de 13 movimientos de taichi chuan. El decimoctavo capítulo expone las características técnicas de los estilos yang y chen de taichi chuan. El último capítulo relata una sesión de entrenamiento y ofrece un ejemplo de programa de entrenamiento. Adjunta la tabla de sonidos curativos, un cuadro resumen de los ejercicios para cada órgano, agradecimientos y direcciones y sitios de interés.

1140. García Romeral, Luis (2006). Tai chi : el placer del movimiento. Iniciación al tai chi y al chikung. Estudio de la forma de 15 ejercicios básicos. Madrid: Tutor. 1aㅡ ed. 167 p. : il. ; 17x24 cm. ISBN: 84-7902-552-2. Depósito legal: M. 2830-2006. Palabras clave: qigong, formas, fundamentos técnicos, ejercicios, taijiquan. Resumen: Manual teórico y técnico de tai chi y chikung. El libro esta compuesto por 5 capítulos. El primero explica brevemente lo que es el tai chi y su historia, y en el segundo pasa a describir la ejecución de ejercicios preparatorios generales y específicos para el tai chi, ilustrando cada ejercicio y haciendo hincapié en los puntos clave de la ejecución. El tercer capítulo presenta e ilustra la secuencia de movimientos de los chikunes de Zhan Zhuang Gong, Guanqifá, 3 ejercicios universales (levantando el cielo, la palma del cosmos o palma de hierro, sujetando la luna), Shuai Shou Gong, y Dragón en el mar; para en el cuarto capítulo detallar los aspectos técnicos de la práctica del tai chi, como son el saludo, las posiciones, los desplazamientos, la colocación de las manos, la respiración durante la práctica y la concentración-visualización. El último capítulo estudia la forma de 15 ejercicios básicos, explicando el movimiento de cada segmento corporal, los cambios de peso, los desplazamientos, la orientación, los ritmos de respiración y todo ello dividiendo cada movimiento en distintas partes e ilustrando cada una de ellas. Adjunta un glosario y fotografías.

1141. Lu, Shengli (2009). Técnicas de combate de taiji, xingyi y bagua : principios y prácticas de las artes marciales internas. Badalona: Paidotribo. 1aㅡ ed. 303 p. : il. ; 21x27,5 cm. ISBN: 978-84-8019-170-8. 
Depósito legal: no. Palabras clave: formas, historia, fundamentos teóricos, táctica, fundamentos técnicos, principios técnicos, ejercicios, combate, entrenamiento, baguazhang, taijiquan, wushu, xinyiquan, aplicación marcial, genealogía. Resumen: Manual teórico y técnico de artes marciales chinas. La monografía esta formada por 5 capítulos. El primer capítulo comenta las características de las artes marciales internas, sus principios filosóficos y sus diferencias con las artes marciales externas además de explicar la historia y linaje, principios básicos y características y un análisis del método de entrenamiento del Xingyi Quan, el Taiji Quan, el Bagua Zhang, y con menor profundidad el Tongbei Quan y el Baji Quan. El segundo capítulo describe e ilustra las zonas de golpeo de todo el cuerpo junto con las principales técnicas de ataque y defensa, las posiciones y los desplazamientos. El tercer capítulo analiza los distintos métodos de entrenamiento de las artes marciales internas, explicando la ejecución, principios técnicos y beneficios de los diversos ejercicios de la posición de pie como un poste (zhuang gong), los pasos de aplicación o entrenamiento de los pies (Bu Fa), el empuje de manos (Tui Shou) y la emisión de la fuerza entrenada (Fa Jin), incluyendo ilustraciones explicativas. El cuarto capítulo ofrece consejos para la práctica de la forma de las 16 posturas, enumera sus posiciones, y describe e ilustra la ejecución y aplicaciones marciales de cada uno de sus movimientos. El último capítulo presenta los principios técnicos y tácticos que deben seguirse en la práctica y entrenamiento de las aplicaciones.

1142. Reid, Howard; Connor, Danny; Chuen, Lam Kam; Sutton, Nigel y Rusher, Robin (1989). Vivir en armonía : una guía a las artes marciales suaves. Esplugues de Llobregat: Plaza \& Janés. 1aㅗ ed. 191 p. : il. ; 16x23 cm. ISBN: 84-01-60789-2. Depósito legal: T0. 344-1989. Palabras clave: qigong, formas, fundamentos teóricos, fundamentos técnicos, principios técnicos, principios filosóficos, ejercicios, baguazhang, taijiquan, xinyiquan, nutrición, respiración, salud. Resumen: Manual teórico y técnico de artes marciales chinas. La obra esta formada por 2 partes, precedidas de una introducción que explica las características de las artes marciales blandas, sus orígenes y filosofía, los rasgos característicos del Chi kung, Hsing I, Pa kua y T'ai chi chuan y ofrece algunos consejos para comenzar su práctica. La primera parte esta compuesta de 4 capítulos, cada uno de ellos dedicado a un arte marcial (chi kung, hsing i, pa kua y t'ai chi chuan). El primer capítulo comenta los orígenes y objetivos del chi kung, explica el concepto de chi y la forma de respiración natural para luego describir e ilustrar la ejecución por partes de varios ejercicios de ba duan jin (las ocho joyas), chi kung básico e intermedio y del paso chi kung. El segundo capítulo expone las características del Hsing I y la teoría de los cinco elementos para luego describir e ilustrar los ejercicios preparatorios de los tres esenciales (San Ti), los ejercicios de los cinco elementos y el ejercicio del tigre como ejemplo de los doce animales. El tercer capítulo explica brevemente la historia y características del Pa Kua, profundiza en el significado de los ocho trigramas y describe, con la ayuda de varias ilustraciones, los ejercicios del paso de pa kua, las ocho posiciones fijas y los giros simples y dobles de las palmas. El cuarto capítulo explica las características y principios técnicos del t'ai chi chuan y describe e ilustra, algunos ejercicios de calentamiento de todo el cuerpo, el paso del t'ai chi, la forma corta de 24 movimientos junto con sus esquemas de movimiento, varios ejercicios por parejas de los poderes básicos y el empuje de manos. La segunda parte esta compuesta de dos capítulos, el primero de ellos profundiza en la teoría de las artes marciales chinas como es el chi, los cinco elementos, los órganos y meridianos, explica los ciclos de la energía, la importancia de una dieta equilibrada junto con las propiedades de cada alimento, el equilibrio de las emociones y del sexo, las características de la meditación y la respiración junto con la descripción e ilustración de varios ejercicios de respiración. El último capítulo presenta la interpretación, según la medicina china, de distintos problemas o enfermedades y propone algunos ejercicios terapéuticos para tratar los dolores de cabeza, la hipertensión, la ansiedad, depresión, insomnio, los problemas digestivos, los dolores en el cuello y la espalda, el reumatismo y artritis, ejercicios para el embarazo y las personas mayores, y para tratar el asma. Adjunta un índice y bibliografía.

1143. Ruiz Vidal, Juan Manuel (2005). La relajación práctica : tai-chi y chi-kung. Badalona: Paidotribo. 1aㅡ ed. 251 p. : il. ; 15x21,5 cm. ISBN: 84-8019-814-1. Depósito legal: no. Palabras clave: qigong, fundamentos técnicos, ejercicios, entrenamiento, taijiquan, medicina tradicional china, rehabilitación. Resumen: Manual teórico y técnico de tai chi y chi kung. La obra esta formada por 11 capítulos. El primer capítulo explica el concepto de chi para luego exponer las reglas para la práctica del chi-kung. El tercer capítulo describe e ilustra varias técnicas de masaje para activar la circulación del chi. El siguiente capítulo explica cómo realizar sesiones de entrenamiento a partir de los contenidos expuestos en el libro. Los siguientes 4 capítulos describen de forma esquemática e ilustran con el apoyo de gráficos y esquemas de movimiento, los ejercicios de dos sesiones de calentamiento, de cinco sesiones de tai chi, de 5 series de ba duan jin o ejercicios de chi kung, y algunas posiciones del estilo de chi-kung Zhan Zhuang. Los siguientes capítulos comentan los principios del reiki o sistema de autosanación integral para eliminar el estrés, describen el trabajo de la respiración con el dan tien, y exponen la descripción de 11 sesiones de ejemplo, completas e ilustradas. El último capítulo incluye el comentario final del autor sobre los objetivos y beneficios del tai-chi y chi-kung. Adjunta bibliografía, y el listado de música empleada para las sesiones y los vídeos. 
1144. Sheng, Keng Yun (1999). El libro de ejercicios de Mu Lan Chuan. Málaga: Sirio. 1aㅡ ed. 172 p. : il. ; $13 \times 21$ cm. ISBN: 84-7808-272-7. Depósito legal: B. 8820-1999. Palabras clave: historia, fundamentos técnicos, ejercicios. Resumen: Manual teórico y técnico de Mu Lan Chuan. El libro esta formado por 8 capítulos precedidos por una dedicatoria, un prefacio que narra la leyenda de Mu Lan y una introducción que resume los contenidos del libro y sus beneficios. El primer capítulo describe la ejecución de la postura de preparación, el vuelo de las dos águilas, la reverencia, la postura del arco, la postura de las piernas cruzadas y la postura de la pierna en media luna acompañadas de su secuencia fotográfica. El segundo capítulo explica las técnicas de postura de preparación, girar las palmas de las manos, sostener el cielo con las palmas de las manos y moviendo los hombros y los brazos junto con sus ilustraciones. El tercer capítulo presenta la ejecución y representación gráfica de la postura de preparación, tocando el laúd, el viento meciendo el sauce, Mu Lan empujando y tirando del telar, y recogiendo el cuello y contrayendo el abdomen. El cuarto capítulo muestra las técnicas postura de preparación, Mu Lan se peina el cabello, Mu Lan lava el tejido y lo pone a secar al sol, presionando los talones de las manos y palmas yin y yang. El quinto capítulo expone la descripción e ilustración de la postura de preparación, echando el cuerpo hacia atrás, girando las ruedas, remando contra el viento y agachándose y acariciando a los peces. El sexto capítulo incluye la descripción técnica y secuencia fotográfica de la postura de preparación, cruzar los antebrazos, buscando entre la hierba, frotar la rodilla y sostener el cielo, y cruzando las piernas y sacudiendo los hombros. El séptimo capítulo explica la realización de las técnicas postura de preparación, alcanzar la nube, mirar dentro del pozo y balancear las manos acompañadas de su ilustraciones explicativas. El último capítulo detalla la ejecución de la postura de preparación, el pato caminando hacia el agua, girar los hombros y mirando al agua junto con su representación gráfica además de relatar la historia de la disputa de los dedos e incluir un breve glosario específico. Adjunta un glosario, un apéndice con la localización de los puntos de acupuntura y canales de energía, un apéndice con varios testimonios sobre los efectos del mu lan chuan, un índice de términos y una breve biografía de la autora.

1145. Tian, Cheng Yang (2003). Conocer el taoísmo : historia, filosofía y práctica. Tai chi, chi kung, feng shui, meditación, masaje taoísta. Barcelona: Kairós. 1aㅡ ed. 232 p. : il. ; 18x24,5 cm. ISBN: 84-7245-531-9. Depósito legal: B. 28548-2002. Palabras clave: qigong, fundamentos teóricos, fundamentos técnicos, principios técnicos, taijiquan, armas, fengshui. Resumen: Manual teórico y técnico de artes marciales chinas. El libro esta formado por 10 capítulos precedidos por una introducción que comenta el contacto del autor con el tao y los objetivos de la presente obra. El primer capítulo narra los orígenes del taoísmo, la biografía de Lao Zi, señala la importancia del tao te king, su relación con el taoísmo, expone la clasificación del contenido taoísta, los libros taoístas, y comenta la filosofía de Lao Zi, Zhuang Zi y del Wu Wei, los fundamentos del Xiu Lian, la relación del taoísmo con el confucianismo, el budismo, la medicina tradicional china y la ciencia, y su expansión. El segundo capítulo presenta los fundamentos teóricos del taoísmo como son la teoría del chi y del chikung. El tercer capítulo expone los principios de la meditación taoísta, sus niveles, su práctica y ofrece algunos consejos. El cuarto capítulo explica la ejecución y beneficios de las ocho partes del masaje taoísta acompañados de su representación gráfica. El quinto capítulo describe la ejecución de los movimientos del chi kung taoísta acompañados de su secuencia fotográfica además de exponer sus principios técnicos. El sexto capítulo analiza los orígenes del tai chi chuan y describe los puntos esenciales para su práctica. El séptimo capítulo incluye la descripción técnica e ilustración de los movimientos del tai chi taoísta denominados el dragón de la primavera, el dragón del verano, el dragón del otoño y el dragón del invierno. El octavo capítulo explica la ejecución de los ejercicios de la espada del tai chi taoísta junto con sus ilustraciones explicativas. El noveno capítulo incluye distintas preguntas y respuestas sobre las diferentes prácticas taoístas. El último capítulo detalla en qué consiste el feng shui, la teoría del yin/yang, la teoría de los cinco elementos, los ocho trigramas y expone la aplicación y principios del feng shui a la vivienda. Adjunta el texto titulado "tai shang lao jun qing jing jing", el currículo del autor y sus obras, notas, bibliografía, la lista de dinastías chinas, un glosario de palabras chinas, un índice topográfico y un índice onomástico.

1146. Yang, Jwing-Ming (1994). La esencia del tai chi chi kung : salud y artes marciales. Villaviciosa de Odón: Mirach. 1aㅡ ed. 174 p. : il. ; 18x23,5 cm. ISBN: 84-87476-60-0. Depósito legal: M. 26217-1994. Palabras clave: qigong, fundamentos teóricos, fundamentos técnicos, principios técnicos, ejercicios, entrenamiento, calentamiento, taijiquan. Resumen: Manual teórico y técnico de taijiquan. El libro esta formado por 4 capítulos precedidos por la biografía del autor y un prólogo que presenta la práctica del chi kung. El primer capítulo define el concepto de chi para luego explicar en qué consiste el chi kung, cuál es su origen, que tipos de prácticas y paradigmas existen, narra la historia del tai chi chuan, estudia la teoría del chi kung, los tipos de energía que existen y los tres tesoros, los principios del entrenamiento, la relación entre tai chi y chi kung y explica cómo utilizar el libro. El segundo capítulo profundiza en la teoría del yin/yang, su aplicación al tai chi chuan y su entrenamiento. El tercer capítulo comienza explicando los principios técnicos del entrenamiento para luego describir por partes e ilustrar los ejercicios de calentamiento, de tai chi chi kung estático, tanto de meditación sedente 
como estática, y de tai chi chi kung en movimiento, tanto en estacionario como en movimiento. El último capítulo comenta los objetivos generales del libro a modo de conclusión. Adjunta un glosario de términos chino y la traducción china de los términos aparecidos en la obra.

1147. Yang, Jwing-Ming (1999). La esencia del taiji qigong : fundamentos internos del taijiquan. Málaga: Sirio. 1a ed. 190 p. : il. ; 17x24 cm. ISBN: 84-7808-305-7. Depósito legal: B. 47434-1999. (2a imp., 2006). Palabras clave: fundamentos teóricos, fundamentos técnicos, ejercicios, qigong, taijiquan, formas. Resumen: Manual teórico y técnico de taijiquan. El libro esta formado por 3 capítulos. El primer capítulo describe en qué consiste la práctica del qigong, sus orígenes, los tipos de qigong junto con sus características y objetivos, la historia del taijiquan, los conceptos teóricos del qigong y su entrenamiento, y la relación entre taijiquan y qigong junto con algunos consejos para los principiantes. El segundo capítulo explica la teoría del yin-yang y analiza su aplicación dentro del taijiquan en la meditación, la respiración y los movimientos. El último capítulo expone los principios fundamentales del entrenamiento, presenta varios ejercicios de qigong de calentamiento para todas las partes del cuerpo, ilustrando cada ejercicio e incluyendo esquemas de movimiento, y describe la ejecución técnica ilustrada de los ejercicios de taiji qigong estático en su práctica meditativa estática y en movimiento, y 3 series del taiji qigong en movimiento a pie firme y una serie de los ejercicios en marcha. Todos los ejercicios están descritos por partes, ilustrados y acompañados de esquemas de movimiento. Adjunta un glosario de términos chinos y su traducción y un glosario general.

\subsubsection{Artes Marciales Japonesas}

1148. Kishi, Yasu (1994). Karate. Barcelona: Ultramar. $1^{a}$ ed. 196 p. : il. ; desc.xdesc. cm. ISBN: 84-7386-7033. Depósito legal: no. (2a ed., 1996). Palabras clave: katas, historia, fundamentos técnicos, ejercicios, combate, entrenamiento, kyusho. Resumen: Manual teórico y técnico de kárate y aikido. El libro esta formado por 27 capítulos. El primer capítulo describe las zonas de golpeo de la mano, el brazo y el codo así como su modo de utilización. Los siguientes cinco capítulos comentan las diferentes técnicas de mano, las principales posiciones, las zonas de golpeo del pie y un breve comentario de algunas de las técnicas de golpeo con los pies y manos. Los siguientes tres capítulos explican cómo endurecer las manos y los pies, además de los aparatos que se utilizan para ello y las formas de golpearlos. Los siete capítulos siguientes describen la ejecución de varias secuencias de técnica básica y de cinco katas. A continuación se describen varias secuencias de combate preestablecido y la localización de los puntos vitales del cuerpo. Los siguientes cuatro capítulos comentan las características del aikido, los principios técnicos de su entrenamiento, las aptitudes requeridas para su práctica, la vestimenta que se utiliza y los grados que se alcanzan. Los dos últimos capítulos describen varias técnicas de defensa contra diferentes ataques y enumera los puntos vitales del cuerpo. Adjunta un glosario.

1149. Kôshirô, Kiba (2007). Kukishin ryu bujutsu : defensa personal japonesa. Libro primero - Bojutsu. Telde: Seigan. 1a ed. 189 p. : il. ; 17x25 cm. ISBN: 978-84-88738-32-5. Depósito legal: GC. 1252-2007. Palabras clave: historia, fundamentos teóricos, fundamentos técnicos, defensa personal, vestimenta, cortesía, armas. Resumen: Manual teórico y técnico del Kukishin Ryu Bojutsu. La obra esta formada por 5 capítulos precedidos de distintas láminas sobre la historia del arte y los consejeros y miembros de apoyo honoríficos de la Kodo Senyokai. El primer capítulo relata brevemente el origen del estilo Kukishin Ryu Bojutsu para luego exponer las reglas de cortesía y saludo en el dojo. El tercer capítulo describe la ejecución técnica de las 6 posturas básicas de guardia, las 8 formas básicas (kihon gata) y las 9 formas de la kuji no kata, ilustrando cada posición y movimiento por partes. El cuarto capítulo describe e ilustra las 25 técnicas o formas de defensa personal con bastón de 3 y 4 pies (hanbo) para finalizar con las 24 formas de defensa para el bastón de 6 pies y la espada.

1150. Lahoz Gómez, Carlos (1992). Taikidoshinbudo : sistema de artes marciales. Zaragoza: Carlos Lahoz Gómez. 1aㅡ ed. 84 p. : il. ; 21x29,5 cm. ISBN: No ISBN. Depósito legal: Z. 2113-1992. Palabras clave: fundamentos teóricos, fundamentos técnicos, pedagogía, vestimenta, cortesía, bujutsu, jujutsu, kárate, kyusho, etiqueta, programa técnico. Resumen: Manual teórico y técnico de taikidoshinbudo. El libro esta formado por 28 capítulos. El primer capítulo explica el significado del nombre y emblema del taikidoshinbudo. El segundo capítulo expone el currículo del autor. El tercer capítulo expone los fundamentos teóricos y características técnicas del taikidoshinbudo. El cuarto capítulo explica los fundamentos técnicos del estilo mientras que el quinto describe la ceremonia y etiqueta del dojo. El sexto capítulo detalla la vestimenta utilizada y el sistema de graduación del taikidoshinbudo. Los siguientes seis capítulos explican los fundamentos técnicos del estilo como son las posturas y posiciones del cuerpo, los desplazamientos, las guardias, las esquivas y los desequilibrios junto con sus principios técnicos y algunas representaciones gráficas. El decimoquinto capítulo presenta las partes del cuerpo utilizadas para golpear o bloquear junto con los principios técnicos generales. El siguiente capítulo detalla el conocimiento y manipulación de los puntos energéticos débiles. El decimoséptimo capítulo señala la importancia de la respiración para el entrenamiento y describe su ejecución. Los 
siguientes tres capítulos enumera los objetivos del kiai y explican los conceptos de hara y de la distancia de combate. El vigésimo primer capítulo expone las estrategias utilizadas en el taikidoshinbudo. Los dos siguientes capítulos detalla las características de los diferentes métodos de entrenamiento del estilo, su metodología de enseñanza, la planificación de la clase y la enseñanza, la estructura de las clases y los principios pedagógicos. El vigésimo cuarto capítulo comenta los principios de la preparación física mientras que el siguiente capítulo enumera las terapias orientales estudiadas en el taikidoshinbudo. Los tres últimos capítulos incluyen los programas técnicos desde $6^{\circ}$ kyu a yudasha del karate-do, ju-jitsu y bu-jitsu del taikidoshinbudo.

1151. Nalda Albiac, José Santos (1991). Bu-jutsu : técnicas de combate. Barcelona: Alas. 1a ed. 221 p. : il. ; 15x21,5 cm. ISBN: 84-203-0258-9. Depósito legal: B. 29123-1991. Palabras clave: katas, historia, fundamentos teóricos, táctica, fundamentos técnicos, combate, vestimenta, cortesía, jojutsu, kenjutsu, tambojutsu, competición, etiqueta, reglamentos. Resumen: Manual teórico y técnico de artes marciales japonesas. El libro esta dividido en 26 capítulos precedidos por un prólogo que comenta los contenidos del libro. El primer capítulo narra el origen e historia del kenjutsu. El segundo capítulo señala los objetivos del reishiki y describe su ejecución acompañada de sus ilustraciones explicativas. Los dos siguientes capítulos describe y representan la ejecución de las distintas guardias y desplazamientos. El quinto capítulo explica el concepto de distancia y sus tipos en el kenjutsu. El sexto capítulo define el término uchi waza, describe como se empuña el sable, sus tipos de entrenamiento y representa las trayectorias de golpeo. Los dos siguientes capítulos exponen los principios técnicos de las técnicas de bloqueo (uke waza) y de desvío por deslizamiento (suri age waza) además de incluir la representación gráfica de algunas de sus técnicas. El noveno capítulo expone los fundamentos de las técnicas de harai waza junto con los gráficos explicativos de sus técnicas fundamentales. El décimo capítulo detalla el objetivo del sen no sen, sus tipos de reacción y presenta la descripción de varios ejercicios de entrenamiento. El capítulo decimoprimero analiza los factores físicos, mentales y psicológicos involucrados en el kaeshi waza, comenta los principios de la defensa y la iniciativa en el combate junto con la descripción e ilustración de varias de sus técnicas. El decimosegundo capítulo expone los principios técnicos y tácticos más importantes en un combate, y describe el desarrollo de un combate tradicional de kenjutsu y su competición moderna. El capítulo decimotercero explica en que consisten las katas y presenta la descripción y representación gráfica de la ejecución de la ko tachi no kata y otras dos katas de kenjutsu. El decimocuarto capítulo relata el origen del jojutsu. El decimoquinto capítulo describe la estructura y características del jo, sus formas de agarre, la representación gráfica del saludo y algunos ejercicios de calentamiento y reflejos. El decimosexto capítulo ilustra las principales posiciones de guardia con el jo. El decimoséptimo capítulo localiza los puntos vitales atacados con el jo, enumera sus direcciones de ataque y representa gráficamente los ataques fundamentales, sus encadenamientos y combinaciones, sus paradas y bloqueos acompañados de sus esquemas de movimiento. El decimoctavo capítulo señala los objetivos del entrenamiento de kumi jo además de presentar la descripción e ilustración de algunas de sus técnicas. El decimonoveno capítulo incluye la representación gráfica de la kata fundamental de jojutsu, la kata de los 31 golpes y la kata de jo contra ken. El vigésimo capítulo comenta la características del tambo jutsu, describe su estructura, algunos ejercicios para su manejo y la forma de saludar acompañados de sus respectivos gráficos. El vigésimo primer capítulo define los conceptos de muga mushi y suki, y representa los tipos de guardia con el tambo. Los dos siguientes capítulos representan gráficamente los ataques y paradas básicas, junto con varios ejercicios para desarrollar los reflejos. El vigésimo cuarto capítulo describe e ilustra algunas técnicas de kumi tambo mientras que los dos últimos capítulos explican el desarrollo de una clase de kenjutsu, jojutsu y tambojutsu así como un proyecto de reglamento de competición para dichas modalidades.

1152. Nalda Albiac, José Santos (2008). Bu-jutsu : técnicas de combate. Barcelona: Alas. 1a ed. 389 p. : il. ; 17x23,5 cm. ISBN: 978-84-203-0447-2. Depósito legal: SE. 2488-2008. Palabras clave: katas, historia, fundamentos teóricos, táctica, fundamentos técnicos, combate, vestimenta, cortesía, jojutsu, kenjutsu, tambojutsu, competición, etiqueta, reglamentos. Resumen: Manual teórico y técnico de artes marciales japonesas. El libro esta dividido en 30 capítulos precedidos por un prólogo que comenta los contenidos del libro, los agradecimientos y dos preámbulos que explican la práctica del kenjutsu. El primer capítulo define el concepto de bujutsu y kenjutsu. El segundo capítulo narra el origen e historia del kenjutsu. El tercer capítulo señala los objetivos del reishiki y describe su ejecución acompañada de sus ilustraciones explicativas. Los dos siguientes capítulos describe y representan la ejecución de las distintas guardias y desplazamientos. El sexto capítulo explica el concepto de distancia y sus tipos en el kenjutsu. El séptimo capítulo define el término uchi waza, describe como se empuña el sable, sus tipos de entrenamiento y representa las trayectorias de golpeo. Los dos siguientes capítulos exponen los principios técnicos de las técnicas de bloqueo (uke waza) y de desvío por deslizamiento (suri age waza) además de incluir la representación gráfica de algunas de sus técnicas. El décimo capítulo expone los fundamentos de las técnicas de harai waza junto con los gráficos explicativos de sus técnicas fundamentales. El capítulo decimoprimero detalla el objetivo del sen no sen, sus tipos de 
reacción y presenta la descripción de varios ejercicios de entrenamiento. El decimosegundo capítulo analiza los factores físicos, mentales y psicológicos involucrados en el kaeshi waza, comenta los principios de la defensa y la iniciativa en el combate junto con la descripción y secuencia fotográfica de varias de sus técnicas. El capítulo decimotercero expone los principios técnicos y tácticos más importantes en un combate, y describe el desarrollo de un combate tradicional de kenjutsu y su competición moderna. El decimocuarto capítulo explica en que consisten las katas y presenta la descripción y representación gráfica de la ejecución de la kotachi no kata. Los dos siguientes capítulos incluyen la descripción y secuencia fotográfica de la wakizashi no kata y los fundamentos técnicos del iai jutsu. El decimoséptimo capítulo relata el origen del jojutsu. El decimoctavo capítulo presenta las distintas guardias con el jo. El siguiente capítulo presenta los fundamentos técnicos del jo jutsu. El vigésimo capítulo incluye un breve glosario de términos específicos de jo jutsu junto con la ilustración de distintas técnicas de combate de jo contra jo. El siguiente incluye la representación gráfica de la kata fundamental de jojutsu y la kata de los 31 golpes. El vigésimo segundo capítulo expone la estructura del tambo, describe su manejo y la forma de saludar. Los siguientes cuatro capítulos presentan las guardias, fundamentos técnicos y las principales secuencias técnicas del tambo jutsu. El vigésimo séptimo capítulo explica en qué consiste el ken jo jutsu, su historia, describe la forma de empuñar el ken además de algunas técnicas básicas acompañadas con sus ilustraciones explicativas. El vigésimo octavo capítulo incluye distintos aforismos sobre el combate. El siguiente capítulo presenta un proyecto de reglamento de competición para las modalidades de ken jutsu, jo jutsu y tambo jutsu, además de presentar el desarrollo de una clase de bu jutsu. El último capítulo incluye varios ensayos sobre los beneficios del bujutsu, su aplicación en las fuerzas armadas y policiales y sus valores.

1153. Pasquale Jr., Michael De (1987). Artes marciales : una introducción al karate, judo y ju-jitsu. Barcelona: Martínez Roca. 1aa ed. 157 p. : il. ; 14x21,5 cm. ISBN: 84-270-1093-1. Depósito legal: B. 203-1987. (2 $2^{\underline{a}}$ ed., 1993). Palabras clave: fundamentos técnicos, judo, kárate, planificación del entrenamiento. Resumen: Manual técnico de karate, judo y de la ju-jitsu kata. La obra esta dividida en 8 capítulos que describen el entrenamiento a realizar en 8 semanas. Comienza con la explicación de algunos ejercicios de acondicionamiento físico general específicos para las artes marciales y continúa con la descripción breve e ilustrada de los principales golpeos, bloqueos y patadas de karate. El tercer capítulo explica las posturas de karate junto con las caídas de judo, para luego pasar a la ilustración de 3 katas básicos de karate. El quinto capítulo centra su atención en las principales proyecciones de judo mientras que el siguiente ofrece una descripción de algunos agarres de muñeca y siete katas de ju-jitsu o formas predeterminadas de ataque y defensa. El séptimo capítulo continúa con las katas de ju-jitsu, ofreciendo otras 7 formas. El último capítulo presenta situaciones de defensa personal ante el ataque de 2 y 3 personas. Adjunta un glosario.

1154. Planellas Vidal, Pau-Ramon (1986). Harai-waza : la técnica de los barridos. Barcelona: Alas. 1a ed. 143 p. : il. ; 15x21,5 cm. ISBN: 84-206-0201-5. Depósito legal: B. 34493-1986. Palabras clave: fundamentos técnicos, entrenamiento. Resumen: Manual técnico especializado en los barridos. Después de explicar y comentar brevemente el equilibrio y desequilibrio corporal, describe los diferentes barridos con las piernas y con las manos con ayuda gráfica. Presenta los barridos realizados en diferentes distancias, ante ataques con arma e incluso desde el suelo. Los últimos cuatro capítulos profundizan en el entrenamiento, reflexionando sobre el aprovechamiento de la oportunidad en la ejecución de un barrido, los diferentes métodos para mejorar la técnica y las lesiones más frecuentes derivadas de los barridos. Adjunta un glosario técnico.

1155. Tassinari, Margherita (2003). Artes marciales : aikido, yudo, kárate, jujitsu, kendo, kung fu. Madrid: Susaeta. $1^{a}$ ed. 95 p. : il. ; 15x21 cm. ISBN: 84-305-3972-7. Depósito legal: M. 31335-2009. (2a ed., 2007, ISBN: 978-84-305-6006-6). Palabras clave: historia, fundamentos técnicos, filosofía, vestimenta, budo, bujutsu, salud, samurái. Resumen: Manual teórico y técnico de artes marciales. La obra esta formada por 9 capítulos. El primer capítulo narra los orígenes históricos y filosóficos de las artes marciales, sus estilos, la difusión del budismo mahayana y su importancia dentro del desarrollo de las artes marciales, y las características de los samuráis. El segundo capítulo detalla algunas nociones básicas de las artes marciales, como la transmisión del conocimiento, las escuelas, los cinturones, el papel del sensei, y explica los objetivos del bujitsu y su transformación posterior en budo. El tercer capítulo clasifica las artes marciales sin armas, profundizando en el sumo y su práctica, incluye un breve comentario del desarrollo del jujitsu, de las armas del guerrero japonés y del kobudo y sus características, exponiendo las principales características de las antiguas escuelas (ryu) y la clasificación de las escuelas tradicionales chinas, para finalizar con una exposición de las luchas de contacto más actuales. Los siguientes 6 capítulos estructuran el estudio del aikido, el yudo, el jujitsu, el kárate, el kendo y el kung fu respectivamente, comenzando con la descripción de la historia, evolución y principios filosóficos que impregnan cada arte marcial y explicar el desarrollo de su combate, quién puede practicar la actividad, cuál es su indumentaria y rituales, las técnicas de entrenamiento y cuáles son los beneficios de cada práctica, incluyendo numerosas fotografías explicativas en cada capítulo. 


\subsubsection{General}

1156. DI SOM y Rodríguez Acevedo, José Luis (1996). Bases científicas del arte marcial. Vigo: José Luis Rodríguez Acevedo. 1aㅡ ed. 169 p. : il. ; 19x26 cm. ISBN: 84-605-5870-3. Depósito legal: VG. 794-1996. Palabras clave: formas, historia, fundamentos teóricos, táctica, fundamentos técnicos, principios técnicos, combate, biomecánica. Resumen: Manual teórico y técnico de artes marciales. El libro esta formado por 4 partes precedidas por una presentación que señala los objetivos del libro. La primera parte consta de 6 capítulos. El primer capítulo explica los objetivos de las artes marciales, la educación física occidental y del ejercicio físico en otras civilizaciones. El segundo capítulo analiza los componentes que configuran el arte marcial. El tercer capítulo estudian la historia de las artes marciales analizando los libros antiguos, rishis, danzas folklóricas, el papel del Emperador Fu-Shi, la lucha envolvente, las enseñanzas budicas y algunos personajes históricos. El cuarto capítulo describe la evolución de las artes marciales comentando los ocho primeros movimientos, el origen de la autodefensa y sus fases de evolución. El quinto capítulo presenta las influencias y fundamentos filosóficos y culturales de las artes marciales mientras que el sexto comenta los factores que intervinieron en la expansión de las artes marciales. La segunda parte consta de 6 capítulos. El primer capítulo define los conceptos básicos de los fundamentos biomecánicos y su aplicación a las artes marciales. El segundo capítulo analiza los factores técnicos de las posiciones, los tipos de posiciones y sus características y las formas de desplazamiento. El tercer capítulo expone los principios de las defensas, sus formas de aplicación y los tipos de bloqueos. El cuarto capítulo detalla el objetivo de los golpes, sus formas de aplicación, clasifica los tipos de golpes y enumera sus factores de eficacia. El quinto capítulo expone las formas de combinar los bloqueos y golpes. El sexto capítulo destaca el origen y simbolismo de las armas, enumera su finalidad, sus fases de entrenamiento y sus tipos. La tercera parte consta de 3 capítulos. El primer capítulo clasifica las técnicas de defensa personal además de incluir la secuencia fotográfica de algunas de sus técnicas. El segundo capítulo expone los principios tácticos básicos del combate, sus fundamentos teóricos, sus factores psicológicos y sus fases de aprendizaje. El tercer capítulo comenta los principios de continuidad, alternancia, ritmo, variedad y distancia que conforman el combate continuado así como algunas sugerencias para su entrenamiento. La cuarta parte consta de dos capítulos. El primer capítulo expone y comenta los criterios de elaboración de las formas de las artes marciales. El segundo capítulo analiza la estructura de las formas y los elementos que conforman sus principios físicos, motrices, técnicos, psicológicos, energéticos y pedagógicos. Adjunta dos apéndices que analizan las deficiencias de las competiciones de artes marciales para proponer un nuevo enfoque y ofrecen algunos consejos para mejorar en la profesionalidad de los profesores. También adjunta bibliografía recomendada e información sobre Di-Som.

1157. Domínguez Sánchez, Germán (1998). Manual práctico del cuchillo. Madrid: Esteban Sanz Martínez. 1a ed. 124 p. : il. ; 12x15 cm. ISBN: 84-85977-66-1. Depósito legal: M: 3204-1998. Palabras clave: historia, fundamentos teóricos, armas, aplicación marcial, tests. Resumen: Manual teórico y técnico del cuchillo. El libro esta formado por 8 capítulos precedidos por una dedicatoria, una breve biografía del autor, agradecimientos, dos prólogos que comentan la utilización del cuchillo en la actualidad y una introducción que resume los contenidos de libro. El primer capítulo explica las características generales del sistema de combate creado por el autor. El segundo capítulo comenta la historia del cuchillo, detalla sus partes y estructura e incluye numerosas fotografías. El tercer capítulo expone las distintas pruebas existentes para comprobar las características y calidad del cuchillo. El cuarto capítulo enumera los posibles usos del cuchillo en situaciones tácticas, de supervivencia o militares. El quinto capítulo describe las formas de agarrar el cuchillo y ofrece algunos consejos para su lanzamiento incluyendo la ilustración de sus diversas posiciones de lanzamiento. El sexto capítulo expone la utilización del machete en distintas culturas así como sus posibles usos. Los dos últimos capítulos ofrecen consejos para la elección de un cuchillo y para mantener el cuchillo en buenas condiciones respectivamente. Adjunta una conclusión final.

1158. Hibbard, Jacques (1988). Artes marciales : rompimientos. Sus técnicas, secretos y su aplicación a la autodefensa. Madrid: Eyras. 1aㅡ ed. 255 p. : il. ; 15x24 cm. ISBN: 84-85269-55-1. Depósito legal: M. 12887-1988. Palabras clave: aplicación marcial, preparación física. Resumen: Manual teórico y práctico sobre los rompimientos. La obra esta dividida en 7 capítulos. Los dos primeros capítulos desarrollan los aspectos teóricos relacionados con los mismos, como la concentración, el acondicionamiento de las partes de golpeo, la importancia de la flexibilidad, los principios biomecánicos para ejecutar un rompimiento, cómo comenzar su entrenamiento, el papel de los ayudantes, etc. El tercer capítulo centra su estudio en los distintos rompimientos con la mano, explicando el movimiento y sus puntos clave y ofreciendo varias fotografías y esquemas de movimiento sobre los mismos. Los siguientes capítulos desarrollan el mismo trabajo pero con las técnicas de pierna, con técnicas avanzadas o combinaciones y con técnicas en salto. El último capítulo 
presenta la ejecución de algunas técnicas de rompimiento para la exhibición de máxima espectacularidad.

1159. Lee, Sam (1998). Cinturón negro. Arganda del Rey: Edimat. 1ae ed. 190 p. : il. ; $13 \times 21$ cm. ISBN: 84-8403066-0. Depósito legal: M. 27399-1998. Palabras clave: katas, fundamentos teóricos, filosofía, defensa personal, aplicación marcial, equipamiento, preparación física. Resumen: Manual teórico y técnico de artes marciales. El libro esta formado por 18 capítulos precedidos por una introducción que comenta el nacimiento del kárate y los objetivos de la obra. El primer capítulo comenta los diferentes métodos que existen dentro del kung fu para acondicionar y endurecer las manos del practicante. El segundo capítulo resalta las capacidades más importantes para el artista marcial y explica su importancia para el entrenamiento. El siguiente capítulo señala las peculiaridades de las situaciones de defensa personal y presenta algunas técnicas especiales de utilización en la calle. El cuarto capítulo describe e ilustra varios ejercicios de fortalecimiento de todo el cuerpo para realizar en solitario y en la naturaleza. Los siguientes tres capítulos estudian el rendimiento del artista marcial mediante la descripción de los diferentes métodos para la mejora de la concentración mental, la elasticidad y el entrenamiento de la competición. El octavo capítulo ofrece algunos consejos para solucionar pequeños problemas emocionales, y continúa con la explicación de cómo construir un saco flotante, un muñeco de madera, un makiwara y un cajón endurecedor. Los dos siguientes capítulos estudian el papel de la fuerza física y mental dentro del entrenamiento del artista marcial, y señalan las similitudes entre los ejercicios de distintas artes marciales junto con sus ventajas e inconvenientes. A continuación expone los principios de velocidad y precisión así como los 10 aspectos técnicos más importantes dentro del entrenamiento. El decimocuarto capítulo estudia los factores decisivos para el rompimiento de objetos, explicando cómo debe realizarse el acondicionamiento de las zonas de golpeo, los principios técnicos aplicados y cuáles son las normas para realizarlo correctamente. Después define las características de los diferentes practicantes atendiendo a su morfología o cinturón, presenta los aspectos generales de las katas junto con los principios técnicos más importantes y el nombre en japonés y castellano de las principales katas. Los dos últimos capítulos resaltan la importancia de la energía interna y su entrenamiento dentro de las artes marciales, incluyen varios ejemplos del trabajo de la energía interna y presenta la entrevista a varios maestros sobre la utilidad del combate.

1160. Lewis, Peter (1998). Las artes marciales : una guía para iniciarse en las técnicas de kung fu, kárate y taekwondo. Madrid: Susaeta. $1^{\underline{a}}$ ed. 146 p. : il. ; 21x28 cm. ISBN: 84-305-8724-1. Depósito legal: no. Palabras clave: historia, fundamentos teóricos, fundamentos técnicos, kárate, taekwondo, wushu. Resumen: Manual teórico y técnico de artes marciales. El libro esta formado por 3 capítulos precedidos por una introducción que comenta la historia del kung fu y las características e historia de las principales artes marciales. El primer capítulo comenta los contenidos técnicos, principios técnicos y entrenamiento del kung fu además de incluir la descripción e ilustración de varias secuencias técnicas. El segundo capítulo describe el desarrollo de una clase de kárate, comenta sus contenidos y principios técnicos, las características de su sistema de grados, los distintos tipos de combate y las tácticas de competición incluyendo la secuencia fotográfica de diversas técnicas y aplicaciones en el combate. El tercer capítulo detalla los ejercicios de calentamiento de una clase de taekwondo, explica la ejecución y principios técnicos de las principales patadas, técnicas de mano y posturas del taekwondo, la combinación de técnicas, las formas o taegeuk, comenta el entrenamiento en las técnicas de destrucción del taekwondo y las características del combate libre además de incluir la secuencia fotográfica de algunas de las técnicas explicadas. Adjunta un glosario e índice terminológico.

1161. Pérez Agustí, Adolfo (1987). El libro de oro del cinturón negro. Madrid: Adolfo Pérez Agustí. 1aㅡ ed. 191 p. : il. ; 15x21,5 cm. ISBN: 84-398-8328-5. Depósito legal: M. 43426-1986. Palabras clave: katas, fundamentos teóricos, filosofía, defensa personal, entrenamiento, aplicación marcial, equipamiento, preparación física. Resumen: Manual teórico y técnico de artes marciales. El libro esta formado por 18 capítulos precedidos por una introducción que comenta el nacimiento del kárate y los objetivos de la obra. El primer capítulo comenta los diferentes métodos que existen dentro del kung fu para acondicionar y endurecer las manos del practicante. El segundo capítulo resalta las capacidades más importantes para el artista marcial y explica su importancia para el entrenamiento. El siguiente capítulo señala las peculiaridades de las situaciones de defensa personal y presenta algunas técnicas especiales de utilización en la calle. El cuarto capítulo describe e ilustra varios ejercicios de fortalecimiento de todo el cuerpo para realizar en solitario y en la naturaleza. Los siguientes tres capítulos estudian el rendimiento del artista marcial mediante la descripción de los diferentes métodos para la mejora de la concentración mental, la elasticidad y el entrenamiento de la competición. El octavo capítulo ofrece algunos consejos para solucionar pequeños problemas emocionales y continúa con la explicación de cómo construir un saco flotante, un muñeco de madera, un makiwara y un cajón endurecedor. Los dos siguientes capítulos estudian el papel de la fuerza física y mental dentro del entrenamiento del artista marcial, y señalan las similitudes entre los ejercicios de distintas artes marciales junto con sus ventajas e inconvenientes. A continuación expone los principios de velocidad y precisión así como los 10 aspectos técnicos más importantes dentro del entrenamiento. El 
decimocuarto capítulo estudia los factores decisivos para el rompimiento de objetos, explicando cómo debe realizarse el acondicionamiento de las zonas de golpeo, los principios técnicos aplicados y cuáles son las normas para realizarlo correctamente. Después define las características de los diferentes practicantes atendiendo a su morfología o cinturón, presenta los aspectos generales de las katas junto con los principios técnicos más importantes y el nombre en japonés y castellano de las principales katas. Los dos últimos capítulos resaltan la importancia de la energía interna y su entrenamiento dentro de las artes marciales, incluyen varios ejemplos del trabajo de la energía interna y presenta la entrevista a varios maestros sobre la utilidad del combate.

1162. Pérez Agustí, Adolfo (1989). El libro de oro de las patadas. Madrid: Adolfo Pérez Agustí. 1ạ ed. 191 p. : il. ; 15x21,5 cm. ISBN: 84-404-5303-5. Depósito legal: M. 33306-1989. Palabras clave: fundamentos técnicos, ejercicios, entrenamiento, capacidades físicas, preparación física. Resumen: Manual teórico y técnico de patadas. El libro esta formado por 21 capítulos precedidos por una introducción que señala la importancia de las técnicas de pierna en las artes marciales y el objetivo del libro. Los doce primeros capítulos describen la ejecución y zona de impacto de la patada frontal, circular, lateral, trasera, trasera en coz, descendentes, en abanico, abanico de $360^{\circ}$, en salto, en tijereta, oblicua, de grulla y algunas de sus variantes acompañadas de sus ilustraciones explicativas. El siguiente capítulo ilustra la aplicación de diversas patadas en situaciones de defensa personal. El décimo cuarto capítulo describe e ilustra dos técnicas de barrido mientras que el siguiente explica la ejecución de cinco combinaciones de patadas. El décimo sexto capítulo expone distintos ejercicios de musculación específicos para las patadas más importantes. El décimo séptimo capítulo enumera los principios técnicos de los estiramientos junto con la descripción e ilustración de varios ejercicios. El siguiente capítulo presenta varios ejercicios para mejorar la flexibilidad de la cadera, mientras que los últimos tres capítulos describen algunos ejercicios avanzados de entrenamiento con el saco, combinaciones con el punching y un ejercicio con el cinturón.

1163. Poponic, Andrew y Brady, Peter (2009). Taichi y aikido. Girona: Tikal. 1aㅡ ed. 256 p. : il. ; 18x23,5 cm. ISBN: 978-84-92678-69-3. Depósito legal: no. Palabras clave: fundamentos teóricos, principios técnicos, fundamentos técnicos, formas, taoísmo, taijiquan, aikido, aplicación marcial, defensa personal. Resumen: Manual teórico y técnico de taichi y aikido. El libro esta formado por dos partes precedidas por una introducción que comenta cómo utilizar este libro y sus contenidos. La primera parte consta de 8 capítulos precedidos por una introducción que explica brevemente en qué consiste el taichi. El primer capítulo presenta los fundamentos teóricos del taoísmo, las características de las artes taoístas internas, la medicina china y el qigong, narra el origen y evolución del taichi, las peculiaridades de sus principales estilos así como del hsing-i y bagua. El segundo capítulo enumera los beneficios derivados de la práctica del taichi, sus fundamentos teóricos, la meditación y sus aplicaciones terapéuticas. El tercer capítulo detalla los principios técnicos del taichi, describe varios ejercicios de respiración, los movimientos básicos de taichi y algunos ejercicios para relajar y liberar el cuerpo de tensiones acompañados de su secuencia fotográfica. El cuarto capítulo describe los principios y movimientos de la forma corta del estilo Wu junto con sus ilustraciones explicativas y esquemas de movimiento. El quinto capítulo ofrece varios consejos prácticos para mejorar en el taichi, explica la ejecución de varios ejercicios de meditación y la práctica denominada "manos que empujan" incluyendo numerosas fotografías, y detalla la aplicación del taichi al combate y a la vida diaria. El séptimo capítulo explica cómo elegir profesor, escuela y estilo de taichi. El último capítulo incluye contactos y lecturas complementarias sobre taichi. La segunda parte consta de 7 capítulos precedidos por una introducción que expone las características de la práctica del aikido. El primer capítulo narra los orígenes y evolución del aikido, sus fundamentos teóricos, sus principios técnicos y filosóficos y su equipamiento. El segundo capítulo describe e ilustra varios ejercicios de preparación así como los movimientos de base del aikido. El tercer capítulo explica la ejecución de las principales técnicas de aikido acompañadas de su secuencia fotográfica. El cuarto capítulo describe la ejecución de varias técnicas con armas así como algunas de sus aplicaciones en la defensa personal junto con sus ilustraciones explicativas. Los dos siguientes capítulos comentan los estilos de aikido y algunas recomendaciones para encontrar un club. El último capítulo incluye contactos y lecturas complementarias sobre aikido. Adjunta un glosario de taichi y aikido, un índice onomástico y agradecimientos.

1164. Sanchís, Santiago (Soke) (2007). Las 50 mejores llaves de brazos y piernas y sus salidas... posibles. Madrid: Budo International. 1aㅡ ed. 175 p. : il. ; 16×24 cm. ISBN: 978-84-96492-74-5. Depósito legal: M. 8215-2007. Palabras clave: fundamentos técnicos. Resumen: Manual teórico y técnico de artes marciales mixtas. El primer capítulo explica las características de las llaves y sus objetivos, comenta los contenidos del libro y sus objetivos, y ofrece algunos consejos para su práctica y sus principios de entrenamiento. El segundo capítulo ilustra la ejecución de las técnicas kote-gaeshi, ude-garami, waki katame, yubi yodan e ippon senaka junto con las distintas salidas posibles a dichas técnicas. El tercer capítulo presenta la secuencia fotográfica de las técnicas juji katame y juji ude además de sus salidas y contraataques. El cuarto capítulo incluye la representación gráfica de la ejecución de las técnicas yoko 
hiji, ude hishigi juji katame, ude garami, ude katame, ude ni waza, hiji waza, yoko juji katame, tebuki shimi, kesa katame, kubi katame, ude ashi katame y ushiro ude senaka junto con sus salidas y aplicación como contraataques. El quinto capítulo ilustra las técnicas mae geri, ashi yoko nage, mawashi geri, ashi maki komi, ushiro geri, kami hasami, la combinación mae geri-ouchi gari, shimi kubi koshi, kakato geri, hiza hiki, la combinación mae geri-mae hiza shimi, además de sus salidas, contraataques y luxaciones a la pierna, tobillo.

\subsection{Defensa Personal}

\subsubsection{Femenina}

1165. Callero González, Felipe Concepción y Hess, Joe (1997). Defensa personal femenina. Las Palmas de Gran Canaria: International Security and Police Association (Felipe Callero González). 1aㅡ ed. 218 p. : il. ; $21 \times 25 \mathrm{~cm}$. ISBN: 84-923535-0-3. Depósito legal: no.

1166. Clara Sánchez, Daniel (2003). Mujer, defiéndete. s.l.: Ambos Mundos. 1a ed. 125 p. : il. ; $15 \times 22$ cm. ISBN: 84-7455-094-7. Depósito legal: S. 1783-2003. (3ª ed., 2006, 110 p., ISBN: 84-96186-26-1). Palabras clave: fundamentos teóricos, fundamentos técnicos, principios técnicos, defensa personal, legislación, principios de actuación, violencia. Resumen: Manual teórico y técnico de defensa personal. El libro esta formado por 10 capítulos precedidos por un prólogo que comenta los contenidos de la obra y una introducción que señala sus objetivos. El primer capítulo expone la situación de la violencia doméstica en España, sus características, consecuencias físicas y psicológicas, las variables que condicionan la permanencia de la mujer maltratada y el maltratador, y las fases de la violencia doméstica. El segundo capítulo señala las características de los malos tratos sociales, psicológicos y económicos. El tercer capítulo enumera las evidencias de los malos tratos mientras que el cuarto analiza al agresor y sus características. El quinto capítulo describe los principios de actuación ante posibles situaciones de peligro como al llegar al domicilio, en el ámbito familiar, en los transportes públicos, ante llamadas telefónicas, en cabinas telefónicas y cajeros automáticos, en parques públicos y al aire libre, y en salidas con desconocidos. El sexto capítulo ofrece varios consejos prácticos para comenzar una actividad física además de los contenidos de cada una de las partes de una sesión de entrenamiento. El séptimo capítulo detalla la utilización correcta del spray de defensa personal, enumera los puntos vitales del cuerpo humano, señala los principios técnicos de la defensa personal y describe diferentes técnicas de defensa personal contra ataques armados y sin armas incluyendo su secuencia fotográfica. El octavo capítulo resume los principios de actuación ante una agresión. Los dos últimos capítulos incluyen la información general sobre los derechos y obligaciones recogidos en la ley 35/1995 y la orden de protección a las víctimas de la violencia doméstica recogida en la ley 27/2003. Adjunta bibliografía y direcciones de contacto de interés.

1167. Ekin Emakumeak Elkartea (2006). Autobabesa. Arrasate: Ekin Emakumeak AED Elkartea. 1a ed. 36 p. : il. ; 14x20,5 cm. ISBN: No ISBN. Depósito legal: VI. 495-2006. Palabras clave: fundamentos técnicos, ejercicios, principios de actuación, relajación, violencia. Resumen: Manual teórico y técnico de defensa personal. El libro esta formado por 6 capítulos precedidos de una introducción que señala los objetivos de la obra. Los dos primeros capítulos define los términos de violencia y defensa personal. El tercer capítulo analiza el concepto de autoestima y sus variables y propone un ejercicio para mejorar la autoestima. El cuarto capítulo expone el modelo para la resolución rápida de conflictos y el desarrollo de una técnica de relajación. El quinto capítulo presenta la secuencia fotográfica de varias técnicas de defensa personal femenina. El último capítulo incluye direcciones y teléfonos de interés.

1168. Grosser, Vicky; Mason, Gaby y Parmar, Rani (1996). Autodefensa para chicas. Santa Marta de Tormes (Salamanca): Lóguez. 1aㅡ ed. 123 p. : il. ; 13x21 cm. ISBN: 84-85334-91-4. Depósito legal: S. 284-1996. Palabras clave: fundamentos teóricos, principios técnicos, defensa personal, entrenamiento, kyusho. Resumen: Manual teórico y técnico de defensa personal femenina. La obra esta formada por 8 capítulos. El primer capítulo explora la situación actual de la autodefensa, las razones para practicarla, algunos de los mitos que la rodean, las razones que suelen aparecer en la violencia contra las mujeres, los sentimientos que suelen acompañar al entrenamiento de defensa personal, los grupos de mayor riesgo de agresión y los beneficios de la autodefensa. El segundo capítulo incluye varias historias sobre situaciones de defensa personal y cómo fueron solucionadas. El tercer capítulo expone algunas técnicas y principios de defensa sin el uso de la fuerza física adjuntando varias ejemplos prácticos. Los dos siguientes capítulos explican e ilustran distintos ejercicios de calentamiento, la ejecución de varias técnicas para tomar la iniciativa o responder a diferentes ataques, los puntos vulnerables del cuerpo, y algunos consejos ante un ataque armado y la utilización de las armas como autodefensa. El sexto capítulo enumera y explica las reacciones y sentimientos después de ser atacado y cómo superarlos. El séptimo capítulo enumera las directrices básicas para programar una clase de autodefensa y finaliza con un comentario sobre el derecho a defenderse y direcciones de contacto en caso de maltrato. 
1169. Hoffer, Bruno (2004). Curso de autodefensa femenina. Barcelona: De Vecchi. 1a ed. 127 p. : il. ; 17x24 cm. ISBN: 84-315-3030-8. Depósito legal: B. 12329-2004. Palabras clave: fundamentos teóricos, fundamentos técnicos, principios técnicos. Resumen: Manual teórico y técnico de defensa personal. El libro esta formado por tres partes. La primera parte incluye 4 capítulos que explican la situación de legítima defensa, algunos consejos generales sobre el entrenamiento, las características de las agresiones, y algunas nociones básicas para evitar las situaciones de peligro en nuestra vida diaria. La segunda parte presenta e ilustra los fundamentos técnicos de la defensa personal, explicando los desvíos, los bloqueos y las paradas, los golpes y las zonas a golpear, las llaves y las torsiones articulares, los desequilibrios, las estrangulaciones, la utilización de los objetos más comunes, cómo soltarse de un agarre, los puntos del cuerpo más dolorosos y las guardias, acompañados de una breve descripción de cada movimiento y varias ilustraciones que presentan la técnica por partes. La última parte describe brevemente las técnicas de defensa personal ante ataques frontales, laterales, por la espalda, en posición sentada, desde el suelo, contra una pared, y con armas, incluyendo la secuencia fotográfica de cada técnica por partes.

1170. Hombre Dopazo, Juan (2006). Taishindó : defensa personal femenina-XCAPE. Madrid: Juan Hombre Dopazo. 1a ed. 150 p. : il. ; 17x24 cm. ISBN: 84-609-9352-3. Depósito legal: no.

1171. Saavedra López, Andoni; Núñez Gorospe, César; Bikandi Elorriaga, Asier y Calvo Valcuende, Iñaki (2004). Emakumeentzako defentsa pertsonala = defensa personal para mujeres. Zornotza: Ukabilak Zornotza. 1aㅡ ed. 143 p. : il. ; 17x24 cm. ISBN: 84-609-3749-6. Depósito legal: BI. 2974-2004. Palabras clave: ejercicios, fundamentos técnicos, defensa personal. Resumen: Manual teórico y técnico de defensa personal femenina. El libro esta formado por 5 capítulos precedidos por una presentación que comenta la educación que recibían las mujeres antiguamente y los objetivos del libro, y una introducción que presenta los contenidos del libro. El primer capítulo describe varios ejercicios para aprender a colocar el cuerpo, la guardia y caer incluyendo su secuencia fotográfica. El segundo capítulo describe la ejecución de algunos golpes con las extremidades superiores, inferiores y con la cabeza junto con su ilustración. El tercer capítulo presenta la descripción e ilustración de varias técnicas de defensa personal ante varios agarres de muñecas, el agarre por el pecho, el cuello y los brazos, cuando caemos al suelo con el agresor encima y cuando nos agreden con un arma blanca. El cuarto capítulo comenta la utilización de elementos cotidianos como el bolso, una carpeta, un bolígrafo y un llavero en situaciones de defensa personal. El último capítulo explica las reacciones habituales ante una agresión y cómo prepararse para ella.

1172. Zoia, Alessandra (1995). Curso de defensa personal para la mujer : la preparación física, la preparación técnica: las posiciones, los puntos vitales, las técnicas psicológicas, los objetos útiles para la defensa, etc. Barcelona: De Vecchi. 1aㅡ ed. 191 p. : il. ; 16x23,5 cm. ISBN: 84-315-1505-8. Depósito legal: B. 437361995. (2a ed., 2000, ISBN: 84-315-2331-X). Palabras clave: fundamentos teóricos, fundamentos técnicos, principios técnicos, defensa personal, entrenamiento, competición, preparación física, violencia, armas. Resumen: Manual teórico y técnico de defensa personal. El libro consta de dos partes. La primera parte esta formada por 6 capítulos. El primer capítulo analiza el problema actual de las agresiones junto con sus causas externas e internas. El segundo capítulo explica los tipos de agresión además de las características de los diferentes agresores. El tercer capítulo describe las reacciones de la persona agredida, sus estados emocional y mental y su comportamiento ante la agresión. El cuarto capítulo expone los principios de la defensa personal y la actuación de la víctima ante ciertas situaciones de agresión. El quinto capítulo describe distintos ejercicios de preparación física para mejorar el tono muscular, la resistencia y la agilidad y elasticidad, acompañados de sus ilustraciones explicativas. El último capítulo los principios y fundamentos técnicos de la defensa personal como son la posición de guardia, los puntos vitales, la respiración, la mirada y la voz. La segunda parte consta de 10 capítulos o lecciones, precedidas por una introducción que explica los contenidos de la segunda parte, propone un plan de entrenamiento y los consejos prácticos para el entrenamiento. La primera lección describe la ejecución técnica de un puñetazo y varios ejercicios para su entrenamiento individual y por parejas. La segunda lección presenta varios ejercicios para mejorar la movilidad y elasticidad de las extremidades inferiores, describe la ejecución de la patada frontal y lateral acompañadas de su representación gráfica, comenta sus principios técnicos, los errores más comunes y cómo utilizarlas. Las dos siguientes lecciones describen la ejecución del codazo y del rodillazo acompañadas de su ilustración y sus aplicaciones. La quinta lección presenta la descripción y aplicación de varias llaves articulares mientras que la sexta lección muestra las defensas, esquivas y formas de caer acompañadas de su representación y consejos prácticos. La séptima lección explica la utilización de las manos y la cabeza como armas describiendo algunas de sus técnicas así como de algunos objetos cotidianos para ser utilizados en una situación de defensa personal. La octava lección presenta la secuencia fotográfica y explicación de varias situaciones de defensa personal ante una tentativa de tirón, el intento de abuso físico, las presas y los forcejeos, los estrangulamientos y las agresiones bajo la amenaza de una jeringuilla. Las dos últimas lecciones describen las técnicas de defensa personal ante una tentativa de violación, el ataque de varios agresores, las agresiones en el 
portal, en el coche, en el ascensor y en una cabina, incluyendo sus correspondientes ilustraciones explicativas.

\subsubsection{General}

1173. Arpin, Louis (1974). Guía de la defensa personal : técnica para hombres y mujeres. Bilbao: Mensajero. 1a ed. 302 p. : il. ; 14x20 cm. ISBN: 84-271-0837-0. Depósito legal: BI. 661-1974. (2ª ed., 1979, 285 p., ISBN: 84-271-0837-0). Palabras clave: fundamentos técnicos, principios técnicos, defensa personal. Resumen: Manual técnico de defensa personal. Después de comenzar con una breve introducción sobre el valor de la defensa personal y su utilización, comienza dando unos consejos técnicos generales para la práctica de la defensa personal. Continua con una breve explicación de las distintas artes marciales en las que se va a apoyar para desarrollar las técnicas de defensa personal (judo, junbi-taiso, aikido, kárate, sumo) que explica a continuación. Describe e ilustra 43 situaciones de defensa personal en las que se utilizan distintas técnicas como respuesta al ataque. Así, aparecen técnicas ante agarres de la cabeza, el cuello, las manos, el hombro, la solapa, el torso, empujones, ataques en una escalera, en un ascensor, sentado en el restaurante, contra golpes y puñetazos, contra armas como cuchillos, bastones, sillas o incluso revólveres. Adjunta una biografía del autor y un índice.

1174. Benzal Mishal, Pedro (2003). El arte de la autodefensa : fundamentos. Valencia: Pedro Benzal Mishal. 1'a ed. 142 p. : il. ; 14x20,5 cm. ISBN: No ISBN. Depósito legal: V. 2898-2003. Palabras clave: fundamentos teóricos, táctica, fundamentos técnicos, principios técnicos, defensa personal, artes marciales, primeros auxilios, legislación, preparación física, preparación psíquica, armas. Resumen: Manual teórico y técnico de defensa personal. El libro esta formado por 7 capítulos precedidos por los agradecimientos y un prólogo que comenta los objetivos del libro. El primer capítulo analiza los factores psíquicos implicados en una situación de defensa personal, comenta la importancia de la respiración, su proceso y propone dos ejercicios para relajarnos. El segundo capítulo define las cualidades físicas, destaca la importancia de la preparación física para la defensa personal y describe distintos ejercicios de fortalecimiento y estiramiento. El tercer capítulo comenta los medios para evitar un ataque, describe los principios técnicos y de actuación ante dicho ataque, la ejecución de la posición de guardia, las principales defensas, ataques, proyecciones y luxaciones acompañadas de sus ilustraciones, además de presentar la descripción y secuencia fotográfica de distintas técnicas de defensa personal ante un sólo atacante y enumerar los principios de actuación ante varios atacantes o ataques armados. El cuarto capítulo expone los delitos y faltas relacionados con la defensa personal junto con sus penas y la legislación relacionada con la defensa personal. El quinto capítulo ofrece algunas medidas preventivas de situaciones peligro así como un comentario sobre el perfil de los agresores. El sexto capítulo expone los primeros auxilios ante una persona inconsciente, fracturas, contusiones, luxaciones y heridas. El último capítulo expone brevemente la historia y características de los monjes shaolin, el kung fu, el kárate, el kobudo, el judo, el aikido, el jiu jitsu, el ninjitsu, el shorinji kempo, el taekwondo y el hapkido. Adjunta un epílogo.

1175. Boillat de Corgemont Sartorio, Marc (2008). Violencia : defensa personal y defensa legítima. Barcelona: Shinden. 1a ed. 250 p. ; 14x21 cm. ISBN: 978-84-96894-08-2. Depósito legal: B. 49684-2008. Palabras clave: defensa personal policial, artes marciales, psicología, deportes de combate, legislación, reglamentos, sociedad, violencia. Resumen: Tratado teórico sobre defensa personal. El libro esta dividido en dos partes, compuestas de 6 y 3 capítulos respectivamente. El primer capítulo describe los factores que engendran la violencia en el individuo y en la sociedad actual, el papel de la empatía para controlar dicha violencia, cómo se focaliza la crueldad hacia grupos sociales indefensos, algunos de los signos predictivos de comportamientos violentos, y las causas y efectos de la deficiencia empática. El segundo capítulo explica en qué consiste la sociedad del miedo y cuáles son sus manifestaciones actuales, analiza la posible utilización de las armas como forma de alcanzar la seguridad ciudadana, el papel de los jóvenes en la sociedad y su evolución, cuáles son los factores de una sociedad pacífica, el proceso de desinformación que promueve la adhesión social, la evolución, características y repercusiones del actual sistema penal, comenta las dos principales teorías sobre la criminalidad, la política del Tribunal Penal Internacional, critica las diferencias penales entre los criminales de guerra y la delincuencia corriente, comenta las causas de posesión de armas del ciudadano corriente y el delincuente, y expone las datos sobre seguridad ciudadana, criminalidad, violencia y armas de fuego en España. El tercer capítulo incluye un breve cuestionario realizado a 7 personas sobre la seguridad ciudadana en EE.UU., discute los datos de seguridad ciudadana de España y el consumo de drogas como la cocaína y la heroína, y comenta los problemas individuales ante la inseguridad ciudadana. El cuarto capítulo define los conceptos de agresividad, violencia, asesinato, homicidio doloso, homicidio culposo, agresión impulsiva y agresión premeditada, además del papel de las artes marciales ante tales comportamientos. El quinto capítulo describe las respuestas fisiológicas y psicológicas de agresor y víctima ante una situación de agresión así como la importancia del factor sorpresa en dicha situación. 
El sexto capítulo expone las características del enfrentamiento combativo y la lucha para luego explicar los objetivos, funciones y características de las artes marciales, deportes de contacto, defensa policial y antidisturbios ante situaciones de confrontación física. La segunda parte aborda la defensa personal desde el ámbito jurídico. El primer capítulo define el concepto de defensa personal, comenta la efectividad de ciertas técnicas defensivas y define los conceptos civil, penal, atenuante y eximente en relación con la defensa legítima. El segundo capítulo diferencia las situaciones de defensa propia y defensa legítima, presenta el artículo 20 del código penal, las condiciones para considerar una situación de defensa legítima, la ley de proporcionalidad, los agravantes de alevosía y de abuso de superioridad junto con algunos ejemplos de las situaciones descritas. El último capítulo incluye el reglamento de armas.

1176. Castro Santiago, Juan Antonio (1995). Goshin-do : camino de la defensa personal. Tarrasa: Gimnasio Zazen. 1a ed. 14 p. : il. ; 15x21 cm. ISBN: No ISBN. Depósito legal: B. 2736-1995. Palabras clave: fundamentos teóricos, fundamentos técnicos, reglamentos, competición. Resumen: Manual teórico de goshin-do. La obra esta formada por 5 capítulos, precedidos por el currículo del autor y una dedicatoria. El primer capítulo explica los conceptos básicos de goshin-do mientras que el segundo comenta los diferentes estilos existentes en la actualidad. El tercer capítulo enumera los contenidos técnicos del goshin-do y sus modalidades deportivas. El cuarto capítulo expone su reglamentación deportiva mientras que el quinto detalla el reglamento de competición del goshin-contact.

1177. Daunis, Julio (1977). Defensa personal. Barcelona: Bruguera. 1aㅡ ed. 32 p. : il. ; 15x21 cm. ISBN: 84-0205064-6. Depósito legal: no.

1178. Di Marino, Stefano (1992). Manual Tutor de autodefensa. Madrid: Tutor. $1 \underline{\underline{a}}$ ed. 187 p. : il. ; $16 \times 24 \mathrm{~cm}$. ISBN: 84-7902-082-2. Depósito legal: M. 33417-1992. Palabras clave: fundamentos técnicos, defensa personal, entrenamiento, táctica, kyusho, armas. Resumen: Manual teórico y técnico de defensa personal. La obra esta compuesta de 6 capítulos precedidos de una introducción que comenta las razones para publicar esta obra y un comentario sobre la utilidad de la defensa personal. El primer capítulo describe las situaciones de violencia de la sociedad actual, la actitud inicial ante dichas situaciones, una clasificación de las posibles agresiones y descripción de los agresores. El segundo capítulo incluye consejos prácticos para afrontar el primer contacto con una agresión además de incluir la descripción e ilustración de varios ejercicios de relajación. El tercer capítulo expone el método de entrenamiento que se expondrá más adelante, detalla la importancia de la condición física para la defensa personal, propone distintos ejercicios de acondicionamiento físico general y una tabla de entrenamiento, explica las técnicas más apropiadas para hombres, mujeres y niños, comenta las posibilidades de ciertas artes marciales para ser utilizadas como método de defensa personal, y describe e ilustra la situación de los puntos vulnerables del cuerpo humano. El cuarto capítulo clasifica las técnicas de la defensa personal, describe la ejecución y los puntos clave e ilustra la posición de guardia, las técnicas de puño, los golpes con los miembros inferiores, las técnicas de presa y dislocación, y las técnicas defensivas. También incluye consejos para elegir dónde, cuándo, cómo entrenar y el proceso de aprendizaje a seguir. El quinto capítulo expone las reacciones correctas ante diversos agresores, presenta la resolución técnica de las agresiones más comunes y describe la posible utilización de instrumentos cotidianos como armas de defensa personal y otras armas. El último capítulo analiza las respuestas de mujeres y niños ante situaciones de violencia. Adjunta un apéndice con distintos tests para evaluar el conocimiento de los contenidos teóricos expuestos, la condición física y la capacidad de defensa personal, un compendio de las directrices más importantes de la defensa personal, un comentario de los efectos legales de la defensa personal y un glosario.

1179. Equipo de Especialistas Júpiter (1995). Guía práctica de defensa personal. Barcelona: De Vecchi. 1a ed. 126 p. : il. ; 14x20,5 cm. ISBN: 84-315-1420-5. Depósito legal: B. 27395-1995. (2ª ed., 2006; $3^{\mathrm{a}}$ ed., 2006, ISBN: 84-315-3331-5). Palabras clave: fundamentos teóricos, principios técnicos, defensa personal, ejercicios, cualidades físicas, armas. Resumen: Tratado teórico y técnico sobre la defensa personal. Esta dividido en 8 capítulos, con los 3 primeros dedicados a la teoría de la defensa personal. El primero de ellos comenta las aportaciones de las artes marciales orientales y occidentales a la defensa personal, para continuar en el segundo con la explicación de las diferentes partes del cuerpo para ser utilizadas como arma. El tercer capítulo presenta la teoría sobre las cualidades físicas y su importancia dentro de la defensa personal. Los siguientes capítulos abordan la propia práctica de la defensa personal, con el cuarto capítulo describiendo sus principios básicos y algunas técnicas. El quinto capítulo ahonda en la defensa personal y su aplicación ante ataques armados, y continua en el siguiente con la descripción de algunas técnicas de mayor nivel de dificultad. El séptimo capítulo presenta una serie de ejercicios para valorar la progresión del practicante en sus entrenamientos. El último capítulo ofrece un resumen de los aspectos más importantes en la defensa personal.

1180. Fu, Leong (1965). Defensa personal en cualquier emergencia. Barcelona: Sintes. $1 \underline{\underline{a}}$ ed. 94 p. : il. ; 12x17,5 cm. ISBN: No ISBN. Depósito legal: B. 8748-1965. Palabras clave: fundamentos teóricos, fundamentos técnicos, defensa personal, entrenamiento, kyusho, armas. Resumen: Manual teórico y técnico de defensa personal. El libro esta compuesto por 13 capítulos precedidos por una introducción 
que comenta la biografía del autor. El primer capítulo ofrece varios consejos para progresar en el entrenamiento. Los siguientes tres capítulos explican la utilización de las manos, pies y codos como armas acompañados de su representación gráfica. El quinto capítulo describe la ejecución de las técnicas de defensa básicas junto con su ilustración. El siguiente capítulo localiza los puntos vitales del cuerpo humano. Los dos siguientes capítulos diversas técnicas de defensa personal ante distintos ataques de frente y por detrás acompañados de su representación gráfica y esquemas de movimiento. Los últimos cinco capítulos explican la ejecución técnica de diversas defensas contra varios atacantes, golpes de palo, ataques con cuchillo, ataques con revólver y contra un ataque estando sentados incluyendo su representación gráfica y esquemas de movimiento.

1181. Galán Sánchez, Manuel (1998). Fu-jitsu : método superior de defensa personal. Madrid: Esteban Sanz Martínez. 1aㅡ ed. 157 p. : il. ; 15x21 cm. ISBN: 84-8597767-X. Depósito legal: M. 10200-1998. Palabras clave: fundamentos técnicos, defensa personal. Resumen: Manual técnico de fu-jitsu. La obra esta compuesta de 15 capítulos. Comienza con la enumeración e ilustración de algunos ejercicios de calentamiento para el tronco, cuello, piernas, cintura y ejercicios en el suelo. El segundo capítulo explica las formas de caer en todas direcciones y el tercero las líneas fundamentales de defensa. Desde el cuarto capítulo hasta el final, presenta y describe con brevedad las defensas contra diferentes ataques como agarres de muñeca, agarres de cuello, agarres del tronco, estrangulaciones, control de hombros, agarres de solapa, ataques de puño a la cara, ataques de pierna de frente, ataques con un palo, ataques con una silla, amenazas con un cuchillo y ataques con un cuchillo.

1182. García García, José Manuel (1985). Defensa personal para todos. Barcelona: Círculo de Lectores. $1^{\text {a }}$ ed. 167 p. : il. ; 15x21 cm. ISBN: 84-226-1954-7. Depósito legal: B. 26735-1985. Palabras clave: fundamentos teóricos, fundamentos técnicos, defensa personal, ejercicios, calentamiento, armas. Resumen: Manual teórico y técnico de defensa personal. El libro esta compuesto por cinco partes. La primera parte expone dónde entrenar, con quién, la vestimenta necesaria, ofrece algunos consejos previos a la práctica y expone el vocabulario utilizado en el libro. La segunda parte describe la ejecución de distintos ejercicios de calentamiento acompañados de sus ilustraciones explicativas. La tercera parte explica la ejecución de las diferentes formas de caer mientras que la cuarta parte presenta la descripción e ilustración de las posiciones y desplazamientos fundamentales junto con sus métodos de entrenamiento y algunos ejercicios técnicos básicos. La quinta parte clasifica los tipos de agresión, las técnicas de defensa personal e incluye la descripción técnica y secuencia fotográfica de las diversas defensas contra agarres de muñeca, estrangulaciones, agarres o presas de cuerpo entero, agarres de solapas, patadas, puñetazos y contra individuos armados con cuchillo, objetos contundentes y pistola. Adjunta un apéndice comenta la historia, características y fundamentos técnicos del jiu-jitsu, judo, aikido y kárate.

1183. Gasco Leranca, Ángel (1989). Curso de defensa personal : técnica general. Barcelona: Orthos, Instituto Español de Educación Física. 1aㅡ ed. 206 p. : il. ; 21x29,5 cm. ISBN: No ISBN. Depósito legal: B. 371641989. Palabras clave: fundamentos teóricos, fundamentos técnicos, ejercicios, calentamiento, legislación, preparación física, armas, defensa personal. Resumen: Manual teórico y técnico de defensa personal. El libro esta formado por una parte precedida por el currículo del autor, los agradecimientos, el objetivo de la obra y un resumen del origen y evolución de las artes desarmadas en Occidente y Oriente. La primera parte consta de 5 capítulos. El primer capítulo define los conceptos de agresividad, violencia, agresión y defensa personal. El segundo capítulo comenta la legislación relacionada con la defensa personal. El tercer capítulo expone los fundamentos teóricos de la preparación física, las características del calentamiento y explica diferentes ejercicios de calentamiento general y específico acompañados de su representación gráfica. El cuarto capítulo incluye el cuadro de técnicas de jiu-jitsu de la Federación Española de Judo y D.A. El quinto capítulo expone los fundamentos teóricos de la defensa personal como son la evaluación de una situación de peligro, las fases del entrenamiento defensivo, la psicología del combate, el ataque y sus tipos, las caídas, las posiciones y guardias, los desplazamientos y esquivas, los bloqueos y desvíos, los puntos vitales, las técnicas básicas,. la lucha en el suelo, el encadenamiento de técnicas, el contraataque, la distancia de combate, los trabajos dinámicos, los objetos contundentes y armas, el arma blanca y el arma de fuego, además de ilustrar sus fundamentos técnicos y las técnicas de defensa personal en las distintas situaciones.

1184. Gasco Leranca, Ángel (1990). Curso de defensa personal : técnica específica. Barcelona: Orthos, Instituto Español de Educación Física. 1a ed. 71 p. : il. ; 21x29,5 cm. ISBN: No ISBN. Depósito legal: B. 178581990. Palabras clave: fundamentos técnicos, defensa personal policial, legislación, programa técnico, armas. Resumen: Manual teórico y técnico de defensa personal. El libro esta formado por una parte que consta de 5 capítulos. El primer capítulo presenta la descripción y secuencia fotográfica de las diferentes técnicas de defensa personal contra distintos agarres, golpeos y ataques armados de un sólo oponente, contra varios oponentes, las formas de control, conducción y cacheo y el manejo y técnicas básicas de la defensa reglamentaria. El segundo capítulo resume la legislación referente al vigilante jurado. El tercer capítulo expone las labores del vigilante jurado en la vigilancia de centros de trabajo y la protección de personalidades. El cuarto capítulo explica la estructura, características y 
funcionamiento de las armas de fuego así como sus fundamentos técnicos. El quinto capítulo incluye el programa de sesiones para el curso de Especialistas en Defensa Personal.

1185. Gladman, George (1955). Cómo defenderse sin armas. Barcelona: Sintes. $1^{\underline{a}}$ ed. 61 p. : il. ; $12 \times 18 \mathrm{~cm}$. ISBN: No ISBN. Depósito legal: no. (2 $2^{\underline{a}}$ ed., 1958; $3^{\underline{a}}$ ed., 1960; $4^{\underline{a}}$ ed., 1961; $5^{\underline{a}}$ ed., 1962; $6^{\underline{a}}$ ed., 1963; $7^{\underline{a}}$ ed., 1965; 8ae ed., 1967; 10ae ed., 1978, ISBN: 84-302-0392-3). Palabras clave: principios técnicos, defensa personal, armas. Resumen: Manual teórico y técnico de defensa personal. La obra consta de 7 capítulos. El primer capítulo expone las características del jiu-jitsu. El segundo capítulo incluye algunos consejos para la práctica y señala algunos de los principios tácticos de la defensa personal. El tercer capítulo explica en qué consiste la defensa personal, algunos de sus ejercicios de fortalecimiento y localiza los puntos vitales del cuerpo humano. El cuarto capítulo describe las técnicas utilizadas ante las presas de muñeca acompañadas de su representación gráfica. El quinto capítulo expone la descripción de varias técnicas ante una presa de estrangulamiento tanto de pie como en el suelo junto con sus ilustraciones explicativas. El sexto capítulo señala los principios de actuación ante un ataque armado de cuchillo, bastón y pistola, y ante un boxeador incluyendo la representación gráfica de su resolución. El último capítulo incluye la secuencia gráfica de varias técnicas de defensa personal ante presas y estrangulamientos así como de algunas técnicas de proyección del adversario.

1186. Gladman, George (1955). Defensa personal : con un apéndice de lucha libre (Catch as catch can). Barcelona: Sintes. $1^{\underline{a}}$ ed. 414 p. : il. ; 13x18,5 cm. ISBN: No ISBN. Depósito legal: no. (2ª ed., 1959, 317 p.; 3ํㅡㄹ. ed., 1962, 317 p.; 4⿳亠丷a ed., 1966, 295 p.). Palabras clave: fundamentos técnicos, defensa personal, armas, kyusho. Resumen: Manual técnico de defensa personal. El libro esta formado por 17 capítulos precedidos por una introducción que comenta las diferencias entre judo y jiu-jitsu respecto a la defensa personal y la descripción de algunos ejercicios para el fortalecimiento de las manos y los pies como preparación para la defensa personal. Los dos primeros capítulos presentan los fundamentos de la defensa personal como son las distintas formas de caer y las posiciones de defensa, describiendo su ejecución e ilustrando cada movimiento por partes. Los siguientes 11 capítulos describen e ilustran las técnicas de defensa ante diferentes ataques y agresiones. Las defensas estudiadas responden contra ataques de frente, presas a la muñeca, ataques por detrás, ataques laterales, defensas contra golpes, defensas contra un boxeador, defensas contra golpes de palo, contra cuchillo, contra golpes de hacha, contra revolver y contra perros. El decimocuarto capítulo describe la localización de los principales puntos débiles del cuerpo humano y las distintas formas de golpear con las partes de la mano, el codo, la cabeza, la rodilla y el pie. El siguiente capítulo describe e ilustra por partes varias técnicas para controlar a un adversario y continua con distintas técnicas de defensa ante un atacante que intenta estrangularnos cuando estamos en el suelo. Finaliza con un conjunto de consejos finales ante cualquier situación de defensa personal. Incluye un apéndice sobre las generalidades del reglamento, el entrenamiento y las técnicas de la lucha libre americana.

1187. Habersetzer, Roland (1974). La defensa personal. Madrid: Espasa-Calpe. 1a ed. 64 p. : il. ; $13 \times 18 \mathrm{~cm}$. ISBN: 84-239-6661-5. Depósito legal: M. 35721-1973. Palabras clave: fundamentos técnicos, principios técnicos, defensa personal femenina, armas. Resumen: Manual teórico y técnico de defensa personal. El libro esta formado por 3 partes precedidas de varios capítulos introductorios que destacan la necesidad de la defensa personal, comentan los contenidos del libro, ofrece algunos consejos para la práctica y algunos principios ante el combate. La primera parte describe la guardia y actitud ante un ataque, la ejecución de las técnicas de regate y fintas, tres proyecciones, algunas técnicas de luxación y golpeo y sus combinaciones, y ofrece varios consejos ante un ataque armado. La segunda parte incluye la descripción e ilustración de 36 técnicas de defensa personal ante ataques a mano limpia, como las presas, abrazos, estrangulaciones, puñetazos y patadas, y ante ataques a mano armada con cuchillo y palo. La tercera parte explica la ejecución de diversas técnicas de defensa personal en situaciones especiales como ante un boxeador, una llave de brazo o un cabezazo, contra varios adversarios y varias técnicas específicas de defensa personal femenina ante diversos ataques. Adjunta una conclusión e índice.

1188. Hervás, Ramón (1966). Cómo defenderse en la calle sin armas. Barcelona: Rodegar. 1aㅡ ed. 158 p. : il. ; 11x15,5 cm. ISBN: No ISBN. Depósito legal: B. 29815-1966. (2ª ed., 1972, 125 p.). Palabras clave: historia, fundamentos teóricos, táctica, fundamentos técnicos, principios técnicos, defensa personal, kyusho, programa técnico, armas. Resumen: Manual teórico y técnico de judo. La obra esta formada por 19 capítulos, precedidos por una introducción que comenta el origen del judo y su evolución, además de un resumen de los contenidos presentados. El primer capítulo comenta los principios tácticos y psicológicos ante una situación de defensa personal. El segundo capítulo expone las partes del cuerpo con las que golpear, su entrenamiento y algunos principios técnicos para el combate. El tercer capítulo localiza los puntos vulnerables del cuerpo humano además de comentar las consecuencias si son golpeados. El cuarto capítulo describe la ejecución técnica por partes de una proyección y los movimientos de reacción del adversario. El quinto capítulo muestra las defensas ante distintos agarres. Los siguientes cinco capítulos detallan la ejecución de varias técnicas de proyección de pierna, de cadera, de hombro, de brazo y diversas técnicas de estrangulamiento. Los siguientes tres 
capítulos presentan las defensas ante ataques con cuchillo, palo y pistola, señalando los principios tácticos y puntos más importantes en su ejecución. El decimocuarto capítulo describe algunos trucos ante un boxeador, el ataque con un lazo al cuello, el estrangulamiento y una presa de cintura. Los dos siguientes capítulos describen las principales técnicas de sacrificio y de inmovilización acompañadas de sus respectivos gráficos. El decimoséptimo capítulo presenta la descripción técnica de varios movimientos peligrosos de luxación junto con su progresión y principios de aprendizaje. El siguiente capítulo comenta los peligros de la sociedad actual y cuál debe ser la actitud del practicante de judo en su aprendizaje. El último capítulo enumera los contenidos técnicos de judo junto con la traducción al castellano de sus nombres.

1189. Hombre Dopazo, Juan (2007). Taishindó : defensa personal escolar. Volumen I : ¡Trabajo básico! España: Juan Hombre Dopazo. $1^{\mathrm{a}}$ ed. 174 p. : il. ; $17 \times 24$ cm. ISBN: 978-84-611-5669-6. Depósito legal: M. 11836-2007. Palabras clave: fundamentos teóricos, fundamentos técnicos, katas, defensa personal. Resumen: Manual teórico y técnico de defensa personal. El libro esta compuesto por 6 capítulos precedidos por un comentario sobre el significado del escudo de la escuela, sus principios de enseñanza, una presentación que comenta las relaciones padre-hijo y dos introducciones dirigidas a los padres e hijos respectivamente comentando su papel y actitud hacia el entrenamiento. El primer capítulo detalla los beneficios del taishindó escolar y describe su lugar de entrenamiento. El segundo capítulo comenta los objetivos del taishindó escolar. El tercer capítulo describe la ejecución del saludo, las posiciones, ataques y defensas básicas así como ejercicios de coordinación por parejas acompañados de su secuencia fotográfica. El cuarto capítulo incluye la descripción e ilustración de varias técnicas de defensa personal ante diferentes agarres. El quinto capítulo explica la ejecución de las 3 primeras katas básicas denominadas minechi no kata ichi, minechi no kata ni y minechi no kata san acompañadas de su representación gráfica. El sexto capítulo reflexiona sobre las actitudes de las personas ante el mundo y sus propias vidas y propone el taishindó como un camino de reflexión y desarrollo personal.

1190. Hombre Dopazo, Juan (2008). Mis artes marciales : J. Hombre 1973-2007. España: Juan Hombre Dopazo. 1aㅡ ed. 187 p. : il. ; 17x24 cm. ISBN: No ISBN. Depósito legal: M. 34649-2008. Palabras clave: historia, ninjutsu, taishindó, wushu, escuelas. Resumen: Ensayo biográfico de Juan Hombre Dopazo. La obra esta compuesta de 15 capítulos. Los 5 primeros capítulos comentan e ilustran las etapas de formación marcial del autor, comenzando con la creación del Sheng Chi Pai, sus investigaciones en el ninjutsu, la creación del shinobi jutsu, la aparición de la Japan Ninjutsu Federation y la formación del taishindó. El sexto capítulo describe los objetivos y filosofía de la escuela de taishindó, para profundizar en los siguientes capítulos en los fundamentos básicos y práctica del taishindó escolar (TEAM), femenino (XKAPE), callejero (XCUDO), policial, militar (TAKS) y de competición (XTREM). Los tres últimos capítulos explican las pruebas del guerrero del movimiento bugenki y un breve comentario del campamento Onbure Dojo y la escuela de formación de taishindó junto con numerosas ilustraciones.

1191. Hombre Dopazo, Juan (2008). Taishindó XKUDO : defensa personal callejera. Volumen I : ${ }_{\text {FFuerza de }}$ Impacto! España: Juan Hombre Dopazo. $2^{\mathrm{a}}$ ed. 159 p. : il. ; 17x24 cm. ISBN: 978-84-611-5855-0. Depósito legal: M. 39842-2008. Palabras clave: fundamentos técnicos, principios técnicos, defensa personal. Resumen: Manual teórico y técnico de defensa personal. El libro esta formado por 6 capítulos. El primer capítulo expone las fases del entrenamiento en el xkudo junto con sus contenidos técnicos, los principios que se aplican en este sistema y la estructura de una sesión. El segundo capítulo explica en qué consiste el taishindo xkudo y cuales son las razones y ventajas para practicarlo. El tercer capítulo describe los fundamentos técnicos del xkudo como son las posiciones, ataques de puño y patadas básicas, y el trabajo por parejas para mejorar la coordinación, con el apoyo de numerosas ilustraciones. El siguiente capítulo presenta 3 ejercicios básicos de golpeo sobre un escudo como aplicación de las técnicas anteriores y otros dos ejercicios para mejorar los desplazamientos y esquivas. El quinto capítulo incluye la descripción de 8 técnicas defensivas y de 4 técnicas de defensa seguidas de un contraataque de asfixia, incluyendo la secuencia fotográfica de cada una de ellas. El último capítulo resume las características y beneficios del taishindo. Adjunta información sobre los cursos de formación.

1192. Junta Central de Educación Física (1954). Lucha y defensa personal. Madrid: Imprenta no 1 de Patronato de Huérfanos de Oficiales del Ejército. 1aㅡ ed. 47 p. : il. ; 12x17 cm. ISBN: No ISBN. Depósito legal: no. Palabras clave: fundamentos técnicos, defensa personal policial, entrenamiento, lucha, competición. Resumen: Manual teórico y técnico de defensa personal. La obra consta de 4 capítulos. El primer capítulo expone los objetivos de la defensa personal y los requisitos previos para su práctica. El segundo capítulo enumera las fases del proceso de instrucción de las técnicas y ofrece algunos consejos sobre la actuación del instructor. El tercer capítulo comenta la importancia del conocimiento de los puntos vitales del cuerpo humano, localiza dichos puntos y comenta los efectos de su manipulación. El último capítulo describe la ejecución técnica de la posición de guardia, las principales caídas, golpes de contraataque o ataque y diversas defensas contra los ataques de puño, las presas de cintura y estrangulamiento, contra ataques de cuchillo y amenaza de pistola, la conducción de 
prisioneros y las principales técnicas de lucha acompañadas de su representación gráfica, junto con el método de enseñanza de las técnicas de lucha, la descripción de la competición de lucha y una propuesta de programa de lecciones de defensa personal.

1193. Lee, Ching-nan y Figueroa, Rubén (1965). Técnicas de defensa personal. Barcelona: Sintes. 1aㅡ ed. 128 p. : il. ; 15x21,5 cm. ISBN: No ISBN. Depósito legal: P.M. 984-1965. Palabras clave: fundamentos técnicos, defensa personal, armas. Resumen: Manual técnico de defensa personal. El libro esta formado por 11 capítulos. El primer capítulo describe e ilustra por partes las formas de caer, con la progresión de sus ejercicios de aprendizaje, la posición de pie, cómo moverse correctamente y cómo romper el equilibrio del contrario. Los dos siguientes capítulos presentan las defensas contra agarres frontales al cuello, las solapas, los hombros y las mangas y las defensas contra presas a los brazos con una o dos manos, las estrangulaciones al cuello, el empujón frontal y el tirón de pelos, incluyendo la secuencia fotográfica de cada técnica, las posibles variantes y algunas recomendaciones. El tercer capítulo expone las defensas contra una patada frontal con la pierna estirada y doblada junto con las ilustraciones de su desarrollo. Los dos siguientes capítulos estudian los ataques por la espalda al cuello, los hombros, los brazos, las estrangulaciones por detrás y por el costado, el taponamiento de la boca con una mano, el tirón de pelo por la espalda, y los abrazos por la espalda al tórax y la cintura, ofreciendo posibles variantes y la secuencia fotográfica de su ejecución por partes. El séptimo capítulo detalla las defensas ante distintos golpes a la cara con sus variantes y el apoyo fotográfico. Los tres siguientes capítulos describen la ejecución de defensas ante agresiones armadas con un bastón, un cuchillo y una pistola desde diferentes direcciones ilustrando cada técnica por partes e incluyendo variantes defensivas. El último capítulo describe e ilustra la ejecución de estrangulaciones y luxaciones en el suelo, incluyendo además algunas fotografías del autor realizando distintas técnicas.

1194. Levine, Darren y Whitman, John (2008). Manual completo de krav maga : la guía definitiva para más de 230 técnicas de combate y defensa personal. Madrid: Tutor. $1^{\mathrm{a}}$ ed. 348 p. : il. ; 19x23,5 cm. ISBN: 978-847902-724-7. Depósito legal: M. 36845-2008. Palabras clave: historia, fundamentos técnicos, programa técnico. Resumen: Manual teórico y técnico de krav maga. El libro esta formado por 5 partes, precedidos por 5 capítulos que explican en qué consiste el krav maga, cuál es su origen, sus principios técnicos, la aplicación de sus principios a la vida diaria, y las instrucciones para utilizar el libro. La primera parte explica los contenidos técnicos de cinturón amarillo y describe e ilustra por partes los fundamentos técnicos que incluyen las posiciones y desplazamientos, los principales ataques tanto de puño como de pierna, las principales defensas, varias situaciones de defensa contra estrangulaciones, agarres de las muñecas y los movimientos y patadas del combate en el suelo. La segunda parte presenta los golpes circulares, las patadas laterales y hacia atrás, la combinación de defensas con contraataques, las defensas contra patadas, situaciones de defensa personal contra estrangulaciones por la espalda y contra abrazos, las caídas laterales y hacia atrás, y las principales defensas del combate en el suelo, describiendo su ejecución técnica por partes con el apoyo de ilustraciones. La tercera parte expone los contenidos técnicos del cinturón verde, explicando los cabezazos, las patadas laterales y hacia atrás más avanzadas, las defensas contra agarres del pelo, defensas exteriores e interiores, las caídas y rodamientos, situaciones de defensa personal ante abrazos por la espalda y técnicas de combate en el suelo de nivel intermedio, con el apoyo de la secuencia fotográfica de cada técnica. La cuarta parte presenta los contenidos técnicos de cinturón azul como son las defensas y ataques más avanzados, las situaciones de defensa personal contra bastón, cuchillo y amenazas con una pistola, luxaciones de muñeca, técnicas para mejorar la posición en el combate en el suelo y varias proyecciones. La última parte explica los contenidos técnicos de cinturón marrón como son las combinaciones de patadas, distintas proyecciones, defensas contra ataques habituales de agarre, las defensas contra arma blanca, arma larga y pistola. Adjunta índice alfabético y currículum de los autores.

1195. Marciano, Rocky y Goldman, Charley (1960). Defensa y ataque : cultura física y boxeo. Nociones de judo por Al Bachman. Barcelona: Hispano Europea. 1aㅡ ed. 198 p. : il. ; 14x20,5 cm. ISBN: No ISBN. Depósito legal: B. 10820-1960. (2 $2^{\underline{a}}$ ed., 1965, 178 p.; $3^{\underline{a}}$ ed., 1967, 178 p.). Palabras clave: fundamentos técnicos, defensa personal, entrenamiento, táctica, nutrición, preparación física. Resumen: Manual teórico y técnico de boxeo. El libro consta de 5 partes. La primera parte esta formada por 5 capítulos. El primer capítulo comenta las cualidades físicas de los deportistas y describe cómo fabricar los aparatos de entrenamiento. El segundo capítulo explica los efectos del entrenamiento sobre el organismo, la importancia de la dieta y la buena alimentación y ofrece un ejemplo de dieta semanal. El tercer capítulo expone las características, requisitos e importancia de las distintas partes de cuerpo en el boxeo. El cuarto capítulo describe e ilustra varios ejercicios para desarrollar los grupos musculares más importantes. El quinto capítulo presenta un programa de entrenamiento semanal. La segunda parte esta formada por 12 capítulos. El primer capítulo describe la guardia básica del boxeo, los distintos estilos y principales errores técnicas y cómo fabricar un saco. Los siguientes cuatro capítulos describen la ejecución de los fundamentos técnicos del boxeo, como son el jab, el cross, el gancho de izquierda, el uppercut, sus defensas y sus contraataques y los golpes combinados de jab-cross, jab-cross-gancho, 
jab-uppercut, jab-uppercut-gancho y cross-gancho, acompañados de su representación gráfica. El sexto capítulo definen el combate cuerpo a cuerpo, el finteo y el boxeo a la defensiva, para en los siguientes tres capítulos profundizar en cada uno de ellos, explicando las características y puntos más importantes del combate cuerpo a cuerpo de un boxeador bajo o alto, cómo se entrena el finteo, cuáles son sus tipos y sus puntos más importantes, y las características del boxeo a la contra, el clinch y cómo cubrirse. El décimo capítulo expone el equipo para practicar con el sparring y ofrece algunos consejos para escoger sparring y finalizar el entrenamiento. Los dos últimos capítulos de la segunda parte comentan el entrenamiento para la competición y algunos consejos técnico-tácticos. La tercera parte esta formada por dos capítulos que presentan el desarrollo de tres asaltos entre un boxeador alto contra un oponente más bajo y un boxeador de poca estatura contra un oponente más alto respectivamente, comentando los ataques y defensas empleadas por cada uno de ellos. La cuarta parte comparan las cualidades de Rocky Marciano y Floyd Patterson para luego describir un hipotético combate entre ambos. La última parte consta de 3 capítulos. El primer capítulo enumera los beneficios del judo y presenta su práctica y fundamentos teóricos. El segundo capítulo describe la ejecución de varios ejercicios ante individuos sin intenciones agresivas. El último capítulo presenta la descripción técnica ante diversas situaciones de defensa personal.

1196. Nalda Albiac, José Santos (1989). Autodefensa integral. Bilbao: Mensajero. 1 a ed. 290 p. : il. ; 15x22 cm. ISBN: 84-271-1595-4. Depósito legal: BU. 267-1989. Palabras clave: fundamentos teóricos, fundamentos técnicos, defensa personal, ejercicios, armas. Resumen: Manual teórico y técnico de defensa personal. La obra esta dividida en 27 capítulos a modo de lecciones o sesiones de entrenamiento. La estructura de cada lección comprende una parte inicial de calentamiento compuesta de ejercicios propios de calentamiento y caídas, una parte principal sobre la ejecución de diversas técnicas de defensa personal y finaliza con un comentario de algunos contenidos teóricos sobre la defensa personal. La primera lección comenta los tipos de calentamiento que existen, incluye una tabla con variados ejercicios tanto individuales como por parejas, describe las cualidades físicas y propone varios ejercicios para mejorar la agilidad y equilibrio. La segunda lección presenta los principios técnicas de las caídas, ilustra su ejecución, y estudia los tipos de emociones y su naturaleza. La tercera lección describe la ejecución técnica de la postura defensiva, los desplazamientos, la esquiva, la distancia, comenta las peculiaridades de la defensa personal femenina y explica cómo reacciona el cuerpo y la mente ante una situación de peligro y los tipos de reacciones. El resto de lecciones explican los fundamentos teóricos sobre el calentamiento incluyendo varios ejercicios para su desarrollo, describe e ilustra las diferentes técnicas de defensa personal contra diversos agarres, estrnagulaciones, presas, patadas, puñetazos, ataques armados, defensas en el suelo y técnicas de control del adversario así como los principios de actuación de la defensa personal y sus fundamentos teóricos como la respiración, el entrenamiento de la conducta, la sugestión, el estado emocional, algunos consejos para la mujer, el coraje, la actitud mental ante la agresión y el entrenamiento técnico-mental, los puntos vitales, la táctica y emociones del practicante, el control del cuerpo, el autodominio, la concentración, la defensa personal ante la ley, la motivación y metodología de la defensa personal y las consideraciones previas ante el ataque con cuchillo.

1197. Nardia, Avi (2007). Krav maga : kapap, lotar, hagana. Madrid: Budo International. 1a ed. 207 p. : il. ; 17x24 cm. ISBN: 978-84-936119-4-1. Depósito legal: M. 50704-2007. Palabras clave: historia, principios técnicos, defensa personal, ejercicios, armas. Resumen: Manual teórico y técnico de krav maga. El libro esta formado por 52 capítulos. Los tres primeros capítulos comentan los principios técnicos del lotar junto con la secuencia fotográfica de tres técnicas de desarme de pistola con las manos esposadas. Los siguientes cuatro capítulos enumeran los principios técnicos del kapap junto con la ilustración de los principales errores ante una pistola. El octavo capítulo detalla la historia de las artes marciales israelíes, su desarrollo, los principios técnicos del combate a corta distancia, los efectos experimentados en una situación de combate. Los cuatro siguientes capítulos ilustran los principales errores ante un ataque con cuchillo. El décimo tercer capítulo ofrece algunos consejos para escoger a un buen profesor e incluye algunas secuencias fotográficas de los primeros instructores de kapap. El siguiente capítulo resume los efectos fisiológicos ante una situación de combate y destaca la importancia de un entrenamiento correcto. Los siguientes cuatro capítulos muestran algunos de los principales ejercicios de calentamiento. El vigésimo capítulo incluye la entrevista realizada a Avi Nardia sobre el krav maga y la unidad Yaman. Continúa con la presentación del sistema point shooting, algunas de sus secuencias técnicas ilustradas realizadas por varios instructores. Los dos siguientes capítulos exponen las características de un entrenamiento realista así como algunos consejos para mejorar dicho entrenamiento. El trigésimo segundo capítulo destaca algunos de los beneficios del kapap sobre el practicante para luego exponer la historia de la prueba de Gedeón. Los siguientes tres capítulos incluyen artículos sobre los principios técnicos del kapap, el palo de combate y la paradoja de las artes marciales israelíes. Continúa con la descripción del principio de posicionamiento básico y varios ejemplos prácticos de su aplicación. El 44oc capítulo explica el entrenamiento mental del kapap para luego detallar la influencia de los sentidos sobre dicho entrenamiento e incluir la secuencia 
fotográfica de algunos ejercicios de estiramiento, su aplicación al combate y un esquema del uso de la fuerza.

1198. Rahn, Erich (1979). El gran libro de la defensa personal. Barcelona: De Vecchi. 1aㅡ ed. 286 p. : il. ; 14x20,5 cm. ISBN: 84-315-6012-6. Depósito legal: B. 6424-1979. Palabras clave: fundamentos técnicos, defensa personal, ejercicios, preparación física, armas. Resumen: Manual técnico de defensa personal. La obra esta compuesta de dos partes precedidas por una introducción que comenta los contenidos de la obra. La primera parte ofrece algunos consejos para la práctica de los ejercicios presentados, expone los principios técnicos de las presas, los ataques y defensas, las caídas, además de incluir la descripción y representación de distintos ejercicios de calentamiento y acondicionamiento, diferentes técnicas de defensa personal ante presas, estrangulaciones y ataques armados, y los golpes con el canto de la mano. La segunda parte continúa describiendo la ejecución de distintas técnicas ante situaciones más complejas de defensa personal. También incluye ejercicios de fortalecimiento.

1199. Rahn, Erich (1983). Manual completo de defensa personal. Barcelona: De Vecchi. $1^{\underline{a}}$ ed. ; $1^{\underline{a}}$ imp. 286 p. :

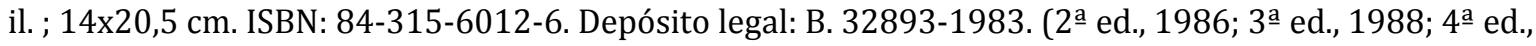
1990; $5^{\underline{a}}$ ed., 1992; $5^{\underline{a}}$ ed. y $1^{\underline{a}}$ imp., 1995; $6^{\underline{a}}$ ed., 1999). Palabras clave: fundamentos técnicos, defensa personal, ejercicios, preparación física, armas. Resumen: Manual técnico de defensa personal. La obra esta compuesta de dos partes precedidas por una introducción que comenta los contenidos de la obra. La primera parte ofrece algunos consejos para la práctica de los ejercicios presentados, expone los principios técnicos de las presas, los ataques y defensas, las caídas, además de incluir la descripción y representación de distintos ejercicios de calentamiento y acondicionamiento, diferentes técnicas de defensa personal ante presas, estrangulaciones y ataques armados, y los golpes con el canto de la mano. La segunda parte continúa describiendo la ejecución de distintas técnicas ante situaciones más complejas de defensa personal. También incluye ejercicios de fortalecimiento.

1200. Rahn, Erich (1989). Manual práctico ilustrado de defensa personal. Barcelona: Río Negro. 1 a ed. 124 p. : il. ; $13 \times 19$ cm. ISBN: 84-315-0803-5. Depósito legal: B. 22952-1989. Palabras clave: fundamentos técnicos, defensa personal, ejercicios, preparación física, armas. Resumen: Manual técnico de defensa personal. La obra esta compuesta de una parte precedida por una introducción que comenta los contenidos de la obra. La primera parte ofrece algunos consejos para la práctica de los ejercicios presentados, expone los principios técnicos de las presas, los ataques y defensas, las caídas, además de incluir la descripción y representación gráfica de distintos ejercicios de calentamiento y acondicionamiento, y diferentes técnicas de defensa personal ante presas, estrangulaciones y ataques armados.

1201. Regoli, Claudio A. y Bonomelli, Roberto (1994). Curso de defensa personal. Barcelona: De Vecchi. 1a ed.

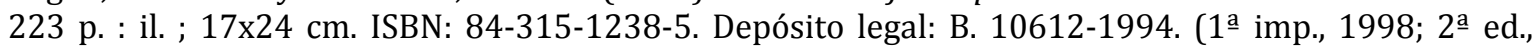
1999, ISBN: 84-315-2305-0). Palabras clave: fundamentos teóricos, principios técnicos, defensa personal, estrategia, artes marciales, kyusho, armas. Resumen: Manual teórico y técnico de defensa personal. La monografía esta compuesta por 10 capítulos, precedidos de una breve introducción sobre el carácter de las artes marciales y la defensa personal. El primer capítulo presenta los principios fundamentales de la defensa personal y su definición. El segundo capítulo comenta brevemente las distintas artes marciales y de defensa personal alrededor del mundo, agrupándolas en sus países de nacimiento, Japón, China, Corea, Vietnam, Tailandia, Filipinas, Indonesia y Malasia, India, Oriente Medio, Europa, Estados Unidos y Brasil, y métodos eclécticos. El tercer capítulo detalla los problemas derivados de la práctica formal de las artes marciales en el gimnasio sobre su aplicación en las situaciones de defensa personal. Continúa con la exposición de los aspectos vinculados a la estrategia de defensa, como son la anticipación, la distancia y el tiempo en el combate, la mirada, la táctica, y la recepción de los ataques. El quinto capítulo aborda el entrenamiento del cuerpo y la mente para maximizar sus posibilidades. Los dos siguientes capítulos describen e ilustran los puntos vulnerables del cuerpo humano, su manipulación, y las distintas partes del cuerpo que pueden ser utilizadas como armas para el golpeo, incluyendo ilustraciones con varios ejemplos de cada una de ellas. El octavo capítulo detalla la ejecución de los fundamentos de la defensa personal, como son las caídas, los desplazamientos, los ángulos de ataque, la guardia, el papel de la voz, y los principios técnicos de las técnicas de proyección, estrangulamiento, de palanca y de presión así como su defensa. El siguiente capítulo explica la defensa contra ataques armados, ofreciendo consejos y ejemplos ilustrados tanto para el manejo y defensa contra un bastón como para la utilización de otros objetos y accesorias habituales que pueden ayudarnos en situaciones de defensa personal. El último capítulo expone los principios a seguir ante situaciones dentro de un ambiente hostil, en un automóvil, contra varios agresores y contra armas blancas y de fuego, incluyendo ejemplos ilustrados de dichas situaciones. En la conclusión final detalla los consejos generales ante cualquier situación de defensa personal.

1202. Repollés Aguilar, José (1970). Aprenda a defenderse. Barcelona: Bruguera. 1aㅡ ed. 218 p. : il. ; 10x17,5 cm. ISBN: No ISBN. Depósito legal: B. 8491-1970. (4⿳亠丷a ed., 1975, ISBN: 84-02-00952-2). Palabras clave: fundamentos teóricos, fundamentos técnicos, defensa personal, judo, kárate, lucha, boxeo. Resumen: Manual técnico de defensa personal. A través de los contenidos técnicos de la lucha, el boxeo, el judo y 
el karate, se explican algunas técnicas a utilizar en situaciones de defensa personal. Comienza la monografía con la descripción de las principales torsiones, golpes y zancadillas de lucha que pueden aplicarse ante un agresor y la forma de defenderse de éstas mismas técnicas. Luego pasa a explicar los aspectos técnicos del boxeo, esto es, las guardias, los desplazamientos, los golpeos y las esquivas. El tercer capítulo estudia los aspectos formales del judo junto con una clasificación de sus técnicas en los distintos grados, cómo se realiza el aprendizaje del judo, algunas de las prohibiciones que existen en la práctica y un breve glosario de términos. El cuarto capítulo se centra en el karate narrando en qué consiste este arte marcial, cuáles son las partes del cuerpo que se utilizan para golpear y cómo lo hacen. El siguiente capítulo describe cuáles son los instrumentos para fortalecer las manos del karateka y cuáles son los puntos vitales que se deben atacar en el cuerpo. Continua con la descripción de las técnicas de la Ten-no-kata extraídas del libro de E.J. Harrison (Manual de karate) y la actitud para realizarlas así como una breve explicación de los otros tipos de kumite. El séptimo capítulo esta compuesto por un conjunto de términos de karate y el octavo pasa a comentar los principios y cómo solucionar algunas de las situaciones más comunes de defensa personal ante golpeos y estrangulaciones. Continua con la explicación de las defensas contra ataques que van dirigidos al cuerpo, métodos para inmovilizar al adversario cuando nos lanza un golpe o nos apresa y defensas ante ataques con un palo, un cuchillo y una pistola. El duodécimo capítulo profundiza en los atemis contra los puntos vulnerables del cuerpo y su entrenamiento para terminar con un compendio de consejos finales cuando la defensa se realiza desde el suelo o con la cabeza.

1203. Rodríguez Román, Francisco Javier (2007). Técnicas básicas de defensa personal. Madrid: Francisco Javier Rodríguez Román. 1aㅡ ed. 91 p. : il. ; 17x21 cm. ISBN: No ISBN. Depósito legal: M. 9424-2007. Palabras clave: fundamentos teóricos, fundamentos técnicos. Resumen: Manual teórico y técnico de defensa personal. El libro esta formado por 4 capítulos. El primer capítulo comenta los requisitos básicos para la práctica de la defensa personal mientras que el segundo explica la actitud ante el enfrentamiento. El tercer capítulo define las distancias de combate y seguridad. El cuarto capítulo clasifica los tipos de ataques, localiza los puntos vitales del cuerpo humano, explica los principios técnicos de las paradas y contraataques y describe las técnicas para conducir a un adversario, contra agarres al pecho, al cuello, a los brazos, a las muñecas y por detrás así como ante puñetazos y ataques con arma blanca, incluyendo su secuencia fotográfica. Adjunta los agradecimientos y la biografía del autor.

1204. Ros Torner, Antonio (1968). Combate : movimientos de defensa y de control. Barcelona: Schotz-Editor. $1^{\underline{a}}$ ed. 90 p. : il. ; 15x22 cm. ISBN: No ISBN. Depósito legal: B. 7717-1968. Palabras clave: fundamentos técnicos, defensa personal policial, rehabilitación, principios técnicos, kyusho, kuatsu, armas. Resumen: Manual técnico de defensa personal. La obra esta dividida en tres partes precedidas por un prólogo que señala la importancia de la obra. La primera parte consta de 4 capítulos que detallan los principios técnicos de los movimientos de defensa además de incluir la descripción y secuencia fotográfica de las diferentes técnicas contra diversos ataques de presas, estrangulaciones y golpes por delante, por los laterales, por detrás y contra adversarios armados con sillas, cuchillos y pistola respectivamente. La segunda parte consta de tres capítulos. El primer capítulo describe las técnicas básicas de kyuso, algunas técnicas de conducción, la forma de atar a un atacante y ejecutar un cacheo además de comentar la actuación ante distintas situaciones de pelea o conducción de un atacante incluyendo numerosas fotografías explicativas. El segundo capítulo expone la utilización de algunos elementos cotidianos como armas mientras que el tercero enumera los puntos sensibles del cuerpo. La tercera parte expone los principios técnicos de las técnicas de reanimación o kuatsu junto con su descripción ante el hipo, las palpitaciones, el ahogo, el desvanecimiento y golpes a los testículos.

1205. s.a. (2008). Técnicas de defensa personal. Madrid: Interconsulting Bureau. $1^{\mathrm{a}}$ ed. 127 p. : il. ; 21x29,5 cm. ISBN: No ISBN. Depósito legal: M. 39609-2008. Palabras clave: fundamentos teóricos, fundamentos técnicos, principios técnicos, defensa personal policial, legislación, principios de actuación. Resumen: Manual teórico y técnico de defensa personal. El libro esta formado por 2 módulos. El primer módulo consta de 3 capítulos. El primer capítulo define el concepto de defensa personal, las cuestiones legales relacionadas con la defensa personal, sus principios de actuación, el material de entrenamiento, los principios técnicos de los golpes, localiza los puntos vitales del cuerpo humano, ofrece algunos consejos de actuación ante distintos tipos de agresores, incluye un breve comentario sobre la defensa personal contra armas, un resumen de los contenidos tratados y un test de aprendizaje. El segundo capítulo analiza los 7 componentes de la defensa personal como son la psicología, inteligencia, selección de víctimas, reconocimientos de predadores, opciones de respuesta, consejos sobre prevención y métodos de entrenamiento; analiza cuáles son las claves de la toma de conciencia en la defensa personal, ofrece algunos consejos sobre la prevención y adjunta un resumen y test de los contenidos tratados. El tercer capítulo clasifica las técnicas de defensa personal para luego explicar la aplicación de técnicas sencillas de defensa personal a mano vacía y con objetos contra distintos tipos de ataque acompañados de su ilustración. También incluye un resumen y test de los contenidos explicados. El segundo modulo consta de 3 capítulos. El primer capítulo expone los 
principios del enfrentamiento a manos, describe las principales zonas del cuerpo utilizadas para golpear, expone los principios técnicas de la posición de guardia y los desplazamientos, analiza la línea de fuerza y las distancias fundamentales de enfrentamiento además de explicar la ejecución de distintas técnicas de percusión con las extremidades inferiores y superiores, e incluir un resumen y test de los contenidos. El segundo capítulo describe la ejecución técnica de varias técnicas de defensa personal contra puñetazos, patadas, golpes de codo y rodilla, agarres por detrás, la utilización de pellizcos, reducciones, técnicas de detención y de esposamiento, la utilización de luxaciones y enumera las consideraciones del agente ante una situación de defensa personal policial. También incluye un resumen y test de los contenidos explicados. El último capítulo explica el concepto de legítima defensa, expone los principios legales que regulan el uso de la fuerza por parte de los agentes policiales junto con la legislación nacional e internacional y analiza los principios de actuación, además de incluir un resumen y test de los contenidos mostrados. Adjunta un glosario de términos específicos, bibliografía y varios cuestionarios de evaluación.

1206. Sanchís, Santiago (2009). 15 trucos que pueden salvar tu vida. Madrid: Budo International. 1ae ed. 95 p. : il. ; 17x24 cm. ISBN: 978-84-92484-47-8. Depósito legal: M. 42258-2009. Palabras clave: fundamentos técnicos, armas, defensa personal. Resumen: Manual técnico de defensa personal. El libro esta formado por 38 capítulos. El primer capítulo incluye numerosas fotos del autor con distintas personalidades. El segundo capítulo incluye el prólogo del editor que comenta los objetivos de la obra. Los dos siguientes capítulos analizan los contenidos de la obra. El quinto capítulo explica a modo de introducción la efectividad de las técnicas explicadas posteriormente. El sexto capítulo ofrece algunos consejos de seguridad para la práctica. Los tres siguientes capítulos analiza el razonamiento lógico ante una situación de peligro. El resto de capítulos ilustran distintas técnicas de defensa personal ante varios agarres, puñetazos, patadas, ataques en el suelo, ataques armados y agresiones al conductor de un vehículo.

1207. Sauvy, Michel (1987). Defensa personal. Barcelona: Editors. 1a ed. 150 p. : il. ; $13 \times 20$ cm. ISBN: 847561-565-1. Depósito legal: B. 36914-1987. (2ª ed., 1990; $3^{a}$ ed., 1991; 4 a ed., 1991, ISBN: 84-7561940-1; $5^{\underline{a}}$ ed., 1993, ISBN: 84-7561-940-1; $6^{\underline{a}}$ ed., 1994; $8^{\underline{a}}$ ed., 1995). Palabras clave: fundamentos teóricos, fundamentos técnicos, principios técnicos, defensa personal, entrenamiento, aikido, kyusho, preparación física, armas. Resumen: Manual teórico y técnico de defensa personal. El libro esta formado por 10 capítulos precedidos por una introducción que explica en qué consiste la defensa personal. El primer capítulo expone los principios técnicos de la defensa personal mientras que el segundo localiza los puntos vulnerables del cuerpo humano, las zonas del cuerpo utilizadas para golpear junto con sus técnicas. El tercer capítulo describe la ejecución de varias técnicas de luxación para dominar a un adversario. El cuarto capítulo describe distintas técnicas de defensa personal contra la estrangulación en el suelo incluyendo su representación gráfica y esquemas de movimiento. El quinto capítulo describe los principales golpes con la mano además de algunos ejercicios de endurecimiento de la misma. El sexto capítulo detalla los principales golpes con las yemas de los dedos y el puño así como algunos métodos de entrenamiento para fortalecerlos acompañados de su representación gráfica. El séptimo capítulo explica los puntos de impacto y técnicas de golpeo realizados con el codo, la cabeza y la rodilla incluyendo la representación gráfica de algunas técnicas junto con sus esquemas de movimiento, mientras que el octavo estudia los golpes ejecutados con el pie. El noveno capítulo incluye la descripción de algunas técnicas de defensa contra ataques de frente, de lado y por detrás, presas a las muñecas, los golpes de puño, puntapiés, cabezazos y rodillazos, contra los ataques armados con un palo, armas de fuego, armas blancas y animales, acompañados de su representación gráfica y esquemas de movimiento. El décimo capítulo comenta en qué consiste el aikido, expone sus principios y reglas de entrenamiento, sus principios técnicos, describe sus fundamentos técnicos y la ejecución de los contenidos técnicos del cinturón blanco. Adjunta una conclusión que resume los principios de la defensa personal.

1208. Sde-Or, Imi y Yanilov, Eyal (2003). Krav maga : el primer y único manual autorizado de autodefensa israelí. Cómo defenderse de un ataque armado. Móstoles: Arkano Books. 1a ed. 254 p. : il. ; 17x24 cm. ISBN: 84-89897-74-3. Depósito legal: M. 30987-2003. (2ª ed., 2006). Palabras clave: fundamentos teóricos, fundamentos técnicos, principios técnicos, defensa personal, entrenamiento, sistemas de entrenamiento, armas. Resumen: Manual teórico y técnico de krav maga. El libro esta formado por 16 capítulos y una introducción que comenta brevemente las características del krav maga y el objetivo deseado de la obra. El primer capítulo define los conceptos de defensa personal y combate cuerpo a cuerpo para luego explicar en qué consiste el krav maga, cómo se originó y cuáles son los principios técnicos y de entrenamiento del mismo. Los siguientes 5 capítulos describen la ejecución técnica de defensas contra ataques con cuchillo, amenazas de cuchillo, con palos, pistolas y rifles, explicando los principios técnicos de cada una de ellas, las variantes desde diferentes ángulos y adjuntando numerosas fotografías. Los dos siguientes capítulos explican cómo neutralizar aquellas situaciones con toma de rehenes en las que se produce una amenaza con granada de mano o con una pistola, y cómo utilizar diferentes objetos cotidianos en situaciones de defensa personal, incluyendo varias opciones y 
fotografías ilustrativas. A continuación presenta varias situaciones de defensa con palo contra un ataque de cuchillo y contra otro palo, describiendo e ilustrando su ejecución técnica por partes. El capítulo decimoprimero expone las defensas contra dos agresores armados para luego estudiar los principios teórico-técnicos que respaldan las técnicas presentadas, las etapas en que se puede dividir una situación de defensa personal y el entrenamiento de cada una de esas etapas. Los siguientes dos capítulos presentan distintos métodos de entrenamiento y las normas de seguridad para realizar dicho entrenamiento. El último capítulo incluye la biografía de los autores. Adjunta apéndices con la biografía del asesor y editor del libro, conceptos y términos utilizados en el krav maga y frases selectas del maestro Imi Sde-Or.

1209. Serapio, Ignacio y Hombre Dopazo, Juan (2006). Programa de entrenamiento de kakuto bugei. Módulo jin. Volumen 7. Toledo: I.K.B.A. 1aㅡ ed. desc.: il. ; desc.xdesc. cm. ISBN: 978-84-611-4853-0. Depósito legal: no.

1210. Serapio, Ignacio y Hombre Dopazo, Juan (2006). Programa de entrenamiento de kakuto bugei. Módulo kai. Volumen 6. Toledo: I.K.B.A. 1aㅡ ed. desc.: il. ; desc.xdesc. cm. ISBN: 978-84-611-4853-0. Depósito legal: no.

1211. Serapio, Ignacio y Hombre Dopazo, Juan (2006). Programa de entrenamiento de kakuto bugei. Módulo pyo. Volumen 3. Toledo: I.K.B.A. 1aㅡ ed. desc.: il. ; desc.xdesc. cm. ISBN: 978-84-611-4853-0. Depósito legal: no.

1212. Serapio, Ignacio y Hombre Dopazo, Juan (2006). Programa de entrenamiento de kakuto bugei. Módulo retsu. Volumen 8. Toledo: I.K.B.A. 1aㅡ ed. desc.: il. ; desc.xdesc. cm. ISBN: 978-84-611-4853-0. Depósito legal: no.

1213. Serapio, Ignacio y Hombre Dopazo, Juan (2006). Programa de entrenamiento de kakuto bugei. Módulo rin. Volumen 2. Toledo: I.K.B.A. 1aㅡ ed. desc.: il. ; desc.xdesc. cm. ISBN: 978-84-611-4853-0. Depósito legal: no.

1214. Serapio, Ignacio y Hombre Dopazo, Juan (2006). Programa de entrenamiento de kakuto bugei. Módulo sha. Volumen 5. Toledo: I.K.B.A. 1ํㅡㄹ ed. desc.: il. ; desc.xdesc. cm. ISBN: 978-84-611-4853-0. Depósito legal: no.

1215. Serapio, Ignacio y Hombre Dopazo, Juan (2006). Programa de entrenamiento de kakuto bugei. Módulo to. Volumen 4. Toledo: I.K.B.A. $1^{\text {a }}$ ed. desc.: il. ; desc.xdesc. cm. ISBN: 978-84-611-4853-0. Depósito legal: no.

1216. Serapio, Ignacio y Hombre Dopazo, Juan (2006). Programa de entrenamiento de kakuto bugei. Módulo zai. Volumen 9. Toledo: I.K.B.A. $1^{\mathrm{a}}$ ed. desc.: il. ; desc.xdesc. cm. ISBN: 978-84-611-4853-0. Depósito legal: no.

1217. Serapio, Ignacio y Hombre Dopazo, Juan (2006). Programa de entrenamiento de kakuto bugei. Módulo zen. Volumen 10. Toledo: I.K.B.A. 1aㅡ ed. desc.: il. ; desc.xdesc. cm. ISBN: 978-84-611-4853-0. Depósito legal: no.

1218. Serapio, Ignacio y Hombre Dopazo, Juan (2007). Kakuto bugei : programa de entrenamiento para cinturón negro. El arte del guerrero místico. Toledo: I.K.B.A. 1a ed. 158 p. : il. ; 14x19 cm. ISBN: 978-84611-4853-0. Depósito legal: M. 3285-2007. Palabras clave: katas, fundamentos teóricos, fundamentos técnicos, principios técnicos, defensa personal, fundamentos filosóficos, planificación del entrenamiento. Resumen: Manual teórico y técnico de kakuto bugei. El libro esta formado por 6 capítulos precedidos por una dedicatoria. El primer capítulo explica el significado del emblema del kakuto bugei, los objetivos y beneficios de su práctica, el significado del ki, la relación entre los cinco elementos y la filosofía bugenki, las pruebas del guerrero y el ki, detalla el sistema de grados, el entrenamiento del kuji y los tipos de personalidad y guerrero. El segundo capítulo presenta los fundamentos técnicos del primer nivel (mukyu) del programa de entrenamiento acompañados de sus ilustraciones explicativas. El tercer capítulo describe brevemente las técnicas básicas de defensa personal ante distintos agarres y de combate callejero incluyendo su secuencia fotográfica y comenta el entrenamiento de tokui waza. El cuarto capítulo explica el significado de las katas y sus principios técnicos además de presentar la secuencia fotográfica de la chi no kata y sui no kata. El quinto capítulo expone el desarrollo de una clase de kakuto bugei y el programa de entrenamiento para el primer nivel. El sexto capítulo incluye la biografía de Seiko Fujita y una entrevista sobre su formación marcial. Adjunta agradecimientos y bibliografía.

1219. Servei Lingüistic de la Unió de Federacions Esportives Catalanes (1993). La defensa personal. Barcelona: Generalitat de Catalunya. 1aㅡ ed. 11 p. : il. ; 21×29,5 cm. ISBN: No ISBN. Depósito legal: B. 23990-1993. Palabras clave: fundamentos teóricos, judo, kárate, taekwondo, competición. Resumen: Manual teórico de artes marciales. El libro esta formado por 3 capítulos precedidos por una introducción que comenta el origen del judo, el kárate y el taekwondo así como los contenidos de la obra. El primer capítulo describe el área de competición, categorías de peso, terminología específica, acciones del judoka y algunas de la decisiones y faltas del combate de judo. El segundo capítulo incluye las categorías de peso del taekwondo, la indumentaria del practicante, el significado de los grados, las principales acciones técnicas del competidor y ciertas decisiones de la competición. El último capítulo 
expone las categorías de peso, vestimenta, principales acciones técnicas y decisiones de la competición de kárate.

1220. Soler Navarro, Juan Manuel (1989). Técnicas corporales básicas de defensa : primera parte. Barcelona: Alas. $1^{\text {a }}$ ed. 108 p. : il. ; 15x21 cm. ISBN: 84-203-0244-9. Depósito legal: B. 41438-1989. Palabras clave: fundamentos técnicos, defensa personal, aplicación marcial. Resumen: Manual técnico de defensa personal. El libro esta formado por 10 capítulos precedidos por un prólogo que comenta la experiencia del autor en la enseñanza de la defensa personal. Los cuatro primeros capítulos describen la ejecución de las principales posturas, distintos tipos de desplazamientos, desplazamientos con guardia y formas de caer de la defensa personal acompañados de sus ilustraciones correspondientes. Los tres siguientes capítulos presentan la descripción técnica y representación gráfica de las principales esquivas, paradas y golpes para luego detallar su aplicación marcial. El noveno capítulo explica algunas formas de escaparse de un agarre de muñeca junto con sus fotografías explicativas. El último capítulo incluye la descripción técnica y secuencia fotográfica de las defensas por golpe, luxación y proyección ante 8 agarres de muñecas distintos.

1221. Soler Navarro, Juan Manuel (1990). Técnicas corporales especializadas de defensa. Segunda parte. Barcelona: Alas. 1aㅡ ed. 93 p. : il. ; 15x21,5 cm. ISBN: 84-203-0245-7. Depósito legal: B. 1427-1990. Palabras clave: fundamentos técnicos, defensa personal policial, aplicación marcial. Resumen: Manual técnico de defensa personal. El libro esta formado por 6 capítulos precedidos por un prólogo que señala los objetivos del libro. Los cuatro primeros capítulos describen la ejecución de diversas técnicas de defensa personal ante distintos agarres, el agarre con una mano y el ataque con la otra, contra algunas estrangulaciones y defensas desde el suelo, acompañadas de su secuencia fotográfica. El quinto capítulo presenta la descripción e ilustración de varias técnicas de inmovilización del agresor en distintas posiciones así como algunas técnicas de conducción. El último capítulo explica la aplicación de algunas de las técnicas de proyección, luxación e inmovilización explicadas ante diferentes ataques de puño, incluyendo sus ilustraciones explicativas.

1222. Thomas, Raymond (1973). Defensa personal : goshin do. Barcelona: Alas. 1 a ed. 94 p. : il. ; $12 \times 16 \mathrm{~cm}$. ISBN: 84-203-0277-5. Depósito legal: B. 10712-1973. (2a ed., 1978; 3a ed., 1981). Palabras clave: katas, historia, fundamentos teóricos, fundamentos técnicos, principios técnicos, defensa personal. Resumen: Manual teórico y técnico de defensa personal. La obra esta dividida en 15 capítulos, precedidos por un prólogo que comenta en qué consiste el goshin do. El primer capítulo narra la historia del goshin do y las diferentes escuelas que lo practican. Los dos siguientes capítulos explican el sistema de grados y el ceremonial. El cuarto capítulo expone la estructura de una sesión práctica para continuar con la descripción técnica y representación gráfica de sus posiciones y posturas. El quinto capítulo comenta las direcciones del kuzushi mientras que el sexto analiza el tai-sabaki. El séptimo capítulo detalla las formas de desplazarse, mientras que los siguientes cuatro capítulos exponen los principios de los barridos, siegas, guardias, paradas y defensas. El décimo segundo capítulo describe la ejecución técnica y nombre de las principales paradas acompañadas de su esquema de movimiento para luego detallar otras paradas. El décimo cuarto capítulo explica las distintas distancias de combate. El último capítulo describe la ejecución de varias técnicas de goshin do ante distintos ataques y la kata Te No Kata So No I, acompañados de su representación gráfica y la explicación de las diferentes tácticas o iniciativas en el combate.

1223. Thomas, Raymond (1975). La defensa personal : goshindo $2^{a}$ y $3^{\underline{a}}$ parte, katas. Barcelona: Alas. $1^{\mathrm{a}}$ ed. 92 p. : il. ; 12x16,5 cm. ISBN: 84-203-0342-9. Depósito legal: B. 34136-1975. (2ª ed., 1978). Palabras clave: katas, fundamentos técnicos. Resumen: Manual teórico y técnico de defensa personal. El primer capítulo explica la diferencia entre arte marcial, defensa personal y deporte de combate. El segundo capítulo enumera las distintas artes marciales japonesas. Los tres siguientes capítulos enumeran los principios técnicos y tácticos del goshin do, ofrece algunos consejos previos, durante y después del combate y presenta las 12 reglas de oro del goshin do. Los siguientes cinco capítulos describen la ejecución técnica de la primera, segunda y tercera serie de movimientos del goshin do junto con las katas Te No Kata So No Ni y Te No Kata So No San acompañadas de sus respectivas ilustraciones. El último capítulo hace un resumen de los principios técnicos y tácticos del goshin do así como de la actitud o espíritu de entrenamiento.

1224. Wagner, Jim (2006). Autodefensa personal y profesional. Madrid: Budo International. 1aㅡ ed. 207 p. : il. ; 16x24 cm. ISBN: 84-96492-08-7. Depósito legal: M. 1390-2006. Palabras clave: fundamentos teóricos, principios técnicos, defensa personal militar, ejercicios, entrenamiento, táctica, principios de actuación, terrorismo, armas. Resumen: Manual teórico y técnico de defensa personal policial y militar. El libro esta formado por 17 capítulos. El primer capítulo expone brevemente los principios ante un ataque con cuchillo. El segundo capítulo comenta el origen del sistema "combatives" de lucha, sus beneficios para el practicante y la descripción de algunas de sus técnicas. El tercer capítulo presenta los principios de actuación y entrenamiento ante un ataque dentro de un avión. El cuarto capítulo resalta la facilidad de manejo de un cuchillo y explica el programa de manejo de cuchillos específico para policías y militares. El sexto capítulo describe los principios de resolución de un combate así como los sentimientos 
aparejados a dicha situación. El séptimo capítulo señala la importancia del entrenamiento en el combate en el suelo, las tácticas para dicho combate y ofrece algunos consejos para un entrenamiento realista. El octavo capítulo comenta las ventajas de la utilización de códigos de colores para la valoración de un conflicto. El noveno capítulo expone las cinco reglas de seguridad y supervivencia para los oficiales de policía. El décimo capítulo narra el trabajo del autor dentro de una operación global contra el terrorismo. Los tres siguientes capítulos detallan los fundamentos teóricos, fundamentos técnicos y principios de actuación y entrenamiento en la esgrima de fusil, la defensa de agarres y llaves de cuello y las técnicas de arresto y control de las fuerzas de seguridad y la policía. El décimo cuarto capítulo enumera algunas razones para llevar el casco policial y describe dos técnicas de defensa contra un ataque frontal y por detrás para romper el cuello. Los dos siguientes capítulos definen el término reality-based dentro de las artes marciales y presenta la propuesta del autor, su programa de entrenamiento, sus principios y material de entrenamiento así como sus ventajas para el practicante. El último capítulo ofrece algunos consejos para la actuación y detección de ataques con bomba así como algunos consejos prácticos para su tratamiento.

1225. Yrayzoz Reyna, Joaquín (1977). Técnicas de autodefensa y seguridad. Barcelona: Alas. $1^{a \underline{a}}$ ed. 133 p. : il. ; 15x21 cm. ISBN: 84-203-0059-4. Depósito legal: B. 25193-1977. (2ª ed., 1981; 3aa ed., 1986). Palabras clave: fundamentos técnicos, defensa personal, principios técnicos, kyusho, armas. Resumen: Manual técnico de defensa personal. La obra esta formada por 8 capítulos. Los dos primeros capítulos ofrecen algunos principios técnicos ante una situación de defensa personal y la localización y manipulación de los principales puntos vitales. Continúa con la descripción de la ejecución y principios de las técnicas básicas de defensa y golpeo junto con su aplicación ante distintos ataques. El cuarto capítulo ilustra varios ejercicios de estiramiento para luego describir por partes la ejecución de las técnicas de caída y los aparatos para el fortalecimiento de las manos, los pies y los tobillos. A continuación presenta las técnicas de defensa contra agarres a la muñeca, la solapa y el tronco desde varias direcciones, estrangulaciones, golpes y patadas dirigidos a la cabeza y al tronco, defensas ante ataques armados con un hacha, un palo, una botella rota, una silla, un cuchillo y una pistola. Después incluye técnicas de defensa ante situaciones especiales como sentado, en el suelo o dentro de un coche y ayudándonos de un palo, paraguas o bastón. Finaliza con varias técnicas de defensa personal especial para la mujer ante ataques armados o agarres.

\subsubsection{Policial y Militar}

1226. Alba Alonso, Carlos (199?). Manual de combate cuerpo a cuerpo. Zaragoza: Academia General Militar. 1a ed. 150 p. : il. ; 21×29,5 cm. ISBN: No ISBN. Depósito legal: no. Palabras clave: fundamentos teóricos, fundamentos técnicos, ejercicios, principios de actuación. Resumen: Manual teórico y técnico de defensa personal militar. El libro esta formado por 5 capítulos precedidos por un prólogo que comenta la importancia del combate cuerpo a cuerpo en las Fuerzas Armadas así como el objetivo de la obra. El primer capítulo expone las finalidades del combate cuerpo a cuerpo, sus características y algunos consejos para la práctica. El segundo capítulo comenta los principios de actuación en el combate cuerpo a cuerpo mientras que el tercero analiza los aspectos técnicos, perceptivos y psicológicos del mismo. El cuarto capítulo señala los objetivos, características, contenido, metodología y evaluación del programa de instrucción de combate cuerpo a cuerpo. El último capítulo incluye las fichas técnicas del programa sobre puntos vitales, armas, fundamentos técnicos básicos, caídas, defensas contra distintos ataques, formas de ataque, de conducción, de control y registro acompañadas de numerosas ilustraciones explicativas. Adjunta tres anexos con la representación gráfica de varios ejercicios de endurecimiento, juegos de ataque y defensa, y ejercicios de entrenamiento.

1227. Alba Alonso, Carlos (2003). Programa de cinturón negro de defensa personal militar. Zaragoza: Academia General Militar. $1^{\underline{a}}$ ed. 86 p. : il. ; 21x29,5 cm. ISBN: No ISBN. Depósito legal: no. Palabras clave: fundamentos teóricos, fundamentos técnicos, programa técnico, ejercicios. Resumen: Manual teórico y técnico de defensa personal militar. El libro esta formado por 4 capítulos precedidos por el decálogo de la defensa personal militar, una explicación sobre la defensa personal militar y su legislación. Los tres primeros capítulos exponen los contenidos teóricos y técnicos de los niveles I, II y III de defensa personal militar, detallando sus posiciones, desplazamientos, armas naturales, técnicas de golpeo, bloqueo, esquivas, de control articular, de proyección, trabajo en suelo, con armas, aplicaciones y métodos de entrenamiento, junto con sus ilustraciones. El último capítulo presenta los contenidos del programa de cinturón negro $1^{\underline{0}}$ dan en defensa personal militar. Adjunta anexos con el programa técnico en defensa personal de niveles I, II y III así como desde $1^{\circ}$ hasta $4^{\circ}$ dan.

1228. Anta, Juan Ángel y Sánchez, José Ramón (2001). Curso de defensa integral : mujer y cuerpos de seguridad y orden público. Bilbao: s.n. 1aㅡ ed. 125 p. : il. ; 21x29,5 cm. ISBN: No ISBN. Depósito legal: BI. 547-2001. Palabras clave: fundamentos teóricos, fundamentos técnicos, psicología. Resumen: Manual teórico y técnico de defensa personal policial. El libro esta formado por 3 capítulos. El primer capítulo presenta 
los contenidos teóricos de los aspectos psicológicos y de defensa personal impartidos en los cursos. El segundo capítulo expone el programa de contenidos del curso de defensa integral de la mujer detallando sus objetivos, aspectos psicológicos y contenidos técnicos del programa básico de suelo. El tercer capítulo incluye el programa de contenidos de defensa integral de cuerpos de seguridad y orden público comentando sus objetivos, los fundamentos teóricos y técnicos del bastón corto, las técnicas de defensa personal, el grappling, la defensa en el suelo, el control, el cacheo y las conducciones.

1229. Anta, Juan Ángel y Sánchez, José Ramón (2001). Programa básico de defensa integral (cuerpos de seguridad). Bilbao: s.n. 1aㅡ ed. 25 p. ; 21x29,5 cm. ISBN: No ISBN. Depósito legal: BI. 548-2001. Palabras clave: fundamentos teóricos, programa técnico. Resumen: Manual teórico de defensa personal policial. El libro esta formado por 2 capítulos. El primer capítulo comenta los objetivos en la administración y el puesto de trabajo de los cursos de defensa personal específicos. El segundo capítulo presenta los programas de contenidos de los cursos de defensa personal, bastón policial y grappling y suelo.

1230. Benito García, José María (2000). Manual básico bastón policial extensible ASP. Barcelona: Andreu Soler i Associats. 1a ed. 76 p. : il. ; 17x24 cm. ISBN: 84-931779-1-1. Depósito legal: no.

1231. Benito García, José María (2003). Katas de defensa personal policial. Madrid: Federación Madrileña de Lucha. $1^{a}$ ed. 80 p. : il. ; $17 \times 24$ cm. ISBN: 84-607-9402-4. Depósito legal: M. 50716-2003. Palabras clave: historia, defensa personal policial. Resumen: Manual técnico de defensa personal. El libro esta dividido en 3 capítulos, precedidos por una introducción que comenta los sistemas de defensa personal de distintos países, el origen de la defensa personal policial en España y un resume de los contenidos del libro. Los tres capítulos comentan los requisitos personales y materiales de cada kata, y describe la ejecución técnica de las katas acompañadas de numerosas fotografías explicativas de cada movimiento.

1232. Benito García, José María y Georgiev, Petar (2005). Manual básico de la Unión Europea de procedimientos de defensa personal policial. Madrid: Federación Madrileña de Lucha. 1ํㅡ ed. 138 p. : il. ; 17x24 cm. ISBN: 84-609-8208-4. Depósito legal: no.

1233. Benito García, José María y Tórtola Sánchez, Francisco (1997). Técnicas de arresto : defensa personal policial. Madrid: Federación Madrileña de Lucha. 1aㅡ ed. 47 p. : il. ; 16×24 cm. ISBN: 84-605-6324-3. Depósito legal: M. 17242-1997. Palabras clave: fundamentos teóricos, fundamentos técnicos, defensa personal policial, principios técnicos, aikido, judo. Resumen: Manual teórico y técnico de defensa personal policial. El libro esta formado por 14 capítulos precedidos por una introducción que define la defensa personal y comenta los contenidos del libro. El primer capítulo define el control de seguridad y explica su ejecución. El segundo capítulo expone los principios de la identificación además de describir su ejecución en distintas situaciones acompañadas de su representación gráfica. Los dos siguientes capítulos describen el cacheo y algunas técnicas de detención al paso incluyendo sus ilustraciones. El quinto capítulo presenta la descripción y representación de varias técnicas de reducción mientras que el sexto describe la utilización de distintas presiones y pellizcos. El séptimo capítulo enumera y representa los tipos de controles articulares mientras que el octavo detalla las técnicas aplicables ante resistencias pasivas. El noveno capítulo define los tipos de estrangulaciones, comenta sus principios técnicos y representa algunas de ellas. El décimo capítulo expone los elementos principales y auxiliares para el esposamiento mientras que los dos siguientes capítulos presentan la descripción e ilustración de distintas formas de esposamiento. Los dos últimos capítulos describen la forma de conducir a un detenido dentro del vehículo policial y cómo quitar los grilletes.

1234. Callero González, Felipe Concepción y Hess, Joe (1994). Defensa personal policial. Las Palmas de Gran Canaria: Felipe Callero y Joe Hess. 1aㅡ ed. 160 p. : il. ; 21x23 cm. ISBN: [84-605-5997-1]. Depósito legal: GC. 613-1994. Palabras clave: fundamentos teóricos, defensa personal, kyusho, legislación, armas. Resumen: Manual teórico y técnico de defensa personal. La obra esta formada por 14 capítulos precedidos por una introducción que resume los contenidos de la obra, comenta el currículo profesional de los autores e incluye varias de sus fotografías impartiendo cursos. El primer capítulo define el concepto de defensa personal policial para luego explicar las connotaciones jurídico-penales de las actuaciones policiales. El tercer capítulo enumera los principales puntos de presión mientras que el cuarto describe la ejecución de varias técnicas a mano vacía contra distintos ataques incluyendo su representación gráfica. Los siguientes cuatro capítulos explican la ejecución de distintas técnicas de defensa contra diferentes agarres, estrangulaciones e intento de arrebatar el arma, acompañadas de su secuencia fotográfica. El noveno capítulo define los términos de inmovilización, control, engrilletamiento, cacheo y transporte además de incluir la descripción e ilustración de varias de estas técnicas. El décimo capítulo clasifica las armas policiales, señala sus características y principales técnicas, incluyendo la secuencia fotográfica de algunas de ellas. Los últimos cuatro capítulos describen la ejecución de técnicas de defensa contra un atacante drogado, ataques con cuchillo, con palo y con armas de fuego.

1235. Carnero Quintairos, Antonio y Castro Martín, Eduardo (2004). El manejo de la defensa extensible. Bilbao: Antonio Carnero Quintairos. 1a ed. 113 p. : il. ; 15x21,5 cm. ISBN: 84-609-0556-X. Depósito legal: BI. 460-2004. Palabras clave: fundamentos técnicos, defensa personal, armas. Resumen: 
Manual técnico de manejo de la defensa extensible. El libro esta dividido en 8 capítulos precedidos por una introducción que comenta los objetivos del libro. Los primeros siete capítulos presentan la descripción técnica y secuencia fotográfica de varias defensas con la defensa extensible ante diferentes agresiones de puño, agresiones de pierna, agarres frontales, agarres por detrás, agresiones con palo y agresiones con cuchillo. El último capítulo incluye la descripción e ilustración de distintas técnicas de detención, reducción y control con la defensa extensible.

1236. Carrascosa de la Torre, Pedro; López-Cuadra Ejarque, Gerardo y Pérez-Ugena Sintas, Mariano (1966). Defensa personal. Toledo: Católica Toledana. $1^{\underline{a}}$ ed. 182 p. : il. ; [12x[17] cm. ISBN: No ISBN. Depósito legal: TO. 18-1966. Palabras clave: fundamentos teóricos, fundamentos técnicos, defensa personal policial, pedagogía, kuatsu, armas. Resumen: Manual teórico y técnico de defensa personal. La obra esta dividida en 3 partes. La primera parte consta de 9 capítulos precedidos por algunos consejos para la enseñanza de los instructores, las precauciones para evitar accidentes, los procedimientos de enseñanza, describe las características del lugar de entrenamiento, enumera y localiza los puntos vitales del cuerpo humano, describe las principales armas naturales y expone los principios técnicos para alcanzar la máxima eficacia. El primer capítulo describe la ejecución de las caídas acompañadas de sus ilustraciones explicativas. Los siguientes cuatro capítulos detalla los principios técnicas y tácticos de la defensa ante los ataques con arma blanca, de pistola, con fusil y metralleta, y fusil con bayoneta, incluyendo la secuencia fotográfica de algunas de sus técnicas y una breve descripción. Los tres siguientes capítulos muestran las diferentes técnicas de cacheo, conducción de detenidos y prisiones, y de mordazas y ataduras aplicables acompañadas de su representación gráfica. El último capítulo presenta algunas de las técnicas de ataque a centinelas. La segunda parte consta de 12 capítulos. Los primeros 11 capítulos explican brevemente e ilustran la secuencia de movimientos de distintas técnicas de defensa personal ante empujones, agarres del muñecas, agarres de solapas, trinchas o mangas, agarres del cuello, agarres del pelo, agarres del brazo y los dos brazos, estrangulaciones, puñetazos, patadas y ataques con palos, porras y botellas. El último capítulo incluye la pronunciación en español, ruso, francés, inglés y alemán de algunos términos específicos del trato con prisioneros. La última parte consta de 2 capítulos. El primero enumera las funciones de los perros que actúan como centinelas, los factores que favorecen y dificultan el seguimiento de un rastro para luego detallar algunas técnicas para evitar ser rastreado y defenderse contra su ataque. El último capítulo define los tipos de contusiones y pérdidas de conocimiento para luego presentar algunas técnicas de kuatsu para su tratamiento.

1237. Coque, José Antonio R. (2005). Defensa personal policial : principios legales y protocolos de intervención. Madrid: Librería Argentina. 1a ed. 156 p. : il. ; 17x24 cm. ISBN: 84-89836-76-0. Depósito legal: M. 18190-2005. Palabras clave: entrenamiento, legislación, pedagogía. Resumen: Manual teórico y técnico de defensa personal policial. La obra esta dividida en 7 capítulos, comenzando con la explicación de los aspectos legales relacionados con el uso de la fuerza. Después explica cómo la defensa personal policial forma parte del trabajo profesional y cuáles son las situaciones de intervención policial, para en el tercer capítulo describir los niveles de resistencia a la autoridad y cuáles son las directrices generales ante cada situación, además de las correspondientes técnicas de defensa personal policial. El cuarto capítulo describe los principios de la detención y cuáles son las técnicas a aplicar en cada situación. Continúa con la descripción del uso del bastón extensible y finaliza con dos capítulos teóricos sobre la enseñanza de la defensa personal policial y sobre la defensa personal policial como disciplina deportiva.

1238. Coque, José Antonio R. (2008). Intervención operativa y defensa personal policial. Madrid: ELINT. 1a ed. 244 p. : il. ; 17x24 cm. ISBN: 978-84-612-6109-3. Depósito legal: M. 40107-2008. Palabras clave: fundamentos teóricos, fundamentos técnicos, legislación, principios de actuación, armas. Resumen: Manual teórico y técnico de defensa personal policial. El libro esta compuesto por 8 capítulos. El primer capítulo explica los aspectos legales relacionados con el uso de la fuerza como los conceptos de legítima defensa, los principios y normas que regulan el uso de la fuerza, la legislación internacional y nacional del uso de la fuerza y analiza los principios que regulan el ejercicio de la fuerza policial. El segundo capítulo comenta las características del estrés producido por un enfrentamiento policial, sus alteraciones, clasifica las situaciones de intervención policial y expone los criterios de evaluación de las mismas, comenta los grados de alerta, el uso graduado de la fuerza y del arma de fuego. El tercer capítulo describe las posiciones del agente y las formas de aproximación, las distancias de aproximación, los desplazamientos básicos, las características del judo verbal y enumera los principios básicos de la intervención policial. El cuarto capítulo clasifica los niveles de resistencia, localiza los puntos de presión del cuerpo humano y describe los principios técnicos y las distintas técnicas contra desobediencias, resistencias físicas leves, resistencias defensivas, agresiones físicas, agresiones armadas y la lucha en el suelo acompañados de su representación gráfica. El quinto capítulo comenta las características y tipos de bastón policial, kubotan, sprays, puño de electrochock, porra eléctrica y pistola Taser así como sus formas de utilización. El sexto capítulo explica el concepto de detención, su legislación, los presupuestos para practicar la detención y su modo de actuación, y describe las técnicas 
de detención a manos vacías, con grilletes y la conducción y traslados de detenidos. El séptimo capítulo explica los principios de actuación ante una identificación, un cacheo y una intervención corporal. El último capítulo expone los principios de actuación y procedimientos para la detención y control de vehículos y sus ocupantes.

1239. Díaz de Tuesta Díez, José (1984). Normas para la utilización de la defensa reglamentaria. Madrid: Ayuntamiento de Madrid, Cuerpo de la Policía Municipal. 1ae ed. 53 p. : il. ; $21 \times 27$ cm. ISBN: No ISBN. Depósito legal: M. 42726-1984. Palabras clave: armas, fundamentos técnicos. Resumen: Manual teórico y técnico de defensa personal policial. El libro esta formado por 2 capítulos precedidos por un preámbulo que comenta los obejtivos de la obra. El primer capítulo detalla las características y estructura de la defensa reglamentaria así como sus diferentes tipos, incluyendo varias ilustraciones explicativas. El segundo capítulo describe e ilustra las posiciones de transporte de la defensa, las formas de sujección y de empleo, sus fundamentos técnicos ante distintos ataques y agarres, explica la utilización de la defensa como elemento de persuasión y coerción, indica los efectos de su utilización sobre las distintas partes del cuerpo y explica su aplicación para reducir a un individuo peligroso, realizar cacheos, conducciones y contenciones junto con su representación gráfica. Adjunta una breve conclusión.

1240. Fernández Prada, José Antonio (1986). Manual del bastón policial. Madrid: Dirección General de la Policía. 1a ed. 86 p. : il. ; 16x23 cm. ISBN: 84-86380-11-1. Depósito legal: M. 5327-1986. Palabras clave: fundamentos teóricos, armas, fundamentos técnicos, principios técnicos. Resumen: Manual teórico y técnico de bastón policial. El libro esta compuesto por 13 capítulos precedidos por una introducción que comenta las características del bastón policial. El primer capítulo narra la historia del bastón policial y explica los diferentes tipos que existen. El segundo capítulo detalla la estructura del bastón policial incluyendo su representación gráfica. El tercer capítulo explica cómo colocar la correa mientras que el quinto describe su transporte. Los siguientes cinco capítulos describen la ejecución, fundamentos y principios técnicos de las formas de desenfunde, el empuñamiento largo, el empuñamiento corto y el empuñamiento doble acompañados de la ilustración de sus técnicas. El décimo capítulo expone los principios de actuación ante varias situaciones de agarre del bastón policial y cómo liberarse junto con su secuencia fotográfica. El siguiente capítulo localiza los principales puntos vitales del cuerpo humano. Los dos últimos capítulos comentan las características de las técnicas de control, resistencia pasiva, acompañamientos obligados y algunas técnicas especiales como el uso de la correa como esposas, el uso del bastón en una persecución a pie y en vehículos, describiendo e ilustrando su ejecución.

1241. Fernández Prada, José Antonio y Tejedor González, José Luis (1998). Defensa personal policial. Valencia: Tirant lo Blanch. 1aㅡ ed. 205 p. : il. ; 17x24 cm. ISBN: 84-8002-648-0. Depósito legal: V. 22121998. Palabras clave: fundamentos técnicos, defensa personal policial, principios técnicos, kyusho, armas. Resumen: Manual teórico y técnico de defensa personal policial. El libro consta de 8 capítulos precedidos por un prólogo que señala la importancia del libro. El primer capítulo comenta la legislación relativa a la defensa personal policial y los objetivos del libro. El segundo capítulo describe la ejecución y principios de la posición de seguridad, localiza los puntos vitales del cuerpo humano, explica la ejecución de las principales técnicas de golpe, bloqueos, esquivas y desplazamientos acompañadas de sus ilustraciones. El tercer capítulo describe la ejecución de las distintas formas de caer así como las técnicas de luxación de la muñeca, del hombro, del codo y de los dedos junto con sus posibles aplicaciones acompañadas de su representación gráfica. El cuarto capítulo incluye la descripción e ilustración de algunas de las principales técnicas de proyección, derribo, estrangulación y presión. El quinto capítulo enumera las normas básicas de seguridad para luego presentar los distintos tipos de esposas y lazos de seguridad así como la descripción de las diferentes formas de esposamiento junto con su secuencia fotográfica. El sexto capítulo comenta los principios del cacheo y presenta algunas de las posibles armas ocultas. El séptimo capítulo expone los tipos y características de armas de fuego, ofrece algunos consejos para su neutralización además de describir la ejecución de varias técnicas de defensa personal ante posibles amenazas con pistola, ataques con arma blanca y armas contundentes acompañadas de sus respectivas ilustraciones. El último capítulo presenta la descripción e ilustración de diversas técnicas de conducción ante resistencias pasivas o en situaciones especiales y de defensa ante agarres o retención del arma de fuego.

1242. Fraguas, José María y Ruano, José V. (1984). Defensa personal para vigilantes jurados y guardas de seguridad : decreto ley, formación. Madrid: Esteban Sanz Martínez. 1aㅡ ed. 171 p. : il. ; 15x21 cm. ISBN: 84-85977-14-9. Depósito legal: M. 35934-1984. Palabras clave: fundamentos teóricos, fundamentos técnicos, defensa personal, aplicación marcial, legislación, terrorismo, armas. Resumen: Manual teórico y técnico de defensa personal. El libro esta compuesto por 15 capítulos precedidos por una dedicatoria, agradecimientos, la biografía de los autores y una introducción que comenta la importancia de las artes marciales en la defensa personal. El primer capítulo enumera los requisitos y el programa de contenidos de la división de vigilancia. El segundo capítulo detalla el proceso de selección y entrenamiento del personal de seguridad. El tercer capítulo presenta el real decreto que 
regula la función de los vigilantes jurados de seguridad. El cuarto capítulo incluye el programa de conservación, mantenimiento y manejo del arma mientras que el quinto explica la forma de agarre correcta de la defensa reglamentaria acompañada de sus ilustraciones correspondientes. Los dos siguientes capítulos explican brevemente e ilustran la ejecución de siete golpes básicos y cuatro bloqueos dobles con la defensa reglamentaria. Los siguientes cinco capítulos describen la ejecución de diversas técnicas de defensa a mano vacía contra un agresor sin arma, un agresor armado y dos agresores desarmados, distintas técnicas con la defensa reglamentaria ante un agresor armado y varias técnicas de cacheo, reducción y colocación de los grilletes, acompañadas de sus secuencias fotográficas. El décimo tercer capítulo enumera los diferentes tipos de seguridad que puede llevar a cabo un vigilante jurado mientras que el siguiente capítulo muestra una ficha para la identificación de sospechosos y comenta algunos de los sistemas de seguridad que ayudan al vigilante. El último capítulo describe el modo de actuación ante una amenaza de bomba.

1243. Fuentes G. de Salazar, Federico (1959). Judo y defensa personal en las Fuerzas Armadas. Toledo: Academia de Infantería. $1^{\underline{a}}$ ed. 244 p. : il. ; desc.xdesc. cm. ISBN: No ISBN. Depósito legal: no. (2 $2^{\underline{a}}$ ed., 1962). Palabras clave: katas, historia, fundamentos técnicos, defensa personal policial, ejercicios, calentamiento, kyusho, competición, grados, reglamentos. Resumen: Manual teórico y técnico de judo. El libro esta formado por 4 partes precedidas por un prólogo que comenta los objetivos de la obra y un preámbulo que comenta las características y beneficios del judo. La primera parte esta compuesta por dos capítulos, relatando el primer capítulo la historia del judo, exponiendo las características de la sala y vestimenta del judo, describiendo las posiciones y momentos de saludar, el agarre, las posturas, los desplazamientos y las formas de caer acompañadas de su representación gráfica. El segundo capítulo expone la ejecución de distintos ejercicios de calentamiento previos a la práctica del judo. La segunda parte incluye cinco capítulos que presentan los fundamentos técnicos del judo. Los cuatro primeros capítulos de esta parte describen la ejecución de las principales técnicas de proyección, inmovilización, estrangulación y luxación respectivamente, además de ilustrarlas. El quinto capítulo incluye las reglas de competición del judo así como las características del tatami y el judogi. La tercera parte esta formada por cinco capítulos, explicando el primero de ellos en qué consiste el ate-waza (arte de golpear), cuáles son las armas naturales para golpear y dónde se encuentran los puntos vulnerables del cuerpo humano. Los dos siguientes capítulos describen la ejecución técnica de la kime-no-kata y goshin-jitsu-no-kata, incluyendo la representación gráfica de sus movimientos. El cuarto capítulo muestra la ejecución de otras técnicas de defensa personal ante presas a las muñecas, al cuerpo, estrangulaciones, ataques armados con palo, cuchillo y amenazas con pistola. El quinto capítulo incluye la descripción técnica de los cacheos, conducción y atadura de prisioneros, y ataque a centinelas junto con sus ilustraciones explicativas. La última parte esta formada por dos capítulos. El primer capítulo explica el sistema de grados del judo incluyendo la tabla de contenidos para cada cinturón. El último capítulo comenta las características y objetivos de las contrapresas y combinaciones además de exponer una relación de las mismas ante distintas técnicas.

1244. Gallego Gredilla, Enrique; San Antonio Hernández, Félix de y Campillo Martínez, Ignacio (1971). Normas sobre gimnasia y defensa personal con arma larga y empleo de la defensa : ponencia. Madrid: Academia de Policia Armada. 1a ed. 63 p. : il.; 15x21 cm. ISBN: No ISBN. Depósito legal: no. Palabras clave: fundamentos técnicos, armas. Resumen: Manual técnico de defensa personal policial. El libro esta formado por 3 capítulos. El primer capítulo incluye la secuencia fotográfica de distintas posiciones ejercicios de gimnasia con arma larga. El segundo capítulo describe e ilustra la posición de guardia con arma y sin ella, las distintas formas de caer con el arma, las técnicas de defensa personal ante culatados, estocadas, golpes y encañonamientos así como los ataques al centinela y sus posibles defensas. El último capítulo explica brevemente la utilización de la defensa y sus efectos sobre las distintas zonas del cuerpo incluyendo diversas ilustraciones explicativas.

1245. García García, José Manuel (1961). El combate cuerpo a cuerpo. Zaragoza: Librería General. 1a ed. 175 p. : il. ; 16x21,5 cm. ISBN: No ISBN. Depósito legal: Z. 2851-1961. Palabras clave: historia, fundamentos técnicos, defensa personal, judo, armas. Resumen: Manual teórico y técnico de defensa personal policial. El libro esta compuesto por 9 capítulos precedidos por un prólogo que expone los objetivos de la obra, una introducción que señala la importancia del judo en el ejército, una dedicatoria, la narración del origen del judo y un listado de sus contenidos técnicos. Los primeros siete capítulos presentan la descripción técnica y secuencia fotográfica de las diversas defensas contra las presas de muñecas, los ataques y presas del cuello con los brazos, las presas frontales y por detrás de la cintura, las presas de las solapas con una o dos manos, las estrangulaciones frontales y por la espalda, los ataques con patadas y puñetazos, y las defensas contra ataques armados con mosquetón, puñal y pistola. El octavo capítulo presenta cuatro ataques distintos a centinelas incluyendo su explicación técnica e ilustraciones explicativas. El último capítulo explica la ejecución técnica de las diferentes formas de caer en judo además de las proyecciones ippon-seoi-nage, o-soto-gari, koshi-guruma, hiza-guruma, kata-guruma y tomoe-nage acompañadas de su secuencia fotográfica. 
1246. García Gazapo, Tomás; González Gutiérrez, Jesús y González Jorquera, José Francisco (2009). Manual de procedimientos operativos de defensa personal en la guardia civil. Madrid: Dykinson. $1 \underline{\text { a }}$ ed. 258 p. : il. ; 17x24,5 cm. ISBN: 978-84-9849-382-5. NIPO: 126-08-092-5. Depósito legal: no. Palabras clave: fundamentos teóricos, fundamentos técnicos, defensa personal policial, principios técnicos, armas, legislación, principios de actuación. Resumen: Manual teórico y técnico de defensa personal policial. La obra esta dividida en 12 capítulos. El primer capítulo presenta y comenta la legislación nacional e internacional sobre el uso policial de la fuerza. El segundo capítulo justifica la inclusión de la defensa personal policial dentro de la guardia civil, explica sus principios y el sistema gradual de la fuerza, y expone el análisis psicológico previo a una intervención, los principios, razonamientos y normas básicas de actuación, y las reacciones ante las situaciones de estrés y peligro. El tercer capítulo describe las distintas posiciones fundamentales en la identificación de personas, define las zonas y distancias de seguridad, explica el procedimiento operativo en la identificación de personas y en el trabajo de suelo, incluyendo las fotografías explicativas de cada técnica. El cuarto capítulo expone la base legal del cacheo y describe los procedimientos operativos en la práctica del cacheo policial en situaciones de normalidad, alerta y peligro, incluyendo fotografías explicativas. El quinto capítulo detalla cómo realizar una detención, cuáles son los medios auxiliares y cuál es el procedimiento operativo en las situaciones de normalidad, alerta y peligro. El sexto capítulo expone el objeto, requisitos y actuación ante las conducciones y traslados de detenidos así como la descripción de los distintos procedimientos operativos. El séptimo capítulo describe e ilustra las técnicas de conducción de un individuo así como las posibles reacciones del mismo y su solución. El siguiente capítulo describe e ilustra diferentes técnicas de proyección y los procedimientos operativos ante un individuo armado, un individuo alterado y un individuo que ataca al guardia civil. El noveno capítulo expone los objetivos de las técnicas de percusión en la Guardia Civil, describe la ejecución de los principales golpes en las distancias media y corta acompañados de sus ilustraciones, explica el procedimiento operativo en la utilización de éstas técnicas y describe la intervención ante distintos ataques realizados en diferentes distancias acompañados de la secuencia fotográfica de las mismas. El décimo capítulo describe la estructura de los diferentes bastones policiales, sus ventajas frente al bastón tradicional, ilustra sus formas de agarre y guardia, las principales técnicas de percusión, control y conducción, y los procedimientos operativos ante diferentes situaciones. El undécimo capítulo explica los fundamentos de las agresiones armadas, ilustra tres procedimientos operativos ante un ataque de palo, comenta los principios de actuación y las distancias ante dichas situaciones, e ilustra varias técnicas para impedir la sustracción del arma de fuego reglamentaria. El último capítulo describe el procedimiento de actuación en la identificación de vehículos en las situaciones de normalidad, alerta y peligro, las técnicas policiales ante resistencias pasivas y activas al abandono del vehículo y en la conducción de detenidos en vehículos, incluyendo la secuencia fotográfica de cada una de ellas. Adjunta bibliografía.

1247. Garrido Domínguez, Ángeles (2006). Defensa policial básica. Vigo: Ángeles Garrido Domínguez. 1aa ed. 53 p. : il. ; $17 \times 24$ cm. ISBN: 84-689-7709-8. Depósito legal: VG. 336-2006. Palabras clave: fundamentos técnicos. Resumen: Manual teórico y técnico de defensa personal policial. El libro esta formado por 3 capítulos precedidos por una introducción que comenta las variantes de la defensa personal y las características concretas de la defensa personal policial. El primer capítulo expone los contenidos de la defensa personal y los contenidos de la obra. El segundo capítulo enumera los principios de actuación de la defensa personal policial. El tercer capítulo describa la ejecución de los principales bloqueos, posiciones, desplazamientos, golpes, caídas y proyecciones de la defensa personal policial junto con sus ilustraciones explicativas y de los controles articulares, luxaciones, presiones y pellizcos. Adjunta una conclusión final sobre la utilidad de la obra.

1248. González Gutiérrez, Jesús y Veleiro Vidal, Juan Carlos (2004). Defensa personal en la Guardia Civil. Madrid: Dykinson. 1a ed. 399 p. : il. ; 17x24 cm. ISBN: 84-9772-432-1. NIPO: 126-04-030-5. Depósito legal: M. 38113-2004. Palabras clave: historia, fundamentos teóricos, táctica, entrenamiento, fundamentos técnicos, principios técnicos, legislación, principios de actuación, armas, defensa personal. Resumen: Manual teórico y técnico de defensa personal policial. La obra esta dividida en 25 capítulos. El primer capítulo expone la legislación relacionada con la defensa personal policial en la guardia civil. El segundo capítulo define la práctica de la defensa personal en la guardia civil y narra su historia y evolución. El tercer capítulo explica los conceptos básicos de la teoría del entrenamiento, las características especiales de la mujer, los efectos del entrenamiento sobre el organismo y propone el trabajo de desarrollo de las cualidades físicas básicas. El cuarto capítulo expone la reacción mental, emocional y hormonal ante las situaciones de estrés o intervención policial, propone métodos para controlar dichas reacciones y la sensación de miedo. El quinto capítulo define los conceptos de identificación y cacheo, enumera sus principios básicos y explica sus diferentes tipos. El sexto capítulo expone las características y factores que afectan a las resistencias leves, para luego describir e ilustrar la actuación ante distintas situaciones. Los dos siguientes capítulos comentan las características de los ataques poco peligrosos y peligrosos respectivamente además de incluir la descripción de las técnicas a utilizar en distintas situaciones de estos tipos. El noveno capítulo expone el control del individuo en 
el suelo, explica la ejecución de las caídas y la defensa cuando la lucha se produce en el suelo. El décimo capítulo analiza las distintas partes del cuerpo utilizadas para golpear, la guardia y desplazamientos utilizados en las agresiones sin armas, la distancia de combate, describe los principios técnicos de las golpes de percusión y los principios tácticos del combate cuerpo a cuerpo y las técnicas de proyección, así como los instrumentos de entrenamiento de dichos golpes. El siguiente capítulo describe e ilustra la ejecución de distintas técnicas ante agresiones graves por golpes. El duodécimo capítulo explica el entrenamiento de los golpeos con los instrumentos específicos y señala los beneficios del entrenamiento de combinaciones. El siguiente capítulo define los términos de patrullar, engrilletar y detener, expone sus tipos, el material utilizado para los mismos y describe la ejecución de un engrilletamiento y una detención junto con sus respectivas ilustraciones. El decimocuarto capítulo presenta las características de los diferentes tipos de bastones policiales acompañadas de la ilustración de algunas de sus técnicas de defensa, golpeo y control; y comenta la regulación, descripción técnica y técnicas del bastón policial extensible. El siguiente capítulo señala las características, efectos y regulación de los sprays de defensa personal. El decimosexto capítulo detalla los principios de actuación ante ataques con armas contundentes, armas blancas y armas de fuego estando el agente en distintas situaciones, continuando con la descripción e ilustración de varias técnicas de defensa personal a manos vacías contra un arma blanca. Los dos siguientes capítulos detallan las normas de actuación en la intervención policial en vehículos ante distintas situaciones de riesgo y describen la ejecución de varias técnicas de táctica policial de intervención. El vigésimo capítulo expone la legislación respecto a la defensa personal en relación con personas afectadas por enfermedad de carácter persistente.

1249. Granados Pacheco, Juan (2003). Defensa personal policial. Málaga: Escuela de Seguridad Pública del Ayuntamiento de Málaga. 1aㅡ ed. 62 p. : il. ; 21x29,5 cm. ISBN: No ISBN. Depósito legal: MA. 647-2003. Palabras clave: fundamentos técnicos, defensa personal. Resumen: Manual teórico y técnico de defensa personal policial. El libro esta compuesto por 18 capítulos a modo de unidades didácticas. El primer capítulo expone los objetivos del programa de formación permanente de defensa personal policial mientras que el segundo enumera sus contenidos técnicos. El tercer capítulo ilustra las distintas formas de caer y continúa con las guardias disimuladas, desplazamientos y esquivas, defensas, técnicas de golpeo, luxaciones, proyecciones y controles. El décimo primer capítulo explica brevemente la ejecución de varias técnicas de reducción acompañadas de su secuencia fotográfica. Los siguientes siete capítulos ilustran diversas técnicas de cacheo, estrangulaciones, conducción, detenciones al paso, esposamientos, uso de la defensa reglamentaria y contra la retención del arma de fuego.

1250. Herráiz Embid, Salvador (1995). Manual para escoltas privados : protección a personalidades. Barcelona: Flash Books. 1aㅡ ed. 258 p. : il. ; 16x23,5 cm. ISBN: 84-89486-03-4. Depósito legal: B. $35597-$ 1995. Palabras clave: fundamentos teóricos, fundamentos técnicos, defensa personal policial, primeros auxilios, legislación, telecomunicaciones, terrorismo. Resumen: Tratado teórico y técnico de defensa policial. El libro esta dividido en 13 capítulos. El primer capítulo expone las características del escolta privado y su trabajo. El segundo capítulo presenta la ley 23/1992 de seguridad privada y el real decreto 2364/1994 de seguridad privada. El tercer capítulo comenta cómo debe realizarse la tarea de protección y las misiones a desarrollar en la teoría de los círculos concéntricos. El siguiente capítulo enumera y explica las técnicas de protección a pie. El quinto capítulo expone los conceptos básicos del tiro con arma corta y su manejo además de la utilización del chaleco antibalas. Los tres siguientes capítulos describen la ejecución de las diversas técnicas de protección con vehículo, la utilización y características de la información que maneja el escolta, y la metodología de la observación. El siguiente capítulo explica las fases de un atentado, la búsqueda y actuación ante diversos tipos de explosivos, las características de los explosivos más frecuentes y cómo realizar una investigación después de una explosión. El décimo capítulo comenta las clases de comunicaciones, el funcionamiento de las transmisiones y las características de los diferentes instrumentos de transmisión. El siguiente capítulo detalla los principios generales que debe seguir el escolta privado ante las situaciones de defensa personal e ilustra distintas técnicas ante diferentes agarres y amenazas con arma. Los dos últimos capítulos describe la ejecución de los cacheos, esposamientos y técnicas de primeros auxilios incluyendo ilustraciones explicativas.

1251. Hombre Dopazo, Juan (2006). Taishindó : defensa personal policial. Vol. I : técnicas de reducción, control y defensa. Madrid: CEP. $1 \underline{a}$ ed. 285 p. : il. ; 17x23,5 cm. ISBN: 84-8354-198-X. 84-8354-201-3 (ISBN de la obra completa). Depósito legal: M. 28427-2006. Palabras clave: historia, fundamentos técnicos, defensa personal policial, instituciones, programa técnico. Resumen: Manual teórico y técnico sobre la defensa personal policial. El libro esta compuesto de 10 capítulos. Los 8 primeros capítulos detallan los aspectos teóricos de la defensa personal policial y en especial de aquella aplicada en el Centro de Instrucción Táctico de Seguridad (CITS). Comienza detallando la historia y origen del CITS, explicando lo que es la defensa personal policial y cuáles son sus objetivos, y la organización de este centro y sus cursos de entrenamiento y graduación. El noveno capítulo incluye el programa técnico dedicado a las 
técnicas de disuasión, de conducción, de engrilletamientos, y defensas contra puños y patadas. Este capítulo comienza con la descripción de los principios generales de actuación ante cualquier situación y luego pasa a describir e ilustrar la ejecución de cada una de éstas técnicas. Finaliza con algunos consejos y conclusiones finales.

1252. Hombre Dopazo, Juan (2006). Taishindó : defensa personal policial. Vol. II : técnicas de defensa contra agarres. Madrid: CEP. 1aㅡ ed. 297 p. : il. ; 17x23,5 cm. ISBN: 84-8354-199-8. 84-8354-201-3 (ISBN de la obra completa). Depósito legal: M. 28428-2006. Palabras clave: fundamentos técnicos, defensa personal policial. Resumen: Manual teórico y técnico de defensa personal policial. La obra esta compuesta de 7 capítulos. Los 4 primeros capítulos explican distintos contenidos teóricos asociados a la defensa personal policial, como son las relaciones humanas, el sentimiento de inseguridad y la necesidad de sentirnos seguros y la actitud de alerta y atención. Los siguientes tres capítulos desarrollan parte del programa técnico, describiendo la ejecución de cada técnica e ilustran las distintas fases del movimiento. Los contenidos prácticos tratados son las defensas ante situaciones en las que se producen agarres por la espalda, la retención del arma por detrás y la retención del arma por delante.

1253. Hombre Dopazo, Juan (2006). Taishindó : defensa personal policial. Vol. III : técnicas de defensa contra arma blanca. Madrid: CEP. $1^{a}$ ed. 297 p. : il. ; 17x23,5 cm. ISBN: 84-8354-200-5. 84-8354-201-3 (ISBN de la obra completa). Depósito legal: M. 28429-2006. Palabras clave: fundamentos técnicos, principios técnicos, defensa personal, entrenamiento, armas. Resumen: Manual teórico y técnico de defensa personal policial. La obra esta compuesta de 9 capítulos, todos ellos dedicados al arma blanca. Comienza con una explicación de las características del arma blanca y de su uso en la actualidad, consejos básicos para situaciones de peligro con arma blanca y cuáles son las características de las situaciones que se pueden presentar en la defensa personal policial. Los siguientes 4 capítulos profundizan en las técnicas a utilizar ante las distintas situaciones antes comentadas con la explicación de cada movimiento y su ilustración, para finalizar con la explicación de los principios del entrenamiento defensivo, la preparación mental ante las situaciones con cuchillo y las características de los guantes anticorte.

1254. Hombre Dopazo, Juan (2006). Taishindó : defensa táctica militar. Vol. I : El cuchillo de asalto. Madrid: Taks. $1^{a}$ ed. 304 p. : il. ; 17x24 cm. ISBN: 84-609-9800-2. Depósito legal: M. 14435-2006. Palabras clave: fundamentos teóricos, fundamentos técnicos, principios técnicos, táctica. Resumen: Manual teórico y técnico de defensa personal militar. El libro esta formado por 12 capítulos. El primer capítulo incluye varias cartas de presentación sobre la obra. El segundo capítulo explica en qué consiste el taishindo mientras que el tercero comenta los objetivos y características de la defensa militar. El cuarto capítulo presenta los grados de entrenamiento. El quinto capítulo explica la aplicación del taishindo militar al ámbito civil. El sexto capítulo describe las distancias de combate así como sus principios técnicos. El séptimo capítulo describe e ilustra los fundamentos técnicos del taishindo militar. El octavo capítulo ofrece numerosos consejos prácticos para el desarrollo de las clases y el combate. El noveno capítulo define las características y estructura del cuchillo de asalto. El décimo capítulo comenta el entrenamiento de taishindo con el cuchillo de asalto y sus fundamentos teóricos. El capítulo decimoprimero explica la ejecución de diversas técnicas de taishindo con el cuchillo de asalto acompañadas de sus ilustraciones. El último capítulo expone los principios tácticos de combate del taishindo militar.

1255. Hombre Dopazo, Juan (2007). Taishindó : defensa personal policial. Acciónate : arma blanca. España: Juan Hombre Dopazo. 1aㅡ ed. 185 p. : il. ; 17x24 cm. ISBN: 978-84-6120-722-0. 978-84-6120-717-6 (ISBN de la obra completa). Depósito legal: M. 51456-2007. Palabras clave: principios técnicos, defensa personal, entrenamiento, armas. Resumen: Manual teórico y técnico de defensa personal policial. El libro esta formado por 3 capítulos precedidos por la presentación de la coautora y una introducción que comenta las generalidades de la defensa personal contra un arma blanca. El primer capítulo comenta la utilización de las armas blancas en la actualidad así como los beneficios de un entrenamiento en su defensa personal. El segundo capítulo expone las fases del entrenamiento en la defensa contra arma blanca, ofrece algunos consejos prácticos y detalla las fases de estrategia en la defensa personal además de exponer las reglas básicas para el entrenamiento y el código de reacción. El último capítulo incluye la descripción y secuencia fotográfica de 10 técnicas de defensa personal contra diferentes ataques con arma blanca finalizando con el control del atacante. Adjunta el programa de contenidos del curso de instructores.

1256. Hombre Dopazo, Juan (2007). Taishindó : defensa personal policial. Aptitud : arma operativa. España: Juan Hombre Dopazo. $1^{a}$ ed. desc.; $17 \times 24$ cm. ISBN: No ISBN. Depósito legal: no.

1257. Hombre Dopazo, Juan (2007). Taishindó : defensa personal policial. Disuasión : reducir sin dañar. España: Juan Hombre Dopazo. 1aㅡ ed. 152 p. : il. ; 17x24 cm. ISBN: 978-84-6120-719-0. 978-84-6120717-6 (ISBN de la obra completa). Depósito legal: M. 51457-2007. Palabras clave: fundamentos teóricos, fundamentos técnicos, defensa personal policial. Resumen: Manual teórico y técnico de defensa personal policial. El libro esta formado por 5 capítulos, precedidos por la presentación del 
coautor de la obra y una introducción que resume los contenidos presentados. El primer capítulo explica en qué consiste el programa de taishindó policial mientras que el segundo capítulo los principios de las técnicas de disuasión y de control. El tercer capítulo expone los fundamentos teóricos de las palancas, inmovilizaciones y técnicas de asfixia además de incluir la descripción y secuencia fotográfica de la ejecución de 7 técnicas de disuasión mientras que el cuarto capítulo explica la ejecución de 4 técnicas de reducción acompañadas de sus ilustraciones explicativas. El quinto capítulo comenta la utilización de los grilletes para luego explicar la ejecución de varias técnicas de engrilletamiento de pie, en la pared y contra cuchillo. Adjunta el programa de los cursos de formación.

1258. Hombre Dopazo, Juan (2007). Taishindó : defensa personal policial. Extensible : adaptarse al medio. España: Juan Hombre Dopazo. 1aㅡ ed. desc.; $17 x 24$ cm. ISBN: No ISBN. Depósito legal: no.

1259. Hombre Dopazo, Juan (2007). Taishindó : defensa personal policial. Reacción : defiende tu integridad. España: Juan Hombre Dopazo. $1^{\text {a }}$ ed. 154 p. : il. ; 17x24 cm. ISBN: 978-84-6120-721-3. 978-84-6120717-6 (ISBN de la obra completa). Depósito legal: M. 51471-2007. Palabras clave: fundamentos técnicos, defensa personal policial. Resumen: Manual teórico y técnico de defensa personal policial. El libro esta formado por 1 capítulo precedido por la presentación del coautor y una introducción que comenta la importancia de la formación en defensa personal y la legislación relacionada con la utilización de la fuerza. El primer capítulo presenta la descripción e ilustración de las ejecución de 10 técnicas de defensa personal en reacción a diversos ataques de puño y pierna, hasta finalizar con el engrilletamiento del atacante. Adjunta el programa de los cursos de formación.

1260. Hombre Dopazo, Juan (2007). Taishindó : defensa personal policial. Recursos : evasión y escape. España: Juan Hombre Dopazo. 1aㅡ ed. 149 p. : il. ; 17x24 cm. ISBN: 978-84-6120-718-3. 978-84-6120-717-6 (ISBN de la obra completa). Depósito legal: M. 51455-2007. Palabras clave: fundamentos teóricos, didáctica, fundamentos técnicos, defensa personal, educación, programa técnico. Resumen: Manual teórico y técnico de defensa personal policial. El libro esta formado por 8 capítulos. El primer capítulo narra los orígenes y formación del taishindo policial, para luego exponer en qué consiste la defensa personal policial y cuáles son los principios del Centro de Instrucción Táctico de Seguridad (CITS). El tercer capítulo explica los niveles de instrucción dentro del CITS y cuáles son sus objetivos didácticos. El cuarto capítulo resalta la importancia de reducir al oponente sin hacerle daño, para luego profundizar en los aspectos del entorno que influyen sobre la personalidad del agente de seguridad y sobre sus relaciones con los ciudadanos. El sexto capítulo expone la importancia de la actitud de alerta y atención que deben tener los agentes de seguridad y cuáles son los métodos para desarrollar dichas capacidades. El siguiente capítulo explica los contenidos teóricos y técnicos que conforman el taishindo CITS y describe la formación de sus instructores. El último capítulo describe diversas técnicas de defensa contra agarres por detrás a la cintura, los hombros, el cuello, el pelo y los brazos, con el apoyo de numerosas ilustraciones. Adjunta un comentario sobre la capacidad de improvisación, la respuesta a las preguntas más frecuentes sobre este sistema de enseñanza y el programa de los cursos de formación.

1261. Hombre Dopazo, Juan (2007). Taishindó : defensa personal policial. Resolución : violencia doméstica. España: Juan Hombre Dopazo. $1^{a}$ ed. 154 p. : il. ; 17x24 cm. ISBN: 978-84-6120-723-7. Depósito legal: M. 51470-2007. Palabras clave: fundamentos técnicos, principios de actuación, violencia. Resumen: Manual teórico y técnico de defensa personal policial. El libro esta formado por 4 capítulos. El primer capítulo describe los principios de la actuación ante una situación de violencia de género ante el agresor y la víctima, y las distintas situaciones que se pueden presentar, para luego explicar la actuación de ambos agentes frente al agresor y la víctima, la entrada en la situación, y los diferentes recursos técnicos para controlar la situación y a ambos involucrados. El tercer capítulo describe e ilustra nueve ejemplos de actuación ante dichas situaciones hasta conseguir el control del agresor, para finalizar exponiendo en qué consiste la defensa personal policial taishindo CITS, sus principios metodológicos y sus objetivos. Adjunta el programa de contenidos del curso de instructores.

1262. Hombre Dopazo, Juan (2007). Taishindó : defensa personal policial. Retención : protege tu equipo. España: Juan Hombre Dopazo. $1^{\mathrm{a}}$ ed. 154 p. : il. ; 17x24 cm. ISBN: 978-84-6120-720-6. 978-84-6120717-6 (ISBN de la obra completa). Depósito legal: M. 51472-2007. Palabras clave: fundamentos técnicos, defensa personal policial, armas. Resumen: Manual teórico y técnico de defensa personal policial. El libro esta formado por 2 capítulos, precedidos por la presentación del coautor y una introducción que ensalza el trabajo policial. El primer capítulo describe la ejecución de diversas técnicas de defensa personal policial ante un agarre del cuello desde diferentes posiciones acompañadas de sus ilustraciones explicativas. El segundo capítulo comenta las peculiaridades del intento de extracción del arma reglamentaria para luego explicar la ejecución de diversas técnicas contra dicho intento tanto por delante como por detrás, incluyendo su secuencia fotográfica. Adjunta el programa de los cursos de formación.

1263. Montesinos Espès, David (1997). Manual técnico del escolta de seguridad privada. Barcelona: Alas. 1a ed. 154 p. : il. ; $17 \times 24$ cm. ISBN: 84-203-0386-0. Depósito legal: B. 47359-1997. Palabras clave: fundamentos teóricos, fundamentos técnicos, vestimenta, cortesía, kyusho, cabuyería, etiqueta, 
telecomunicaciones, armas. Resumen: Manual teórico y técnico de defensa personal policial. El libro esta formado por 22 capítulos precedidos por los agradecimientos, una dedicatoria, la biografía del autor y una introducción que resume los contenidos y objetivos de la obra. El primer capítulo comenta las funciones del escolta. El segundo capítulo expone los contenidos teóricos de la formación de los escoltas. El tercer capítulo presenta las características que debe reunir un escolta. El cuarto capítulo detalla la vestimenta y equipamiento del escolta. El quinto capítulo explica el método de diagnosis de la seguridad y analiza los principales riesgos y amenazas. El sexto capítulo describe los requisitos del comportamiento del escolta. El séptimo capítulo presenta la descripción de las técnicas básicas de primeros auxilios. El octavo capítulo explica en qué consiste la mnemotécnica y describe algunos ejercicios para su desarrollo. El noveno capítulo explica las reglas de seguridad en el empleo del arma mientras que los dos siguientes describen las partes y mecanismos de la pistola, y las partes de los cartuchos y munición. El decimosegundo capítulo describe las técnicas básicas de protección y cubrimiento de la personalidad acompañadas de su representación gráfica. El capítulo decimotercero presenta diversas técnicas de caracterización del rostro. Los dos siguientes capítulos analizan los estados de ánimo en función del rostro y comentan el significado de ciertos gestos y conductas. El decimosexto capítulo explica la ejecución de varias técnicas de cabuyería acompañadas de su representación gráfica. El siguiente capítulo presenta las señales de auxilio y los códigos Morse e internacional de comunicaciones acompañados de ilustraciones explicativas. El decimoctavo capítulo analiza algunas noticias periodísticas para destacar los principios de actuación del escolta y la seguridad. El decimonoveno capítulo comenta la utilización de las escuchas ilegales mientras que el siguiente describe las características de los receptores especiales. Los dos últimos capítulos comentan la utilización de utensilios comunes en las tareas del escolta y localiza los puntos vitales del cuerpo humano.

1264. Montesinos Espès, David (2001). Manual avanzado del escolta de seguridad privada : destinado a

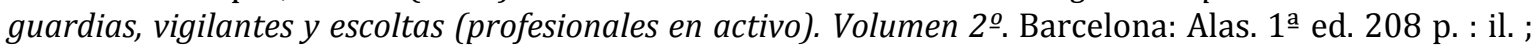
17x24 cm. ISBN: 84-203-0405-0. Depósito legal: B. 458-2001. Palabras clave: fundamentos técnicos, principios de actuación, terrorismo, armas. Resumen: Manual teórico y técnico de defensa personal policial. El libro esta formado por 26 capítulos precedidos por un prólogo que comenta los objetivos de la obra y una introducción que resume algunos de sus contenidos. El primer capítulo señala las ventajas de las artes marciales para el escolta y describe la ejecución de algunas técnicas de defensa personal utilizadas por el autor acompañadas de su representación gráfica. Los tres siguientes capítulos explican la ejecución de las técnicas para evacuar al VIP, como neutralizar al adversario y el protocolo de seguridad norteamericano-israelí. El quinto capítulo expone las distintas pistolas adaptadas a los escoltas mientras que el sexto comenta las características de los chalecos antibalas. El séptimo capítulo detalla la misión del escolta y ofrece algunos consejos para evitar el seguimiento. El octavo capítulo presenta la figura del ojeador. Los siguientes seis capítulos analizan las premisas fundamentales del servicio de protección, los aspectos a proteger, las medidas de seguridad preventivas, los diferentes dispositivos de espera, las técnicas de formación a pie y la protección de lugares cerrados. El decimoquinto capítulo detalla como abrir grilletes y candados junto con sus ilustraciones explicativas. El decimosexto capítulo detalla los principios de la protección en vehículos, sus técnicas, operaciones y maniobras. Los dos siguientes capítulos comentan las características de los explosivos y las medidas de prevención de los paquetes y cartas explosivas. El decimonoveno capítulo incluye una clasificación de los grupos terroristas y analiza sus métodos de actuación mientras que el siguiente detalla las características de los principales grupos terroristas. El vigésimo primer capítulo comenta la inclusión de Estados Unidos e Israel como países terroristas. El vigésimo segundo capítulo narra el atentado en Buenos Aires de 1994. Los dos siguientes capítulos exponen algunos casos de terrorismo político y tres ejemplos de lucha antiterrorista respectivamente. El vigésimo quinto capítulo describe el control de los datos personales en España. El último capítulo describe algunos casos históricos de protección de VIPs, sus causas y defectos. Adjunta un epílogo.

1265. Montesinos Espès, David (2004). Manual superior del escolta de seguridad privada : defensa personal policial dinámica, técnicas para escoltas, introducción al krav maga. Volumen 3o․ Barcelona: Alas. 1aㅡ ed. 171 p. : il. ; $17 \times 24$ cm. ISBN: 84-203-0430-1. Depósito legal: B. 38589-2004. Palabras clave: fundamentos técnicos, defensa personal policial, terrorismo, armas. Resumen: Manual teórico y técnico de defensa personal policial. El libro esta formado por 18 capítulos precedidos por los agradecimientos y una introducción que comenta los contenidos del libro, la definición de la defensa personal policial y sus contenidos técnicos. El primer capítulo detalla la vestimenta y equipamiento del vigilante de seguridad. El segundo capítulo describe las posiciones neutras para interpelar a una persona acompañadas de su representación gráfica. Los dos siguientes capítulos detallan los principios de actuación y técnicas para el control de los accesos. El quinto capítulo ofrece recomendaciones para actuar en espacio públicos acompañados de ilustraciones explicativas. El sexto capítulo enumera los principios para realizar una detención además de describir la ejecución de algunas de sus técnicas. El séptimo capítulo presenta los tipos de esposas y explica las diferentes técnicas para esposar junto con 
su representación gráfica y esquemas de movimiento. El octavo capítulo expone las reglas del cacheo, las técnicas de identificación y las técnicas de cacheo en distintas situaciones de peligro. El noveno capítulo describe la estructura de la defensa, su utilización y las técnicas básicas para su manejo acompañadas de sus ilustraciones explicativas. El décimo capítulo comenta las características del krav maga así como las funciones de un "rompedor" y la descripción de la conducción de un sujeto, el enfrentamiento armado cuerpo a cuerpo y la extracción de un arma o artefacto. El capítulo decimoprimero incluye varias explicaciones sobre las técnicas de los escoltas bajo diversas situaciones y su desarrollo profesional. El decimosegundo capítulo comenta la historia de la kaleborroka y comenta sus actuaciones. El siguiente capítulo analiza las técnicas y tácticas de los kamikazes. El decimocuarto capítulo señala la importancia de las pruebas físicas para acceder a un puesto de vigilante de seguridad. El decimoquinto capítulo expone los rasgos físicos que denotan engaños. El decimosexto capítulo presenta los términos de la psicopatía y sociopatía y sus características. Los dos últimos capítulos narran los casos concretos de famosos caníbales y asesinos en serie.

1266. Muñoz Domínguez, Manuel (1995). Defensa personal. Sevilla: Escuela de Seguridad Pública de Andalucía. $1^{\mathfrak{a}}$ ed. 335 p. : il. ; 15x21 cm. ISBN: No ISBN. Depósito legal: SE. 2089-1995. Palabras clave: fundamentos teóricos, fundamentos técnicos, armas, defensa personal. Resumen: Manual teórico y técnico de defensa personal. El libro esta formado por 14 temas precedidos una dedicatoria, los agradecimientos, un prólogo que presenta la obra, la formación del autor, una introducción que señala la importancia de la defensa personal en la sociedad actual y dos capítulos que señalan la importancia de la preparación física para la defensa personal y describen las características de los ejercicios preparatorios junto con la ilustración de varios de ellos. El primer capítulo ilustra los principales desplazamientos y esquivas mientras que el segundo presenta los tipos de defensas y distancias de combate. Los dos siguientes capítulos incluyen la secuencia fotográfica de distintas técnicas de reducción y las caídas. El quinto capítulo ilustra las armas naturales del cuerpo y explica los factores que intervienen en un golpe. Los tres siguientes capítulos ilustran las distintas posiciones, las técnicas fundamentales de lucha y los estilos de guardia. El noveno capítulo presenta varias técnicas de defensa contra ataques de puño y pierna mientras que el décimo incluye la secuencia fotográfica ante distintos agarres. El capítulo decimoprimero explica los objetivos de la defensa personal ante ataques con arma blanca o de fuego, sus principios de actuación e ilustra varias técnicas de desarme y neutralización. El decimosegundo capítulo compara las ventajas e inconvenientes de la defensa reglamentaria con otros tipos de defensas además de incluir la ilustración de varias técnicas con la defensa, la porra y el tonfa. El capítulo decimotercero enumera los principios de actuación de las técnicas de detención, cacheo, reducción, conducción y esposamiento junto con la secuencia fotográfica de varias de sus técnicas. El último capítulo presenta distintas técnicas de defensa personal contra varios objetos y agresores. Adjunta varios apéndices sobre la anatomía y fisiología humana, los puntos vitales, un resumen de los principios de actuación y un glosario específico.

1267. Ortega Álvarez, Pablo y Fernández Novas, José Antonio (2003). Introducción a la defensa personal policial. s.l.: s.n. 1aㅡ ed. 105 p. : il. ; 21x29,5 cm. ISBN: 84-95668-10-6. Depósito legal: PO. 40-2003. Palabras clave: fundamentos teóricos, fundamentos técnicos, principios técnicos, ejercicios, combate, preparación física, armas, defensa personal. Resumen: Manual teórico y técnico de defensa personal policial. El libro esta dividido en 2 partes. La primera parte esta compuesto de12 capítulos precedidos por una introducción que comenta las características del sanda. El primer capítulo narra la historia del sanda, comenta las características de su competición y su influencia sobre la defensa personal. El segundo capítulo define el concepto de defensa personal mientras que el tercero detalla sus distintas prácticas y el enfoque de ciertas artes marciales sobre la defensa personal. El cuarto capítulo analiza la aplicación del sanda a la defensa personal. El quinto capítulo explica los objetivos de la defensa personal policial mientras que el sexto describe los fundamentos teóricos de la defensa personal integral, policial y especial. El séptimo capítulo enumera los principios técnicos de la defensa personal policial. El octavo capítulo reflexiona sobre la preparación en defensa personal policial como la utilización de las armas naturales del cuerpo, las técnicas de inmovilización, la defensa contra armas, la defensa contra varios agresores y la preparación física. El noveno capítulo expone la estructura didáctica de una sesión así como los contenidos de cada una de ellas. El décimo capítulo enumera los elementos físicos, técnicos, psicológicos, tácticos y habilidades que intervienen en una situación de defensa personal policial. El siguiente capítulo incluye la presentación del modelo básico de intervención pedagógica. El último capítulo enumera los contenidos técnicos de la defensa personal policial. La segunda parte esta compuesta por 11 capítulos. El primer capítulo describe e ilustra distintos ejercicios de calentamiento y preparación física. Los siguientes 5 capítulos explican la ejecución de las técnicas contra distintos tipos de agarres, contra ataques de puño, agarres al pelo y al pecho y contra ataques de puño descendentes acompañados de su secuencia fotográfica. Los dos siguientes capítulos describen brevemente las distintas técnica de defensa con tonfa y defensa reglamentaria ante diversos ataques junto con sus ilustraciones explicativas. El noveno capítulo presenta algunas técnicas de defensa contra ataques de cuchillo a la cara, circular y al abdomen 
incluyendo su representación gráfica. El décimo capítulo describe las técnicas de esposamiento en el coche, contra una pared y a dos personas acompañadas de sus ilustraciones. El último capítulo presenta la descripción e ilustración de varias técnicas de defensa personal contra amenazas de pistola por detrás y al pecho. Adjunta el currículo de los autores.

1268. Ortega Álvarez, Pablo y Fernández Novas, José Antonio (2003). Introducción a la defensa personal policial : esposamientos. s.l.: s.n. 1aㅡ ed. 115 p. : il. ; 21x29,5 cm. ISBN: 84-95668-11-4. Depósito legal: PO. 41-2003. Palabras clave: fundamentos técnicos. Resumen: Manual teórico y técnico de defensa personal policial. El libro esta compuesto por 23 capítulos. El primer capítulo presenta el material utilizado en las técnicas de defensa personal policial que presenta la obra. Los dos siguientes capítulos describen cómo utilizar un cordel como esposas y realizar un esposamiento. El cuarto capítulo describe cómo sujetar los grilletes y esposar junto con su descripción fotográfica. Los siguientes 5 capítulos presentan la descripción e ilustración de distintas técnicas de esposamientos contra la pared, la colocación correcta de los grilletes y algunas técnicas de esposamiento con grilletes rígidos, semirígidos y normales. El décimo capítulo comenta algunos de los inconvenientes de los grilletes normales. El siguiente capítulo detalla el esposamiento por delante acompañado de numerosas ilustraciones mientras que el decimosegundo capítulo presenta la utilización de lazos para el esposamiento. El siguiente capítulo describe e ilustra una variante al engrilletamiento normal. El decimocuarto capítulo detalla como tener preparados los grilletes para esposar de forma rápida junto con sus ilustraciones explicativas. Los dos siguientes capítulos exponen la ejecución del engrilletamiento al paso y en el suelo acompañadas de su secuencia fotográfica. El decimoséptimo capítulo explica como levantar al detenido esposado del suelo. El decimoctavo capítulo incluye la descripción e ilustración del esposamiento de rodillas. Los siguientes 4 capítulos explican la utilización de los grilletes para soltarse de un agarre al pecho, la utilización del cubotán, la utilización del tonfa para soltarse de un agarre y como conducir a un detenido incluyendo la secuencia fotográfica de cada técnica. El último capítulo detalla la ejecución del esposamiento en el suelo junto con su ilustración. Adjunta el currículo de los autores.

1269. Quintero Mora, Alfonso y Mora Moro, Francisco Javier (2007). Curso básico táctica policial para policías locales. s.l.: CSI-CSIF Sector Local Andalucía. 1aㅡ ed. 111 p. : il. ; 17x21 cm. ISBN: No ISBN. Depósito legal: M. 7956-2007. ( $2^{a}$ ed., 2007). Palabras clave: fundamentos teóricos, fundamentos técnicos, defensa personal policial, principios de actuación, armas. Resumen: Manual teórico y técnico de defensa personal policial. El libro esta formado por 5 capítulos precedidos por una presentación que comenta los objetivos y planteamiento de la obra. El primer capítulo explica las características de las situaciones de estrés de las actuaciones policiales, describe el equipo básico del agente, describe e ilustra sus fundamentos técnicos, define las actitudes de seguridad, los niveles de fuerza y enumera algunos de los ejercicios preparatorios del entrenamiento. El segundo capítulo describe la ejecución de varias técnicas de engrilletamiento en superficies verticales y horizontales acompañadas de sus secuencias fotográficas. El tercer capítulo comenta los principios de actuación de los cacheos junto con la descripción de sus técnicas mientras que el cuarto capítulo explica la técnica de izado y conducción del detenido. El último capítulo describe brevemente las técnicas de defensa personal policial ante puñetazos, agarres, ataques armados con arma blanca y pistola y las técnicas de extracción de un vehículo y una moto. Adjunta bibliografía y agradecimientos.

1270. s.a. (2007). Intervención policial en situaciones conflictivas. Málaga: Espacio Formación. 1a ed. 273 p. : il. ; $21 \times 29,5$ cm. ISBN: No ISBN. Depósito legal: M. 46186-2007. (2 $2^{a}$ ed., 2008). Palabras clave: fundamentos teóricos, fundamentos técnicos, principios técnicos, legislación, principios de actuación. Resumen: Manual teórico y técnico de defensa personal. El libro esta formado por 3 módulos. El primer módulo consta de 8 capítulos. El primer capítulo expone la legislación referente a las fuerzas y cuerpos de seguridad así como sus funciones. El segundo capítulo define las habilidades sociales, sus funciones y aplicaciones. El tercer capítulo explica los fundamentos teóricos de la prevención del delito, los objetivos de la policía de barrio, sus funciones y actuaciones. El cuarto capítulo incluye la normativa referente a las funciones de la policía de barrio dentro de la policía judicial. El quinto capítulo define el concepto de detención, sus principios de actuación y el uso de la fuerza y del arma reglamentaria. El sexto capítulo expone los principios colaboradores de la policía. El séptimo capítulo comenta algunos principios de actuación en las situaciones de autoprotección. El octavo capítulo ofrece algunos consejos de seguridad ciudadana, define los conceptos relacionados con los servicios sociales y comenta las funciones de los servicios sociales comunitarios y especializados así como de la policía. El segundo módulo consta de 3 capítulos. El primer capítulo define el concepto de defensa personal, las cuestiones legales relacionadas con la defensa personal, sus principios de actuación, el material de entrenamiento, los principios técnicos de los golpes, localiza los puntos vitales del cuerpo humano, ofrece algunos consejos de actuación ante distintos tipos de agresores e incluye un breve comentario sobre la defensa personal contra armas. El segundo capítulo analiza los 7 componentes de la defensa personal como son la psicología, inteligencia, selección de víctimas, reconocimientos de predadores, opciones de respuesta, consejos sobre prevención y métodos de entrenamiento; analiza cuáles son las 
claves de la toma de conciencia en la defensa personal y ofrece algunos consejos sobre la prevención. El tercer capítulo clasifica las técnicas de defensa personal para luego explicar la aplicación de técnicas sencillas de defensa personal a mano vacía y con objetos contra distintos tipos de ataque acompañados de su ilustración. El tercer módulo consta de 3 capítulos. El primer capítulo expone los principios del enfrentamiento a manos, describe las principales zonas del cuerpo utilizadas para golpear, expone los principios técnicos de la posición de guardia y los desplazamientos, analiza la línea de fuerza y las distancias fundamentales de enfrentamiento además de explicar la ejecución de distintas técnicas de percusión con las extremidades inferiores y superiores. El segundo capítulo describe la ejecución técnica de varias técnicas de defensa personal contra puñetazos, patadas, golpes de codo y rodilla, agarres por detrás, la utilización de pellizcos, reducciones, técnicas de detención y de esposamiento, la utilización de luxaciones y enumera las consideraciones del agente ante una situación de defensa personal policial. El último capítulo explica el concepto de legítima defensa, expone los principios legales que regulan el uso de la fuerza por parte de los agentes policiales junto con la legislación nacional e internacional y analiza los principios de actuación. Adjunta un anexo con la ley 13/2001 de coordinación de las policías locales, un glosario de términos específicos, bibliografía y varios cuestionarios de evaluación.

1271. s.a. (2007). Técnicas y tácticas de arresto : nivel 1. Málaga: Espacio Formación. 1a ed. 187 p. : il. ; 21x29,5 cm. ISBN: No ISBN. Depósito legal: M. 21432-2007. (2 a ed., 2008). Palabras clave: fundamentos teóricos, fundamentos técnicos, defensa personal policial, principios técnicos, armas, legislación, principios de actuación. Resumen: Manual teórico y técnico de defensa personal. El libro esta formado por 3 módulos. El primer módulo consta de 3 capítulos. El primer capítulo define el concepto de defensa personal, las cuestiones legales relacionadas con la defensa personal, sus principios de actuación, el material de entrenamiento, los principios técnicos de los golpes, localiza los puntos vitales del cuerpo humano, ofrece algunos consejos de actuación ante distintos tipos de agresores e incluye un breve comentario sobre la defensa personal contra armas. El segundo capítulo analiza los 7 componentes de la defensa personal como son la psicología, inteligencia, selección de víctimas, reconocimientos de predadores, opciones de respuesta, consejos sobre prevención y métodos de entrenamiento; analiza cuáles son las claves de la toma de conciencia en la defensa personal y ofrece algunos consejos sobre la prevención. El tercer capítulo clasifica las técnicas de defensa personal para luego explicar la aplicación de técnicas sencillas de defensa personal a mano vacía y con objetos contra distintos tipos de ataque acompañados de su ilustración. El segundo modulo consta de 3 capítulos. El primer capítulo expone los principios del enfrentamiento a manos, describe las principales zonas del cuerpo utilizadas para golpear, expone los principios técnicas de la posición de guardia y los desplazamientos, analiza la línea de fuerza y las distancias fundamentales de enfrentamiento además de explicar la ejecución de distintas técnicas de percusión con las extremidades inferiores y superiores. El segundo capítulo describe la ejecución técnica de varias técnicas de defensa personal contra puñetazos, patadas, golpes de codo y rodilla, agarres por detrás, la utilización de pellizcos, reducciones, técnicas de detención y de esposamiento, la utilización de luxaciones y enumera las consideraciones del agente ante una situación de defensa personal policial. El último capítulo explica el concepto de legítima defensa, expone los principios legales que regulan el uso de la fuerza por parte de los agentes policiales junto con la legislación nacional e internacional y analiza los principios de actuación. El tercer módulo consta de 4 capítulos. El primer capítulo define el concepto de detención, sus principios de actuación, el uso de la fuerza y del arma reglamentaria y las normas de actuación en los cacheos. El segundo capítulo define los distintos tipos de armas de fuego, la clasificación de las armas, el listado de armas prohibidas y comentario sobre la utilización de los medios de defensa. El tercer capítulo expone los principios de actuación para la detención de un vehículo. El cuarto capítulo analiza la situación actual de las armas y comenta la normativa reguladora de la ejecución de disparos policiales. Adjunta anexos con la norma jurídica R.D. 1338/84 y la Ley Orgánica 2/1986, de 13 marzo, de Fuerzas y Cuerpos de Seguridad, un glosario de términos específicos, bibliografía y varios cuestionarios de evaluación.

1272. s.a. (2008). Técnicas de defensa policial. Málaga: Espacio Formación. 1ae ed. 304 p. : il. ; 21x29,5 cm. ISBN: No ISBN. Depósito legal: M. 37815-2007. Palabras clave: fundamentos teóricos, fundamentos técnicos, defensa personal policial, principios técnicos, armas, legislación, principios de actuación. Resumen: Manual teórico y técnico de defensa personal. El libro esta formado por 4 módulos. El primer módulo consta de 3 capítulos. El primer capítulo define el concepto de defensa personal, las cuestiones legales relacionadas con la defensa personal, sus principios de actuación, el material de entrenamiento, los principios técnicos de los golpes, localiza los puntos vitales del cuerpo humano, ofrece algunos consejos de actuación ante distintos tipos de agresores e incluye un breve comentario sobre la defensa personal contra armas. El segundo capítulo analiza los 7 componentes de la defensa personal como son la psicología, inteligencia, selección de víctimas, reconocimientos de predadores, opciones de respuesta, consejos sobre prevención y métodos de entrenamiento; analiza cuáles son las claves de la toma de conciencia en la defensa personal y ofrece algunos consejos sobre la prevención. 
El tercer capítulo clasifica las técnicas de defensa personal para luego explicar la aplicación de técnicas sencillas de defensa personal a mano vacía y con objetos contra distintos tipos de ataque acompañados de su ilustración. El segundo modulo consta de 3 capítulos. El primer capítulo expone los principios del enfrentamiento a manos, describe las principales zonas del cuerpo utilizadas para golpear, expone los principios técnicas de la posición de guardia y los desplazamientos, analiza la línea de fuerza y las distancias fundamentales de enfrentamiento además de explicar la ejecución de distintas técnicas de percusión con las extremidades inferiores y superiores. El segundo capítulo describe la ejecución técnica de varias técnicas de defensa personal contra puñetazos, patadas, golpes de codo y rodilla, agarres por detrás, la utilización de pellizcos, reducciones, técnicas de detención y de esposamiento, la utilización de luxaciones y enumera las consideraciones del agente ante una situación de defensa personal policial. El último capítulo explica el concepto de legítima defensa, expone los principios legales que regulan el uso de la fuerza por parte de los agentes policiales junto con la legislación nacional e internacional y analiza los principios de actuación. El tercer módulo consta de 4 capítulos. El primer capítulo define el concepto de detención, sus principios de actuación, el uso de la fuerza y del arma reglamentaria y las normas de actuación en los cacheos. El segundo capítulo define los distintos tipos de armas de fuego, la clasificación de las armas, el listado de armas prohibidas y comentario sobre la utilización de los medios de defensa. El tercer capítulo expone los principios de actuación para la detención de un vehículo. El cuarto capítulo analiza la situación actual de las armas, comenta la normativa reguladora de la ejecución de disparos policiales. El cuarto módulo consta de 4 capítulos. El primer capítulo define el concepto de seguridad, describe las técnicas de protección, la planificación de la seguridad, la distribución de medios, los niveles de protección, la teoría de los cuatro niveles de protección, de las esferas de protección, enumera los medios organizativos y humanos de seguridad, las premisas fundamentales del servicio de protección, comenta la misión del escolta y las técnicas de protección a pie. El segundo capítulo define el concepto de autoprotección, analiza las características de la actividad terrorista, enumera los rasgos de los vehículos y personas sospechosas, expone las normas de seguridad y autoprotección, de la seguridad en los desplazamientos y en los vehículos, la detección de vigilancias, analiza las características del secuestro y las normas de actuación ante atentados con explosivos. El tercer capítulo explica la teoría de los círculos concéntricos, describe las técnicas de protección a pie, la escolta de 2, 3 y 4 agentes, el sistema francés, el sistema israelí, el equipo de cinco escoltas, la protección en lugares cerrados y las técnicas de protección con vehículos. El cuarto capítulo analiza los medios humanos, medidas organizativas, medios técnicos o seguridad electrónica y los medios físicos o seguridad física de la protección estática de la residencia de una personalidad. Todos los capítulos incluyen un resumen y un test sobre los contenidos explicados. Adjunta anexos con la norma jurídica R.D. 1338/84 y la Ley Orgánica 2/1986, de 13 marzo, de Fuerzas y Cuerpos de Seguridad, un glosario de términos específicos, bibliografía y varios cuestionarios de evaluación.

1273. s.a. (2008). Técnicas y tácticas de arresto : nivel 1. s.l.: Interconsulting Bureau. 1aㅡ ed. 187 p. : il. ; 21x29,5 cm. ISBN: No ISBN. Depósito legal: M. 39610-2008. Palabras clave: fundamentos teóricos, fundamentos técnicos, defensa personal policial, principios técnicos, armas, legislación, principios de actuación. Resumen: Manual teórico y técnico de defensa personal. El libro esta formado por 3 módulos. El primer módulo consta de 3 capítulos. El primer capítulo define el concepto de defensa personal, las cuestiones legales relacionadas con la defensa personal, sus principios de actuación, el material de entrenamiento, los principios técnicos de los golpes, localiza los puntos vitales del cuerpo humano, ofrece algunos consejos de actuación ante distintos tipos de agresores e incluye un breve comentario sobre la defensa personal contra armas. El segundo capítulo analiza los 7 componentes de la defensa personal como son la psicología, inteligencia, selección de víctimas, reconocimientos de predadores, opciones de respuesta, consejos sobre prevención y métodos de entrenamiento; analiza cuáles son las claves de la toma de conciencia en la defensa personal y ofrece algunos consejos sobre la prevención. El tercer capítulo clasifica las técnicas de defensa personal para luego explicar la aplicación de técnicas sencillas de defensa personal a mano vacía y con objetos contra distintos tipos de ataque acompañados de su ilustración. El segundo modulo consta de 3 capítulos. El primer capítulo expone los principios del enfrentamiento a manos, describe las principales zonas del cuerpo utilizadas para golpear, expone los principios técnicas de la posición de guardia y los desplazamientos, analiza la línea de fuerza y las distancias fundamentales de enfrentamiento además de explicar la ejecución de distintas técnicas de percusión con las extremidades inferiores y superiores. El segundo capítulo describe la ejecución técnica de varias técnicas de defensa personal contra puñetazos, patadas, golpes de codo y rodilla, agarres por detrás, la utilización de pellizcos, reducciones, técnicas de detención y de esposamiento, la utilización de luxaciones y enumera las consideraciones del agente ante una situación de defensa personal policial. El último capítulo explica el concepto de legítima defensa, expone los principios legales que regulan el uso de la fuerza por parte de los agentes policiales junto con la legislación nacional e internacional y analiza los principios de actuación. El tercer módulo consta de 4 capítulos. El primer capítulo define el concepto de detención, sus principios de actuación, el uso de la 
fuerza y del arma reglamentaria y las normas de actuación en los cacheos. El segundo capítulo define los distintos tipos de armas de fuego, la clasificación de las armas, el listado de armas prohibidas y comentario sobre la utilización de los medios de defensa. El tercer capítulo expone los principios de actuación para la detención de un vehículo. El cuarto capítulo analiza la situación actual de las armas y comenta la normativa reguladora de la ejecución de disparos policiales. Adjunta anexos con la norma jurídica R.D. 1338/84 y la Ley Orgánica 2/1986, de 13 marzo, de Fuerzas y Cuerpos de Seguridad, un glosario de términos específicos, bibliografía y varios cuestionarios de evaluación.

1274. s.a. (2009). Bastón policial extensible. s.l.: Interconsulting Bureau. 1a ed. 114 p. : il. ; 21x29,5 cm. ISBN: No ISBN. Depósito legal: M. 46048-2009. Palabras clave: fundamentos teóricos, fundamentos técnicos, principios técnicos, defensa personal policial, legislación, principios de actuación. Resumen: Manual teórico y técnico de defensa personal policial. El libro esta formado por 6 capítulos precedidos por un prólogo que comenta lo objetivos de la obra. El primer capítulo incluye la legislación de la policía en la Constitución y las funciones de los cuerpos de la policía en la ley orgánica de fuerzas y cuerpos de seguridad. El segundo capítulo comenta los principios básicos de actuación de la policía y su preparación mental. El tercer capítulo expone los fundamentos básicos de seguridad en el trabajo policial como la definición del nivel básico de seguridad, la valoración objetiva de las situaciones, los hábitos de actuación y la actuación práctica en la identificación policial. El cuarto capítulo expone el uso legítimo de la fuerza, las características del bastón policial y su legislación. El quinto capítulo clasifica los tipos de defensa extensible además de describir algunas técnicas de control, conducción y proyección con la misma. El sexto capítulo comenta las características del bastón policial, narra la historia de la defensa personal policial, describe la posición de seguridad, los puntos vitales del cuerpo humano, las técnicas de golpeo, los bloqueos, las esquivas, los desplazamientos, las caídas y las técnicas de luxación acompañados de sus ilustraciones explicativas, comenta los contenidos del choson mu sul (hapkido policial), la utilización del aikido y otros sistemas defensivos en las fuerzas de seguridad así como las características de los equipos especiales. Adjunta anexos con el reglamento de armas y la ley orgánica 2/1986 reguladora de los cuerpos de seguridad del Estado, de las policías de las Comunidades Autónomas y de las policías locales, un glosario específico y bibliografía.

1275. Vera Jiménez, José Carlos (2007). Intervención táctica policial. s.l.: CSI-CSIF Sector Local Andalucía. 1a ed. 195 p. : il. ; 17x21 cm. ISBN: No ISBN. Depósito legal: M. 23774-2007. Palabras clave: fundamentos teóricos, fundamentos técnicos, principios de actuación, armas, defensa personal. Resumen: Manual teórico y técnico de defensa personal policial. El libro esta formado por 21 capítulos precedidos por una dedicatoria, los agradecimientos, un prólogo que señala los objetivos de la obra, el currículo del autor y un breve comentario sobre los objetivos de la intervención policial. El primer capítulo señala los principios básicos de los procedimientos tácticos policiales. El segundo capítulo describe las posiciones de seguridad y sus características. El tercer capítulo describe la posición de guardia, las principales esquivas, bloqueos y desvíos junto con sus ilustraciones. El cuarto capítulo explica la ejecución de las principales técnicas ofensivas con los puños, codos y piernas de la defensa personal policial acompañadas de sus secuencias fotográficas. El quinto capítulo incluye la descripción e ilustración de 3 técnicas de luxación e inmovilización para conducir a un detenido. El sexto capítulo explica varias técnicas de neutralización contra distintos ataques de puño y pierna. Los siguientes tres capítulos presentan la ejecución de diversas técnicas de desarme contra armas cortas de fuego, armas blancas y armas contundentes junto con su representación gráfica. El décimo capítulo incluye la descripción e ilustración de varias técnicas de resolución contra agarres. Los siguientes tres capítulos detallan las técnicas básicas de esposamiento, el cacheo y las conducciones ante resistencias pasivas. Los dos siguientes capítulos describen los fundamentos técnicos de la defensa tradicional y el tonfa policial así como las técnicas contra la retención de nuestra propia arma de fuego. Los siguientes cinco capítulos comentan el trabajo coordinado entre dos o más policías en técnicas de defensa táctica policial y detallan las técnicas para sacar a un individuo de un coche, desmontar a un individuo de una moto, repeler una agresión cuando se conduce un vehículo patrulla e introducir a un detenido en un coche patrulla. El último capítulo ilustra los puntos vitales del cuerpo humano. Adjunta información sobre el curso semipresencial de defensa y autodefensa en la intervención policial.

1276. Vera Jiménez, José Carlos (2009). Operativa táctica policial. s.l.: Central Sindical Independiente y de Funcionarios, Sector de Administración Local de Andalucía. 1a ed. 167 p. : il. ; 17x21 cm. ISBN: No ISBN. Depósito legal: M. 15434-2009. Palabras clave: fundamentos técnicos, defensa personal policial, kyusho, legislación, principios de actuación, armas. Resumen: Manual teórico y técnico de defensa personal policial. El libro esta compuesto por 13 capítulos precedidos por un prólogo que comenta las carencias de la enseñanza de la defensa personal policial, enumera las necesidades del policía a pie de calle, presenta el título de experto universitario en tácticas operativas policiales, sus objetivos y el currículo del autor. El primer capítulo comenta los principios básicos sobre el empleo de la fuerza y armas de fuego así como la legislación que los regula. El segundo capítulo describe las características de las técnicas de posición de seguridad, de guardia, los apoyos, los desplazamientos y la distancia. El tercer capítulo expone los distintos recursos defensivos además de describir las principales técnicas de 
esquiva, bloqueo y desvío acompañadas de sus ilustraciones explicativas. El cuarto capítulo describe la ejecución de varias técnicas de luxación e inmovilización acompañadas de su secuencia fotográfica. El quinto capítulo expone las características de los grilletes, sus tipos, su forma de colocación y la descripción de distintas técnicas de esposamiento. El sexto capítulo explica la ejecución de algunas técnicas de neutralización contra ataques de puño y pierna junto con sus ilustraciones. Los dos siguientes capítulos presentan la descripción e ilustración de varias técnicas de neutralización contra armas contundentes y armas blancas. Los siguientes tres capítulos explican las técnicas de neutralización contra armas cortas de fuego, contra la retención de tu propia arma de fuego y contra distintos agarres incluyendo su secuencia fotográfica. El decimosegundo capítulo expone la legislación sobre el cacheo, sus tipos, las medidas de seguridad y los diferentes procedimientos de actuación. El último capítulo enumera los principales puntos vitales del cuerpo humano.

1277. Vera Jiménez, José Carlos (2009). Operativa táctica policial : evolución en los sistemas de intervención policial. s.l.: s.n. $1 \underline{a}$ ed. 167 p. : il. ; 14x21 cm. ISBN: 978-84-691-8849-1. Depósito legal: M. 7578-2009. Palabras clave: fundamentos técnicos, defensa personal policial, kyusho, legislación, principios de actuación, armas. Resumen: Manual teórico y técnico de defensa personal policial. El libro esta compuesto por 13 capítulos precedidos por un prólogo que comenta las carencias de la enseñanza de la defensa personal policial, enumera las necesidades del policía a pie de calle, presenta el título de experto universitario en tácticas operativas policiales, sus objetivos y el currículo del autor. El primer capítulo comenta los principios básicos sobre el empleo de la fuerza y armas de fuego así como la legislación que los regula. El segundo capítulo describe las características de las técnicas de posición de seguridad, de guardia, los apoyos, los desplazamientos y la distancia. El tercer capítulo expone los distintos recursos defensivos además de describir las principales técnicas de esquiva, bloqueo y desvío acompañadas de sus ilustraciones explicativas. El cuarto capítulo describe la ejecución de varias técnicas de luxación e inmovilización acompañadas de su secuencia fotográfica. El quinto capítulo expone las características de los grilletes, sus tipos, su forma de colocación y la descripción de distintas técnicas de esposamiento. El sexto capítulo explica la ejecución de algunas técnicas de neutralización contra ataques de puño y pierna junto con sus ilustraciones. Los dos siguientes capítulos presentan la descripción e ilustración de varias técnicas de neutralización contra armas contundentes y armas blancas. Los siguientes tres capítulos explican las técnicas de neutralización contra armas cortas de fuego, contra la retención de tu propia arma de fuego y contra distintos agarres incluyendo su secuencia fotográfica. El decimosegundo capítulo expone la legislación sobre el cacheo, sus tipos, las medidas de seguridad y los diferentes procedimientos de actuación. El último capítulo enumera los principales puntos vitales del cuerpo humano.

1278. Vera Nicolás, Pedro Pascual (1994). Manual básico en defensa personal policial : aplicaciones a todos los cuerpos policiales, militares y de seguridad. Murcia: Compobell. 1 a ed. 160 p. : il. ; $17 \times 24 \mathrm{~cm}$. ISBN: 84606-1765-3. Depósito legal: MU. 397-1994. Palabras clave: fundamentos técnicos, principios técnicos, defensa personal, armas. Resumen: Manual teórico y técnico de defensa personal policial. El libro esta dividido en 15 capítulos precedidos por una introducción que señala la importancia del libro y un prefacio que describe la realización del trabajo. El primer capítulo comenta las consideraciones para colocarse ante un detenido además de ilustrar algunas situaciones. El segundo capítulo define los tipos de atemis además de incluir la representación gráfica de algunos ejemplos. El tercer capítulo describe la ejecución de diversas técnicas de luxación acompañadas de su secuencia fotográfica. El cuarto capítulo define los conceptos de detención y conducción, explica sus principios de actuación y presenta la descripción e ilustración de distintas técnicas de reducción y conducción. El quinto capítulo clasifica los tipos de agarres y defensas ante dichos agarres presentando la explicación de varias de sus técnicas. El sexto capítulo muestra algunas de las defensas básicas ante patadas y puñetazos. El séptimo capítulo presenta la descripción e ilustración de la utilización de la porra o tonfa policial en diversas situaciones. El octavo capítulo detalla los principios de actuación ante los ataques armados, los métodos de entrenamiento de dichas situaciones y explica la ejecución de varias técnicas de defensa ante distintos ataques con cuchillo y amenaza de pistola. El noveno capítulo expone varias técnicas de defensa y reducción ante perturbados psíquicos. El décimo capítulo enumera los principios de actuación ante un cacheo además de incluir la descripción e ilustración de sus diversas técnicas. Los siguientes cuatro capítulos explican la ejecución de diversas técnicas de defensa personal desde el suelo, contra varios adversarios con y sin armas y en situaciones especiales como dentro de un vehículo y una conducción por la espalda acompañadas de su secuencia fotográfica. El último capítulo comenta el coeficiente de supervivencia con y sin armas además de presentar la ilustración de algunos ejercicios de entrenamiento.

1279. Young, Mike (2008). Técnicas de artes marciales para los agentes de la ley. Móstoles: Arkano Books. $1^{\mathrm{a}}$ ed. 276 p. : il. ; 16x24 cm. ISBN: 978-84-96111-40-0. Depósito legal: M. 26490-2008. Palabras clave: fundamentos teóricos, táctica, fundamentos técnicos, principios técnicos, defensa personal, entrenamiento, kyusho, legislación, armas. Resumen: Manual teórico y técnico de defensa personal policial. El libro consta de 19 capítulos precedidos por los agradecimientos y una introducción que 
resume los contenidos y objetivos de la presente obra. El primer capítulo explica la ley de proporcionalidad de la fuerza y expone algunos ejemplos prácticos. El segundo capítulo comenta las cualidades y principios técnico-tácticos ante una situación de defensa personal. Los dos siguientes capítulos describen la ejecución de la postura básica de autodefensa y de los desplazamientos incluyendo algunos gráficos explicativos. Los dos siguientes capítulos describe la ejecución de los principales golpes de brazo y pierna junto con sus ilustraciones. El séptimo capítulo expone la descripción técnica de las principales maniobras y bloqueos defensivos acompañadas de numerosas fotografías. Los dos siguientes capítulos localizan los puntos vulnerables del cuerpo humano y describen los golpes y presiones dirigidos a los mismos. El décimo capítulo explica la ejecución de varias llaves y presas para conducir a una persona, mientras que el capítulo decimoprimero analiza la ejecución de algunas técnicas de derribo o barridos. Los siguientes seis capítulos explican la ejecución de la llave de obstrucción de la carótida, distintas defensas desde el suelo, contra un arma blanca, un arma de fuego y a manos desnudas incluyendo la representación gráfica de cada una de ellas. Los dos últimos capítulos ofrecen consejos para el entrenamiento y destacan la importancia de la voluntad de sobrevivir ante una situación de defensa personal. Adjunta un apéndice con datos sobre los asaltos sobre los agentes de la ley y la biografía del autor.

\subsection{Filosofía, Historia, Educación...}

1280. Amador Ramírez, Fernando; Álamo Mendoza, José Miguel; Dopico Calvo, Jorge e Iglesias Soler, Eliseo (2009). Fundamentos estructurales y pedagógicos del judo. Las Palmas de Gran Canaria: Universidad de las Palmas de Gran Canaria, Servicio de Publicaciones. 1a ed. 229 p. : il. ; $17 x 24$ cm. ISBN: 978-8492777-08-2. Depósito legal: GC. 238-2009. Palabras clave: historia, fundamentos teóricos, pedagogía, iniciación deportiva, programa técnico. Resumen: Tratado teórico de los deportes de lucha. El libro esta formado por 7 capítulos, precedidos por una introducción que comenta los contenidos y objetivos de la obra. El primer capítulo define los deportes de lucha y su evolución histórica, comenta el origen y evolución del judo junto con el análisis de su estructura, su aplicación dentro de la Educación Física, y un comentario sobre la enseñanza del judo y los deportes de lucha en el currículum escolar. El segundo capítulo define el término iniciación deportiva, señala los contenidos de la iniciación a los deportes de lucha, describe los principios pedagógicos de dicha iniciación, presenta la secuenciación de los contenidos y ofrece algunos ejemplos de ejercicios psicomotrices y juegos de oposición y lucha. El tercer capítulo incluye distintas clasificaciones sobre las habilidades específicas del judo. El cuarto capítulo analiza las demandas psicomotrices del judo para luego proponer una clasificación de sus habilidades atendiendo a sus criterios motrices. El quinto capítulo presenta una propuesta de clasificación de las habilidades del judo en el suelo junto con ejemplos prácticos ilustrados. El sexto capítulo define el proceso de enseñanza-aprendizaje, el concepto de habilidad básica y habilidad motriz específica, sus características, presenta una clasificación de las habilidades motrices de lucha y explica el concepto de esquema de habilidad motriz de lucha. El último capítulo incluye la bibliografía.

1281. Amdur, Ellis (2007). Koryu : escuela antigua. Ensayos sobre las tradiciones marciales japonesas. Barcelona: Shinden. 1aㅡ ed. 295 p. : il. ; 16x23 cm. ISBN: 978-84-96894-01-3. Depósito legal: B. 301232007. Palabras clave: historia, fundamentos teóricos, filosofía, escuelas, ninjutsu, armas. Resumen: Tratado teórico sobre las tradiciones marciales japonesas. La obra esta formada por 3 partes. La primera parte describe el origen, formación, evolución, sistema de entrenamiento, características técnicas y situación actual de las tradiciones marciales de las escuelas Tenshin Shoden Katori Shintoryu, Maniwa Nan-ryu e Higo Ko-ryu. La segunda parte esta formada por 4 capítulos que explican la introducción de las armas en Japón junto con las características y utilización de las mismas; describen la historia y evolución de la naginata, sus características físicas, sus tipos y su utilización y comenta la desaparición de la naginata y su utilización por parte de las mujeres; exponen las características físicas del chigiriki, su utilización y su entrenamiento dentro de las escuelas Kiraku-ryu y Araki-ryu; y presentan las posibles orígenes del kusarigama, las características físicas de los tres tipos que existen, su utilización y los sistemas de entrenamiento que reciben en las escuelas Toda-ha Buko-ryu e Isshinryu. La última parte esta formada por 3 capítulos que explican el papel de las mujeres guerreras en la historia de Japón, desde la naginata como arma de la mujer hasta su entrenamiento dentro de las escuelas Tendo-ryu, Jikishin Kage-ryu Naginata-do y su formación marcial en los tiempos modernos; relata los orígenes de la escuela Araki-ryu y sus relaciones con otras escuelas; y finaliza explicando el significado de pertenencia a una ryu y los preceptos que componen el juramento antes de comenzar el estudio del ryu. Adjunta textos originales en japonés del araki-ryu narabi ni saitan no jo y kishomon mae gaki no koto, un glosario y bibliografía.

1282. Araujo, Alfonso y Ruy Quijano, Víctor (2005). La espada de la vida. Madrid: Edaf. $1 \underline{a}$ ed. 151 p. : il. ; 13x21 cm. ISBN: 84-414-1739-3. Depósito legal: M. 49068-2005. Palabras clave: historia, filosofía, relatos, aforismos, armas. Resumen: Tratado teórico sobre la espada de la vida. El libro esta formado 
por 5 capítulos. El primer capítulo expone las características del texto "la espada de la vida", del pensamiento chino y su filosofía. El segundo capítulo relata la historia de la espada y los significados atribuidos a la misma. El tercer capítulo comenta el significado de la espada en Japón y China, relata la dignidad de la espada, incluye algunos textos sobre héroes y espadas famosas, tradiciones y mitos. El cuarto capítulo incluye 37 aforismos presentes en la primera parte de la obra titulada "La espada de la vida" mientras que el último capítulo ofrece un comentario sobre el significado de cada aforismo incluyendo numerosos ejemplos.

1283. Atencia Henares, David (2000). Deportes de lucha. Barcelona: INDE. 1a ed. 104 p. : il. ; 17x24 cm. ISBN: 84-95114-29-1. Depósito legal: Z. 547-2000. Palabras clave: historia, fundamentos teóricos, entrenamiento, estrategia, táctica, instalaciones, reglamentos, fundamentos técnicos, programa técnico. Resumen: Tratado teórico de los deportes de lucha. La obra esta dividida en 7 capítulos, precedidos por una introducción que resume el contenido del libro. El primer capítulo explica que son los deportes de lucha, los beneficios de su práctica, sus características y similitudes. El segundo capítulo profundiza en la historia de los deportes de lucha desde la época primitiva hasta la actualidad pasando por las civilizaciones arcaicas, Grecia, Roma, la época medieval, moderna y contemporánea, y la historia de los deportes de lucha en España. El tercer capítulo ofrece las distintas clasificaciones de los deportes de lucha, según la finalidad del enfrentamiento, la acción motriz, y sus competidores, según su edad, peso y nivel técnico. El cuarto capítulo presenta algunas de las modalidades de deportes de lucha más conocidas y extendidas dividiéndolas según sus finalidades. El quinto capítulo presenta las instalaciones, dimensiones y características habituales de los deportes de lucha junto con los fundamentos técnicos, tácticos y estratégicos en cada uno de ellos. El sexto capítulo aborda la iniciación, requisitos y enseñanza de los deportes de lucha además de presentar una propuesta de programación a la enseñanza de los mismos. El séptimo capítulo comenta los principios del entrenamiento así como las cualidades físicas que requieren los deportes de lucha. Adjunta la solución de los pasatiempos presentados, una evaluación de los contenidos, un resumen final y bibliografía.

1284. Bartolone, Enzo y Gobbi, Pietro (2006). Geisha y samurái : amor y guerra en el antiguo Japón. Fuenlabrada: Ayuntamiento de Fuenlabrada y Centro de Arte Tomás y Valiente. $1^{a}$ ed. 121 p. : il. ; 24x26 cm. ISBN: 84-606-39-59-2. Depósito legal: M. 21672-2006. Palabras clave: historia, filosofía, fotografía, geisha, pintura, samurái. Resumen: Tratado teórico sobre la exposición Geishas y Samuráis. El libro esta dividido en 6 partes precedidas por una introducción que comenta la historia del ukiyo-e, sus características y simbología, narra la historia de los 47 ronin y comenta la lectura lingüística, texto explicativo, lectura icónica y sellos de una ilustración sobre tal historia. La primera parte describe la técnica empleada en el ukiyo-e además de presentar un glosario específico y varias ilustraciones. La segunda parte analiza la figura femenina en el tiempo de ukiyo como la geisha, oiran (cortesana de alto rango) y el kimono acompañadas de varias ilustraciones explicativas. La tercera parte relata brevemente la historia militar de Japón en sus diferentes épocas y el significado del samurái junto con numerosas ilustraciones del mismo. La cuarta parte explica el significado de la naturaleza, el teatro kabuki y no, y el erotismo en el ukiyo-e, incluyendo varias láminas sobre dicha temática. La quinta parte comenta la aparición del daguerrotipo, su introducción en Japón y algunas de sus fotografías. La última parte presenta los datos técnicas de las ilustraciones presentadas junto con un breve comentario de las mismas.

1285. Boillat de Corgemont Sartorio, Marc (2002). Las enseñanzas de un guerrero. Barcelona: Alas. $1^{\mathfrak{a}}$ ed. 347 p. : il. ; 17x24 cm. ISBN: 84-203-0419-0. Depósito legal: B. 20171-2002. Palabras clave: fundamentos filosóficos. Resumen: Compendio de extractos sobre la filosofía del guerrero. La obra incluye diferentes relatos extraídos de la obra de Eiji Yoshikawa sobre la vida de Miyamoto Musashi para reflexionar sobre la filosofía del guerrero. Los temas tratados y analizados son la naturaleza humana, el karma, el cambio, la vida fácil, las batallas de la vida, la fuerza exterior y la fuerza interior, los errores, la autodisciplina, la autoevaluación, las emociones, la debilidad, la capacidad de juicio, el aprendizaje, la mezquindad, las añoranzas, la impermanencia, la flexibilidad, la moderación, las apariencias, las insignificancias, la fuerza del yin, las estrategias, el odio, el dinero y el sexo, la impulsividad, la educación, la paciencia, la impasibilidad, la intuición, los padres e hijos, la dignidad y el orgullo, el prestigio, el tiempo, la empatía, el egoísmo, la amistad, la fama, las ideas claras, la muerte y el ego, la mente original, la veracidad, los conflictos interiores, el segundo cambio, los jóvenes y los viejos, los ídolos, la perseverancia, la indecisión, las enmiendas, la batalla final, las enseñanzas cruciales y algunas consideraciones sobre los autorrealizados, las cinco virtudes, la respiración y la ayuda. Adjunta bibliografía.

1286. Boillat de Corgemont Sartorio, Marc (2005). Las enseñanzas de un guerrero. 2ª parte. Barcelona: Alas. 1 a ed. 317 p. : il. ; 17x24 cm. ISBN: 84-203-0435-2. Depósito legal: B. 27236-2005. Palabras clave: fundamentos filosóficos. Resumen: Compendio de extractos sobre la filosofía del guerrero. La obra incluye diferentes relatos extraídos de la obra de Eiji Yoshikawa sobre la vida de Miyamoto Musashi para reflexionar sobre la filosofía del guerrero. Los temas tratados y analizados son la reconciliación de los extremos, la soledad, el temor, el avance, la consideración, los educadores y discípulos, la fuerza 
interior, el agua y el fuego, el dominio, la decadencia, la prisa, la mente fría, las ilusiones, la vejez, dar consejos, la autocrítica, la autosuficiencia, la conciencia limpia, la gratitud, equilibrar las dificultades, la insatisfacción, la naturalidad, las habilidades, las alternativas, la mezquindad, el ajuste de cuentas, los arrepentimientos, la maestría, el aquí y ahora, la urbanidad, el desafío, la incompetencia, el inconsciente, la magia del momento, la rigidez interior, la moderación, los caracteres singulares, el discernimiento, las estrategias, la congoja, el sentimiento de inferioridad, la autorrealización, la exaltación, la inseguridad, el autoconocimiento, las imposiciones, el pánico, la eficacia, la armonía, la lealtad, la susceptibilidad, la imperturbabilidad, el arte de la ventaja, las contradicciones de siempre, el karma, el mundo real, el instinto, el peligro de la fama, la liberación, las hojas y las ramas, el último desafío y la mente original. Adjunta bibliografía.

1287. Bryant, Anthony J. (1994). Los samuráis. Madrid: Del Prado. 1a ed. 63 p. : il. ; 18x24,5 cm. ISBN: 847838-512-6. 84-7838-472-3 (ISBN de la obra completa). Depósito legal: M. 35133-1994. Palabras clave: historia, vestimenta, política, batallas, armas. Resumen: Tratado teórico de los samuráis. La obra describe el origen de la clase guerrera y su evolución histórica, el desarrollo de la guerra de Genpei entre las familias Minamoto y Taira, el establecimiento del bakufu y sus continuos problemas, la guerra entre las cortes septentrional y meridional, el periodo Muromachi y sus guerras, la organización de la defensa y el ataque en el Japón Muromachi y Momoyama, las influencias europeas en el arte de la guerra, la era Sengoku con las batallas de Kawanakajima y los Ikko-ikkis, el mando de Hashiba Hideyoshi, el retorno del sogún, la utilización y características de las armas y armaduras durante los períodos Heian y Kamakura, y durante los períodos Muromachi y Momoyama, y la explicación de las láminas que se incluyen en el centro del libro.

1288. Cáliz Lillo, Ignacio (1996). Las artes del guerrero : técnicas taoístas de defensa. Madrid: Las 4 fuentes. 1 ạ ed. 239 p. : il. ; 16x24 cm. ISBN: 84-88769-41-5. Depósito legal: M. 6325-1996. Palabras clave: principios técnicos, aforismos, fundamentos filosóficos, medicina, meditación. Resumen: Manual filosófico sobre las artes marciales. El libro esta formado por 17 capítulos. El primer capítulo explica el significado de las artes marciales y las técnicas taoístas. El segundo capítulo señala la importancia del ritual dentro de las artes marciales. El tercer capítulo analiza la concentración para la práctica de las artes marciales. El cuarto capítulo reflexiona sobre el significado del honor. Los siguientes ocho capítulos presentan los principios de las técnicas de defensa taoístas como son el instinto, la voluntad, el no-hacer, la flexibilidad, el vacío y el lleno, el fluido, la libertad y la danza de la armonía. El capítulo decimotercero comenta las características del entrenamiento mientras que el siguiente comenta los beneficios de la meditación taoísta y su aplicación. El decimoquinto capitulo incluye varios aforismos sobre el comportamiento del guerrero y los miedos que tiene que vencer. El decimosexto capítulo presenta las propiedades curativas de las plantas. El último capítulo explica las propiedades de algunas vitaminas, del masaje y su relación con la energía sexual, una tabla de tai chi chuan y varios aforismos sobre la vía del guerrero.

1289. Cáliz Lillo, Ignacio (2002). Las artes del guerrero : técnicas taoístas de defensa. Madrid: Dilema. $1^{\mathrm{a}}$ ed. 237 p. : il. ; 16x24 cm. ISBN: 84-96079-08-2. Depósito legal: M. 46911-2002. Palabras clave: principios técnicos, aforismos, fundamentos filosóficos, medicina, meditación. Resumen: Manual filosófico sobre las artes marciales. El libro esta formado por 17 capítulos. El primer capítulo explica el significado de las artes marciales y las técnicas taoístas. El segundo capítulo señala la importancia del ritual dentro de las artes marciales. El tercer capítulo analiza la concentración para la práctica de las artes marciales. El cuarto capítulo reflexiona sobre el significado del honor. Los siguientes ocho capítulos presentan los principios de las técnicas de defensa taoístas como son el instinto, la voluntad, el no-hacer, la flexibilidad, el vacío y el lleno, el fluido, la libertad y la danza de la armonía. El capítulo decimotercero comenta las características del entrenamiento mientras que el siguiente comenta los beneficios de la meditación taoísta y su aplicación. El decimoquinto capitulo incluye varios aforismos sobre el comportamiento del guerrero y los miedos que tiene que vencer. El decimosexto capítulo presenta las propiedades curativas de las plantas. El último capítulo explica las propiedades de algunas vitaminas, del masaje y su relación con la energía sexual, una tabla de tai chi chuan y varios aforismos sobre la vía del guerrero.

1290. Calle, Ramiro A. (1968). Zen y artes marciales japonesas. Barcelona: Cedel. 1a ed. 251 p. : il. ; desc.xdesc. cm. ISBN: No ISBN. Depósito legal: B. 31270-1968. (2ª ed., 1977, ISBN: 84-352-0743-1).

1291. Casero Abellán, Rogelio (2009). Combate de entrenamiento : iniciación al combate no competitivo. Barcelona: Alas. 1a ed. 146 p. : il. ; 17x23,5 cm. ISBN: 978-84-203-0452-6. Depósito legal: B. 9592-2009. Palabras clave: fundamentos técnicos, pedagogía, ejercicios, entrenamiento, estrategia, programa técnico. Resumen: Manual teórico y técnico de combate. El libro esta formado por 9 capítulos precedidos por los agradecimientos, una breve biografía del autor, un prólogo que comenta los objetivos del libro y una introducción que diferencia la práctica del combate de la defensa personal, explica los tipos de combate y los principios metodológicos para su aprendizaje. El primer capítulo analiza los principios de adaptabilidad de la técnica al combate, el principio de las respuestas suficientes antes de comenzar el combate y el principio de aplicabilidad de las técnicas. El segundo 
capítulo estudia los elementos que componen el ataque. El tercer capítulo detalla las fases de aprendizaje de las defensas, los tipos de defensa y analiza los factores de eficacia de las defensas. El cuarto capítulo enumera los requisitos de los ejercicios de automatización además de comentar sus tipos acompañados de su secuencia fotográfica. El quinto capítulo presenta las características de los 6 niveles de aprendizaje del combate atendiendo al nivel del practicante junto con la ilustración de distintos ejercicios para cada nivel. El sexto capítulo explica los objetivos y características de otros ejercicios de combate acompañados de sus ilustraciones explicativas. El séptimo capítulo comenta la utilidad de las protecciones en el entrenamiento del combate e incluye una secuenciación del uso de las protecciones en el entrenamiento. El octavo capítulo define el término estrategia, analiza los elementos que intervienen en la estrategia, analiza las estrategias ofensivas y defensivas, y comenta algunas de sus acciones técnico-tácticas acompañadas de su secuencia fotográfica. El último capítulo analiza la ausencia de pensamientos, intenciones y emociones durante el combate.

1292. Castaneda, Marilyn (2007). Lo que me contó la luna. Logroño: Pablo Pereda González. 1a ed. 173 p. ; 14x20,5 cm. ISBN: 84-611-2427-8. Depósito legal: no. Palabras clave: historia, kárate, to-de, katas. Resumen: Tratado filosófico de artes marciales. El libro esta compuesto por 11 capítulos precedidos por un prólogo que comenta los contenidos de la obra. El primer capítulo narra el contacto de la autora con los Atlantes. El segundo capítulo describe el primer contacto de la autora con Matsu. El tercer capítulo comenta el viaje de la autora y Matsu hasta México para encontrarse con los chamanes. El cuarto capítulo relata el contacto con los chamanes y las reflexiones posteriores de la autora con Matsu. El quinto capítulo expone la grabación de los movimientos aprendidos de los chamanes. Los siguientes seis capítulos describen los entrenamientos, viajes, charlas y entrevistas de la autora con Matsu sobre su formación marcial, desarrollo profesional e historia del to-de. Adjunta un epílogo.

1293. Cleary, Thomas (1992). El arte japonés de la guerra : entendiendo la sabiduría de la estrategia. Madrid: Edaf. $1 \underline{a}$ ed. 165 p. ; 14x20,5 cm. ISBN: 84-7640-624-X. Depósito legal: M. 32878-1992. Palabras clave: historia, filosofía, artes marciales, zen, Japón, maestros. Resumen: Tratado teórico sobre la guerra. El libro esta dividido en 8 capítulos precedidos por una introducción que comenta la mistificación de Oriente. El primer capítulo narra la historia de Japón en relación con sus guerras. El segundo capítulo relata la introducción del zen en el Japón y su aplicación social. El tercer capítulo analiza las obras tituladas "Libro de los cinco anillos" y "Huainanzi" así como su contexto histórico en relación con el bushido y las artes marciales. El cuarto capítulo expone los principios del zen sobre el proceso de enseñanza-aprendizaje. El quinto capítulo compara las estrategias y preparación del guerrero de Musashi y Yagyu. El sexto capítulo incluye la traducción y comentario de la obra titulada "Treinta y seis estrategias". El séptimo capítulo profundiza en los fundamentos morales de la sociedad japonesa, su evolución y el papel del cristianismo. El último capítulo analiza los problemas actuales para el estudio del zen. Adjunta un resumen del libro.

1294. Cleary, Thomas (1996). El arte japonés de la guerra : entendiendo la sabiduría de la estrategia. Madrid: Edaf. 1aㅡ ed. 199 p. ; $12 \times 18$ cm. ISBN: 84-414-0037-7. Depósito legal: M. 37852-1996. (2ª ed., 1997; 5a ed., 2001, ISBN: 84-414-0037-1). Palabras clave: historia, filosofía, artes marciales, zen, Japón, maestros. Resumen: Tratado teórico sobre la guerra. El libro esta dividido en 8 capítulos precedidos por una introducción que comenta la mistificación de Oriente. El primer capítulo narra la historia de Japón en relación con sus guerras. El segundo capítulo relata la introducción del zen en el Japón y su aplicación social. El tercer capítulo analiza las obras tituladas "Libro de los cinco anillos" y "Huainanzi" así como su contexto histórico en relación con el bushido y las artes marciales. El cuarto capítulo expone los principios del zen sobre el proceso de enseñanza-aprendizaje. El quinto capítulo compara las estrategias y preparación del guerrero de Musashi y Yagyu. El sexto capítulo incluye la traducción y comentario de la obra titulada "Treinta y seis estrategias". El séptimo capítulo profundiza en los fundamentos morales de la sociedad japonesa, su evolución y el papel del cristianismo. El último capítulo analiza los problemas actuales para el estudio del zen. Adjunta un resumen del libro.

1295. Cleary, Thomas (2000). Camino de guerreros, código de reyes : lecciones de estrategia de los textos clásicos chinos. Madrid: Edaf. 1aㅡ ed. 189 p. ; 13x18,5 cm. ISBN: 84-414-0677-4. Depósito legal: M. 48534-1999. Palabras clave: fundamentos teóricos, combate, guerra, estrategia, táctica, ética. Resumen: Tratado estratégico sobre la guerra. La obra recoge numerosos aforismos seleccionados de los textos clásicos chinos titulados "El arte de la guerra" de Wu Qi, las enseñanzas del maestro Wei Liao, "Tres estrategias", "Seis estrategias", "El código guerrero de los aurigas" y "El arte de la guerra" de Sun Tzu. Los aforismos estudian la organización, dirección, planificación, estrategia, principios tácticos, principios técnicos, principios morales y características de la guerra.

1296. Cleary, Thomas (2006). El alma del samurái : una traducción contemporánea de tres clásicos del zen y el bushido a cargo de Thomas Cleary. Barcelona: Kairós. 1a ed. 163 p. : il. ; 13x20 cm. ISBN: 84-7245-634X. Depósito legal: B. 44479-2006. (2a ed., 2008). Palabras clave: fundamentos teóricos, táctica, principios técnicos, principios filosóficos, artes marciales, filosofía, zen, esgrima, ética, samurái. Resumen: Traducción y análisis de tres obras sobre artes marciales y zen. Las obras se titulan "Artes marciales: libro de las tradiciones familiares", "La inescrutable sutileza de la sabiduría inmutable" y 
"Tai-a ki: notas sobre la espada sin rival". La primera obra esta compuesta por 3 libros que relacionan la esgrima y el zen. El primer libro comenta la importancia de la estrategia, el camino del aprendizaje, la actitud y principios del practicante ante el aprendizaje, la práctica y el combate, y las características de los niveles de aprendizaje. El segundo libro profundiza en los principios técnicos y tácticos del combate desde el punto de vista del zen. El tercer libro analiza la última etapa del aprendizaje o entrenamiento, explicando el objetivo del entrenamiento de las artes marciales y sus implicaciones filosóficas. La segunda obra expone y analiza los principios y estados mentales del practicante ante el combate además de incluir el consejo del maestro Takuan Soho a Yagyu Munenori. La última obra presenta los principios éticos de la espada sin rival (Tai-A). Adjunta bibliografía.

1297. Cleary, Thomas (2009). La mente del samurái : una antología del bushido. Madrid: Edaf. 1a ed. 274 p. : il. ; 15x23 cm. ISBN: 978-84-414-2115-8. Depósito legal: M. 27045-2009. Palabras clave: historia, fundamentos técnicos, filosofía, táctica, política, bushido, samurái. Resumen: Tratado teórico de estrategia. El libro esta formado por 22 capítulos precedidos por una introducción que comenta la historia de Japón, la evolución de su sistema filosófico y religioso, y la aparición de los samuráis. Los 22 capítulos comentan el contexto histórico y pensamiento de distintos guerreros, sabios, políticos y educadores. El primer capítulo debate el desarrollo moral y psicológico del guerrero por Shiba Yoshimasa. El segundo capítulo presenta los consejos para un buen gobierno de Ichijo Kaneyoshi. El tercer capítulo analiza la relación entre cultura y milicia propuesta por Nakae Toju. El cuarto capítulo muestra la psicología zen interior aplicada por Suzuki Shosan a los samuráis. El quinto capítulo expone la formación cultural y marcial de los samuráis de Kumazawa Banzan. El sexto capítulo expone los consejos de comportamiento de Yamaga Soko. El séptimo capítulo presenta los conceptos de táctica militar de Kaibara Ekken. El octavo capítulo detalla los orígenes de la milicia, de la guerra y discute los principios esenciales de la guerra según Naganuma Muneyoshi. El noveno capítulo presenta la comparación de El arte de la guerra de Sun Bin y Han Xin realizada por Muro Naokiyo. El décimo capítulo incluye varios extractos del texto Hagakure de Yamamoto Tsunetomo. El capítulo decimoprimero ofrece distintos consejos para el comportamiento del samurái propuestos por Izawa Nagahide. El decimosegundo capítulo analiza los comportamientos deshonrosos según Yamamoto Ujihide. El capítulo decimotercero incluye las enseñanzas para un samurái de Hakuin Ekaku. El decimocuarto capítulo presenta varias textos extraídos de las Instrucciones para el Camino del Caballero de Hojo Chukiho-shi. El decimoquinto capítulo resume la ciencia política y militar tradicional según Takayama Kentei. El decimosexto capítulo analiza el armamento y combate de una nación insular estudiado por Hayashi Shihei. El decimoséptimo capítulo expone las actitudes de cortesía, aprendizaje y el peligro del budismo presentadas por Tomida Dairai. El decimoctavo capítulo comenta los fundamentos tácticos de Adachi Masahiro. El decimonoveno capítulo analiza el origen de los samuráis y su contexto social y político según Hoshino Tsunetomi. El vigésimo capítulo incluye los estudios de Hirayama Eigen sobre el estado de alerta del samurái. El vigésimo primer capítulo comenta las propuestas para la defensa de Japón de Sato Nobuhiro. El último capítulo narra el origen de los samuráis, su espíritu, disciplina, actitud y código de conducta según Saito Totsudo. Adjunta un glosario de términos específicos y bibliografía.

1298. Cleary, Thomas (2009). La sabiduría del samurái : cinco textos clásicos de la cultura guerrera japonesa. Barcelona: Kairós. 1ae ed. 347 p. ; 13×20 cm. ISBN: 978-84-7245-712-6. Depósito legal: B. 35551-2009. Palabras clave: fundamentos teóricos, principios filosóficos, principios éticos, educación, guerra, estrategia, cortesía, política. Resumen: Tratado teórico sobre el samurái. La obra esta formada por 5 libros precedidos por una introducción que comenta el objetivo del bushido, las influencias del confucianismo, budismo y sintoísmo al bushido y presenta las características y educación de los autores de los escritos incluidos. El primer libro expone la educación, principios morales y filosóficos, y comportamiento social del samurái. El segundo libro expone las virtudes de un samurái así como sus requisitos y conocimientos para gobernar. El tercer libro detalla la biografía de los transmisores del sistema de educación del guerrero, y expone y comenta los principios que rigen la ciencia militar. El cuarto libro describe los orígenes de la humanidad, del camino y de los fenómenos, además de explicar los fundamentos teóricos y prácticos del liderazgo y de la estrategia de la guerra. El último libro expone las normas y consejos de conducta del samurái. Adjunta bibliografía e índice terminológico.

1299. Conches Guillén, Aurelio David (1994). Tras el corazón del guerrero: hao han xin kan. Barcelona: Alas. $1^{\underline{a}}$ ed. 144 p. : il. ; 17x24 cm. ISBN: 84-203-0294-5. Depósito legal: no. Palabras clave: fundamentos teóricos, entrenamiento, filosofía, artes marciales, aforismos, maestros. Resumen: Compendio de historias y proverbios de artes marciales. El libro esta formado por 50 capítulos que exponen las características de los guerreros marciales y sus virtudes junto con varios aforismos y proverbios sobre la conducta del guerrero. Adjunta las conclusiones finales.

1300. Conlan, Tomas D. (2009). Armas y técnicas bélicas del samurái (1200-1877). Alcobendas: Libsa. 1aㅡ ed. 215 p. : il. ; 23x30,5 cm. ISBN: 978-84-662-1939-6. Depósito legal: no. Palabras clave: historia, combate, guerra, estrategia, vestimenta, política, ciencia militar, Fuerzas Armadas, armas. Resumen: Tratado teórico del samurái. El libro esta formado por 6 capítulos ampliamente ilustrados precedidos 
por una introducción que explica el significado histórico del término samurái, describe su papel social y militar, la evolución de sus armas y las consecuencias de su decadencia, acompañada por numerosas ilustraciones explicativas. El primer capítulo describe las generalidades de la sociedad guerrera de los siglos XIII y XIV, introducción de los samurái dentro de las tareas administrativas, comenta las características, ventajas e inconvenientes de los caballos japoneses, sus sillas, la vestimenta de los samuráis a caballo, el arco y su utilización a caballo además de relatar el desarrollo de un enfrentamiento de caballería. El segundo capítulo describe las características de las armaduras simplificadas, las tácticas de combate en las escaramuzas, la estructura de la espada de los soldados a pie y sus tácticas de combate así como las características de las fortificaciones y el relato de la batalla campal de1336. El tercer capítulo expone las características de las lanzas, sus tácticas de combate y el relato de la guerra de Onin. El cuarto capítulo analiza la evolución en las tácticas militares, la tecnología de los castillos, los consecuentes cambios en las armas y armaduras y las estrategias militares de los clanes familiares Ouchi, Hojo tardío y Uesugi. El quinto capítulo presenta la evolución de las armas de fuego en Japón, sus tipos y estructura, sus formas de utilización y fabricación, sus tácticas militares y relata la batalla de nagashino. El sexto capítulo analiza la artillería asiática, la fabricación y utilización de los primeros cañones, la evolución simultánea de las fortificaciones así como sus estrategias militares y un comentario sobre el final de los samuráis. Adjunta un glosario de términos específicos, un listado de lecturas recomendadas, un índice terminológico y los créditos fotográficos.

1301. Coquet, Michel y Ríos, Carmelo H. (1988). Budo secreto. Barcelona: Obelisco. 1a ed. 156 p. : il. ; $20 x 27$ cm. ISBN: 84-7720-080-7. Depósito legal: B. 45217-1988. (2a ed., 1998, ISBN: 84-7720-656-2). Palabras clave: fundamentos teóricos, filosofía, escuelas, ninjutsu, iaido, kárate, kyudo, maestros, shugendo. Resumen: Tratado teórico de artes marciales. El libro esta compuesto de 16 capítulos. Comienza con la exposición de las distintas vías marciales y sus principios fundamentales, destacando los elementos esotéricos que aparecen en todas ellas. Los siguientes cinco capítulos profundizan en los aspectos históricos y filosóficos del karate, el ninjutsu, el iai-do, la tenshin shoden katori shinto ryu y el kyudo. El séptimo capítulo relata las fases de perfeccionamiento por las que pasa el practicante de artes marciales hasta alcanzar el grado de maestro, y continua con la clasificación y explicación de los diferentes grados o títulos que se alcanzan al progresar en las artes marciales. Los dos siguientes capítulos profundizan en la doctrina del hara, detallando la importancia física, técnica y espiritual del mismo, y la historia y significado del mudra. El undécimo capítulo expone la biografía del maestro Kukai, fundador de la escuela esotérica Shingon. Después narra el origen, las prácticas y las fases del shuguendo; para en los dos siguientes capítulos detallar el significado de dos ejercicios de perfeccionamiento espiritual como son la prueba del agua bajo las cascadas y la marcha sobre el fuego. Finaliza con la narración del descubrimiento del buddhismo shingon y la práctica ascética desarrollada en Japón por el autor, y una breve descripción de los principios del buddhismo shingon. Adjunta la narración de la formación marcial del maestro Ueshiba y un compendio de sus aforismos. También adjunta bibliografía.

1302. Coronado Gavilán, Ana (2003). Herca : la historia de una familia. Torrent: Ajuntament de Torrent. $1^{\underline{a}}$ ed. 106 p. : il. ; 21x27 cm. ISBN: No ISBN. Depósito legal: V. 1778-2003. Palabras clave: historia, biografía, clubes, competición. Resumen: Tratado histórico de judo. La obra esta formada por 11 capítulos ampliamente ilustrados. El primer capítulo narra los orígenes y creación del gimnasio Herca. Los siguientes seis capítulos detallan la biografía personal, profesional y deportiva de Paco Carratalá Deval, Enrique Carratalá Deval, José Carratalá Deval, Gonzalo Carratalá Deval, Carmen Carratalá Deval y Vicente Carratalá Deval incluyendo numerosas fotografías. El octavo capítulo incluye una nota de la redacción. El noveno capítulo expone el historial deportivo de la familia Carratalá para continuar con los éxitos alcanzados por el gimnasio Herca. El décimo primer capítulo describe la evolución de los juegos aniversario Herca. Adjunta varias cartas de felicitación.

1303. De Mente, Boyé Lafayette (2006). Estrategias samuráis : 42 secretos marciales del Libro de los cinco anillos de Musashi. Madrid: Tutor. 1aㅡ ed. 142 p. ; 13x19,5 cm. ISBN: 978-84-7902-621-9. Depósito legal: M. 43218-2006. Palabras clave: filosofía, combate, entrenamiento, estrategia, textos, samurái. Resumen: Tratado técnico y filosófico sobre la estrategia del combate y/o la guerra. El libro esta formado por 42 capítulos precedidos por un prólogo que comenta las características de la obra de Musashi, expone el objetivo de la presente obra, y una introducción que comenta el contexto histórico y la biografía de Musashi. Los siguientes 42 capítulos comentan los principios técnicos, estratégicos y filosóficos más importantes extraídos de la obra "Libro de los Cinco Anillos" y que reflexionan sobre fijarse metas, disciplina de vida o muerte, entrenarse para vencer, estar preparado, la forma es ilusoria, integridad absoluta, entrenar la mente, vaciar la mente, la fuerza del vacío, aprender de los adversarios, prestar atención a los detalles, la fuerza del silencio, cambiar las reglas del juego, la fuerza del miedo, desconcertar al adversario, la mente como arma, ver lo que no puede ser, no apegarse a un solo estilo, la importancia de la flexibilidad, tener siempre una visión global, usar el tiempo como un arma, no dejar nunca de aprender, ataca primero y ataca con fuerza, usar todas nuestras armas, el samurái y el carpintero, tomar la iniciativa, conocer el entorno, esperar un desmoronamiento, 
convertirse en el adversario, atraer al adversario, no emplear nunca dos veces la misma táctica, obligar al adversario a cambiar su estilo de combate, comportarse como si ya se estuviera muerto, evitar estancamientos, no dar nunca al adversario otra oportunidad, llegar hasta el final, la importancia del arte en la vida, la espada del espíritu, concentrarse en vencer, cabeza de rata y cuello de toro, superar hoy lo que se era ayer, perseverancia y diligencia. Adjunta una conclusión que comenta la renovación del espíritu samurái en la década de los años 90.

1304. Deshimaru, Taisen (1980). Zen y artes marciales. Madrid: Luis Cárcamo. 1aㅡ ed. 164 p. : il. ; 14×21,5 cm. ISBN: 84-85316-41-X. Depósito legal: M. 24659-1980. (2ª ed., 1993, ISBN: 84-7627-083-6; 3를., 2006, ISBN: 84-7627-083-6). Palabras clave: filosofía, zen, artes marciales. Resumen: Tratado teórico comparativo del zen y las artes marciales. El libro esta formado por 5 capítulos. El primer capítulo reflexiona sobre el bushido, aplicando el zen a la fuerza y sabiduría, la nobleza del combate, los siete principios del bushido, sus tres etapas, cómo dirigir el espíritu y cómo poner en práctica el zen en la práctica. El segundo capítulo incluye preguntas y respuestas generales sobre la aplicación del zen en diversas artes marciales. El tercer capítulo estudia aspectos como la armonía entre cielo y tierra, el ki, la sabiduría inmóvil, el significado de sutemi y la importancia de no pensar. El cuarto capítulo vuelve a dedicarse a preguntas y respuestas generales sobre la relación del zen con las artes marciales y finaliza con un análisis de la vida y la muerte, explicando la enseñanza a un samurái, cómo se realiza zazen y la unidad del cuerpo y el espíritu. Adjunta una nota final y glosario.

1305. Deshimaru, Taisen (2000). El blanco invisible : el zen en las artes marciales. Valencia: Ahimsa. 1aㅡ ed. 223 p. : il. ; 13x21 cm. ISBN: 84-931254-3-1. Depósito legal: M. 2665-2000. Palabras clave: entrenamiento, artes marciales, filosofía, zen, relatos. Resumen: Compendio de ensayos sobre zen y artes marciales. El libro esta formado por 11 capítulos. El primer capítulo estudia la vía del samurái, la relación entre fuerza y sabiduría, el significado de la vía, los principios y etapas que rigen esta vía, la importancia de dirigir el espíritu, e incluye una entrevista con el maestro Deshimaru. El segundo capítulo explica cómo seguir la vía y cuáles son sus principios, incluyendo un apartado de preguntas y respuestas. El tercer capítulo presenta las enseñanzas del maestro Daichi a un samurái respecto al origen de la vía. El cuarto capítulo comenta la transmisión del conocimiento en las artes marciales, el origen del wushu, y del budo y bujutsu. El quinto capítulo narra varios cuentos y anécdotas de los grandes maestros de artes marciales y las extraordinarias capacidades que poseían por medio del entrenamiento y la vía. Los siguientes tres capítulos recopilan varios relatos sobre el entrenamiento de la vía, los problemas que aparecen en el entrenamiento y sobre el miedo y la determinación en las acciones que se toman. El noveno capítulo incluye varias historias sobre la grandeza e importancia de las enseñanzas de los maestros zen. Los dos últimos capítulos recopilan varios relatos sobre el vencer a un adversario sin combatir y cómo alcanzar la iluminación. Adjunta notas y un glosario.

1306. Dunn, Philip (2006). El arte de la paz : equilibrio, en lugar del conflicto, en El arte de la guerra de SunTzu. Móstoles: Neo Person. 1a ed. 189 p. ; 14x21 cm. ISBN: 84-95973-19-7. Depósito legal: M. 36642006. Palabras clave: guerra, estrategia, táctica. Resumen: Tratado teórico sobre la estrategia del combate. La obra esta dividida en 11 partes, precedidas por 4 capítulos introductorios que comentan las características del sistema chino de escritura y del guerrero, analiza el equilibrio entre guerra y paz en las distintas sociedades y expone los objetivos perseguidos con esta versión. Las siguientes 11 partes exponen la traducción de la obra "El arte de la guerra" junto con los comentarios del autor. La traducción esta basada en el doble sentido de los ideogramas de la escritura china, para proponer una traducción que fomenta la resolución de los conflictos mediante un método más pacífico.

1307. Escuela Deportiva Herca (1992). 25 aniversario : escuela deportiva Herca. 1991. Valencia: Gráficas Ronda. 1a ed. 199 p. : il. ; 21x29,5 cm. ISBN: No ISBN. Depósito legal: no. Palabras clave: historia, competición. Resumen: Tratado histórico de judo. La obra esta dividida en 2 partes. La primera parte comenta la fundación del club Herca y los objetivos de la obra además de incluir un resumen del historial deportivo del club Herca desde 1966 hasta 1991 incluyendo numerosas fotografías y tablas explicativas. La segunda parte expone las características de los juegos aniversario Herca a través de sus diferentes etapas junto con los resultados y fotografías de su celebración desde 1968 hasta 1991. Adjunta un capítulo final que resume los objetivos y contenidos de la obra.

1308. Faulliot, Pascual (1982). El blanco invisible : cuentos y narraciones de las artes marciales. Barcelona: Teorema. 1a ed. 149 p. ; $13 \times 21 \mathrm{~cm}$. ISBN: 84-85958-16-0. Depósito legal: no. Palabras clave: fundamentos teóricos, principios técnicos. Resumen: Compendio de cuentos sobre artes marciales. El libro esta formado por 8 capítulos precedidos por una introducción que comenta los contenidos e importancia de la obra. El primer capítulo explica el objetivo de los cuentos y las artes marciales, los paradigmas de las artes marciales, el origen de las artes marciales chinas y el templo shaolin, las características de los estilos internos, las diferencias entre budo y bujutsu así como las características e historia de las bujutsu armadas y a mano desnuda. El segundo capítulo expone el significado y aplicaciones del ki además de incluir la narración de nueve cuentos sobre la demostración del ki. El tercer capítulo comenta el significado de la vía de las artes marciales junto con el relato de cinco cuentos sobre el aprendizaje de la vía de las artes marciales. El cuarto capítulo analiza la importancia 
de las apariencias en el combate e incluye la narración de 5 cuentos sobre el papel de las apariencias en las artes marciales. El quinto capítulo analiza los problemas derivados del miedo en la práctica de las artes marciales y presenta 6 cuentos sobre el control del miedo. El sexto capítulo expone el significado del zen y su relación con las artes marciales además de incluir la narración de 5 cuentos. El séptimo capítulo expone los principios de vencer sin combatir y de no-resistencia en el combate así como su exposición en 7 cuentos. El último capítulo explica los principios para alcanzar la maestría en las artes marciales y presenta la narración de 2 cuentos sobre este tema.

1309. Fleitas González, Pedro (1992). Tenchijin ryaku no maki : los principios del Cielo, la Tierra y el Hombre. Telde: Seigan. $1^{\underline{a}}$ ed. 69 p. : il. ; 21x30 cm. ISBN: 84-604-4242-X. Depósito legal: no.

1310. Fraguas, José María (1983). Los grandes maestros del budo. Barcelona: Alas. 1a ed. 141 p. : il. ; $15 \times 21$ cm. ISBN: 84-203-0152-3. Depósito legal: B. 32827-1983. (2 ed., 1987, ISBN: 84-203-0056-X). Palabras clave: biografía, artes marciales. Resumen: Compendio biográfico de distintos maestros de artes marciales. El libro esta formado por 26 capítulos, precedidos por una breve biografía del autor, una introducción que comenta los contenidos y objetivos de la obra además de un conjunto de frases célebres de los maestros referenciados. Los siguientes capítulos detallan la biografía profesional y aportación al mundo de las artes marciales de los maestros Gichin Funakoshi, Jigoro Kano, Morihei Ueshiba, Shigeru Egami, Masutatsu Oyama, Kenwa Mabuni, Tsutomu Oshima, James M. Mitose, Masatoshi Nakayama, Gogen Yamaguchi, Hidetaka Nishiyama, Robert A. Trias, Ed Parker, John Rhee, Bruce Lee, Mike Stone, Chuck Norris, Jun Chong, Joe Lewis, Bill Wallace, Dan Inosato, Hirokazu Kanazawa, Benny Urquidez, Fumio Demura, Hee Il Cho y Dominique Valera, incluyendo numerosas fotografías de los mismos. Adjunta otra serie de frases célebres de los maestros referenciados.

1311. Fraguas, José María (1995). La sabiduría de los maestros. Madrid: Eyras. 1aㅡ ed. 191 p. : il. ; 15x24 cm. ISBN: 84-85269-79-9. Depósito legal: M. 1643-1995. Palabras clave: fundamentos teóricos, entrenamiento, filosofía, artes marciales, aforismos, maestros. Resumen: Compendio de aforismos sobre las artes marciales. La obra esta formada por 30 capítulos cada uno de ellos dedicado a un maestro marcial. Cada capítulo esta compuesto por una breve presentación del maestro y su aportación al mundo de las artes marciales y un conjunto de sus aforismos sobre su arte marcial, el entrenamiento, la técnica, el combate, la filosofía o cualquier otro aspecto marcial. Los maestros incluidos en la obra son: Masatoshi Nakayama, Ed Parker, Bruce Lee, Kisshomaru Ueshiba, Masaaki Hatsumi, Rorion Gracie, Gogen Yamaguchi, Dan Inosato, Adriano D. Emperado, Benny Urquidez, Hirokazu Kanazawa, Jackie Chan, Nobuyoshi Tamura, Steven Seagal, Leung Ting, Bill Wallace, Taiji Kase, Surachai Sirisute, Wong Shun Leung, Stephen Hayes, Jean Claude Van Damme, Morio Higaonna, Doc Fai Wong, Edgar G. Sulite, Chuck Norris, William Cheung, Larry Hartsell, Yoshinao Nambu, Jean Yves Theriault y Tsuguo Sakumoto.

1312. Fromm, Mallory (2000). El libro del ki. Málaga: Sirio. 1a ed. 125 p. : il. ; 17x24 cm. ISBN: 84-7808-327-8. Depósito legal: B. 10019-2000. Palabras clave: fundamentos teóricos, ejercicios, relatos, aplicación terapéutica. Resumen: Manual teórico y técnico de ki. El libro esta formado por 2 partes precedidas por un prefacio que comenta los contenidos de la obra y una introducción que narra la biografía del autor. La primer parte consta de 5 capítulos. El primer capítulo explica el concepto de ki. El segundo capítulo describe los procedimientos estándar y avanzado para acceder al propio ki. El tercer capítulo explica la ejecución de varios ejercicios sentados y de pie para entrenar el ki. El cuarto capítulo detalla los principios técnicos para utilizar el ki como sanación junto con la localización de los puntos. El quinto capítulo explica los ejercicios de ki para el tratamiento del dolor de espalda, la incontinencia, la conducta compulsiva, el estreñimiento, la digestión, los dolores en el codo, la vista cansada, la fatiga, la caída del cabello, el dolor de cabeza, los riñones, los dolores de rodilla, los problemas menstruales, el dolor de cuello, los problemas respiratorios, el dolor y la rigidez de hombros, los trastornos del sueño, la tensión y el dolor de muelas. La segunda parte consta de 3 capítulos que narran las experiencias sanadoras de Kayoko Matsuura.

1313. Garrido Troncoso, Víctor (1983). Prontuario-guía de la Federación Española de Judo, Taekwondo, Kendo, Aikido, Jiu-jitsu. Madrid: Barlovento. 1a ed. 313 p. : il. ; 15x21 cm. ISBN: 84-85843-08-8. Depósito legal: M. 37553-1983. (2a ed., 1992, 392 p., ISBN: 84-604-3181-9). Palabras clave: historia, aikido, judo, jujutsu, kendo, taekwondo, instituciones, legislación, programa técnico, reglamentos. Resumen: Tratado teórico del judo y los disciplinas asociadas. La obra esta dividida en 7 capítulos, comenzando con la descripción de la federación de judo, su junta de gobierno, las federaciones provinciales y una relación de los clubes. Los siguientes 5 capítulos están dedicados, cada uno de ellos, a una de las artes marciales que integran esta federación de judo, comenzando con el propio judo y siguiendo con el taekwondo, el aikido, el kendo y el jiu-jitsu. Cada capítulo tiene la misma estructura, comenzando con una explicación de la historia de dicho arte en España, enumerando la lista de cinturones negros, su normativa de examen, el programa técnico, la relación de maestros, de árbitros, los reglamentos de competición, y las normas de enseñanza. Además, en el capítulo dedicado al judo aparecen la tabla de campeones y el significado de las técnicas en castellano. El último capítulo presenta los estatutos de la 
Federación Española de Judo y Disciplinas Asociadas, el reglamento de régimen disciplinario deportivo, la ley de la cultura física y del deporte y un glosario japonés-español.

1314. Gaskin, Carol y Hawkins, Vince (2004). Breve historia de los samuráis. Madrid: Nowtilus. 1 a ed. 130 p. : il. ; 13x19 cm. ISBN: 84-9763-140-4. Depósito legal: M. 46519-2004. (2를. ed., 2005; 3르 ed., 2007, 140 p.). Palabras clave: historia, educación, entrenamiento, guerra, artes marciales, relatos, cultura, maestros, samurái, armas. Resumen: Tratado teórico sobre los samuráis. El libro esta formado por 9 capítulos precedidos por una breve biografía de los autores y un prólogo que comenta las características generales de los samuráis. El primer capítulo explica el significado del término samurái y el valor de la espada para el mismo. El segundo capítulo narra las guerras entre los clanes Taira y Minamoto hasta que Yoritomo se hizo sogún de Japón. El tercer capítulo comenta las invasiones mongolas, el cénit de los samuráis, la sucesión de poder, las características de los castillos japoneses y relata el asalto al castillo de Osaka. El cuarto capítulo expone las características de los ronin, describe la vida y obra de Miyamoto Musashi, la historia de los 47 ronins. El quinto capítulo presenta la casa del samurái, su religión, su educación, su comida y vestimenta, y sus pasatiempos. El sexto capítulo comenta las costumbres del samurái así como su armadura, armas y entrenamiento para el combate. El séptimo capítulo presenta las características técnicas e historia del ninjutsu. El octavo capítulo expone los orígenes, características técnicas y objetivos del kendo, judo, aikido, karate y taekwondo y kung fu. El último capítulo comenta brevemente el legado de los samuráis. Adjunta el relato de la cuarta batalla de Kawanakajima, la batalla de Nagashino, el desarrollo de las armas de fuego en Japón, una tabla de los emperadores, regentes y sogunes de Japón y un glosario.

1315. Gaspar, Luis (1980). Teoría de las artes marciales. Madrid: Luis Gaspar. $1 \underline{a}$ ed. 176 p. : il. ; 13×19,5 cm. ISBN: 84-300-3411-0. Depósito legal: M. 37419-1980. Palabras clave: historia, artes marciales. Resumen: Tratado evolutivo sobre las artes marciales. La obra esta compuesta de 12 capítulos que profundizan en el nacimiento de las artes marciales, sus representaciones y sus significados actuales. Comienza explicando cómo aparecieron las artes marciales en Occidente, para así retroceder en el tiempo y detallar la formación de las artes marciales primitivas, el papel de la danza ancestral en la formación de los futuros guerreros y como conservador de la tradición, la doble funcionalidad de las armas de combate, tanto para la guerra como para la caza, las características de las artes desarmadas, las peculiaridades de distintos paradigmas como el juego, el deporte y el espectáculo en relación con las artes marciales y la aparición del mito. Finaliza con dos capítulos dedicados al ceremonial atávico y a la dualidad cuerpo-mente o cartesianismo-zen en las artes marciales.

1316. González Vallés, Jesús (2009). Filosofía de las artes japonesas : artes de guerra y caminos de paz. Madrid: Verbum. $1^{a}$ ed. 399 p. ; 14x20 cm. ISBN: 978-84-7962-385-2. Depósito legal: SE. 1421-2009. Palabras clave: historia, fundamentos teóricos, aikido, iaido, judo, kárate, kendo, kyudo, fundamentos filosóficos, bushido, caligrafía, jardinería, pintura. Resumen: Tratado filosófico de artes marciales. El libro esta dividido en 3 partes precedidas por un prólogo que detalla la formación del autor y su obra, y una introducción que comenta el significado del "do", las características del pueblo japonés y de la cultura japonesa. La primera parte consta de 4 capítulos. El primer capítulo explica los fundamentos teóricos, filosóficos y características del shintoismo mientras que el segundo presenta los fundamentos teóricos e influencias del budismo. Los dos últimos capítulos exponen los fundamentos teóricos y filosóficos del confucianismo y el taoísmo. La segunda parte consta de 7 capítulos. El primer capítulo analiza el contexto histórico del bushido, su relación con el cristianismo, su papel social, sus fundamentos ideológicos y éticos. El segundo capítulo narra la historia y evolución de la espada en Japón, los fundamentos filosóficos del kenjutsu y el significado de la espada. El tercer capítulo relata la historia del kyudo así como sus fundamentos filosóficos. El cuarto capítulo comenta los antecedentes históricos del iaido y sus fundamentos teóricos. El quinto capítulo expone la creación e historia del judo y sus fundamentos filosóficos y morales. El sexto capítulo explica la historia del karatedo así como sus fundamentos filosóficos y morales. El séptimo capítulo narra la historia del aikido, sus fundamentos teóricos y filosóficos y presenta otras prácticas marciales. La tercera parte consta de 6 capítulos. El primer capítulo narra la historia de la caligrafía ideográfica, de su tradición japonesa y explica sus fundamentos filosóficos. El segundo capítulo analiza la evolución y etapas de la pintura sumie y sus fundamentos espirituales. El tercer capítulo expone la historia de la ceremonia del té, describe su desarrollo y contexto así como sus fundamentos filosóficos. El cuarto capítulo analiza la evolución histórica del ikebana, sus escuelas y sus fundamentos teóricos. El quinto capítulo comenta las características de la poesía en la tradición japonesa, sus contenidos y fundamentos filosóficos. El último capítulo explica la evolución de los jardines y sus características en la historia japonesa además de los fundamentos filosóficos de la jardinería japonesa. Adjunta una conclusión final, bibliografía, índice de nombres japoneses, vocabulario japonés e índice analítico.

1317. Gummerson, Tony (1993). Enseñanza de las artes marciales. Barcelona: Paidotribo. $1^{a}$ ed. 183 p. : il. ; 15x21,5 cm. ISBN: 84-8019-073-6. Depósito legal: B. 5365-1993. Palabras clave: pedagogía, entrenamiento, planificación del entrenamiento. Resumen: Tratado teórico sobre la enseñanza en las artes marciales. Después de constatar en los dos primeros capítulos un conjunto de deficiencias tanto 
de los regímenes de entrenamiento pasados y los actuales, y de algunos términos sinónimos como los de instructor, entrenador, maestro o preparador que generan discrepancias en las enseñanzas que ofrecen, los siguientes capítulos desarrollan una teoría de enseñanza de las artes marciales. Así, comienza con un análisis de las capacidades necesarias para ser un buen entrenador, cómo el Reino Unido a creado una asociación para educar a los entrenadores de artes marciales, cual es el mejor ambiente para el aprendizaje de los alumnos, cómo hay que adaptar los entrenamientos a la edad y características de los practicantes, cual es la función de los sentidos en el proceso de aprendizaje, cuales deberían ser las funciones del entrenador, cómo se debe planificar y programar el entrenamiento, cómo planificar las sesiones de entrenamiento, cuáles son las fases del proceso de aprendizaje, cómo enseñar una nueva técnica, la importancia del repaso y la valoración de los practicantes, y algunos consejos sobre la preparación mental del practicante.

1318. Gutiérrez Santiago, Alfonso (2008). El parámetro temporal en la actividad físico-deportiva : especial referencia al judo y otros deportes de adversario. Sevilla: Wanceulen. $1^{\underline{a}}$ ed. 114 p. : il. ; 17x23,5 cm. ISBN: 978-84-9823-502-9. Depósito legal: SE 5892-2008. Palabras clave: educación, judo, lucha canaria, lucha leonesa, lucha olímpica, taekwondo, deporte. Resumen: Tratado teórico sobre el estudio de la variable tiempo en distintos deportes. La obra esta dividida en 6 partes, precedidas por una introducción que señala la metodología utilizada en el estudio. La primera parte esta formada por dos capítulos, que explican y comentan el estudio de la variable tiempo dentro de las investigaciones relacionadas con el judo y otros deportes de lucha, como la lucha canaria, la lucha leonesa, la lucha olímpica y el taekwondo, respectivamente. La segunda parte esta formada por dos capítulos que analizan las investigaciones desarrolladas en el fútbol en primer lugar, y con otros deportes de equipo, en segundo lugar, como son el balonmano, baloncesto, voleibol, fútbol sala, hockey, waterpolo y el estudio comparado de varios deportes de equipo. La tercera parte estudia y discute los resultados obtenidos, respecto a la variable tiempo, en las investigaciones del badminton, tenis, squash y "pilota valenciana". La cuarta parte resalta y discute los principales resultados de las investigaciones realizadas en la escalada, atletismo, natación y acrosport respecto a la variable tiempo. La quinta parte presenta el estudio de la variable tiempo en dos investigaciones sobre el tiempo en las clases de Educación Física y en la actividad deportiva, señalando las conclusiones principales de ambos estudios. La última parte expone las conclusiones extraídas del análisis de todas las investigaciones analizadas. Adjunta bibliografía.

1319. Gutiérrez Santiago, Alfonso y Maceira Gago, Antonio Delfín (2003). Deportes de loita. Santiago de Compostela: Igapepsa. $1^{a}$ ed. 239 p. : il. ; 17x24 cm. ISBN: 84-607-9867-4. Depósito legal: C. 2929-2003. Palabras clave: historia, fundamentos teóricos, fundamentos técnicos, combate, vestimenta, cortesía, competición, etiqueta, instituciones, reglamentos, salud. Resumen: Tratado teórico de artes marciales. La obra esta formada por 7 capítulos precedidos por una introducción que comenta las diferentes clasificaciones existentes sobre las actividades de lucha, describe brevemente la historia de la lucha en las distintas civilizaciones y señalan la importancia de la lucha a lo largo de la historia de la humanidad. El primer capítulo narra la historia del boxeo y sus modalidades, describe sus aspectos formales y conceptos generales, detalla las repercusiones de su práctica sobre los deportistas, enumeran las federaciones y asociaciones a nivel internacional, nacional y gallego que controlan el boxeo junto con una breve descripción de los deportistas más destacados y ofrecen un listado con las direcciones y composición de las principales federaciones y asociaciones a nivel internacional, nacional y gallego. El segundo capítulo explica la práctica de la esgrima, relata su historia y evolución así como de sus modalidades, presenta sus términos técnicos y conceptos generales, describe su equipamiento, reglas básicas de competición y fundamentos técnicos, comenta sus beneficios sobre el practicante, detalla la institucionalización de la esgrima a nivel internacional, nacional y gallego, muestra el ranking de sus competidores a nivel gallego y ofrece un listado con las direcciones y composición de las principales federaciones y asociaciones a nivel internacional, nacional y gallego. El tercer capítulo explica las prácticas del jiu-jitsu, wushu, aikido, kendo y judo, describe los fundamentos técnicos del judo junto con sus aspectos formales de vestimenta, instalación y sistema de graduación, destaca los beneficios de su práctica, narra la práctica y difusión del judo a nivel internacional, nacional y gallego, y ofrece un listado con las direcciones y composición de las federaciones nacionales, internacional y gallegas que controlan el judo además de los resultados de los Juegos Olímpicos y Mundiales de judo. El cuarto capítulo describe la práctica, origen y evolución del kárate y sus diferentes estilos, detalla las características de sus contenidos técnicos, explica sus aspectos formales, enumera los beneficios derivados de su práctica, comenta la introducción y desarrollo del kárate a nivel internacional, nacional y gallego, enumera a sus principales deportistas nacionales y presenta un listado con las direcciones y composición de las federaciones nacionales, internacional y gallegas de kárate. El quinto capítulo narra la historia del kick boxing y su evolución, describe sus fundamentos técnicos, la organización y reglamento de su competición, presenta el equipamiento e instalaciones necesarios para su práctica, enumera las precauciones a tener en cuenta tras una lesión, expone la práctica y difusión del kick boxing a nivel internacional, nacional y gallego junto con sus deportistas más 
destacados y una guía con las direcciones y composición de los órganos de gobierno del kick boxing a nivel internacional, nacional y gallego. El sexto capítulo relata la historia de la lucha y sus competiciones, presenta sus beneficios, comenta las instituciones y deportistas destacadas a nivel internacional, nacional y gallego y presenta la dirección y composición de dichas instituciones. El séptimo capítulo expone la historia del taekwondo y su evolución, comenta el equipamiento e instalaciones necesarias para su práctica, señala sus beneficios, presenta la práctica y difusión internacional, nacional y gallega del taekwondo junto con un resumen de sus últimos resultados deportivos y un listado de las direcciones de sus federaciones internacional nacional y gallega. Adjunta bibliografía básica.

1320. Gutiérrez Santiago, Alfonso y Prieto Lage, Iván (2008). Teoría y praxis del juego en las actividades de lucha : una perspectiva basada en el conocimiento del error. Sevilla: Wanceulen. $1^{\underline{a}}$ ed. 156 p. : il. ; 17x23,5 cm. ISBN: 978-84-9823-212-7. Depósito legal: SE. 4309-2008. Palabras clave: principios técnicos, judo, iniciación deportiva, investigación, juegos. Resumen: Tratado teórico y práctica de actividades de lucha. El libro esta dividido en 2 partes precedidas por una presentación que comenta los objetivos y contenidos de la obra. La primera parte consta de 6 capítulos. El primer capítulo introduce los contenidos de esta parte. El segundo capítulo incluye las distintas clasificaciones existentes sobre los juegos luctatorios junto con algunos ejemplos prácticos ilustrados. El tercer capítulo expone las distintas modificaciones que se pueden aplicar a los juegos dependiendo de su objetivo. El cuarto capítulo incluye varias propuestas de iniciación al judo en la iniciación deportiva y en el ámbito escolar. El quinto capítulo señala las ventajas y desventajas de la introducción de la actividades de lucha en la educación física escolar. El sexto capítulo expone las características de los 3 paradigmas de utilización del juego en las actividades de lucha. La segunda parte consta de 5 capítulos. El primer capítulo presenta los objetivos de la investigación desarrollada por los autores para conocer los errores más comunes en las proyecciones de judo. El segundo capítulos detalla los materiales y métodos utilizados mientras que el tercero señala los resultados obtenidos en las técnicas de proyección analizadas. El cuarto capítulo discute los resultados obtenidos mientras que el último señala los errores comunes a las técnicas estudiadas y presentan distintos juegos para corregirlos. Adjunta referencias bibliográficas.

1321. Haskew, Michael E.; Jörgensen, Christer; McNab, Chris; Niderost, Eric y Rice, Rob S. (2009). Técnicas bélicas del mundo oriental, 1200-1860 : equipamiento, técnicas y tácticas de combate. Alcobendas: Libsa. $1^{\underline{a}}$ ed. 256 p. : il. ; 20x27 cm. ISBN: 978-84-662-1781-1. Depósito legal: no. Palabras clave: guerra, estrategia, táctica, equipamiento, Fuerzas Armadas, fundamentos técnicos. Resumen: Tratado teórico de artes marciales. La monografía esta formada por 5 capítulos ilustrados. El primer capítulo describe las características, objetivos, funciones, técnicas y tácticas de la infantería china y japonesa, su papel en el desarrollo de las batallas de Tumu, Maymyo, Kawanakajima y Nagashino, además de comentar la evolución en sus armaduras, el papel de las lanzas y espadas en el combate y la aparición de la tecnología de las armas de fuego. El segundo capítulo describe la utilización de la caballería en el campo de batalla por el ejército mongol en las batallas del Paso de Nankuo, Vochan, las invasiones a Japón, Ulan Butung y Jaghun Modo además del papel del jinete arquero. El tercer capítulo analiza las estrategias y tácticas de combate de los mongoles, coreanos y japoneses a través de la descripción de las batallas del río Kalka, de Bun'ei, de Hansando y de Sekigahara. El cuarto capítulo describe las fortificaciones y armamento de asedio de los ejércitos chinos, japoneses, mongoles y coreanos así como las batallas del sitio de Xiangyang, el asedio de Osaka, el sitio de Chinju y las batallas de los fuerte de Dagu. El último capítulo explica la tecnología naval, técnicas y tácticas en el Extremo Oriente y su evolución junto con la narración de la invasión mongola de Japón, la batalla del lago Poyang, de Sacheon y de Wusung-Shanghai. Adjunta un índice de palabras clave.

1322. Hino, Akira (2004). Kokoro no katachi : la imagen del corazón. Barcelona: Fernando Aixa y Seigan. 1a ed. 191 p. : il. ; 14x21 cm. ISBN: 84-933469-1-8. Depósito legal: B. 35794-2004. Palabras clave: fundamentos filosóficos, cultura, maestros. Resumen: Tratado filosófico de artes marciales. El libro esta compuesto por 9 capítulos precedidos por una carta de recomendación de la obra, y dos prefacios que resaltan la importancia de la sensibilidad y los contenidos de la obra. El primer capítulo comenta la imagen del maestro y la tradicional marcial japonesa. El segundo capítulo expone el currículo de Masaaki Hatsumi y presenta la crónica de su seminario en Holanda. El tercer capítulo relata los contactos del autor con el maestro Hatsumi y sus aprendizajes. El cuarto capítulo expone las relación entre maestro y discípulo a través de varias anécdotas. El quinto capítulo reflexiona sobre los requisitos para ser un maestro marcial. El sexto capítulo expone los problemas relacionados con el budo tradicional y lo compara con la arquitectura japonesa. El séptimo capítulo explica el significado de la sensibilidad o kokoro. El octavo capítulo expone los tipos de contacto y los niveles de progreso en el sentimiento de sensibilidad o kokoro. El último capítulo describe el proceso de aprendizaje del kokoro por parte del maestro Hatsumi y sus enseñanzas. Adjunta un epílogo y el currículo del autor.

1323. Iedwab, Claudio A. y Standefer, Roxanne L. (2000). Artes marciales : el arte secreto de la salud y la buena forma física. Desveladas a partir de las enseñanzas de los maestros de las artes marciales. Madrid: 
Miraguano. $1^{\text {a }}$ ed. 247 p. : il. ; 17x24 cm. ISBN: 84-7813-213-9. Depósito legal: M. 38168-2000. Palabras clave: historia, fundamentos teóricos, defensa personal, entrenamiento, artes marciales, filosofía, kyusho, respiración. Resumen: Tratado teórico y técnico de artes marciales. El libro esta dividido en nueve capítulos. El primer capítulo comenta el origen y evolución de las artes marciales, las causas de su evolución, los distintos puntos de origen de las mismas y su desarrollo hasta las prácticas actuales. El segundo capítulo explica la importancia de la respiración dentro de las artes marciales para luego detallar la fisiología del sistema respiratorio, su utilización durante el entrenamiento y en distintas artes marciales, y describe e ilustra tres ejercicios, con dos niveles de dificultad, para mejorar la respiración. El tercer capítulo señala la importancia y principios técnicos de la alineación correcta de la columna vertebral para la práctica de las artes marciales y describe e ilustra tres ejercicios para recuperar la alineación de la columna. El cuarto capítulo estudia los requisitos físicos y mentales del practicante de artes marciales, los objetivos de la práctica, los principios del entrenamiento, los principios técnicos generales a cualquier arte marcial e incluye la descripción de varios ejercicios para fortalecer y estirar todo el cuerpo. El quinto capítulo presenta la teoría del ki, su aplicación al entrenamiento de artes marciales, sus beneficios, localiza los puntos vitales del cuerpo humano y comenta la utilización que hacen las artes marciales de los mismos además de incluir dos ejercicios de luxación de la muñeca. Continúa con la descripción de la teoría del kiai, su aplicación en la práctica de las artes marciales y describe e ilustra dos ejercicios para alcanzar la armonía de la energía. El séptimo capítulo detalla las formas de desarrollar la fuerza, resistencia y velocidad por medio de las artes marciales, explica los principios técnicos del entrenamiento de kata y kumite, y describe la ejecución de varios ejercicios de kihon y kata de la escuela del autor (gorindo). El octavo capítulo resalta los beneficios que produce la práctica de las artes marciales sobre la capacidad del artista marcial para afrontar situaciones de defensa personal e incluye la descripción e ilustración de varios ejercicios de defensa personal. El último capítulo comenta la actitud del practicante de artes marciales para progresar y desarrollarse mediante el entrenamiento y los beneficios que reporta el estudio de las artes marciales. Adjunta un listado de lecturas recomendadas.

1324. Iedwab, Claudio A. y Standefer, Roxanne L. (2002). El sendero pacífico : guía de las artes marciales para niños. Barcelona: Oniro. 1aㅡ ed. 119 p. : il. ; 18x23,5 cm. ISBN: 84-9754-028-X. Depósito legal: B. 320562002. Palabras clave: fundamentos teóricos, artes marciales, zen, aplicación social. Resumen: Tratado introductorio a las artes marciales. La obra presenta con un lenguaje sencillo, y de forma genérica, el mundo de las artes marciales, comenzando con las razones por las que el practicante se acerca a éste mundo. Continua con la presentación del lugar de entrenamiento (dojo) y sus normas, cómo se desarrolla una clase normal de artes marciales y la graduación de los niveles de aprendizaje por cinturones y su significado. Los siguientes dos capítulos abordan las actitudes que se deben tener en las exhibiciones y competiciones así como la responsabilidad creada al convertirse en practicante de artes marciales. A continuación propone algunos consejos para evitar las situaciones de defensa personal y cuál debe ser la mentalidad del practicante ante estas situaciones. El octavo capítulo aplica los conocimientos que se adquieren en las artes marciales a otras esferas de nuestra vida; y el noveno comenta el origen y evolución de las artes marciales. El último capítulo recopila las grandes ideas, o principios filosóficos, del zen que reinan en las artes marciales.

1325. Isidro Casas, José Luis (2005). Reflexiones de un guerrero : la vía de la estrategia. Madrid: Librería Argentina. $1^{a}$ ed. 143 p. : il. ; $17 \times 24$ cm. ISBN: 84-89836-72-8. Depósito legal: M. 2245-2005. Palabras clave: artes marciales, filosofía, ética. Resumen: Compendio de reflexiones. La monografía esta formada por 44 capítulos que reflexionan sobre los aspectos que rodean al artista marcial. Los temas tratados son el equilibrio entre los extremos, la consciencia del guerrero en la práctica, las actitudes del guerrero, el maestro y el discípulo ante el entrenamiento, los beneficios de los distintos tipos de entrenamiento del aikido, las formas de trabajo con el sable dentro del aikido, las razones para no incluir al aikido como deporte, el egoísmo, la templanza y la moralidad del guerrero, conceptos básicos como kokyu, tai-sabaki y ma-ai, la relación entre el héroe y el guerrero, el amor como antagónico de la guerra, la respiración como método de autocontrol, el control de la distancia en el combate, la sabiduría y el deseo de aprendizaje, el dolor, la felicidad, los beneficios del aikido, el comportamiento del samurái, las actitudes ante la defensa personal, el abuso, la forma de actuar del guerrero, la ignorancia, la enseñanza, la violencia, el miedo, la justicia, la ira, la amistad, la tiranía, la tolerancia, el arte, la vida, la muerte, la política, la inteligencia, las diferencias, el terrorismo, la comprensión, la certeza, el camino, el olvido, la edad y las limitaciones.

1326. James, Andy (2005). El legado espiritual del templo Shaolín : el budismo, el taoísmo y las artes energéticas. Móstoles: Arkano Books. 1ํㅡㄹ. ed. 253 p. : il. ; 14x21 cm. ISBN: 84-96111-17-2. Depósito legal: M. 41941-2005. Palabras clave: historia, fundamentos teóricos, ejercicios, fundamentos filosóficos, budismo, confucianismo, taoísmo. Resumen: Tratado teórico y técnico sobre el templo shaolin. El libro esta dividido en 3 partes precedidas por una presentación que comenta los contenidos de la obra, un prefacio que señala la importancia del legado del templo shaolin y los agradecimientos. La primera parte esta formada por un capítulo que narra la biografía del autor, su formación académica y marcial, 
y la evolución de su carrera profesional. La segunda parte consta de 5 capítulos. El primer capítulo narra el origen del templo shaolin, la llegada de Bodhidharma y la aparición y aportación del budismo Chan a China. El segundo capítulo analiza la relación entre confucianismo, taoísmo y budismo Chan así como sus fundamentos teóricos. El tercer capítulo comenta las fases del raja yoga, los fundamentos teóricos del tantra, la aparición del qigong, la teoría del yin-yang y de los cinco elementos, y expone las aplicaciones del qigong. El cuarto capítulo analiza la relación entre espiritualidad y combate, detalla las características de las artes marciales internas y externas, y profundiza en la historia, fundamentos teóricos y práctica del taijiquan, baguazhang y xingyiquan. El quinto capítulo analiza los problemas espirituales en la actualidad, los beneficios de la espiritualidad budista-taoísta para solucionar dichos problemas y sus repercusiones sobre la vida diaria. La última parte consta de un capítulo que explica los principios técnicos y describe la ejecución de la postura wuji, el caminar taijiquan, la meditación de pie yi quan, la órbita microcósmica y la meditación vipassana. Adjunta una conclusión final y notas.

1327. Josselin, Jacques (1990). Los samuráis en el antiguo Japón. Madrid: S.M. 1aㅡ ed. 71 p. : il. ; 11×18 cm. ISBN: 84-348-3112-0. Depósito legal: M. 11305-1990. Palabras clave: relatos, cultura, Japón. Resumen: Ensayo sobre los samuráis. El libro esta formado por 6 capítulos. El primer capítulo relata el nacimiento de Japón como nación, sus religiones y su formación cultural. El segundo capítulo presenta el aprendizaje del samurái y continúa explicando el código del samurái y la importancia del ki. El cuarto capítulo detalla la vida cotidiana de un samurái como sus armas, alimentación y armadura. El quinto capítulo detalla las guerras entre los samuráis y su unión para combatir a los chinos en la batalla de Kyushu. El último capítulo relata anécdotas de los tres más famosos samuráis, Kusunoki Masashige, Amakuja Shiro y Saigo Takamori, además del ritual del harakiri. Adjunta un pequeño vocabulario, una breve cronología de la historia de Japón, España y el resto del mundo, y unos apuntes literarios y cinematográficos para saber más sobre Japón y los samuráis.

1328. Juní Cadenet, Jesús (1983). Shogun, señor de samuráis. Barcelona: Alas. 1ae ed. 32 p. : il. ; 17x24 cm. ISBN: 84-203-0147-7. Depósito legal: B. 15215-1983. Palabras clave: historia, Japón. Resumen: Tratado histórico de Japón. El libro esta formado por 4 capítulos. El primer capítulo relata los orígenes de Japón, su formación social, las sucesiones en el poder y la formación de los samuráis. El segundo capítulo narra las guerras entre los Taira y los Yoritomo hasta el acceso al poder de éstos y la fundación del shogunato. El tercer capítulo describe la historia de Tokugawa Ieyasu. El último capítulo narra la época de aislamiento de Japón desde 1609 hasta el final de la era Tokugawa en 1853. Incluye fotografías de la serie de televisión.

1329. Kane, Lawrence A. (2008). Instrucción en artes marciales : cómo aplicar la teoría de la enseñanza y las técnicas de comunicación en el dojo. Móstoles: Arkano Books. 1a ed. 188 p. : il. ; 17x24 cm. ISBN: 97884-96111-39-4. Depósito legal: M. 23572-2008. Palabras clave: katas, pedagogía, didáctica, kárate, psicología, personalidad, planificación del entrenamiento, unidades didácticas. Resumen: Tratado pedagógico de artes marciales. La monografía esta formada por 6 capítulos, precedidos por un prefacio que comenta las implicaciones de la enseñanza de artes marciales, agradecimientos y una introducción que resume los contenidos del libro. El primer capítulo resalta la importancia de una metodología de enseñanza en las artes marciales diferenciada para cada tipo de alumnos según su modo de aprender y explica las características y recomendaciones pedagógicas para los estudiantes auditivos, cinestésicos y visuales. El segundo capítulo explica en qué consiste el indicador de tipo Myers-Briggs, las características de personalidad de sus cuatro dimensiones dicotómicas conducentes a 16 combinaciones de tipo de personalidad, el modo de aprendizaje de los alumnos según dicho tipo de personalidad, ofrece varios criterios para convertirse en oyente activo, destaca la importancia de la motivación en las artes marciales, describe las características y énfasis didáctico en la enseñanza a niños y adultos así como la importancia de juegos y competiciones para mantener la atención y motivación. El tercer capítulo describe las características, metodología y aplicación a la clase de artes marciales de 6 estilos de enseñanza como son servir de modelo, dar una conferencia, ejecución cooperativa, ejecución individual, captura del conocimiento e inversión de papeles. El cuarto capítulo comenta las características que favorecen la creación de un ambiente positivo de aprendizaje como son la actitud del profesor, las normas de etiqueta, el respeto de las tradiciones, la creación de un entorno emocional estable y un entorno físico seguro, la capacidad de adaptarse a las necesidades de alumnos especiales, enumera las características de un alumno y un maestro ejemplar y ofrece algunos consejos para mantener la relación profesor-alumno. El quinto capítulo expone los contenidos necesarios de una planificación anual de enseñanza de artes marciales, los requisitos que conforman los planes para las clases individuales, explica como gestionar la clase y el ritmo de enseñanza, los principios y formas de examen y ascenso de nivel, ofrece consejos para mantener la progresión de las actividades de clase y resalta la importancia de las katas, el bunkai, el kiso kumite y la defensa personal así como sus principios pedagógicos. El último capítulo resume los contenidos expuestos y las fases de la enseñanza. Adjunta apéndices sobre los requisitos de ascenso de nivel hokusei yudanshakai (hasta shodan), las características de las principales katas de Goju Ryu, el cuestionario de determinación del tipo psicológico, un ejemplo de plan lectivo, agradecimientos, notas y un glosario. 
1330. Kim, Richard (2008). Zen en movimiento : la sabiduría de las artes marciales. Madrid: Budo International. 1a ed. 95 p. : il. ; 17x24 cm. ISBN: 978-84-92484-23-2. Depósito legal: M. 58544-2008. Palabras clave: fundamentos teóricos, artes marciales, filosofía. Resumen: Tratado filosófico de artes marciales. La obra esta formada por 22 capítulos precedidos por un prólogo que comenta los contenidos de la obra. El primer capítulo narra la historia de Hariya Sekiun. El segundo capítulo reflexiona sobre el aprendizaje de las katas. El tercer capítulo describe brevemente la biografía de Chojun Miyagi. El cuarto capítulo comenta la actitud ante el aprendizaje de artes marciales. Los dos siguientes capítulos reflexionan sobre la igualdad y las ilusiones en el entrenamiento. El séptimo capítulo analiza la complacencia. El octavo capítulo expone el entrenamiento de Miyagi. Los siguientes seis capítulos analizan la actitud ante el combate, el objetivo de las artes marciales, sus métodos de aprendizaje y su cortesía. El decimoquinto capítulo expone los principios rectores del kárate mientras que el siguiente narra la biografía de Funakoshi. El decimoséptimo capítulo explica el entrenamiento mental de las artes marciales. Los dos siguientes capítulos presentan a Tsuji Gettan y Nishimura Mitsuya. El vigésimo capítulo analiza los principios de la progresión en el aprendizaje de artes marciales. Los dos últimos capítulos relatan las historias del maestro de lanza y el arquero, y el contador de historias y el maestro de espada.

1331. Labodía Doce, Miguel y Labodía Doce, David (2009). Oda Nobunaga: campaña de Nagashima. Barcelona: Alas. 1aㅡ ed. 79 p. : il. ; 14x21 cm. ISBN: 978-84-203-0457-1. Depósito legal: B. 28931-2009. Palabras clave: historia, guerra. Resumen: Tratado histórico sobre el asalto a las siete islas. El libro esta compuesto por 3 partes precedidas por una dedicatoria, un prólogo que señala la relevancia de la obra y una introducción que presenta los contenidos de la obra. La primera parte consta de tres capítulos. El primer capítulo narra la toma de decisión de atacar Nagashima por parte de Oda Nobunaga. El segundo capítulo describe el asalto a un waju y la defensa de sus monjes. El tercer capítulo detalla la retirada del ejército, la conquista del monte Hiei y la aniquilación del castillo de los monto. La segunda parte consta de 3 capítulos. El primer capítulo comenta la preparación del asalto al castillo de Nagashima mientras que el segundo relata el desarrollo de dicho asalto y su retirada final. El tercer capítulo comenta el regreso al castillo de Gifu y la llegada del pirata Kuki para hablar con Nobunaga. La tercera parte consta de 3 capítulos. El primer capítulo expone la lucha de los piratas con los barcos de suministro de los monjes y la destrucción de los islotes y waju más exteriores. El segundo capítulo narra la construcción de una empalizada alrededor del castillo de Nagashima tras la rendición de los monjes. El último capítulo describe la destrucción del castillo. Adjunta un epílogo comentando la muerte de Nobunaga.

1332. Lee, San (1998). Grandes mitos de las artes marciales. Arganda del Rey: Edimat. 1aㅡ ed. 188 p. : il. ; $13 \times 21$ cm. ISBN: 84-8403-087-3. Depósito legal: M. 16373-1998. Palabras clave: biografía, cine, actores, maestros. Resumen: Compendio biográfico de distintos artistas marciales. El libro esta formado por 28 capítulos precedidos por un comentario sobre el papel de los ídolos. Los siguientes capítulos comentan la biografía, actividad profesional, aportaciones al mundo de las artes marciales y fragmentos de entrevistas realizadas a Anton Geesink, Arnold Schwrzenegger, Benny Urquídez, Bill Wallace, Bruce Lee, Brandon Lee, Chuck Norris, Dan Inosato, David Carradine, Dominique Valera, Ed Parker, Jackie Chan, Jay T. Will, Joe Lewis, Leung Ting, Mas Oyama, Michel Coquet, Morihei Ueshiba, Nakayama, Ralph Macchio, Roger Paschi, Silvester Stallone, Stephen Hayes, Yamaguchi, Yasuhiro Yamashita, Jean Claude Van Damme y Steven Seagal incluyendo numerosas fotografías. Adjunta bibliografía.

1333. Louis, Thomas y Ito, Tommy (2008). Samurái : el código del guerrero. Madrid: Paraninfo Cengage Learning. $1^{\mathrm{a}}$ ed. 205 p. : il. ; 16x24 cm. ISBN: 978-84-283-2961-3. Depósito legal: no. Palabras clave: historia, entrenamiento, biografía, guerra, vestimenta, relatos, bushido, cultura, maestros, samurái, sistemas de entrenamiento, armas, seppuku. Resumen: Tratado teórico sobre el samurái. La obra esta dividida en 5 capítulos precedidos por una introducción que comenta de forma breve el contenido del libro, y una tabla cronológica de los sucesos históricos más importantes de Japón. El primer capítulo describe el origen, evolución histórica a través de las guerras y declive de los samuráis, además de incluir la biografía de Akamatsu Mitsusuke y Anayama Beisetsu. El segundo capítulo detalla cómo trascurría la vida diaria de los samuráis, cómo era el entrenamiento, dónde vivían, sus costumbres alimentarias y de ocio, su código de comportamiento (bushido), sus creencias religiosas, sus formas de seppuku, y presenta las historias de suicidio colectivo de Kamakura y de los 47 ronin, y las biografías de Ashikaga Takauji y Baba Nobufasa. El tercer capítulo describe e ilustra los diferentes tipos de armaduras y accesorios que portaban los samuráis, cómo se colocaban, y presenta las biografías de Hattori Hanzo y Hojo Soun. El cuarto capítulo explica las diferentes armas que fue utilizando el samurái durante su historia junto con su utilización y características físicas, e incluye las biografías de Imagawa Yoshimoto y Miyamoto Musashi. El último capítulo describe la preparación del samurái para el combate, explica el desarrollo técnico, táctico y logístico de una guerra, y presenta las biografías de Kusunoki Masashige y Minamoto Yoshitsune. Adjunta un epílogo, que comenta el final de los samuráis, un glosario y láminas en color. 
1334. Lynn Peterson, Susan (2004). Leyendas de los maestros de artes marciales : veinte apasionantes historias acerca de grandes héroes. Madrid: Tutor. 1aㅡ ed. 123 p. : il. ; 13x20 cm. ISBN: 84-7902-480-1. Depósito legal: M: 42698-2004. Palabras clave: relatos, maestros. Resumen: Compendio de 20 relatos sobre los grandes maestros de las artes marciales. Relata historias sobre Sokon Matsumura, Onami (luchador de sumo), Robert Trias, la leyenda de los tres hijos, Tsukahara Bokuden, Yasutsune "Anko" Itosu, la balada de Mu-lan, Nai Khanom Tom, Wing Chun, Tamo (Bodhidharma), Miyamoto Musashi, Hisamori Takenouchi, Gichin Funakoshi, Morihei Ueshiba, Masutatsu Oyama, Chatan Yara, un maestro de té, Gogen Yamaguchi, el taekyon, un maestro de kyudo, y 50000 paradas ascendentes.

1335. Maestro Gali (1980). Pedazos de ti mismo. Barcelona: Editorial Tr3s. 1ae ed. 185 p. : il. ; 20x27,5 cm. ISBN: 84-300-2361-5. Depósito legal: B. 11421-1980. Palabras clave: fundamentos teóricos, biomecánica, kyusho, física, legislación, lesiones. Resumen: Manual teórico de artes marciales. La obra expone brevemente los puntos vitales del cuerpo humano así como su ataque, la estructura ósea del puño y la forma correcta de golpeo, detalla los delitos contra la vida humana, los delitos contra la salud y la integridad personal, y las faltas contra las personas, describe la mecánica de las articulaciones, la estructura de los ligamentos, su distensión y tratamiento, explica los principios físicos aplicables a las artes marciales como el centro de gravedad, la inercia y el equilibrio, y explica las contusiones, heridas, hemorragias, luxaciones y fracturas junto con sus causas. El texto esta intercalado con aforismos sobre el combate, el guerrero, el dojo, la práctica marcial y numerosas fotografías.

1336. Manzano, Irune (2007). De Okinawa al corazón. Logroño: Tomari. 1a ed. 102 p. : il. ; 14x20,5 cm. ISBN: 978-84-935563-3-4. Depósito legal: no. Palabras clave: principios filosóficos, kárate, aplicación social. Resumen: Tratado filosófico de kárate. El libro esta formado por 20 capítulos precedidos por los reconocimientos, un prólogo que comenta las características de la obra, una introducción que comenta la historia del karate y la importancia de los principios de Funakoshi para la vida diaria, y la enumeración de los principios filosóficos de Funakoshi. Los siguientes 20 capítulos citan los principios rectores del kárate expuestos por Funakoshi y comentan su aplicación a la vida diaria.

1337. Martín García, José (1978). Manos desnudas : iniciación a las artes marciales. Madrid: Doble-R. 1a ed. 96 p. : il. ; 14x20,5 cm. ISBN: 84-85362-09-8. Depósito legal: M. 40163-1978. Palabras clave: historia, fundamentos teóricos, judo, kárate, taekwondo, wushu, artes marciales. Resumen: Manual teórico y técnico de artes marciales. El libro esta compuesto por 12 capítulos. El primer capítulo define el termino "artes marciales". El segundo capítulo relata la historia del kung-fu y sus escuelas. El tercer capítulo describe las técnicas básicas del kung-fu incluyendo algunas ilustraciones. Los tres siguientes capítulos narran la historia del jujutsu, la creación del judo y presentan los términos específicos básicos del judo además del significado de sus contenidos técnicos. El séptimo capítulo detalla la historia del kárate, la biografía de Gichin Funakoshi y la creación de la Asociación Japonesa de Kárate. El siguiente capítulo incluye el significado de los fundamentos técnicos y aspectos formales básicos del kárate además varias fotografías. El noveno capítulo describe el descubrimiento del taekwondo, explica en qué consiste su práctica y la aportación de algunos maestros a este arte. El décimo capítulo incluye el significado de los fundamentos técnicos del taekwondo junto con las fotografías de las distintas partes del cuerpo con las que golpear y la localización de los puntos vulnerables del cuerpo humano. El siguiente capítulo resalta la importancia de la correcta respiración en las artes marciales; para finalizar con la ilustración de varias técnicas de combate de kárate. Adjunta un epílogo que destaca el objetivo principal del libro.

1338. Mendoza Álvarez, J. David (2008). Historia y filosofía orientales a través de las artes marciales : Nihón Tai-Jitsu. Sevilla: Ituci Siglo XXI. 1ae ed. 346 p. : il. ; 15x20,5 cm. ISBN: 978-84-935006-7-2. Depósito legal: SE. 6982-2008. Palabras clave: historia, fundamentos técnicos, programa técnico, pedagogía, filosofía, defensa personal policial, primeros auxilios, nutrición, armas. Resumen: El primer capítulo presenta una tabla cronológica de la historia japonesa, occidental y china. El segundo capítulo describe los fundamentos de las artes marciales, como son las características del calentamiento, de los ejercicios isométricos, comenta el papel de la resistencia, la flexibilidad, la fatiga y la elasticidad sobre el entrenamiento, expone el esquema de una clase normal, el significado del cinturón en las artes marciales y sus distintos grados, el significado del dojo y sus normas de conducta, la importancia del kiai y el ki, y describe las guardias, los wazas, las caídas y los katas. El tercer capítulo muestra la evolución técnica del nihon tai-jitsu así como su historia junto con las características e historia del judo, taekwondo, aikido, karate, hapkido, jiu-jitsu, kendo hoyo-jutsu, bujutsu y bugei, kung-fu, kempo, ninjutsu, jeet kune do, full contact, wing-chun, krav maga, defensa personal policial, kempo-contact y fu-shih kempo. El cuarto capítulo algunos conceptos básicos de la pedagogía, las características de las etapas de desarrollo de la inteligencia de Piaget, los juegos aplicados en el nihon tai-jitsu y sus objetivos, los principios pedagógicos para cada etapa evolutiva, enumera los beneficios de las artes marciales y la aplicación de las artes marciales como terapia contra el miedo. El quinto capítulo describe los principios y las técnicas de primeros auxilios así como las características de las heridas, luxaciones y fracturas, esguinces, lumbalgia, ciática, hernia discal, artrosis cervical, hombro o rodilla dañados, artrosis de rodilla o cadera y osteoporosis, localiza los puntos vitales del cuerpo humano y 
comenta las funciones de los músculos y tendones. El sexto capítulo incluye el programa técnico desde cinturón blanco hasta cinturón $6^{0}$ dan del nihón tai-jitsu. El séptimo capítulo explica las características que marcan la personalidad para luego comentar las distintas personalidades existentes en las artes marciales, la aportación de la filosofía a las diferentes artes marciales, los efectos del miedo sobre el organismo y sus diferentes tipos y explica el proceso de aprendizaje. El octavo capítulo expone el pensamiento ideológico del atomismo, los sofistas, Sócrates, Platón, Aristóteles y Freud. El noveno capítulo describe la historia y características de las distintas armas utilizadas en las artes marciales así como en la defensa personal policial y los principios tácticos para su manejo y defensa además de incluir la descripción e ilustración de varias situaciones de defensa personal policial contra un ataque con pistola, un empujón, un golpe, un cuchillo, un palo, así como la descripción de la ejecución de un cacheo, las caídas, las guardias y las defensas básicas. El décimo capítulo presenta algunas recomendaciones alimentarias específicas para el artista marcial. Adjunta un glosario y bibliografía.

1339. Miguel Medrano, José (coord.) (2002). Budismo, monjes, comerciantes, samuráis : 1000 años de estampa japonesa. Madrid: Centro Cultural del Conde Duque. 1르 ed. 223 p. : il. ; 22x27,5 cm. ISBN: 84-88006-87X. Depósito legal: M. 4006-2002. Palabras clave: historia, fundamentos teóricos, fundamentos técnicos, fundamentos filosóficos, pintura. Resumen: Tratado teórico y técnico de ukiyo-e. El libro esta dividido en 6 partes precedidas por una introducción que comenta las características y relevancia de la exposición presentada. La primera parte narra la historia de los grabados budistas y el ukiyo-e. La segunda parte describe la evolución del pensamiento japonés desde la era Heian hasta la era Edo. La tercera parte explica el desarrollo del grabado budista desde la época Nara hasta la era Edo. La cuarta parte analiza los orígenes del ukiyo-e, sus fundadores y su desarrollo en Edo, Kamigata y otras escuelas. La quinta parte describe los fundamentos teóricos de la técnica de grabado en madera tradicional japonés e incluye un glosario de términos específicos. La última parte presenta las imágenes religiosas, ukiyo-e y libros ilustrados que componen la exposición acompañados de un breve comentario sobre sus características y datos catalográficos.

1340. Mishima, Yukio (2001). Lecciones espirituales para los jóvenes samuráis y otros ensayos. Madrid: La esfera de los libros. 1a ed. 253 p. ; 21x14,5 cm. ISBN: 84-9734-005-1. Depósito legal: M. 35638-2001. (2aㅡ ed., 2001; 3aㅡ ed., 2002; 4aㅡ ed., 2006, ISBN: 84-935003-6-4). Palabras clave: filosofía. Resumen: Ensayo filosófico sobre la sociedad japonesa. La obra esta compuesta por 5 libros, precedidas por una introducción que comenta la vida y obra del autor. El primer libro, titulado "Lecciones espirituales para los jóvenes samuráis", reflexiona sobre los valores que el autor considera fundamentales para la juventud japonesa y que se han perdido, como la vida, el arte, la política, la valentía, la etiqueta, el cuerpo, el mantenimiento de la palabra dada, el placer, el pudor, la urbanidad, la vestimenta, el respeto por los ancianos, los intelectuales afeminados y el esfuerzo. El segundo libro, titulado "La sociedad de los escudos", comenta los orígenes, organización, objetivos y entrenamiento de la sociedad creada por el autor. El tercer libro, titulado "Introducción a la filosofía de la acción", explica el significado, características y aplicación de la acción en la vida. En el cuarto libro, titulado "Mis últimos veinticinco años", el autor hace una autovaloración de su labor literaria. El último libro, titulado "Proclama del 25 de Noviembre", expone el texto que desplegó el autor antes de su suicidio en el que insta a la sociedad japonesa a que se oponga a la Constitución y el levantamiento del ejército japonés.

1341. Morgan, Forrest E. (2004). Vivir a lo marcial : manual sobre cómo debería pensar el guerrero moderno. Barcelona: Obelisco. $1 \underline{\text { a }}$ ed. 346 p. : il. ; 15x23,5 cm. ISBN: 84-9777-048-X. Depósito legal: B. 212712004. Palabras clave: fundamentos teóricos, pedagogía, principios teóricos, entrenamiento, fundamentos filosóficos, ética, preparación física. Resumen: Tratado teórico de artes marciales. El libro esta formado por 3 partes precedidas por los agradecimientos, un prólogo que comenta la labor profesional del autor y una introducción que comenta el origen de las artes marciales, la diferencia entre arte y camino marcial, los beneficios de los caminos marciales y comenta los contenidos y objetivos de la obra. La primera parte consta de 5 capítulos. El primer capítulo analiza las motivaciones internas y externas de los practicantes de artes marciales. El segundo capítulo expone las variables a tener en cuenta para escoger un arte marcial y señala la forma de progresar en el entrenamiento. El tercer capítulo señala los principios de progresión en el entrenamiento y el aprendizaje de las artes marciales. El cuarto capítulo expone los principios estratégicos y tácticos ante un combate. El quinto capítulo define los conceptos de kiai, aiki, kokoro, haragei, kokyu chikara, kime, kata, mushin y zanshin así como su aplicación en la práctica de artes marciales. La segunda parte consta de 3 capítulos. El primer capítulo expone el código ético del artista marcial. El segundo capítulo explica la aplicación del honor en la vida cotidiana a través de la veracidad, cortesía, moderación, lealtad y servicio. El tercer capítulo narra la historia de los 47 ronin, analiza la venganza y el suicidio, y enumera las normas para planificar la venganza y el suicidio. La tercera parte consta de 4 capítulos. El primer capítulo enumera las cualidades físicas de un guerrero, los tipos anatómicos y proponer diferentes entrenamientos para la fuerza, capacidad aeróbica y flexibilidad, y ofrecer algunos consejos nutricionales. El segundo capítulo detalla los fundamentos filosóficos de las artes marciales. El tercer capítulo analiza las variables de la dignidad del guerrero y explica su significado. El último capítulo describe los principios 
para alcanzar la maestría marcial. Adjunta dos apéndices con un glosario de términos específicos y bibliografía.

1342. Moronta Peña, David (2007). Unión de las budo : 1906-2006. Madrid: Vision Libros. 1a ed. 101 p. : il. ; 14x21 cm. ISBN: 978-84-9821-712-4. Depósito legal: M. 27533-2007. Palabras clave: artes marciales, eventos. Resumen: Tratado histórico de artes marciales. El libro esta formado por 5 capítulos precedidos por los agradecimientos, una introducción que comenta las características generales de la reunión de maestros de 1906, y un prólogo que expone los objetivos de la obra. El primer capítulo explica las características generales, objetivos y contenidos técnicos de las artes marciales presentadas durante la celebración de "Unión de las budo 2006" como el judo educativo, tai jitsu, ju jitsu, ju jutsu budo goshin jutsu ryu, karate do, jiu jitsu ne fuseng ryu, kansen ryu, butoku-dojo, judo, kenpo jitsu y judo, e incluyendo fotografías de sus exhibiciones. El segundo capítulo incluye los documentos de presentación e inscripción al evento. El tercer capítulo presenta varias fotografías sobre el evento. El cuarto capítulo enumera los participantes en la exhibición. El último capítulo incluye el discurso de clausura. Adjunta bibliografía.

1343. Musashi, Miyamoto (2008). Dokkodo : el camino de la marcha solitaria. Barcelona: Shinden. $1^{\mathrm{a}}$ ed. $21 \mathrm{p}$. ; 13x19,5 cm. ISBN: 978-84-96894-12-9. Depósito legal: B. 32850-2008. Palabras clave: principios filosóficos, filosofía, aforismos, samurái. Resumen: Tratado filosófico sobre el combate. La obra esta compuesta de 2 partes, precedidas por una introducción que explica la autoría del texto incluido. La primera parte relata la vida de Miyamoto Musashi, su infancia, sus familiares, sus combates, su retiro y sus obras. La segunda parte incluye el texto original japonés y la traducción de los 21 preceptos sobre el camino del guerrero que componen el dokkodo.

1344. Nagashima, Sato (seud. de Nalda Albiac, José Santos) (2009). Vencer sin combatir : la vida, lugar de entrenamiento. Barcelona: Alas. 1aㅡ ed. 239 p. : il. ; 17x23,5 cm. ISBN: 978-84-203-0454-0. Depósito legal: B. 23996-2009. Palabras clave: fundamentos teóricos, táctica, principios técnicos, filosofía, aplicación social. Resumen: Tratado teórico y filosófico de artes marciales. La obra esta dividida en 36 lecciones que explican los fundamentos teóricos y filosóficos de las artes marciales para después aplicarlos a la vida cotidiana. Las tres primeras lecciones explican el significado de rei shiki (arte de saludar); las posiciones de kamae, shisei (actitud mental y anímica) y mu kamae; y el concepto de ma ai (distancia) junto con las variables que influyen en la gestión del espacio y el tiempo; además de su aplicación y utilidad en la vida diaria. El siguiente capítulo es un anexo que comenta los beneficios de la práctica del kárate. El cuarto capítulo presenta algunos conceptos básicos sobre la respiración en el ser humano para luego explicar la relación existente entre la respiración y la mente, la sincronización con el movimiento, los tipos de respiración y cómo se ejecutan. El quinto capítulo expone los principios de omote, ura-irimi y tenkan dentro de las artes marciales y cómo pueden aplicarse en la resolución de los problemas cotidianos. La sexta lección define los atemi waza y sus distintos objetivos, comenta su utilización como protección y explica en qué consiste el kiai y cómo puede utilizarse. La siguiente lección comenta el significado del ukemi waza y sus características para después explicar cómo afrontar un problema. Las dos siguientes lecciones describen los principios de tai sabaki y kuzushi dentro de las artes marciales además de exponer algunos ejemplos de sus formas de aplicación. La décima lección describe el origen del tao, de la teoría del yin/yang, sus principios y aplicación en las artes marciales así como fuera de ellas. Las tres lecciones siguientes profundizan en los principios tácticos de las artes marciales como son de ai (momento oportuno), la no-resistencia y el sen-no-sen, sus diferentes formas y cómo pueden ser aplicados. La decimocuarta lección comenta la importancia de la mirada o metsuke waza en las artes marciales para enfrentarse a un adversario y cómo aprovechar su entrenamiento en la vida cotidiana. El siguiente capítulo es un anexo que describe las actitudes y valores que transmite el entrenamiento en las artes marciales. Las dos siguientes lecciones exponen y comentan el significado de los aforismos Icho go-Ichi e (un encuentro, una oportunidad) y carpe diem como moduladores de nuestra actitud marcial y ante la vida. La lección decimoséptima define los términos atención, concentración y zanshin para luego describir la consciencia sensorial y cómo entrenarla. Los siguientes cuatro capítulos definen y aplican los términos zanshin, hen-ho (adaptabilidad permanente), seiryoku zenkyo (mínimo esfuerzo, máximo rendimiento) y hara a las artes marciales y vida cotidiana. Los siguientes capítulos profundización en la forma de crear una oportunidad ante un adversario o en el día a día, el origen y sentido del principio wu-wei, los conceptos de mujushin (mente espejo), mushin (mente vacía) y fudoshin; y los términos de agresividad, miedo, conflicto y no-violencia junto con su origen, tipos y forma de superarlos. El siguiente capítulo es un anexo que relaciona la obra del autor con el pensamiento de varios filósofos. Los dos siguientes capítulos comentan el significado del perdón y sus características además de la interpretación del sufrimiento desde distintas religiones. El siguiente capítulo es un anexo que narra la aportación del budo en la superación de una enfermedad. Los últimos tres capítulos definen la meditación y en qué consiste su práctica, sus formas y efectos; la actitud de no-apego y el principio de jita kyoei (ayuda y prosperidad mutua). Finaliza con tres apéndices que comentan los valores educacionales del budo, los 
principios del código de honor del samurái (bushido) y la utilidad de las artes marciales en la vida diaria.

1345. Nalda Albiac, José Santos (1985). Los secretos del budo. Barcelona: Alas. 1ae ed. 128 p. : il. ; 15x21,5 cm. ISBN: 84-203-0181-7. Depósito legal: B. 23498-1985. Palabras clave: fundamentos teóricos, fundamentos técnicos, principios técnicos, ejercicios, combate, entrenamiento, estrategia. Resumen: Tratado teórico de artes marciales. El libro esta dividido en tres partes precedidas por una presentación que comenta las características de la obra y un prólogo que explica en qué consisten los secretos de las artes marciales y un resumen de los contenidos. La primera parte consta de 14 capítulos. Los dos primeros capítulos definen los conceptos de bushido y budo. El tercer capítulo explica en qué consiste conocerse a uno mismo, la naturaleza del hombre y define los conceptos relacionados con el cuerpo, la mente y el espíritu, además de incluir la descripción e ilustración de diversos ejercicios para adiestrar el cuerpo, la mente y el espíritu. Los tres siguientes capítulos definen la confianza en uno mismo, la intuición y la voluntad y algunas formas y principios para desarrollarlas. Los dos siguientes capítulos detallan los tipos y cambios fisiológicos de las emociones y el miedo. El noveno capítulo expone la actitud de no-violencia. El décimo capítulo comenta las características de la autosugestión, sus tipos y su forma de actuar. El siguiente capítulo enumera los principios de la coordinación cuerpo-espíritu. El decimosegundo capítulo detalla la repercusión de la coordinación cuerpo-mente en el entrenamiento del budoka. Los dos últimos capítulos explican el significado de la actitud "mushin no kyo", el ki y el kiai además de detallar su aplicación en las artes marciales. La segunda parte consta de 11 capítulos. El primer capítulo explica el proceso de percepción, toma de decisión y reacción junto con la descripción e ilustración de varios ejercicios de velocidad de reacción. El segundo capítulo enumera los fundamentos y principios técnicos de la actitud de flexibilidad y noresistencia en las artes marciales incluyendo la descripción e ilustración de varios ejercicios para su desarrollo. El tercer capítulo detalla la disposición psíquica ante una competición. El cuarto capítulo describe la ejecución de las caídas junto con su representación gráfica. El quinto capítulo presenta los fundamentos teóricos y técnicos del kuzushi además de las distintas posiciones de los pies. El sexto capítulo expone los principios técnicos de la posición de guardia o kamae. El séptimo capítulo señala la importancia y control de la distancia en las artes marciales. Los dos siguientes capítulos explican la ejecución técnica del shintai y tai-sabaki incluyendo la descripción e ilustración de algunos ejercicios de tai-sabaki. El décimo capítulo analiza las variables de la estrategia de combate incluyendo ejemplos de su aplicación. El último capítulo describe diversos ejercicios de kakari-geiko, randori y jiyu-waza junto con su representación gráfica. La tercera parte consta de 6 capítulos. El primer capítulo expone los fundamentos teóricos de la respiración y sus tipos e incluye la descripción de algunos de sus ejercicios. El segundo capítulo comenta los centros de energía del cuerpo humano. El tercer capítulo explica la importancia del hara en las artes marciales y describe el ejercicio de kikai-tanden. El cuarto capítulo expone los principios del entrenamiento, define las cualidades físicas y propone ejercicios para su desarrollo. El quinto capítulo explica los principios técnicos de los atemis. El último capítulo detalla en qué consiste el kuatsu y su forma de aplicación ante síncopes.

1346. Nalda Albiac, José Santos (1987). Budo : formación superior. Barcelona: Alas. 1a ed. 159 p. : il. ; 15x21,5 cm. ISBN: 84-203-0213-9. Depósito legal: B. 41366-1987. Palabras clave: fundamentos teóricos, táctica, entrenamiento, pedagogía, principios técnicos, principios éticos, didáctica, ejercicios, biomecánica, calentamiento, estrategia, vestimenta, cortesía, zen, psicología evolutiva, exámenes, instalaciones, medicina, tests, planificación del entrenamiento, sistemas de entrenamiento. Resumen: Tratado teórico de artes marciales. El libro esta formado por 30 capítulos precedidos por una presentación del libro y un prólogo que narra el origen del bujutsu. Los dos primeros capítulos definen los conceptos de pedagogía, didáctica y metodología y comentan las características de los distintos métodos de enseñanza en las artes marciales. El tercer capítulo expone los elementos de un programa de enseñanza mientras que el cuarto detalla el desarrollo de una lección y comenta sus condicionantes. El quinto capítulo analiza el interés y la atención durante las clases de artes marciales. El sexto capítulo define la sociometría y sus características. El séptimo capítulo profundiza en los requisitos y cualidades del profesor. El octavo capítulo presenta las características de un examen, detalla su duración para cada grado y enumera las cualidades que debe evaluar el examinador. El noveno capítulo expone las características físicas, psíquicas, éticas, necesidades, lesiones más frecuentes y pedagogía para los niños de 6 a 9 años, de 9 a 12 años, de 13 a 15 años, así como las características especiales de las mujeres y de las personas de más de 40 años. Los dos siguientes capítulos definen las generalidades del examen médico antes de la práctica de actividad física, enumeran las contraindicaciones para su práctica y describen diversos tests para evaluar su condición física. El decimosegundo capítulo expone los principios del calentamiento, propone una tabla de ejercicios y representa gráficamente varios de ellos. El capítulo decimotercero describe e ilustra varios ejercicios de respiración y de coordinación cuerpo-mente previos al entrenamiento. El siguiente capítulo describe el desarrollo de una sesión de entrenamiento y estudiar los automatismos de base y la fatiga muscular. El decimoquinto capítulo presenta el método de control del esfuerzo a través de las pulsaciones mientras que el siguiente señala 
importancia de una vuelta a la calma activa. El décimo séptimo capítulo presenta la fisiología del sistema respiratorio, señala su aplicación en distintas artes marciales y describe varios ejercicios de aplicación. El decimoctavo capítulo profundiza en los movimientos voluntarios e involuntarios, explica la ley del hábito y expone algunos de sus principios en el entrenamiento. El decimonoveno capítulo enumera los tipos de reacciones ante el ataque, los estados del espíritu y las tres distancias en el combate. El vigésimo capítulo describe los papeles de tori y uke en el proceso de aprendizaje mientras que el siguiente capítulo explica los principios técnicos de las artes marciales, las fases en la ejecución de una técnica y las leyes físicas aplicables a las artes marciales. El vigésimo segundo capítulo expone la teoría del yin/yang junto con algunos de sus ejercicios. El vigésimo tercer capítulo define el concepto de tai sabaki y presenta varios ejercicios para su desarrollo junto con su representación gráfica y esquemas de movimiento. El vigésimo cuarto capítulo comenta las características y desarrollo de los diferentes sistemas de entrenamiento. El vigésimo quinto capítulo enumera los principios tácticos del combate, analiza el timing y ofrece algunos consejos tácticos y la actitud mental para el desarrollo de un combate. Los dos siguientes capítulos detallan el significado, estructura y organización del dojo junto con sus reglas de cortesía y etiqueta. El vigésimo octavo capítulo explica el significado del cinturón negro, el desarrollo de su examen y la ceremonia de entrega. El siguiente capítulo analiza brevemente la relación entre el zen y las artes marciales mientras que el último capítulo enumera los principios éticos del kárate, judo y aikido junto con los kanjis de algunas artes marciales, los números y el alfabeto silábico katakana.

1347. Nalda Albiac, José Santos (1988). ¿Buscas un maestro...? Bilbao: Mensajero. 1aㅡ ed. 173 p. : il.; $15 \times 22$ cm. ISBN: 84-271-1507-5. Depósito legal: BU. 165-1988. Palabras clave: principios filosóficos, filosofía, ejercicios, artes marciales, zen, psicología, bushido, maestros, meditación, respiración. Resumen: Manual teórico del profesor de artes marciales. El libro esta formado por 12 capítulos precedidos por una introducción que comenta los contenidos del libro y un prólogo que expone sus objetivos. El primer capítulo explica el origen y el papel de los maestros en el desarrollo del conocimiento, comenta la biografía de distintos maestros religiosos y de las artes marciales, describe las etapas de superación personal y su aplicación en las artes marciales. El segundo capítulo analiza el aspecto físico del hombre, ofrece algunos consejos sobre nutrición, señala la importancia del hara y la respiración incluyendo la descripción de algunos de sus ejercicios, y explica el funcionamiento del sistema nervioso. El tercer capítulo define los tipos de emociones y sus causas además de presentar algunos consejos para su dominio. El cuarto capítulo señala las funciones de la mente, los grados de conciencia, las características del pensamiento y enumera algunas normas para educar la mente. El quinto capítulo define el concepto de intuición. El sexto capítulo analiza la agresividad y la preocupación, ofrece algunos consejos para controlar la preocupación, el sufrimiento y detalla distintas normas para conseguir la adaptación personal de la psique. El séptimo capítulo explica los aspectos místicos que preocupan al hombre, detalla algunas normas para desarrollar un conjunto de valores, describe varios ejercicios para conocerse a sí mismo y señala el papel de la religión en la vida del hombre. El siguiente capítulo detalla los objetivos pedagógicos del maestro respecto al desarrollo global de sus estudiantes. El noveno capítulo explica el modo de ser del maestro, sus roles y los principios del bushido. El décimo capítulo ofrece algunos consejos sobre los métodos de enseñanza. El décimo primer capítulo detalla la forma de actuar del maestro y las formas de ejercer la autoridad. El décimo segundo capítulo enumera las condiciones y etapas de la vía iniciática además de describir varios ejercicios de meditación.

1348. Nalda Albiac, José Santos (1993). Educación física y artes marciales. Bilbao: Mensajero. 1aㅡ ed. 191 p. : il. ; 15x22 cm. ISBN: 84-271-1822-8. Depósito legal: BU. 7-1993. Palabras clave: entrenamiento, anatomía, fisiología, tests. Resumen: Compendio de introducción al conocimiento del cuerpo humano, su funcionamiento, su entrenamiento, las lesiones y la alimentación. Presenta contenidos básicos, explicados de forma clara y concisa con el apoyo de viñetas, sobre la evaluación física del practicante a través de la batería Eurofit, sobre la anatomía ósea y muscular del cuerpo humano y sobre su sistema cardiorrespiratorio. A continuación describe los principios y estructura del entrenamiento para luego pasar a las cualidades motrices, sus distintas manifestaciones y su importancia en las artes marciales. También explica los fundamentos del calentamiento y propone diferentes calentamientos dependiendo de la época del año o la ayuda de un compañero. El siguiente capítulo trata las lesiones, sus causas y algunas pautas para evitarlas. Continua con recomendaciones para la vuelta a la calma después de la práctica y la programación del entrenamiento, ofreciendo planillas y gráficos para su evaluación y ejecución respectivamente. Los últimos cuatro capítulos tratan brevemente sobre el entrenamiento mental y su puesta en práctica, la sudoración y la importancia de la ingesta de líquidos, y algunas consideraciones mínimas sobre la calorimetría y la alimentación.

1349. Nalda Albiac, José Santos (1998). Artes marciales : escuela de vida. Barcelona: Alas. 1a ed. 142 p. : il. ; 17x24 cm. ISBN: 84-203-0389-5. Depósito legal: B. 18193-1998. Palabras clave: historia, fundamentos teóricos, táctica, principios éticos, biografía, aikido, budo, bujutsu, iaido, judo, jujutsu, kárate, kendo, kyudo, zen, bushido, competición, maestros, respiración, violencia. Resumen: Tratado teórico de artes marciales. La obra esta compuesta por 3 partes precedidas por la presentación de la 
obra y un prólogo que señala sus objetivos. La primera parte consta de 11 capítulos precedidos por la explicación del símbolo sakura. El primer capítulo define el término bujutsu y relata la historia de los samuráis. El segundo capítulo comenta la biografía de Miyamoto Musashi y resume los principios expuestos en su libro "Go rin no sho". El tercer capítulo narra la biografía de Takuan Soho, expone sus enseñanzas y las de su discípulo Munenori. El cuarto capítulo presenta la evolución del bujutsu al budo además de comentar los principios morales del budo. El quinto capítulo relata la historia y principios del kyudo. El sexto capítulo explica el significado del sable para el samurái, las características del kenjutsu, kendo e iaido junto con su historia y principios. El séptimo capítulo presenta la historia del jujutsu y su evolución además de las entrevistas realizadas a José Manual García García y Javier Sanz Martín. El octavo capítulo describe el papel de Jigoro Kano en la creación del judo, expone sus fundamentos teóricos y principios, su situación actual e incluye la entrevista realizada a Julio Giménez Muñoz. El noveno capítulo relata el origen del karatedo, la biografía de Gichin Funakoshi, los contenidos técnicos del kárate y las entrevistas realizadas a Jean Marc Ortega y Armando Arjol. El décimo capítulo detalla las características del aikido, resume la biografía de Morihei Ueshiba, describe su evolución y sus distintas escuelas e incluye las entrevistas realizadas a Michel Hamon y Walter Vergallo. El décimo primer capítulo analiza la preparación y estrategias para la competición de artes marciales. La segunda parte consta de 4 capítulos. El primer capítulo narra el origen del zen y estudia la relación entre el zen y las artes marciales. El segundo capítulo expone los principios estratégicos del zen aplicados a las artes marciales. El tercer capítulo ofrece algunos consejos prácticos del zen para el progreso en el entrenamiento de artes marciales. El cuarto capítulo explica la fisiología de la respiración, su relación con el ejercicio y las artes marciales, y describe algunas técnicas de respiración para distintas situaciones. La tercera parte consta de 5 capítulos. El primer capítulo define el término bushido y su formación. El segundo capítulo expone y comenta los preceptos del bushido. El tercer capítulo enumera los principios del fair play, su aplicación a las artes marciales y las normas de fair play del judo, kárate y aikido. El cuarto capítulo detalla las cualidades de un buen profesor y describe su autoevaluación. El quinto capítulo analiza la violencia en la sociedad actual y la actitud del budoka ante el conflicto.

1350. Nalda Albiac, José Santos (2001). El ki en las artes marciales. Barcelona: Alas. 1ae ed. 222 p. : il. ; 17x24 cm. ISBN: 84-203-0408-5. Depósito legal: B. 28504-2001. (2 $2^{\mathrm{a}}$ ed., 2009, ISBN: 978-84-203-0408-3). Palabras clave: fundamentos teóricos, principios técnicos, aikido, iaido, judo, jujutsu, kárate, kendo, taijiquan, bioenergética, respiración, física. Resumen: Manual teórico y técnico de ki aplicado a las artes marciales. La obra esta compuesta por 26 capítulos. El primer capítulo explica desde el punto de vista de la física el concepto de energía para luego exponer las distintas concepciones dadas al ki y su interpretación china. Los siguientes tres capítulos presentan la historia de Japón y sus guerreros, la búsqueda del ki por parte de los samuráis y los monjes guerreros y la aplicación del ki en el tiro con arco. Los siguientes 15 capítulos detallan la aplicación y entrenamiento del ki en el kenjutsu, el iaido y kendo, el jujutsu, el judo, el jiujitsu, el karate, en el grito propio de las artes marciales, el aikido, y el tai chi chuan, además de describir la historia y fundamentos de estas prácticas. El vigésimo-primer capítulo detalla el funcionamiento del sistema respiratorio, las diferentes formas y tipos de respiración, y su influencia sobre el ki. El siguiente capítulo explica los fundamentos de la bioenergética y comenta su aplicación en la vida cotidiana. Los últimos capítulos detallan la relación entre fuerza muscular y ki, describen el papel e importancia del hara en las artes marciales, y presentan los contenidos técnicos y desarrollo de las sesiones de un posible cursillo de ki aplicado al judo, al kárate y al aikido, y cuál es el papel del ki sobre la mente y el espíritu.

1351. Nalda Albiac, José Santos (2005). Wa-shin-tai : armonía-cuerpo-mente. Barcelona: Alas. 1a ed. 238 p. : il. ; 17x24 cm. ISBN: 84-203-0434-4. Depósito legal: B. 35115-2005. Palabras clave: fundamentos teóricos, principios técnicos, ejercicios, aikido, judo, kárate, yoga, meditación, personalidad. Resumen: Tratado teórico de artes marciales. El libro esta formado por 26 capítulos. El primer capítulo explica el significado del término armonía en las distintas civilizaciones y su relación con el budo. El segundo capítulo expone las teorías sobre la realidad psicosomática. El tercer capítulo expone la visión occidental y oriental del cuerpo y sus divisiones. El cuarto capítulo comenta las características de la postura, el tono muscular y la relajación. El quinto capítulo define el término de conciencia sensorial, describe cómo ejercitarla y el significado del lenguaje corporal. El sexto capítulo comenta los tipos de respiración. El séptimo capítulo expone las generalidades de la flexibilidad además de describir e ilustrar algunos de sus ejercicios. El octavo capítulo enumera los factores que intervienen en la coordinación. El noveno capítulo analiza la armonía en los movimientos de las artes marciales y su aplicación práctica. Los siguientes cuatro capítulos exponen los requisitos previos para la práctica de los ejercicios de judo taiso, karate taiso, aiki taiso y yoga taiso junto con su descripción e ilustración. El decimocuarto capítulo comenta las características del tai chi, sus estilos, sus fundamentos teóricos y su práctica. Los dos siguientes capítulos analizan la relación del judo, el kárate y el aikido con la armonía. El decimoséptimo capítulo expone las características y beneficios derivados del zen. El decimoctavo capítulo expone las relaciones de armonía entre uke y tori. El siguiente capítulo presenta las ciencias 
que estudian la relación entre la psique y el cuerpo y ofrece algunos consejos para mantener la armonía de la mente. El vigésimo capítulo explica el funcionamiento de la mente. El siguiente capítulo detalla el proceso de meditación, sus objetivos, sus formas y efectos, sus requisitos y sus tipos. El vigésimo segundo capítulo analiza los tipos de emociones, su relación con el comportamiento y el mecanismo del control emocional. Los dos siguientes capítulos señalan algunas actitudes convenientes para alcanzar la armonía personal e interpersonal. El vigésimo quinto capítulo define la serenidad y cómo adquirirla. El último capítulo analiza la armonía religiosa del individuo.

1352. Norris, Chuck (1998). Soluciones zen a los problemas cotidianos. Barcelona: Obelisco. $1 \underline{\text { a }}$ ed. 196 p. : il. ; 13x21 cm. ISBN: 84-7720-672-4. Depósito legal: B. 46455-1998. Palabras clave: biografía, actores, filosofía. Resumen: Biografía de Chuck Norris. El libro consta de 30 capítulos precedidos por un prefacio que detalla la introducción del autor en el zen. La obra presentan la biografía de Chuck Norris y sus reflexiones, experiencias y aprendizajes derivados del zen. Adjunta la biografía de Wieland Norris y el currículo deportivo y filmografía del autor.

1353. Nukariya, Kaiten (2005). La religión de los samurái. Barcelona: Paidós Ibérica. 1ae ed. 301 p. ; 15x22 cm. ISBN: 84-493-1715-0. Depósito legal: B. 9328-2005. Palabras clave: historia, filosofía, escuelas, zen, meditación, religión. Resumen: Tratado teórico sobre el zen. El libro esta formado por 8 capítulos. Los dos primeros capítulos narran el origen del zen en la India, la introducción del zen en China por parte de Bodhidharma y sus sucesores, la introducción del zen en Japón y sus diferentes escuelas, la relación del zen con los monjes y los samuráis, y su evolución histórica. El tercer capítulo comenta las características de las escrituras del zen y sus contenidos. El siguiente capítulo explica la interpretación dada por el zen a Buda, la vida, el cambio y la vida universal. El quinto capítulo analiza las interpretaciones hechas sobre la naturaleza del ser humano y su moralidad por parte de Mencio, Siun Tzu, Yan Hiung, Su Shih, además de incluir algunas parábolas. El sexto capítulo estudia la iluminación a través de sus características y contenidos. El séptimo capítulo comenta la visión zen de la vida para finalizar con la descripción del entrenamiento de la mente y la práctica de la meditación, sus fases y sus principios técnicos. Adjunta la obra "El origen del hombre" de Tsung Mi sobre la interpretación del origen de la vida y del universo desde el taoísmo, confucianismo, hinayanismo y mahayanismo.

1354. Pagès Guix, Joan (2009). Les arts marcials a la Garrotxa. s.l.: J. Pagès. 1aㅡ ed. 120 p. : il. ; $16 \times 23$ cm. ISBN: No ISBN. Depósito legal: GI. 1165-2009. Palabras clave: historia, artes marciales, maestros. Resumen: Tratado histórico de artes marciales. El libro esta formado por 17 capítulos precedidos por una introducción que comenta las características de las artes marciales y el currículo del autor. El primer capítulo define el concepto de arte marcial mientras que el segundo capítulo explica los términos de agresividad y violencia. El tercer capítulo analiza la justificación de ciertos actos violentos. El cuarto capítulo comenta la igualdad de género en las artes marciales. El quinto capítulo incluye la opinión personal del autor sobre el entrenamiento a partir de los cincuenta años. El sexto capítulo narra la historia del primer practicante de artes marciales nacido en la Garrotxa. El séptimo capítulo comenta el significado y características del bushido. El octavo capítulo comenta los principios del entrenamiento de las artes marciales. El noveno capítulo relata la aparición del kárate en Olot. El décimo capítulo expone los fundamentos teóricos de las artes marciales más emblemáticas de la Garrotxa. Los siguientes seis capítulos presentan a los profesores e historia del judo, kárate, taekwondo, jiu-jitsu, kendo e iaido y aikido practicado en la Garrotxa incluyendo numerosas fotografías. El último capítulo incluye un comentario final sobre la situación actual de las artes marciales en la Garrotxa.

1355. Paniagua Tébar, José Luis (1981). Artes marciales : equilibrio cuerpo-mente. Madrid: Miraguano. 1a ed. 185 p. : il. ; 19x25 cm. ISBN: 84-85639-16-2. Depósito legal: M. 8882-1981. (2ª ed., 1987, 175 p.). Palabras clave: historia, entrenamiento, artes marciales, psicología, competición. Resumen: Tratado teórico sobre la aplicación de la psicología dinámica a las artes marciales. El libro esta formado por 27 capítulos precedidos por un prólogo que comenta la formación del autor, un preámbulo que señala los beneficios de las artes marciales, una introducción que expone los contenidos y enfoque de la obra y unas primeras palabras que resumen los objetivos de las artes marciales. Los primeros tres capítulos detallan las relaciones entre las artes marciales, el practicante y la naturaleza, para fundamentar la importancia de la psicología. Continua con 3 capítulos que profundizan en la historia y evolución de las artes marciales. Los siguientes 19 capítulos analizan algunos aspectos de las artes marciales, como la competición, el cuerpo, la respiración, la agresividad, el kiai, la práctica grupal, la relación maestroalumno, sus ritos, su filosofía, su simbología, las katas, el equilibrio psico-somático. Finaliza con dos capítulos dedicados a la relación entre cuerpo, artes marciales y problemas psicológicos, y otro sobre cómo debe ser la enseñanza corporal durante el aprendizaje. Adjunta tres anexos con un resumen general de la obra, un conjunto de fotografías de estiramientos y lecturas recomendadas.

1356. Paniagua Tébar, José Luis (2001). El equilibrio cuerpo mente. Madrid: Librería Argentina. 1ae ed. 257 p. : il. ; 17x24 cm. ISBN: 84-89-836-12-4. Depósito legal: M. 22622-2001. Palabras clave: artes marciales, nutrición, fundamentos teóricos, historia, pedagogía. Resumen: Tratado teórico de artes marciales. El libro esta dividido en cuatro partes precedidas por un prólogo que comenta las características de la especia humana, un preámbulo que detalla la interrelación de las artes marciales con los niveles 
cognitivos, afectivos y corporales, una introducción que señala los principios del equilibrio cuerpomente y unas primeras palabras que explican las funciones de las artes marciales dentro de dicho equilibrio. La primera parte consta de dos capítulos. El primer capítulo analiza la composición de la materia y la energía. El segundo capítulo ofrece algunos consejos sobre la alimentación y la higiene. La segunda parte consta de ocho capítulos. El primer capítulo señala los beneficios del ejercicio corporal, de la dinámica corporal y las áreas del comportamiento humano. El segundo capítulo analiza las diferentes formas de comunicación no verbal. El tercer capítulo señala los beneficios de la respiración mientras que el cuarto analiza la función del grito, sus beneficios y su aplicación en las artes marciales. El quinto capítulo define el concepto de agresividad, sus teorías, sus tipos y características. El sexto capítulo analiza las características del juego, sus beneficios para la dinámica corporal y su relación y aplicación en las artes marciales. El séptimo capítulo expone las exigencias, riesgos y beneficios en el aprendizaje de las actividades mentales, corporales, ociosas y amorosas. El octavo capítulo señala las peculiaridades de las artes marciales respecto a otras formas de arte. La tercera parte consta de once capítulos. El primer capítulo analiza el origen, finalidad y evolución de las artes marciales. El segundo capítulo expone la relación entre el zen y las artes marciales. El tercer capítulo detalla las exigencias en la práctica de las artes marciales. El cuarto capítulo expone los objetivos, contenidos y metodología de las artes marciales para alcanzar el equilibrio cuerpo-mente. El quinto capítulo analiza la relación maestro-alumno. El sexto capítulo detalla las variables del contexto que influyen en el aprendizaje de las artes marciales. El séptimo capítulo explica los distintos ritos y símbolos de las artes marciales además de comentar el significado de las katas. El octavo capítulo detalla las características y objetivos del combate en las artes marciales y sus diferentes tipos. El noveno capítulo comenta la relación entre los conceptos de contenido y forma, y su aplicación en las artes marciales. El décimo capítulo enumera las motivaciones del practicante de artes marciales. El capítulo decimoprimero presenta las características y aplicación del hatha-yoga y la música a las artes marciales. La cuarta parte consta de cuatro capítulos. El primer capítulo define los conceptos de energía, entropía, núcleos básicos de personalidad y sus alteraciones. El segundo capítulo analiza los conflictos en el equilibrio psico-físico expresados a través del cuerpo. El tercer capítulo presenta la metodología de enseñanza corporal en el aprendizaje de artes marciales. El último capítulo resume los objetivos de la obra.

1357. Paniagua Tébar, José Luis (2009). Por el camino del guerrero : la técnica. Energía, actitudes y emociones. Madrid: Librería Argentina. 1a ed. 190 p. : il. ; 17x24 cm. ISBN: 978-84-85895-67-0. Depósito legal: M. 1919-2009. Palabras clave: fundamentos teóricos, fundamentos técnicos, pedagogía, principios técnicos, principios teóricos, entrenamiento. Resumen: El libro esta dividido en 4 partes precedidas por un prólogo que comenta los contenidos de la obra y varios capítulos que reflexionan sobre las artes marciales, su práctica y entrenamiento. La primera parte analiza el equilibrio y sus variables, su aplicación al ser humano y las artes marciales, describe las características de las posiciones de atención y de acción, sus principios técnicos, expone los conceptos fundamentales para practicar las artes marciales como vías de autoconocimiento, propone distintos ejercicios para sensibilizar el hara, comenta las acciones y movimiento de la pelvis incluyendo algunos ejercicios para practicarlos, explica cómo cerrar el puño, el principio de acción-reacción, las formas de golpear y bloquear, los principios técnicos de los ataques de puño y pierna, de los bloqueos, presenta un conjunto de ejercicios para el aprendizaje de los bloqueos, detalla el mecanismo de la respiración y sus funciones, analiza la anatomía y fisiología de la pierna, enumera los principios del entrenamiento para las técnicas de pierna además de describir varios de sus ejercicios y proponer secuencias técnicas para mejorar la técnica elemental. La segunda parte analiza los movimientos circulares de las artes marciales, de los desplazamientos, saltos, barridos y desequilibrios, movimientos simultáneos de brazos y piernas junto con propuestas de entrenamiento para los mismos acompañadas de representaciones gráficas. La tercera parte analiza la ejecución de las katas, los conceptos básicos en el desarrollo de un combate, los principios para el aprendizaje del tai chi chuan, la meditación y su eficacia. La última parte comenta el significado de los exámenes para el practicante, su relación con el aprendizaje emocional y los beneficios de la práctica de las artes marciales para el cuerpo, mente y espíritu. Adjunta varios apéndices que analizan la enseñanza de artes marciales, la transferencia negativa de la terapia psicoanalítica, la relación entre el zen y las artes marciales, la importancia del abdomen en las artes marciales y ofrecen una programación de las clases y el relato del idiota y el camello que pastaba.

1358. Pater, Robert (1990). Las artes marciales y el arte de la dirección. Bilbao: Deusto. $1^{\mathfrak{a}}$ ed. 259 p. : il. ; 15x23 cm. ISBN: 84-234-0919-8. Depósito legal: BI. 2231-1990. Palabras clave: estrategia, artes marciales, gestión empresarial. Resumen: Tratado teórico de artes marciales aplicadas a la dirección de empresas. La obra esta compuesta de 3 partes, formadas por 3 capítulos cada una de ellas en las que se analizan los principios técnicos, tácticos y estratégicos de las artes marciales, su aplicación al mundo empresarial y se exponen casos reales de dicha aplicación. El primer capítulo explica las similitudes y aplicaciones de las artes marciales sobre la dirección de empresas y comenta los principios de aprendizaje para convertirse en un buen directivo incluyendo ejemplos reales de los mismos. El segundo capítulo analiza cómo vencer el miedo, los principios para alcanzar el autocontrol y dominar 
una situación, la actitud ante un enfrentamiento. El tercer capítulo relaciona los principios técnicos y de entrenamiento de las artes marciales con el aumento de la capacidad de trabajo del directivo. El cuarto capítulo explica el significado del do y de la actitud del practicante ante dicho camino para que los directivos no pierdan de vista sus objetivos. El quinto capítulo estudia los principios tácticos del combate para manejar, dirigir y motivar a los empleados. El sexto capítulo analiza las estrategias de combate de diferentes estilos de artes marciales para aplicarlos a la resolución de conflictos empresariales. El séptimo capítulo presenta el principio de adaptabilidad al cambio y cómo aplicarlo dependiendo de los objetivos. El octavo capítulo estudia la planificación de las distintas estrategias en la guerra para su aplicación en la gestión empresarial. El último capítulo analiza cómo dirigir al adversario para dirigir al personal a su cargo. Adjunta un glosario, bibliografía e índice alfabético.

1359. Pater, Robert (1994). Las artes marciales y el arte de la dirección. Madrid: Planeta DeAgostini. 1a ed. 259 p. : il. ; desc.xdesc. cm. ISBN: 84-234-1310-1. Depósito legal: no. Palabras clave: estrategia, artes marciales, gestión empresarial. Resumen: Tratado teórico de artes marciales aplicadas a la dirección de empresas. La obra esta compuesta de 3 partes, formadas por 3 capítulos cada una de ellas en las que se analizan los principios técnicos, tácticos y estratégicos de las artes marciales, su aplicación al mundo empresarial y se exponen casos reales de dicha aplicación. El primer capítulo explica las similitudes y aplicaciones de las artes marciales sobre la dirección de empresas y comenta los principios de aprendizaje para convertirse en un buen directivo incluyendo ejemplos reales de los mismos. El segundo capítulo analiza cómo vencer el miedo, los principios para alcanzar el autocontrol y dominar una situación, la actitud ante un enfrentamiento. El tercer capítulo relaciona los principios técnicos y de entrenamiento de las artes marciales con el aumento de la capacidad de trabajo del directivo. El cuarto capítulo explica el significado del do y de la actitud del practicante ante dicho camino para que los directivos no pierdan de vista sus objetivos. El quinto capítulo estudia los principios tácticos del combate para manejar, dirigir y motivar a los empleados. El sexto capítulo analiza las estrategias de combate de diferentes estilos de artes marciales para aplicarlos a la resolución de conflictos empresariales. El séptimo capítulo presenta el principio de adaptabilidad al cambio y cómo aplicarlo dependiendo de los objetivos. El octavo capítulo estudia la planificación de las distintas estrategias en la guerra para su aplicación en la gestión empresarial. El último capítulo analiza cómo dirigir al adversario para dirigir al personal a su cargo. Adjunta un glosario, bibliografía e índice alfabético.

1360. Payne, Peter (1990). Artes marciales : la dimensión espiritual. Madrid: Debate. $1^{a}$ ed. 96 p. : il. ; 20x27,5 cm. ISBN: 84-7444-391-1. Depósito legal: M. 15320-1990. (2ª ed., 1994). Palabras clave: fundamentos teóricos, filosofía. Resumen: Tratado teórico sobre artes marciales. La obra esta dividida en 3 partes como son la introducción, un conjunto de láminas y un compendio de artículos y comentarios. La introducción explica las distintas clasificaciones que se pueden realizar en las artes marciales, cuáles son los fundamentos técnicos de las mismas, el entrenamiento espiritual y psicológico que impregna a todas ellas, y la relación entre cuerpo, energía, mente y espíritu para alcanzar el desarrollo espiritual. La segunda parte recoge un conjunto de láminas que representan algunas de las ideas que rodean a las artes marciales y sus características. La última parte explica e ilustra algunos de los conceptos generales que presentan las artes marciales y unen al cuerpo, la mente y el espíritu; como son la importancia del enraizamiento en las posiciones, el papel del ki y su movimiento dentro del cuerpo, algunas nociones sobre las técnicas de curación, las armas que se utilizan en las diferentes artes marciales, y ofrece varios ejemplos sobre la espontaneidad y la mente vacía en las artes marciales. Adjunta bibliografía.

1361. Pereda González, Pablo (1999). Tomari-te. Logroño: Tomari. 1a ed. 172 p. ; 14x20,5 cm. ISBN: 978-84937275-4-3. Depósito legal: no. Palabras clave: historia, entrenamiento, kárate, aplicación terapéutica, maestros. Resumen: Tratado teórico de kárate. El libro esta formado por 13 capítulos precedidos por un prólogo que comenta la personalidad del autor y un comentario sobre la práctica actual de las artes marciales y su transmisión de valores. El primer capítulo reflexiona sobre los valores transmitidos en la actualidad por el kárate. El segundo capítulo expone los contactos de los antepasados del autor con la isla de Okinawa. El tercer capítulo narra las estancias del maestro Masashi en España, describe las costumbres orientales, su formación marcial, explica la historia y características del chuan fa, su formación universitaria y sus enseñanzas marciales. El cuarto capítulo comenta las características técnicas del chuan fa del loto blanco, sus efectos terapéuticos y algunas de sus aplicaciones marciales por el autor. El quinto capítulo relata el contacto del autor con el maestro Takuji y la historia del chatan shionja te y takahara to-de. El sexto capítulo comenta el contacto del autor con la familia Higa, la historia y evolución de la escuela tomari-te higa, sus características técnicas y el entrenamiento del autor con la hija de Higa. El séptimo capítulo narra brevemente la historia de Okinawa y Japón, explica el sistema de castas en el kárate y la situación actual de Japón y sus artes marciales. El octavo capítulo presenta los principios del secreto de la invulnerabilidad, comenta las características y significados de la ceremonia del té e incluye la historia de Sen No Rikyu y el armero. El noveno capítulo expone el entrenamiento del autor con Masashi y Takuji, el trabajo de rompimientos y sus precauciones, y la transmisión de las katas por parte de Takuji. El décimo capítulo 
relata los entrenamientos del autor con Takuji, Higa e Ikuko y el fin de su estancia en Burdeos. El capítulo decimoprimero explica las primeras clases de karaterapia impartidas en España, la creación del estilo Garyu ryu, la presentación de la karaterapia en los JJPP, e incluye varios textos para la meditación y reflexión así como las últimas palabras del maestro Higa para el autor. El decimosegundo capítulo expone los distintos cursos realizados por el autor, las características y problemas de los shidis, el poder del kata, y recuerda a sus alumnos más importantes. El último capítulo describe el contacto del autor con el chamanismo y el tai chi además de comentar su relación con los maestros Surace, Francisco Galán y Francisco Royo. Adjunta un epílogo.

1362. Pereda González, Pablo (2008). El kata como conocimiento : estudio antropológico y socio cultural. Sánjing/Zhán-jing : las tres esencias. Logroño: Pablo Pereda González. 1aa ed. 105 p. : il. ; 14x20,5 cm. ISBN: 84-935563-6-X. 978-84-935563-6-5. Depósito legal: no. Palabras clave: katas, historia, fundamentos teóricos, entrenamiento, to-de, aplicación terapéutica. Resumen: Tratado teórico de kárate. El libro esta formado por 13 capítulos precedidos por una introducción que comenta los contenidos de la obra. El primer capítulo explica las características generales de los 8 homúnculos, los objetivos de la práctica de relajación y la descripción del cerebro. El segundo capítulo incluye la narración sobre la kata sanchin de Toyohama. El tercer capítulo comenta las fuentes documentales utilizadas en la obra. El cuarto capítulo explica las prácticas e historia del to-de y okinawa-te. El quinto capítulo comenta la evolución de las katas waishinzan y turuashi. El sexto capítulo expone los problemas derivados de una mala ejecución del kata sán-jing. El séptimo capítulo define las características del kata tántrico. El octavo capítulo describe los entrenamientos del cuerpo energético y espiritual. El noveno capítulo expone las enseñanzas de Higa sobre la última kata. El décimo capítulo comenta el campo de estudio de la phrenosofía y los objetivos de la kata sán-jing. El siguiente capítulo define la energía interna. El decimosegundo capítulo describe la práctica energética del kata sanchin junto con los niveles de consciencia organizados y patológicos. El último capítulo comenta las aplicaciones terapéuticas actuales de la kata sanchin junto con las conclusiones de la obra. Adjunta agradecimientos, bibliografía, el manuscrito con las notas realizadas sobre zan-jing, sus fotos y transcripción, la descripción de la secuencia de ejecución de sanchin y una carta de Vernon Bell.

1363. Pérez Agustí, Adolfo (1986). El libro de oro de los grandes mitos. Madrid: Adolfo Pérez Agustí. 1aㅡ ed. 191 p. : il. ; 15x21 cm. ISBN: 84-398-6161-3. Depósito legal: M. 8895-1986. Palabras clave: biografía, cine, actores, maestros. Resumen: Compendio biográfico de distintos artistas marciales. El libro esta formado por 28 capítulos precedidos por un comentario sobre el papel de los ídolos. Los siguientes capítulos comentan la biografía, actividad profesional, aportaciones al mundo de las artes marciales y fragmentos de entrevistas realizadas a Anton Geesink, Arnold Schwrzenegger, Benny Urquídez, Bill Wallace, Bruce Lee, Chuck Norris, Dan Inosato, David Carradine, Dominique Valera, Ed Parker, Jackie Chan, Jay T. Will, Jim Kelly, Joe Lewis, Leung Ting, Mas Oyama, Michel Coquet, Morihei Ueshiba, Nakayama, Ralph Macchio, Roger Paschi, Silvester Stallone, Stephen Hayes, Yamaguchi y Yamashita incluyendo numerosas fotografías. Adjunta bibliografía.

1364. Pérez Gutiérrez, Mikel y Gutiérrez García, Carlos (2008). 100 años de artes marciales: repertorio bibliográfico de monografías publicadas en España (1906-2006). León: Secretariado de Publicaciones de la Universidad de León. 1aㅡ ed. 110 p. ; 17x23,5 cm. ISBN: 978-84-9773-396-0. Depósito legal: LE. 4302008. Palabras clave: artes marciales, bibliografía. Resumen: Repertorio bibliográfico de los libros de artes marciales asiáticas publicados en España. El libro esta dividido en 16 capítulos que clasifica los libros de artes marciales atendiendo a su lugar de origen y arte marcial así como las ciencias que estudian o aplican sus conocimientos al ámbito de las artes marciales. Las referencias se encuentran ordenadas alfabéticamente y cronológicamente. Adjunta un índice onomástico.

1365. Pilato, Herbie J. (1999). La sabiduría del kung-fu : sabios consejos de la serie original de televisión. Barcelona: Obelisco. $1^{\mathrm{a}}$ ed. 127 p. ; 13x21 cm. ISBN: 84-7720-686-4. Depósito legal: B. 10115-1999. Palabras clave: filosofía, aforismos, artes marciales. Resumen: Compendio de aforismos. El libro consta de 30 capítulos precedidos por los agradecimientos, un prefacio que relata la creación de la serie kung-fu a manos de Ed Spielman y una introducción que resume el guión de la serie de televisión . El conjunto de capítulos recoge las frases o aforismos aparecidos en la serie de televisión, junto con el apunte de su narrador y capítulo, que reflexionan sobre los conceptos de aceptación, amistad, amor, apreciación, armonía, confianza, destino, disciplina, discreción, diversidad, divinidad, felicidad, fuerza, herencia, humildad, justicia, karma, libertad, el más allá, meditación, paz, perdón, prioridades, resistencia, respeto, sueños, valentía, verdad, verdades universales y el yo. Adjunta un sumario de los episodios y una breve biografía del autor.

1366. Planells i Garcés, Encarna (2009). Fuentes documentales y testimoniales para el estudio de las artes marciales en España : ju-jutsu, judo y aikido. s.l.: Encarna Planells. $1^{a}$ ed. 509 p. : il. ; $15 \times 22$ cm. ISBN: 978-84-613-6894-5. Depósito legal: B. 47561-2009. Palabras clave: historia, principios técnicos, filosofía, maestros, personalidad. Resumen: Tratado histórico de ju-jutsu, judo y aikido. La obra consta de 4 partes precedidas por los agradecimientos, una introducción que comenta las razones para la aparición de esta obra y la presentación de las hipótesis de la investigación. La primera parte expone 
los fundamentos teóricos del método histórico así como la descripción de los métodos y fuentes utilizadas en la presente investigación. La segunda parte resume la historia de las artes marciales, de la filosofía japonesa, los fundamentos biomecánicos del judo y el aikido, analiza el contexto histórico, introducción y desarrollo del ju-jutsu, judo y el aikido en España, sus principales difusores y acontecimientos y un breve comentario sobre algunos personajes famosos practicantes de estas artes marciales. La tercera parte incluye las conclusiones de la investigación además de las propuestas de futuro. La última parte presenta las referencias de las fuentes documentales y la bibliografía utilizada.

1367. Polly, Mathew (2008). El shaolín occidental. Madrid: Kailas. 1aㅡ ed. 458 p. ; $14 \times 21$ cm. ISBN: 978-8489624-46-7. Depósito legal: M. 37687-2008. Palabras clave: combate, competición, cultura, sociedad. Resumen: Ensayo sobre el entrenamiento de un occidental en el templo shaolín. La obra esta dividida en cinco libros. El primer libro, compuesto de 7 capítulos, relata la toma de decisión del autor y su viaje a China para encontrar el templo Shaolin y practicar el kung-fu, el primer contacto del autor con el templo, los monjes, el entrenamiento y la vida diaria. El segundo libro, formado por 6 capítulos, profundiza en los entrenamientos del autor dentro del templo shaolín, las relaciones entabladas con varios de los monjes y relata las anécdotas de éstos durante su primer periodo de estancia. El tercer libro, formado por 7 capítulos, comenta el entrenamiento del autor en el sanda, algunas de las costumbres sociales de china y su sistema político, y cuáles son los entretenimientos de los monjes shaolín. El cuarto libro, formado por 7 capítulos, expone la época de aprendiz del autor, describiendo algunos de los problemas asociados al sistema social y sanitario de China, la integración del autor dentro del conjunto de monjes shaolín y sus primeros combates y desafíos. El último libro, compuesto por 6 capítulos, narra el último periodo de estancia del autor en el templo shaolín y China, describiendo su participación en el campeonato nacional de sanda, su rutina de entrenamiento y su adaptación a la sociedad americana. El epílogo comenta el regreso del autor tras diez años al templo shaolín. Adjunta notas y agradecimientos.

1368. Ratti, Oscar y Westbrook, Adele (1994). Los secretos del samurái : una investigación sobre las artes marciales del Japón feudal. Madrid: Alianza. 1a ed. 538 p. : il. ; 15x23 cm. ISBN: 84-206-5710-7. Depósito legal: M. 21543-1994. Palabras clave: historia, estrategia, vestimenta, bujutsu, escuelas, fundamentos filosóficos, artes marciales, ética, samurái, armas. Resumen: Tratado sobre el samurái y su entrenamiento marcial. La obra esta dividida en tres partes, que son precedidas por una introducción en la que se aclaran los conceptos de bujutsu, los matices que tenía dicho término y cuáles son sus orígenes. La primera parte profundiza sobre la conformación de los practicantes de artes marciales, cómo se formó la clase bushi y cuál era su papel dentro de la sociedad, quienes eran los heimin y cuáles eran sus prácticas, y qué significado tenían las ryu y el sensei dentro de su proceso de formación marcial. La segunda parte describe los factores externos del bujutsu y así explica la evolución y características de las armaduras, de las principales artes marciales, de las artes marciales menores, de los métodos de combate secundarios y del bujutsu sin armas. La tercera parte estudia los factores internos del bujutsu, como son los conceptos de control y fuerza, los principios estratégicos y la moralidad del bujutsu.

1369. Ratti, Oscar y Westbrook, Adele (2000). Secretos de los samurái : estudio de las artes marciales del Japón feudal. Barcelona: Paidotribo. 1a ed. 578 p. : il. ; 15x21,5 cm. ISBN: 84-8019-492-8. Depósito legal: no. ( $2^{\mathrm{a}}$ ed., 2004). Palabras clave: historia, estrategia, vestimenta, bujutsu, escuelas, fundamentos filosóficos, artes marciales, ética, samurái, armas. Resumen: Tratado sobre el samurái y su entrenamiento marcial. La obra esta dividida en tres partes, que son precedidas por una introducción en la que se aclaran los conceptos de bujutsu, los matices que tenía dicho término y cuáles son sus orígenes. La primera parte profundiza sobre la conformación de los practicantes de artes marciales, cómo se formó la clase bushi y cuál era su papel dentro de la sociedad, quienes eran los heimin y cuáles eran sus prácticas, y qué significado tenían las ryu y el sensei dentro de su proceso de formación marcial. La segunda parte describe los factores externos del bujutsu y así explica la evolución y características de las armaduras, de las principales artes marciales, de las artes marciales menores, de los métodos de combate secundarios y del bujutsu sin armas. La tercera parte estudia los factores internos del bujutsu, como son los conceptos de control y fuerza, los principios estratégicos y la moralidad del bujutsu.

1370. Ríos, Carmelo H. (1990). Ronin : la vía del guerrero errante. Barcelona: Obelisco. 1a ed. 268 p. : il. ; 13x21 cm. ISBN: 84-7720-118-8. Depósito legal: B. 9658-1990. (2ª ed., 2000; 3ª ed., 2008, ISBN: $978-$ 84-9777-478-9). Palabras clave: budo, filosofía, iaido, bushido, meditación. Resumen: Tratado filosófico sobre las artes marciales. La obra esta formada por 19 capítulos en los que a través de la narración del modo de vida del ronin, la vía del sable, la realización de la kata de Iai y de varios relatos, explica los aspectos filosóficos que rodean a las artes marciales, la actitud del practicante y la vía de la iluminación. De este modo, profundiza y comenta conceptos como: ki, dojo, hara, rei, zanshin, nukitsuke, sepukku, katana, kata, zen, satori, fudoshin, furikabute, kiai, mushotoku, guerra, kiri-tsuke, shiburi, noto-tsuke, budo, bushido, muga y ku. Finaliza ofreciendo consejos prácticos generales para guiarnos hacia la iluminación. 
1371. Ríos, Carmelo H. (1991). El espíritu de las artes marciales. Barcelona: Obelisco. 1aㅡ ed. 89 p. : il. ; $13 \times 21$ cm. ISBN: 84-7720-210-9. Depósito legal: B. 24007-1991. (2ª ed., 1996). Palabras clave: filosofía, aforismos. Resumen: Compendio de aforismos relacionados con las artes marciales. Recopila la ideología de los principales maestros marciales sobre la actitud ante el combate, la vida y la muerte, la guerra y la paz, el camino de las artes marciales, el dojo, el ki, el kiai, el hara, la práctica, el objetivo del kárate, del judo y del aikido, la práctica del Iaido y el Kyudo, la etiqueta, y de conceptos como musubi, zanshin, musotoku, sosei, kokoro, fudoshin, mushin y satori.

1372. Rosa, Raúl de la (compil.) (2008). El camino del guerrero : sabiduría samurái. Valencia: Ediciones i. 1a ed. 131 p. : il. ; 17x17 cm. ISBN: 978-84-96851-30-6. Depósito legal: V. 1742-2008. Palabras clave: principios técnicos, combate, estrategia, filosofía, relatos, samurái, fundamentos técnicos. Resumen: Compendio de 23 relatos breves sobre las artes marciales. Incluye poemas, historias y anécdotas que reflexionan sobre las características y filosofía que impregnan a las artes marciales, sus practicantes y grandes maestros. Incluye un poema sobre la vida del ronin y relatos sobre la sensibilidad de los grandes maestros, los beneficios del entrenamiento, la humildad del practicante ante el aprendizaje, la autoconfianza y la motivación ante el combate, la concentración en la práctica, las cualidades físicas que desarrollan las artes marciales, el carácter del guerrero, la ética de las artes marciales, la importancia de la estrategia y la técnica y algunos de los principios del combate.

1373. Rosenbaum, Michael (2007). Kata : la transmisión del conocimiento en las artes marciales tradicionales. Móstoles: Arkano Books. 1aㅡ ed. 249 p. : il. ; 14x21 cm. ISBN: 978-84-96111-38-7. Depósito legal: M. 50722-2007. Palabras clave: katas, historia, filosofía, deportes de combate. Resumen: Análisis histórico-contextual de las influencias que conformaron las artes marciales tradicionales y su método de transmisión del conocimiento. En primer lugar estudia las artes marciales tradicionales, griegas y japonesas, describiendo su nacimiento como consecuencia de las causas históricas que tuvieron lugar en cada civilización. A continuación profundiza sobre las diferentes formas de transmisión del conocimiento, cómo estos procesos son análogos en la escritura, la danza y la poesía, y como fueron evolucionando hasta conformar sistemas eficientes de transmisión. Tras analizar los diferentes sistemas de lucha y su armamento, ya que el origen de las armas dio lugar a la posterior creación de los métodos para transmitir el conocimiento sobre su utilización, afirma que el combate fue el impulsor del desarrollo de dichos métodos. Continúa con la descripción de los significados morales, filosóficos y simbólicos que se fueron añadiendo a las katas hasta adoptar, con la aparición de las armas de fuego, sus significados actuales. Adjunta notas.

1374. Ruy-San (seud. de Mendoza, Ruy San de) (1998). El libro de las cinco puertas : nin bu tao kris zen (vía de los maestros). Málaga: Dardo. 1aㅡ ed. 30 p. ; 15x21 cm. ISBN: No ISBN. Depósito legal: MA. 413-1998. Palabras clave: ninjutsu, fundamentos filosóficos, samurái, zen. Resumen: Tratado filosófico sobre el guerrero. El libro esta formado por cuatro capítulos. El primer capítulo incluye algunos de los versículos de los maestros sobre la vida, la sabiduria y las revelaciones. El segundo capítulo presenta la vía del nin sobre la actitud del guerrero ninja. El tercer capítulo expone un poema sobre la vía del tao y sus fundamentos teóricos escrito en portugués. El cuarto capítulo explica los fundamentos del tao, el zen y krishna así como dos poemas sobre la sabiduría y Arjuna en portugués.

1375. Schwentker, Wolfgang (2005). Los samuráis. Madrid: Alianza. $1^{a}$ ed. 180 p. : il. ; 11x17,5 cm. ISBN: 84206-6000-0. Depósito legal: M. 48121-2005. (2ª ed., 2006). Palabras clave: historia, historia, política, bushido, cultura, economía, samurái, sociedad. Resumen: Tratado histórico sobre los samuráis. El libro esta formado por 9 capítulos. El primer capítulo relata la historia de la venganza de los 47 samuráis, el origen de la casta guerrera y sus diversas denominaciones y su papel social en líneas generales. El segundo capítulo describe los acontecimientos sociales, políticos, económicos, militares y culturales que dieron lugar a los samuráis. El tercer capítulo narra la guerra Gempei, la jerarquía militar en la era Kamakura junto con el nuevo papel de los samuráis, la expansión del zen por el Japón, y las intrusiones mongolas durante la época. El cuarto capítulo describe la actuación de los samuráis durante la época Muromachi, las repercusiones de los comienzos de la unificación del imperio y las reformas de Toyotomi Hideyoshi así como la descripción y significado atribuido a las armas y armaduras utilizadas por los samuráis. El quinto capítulo explica los aspectos de la vida cotidiana del samurai, desde su vida familiar, esposas e hijos hasta su sexualidad, vivienda, alimentación, indumentaria y formas de morir. El sexto capítulo expone la entrada de los samuráis dentro del ámbito administrativo durante la época Tokugawa, su estatus social y económico dependiente de la clasificación social y comenta el código del samurai (bushido). El siguiente capítulo describe el declive económico de Japón a mediados del siglo XVII y su repercusión social, la pérdida de poder de los samuráis, los primeros contactos de Japón con las potencias extranjeras y la respuesta armada de los samuráis a dicha apertura (Restauración Meiji). El octavo capítulo explica el programa de cambios sociales, políticos y económicos que dieron lugar a la nueva estructura social tras la restauración Meiji y que afectaron a los samuráis, y los levantamientos promovidos por los samuráis debido a su pérdida de poderes e inclusión dentro de la sociedad moderna. El último capítulo detalla los efectos del código samurai en el Japón moderno, su utilización por parte del Estado, comenta las características del cine 
samurai y la aplicación de la mentalidad guerrera al campo económico. Adjunta bibliografía, un glosario de términos japoneses, créditos de las ilustraciones y un índice de topónimos y antropónimos.

1376. Seward, Jack (1988). Hara-kiri. Madrid: Eyras. 1aㅡ ed. 119 p. : il. ; $11 \times 18$ cm. ISBN: 84-85269-59-4. Depósito legal: M. 29341-1988. Palabras clave: historia, fundamentos técnicos, bushido, Japón, seppuku. Resumen: Tratado teórico sobre el seppuku. La obra esta compuesta por cinco capítulos precedidos por una introducción que comenta los objetivos del libro y la evolución del pensamiento japonés desde el Japón antiguo hasta la actualidad. El primer capítulo explica el significado del término seppuku, las formas de ejecutar a los condenados y relata el primer relato de un testigo occidental del seppuku y la ruptura de dicha tradición en ciertas ocasiones. El segundo capítulo estudia el origen y tipos de seppuku, comenzando por la explicación del origen del sacrificio, la presentación de varios documentos que relatan su aplicación, el código penal feudal que se aplicaba a los samuráis, cuales son las razones para escoger el abdomen como zona de suicidio, y los tipos de seppuku atendiendo al motivo de la condena, la forma de llevarlo a cabo y la gravedad de la ofensa, además de presentar la evolución histórica de los mismos. El tercer capítulo describe las características de los lugares donde se realizaba el seppuku, cual era el protocolo para ordenar el seppuku, quienes eran las personas encargadas de llevarlo a cabo y sus funciones, cómo se desarrollaba la ceremonia desde la sentencia del condenado hasta su muerte, la introducción del kaishaku (ayuda al samurái en el seppuku) y su ritual, y cómo fue degradándose el ritual del suicidio. El cuarto capítulo explica brevemente las relaciones entre los hombres y las mujeres en la sociedad japonesa durante la época confucionista para luego comparar el seppuku y el shinju (suicidio doble). Después presenta algunos relatos históricos sobre la formación del sistema moral feudal, la desintegración del sistema feudal y la decadencia del bushido, y explica el significado de la ceremonia del gempuku (paso de la niñez a la edad adulta), el aprendizaje del seppuku dentro de la misma y las críticas que aparecieron en el periodo Edo sobre la vida de los samuráis. El último capítulo describe el contexto social de la Restauración Meiji, la nueva redacción del código militar imperial, los principios dominantes durante dicho periodo y la desaparición progresiva del seppuku en 1945 tras las numerosas guerras de Japón. Adjunta un glosario.

1377. Shibata, Maryse y Shibata, Masumi (1991). Misterios de la sabiduría inmóvil del maestro Takuán. Barcelona: Paidós. 1aㅡ ed. 112 p. ; 13x19,5 cm. ISBN: 84-7509-660-3. Depósito legal: B. 1607-1991. Palabras clave: principios técnicos, principios éticos, filosofía, zen, relatos, maestros, samurái, sintoísmo. Resumen: La obra esta formada por 5 capítulos. El primer capítulo comenta la biografía del maestro Takuán y presenta su formación y algunos de sus escritos más importantes. Los siguientes tres capítulos presentan los 3 libros de Takuán titulados "Misterios de la sabiduría inmóvil", "Cuentos nocturnos del Mar Este" y "Transparencia" que recogen los principios filosóficos y técnicos aplicables a las artes marciales, ofrecen consejos y relatos sobre la forma de entrenar y alcanzar la sabiduría inmóvil y los principios éticos que deben guiar al monje o samuráis. El epílogo de la obra reúne varias historias de fisonomistas dentro del texto de historias del pasado (Konjaku-monogatari), comenta las características del shogun Minamoto-no-Yoritomo, la relación entre el shogun Tokugawa Ieyasu y los samuráis de la provincia de Mikawa, las historias de los samuráis Yamaoka Tesshu y Katsu Kaishu sobre su formación zen y un relato del creador del aikido sobre el objetivo de las artes marciales.

1378. Shodan (seud. de Nalda Albiac, José Santos) (1991). Zen y artes marciales. Barcelona: Edicomunicación. 1aㅡ ed. 154 p. : il. ; 13×20 cm. ISBN: 84-7672-382-2. Depósito legal: B. 36573-1991. Palabras clave: fundamentos teóricos, pedagogía, armas. Resumen: Tratado teórico de artes marciales. El libro esta dividido en 4 partes. La primera parte esta formada por 9 capítulos. El primer capítulo detalla los objetivos del zen. El segundo capítulo comenta las características del zen. El tercer capítulo expone la relación entre el zen y las artes marciales. El cuarto capítulo señala las características del verdadero budoka. El quinto capítulo relata varias historias sobre los principios del zen. El sexto capítulo presenta la relación entre el zen y la intuición. El séptimo capítulo señala los propósitos del zen. El octavo capítulo define el concepto de satori, las prácticas de los mondo y los koan, describe la meditación zazen, la influencia del zen sobre el kyudo, el kendo, la ceremonia del té y el ikebana. El noveno capítulo incluye diversos aforismos sobre el zen. La segunda parte consta de 13 capítulos. El primer capítulo comenta las dificultades de las artes marciales. El segundo capítulo narra los antecedentes de las artes marciales. El tercer capítulo ofrece varios consejos para el futuro practicante de artes marciales. El cuarto capítulo señala las características del aprendizaje de cualquier arte marcial. El quinto capítulo presenta consejos sobre alimentación e higiene. El sexto capítulo describe la forma correcta de respirar. El séptimo capítulo explica el desarrollo de un test cardíaco. El octavo capítulo define las características del sobreentrenamiento. Los dos siguientes capítulos comenta el entrenamiento de los cinco animales y el entrenamiento mental. Los últimos tres capítulos definen los conceptos de ki, kiai y mokuzo. La tercera parte consta de 4 capítulos. El primer capítulo señala las características de algunas armas marciales. El segundo capítulo comenta las características del samurái. El tercer capítulo enumera las virtudes del samurái. El cuarto capítulo explica las costumbres y conductas del samurái. La cuarta parte comenta los fundamentos teóricos y características del aikido, 
aiki-jutsu, t'aikido, judo, kendo, kyudo, yabusame, kobudo, karatedo, mushindo-karatedo, taekwondo, naginatado, bo-jutsu, ho-jutsu, nin-jutsu y sumo.

1379. Solís Miranda, José Antonio (2004). El último samurái : la verdad de la historia. Asturias: El arca de papel. $1^{a}$ ed. 60 p. : il. ; 15x21,5 cm. ISBN: 84-9765-175-8. Depósito legal: AS. 297-2004. (2ª ed., 2007; $3{ }^{a}$ ed., 2009, ISBN: 978-84-9765-653-5). Palabras clave: historia, vestimenta, bushido, Japón, religión, samurái, armas. Resumen: Tratado teórico sobre los samuráis. La obra esta formada por 6 capítulos precedidos por una tabla cronológica que señala los principales eventos de la historia de Japón. El primer capítulo narra el contexto histórico, social y político de las épocas de Japón. El segundo capítulo analiza las características sociales y políticas de los shogunatos ashikaga y tokugawa. El tercer capítulo describe el papel y formación de los samuráis, comenta los valores transmitidos en el bushido y el significado del hara-kiri. El cuarto capítulo expone los siete principios del código del bushido, el credo del samurái, comenta sus orígenes e influencias en el budismo, sintoísmo, zen y confucianismo, y describe el combate del samurái en la batalla. El quinto capítulo explica el significado de los escudos heráldicos en Japón y su utilización, detalla la estructura y evolución de las armaduras de los samuráis, y comenta las características, estructura y utilización de la espada, el arco, la naginata, el yari y el teppo. El último capítulo narra la historia y significado de la espada japonesa, su desarrollo y evolución hasta la katana, comenta la decadencia de la era Tokugawa, el contexto histórico de la Restauración Meiji y las características de la producción de espadas durante esta época, y analiza la situación actual de la espada japonesa y las normas para su producción.

1380. Solís Miranda, José Antonio (2007). El último samurái : el último luchador por una filosofía de vida perdida. s.l.: Solís Miranda, José Antonio. 1aㅡ ed. 144 p. : il. ; 15x22 cm. ISBN: 978-84-96930-22-3. Depósito legal: no. (2 ${ }^{\mathrm{a}}$ ed., 2008).

1381. Stevens, John (2002). Secretos del budo : enseñanzas de los maestros de artes marciales. Madrid: Edaf. $1^{\mathrm{a}}$ ed. 125 p. : il. ; $13 \times 21$ cm. ISBN: 84-414-1039-9. Depósito legal: M. 54356-2001. Palabras clave: principios filosóficos, budo, filosofía, ética, maestros. Resumen: Compendio de extractos sobre el budo. El libro esta dividido en tres partes. La primera parte recopila diversos textos que comentan los principios del budo a través del arte de sable, el kárate, el judo, el aikido y el ninjutsu. La segunda parte incluye varios ensayos sobre la filosofía del budo, como son: las maravillosas técnicas del viejo gato, los secretos de la natación para un samurái, el secreto arte del cepillo del carpintero de Tesshu Yamaoka, y las enseñanzas de Tempo Nakamura y Morihei Ueshiba. La última parte compila algunas de las historias sobre los maestros de artes marciales además de varias ilustraciones de algunos de estos maestros.

1382. Stork, Peter L. (2009). Maestros samuráis : secretos del Lejano Oriente. León: Evergráficas. $1^{a}$ ed. 40 p. : il. ; 20x22,5 cm. ISBN: 978-84-937329-8-1. Depósito legal: LE. 1406-2009. Palabras clave: fundamentos teóricos, artes marciales. Resumen: Manual teórico de artes marciales. El libro esta formado por 16 capítulos. Los tres primeros capítulos comentan las características de Japón, China y Corea. Los siguientes ocho capítulos exponen algunas de las características técnicas y fundamentos del aikido, jiu-jitsu, judo, kárate, kung-fu, kendo, sumo y taekwondo. Los dos siguientes capítulos presentan los contenidos técnicos de varios estilos de kung-fu. Los tres últimos capítulo explican la figura del samurái, el ninja y los monjes de shaolín.

1383. Tabata, Kazumi (2004). Secretos de las artes marciales : lecciones de los grandes maestros de las artes marciales. Madrid: Edaf. $1^{\mathrm{a}}$ ed. 194 p. : il. ; 13x21 cm. ISBN: 84-414-1480-7. Depósito legal: M. 279542004. Palabras clave: filosofía, artes marciales. Resumen: Compendio de ensayos sobre las artes marciales. La monografía esta dividida en 3 libros, cada uno de ellos centrado en un tema concreto. El primer libro recoge aquellos escritos de los maestros antiguos de artes marciales que hablan sobre el entrenamiento en artes marciales. El segundo libro profundiza en el liderazgo del maestro y la moralidad que debe regir dicho liderazgo, para finalizar el tercer libro con un extracto de ensayos que reflexiona sobre el camino hasta alcanzar la iluminación o armonía a través de la práctica de artes marciales. Adjunta bibliografía.

1384. Takuan, Soho (2005). El espíritu indomable del samurái : versión de Norberto Tucci. Madrid: Librería Argentina. $1^{\mathfrak{a}}$ ed. 92 p. : il. ; 14x21 cm. ISBN: 84-89836-84-1. Depósito legal: M: 37177-2005. Palabras clave: aforismos, fundamentos filosóficos. Resumen: Tratado teórico y filosófico sobre el combate. El libro esta formado por tres partes precedidas por una breve biografía del autor, un comentario sobre la relevancia del autor y los contenidos de la obra y un breve análisis del zen. La primera parte incluye el texto titulado "el registro misterioso de la sabiduría inmóvil" que ofrece consejos sobre el combate. La segunda parte presenta el texto "el sonido cristalino de las joyas" que reflexiona sobre la consciencia y el conocimiento de sí mismo. La tercera parte incluye el texto "los anales de la espada Taia" que presenta distintos aforismos comentados sobre los aspectos técnicos del manejo de la espada.

1385. Thomas, Raymond (1971). Relación práctica del zen al budo (artes marciales). Barcelona: Alas. 1a ed. 77 p. : il. ; 11x18,5 cm. ISBN: No ISBN. Depósito legal: B. 36997-1971. (2ª ed., 1981, ISBN: 84-203-0001-2). Palabras clave: ejercicios, entrenamiento, artes marciales, respiración, sistemas de entrenamiento. Resumen: Tratado teórico de zen. La obra esta formada por 16 capítulos. El primer capítulo ofrece 
algunos consejos para la práctica y el entrenamiento. El segundo capítulo detalla las características de las etapas de comprensión en el zen. El tercer capítulo detalla los elementos de entrenamiento de la eficacia en el budo. El cuarto capítulo expone la relación existente entre el zen y las artes marciales. El quinto capítulo describe brevemente los aspectos prácticos del zen para luego explicar el principios de calma y serenidad. El séptimo capítulo explica en qué consiste la práctica del zazen y continúa detallando la vestimenta para su ejecución, cómo sentarse y saludar. El noveno capítulo describe la ejecución de las distintas posturas para sentarse en zazen acompañadas de su representación gráfica. El décimo capítulo enumera los principios técnicos de dichas posturas. El siguiente capítulo expone la ejecución de tres ejercicios de respiración y de haragei. El décimo segundo capítulo señala los efectos del miedo sobre el cuerpo y ofrece un ejercicio para controlarlo. El siguiente capítulo ofrece varios consejos para afrontar el combate mientras que el décimo tercer capítulo expone los fundamentos filosóficos y morales de las artes marciales y su relación con el zen. El décimo cuarto capítulo señala la importancia de la voluntad en las artes marciales, explica cómo se puede entrenar, incluye algunas preguntas para conocerse a sí mismo y detalla las normas del código del bushido. El siguiente capítulo señala el desarrollo moderno del budo y continúa explicando los objetivos y características de las artes japonesas y su relación con el zen. Adjunta una conclusión que resume los contenidos del libro.

1386. Tohei, Koichi (1992). El libro del ki : armonizando la mente y el cuerpo en la vida diaria. Madrid: Edaf. $1^{\mathrm{a}}$ ed. 123 p. : il. ; 17x23,5 cm. ISBN: 84-7640-677-0. Depósito legal: M. 38529-1992. (2ª ed., 1995; 7aㅡ ed., 2001; 8 a ed., 2003). Palabras clave: historia, principios técnicos, biografía, salud. Resumen: Manual teórico y técnico de ki. La obra esta formada por 5 capítulos. El primer capítulo expone en qué consiste el ki. El segundo capítulo explica los cuatro principios y su relación para unificar cuerpo y mente además de incluir algunos ejercicios para experimentar dichos principios. El tercer capítulo expone los principios para aplicar el ki al entrenamiento del cuerpo y la mente, desarrollar la inteligencia, curar un shock físico, permanecer tranquilo frente a la gente, dormir profundamente, vencer su enfermedad, aumentar su suerte en el juego, eliminar su hándicap en el golf, hacer que un niño se vuelva fuerte y aumentar la fuerza sexual. El cuarto capítulo narra la biografía del autor desde su infancia y cómo fue profundizando en el estudio del ki a lo largo de su vida. El último capítulo describe las enseñanzas del autor sobre el aikido y el ki en Hawai, Maui, Kauai Honolulú y Estados Unidos.

1387. Tohei, Koichi (2003). El libro del ki. Barcelona: RBA. 1ạ ed. 142 p. : il. ; $13 \times 19$ cm. ISBN: 84-473-2815-5. Depósito legal: M. 14654-2003. Palabras clave: historia, principios técnicos, biografía, salud. Resumen: Manual teórico y técnico de ki. La obra esta formada por 5 capítulos. El primer capítulo expone en qué consiste el ki. El segundo capítulo explica los cuatro principios y su relación para unificar cuerpo y mente además de incluir algunos ejercicios para experimentar dichos principios. El tercer capítulo expone los principios para aplicar el ki al entrenamiento del cuerpo y la mente, desarrollar la inteligencia, curar un shock físico, permanecer tranquilo frente a la gente, dormir profundamente, vencer su enfermedad, aumentar su suerte en el juego, eliminar su hándicap en el golf, hacer que un niño se vuelva fuerte y aumentar la fuerza sexual. El cuarto capítulo narra la biografía del autor desde su infancia y cómo fue profundizando en el estudio del ki a lo largo de su vida. El último capítulo describe las enseñanzas del autor sobre el aikido y el ki en Hawai, Maui, Kauai Honolulú y Estados Unidos.

1388. Tokitsu, Kenji (2006). La búsqueda del ki. Badalona: Paidotribo. 1a ed. 175 p. : il. ; 15x21,5 cm. ISBN: 84-8019-840-0. Depósito legal: no. Palabras clave: fundamentos teóricos, aplicación marcial, salud. Resumen: Ensayo teórico y práctico sobre el concepto ki y su práctica. El primer capítulo describe el proceso histórico del autor hasta encontrar la práctica del ki, narrando su conocimiento en otras artes marciales y las razones que le fueron acercando hasta el kiko (qigong). Continua con el relato de su acercamiento al doctor Yayama y a su método de curación a través del ki, aportando algunas interpretaciones teóricas sobre su funcionamiento. El tercer capítulo presenta el método Yayama, ofreciendo una descripción de los movimientos y recomendaciones sobre su práctica, mientras que el siguiente capítulo describe brevemente la fundamentación teórica del kiko y el método Yayama. El quinto capítulo aplica el ki a las artes marciales, describiendo el método creado por el autor y formado por la aglutinación de diferentes conceptos y prácticas. El sexto capítulo aplica el ki a la salud, a través del tai chi chuan, describiendo la forma correcta para realizarlo y comparándolo con otras prácticas. El último capítulo presenta los fundamentos y objetivos de la danza de la energía, método creado por el autor para movilizar y fortalecer el ki, además de presentar las diferencias respecto a las artes marciales. Finaliza con un breve resumen de las ideas principales comentadas a modo de conclusión.

1389. Tokitsu, Kenji (2007). Budo : el ki y el sentido del combate. Badalona: Paidotribo. 1 a ed. 134 p. : il. ; 15x21,5 cm. ISBN: 978-84-8019-912-4. 84-8019-912-1. Depósito legal: no. Palabras clave: historia, fundamentos técnicos, filosofía, budo, fundamentos teóricos. Resumen: Manual técnico sobre el budo. Estudia el budo, su transmisión, sus significados culturales, sus aspectos técnicos y cómo, todo ello, es entendido en Japón y cómo debería entenderlo el practicante occidental de artes marciales. Explica que el ki es una clave para valorar el budo y que su control y modulación por parte del practicante puede ayudarle a ganar un combate. Ofrece consejos prácticos para aplicar eficazmente el ki en combate. 
1390. Torres Casado, Guillermo (1990). 1000 ejercicios y juegos de actividades de lucha. Barcelona: Paidotribo. $1^{\underline{a}}$ ed. 472 p. : il. ; 15x21,5 cm. ISBN: 84-86475-57-0. Depósito legal: B. 35457-1990. Palabras clave: fundamentos teóricos, pedagogía, ejercicios, combate, deportes de combate, juegos, unidades didácticas. Resumen: Manual teórico de actividades de lucha. La obra esta formada por 10 capítulos precedidos por un prólogo que analiza el origen de la lucha. El primer capítulo comenta el papel pedagógico de las actividades luctatorias, clasifica dichas actividades, define el término unidad motriz luctatoria, expone los objetivos de las actividades luctatorias y ofrece algunos consejos metodológicos. El segundo capítulo clasifica los tipos de caídas, analiza sus factores biomecánicos e incluye la ficha compuesta por descripción, material necesario, consigna, objetivo, unidad motriz y representación gráfica, de numerosos juegos sobre las caídas. Los siguientes ocho capítulos definen las unidades motrices de tirar y empujar, inmovilizar y volcar, derribar, tocar con miembros superiores o inferiores, parar y esquivar, tocar con objetos, ejercicios combinados y actividades luctatorias en el medio acuático, presentan sus secuencias de acciones e incluyen la ficha de descripción compuesta por descripción, material necesario, consigna, objetivo, unidad motriz y representación gráfica, de numerosos juegos y actividades dedicados a dichas unidades motrices. Adjunta bibliografía.

1391. Tucci, Alfredo (1991). El último horizonte del budo : la guía de los maestros para la maestría en el arte marcial. Madrid: Eyras. 1aㅡ ed. 117 p. ; 15x24 cm. ISBN: 84-85269-71-3. Depósito legal: M. 23301-1991. Palabras clave: filosofía, budo, aforismos. Resumen: Compendio de aforismos sobre el significado de las artes marciales. Tras una breve introducción y la explicación del significado de las artes marciales en Oriente y Occidente, se desarrollan 6 capítulos que abordan la esencia del budo desde diferentes perspectivas con una breve introducción sobre el tema y la recopilación de aforismos de los más grandes artistas marciales de todos los tiempos. El primer capítulo estudia el objetivo final del budo y del practicante, para continuar con la valoración del arma del guerrero, la estrategia, y las reflexiones más importantes sobre la misma. El tercer capítulo concreta el arma del budoka en su puesta en práctica, esto es, en la táctica. El cuarto capítulo recoge en sus aforismos la sabiduría de la experiencia de los grandes maestros y continúa con las reflexiones sobre el proceso de enseñanza y aprendizaje, de la relación entre maestro y alumno. El último capítulo recopila 6 propuestas de explicación del objetivo final del budo. Adjunta bibliografía.

1392. Tucci, Alfredo (2003). El guerrero consciente. Madrid: Budo International. $1^{a}$ ed. 255 p. : il. ; 17x24,5 cm. ISBN: 84-85269-91-8. Depósito legal: M. 37799-2003. Palabras clave: pedagogía, artes marciales, fundamentos filosóficos. Resumen: Compendio de 54 artículos publicados en la revista Cinturón Negro, precedidos por los agradecimientos, dos prólogos que comentan los contenidos del libro y un prefacio que exponen la tarea realizada por el autor. Los artículos exponen la historia entre Sun Tzu y el emperador, compara las artes marciales y el toreo, señala las cualidades de un maestro, reflexiona sobre el proceso de aprendizaje y entrenamiento de las artes marciales, define los términos sector, secta, sectarismo, las dualidades de fuerza-debilidad, facilidad-dificultad, igualdad-diferencia, amorguerra, discute el valor de las cosas, el éxito, la vía del guerrero, sus cualidades, el miedo, la violencia, la relación profesor-alumno, explica la teoría de la termorregulación y los aspectos filosóficos relacionados con las artes marciales.

1393. Tucci, Alfredo (2006). Encrucijadas : guerreros del siglo XXI. Madrid: Budo International. $1^{\mathrm{a}}$ ed. 207 p. : il. ; 17x24 cm. ISBN: 84-96492-31-1. Depósito legal: M. 23916-2006. Palabras clave: fundamentos filosóficos, artes marciales. Resumen: Tratado filosófico de artes marciales. El libro esta compuesto por 38 capítulos precedidos por un comentario sobre la actitud del guerrero y un prólogo que comenta los contenidos de la obra. Los 38 capítulos incluyen las reflexiones del autor sobre los beneficios de la práctica del budo, el significado del arte, los problemas de las artes marciales, la amistad, la perseverancia ante los problemas, los beneficios de las artes marciales, el cine marcial, la relación de la masculinidad y la feminidad con las artes marciales, el significado de las katas, la evolución de la defensa personal, el sexto sentido, la mercantilización de las artes marciales, las reglas de oro del kárate, la organización de las artes marciales, la relación entre sexo y violencia, la filosofía del aikido, la concentración y meditación, el fanatismo, la evolución de las artes marciales, la relación entre el toreo y las artes marciales, la deportivización de las artes marciales, el miedo y los factores que mejoran la técnica.

1394. Tucci, Alfredo (2007). El samurai que llevas dentro : la concordancia de lo recto. Madrid: Budo International. 1aㅡ ed. 111 p. : il. ; 17x24 cm. ISBN: 978-84-935919-9-1. Depósito legal: M. 49341-2007. Palabras clave: fundamentos filosóficos, artes marciales. Resumen: El libro esta formado por 14 capítulos precedidos por dos prólogos que comentan los contenidos del libro y una introducción que comenta sus objetivos. El primer capítulo analiza el sentido último de las artes marciales. El segundo capítulo comenta el estado actual de las artes marciales y su futuro. El tercer capítulo expone las consecuencias de la inmigración. El cuarto capítulo reflexiona sobre la magia y la fluidez en la vida cotidiana y el entrenamiento de artes marciales. El quinto capítulo expone la relación entre guerra y paz, y la función de las artes marciales. El sexto capítulo describe los beneficios y efectos derivados de la práctica de artes marciales. El séptimo capítulo analiza la sociedad actual y sus valores. El octavo 
capítulo analiza el calentamiento global y la actitud de los hombres ante ella. El noveno capítulo analiza el principio de libertad de la sociedad actual. El décimo capítulo expone los efectos terapéuticos de las artes marciales. El capítulo decimoprimero desarrolla la relación entre las artes marciales y la muerte. El decimosegundo capítulo explica la importancia de la voluntad del guerrero. El capítulo decimotercero señala los principios de educación de las artes marciales. El último capítulo describe el proceso de transformación y consciencia de las artes marciales.

1395. Tucci, Alfredo (2009). El guerrero sagrado. Madrid: Budo International. 1 a ed. 111 p. : il. ; $17 x 24 \mathrm{~cm}$. ISBN: 978-84-92484-32-4. Depósito legal: M. 12135-2009. Palabras clave: fundamentos filosóficos, artes marciales. Resumen: El libro esta compuesto por 15 capítulos precedidos por un prefacio que señala los objetivos del libro y dos prólogos que señalan la importancia de la obra. El primer capítulo describe las prácticas incluidas en las artes marciales y sus características. El segundo capítulo señala la importancia de la capacidad de adaptación en las artes marciales. Los dos siguientes capítulos reflexionan sobre la vida. El quinto capítulo analiza el devenir de las artes marciales en Europa. El sexto capítulo analiza la actitud del guerrero ante el engaño. El séptimo capítulo señala los beneficios de las artes marciales. El octavo capítulo comenta los beneficios de la práctica de las artes marciales en la crisis actual. Los dos siguientes capítulos analizan los sentimientos de necesidad, deseo, propósito y violencia desde el punto de vista de las artes marciales. Los siguientes tres capítulos señalan las cualidades de un buen maestro y los niveles de maestría. El decimocuarto capítulo reflexiona sobre el estado antimilitarista de Europa. El último capítulo expone la complementariedad de lo masculino y femenino.

1396. Tucci, Norberto (2006). El blanco si es visible : el budo y el bushido. Cuentos y relatos de samuráis. Madrid: Librería Argentina. 1aㅡ ed. 94 p. : il. ; 17x24 cm. ISBN: 84-89836-45-0. Depósito legal: M. 85112006. Palabras clave: textos, zen, relatos, fundamentos filosóficos, bushido, maestros. Resumen: Tratado teórico sobre las artes marciales. El libro esta formado por 12 capítulos. El primer capítulo explica el significado del "do". El segundo capítulo comenta los fundamentos taoístas de las artes marciales y su clasificación. El tercer capítulo expone el bushido y el origen de las artes marciales japonesas. El cuarto capítulo comenta la relación entre el zen y las artes marciales para luego explicar el estado de satori. El sexto capítulo detalla las características y enseñanzas de las obras tituladas "el arte de la guerra" de Sun Tzu y "las seis enseñanzas secretas" de T'ai Kung. El séptimo capítulo presenta la figura del samurái, presenta el "Hagakure" y la vida y obra de Miyamoto Musashi. El octavo capítulo expone la vida, obra y enseñanzas de Takuan Soho. El noveno capítulo presenta las características y enseñanzas de las obras tituladas "tao te king" y "I ching". El décimo capítulo resalta la importancia de las historias en el aprendizaje de las artes marciales. El capítulo decimoprimero comenta el proceso de aprendizaje y desarrollo en las artes marciales. El último capítulo incluye numerosos cuentos y relatos sobre los samuráis y la vía del guerrero.

1397. Turnbull, Stephen (2004). Samuráis : la historia de los grandes guerreros de Japón. Madrid: Libsa. 1aㅡ ed. 240 p. : il. ; 23x29 cm. ISBN: 84-662-1229-9. Depósito legal: no. (2ae ed., 2006). Palabras clave: historia, filosofía, cultura, samurái, armas. Resumen: Tratado teórico sobre los samuráis. El libro esta dividido en 8 capítulos. Los tres primeros capítulos describen la situación social antes de la aparición de los samuráis, su nacimiento y las causas que hicieron posible su aparición y su época de decadencia. El cuarto capítulo describe la estructura del ejército samurái y su forma de vida privada, social, marcial e incluso alimenticia. Continua con la descripción de las diferentes armaduras que utilizaron los samuráis y cómo fueron evolucionando para luego pasar, en los dos siguientes capítulos, a describir la fabricación y utilización de las armas de hoja cortante y arrojadizas respectivamente. El último capítulo narra las tácticas de combate utilizadas en las distintas épocas y ante distintos objetivos. Adjunta un apéndice cronológico de los hechos más significativos, algunos términos japoneses usuales, bibliografía e índice.

1398. Universidad Complutense de Madrid (2004). Flores de Edo : samuráis, artistas y geishas. Grabados y libros japoneses de la biblioteca de la Facultad de Bellas Artes. Madrid: Universidad Complutense de Madrid. 1aㅡ ed. 157 p. : il. ; 17x25 cm. ISBN: 84-95215-90-X. Depósito legal: M. 48646-2004. Palabras clave: historia, fundamentos técnicos, escuelas, pintura. Resumen: Tratado teórico y técnico de ukiyoe. El libro esta dividido en 5 partes, precedidas por una presentación que comenta la historia de la Facultad de Bellas Artes de la Universidad Complutense de Madrid. La primera parte describe la realización de la presente obra. La segunda parte explica como han llegado los libros y estampas presentados en el libro a la biblioteca y la biografía de su donante. La tercera parte describe las características de la colección de libros y estampas ukiyo-e, explica el significado de la flor durante el periodo Tokugawa, narra la historia del estilo ukiyo-e, de la escuela de kamigata y otras, detalla la formación del artista de ukiyo-e, las técnicas del ukiyo-e, comenta las características de las escuelas de Kyoto y Edo así como de otras escuelas menos importantes y diferentes artistas, narra la historia del libro ilustrado en Japón, la historia y características del teatro kabuki y su inclusión en el ukiyo-e, y describe las características de otras temáticas como la prostitución, el paisaje, el príncipe Genji, la comparación, la naturaleza, los guerreros, el sumo, el erotismo y otros temas secundarios. La cuarta 
parte presenta una selección de ilustraciones de ukiyo-e. La última parte incluye la ficha de descripción catalográfica de las obras incluidas dentro de la colección de estampas de ukiyo-e de la biblioteca de la Facultad de Bellas Artes de la Universidad Complutense de Madrid. También presenta la biografía de los artistas, la bibliografía consultada e índice de ilustraciones.

1399. Velasco Morral, Jordi (2004). La historia de las artes marciales coreanas y sus armas de combate: volumen primero. Barcelona: Alas. 1aㅡ ed. 134 p. : il. ; 21x30,5 cm. ISBN: 84-203-0429-8. Depósito legal: B. 34922-2004. Palabras clave: historia, escuelas, instituciones, sociedad. Resumen: Tratado histórico sobre el origen y desarrollo de las artes marciales coreanas. Después de una breve introducción sobre el nacimiento de las artes marciales en general y las coreanas en particular, los capítulos detallan, de forma cronológica, las características de las distintas épocas por las que han pasado las artes marciales japonesas. Así, el segundo capítulo presenta la historia antigua de las tribus y cómo su modo de vida dio lugar a un determinado tipo de combate marcial. Continúa con la narración de las luchas entre los reinos de Corea y el nacimiento de las artes marciales de la corte real. El cuarto capítulo describe las artes marciales budistas, cuáles fueron las razones para que creasen dichos métodos de defensa y continúa en el siguiente capítulo con la relación existente entre los monjes budistas y los guerreros de élite coreanos (Hwa Rang). El sexto capítulo ahonda en la dinastía Silla, su contexto social y las personas más influyentes de dicha época; y de igual manera lo hacen los siguientes capítulos, centrados en la dinastía Koryo, la dinastía Yi, la época del protectorado japonés, la ocupación japonesa, y la situación de Corea tras la II Guerra Mundial. El decimosegundo capítulo describe la división de las dos Coreas, sus causas y consecuencias políticas y sociales, y como este nuevo contexto social dio vida a distintos estilos y organizaciones. El siguiente capítulo hace una introducción a los nuevos estilos que se han esparcido mundialmente y a los maestros que han posibilitado dicho crecimiento. Los dos últimos capítulos muestran el nacimiento de la organización Kuk Sool Won y sus principales elementos; y la historia del fundador de esta organización, el maestro In Hyuk Suh. Añade un apéndice como capítulo final en el que apunta algunos datos sobre la vida de algunos personajes militares. Incluye una tabla cronológica y bibliografía.

1400. Vilella, Yanis (2008). Lañ do cheñ siue pay : escuela de metamorfosis a través de las artes marciales. Madrid: Budo International. 1aㅡ ed. 119 p. : il. ; 17x24 cm. ISBN: 978-84-92484-19-5. Depósito legal: M. 46907-2008. Palabras clave: fundamentos teóricos, fundamentos técnicos, pedagogía, entrenamiento, grados, sistemas de entrenamiento. Resumen: Manual teórico y técnico de Lañ Do Cheñ Siue Pay. El libro esta dividido en 9 partes precedidas por un prólogo que comenta las características del estilo y una introducción que señala el objetivo del Lañ Do Cheñ Siue Pay. La primera parte expone el trabajo mental de dragón de la práctica plástica. La segunda parte comenta la historia del Lañ Do Cheñ Siue Pay, sus fundamentos técnicos, los beneficios derivados de su práctica, su aplicación marcial, explica el significado del símbolo de la escuela, las etapas de aprendizaje y presenta algunos ejemplos del trabajo con los elementos primarios. La tercera parte detalla los principios tácticos incluidos en la obra titulada "la rama perdida". La cuarta parte enumera los beneficios derivados de la práctica de las katas, expone las características técnicas de sus cinco katas y sus métodos de práctica, incluye algunos comentarios sobre los principios del arte y presenta las características y métodos de la escuela como meditación en las artes marciales y en las artes gráficas. La quinta parte detalla los principios técnicos del Lañ Do Cheñ Siue Pay. La sexta parte explica el proceso de entrenamiento en el dojo, los contenidos de las etapas de aprendizaje y enumera los tipos de defensas y su clasificación. La séptima parte señala los aspectos psicológicos trabajados en la escuela Lañ Do Cheñ Siue Pay, los tres tipos de entrenamiento y las características de las clases. La octava parte comenta las etapas del practicante en su contacto con las artes marciales y su sistema de grados. La última parte señala los principios de enseñanza del Lañ Do Cheñ Siue Pay. Adjunta un epílogo, los agradecimientos y varios anexos con la biografía de Agustín Yan-Lu, distintas opiniones sobre este arte y un comentario final sobre el satori.

1401. Villahizán, Javier (2007). Samuráis, ninjas y geishas : todos los aspectos de la tradición japonesa. Alcobendas: Libsa. 1aㅡ ed. 287 p. : il. ; 17x24 cm. ISBN: 978-84-662-1493-3. Depósito legal: C0. 83-2007. Palabras clave: historia, filosofía, cultura, Japón. Resumen: Tratado teórico sobre samuráis, ninjas y geishas. La obra esta formada por 4 partes. La primera parte describe los aspectos filosóficos, religiosos e históricos que conformaron Japón como país, los principales significados de la cultura japonesa, y la historia moderna de Japón. La segunda parte profundiza en los orígenes históricos de la clase samurái, su formación como clase social y su papel a través de las distintas épocas, el significado de las armas del samurái, en especial la espada, las costumbres de vida de los samuráis, su vivienda y alimentación, las tácticas de combate que utilizaban en la guerra, el significado de la muerte del guerrero y de cortar la cabeza al enemigo, el papel de los samuráis como élite administrativa, la aparición del código del samurái, y la relevancia de los samuráis en el final de la era Tokugawa, tras la Restauración Meiji y en la actualidad. La tercera parte describe el origen de los ninjas y su rol social hasta la actualidad, sus principales disciplinas de estudio, los niveles de entrenamiento, los principios filosóficos que fundamentan su práctica, explica ciertos aspectos prácticos complementarios al entrenamiento del ninja como la meditación, el sexto sentido y la concentración, y expone las 
características de su lugar de entrenamiento, las técnicas de kárate utilizadas, el trabajo en vacío, el arte de la proyección, el arte de la inmovilización, las luxaciones, pellizcos y estrangulaciones, la utilización de las armas de puño y el sable, las armas de lanzamiento, el arte de la invisibilidad, la escalada y el descenso en rappel, la natación, las características del sable del ninja y las armas de fuego. La última parte describe el proceso de formación de la geisha, sus orígenes históricos, la estructura de un hanamachi (barrio de geishas), las etapas de aprendizaje de maiko y geiko, las geishas varones, las hanamachi más famosas, expone las artes tradicionales aprendidas por las geishas como la ceremonia del té, el arreglo floral, la caligrafía, detalla su vestimenta desde el quimono hasta el obi, el peinado, el maquillaje, el calzado y ropa interior, las sombrillas y bolsos, y finaliza describiendo el proceso de formación de una geisha, desde su contratación hasta las diferentes etapas de aprendizaje, su vida cotidiana, sus normas y su retiro. También incluye una breve descripción de la situación actual de las geishas en Japón. Adjunta apéndices sobre aspectos destacados de la cultura japonesa como los jardines, las flores, la ceremonia del té, la pintura con tinta china, la caligrafía, la poesía, el teatro No, el camino de la espada y el camino del arco.

1402. Villar Gil, Jorge (2008). Reflexiones sobre el combate. Madrid: Los libros del comienzo. $1^{\mathrm{a}}$ ed. 72 p. : il. ; 13x21 cm. ISBN: 978-84-87598-82-1. Depósito legal: SE. 3395-2008. Palabras clave: fundamentos teóricos, katas, combate, meditación. Resumen: Tratado filosófico sobre el combate marcial. El libro esta formado por 18 capítulos precedidos por un prólogo que comenta los contenidos de la obra. El primer capítulo explica el significado del combate. Los siguientes siete capítulos reflexionan sobre la preparación del combate, sus normas, la importancia de la técnica básica, el entrenamiento, la actitud de vacío de sentimiento en el combate, cómo identificar al rival y la mente del samurái. Los siguientes seis capítulos analizan el ritmo, momento de oportunidad, distancia de seguridad, potencia, afán de superación y cómo ocultar las debilidades para vencer en el combate. El decimoquinto capítulo describe la belleza del combate y su protocolo, mientras que el siguiente expone los beneficios de la fuerza mental del practicante. Los dos últimos capítulos exponen las características de las katas y el combate como métodos de meditación y concentración. Adjunta bibliografía.

1403. Wilson, William Scott (2007). El samurái solitario : la vida de Miyamoto Musashi. Móstoles: Arkano Books. $1^{a}$ ed. 311 p. : il. ; 14x21 cm. ISBN: 84-96111-25-7. Depósito legal: M. 43285-2007. Palabras clave: biografía, maestros, relatos. Resumen: Tratado biográfico sobre Miyamoto Musashi. El libro esta compuesto por 4 capítulos precedidos por un prefacio que comenta las investigaciones que han dado lugar a la obra, un mapa de Japón que localiza los combates protagonizados por Musashi y un prólogo que presenta la figura y mito de Musashi. Los siguientes cuatro capítulos relatan la vida, formación marcial y artística, influencias, combates, creación artística y contexto social de Miyamoto Musashi. Adjunta tres apéndices que exponen los relatos e historias creados a partir de la figura de Musashi, explican las influencias y relaciones de El libro de los cinco anillos con otras obras militares y maestros y detallan la filmografía relativa a la vida de Miyamoto Musashi. También adjunta notas explicativas y un glosario.

\subsection{Cine, Estrellas de Cine y Televisión}

1404. Arguiriadis, Kostas; De Cesaris, Marco; Herráiz Embid, Salvador; Alpanseque, Emilio; Zerpa, Carlos y Tucci, Alfredo (1989). Cinturón negro : la historia y los protagonistas del cine marcial. Madrid: Budo International. 1aㅡ ed. 96 p. : il. ; 21x29,5 cm. ISBN: 84-85269-96-9. Depósito legal: M. 7541-1989. Palabras clave: historia, biografía, cine, filmografía, artes marciales. Resumen: Manual teórico de cine marcial. El coleccionable esta formado por 14 capítulos precedidos de una introducción que analiza la actualidad del cine marcial y de acción. El primer capítulo comenta la historia, características, personajes y guión de la serie "The green hornet". El segundo capítulo analiza los primeros años de Bruce Lee en el mundo del cine desde 1967 a 1970. El tercer capítulo narra el desarrollo de las películas que hicieron famoso a Bruce Lee mientras que el cuarto explica sus últimos proyectos cinematográficos. Los dos siguientes capítulos incluyen una entrevista realizada a Cynthia Rothrock y la descripción de su carrera cinematográfica y sus principales interpretaciones. El séptimo capítulo relata la carrera profesional de Vincent Lyn. El octavo capítulo presenta la formación marcial de Richard Norton, un resumen de su trabajo en el mundo del cine y una entrevista sobre su filosofía de las artes marciales. El noveno capítulo relata la evolución de Jackie Chan en el mundo del cine además de comentar sus últimas producciones. El décimo capítulo incluye un artículo de opinión sobre las últimas películas del cine marcial y sus características. El capítulo decimoprimero analiza las causas de la influencia de Bruce Lee sobre las artes marciales. El decimosegundo capítulo comenta la biografía y carrera profesional de Chuck Norris incluyendo su historial deportivo y filmografía. El siguiente capítulo narra la carrera cinematográfica de Jean Claude Van Damme y su filmografía. El último capítulo comenta las características de las artes marciales artísticas y presenta a Teo García. 
1405. Carranza Gesa, Jorge (1974). David Carradine : "historia de un justiciero". Kung-fu. Barcelona: Este. $1^{\mathrm{a}}$ ed. 12 p. : il. ; 17x23,5 cm. ISBN: No ISBN. Depósito legal: B. 21132-1974. Palabras clave: biografía, cine, wushu. Resumen: Tratado biográfico de David Carradine. El libro esta formado por 5 capítulos ilustrados, precedidos por una introducción que resalta el éxito de la serie kung-fu. El primer capítulo describe el origen de la serie mientras que el segundo explica en qué consiste el kung-fu. El tercer capítulo comenta la carrera artística de la familia Carradine, mientras que los dos siguientes capítulos comentan los primeros pasos profesionales de David Carradine y sus papeles en el mundo del cine.

1406. Díez Sanchis, Ricardo (2003). Bruce Lee siempre... Barcelona: Alas. 1a ed. 123 p. : il. ; 17x24 cm. ISBN: 84-203-0426-3. Depósito legal: B. 30994-2003. Palabras clave: fundamentos teóricos, fundamentos técnicos, principios técnicos, entrenamiento, biografía, filmografía, jeet kune do, historia, instituciones, maestros. Resumen: Tratado biográfico y teórico de Bruce Lee. El libro esta formado por 12 capítulos precedidos por los agradecimientos, la biografía del autor, un prólogo que comenta los objetivos del libro, una introducción que narra la formación marcial en Jeet Kune Do de Tim Tackett y un comentario sobre los contenidos del libro. Los dos primeros capítulos incluyen las tablas cronológicos de la biografía y filmografía de Bruce Lee. El tercer capítulo comenta la vida de Linda Lee. El cuarto capítulo incluye la biografía de Brandon Lee y Shannon Lee. El quinto capítulo enumera los principios técnicos del jeet kune do, la formación marcial de Bruce Lee, expone algunas de sus fundamentos teóricos, comenta la relación de Bruce Lee con el boxeo, la esgrima y el grappling, describe los fundamentos y ejecución de la técnica "falling step", los cinco ataques, el juego de pies, los atrapes, la guardia, las principales técnicas de puño y pierna, y detalla las tres etapas de aprendizaje. El sexto capítulo presenta el plan de entrenamiento y ejercicios de Bruce Lee, enumera las aspectos físicos más importantes y describe la ejecución de varios ejercicios para realizar el golpe de la pulgada. El séptimo capítulo analiza las ventajas y desventajas de Bruce Lee en un combate de Vale Tudo. El octavo capítulo presenta las biografías de Dan Inosanto y Ted Wong. El noveno capítulo explica los programas de enseñanza del Núcleo Jun Fan Jeet Kune Do y del Jeet Kune Do Concepts. El décimo capítulo narra la relación de Bruce Lee con España a través de una cena con varios pelotaris. El décimo primer capítulo incluye una entrevista a Bruce Lee sobre las artes marciales, el entrenamiento, su vida y su filosofía. El décimo segundo capítulo presenta la opinión de varios artistas marciales, actores y amigos sobre Bruce Lee. Adjunta una explicación de la portada y contraportada del libro y bibliografía.

1407. Fernando, Isabel (2001). La verdadera historia de Bruce Lee. Barcelona: Freelive. 1a ed. 64 p. : il. ; 16x24 cm. ISBN: No ISBN. Depósito legal: B. 46650-2001. Palabras clave: fundamentos teóricos, fundamentos técnicos, principios técnicos, principios filosóficos, vestimenta, cortesía, etiqueta, historia, instituciones. Resumen: Tratado teórico y biográfica de Bruce Lee. El libro esta formado por 7 capítulos. El primer capítulo explica en qué consiste el kung fu y narra sus orígenes e historia. El segundo capítulo relata la biografía de Bruce Lee, su crecimiento en Hong Kong, su traslado a América, sus primeros pasos en Hollywood, su regreso a Hong Kong, la grabación y contenidos de sus películas, sus problemas de salud, su muerte y funeral, los rumores tras su muerte y la maldición de la familia Lee. El tercer capítulo expone los fundamentos filosóficos de Bruce Lee. El cuarto capítulo explica en qué consiste el jeet kune do, sus principios técnicos, sus contenidos técnicos, las normas de sus seminarios y sus distintos sistemas de grados. El quinto capítulo expone las reglas generales del Instituto Jun Fan Kung Fu e incluye la guía para el desarrollo de las habilidades técnicas del jeet kune do. El sexto capítulo describe la posición de guardia, la actitud ante el combate, los principios técnicos y tácticos de la provocación, las fintas, las patadas, las técnicas de puñetazo, las tácticas de bloqueo, la distancia en el combate y los desvíos protectores, señala la importancia de la movilidad en el combate y explica las técnicas de avance del cuerpo, las cinco formas de empezar un ataque y las seis enfermedades o errores principales. El último capítulo incluye una cronología de la vida de Bruce Lee.

1408. Herráiz Embid, Salvador (1994). Jean Claude van Damme. Guadalajara: Salvador Herráiz Embid. 1a ed. 32 p. : il. ; 21x29,5 cm. ISBN: No ISBN. Depósito legal: GU. 35-1994. Palabras clave: biografía, cine, filmografía. Resumen: Tratado biográfico de Jean-Claude Van Damme. El libro esta formado por 5 capítulos ilustrados, precedidos por una introducción que señala el papel de Jean-Claude Van Damme en el mundo del cine de artes marciales. El primer capítulo narra la biografía de Jean-Claude Van Damme, su entrenamiento marcial y competiciones. El segundo capítulo describe sus viajes a Norteamérica, sus primeros contactos con el mundo del cine y sus dificultades. El tercer capítulo describe su entrada en el mundo del cine, sus primeras películas y crecimiento profesional. El cuarto capítulo comenta la consagración del actor dentro del cine de acción, comenta el guión de sus películas, su evolución profesional y sus problemas. El quinto capítulo incluye su filmografía.

1409. Herráiz Embid, Salvador (1994). Jean-Claude van Damme. Barcelona: Royal Books. 1 a ed. 60 p. : il. ; 23x29 cm. ISBN: 84-8135-026-5. Depósito legal: B. 14736-1994. Palabras clave: biografía, cine, filmografía. Resumen: Tratado biográfico de Jean-Claude Van Damme. El libro esta formado por 5 capítulos ilustrados, precedidos por una introducción que señala el papel de Jean-Claude Van Damme en el mundo del cine de artes marciales. El primer capítulo narra la biografía de Jean-Claude Van Damme, su entrenamiento marcial y competiciones. El segundo capítulo describe sus viajes a 
Norteamérica, sus primeros contactos con el mundo del cine y sus dificultades. El tercer capítulo describe su entrada en el mundo del cine, sus primeras películas y crecimiento profesional. El cuarto capítulo comenta la consagración del actor dentro del cine de acción, comenta el guión de sus películas, su evolución profesional y sus problemas. El quinto capítulo incluye su filmografía.

1410. Herráiz Embid, Salvador (1995). Bruce Lee retratos. Barcelona: Royal Books. 1a ed. 60 p. : il. ; $20 x 27$ cm. ISBN: 84-8135-072-9. Depósito legal: B. 15541-1995. Palabras clave: biografía, cine, filmografía. Resumen: Ensayo biográfico de Bruce Lee. El libro esta formado por 16 capítulos ampliamente ilustrados. El primer capítulo resalta el mito de Bruce Lee dentro del mundo de las artes marciales. El segundo capítulo relata sus primeros años en el cine y su comienzo en las artes marciales. El tercer capítulo explica su primer encuentro con Yip Man, sus problemas callejeros y su viaje a Estados Unidos. El cuarto capítulo narra su llegada a Estados Unidos, su contacto con Linda Emery y la publicación de su primer libro. El quinto capítulo detalla la apertura y problemas de su gimnasio y su primer papel en la televisión. El sexto capítulo describe su actuación en la serie "Green Hornet". El séptimo capítulo describe la actuación de Bruce Lee en la exhibición de Long Beach y su entrenamiento. El octavo capítulo relata sus numerosos papeles en el cine y la televisión. El noveno capítulo detalla algunos de los proyectos malogrados de Bruce Lee mientras que el décimo expone su regreso a Hong Kong. El décimo primer capítulo presenta las características y éxito de su película titulada "Furia oriental" para continuar con "El furor del dragón", "Operación dragón" y el rodaje de "Juego con la muerte". El décimo quinto capítulo narra la muerte del Bruce Lee mientras que el siguiente detalla sus repercusiones. Adjunta un capítulo recordatorio, su filmografía y la sinopsis de sus películas americanas.

1411. Herráiz Embid, Salvador (1995). Steven Seagal : retratos. Barcelona: Royal Books. 1ạ ed. 60 p. : il. ; 20x27 cm. ISBN: 84-8135-071-0. Depósito legal: B. 15540-1995. Palabras clave: biografía, cine, filmografía. Resumen: Tratado biográfico de Steven Seagal. El libro esta formado por 4 capítulos ampliamente ilustrados, precedidos por una introducción que presente los contenidos de la obra. El primer capítulo comenta la biografía de Steven Seagal, su contacto con las artes marciales, su llegada a Japón y su comienzo en el cine. El segundo capítulo narra sus primeros papeles cinematográficos y su consolidación profesional mientras que el tercer capítulo explica su segunda etapa y renovación del papel de héroe que interpreta en sus películas además de comentar el argumento de las mismas. El cuarto capítulo incluye un resumen comentado de su filmografía.

1412. Juan Payán, Miguel (2007). Las cien mejores películas de artes marciales. San Sebastián de los Reyes: Cacitel. $1^{a}$ ed. 254 p. : il. ; 15x21,5 cm. ISBN: 978-84-96613-17-1. Depósito legal: M. 38691-2007. Palabras clave: historia, fundamentos teóricos, actores, películas, series TV. Resumen: Tratado teórico de cine de artes marciales. La obra esta formada por 3 partes precedidas por una introducción que resalta la importancia de las artes marciales centro del cine y la televisión de la actualidad. La primera parte narra la evolución de las películas de artes marciales dentro del género cinematográfico, las principales compañías y hechos que fueron posibilitando su expansión y la biografía de sus principales estrellas. La segunda parte expone y comenta las distintas clasificaciones que existen sobre las películas de artes marciales, la recaudación de las más exitosas, las películas galardonas junto con sus premios, el listado de las 100 mejores películas de artes marciales según el autor, seguido de un análisis detallado de cada una de ellas en el que comenta la sinopsis de la película, resalta las consideraciones y anécdotas más importantes e incluye la ficha técnica, artística y su póster. La tercera parte incluye la ficha técnica, la sinopsis y el póster de otras películas interesantes para el autor. Adjunta dos anexos, el primero de ellos sobre el boom cinematográfico aparecido tras la muerte de Bruce Lee en el que se resaltan las biofilmografías de sus dobles y los documentales sobre su vida; y el segundo de ellos comentando las series de televisión que tuvieron como temática principal las artes marciales.

1413. Juan Payán, Miguel y Juan Payán, Javier (1995). Grandes estrellas del cine de artes marciales. Madrid: Nuer. $1^{a}$ ed. 96 p. : il. ; 16x24 cm. ISBN: 84-8068-031-8. Depósito legal: M. 36856-1995. Palabras clave: biografía, cine, actores, filmografía. Resumen: Tratado teórico de estrellas de cine. La obra esta compuesta por 12 capítulos, precedidos de una introducción que narra el origen y expansión del cine de artes marciales, las peculiaridades de sus etapas y la evolución del género. A continuación se presentan 11 capítulos que detallan la vida profesional, la filmografía, la frase célebre y anécdotas de la biografía de los artistas del cine de artes marciales: Bruce Lee, Jim Kelly, Wang Yu, Chuck Norris, Sonny Chiba, Jackie Chan, Cynthia Rothrock, Dolph Lundgren, Jean-Claude Van Damme, Steven Seagal y Brandon Lee, incluyendo numerosas fotografías de los actores y sus películas. El último capítulo presenta brevemente la biofilmografía de otros artistas del cine de artes marciales como Sofia Crawford, Mark Dacascos, Michael Dudikoff, Sam Firstemberg, Thomas Ian Griffith, King Hu, Steve James, Pat Johnson, Sho Kosugi, Conan Lee, Kathy Long, Sze Yuen Ng, Jeff Pruitt, Karen Sheperd, Jeff Speakman, Don "The Dragon" Wilson, Jeff Wincott y Carter Wong. Adjunta bibliografía, citas e índice de personajes y películas citadas.

1414. Lee, Sam (1998). Bruce Lee. Arganda del Rey: Edimat. 1a ed. 187 p. : il. ; 13x21 cm. ISBN: 84-8403-0903. Depósito legal: M. 16376-1998. Palabras clave: fundamentos teóricos, táctica, fundamentos 
técnicos, principios técnicos. Resumen: Manual teórico y técnico de Jeet Kune Do. La obra esta compuesta de 23 capítulos precedidos por una introducción que comenta los contenidos de la obra. El primer capítulo ofrece la visión de Bruce Lee sobre su arte marcial y sus principios técnicos. Continúa con unas breves nociones sobre el calentamiento, la importancia de la posición de guardia y sus beneficios, la importancia de la coordinación en los movimientos y la forma de desplazarse y un análisis de las cualidades físicas y psíquicas más importantes en el combate. El sexto capítulo explica la ejecución del golpe de parada y su utilización ante diversas situaciones, continua analizando la actitud ante el combate y la importancia de las evasivas y el engaño. Los siguientes cinco capítulos clasifican y describen la ejecución de las patadas, el puñetazo directo con la mano adelantada y los principales ataques de mano, junto con las fintas y los desvíos. El decimocuarto capítulo explica la utilización correcta de golpear el ataque del adversario para luego profundizar en las distancias de combate y su correcta utilización. Los siguientes capítulos analizan la movilidad durante el combate, el avance de los pies, expone los criterios técnicos del ataque, junto con la aplicación de cada uno de ellos en determinados momentos y después revisa el contraataque. Los siguientes tres capítulos analizan la táctica y su rol en el combate, la respuesta o ataque después de una defensa y recopila los consejos prácticos para avanzar en el entrenamiento y no caer en los errores habituales. El último capítulo presenta la biografía de Bruce Lee, su formación marcial y un breve comentario de los principales maestros de jeet kune do.

1415. Lee, Sam (1998). Las artes marciales en el cine. Arganda del Rey: Edimat. 1a ed. 190 p. : il. ; $13 \times 21 \mathrm{~cm}$. ISBN: 84-8403-067-9. Depósito legal: M. 16375-1998. Palabras clave: cine, películas. Resumen: Manual teórico sobre el cine de artes marciales. El libro esta dividido en 5 partes. La primera parte discute la calidad del cine de artes marciales. Las siguientes cuatro partes presentan los datos filmográficos y un comentario de algunas de las películas y series de artes marciales producidas en los años 60, 70, 80 y 90 respectivamente, acompañadas de numerosas ilustraciones explicativas. Las películas y series producidas en los años 60 fueron: Los siete samuráis; Marlowe, detective muy privado; y El retorno del dragón. Las películas y series de artes marciales presentadas en la tercera parte son: Kung fu; Kárate a muerte en Bangkok; Furia oriental; El furor del dragón; Operación dragón; La serpiente a la sombra del águila; El mono borracho en el ojo del tigre; La última aventura de Bruce Lee; El kárate, el colt y el impostor; Los demoledores; Yakuza; El círculo de hierro; Cinturón negro; Juego con la muerte; La leyenda de Bruce Lee; Los valientes visten de negro y Furia silenciosa. La cuarta parte incluye las películas y series de artes marciales pertenecientes a la década de los 80 tituladas: El templo de oro; El héroe y el terror; Duelo final; Retroceder nunca, rendirse jamás; Black eagle; Contacto sangriento; De profesión: duro; Con su propia ley; El guerrero del amanecer; Desaparecido en combate; Braddock: desaparecido en combate III; La justicia del ninja; La venganza del ninja; La dominación; Shogun, seños de samuráis; Código de silencio; Fuerza 7; El último dragón; El felino; Golpe por golpe; McQuade, lobo solitario; Delta force; La furia de Chicago; Cyborg; Kamikaze Detroit; Made in China; Marcado para morir; El guerrero americano; Invasión USA; Los supercamorristas; El protector; Karate kid, el momento de la verdad; Las tortugas ninja y Por encima de la ley. La última parte presenta las películas de artes marciales producidas en la década de los años 90 tituladas: Difícil de matar; Kick boxer; Ley marcial; Señalado por la muerte; Doble impacto; Libertad para morir; Lionheart, el luchador; Arma perfecta; Combate sangriento; Ataque frontal; Rapid fire; Buscando justicia; Dragón: la vida de Bruce Lee; Soldado universal; Sin escape; Alerta máxima; Blanco humano; Juntos para vencer; El mensajero del infierno; Hitman; En tierra peligrosa; El nuevo karate kid; El cuervo y Policía en el tiempo.

1416. Little, John (2008). Bruce Lee : artista de la vida. Móstoles: Dojo. 1a ed. 343 p. : il. ; 14x21 cm. ISBN: $978-$ 84-935400-2-9. Depósito legal: M. 815-2008. Palabras clave: entrenamiento, filosofía, jeet kune do, wushu, correo, maestros, poesía. Resumen: Compendio de reflexiones de Bruce Lee. Esta dividido en ocho capítulos principales, para reflexionar en cada uno de ellos sobre un tema. La primera parte presenta las reflexiones de Bruce Lee sobre el kung fu, su práctica, su entrenamiento, la defensa personal y su psicología o cómo elegir instructor. La segunda parte esta compuesta de los pensamientos que desarrolló sobre filosofía, centrándose en los principios del taoísmo, Platón, Sócrates y Descartes. La tercera parte aborda los pensamientos e ideas de Bruce respecto a la psicología, los mecanismos de aprendizaje y cómo funciona nuestra mente en el devenir diario. La cuarta parte recopila algunos de los poemas escritos por Lee, mientras que la quinta parte presenta los fundamentos del Jeet Kune Do, cómo se debe entender este arte marcial, cuáles son sus principios y objetivos, cuál debe ser la actitud del practicante y los problemas que se encuentra el practicante al entrenar y la manera de solucionarlos. La sexta parte aborda la faceta de Bruce como actor y la interpretación que hacía de su vida profesional. La séptima parte reflexiona sobre el conocimiento de sí mismo, cómo se lleva a cabo este proceso y cómo lo hizo él mismo. La última parte incluye algunas de las cartas que Bruce mandó a sus amigos, con distintas temáticas pero siempre desde un punto de vista reflexivo y filosófico. Adjunta notas y agradecimientos. 
1417. Little, John (2008). Cartas del Dragón : correspondencia, 1958-1973. Antología de la correspondencia de Bruce Lee con su familia, amigos y admiradores, 1958-1973. Móstoles: Dojo. 1a ed. 190 p. : il. ; $14 \times 21 \mathrm{~cm}$. ISBN: 978-84-935400-4-3. Depósito legal: M. 19783-2008. Palabras clave: correo. Resumen: Compendio de cartas escritas por Bruce Lee. Las cartas están divididas en 5 capítulos atendiendo a la fecha de su envío. Así, los periodos comprendidos son: 1958-1963 (Descubriendo América), 19641966 (Del kung fu a El Avispón Verde), 1967-1970 (El jeet kune do y el arte del cultivo del optimismo), 1971-1972 (Una estrella en ascenso), y 1973 (El último año). Cada carta esta precedida del nombre de la persona a la que va dirigida, el lugar de envío o matasellos y su fecha, incluyendo además fotografías e ilustraciones de los realizados por Bruce Lee en las mismas.

1418. Little, John (2008). Pensamientos extraordinarios, sabiduría para la vida : Bruce Lee. Móstoles: Dojo. $1^{a}$ ed. 188 p. : il. ; 14x21 cm. ISBN: 978-84-935400-3-6. Depósito legal: M. 7357-2008. Palabras clave: filosofía, aforismos. Resumen: Compendio de aforismos. Dividido en 8 capítulos principales, cada uno de ellos esta dividido en temas más concretos que son comentados con un breve aforismo y cuyas ideas se pueden aplicar a infinidad de situaciones vitales. El primer capítulo reflexiona sobre los primeros principios, como la vida, la existencia, el tiempo, la raíz, el Ahora, la realidad, las leyes, la interdependencia, el vacío y la muerte. El segundo capítulo aborda el estudio del ser humano, concentrándose en el ser humano, la acción, la Wu-wei, la mente, el pensamiento, las abstracciones, el conocimiento, las ideas, la percepción, el ego, la concentración, la razón, la emoción, la felicidad, el miedo, la fuerza de voluntad y la buena voluntad, los sueños y la espiritualidad. El tercer capítulo presenta cuestiones relacionadas con la existencia, como son la salud, el noviazgo, el amor, el matrimonio, la crianza de los hijos, la educación, la enseñanza, la ética, el racismo, la adversidad, la confrontación, la adaptabilidad y la filosofía. El cuarto capítulo ahonda en los logros de las personas, como el trabajo, la calidad, la motivación, los objetivos, la fé, el éxito, el dinero, la fama y la adulación. El quinto capítulo esta dedicado al arte y sus artistas, para reflexionar sobre el arte, el cine y la actuación. El sexto capítulo presenta el camino hacia la liberación, con aforismos que tratan el condicionamiento, los sistemas, el desapego, la No-mente, el budismo zen, la meditación, el mantenerse centrado y la libertad. El séptimo capítulo reflexiona sobre el proceso de transformación de la persona, abordando la autoactualización, la autoayuda, el autoconocimiento, la autoexpresión, el crecimiento y la simplicidad. El último capítulo estudia los principios finales, esto es, el yin-yang, la totalidad, el tao y la verdad. Adjunta un índice aforismos.

1419. Little, John (comp.) (2008). Palabras del Dragón : entrevistas, 1958-1973. Móstoles: Dojo. $1^{\mathfrak{a}}$ ed. 188 p. : il. ; 14x21 cm. ISBN: 978-84-935400-5-0. Depósito legal: M. 41543-2008. Palabras clave: cine, artes marciales, periodismo. Resumen: Compendio de artículos periodísticos realizados sobre Bruce Lee. La obra consta de cuatro partes precedidas por los agradecimientos, un prefacio que comenta la visión de Bruce Lee que tenía su mujer, una introducción que describe el desarrollo del presente libro y sus contenidos, y una lista cronológica de las obras principales de Bruce Lee. La primera parte presenta cuatro artículos que comentan sus primeras apariciones en el mundo del cine, su explicación del kung fu, su biografía y la presentación de una exhibición a manos de Bruce Lee. La segunda parte consta de 16 artículos que presentan su papel en la serie "El avispón verde". La tercera parte incluye 9 artículos que describen su etapa en Hollywood y su filosofía respecto a las artes marciales. La última parte consta de 16 artículos que presentan sus éxitos en el mundo del cine y sus reflexiones sobre la vida, el jeet kune do y el mundo del cine, y su muerte. Todas partes incluyen un capítulo final de notas aclaratorias.

1420. López Tortosa, Domingo (1997). Made in Hong Kong. Valencia: Midons. 1ạ ed. 223 p. : il. ; 17x23,5 cm. ISBN: 84-89240-34-5. Depósito legal: no. Palabras clave: películas, cine, actores. Resumen: Diccionario comentado de películas de artes marciales. La obra agrupa las películas comentadas alfabéticamente precedidas por un prólogo que analiza el éxito de las películas de artes marciales, una introducción que comenta los contenidos del libro y un glosario de términos específicos del cine de artes marciales. El diccionario incluye los datos filmográficos de la mayoría de las películas de artes marciales realizadas con posterioridad a 1983 y algunas representaciones del cine de los años 70, además de incluir su puntuación, un comentario crítico de sus guiones y numerosas ilustraciones. Adjunta un índice de actores y directores, un índice de títulos de películas, los agradecimientos y un comentario sobre la carrera profesional del autor.

1421. Martínez Fariñas, Enrique (1979). Bruce Lee : el rey del kung-fu. Barcelona: Producciones Editoriales. 1 a ed. 80 p. : il. ; 20x27 cm. ISBN: 84-365-1425-4. Depósito legal: 6862-1979. Palabras clave: historia, principios técnicos, filosofía, entrenamiento, biografía, jeet kune do, aforismos, artes marciales. Resumen: Tratado teórico de artes marciales. El primer capítulo presenta algunas de las frases y reflexiones de Bruce Lee sobre las artes marciales y su filosofía. El segundo capítulo narra el origen de las artes marciales, expone algunos de los conceptos enunciados por Confucio sobre la educación, explica la evolución de las artes marciales, señala la importancia del templo shaolín en dicho proceso, comenta su tipo de entrenamiento y la formación definitiva del kung fu. El tercer capítulo presenta el código del kung fu. El cuarto capítulo expone algunos de los principios del entrenamiento y la actitud 
del practicante de kung fu ante el combate. El quinto capítulo relata los enfrentamientos contra los manchúes y la rebelión de los boxers además de la influencia de estos hechos sobre la expansión del kung fu. El sexto capítulo analiza las influencias marciales que recibió Bruce Lee a lo largo de su vida. El séptimo capítulo narra los conflictos de Bruce Lee con la comunidad de artes marciales de San Francisco para luego presentar los principios técnicos y fundamentos del jeet kune do. El noveno capítulo expone los métodos de entrenamiento de Bruce Lee, mientras que el décimo capítulo describe su entrenamiento con los nunchaku. El último capítulo incluye numerosos consejos para el entrenamiento, el aprendizaje y el progreso en las artes marciales. Adjunta un cómic titulado "Matad a Okada" y numerosas laminas e ilustraciones durante el texto.

1422. Martínez Fariñas, Enrique (1988). Bruce Lee : el rey del kung-fu. Barcelona: Antalbe. 1a ed. 95 p. : il. ; 21x28 cm. ISBN: 84-7656-079-6. Depósito legal: B. 6940-1988. Palabras clave: historia, principios técnicos, filosofía, entrenamiento, biografía, jeet kune do, aforismos, artes marciales. Resumen: Tratado teórico de artes marciales. El primer capítulo presenta algunas de las frases y reflexiones de Bruce Lee sobre las artes marciales y su filosofía. El segundo capítulo narra el origen de las artes marciales, expone algunos de los conceptos enunciados por Confucio sobre la educación, explica la evolución de las artes marciales, señala la importancia del templo shaolín en dicho proceso, comenta su tipo de entrenamiento y la formación definitiva del kung fu. El tercer capítulo presenta el código del kung fu. El cuarto capítulo expone algunos de los principios del entrenamiento y la actitud del practicante de kung fu ante el combate. El quinto capítulo relata los enfrentamientos contra los manchúes y la rebelión de los boxers además de la influencia de estos hechos sobre la expansión del kung fu. El sexto capítulo analiza las influencias marciales que recibió Bruce Lee a lo largo de su vida. El séptimo capítulo narra los conflictos de Bruce Lee con la comunidad de artes marciales de San Francisco para luego presentar los principios técnicos y fundamentos del jeet kune do. El noveno capítulo expone los métodos de entrenamiento de Bruce Lee, mientras que el décimo capítulo describe su entrenamiento con los nunchaku. El último capítulo incluye numerosos consejos para el entrenamiento, el aprendizaje y el progreso en las artes marciales. Adjunta un cómic titulado "Matad a Okada" y numerosas laminas e ilustraciones durante el texto.

1423. Monzó Landeira, Germán (1983). Los misterios del templo de shaolin. Barcelona: Alas. 1a ed. 32 p. : il. ; 16x23,5 cm. ISBN: 84-203-0154-X. Depósito legal: B. 33476-1983. Palabras clave: historia, cine. Resumen: Tratado teórico sobre el templo de shaolín. El libro esta formado por 7 capítulos. El primer capítulo expone algunos de los personajes del templo shaolín y su expansión. El segundo capítulo narra la historia del templo shaolín, describe su arquitectura y comenta el origen del kung-fu shaolín y sus contenidos técnicos. El tercer capítulo explica la creación del shorinji kempo. El cuarto capítulo describe el intercambio de conocimientos entre el templo shaolin y el shorinji kempo. El quinto capítulo incluye una breve descripción de las habilidades marciales de los luchadores de la película sobre el templo de shaolín. El sexto capítulo describe la biografía y formación marcial del protagonista de la película sobre el templo de shaolín, Li Lin Jei. El último capítulo presenta algunas de las artes marciales del sureste de Asia.

1424. Moore, Richard S. (1975). Bruce Lee inédito. Barcelona: Producciones Editoriales. 1a ed. 95 p. : il. ; 20x27 cm. ISBN: 84-365-0797-5. Depósito legal: B. 46030-1975. Palabras clave: biografía, cine, jeet kune do. Resumen: Ensayo biográfico sobre Bruce Lee. A través de los ocho capítulos del libro narra la vida personal de Bruce Lee, como pensaba siendo maestro de artes marciales, su pensamiento pedagógico, el entrenamiento que realizaba, su relación con el mundo del cine, su muerte y algunos comentarios de sus amigos; entremezclando algunas anécdotas y datos históricos. Adjunta algunos ejercicios terapéuticos extraídos de las técnicas de kung-fu.

1425. Ocaña Rizo, Marcos (2003). Bruce Lee : el hombre detrás de la leyenda. Madrid: T\&B. $1^{\mathfrak{a}}$ ed. 327 p. : il. ; 16x24 cm. ISBN: 84-95602-47-4. Depósito legal: M. 20763-2003. (2aㅡ ed., 2003). Palabras clave: principios técnicos, filosofía, biografía, cine, jeet kune do, maestros. Resumen: Biografía de Bruce Lee. La monografía esta compuesta por 22 capítulos en los que se describe la vida y obra de Bruce Lee así como los acontecimientos y condicionantes que presentó su vida, incluyendo numerosas ilustraciones de cada acontecimiento. Siguiendo el orden cronológico de los hechos, comienza explicando el nacimiento de Bruce Lee y la situación social y familiar que rodeó dicho nacimiento; ahonda en sus primeros papeles como actor; y detalla su formación marcial durante su infancia. El cuarto capítulo narra el viaje de Bruce a Seattle y cómo fue su llegada a los Estados Unidos. Continúa con la descripción de su verano en Hong Kong durante 1963; el comienzo de la relación con su futura mujer Linda; su etapa de entrenamiento y clases en Oakland; y la narración de su primera prueba de pantalla para la 20th Century Fox. A partir del noveno capítulo, explica sus comienzos televisivos dentro de la serie "El avispón verde", la apertura del 3er Instituto Jun Fan Gung Fu en Los Angeles, y su etapa televisiva. El siguiente capítulo detalla los deseos de Bruce Lee de realizar una película que mostrase la belleza y significado de las artes marciales y todos los problemas que rodearon dicha producción, para luego pasar al análisis de sus películas, y los pormenores de su realización, "Longstreet", "The big boss", "Furia oriental", "El furor del dragón", "Juego con la muerte", y "Operación Dragón". Los dos siguientes 
capítulos detallan sus problemas de salud, su muerte y los hechos que rodearon este suceso, así como la aparición de un nuevo mercado alrededor de la imagen de Bruce Lee y sus películas. Finaliza con una explicación de los principios del Jeet Kune Do y la filosofía de Bruce Lee respecto a las artes marciales y la vida. Adjunta una amplia y completa filmografía, desde sus películas infantiles hasta su aparición en la serie "El avispón verde", sus apariciones como artista invitado, su papel como coreógrafo de artes marciales, y sus películas; incluyendo una ficha técnica de cada aparición y numerosas imágenes. También adjunta bibliografía.

1426. Pérez Agustí, Adolfo (1987). El libro de oro de Bruce Lee. Fuenlabrada: Gráficas Bogotá. 1aㅡ ed. 173 p. : il. ; 15x21,5 cm. ISBN: 84-398-9824-X. Depósito legal: M. 22534-1987. Palabras clave: fundamentos teóricos, táctica, fundamentos técnicos, principios técnicos. Resumen: Manual teórico y técnico de Jeet Kune Do. La obra esta compuesta de 20 capítulos. El primer capítulo ofrece la visión de Bruce Lee sobre su arte marcial y sus principios técnicos. Continúa con unas breves nociones sobre el calentamiento, la importancia de la posición de guardia y sus beneficios, la importancia de la coordinación en los movimientos y la forma de desplazarse y un análisis de las cualidades físicas y psíquicas más importantes en el combate. El sexto capítulo explica la ejecución del golpe de parada y su utilización ante diversas situaciones, continua analizando la actitud ante el combate y la importancia de las evasivas y el engaño. Los siguientes tres capítulos clasifican y describen la ejecución de las patadas, el puñetazo directo con la mano adelantada y los principales ataques de mano, junto con las fintas y los desvíos. El duodécimo capítulo explica la utilización correcta de golpear el ataque del adversario para luego profundizar en las distancias de combate y su correcta utilización. Los siguientes capítulos analizan la movilidad durante el combate, el avance de los pies, expone los criterios técnicos del ataque, junto con la aplicación de cada uno de ellos en determinados momentos y después revisa el contraataque. Los últimos tres capítulos analizan la táctica y su rol en el combate, la respuesta o ataque después de una defensa y recopila los consejos prácticos para avanzar en el entrenamiento y no caer en los errores habituales. El texto esta intercalado con numerosas fotografías de Bruce Lee.

1427. Pérez Agustí, Adolfo (1994). El libro de oro de Jean Claude Van Damme. Madrid: Adolfo Pérez Agustí. 1a ed. 154 p. : il. ; 15x21,5 cm. ISBN: 84-605-0004-7. Depósito legal: M. 16182-1994. Palabras clave: biografía, filmografía, entrevistas. Resumen: Tratado biográfico de Jean Claude Van Damme. El libro esta formado por 18 capítulos precedidos por un prólogo que comenta los artistas marciales del cine tras Bruce Lee hasta la aparición de Van Damme. El primer capítulo narra la biografía de Jean Claude Van Damme. El segundo capítulo comenta la entrada de Van Damme en el cine. Los siguientes 11 capítulos presentan la ficha descriptiva y el resumen del guión de las películas tituladas "Retroceder nunca, rendirse jamas", "Contacto sangriento", "Black eagle", "Ciborg", "Kick boxer", "Lionheart, el luchador", "Libertad para morir", "Doble impacto", "Soldado universal", "Sin escape" y "Blanco humano" acompañadas de numerosas fotografías de distintas escenas de dichas películas. El decimocuarto capítulo incluye los comentarios de Jean Claude Van Damme sobre algunos de los artistas marciales famosos. El decimoquinto capítulo describe la ejecución de varios ejercicios de musculación para las piernas junto con sus ilustraciones explicativas. El siguiente capítulo incluye una breve entrevista a Jean Claude Van Damme sobre su comienzo en las artes marciales y su entrenamiento. Los dos últimos capítulos presentan la opinión de Van Damme sobre el cine y su carrera profesional.

1428. Pérez Agustí, Adolfo (1995). 40 años del cine de artes marciales. Madrid: Adolfo Pérez Agustí. 1aㅡ ed. 235 p. : il. ; 15x21,5 cm. ISBN: No ISBN. Depósito legal: M. 328-1995. Palabras clave: fundamentos teóricos, películas, artes marciales. Resumen: Recopilatorio de la filmografía de artes marciales desde 1960 hasta la actualidad. La obra esta dividida por décadas y cada película incluye una breve ficha de descripción (director e intérpretes) así como un breve comentario crítico sobre los aspectos técnicos, históricos o marciales de la película, además de varios fotogramas de la propia película o sus actores.

1429. Prat Banús, José María (1980). Kung fu cinema especial : Bruce Lee - Jackie Chan. Barcelona: Alas. 1a ed. 62 p. : il. ; $17 \times 24$ cm. ISBN: 84-203-0098-5. Depósito legal: B. 8221-1980. Palabras clave: fundamentos teóricos, filmografía. Resumen: Tratado biográfico de Bruce Lee y Jackie Chan. El libro esta formado por 10 capítulos. El primer capítulo comenta la importancia de Bruce Lee. El segundo capítulo incluye la descripción y resumen del libro "Chinese Gung Fu: the Philosophical Art of Self Defense" escrito por Bruce Lee sobre los fundamentos del kung fu chino. El tercer capítulo comenta el argumento de la película titulada "La serpiente a la sombra del águila" y protagonizada por Jackie Chan. El cuarto capítulo presenta y analiza el guión de la serie titulada "El avispón verde". El quinto capítulo expone el argumento de la película "El mono borracho en el ojo del tigre". El sexto capítulo explica los fundamentos teóricos del estilo chui pa hsien (el boxeo de los ocho inmortales borrachos) así como un comentario sobre las características de los estilos actuales que aún contienen esta práctica. El séptimo capítulo presenta la interpretación de Bruce Lee en la serie titulada "Marlowe, detective muy privado". El octavo capítulo incluye varios poemas de Bruce Lee. El noveno capítulo 
comenta el guión de la serie titulada "Longstreet" así como algunos de sus mejores diálogos. El último capítulo expone el argumento de la película titulada "Karate a muerte en Bangkok".

1430. Prat Banús, José María (1981). Jackie Chan : la furia de Chicago. Su estilo de kung fu. Barcelona: Alas. 1a ed. 32 p. : il. ; 17x24 cm. ISBN: 84-203-0116-7. Depósito legal: no.

1431. Prat Banús, José María (1982). La justicia de ninja. Barcelona: Alas. 1aㅡ ed. 32 p. : il. ; 17x24 cm. ISBN: 84-203-0129-9. Depósito legal: no.

1432. Prat Banús, José María (1984). Bruce Lee - Jackie Chan. Barcelona: Alas. 2ª ed. 48 p. : il. ; $17 \times 24$ cm. ISBN: 84-203-0098-5. Depósito legal: no.

1433. Prat Banús, José María (1987). Bruce Lee : juego con la muerte. Barcelona: Alas. 1a ed. 32 p. : il. ; 21x26,5 cm. ISBN: 84-203-0080-2. Depósito legal: B. 42119-1987. Palabras clave: biografía, cine. Resumen: Tratado teórico sobre la película "Juego con la Muerte" y Bruce Lee. El libro esta formado por 10 capítulos precedidos por una editorial que comenta las dificultades para la publicación de esta obra. El primer capítulo incluye la ficha técnica y artística de la película. El segundo capítulo comenta la sinopsis de Juego con la muerte. El tercer capítulo analiza el carisma cinematográfico de Bruce Lee y lo compara con James Dean. El cuarto capítulo analiza la producción final y ajustes de la película Juego con la muerte tras la muerte de Bruce Lee. El quinto capítulo expone la entrevista realizada a Jose $M^{\underline{a}}$ Prat sobre la creación del Club Bruce Lee en España y la figura del mismo. El sexto capítulo presenta los métodos de entrenamiento de Bruce Lee a través de los comentarios de algunos de sus alumnos. El séptimo capítulo expone la historia y contenidos técnicos del wing chun. El octavo capítulo resume la vida de Bruce Lee. El noveno capítulo detalla la formación marcial de Bruce Lee y sus distintos maestros en Hong Kong y Estados Unidos. El último capítulo describe y comenta la muerte de Bruce Lee. Adjunta un poster central sobre la película.

1434. s.a. (1988). Bruce Lee : hombre de acero. Barcelona: Antalbe. 1a ed. 85 p. : il. ; 21x28 cm. ISBN: 84-656086-9. Depósito legal: B. 19642-1988. Palabras clave: biografía, fundamentos filosóficos. Resumen: Tratado biográfico de Bruce Lee. El libro esta formado por 7 capítulos ampliamente ilustrados con fotografías del protagonismo y contenidos de diversas artes marciales. El primer capítulo analiza las causas que convirtieron a Bruce Lee en una leyenda junto con algunos de sus comentarios. El segundo capítulo narra la introducción de Bruce Lee en las artes marciales y sus entrenamientos. El tercer capítulo narra su llegada a Estados Unidos, su desarrollo profesional, su método de enseñanza de kung fu y sus problemas con la prensa y otros artistas marciales. El cuarto capítulo comenta el orgullo de Bruce Lee por el pueblo chino y señala sus esfuerzos por demostrar la valía del pueblo chino. El quinto capítulo expone la reacción de Bruce Lee ante la serie kung fu. El sexto capítulo detalla los fundamentos filosóficos de Bruce Lee. El último capítulo narra el estrés y los problemas físicos de Bruce Lee hasta su muerte, resaltando su filosofía de vida. Adjunta un diálogo entre el pequeño dragón y su maestro además de la descripción e ilustración de algunas de las técnicas de kung-fu.

1435. s.a. (1993). Dragón : la vida de Bruce Lee. Película basada en el libro escrito por su esposa Linda Lee. Barcelona: Alas. 1a ed. 38 p. : il. ; 21x27,5 cm. ISBN: 84-203-0281-3. Depósito legal: B. 29154-1993. Palabras clave: fundamentos teóricos, biografía, cine, jeet kune do. Resumen: Tratado teórico sobre la película "Dragón: la vida de Bruce Lee". El libro esta formado por 13 capítulos precedidos por la ficha artística y técnica de la película y una introducción que comenta la relevancia de la película para las artes marciales. El primer capítulo incluye la sinopsis de la película. El segundo capítulo comenta las características del rodaje y su fundamentación. El tercer capítulo expone la biografía y carrera cinematográfica de los actores de la película mientras que el cuarto capítulo presenta la formación de los técnicos. El quinto capítulo resume la carrera cinematográfica de Bruce Lee. El sexto capítulo relata la llegada de Bruce Lee a América y sus primeras clases de kung-fu. El séptimo capítulo incluye el testimonio de Ronald Kealoha sobre un enfrentamiento de Bruce Lee con un karateka. El octavo capítulo narra la discusión de Bruce Lee con los maestros de kung-fu de San Francisco. El noveno capítulo detalla el planteamiento de entrenamiento de Bruce Lee. El décimo capítulo explica la formación marcial de Bruce Lee además de incluir sus comentarios sobre el kung-fu y algunas de las cartas publicadas en la revista "Black belt". El capítulo decimoprimero presenta la personalidad de Bruce Lee a través de las palabras y comentarios de Dan Inosanto. El decimosegundo capítulo relata el origen e historia del jeet kune do así como los contenidos técnicos de su entrenamiento y su sistema de graduación. El último capítulo resume las enseñanzas fundamentales de Bruce Lee.

1436. Vera Sho-Dan, (seud. de Vera Ramírez, Antonio) (1976). Bruce Lee : artes marciales. Barcelona: Producciones Editoriales. $1^{a}$ ed. 96 p. : il. ; 20x26,5 cm. ISBN: 84-365-0890-4. Depósito legal: B. 138981976. Fotos y terminar de resumir. Palabras clave: historia, fundamentos técnicos, artes marciales, armas. Resumen: Manual teórico de artes marciales. El libro esta formado por 6 capítulos. El primer capítulo expone la biografía de Bruce Lee junto con la influencia que tuvieron sus enseñanzas y películas sobre el mundo de las artes marciales. El segundo capítulo comenta los requisitos previos para comenzar el entrenamiento de artes marciales además de definir los conceptos de ki, kiai, mokuzo y sensei. El tercer capítulo describe las características de las armas como el bo, bokken, jitte, katana, katana-zutsu, kusarigama, kyotetsu, koge, manrikikigusari, naginata, nunte, sai, shinai, shuko, shuri- 
ken, tachi, tanto, aikuchi, tessen, tetsu bichi, tonfa, wakizashi, ya, yumi yari y yawara. El cuarto capítulo enumera las máximas del samurái, explica el ritual del seppuku y las características del ikebana. El quinto capítulo incluye un haiku y define los conceptos de bugei, budo, budoka y bushido. El último capítulo explica la historia, características, principios y contenidos técnicas de otras artes marciales como el aikido, judo, kendo, kyudo, kobudo, karate-do, tae kwon do, naginata-do, bo-jutsu, ho-jutsu, nin-jutsu, sumo y kung fu, incluyendo representaciones gráficas de algunas de sus técnicas. Adjunta láminas a color intercaladas con el texto.

1437. Vera Sho-Dan, (seud. de Vera Ramírez, Antonio) (1977). Bruce Lee : el hombre que nunca murió. Madrid: Demiguel. 1aㅡ ed. 41 p. : il. ; 16x23 cm. ISBN: 84-85394-02-X. Depósito legal: no. (2ª ed., 1978). Palabras clave: fundamentos teóricos, filosofía, biografía, cine, filmografía, jeet kune do, aforismos, fundamentos filosóficos, religión. Resumen: Ensayo biográfico de Bruce Lee. El libro esta formado por 15 capítulos ampliamente ilustrados. El primer capítulo incluye la ficha personal de Bruce Lee. El segundo capítulo comenta sus inicios en el mundo del cine además de enumerar su filmografía más importante. El tercer capítulo narra su primeros años de vida, sus peleas callejeras y sus inicios en el kung fu. El cuarto capítulo describe su llegada a los Estados Unidos y la apertura de su primer gimnasio. El quinto capítulo expone los fundamentos teóricos y características técnicas del jeet kune do y lo compara con otras artes marciales. El sexto capítulo presenta la opinión de Bruce Lee sobre la religión mientras que el séptimo capítulo comenta sus reflexiones sobre la vida y la muerte además de incluir algunos relatos. El octavo capítulo describe los primeros pasos de Bruce Lee en la televisión y el cine así como su aportación al mundo de las artes marciales. El noveno capítulo detalla las explicaciones y comentarios sobre la muerte de Bruce Lee. Los siguientes tres capítulos incluyen algunos aforismos de Confucio, distintos proverbios chinos y algunas frases de la sabiduría china. El décimo tercer capítulo expone las virtudes básicas del samurái además de definir los términos bugei, budo, budoka y bushido. Los dos últimos capítulos enumeran distintas artes marciales y armas.

1438. Vigil, Luis (1976). Bruce Lee : el pequeño dragón. Barcelona: Producciones Editoriales. 1 ạ ed. 88 p. : il. ; 20x27 cm. ISBN: 84-365-0972-2. Depósito legal: B. 54789-1976. Palabras clave: historia, biografía, cine. Resumen: Ensayo biográfico de Bruce Lee. El libro narra la biografía de Bruce Lee, describiendo sus primeros años de vida, sus problemas sociales, su formación marcial, sus comienzos y evolución en el cine, sus éxitos cinematográficos, su vida privada, su muerte y funeral además de incluir un comentario sobre el desarrollo de las compañías de cine orientales, algunas anécdotas de su vida personal, los rumores tras su muerte y numerosas ilustraciones.

1439. Von Sohel, Helmut (seud.) (1977). Bruce Lee : hombre de acero. Barcelona: Producciones Editoriales. $1^{\mathrm{a}}$ ed. 78 p. : il. ; 20x27 cm. ISBN: 84-365-1117-4. Depósito legal: B. 29558-1977. Palabras clave: biografía, fundamentos filosóficos. Resumen: Tratado biográfico de Bruce Lee. El libro esta formado por 7 capítulos ampliamente ilustrados con fotografías del protagonismo y contenidos de diversas artes marciales. El primer capítulo analiza las causas que convirtieron a Bruce Lee en una leyenda junto con algunos de sus comentarios. El segundo capítulo narra la introducción de Bruce Lee en las artes marciales y sus entrenamientos. El tercer capítulo narra su llegada a Estados Unidos, su desarrollo profesional, su método de enseñanza de kung fu y sus problemas con la prensa y otros artistas marciales. El cuarto capítulo comenta el orgullo de Bruce Lee por el pueblo chino y señala sus esfuerzos por demostrar la valía del pueblo chino. El quinto capítulo expone la reacción de Bruce Lee ante la serie kung fu. El sexto capítulo detalla los fundamentos filosóficos de Bruce Lee. El último capítulo narra el estrés y los problemas físicos de Bruce Lee hasta su muerte, resaltando su filosofía de vida. Adjunta un diálogo entre el pequeño dragón y su maestro.

\subsection{Clásicos}

1440. Allyn, John (1988). Los cuarenta y siete samurái : la historia de los cuarenta y siete ronin. Madrid: Eyras. $1^{\underline{a}}$ ed. 215 p. ; $15 \times 24$ cm. ISBN: 84-85269-56-X. Depósito legal: M. 21516-1988. Palabras clave: historia. Resumen: Relato de artes marciales. El libro esta formado por 20 capítulos precedidos por un prefacio que comenta el contexto social donde se produjo esta historia. Los 20 capítulos narran la historia de venganza de los cuarenta y siete ronin.

1441. Encel, Frédéric (2002). El arte de la guerra : estrategas y batallas. Madrid: Alianza. $1^{a}$ reimp. 284 p. : il. ; 11x17,5 cm. ISBN: 84-206-7303-X. Depósito legal: M. 23442-2002. Palabras clave: guerra, estrategia, política, ciencia militar, maestros. Resumen: Tratado teórico sobre estrategia militar. La obra consta de dos partes., precedidas de una introducción que discute el concepto de política y estrategia y comenta los contenidos de la obra. La primera parte incluye la biografía y pensamiento militar de los siguientes hombres, en orden cronológico: Sun Tsé, Jenofonte, Alejandro Magno, Aníbal, Julio César, Gengis Khan, Bertrand du Guesclin, Tamerlán, Sébastien Le Prestre de Vauban, Federico el Grande, Napoleón Bonaparte, Arthur Willesley, duque de Wellington, Simón Bolivar, Carl von Clausewitz, Ferdinand Foch, Thomas Edward Lawrence, Mao Tse-tung, Charles De Gaulle, Adolf Hitler y Moshé 
Dayán. La segunda parte relata las batallas de: Maratón, Gaugamela, Alesia, Masada, Los Campos Catalaúnicos, Roncesvalles, Azincourt, Caída de Constantinopla, Marignano y Pavía, Lepanto, Trafalgar, Austerlitz, Jena y Auerstädt, Waterloo, Gettysburg, Sadowa, Sedán, Los Dardanelos, Verdún, la batalla de Inglaterra, Midway, El-Alamein, Stalingrado, Iwo Jima y Okinawa, Guerra de los Seis Días y Guerra del Yom Kippur.

1442. Hanzhang, Tao (2008). El arte de la guerra de Sun Tzu : sabiduría oriental para guiarle ante los problemas de la vida diaria. Barcelona: Bresca. 1르 ed. 152 p. ; 16x23 cm. ISBN: 978-84-936084-0-8. Depósito legal: B. 5124-2008. Palabras clave: guerra, estrategia, táctica. Resumen: Ensayo interpretativo de "El arte de la guerra". La obra esta dividida en 2 partes, precedidas por la nota del traductor que explica las características de la obra, la introducción que comenta el contexto histórico y características de la obra "El arte de la guerra", enumera las teorías del mariscal Liu Bocheng sobre Sun Tzu y resalta la validez de su obra en la actualidad, y la traducción del libro "El arte de la guerra" que contiene 13 capítulos que explican los conceptos tácticos y estratégicos más significativos de la batalla y son comentados posteriormente. Ofrece criterios estratégicos, explica el comportamiento en medio de una batalla, como planificar un asalto, las fases y ritmos de la batalla, algunos consejos prácticos sobre la preparación y el propio combate, estudia algunas de las variables y maniobras militares, el terreno, sus tipos y ventajas-inconvenientes. Finaliza con las reflexiones sobre la utilización del fuego en la guerra y la utilización de los espías. La primera parte consta de 7 capítulos que analizan la obra de Sun Tzu y presentan las interpretaciones del general Hanzhang respecto a las consideraciones estratégicas, la postura del ejército, las fuerzas ordinarias y extraordinarias, la vacuidad y la plenitud, la iniciativa y flexibilidad en las guerras, el uso de espías y la geografía. La segunda parte consta de 4 capítulos. El primer capítulo narra el contexto histórico de "El arte de la guerra" y su influencia sobre el planteamiento militar del autor. El segundo capítulo analiza la presencia de ideas del materialismo simple y la dialéctica primitiva en la obra. El tercer capítulo expone las leyes universales de la guerra y analiza sus aspectos políticos, económicos y el arte de la dirección de la misma. El último capítulo explica las contradicciones e ideas obsoletas de la obra de Sun Tzu.

1443. Kaufman, Stephen F. (2000). El arte de la guerra : la interpretación definitiva del libro clásico de Sun Tzu. Barcelona: Paidotribo. $1^{\underline{a}}$ ed. 92 p. ; 15x21,5 cm. ISBN: 84-8019-474-X. Depósito legal: no. (2를. ed., 2001; 3a ed., 2005). Palabras clave: fundamentos teóricos, principios técnicos, combate, guerra, estrategia, táctica. Resumen: Tratado estratégico sobre la guerra. La obra esta dividida en 13 capítulos, precedidos por un prólogo que comenta las consideraciones del autor al traducir la obra. Los siguientes 13 capítulos explican los conceptos tácticos y estratégicos más significativos de la batalla. Ofrece criterios estratégicos, explica el comportamiento en medio de una batalla, cómo planificar un asalto, las fases y ritmos de la batalla, algunos consejos prácticos sobre la preparación y el propio combate, estudia algunas de las variables y maniobras militares, el terreno, sus tipos y ventajasinconvenientes. Finaliza con las reflexiones sobre la utilización del fuego en la guerra y la utilización de los espías. Adjunta una breve biografía del autor.

1444. Krause, Donald G. (1997). El arte de la guerra para ejecutivos : el texto clásico de Sun Tzu adaptado al mundo de hoy. Madrid: Edaf. 1aㅡ ed. 142 p. ; 13x18,5 cm. ISBN: 84-414-0245-0. Depósito legal: M. 36607-1997. (16a ed., 2006, ISBN: 84-414-1820-9). Palabras clave: guerra, estrategia, táctica, gestión empresarial. Resumen: Tratado estratégico sobre la guerra aplicado al entorno empresarial. La obra esta dividida en 13 capítulos precedidos por los agradecimientos y una introducción que explica la biografía de Sun Tzu, su planteamiento estratégico, sus principios tácticos y un comentario sobre la organización de la obra. Los siguientes trece capítulos interpretan el pensamiento de Sun Tzu sobre el arte de la guerra en el entorno empresarial, detallando la planificación, los actos competitivos, la estrategia competitiva, la toma de posiciones, la oportunidad y la elección del momento, el control, la gestión del conflicto directo, la flexibilidad, las maniobras, los tipos de situaciones competitivas y las causas de los fracasos, las condiciones competitivas y la estrategia ofensiva, la destrucción de la reputación y la recogida de información a través de aforismos. Adjunta un apéndice que explica los principios de Sun Tzu para el éxito.

1445. Kung, T'ai (2004). Las seis enseñanzas secretas "para vencer sin luchar". Madrid: Librería Argentina. 1a ed. 138 p. ; 14x21 cm. ISBN: 84-89836-49-3. Depósito legal: M. 15706-2004. Palabras clave: fundamentos teóricos, táctica, combate, guerra, estrategia. Resumen: Tratado estratégico sobre la guerra. La obra esta dividida en 6 partes precedidas por un comentario sobre la importancia de la obra, el análisis de su contexto histórico, una breve biografía de su autor, la aplicación de la obra a otros campos de conocimiento, el análisis comparativo entre Sun Tzu y T'ai Kung y las notas a la presente edición. La primera parte incluye varios relatos que reflexionan sobre la dirección del estado. La segunda parte analiza las instrucciones para desarrollar una ofensiva civil y conseguir el apoyo del pueblo. La tercera parte describe la formación del ejército, la elección de los generales y cómo dirigir al ejército. La cuarta parte expone el equipamiento del ejército y las estrategias de combate mientras que la quinta parte presenta otras estrategias y tácticas de combate. La última parte analiza la utilización correcta de los medios disponibles para la guerra. Adjunta un breve comentario sobre el traductor. 
1446. Michaelson, Gerald A. (2000). Sun Tzu : el arte de la guerra para directivos. Barcelona: Gestión 2000. $1^{\text {a }}$ ed. 177 p. ; 16x23 cm. ISBN: 84-8088-401-0. Depósito legal: B. 9590-2000. (2ª ed., 2001; 3ª ed., 2003). Palabras clave: fundamentos teóricos, principios técnicos, guerra, estrategia, táctica, gestión empresarial. Resumen: Tratado estratégico sobre la guerra. El libro esta compuesto por 13 capítulos precedidos de los agradecimientos, el relato de Sun Tzu y el rey de Wu y una introducción que comenta las características de El arte de la guerra y los contenidos de la obra. Los siguientes trece capítulos presentan la traducción del libro El arte de la guerra junto con los comentarios y aplicaciones de sus principios al mundo empresarial y algunos ejemplos reales. Los trece capítulos explican los conceptos tácticos y estratégicos más significativos de la batalla, ofrecen criterios estratégicos, explican el comportamiento en medio de una batalla, como planificar un asalto, las fases y ritmos de la batalla, incluyen algunos consejos prácticos sobre la preparación y el propio combate, estudian algunas de las variables y maniobras militares, el terreno, sus tipos y ventajas-inconvenientes, y finalizan con las reflexiones sobre la utilización del fuego en la guerra y la utilización de los espías. Adjunta un apéndice con un resumen de los conceptos claves para ejecutivos, notas bibliográficas de cada capítulo y bibliografía.

1447. Michaelson, Gerald A. y Michaelson, Steven (2003). Sun Tzu para el éxito : cómo utilizar "El arte de la guerra" para superar los desafíos y conseguir los objetivos más importantes de su vida. Barcelona: Deusto. 1a ed. 247 p. ; 16x23 cm. ISBN: 84-234-2141-4. Depósito legal: B. 47086-2003. (2ª ed., 2004, 255 p., ISBN: 84-234-3511-3). Palabras clave: fundamentos teóricos, principios técnicos, guerra, estrategia, táctica, gestión empresarial. Resumen: Tratado estratégico sobre la guerra. El libro esta dividido en 2 partes precedidas por una introducción que comenta los contenidos de la obra y el relato de Sun Tzu y el rey de Wu. La primera parte consta de 13 capítulos que presentan la traducción del libro El arte de la guerra. Los trece capítulos explican los conceptos tácticos y estratégicos más significativos de la batalla, ofrecen criterios estratégicos, explican el comportamiento en medio de una batalla, como planificar un asalto, las fases y ritmos de la batalla, incluyen algunos consejos prácticos sobre la preparación y el propio combate, estudian algunas de las variables y maniobras militares, el terreno, sus tipos y ventajas-inconvenientes, y finalizan con las reflexiones sobre la utilización del fuego en la guerra y la utilización de los espías. La segunda parte consta de 5 secciones que analizan la obra de Sun Tzu y aplican sus contenidos para alcanzar el éxito personal. La primera sección analiza las características personales. La segunda sección explica las estrategias de éxito mientras que la tercera comenta las tácticas. La cuarta sección analiza las claves del éxito competitivo y sus principios de actuación. La última sección incluye el comentario sobre algunos ejemplos de éxito.

1448. Monfort, Toni (2008). L'art de la guerra. Vilafranca del Penedès: Gráficas del Foix. 1a ed. 155 p. ; 8x12,5 cm. ISBN: No ISBN. Depósito legal: B. 38920-2008. Palabras clave: guerra, estrategia, táctica, política, economía, sociedad. Resumen: Tratado estratégico sobre la guerra. La obra esta dividida en 2 partes. La primera parte incluye 3 capítulos. El primer capítulo comenta a modo de introducción los conflictos sociales y políticos actuales. El segundo capítulo analiza la noción de conflicto y guerra a lo largo de la historia. El tercer capítulo discute el modelo social y económico mundial actual. La segunda parte incluye 13 capítulos que explican los conceptos tácticos y estratégicos más significativos de la batalla. Ofrece criterios estratégicos, explica el comportamiento en medio de una batalla, cómo planificar un asalto, las fases y ritmos de la batalla, algunos consejos prácticos sobre la preparación y el propio combate, estudia algunas de las variables y maniobras militares, el terreno, sus tipos y ventajasinconvenientes. Finaliza con las reflexiones sobre la utilización del fuego en la guerra y la utilización de los espías. Adjunta las letras de las canciones que acompañan a cada uno de los capítulos.

1449. Musashi, Miyamoto (1984). Escritos sobre las cinco ruedas. Madrid: Luis Cárcamo. 1a ed. 130 p. ; $13 \times 21$ cm. ISBN: 84-85316-88-6. Depósito legal: M. 3205-1984. Palabras clave: historia, filosofía, combate, entrenamiento, biografía, estrategia, textos, samurái. Resumen: Tratado técnico y filosófico sobre el manejo de los dos sables y la estrategia del combate y/o la guerra. El libro esta dividido en seis capítulos precedidos por un prefacio que comenta las características de la traducción y una introducción que narra la biografía de Musashi, un resumen de los contenidos del libro y un análisis de la situación del libro en la historia del pensamiento japonés. El primer capítulo incluye presenta el prólogo de la obra que resume la vía y experiencia del autor. El segundo capítulo es el libro de la tierra, que explica el camino de la estrategia desde la escuela del autor. El tercer capítulo es el del agua, que muestra la esencia o aspectos técnicos y tácticos de dicha escuela. El cuarto capítulo es el del fuego y ahonda en el propio combate y su entrenamiento. El quinto capítulo es el del viento y estudia las tradiciones o formas de hacer del resto de escuelas, comparando sus conocimientos con los de la escuela del autor. Por último, el libro del vacío profundiza en los principios generales de la práctica de artes marciales y cómo se debe recorrer el camino propuesto en los libros anteriores. Adjunta un epílogo que analiza la base de la espiritualidad japonesa, resume el contexto histórico de Miyamoto Musashi y la elección del emblema nacional japonés.

1450. Musashi, Miyamoto (1987). El libro de los cinco anillos (Go Rin No Sho). Madrid: Miraguano. 1a ed. 124 p. : il. ; 11x18,5 cm. ISBN: 84-85639-85-5. Depósito legal: M. 15541-1987. (2ª ed., 1989; 3ª ed., 1992; 4ํㅜㄹ 
ed., 1997; 5a ed., 2000; 6 ed., 2004). Palabras clave: filosofía, combate, entrenamiento, estrategia, textos, samurái. Resumen: Tratado técnico y filosófico sobre el manejo de los dos sables y la estrategia del combate y/o la guerra. Está dividido en cinco capítulos, el primero de ellos es el libro de la tierra, que explica el camino de la estrategia desde la escuela del autor. El segundo libro es el del agua, que muestra la esencia o aspectos técnicos y tácticos de dicha escuela. El tercer libro es el del fuego y ahonda en el propio combate y su entrenamiento. El cuarto libro es el del viento y estudia las tradiciones o formas de hacer del resto de escuelas, comparando sus conocimientos con los de la escuela del autor. Por último, el libro del vacío profundiza en los principios generales de la práctica de artes marciales y cómo se debe recorrer el camino propuesto en los libros anteriores.

1451. Musashi, Miyamoto (1996). El libro de los cinco anillos. Móstoles: Edaf. 1a ed. 125 p. ; 11x18 cm. ISBN: 84-414-0062-8. Depósito legal: M. 13326-1996. (2ª ed., 1998; 4⿳亠丷a ed.; 1999; $6^{\underline{a}}$ ed., 2001; $8^{\mathrm{a}}$ ed., 2004; $10^{\underline{a}}$ ed., 2005; $11^{\underline{a}}$ ed., 2006; $12^{\underline{a}}$ ed.; 2007; $13^{\underline{a}}$ ed., 2008; $14^{\underline{a}}$ ed., 2008; $15^{\underline{a}}$ ed., 2009). Palabras clave: filosofía, combate, entrenamiento, estrategia, textos, samurái. Resumen: Tratado técnico y filosófico sobre el manejo de los dos sables y la estrategia del combate y/o la guerra. El libro esta formado por cinco capítulos precedidos de una introducción que comenta las características de creación y escritura de "El libro de los cinco anillos", una breve descripción histórica de los samuráis a través de sus distintas épocas y algunas notas biográficas de Miyamoto Musashi. El primer capítulo o libro es el libro de la tierra, que explica el camino de la estrategia desde la escuela del autor. El segundo libro es el del agua, que muestra la esencia o aspectos técnicos y tácticos de dicha escuela. El tercer libro es el del fuego y ahonda en el propio combate y su entrenamiento. El cuarto libro es el del viento y estudia las tradiciones o formas de hacer del resto de escuelas, comparando sus conocimientos con los de la escuela del autor. Por último, el libro del vacío profundiza en los principios generales de la práctica de artes marciales y cómo se debe recorrer el camino propuesto en los libros anteriores. Adjunta notas y bibliografía.

1452. Musashi, Miyamoto (2001). Tratado de las cinco ruedas (Gorin no Sho). Palma de Mallorca: José J. de

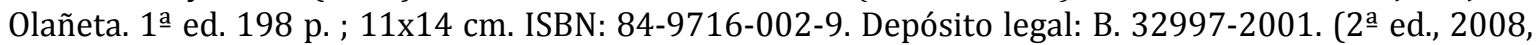
188 p., ISBN: 978-84-9716-599-0). Palabras clave: historia, filosofía, combate, entrenamiento, guerra, estrategia, táctica, textos, samurái. Resumen: Tratado teórico y filosófico sobre el manejo de los dos sables y la estrategia del combate y/o la guerra. El libro esta compuesto de 2 partes. La primera parte esta compuesta de 3 capítulos. El primer capítulo comenta la vida, combates y anécdotas de Musashi. El segundo capítulo explica la estructura del libro Gorin No Sho (tratado de las cinco ruedas) mientras que el tercero relaciona este libro con los libros complementarios titulados Kojiki y Diálogos en el sueño. La segunda parte presenta el texto de la obra Tratado de las cinco ruedas (gorin no sho), dividiendo el texto en cinco capítulos. El primero de ellos es el libro de la tierra, que explica el camino de la estrategia desde la escuela del autor. El segundo libro es el del agua, que muestra la esencia o aspectos técnicos y tácticos de dicha escuela. El tercer libro es el del fuego y ahonda en el propio combate y su entrenamiento. El cuarto libro es el del viento y estudia las tradiciones o formas de hacer del resto de escuelas, comparando sus conocimientos con los de la escuela del autor. Por último, el libro del vacío profundiza en los principios generales de la práctica de artes marciales y cómo se debe recorrer el camino propuesto en los libros anteriores. Adjunta un epílogo que analiza el objetivo filosófico de este texto, los hechos históricos que sucedieron durante su elaboración y justifica la elección del emblema nacional japonés.

1453. Musashi, Miyamoto (2002). Tratado de las cinco ruedas / El arte de la guerra. Barcelona: RBA. 1a ed. 172 p. ; $14 \times 22$ cm. ISBN: 84-473-2509-1. Depósito legal: NA. 1855-2002. Palabras clave: historia, filosofía, combate, entrenamiento, guerra, estrategia, táctica, textos, samurái. Resumen: Tratado teórico y filosófico sobre la guerra. El libro esta compuesto de 2 partes. La primera parte esta compuesta de 3 capítulos. El primer capítulo comenta la vida, combates y anécdotas de Musashi, explica la estructura del libro Gorin No Sho (tratado de las cinco ruedas) y relaciona este libro con los libros complementarios titulados Kojiki y Diálogos en el sueño. El segundo capítulo presenta el texto de la obra Tratado de las cinco ruedas mientras que el tercero, a modo de epílogo, analiza el objetivo filosófico de este texto, los hechos históricos que sucedieron durante su elaboración y justifica la elección del emblema nacional japonés. La segunda parte incluye el texto de El arte de la guerra de Sun Tzu así como los relatos de Sun Tzu y el rey de U y de su descendiente Sun Pin y Pang Tchuan.

1454. Musashi, Miyamoto (2003). El libro de los cinco anillos : versión de Norberto Tucci. Madrid: Librería Argentina. $1^{\mathrm{a}}$ ed. 92 p. : il. ; 14x21 cm. ISBN: 84-89836-41-8. Depósito legal: SE. 3048-2003. (2⿳亠口冋 ed., 2004). Palabras clave: filosofía, combate, entrenamiento, estrategia, textos, samurái. Resumen: Tratado técnico y filosófico sobre el manejo de los dos sables y la estrategia del combate y/o la guerra. Está dividido en cinco capítulos, precedidos por una introducción que resume los contenidos de la obra, una pequeña biografía del autor, su contexto histórico y algunas notas sobre la presente edición. El primer capítulo es el libro de la tierra, que explica el camino de la estrategia desde la escuela del autor. El segundo libro es el del agua, que muestra la esencia o aspectos técnicos y tácticos de dicha escuela. El tercer libro es el del fuego y ahonda en el propio combate y su entrenamiento. El cuarto 
libro es el del viento y estudia las tradiciones o formas de hacer del resto de escuelas, comparando sus conocimientos con los de la escuela del autor. Por último, el libro del vacío profundiza en los principios generales de la práctica de artes marciales y cómo se debe recorrer el camino propuesto en los libros anteriores.

1455. Musashi, Miyamoto (2005). El libro de los 5 anillos. Barcelona: Obelisco. 1aㅡ ed. 124 p. : il. ; $13 \times 21 \mathrm{~cm}$. ISBN: 84-9777-164-8. Depósito legal: B. 45169-2005. Palabras clave: filosofía, combate, entrenamiento, estrategia, textos, samurái. Resumen: Tratado técnico y filosófico sobre el manejo de los dos sables y la estrategia del combate y/o la guerra. El libro esta formado por cinco libros o capítulos precedidos por un prólogo que comenta la vida y obra de Miyamoto Musashi. El primer capítulo es el libro de la tierra, que explica el camino de la estrategia desde la escuela del autor. El segundo libro es el del agua, que muestra la esencia o aspectos técnicos y tácticos de dicha escuela. El tercer libro es el del fuego y ahonda en el propio combate, sus principios y su entrenamiento. El cuarto libro es el del viento y estudia las tradiciones o formas de hacer del resto de escuelas, comparando sus conocimientos con los de la escuela del autor. Por último, el libro del vacío profundiza en los principios generales de la práctica de artes marciales y cómo se debe recorrer el camino propuesto en los libros anteriores.

1456. Musashi, Miyamoto (2005). Escritos sobre los cinco anillos (gorin-no-sho) : estrategia del samurái. Madrid: Luis Cárcamo. 1ae ed. 147 p. ; 13x21 cm. ISBN: 84-7627-129-8. Depósito legal: B. 3777-2005. Palabras clave: guerra, estrategia, táctica. Resumen: Tratado técnico y filosófico sobre el manejo de los dos sables y la estrategia del combate y/o la guerra. El libro está dividido en cinco capítulos, precedidos por un prefacio que comenta las características de la obra y una introducción que narra la biografía de Musashi, un comentario sobre los contenidos de la obra y su importancia en la historia del pensamiento japonés. El primer capítulo es el libro de la tierra, que explica el camino de la estrategia desde la escuela del autor. El segundo capítulo es el del agua, que muestra la esencia o aspectos técnicos y tácticos de dicha escuela. El tercer capítulo es el del fuego y ahonda en el propio combate y su entrenamiento. El cuarto capítulo es el del viento y estudia las tradiciones o formas de hacer del resto de escuelas, comparando sus conocimientos con los de la escuela del autor. Por último, el capítulo del vacío profundiza en los principios generales de la práctica de artes marciales y cómo se debe recorrer el camino propuesto en los libros anteriores. Adjunta un epílogo que analiza la filosofía japonesa, el contexto histórico de la obra y la elección del emblema nacional japonés.

1457. Musashi, Miyamoto (2006). El libro de los cinco anillos ilustrado. Madrid: Edaf. 1aㅡ ed. 192 p. : il. ; 21x24 cm. ISBN: 978-84-414-1875-2. 84-414-1875-6. Depósito legal: M. 44308-2006. Palabras clave: principios técnicos, filosofía, combate, entrenamiento, estrategia, táctica, textos, maestros, samurái, fundamentos técnicos. Resumen: Tratado técnico y filosófico sobre la lucha y la estrategia del combate y/o la guerra. El libro consta de dos partes ampliamente ilustradas, precedidas por una introducción que comenta el contexto histórico de las obras presentadas, un resumen de la vida y obra de Miyamoto Musashi y Yagyu Munenori, y un comentario sobre la relación entre zen y artes marciales. La primera parte incluye la traducción de la obra de Miyamoto Musashi "El libro de los cinco anillos" dividida en cinco capítulos. El primer capítulo es el libro de la tierra, que explica el camino de la estrategia desde la escuela del autor. El segundo libro es el del agua, que muestra la esencia o aspectos técnicos y tácticos de dicha escuela. El tercer libro es el del fuego y ahonda en el propio combate y su entrenamiento. El cuarto libro es el del viento y estudia las tradiciones o formas de hacer del resto de escuelas, comparando sus conocimientos con los de la escuela del autor. Por último, el libro del vacío profundiza en los principios generales de la práctica de artes marciales y cómo se debe recorrer el camino propuesto en los libros anteriores. La segunda parte incluye la traducción de "El libro de las tradiciones familiares sobre el arte de la guerra" de Yagyu Munenori. Este libro esta dividido en 3 capítulos. El primer capítulo explica los fundamentos técnicos, tácticos y mentales del entrenamiento y la guerra, mientras que el segundo capítulo expone los principios técnicos, tácticos y mentales del combate. El tercer capítulo discute los principios filosóficos y morales del arte de la guerra. Adjunta notas, bibliografía y créditos de las ilustraciones.

1458. Nitobe, Inazo (1989). Bushido : el corazón de Japón. Barcelona: Obelisco. 1ae ed. 150 p. : il. ; 13x21 cm. ISBN: 84-7720-091-2. Depósito legal: B. 11351-1988. (2ª ed., 1995, ISBN: 84-7720-373-3; 3르 ed., 2000, ISBN: 84-7720-373-3; 4⿳亠丷厂 ed., 2002, ISBN: 84-7720-960-X; 5a ed., 2004, ISBN: 84-7720-960-X; 6르. ed., 2005, ISBN: 84-7720-960-X; 7ạ ed., 2009, ISBN: 978-84-7720-960-7). Palabras clave: educación, filosofía, ética, samurái, seppuku. Resumen: Tratado teórico y filosófico del bushido. La obra esta compuesta de 17 capítulos. Los dos primeros capítulos explican el origen de la caballería y las fuentes filosóficas y sociales que dieron lugar al bushido. A continuación profundiza en la explicación de los valores y actitudes que regían el bushido, esto es, la rectitud, el valor, la bondad, la cortesía, la sinceridad, el honor y el deber de fidelidad. Continúa con la narración del tipo de educación que recibía el samurái y el control de si mismo que tenía. Los dos siguientes capítulos detallan el significado del suicidio, de la reparación de los agravios, y del sable como el alma del samurái; para después explicar 
la condición de la mujer y su educación. Finaliza con el análisis de la influencia del bushido en el resto de la sociedad, su repercusión en la sociedad actual y su porvenir dentro de ella.

1459. Nitobe, Inazo (2002). El bushido : el alma del Japón. Exposición del pensamiento japonés. Palma de Mallorca: José J. de Olañeta. 1aㅡ ed. 181 p. : il. ; 11x14 cm. ISBN: 84-9716-023-1. Depósito legal: B. 68692002. (2 ${ }^{a}$ ed., 2006). Palabras clave: historia, filosofía, bushido. Resumen: Tratado teórico sobre el código bushido. Comienza explicando el origen y significado del bushido, para luego explicar las teorías o fuentes que impregnan este código. A partir del tercer capítulo describe el significado de ciertos valores, como la rectitud, el valor, la benevolencia, la cortesía, la veracidad y sinceridad, el honor, la lealtad, la educación y el dominio de sí mismo, que eran los principios que regían el comportamiento de los samuráis. Continúa presentando el suicidio, el desagravio y la espada, aspectos importantes dentro de la vida del samurái y teoriza sobre estos hechos tomando las ideas de grandes pensadores. Finaliza con la explicación de cuál era la formación de las mujeres, y ofrece una visión general de las relaciones entre bushido y sociedad del pasado, presente y futuro.

1460. Nitobe, Inazo (2005). Bushido : el código ético del samurái y el alma de Japón. Madrid: Miraguano. 1a ed. 294 p. : il. ; $12 \times 19$ cm. ISBN: 84-7813-293-7. Depósito legal: M. 42572-2005. Palabras clave: educación, filosofía, ética, samurái, seppuku. Resumen: Tratado teórico y filosófico del bushido. La obra esta compuesta por 17 capítulos ampliados por las notas y explicaciones del autor y traductor. Los dos primeros capítulos explican el origen de la caballería y las fuentes filosóficas y sociales que dieron lugar al bushido. A continuación profundiza en la explicación de los valores y actitudes que regían el bushido, esto es, la rectitud, el valor, la bondad, la cortesía, la sinceridad, el honor y el deber de fidelidad. Continúa con la narración del tipo de educación que recibía el samurái y el control de si mismo que tenía. Los dos siguientes capítulos detallan el significado del suicidio, de la reparación de los agravios, y del sable como el alma del samurái; para después explicar la condición de la mujer y su educación. Finaliza con el análisis de la influencia del bushido en el resto de la sociedad, su repercusión en la sociedad actual y su porvenir dentro de ella.

1461. Nitobe, Inazo (2009). Bushido : el código del honor de los samuráis. El alma del Japón. Madrid: Librería Argentina. $1^{\mathrm{a}}$ ed. 134 p. : il. ; 16x24 cm. ISBN: 978-84-85895-73-1. Depósito legal: M. 18766-2009. Palabras clave: historia, educación, filosofía, ética, samurái, seppuku. Resumen: Tratado teórico y filosófico del bushido. La obra esta compuesta dividida en dos partes. La primera parte explica el camino del do, los antecedentes históricos del bushido, comenta su significado, su contexto histórico, el significado de dicho término, la influencia de otras filosofías sobre el bushido, detalla la actitud del samurái ante el bushido, enumera los principios del bushido y comenta la biografía del autor. La segunda parte consta de 17 capítulos precedidos por una introducción que comenta el contenido de la obra. Los dos primeros capítulos explican el origen de la caballería y las fuentes filosóficas y sociales que dieron lugar al bushido. A continuación profundiza en la explicación de los valores y actitudes que regían el bushido, esto es, la rectitud, el valor, la bondad, la cortesía, la sinceridad, el honor y el deber de fidelidad. Continúa con la narración del tipo de educación que recibía el samurái y el control de si mismo que tenía. Los dos siguientes capítulos detallan el significado del suicidio, de la reparación de los agravios, y del sable como el alma del samurái; para después explicar la condición de la mujer y su educación. Finaliza con el análisis de la influencia del bushido en el resto de la sociedad, su repercusión en la sociedad actual y su porvenir dentro de ella.

1462. Ortemberg, Adriana (2004). El arte de la guerra para mujeres : milenarias armas de mujer para hacer que el enemigo se rinda a tus pies. Barcelona: Obelisco. $1^{\underline{a}}$ ed. 110 p. : il. ; 13x21 cm. ISBN: 84-9777-1540. Depósito legal: B. 48408-2004. (3a ed., 2009, ISBN: 978-84-9777-154-2). Palabras clave: guerra, estrategia, táctica, amor. Resumen: Tratado estratégico sobre la guerra. La obra esta dividida en 13 capítulos, precedidos por un prólogo que comenta la aplicación del texto clásico en el amor y una introducción que describe la vida y obra del autor, los principios fundamentales de la estrategia y sus enseñanzas esenciales. Los siguientes 13 capítulos explican los conceptos tácticos y estratégicos más significativos de la batalla, incluyendo notas explicativas de su aplicación en el amor. Ofrece criterios estratégicos, explica el comportamiento en medio de una batalla, como planificar un asalto, las fases y ritmos de la batalla, algunos consejos prácticos sobre la preparación y el propio combate, estudia algunas de las variables y maniobras militares, el terreno, sus tipos y ventajas-inconvenientes. Finaliza con las reflexiones sobre la utilización del fuego en la guerra y la utilización de los espías. Adjunta un epílogo.

1463. Oshima, Hitoshi (2007). La vía del samurái : Libro de los Cinco Anillos de Miyamoto Musashi y Hagakure de Yamamoto Tsunetomo. Madrid: La esfera de los libros. 1aㅡ ed. 420 p. : il. ; 16×24,5 cm. ISBN: 978-849734-678-8. Depósito legal: M. 44645-2007. (1a reimp., 2009). Palabras clave: textos, filosofía, combate, entrenamiento, estrategia, samurái, ética. Resumen: Tratado teórico sobre la estrategia de combate y el código samurái. El libro esta dividido en dos partes, precedidas de un prólogo que comenta la historia de las obras que incluye la biografía de sus autores y explica el significado de la palabra samurái, su aparición y contexto histórico. La primera parte incluye la traducción de la obra 
"Libro de los Cinco Anillos" junto con el manuscrito que dejo Miyamoto Musashi antes de su muerte, mientras que la segunda parte incluye la traducción de la obra "Hagakure". Adjunta bibliografía.

1464. Ramírez Bellerín, Laureano (Edición, traducción y notas) (2006). Arte de la guerra de Sunzi : versión restaurada a partir del manuscrito de Yinqueshan. Madrid: La esfera de los libros. 1aㅡ ed. 380 p. : il. ; 16x24,5 cm. ISBN: 84-9734-509-6. Depósito legal: M. 32648-2006. Palabras clave: fundamentos teóricos, combate, guerra, estrategia, táctica, textos. Resumen: Ensayo interpretativo de "El arte de la guerra". Comienza con la explicación de los datos disponibles sobre Sunzi, la obra, las distintas ediciones y su procedencia, las características de los comentadores, el contexto histórico de su creación, los principios militares sobre los que se fundamenta y cuál ha sido la metodología utilizada para crear la versión actual. A continuación se ofrece la versión de El arte de la guerra, estando cada capítulo precedido del texto original en japonés y apoyada en una multitud de notas aclaratorias. Los apéndices están dedicados a los textos apócrifos de Yinqueshan, Tongdian, otros fragmentos menores y el episodio de las concubinas según los registros históricos y según "Primaveras y otoños de Wu y Yue". Finalmente presenta los textos originales en japonés de Yinqueshan, Shiyi jia zhu Sunzi, y Sunzi bingfa. Incluye un índice onomástico.

1465. Salazar, Domingo (2003). Cómo triunfar en su vida : aplicando el arte de la guerra de Sun Tzu a Clausewitz. La estrategia de la guerra aplicada a la lucha constante que es nuestra vida. La Coruña: El arca de papel. $1^{a}$ ed. 61 p. ; 15x21,5 cm. ISBN: 84-9765-152-9. Depósito legal: AS. 4488-2003. Palabras clave: guerra, estrategia, táctica. Resumen: Tratado estratégico sobre la guerra. El libro esta compuesto por 7 capítulos. El primer capítulo explica cómo interpretar El arte de la guerra. El segundo capítulo explica la aplicación de los contenidos del libro El arte de la guerra. El tercer capítulo incluye un resumen de los trece capítulos del arte de la guerra que ofrecen criterios estratégicos, explican el comportamiento en medio de una batalla, como planificar un asalto, las fases y ritmos de la batalla, incluyen algunos consejos prácticos sobre la preparación y el propio combate, estudian algunas de las variables y maniobras militares, el terreno, sus tipos, ventajas-inconvenientes, y reflexionan sobre la utilización del fuego en la guerra y la utilización de los espías. El cuarto capítulo comenta brevemente la obra de Sun Bin y enumera sus principios estratégicos más importantes. El quinto capítulo expone la biografía de Miyamoto Musashi y comenta sus técnicas y tácticas de combate. El sexto capítulo incluye los planteamientos estratégicos de Clausewitz. El último capítulo resume los principios del combate y la guerra.

1466. Serra, Esteve (2009). Los cuarenta y siete ronin. Palma de Mallorca: José J. de Olañeta. $2^{\underline{a}}$ ed. 81 p. ; 11x14 cm. ISBN: 978-84-9716-647-8. Depósito legal: B. 34859-2009. Palabras clave: historia, relatos. Resumen: Relato de artes marciales. La obra presenta un prólogo que comenta las características del cementerio donde están enterrados los cuarenta y siete ronin. El libro narra la historia de venganza de los cuarenta y siete ronin además de explicar los contenidos de los documentos que se conservan como reliquias y una anécdota sobre la santidad de sus tumbas.

1467. Sun, Bin (1996). El arte de la guerra II : versión y comentarios de Thomas Cleary. Continuación del clásico texto de Sun Tzu. Madrid: Edaf. 1a ed. 197 p. ; 11x18 cm. ISBN: 84-414-0117-9. Depósito legal: M.

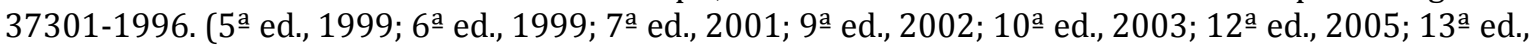

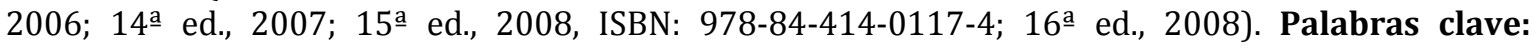
fundamentos teóricos, principios técnicos, combate, guerra, estrategia, táctica. Resumen: Tratado teórico sobre la estrategia y táctica de combate. La obra va relatando diferentes historias y reflexiones sobre situaciones de combate, decisiones tácticas y técnicas, que se deben tomar en la guerra ante determinadas situaciones. Explora algunas situaciones de combate y su forma de atacar, organizar y planificar. Adjunta reflexiones sobre el liderazgo y su importancia en las artes marciales, la organización para el combate y la estrategia necesaria para obtener la victoria.

1468. Sun, Bin (2006). El arte de la guerra II : versión y comentarios de Thomas Cleary. Continuación del clásico texto de Sun Tzu. Madrid: Edaf. 1aㅡ ed. 199 p. ; 13x21,5 cm. ISBN: 978-84-414-1756-4. 84-414-1756-3. Depósito legal: M. 6798-2006. (2ª ed., 2006; $3^{a}$ ed., 2007). Palabras clave: fundamentos teóricos, principios técnicos, combate, guerra, estrategia, táctica. Resumen: Tratado teórico sobre la estrategia y táctica de combate. La obra va relatando diferentes historias y reflexiones sobre situaciones de combate, decisiones tácticas y técnicas, que se deben tomar en la guerra ante determinadas situaciones. Explora algunas situaciones de combate y su forma de atacar, organizar y planificar. Adjunta reflexiones sobre el liderazgo y su importancia en las artes marciales, la organización para el combate y la estrategia necesaria para obtener la victoria.

1469. Sun, Tzu (1974). El arte de la guerra. Madrid: Fundamentos. $1^{\text {a }}$ ed. 164 p. ; 13x19,5 cm. ISBN: 84-2450126-8. Depósito legal: M. 24883-1974. (2 ${ }^{\underline{a}}$ ed., 1981; $4^{\underline{a}}$ ed., 1990; 7aㅡ ed., 1994; 9aㅡ ed., 1998; $10^{\underline{a}}$ ed.,

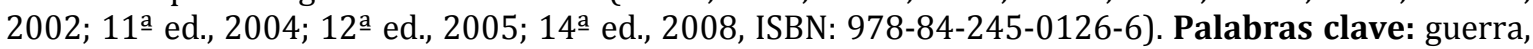
estrategia, táctica. Resumen: Tratado estratégico sobre la guerra. La obra esta dividida en 13 capítulos, precedidos por una introducción que discute la existencia del autor, analiza el contexto histórico de China y su evolución en las artes militares, y comenta la biografía y pensamiento militar de Mao Tse Tung. Los siguientes 13 capítulos explican los conceptos tácticos y estratégicos más 
significativos de la batalla, incluyendo notas aclaratorias. Ofrece criterios estratégicos, explica el comportamiento en medio de una batalla, como planificar un asalto, las fases y ritmos de la batalla, algunos consejos prácticos sobre la preparación y el propio combate, estudia algunas de las variables y maniobras militares, el terreno, sus tipos y ventajas-inconvenientes. Finaliza con las reflexiones sobre la utilización del fuego en la guerra y la utilización de los espías. Adjunta bibliografía.

1470. Sun, Tzu (1980). El arte de la guerra. Madrid: Ejército de Tierra. Estado Mayor. Servicio de Publicaciones. 1a ed. 95 p. ; 14x20 cm. ISBN: 84-500-3743-3. Depósito legal: no. Palabras clave: guerra, estrategia, táctica. Resumen: Tratado estratégico sobre la guerra. La obra esta dividida en 13 capítulos que explican los conceptos tácticos y estratégicos más significativos de la batalla. Ofrece criterios estratégicos, explica el comportamiento en medio de una batalla, cómo planificar un asalto, las fases y ritmos de la batalla, algunos consejos prácticos sobre la preparación y el propio combate, estudia algunas de las variables y maniobras militares, el terreno, sus tipos y ventajas-inconvenientes. Finaliza con las reflexiones sobre la utilización del fuego en la guerra y la utilización de los espías.

1471. Sun, Tzu (1984). El arte de la guerra. Barcelona: ATE (Mitre). 1aㅡ ed. 241 p. : il. ; $13 \times 19$ cm. ISBN: 847442-354-6. Depósito legal: B. 2820-1984. Palabras clave: historia, fundamentos teóricos, táctica, combate, guerra, estrategia, textos. Resumen: Tratado estratégico sobre la guerra. La obra esta dividida en 13 capítulos precedidos por un prólogo que compara las obras de Tzu y Clausewitz y señala sus aportaciones a la guerra; unas notas del autor sobre el contexto histórico de la presente obra, analiza sus aportaciones a la ciencia militar la época, la relación entre esta obra y los "Trece Capítulos" atribuidos a Su Machien y comenta el desarrollo del tiempo de los "Reinos Combatientes"; un estudio sobre las tácticas militares utilizadas en la época de Sun Tzu; un estudio sobre la vida y formación de Mao Tse Tung y un breve comentario sobre la biografía de Sun Tzu. Los 13 capítulos principales de la obra explican los conceptos tácticos y estratégicos más significativos de la batalla y son comentados posteriormente. Ofrece criterios estratégicos, explica el comportamiento en medio de una batalla, como planificar un asalto, las fases y ritmos de la batalla, algunos consejos prácticos sobre la preparación y el propio combate, estudia algunas de las variables y maniobras militares, el terreno, sus tipos y ventajas-inconvenientes. Finaliza con las reflexiones sobre la utilización del fuego en la guerra y la utilización de los espías. Adjunta un apéndice con la obra de Wu Chi compuesta por los capítulos de cómo se proyectan las operaciones contra los Estados, cómo juzgar al enemigo, el mando de las tropas, acerca del mando, cómo reaccionar a los cambios de circunstancias y el estímulo de los oficiales. También incluye las biografías de los comentaristas.

1472. Sun, Tzu (1988). Los trece artículos sobre el arte de la guerra. Madrid: Ministerio de Defensa. 1 a ed. 131 p. : il. ; 17x24 cm. ISBN: 84-7823-007-6. NIPO: 076-88-073-2. Depósito legal: M. 37900-1988. Palabras clave: guerra, estrategia, táctica. Resumen: Tratado estratégico sobre la guerra. La obra esta dividida en 13 capítulos, precedidos por una nota preliminar que explica la relevancia e interés de la obra, dos poemas de Tchung Tchang-Tung y un comentario sobre la vida de Sun Tse. Los siguientes 13 capítulos explican los conceptos tácticos y estratégicos más significativos de la batalla. Ofrece criterios estratégicos, explica el comportamiento en medio de una batalla, como planificar un asalto, las fases y ritmos de la batalla, algunos consejos prácticos sobre la preparación y el propio combate, estudia algunas de las variables y maniobras militares, el terreno, sus tipos y ventajas-inconvenientes. Finaliza con las reflexiones sobre la utilización del fuego en la guerra y la utilización de los espías.

1473. Sun, Tzu (1992). El arte de la guerra. Madrid: Andersen Consulting. $1^{\underline{a}}$ ed. 117 p. : il. ; $25 \times 26$ cm. ISBN: No ISBN. Depósito legal: no. Palabras clave: guerra, estrategia, táctica. Resumen: Tratado estratégico sobre la guerra. La obra esta dividida en 13 capítulos que explican los conceptos tácticos y estratégicos más significativos de la batalla. Ofrece criterios estratégicos, explica el comportamiento en medio de una batalla, cómo planificar un asalto, las fases y ritmos de la batalla, algunos consejos prácticos sobre la preparación y el propio combate, estudia algunas de las variables y maniobras militares, el terreno, sus tipos y ventajas-inconvenientes. Finaliza con las reflexiones sobre la utilización del fuego en la guerra y la utilización de los espías.

1474. Sun, Tzu (1992). El arte de la guerra. Madrid: Artes Gráficas Clarión. $1^{a}$ ed. 117 p. : il. ; desc.xdesc. cm. ISBN: No ISBN. Depósito legal: no. Palabras clave: guerra, estrategia, táctica. Resumen: Tratado estratégico sobre la guerra. La obra esta dividida en 13 capítulos que explican los conceptos tácticos y estratégicos más significativos de la batalla. Ofrece criterios estratégicos, explica el comportamiento en medio de una batalla, cómo planificar un asalto, las fases y ritmos de la batalla, algunos consejos prácticos sobre la preparación y el propio combate, estudia algunas de las variables y maniobras militares, el terreno, sus tipos y ventajas-inconvenientes. Finaliza con las reflexiones sobre la utilización del fuego en la guerra y la utilización de los espías.

1475. Sun, Tzu (1993). El arte de la guerra : versión de Thomas Cleary. Madrid: Edaf. $1^{\mathrm{a}}$ ed. 125 p. ; 11x18 cm.

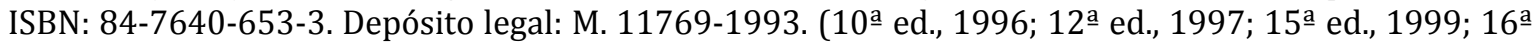
ed., 1999; $17^{\underline{a}}$ ed., 1999; $20^{\underline{a}}$ ed., 2001; $21^{\underline{a}}$ ed., 2001; $22^{\underline{a}}$ ed., 2001; $23^{\underline{a}}$ ed., 2002; $24^{\underline{a}}$ ed., 2002; $25^{\underline{a}}$

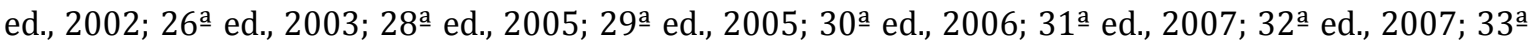

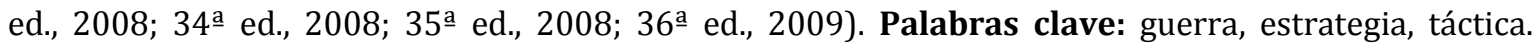


Resumen: Tratado estratégico sobre la guerra. La obra esta dividida en 13 capítulos, que explican los conceptos tácticos y estratégicos más significativos de la batalla y son comentados posteriormente. Ofrece criterios estratégicos, explica el comportamiento en medio de una batalla, como planificar un asalto, las fases y ritmos de la batalla, algunos consejos prácticos sobre la preparación y el propio combate, estudia algunas de las variables y maniobras militares, el terreno, sus tipos y ventajasinconvenientes. Finaliza con las reflexiones sobre la utilización del fuego en la guerra y la utilización de los espías.

1476. Sun, Tzu (1993). El arte de la guerra : versión de Thomas Cleary. Madrid: Tiempo. $1^{a}$ ed. 96 p. ; 12x20,5 cm. ISBN: 84-8130-025-X. Depósito legal: B. 26342-1993. (17a ed., 1999). Palabras clave: guerra, estrategia, táctica. Resumen: Tratado estratégico sobre la guerra. La obra esta dividida en 13 capítulos, que explican los conceptos tácticos y estratégicos más significativos de la batalla y son comentados posteriormente. Ofrece criterios estratégicos, explica el comportamiento en medio de una batalla, como planificar un asalto, las fases y ritmos de la batalla, algunos consejos prácticos sobre la preparación y el propio combate, estudia algunas de las variables y maniobras militares, el terreno, sus tipos y ventajas-inconvenientes. Finaliza con las reflexiones sobre la utilización del fuego en la guerra y la utilización de los espías.

1477. Sun, Tzu (1995). Gerraren antzea. Tafalla: Txalaparta. 1a ed. 113 p. ; $12 x 19$ cm. ISBN: 84-8136-014-7. Depósito legal: NA. 1437-1995. Palabras clave: guerra, estrategia, táctica. Resumen: Tratado estratégico sobre la guerra. La obra esta dividida en 13 capítulos, precedidos por el relato de Sun Tzu y el rey de $\mathrm{Wu}$. Los siguientes 13 capítulos explican los conceptos tácticos y estratégicos más significativos de la batalla, incluyendo notas aclaratorias. Ofrece criterios estratégicos, explica el comportamiento en medio de una batalla, como planificar un asalto, las fases y ritmos de la batalla, algunos consejos prácticos sobre la preparación y el propio combate, estudia algunas de las variables y maniobras militares, el terreno, sus tipos y ventajas-inconvenientes. Finaliza con las reflexiones sobre la utilización del fuego en la guerra y la utilización de los espías. Adjunta bibliografía.

1478. Sun, Tzu (1996). El arte de la guerra. Madrid: Eyras. $1^{a}$ ed. 180 p. : il. ; desc.xdesc. cm. ISBN: 84-8526984-5. Depósito legal: no. Palabras clave: guerra, estrategia, táctica. Resumen: Tratado estratégico sobre la guerra. La obra esta dividida en 13 capítulos precedidos por un prólogo que comenta los objetivos y metodología utilizada en la traducción de la obra y una introducción que interpreta los contenidos del libro. Los siguientes trece capítulos explican y comentan los conceptos tácticos y estratégicos más significativos de la batalla y son comentados posteriormente. Ofrece criterios estratégicos, explica el comportamiento en medio de una batalla, como planificar un asalto, las fases y ritmos de la batalla, algunos consejos prácticos sobre la preparación y el propio combate, estudia algunas de las variables y maniobras militares, el terreno, sus tipos y ventajas-inconvenientes. Finaliza con las reflexiones sobre la utilización del fuego en la guerra y la utilización de los espías.

1479. Sun, Tzu (1999). El arte de la guerra. Barcelona: Edicomunicación. 1aㅡ ed. 185 p. ; 11x18 cm. ISBN: 847672-877-8. Depósito legal: B. 36407-1999. Palabras clave: guerra, estrategia, táctica. Resumen: Tratado estratégico sobre la guerra. La obra esta dividida en 14 capítulos precedidos por un estudio preliminar comenta el contexto histórico de la obra, su traducción en distintos países y la importancia de sus aportaciones. El primer capítulo narra la anécdota de Sun Tzu con el rey de Wu. Los siguientes 13 capítulos explican los conceptos tácticos y estratégicos más significativos de la batalla y son comentados posteriormente. Ofrece criterios estratégicos, explica el comportamiento en medio de una batalla, como planificar un asalto, las fases y ritmos de la batalla, algunos consejos prácticos sobre la preparación y el propio combate, estudia algunas de las variables y maniobras militares, el terreno, sus tipos y ventajas-inconvenientes. Finaliza con las reflexiones sobre la utilización del fuego en la guerra y la utilización de los espías.

1480. Sun, Tzu (1999). El arte de la guerra : edición de José Ramón Ayllón. Barcelona: Martínez Roca. 1ạ ed. 188 p. ; 13x18,5 cm. ISBN: 84-270-2499-1. Depósito legal: B. 45491-1999. (2 $2^{\underline{a}}$ ed., 2002; $5^{\mathrm{a}}$ ed., 2004;

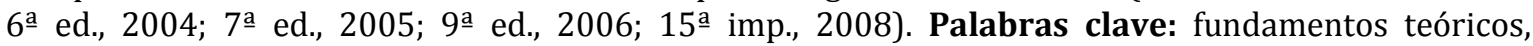
principios técnicos, combate, guerra, estrategia, táctica. Resumen: Tratado estratégico sobre la guerra. La obra esta dividida en 13 capítulos, precedidos por una introducción que comenta las características de la obra y compara a Sun Tzu con Homero, Jenofonte y Julio César. La parte principal de la obra explica los conceptos tácticos y estratégicos más significativos de la batalla y son comentados posteriormente. Ofrece criterios estratégicos, explica el comportamiento en medio de una batalla, como planificar un asalto, las fases y ritmos de la batalla, algunos consejos prácticos sobre la preparación y el propio combate, estudia algunas de las variables y maniobras militares, el terreno, sus tipos y ventajas-inconvenientes. Finaliza con las reflexiones sobre la utilización del fuego en la guerra y la utilización de los espías.

1481. Sun, Tzu (1999). El arte de la guerra ilustrado : versión de Thomas Cleary. Madrid: Edaf. $1^{a}$ ed. 223 p. : il. ; 21x24 cm. ISBN: 84-414-0642-1. Depósito legal: M. 37960-1999. (3a ed., 2001; 4⿳亠丷厂 ed., 2001; $5^{a}$ ed., 2002; 7a ed., 2003; $8^{\underline{a}}$ ed., 2004; $10^{\underline{a}}$ ed., 2005; $11^{\underline{a}}$ ed., 2006; $12^{\underline{a}}$ ed., 2007; $13^{\underline{a}}$ ed., 2008, ISBN: $978-$ 84-414-0642-1). Palabras clave: fundamentos teóricos, táctica, combate, guerra, estrategia. 
Resumen: Tratado estratégico sobre la guerra. La obra esta dividida en 13 capítulos, precedidos por una introducción que comenta la relación entre el taoísmo y el arte de la guerra, analiza la estructura y contenido de la obra, relata sus antecedentes históricos, analiza los comentarios seleccionados para la traducción y la metodología utilizada. La parte principal de la obra explica y comenta los conceptos tácticos y estratégicos más significativos de la batalla, incluyendo ilustraciones en color sobre diversos aspectos militares chinos. Ofrece criterios estratégicos, explica el comportamiento en medio de una batalla, como planificar un asalto, las fases y ritmos de la batalla, algunos consejos prácticos sobre la preparación y el propio combate, estudia algunas de las variables y maniobras militares, el terreno, sus tipos y ventajas-inconvenientes. Finaliza con las reflexiones sobre la utilización del fuego en la guerra y la utilización de los espías.

1482. Sun, Tzu (2000). El arte de la guerra : los trece artículos. Palma de Mallorca: José J. de Olañeta. 1a ed. 176 p. ; 11x14 cm. ISBN: 84-7651-807-2. Depósito legal: B. 273-2000. (2ª ed., 2005). Palabras clave: guerra, estrategia, táctica. Resumen: Tratado estratégico sobre la guerra. La obra esta dividida en 13 capítulos, que explican los conceptos tácticos y estratégicos más significativos de la batalla. Ofrece criterios estratégicos, explica el comportamiento en medio de una batalla, cómo planificar un asalto, las fases y ritmos de la batalla, algunos consejos prácticos sobre la preparación y el propio combate, estudia algunas de las variables y maniobras militares, el terreno, sus tipos y ventajas-inconvenientes. Finaliza con las reflexiones sobre la utilización del fuego en la guerra y la utilización de los espías. Adjunta un apéndice que relata la anécdota de Sun Tzu y el rey de U.

1483. Sun, Tzu (2000). L'art de la guerra : els tretze articles. Palma de Mallorca: José J. de Olañeta. 1a ed. 176 p. ; 11x14 cm. ISBN: 84-7651-811-0. Depósito legal: B. 279-2000. Palabras clave: guerra, estrategia, táctica. Resumen: Tratado estratégico sobre la guerra. La obra esta dividida en 13 capítulos, que explican los conceptos tácticos y estratégicos más significativos de la batalla. Ofrece criterios estratégicos, explica el comportamiento en medio de una batalla, cómo planificar un asalto, las fases y ritmos de la batalla, algunos consejos prácticos sobre la preparación y el propio combate, estudia algunas de las variables y maniobras militares, el terreno, sus tipos y ventajas-inconvenientes. Finaliza con las reflexiones sobre la utilización del fuego en la guerra y la utilización de los espías. Adjunta un apéndice que relata la anécdota de Sun Tzu y el rey de U.

1484. Sun, Tzu (2001). El arte de la guerra. Madrid: Eyras y Budo International Publising. 1aㅡ ed. 128 p. : il. ; 17x24,5 cm. ISBN: 84-85269-87-X. Depósito legal: M. 15299-2001. Palabras clave: guerra, estrategia, táctica. Resumen: Tratado estratégico sobre la guerra. La obra esta dividida en 13 capítulos precedidos por un prólogo que comenta los objetivos y metodología utilizada en la traducción de la obra y una introducción que interpreta los contenidos del libro. Los siguientes trece capítulos explican y comentan los conceptos tácticos y estratégicos más significativos de la batalla y son comentados posteriormente. Ofrece criterios estratégicos, explica el comportamiento en medio de una batalla, como planificar un asalto, las fases y ritmos de la batalla, algunos consejos prácticos sobre la preparación y el propio combate, estudia algunas de las variables y maniobras militares, el terreno, sus tipos y ventajas-inconvenientes. Finaliza con las reflexiones sobre la utilización del fuego en la guerra y la utilización de los espías.

1485. Sun, Tzu (2001). El arte de la guerra : versión, estudio y notas del Grupo Denma. Madrid: Edaf. 1a ed. 260

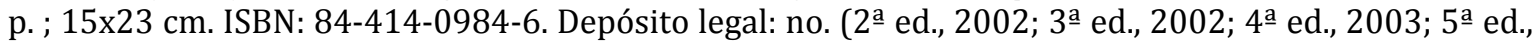
2004; 8a ed., 2005; 9a ed., 2006). Palabras clave: guerra, estrategia, táctica. Resumen: Tratado estratégico sobre la guerra. La obra esta dividida en 3 partes, precedidas por una introducción que resalta los contenidos y aplicaciones de la obra, además de ofrecer consejos para su lectura. La primera parte incluye la traducción de los 13 capítulos que componen "el arte de la guerra" y que explican los conceptos tácticos y estratégicos más significativos de la batalla como son los criterios estratégicos, el comportamiento en medio de una batalla, cómo planificar un asalto, las fases y ritmos de la batalla, los consejos prácticos sobre la preparación y el propio combate, el estudio de las variables y maniobras militares, el terreno, sus tipos y ventajas-inconvenientes, la utilización del fuego en la guerra y la utilización de los espías. La segunda parte presenta tres ensayos que profundizan en el análisis de la obra, explicando la visión del mundo como una totalidad, las características y papel del general, y el contexto histórico donde se originó esta obra. La tercera parte comenta cada uno de los capítulos de la traducción. Adjunta apéndices sobre la traducción del texto, la presentación de una página-web donde continuar la discusión sobre la obra, los datos del grupo de traducción y agradecimientos.

1486. Sun, Tzu (2002). El arte de la guerra. Madrid: Librería Argentina. 1aㅡ ed. 126 p. ; $12 \times 17$ cm. ISBN: 8489836-16-7. Depósito legal: no. Palabras clave: guerra, estrategia, táctica. Resumen: Tratado estratégico sobre la guerra. La obra esta dividida en 13 capítulos, precedidos por una introducción que presenta el contexto histórico de la obra, la metodología utilizada para la traducción y los objetivos de la obra. Los siguientes 13 capítulos explican los conceptos tácticos y estratégicos más significativos de la batalla incluyendo los comentarios del traductor a cada párrafo. Ofrece criterios estratégicos, explica el comportamiento en medio de una batalla, como planificar un asalto, las fases y ritmos de la batalla, algunos consejos prácticos sobre la preparación y el propio combate, estudia algunas de las variables y 
maniobras militares, el terreno, sus tipos y ventajas-inconvenientes. Finaliza con las reflexiones sobre la utilización del fuego en la guerra y la utilización de los espías. Adjunta una breve biografía del traductor.

1487. Sun, Tzu (2003). El arte de la guerra. Madrid: Librería Argentina. 1a ed. ; $1^{\mathrm{a}}$ imp. 97 p. ; $14 \times 21 \mathrm{~cm}$. ISBN: 84-89836-38-8. Depósito legal: no. (3ª ed., 2004). Palabras clave: guerra, estrategia, táctica. Resumen: Tratado estratégico sobre la guerra. La obra esta dividida en 13 capítulos, precedidos por una introducción que presenta el contexto histórico de la obra, la metodología utilizada para la traducción y los objetivos de la obra. Los siguientes 13 capítulos explican los conceptos tácticos y estratégicos más significativos de la batalla incluyendo los comentarios del traductor a cada párrafo. Ofrece criterios estratégicos, explica el comportamiento en medio de una batalla, como planificar un asalto, las fases y ritmos de la batalla, algunos consejos prácticos sobre la preparación y el propio combate, estudia algunas de las variables y maniobras militares, el terreno, sus tipos y ventajasinconvenientes. Finaliza con las reflexiones sobre la utilización del fuego en la guerra y la utilización de los espías. Adjunta una breve biografía del traductor.

1488. Sun, Tzu (2003). El arte de la guerra. Madrid: Planeta DeAgostini. 1a ed. 188 p. ; 13x20 cm. ISBN: 84674-0458-2. Depósito legal: no. Palabras clave: guerra, estrategia, táctica. Resumen: Tratado estratégico sobre la guerra. La obra esta dividida en 13 capítulos que explican los conceptos tácticos y estratégicos más significativos de la batalla. Ofrece criterios estratégicos, explica el comportamiento en medio de una batalla, cómo planificar un asalto, las fases y ritmos de la batalla, algunos consejos prácticos sobre la preparación y el propio combate, estudia algunas de las variables y maniobras militares, el terreno, sus tipos y ventajas-inconvenientes. Finaliza con las reflexiones sobre la utilización del fuego en la guerra y la utilización de los espías.

1489. Sun, Tzu (2004). El arte de la guerra : versión, estudio y notas del Grupo Denma. Madrid: Edaf. 1a ed. 194 p. ; $13 \times 17$ cm. ISBN: 84-414-1469-6. Depósito legal: no. (2ª ed., 2009, ISBN: 978-84-414-1469-3). Palabras clave: guerra, estrategia, táctica. Resumen: Tratado estratégico sobre la guerra. La obra esta dividida en 2 partes, precedidas por una introducción que resalta los contenidos y aplicaciones de la obra, además de ofrecer consejos para su lectura. La primera parte incluye la traducción de los 13 capítulos que componen "el arte de la guerra" y que explican los conceptos tácticos y estratégicos más significativos de la batalla como son los criterios estratégicos, el comportamiento en medio de una batalla, cómo planificar un asalto, las fases y ritmos de la batalla, los consejos prácticos sobre la preparación y el propio combate, el estudio de las variables y maniobras militares, el terreno, sus tipos y ventajas-inconvenientes, la utilización del fuego en la guerra y la utilización de los espías. La segunda parte presenta tres ensayos que profundizan en el análisis de la obra, explicando la visión del mundo como una totalidad, las características y papel del general, y el contexto histórico donde se originó esta obra. Adjunta apéndices sobre la traducción del texto, la presentación de una página-web donde continuar la discusión sobre la obra, los datos del grupo de traducción y agradecimientos.

1490. Sun, Tzu (2005). El arte de la guerra. Barcelona: Salvat. 1a ed. 223 p. ; 12x21 cm. ISBN: 84-471-0239-4. 84-471-0224-6 (ISBN colección completa). Depósito legal: B. 38953-2005. Palabras clave: guerra, estrategia, táctica. Resumen: Tratado estratégico sobre la guerra. La obra esta dividida en 3 partes, precedidas por una introducción resalta los contenidos y aplicaciones de la obra, además de ofrecer consejos para su lectura. La primera parte incluye la traducción de los 13 capítulos que componen "el arte de la guerra" y que explican los conceptos tácticos y estratégicos más significativos de la batalla como son los criterios estratégicos, el comportamiento en medio de una batalla, cómo planificar un asalto, las fases y ritmos de la batalla, los consejos prácticos sobre la preparación y el propio combate, el estudio de las variables y maniobras militares, el terreno, sus tipos y ventajas-inconvenientes, la utilización del fuego en la guerra y la utilización de los espías. La segunda parte presenta tres ensayos que profundizan en el análisis de la obra, explicando la visión del mundo como una totalidad, las características y papel del general, y el contexto histórico donde se originó esta obra. La tercera parte comenta cada uno de los capítulos de la traducción. Adjunta apéndices sobre la traducción del texto, la presentación de una página-web donde continuar la discusión sobre la obra, los datos del grupo de traducción y agradecimientos.

1491. Sun, Tzu (2006). El arte de la guerra : versión y comentarios de Thomas Cleary. Madrid: Edaf. 1a ed. 157 p. ; 13x21,5 cm. ISBN: 84-414-1755-5. Depósito legal: M. 6797-2006. (2ª ed., 2006, ISBN: 978-84-4141755-7; 5a ed., 2008, ISBN: 978-84-414-1755-7). Palabras clave: guerra, estrategia, táctica. Resumen: Tratado estratégico sobre la guerra. La obra esta dividida en 13 capítulos, precedidos por un prefacio que explica la aplicación de la obra al mundo actual y una introducción que comenta el objetivo final de la obra. Los siguientes 13 capítulos explican los conceptos tácticos y estratégicos más significativos de la batalla, incluyendo comentarios aclaratorios. Ofrece criterios estratégicos, explica el comportamiento en medio de una batalla, como planificar un asalto, las fases y ritmos de la batalla, algunos consejos prácticos sobre la preparación y el propio combate, estudia algunas de las variables y maniobras militares, el terreno, sus tipos y ventajas-inconvenientes. Finaliza con las reflexiones sobre la utilización del fuego en la guerra y la utilización de los espías. 
1492. Sun, Tzu (2007). El arte de la guerra. Madrid: B.O. \& G. $1^{\text {a }}$ ed. 119 p. ; $10 x 17$ cm. ISBN: 978-84-9360101-0. Depósito legal: M. 39964-2007. Palabras clave: guerra, estrategia, táctica. Resumen: Tratado estratégico sobre la guerra. La obra esta dividida en 13 capítulos, precedidos por un breve comentario de los novios, un prólogo sobre el contenido e influencia de la obra y una introducción que comenta la historia del autor, la obra y la influencia de sus ideas hasta la actualidad. Los siguientes 13 capítulos explican los conceptos tácticos y estratégicos más significativos de la batalla, incluyendo notas aclaratorias. Ofrece criterios estratégicos, explica el comportamiento en medio de una batalla, como planificar un asalto, las fases y ritmos de la batalla, algunos consejos prácticos sobre la preparación y el propio combate, estudia algunas de las variables y maniobras militares, el terreno, sus tipos y ventajasinconvenientes. Finaliza con las reflexiones sobre la utilización del fuego en la guerra y la utilización de los espías. Adjunta bibliografía.

1493. Sun, Tzu (2007). El arte de la guerra. Sant Boi de Llobregat: Tayrona. 1aㅡ ed. 259 p. : il. ; $13 \times 20,5$ cm. ISBN: 978-84-8418-331-0. Depósito legal: no. Palabras clave: biografía, guerra, estrategia, táctica. Resumen: Tratado estratégico sobre la guerra. La obra esta dividida en 4 partes, precedidos por dos prólogos que comentan las características e importancia de la obra, los agradecimientos y una lista de abreviaturas utilizadas. La primera parte comenta la biografía del autor y su contexto histórico, analiza las características del texto, describe el periodo de los estados combatientes, explica las tácticas de guerra en la época de Sun Tzu, comenta las ideas principales de Sun Tzu sobre la guerra y compara a Sun Tzu con Mao Tse-Tung. La segunda parte narra la historia de Sun Tzu con el rey de Wu e incluye los 13 capítulos traducidos y comentados de "El arte de la guerra", que explican los conceptos tácticos y estratégicos más significativos de la batalla, como los criterios estratégicos, el comportamiento en medio de una batalla, cómo planificar un asalto, las fases y ritmos de la batalla, consejos prácticos sobre la preparación y el propio combate, estudia las variables y maniobras militares, el terreno, sus tipos y ventajas-inconvenientes, finalizando con las reflexiones sobre la utilización del fuego en la guerra y la utilización de los espías. La tercera parte incluye cuatro apéndices sobre el arte de la guerra de Wu Chi, un análisis de la influencia de Sun Tzu sobre el pensamiento militar japonés, un comentario sobre las principales traducciones de El arte de la guerra en Occidente y una breve biografía de los comentaristas. La cuarta parte presenta la bibliografía utilizada.

1494. Sun, Tzu (2007). El arte de la guerra : traducción y comentarios de Norberto Tucci. Madrid: Librería Argentina. $1^{\text {a }}$ ed. 141 p. : il. ; 17x24 cm. ISBN: 978-84-85895-35-9. Depósito legal: M. 38816-2007. Palabras clave: guerra, estrategia, táctica. Resumen: Tratado estratégico sobre la guerra. La obra esta dividida en 13 capítulos, precedidos por una introducción que presenta el contexto histórico de la obra, la metodología utilizada para la traducción y los objetivos de la obra. Los siguientes 13 capítulos explican los conceptos tácticos y estratégicos más significativos de la batalla incluyendo los comentarios del traductor a cada párrafo. Ofrece criterios estratégicos, explica el comportamiento en medio de una batalla, como planificar un asalto, las fases y ritmos de la batalla, algunos consejos prácticos sobre la preparación y el propio combate, estudia algunas de las variables y maniobras militares, el terreno, sus tipos y ventajas-inconvenientes. Finaliza con las reflexiones sobre la utilización del fuego en la guerra y la utilización de los espías. Incluye fotografías a color durante el texto. Adjunta una breve biografía del traductor.

1495. Sun, Tzu (2008). El arte de la guerra. s.l.: Adeire Publicaciones. 1a ed. 162 p. ; $17 x 21$ cm. ISBN: 978-84935096-9-9. Depósito legal: no. Palabras clave: guerra, estrategia, táctica. Resumen: Tratado estratégico sobre la guerra. La obra esta dividida en 13 capítulos que explican los conceptos tácticos y estratégicos más significativos de la batalla. Ofrece criterios estratégicos, explica el comportamiento en medio de una batalla, cómo planificar un asalto, las fases y ritmos de la batalla, algunos consejos prácticos sobre la preparación y el propio combate, estudia algunas de las variables y maniobras militares, el terreno, sus tipos y ventajas-inconvenientes. Finaliza con las reflexiones sobre la utilización del fuego en la guerra y la utilización de los espías.

1496. Sun, Tzu (2008). El arte de la guerra. Madrid: B.O. \& G. 1aㅡ ed. 80 p. : il. ; $11 \times 17$ cm. ISBN: 978-84-6115773-0. 84-611-5773-7. Depósito legal: no. Palabras clave: guerra, estrategia, táctica. Resumen: Tratado estratégico sobre la guerra. La obra esta dividida en 13 capítulos, precedidos por un breve comentario de los novios, un prólogo sobre el contenido e influencia de la obra y una introducción que comenta la historia del autor, la obra y la influencia de sus ideas hasta la actualidad. Los siguientes 13 capítulos explican los conceptos tácticos y estratégicos más significativos de la batalla, incluyendo notas aclaratorias. Ofrece criterios estratégicos, explica el comportamiento en medio de una batalla, como planificar un asalto, las fases y ritmos de la batalla, algunos consejos prácticos sobre la preparación y el propio combate, estudia algunas de las variables y maniobras militares, el terreno, sus tipos y ventajas-inconvenientes. Finaliza con las reflexiones sobre la utilización del fuego en la guerra y la utilización de los espías. Adjunta bibliografía.

1497. Sun, Tzu (2008). El arte de la guerra. Madrid: Vision Libros. 1aㅡ ed. 116 p. ; $11 \times 17$ cm. ISBN: 978-849886-124-2. Depósito legal: no. Palabras clave: guerra, estrategia, táctica. Resumen: Tratado estratégico sobre la guerra. La obra esta dividida en 13 capítulos que explican los conceptos tácticos y 
estratégicos más significativos de la batalla. Ofrece criterios estratégicos, explica el comportamiento en medio de una batalla, cómo planificar un asalto, las fases y ritmos de la batalla, algunos consejos prácticos sobre la preparación y el propio combate, estudia algunas de las variables y maniobras militares, el terreno, sus tipos y ventajas-inconvenientes. Finaliza con las reflexiones sobre la utilización del fuego en la guerra y la utilización de los espías.

1498. Sun, Tzu (2008). El arte de la guerra. Madrid: Vision Libros. 1a ed. 116 p. ; $11 \times 17$ cm. ISBN: 978-849886-101-3. Depósito legal: no. Palabras clave: guerra, estrategia, táctica. Resumen: Tratado estratégico sobre la guerra. La obra esta dividida en 13 capítulos que explican los conceptos tácticos y estratégicos más significativos de la batalla. Ofrece criterios estratégicos, explica el comportamiento en medio de una batalla, cómo planificar un asalto, las fases y ritmos de la batalla, algunos consejos prácticos sobre la preparación y el propio combate, estudia algunas de las variables y maniobras militares, el terreno, sus tipos y ventajas-inconvenientes. Finaliza con las reflexiones sobre la utilización del fuego en la guerra y la utilización de los espías.

1499. Sun, Tzu (2009). El arte de la guerra. s.l.: Brontes. 1르 ed. 190 p. ; $12 \times 18$ cm. ISBN: 978-84-96975-33-0. Depósito legal: no. Palabras clave: guerra, estrategia, táctica. Resumen: Tratado estratégico sobre la guerra. La obra esta dividida en 13 capítulos que explican los conceptos tácticos y estratégicos más significativos de la batalla. Ofrece criterios estratégicos, explica el comportamiento en medio de una batalla, cómo planificar un asalto, las fases y ritmos de la batalla, algunos consejos prácticos sobre la preparación y el propio combate, estudia algunas de las variables y maniobras militares, el terreno, sus tipos y ventajas-inconvenientes. Finaliza con las reflexiones sobre la utilización del fuego en la guerra y la utilización de los espías.

1500. Sun, Tzu (2009). El arte de la guerra. Madrid: Edaf. 1a ed. 200 p. ; 13x19,5 cm. ISBN: 978-84-414-21332. Depósito legal: no. (2 $2^{\mathrm{a}}$ ed., 2009). Palabras clave: guerra, estrategia, táctica. Resumen: Tratado estratégico sobre la guerra. La obra esta dividida en 13 capítulos, precedidos por un prefacio que explica la aplicación de la obra al mundo actual y una introducción que comenta el objetivo final de la obra. Los siguientes 13 capítulos explican los conceptos tácticos y estratégicos más significativos de la batalla, incluyendo comentarios aclaratorios. Ofrece criterios estratégicos, explica el comportamiento en medio de una batalla, como planificar un asalto, las fases y ritmos de la batalla, algunos consejos prácticos sobre la preparación y el propio combate, estudia algunas de las variables y maniobras militares, el terreno, sus tipos y ventajas-inconvenientes. Finaliza con las reflexiones sobre la utilización del fuego en la guerra y la utilización de los espías.

1501. Sun, Tzu (2009). El arte de la guerra. s.l.: Gaia Ediciones. 1aㅡ ed. desc.; desc.xdesc. cm. ISBN: 978-848445-271-3. Depósito legal: no. Palabras clave: guerra, estrategia, táctica. Resumen: Tratado estratégico sobre la guerra. La obra esta dividida en 13 capítulos que explican los conceptos tácticos y estratégicos más significativos de la batalla. Ofrece criterios estratégicos, explica el comportamiento en medio de una batalla, cómo planificar un asalto, las fases y ritmos de la batalla, algunos consejos prácticos sobre la preparación y el propio combate, estudia algunas de las variables y maniobras militares, el terreno, sus tipos y ventajas-inconvenientes. Finaliza con las reflexiones sobre la utilización del fuego en la guerra y la utilización de los espías.

1502. Sun, Tzu (2009). El arte de la guerra. Barcelona: Obelisco. $1^{\underline{a}}$ ed. ; $2^{\underline{a}}$ imp. desc.; $13 \times 19$ cm. ISBN: 97884-9777-531-1. Depósito legal: no. Palabras clave: guerra, estrategia, táctica. Resumen: Tratado estratégico sobre la guerra. La obra esta dividida en 13 capítulos que explican los conceptos tácticos y estratégicos más significativos de la batalla. Ofrece criterios estratégicos, explica el comportamiento en medio de una batalla, cómo planificar un asalto, las fases y ritmos de la batalla, algunos consejos prácticos sobre la preparación y el propio combate, estudia algunas de las variables y maniobras militares, el terreno, sus tipos y ventajas-inconvenientes. Finaliza con las reflexiones sobre la utilización del fuego en la guerra y la utilización de los espías.

1503. Sun, Tzu (2009). El arte de la guerra. Madrid: Popular. $1^{a}$ ed. 134 p. : il. ; desc.xdesc. cm. ISBN: 978-847884-430-2. Depósito legal: no. Palabras clave: guerra, estrategia, táctica. Resumen: Tratado estratégico sobre la guerra. La obra esta dividida en 13 capítulos que explican los conceptos tácticos y estratégicos más significativos de la batalla. Ofrece criterios estratégicos, explica el comportamiento en medio de una batalla, cómo planificar un asalto, las fases y ritmos de la batalla, algunos consejos prácticos sobre la preparación y el propio combate, estudia algunas de las variables y maniobras militares, el terreno, sus tipos y ventajas-inconvenientes. Finaliza con las reflexiones sobre la utilización del fuego en la guerra y la utilización de los espías.

1504. Sun, Tzu (2009). El arte de la guerra de Sunzi : versión restaurada a partir del manuscrito de Yinqueshan. Madrid: La esfera de los libros. 1를 ed. 384 p. : il. ; 16x24 cm. ISBN: 978-84-9734-820-1. Depósito legal: no. Palabras clave: fundamentos teóricos, combate, guerra, estrategia, táctica, textos. Resumen: Ensayo interpretativo de "El arte de la guerra". Comienza con la explicación de los datos disponibles sobre Sunzi, la obra, las distintas ediciones y su procedencia, las características de los comentadores, el contexto histórico de su creación, los principios militares sobre los que se fundamenta y cuál ha sido la metodología utilizada para crear la versión actual. A continuación se 
ofrece la versión de El arte de la guerra, estando cada capítulo precedido del texto original en japonés y apoyada en una multitud de notas aclaratorias. Los apéndices están dedicados a los textos apócrifos de Yinqueshan, Tongdian, otros fragmentos menores y el episodio de las concubinas según los registros históricos y según "Primaveras y otoños de Wu y Yue". Finalmente presenta los textos originales en japonés de Yinqueshan, Shiyi jia zhu Sunzi, y Sunzi bingfa. Incluye un índice onomástico.

1505. Sun, Tzu y Lawson, Jack (2003). El arte de la guerra para ejecutivos y directivos. Barcelona: Obelisco. $1^{\mathrm{a}}$ ed. 93 p. ; 13x21 cm. ISBN: 84-9777-060-9. Depósito legal: B. 44250-2003. Palabras clave: guerra, estrategia, táctica, gestión empresarial. Resumen: Tratado estratégico sobre la guerra. La obra esta dividida en 13 capítulos, precedidos por un prólogo que señala la importancia de la obra, sus características principales, su aplicación a los negocios y un resumen de sus principales enseñanzas. Los siguientes 13 capítulos explican los conceptos tácticos y estratégicos más significativos de la batalla incluyendo comentarios sobre su aplicación a los negocios. Ofrece criterios estratégicos, explica el comportamiento en medio de una batalla, como planificar un asalto, las fases y ritmos de la batalla, algunos consejos prácticos sobre la preparación y el propio combate, estudia algunas de las variables y maniobras militares, el terreno, sus tipos y ventajas-inconvenientes. Finaliza con las reflexiones sobre la utilización del fuego en la guerra y la utilización de los espías.

1506. Sun, Tzu y Mariscal, Enrique (1996). El arte de la guerra : para nuevos líderes. Una visión creativa y moderna del arte de la estrategia. Barcelona: Obelisco. 1a ed. 87 p. ; 13x21 cm. ISBN: 84-7720-505-1. Depósito legal: B. 38436-1996. Palabras clave: guerra, estrategia, táctica. Resumen: Tratado estratégico sobre la guerra. La obra esta dividida en 13 capítulos, precedidos por un prólogo que analiza los distintos tratados sobre la estrategia de la guerra y su evolución hasta la actualidad. Los siguientes 13 capítulos explican los conceptos tácticos y estratégicos más significativos de la batalla incluyendo comentarios sobre su interpretación actual. Ofrece criterios estratégicos, explica el comportamiento en medio de una batalla, como planificar un asalto, las fases y ritmos de la batalla, algunos consejos prácticos sobre la preparación y el propio combate, estudia algunas de las variables y maniobras militares, el terreno, sus tipos y ventajas-inconvenientes. Finaliza con las reflexiones sobre la utilización del fuego en la guerra y la utilización de los espías.

1507. Sun, Tzu y Puell de la Villa, Fernando (2000). El arte de la guerra. Madrid: Biblioteca Nueva. 1a ed. 160 p. ; $14 \times 21$ cm. ISBN: 978-84-9742-854-5. Depósito legal: no. (2ª ed., 2001; $3^{a}$ ed., 2005). Palabras clave: guerra, estrategia, táctica, textos. Resumen: Tratado estratégico sobre la guerra. La obra esta dividida en 3 partes, precedidos por una introducción que analiza el origen y repercusiones de la obra, su llegada y expansión por Occidente, detalla el contexto histórico de origen de la obra, discute la existencia de Sun-zi, compara la obra con los tratados militares chinos pre-dinásticos, y expone la metodología utilizada para presentar esta obra. La primera parte incluye los 13 capítulos traducidos y comentados de "El arte de la guerra", que explican los conceptos tácticos y estratégicos más significativos de la batalla, como los criterios estratégicos, el comportamiento en medio de una batalla, cómo planificar un asalto, las fases y ritmos de la batalla, consejos prácticos sobre la preparación y el propio combate, estudia las variables y maniobras militares, el terreno, sus tipos y ventajasinconvenientes, finalizando con las reflexiones sobre la utilización del fuego en la guerra y la utilización de los espías. La segunda parte incluye cinco capítulos adicionales, encontrados en la necrópolis de Yin-que, que presentan las preguntas del rey de $\mathrm{Wu}$ al maestro Sun, un compendio de precauciones militares, la historia del ataque del emperador amarillo al emperador rojo, un conjunto de consideraciones tácticas respecto al terreno, y la transcripción de una entrevista con el rey Wu. La tercera parte esta formada por 6 capítulos que incluyen otros textos atribuidos a Sun-zi, datados en diferentes épocas y que son textos caligrafiados y extractos de libros. Adjunta bibliografía.

1508. Sun, Tzu y Sun, Bin (2008). El arte de la guerra I y II. Barcelona: Círculo de Lectores. 1a ed. 293 p. ; 13x21 cm. ISBN: 978-84-672-3187-8. Depósito legal: B. 30090-2008. Palabras clave: fundamentos teóricos, principios técnicos, combate, guerra, estrategia, táctica. Resumen: Tratado estratégico sobre la guerra. La obra consta de 2 partes. La primera parte esta dividida en 13 capítulos precedidos por un prefacio que explica la aplicación de la obra al mundo actual y una introducción que comenta el objetivo final de la obra. Los siguientes 13 capítulos explican los conceptos tácticos y estratégicos más significativos de la batalla, incluyendo comentarios aclaratorios. Ofrece criterios estratégicos, explica el comportamiento en medio de una batalla, como planificar un asalto, las fases y ritmos de la batalla, algunos consejos prácticos sobre la preparación y el propio combate, estudia algunas de las variables y maniobras militares, el terreno, sus tipos y ventajas-inconvenientes. Finaliza con las reflexiones sobre la utilización del fuego en la guerra y la utilización de los espías. La segunda parte esta dividida en 30 capítulos precedidos por una introducción que presenta a los maestros de Sun Bin, su contexto histórico y comenta sus contenidos. Los siguientes 30 capítulos van relatando diferentes historias y reflexiones sobre situaciones de combate, decisiones tácticas y técnicas, que se deben tomar en la guerra ante determinadas situaciones. Explora algunas situaciones de combate y su forma de atacar, organizar y planificar. Adjunta reflexiones sobre el liderazgo y su importancia en las artes marciales, la organización para el combate y la estrategia necesaria para obtener la victoria. 
1509. Sun, Zi (2008). El arte de la guerra. Algete: Jorge A. Mestas. Ediciones Escolares. 1aㅡ ed. 91 p. ; $12 \times 19$ cm. ISBN: 978-84-95994-83-7. Depósito legal: M. 42657-2008. Palabras clave: guerra, estrategia, táctica. Resumen: Tratado estratégico sobre la guerra. La obra esta dividida en 13 capítulos, precedidos por una introducción que presenta los orígenes de la antigua china, las características y contexto histórico de la obra e incluye un breve resumen y comentario de cada uno de los capítulos que la integran. Los siguientes 13 capítulos explican los conceptos tácticos y estratégicos más significativos de la batalla, incluyendo notas aclaratorias. Ofrece criterios estratégicos, explica el comportamiento en medio de una batalla, como planificar un asalto, las fases y ritmos de la batalla, algunos consejos prácticos sobre la preparación y el propio combate, estudia algunas de las variables y maniobras militares, el terreno, sus tipos y ventajas-inconvenientes. Finaliza con las reflexiones sobre la utilización del fuego en la guerra y la utilización de los espías. Adjunta bibliografía.

1510. Sunzi (Sun, Tzu) (2000). El arte de la guerra. Madrid: Biblioteca Nueva. $1^{a}$ ed. 157 p. ; $14 \times 21 \mathrm{~cm}$. ISBN: 84-7030-744-4. Depósito legal: no. (2ª ed., 2001; 3aㅡ ed., 2005; 4ae ed., 2005). Palabras clave: guerra, estrategia, táctica, textos. Resumen: Tratado estratégico sobre la guerra. La obra esta dividida en 3 partes, precedidos por una introducción que analiza el origen y repercusiones de la obra, su llegada y expansión por Occidente, detalla el contexto histórico de origen de la obra, discute la existencia de Sunzi, compara la obra con los tratados militares chinos pre-dinásticos, y expone la metodología utilizada para presentar esta obra. La primera parte incluye los 13 capítulos traducidos y comentados de "El arte de la guerra", que explican los conceptos tácticos y estratégicos más significativos de la batalla, como los criterios estratégicos, el comportamiento en medio de una batalla, cómo planificar un asalto, las fases y ritmos de la batalla, consejos prácticos sobre la preparación y el propio combate, estudia las variables y maniobras militares, el terreno, sus tipos y ventajas-inconvenientes, finalizando con las reflexiones sobre la utilización del fuego en la guerra y la utilización de los espías. La segunda parte incluye cinco capítulos adicionales, encontrados en la necrópolis de Yin-que, que presentan las preguntas del rey de $\mathrm{Wu}$ al maestro Sun, un compendio de precauciones militares, la historia del ataque del emperador amarillo al emperador rojo, un conjunto de consideraciones tácticas respecto al terreno, y la transcripción de una entrevista con el rey Wu. La tercera parte esta formada por 6 capítulos que incluyen otros textos atribuidos a Sun-zi, datados en diferentes épocas y que son textos caligrafiados y extractos de libros. Adjunta bibliografía.

1511. Sunzi (Sun, Tzu) (2000). El arte de la guerra. Madrid: Biblioteca Nueva. $1^{a}$ ed. 157 p. ; $13 \times 21 \mathrm{~cm}$. ISBN: 978-84-9742-855-2. Depósito legal: no. (2ª ed., 2001; 3aㅡ ed., 2005; $4^{\mathrm{a}}$ ed., 2008). Palabras clave: guerra, estrategia, táctica, textos. Resumen: Tratado estratégico sobre la guerra. La obra esta dividida en 3 partes, precedidos por una introducción que analiza el origen y repercusiones de la obra, su llegada y expansión por Occidente, detalla el contexto histórico de origen de la obra, discute la existencia de Sun-zi, compara la obra con los tratados militares chinos pre-dinásticos, y expone la metodología utilizada para presentar esta obra. La primera parte incluye los 13 capítulos traducidos y comentados de "El arte de la guerra", que explican los conceptos tácticos y estratégicos más significativos de la batalla, como los criterios estratégicos, el comportamiento en medio de una batalla, cómo planificar un asalto, las fases y ritmos de la batalla, consejos prácticos sobre la preparación y el propio combate, estudia las variables y maniobras militares, el terreno, sus tipos y ventajasinconvenientes, finalizando con las reflexiones sobre la utilización del fuego en la guerra y la utilización de los espías. La segunda parte incluye cinco capítulos adicionales, encontrados en la necrópolis de Yin-que, que presentan las preguntas del rey de $\mathrm{Wu}$ al maestro Sun, un compendio de precauciones militares, la historia del ataque del emperador amarillo al emperador rojo, un conjunto de consideraciones tácticas respecto al terreno, y la transcripción de una entrevista con el rey Wu. La tercera parte esta formada por 6 capítulos que incluyen otros textos atribuidos a Sun-zi, datados en diferentes épocas y que son textos caligrafiados y extractos de libros. Adjunta bibliografía.

1512. Sunzi (Sun, Tzu) (2000). L'art de la guerra. Barcelona: Proa, Serveis d'Edicions de la UAB y de les Edicions de la Universitat de Barcelona. 1aㅡ ed. 109 p. ; 13x19,5 cm. ISBN: 84-8256-841-8. Depósito legal: B. 28627-2000. Palabras clave: guerra, estrategia, táctica. Resumen: Tratado estratégico sobre la guerra. La obra esta dividida en 13 capítulos precedidos por una introducción que comenta las características del contexto histórico y social de la obra, el pensamiento de su autor, las características de la obra y bibliografía. Los 13 capítulos explican los conceptos tácticos y estratégicos más significativos de la batalla y son comentados posteriormente. Ofrece criterios estratégicos, explica el comportamiento en medio de una batalla, como planificar un asalto, las fases y ritmos de la batalla, algunos consejos prácticos sobre la preparación y el propio combate, estudia algunas de las variables y maniobras militares, el terreno, sus tipos y ventajas-inconvenientes. Finaliza con las reflexiones sobre la utilización del fuego en la guerra y la utilización de los espías.

1513. Sunzi (Sun, Tzu) (2001). El arte de la guerra : introducción, traducción y notas de Albert Galvany. Madrid: Trotta. 1a ed. 234 p. ; 12x20 cm. ISBN: 84-8164-492-7. Depósito legal: M. 49324-2001. (2를. ed.,

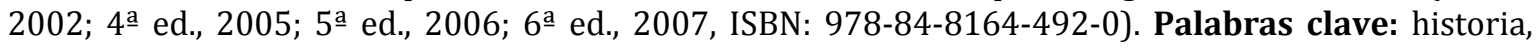
fundamentos teóricos, principios técnicos, combate, guerra, estrategia, táctica. Resumen: Tratado 
estratégico sobre la guerra. La obra esta dividida en 2 partes, precedidas por un prólogo que comenta la importancia de la obra y la reflexión china sobre la guerra. La primera parte consta de cuatro capítulos. El primer capítulo estudia la autoria y datación de la obra. El segundo capítulo analiza la situación socio-política así como el significado de la guerra durante la época de las primaveras y otoños. El tercer capítulo explica las transformaciones socio-políticas y la organización militar durante el periodo de los Reinos Combatientes, y su influencia sobre la transformación de los guerreros. El cuarto capítulo discute los fundamentos de la estrategia militar china, analizando ciertos fragmentos de la obra. También adjunta notas aclaratorias, una selección bibliográfica, una tabla cronológica de las dinastías chinas y un glosario de obras y textos clásicos. La segunda parte consta de 13 capítulos, que explican y comentan los conceptos tácticos y estratégicos más significativos de la batalla, ofrecen criterios estratégicos, explican el comportamiento en medio de una batalla, cómo planificar un asalto, las fases y ritmos de la batalla, algunos consejos prácticos sobre la preparación y el propio combate, estudian algunas de las variables y maniobras militares, el terreno, sus tipos y sus ventajas e inconvenientes. Finaliza con las reflexiones sobre la utilización del fuego en la guerra y la utilización de los espías.

1514. Sunzi (Sun, Tzu) (2007). L'art de la guerra. Barcelona: Servei Publicaciones Universitat Autonoma de Barcelona y Fundació Abadia de Montserrat. 2a ed. 75 p. ; 13x19,5 cm. ISBN: 978-84-8415-931-5 (Publicacions de l'Abadia de Montserrat). 978-844-90-2496-2 (Servei Publicaciones UAB). Depósito legal: B. 26874-2007. Palabras clave: historia, biografía, guerra, estrategia, táctica. Resumen: Tratado estratégico sobre la guerra. La obra esta dividida en 2 partes. La primera parte comenta el contexto histórico y social de la obra, analiza al autor y su obra, señala la difusión y relevancia de esta obra, comenta las notas del traductor e incluye la bibliografía consultada. La segunda parte incluye 13 capítulos que explican los conceptos tácticos y estratégicos más significativos de la batalla. Ofrece criterios estratégicos, explica el comportamiento en medio de una batalla, cómo planificar un asalto, las fases y ritmos de la batalla, algunos consejos prácticos sobre la preparación y el propio combate, estudia algunas de las variables y maniobras militares, el terreno, sus tipos y ventajas-inconvenientes. Finaliza con las reflexiones sobre la utilización del fuego en la guerra y la utilización de los espías. Adjunta un apéndice que relata la anécdota de Sun Tzu y el rey de U.

1515. Taira, Shigesuke (Yuzan, Daidoji) (2005). El código del samurái : una traducción de Thomas Cleary del Bushido Shoshinshu. Barcelona: Kairós. 1aㅡ ed. 154 p. : il. ; 13×20 cm. ISBN: 84-7245-585-8. Depósito legal: B. 525-2005. Palabras clave: principios filosóficos, ética, samurái. Resumen: Tratado filosófico sobre la vida del samurái. Está dividido en tres capítulos, los cuales exponen los principios que rigen la vida del guerrero en sus múltiples facetas. El primer capítulo aborda los principios fundamentales sobre los que se cimienta el comportamiento, actitud y manera de pensar del samurái. El segundo capítulo presenta los principios que rigen su vida diaria desde la familia hasta los amigos. El último capítulo describe los preceptos del samurái ante su vida social y su señor.

1516. Tamenaga, Shunsui (1999). Los cuarenta y siete ronin : la historia de los leales samuráis de Akó. Madrid: Miraguano. $1^{a}$ ed. 286 p. : il. ; 12x19 cm. ISBN: 84-7813-176-0. Depósito legal: M. 3422-1999. Palabras clave: historia. Resumen: Relato de artes marciales. El libro esta formado por 40 capítulos precedidos por un prefacio que comenta la transmisión de esta historia. Los 40 capítulos desarrollan la historia de venganza de los cuarenta y siete ronin. Adjunta un glosario específico y el listado con los nombres de los cuarenta y siete ronin. También adjunta un folleto que comenta las características sociales de la época en que se desarrolló la historia, el significado del seppuku, del bushido y explica la labor literaria de Tamenaga Shunsui y las diferentes versiones en castellano de esta obra.

1517. Tamenaga, Shunsui (2001). Los cuarenta y siete ronin : la historia de los leales samuráis de Akó. Barcelona: RBA. 1a ed. 169 p. ; 13x21 cm. ISBN: 84-473-1988-1. Depósito legal: B. 16692-2001. Palabras clave: historia. Resumen: Relato de artes marciales. El libro esta formado por 40 capítulos precedidos por un prefacio que comenta la transmisión de esta historia. Los 40 capítulos desarrollan la historia de venganza de los cuarenta y siete ronin. Adjunta un glosario específico y el listado con los nombres de los cuarenta y siete ronin.

1518. Tokitsu, Kenji (2008). Miyamoto Musashi : maestro del sable japonés, el hombre y la obra, mito y realidad. Badalona: Paidotribo. $1^{a}$ ed. 414 21x27,5 cm. ISBN: 978-84-8019-976-6. Depósito legal: no. Palabras clave: biografía, maestros. Resumen: Análisis detallado de su obra, vida y arte marcial. Partiendo de la descripción de su persona como figura legendaria de la cultura japonesa, de los periodos de la vía del sable y la cronología de su vida, expone e interpreta, en el primer capítulo, los Escritos sobre los cinco elementos (Gorin-no-sho) con una explicación detallada de los conceptos más significativos en cada página; anota el título de los artículos incluidos en El espejo de la vía de la estrategia (Hyodokyo); traduce el texto Treinta y cinco instrucciones sobre estrategia (Hyoho sanjugo-kajo) pero sin repetir aquellos pasajes repetidos del Gorin-no-sho, al igual que con el texto Cuarenta y dos instrucciones sobre estrategia (Hyoho-shiju-ni-kajo), estando formados ambos por artículos en su mayoría idénticos; traduce e interpreta los artículos de La vía que hay que seguir solo (Dokkodo) e incluye las notas de sus discípulos sobre la práctica de la escuela. El segundo capítulo divide su vida en 
tres periodos, infancia y formación, combates y profundización. El periodo de infancia y formación data el nacimiento de Musashi y aclara algunas cuestiones sobre sus progenitores, para luego dedicarse a narrar su primer duelo y la formación de la escuela de los dos sables, las tres explicaciones sobre la fundación de dicha escuela y las dos fuentes que la dieron lugar, así como las distintas escuelas de los dos sables existentes y sus diferencias. En el apartado de combates se estudian y discuten en orden cronológico sus principales enfrentamientos, algunos de ellos narrados en distintos textos. El apartado de profundización detalla los hechos más destacables de sus últimos años de vida, como son la adopción de sus dos hijos, los últimos duelos y batallas, la redacción del Gorin-no-sho y su muerte. Por último, el tercer capítulo estudia su arte marcial, detallando las ramas de la escuela de Musashi y su transmisión tanto a través de sus escritos como de su práctica. También incluye el estudio que realizó Morita Monjuro sobre el arte de Musashi así como las interpretaciones que sobre las armas y su utilización se desprenden de los escritos de Musashi, para terminar con la aparición del budo y el análisis cualitativo del mismo a través de las relaciones entre los adversarios. Adjunta anexos, explicando las consideraciones metodológicas del autor en la traducción del Gorin-no-sho, la toma de iniciativa en el combate de Musashi y las influencias externas sobre el arte del sable japonés, bibliografía y glosario.

1519. Tse, Sun (Sun, Tzu) (1974). Los trece artículos sobre el arte de la guerra. Barcelona: Anagrama. 1a ed. 140 p. ; 10x17,5 cm. ISBN: 84-339-0378-0. Depósito legal: B. 40379-1974. Palabras clave: guerra, estrategia, táctica. Resumen: Tratado estratégico sobre la guerra. La obra esta dividida en 13 capítulos, precedidos por una nota preliminar que explica la relevancia e interés de la obra, dos poemas de Tchung Tchang-Tung e incluye varios relatos sobre los conocimientos militares de Sun Tse y su descendiente Sun Pin. Los siguientes 13 capítulos explican los conceptos tácticos y estratégicos más significativos de la batalla. Ofrece criterios estratégicos, explica el comportamiento en medio de una batalla, como planificar un asalto, las fases y ritmos de la batalla, algunos consejos prácticos sobre la preparación y el propio combate, estudia algunas de las variables y maniobras militares, el terreno, sus tipos y ventajas-inconvenientes. Finaliza con las reflexiones sobre la utilización del fuego en la guerra y la utilización de los espías.

1520. Yamamoto, Jocho (seud. de Yamamoto, Tsunetomo) (2000). Hagakure : el libro secreto de los samuráis. Madrid: Edaf. 1aㅡ ed. 132 p. : il. ; 11x18 cm. ISBN: 84-414-0761-6. Depósito legal: M. 32111-2000. (2ª ed., 2002; $3^{a}$ ed., 2004). Palabras clave: filosofía, bushido, ética, samurái. Resumen: Compendio filosófico sobre el camino del guerrero. El libro presenta la traducción del texto Hagakure, precedido de un prólogo que explica las características, valores y formación del guerrero y la biografía de Yamamoto. A través de pequeños capítulos, máximas filosóficas, historias y anécdotas va describiendo el comportamiento y actitud del samurái tanto en su vida diaria como en el combate, su entrenamiento y los principios que rigen su vida. Incluye varias ilustraciones y pinturas sobre los samurái.

1521. Yamamoto, Tsunetomo (2004). Hagakure : el libro del samurái. Palma de Mallorca: José J. de Olañeta. 1a ed. 143 p. ; 11x14 cm. ISBN: 84-9716-357-5. Depósito legal: B. 32478-2004. Palabras clave: filosofía, bushido, ética, samurái. Resumen: Compendio filosófico sobre el camino del guerrero. El libro presenta la traducción del texto Hagakure, precedido de una nota previa que analiza los valores presentados en la obra. A través de pequeños capítulos, máximas filosóficas, historias y anécdotas va describiendo el comportamiento y actitud del samurai tanto en su vida diaria como en el combate, su entrenamiento y los principios que rigen su vida. Adjunta un apéndice que enumera los cuatro votos de Yamamoto y una nota final que narra la biografía del autor. También adjunta un glosario de la edición española.

1522. Yamamoto, Tsunetomo (2005). Bushido : el camino del samurái. Badalona: Paidotribo. 1 a ed. 111 p. : il. ; 15x21,5 cm. ISBN: 84-8019-843-5. Depósito legal: no. (2ª reimp., 2009, ISBN: 978-84-8019-843-1). Palabras clave: filosofía, bushido, ética, samurái. Resumen: Trascripción de Hagakure. Presenta el libro Hagakure de Tsunetomo Yamamoto con una breve introducción que hace referencia al marco histórico en el que fue escrito. El Hagakure esta dividido en 11 libros, cada uno de ellos con consejos breves y concisos sobre la manera de pensar y actuar de los samuráis. Adjunta notas, glosario y un índice alfabético.

1523. Yamamoto, Tsunetomo (2005). Hagakure : el camino del samurái. Móstoles: Arkano Books. 1ạ ed. 218 p. : il. ; 14x21 cm. ISBN: 84-89897-75-1. Depósito legal: M. 16902-2005. (2ª ed., 2005; 3aㅡ ed., 2008, ISBN: 978-84-89897-75-5). Palabras clave: filosofía, relatos, bushido, samurái. Resumen: Compendio de apartados (300) del texto original. La obra esta dividida en 11 capítulos, compuestos por breves relatos sobre el bushido, la vida del samurái, la muerte, la cobardía, el suicidio y el papel del kaishaku, o el comportamiento del samurái. Finaliza con unas divagaciones del autor y un glosario de términos, nombres y lugares. Adjunta notas de los capítulos.

1524. Yamamoto, Yosho (seud. de Yamamoto, Tsunetomo) (1989). Hagakure : brevario del samurái. Barcelona: Obelisco. 1aㅡ ed. 72 p. ; $13 \times 21$ cm. ISBN: 84-7720-108-0. Depósito legal: B. 24358-1989. (2 $2^{\mathrm{a}}$ ed., 2000, ISBN: 84-7720-763-1; 3ae ed., 2001, ISBN: 84-7720-763-1; 6ae ed., 2006, ISBN: 84-7720-7631). Palabras clave: principios filosóficos, ética, samurái. Resumen: Compendio filosófico sobre el 
camino del guerrero. A través de pequeños capítulos va desarrollando el comportamiento y actitud del samurái tanto en su vida diaria como en el combate, su entrenamiento y los principios que rigen su vida.

1525. Yamamoto, Yosho (seud. de Yamamoto, Tsunetomo) (2003). Hagakure : el código secreto del samurái. Madrid: Librería Argentina. 1aㅡ ed. 97 p. : il. ; 14x21,5 cm. ISBN: 84-89836-35-3. Depósito legal: SE. 3046-2003. (2a ed., 2004, 90 p.). Palabras clave: filosofía, bushido, ética, samurái. Resumen: Compendio filosófico sobre el camino del guerrero. El libro presenta la traducción del texto Hagakure, precedido de una introducción que comenta el contexto histórico de la obra, las influencias culturales y filosóficas, y la figura del samurái, además de una breve explicación del autor y las notas a la presente edición. A través de pequeños capítulos, máximas filosóficas, historias y anécdotas va describiendo el comportamiento y actitud del samurai tanto en su vida diaria como en el combate, su entrenamiento y los principios que rigen su vida. Incluye varias ilustraciones y pinturas sobre los samurái. Adjunta un anexo con el credo del samurái.

1526. Yamamoto, Yosho (seud. de Yamamoto, Tsunetomo) (2005). Hagakure : el libro del samurái. Asturias: Madú. $1^{\underline{a}}$ ed. 93 p. ; 11x16,5 cm. ISBN: No ISBN. Depósito legal: AS. 6209-2005. Palabras clave: filosofía, bushido, ética, samurái. Resumen: Compendio filosófico sobre el camino del guerrero. El libro presenta la traducción del texto Hagakure, precedido de un prólogo que explica las características del contexto histórico de la obra. A través de pequeños capítulos, máximas filosóficas, historias y anécdotas va describiendo el comportamiento y actitud del samurai tanto en su vida diario como en el combate, su entrenamiento y los principios que rigen su vida.

1527. Yuzan, Daidoji (1998). El código del samuray : el espíritu del bushido japonés y la vía del guerrero. Madrid: Edaf. 1a ed. 126 p. ; 11x18 cm. ISBN: 84-414-0294-9. Depósito legal: M. 2180-1998. (2a ed., 1998; 3ํㅡㄹ. ed., 1999; $4^{\underline{a}}$ ed., 2001; $6^{\underline{a}}$ ed., 2004). Palabras clave: principios filosóficos, ética, samurái. Resumen: Tratado filosófico sobre la vida del samurái. Esta dividido en tres capítulos, los cuales exponen los principios que rigen la vida del guerrero en sus múltiples facetas. El primer capítulo aborda los principios fundamentales sobre los que se cimienta el comportamiento, actitud y manera de pensar del samurái. El segundo capítulo presenta los principios que rigen su vida diaria desde la familia hasta los amigos. El último capítulo describe los preceptos del samurái ante su vida social y su señor.

\subsection{Diccionarios y Enciclopedias}

1528. Albuixech, Juan José (1999). Enciclopedia de los deportes de contacto. Barcelona: Alas. 1a ed. 276 p. : il. ; $17 \times 24 \mathrm{~cm}$. ISBN: 84-203-0396-8 . Depósito legal: B. 42508-1999. Palabras clave: historia, fundamentos técnicos, combate, entrenamiento, full-contact, kickboxing, muay thai, boxeo, nutrición, preparación física, savate. Resumen: Manual teórico y técnico de artes marciales. La obra esta formada por 13 capítulos. El primer capítulo narra la historia del boxeo y su evolución en España, la descripción de los ataques, bloqueos, esquivas y contras, el combate cuerpo a cuerpo y la colocación de la cabeza, acompañado de numerosos gráficos, ilustraciones y esquemas de movimiento. El segundo capítulo analiza el soft-combat, su historia y los resultados del 1er campeonato de España, la descripción de las zonas de golpeo, los tipos de casco, las técnicas más comunes, las contras y sus diferentes modalidades de competición, acompañando las explicaciones con numerosos gráficos. El tercer capítulo presenta la historia del boxeo birmano, para continuar con el relato de la historia del kick-boxing a nivel mundial y en España, las ilustraciones de los campeones españoles, la historia del kick-boxing en Cataluña, el listado de direcciones de interés de este arte, y la descripción de sus fundamentos técnicos, desde sus zonas de golpeo hasta sus técnicas principales adjuntando gráficos, ilustraciones y esquemas de movimiento de cada una de ellas. El quinto capítulo profundiza en los aspectos técnicos del fullcontact, describiendo la ejecución de sus principales patadas, los contraataques y combinaciones, puñetazos y desplazamientos. El sexto capítulo comenta la situación actual del muay-thai y sus competiciones, describe e ilustra su ejecución técnica comparándola con la del boxeo, y narra el desarrollo del saludo al maestro y la biografía de Samart Payakaroon. El séptimo capítulo enumera las distintas competiciones de savate, relata su historia y describe la ejecución de sus fundamentos técnicos acompañándolo con numerosos gráficos y fotografías. El octavo capítulo comenta el origen del sanda, su reglamento y técnicas y las protecciones obligatorias en el combate. El noveno capítulo estudia los aspectos relacionados con las tareas del entrenador como son la preparación psicológica, el vendaje de las mano, los tobillos, el uso de la vaselina, las distintas tácticas de combate y los tipos de respiración; para en el décimo capítulo analizar las características y técnicas de los peleadores zurdos. El undécimo capítulo describe el entrenamiento con el saco, las gomas y en las cuerdas. Finaliza con dos capítulos dedicados a la preparación física, su planificación y la nutrición, dietas y regulación del peso para estos deportes. 
1529. Albuixech, Juan José (2007). Enciclopedia de los deportes de contacto. Barcelona: Alas. $1 \underline{a}$ ed. 277 p. : il. ; 17x23,5 cm. ISBN: 978-84-203-0396-3. 84-203-0396-8. Depósito legal: B. 56472-2007. Palabras clave: historia, fundamentos técnicos, combate, entrenamiento, full-contact, kickboxing, muay thai, boxeo, nutrición, preparación física, savate. Resumen: Manual teórico y técnico de artes marciales. La obra esta formada por 13 capítulos. El primer capítulo narra la historia del boxeo y su evolución en España, la descripción de los ataques, bloqueos, esquivas y contras, el combate cuerpo a cuerpo y la colocación de la cabeza, acompañado de numerosos gráficos, ilustraciones y esquemas de movimiento. El segundo capítulo analiza el soft-combat, su historia y los resultados del 1er campeonato de España, la descripción de las zonas de golpeo, los tipos de casco, las técnicas más comunes, las contras y sus diferentes modalidades de competición, acompañando las explicaciones con numerosos gráficos. El tercer capítulo presenta la historia del boxeo birmano, para continuar con el relato de la historia del kick-boxing a nivel mundial y en España, las ilustraciones de los campeones españoles, la historia del kick-boxing en Cataluña, el listado de direcciones de interés de este arte, y la descripción de sus fundamentos técnicos, desde sus zonas de golpeo hasta sus técnicas principales adjuntando gráficos, ilustraciones y esquemas de movimiento de cada una de ellas. El quinto capítulo profundiza en los aspectos técnicos del full-contact, describiendo la ejecución de sus principales patadas, los contraataques y combinaciones, puñetazos y desplazamientos. El sexto capítulo comenta la situación actual del muay-thai y sus competiciones, describe e ilustra su ejecución técnica comparándola con la del boxeo, y narra el desarrollo del saludo al maestro y la biografía de Samart Payakaroon. El séptimo capítulo enumera las distintas competiciones de savate, relata su historia y describe la ejecución de sus fundamentos técnicos acompañándolo con numerosos gráficos y fotografías. El octavo capítulo comenta el origen del sanda, su reglamento y técnicas y las protecciones obligatorias en el combate. El noveno capítulo estudia los aspectos relacionados con las tareas del entrenador como son la preparación psicológica, el vendaje de las mano, los tobillos, el uso de la vaselina, las distintas tácticas de combate y los tipos de respiración; para en el décimo capítulo analizar las características y técnicas de los peleadores zurdos. El undécimo capítulo describe el entrenamiento con el saco, las gomas y en las cuerdas. Finaliza con dos capítulos dedicados a la preparación física, su planificación y la nutrición, dietas y regulación del peso para estos deportes.

1530. Casero Abellán, Rogelio (2004). Diccionario de estilos de artes marciales. Barcelona: Alas. 1a ed. 267 p. : il. ; 17x24 cm. ISBN: 84-203-0402-6. Depósito legal: B. 19566-2004. Palabras clave: escuelas. Resumen: Diccionario de términos relacionados con los diferentes estilos, escuelas o artes marciales, que incluye un cierto comentario sobre las características, maestro e historia de cada uno de ellos.

1531. Crompton, Paul (1996). Artes marciales : técnicas ilustradas. Barcelona: Folio. 1aㅡ ed. 208 p. : il. ; 20x28,5 cm. ISBN: 84-413-0208-1. Depósito legal: B. 11271-1996. Palabras clave: historia, fundamentos teóricos, principios técnicos, competición. Resumen: Manual teórico de artes marciales. El libro esta formado por 25 capítulos, cada uno de ellos dedicado a un arte marcial distinto. Cada capítulo define el arte marcial estudiado, su historia, principales características y principios técnicos, su sistema de competición si tiene e incluye numerosas fotografías de sus fundamentos técnicos. Las artes marciales analizadas son kárate, judo, aikido, jiu-jitsu, kendo, iaido, kyudo, ryukyu kobujitsu, ninjutsu y shurikendo, sumo, shorinji kempo, jodo, kung-fu chino, t'ai chi chuan, hsing-i chuan, pakua, wushu, kung fu wing chun, escrima, pentjak silat, taekwondo, boxeo con manos y pies, savate, híbridos y artes marciales hindúes. Adjunta un índice.

1532. Frederic, Louis (1989). Diccionario ilustrado de las artes marciales. Madrid: Eyras. $1 \underline{\text { a }}$ ed. 367 p. : il. ; 15x24 cm. ISBN: 84-85269-64-0. Depósito legal: M. 30188-1989. Palabras clave: fundamentos técnicos, biografía, reglamentos. Resumen: Diccionario de artes marciales. El diccionario esta precedido de un prólogo que explica brevemente la historia de las artes marciales, su origen y desarrollo como prácticas, su repercusión social de las mismas y el secreto de la energía. La presentación describe los criterios de inclusión, razones históricas y sociales de los términos recogidos. El diccionario recopila términos, biografías de los grandes maestros, descripción de técnicas, reglamentos de competición, conceptos filosóficos y la historia de algunas artes marciales. Esta ilustrado con dibujos y fotografías.

1533. Huguet i Parellada, Jordi (dir.) (1989). 20 artes marciales. Barcelona: Editorial 92. 1 a ed. 112 p. : il. ; 13x21 cm. ISBN: 84-87254-20-9. 84-87254004 (ISBN de la colección). Depósito legal: no. Palabras clave: historia, fundamentos técnicos, filosofía, aikido, judo, kárate, kendo, kyudo, sumo, taekwondo, wushu, clubes, competición, reglamentos. Resumen: Manual teórico y técnica de artes marciales. La obra esta formada por 3 partes, precedidas de una introducción que ofrece una idea general de las artes marciales. La primera parte del libro explica el origen mitológico de las artes marciales, comenta el significado del Do, la filosofía taoísta, la teoría del yin/yang, el chi, el bushido, y expone la evolución histórica y deportiva del judo, el kárate, el taekwondo, el aikido, el kung fu, el kendo, el kyudo y el sumo, así como la evolución de todas ellas hacia el aspecto deportivo. La segunda parte del libro comenta los aspectos técnicos de las artes marciales en general y la utilización de las katas para luego profundizar en los fundamentos técnicos del judo, el kárate y el kung fu, además de señalar los puntos 
vitales del cuerpo humano y la utilización de las armas dentro de estas artes. La tercera parte explica los aspectos formales de la práctica de las artes marciales como son el dojo, el tatami, los cinturones y la vestimenta, las normas que rigen dentro del dojo y presenta el reglamento oficial de competición del judo. Adjunta una pequeña biografía de los artistas marciales más destacados dentro de sus disciplinas, un glosario de términos de artes marciales, los resultados internacionales de judo y taekwondo así como un listado de clubes y entidades afiliadas a la federación española de judo y deportes asociados.

1534. Lee, San (1998). Armas orientales. Arganda del Rey: Edimat. $1^{a}$ ed. 190 p. : il. ; $13 \times 21$ cm. ISBN: 848403-331-7. Depósito legal: M. 30033-1998. Palabras clave: historia, fundamentos teóricos, armas. Resumen: Tratado teórico de armas orientales. El libro esta formado por 30 capítulos precedidos por una presentación que señala los objetivos del libro. El primer capítulo narra el origen e historia de las armas japonesas. El segundo capítulo incluye varias fotografías del manejo del arco. El tercer capítulo comenta la historia y estructura del bo junto con la ilustración de algunas de sus técnicas. Los dos siguientes capítulos explican los lugares de utilización de los cuchillos mariposa y la historia y manejo de la espada tou respectivamente. El siguiente capítulo presenta la ilustración de varias fotografías de las espadas mariposa. El séptimo capítulo detalla el origen del kali, sus fundamentos técnicos junto con algunas de sus fotografías para luego presentar el kama, la katana, el kris y el kusarigama. El décimo segundo capítulo incluye varias fotografías sobre la utilización del kyoketshu shogue. El siguiente capítulo describe los distintos tipos de lanzas yari existentes para continuar con la explicación del manejo y estructura del manriquigusari y la naginata. El décimo sexto capítulo ilustra algunas técnicas de nunchaku para en el siguiente capítulo narra el origen y estructura del nunchaku de tres secciones. El décimo octavo capítulo presenta las características técnicas del sai y su estructura mientras que el siguiente incluye la ilustración de varias técnicas con el shinobi zue. Los siguientes siete capítulos comenta el origen, estructura, utilización y manejo del shuriken, tonfa, tambo, tanto, tessen y yawara respectivamente incluyendo numerosas fotografías de su manejo. El siguiente capítulo comenta la estructura de algunas armas menos habituales para finalizar con un comentario sobre la utilización del don-do, el jitte y las armas ninja.

1535. Mitchell, David (1992). El libro completo de las artes marciales. Barcelona: Paidotribo. 1 a ed. 175 p. : il. ; 22×30,5 cm. ISBN: 84-8019-018-3. Depósito legal: no. Palabras clave: fundamentos teóricos, fundamentos filosóficos, artes marciales. Resumen: Manual teórico y técnico de artes marciales. El libro esta compuesto de 25 capítulos. Los cinco primeros capítulos abordan de forma general el estudio de las artes marciales, comenzando por la filosofía que las caracteriza y continuando con algunas nociones básicas del entrenamiento aplicado a las artes marciales, el desarrollo de la fuerza en las diferentes escuelas, la descripción de la utilización de las armas naturales del cuerpo humano, la ejecución técnica de las posturas y los movimientos entre ellas, y los distintos bloqueos existentes en las artes marciales. Los siguientes capítulos están dedicados, de forma individual, a la introducción teórica de diferentes artes marciales, explicando brevemente su historia, sus maestros y estilos, sus técnicas, aprendizaje y competición. Las artes marciales revisadas son: aikido, budo y bujutsu, full contact, hapkido, iai jutsu e iaido, artes de lucha de la India y Pakistán, judo y jiu jitsu, kárate, kenjutsu y kendo, kobujutsu y kobudo, kung fu o wu-shu, kyudo, ninjutsu, shorinji kempo, silat, sumo, taekwondo, taiho jutsu, tang soo do, y boxeo tailandés. Adjunta un glosario e índice.

1536. Oliva Seba, Antonio (dir.) (1981). Artes marciales : enciclopedia práctica. Tomo I. Madrid: Nueva Lente. $1^{\text {a }}$ ed. 260 p. : il. ; $22 \times 29$ cm. ISBN: 84-85246-65-9. 84-85246-63-2 (ISBN de la obra completa). Depósito legal: M. 29379-1981. (2ª ed., 1983). Palabras clave: katas, pumses, formas, kumite, fundamentos teóricos, táctica, fundamentos técnicos, programa técnico, principios técnicos, filosofía, defensa personal, combate, entrenamiento, vestimenta, cortesía, artes marciales, judo, kárate, taekwondo, aplicación marcial, cualidades físicas, etiqueta, sistemas de entrenamiento, armas. Resumen: Manual teórico y técnico de artes marciales. La obra intercala los apartados dedicados al kárate, judo, taekwondo, defensa personal, otros complementos de las artes marciales y otras artes marciales. El apartado del kárate describe las posiciones, paradas, patadas y defensas tanto básicas como avanzadas; su modo de entrenamiento; las katas heian, hangetsu, jion, jitte, wankan, goju-shihoso y unsu, además algunas de sus aplicaciones marciales; los diferentes métodos de entrenamiento de kumite; los conceptos tácticos del combate; el reglamento de competición y un comentario sobre la psicología de la competición, incluyendo fotografías explicativas de cada contenido. El apartado del judo presenta la descripción técnica e ilustración de las técnicas comprendidas en el programa técnico del gokyo; sus principios técnicos; los distintos métodos de entrenamiento; las tácticas de combate; la nague-no-kata, katame-no-kata y kime-no-kata; y algunos ejemplos de las técnicas, encadenamientos y contraataques de competición. El apartado dedicado al taekwondo incluye la descripción de sus fundamentos técnicos acompañados de su secuencia fotográfica; los pumses básicos junto con los pumse koryo, kungang, taebek y pyongwon; las técnicas y entrenamiento de competición; además de presentar el reglamento de competición y arbitraje. El apartado dedicado a la defensa personal presenta la resolución de distintas situaciones de defensa personal ante el ataque de varios adversarios, los ataques con armas de fuego y arma blanca desde distintas posiciones, así como un 
comentario sobre la utilización de armas de fuego, la defensa personal femenina, la legítima defensa, los principios técnicos y tácticas ante una situación de defensa personal, y un resumen de sus antecedentes históricos. El apartado referido a los complementos de las artes marciales comentan los conceptos de maestro y alumno, escuela, la vestimenta, el concepto de "do", la respiración, el calentamiento, las cualidades físicas, las armas corporales, el grito, señala los beneficios de las artes marciales, los tipos de energía, la evolución de las artes marciales, la planificación del entrenamiento, los rompimientos, el esoterismo y su relación con las artes marciales, la actitud mental, el taoísmo, el yoga, las artes marciales y los medios de comunicación y un ensayo sobre la evolución de las artes marciales a lo largo de la historia. El último apartado esta dedicado a los fundamentos históricos, teóricos y técnicos de otras artes marciales como la naginata, kendo, kyudo, aikido, kung-fu, kobudo, kenpo, ninjutsu, yodo, sumo, hapkido, viet vo dao, jeet kune do, taijitsu, full contact y aquellas luchas desarrolladas en la India, Birmania, Thailandia, Indonesia, Malasia y Filipinas. Adjunta varios apéndices con dos ensayos sobre la vinculación de las artes marciales al zen y el futuro desarrollo de las artes marciales, y la secuencia fotográfica y comentario de las formas itsutsu-no-kata y hwa-rang.

1537. Oliva Seba, Antonio (dir.) (1981). Artes marciales : enciclopedia práctica. Tomo II. Madrid: Nueva Lente.

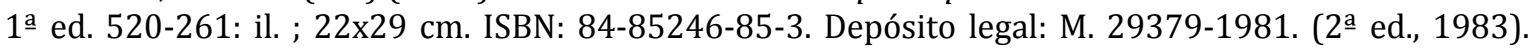
Palabras clave: katas, pumses, formas, kumite, fundamentos teóricos, táctica, fundamentos técnicos, programa técnico, principios técnicos, filosofía, defensa personal, combate, entrenamiento, vestimenta, cortesía, artes marciales, judo, kárate, taekwondo, aplicación marcial, cualidades físicas, etiqueta, sistemas de entrenamiento, armas. Resumen: Manual teórico y técnico de artes marciales. La obra intercala los apartados dedicados al kárate, judo, taekwondo, defensa personal, otros complementos de las artes marciales y otras artes marciales. El apartado del kárate describe las posiciones, paradas, patadas y defensas tanto básicas como avanzadas; su modo de entrenamiento; las katas heian, hangetsu, jion, jitte, wankan, goju-shiho-so y unsu, además algunas de sus aplicaciones marciales; los diferentes métodos de entrenamiento de kumite; los conceptos tácticos del combate; el reglamento de competición y un comentario sobre la psicología de la competición, incluyendo fotografías explicativas de cada contenido. El apartado del judo presenta la descripción técnica e ilustración de las técnicas comprendidas en el programa técnico del gokyo; sus principios técnicos; los distintos métodos de entrenamiento; las tácticas de combate; la nague-no-kata, katame-no-kata y kime-no-kata; y algunos ejemplos de las técnicas, encadenamientos y contraataques de competición. El apartado dedicado al taekwondo incluye la descripción de sus fundamentos técnicos acompañados de su secuencia fotográfica; los pumses básicos junto con los pumse koryo, kungang, taebek y pyongwon; las técnicas y entrenamiento de competición; además de presentar el reglamento de competición y arbitraje. El apartado dedicado a la defensa personal presenta la resolución de distintas situaciones de defensa personal ante el ataque de varios adversarios, los ataques con armas de fuego y arma blanca desde distintas posiciones, así como un comentario sobre la utilización de armas de fuego, la defensa personal femenina, la legítima defensa, los principios técnicos y tácticas ante una situación de defensa personal, y un resumen de sus antecedentes históricos. El apartado referido a los complementos de las artes marciales comentan los conceptos de maestro y alumno, escuela, la vestimenta, el concepto de "do", la respiración, el calentamiento, las cualidades físicas, las armas corporales, el grito, señala los beneficios de las artes marciales, los tipos de energía, la evolución de las artes marciales, la planificación del entrenamiento, los rompimientos, el esoterismo y su relación con las artes marciales, la actitud mental, el taoísmo, el yoga, las artes marciales y los medios de comunicación y un ensayo sobre la evolución de las artes marciales a lo largo de la historia. El último apartado esta dedicado a los fundamentos históricos, teóricos y técnicos de otras artes marciales como la naginata, kendo, kyudo, aikido, kung-fu, kobudo, kenpo, ninjutsu, yodo, sumo, hapkido, viet vo dao, jeet kune do, taijitsu, full contact y aquellas luchas desarrolladas en la India, Birmania, Thailandia, Indonesia, Malasia y Filipinas. Adjunta varios apéndices con dos ensayos sobre la vinculación de las artes marciales al zen y el futuro desarrollo de las artes marciales, y la secuencia fotográfica y comentario de las formas itsutsu-no-kata y hwa-rang.

1538. Oliva Seba, Antonio (dir.) (1981). Artes marciales : enciclopedia práctica. Tomo III. Madrid: Nueva Lente. 1a ed. 780-521: il. ; 22x29 cm. ISBN: 84-85246-86-1. Depósito legal: M. 29379-1981. (2a ed., 1983). Palabras clave: katas, pumses, formas, kumite, fundamentos teóricos, táctica, fundamentos técnicos, programa técnico, principios técnicos, filosofía, defensa personal, combate, entrenamiento, vestimenta, cortesía, artes marciales, judo, kárate, taekwondo, aplicación marcial, cualidades físicas, etiqueta, sistemas de entrenamiento, armas. Resumen: Manual teórico y técnico de artes marciales. La obra intercala los apartados dedicados al kárate, judo, taekwondo, defensa personal, otros complementos de las artes marciales y otras artes marciales. El apartado del kárate describe las posiciones, paradas, patadas y defensas tanto básicas como avanzadas; su modo de entrenamiento; las katas heian, hangetsu, jion, jitte, wankan, goju-shiho-so y unsu, además algunas de sus aplicaciones marciales; los diferentes métodos de entrenamiento de kumite; los conceptos tácticos del combate; el reglamento de competición y un comentario sobre la psicología de la competición, incluyendo 
fotografías explicativas de cada contenido. El apartado del judo presenta la descripción técnica e ilustración de las técnicas comprendidas en el programa técnico del gokyo; sus principios técnicos; los distintos métodos de entrenamiento; las tácticas de combate; la nague-no-kata, katame-no-kata y kime-no-kata; y algunos ejemplos de las técnicas, encadenamientos y contraataques de competición. El apartado dedicado al taekwondo incluye la descripción de sus fundamentos técnicos acompañados de su secuencia fotográfica; los pumses básicos junto con los pumse koryo, kungang, taebek y pyongwon; las técnicas y entrenamiento de competición; además de presentar el reglamento de competición y arbitraje. El apartado dedicado a la defensa personal presenta la resolución de distintas situaciones de defensa personal ante el ataque de varios adversarios, los ataques con armas de fuego y arma blanca desde distintas posiciones, así como un comentario sobre la utilización de armas de fuego, la defensa personal femenina, la legítima defensa, los principios técnicos y tácticas ante una situación de defensa personal, y un resumen de sus antecedentes históricos. El apartado referido a los complementos de las artes marciales comentan los conceptos de maestro y alumno, escuela, la vestimenta, el concepto de "do", la respiración, el calentamiento, las cualidades físicas, las armas corporales, el grito, señala los beneficios de las artes marciales, los tipos de energía, la evolución de las artes marciales, la planificación del entrenamiento, los rompimientos, el esoterismo y su relación con las artes marciales, la actitud mental, el taoísmo, el yoga, las artes marciales y los medios de comunicación y un ensayo sobre la evolución de las artes marciales a lo largo de la historia. El último apartado esta dedicado a los fundamentos históricos, teóricos y técnicos de otras artes marciales como la naginata, kendo, kyudo, aikido, kung-fu, kobudo, kenpo, ninjutsu, yodo, sumo, hapkido, viet vo dao, jeet kune do, taijitsu, full contact y aquellas luchas desarrolladas en la India, Birmania, Thailandia, Indonesia, Malasia y Filipinas. Adjunta varios apéndices con dos ensayos sobre la vinculación de las artes marciales al zen y el futuro desarrollo de las artes marciales, y la secuencia fotográfica y comentario de las formas itsutsu-no-kata y hwa-rang.

1539. Oliva Seba, Antonio (dir.) (1981). Artes marciales : enciclopedia práctica. Tomo IV. Madrid: Nueva Lente. $1^{\text {a }}$ ed. 1040-781: il. ; 22x29 cm. ISBN: 84-85246-87-X. 84-85246-63-2 (ISBN de la obra completa). Depósito legal: M. 29379-1981. (2 ${ }^{\mathrm{a}}$ ed., 1983). Palabras clave: katas, pumses, formas, kumite, fundamentos teóricos, táctica, fundamentos técnicos, programa técnico, principios técnicos, filosofía, defensa personal, combate, entrenamiento, vestimenta, cortesía, artes marciales, judo, kárate, taekwondo, aplicación marcial, cualidades físicas, etiqueta, sistemas de entrenamiento, armas. Resumen: Manual teórico y técnico de artes marciales. La obra intercala los apartados dedicados al kárate, judo, taekwondo, defensa personal, otros complementos de las artes marciales y otras artes marciales. El apartado del kárate describe las posiciones, paradas, patadas y defensas tanto básicas como avanzadas; su modo de entrenamiento; las katas heian, hangetsu, jion, jitte, wankan, goju-shihoso y unsu, además algunas de sus aplicaciones marciales; los diferentes métodos de entrenamiento de kumite; los conceptos tácticos del combate; el reglamento de competición y un comentario sobre la psicología de la competición, incluyendo fotografías explicativas de cada contenido. El apartado del judo presenta la descripción técnica e ilustración de las técnicas comprendidas en el programa técnico del gokyo; sus principios técnicos; los distintos métodos de entrenamiento; las tácticas de combate; la nague-no-kata, katame-no-kata y kime-no-kata; y algunos ejemplos de las técnicas, encadenamientos y contraataques de competición. El apartado dedicado al taekwondo incluye la descripción de sus fundamentos técnicos acompañados de su secuencia fotográfica; los pumses básicos junto con los pumse koryo, kungang, taebek y pyongwon; las técnicas y entrenamiento de competición; además de presentar el reglamento de competición y arbitraje. El apartado dedicado a la defensa personal presenta la resolución de distintas situaciones de defensa personal ante el ataque de varios adversarios, los ataques con armas de fuego y arma blanca desde distintas posiciones, así como un comentario sobre la utilización de armas de fuego, la defensa personal femenina, la legítima defensa, los principios técnicos y tácticas ante una situación de defensa personal, y un resumen de sus antecedentes históricos. El apartado referido a los complementos de las artes marciales comentan los conceptos de maestro y alumno, escuela, la vestimenta, el concepto de "do", la respiración, el calentamiento, las cualidades físicas, las armas corporales, el grito, señala los beneficios de las artes marciales, los tipos de energía, la evolución de las artes marciales, la planificación del entrenamiento, los rompimientos, el esoterismo y su relación con las artes marciales, la actitud mental, el taoísmo, el yoga, las artes marciales y los medios de comunicación y un ensayo sobre la evolución de las artes marciales a lo largo de la historia. El último apartado esta dedicado a los fundamentos históricos, teóricos y técnicos de otras artes marciales como la naginata, kendo, kyudo, aikido, kung-fu, kobudo, kenpo, ninjutsu, yodo, sumo, hapkido, viet vo dao, jeet kune do, taijitsu, full contact y aquellas luchas desarrolladas en la India, Birmania, Thailandia, Indonesia, Malasia y Filipinas. Adjunta varios apéndices con dos ensayos sobre la vinculación de las artes marciales al zen y el futuro desarrollo de las artes marciales, y la secuencia fotográfica y comentario de las formas itsutsu-no-kata y hwa-rang.

1540. Oliva Seba, Antonio (dir.) (1991). Artes marciales : enciclopedia práctica. Tomo I. Madrid: F\&G. 1a ed. 260 p. : il. ; 21x28,5 cm. ISBN: 84-87437-68-0. 84-87437-67-2 (ISBN de la obra completa). Depósito 
legal: M. 8535-1991. Palabras clave: katas, pumses, formas, kumite, fundamentos teóricos, táctica, fundamentos técnicos, programa técnico, principios técnicos, filosofía, defensa personal, combate, entrenamiento, vestimenta, cortesía, artes marciales, judo, kárate, taekwondo, aplicación marcial, cualidades físicas, etiqueta, sistemas de entrenamiento, armas. Resumen: Manual teórico y técnico de artes marciales. La obra intercala los apartados dedicados al kárate, judo, taekwondo, defensa personal, otros complementos de las artes marciales y otras artes marciales. El apartado del kárate describe las posiciones, paradas, patadas y defensas tanto básicas como avanzadas; su modo de entrenamiento; las katas heian, hangetsu, jion, jitte, wankan, goju-shiho-so y unsu, además algunas de sus aplicaciones marciales; los diferentes métodos de entrenamiento de kumite; los conceptos tácticos del combate; el reglamento de competición y un comentario sobre la psicología de la competición, incluyendo fotografías explicativas de cada contenido. El apartado del judo presenta la descripción técnica e ilustración de las técnicas comprendidas en el programa técnico del gokyo; sus principios técnicos; los distintos métodos de entrenamiento; las tácticas de combate; la nague-no-kata, katameno-kata y kime-no-kata; y algunos ejemplos de las técnicas, encadenamientos y contraataques de competición. El apartado dedicado al taekwondo incluye la descripción de sus fundamentos técnicos acompañados de su secuencia fotográfica; los pumses básicos junto con los pumse koryo, kungang, taebek y pyongwon; las técnicas y entrenamiento de competición; además de presentar el reglamento de competición y arbitraje. El apartado dedicado a la defensa personal presenta la resolución de distintas situaciones de defensa personal ante el ataque de varios adversarios, los ataques con armas de fuego y arma blanca desde distintas posiciones, así como un comentario sobre la utilización de armas de fuego, la defensa personal femenina, la legítima defensa, los principios técnicos y tácticas ante una situación de defensa personal, y un resumen de sus antecedentes históricos. El apartado referido a los complementos de las artes marciales comentan los conceptos de maestro y alumno, escuela, la vestimenta, el concepto de "do", la respiración, el calentamiento, las cualidades físicas, las armas corporales, el grito, señala los beneficios de las artes marciales, los tipos de energía, la evolución de las artes marciales, la planificación del entrenamiento, los rompimientos, el esoterismo y su relación con las artes marciales, la actitud mental, el taoísmo, el yoga, las artes marciales y los medios de comunicación y un ensayo sobre la evolución de las artes marciales a lo largo de la historia. El último apartado esta dedicado a los fundamentos históricos, teóricos y técnicos de otras artes marciales como la naginata, kendo, kyudo, aikido, kung-fu, kobudo, kenpo, ninjutsu, yodo, sumo, hapkido, viet vo dao, jeet kune do, taijitsu, full contact y aquellas luchas desarrolladas en la India, Birmania, Thailandia, Indonesia, Malasia y Filipinas. Adjunta varios apéndices con dos ensayos sobre la vinculación de las artes marciales al zen y el futuro desarrollo de las artes marciales, y la secuencia fotográfica y comentario de las formas itsutsu-no-kata y hwa-rang.

1541. Oliva Seba, Antonio (dir.) (1991). Artes marciales : enciclopedia práctica. Tomo II. Madrid: F\&G. 1a ed. 520-261: il. ; 21x28,5 cm. ISBN: 84-87437-69-9. 84-87437-67-2 (ISBN de la obra completa). Depósito legal: M. 8535-1991. Palabras clave: katas, pumses, formas, kumite, fundamentos teóricos, táctica, fundamentos técnicos, programa técnico, principios técnicos, filosofía, defensa personal, combate, entrenamiento, vestimenta, cortesía, artes marciales, judo, kárate, taekwondo, aplicación marcial, cualidades físicas, etiqueta, sistemas de entrenamiento, armas. Resumen: Manual teórico y técnico de artes marciales. La obra intercala los apartados dedicados al kárate, judo, taekwondo, defensa personal, otros complementos de las artes marciales y otras artes marciales. El apartado del kárate describe las posiciones, paradas, patadas y defensas tanto básicas como avanzadas; su modo de entrenamiento; las katas heian, hangetsu, jion, jitte, wankan, goju-shiho-so y unsu, además algunas de sus aplicaciones marciales; los diferentes métodos de entrenamiento de kumite; los conceptos tácticos del combate; el reglamento de competición y un comentario sobre la psicología de la competición, incluyendo fotografías explicativas de cada contenido. El apartado del judo presenta la descripción técnica e ilustración de las técnicas comprendidas en el programa técnico del gokyo; sus principios técnicos; los distintos métodos de entrenamiento; las tácticas de combate; la nague-no-kata, katameno-kata y kime-no-kata; y algunos ejemplos de las técnicas, encadenamientos y contraataques de competición. El apartado dedicado al taekwondo incluye la descripción de sus fundamentos técnicos acompañados de su secuencia fotográfica; los pumses básicos junto con los pumse koryo, kungang, taebek y pyongwon; las técnicas y entrenamiento de competición; además de presentar el reglamento de competición y arbitraje. El apartado dedicado a la defensa personal presenta la resolución de distintas situaciones de defensa personal ante el ataque de varios adversarios, los ataques con armas de fuego y arma blanca desde distintas posiciones, así como un comentario sobre la utilización de armas de fuego, la defensa personal femenina, la legítima defensa, los principios técnicos y tácticas ante una situación de defensa personal, y un resumen de sus antecedentes históricos. El apartado referido a los complementos de las artes marciales comentan los conceptos de maestro y alumno, escuela, la vestimenta, el concepto de "do", la respiración, el calentamiento, las cualidades físicas, las armas corporales, el grito, señala los beneficios de las artes marciales, los tipos de energía, la evolución de las artes marciales, la planificación del entrenamiento, los rompimientos, el esoterismo y su relación 
con las artes marciales, la actitud mental, el taoísmo, el yoga, las artes marciales y los medios de comunicación y un ensayo sobre la evolución de las artes marciales a lo largo de la historia. El último apartado esta dedicado a los fundamentos históricos, teóricos y técnicos de otras artes marciales como la naginata, kendo, kyudo, aikido, kung-fu, kobudo, kenpo, ninjutsu, yodo, sumo, hapkido, viet vo dao, jeet kune do, taijitsu, full contact y aquellas luchas desarrolladas en la India, Birmania, Thailandia, Indonesia, Malasia y Filipinas. Adjunta varios apéndices con dos ensayos sobre la vinculación de las artes marciales al zen y el futuro desarrollo de las artes marciales, y la secuencia fotográfica y comentario de las formas itsutsu-no-kata y hwa-rang.

1542. Oliva Seba, Antonio (dir.) (1991). Artes marciales : enciclopedia práctica. Tomo III. Madrid: F\&G. 1a ed. 780-521: il. ; 21x28,5 cm. ISBN: 84-87437-70-2. 84-87437-67-2 (ISBN de la obra completa). Depósito legal: M. 8535-1991. Palabras clave: katas, pumses, formas, kumite, fundamentos teóricos, táctica, fundamentos técnicos, programa técnico, principios técnicos, filosofía, defensa personal, combate, entrenamiento, vestimenta, cortesía, artes marciales, judo, kárate, taekwondo, aplicación marcial, cualidades físicas, etiqueta, sistemas de entrenamiento, armas. Resumen: Manual teórico y técnico de artes marciales. La obra intercala los apartados dedicados al kárate, judo, taekwondo, defensa personal, otros complementos de las artes marciales y otras artes marciales. El apartado del kárate describe las posiciones, paradas, patadas y defensas tanto básicas como avanzadas; su modo de entrenamiento; las katas heian, hangetsu, jion, jitte, wankan, goju-shiho-so y unsu, además algunas de sus aplicaciones marciales; los diferentes métodos de entrenamiento de kumite; los conceptos tácticos del combate; el reglamento de competición y un comentario sobre la psicología de la competición, incluyendo fotografías explicativas de cada contenido. El apartado del judo presenta la descripción técnica e ilustración de las técnicas comprendidas en el programa técnico del gokyo; sus principios técnicos; los distintos métodos de entrenamiento; las tácticas de combate; la nague-no-kata, katameno-kata y kime-no-kata; y algunos ejemplos de las técnicas, encadenamientos y contraataques de competición. El apartado dedicado al taekwondo incluye la descripción de sus fundamentos técnicos acompañados de su secuencia fotográfica; los pumses básicos junto con los pumse koryo, kungang, taebek y pyongwon; las técnicas y entrenamiento de competición; además de presentar el reglamento de competición y arbitraje. El apartado dedicado a la defensa personal presenta la resolución de distintas situaciones de defensa personal ante el ataque de varios adversarios, los ataques con armas de fuego y arma blanca desde distintas posiciones, así como un comentario sobre la utilización de armas de fuego, la defensa personal femenina, la legítima defensa, los principios técnicos y tácticas ante una situación de defensa personal, y un resumen de sus antecedentes históricos. El apartado referido a los complementos de las artes marciales comentan los conceptos de maestro y alumno, escuela, la vestimenta, el concepto de "do", la respiración, el calentamiento, las cualidades físicas, las armas corporales, el grito, señala los beneficios de las artes marciales, los tipos de energía, la evolución de las artes marciales, la planificación del entrenamiento, los rompimientos, el esoterismo y su relación con las artes marciales, la actitud mental, el taoísmo, el yoga, las artes marciales y los medios de comunicación y un ensayo sobre la evolución de las artes marciales a lo largo de la historia. El último apartado esta dedicado a los fundamentos históricos, teóricos y técnicos de otras artes marciales como la naginata, kendo, kyudo, aikido, kung-fu, kobudo, kenpo, ninjutsu, yodo, sumo, hapkido, viet vo dao, jeet kune do, taijitsu, full contact y aquellas luchas desarrolladas en la India, Birmania, Thailandia, Indonesia, Malasia y Filipinas. Adjunta varios apéndices con dos ensayos sobre la vinculación de las artes marciales al zen y el futuro desarrollo de las artes marciales, y la secuencia fotográfica y comentario de las formas itsutsu-no-kata y hwa-rang.

1543. Oliva Seba, Antonio (dir.) (1991). Artes marciales : enciclopedia práctica. Tomo IV. Madrid: F\&G. 1aㅡ ed. 1040-781: il. ; 21x28,5 cm. ISBN: 84-87437-71-0. 84-87437-67-2 (ISBN de la obra completa). Depósito legal: M. 8535-1991. Palabras clave: katas, pumses, formas, kumite, fundamentos teóricos, táctica, fundamentos técnicos, programa técnico, principios técnicos, filosofía, defensa personal, combate, entrenamiento, vestimenta, cortesía, artes marciales, judo, kárate, taekwondo, aplicación marcial, cualidades físicas, etiqueta, sistemas de entrenamiento, armas. Resumen: Manual teórico y técnico de artes marciales. La obra intercala los apartados dedicados al kárate, judo, taekwondo, defensa personal, otros complementos de las artes marciales y otras artes marciales. El apartado del kárate describe las posiciones, paradas, patadas y defensas tanto básicas como avanzadas; su modo de entrenamiento; las katas heian, hangetsu, jion, jitte, wankan, goju-shiho-so y unsu, además algunas de sus aplicaciones marciales; los diferentes métodos de entrenamiento de kumite; los conceptos tácticos del combate; el reglamento de competición y un comentario sobre la psicología de la competición, incluyendo fotografías explicativas de cada contenido. El apartado del judo presenta la descripción técnica e ilustración de las técnicas comprendidas en el programa técnico del gokyo; sus principios técnicos; los distintos métodos de entrenamiento; las tácticas de combate; la nague-no-kata, katameno-kata y kime-no-kata; y algunos ejemplos de las técnicas, encadenamientos y contraataques de competición. El apartado dedicado al taekwondo incluye la descripción de sus fundamentos técnicos acompañados de su secuencia fotográfica; los pumses básicos junto con los pumse koryo, kungang, 
taebek y pyongwon; las técnicas y entrenamiento de competición; además de presentar el reglamento de competición y arbitraje. El apartado dedicado a la defensa personal presenta la resolución de distintas situaciones de defensa personal ante el ataque de varios adversarios, los ataques con armas de fuego y arma blanca desde distintas posiciones, así como un comentario sobre la utilización de armas de fuego, la defensa personal femenina, la legítima defensa, los principios técnicos y tácticas ante una situación de defensa personal, y un resumen de sus antecedentes históricos. El apartado referido a los complementos de las artes marciales comentan los conceptos de maestro y alumno, escuela, la vestimenta, el concepto de "do", la respiración, el calentamiento, las cualidades físicas, las armas corporales, el grito, señala los beneficios de las artes marciales, los tipos de energía, la evolución de las artes marciales, la planificación del entrenamiento, los rompimientos, el esoterismo y su relación con las artes marciales, la actitud mental, el taoísmo, el yoga, las artes marciales y los medios de comunicación y un ensayo sobre la evolución de las artes marciales a lo largo de la historia. El último apartado esta dedicado a los fundamentos históricos, teóricos y técnicos de otras artes marciales como la naginata, kendo, kyudo, aikido, kung-fu, kobudo, kenpo, ninjutsu, yodo, sumo, hapkido, viet vo dao, jeet kune do, taijitsu, full contact y aquellas luchas desarrolladas en la India, Birmania, Thailandia, Indonesia, Malasia y Filipinas. Adjunta varios apéndices con dos ensayos sobre la vinculación de las artes marciales al zen y el futuro desarrollo de las artes marciales, y la secuencia fotográfica y comentario de las formas itsutsu-no-kata y hwa-rang.

1544. Ory, Jean Baptiste y Ory, Mar (1986). Diccionario de las artes marciales. Barcelona: Obelisco. 1aㅡ ed. 227 p. : il. ; 13x21 cm. ISBN: 84-86000-88-2. Depósito legal: B. 25374-1986. (2ª ed., 1995, ISBN: 84-7720372-5). Palabras clave: historia, fundamentos técnicos, maestros. Resumen: Diccionario específico de artes marciales. El libro incluye algunos de los términos, ideas y conceptos generales relacionados con las artes marciales, su práctica, técnica, historia y maestros, detallando el origen de cada palabra y su significado. Incluye ilustraciones.

1545. Pérez Agustí, Adolfo (1987). El libro de oro de las armas orientales. Madrid: Adolfo Pérez Agustí. 1a ed. 183 p. : il. ; 15x21,5 cm. ISBN: 84-404-0581-2. Depósito legal: M. 38392-1987. Palabras clave: historia, fundamentos teóricos, armas. Resumen: Manual teórico y técnico sobre armas orientales. La obra esta formada por 28 capítulos. El primer capítulo narra la introducción del chuan fa chino y las armas en Japón. Los siguientes capítulos comentan la historia de cada arma, su utilización, sus características físicas y las ventajas e inconvenientes, además de incluir varias fotografías sobre sus fundamentos técnicos. Las armas presentadas son: el arco, el bo (bastón largo), los cuchillos mariposa (balisong), la espada tou (de un sólo filo), las espadas mariposa, el kali, el kama, el kris, el kusarigama, el kyoketshu shogue, las lanzas yari, el manriquigusari (arma de los mil poderes), la naginata, el nunchaku, el nunchaku de tres secciones, el sai, el shinobi zue, el shuriken, el tonfa, el tambo (bastón corto), el tanto, el tessen, el yawara, la espada china ancha, el jitte, y un conjunto de armas raras.

1546. Pérez Agustí, Adolfo (2004). Manual de las artes marciales. Alcobendas: Libsa. $1^{a}$ ed. 288 p. : il. ; desc.xdesc. cm. ISBN: 84-662-0645-0. Depósito legal: M. 17762-2003. Palabras clave: historia, fundamentos teóricos, biografía, estrategia, artes marciales, jeet kune do, aplicación marcial, competición, maestros. Resumen: Compendio introductorio a las distintas artes marciales y sus características principales. El primer capítulo presenta la historia de las artes marciales así como una breve descripción de las más extendidas mundialmente. A continuación, agrupa las artes marciales en japonesas, chinas y derivadas en capítulos distintos para detallar sus características y sus fundamentos técnicos. El capítulo 5 observa el significado del cinturón negro y ofrece algunos consejos técnicos tanto para el entrenamiento técnico como táctico. Después de comentar brevemente la técnica de rompimiento en el siguiente capítulo, pasa a describir los aspectos y recomendaciones más prácticos del entrenamiento tradicional (la defensa para mujeres y la defensa contra cuchillo) y del entrenamiento con saco. El capítulo 9 evalúa el combate deportivo y las estrategias a seguir ante los diferentes competidores, para exponer en el último capítulo la biografía de Bruce Lee y los aspectos técnicos del Jeet Kune Do.

1547. Planellas Vidal, Pau-Ramon (2002). Enciclopedia de las armas japonesas : historia, leyendas, mitología, técnica, morfología, filosofía, ética, artes marciales. Volumen primero. Barcelona: Alas. 1aㅡ ed. 195 p. : il. ; 21x29,5 cm. ISBN: 84-203-0415-8. 84-203-0418-2 (ISBN de la obra completa). Depósito legal: B. 20165-2002. Palabras clave: historia, fundamentos teóricos, armas. Resumen: Tratado sobre la historia, características y manejo de las armas japonesas. La obra esta compuesta por 6 capítulos precedidos de una introducción en donde se explica el origen y evolución de la sociedad japonesa. El primer capítulo detalla las distintas épocas por las que pasó el sable y que dio lugar a distintas formas, las partes que componen el sable, y las características e historia del wakizashi, el tanto y el resto de pequeñas dagas. El segundo capítulo explica el origen de los sables de entrenamiento, las características técnicas de las distintas escuelas del arte de combate con el sable, así como la ilustración de algunas técnicas de iaido. El tercer capítulo explica las pruebas de corte que se realizaban a los sables así como otros tipos de sable. Continúa con la descripción de las lanzas hoko y yari, sus partes, usos y escuelas. El quinto capítulo explica las partes y la utilización de otras armas 
largas para luchar contra un adversario montado a caballo, como el sasumata, kumade, mojiri, tsukubo y sode garami. El último capítulo describe las partes del naginata, cuál era su uso, cuáles son las escuelas que existen y algunas de sus técnicas básicas.

1548. Planellas Vidal, Pau-Ramon (2002). Enciclopedia de las armas japonesas : historia, leyendas, mitología, técnica, morfología, filosofía, ética, artes marciales. Volumen segundo. Barcelona: Alas. $1 \underline{a}$ ed. 253 p. : il. ; 20x29,5 cm. ISBN: 84-203-0416-6. 84-203-0418-2 (ISBN de la obra completa). Depósito legal: B. 30974-2002. Palabras clave: armas, seppuku. Resumen: Tratado sobre la historia, características y manejo de las armas japonesas. La obra esta compuesta por 11 capítulos. Comienza con la explicación del origen, de las características y de las técnicas básicas del palo largo japonés; y continua con el arco y las armas arrojadizas como el shuriken y la cerbatana. El décimo capítulo estudia la introducción de las armas de fuego en la sociedad japonesa y sus características; para luego pasar a detallar la utilización de las armas flexibles como la cadena y la cuerda. El siguiente capítulo introduce aquellas armas que incorporaron la cadena lastrada, ilustrando sus partes y algunas de sus técnicas. Los siguientes capítulos estudian e ilustran las armas pequeñas utilizadas por las escuelas de jujutsu; algunas armas especiales como el jutte, tessen y gunbai; el ritual del seppuku y las armas de las islas Ryukyu, además de explicar algunas de sus técnicas.

1549. Planellas Vidal, Pau-Ramon (2002). Enciclopedia de las armas japonesas : historia, leyendas, mitología, técnica, morfología, filosofía, ética, artes marciales. Volumen tercero. Barcelona: Alas. 1a ed. 251 p. : il. ; 21x29,5 cm. ISBN: 84-203-0417-4. 84-203-0418-2 (ISBN de la obra completa). Depósito legal: B. 30975-2002. Palabras clave: escuelas, kyusho, relatos, ética, maestros, armas, defensa personal policial. Resumen: Tratado sobre la historia, características y manejo de las armas japonesas. El primer capítulo de este volumen ofrece una aplicación de aquellos utensilios de la vida diaria japonesa que podían ser utilizados como arma. Continua con la descripción de las armas policiales japonesas y su utilización; para en el siguiente capítulo describir la relación existente entre las armas y las artes marciales japonesas. Los siguientes capítulos explican el código de utilización de las armas japonesas, los puntos vitales, algunos relatos mitológicos y leyendas del Japón; para finalizar con tres apéndices que enumeran los maestros, escuelas y disciplinas más significativas que han contribuido al desarrollo de las artes marciales japonesas.

1550. Thomas, Raymond (dir.) (1978). Diccionario del budo. Barcelona: Alas. 1aㅡ ed. 124 p. : il. ; 11x16,5 cm. ISBN: 84-203-0069-1. Depósito legal: B. 8896-1978. Palabras clave: historia, fundamentos teóricos, fundamentos técnicos, filosofía, vestimenta, cortesía, etiqueta, samurái, armas. Resumen: Diccionario de términos relacionados con la práctica, fundamentos técnicos, fundamentos teóricos, aspectos formales y filosóficos de las principales artes marciales. Adjunta un comentario sobre la historia de la fabricación de los sables samurái en sus diferentes periodos.

1551. Vera Sho-Dan, (seud. de Vera Ramírez, Antonio) (1985). Guía de las artes marciales. Barcelona: Bruguera. $1^{\mathrm{a}}$ ed. 204 p. : il. ; 10x17,5 cm. ISBN: 84-02-10122-4. Depósito legal: B. 20700-1984. Palabras clave: historia, fundamentos teóricos, principios técnicos, vestimenta, cortesía, bushido, etiqueta, armas. Resumen: Manual teórico y técnico de artes marciales. El libro esta formado por 7 capítulos precedidos por un prólogo que destaca la importancia de la obra. El primer capítulo explica en qué consisten las artes marciales y cuál es el camino del budoka. El segundo capítulo comenta los requisitos para la práctica de las artes marciales, las características del entrenamiento y el sobreentrenamiento, el entrenamiento mental, explica los conceptos del ki, el kiai, el mokuzo y las cualidades de un buen maestro. El tercer capitulo comenta las características y estructura de algunas de las armas utilizadas en las artes marciales como el bo, bokken, jitte, katana, katana zutsu, kusarigama, kyotetsu-koge, manrikigusari, naginata, nunte, sai, shinai, shuko, shuriken, tachi, kozuka y aikuchi, tessen, tetsu bishi, tonfa, wakizashi, ya y yumi, yari y yawara, acompañados de sus ilustraciones. El cuarto capítulo enumera las máximas del samurái, sus virtudes, explica la ceremonia del hara-kiri y del ikebana. El quinto capítulo incluye un haiku, describe el desarrollo de la ceremonia kagami biraki, define los conceptos de bugei, budo y budoka, y comenta el espíritu del budo y el significado del bushido. El sexto capítulo presenta la historia, fundamentos teóricos y principios técnicos del aikido, aikijutsu, aiki-kendo, t'aikido, judo, kendo, kyudo, yabusame, kobudo y kárate. El último capítulo enumera los principales estilos de kárate y detalla la historia, fundamentos teóricos y contenidos técnicos del taekwondo, naginata-do, bo-jutsu, ho-jutsu, ninjutsu, sumo y kung fu.

1552. Yrayzoz Reyna, Joaquín (1975). Armas antiguas orientales : su descripción y utilidad. Barcelona: Alas. 1a ed. 79 p. : il. ; 15x21 cm. ISBN: 84-203-0333-X. Depósito legal: B. 20912-1975. (2ª ed., 1980, ISBN: 84203-0332-1; 3 a ed., 1985, ISBN: 84-203-0332-1). Palabras clave: fundamentos teóricos, armas. Resumen: Manual teórico de armas. La obra describe la estructura, historia, formas de agarre y utilización de las armas antiguas orientales como el sai, nunte, tessen, yawara, nunchaku, kusarigama, kama, manrikigusari, aikuchi, tanto, katana, wakizashi, jitte, bo, tambo, naginata, lanzas yari, shaken, shuriken y tonfa, además de incluir numerosas fotografías explicativas. 


\subsection{Condición Física}

1553. Cochran, Sean (2004). Entrenamiento físico integral para las artes marciales. Móstoles: Arkano Books. 1aㅡ ed. 188 p. : il. ; 17x24 cm. ISBN: 84-89897-97-2. Depósito legal: M. 44380-2004. Palabras clave: fundamentos teóricos, ejercicios, entrenamiento, capacidades físicas, planificación del entrenamiento, preparación física, sistemas de entrenamiento, tests. Resumen: Manual teórico y práctico sobre la preparación física aplicada a las artes marciales. El primer capítulo presenta las nociones básicas sobre las cualidades físicas, las artes marciales y la teoría del entrenamiento; para en el segundo capítulo mostrar los métodos de evaluación de la forma física. El tercer capítulo justifica el entrenamiento de la flexibilidad y su importancia en cualquier arte marcial además de proponer ejercicios, explicados de forma concisa y gráficamente, para desarrollarla; y del mismo modo se realiza en los capítulos 4 y 5 con la estabilización de las articulaciones y el fortalecimiento del torso respectivamente. El sexto capítulo propone ejercicios básicos para desarrollar la fuerza muscular y algunas recomendaciones básicas para este tipo de entrenamiento, estando cada ejercicio representado de forma gráfica e indicados los músculos que intervienen y la ejecución del movimiento. El siguiente capítulo estudia las pliometrías, la realización de algunos de sus ejercicios y el diseño de programas de entrenamiento. De forma breve, el octavo capítulo describe el trabajo de resistencia y algunos ejercicios, y el noveno capítulo las recomendaciones para una correcta nutrición y recuperación, que nos ayude a mejorar nuestro rendimiento. Por último, enseña a crear nuestro propio programa de entrenamiento, atendiendo a los distintos objetivos que tengamos y ofrece ejemplos de distintos programas.

1554. Conde Marina, Pedro (1995). Todo sobre la elasticidad. Madrid: Ohara Publicaciones. 1 a ed. 95 p. : il. ; 21x28 cm. ISBN: No ISBN. Depósito legal: M. 14285-1995. Palabras clave: fundamentos teóricos, fundamentos técnicos, principios técnicos, principios teóricos, entrenamiento. Resumen: Manual teórico y técnico de artes marciales. El libro esta formado por 7 capítulos precedidos por una introducción que comenta los contenidos de la obra. El primer capítulo señala la importancia y beneficios de la elasticidad en las artes marciales. El segundo capítulo comenta los diferentes tipos de elasticidad y sus características así como los 25 consejos para la práctica de la elasticidad. El tercer capítulo explica la relación entre la edad y la elasticidad. El cuarto capítulo describe numerosos ejercicios de estiramientos y elasticidad acompañados de su representación gráfica y sus observaciones técnicas. El quinto capítulo analiza los factores implicados en el perfeccionamiento de las patadas. El sexto capítulo presenta la descripción e ilustración de varios ejercicios y técnicas para el perfeccionamiento de las patadas. El último capítulo describe los diferentes tipos de patadas existentes en las artes marciales incluyendo numerosos ejemplos ilustrados.

1555. Delp, Christoph (2007). Preparación física para deportes de contacto. Móstoles: Arkano Books. $1^{\mathfrak{a}}$ ed. 249 p. : il. ; $17 \times 24$ cm. ISBN: 978-84-96111-41-7. Depósito legal: M. 47880-2007. Palabras clave: fundamentos teóricos, ejercicios, entrenamiento, anatomía, capacidades físicas, nutrición, planificación del entrenamiento. Resumen: Manual práctico sobre la teoría del entrenamiento y su programación aplicada a las artes marciales. El primer capítulo introduce brevemente los conceptos básicos de la preparación física, cualidades físicas, anatomía y alimentación. En el segundo, tercer y cuarto capítulo, después de presentar las condiciones de entrenamiento de la flexibilidad, la resistencia y la fuerza respectivamente, describe los ejercicios para desarrollar estas cualidades. El último capítulo centra su atención en la aplicación práctica de la teoría del entrenamiento (programación, planificación, control, determinación del peso, registro del entrenamiento) para terminar con la sugerencia de planes de entrenamiento para cada cualidad así como para cada nivel del practicante.

1556. Dienersberger, Robbi (2004). Thai-bo : el nuevo método para estar en forma. L'Hospitalet: Hispano Europea. 1ํㅡㄹ ed. 32 p. : il. ; 16x19 cm. ISBN: 84-255-1553-X. Depósito legal: B. 41205-2004. Palabras clave: historia, fundamentos técnicos, entrenamiento. Resumen: Manual teórico y técnico de thai-bo. La obra esta formada por 3 capítulos. El primer capítulo comenta los orígenes del thai-bo, explica sus fundamentos y principios metodológicos, y justifica su práctica en determinados grupos de personas. El segundo capítulo describe la ejecución de sus técnicas básicas como son las posiciones básicas, los golpes de puño y las técnicas de pierna, incluyendo fotografías aclarativas. El último capítulo expone el desarrollo de una sesión de entrenamiento de thai-bo, desde su parte inicial de calentamiento y estiramientos, hasta las actividades de la parte principal y el trabajo de vuelta a la calma, explicando las actividades y ofreciendo consejos sobre la intensidad del trabajo.

1557. Fraguas, José María y Malota Lulgjuraj, Peter (1983). Guía de elasticidad y flexibilidad para las artes marciales. Barcelona: Alas. 1aㅡ ed. 93 p. : il. ; 15x21,5 cm. ISBN: 84-203-0161-2. Depósito legal: B. 10499-1983. (2 $2^{\mathrm{a}}$ ed., 1985; $3^{\mathrm{a}}$ ed., 1987). Palabras clave: entrenamiento, capacidades físicas, preparación física. Resumen: Manual teórico y técnico de flexibilidad. El primer capítulo expone los consejos generales para el calentamiento para luego describir e ilustrar los ejercicios de calentamiento para la parte superior del cuerpo y de estiramientos para la parte inferior del cuerpo. Los dos siguientes capítulos presentan distintos ejercicios por parejas y ejercicios avanzados para mejorar la 
flexibilidad del tren inferior. El sexto capítulo expone los diferentes métodos de trabajo existentes para mejorar la velocidad, la potencia, la precisión, la técnica y la musculatura de las piernas en su acción en las patadas. Finaliza con la descripción de varios ejercicios para realizar en casa, con ayuda de una silla, para desarrollar la flexibilidad de las piernas. Adjunta gráficos con otros aparatos y ejercicios para el entrenamiento.

1558. Gummerson, Tony (1993). Teoría del entrenamiento para las artes marciales. Barcelona: Paidotribo. $1^{\mathrm{a}}$ ed. 135 p. : il. ; 15x21,5 cm. ISBN: 84-8019-072-8. Depósito legal: B. 5364-1993. Palabras clave: entrenamiento, artes marciales, tests. Resumen: Tratado teórico sobre la planificación y evaluación del entrenamiento y su aplicación a las artes marciales. La monografía esta dividida en 13 capítulos con los cuatro primeros desarrollando los conceptos básicos del entrenamiento, desde el papel del entrenador hasta sus principios generales y consideraciones fisiológicas. Los dos siguientes capítulos se acercan a la labor del entrenador, con la explicación de la determinación de la carga y el desarrollo de las cualidades físicas en las artes marciales. A continuación describe la teoría sobre la planificación del entrenamiento así como un decálogo de consideraciones generales sobre el entrenamiento. El noveno capítulo describe la periodización del entrenamiento con sus fases y continúa con una reflexión sobre la planificación a largo plazo. El decimoprimer capítulo comenta los objetivos del entrenamiento y finaliza con la exposición de pruebas para evaluar la condición física del practicante y un decálogo de pruebas que sirven para controlar el entrenamiento.

1559. Kim, Sang Hwan (2006). Flexibilidad extrema : guía completa de estiramientos para artes marciales. Badalona: Paidotribo. 1aㅡ ed. 303 p. : il. ; 21x27,5 cm. ISBN: 84-8019-874-5. Depósito legal: no. (1aㅗ reimp., 2009). Palabras clave: fundamentos teóricos, ejercicios, entrenamiento, capacidades físicas. Resumen: Manual teórico y práctico sobre la flexibilidad, los estiramientos y su entrenamiento. La obra esta dividida en 7 capítulos. El primer capítulo recopila los aspectos generales que deben considerar el principiante, el experto y el deportista de alto nivel de artes marciales para el entrenamiento de la flexibilidad. Los siguientes dos capítulos describen la teoría de la flexibilidad y de los estiramientos, desde los factores que influyen sobre dichos conceptos hasta sus tipos, beneficios, métodos o mecánica. El cuarto capítulo estudia las partes del cuerpo, cuáles son los músculos que las rodean y que ejercicios hay que realizar para iniciar el entrenamiento de la flexibilidad, mantenerla, mejorarla o recuperarla después de una lesión. El quinto capítulo ofrece las consideraciones prácticas y las recomendaciones generales vinculadas con el plan de entrenamiento y su ejecución. El siguiente capítulo presenta los ejercicios de flexibilidad, divididos según la parte del cuerpo que se trabaje, con breves descripciones y el apoyo gráfico. El último capítulo ahonda en los ejercicios de flexibilidad dependiendo en los objetivos del entrenamiento o el tipo de arte marcial practicada, sus ejercicios preferidos, tablas con el grado de dificultad de los ejercicios presentados y consejos para hacer la tijera y realizar patadas altas. Adjunta un índice alfabético de términos utilizados así como una pequeña biografía de autor.

1560. Little, John (2007). Bruce Lee : el arte de expresarse con el cuerpo. Badalona: Paidotribo. $1^{\text {a }}$ ed. 362 p. : il. ; 15x21,5 cm. ISBN: 978-84-8019-907-0. Depósito legal: no. (1르 reimp., 2007). Palabras clave: fundamentos teóricos, entrenamiento, ejercicios, biografía, sistemas de entrenamiento. Resumen: Manual teórico y técnico sobre preparación física. El libro esta formado por 24 capítulos precedidos por un prólogo que comenta los contenidos de la obra, un comentario sobre los fundamentos teóricos de Bruce Lee sobre la preparación física, un prefacio que expone los objetivos del libro, un conjunto de comentarios sobre el físico de Bruce Lee y una introducción que presenta la actitud de Bruce Lee hacia el entrenamiento físico. El primer capítulo explica los fundamentos teóricos de Bruce Lee sobre el entrenamiento de la fuerza e incluye una tabla de ejercicios. El segundo capítulo describe la ejecución de los ocho ejercicios isométricos básicos y la aplicación de Bruce Lee. El tercer capítulo comenta los primeros entrenamientos de pesas de Bruce Lee junto con la descripción de sus ejercicios, mientras que el cuarto capítulo presenta 12 ejercicios de desarrollo físico general. Los siguientes cuatro capítulos describe los fundamentos y ejercicios que componían las rutinas de los 20 minutos de fuerza y forma, del entrenamiento en circuito para un estado físico pleno y una musculatura aumentada, y la rutina especial de pesas de Bruce Lee. Los dos siguientes capítulos detallan el entrenamiento específico de abdominales y antebrazos junto con algunas recomendaciones. El décimo capítulo explica los siete ejercicios de Bruce Lee para el cuello y los hombros además de la justificación de dicho entrenamiento. Los siguientes cuatro capítulos presentan los ejercicios principales para el pecho, la espalda, los brazos, y las piernas y gemelos. El decimosexto capítulo detalla los fundamentos teóricos del entrenamiento de flexibilidad de Bruce Lee junto con la descripción de algunos de sus ejercicios. El siguiente capítulo expone el sistema de entrenamiento de la resistencia de Bruce Lee junto con sus fundamentos teóricos. El decimoctavo capítulo ofrece distintas rutinas de entrenamiento con el saco pesado, las recomendaciones para su práctica y algunos errores a evitar. El decimonoveno capítulo explica los sistemas de entrenamiento interválico de Bruce Lee. El vigésimo capítulo presenta los fundamentos teóricos de la nutrición, los suplementos y la dieta de Bruce Lee. Los dos siguientes capítulos presentan las rutinas semanales de entrenamiento de Bruce Lee en distintas épocas y 
algunos extractos de sus diarios de entrenamiento. Los dos últimos capítulos recopilan los planes de entrenamiento y rutinas diseñadas por Bruce Lee para sí mismo o sus amigos. Adjunta dos apéndices con las medidas corporales de Bruce Lee y el relato de la recuperación de la máquina de entrenamiento utilizada por él. También adjunta notas sobre las fuentes utilizadas e índice alfabético.

1561. Malota Lulgjuraj, Peter (1991). Super stretching : guía completa de elasticidad y flexibilidad. Madrid: Multideporte. $1^{\underline{a}}$ ed. 64 p. : il. ; 17x24 cm. ISBN: 84-87967-00-0. Depósito legal: M. 12861-1991. Palabras clave: ejercicios, entrenamiento. Resumen: Manual de estiramientos. Tras hacer una breve introducción sobre la importancia de la elasticidad en el entrenamiento, pasa a describir textual y gráficamente ejercicios de estiramiento para todo el cuerpo, estiramientos con un aparato, estiramientos por parejas y estiramientos dinámicos. Finaliza con un compendio de ejercicios para el acondicionamiento físico general.

1562. Mora Rafart, Pedro de la (1988). La flexibilidad en las artes marciales : bases médicas para desarrollarla. Barcelona: Alas. 1aㅡ ed. 110 p. : il. ; 15x21 cm. ISBN: 84-203-0232-5. Depósito legal: B. 47547-1988. (2ª ed., 1989). Palabras clave: ejercicios, entrenamiento, anatomía, capacidades físicas, fisiología, lesiones. Resumen: Manual teórico y técnico de entrenamiento. La obra esta formada por 3 partes precedidas por una introducción que señala los objetivos de la obra. La primera parte define los conceptos de flexibilidad y elasticidad, describe la estructura y funcionamiento de una articulación, comenta las causas de las diferencias de flexibilidad entre los individuos, la relación entre la masa muscular y la elasticidad, analiza los tipos de movimientos, el estiramiento de los nervios y la fisiología muscular, incluye una tabla de ejercicios de calentamiento junto con sus técnicas de respiración y algunos consejos prácticos sobre el desarrollo del entrenamiento de la flexibilidad. La segunda parte estudia la anatomía y movimientos de las articulaciones del hombro, codo, muñeca, cadera, rodilla, tobillo y columna incluyendo la descripción e ilustración de distintos ejercicios para mejorar su flexibilidad. La tercera parte expone los beneficios de los ejercicios de flexibilidad, explica la intervención quirúrgica de los aductores y sus inconvenientes, y comenta las características, síntomas y tratamiento de las principales lesiones de huesos, músculos y ligamentos además de las heridas, hemorragias nasales, golpes en el abdomen y en la cabeza.

1563. Pérez Agustí, Adolfo (1977). Preparación física para las artes marciales. Madrid: Amsa. 1ae ed. 96 p. : il. ; 21x28 cm. ISBN: No ISBN. Depósito legal: M. 34398-1977. Palabras clave: entrenamiento, nutrición, preparación física. Resumen: Manual teórico y técnico de preparación física para las artes marciales. El libro esta compuesto de 20 capítulos precedidos de un prólogo que ofrece algunos consejos sobre la práctica de actividad física. El primer capítulo enumera las normas básicas de la alimentación de un deportista. Los siguientes cinco capítulos analiza las características de los hidratos de carbono, proteínas, grasas, vitaminas y minerales. El séptimo capítulo comenta la ingesta de alimentos en el entrenamiento y competición. Los dos siguientes capítulos explican brevemente la anatomía y sistema muscular del cuerpo humano junto con algunas recomendaciones prácticas. El décimo capítulo comenta los objetivos y características del calentamiento además de incluir la descripción e ilustración de numerosos ejercicios de calentamiento y estiramiento. Los siguientes tres capítulos definen las cualidades físicas de resistencia, velocidad y potencia y ofrecen consejos para su desarrollo en el entrenamiento de artes marciales. El decimocuarto capítulo presenta la descripción e ilustración de diversos ejercicios de musculación. El decimoquinto capítulo explica en qué consiste el footing, los requisitos básicos para su entrenamiento y ofrece algunos consejos prácticos. El siguiente capítulo analiza y comenta algunos de los factores que causan la disminución del rendimiento de un deportista. El decimoséptimo capítulo define los términos de elasticidad, flexibilidad y elongación, expone los fundamentos teóricos para su entrenamiento e ilustra algunos de sus ejercicios. Los dos siguientes capítulos comentan la importancia del endurecimiento en las artes marciales, sus fases, las características del saco y makiwara así como la ilustración de la ejecución de algunas técnicas sobre los mismos. El último capítulo comenta las características y tratamiento de las principales lesiones de las artes marciales. Adjunta una breve entrevista al autor y la dedicatoria.

1564. Rosso, Edoardo (1998). Power stretching : estiramientos aplicados a las artes marciales. Madrid: Tutor. $1^{\underline{a} \text { ed. }} 122$ p. : il. ; 15x23,5 cm. ISBN: 84-7902-206-X. Depósito legal: M. 29592-1998. (2aㅡ ed., 2003). Palabras clave: fundamentos técnicos, entrenamiento. Resumen: Manual teórico y técnico de stretching. Está compuesto por 11 capítulos. Comienza explicando los beneficios del stretching, detallando los tipos de stretching que existen y cuándo realizar estos ejercicios. Después explica los distintos tipos de stretching: balístico, dinámico, estático, matutino, PNF y power stretching. Estos capítulos incluyen ejercicios ilustrados y descritos por partes del stretching dinámico, del estático, del PNF y del power stretching. El siguiente capítulo explica el material disponible para realizar el stretching en casa o sin compañero y continúa con algunas preguntas y respuestas sobre la práctica, un compendio de trucos o ejercicios caseros de stretching, la ejecución de las aperturas, algunos consejos para realizar el stretching en situaciones diarias y una pequeña demostración. 


\section{3. Índices y referencias}

\subsection{Listado de abreviaturas}

Cm.: Centímetros.

Il.: Ilustraciones.

Cols.: Colaboradores.

Imp.: Impresión.

Comp.: Compilador.

P.: Páginas.

Coord.: Coordinador.

Reimp.: Reimpresión.

Coords.: Coordinadores.

S.a.: Sin autor.

Desc.: Desconocido.

S.l.: Sin lugar de edición.

Dir.: Director.

S.n.: Sin nombre de editor.

Ed.: Edición.

Ed. corr. y aum.: Edición corregida y aumentada.

Seud.: Seudónimo.

Trad.: Traductor.

Ed. desc.: Edición desconocida.

Vol.: Volumen.

Et al.: Y otros.

\section{2. Índice onomástico}

A

Acker, William R. B. · 534

Adams, Neil $\cdot 77,78$

Aguilar Cruz, Miguel Angel $\cdot 79$

Aguilar, Huang $\cdot 898$

Akeshi, Sueyoshi · 498, 499

Álamo Mendoza, José Miguel · 80, 1281

Alavedra, José • 81, 82

Alba Alonso, Carlos · 83, 1227, 1228

Albuixech, Juan José · 1101, 1102, 1529, 1530

Alcántara Castilla, Fermín · 899

Alcocer, Enrique $\cdot 900$

Aledo Bañuls, Enrique $\cdot 292$

Allyn, John $\cdot 1441$

Alonso, Marcelo $\cdot 84,1103$

Alonso, Rafael $\cdot 737$

Alpanseque, Emilio $\cdot 1405$

Álvarez, Vicente $\cdot 85$

Amador Mouchet, Enrique $\cdot 1134$

Amador Ramírez, Fernando • 86, 1281

Amdur, Ellis $\cdot 1282$

Andaluz Domínguez, Michael • 1089

André, Émile $\cdot 1$

Andreu Cortés, Juan 525

Anta, Juan Ángel · 1229, 1230

Antón López, Julio $\cdot 87$

Aoki, Osamu ·293, 294, 295

Arakaki, Kiyoshi $\cdot 296$

Araujo, Alfonso $\cdot 1283$

Aribau Montón, Elisa $\cdot 1084$

Aribau, Elisa $\cdot 1064$

Arlandes, Gerard $\cdot 738$

Armstead, John $\cdot 297$

Arpin, Louis · 88, 89, 1174
Arruza Gabilondo, Josean $\cdot 90$

Artímez, José Antonio · 91, 159

Asanaro $\cdot 1099,1100$

Aso, Rafael $\cdot 1036$

Atencia Henares, David · 1284

Augusto, Jordan $\cdot 535$

Azcarate Sumalde, Enrique · 92

$\overline{\mathbf{B}}$

Babiloni Guasch, José · 298

Babiloni Saiz, Javier $\cdot 298$

Bádenas Padilla, José (Capitán) · 2

Bagnulo, Giancarlo $\cdot 93$

Bagué, Esteban · 900, 901

Balbastre Gimeno, Rafael 1023

Bardina, Joan $\cdot 14$

Bargados Díaz, Félix · 299, 300

Barioli, César · Véase Barioli, Cesare

Barioli, Cesare · 94, 95, 96, 97, 301, 302, 303, 304, 305, 306, 902, 903

Barra Nogués, Armando • 98, 99, 100

Barra Nogués, Carlos · 98, 99, 100

Barros García, José María · 307, 308

Bartolone, Enzo $\cdot 1285$

Basile, Augusto $\cdot 309,310,311,312,313,314,315,515$

Bastenier, M.A. $\cdot 82$

Benaiges Gomá, Jaime · 538

Benítez de Aragón, Salvador · 101, 102

Benito García, José María · 1231, 1232, 1233, 1234

Benner, Hans $\cdot 739$

Benzal Mishal, Pedro $\cdot 1175$

Berbel Jiménez, Sonia $\cdot 103$

Bergua Bernués, Marta $\cdot 175$

Bernasconi C., Bruno $\cdot 627$

Berrenechea, Juan Ignacio 1097 
Bikandi Elorriaga, Asier · 1172

Blanco Dopazo, Fernando 904

Blas Pérez, Fernando $\cdot 86$

Blawyn, Elrond $\cdot 644,1135$

Blawyn, Juliana $\cdot 644,1135$

Blawyn, Sophia $\cdot 644,1135$

Boillat de Corgemont Sartorio, Marc · 645, 646, 740, 1176, 1286, 1287

Bonet Escandell, Ferrán · 741

Bonomelli, Roberto $\cdot 551,1202$

Bosch Espinal, José $\cdot 538$

Bouzas Hermida, José Enrique $\cdot 316$

Brady, Peter $\cdot 1164$

Bridge, Jane $\cdot 116$

Brieva Ortega, Javier $\cdot 1104$

Brown, Marjorie Ann $\cdot 742$

Bryant, Anthony J. $\cdot 1288$

Bryant, Graham $\cdot 743$

Bunnag, Tew $\cdot 744,745,746,747$

Burger, Roland $\cdot 104$

Butcher, Alex $\cdot 105$

Butler, Pat · 106, 107

\section{C}

C.D.T. 3

Caballero Molina, Antonio $\cdot 1054$

Cabiles, Evelyn A. $\cdot 748$

Cabot Saval, Toni $\cdot 108$

Cáceres Madrid, José $\cdot 317$

Cáceres, Diego $\cdot 759$

Caffary, Brian $\cdot 109$

Calamonte Zorzo, Diego $\cdot 1105$

Cáliz Lillo, Ignacio • 647, 648, 749, 750, 751, 752, 753, $754,755,1289,1290$

Calle, Ramiro A. $\cdot 1291$

Callero González, Felipe Concepción · 1166, 1235

Calpe Rufat, Isabel $\cdot 649$

Calvo Caballero, Ángel · 1136

Calvo Valcuende, Iñaki $\cdot 1172$

Camín Jarnés, Gabriel 549

Camino Olea, Antonio Miguel $\cdot 1037$

Campillo Martínez, Ignacio $\cdot 1245$

Campo y Cañas, Francisco Jesús del 1106

Campos Andrés, Natalia $\cdot 216,217$

Camps Meseguer, Hermenegildo · 318, 319, 320, 321, 322

Cangelosi, Paolo $\cdot 756,905,906$

Canneti, Rafael $\cdot 1137$

Carbonell Vicen, André · 1024, 1025, 1026, 1038

Carmeni, Bruno $\cdot 110$

Carnero Quintairos, Antonio 1236

Carranza Gesa, Jorge $\cdot 1406$

Carrasco Millán, Mariano $\cdot 325$

Carrascosa de la Torre, Pedro $\cdot 1237$

Carratalá Deval, Vicente $\cdot 86,111$

Carratalá Sánchez, Enrique $\cdot 111$

Carretero Alonso, Pablo $\cdot 1039$

Carrillo Vigueras, Jesús · 757

Cartwright, Robert $\cdot 1040$

Casado, José A. 1107

Casal Piñeiro, Julio $\cdot 907$

Casarella, Antonello $\cdot 908$

Casero Abellán, Rogelio · 1108, 1109, 1292, 1531

Castaneda, Marilyn $\cdot 1293$

Castarlenas, Josep Lluis $\cdot 112$

Castillo Escalona, Francisco $\cdot 550$

Castro Martín, Eduardo $\cdot 1236$
Castro Santiago, Juan Antonio · 1177

Cave, Eddie $\cdot 1110$

Ceballos Ledesma, Jesús · 203

Cecchini Estrada, José Antonio $\cdot 113$

Centro de Cultura por Correspondencia $\cdot 114$

Ceracchini, Augusto $\cdot 115$

Ceresa, Fabio $\cdot 15$

Cerezo Arias, Santiago $\cdot 322$

\section{Ch}

Challant, Ken $\cdot 551$

Chambers, Quintin 576

Chan, Susana $\cdot 619$

Chang, Dsu Yao $\cdot 758,909,910,911$

Chang, Weizhen $\cdot 650$

Charlot, Emmanuel $\cdot 116$

Cheek, Soke Bryan $\cdot 117$

Chen, Guang Fu $\cdot 651$

Chen, Jaime $\cdot 912$

Chen, Sheng Yu $\cdot 759$

Chen, William C. C. $\cdot 760,761$

Cheng, Man-Ching $\cdot 762,763,764,765$

Chia, Maneewan $\cdot 660,661$

Chia, Mantak · 652, 653, 654, 655, 656, 657, 658, 659, $660,661,662,1138$

Chiang, Lee $\cdot 887$

China Sports Magazine $\cdot 663$

Cho, Sihak Henry $\cdot 323$

Choe, Hui Son · 1027, 1028, 1029

Choi, Sang Ho $\cdot 1030$

Choi, Won Chul · 1030, 1041, 1042, 1052

Chong, Soo-Park $\cdot 1043,1044$

Choy, Howard $\cdot 664$

Chuen, Lam Kam • 665, 666, 667, 668, 766, 767, 768, 1143

Chun, Yip $\cdot 888$

Chutang, Ling $\cdot 118,913,914$

$\mathbf{C}$

Clara Sánchez, Daniel · 1167

Clark, Rick 539

Clavel San Emeterio, Iván · 126

Cleary, Thomas · 1294, 1295, 1296, 1297, 1298, 1299

Club de Judo Fon-Do-Kan · 119

Club de Karate Shotokan de Xixona 324

Clyman, Gary J. $\cdot 669$

Cochran, Sean $\cdot 1554$

Cohen, Kenneth S. $\cdot 670$

Coll Alentà, Ricard · 16

Collado Valencia, José Manuel · 552, 553

Colmenero Firvida, Carlos 1045

Colmenero, Manuel $\cdot 1046$

Conches Guillén, Aurelio David • 915, 916, 917, 918, 919, 920, 921, 953, 991, 1016, 1300

Conde Marina, Pedro $\cdot 373,1555$

Conlan, Tomas D. $\cdot 1301$

Connor, Danny $\cdot 769,888,1143$

Cónsul Peñalvert, Josep · 325

Copping, Rupert $\cdot 770$

Coque, José Antonio R. • 1238, 1239

Coquet, Michel $\cdot 1302$

Coronado Gavilán, Ana $\cdot 1303$

Corriente Basús, Federico 628

Costa, Cosimo $\cdot 120$

Crompton, Paul $\cdot 771,772,773,774,1532$ 
Cuturello, Ignazio $\cdot 922$

\section{D}

Dang, Tri Thong $\cdot 775$

Daniele, Flavio $\cdot 776$

Daunis, Julio $\cdot 1178$

De Cesaris, Marco $\cdot 1092,1093,1094,1405$

De Mente, Boyé Lafayette 1304

Dean, Richard · 923, 924, 925, 926, 927, 928

Delcourt, Jacques $\cdot 326$

Delgado Tostado, Juan $\cdot 146$

Delp, Christoph $\cdot 1556$

Deming, $\mathrm{Li} \cdot 671$

Departament de Cultura de la Generalitat de Catalunya . 121,1047

Deshimaru, Taisen $\cdot 1305,1306$

Despeux, Catherine $\cdot 777$

Di Marino, Stefano $\cdot 1111,1179$

Di Marino, Stéfano $\cdot 327$

DI SOM $\cdot 929,930,1157$

Diago Marco, Marta $\cdot 510$

Díaz de Tuesta Díez, José $\cdot 1240$

Díaz González, Paz • 145

Díaz Martínez, Juan José · 122, 328

Didier, Francis $\cdot 329$

Diego, Antonio $\cdot 1087$

Dienersberger, Robbi $\cdot 1557$

Diepersloot, Jan $\cdot 1011$

Díez Coello, Carlos Antonio · 846, 931

Díez Sanchis, Ricardo $\cdot 1407$

Ding, Li $\cdot 672,1139$

Domínguez González, Julio 123

Domínguez Sánchez, Germán • 1158

Dominy, Eric $\cdot 124$

Dong, Liu $\cdot 673$

Dopico Calvo, Jorge $\cdot 86,125,126,1281$

Douté, Pascal · 19

Drewe, James $\cdot 778$

Drobnic Martinez, Franchek $\cdot 1064,1084$

Dunn, Philip $\cdot 1307$

\section{$\mathbf{E}$}

Egea Cáceres, José Manuel • 463, 464

Ekin Emakumeak Elkartea 1168

Encel, Frédéric · 1442

Equipo de Especialistas Júpiter • 932, 1180

Equipo Lidisa $\cdot 127$

Escoriza Archela, Antonio $\cdot 330$

Escrig, Joaquín $\cdot 1126$

Escuela Deportiva Herca 1308

Espartero Casado, Julián · 86

Esteve Calero, Alex $\cdot 554$

Esteve Orozco, Jesús · 933, 934, 935, 936

Ewen, Harry $\cdot 128$

\section{$\mathbf{F}$}

Falsoni, Ennio $\cdot 129,331,332,1112$

Fargas Fernández, Ireno $\cdot 1048,1049$

Fassi, Roberto $\cdot 758,909,910,911$

Faulliot, Pascual $\cdot 1309$

Federación Catalana de Kárate $\cdot 333$
Federación Española de Judo • 130, 131, 132, 207, 213, $224,246,257,269,1184,1314$

Federación Española de Judo y Disciplinas Asociadas . 133,1314

Federación Española de Judo y Disciplinas Asociadas, Departamento Nacional de Aikido $\cdot 17$

Federación Española de Kárate, Departamento Nacional de Kung-Fu 937

Federación Española de Kárate, Escuela Nacional de Entrenadores $\cdot 334$

Federación Española de Lucha, Departamento Nacional de Judo $\cdot 134$

Federación Española de Lucha, Departamento Nacional de Yawara-jitsu $\cdot 611$

Federación Española de Taekwondo · 1050, 1051

Federación Mundial de Tae Kwon-Do · 1052, 1073

Fengming, Wang $\cdot 779$

Fenton, Peter $\cdot 674$

Fernández Almodóvar, Amadeo 135

Fernández Benzo, Julián • 433

Fernández Casanova, Víctor Manuel · 1140

Fernández de Castro, Ángel · 708, 780, 781, 782, 783, 784, $785,786,787,788,789,790,824$

Fernández Novas, José Antonio · 938, 1268, 1269

Fernández Prada, José Antonio · 1241, 1242

Fernández Solís, Luis · 335, 336

Fernández, Víctor · 675, 676, 677

Fernández-Bravo del Prado, Francisco Javier · 337

Fernando, Isabel $\cdot 1408$

Ferrán · Véase Mariano Luna, Fernando Rafael

Ferraro, Dominique $\cdot 678,679$

Ferré i Odena, Alberto $\cdot 338,516,517,518$

Ferret, José · 136

Ferrie, Eddie $\cdot 78$

Figueroa, Rubén · 1194

Fleitas González, Pedro • 500, 555, 556, 557, 558, 559 $560,561,562,563,564,1310$

Font Roig, Fidel $\cdot 18,791,940$

Fontan, J. 235

Fraga, José Luis $\cdot 612$

Fraguas, José María · 339, 941, 942, 943, 980, 1113, 1243, $1311,1312,1558$

Franco de Sarabia, Fernando • 114, 137, 138, 139, 140, $141,142,143$

Fratkin, Jake $\cdot 680$

Frederic, Louis $\cdot 1533$

Friedrich, Andreas W. 792

Fromm, Mallory $\cdot 1313$

Frutos Molinero, José Luis de • 144, 219

$\mathrm{Fu}$, Leong $\cdot 1181$

Fu, Zhongwen $\cdot 793$

Fuentes G. de Salazar, Federico $\cdot 1244$

Funakoshi, Gichin · 340, 341, 342, 343, 344, 345, 346

$\overline{\mathbf{G}}$

Galán Sánchez, Manuel · 1182

Galán, Eduardo $\cdot 219$

Galán, Francisco Javier $\cdot 501$

Galante, Lawrence $\cdot 794$

Galende, Juliana $\cdot 535$

Gallego Gredilla, Enrique · 1245

Gallego, Javier · 930

Gandini, Maurizio $\cdot 681$

Gante, Emilio $\cdot 4$

Gaozhong, $\mathrm{Li} \cdot 1007$

García Barbero, Juan $\cdot 213$ 
García Barbero, Víctor · 213

García Espada, Luis Alberto $\cdot 347,348$

García García, Carlos • 618, 1017

García García, José Manuel • 145, 146, 272, 1183, 1246

García Gazapo, Tomás · 1247

García López, Gaspar Jorge • 621, 622

García Romeral, Luis · 795, 1141

García Sáez de Samaniego, José Ignacio · 713

García Soldado, Ángel · 1113, 1114

Garrido Domínguez, Ángeles · 1248

Garrido Troncoso, Víctor $\cdot 1314$

Gasco Leranca, Ángel · 1184, 1185

Gaskin, Carol $\cdot 1315$

Gaspar Cortina, Víctor Manuel · 147, 148, 149, 150, 151

Gaspar, Luis $\cdot 1316$

Georgiev, Petar 1233

Gérome, Pierre H. A. $\cdot 944$

Ghetti, Roberto $\cdot 152,327$

Ghezzi, Giuseppe $\cdot 922$

Gil, Antonio $\cdot 27$

Gimnasio Club Abascal $\cdot 153$

Girona, Francisco $\cdot 1020$

Gistau, Miguel $\cdot 5$

Gladman, George $\cdot 154,1186,1187$

Gleeson, G. R. 155

Gobbi, Pietro $\cdot 1285$

Goenaga Larrañaga, Amaia $\cdot 156$

Goldman, Charley $\cdot 1196$

Gómez Vivar, Ángel · 349

Gómez, Dardo $\cdot 157$

Gómez-Trigo Ochoa, Gerardo · 350, 351

González Álvarez, Amador $\cdot 158$

González Enríquez, Victorino 159

González Gutiérrez, Jesús · 1247, 1249

González Humanes, Ángel Luis · 160

González Jorquera, José Francisco $\cdot 1247$

González López, Luis · 1115

González Núñez, Anton · 161

González Rincón, Juan Sebastián • 623, 682, 683, 796, 797

González Vallés, Jesús · 1317

González, Argimiro • 945

Gorostidi Berrondo, Juan · 798, 799, 800, 801

Granados Pacheco, Juan 1250

Grandi, Tiziano $\cdot 802$

Grosser, Vicky $\cdot 1169$

Grupo Gimnasios Unidos Madrid $\cdot 162$

Grupos Universitarios de Lucha del S.E.U. • 163, 164

Grupp, Joachim · 352, 353

Gualinga Yasacama, Arturo $\cdot 946$

Guedea Adiego, José Ángel · 165, 166

Gummerson, Tony $\cdot 1318,1559$

Gutiérrez García, Carlos · 167, 1365

Gutiérrez Martínez, Francisco $\cdot 354$

Gutiérrez Santiago, Alfonso $\cdot 1319,1320,1321$

Gutiérrez, Raúl · 355, 519, 947, 948, 949, 950, 1116, 1117, $1118,1119,1120,1121$

Gutiérrez, Víctor · 889, 890

\section{$\mathbf{H}$}

Habersetzer, Roland $\cdot 356,357,1188$

Hanche, Christian F. 803

Hang, Enrich · 951

Hansenne, Marcel $\cdot 168$

Hanzhang, Tao $\cdot 1443$

Harrington, Anthony Patrick 169

Harrington, Patricia $\cdot 170$
Harrison, E. J. · 171, 172, 358, 359, 360

Hasemeier, Alfred · 361, 362

Haskew, Michael E. 1322

Hatsumi, Masaaki · 565, 566, 567, 568, 569, 570, 571, 572, $573,574,575,576$

Hawkins, Vince $\cdot 1315$

Hayashi, Kenji · 520, 521

Hayes, Stephen $\cdot 577$

Hazard, Dave $\cdot 493$

Heim, Jean $\cdot 173$

Hentona, Choyu $\cdot 522$

Herguedas, Justo $\cdot 271,272$

Hernández Beltrán, Sergio 1116

Hernández Martos, Alonso $\cdot 363$

Herráiz Embid, Salvador · 364, 365, 366, 367, 368, 369, $370,371,372,373,1251,1405,1409,1410,1411$, 1412

Herrigel, Eugen · 536

Hervás, Ramón · 1189

Hess, Joe $\cdot 1166,1235$

Heydt Dietzold, Cristina $\cdot 174$

Heyoten, Louis Wan der · 804, 805

Hibbard, Jacques $\cdot 1159$

Hierro Jarne, José Ángel · 175

Hiew, Chok C. $\cdot 707$

Higaonna, Morio $\cdot 374,375,376,377$

Hilt, Michael $\cdot 806$

Hine, John $\cdot 807$

Hino, Akira $\cdot 1323$

Hinterthür, Petra $\cdot 704$

Hirota, Yoshiho $\cdot 523$

Hoffer, Bruno $\cdot 19,1170$

Hombre Dopazo, Juan · 578, 579, 580, 581, 582, 583, 584, $585,586,587,588,589,1171,1190,1191,1192,1210$, $1211,1212,1213,1214,1215,1216,1217,1218$, $1219,1252,1253,1254,1255,1256,1257,1258$, $1259,1260,1261,1262,1263$

Homma, Gaku $\cdot 20$

Hooton, Claire $\cdot 710,808$

Hsi, Rainer $\cdot 809$

$\mathrm{Hu}$, Bin $\cdot 684$

Huang, Al Chungliang $\cdot 810,811$

Hubert, John $\cdot 378$

Huguet i Parellada, Jordi · 1534

I

Iborra Montells, Antonio $\cdot 1018,1122$

Idarreta Galarraga, Julen $\cdot 86$

Iedwab, Claudio A. $\cdot 1324,1325$

Iglesias Soler, Eliseo · 86, 125, 126, 1281

Iglesias, Alejandro $\cdot 1123$

Inman, Roy $\cdot 176$

Iñarra, Joxean $\cdot 379$

Isidro Casas, José Luis · 21, 22, 23, 524, 1326

Itier, Roger $\cdot 952$

Ito, Tommy $\cdot 1334$

Iwai, Kohaku $\cdot 380$

Izquierdo García, Ángel Luis · 177

Izquierdo, Pedro $\cdot 953$

J

James, Andy $\cdot 1327$

James, Lorraine $\cdot 743$

Javy-San $\cdot 590$ 
Jazarin, J.L. $\cdot 178$

Jiménez Ramírez, Luis · 1022

Jin, Xiaoguang $\cdot 691$

Jones, Suzanne $\cdot 644,1135$

Jörgensen, Christer $\cdot 1322$

Josselin, Jacques $\cdot 1328$

Juan Payán, Javier $\cdot 1414$

Juan Payán, Miguel · 1413, 1414

Juan Sancho, Gabriel $\cdot 179$

Judo-Barcelona $\cdot 180$

Juní Cadenet, Jesús · 1095, 1329

Junta Central de Educación Física 1193

Justes López, Arturo · 541, 542

\section{K}

Kanazawa, Hirokazu $\cdot$ 381, 382

Kanben Rei Ryu $\cdot 514$

Kane, Lawrence A. $\cdot 1330$

Kano, Jigoro $\cdot 181$

Kashiwazaki, Katsuhiko $\cdot 182,183,184$

Kaufman, Stephen F. · 1444

Kawaishi, Mikonosuke · 185, 186, 187, 188, 189, 190, 191

Kernspecht, Keith Ronald • 891

Kim, Ashida 591

Kim, Boo Hyang · 1053, 1054

Kim, Gwabg il $\cdot 1055$

Kim, Richard $\cdot 1331$

Kim, Sang Hwan $\cdot 1560$

Kimura, Masahiko $\cdot 192$

Kishi, Yasu • 193, 383, 1149

Kitaura, Yasunari $\cdot 24$

Kohata, Hiromichi $\cdot 384$

Koike, Tadashi $\cdot 194$

Kolychkine Thomson, Andrés 195

Koriko, Michouko · Véase Repollés Aguilar, José

Kôshirô, Kiba $\cdot 1150$

Koyama, A. 6

Kozuki, Russell $\cdot 386$

Krause, Donald G. 1445

Kudo, Kazuzo • 196, 197

Kung, T'ai $\cdot 1446$

\section{$\mathbf{L}$}

Labarta, Concha $\cdot 387$

Labodía Doce, David 1332

Labodía Doce, Miguel $\cdot 1332$

Lahoz Gómez, Carlos · 1151

Lam, Tin-Yu $\cdot 812$

Lanz García, José Armando · 198

Lasserre, Robert · 199, 200, 388, 540

Latorre Ramos, Jesús · 389, 390

Lawson, Jack 1506

Lee, Bruce $\cdot 629,630,631,632,633$

Lee, Ching-nan $\cdot 1194$

Lee, Kyong Myong $\cdot 1057,1058$

Lee, Kyu Hong · 1056

Lee, Sam · 391, 1059, 1124, 1160, 1415, 1416

Lee, San · 592, 593, 1333, 1535

Lee, Won Il $\cdot 1060,1061,1062$

Leonelli, Núria $\cdot 685,813$

Levet, Patrick · 1098

Levine, Darren · 1195

Levy, Joel $\cdot 594$

Lewis, Peter $\cdot 1161$
Li, Juan $\cdot 1138$

Liang, Shou-Yu · 814, 815, 1012, 1013

Liang, Yin Chuan $\cdot 954$

Liao, Waysun $\cdot 816$

Lie, Foen Tjoeng $\cdot 817$

Lien-Ying, Kuo $\cdot 818$

Little, John · 634, 635, 636, 1417, 1418, 1419, 1420, 1561

Ll

Lluch, Salvador $\cdot 819$

$\mathbf{L}$

Longyun, Cai · 955

López Crespo, Juan Antonio · 595

López Domínguez, Mario · 201

López Linares, Alejandro $\cdot 202$

López Mayoral, Gerardo $\cdot 203$

López Megía, Víctor 392

López Merz, Francisco 1086

López Reiz, Enrique $\cdot 393$

López Romero, Francisco $\cdot 7$

López Tortosa, Domingo $\cdot 1421$

López-Cuadra Ejarque, Gerardo · 1237

Lorini, Walter $\cdot 820$

Losito, Giuseppe $\cdot 1063$

Louis, Thomas $\cdot 1334$

Lowenthal, Wolfe $\cdot 821,822$

Lu, Shengli $\cdot 1142$

Ly, Antoine $\cdot 686$

Lynn Peterson, Susan $\cdot 1335$

$\mathbf{M}$

Mabuni, Kenei $\cdot 394$

Mabuni, Kenwa 395

Maceira Gago, Antonio Delfín • 1320

MacRitchie, James $\cdot 687$

Madrigal, Sergio $\cdot 163,164$

Maestro Gali $\cdot 1336$

Mahillo Monte, Javier · 396, 1125

Majoral Cabrera, Cristina $\cdot 1064,1084$

Makiyama, Thomas H. $\cdot 25$

Malori, Daniele $\cdot 1129,1130$

Malota Lulgjuraj, Peter $\cdot 1065,1558,1562$

Mansur, Francisco $\cdot 204$

Mantovani, Cesarino $\cdot 26$

Manzano, Irune $\cdot 1337$

Marcello, Joseph $\cdot 691$

Marciano, Rocky $\cdot 1196$

Mariano Luna, Fernando Rafael · 939

Marín Ferrer, Bibiana $\cdot 823$

Mariscal, Enrique $\cdot 1507$

Martell, Pierre $\cdot 205$

Martín Alarcón, Pedro • 596, 597, 598, 599

Martín García, José · 397, 1338

Martínez Barrera, José Miguel · 206

Martínez Fariñas, Enrique · 1422, 1423

Martínez Serrano, José Fernando 398

Martínez Suárez, Xoán Carlos • 1066, 1067

Martínez-Villasante, Luis Gonzalo · 207

Marwood, Des $\cdot 208$

Masniéres, Jean-Luc $\cdot 399$ 
Mason, Gaby $\cdot 1169$

Mayoral Sánchez, Francisco • 400, 401

Maza, Rafael de la $\cdot 824$

McCarthy, Patrick $\cdot 402$

McFarlane, Stewart $\cdot 825$

McKissock, John W. G. 1068

McNab, Chris $\cdot 1322$

Medrano, Antonio $\cdot 737$

Mendoza Álvarez, J. David · 1339

Mendoza, Ana de $\cdot 575$

Mendoza, Ruy San de · 575, 606, 607, 1375

Menkyo, Soke $\cdot 403$

Mercado Aguado, Felipe · 637, 1088, 1089

Mertens, Wilhelm $\cdot 688$

Michaelson, Gerald A. $\cdot 1447,1448$

Michaelson, Steven $\cdot 1448$

Miguel Medrano, José $\cdot 1340$

Miguel Santos, Javier de $\cdot 1126$

Minami, K. 6

Miñana Patiño, Francisco Javier · 826

Mirallas Sariola, Jaume Antón · 209, 210

Mishima, Yukio $\cdot 1341$

Mitchell, David · 404, 1069, 1070, 1536

Mitose, James M. $\cdot 1127$

Moegling, Barbara $\cdot 827$

Moegling, Klaus $\cdot 827$

Molina Zapata, Fulgencio $\cdot$ 405, 406

Molina, J. Pere $\cdot 112$

Monclús Arbó, Fermín · 27

Monclús, Javier $\cdot 27$

Monfort, Toni $\cdot 1449$

Mongksan $\cdot 1096$

Monreal Sevilla, Miguel Ángel $\cdot 28$

Montanari, Enzo $\cdot 407$

Montesinos Espès, David · 1264, 1265, 1266

Montespín, Barón René De $\cdot 8$

Monzó Landeira, Germán · 619, 975, 1424

Moore, Richard S. $\cdot 1425$

Mora Moro, Francisco Javier $\cdot 1270$

Mora Rafart, Pedro de la $\cdot 1563$

Morales Negrillo, Laura $\cdot 211$

Morales Nogales, Francisco Javier $\cdot 525$

Moreira, Carlos $\cdot 624$

Moreno García, Jorge $\cdot 828$

Morente Sánchez, Jaime $\cdot 212$

Morgan, Forrest E. 1342

Moriel Rivera, Santiago 956

Morillo del Río, Enrique $\cdot 213$

Moronta Peña, David · 214, 215, 216, 217, 1343

Motobu, Choki $\cdot 408$

Muñiz González, Joaquín · 613

Muñoz Costas, Josep 689

Muñoz Domínguez, Manuel $\cdot 1267$

Muñoz Martín, Ignacio $\cdot$ 829, 830

Muñoz, Carlos $\cdot 409$

Muñoz, Oscar $\cdot 218$

Musashi, Miyamoto · 1344, 1450, 1451, 1452, 1453, 1454, $1455,1456,1457,1458$

Muzas, Mario $\cdot 219$

\section{$\mathbf{N}$}

Nacenta Navarro, Antonio $\cdot 220$

Nagashima, Sato · Véase Nalda Albiac, José Santos, Véase Nalda Albiac, José Santos

Nakanishi, Hidetoshi $\cdot 184,221$

Nakasone, Genwa 395
Nakayama, Masatoshi • 410, 411, 412, 413, 414, 415, 416, $417,418,419,420,421,422,423,424,425,426,427$, $428,429,430,431$

Nalda Albiac, José Santos · 29, 30, 31, 32, 33, 34, 35, 36, $37,38,39,40,41,42,43,44,222,223,502,503,504$, $505,526,527,528,537,541,542,1152,1153,1197$, $1345,1346,1347,1348,1349,1350,1351,1352,1379$

Nardia, Avi $\cdot 1198$

Navarro de Palencia Pérez, José $\cdot 224$

Navarro Mouchet, Jesús · 434

Navarro Parra, José 506

Nidan $\cdot 225,395$

Niderost, Eric $\cdot 1322$

Nieto, Marco $\cdot 957$

Nitobe, Inazo • 9, 10, 1459, 1460, 1461, 1462

Nomura, Kazuo $\cdot 45$

Nong, Chong $\cdot 1134$

Norris, Chuck $\cdot 1353$

Nowoisky, Heinz $\cdot 226$

Nukariya, Kaiten $\cdot 1354$

Núñez Gorospe, César · 1172

$\mathbf{0}$

Oberlack, Helmut · 688, 831

Ocaña Rizo, Marcos $\cdot 1426$

Oellibrandt, Dirk · 662

Ohtsuka, Hironori $\cdot 432$

Oliva Seba, Antonio · 433, 434, 1537, 1538, 1539, 1540, $1541,1542,1543,1544$

Olivares García, José $\cdot 227$

Orlandi, Rinaldo $\cdot 228$

Ortega Álvarez, Pablo • 938, 1268, 1269

Ortega Fernández, Rafael · 229, 230

Ortemberg, Adriana $\cdot 1463$

Ortíz Perea, José $\cdot 892$

Ory, Jean Baptiste $\cdot 1545$

Ory, Mar $\cdot 1545$

Oshima, Eisuke $\cdot 291$

Oshima, Hitoshi $\cdot 1464$

Oyaga Jimeno, Fermín · 231

$\overline{\mathbf{P}}$

Pabst, Manfred · 958

Padilla Corral, José Luis $\cdot 690$

Padrón, Miguel · 912, 959, 960

Páez-Centella García-Diego, César · 232, 233

Pagès Guix, Joan · 1355

Panchamé Munté, John • 507, 1071, 1072, 1073

Pang, Ming $\cdot 691$

Paniagua Tébar, José Luis · 832, 1356, 1357, 1358

Pantazi, Evan · 543, 544, 545, 546

Park, Pil-Won $\cdot 1074$

Parmar, Rani $\cdot 1169$

Parra, Isidoro $\cdot 961$

Parry, Robert · 833, 834, 835, 836

Pascual Martín, Santiago $\cdot 893$

Pasquale Jr., Michael De $\cdot 1154$

Pastor Albella, Tomás · 234

Pater, Robert · 1359,1360

Pavia, J.J. $\cdot 235$

Pawlett, Raymond $\cdot 837$

Payne, Peter $\cdot 1361$

Paz Gútiez, Eduardo de $\cdot 610$

Peck, Alan · 838 
Pedregal Canga, Manuel $\cdot 435$

Peidro Payá, Luís · 236

Pellegrini, John $\cdot 1031$

Pereda González, Pablo • 387, 436, 437, 438, 439, 440, 441, 1362, 1363

Pérez Agustí, Adolfo • 442, 600, 601, 602, 605, 638, 954, $962,963,964,1128,1162,1163,1364,1427,1428$, $1429,1546,1547,1564$

Pérez García, Fernando $\cdot 443$

Pérez Gutiérrez, Mikel · 1365

Pérez Peña, Ishana 46

Pérez-Carrillo, Miguel J. • 237, 614, 615, 616

Pérez-Ugena Sintas, Mariano 1237

Pericás Álvarez, Francisco • 692, 965

Perreca, Giorgio · 1129, 1130

Perry, Paul J. • 444

Pflüger, Albrecht · 445

Pilato, Herbie J. 1366

Pintat Mateu, Neus $\cdot 693,694$

Piñero Lazaro, Antonio · 446, 447, 494

Planellas Vidal, Pau-Ramon · 529, 530, 547, 603, 617, 1155, 1548, 1549, 1550

Planells i Garcés, Encarna • 47, 1367

Pla-Xiberta, Feliciano $\cdot 839$

Pöhler, Ralf $\cdot 238$

Polly, Mathew $\cdot 1368$

Pons Botella, Mario $\cdot 1075,1076$

Poponic, Andrew $\cdot 1164$

Prat Banús, José María · 54, 695, 735, 881, 894, 895, 966, 967, 968, 969, 970, 971, 972, 973, 974, 975, 976, 1003, $1014,1019,1020,1090,1131,1430,1431,1432$, 1433, 1434

Prieto Lage, Iván · 1321

Protin, André $\cdot 48$

Prouzet, Aimé $\cdot 696$

Puell de la Villa, Fernando $\cdot 1508$

Puig-Siscar · 49, 448, 449

Pujol Amat, Pere $\cdot 1064,1084$

\section{$\mathbf{Q}$}

Qu, Lei Lei $\cdot 840$

Quintero Mora, Alfonso 1270

Quirós Martínez, Juan Antonio · 450, 451

\section{$\mathbf{R}$}

Raga Díaz, Jorge $\cdot 239$

Rahn, Erich · 1199, 1200, 1201

Ramírez Bellerín, Laureano · 1465

Ratti, Oscar $\cdot 76,1369,1370$

Reay, Tony $\cdot 240$

Regoli, Claudio A. · 452, 453, 508, 977, 1202

Reid, Daniel $\cdot 697$

Reid, Howard · 1143

Renault, Jean-François · 241

Repollés Aguilar, José · 385, 1004, 1203

Requena, Yves $\cdot 680,698,699,700,701,710$

Reyna, Salvador $\cdot 976$

Rice, Rob S. · 1322

Richardson, Burton $\cdot 639$

Ricketts, Christopher $\cdot 1087$

Rico Artigas, Pedro $\cdot 626$

Rico, Alberto $\cdot 841$

Riera Alfonso, Alfonso • 454, 455

Ríos, Carmelo H. · 509, 1302, 1371, 1372
Rit-Jou-Ku 11

Rivero de la Corte, Francisco 456

Robebrt, Louis · 242

Robinson, Ronnie $\cdot 842$

Rochford, Matthew $\cdot 843$

Rodríguez Acevedo, José Luis $\cdot 1157$

Rodríguez Dabauza, Pedro · 243, 244, 245, 246, 247, 248, $249,250,272$

Rodríguez Román, Francisco Javier · 1204

Rodríguez, José • 457, 702, 844

Rojas Torres, Pedro $\cdot 604$

Román, Francisco I. $\cdot 271$

Romay, Bernardo $\cdot 125$

Ros Torner, Antonio $\cdot 1205$

Rosa, Raúl de la $\cdot 1373$

Rosenbaum, Michael $\cdot 1374$

Rossell Sellart, Tony · 942, 943, 978, 979, 980, 981, 989

Rossell, A. $\cdot 1021$

Rosso, Edoardo $\cdot 1565$

Rosuro Sensei $\cdot 605$

Rouge, Jean-Luc $\cdot 251$

Roy, Ángel V. $\cdot 845$

Royo, Francisco $\cdot 501,510$

Ruano, José V. · 1243

Rubio Galán, Isaac $\cdot 252,253$

Rudek, Sandro $\cdot 254$

Rueda Castaño, José Luis 1032

Ruglioni, Giuseppe $\cdot 50$

Ruiz Garro, Guzmán · 1033, 1034

Ruiz Varea, Agustín · 846

Ruiz Vidal, Juan Manuel $\cdot 1144$

Rusher, Robin $\cdot 1143$

Ruy Quijano, Víctor · 1283

Ruy-San · Véase Mendoza, Ruy San de

$\mathbf{S}$

s.a. $12,13,51,255,256,257,258,259,260,261,262$, $263,264,458,459,460,608,703,847,848,982,983$, $984,1077,1078,1079,1080,1206,1271,1272,1273$, $1274,1275,1435,1436$

Saavedra López, Andoni $\cdot 1172$

Sáenz Fernández, Félix · 293, 294, 295, 461, 462, 463, 464

Sagarra Pérez de Óbanos, Josetxo 1081

Saimbraum, Dr. • Véase Bardina, Joan

Sakay, Yoshihito $\cdot 531$

Salazar, Domingo $\cdot 1466$

Salsas Moreno, José $\cdot 198$

Sampayo, Carlos $\cdot 465,466$

San Antonio Hernández, Félix de $\cdot 1245$

San Bartolomé, Alfredo $\cdot 265$

Sánchez Díaz, Tomás · 52, 53, 54

Sánchez, José Ramón · 1229, 1230

Sanchis, Rafael · 163, 164

Sanchís, Santiago $\cdot 1165,1207$

Sancho Illa, Armand · 467, 468

Santiago Alonso, Miguel · 307, 308

Saotome, Mitsugi $\cdot 55,56$

Sapin, Jean-Claude $\cdot 849$

Sato, Nobuyuki $\cdot 266$

Saudi, Aine $\cdot 267$

Sauvage, Philippe $\cdot 469$

Sauvy, Michel 1208

Savine, Ives $\cdot 470$

Schillings, Astrid $\cdot 704$

Schlatt $\cdot 471$

Schwentker, Wolfgang $\cdot 1376$ 
Sde-Or, Imi $\cdot 1209$

Seabourne, Tom $\cdot 1132$

Seguí, Rafael $\cdot 157$

Serapio, Ignacio $\cdot 1210,1211,1212,1213,1214,1215$, 1216, 1217, 1218, 1219

Serra Ortells, Vicente $\cdot 1082$

Serra, Esteve $\cdot 1467$

Serra, José Luis · 850, 1010

Serrano Aguilar, Mario René $\cdot 851$

Serrano García, Miguel Ángel · 472

Serrano, Manuel $\cdot 981$

Serrato Rodríguez, Juan Carlos · 852, 985, 986, 1022

Servei Lingüistic de la Unió de Federacions Esportives Catalanes $\cdot 1220$

Seward, Jack $\cdot 1377$

Shankang, Shao $\cdot 955$

Sheng, Keng Yun $\cdot 705,706,1145$

Shibata, Maryse $\cdot 1378$

Shibata, Masumi $\cdot 1378$

Shing, Yen-Ling $\cdot 853,854,855$

Shioda, Gozo $\cdot 57$

Shioda, Yasuhisa 57

Shodan · Véase Nalda Albiac, José Santos

Shotokan Karate-do de España · 473

Sierra de Cardenas, Antonio Vicente $\cdot 987$

Simon Wack, Wolfgang Josep $\cdot 86$

Sitruk, Guy $\cdot 329$

Smit, Sanette $\cdot 474$

Soames, Nicolas $\cdot 176$

Soler Navarro, Juan Manuel • 1221, 1222

Soler, Gabriel · 988, 989

Solís Miranda, José Antonio · 1380, 1381

Songel $\cdot 5$

Soon-Yeong, Yap $\cdot 707$

Soria, Francisco $\cdot 219$

Soto Caride, José Ricardo $\cdot 856$

Speziale, Ana María · 708

Standefer, Roxanne L. $\cdot 1324,1325$

Stepan, Charles A. 1083

Stevanovitch, Vlady $\cdot 709,710$

Stevens, John $\cdot 58,59,1382$

Stork, Peter L. $\cdot 1383$

Strohm, Franz Eberhard Eckard $\cdot 548$

Su, Yu-chang • 990, 991

$\mathrm{Su}$, Yu-Chang $\cdot 857,858$

Suenaka, Roy $\cdot 60$

Sugai, Hitoshi $\cdot 268$

Sun, Bin $\cdot 1468,1469,1509$

Sun, Junqing $\cdot 711,712$

Sun, Quing $\cdot 713$

Sun, Tzu $\cdot 1470,1471,1472,1473,1474,1475,1476$, $1477,1478,1479,1480,1481,1482,1483,1484$, $1485,1486,1487,1488,1489,1490,1491,1492$, $1493,1494,1495,1496,1497,1498,1499,1500$, $1501,1502,1503,1504,1505,1506,1507,1508$, $1509,1511,1512,1513,1514,1515,1520$

Sun, $\mathrm{Zi} \cdot 1510$

Sunadomari, Kanshu $\cdot 61$

Sunzi · Véase Sun, Tzu

Sutomo, Bambang $\cdot 1139$

Sutton, Nigel $\cdot 859,860,1143$

\section{T}

Tabata, Kazumi $\cdot 1384$

Tackett, Tim $\cdot 640$

Taira, Shigesuke $\cdot 1516$
Taira, Shu $\cdot 269,270,271,272$

Takuan, Soho $\cdot 1385$

Talens Coral, Francisco $\cdot 273$

Tamano, Toshio $\cdot 475,532$

Tamayo Fajardo, Javier Antonio $\cdot 274$

Tamenaga, Shunsui $\cdot 1517,1518$

Tamura, Nobuyoshi $\cdot 62$

Tamura, Ryo $\cdot 476$

Tang, Cheong Shing $\cdot 1015$

Tang, Peter P. $\cdot 992$

Tapia Rodríguez, Javier $\cdot 861$

Tarragó Tomás, Ferrán · 625, 862, 863, 993, 994

Tassinari, Margherita $\cdot 1156$

Tawm, Kim $\cdot 714$

Tcheng-Tsiun · Véase Thomas, Raymond

Teixidó Iglesias, Xavier $\cdot 275$

Teixidó Orga, Francisco $\cdot 276$

Tejedor González, José Luis • 1242

Thabot, Dominique $\cdot 277$

Thelen, Yves $\cdot 609$

Thomas, Raymond $\cdot 63,64,65,278,279,280,281,477$, $478,479,480,481,482,483,484,485,486,487,488$, $489,490,491,511,533,864,865,866,995,996,1223$, $1224,1386,1551$

Thompson, Chris $\cdot 492$

Tian, Cheng Yang $\cdot 1146$

Ting, Leung $\cdot 896,897$

Toba, Rafael $\cdot 997$

Tohei, Koichi $\cdot 1387,1388$

Tokitsu, Kenji $\cdot 1389,1390,1519$

Torrent Rodrigo, Francisco Javier 1035

Torres Baena, Fernando $\cdot 434$

Torres Casado, Guillermo $\cdot 86,1391$

Tórtola Sánchez, Francisco $\cdot 1234$

Trimble, Aidan 493

Tse, Sun • Véase Sun, Tzu

Tucci, Alfredo · 66, 84, 373, 1050, 1051, 1392, 1393, 1394, $1395,1396,1405$

Tucci, Norberto $\cdot 1397$

Tung, Timothy $\cdot 998,999$

Turnbull, Stephen $\cdot 1398$

Tzu, Kuo Shih · 715, 716

$\mathbf{U}$

Ueshiba, Kisshomaru $\cdot 28,67,68,69$

Ueshiba, Morihei $\cdot 70,71,72,73,75$

Ueshiba, Moriteru $\cdot 28,74$

Ungría, Bernardo $\cdot 153$

Universidad Complutense de Madrid 1399

Uyehara, M. · 630, 631, 632, 633

Uzawa, Toshiyasu $\cdot 282,283,284$

$\mathbf{V}$

Valencia, Pedro $\cdot 624$

Valera, Dominic 494

Valle Díaz, Sagrario del • 145

Valle, Fabián Vicente del · 285

Vallés, Yolanda $\cdot 901$

Van Nghi, Nguyen $\cdot 717,718$

Vázquez Lazo, Juan Carlos 307

Velasco Morral, Jordi $\cdot 1400$

Velázquez Velázquez, Remedios · 145

Veleiro Vidal, Juan Carlos $\cdot 1249$

Velilla Fuentes, Santiago 495 
Vera Jiménez, José Carlos · 1276, 1277, 1278

Vera Nicolás, Pedro Pascual $\cdot 1279$

Vera Ramírez, Antonio · 1437, 1438, 1552

Vera Sho-Dan · Véase Vera Ramírez, Antonio

Verdaguer Codina, Joan $\cdot 1084$

Verdugo, Esther $\cdot 868$

Vicent Ciscar, Antonio $\cdot 433$

Vidal, Shihan $\cdot 1133$

Vigil, Luis $\cdot 1439$

Vignati, Alejandro $\cdot 286$

Vilá Oliveras, Jordi $\cdot 620,1000,1001$

Vilalta i Casas, Esther $\cdot 232,233$

Vilar-Sancho Aguirre, Luis $\cdot 287$

Vilella, Yanis $\cdot 1401$

Villahizán, Javier · 1402

Villamón Herrera, Miguel · 86, 288

Villanueva Domínguez, Gabriel 1091

Villar Gil, Jorge $\cdot 1403$

Von Sohel, Helmut $\cdot 1440$

Vunak, Paul $\cdot 641$

\section{W}

Wa Rei Ryu · 512, 513, 514

Wagner, Jim $\cdot 1225$

Wang, Maestro $\cdot 869$

Watson, Christopher $\cdot 60$

Wespin, Dominique de $\cdot 870$

Westbrook, Adele · 76, 1369, 1370

Whitman, John $\cdot 1195$

Wile, Douglas $\cdot 871,872,873,874$

Williams, Bryn $\cdot 496$

Wilson, Stanley $\cdot 719$

Wilson, William Scott $\cdot 1404$

Wo, Lu Tao $\cdot 1085$

Wong, Doc-Fai $\cdot 626$

Wong, Kiew Kit · 720, 721, 875, 1002

Wong, Ping Pui $\cdot 1003$

Wong, Robert · Véase Repollés Aguilar, José

Wu, Wen-Ching $\cdot 814,815$
$\mathbf{X}$

Xifró, Emilio $\cdot 1036$

Xinde, Wang $\cdot 1005,1006$

$\mathbf{Y}$

Yamaguchi, Gogen $\cdot 497$

Yamamoto, Jocho · Véase Yamamoto, Tsunetomo

Yamamoto, Tsunetomo · 1521, 1522, 1523, 1524, 1525 , 1526,1527

Yamamoto, Yosho $\cdot$ Véase Yamamoto, Tsunetomo

Yamashita, Yasuhiro $\cdot 289$

Yang, Jwing-Ming · 710, 722, 723, 724, 725, 726, 727, 728, $729,730,731,732,733,734,876,877,878,879,1012$, $1013,1147,1148$

Yang, Peter $\cdot 735,880,881$

Yang, Shaoqing $\cdot 736$

Yanilov, Eyal $\cdot 1209$

Yerkow, Charles $\cdot 290$

Yokoyama, Sakujiro $\cdot 291$

Young, Mike $\cdot 1280$

Yrayzoz Reyna, Joaquín · 1226, 1553

$\mathrm{Yu}, \mathrm{Tricia} \cdot 882,883$

Yudelove, Eric Steven · 710

Yuntai, Xi $\cdot 1007$

Yunzben, Ma $\cdot 884$

Yuzan, Daidoji $\cdot 1516,1528$

$\mathbf{Z}$

Zamudio Cabeza, Juan José · 642, 643

Zerpa, Carlos $\cdot 1405$

Zhang, Fuxing $\cdot 885$

Zhaoming, Shao $\cdot 886$

Zhenbang, Ma $\cdot 1008$

Zhou, Ma Xu $\cdot 679$

Ziping, Wang $\cdot 1009$

Zoia, Alessandra $\cdot 1173$

Zumou, Yuan $\cdot 1010$ 


\section{3. Índice de palabras clave}

\section{$\boldsymbol{A}$}

actores $\cdot 1333,1353,1364,1413,1414,1421$

acupuntura $\cdot 656,706,779,966$

aforismos $\cdot 71,75,216,400,555,564,870,1283,1289$, $1290,1300,1312,1344,1366,1372,1385,1392$, $1419,1422,1423,1438$

aikido $\cdot 18,21,24,25,28,34,50,55,59,60,72,96,524$, $1164,1208,1234,1314,1317,1350,1351,1352$, 1534

amor $\cdot 439,1463$

anatomía $\cdot 2,32,43,456,538,541,542,544,653,657$, $674,706,725,731,850,870,887,937,1034,1036$, $1120,1124,1349,1556,1563$

aplicación marcial · 50, 54, 98, 99, 137, 161, 169, 187, $189,225,248,249,316,317,352,353,354,355$, $364,370,374,375,378,384,386,389,390,394$, $395,422,423,430,431,442,449,468,470,483$, $484,485,486,487,488,489,490,499,516,521$, $523,526,530,539,544,546,555,557,586,620$, $621,623,626,721,729,753,756,758,759,764$, $779,796,802,805,813,814,844,877,886,894$, $896,897,901,906,922,923,924,926,927,942$, $943,947,950,960,962,969,976,983,1005,1010$, $1012,1019,1020,1028,1070,1083,1090,1091$, $1121,1142,1158,1159,1160,1162,1164,1221$, $1222,1243,1389,1537,1538,1539,1540,1541$, $1542,1543,1544,1547$

aplicación social $\cdot 1325,1337,1345$

aplicación terapéutica · 370, 436, 438, 441, 510, 541, $542,547,652,655,656,659,662,663,665,666$, $670,674,678,683,684,687,690,695,696,701$, $705,707,711,712,717,718,719,723,728,738$, $742,745,755,764,772,802,832,844,863,870$, $998,999,1099,1109,1140,1313,1362,1363$

arbitraje $\cdot 134,150,170,175,246,258,262,284,307$, $448,456,458,508,1052,1053,1073$

$\operatorname{armas} \cdot 5,21,22,26,32,33,34,64,74,82,85,93,96$, $117,146,169,187,189,193,199,242,243,250$, $260,275,285,303,304,365,370,378,385,468$, $470,476,477,502,505,510,511,512,514,515$, $516,519,521,523,524,526,527,533,547,551$, $555,561,563,566,567,575,576,577,578,581$, $584,585,590,593,594,600,601,602,603,607$, $612,616,617,623,624,626,639,670,771,855$, $875,893,895,897,898,905,907,923,924,927$, $938,942,945,952,953,954,963,966,977,979$, $980,983,993,1003,1004,1015,1016,1017,1020$, $1023,1026,1028,1030,1031,1062,1087,1091$, $1119,1126,1127,1146,1150,1158,1173,1175$, $1179,1180,1181,1183,1184,1185,1186,1187$, $1188,1189,1194,1197,1198,1199,1200,1201$, $1202,1205,1207,1208,1209,1225,1226,1235$, $1236,1237,1239,1240,1241,1242,1243,1245$, $1246,1247,1249,1254,1256,1263,1264,1265$, $1266,1267,1268,1270,1272,1273,1274,1276$, $1277,1278,1279,1280,1282,1283,1288,1301$, $1315,1334,1339,1369,1370,1379,1380,1398$, $1437,1535,1537,1538,1539,1540,1541,1542$, $1543,1544,1546,1548,1549,1550,1551,1552$, 1553

arnis $\cdot 1088$

arquitectura $\cdot 24$ artes marciales $\cdot 167,320,372,512,538,695,720,721$, $771,849,865,1012,1035,1175,1176,1202,1294$, $1295,1297,1300,1305,1306,1311,1312,1315$, $1316,1324,1325,1326,1331,1338,1343,1348$, $1355,1356,1357,1359,1360,1365,1366,1369$, $1370,1383,1384,1386,1393,1394,1395,1396$, $1405,1420,1422,1423,1429,1437,1536,1537$, $1538,1539,1540,1541,1542,1543,1544,1547$, 1559

astrología $\cdot 330,1117$

atemijutsu $\cdot 275,348$

\section{B}

baguazhang $\cdot 619,902,903,905,941,963,964,977$, 1142,1143

batallas $\cdot 1288$

bellas artes $\cdot 700$

bibliografía $\cdot 167,798,1365$

bioenergética $\cdot 544,1351$

biografía · 15, 16, 21, 58, 60, 71, 75, 91, 217, 287, 298, $340,345,366,367,368,373,380,392,405,406$, $497,554,635,637,638,760,784,821,824,874$, $947,964,968,985,988,989,1012,1017,1075$, $1101,1103,1116,1140,1303,1311,1333,1334$, $1350,1353,1364,1387,1388,1404,1405,1406$, $1407,1409,1410,1411,1412,1414,1422,1423$, $1425,1426,1428,1434,1435,1436,1438,1439$, $1440,1450,1494,1515,1519,1533,1547,1561$

biomecánica · 41, 158, 209, 226, 277, 296, 357, 415, $417,425,451,461,467,612,1035,1049,1053$, $1157,1336,1347$

bojutsu $\cdot 573$

boxeo $\cdot 4,11,157,1203,1529,1530$

budismo $\cdot 320,560,649,695,1327$

budo $\cdot 46,167,320,392,524,1156,1350,1371,1382$, 1390,1392

bujutsu $\cdot 167,1151,1156,1350,1369,1370$

bushido · 31, 320, 511, 512, 1298, 1317, 1334, 1348, $1350,1371,1376,1377,1380,1397,1460,1521$, $1522,1523,1524,1526,1527,1552$

$\mathbf{C}$

cabuyería $\cdot 1264$

calentamiento $\cdot 34,43,115,144,169,173,237,286$, $309,364,476,518,527,533,559,717,718,738$, $742,774,813,831,840,905,909,933,945,978$, 1017, 1030, 1036, 1040, 1060, 1071, 1133, 1147, $1183,1184,1244,1347$

caligrafía $\cdot 763,810,811,1317$

capacidades físicas · 226, 333, 334, 379, 399, 631, 831, $1059,1119,1124,1128,1129,1163,1554,1556$, $1558,1560,1563$

\section{Ch}

choy lee fut $\cdot 941,963,964,968,977$ 


\section{C}

ciencia militar $\cdot 1301,1442$

cine $\cdot 415,1004,1333,1364,1405,1406,1409,1410$, $1411,1412,1414,1416,1420,1421,1424,1425$, $1426,1434,1436,1438,1439$

clubes $\cdot 28,119,175,180,215,231,236,239,324,337$, $460,562,608,800,1303,1534$

combate $\cdot 74,100,121,200,294,341,356,362,383$, $386,391,395,407,428,434,465,466,477,498$, $501,502,508,526,555,620,632,639,641,742$, $750,753,763,771,774,793,797,799,803,807$, $822,825,830,834,841,842,844,857,875,877$, $885,888,441895,897,905,907,908,910,911,934$, $935,936,940,952,965,981,990,993,998,999$, $1000,1001,1013,1015,1017,1019,1022,1027$, $1040,1041,1042,1047,1054,1055,1060,1065$, $1069,1070,1074,1075,1087,1093,1098,1107$, $1116,1133,1142,1149,1152,1153,1157,1268$, $1296,1301,1304,1320,1346,1368,1373,1391$, $1403,1444,1446,1450,1451,1452,1453,1454$, $1455,1456,1458,1464,1465,1468,1469,1472$, $1481,1482,1505,1509,1514,1529,1530,1537$, $1538,1539,1540,1541,1542,1543,1544$

competición · 42, 77, 80, 82, 87, 91, 97, 101, 102, 105, $108,109,110,114,115,121,128,134,156,157$, $160,165,173,176,179,180,200,201,203,214$, $219,220,222,230,231,232,233,236,238,240$, $241,246,248,249,251,255,260,263,264,267$, $273,286,287,307,308,309,324,326,329,330$, $336,337,362,364,392,399,403,433,448,452$, $453,456,458,461,468,471,474,492,502,508$, 511, 519, 610, 933, 936, 985, 986, 993, 997, 1036, $1037,1038,1041,1042,1048,1049,1053,1054$, $1058,1068,1073,4411078,1079,1080,1081,1083$, $1093,1097,1098,1101,1106,1110,1124,1133$, $1152,1153,1173,1177,1193,1220,1244,1303$, $1308,1320,1350,1356,1368,1532,1534,1547$ confucianismo $\cdot 320,1327$

correo $\cdot 1417,1418$

cortesía · 15, 46, 48, 80, 136, 225, 235, 279, 317, 364, $385,398,502,508,526,535,554,562,599,608$, 612, 627, 966, 1001, 1010, 1023, 1026, 1032, 1035, $1053,1054,1066,1067,1075,1081,1121,1133$, $1134,1150,1151,1152,1153,1264,1299,1320$, $1347,1408,1537,1538,1539,1540,1541,1542$, $1543,1544,1551,1552$

cualidades físicas · 113, 125, 333, 846, 1130, 1180, $1537,1538,1539,1540,1541,1542,1543,1544$ cultura · 16, 581, 624, 738, 988, 1315, 1323, 1328, $1334,1368,1376,1398,1402$

D

defensa personal $\cdot 1,2,3,4,5,7,8,11,14,21,23,25,31$, $32,33,39,43,49,57,64,68,77,82,85,93,96,99$, $105,112,114,120,127,137,138,139,140,141$, $146,153,161,169,173,187,189,196,199,201$, $203,204,205,225,228,235,242,243,245,246$, $250,251,260,266,272,283,285,289,297,302$, $303,304,305,306,310,341,347,349,356,361$, $375,378,385,395,446,451,468,470,474,476$, $477,479,491,505,516,518,519,523,526,529$, $530,543,576,614,615,616,617,621,623,630$, $770,780,790,794,807,815,872,889,890,891$, $907,911,917,919,921,926,927,931,938,943$, $951,953,960,962,976,980,982,983,997,1003$,
$1004,1023,1024,1025,1026,1028,1029,1030$, $1031,1033,1040,1062,1083,1086,1098,1104$, $1110,1113,1115,1117,1118,1119,1126,1127$, $1133,1150,1160,1162,1164,1167,1169,1172$, $1173,1174,1175,1176,1179,1180,1181,1182$, $1183,1184,1185,1186,1187,1188,1189,1190$, $1192,1193,1194,1196,1197,1198,1199,1200$, $1201,1202,1203,1205,1206,1207,1208,1209$, $1219,1221,1222,1223,1225,1226,1232,1234$, 1235, 1236, 1237, 1242, 1243, 1244, 1246, 1247 , $1249,1250,1251,1252,1253,1254,1256,1258$, $1260,1261,1263,1266,1267,1268,1270,1272$, $1273,1274,1275,1276,1277,1278,1279,1280$, $1324,1339,1537,1538,1539,1540,1541,1542$, $1543,1544,1550$

defensa personal femenina $\cdot 1028,1127,1188$

defensa personal policial · 196, 890, 1176, 1185, 1193, $1205,1206,1222,1232,1234,1237,1242,1244$, $1247,1251,1252,1253,1258,1260,1263,1266$, $1270,1272,1273,1274,1275,1277,1278,1339$, 1550

deporte $\cdot 8,1319$

deportes de combate $\cdot 80,112,126,1176,1374,1391$ didáctica · 30, 39, 62, 86, 87, 111, 112, 145, 156, 158,

$159,161,165,166,170,174,207,209,210,219$, $223,232,233,238,247,274,277,288,328,379$, $434,461,462,472,613,636,740,741,791,856$, $863,930,937,1015,1261,1330,1347$ dopaje $\cdot 1048,1124,1128$

$\overline{\mathbf{E}}$

economía $\cdot 1376,1449$

educación • 9, 10, 23, 80, 112, 160, 272, 274, 288, 587, $800,856,1070,1261,1299,1315,1319,1459,1461$, 1462

ejercicios $\cdot 7,29,30,32,34,43,45,85,87,115,169$, $173,286,309,321,333,334,364,379,383,385$, $440,449,452,465,466,467,470,476,477,492$, $495,501,508,510,513,516,517,518,526,527$, $533,540,555,559,572,591,618,620,622,623$, $624,626,628,640,641,643,644,646,647,648$, $650,651,652,653,654,655,656,657,658,660$, $661,662,663,665,666,670,671,673,674,675$, $676,677,678,679,680,681,682,683,684,685$, $687,688,689,690,691,692,694,695,696,697$, $698,699,700,701,702,703,704,705,706,707$, $708,709,710,711,712,713,714,722,723,724$, $725,727,728,729,730,731,733,734,736,738$, $742,745,748,749,757,763,766,767,768,779$, $781,795,803,804,806,810,811,812,813,815$, $816,826,828,831,832,834,839,840,841,842$, $846,848,850,851,861,863,869,870,875,892$, $897,909,910,912,921,929,931,933,934,937$, $938,942,945,949,962,972,978,981,984,995$, $998,999,1001,1004,1005,1009,1011,1012,1015$, $1017,1018,1021,1024,1027,1030,1036,1040$, $1048,1059,1060,1061,1065,1071,1075,1085$, 1090, 1094, 1099, 1111, 1112, 1119, 1120, 1124, $1128,1129,1133,1134,1135,1136,1137,1140$, $1141,1142,1143,1144,1145,1147,1148,1149$, $1163,1168,1172,1180,1183,1184,1197,1198$, $1199,1200,1201,1225,1227,1228,1244,1268$, $1292,1313,1327,1346,1347,1348,1352,1386$, $1391,1554,1556,1560,1561,1562,1563$

enfermedades $\cdot 47,110,438,548,665,666,674,678$, $679,698,700,703,717,718,757,799$ 
entrenamiento $\cdot 7,16,21,28,32,34,35,37,42,61,67$, $69,70,71,73,74,75,76,78,82,86,87,90,94,95$, $96,97,98,103,114,115,117,125,127,136,150$, $156,161,165,166,182,183,193,203,205,218$, $220,221,229,234,238,251,266,268,269,270$, $272,276,280,284,288,289,297,299,300,308$, $309,321,333,334,338,341,348,354,357,358$, $359,360,377,378,381,383,385,392,393,399$, $415,434,448,449,456,461,465,466,467,470$, $471,474,477,483,492,498,502,508,533,538$, $543,566,570,575,581,582,593,594,595,601$, $610,613,618,620,623,625,626,631,636,639$, $641,642,643,649,652,654,655,658,665,666$, $669,670,676,677,689,697,702,708,709,721$, $723,725,727,728,731,738,739,756,763,779$, $799,801,804,808,818,821,822,824,826,831$, $836,838,853,860,875,889,892,895,896,915$, $921,929,931,937,940,949,950,951,952,954$, $962,965,966,972,984,986,995,1001,1005,1008$, $1011,1015,1016,1017,1022,1035,1036,1037$, $1038,1039,1040,1048,1058,1059,1061,1062$, $1066,1067,1069,1071,1072,1085,1090,1092$, 1093, 1094, 1098, 1101, 1106, 1107, 1112, 1117, $1120,1124,1128,1129,1130,1132,1133,1142$, $1144,1147,1149,1155,1162,1163,1169,1173$, $1179,1181,1193,1196,1208,1209,1225,1238$, $1249,1254,1256,1280,1284,1292,1300,1304$, $1306,1312,1315,1318,1324,1334,1342,1346$, $1347,1349,1356,1358,1362,1363,1386,1401$, $1407,1417,1422,1423,1450,1451,1452,1453$, $1454,1455,1456,1458,1464,1529,1530,1537$, $1538,1539,1540,1541,1542,1543,1544,1554$, $1555,1556,1557,1558,1559,1560,1561,1562$, $1563,1564,1565$

entrevistas $\cdot 45,51,66,84,366,373,554,561,563,564$, $570,578,588,638,735,780,898,1093,1103,1116$, 1120,1428

equipamiento $\cdot 7,121,199,303,304,309,377,378$, $408,448,449,465,466,470,538,594,624,642$, $892,895,897,950,1036,1040,1048,1129,1160$, 1162,1322

escuelas $\cdot 21,59,60,231,296,297,301,320,322,367$, $369,380,391,392,404,442,458,503,504,505$, $509,513,551,554,556,557,559,561,562,563$, $564,565,573,575,581,593,600,601,603,608$, $618,695,697,698,711,719,748,749,750,752$, $754,756,758,761,774,776,777,778,780,782$, $784,785,790,792,793,794,795,796,797,804$, $807,808,813,814,820,824,829,831,833,836$, $839,840,842,843,844,849,850,851,853,858$, $862,863,868,872,875,877,878,879,880,881$, $882,883,885,886,902,903,904,905,908,915$, $916,932,941,952,954,956,958,959,963,964$, $966,973,977,986,990,992,1000,1001,1002$, $1003,1017,1126,1134,1140,1191,1282,1302$, $1354,1369,1370,1399,1400,1531,1550$

esgrima $\cdot 514,1297$

eskrima $\cdot 1088$

estrategia $\cdot 176,307,349,505,529,551,583,589,593$, $600,601,605,642,877,907,1087,1107,1202$, $1284,1292,1296,1299,1301,1304,1307,1322$, $1346,1347,1359,1360,1369,1370,1373,1442$, $1443,1444,1445,1446,1447,1448,1449,1450$, $1451,1452,1453,1454,1455,1456,1457,1458$, $1463,1464,1465,1466,1468,1469,1470,1471$, $1472,1473,1474,1475,1476,1477,1478,1479$, $1480,1481,1482,1483,1484,1485,1486,1487$, $1488,1489,1490,1491,1492,1493,1494,1495$, $1496,1497,1498,1499,1500,1501,1502,1503$,
$1504,1505,1506,1507,1508,1509,1510,1511$, $1512,1513,1514,1515,1520,1547$

ética $\cdot 9,10,42,297,622,1296,1297,1326,1342,1369$, $1370,1382,1459,1461,1462,1464,1516,1521$, $1522,1523,1525,1526,1527,1528,1550$

etiqueta $15,46,48,80,136,225,235,279,317,364$, $385,398,508,535,554,562,599,608,627,1001$, $1023,1026,1032,1035,1075,1081,1133,1151$, $1152,1153,1264,1320,1408,1537,1538,1539$, $1540,1541,1542,1543,1544,1551,1552$

eventos $\cdot 28,167,324,337,1343$

exámenes · 27, 40, 52, 53, 160, 201, 220, 227, 248, 249, $253,363,456,472,570,753,936,1024,1056,1108$, 1109,1347

$\mathbf{F}$

fengshui $\cdot 1146$

filmografía · 643, 1405, 1407, 1409, 1410, 1411, 1412, $1414,1428,1430,1438$

filosofía · 9, 10, 22, 24, 31, 39, 42, 55, 56, 58, 59, 61, 66, $67,69,89,178,234,247,280,288,322,402,509$, $512,535,536,558,586,588,591,629,635,636$, $641,642,649,658,673,704,714,720,737,738$, $739,749,776,782,785,789,794,795,796,797$, $802,810,811,818,822,857,881,898,902,903$, $905,940,951,952,1002,1003,1014,1057,1104$, $1156,1160,1162,1282,1283,1285,1294,1295$, $1297,1298,1300,1302,1304,1305,1306,1312$, $1324,1326,1331,1339,1341,1344,1345,1348$, 1353, 1354, 1361, 1366, 1367, 1371, 1372, 1373, $1374,1378,1382,1384,1390,1392,1398,1402$, $1417,1419,1422,1423,1426,1438,1450,1451$, $1452,1453,1454,1455,1456,1458,1459,1460$, $1461,1462,1464,1521,1522,1523,1524,1526$, $1527,1534,1537,1538,1539,1540,1541,1542$, $1543,1544,1551$

física $\cdot 1336,1351$

fisiología · 39, 43, 90, 357, 538, 541, 542, 544, 653, 697, $698,725,731,1034,1124,1349,1563$

fisioterapia $\cdot 572,646,670,678,679,681,683,689$, $692,698,699,702,710,712,726,730,732,738$, $745,748,757,821,840,846,848,870,998,999$ fitoterapia $\cdot 402,583,593,601,966$

formas · 350, 351, 387, 604, 619, 622, 623, 625, 648, $670,674,685,686,688,696,699,701,704,719$, $738,742,743,748,750,751,752,753,754,755$, $756,758,759,760,761,763,768,769,770,772$, $773,774,775,778,780,782,785,789,792,793$, $795,796,797,804,805,807,808,813,814,815$, $816,817,819,820,823,824,825,828,829,830$, $831,832,834,835,836,837,839,840,842,843$, $844,847,848,849,850,851,853,854,855,858$, $862,863,864,867,868,869,870,875,877,880$, $881,882,883,884,885,888,893,895,896,897$, $899,900,901,906,910,911,915,918,919,922$, 923, 924, 926, 927, 933, 934, 935, 942, 943, 945, $949,950,953,957,960,962,965,967,970,971$, $975,976,978,979,981,985,986,988,990,991$, $993,996,998,999,1000,1002,1012,1013,1014$, 1016, 1017, 1019, 1020, 1022, 1040, 1085, 1093, $1097,1109,1134,1138,1140,1141,1142,1143$, $1148,1157,1164,1537,1538,1539,1540,1541$, $1542,1543,1544$

fotografía $\cdot 28,215,337,1285$

Fuerzas Armadas · 167, 1301, 1322

full-contact · 1529, 1530 
fundamentos éticos $\cdot 298,459$

fundamentos filosóficos · 48, 320, 348, 365, 392, 432, $471,554,560,578,579,603,609,618,620,682$, $690,696,740,741,742,744,746,747,756,762$, $764,765,781,798,799,801,816,827,834,845$, $847,850,875,895,909,966,1098,1100,1117$, $1127,1137,1219,1286,1287,1289,1290,1317$, $1323,1327,1340,1342,1369,1370,1375,1385$, $1393,1394,1395,1396,1397,1435,1438,1440$, 1536

fundamentos técnicos • 1, 2, 3, 4, 5, 11, 12, 13, 14, 15, 19, $21,23,25,26,27,29,30,31,32,37,38,40,41,42$, $43,45,46,49,52,53,54,55,56,57,59,60,63,64$, $65,68,70,72,73,74,77,78,81,82,83,85,88,89$, $91,92,93,94,95,96,97,98,101,102,103,104$, $106,107,109,114,115,116,117,118,120,121$, $122,124,127,128,129,130,131,132,133,135$, $136,137,138,139,140,141,143,144,146,147$, $148,149,150,151,152,153,154,155,156,157$, $159,160,161,162,163,164,166,169,170,171$, $172,173,174,175,176,177,181,182,183,184$, $186,187,189,190,191,192,193,194,195,196$, $197,198,199,200,201,203,204,205,206,207$, $208,209,210,211,213,216,217,218,220,221$, $224,225,227,228,229,230,234,235,237,238$, $240,241,242,244,245,248,249,251,252,253$, $254,255,256,257,260,261,262,265,266,267$, $268,269,270,271,273,275,276,278,279,280$, $281,282,284,285,286,287,289,290,291,292$, 293, 294, 295, 296, 297, 298, 299, 300, 302, 303, $304,305,306,307,308,309,310,311,312,313$, $314,315,317,318,319,321,323,325,326,327$, $328,329,331,332,338,339,341,342,344,346$, $347,349,355,356,357,358,359,360,361,362$, $363,364,365,366,370,374,376,377,378,379$, $381,382,383,385,386,388,390,391,392,393$, 394, 395, 396, 399, 400, 401, 402, 403, 404, 405, $406,408,409,410,411,412,413,414,415,416$, $417,418,419,420,421,422,424,425,426,427$, $428,429,430,432,435,441,442,443,444,446$, $450,452,453,456,457,458,459,461,463,464$, $465,466,467,468,469,470,471,472,474,475$, $476,477,478,479,480,491,492,493,494,495$, $496,498,499,500,501,502,503,504,505,506$, $507,508,509,510,511,513,514,515,516,517$, $518,519,520,521,522,524,525,526,527,528$, $530,532,533,534,535,536,537,539,540,541$, $542,543,544,547,548,550,551,552,553,555$, $556,557,559,564,565,566,567,568,569,570$, $573,574,575,576,578,579,580,582,583,584$, $585,586,587,588,589,590,591,593,595,596$, $597,598,600,601,602,603,604,605,606,607$, $609,611,612,613,614,615,616,617,618,620$, $622,623,624,625,626,627,628,630,631,632$, $633,634,636,637,640,641,643,644,645,650$, $651,652,653,654,655,656,658,659,660,661$, $662,665,666,667,668,669,671,673,675,676$, $677,680,681,684,688,689,691,692,696,699$, $701,702,705,708,710,711,712,713,715,716$, $717,718,719,720,721,722,723,724,726,727$, $728,729,730,732,733,734,736,738,739,743$, $749,750,751,752,753,754,756,757,758,760$, 761, 766, 767, 768, 770, 772, 773, 775, 778, 779, $780,791,792,795,796,803,808,814,817,820$, $823,825,827,828,829,830,831,833,834,835$, $837,838,840,842,843,844,846,847,848,849$, $850,851,853,854,855,857,861,862,863,864$, $865,866,867,868,869,870,875,877,878,879$, $882,883,884,885,886,887,888,889,890,891$,
892, 893, 894, 896, 899, 900, 901, 902, 903, 906, $907,908,909,910,911,912,913,914,915,917$, $918,919,921,922,924,926,927,931,932,933$, $935,936,938,939,940,941,942,946,947,948$, $949,952,953,954,955,957,958,960,962,963$, $964,965,966,967,968,969,970,971,972,974$, $975,976,977,978,980,982,984,985,986,988$, $989,990,991,992,993,995,997,998,999,1000$, $1001,1002,1003,1004,1005,1006,1007,1009$, $1010,1012,1013,1014,1015,1016,1017,1018$, $1019,1020,1021,1022,1023,1024,1025,1026$, $1027,1028,1029,1031,1032,1033,1034,1035$, $1036,1038,1039,1040,1041,1042,1043,1044$, $1045,1047,1048,1049,1052,1053,1054,1055$, $1056,1057,1058,1059,1060,1061,1062,1063$, $1065,1068,1069,1070,1074,1075,1077,1081$, $1083,1085,1086,1087,1088,1089,1090,1091$, 1092, 1093, 1094, 1095, 1096, 1097, 1098, 1099, $1100,1101,1103,1104,1105,1106,1107,1108$, $1109,1110,1111,1112,1113,1114,1115,1116$, $1117,1118,1119,1120,1123,1124,1125,1126$, $1127,1128,1129,1130,1132,1133,1135,1137$, $1138,1139,1141,1142,1143,1144,1145,1146$, $1147,1148,1149,1150,1151,1152,1153,1154$, $1155,1156,1157,1161,1163,1164,1165,1167$, $1168,1170,1172,1173,1174,1175,1177,1179$, $1181,1182,1183,1184,1185,1187,1188,1189$, $1190,1192,1193,1194,1195,1196,1197,1199$, $1200,1201,1203,1204,1205,1206,1207,1208$, $1209,1219,1221,1222,1223,1224,1226,1227$, $1228,1229,1234,1236,1237,1239,1240,1241$, $1242,1243,1244,1245,1246,1247,1248,1249$, $1250,1251,1252,1253,1254,1255,1258,1260$, $1261,1262,1263,1264,1265,1266,1267,1268$, $1269,1270,1271,1272,1273,1274,1275,1276$, $1277,1278,1279,1280,1284,1292,1298,1320$, $1322,1339,1340,1346,1358,1373,1377,1390$, $1399,1401,1407,1408,1415,1427,1437,1458$, $1529,1530,1533,1534,1537,1538,1539,1540$, $1541,1542,1543,1544,1545,1551,1555,1557$, 1565

fundamentos teóricos $\cdot 2,5,7,8,13,15,16,21,31,32$, $34,35,36,37,38,39,40,42,44,45,46,47,48,49$, $50,53,55,56,58,62,67,69,70,71,73,74,75,76$, $78,81,86,89,94,98,99,101,102,103,105,106$, $113,116,124,126,127,133,147,150,154,156$, $159,162,168,169,170,171,177,186,190,195$, $197,201,209,211,219,223,225,229,230,234$, $237,238,240,241,242,243,245,252,260,265$, $272,275,279,281,282,285,287,288,292,296$, $301,303,304,309,320,321,330,333,334,343$, $347,349,354,355,356,357,361,364,369,370$, $379,380,381,386,392,393,394,398,403,404$, $405,406,407,415,432,433,434,437,438,441$, $442,448,454,455,457,461,465,466,470,484$, $485,486,492,495,496,500,502,506,508,509$, $510,511,519,520,521,525,526,527,529,530$, $533,535,538,539,540,541,542,544,546,548$, $552,553,554,555,559,560,561,563,564,572$, $574,575,576,577,578,579,582,587,590,591$, $593,594,595,596,597,598,599,600,601,607$, $610,611,612,618,619,622,624,626,627,629$, $635,636,637,638,640,641,642,644,645,646$, $647,648,649,651,652,653,654,655,656,657$, $658,659,660,661,662,664,667,668,669,670$, $672,673,674,675,676,678,679,680,682,683$, $684,685,687,688,689,690,691,692,693,694$, $695,696,697,698,699,700,701,702,704,705$, $707,708,709,710,711,712,713,715,716,717$, 
718, 719, 720, 721, 722, 723, 724, 725, 726, 727, $728,729,730,731,732,733,734,735,738,740$, $744,745,749,750,752,753,754,756,757,758$, $759,760,762,764,765,769,770,771,772,773$, $776,777,778,779,780,782,785,788,790,791$, $792,793,798,799,800,801,803,804,805,807$, $809,810,811,812,813,814,815,816,817,818$, $823,827,828,830,831,834,836,837,838,844$, $845,846,847,850,851,853,856,859,860,861$, $862,863,869,870,872,875,880,882,883,886$, $887,889,891,893,895,899,900,901,905,906$, $909,915,917,923,930,933,937,938,940,941$, $942,948,954,966,991,993,996,1000,1004,1010$, $1011,1012,1015,1016,1017,1020,1023,1032$, $1034,1035,1037,1038,1047,1053,1066,1067$, $1068,1070,1075,1081,1087,1088,1090,1091$, $1094,1099,1100,1106,1108,1109,1111,1117$, $1119,1120,1122,1126,1134,1135,1137,1138$, $1140,1142,1143,1146,1147,1148,1150,1151$, $1152,1153,1157,1158,1160,1161,1162,1164$, $1167,1169,1170,1173,1175,1177,1180,1181$, $1183,1184,1189,1190,1197,1202,1203,1204$, $1206,1208,1209,1219,1220,1223,1225,1227$, $1228,1229,1230,1234,1235,1237,1239,1241$, $1243,1247,1249,1251,1255,1258,1261,1264$, $1267,1268,1270,1271,1272,1273,1274,1275$, $1276,1280,1281,1282,1284,1296,1297,1299$, $1300,1302,1309,1312,1313,1317,1320,1324$, $1325,1327,1331,1336,1338,1340,1342,1345$, $1346,1347,1350,1351,1352,1357,1358,1361$, $1363,1379,1383,1389,1390,1391,1401,1403$, $1407,1408,1413,1415,1427,1429,1430,1436$, $1438,1444,1446,1447,1448,1465,1468,1469$, $1472,1481,1482,1505,1509,1514,1532,1535$, $1536,1537,1538,1539,1540,1541,1542,1543$, $1544,1546,1547,1548,1551,1552,1553,1554$, $1555,1556,1560,1561$

\section{$\overline{\mathbf{G}}$}

geisha $\cdot 1285$

genealogía $\cdot 850,988,1127,1142$

gestión empresarial · 1359, 1360, 1445, 1447, 1448, 1506

grados $\cdot 31,40,41,49,52,53,63,116,128,135,136$, $220,225,227,234,239,240,242,255,265,267$, $354,448,458,459,554,557,896,909,945,1039$, $1098,1133,1244,1401$

guerra $\cdot 1032,1296,1299,1301,1307,1315,1322$, $1332,1334,1442,1443,1444,1445,1446,1447$, $1448,1449,1453,1454,1457,1463,1465,1466$, $1468,1469,1470,1471,1472,1473,1474,1475$, $1476,1477,1478,1479,1480,1481,1482,1483$, $1484,1485,1486,1487,1488,1489,1490,1491$, $1492,1493,1494,1495,1496,1497,1498,1499$, $1500,1501,1502,1503,1504,1505,1506,1507$, $1508,1509,1510,1511,1512,1513,1514,1515$, 1520

\section{$\mathbf{H}$}

habilidades motrices $\cdot 125,334$

hinduismo $\cdot 320$

historia $\cdot 2,7,13,16,21,26,27,28,34,48,49,54,55$, $60,63,66,67,68,69,80,83,84,86,88,91,93,97$, $101,102,103,104,105,108,109,114,116,117$,
$119,126,136,150,154,156,157,159,160,161$, $162,167,168,172,175,176,177,179,180,185$, $188,191,192,195,200,203,205,206,211,214$, $215,219,225,227,231,234,236,239,240,245$, $247,251,252,253,255,257,258,261,265,267$, $270,271,275,278,281,286,287,288,297,298$, $301,308,309,310,320,322,323,324,325,337$, $338,339,340,342,344,345,346,348,352,353$, $354,356,358,359,360,361,362,364,365,366$, $367,368,369,370,371,372,377,379,380,383$, $384,385,387,391,392,393,394,395,396,397$, $398,399,400,401,402,403,404,405,406,407$, $408,414,435,436,437,441,442,443,452,453$, $454,457,458,465,466,467,470,473,475,476$, $481,484,485,486,488,489,492,495,497,500$, $501,502,511,512,513,514,517,518,519,521$, $523,524,527,529,530,531,533,538,540,551$, $552,553,554,557,561,563,565,566,567,573$, $575,577,578,579,580,581,582,583,593,594$, 595, 596, 597, 598, 599, 600, 601, 602, 603, 604, $605,606,609,610,611,613,618,620,621,623$, $624,625,626,627,637,642,645,663,664,670$, $672,674,675,676,677,682,683,684,687,695$, $696,697,698,701,702,704,707,712,715,716$, $722,723,724,727,728,729,733,734,736,737$, 738, 740, 742, 746, 747, 748, 749, 750, 755, 756, $758,772,774,775,777,781,782,783,784,785$, $786,788,789,790,791,792,794,796,797,799$, $803,804,805,807,809,810,811,814,815,816$, $817,820,822,824,826,828,829,830,832,839$, $841,845,848,850,857,863,864,868,871,872$, $873,874,875,881,885,886,887,892,893,894$, $895,896,897,898,899,901,902,903,904,905$, $906,907,908,909,912,915,916,917,918,921$, 922, 923, 924, 927, 932, 940, 941, 942, 943, 945, $947,948,952,953,954,955,958,959,960,963$, $964,965,966,967,968,969,970,971,973,974$, $975,976,977,979,981,984,985,986,988,989$, $990,993,995,996,1000,1001,1002,1003,1004$ $1006,1008,1010,1011,1012,1013,1015,1016$, $1017,1019,1020,1021,1022,1023,1024,1025$, $1026,1027,1032,1033,1035,1037,1038,1040$, $1049,1052,1053,1055,1056,1057,1058,1060$, $1061,1065,1072,1073,1074,1075,1076,1078$, 1086, 1087, 1088, 1089, 1090, 1091, 1092, 1093, $1094,1095,1098,1101,1103,1104,1105,1107$, $1108,1111,1112,1113,1114,1115,1117,1118$, $1120,1121,1123,1125,1126,1127,1129,1130$, $1134,1138,1140,1142,1145,1149,1150,1152$, $1153,1156,1157,1158,1161,1189,1191,1195$, $1198,1223,1232,1244,1246,1249,1252,1281$, $1282,1283,1284,1285,1288,1293,1294,1295$, $1298,1301,1303,1308,1314,1315,1316,1317$, $1320,1324,1327,1329,1332,1334,1338,1339$, $1340,1350,1354,1355,1356,1357,1362,1363$, $1367,1369,1370,1374,1376,1377,1380,1387$, 1388, 1390, 1398, 1399, 1400, 1402, 1405, 1407, $1408,1413,1422,1423,1424,1437,1439,1441$, $1450,1453,1454,1460,1462,1467,1472,1514$, $1515,1517,1518,1529,1530,1532,1534,1535$, $1545,1546,1547,1548,1551,1552,1557$

iaido $\cdot 40,503,504,512,1302,1317,1350,1351,1371$ iniciación deportiva $\cdot 126,288,1281,1321$ 
instalaciones · 46, 121, 128, 180, 240, 256, 264, 298, $324,364,562,575,608,612,1047,1079,1284$, 1347

instituciones · $60,101,102,121,167,170,214,264$, $288,320,364,365,367,368,369,370,371,554$, $562,606,608,627,640,896,906,985,1032,1047$, $1057,1066,1067,1073,1079,1101,1130,1252$, $1314,1320,1400,1407,1408$

investigación · 86, 438, 715, 716, 1064, 1084, 1321

\section{$\overline{\mathbf{J}}$}

Japón · 15, 556, 1294, 1295, 1328, 1329, 1377, 1380, 1402

jardinería $\cdot 1317$

jeet kune do $\cdot 635,638,958,1407,1417,1422,1423$, $1425,1426,1436,1438,1547$

jojutsu $\cdot 573,1152,1153$

judo $\cdot 90,96,99,101,102,111,112,119,129,145,146$,

$157,169,176,179,209,225,231,263,283,1154$, $1203,1220,1234,1246,1314,1317,1319,1321$, $1338,1350,1351,1352,1534,1537,1538,1539$, $1540,1541,1542,1543,1544$

juegos $\cdot 122,145,156,160,210,263,264,934,935$, $1062,1066,1067,1071,1077,1078,1079,1321$, 1391

jujutsu $\cdot 4,8,11,84,96,99,102,114,129,167,225$, $242,1151,1314,1350,1351$

\section{$\mathbf{K}$}

\section{kali $\cdot 1088$}

kárate $\cdot 96,129,275,296,301,322,330,339,352,353$, $369,370,376,377,389,390,398,401,407,433$, $436,445,475,497,523,530,531,913,914,1040$, $1115,1151,1154,1161,1203,1220,1293,1302$, $1317,1330,1337,1338,1350,1351,1352,1362$, $1534,1537,1538,1539,1540,1541,1542,1543$, 1544

katas $\cdot 32,40,54,92,97,100,106,109,112,127,135$, $143,146,150,162,181,185,188,191,200,203$, $216,217,224,237,246,247,248,249,262,272$, 286, 290, 293, 294, 295, 296, 298, 302, 305, 306, $311,312,313,314,315,316,317,319,326,327$, $331,332,338,339,341,342,344,346,347,348$, $352,353,354,355,358,359,360,363,364,365$, $370,374,376,380,381,383,384,386,389,390$, 392, 394, 395, 396, 397, 398, 403, 406, 410, 411, $412,413,416,420,421,422,423,424,428,429$, $430,431,432,435,441,443,445,446,452,453$, $454,455,456,457,458,467,468,471,476,480$, $481,482,483,484,485,486,487,488,489,490$, $497,501,502,503,504,505,506,507,509,510$, $516,517,519,526,527,532,533,539,568,573$, $591,597,598,612,614,615,997,1003,1060,1104$, $1116,1117,1121,1126,1133,1149,1152,1153$, $1160,1162,1190,1219,1223,1224,1244,1293$, $1330,1363,1374,1403,1537,1538,1539,1540$, $1541,1542,1543,1544$

kendo $\cdot 510,1314,1317,1350,1351,1534$

kenjutsu • 20, 67, 69, 512, 513, 514, 1152, 1153

kickboxing $\cdot 1132,1529,1530$

kobudo $\cdot 392,524$

kuatsu $\cdot 2,12,249,267,477,495,540,1205,1237$

kumite $\cdot 293,294,295,302,303,304,305,306,309$, $317,321,327,331,332,338,341,348,357,358$,
$359,360,364,365,370,375,381,382,392,393$, $394,403,406,408,418,419,424,426,427,443$, $449,452,456,457,461,468,470,476,480,489$, $494,520,532,1117,1537,1538,1539,1540,1541$, $1542,1543,1544$

kyudo $\cdot 154,510,536,1302,1317,1350,1534$

kyusho · 85, 96, 98, 117, 160, 187, 189, 199, 285, 341, $358,359,360,361,364,378,383,385,399,402$, $403,405,407,448,453,465,466,470,476,477$, $538,539,544,545,546,547,548,590,595,597$, $598,612,632,779,915,963,1024,1025,1031$, $1034,1053,1060,1085,1124,1126,1149,1151$, $1169,1179,1181,1187,1189,1202,1205,1208$, $1226,1235,1242,1244,1264,1277,1278,1280$, $1324,1336,1550$

$\mathbf{L}$

legislación · 21, 23, 39, 43, 93, 98, 110, 246, 468, 538, $1167,1175,1176,1184,1185,1206,1235,1238$, $1239,1243,1247,1249,1251,1271,1272,1273$, $1274,1275,1277,1278,1280,1314,1336$

lesiones · 16, 47, 109, 116, 300, 333, 444, 456, 538, 540, $541,542,1037,1336,1563$

lucha $\cdot 1193,1203$

lucha canaria $\cdot 1319$

lucha leonesa $\cdot 1319$

lucha olímpica 1319

\section{M}

maestros $\cdot 15,16,18,21,22,24,26,51,54,59,66,67$, $69,84,91,126,161,167,179,206,217,239,247$, $260,286,287,288,298,301,320,365,366,367$, $368,369,373,380,387,392,397,405,406,435$, $437,439,460,505,554,564,566,569,570,573$, $578,591,606,618,625,637,638,642,643,760$, $780,782,783,784,785,786,788,809,822,823$, $825,850,851,888,895,897,898,916,922,942$, $943,947,964,967,968,971,974,979,981,985$, $988,989,990,1000,1011,1013,1015,1017,1025$, $1075,4451101,1113,1114,1116,1140,1294,1295$, $1300,1302,1312,1315,1323,1333,1334,1335$, $1348,1350,1355,1362,1364,1367,1378,1382$, $1397,1404,1407,1417,1426,1442,1458,1519$, $1545,1547,1550$

medicina $\cdot 47,348,402,444,514,539,591,626,646$, $675,679,682,685,694,696,704,707,721,723$, $725,726,728,730,731,732,738,799,826,836$, $851,966,988,998,999,1140,1144,1289,1290$, 1347

medicina tradicional china $\cdot 348,402,539,626,646$, $675,679,682,685,694,696,704,707,721,723$, $725,726,728,730,731,732,738,826,836,851$, $966,1140,1144$

meditación $\cdot 31,206,612,618,644,658,660,661,662$, $670,674,683,685,696,698,701,702,707,719$, $745,746,747,763,780,807,813,821,828,839$, $841,842,861,864,869,886,905,927,951,1002$, $1004,1099,1116,1135,1140,1289,1290,1348$, $1352,1354,1371,1403$

moxibustión $\cdot 966$ muay thai $\cdot 1093,1096,1529,1530$ musculación · 399, 1124, 1128 música $\cdot 618,880,1013$ 
$\mathbf{N}$

ninjutsu $\cdot 554,556,557,559,562,564,565,573,575$, $580,581,583,588,593,601,605,608,1191,1282$, 1302,1375

nutrición $\cdot 246,378,670,714,836,874,1037,1048$, $1124,1128,1129,1143,1196,1339,1357,1529$, $1530,1556,1564$

\section{$\mathbf{P}$}

pedagogía $\cdot 34,39,46,48,50,62,80,95,97,103,110$, $111,112,113,122,125,126,155,158,165,195$, $232,233,238,243,246,277,288,328,461,462$, $483,536,560,575,640,740,741,798,799,821$, $828,845,889,930,936,937,1018,1091,1151$, $1237,1238,1281,1292,1318,1330,1339,1342$, $1347,1357,1358,1379,1391,1393,1401$ películas $\cdot 1413,1416,1421,1429$

periodismo $\cdot 570,1420$

personalidad $\cdot 113,330,644,1135,1136,1330,1352$, 1367

pintura $\cdot 24,763,1285,1317,1340,1399$

planificación del entrenamiento $\cdot 41,80,126,195,207$, $238,307,333,381,462,636,654,670,721,929$, $940,1065,1112,1140,1154,1219,1318,1330$, $1347,1554,1556$

poesía $\cdot 763,771,1013,1417$

política $\cdot 1288,1298,1299,1301,1376,1442,1449$

praxiología $\cdot 434$

preparación física $\cdot 42,82,85,96,109,160,229,246$, $272,275,276,280,297,307,333,334,349,362$, $377,385,399,407,448,449,467,476,486,538$, $624,626,654,929,937,949,962,981,992,1002$, $1017,1027,1037,1040,1058,1059,1061,1065$, $1070,1072,1075,1106,1112,1120,1130,1159$, $1160,1162,1163,1173,1175,1184,1196,1199$, $1200,1201,1208,1268,1342,1529,1530,1554$, 1558,1564

preparación psíquica $\cdot 41,42,43,349,929,937,1037$, 1175

primeros auxilios $\cdot 162,246,548,937,1175,1251$, 1339

principios de actuación · 5, 1167, 1168, 1206, 1225, $1227,1239,1247,1249,1262,1265,1270,1271$, $1272,1273,1274,1275,1276,1277,1278$

principios éticos $\cdot 21,24,432,538,565,895,1054$, $1299,1347,1350,1378$

principios filosóficos $\cdot 24,41,43,48,71,75,260,343$, $344,346,368,370,379,396,436,572,586,588$, $805,812,821,874,1018,1108,1116,1126,1133$, $1143,1297,1299,1337,1344,1348,1382,1408$, $1516,1525,1528$

principios técnicos $\cdot 12,15,16,21,31,32,34,36,37,41$, $42,43,44,48,50,52,53,57,60,63,66,67,69,70$, $71,73,75,76,82,83,88,91,96,99,105,106,107$, $109,114,115,117,124,128,133,136,146,153$, $154,169,171,172,181,182,186,190,192,196$, $197,203,205,218,221,225,226,229,234,235$, $237,240,243,245,253,262,268,270,275,278$, $280,281,284,288,289,291,303,304,309,316$, $317,321,322,341,342,343,349,355,364,366$, $368,370,385,386,392,393,394,395,398,399$, $400,401,414,423,426,427,431,432,435,438$, $451,452,453,455,461,467,476,477,487,499$, $502,506,508,511,519,525,527,529,530,533$, $534,538,550,554,559,570,573,575,594,596$,
$597,598,599,600,602,609,612,617,618,623$, $624,627,628,629,634,636,638,639,640,641$, $642,646,648,649,653,658,659,663,664,665$, $666,669,670,672,673,675,676,677,683,684$, $685,691,695,697,703,704,705,706,707,712$, $713,719,721,722,723,724,725,726,728,729$, $731,732,733,736,737,740,746,747,749,750$, $752,753,754,756,757,758,759,762,763,765$, $770,773,777,779,780,781,782,785,787,788$, $790,791,792,793,795,805,806,808,809,813$, $814,815,816,817,821,822,823,824,826,828$, $829,831,835,836,837,838,839,840,841,842$, $845,846,847,850,851,853,859,860,862,864$, $865,870,872,874,875,877,880,881,884,885$, $887,889,890,891,892,893,895,898,902,903$, $907,917,921,922,927,938,943,950,955,958$, $960,977,986,990,997,998,999,1000,1001,1004$, $1005,1006,1007,1008,1010,1011,1012,1013$, $1015,1016,1018,1020,1023,1026,1028,1031$, 1033, 1036, 1040, 1054, 1074, 1085, 1087, 1093, $1098,1099,1100,1107,1108,1109,1116,1119$, $1120,1124,1126,1133,1134,1136,1138,1142$, $1143,1146,1147,1157,1164,1167,1169,1170$, $1173,1174,1175,1180,1186,1188,1189,1192$, $1198,1202,1205,1206,1208,1209,1219,1223$, $1225,1226,1234,1241,1242,1247,1249,1254$, $1255,1256,1268,1271,1272,1273,1274,1275$, $1279,1280,1289,1290,1297,1309,1321,1345$, $1346,1347,1351,1352,1358,1367,1373,1378$, $1387,1388,1407,1408,1415,1422,1423,1426$, $1427,1444,1447,1448,1458,1468,1469,1481$, $1509,1514,1532,1537,1538,1539,1540,1541$, $1542,1543,1544,1552,1555$

principios teóricos $\cdot 483,593,601,669,676,708,723$, $728,763,802,824,853,874,1022,1126,1342$, 1358, 1555

programa técnico $\cdot 21,27,41,46,80,83,88,94,97,101$, $102,103,106,115,117,126,127,143,146,150$, $160,161,172,175,177,217,220,223,227,237$, $248,249,253,256,257,260,261,262,269,270$, $272,278,280,281,288,292,298,322,336,363$, $459,467,468,556,573,579,587,611,621,829$, $889,899,931,933,936,1015,1024,1025,1035$, $1045,1068,1081,1123,1151,1185,1189,1195$, $1228,1230,1252,1261,1281,1284,1292,1314$, $1339,1537,1538,1539,1540,1541,1542,1543$, 1544

psicología $\cdot 87,113,514,805,849,937,1048,1176$, $1229,1330,1348,1356$

psicología evolutiva $\cdot 207,798,1066,1067,1347$

pumses $\cdot 1040,1043,1044,1045,1050,1051,1052$, $1053,1054,1056,1057,1062,1066,1067,1070$, $1071,1072,1075,1076,1077,1085,1537,1538$, $1539,1540,1541,1542,1543,1544$

$\mathbf{Q}$

qigong $\cdot 495,644,645,646,656,662,663,670,679$, $681,682,685,686,687,688,693,694,696,699$, $702,703,706,710,713,719,720,726,732,735$, $742,745,748,749,757,768,769,771,776,781$, $795,807,809,815,828,834,836,848,857,868$, $875,878,886,942,954,966,998,999,1012,1013$, $1134,1135,1136,1140,1141,1143,1144,1146$, 1147,1148 


\section{$\mathbf{R}$}

reglamentos $\cdot 27,34,101,102,115,126,128,134,156$, $157,160,170,173,200,201,203,222,235,238$, $248,249,255,260,262,263,264,267,273,277$, $282,284,286,288,298,308,309,326,362,363$, $364,370,403,448,456,468,492,508,511,610$, 933, 936, 985, 986, 993, 1043, 1044, 1048, 1049, $1052,1053,1054,1056,1069,1073,1078,1079$, $1080,1081,1098,1105,1106,1107,1112,1115$, $1120,1133,1152,1153,1176,1177,1244,1284$, $1314,1320,1533,1534$

rehabilitación · 47, 96, 181, 183, 408, 540, 541, 542, $544,1144,1205$

relatos $\cdot 55,66,114,220,320,340,342,345,375,387$, $547,561,563,566,572,579,581,594,663,706$, 779, 784, 821, 865, 968, 1019, 1283, 1306, 1313, $1315,1328,1334,1335,1373,1378,1397,1404$, $1467,1524,1550$

religión · 22, 320, 948, 971, 1354, 1380, 1438 respiración · 21, 31, 45, 98, 286, 297, 378, 544, 647, $658,670,675,682,683,692,694,695,699,705$, $708,721,738,749,757,771,804,805,823,828$, $832,839,851,864,868,869,899,951,978,995$, $1004,1060,1099,1134,1140,1143,1324,1348$, $1350,1351,1386$

\section{$\mathbf{S}$}

salud $\cdot 27,257,258,344,346,393,460,486,649,664$, $671,679,680,697,700,703,706,707,720,721$, $729,737,739,773,780,796,799,803,805,813$, $823,829,832,836,874,875,881,889,1100,1136$, $1139,1143,1156,1320,1387,1388,1389$

samurái · 9, 10, 21, 511, 512, 600, 1156, 1285, 1297, $1298,1304,1315,1334,1344,1369,1370,1373$, $1375,1376,1378,1380,1398,1450,1451,1452$, $1453,1454,1455,1456,1458,1459,1461,1462$, $1464,1516,1521,1522,1523,1524,1525,1526$, $1527,1528,1551$

savate $\cdot 1529,1530$

seppuku $\cdot 9,10,439,514,1334,1377,1459,1461$, 1462,1549

series TV $\cdot 570,1413$

sexo $\cdot 545,670,714,1140$

shorinji kempo $\cdot 902,903$

shugendo $\cdot 1302$

sintoísmo $\cdot 320,560,1378$

sistemas de entrenamiento $\cdot 29,70,73,95,103,114$, $115,150,161,203,234,269,270,288,308,334$, $341,348,454,455,502,511,628,642,715,716$, $724,733,734,779,889,892,972,1001,1005,1011$, $1017,1062,1090,1091,1098,1128,1209,1334$, $1347,1386,1401,1537,1538,1539,1540,1541$, $1542,1543,1544,1554,1561$

sociedad $\cdot 60,167,906,1176,1368,1376,1400,1449$ sumo $\cdot 154,1534$

\section{$\mathbf{T}$}

táctica · 98, 99, 169, 176, 182, 195, 210, 225, 241, 243, $251,268,281,285,289,307,309,321,330,341$, $343,349,361,364,418,505,508,529,530,551$, $575,577,593,594,601,605,620,628,632,633$, $638,642,758,790,872,875,889,891,895,1020$,
$1037,1107,1108,1119,1120,1129,1142,1152$, $1153,1157,1175,1179,1189,1196,1225,1249$, $1255,1280,1284,1296,1297,1298,1307,1322$, $1345,1347,1350,1415,1427,1443,1444,1445$, $1446,1447,1448,1449,1453,1454,1457,1458$, $1463,1465,1466,1468,1469,1470,1471,1472$, $1473,1474,1475,1476,1477,1478,1479,1480$, $1481,1482,1483,1484,1485,1486,1487,1488$, $1489,1490,1491,1492,1493,1494,1495,1496$, $1497,1498,1499,1500,1501,1502,1503,1504$, $1505,1506,1507,1508,1509,1510,1511,1512$, $1513,1514,1515,1520,1537,1538,1539,1540$, $1541,1542,1543,1544$

taekwondo $\cdot 1064,1066,1067,1073,1078,1084,1161$, $1220,1314,1319,1338,1534,1537,1538,1539$, $1540,1541,1542,1543,1544$

taijiquan $\cdot 683,710,735,738,748,749,750,752,754$, $757,758,761,774,777,778,780,782,784,785$, $790,792,793,794,795,796,797,798,802,804$, $807,808,813,814,816,820,824,831,833,836$, $839,840,842,843,844,848,849,850,851,853$, $855,858,862,863,868,869,870,872,873,875$, $877,878,879,880,881,882,883,886,902,903$, $905,913,914,941,952,963,964,977,998,999$, $1011,1136,1140,1141,1142,1143,1144,1146$, $1147,1148,1164,1351$

taijutsu $\cdot 20$

taishindó $\cdot 1191$

tambojutsu $\cdot 1152,1153$

taoísmo $\cdot 320,434,618,634,649,659,695,697,704$, $714,750,789,826,844,849,862,875,964,1164$, 1327

telecomunicaciones $\cdot 1251,1264$

terrorismo $\cdot 1225,1243,1251,1265,1266$

tests $\cdot 90,333,334,1158,1347,1349,1554,1559$ textos $\cdot 475,588,591,734,758,762,765,780,781,783$, $784,787,788,789,790,793,809,810,811,816$, $824,851,868,871,872,875,888,945,958,996$, $1012,1013,1017,1304,1397,1450,1451,1452$, $1453,1454,1455,1456,1458,1464,1465,1472$, $1505,1508,1511,1512$

to-de $\cdot 437,440,1293,1363$

\section{$\overline{\mathbf{U}}$}

unidades didácticas · 30, 42, 112, 232, 233, 277, 299, $300,338,613,696,856,863,930,1330,1391$

$\overline{\mathbf{V}}$

vale tudo $\cdot 84,1103$

vestimenta $\cdot 15,16,21,26,31,34,46,48,55,80,128$, $136,147,157,173,225,235,239,240,253,267$, $279,288,317,364,385,398,458,498,502,506$, $508,527,535,554,562,599,603,608,627,803$, 933, 945, 946, 1001, 1010, 1023, 1026, 1032, 1035, $1054,1075,1081,1133,1150,1151,1152,1153$, $1156,1264,1288,1301,1320,1334,1347,1369$, $1370,1380,1408,1537,1538,1539,1540,1541$, $1542,1543,1544,1551,1552$

violencia $\cdot 31,1167,1168,1173,1176,1262,1350$ vista $\cdot 110,1064,1084$ 


\section{$\mathbf{W}$}

wing chun $\cdot 887,890,905,941,958,963,964,977$

wushu · 154, 671, 698, 902, 903, 905, 916, 941, 952,

$956,958,959,963,964,973,977,990,992,1003$,

$1126,1142,1161,1191,1338,1406,1417,1534$

$\mathbf{X}$

xinyiquan $\cdot 941,963,964,977,1011,1013,1142,1143$

$\mathbf{Y}$

yoga $\cdot 497,644,828,1135,1352$

$\overline{\mathbf{Z}}$

zen $\cdot 40,206,497,513,514,536,565,612,996,1004$, $1294,1295,1297,1305,1306,1325,1347,1348$,

$1350,1354,1375,1378,1397$ 


\subsection{Referencias}

Acevedo, W., Gutiérrez-García, C., \& Cheung, M. (2010) Breve historia del Kung-fu. Madrid: Nowtilus. AENOR. (1990). Documentación: preparación de resúmenes. UNE 50-103-1990. Madrid: AENOR.

AENOR. (1991). Documentación: métodos para el análisis de documentos, determinación de su contenido y selección de los términos de indización. UNE 50-121-1991. Madrid: AENOR.

AENOR. (1994). Referencias bibliográficas: contenido, forma y estructura. UNE 50-104-1994. Madrid: AENOR.

André, É. (1906). 100 lances de jiu-jitsu (ataques y quites) (1aa ed. ed.). París: Librería de la Viuda de Ch. Bouret.

Baldwin, L. (1982). The Maccarrone-Kresge Martial Arts Book Collection at the Patchogue-Medford Library: an annotated bibliography. Patchogue, N.Y.: Patchogue-Medford Library.

Blanco y Sánchez, R. (1927). Bibliografia general de la educación física. Madrid: [s.n.].

Choi, W. C. (1974). Kárate taekwondo : técnicas para la competición ([1ae ed.] ed.). Barcelona: Alas.

Consejo Superior de Deportes (2000). El deporte en el libro antiguo. Catálogo colectivo [CD-Rom]. Madrid: Consejo Superior de Deportes. Ministerio de Educación, Cultura y Deporte

European Society for the Scientific Study of Judo. (1989). Bibliographical notes. Bourdeaux: Laboratoire de Mesures en Activités Physiques et Sportives.

Gali, M. (1980). Pedazos de ti mismo (1aㅡ ed. ed.). Barcelona: Editorial Tr3s.

Gutiérrez-García, C. (2003). Introducción y desarrollo del judo en España (de principios del siglo XX a 1965): el proceso de implantación de un método educativo y de combate importado de Japón. León: Tesis [Inédita].

Gutiérrez-García, C. (2004). Introducción y desarrollo del judo en España (de principios del siglo XX a 1965): el proceso de implantación de un método educativo y de combate importado de Japón. León: Universidad de León.

Gutiérrez-García, C. (2007). Estudio de las primeras obras sobre artes marciales escritas en español. Revista de Artes Marciales Asiáticas, 2(1), 8-27.

Gutiérrez-García, C., \& Pérez-Gutiérrez, M. (2008). Evolución histórica de la producción de monografías sobre judo en España (1906-2006) CD de Actas del I European Judo Scientific Congress of Judo: Learning and performance. Lisboa.

Hunt, L. (2003). Kung Fu Cult Masters. From Bruce Lee to Crouching Tiger. London: Wallflower Press. Jacob, R. (2005). Martial arts biographies: an annotated bibliography. New York: iUniverse.

Jones, H. D. (1943). Judo, jiu-jitsu, and hand-to-hand fighting: a list of references. Washington: The Library of Congress.

Kjöstolf, K. (1950). Bibliographical notes on some works about jiu jitsu and judo including references to various subjects connected with Japan and the Japanese art of self-defence. Sarpsborg: Kjell Kjöstolf.

Moreiro González, J. A. (2004). El contenido de los documentos textuales: su análisis y representación mediante el lenguaje natural. Gijón: Trea.

Nelson, R. F., \& Whitaker, K. C. (1988). The martial arts: an annotated bibliography. New York: Garland.

Palmer, B., Palmer, K., \& Meyers, R. (1995). The encyclopedia of martial arts movies. Lanham: Scarecrow Press.

Pastor Pradillo, J. L. (1995). La educación física en España: fuentes y bibliografía básicas. Alcalá: Servicio de Publicaciones de la Universidad de Alcalá.

Pérez-Gutiérrez, M. (2012). Repertorio bibliográfico, análisis bibliométrico y sociocultural de las monografías sobre artes marciales asiáticas publicadas en España [Tesis Doctoral]. León: Servicio de Publicaciones de la Universidad de León. Disponible en http://hdl.handle.net/10612/2327.

Pérez-Gutiérrez, M., \& Gutiérrez-García, C. (2008a). 100 años de artes marciales: repertorio bibliográfico de monografías publicadas en España (1906-2006). León: Secretariado de Publicaciones de la Universidad de León.

Pérez-Gutiérrez, M., \& Gutiérrez-García, C. (2008b). Estudio bibliométrico sobre las monografías de artes marciales publicadas en España (1906-2006). Revista de Artes Marciales Asiáticas, $3(4), 22-33$. 
Pérez-Gutiérrez, M., \& Gutiérrez-García, C. (2009). Bibliometric analysis of karate monographs in Spain (1963-2006). In W. J. Cynarski (Ed.), Martial Arts and Combat Sports - Humanistic Outlook (pp. 116-126). Rzeszow: Wydawnictwo universytetu Rzeszowskiego.

Perreca, G., \& Malori, D. (2000). Full contact: técnicas y preparación para el combate. Madrid: Tutor. Perreca, G., \& Malori, D. (2003). Kick boxing: preparación, técnicas, combate. Madrid: Tutor.

Poponic, A. y. B., Peter. (2009). Taichi y aikido. Girona: Tikal.

Salling, K. (1983). Bibliographical notes on some scientific works about judo and jiu-jitsu. Sarpsborg: K. Salling.

Smith, R. W. (1959). A Complete Guide to Judo. Its story and practice. Rutland, Vt., Tokyo: Charles E. Tuttle.

Steiner, B. J. (1979). Manuals on Mayhem: an annotated bibliography of books on combat martial arts and self-defense. USA: Loompanics.

\section{Datos biográficos de los autores}

Mikel Pérez-Gutiérrez es Doctor con Mención Europea en Ciencias de la Actividad Física y del Deporte (Universidad de León) y profesor en la Universidad Autónoma de Chile. Ha participado en diversas publicaciones nacionales e internacionales sobre artes marciales y deportes de combate y tiene experiencia en el análisis bibliométrico y documental. También ha participado en diversos proyectos como investigador colaborador. E-mail: mikel.perez@uautonoma.cl.

Eduardo Álvarez del Palacio es Doctor en Ciencias de la Actividad Física y del Deporte por la Universidad de León y Profesor Titular de Universidad, adscrito al Departamento de Educación Física y Deportiva de la Universidad de León. Secretario del Instituto de Investigación LOU de Humanismo y Tradición Clásica de la Universidad de León. Autor de diversos trabajos sobre el ejercicio corporal y su consideración en los ámbitos pedagógico e higiénico durante el Humanismo renacentista europeo y español. E-mail: eduardo.alvarez@unileon.es.

Carlos Gutiérrez-García es Doctor en Ciencias de la Actividad Física y del Deporte y Profesor Titular de Universidad del Departamento de Educación Física y Deportiva de la Universidad de León. Dirige la Revista de Artes Marciales Asiáticas desde su creación en el año 2006. Ha publicado numerosos trabajos sobre artes marciales y deportes de combate, particularmente sobre judo, disciplina que imparte en los estudios de Ciencias de la Actividad Física y del Deporte de la Universidad de León. E-mail: carlos.gutierrez@unileon.es. 